\title{
FACULTAD DE FILOLOGÍA
}

\section{DEPARTAMENTO DE LENGUA ESPAÑOLA}

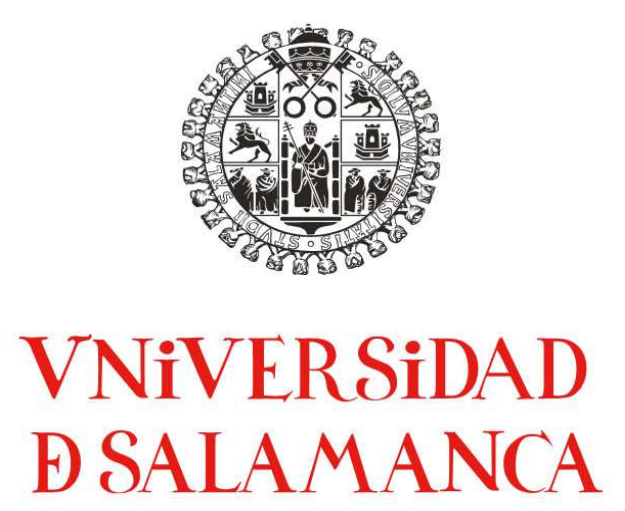

El léxico de los ingenios y máquinas en el Renacimiento

TESIS DOCTORAL

Cristina Martín Herrero

Directora: Dra. María Jesús Mancho DuQue

Salamanca, junio de 2013 

A mis padres, por todo. 



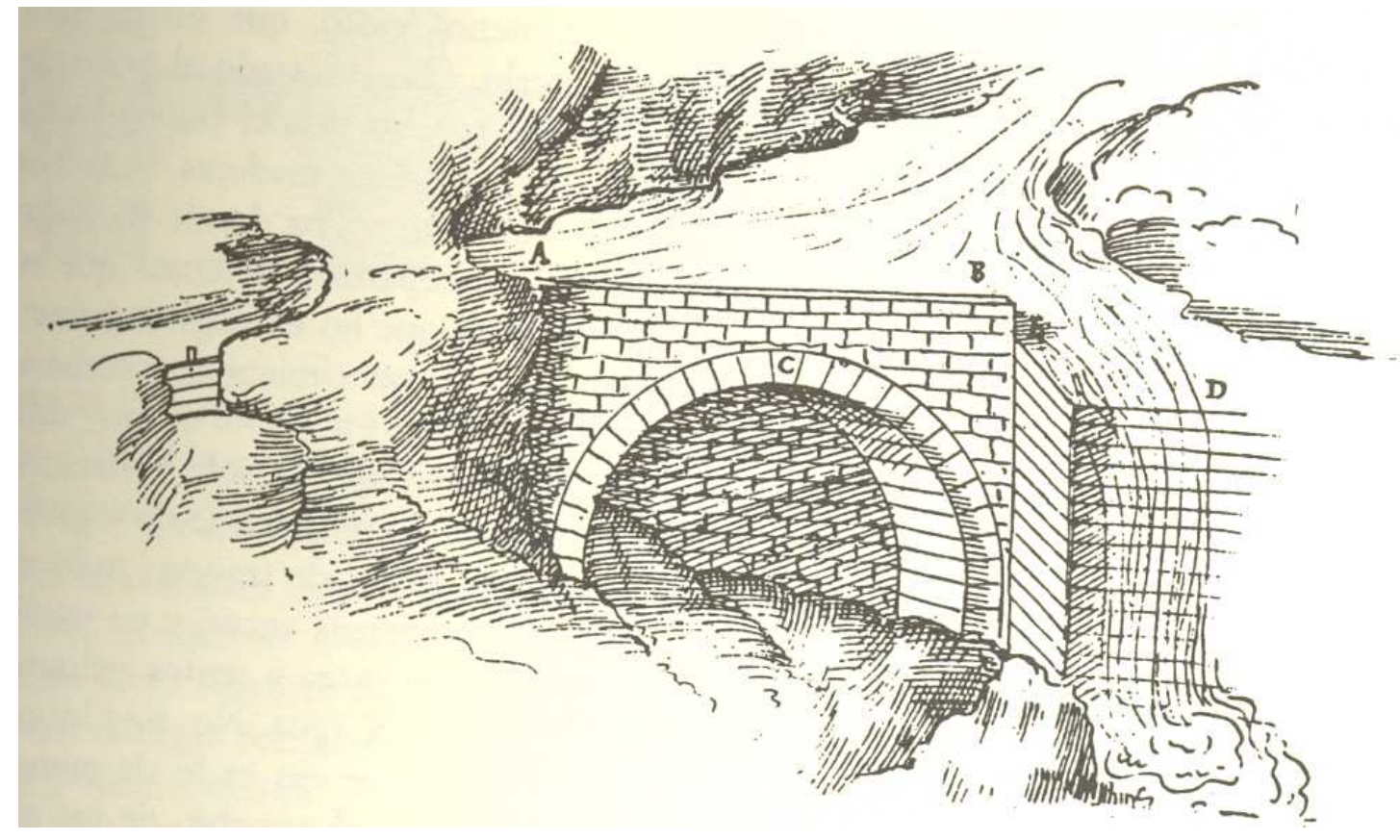

Azud de piedra

Los Veinte y un libros de los ingenios y máquinas de Juanelo (a. 1605), mss.

«Los primeros refugios de los hombres creemos que fueron las sombras, bien las que existían en la naturaleza ofrecidas por las ramas de los árboles lozanos, o bien las que se procuraron con su ingenio" Benito Arias Montano, Libro de José o sobre el lenguaje arcano (1571). 



\section{AGRADECIMIENTOS}

Son muchas las personas a las que debo gratitud en estos momentos. El proceso de elaboración de esta tesis doctoral ha sido largo y complejo y la completitud de esta tesis no hubiera sido posible sin los grandes apoyos con los que he tenido la suerte de contar.

En primer lugar, agradezco a la Dra. María Jesús Mancho Duque, directora de esta tesis, que haya confiado en mí como doctoranda para llevar a cabo una tesis bajo su tutela. La Dra. Mancho ha sido siempre comprensiva conmigo y he de agradecerle sus sabias directrices y correcciones, su ánimo en los momentos más complicados y su entusiasmo siempre que hemos ido avanzando en el desarrollo de esta investigación. Sin la ardua labor de la Dra. Mancho, esta tesis no hubiera tenido lugar, así que mi más sincero y primer reconocimiento y agradecimiento es para ella.

En segundo lugar, agradezco al Centro de Investigaciones Lingüísticas de la Universidad de Salamanca el haberme ofrecido el marco idóneo para realizar esta tesis doctoral. Allí he tenido la oportunidad de trabajar con los medios adecuados, tanto bibliográficos como informatizados, $\mathrm{y}$ fundamentalmente, he recibido el apoyo de otros compañeros del equipo del DICTER. A todos ellos les doy las gracias (a Guille, Javi, Marta, Fani, etc.), pero especialmente quisiera nombrar aquí a Ana, secretaria del CILUS, por su pronta tarea burocrática, y a Atilano, filólogo e informático, por su disposición siempre cordial en situaciones en las que he necesitado ayuda con las aplicaciones informáticas.

Seguidamente, quisiera dar las gracias a la Facultad de Filología de la Universidad de Salamanca, y en concreto al Departamento de Lengua Española y a su director D. José Antonio Bartol, por permitirme realizar la defensa de la presente tesis doctoral. También doy las gracias a todos los profesores que configuran y que han configurado, ya no solo el departamento, sino la facultad, pues sin sus clases, sus consejos y sus directrices, a lo largo de todos los cursos 
académicos de la carrera y del doctorado, yo no hubiera llegado hasta aquí. Especial mención merecen para mí, en este caso, los Dres. Ciriaco Ruiz, Luis Santos Río, Gómez Asencio, Rodríguez de la Flor, Pedro Serra, Emilio de Miguel, Luis García Jambrina, Mariano Quirós y José Ramón Carriazo.

También agradezco al antiguo Ministerio de Educación y Ciencia (actual Ministerio de Educación, Cultura y Deporte) su concesión de una beca de investigación FPI en septiembre de 2005, con la que pude comenzar mi etapa investigadora, elaborar y defender mi trabajo de grado, presentar el Diploma de Estudios Avanzados y realizar dos estancias de investigación: en el Centre for Advanced Research in English de la Universidad de Birmingham (Reino Unido), dirigida por el desgraciadamente fallecido Dr. Murray Knowles, y en la Fundación Juanelo Turriano. Mi más sincero agradecimiento a estas dos instituciones por acogerme, y especialmente a la Fundación Juanelo Turriano, a su patronato y a su director D. Bernardo Revuelta, por haberme concedido en 2010 una beca de doctorado, gracias a la cual he podido finalizar esta tesis.

Finalmente, aunque no por ello menos importante, quisiera dar las gracias a mi familia por su apoyo, ánimos y comprensión. A mi padre, Jesús Antonio, por sus sabias y oportunas palabras, que me han aportado siempre valor y coraje y me han animado a continuar. A mi madre, María Amparo, por su cariño, su paciencia y su consuelo en los momentos difíciles. Ninguno de los dos están doctorados en la universidad, pero para mí los dos siempre serán doctores en mi corazón.

Quisiera dar las gracias a mis hermanos Abraham, Jesús y Blanca, por todo lo que han hecho por mí y porque, a pesar de la distancia física, siempre han estado ahí. A mis amigas de toda la vida, María, Laura, Silvia, Sara, Mónica y Elisa; a mis amigos Daniel y Óscar; al Grupo de Cámara Gaudium; y a mis amigos y compañeros de la Universidad de Salamanca, especialmente a Jorge, Jaime, Julia, Cristina, Teresa, Carol, Vane y Carmen; a todos ellos, y a muchos que, por motivos de espacio, no he podido nombrar, gracias por haber formado parte de esta etapa de mi vida. 


\section{ÍNDICE}

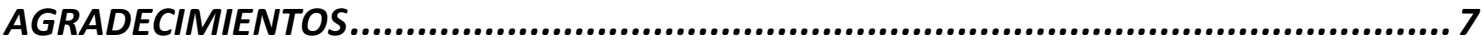

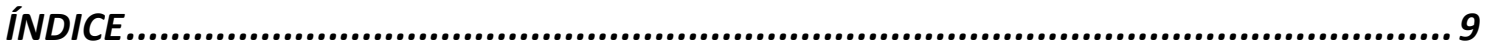

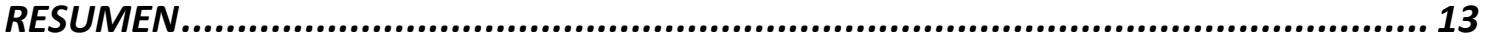

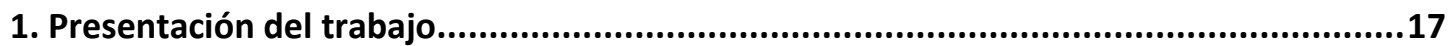

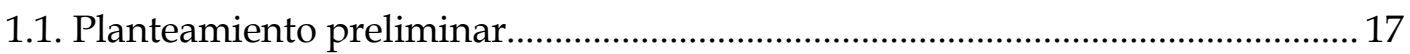

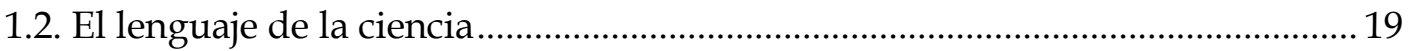

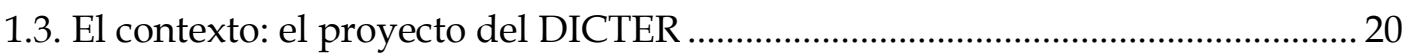

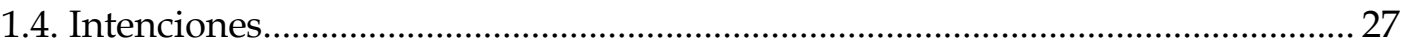

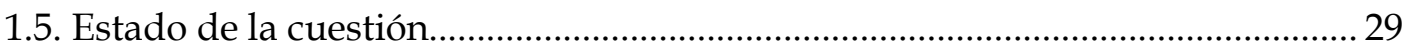

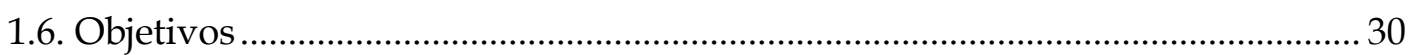

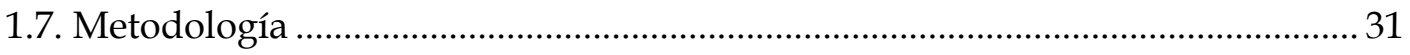

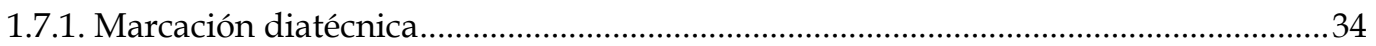

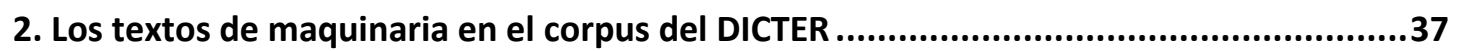

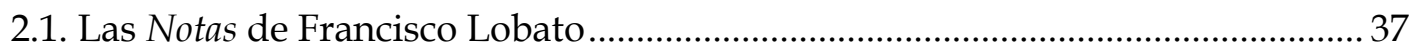

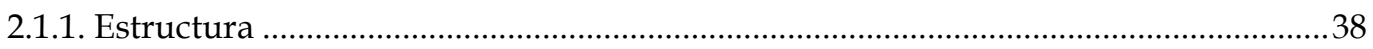

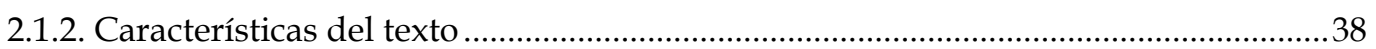

2.2. Los Veinte y un libros de los Yngenios y Máquinas de Juanelo.................................... 44

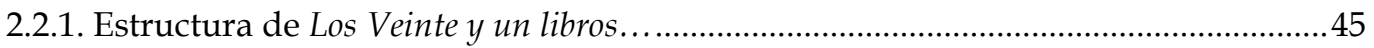

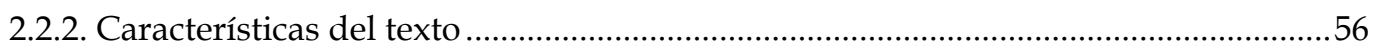

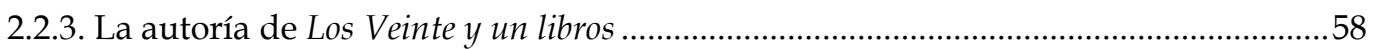

2.2.3.1. Conclusiones sobre la autoría de Los Veinte y un libros.............................................63

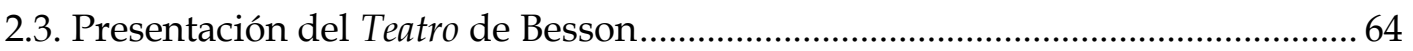

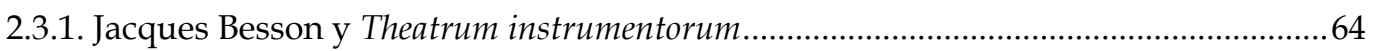

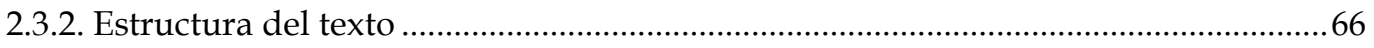

3. Ingeniería y maquinaria en el Renacimiento hispano...................................................68

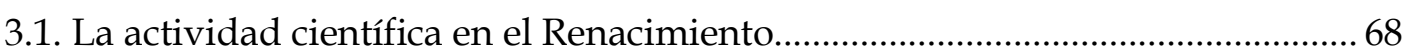

3.2. En torno al ingenio, los ingenios y el ingeniero .................................................. 71

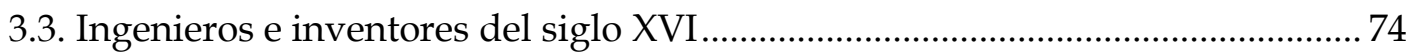

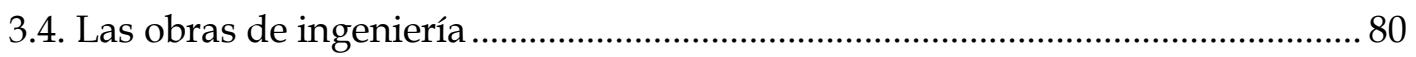

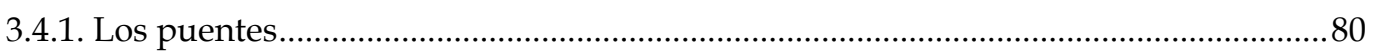

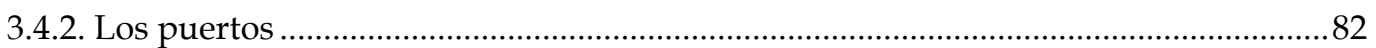

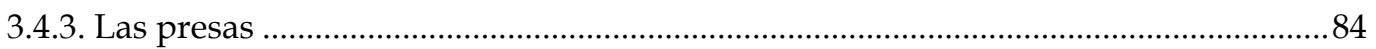

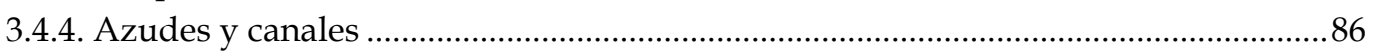

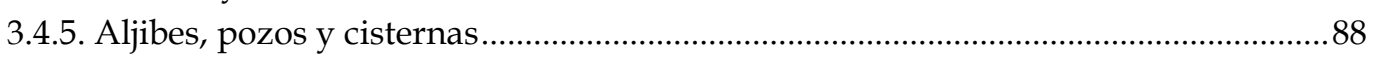

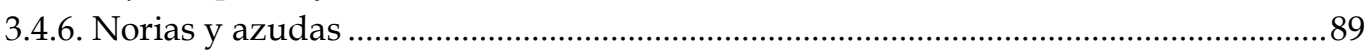

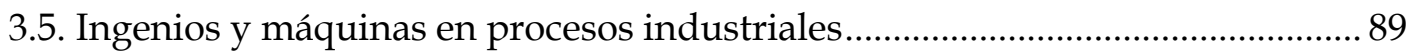

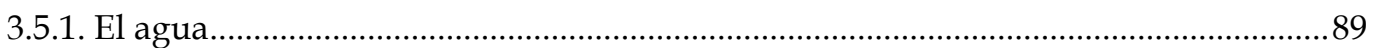

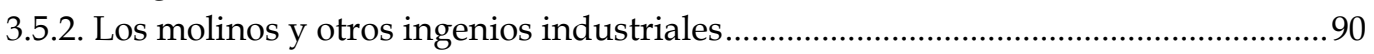

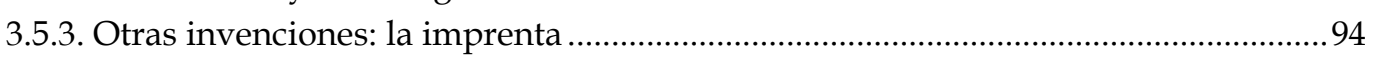

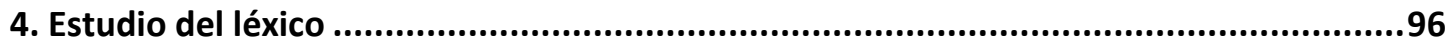

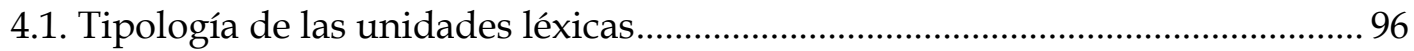

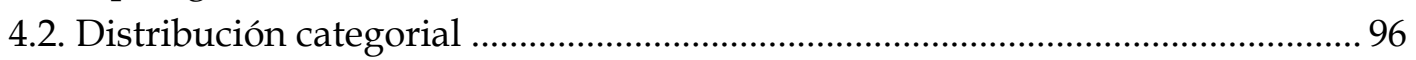




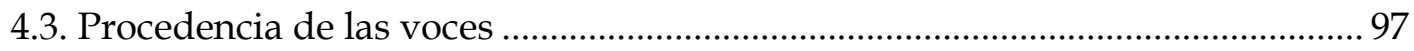

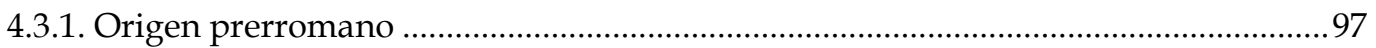

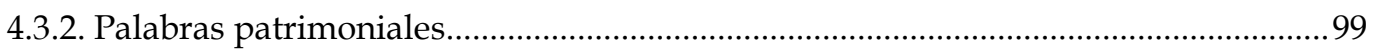

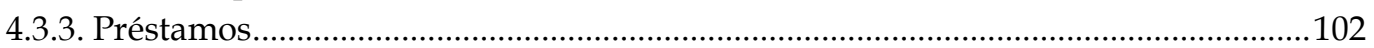

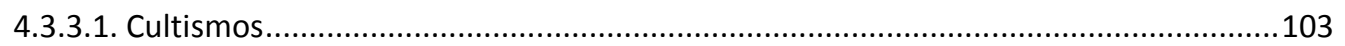

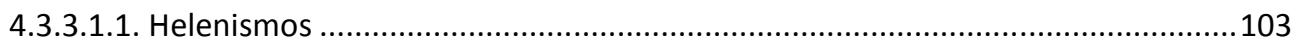

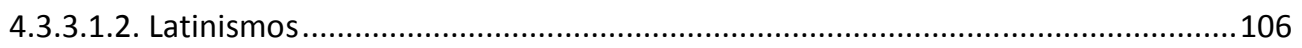

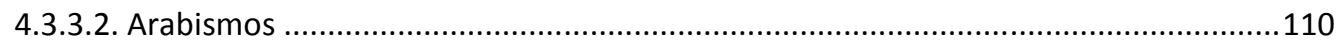

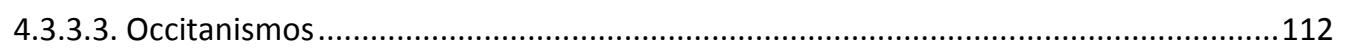

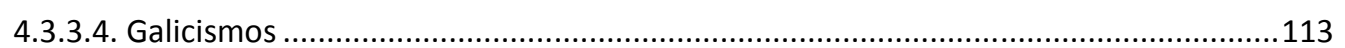

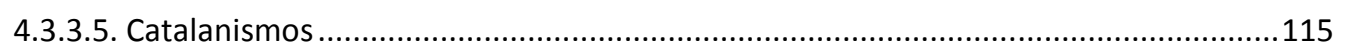

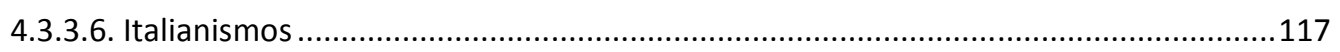

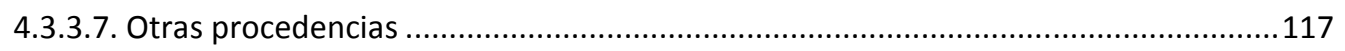

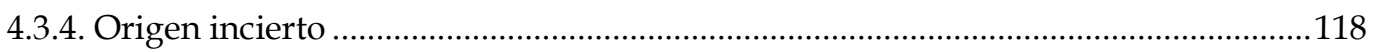

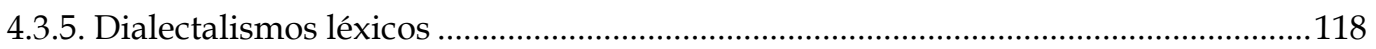

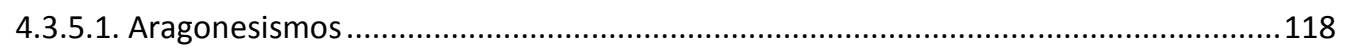

4.3.5.1.1. Procedencia de los aragonesismos ............................................................. 121

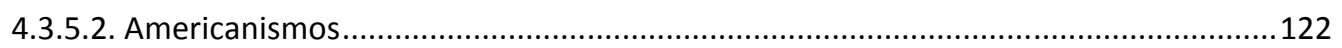

4.3.6. Conclusiones sobre la procedencia de las voces ......................................................122

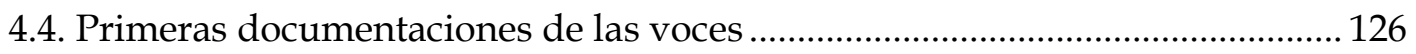

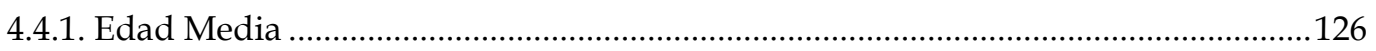

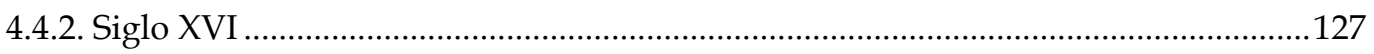

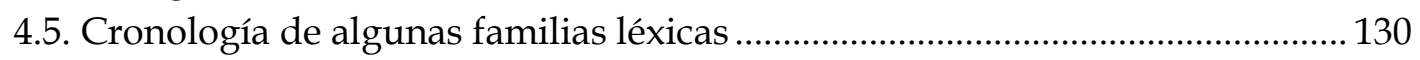

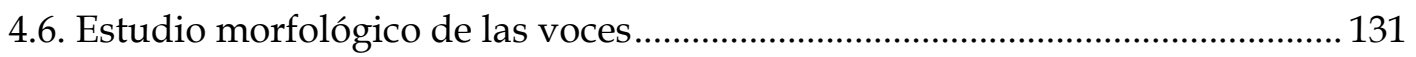

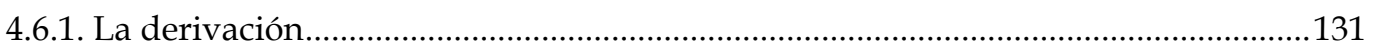

4.6.1.1. Sufijación (no apreciativa) en la formación de sustantivos denominales..................132

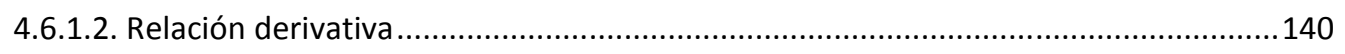

4.6.1.3. La sufijación apreciativa..................................................................................... 141

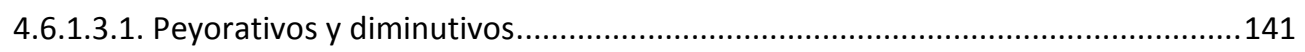

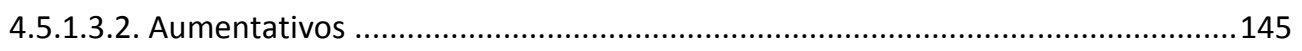

4.6.1.4. Sufijación en la formación de sustantivos deadjetivales ..........................................147

4.6.1.5. Sufijación en la formación de sustantivos deverbales ...............................................149

4.6.1.6. Sufijación en la formación de adjetivos denominales...............................................157

4.6.1.7. Sufijación en la formación de adjetivos deadjetivales ..............................................159

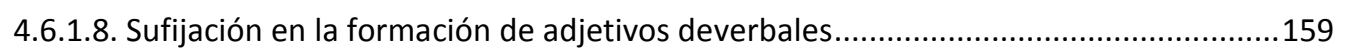

4.6.1.9. Sufijación en la formación de verbos denominales .................................................162

4.6.1.10. Sufijación en la formación de verbos deadjetivales..................................................164

4.6.1.11. Sufijación en la formación de verbos derivados de locuciones ................................164

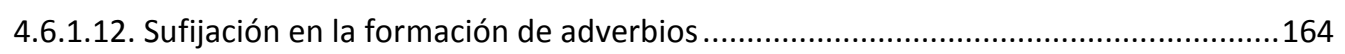

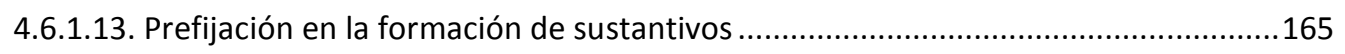

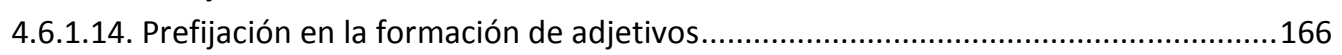

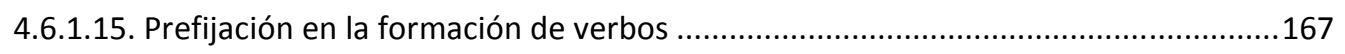

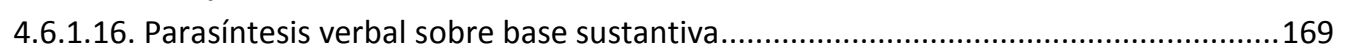

4.6.1.17. Parasíntesis verbal sobre base adjetival .........................................................171

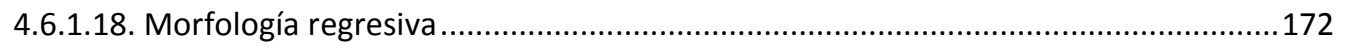

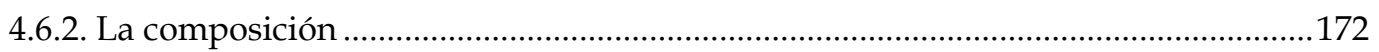

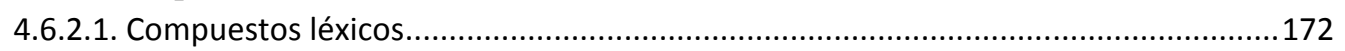

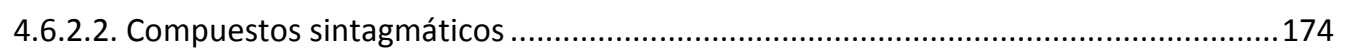

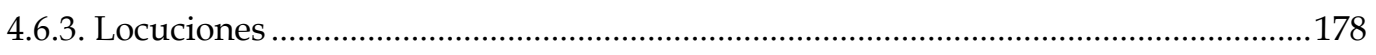




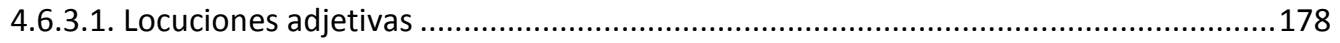

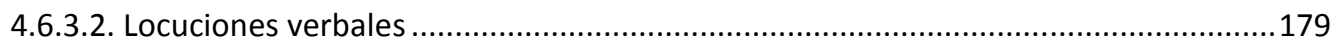

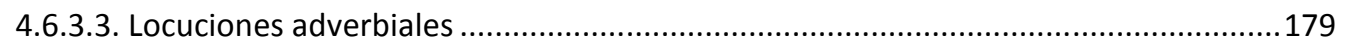

4.6.4. Conclusiones del estudio morfológico .....................................................................179

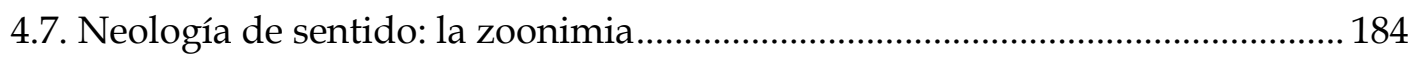

4.8. Distribución por campos léxico-semánticos ................................................ 184

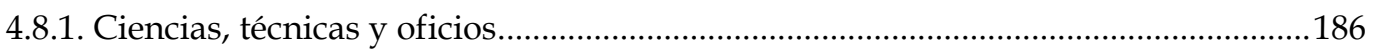

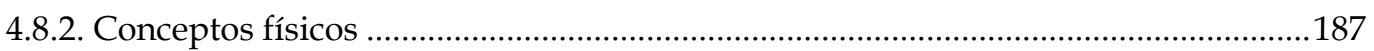

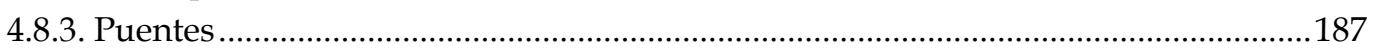

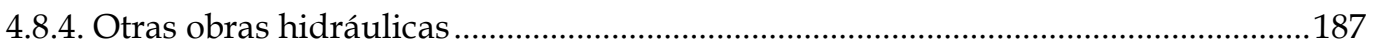

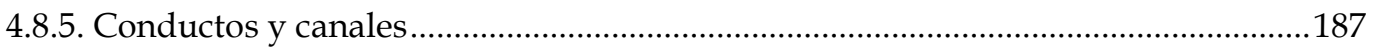

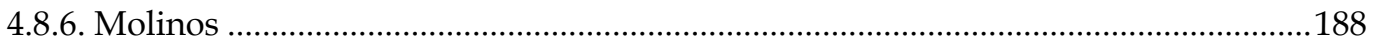

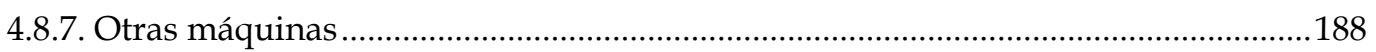

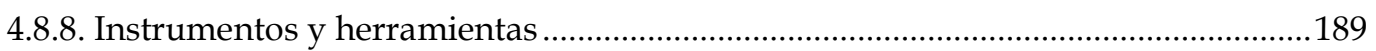

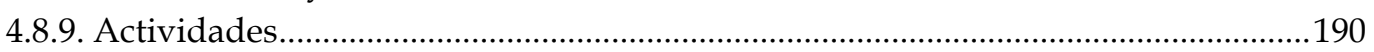

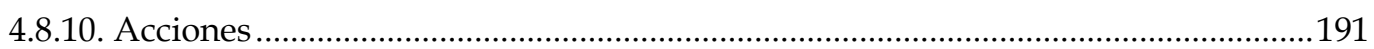

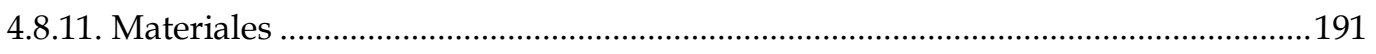

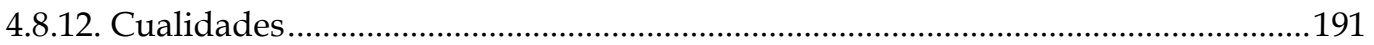

5. Conclusiones finales .................................................................................. 193

5.1. La ciencia y la técnica en el Renacimiento .................................................... 193

5.2. Los textos renacentistas de ingeniería y maquinaria ................................... 194

5.3. Los ingenieros ......................................................................................... 195

5.4. Ingenios y máquinas en el siglo XVI......................................................... 195

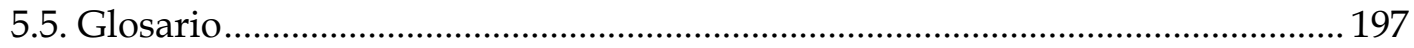

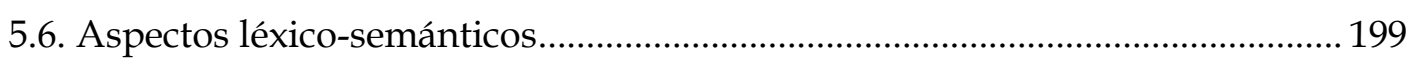

5.7. Procedencia de las voces .......................................................................... 200

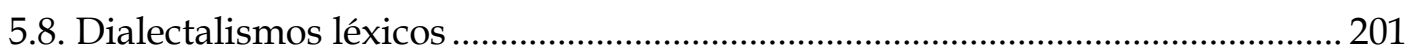

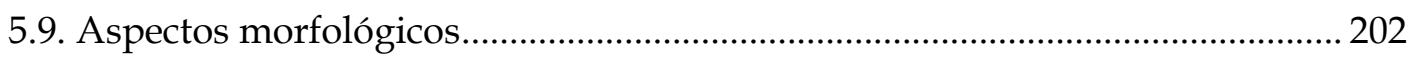

5.10. Aspectos históricos ............................................................................... 203

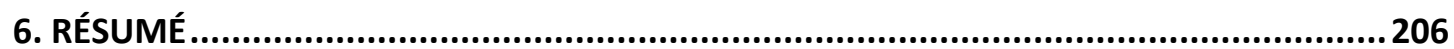

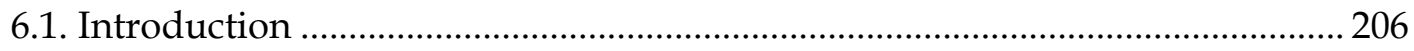

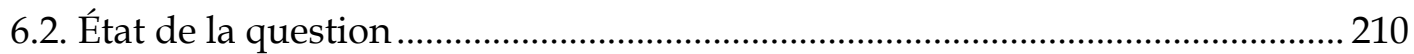

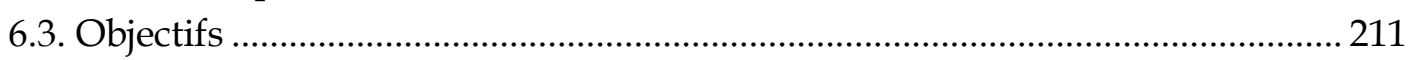

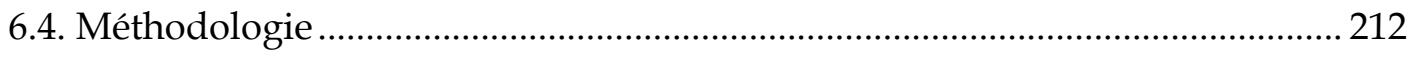

6.5. La marque diatechnique ........................................................................... 214

6.6. Les Notas de Francisco Lobato...................................................................... 216

6.7. Los Veinte y un libros de los Yngenios y Máquinas de Juanelo.................................. 217

6.8. Le Teatro de Jacques Besson ........................................................................... 218

6.9. L'activité scientifique à la Renaissance ........................................................ 219

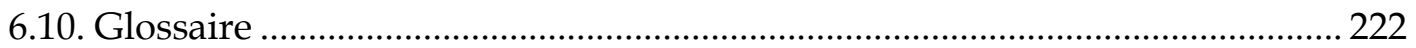

6.11. Étude du lexique..................................................................................... 223

6.11.1. Typologie des unités lexicales..............................................................................223

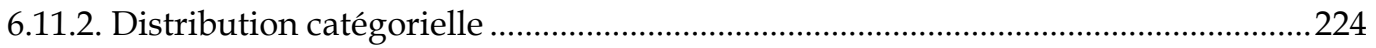

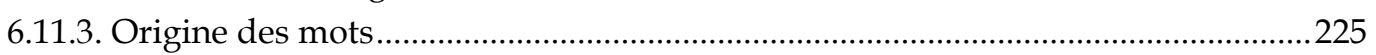

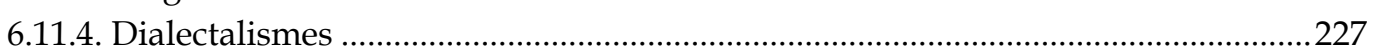




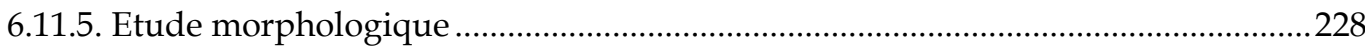

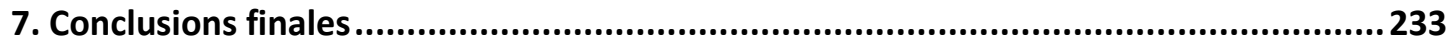

7.1. La science et la technique à la Renaissance................................................. 233

7.2. Les textes renaissantistes d'ingénierie et de machinerie................................ 234

7.3. Les ingénieurs ........................................................................................... 235

7.4. Engins et machines au XVIème siècle ............................................................. 235

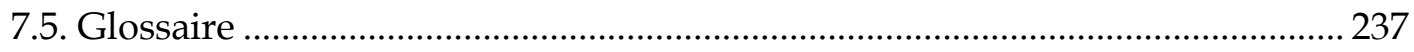

7.6. Aspects lexico-sémantiques ......................................................................... 239

7.7. Provenance des lemmes ....................................................................... 240

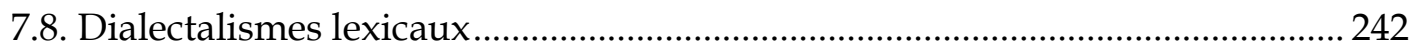

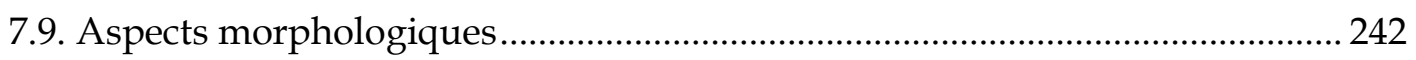

7.10. Aspects historiques ............................................................................... 243

8. Glosario: Ingeniería y maquinaria en el Renacimiento .................................... 247

9. Selección de imágenes........................................................................... 717

9.1. Imágenes de las Notas (a. 1585) de Francisco Lobato ...................................... 727

9.2. Imágenes del Teatro de los instrumentos (1602) de Diego de Besson (traducción de Horacio Cardon) ............................................................................................. 753

9.3. Imágenes de Los veinte y un libros de los yngenios y máquinas de Juanelo (c. 1605)

9.4. Imagen de la traducción de Lázaro de Velasco (a. 1564) de Los X libros de architectura de Marco Vitruvio Polión ........................................................................ 851

9.5. Imagen del Tratado de la artillería (1613) de Diego de Ufano ............................ 853

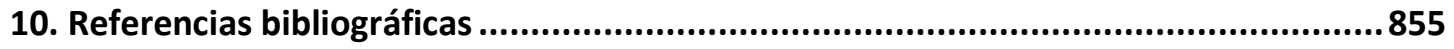

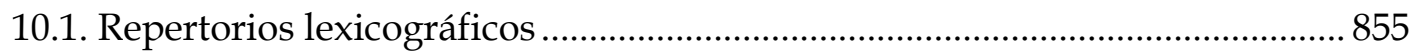

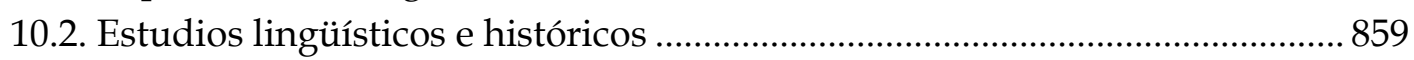




\section{RESUMEN}

Con la presente tesis doctoral pretendemos llevar a cabo un glosario y un análisis y estudio del léxico renacentista de la ingeniería y la maquinaria. No nos hubiera sido posible lograr este objetivo sin la ayuda, tanto humana como informatizada, de la que hemos dispuesto.

Por un lado, la tesis doctoral se integra en uno de los proyectos de investigación que se están realizando en el CILUS (Centro de Investigaciones Lingüísticas de la Universidad de Salamanca), en concreto en el proyecto DICTER (El Diccionario de la Ciencia y la Técnica del Renacimiento), dirigido por la Dra. Mancho Duque.

Gracias a una beca de investigación FPI y a otra de la Fundación Juanelo Turriano, hemos tenido la oportunidad de poder conocer y utilizar los lugares y materiales adecuados para completar esta tesis con el apoyo humano, bibliográfico y económico necesarios. También nos ha sido posible realizar una estancia de investigación en el Centre for Advanced Research in English de la Universidad de Birmingham (Reino Unido).

En cuanto a la metodología, nos hemos servido, como miembros del equipo, de la del DICTER, una metodología de vanguardia destinada a la elaboración lexicográfica y al análisis y estudio lexicográficos y lexicológicos (V. Mancho Duque et alii 2004, Mancho Duque 2012²). Hemos sido afortunados al contar con un corpus informatizado de textos científico-técnicos renacentistas, un programa de búsquedas, UltraEdit, y dos ficheros, realizados en FileMaker, adaptados a las necesidades específicas para la confección de glosarios especializados. Asimismo, nos ha sido posible disfrutar de los numerosos materiales bibliográficos de que dispone el CILUS y hemos podido realizar peticiones bibliográficas concretas cuando nos ha sido necesario.

La tesis está conformada por distintos apartados, siendo su grueso fundamental el Glosario de los Ingenios y Máquinas en el Renacimiento. Ha 
sido nuestra intención la de ofrecer el significado de los términos más relevantes del área léxica que nos ocupa, así como presentar informaciones que consideramos pertinentes sobre esos términos, como sus variantes gráficas, su procedencia etimológica, su primera documentación en el $\mathrm{DECH}$, su primera documentación en el corpus...También hemos insertado ejemplos de los términos extraidos de los textos, así como una definición de cada voz, bien seleccionada entre las existentes en diversos diccionarios, bien creada por nosotros mismos. Hay que tener en cuenta que, dentro de esta información lexicográfica, hemos incluido la marcación gramatical $\mathrm{y}$, en su caso, la marcación diatécnica, la diatópica u otras marcas, habituales en los repertorios lexicográficos especializados, que hemos creído oportunas. Además, nos hemos servido en muchas ocasiones de imágenes presentes en los textos y hemos incorporado a la entrada la información enciclopédica en aquellas voces que considerábamos que la precisaban.

Añadido a este Glosario de Ingeniería y Maquinaria en el Renacimiento, compone nuestra tesis, por tanto, el apartado Selección de Imágenes, formado por casi un centenar de imágenes, grabados y dibujos, gracias a los cuales podemos aclarar el significado de muchas voces del glosario. Este apartado es bastante amplio y recoge imágenes de gran valor histórico y documental, pues sin ellas muchos términos presentes en los textos resultarían oscuros.

Otra de las partes fundamentales de la tesis es el Estudio del Léxico, el cual se desglosa en varios apartados, pues en él nos hemos dedicado fundamentalmente al análisis, pero también hemos obtenido algunas de las estadísticas. Por un lado, hemos realizado un estudio gramatical, por otro, uno etimológico. En general, hemos profundizado bastante en el análisis morfológico, sin que falten distintas cuestiones diatópicas y diacrónicas, para después añadir un esquema semántico en el que hemos señalado distintos grupos.

Pero todo esto no tendría cabida sin la primera parte de la tesis, su presentación, en la que detallamos las partes que la componen, los objetivos o 
fines propuestos y la metodología. También es muy importante, a este respecto, el apartado de bibliografía: ya que nuestra tesis es lo suficientemente transversal como para abarcar distintas disciplinas, nuestra selección bibliográfica es muy variada y creemos que puede ser de interés.

Por otro lado, conforma una parte importante de la tesis la presentación de los textos fundamentales de ingeniería y maquinaria del corpus, presentación que, aunque es breve, dadas las circunstancias, sí que pensamos que podría ser interesante puesto que algunos de los textos del área léxica que nos ocupa son prácticamente desconocidos.

Nos hemos adentrado en otro capítulo, desde la modestia y la consciencia de que somos filólogos, en el área de la historia de la ingeniería, para ofrecer algunos datos sobre determinados ingenios, obras civiles o artificios de especial envergadura llevados a cabo durante el Renacimiento. También hemos prestado atención a la palabra ingenio y a algunos de sus derivados, asunto sobre el que hemos divagado un tanto.

Finalmente, quisiéramos enmarcar nuestra investigación en los márgenes del "Doctorado Europeo", motivo por el que hemos añadido un resumen y las conclusiones de la tesis en francés, uno de los idiomas permitidos para la obtención de dicha mención doctoral. 


\section{PRESENTACIÓN DEL TRABAJO}

\subsection{PLANTEAMIENTO PRELIMINAR}

Transcurrida más de una centuria desde que Asciclo Fernández Vallín compusiera el discurso que presentó en su ingreso en la Real Academia de Ciencias Exactas, Físicas y Naturales ${ }^{1}$, nos viene a colación citarlo en el preámbulo de esta tesis puesto que nos llama la atención uno de los motivos que él incluía en su discurso: "el ver que en el último tercio del siglo XIX, cuando tanto ha avanzado en todas las direcciones el genio de la investigación histórica, aún esté casi enteramente inexplorada la ciencia ibérica de los pasados tiempos" (Fernández Vallín 1989 [1893]: 13).

Aunque un largo camino se ha recorrido ya desde la aparición de la obra en la que se incluía dicho discurso, y que se trataba de un compendio o catálogo de los principales obras y autores de muchas ramas del saber científico renacentista, parece continuar presente hoy en día en los historiadores de la ciencia hispánica la idea de que esta parcela del conocimiento aún no ha sido suficientemente explorada:

En la última década se han realizado diversas visiones panorámicas del proceso histórico que ha configurado a la actual sociedad española. A pesar de sus indudables méritos, se observa en ellas una llamativa ausencia: la de la ciencia, y la de sus cultivadores (López-Ocón 2003: 9).

Por otro lado, recordamos aquí que esa omisión historiográfica de la ciencia en España, continua interpretándose, en estos momentos y en ciertos círculos, como omisión de la propia ciencia en nuestro país, interpretación en la que, a nuestro modo de ver, se halla presente el sentimiento de inferioridad científica que nos indujera ya siglos atrás la crítica lanzada por Masson (1782):

El español tiene aptitud para las ciencias, existen muchos libros, $y$, sin embargo, quizás sea la nación más ignorante de Europa. ¿Qué se puede pensar de un pueblo que necesita permiso de un fraile para leer

\footnotetext{
${ }^{1}$ Y publicado en la obra La cultura científica española en el siglo XVI.
} 
y pensar? [...] y son un miserable franciscano o un bárbaro dominico quienes deben permitir a un hombre de letras tener genio (Masson 1782, en López Piñero 1979: 21).

Crítica que algunos historiadores y científicos, por diversas circunstancias, decidieron aceptar sin protesta:

No ha sido España un lugar fácil para los científicos; no hemos estado, salvo muy honrosas excepciones, a la altura de otras naciones en este apartado (Maldonado y García 2002: 9).

Sin embargo, en los márgenes discursivos de la "polémica de la ciencia en España" (V. Sánchez Ron 1999: 7) cabe preguntarse por el significado de esa señalada omisión historiográfica para poder definir la ciencia en España enfocada en algunos parámetros

Esta sorprendente omisión historiográfica, común a tantas otras obras, ¿significa que la ciencia ha carecido de importancia en el devenir de las sociedades que han configurado la España actual?, o ¿más bien es un producto de un desenfoque del pasado histórico y científico por parte de sus estudiosos: los historiadores? (López-Ocón 2003: 9-10).

que podrían incluir la falta de diálogo entre historiadores e historiadores de la ciencia, la insuficiente institucionalización de la enseñanza e investigación histórico-científica (V. López Piñero 1979: 16) y que separó triunfalistas de lamentadores pesimistas:

Consistió en una mera proyección de imágenes a priori procedentes de ideologías que mantenían posturas opuestas en los terrenos socioeconómico, político y cultural. Los panegiristas ensalzaron las "glorias de la ciencia española" con la intención de justificar la misma organización sociopolítica y el mismo sistema de valores que los pesimistas pretendían invalidar con su negra imagen de "látigo, hierro, sangre y rezos". Sin embargo, los excesos retóricos triunfalistas, revestidos en ocasiones de alardes de falsa erudición, y las lamentaciones pesimistas de sus contradictores coincidieron en un completo rechazo por la investigación histórica del tema (López Piñero 2002: 11). 
Por lo que quizás quisiéramos conciliar, a través de nuestro estudio y la metodología de la que es resultado, todas estas carencias en la investigación de la historia de la ciencia con otra carencia de comunicación aún más amplia: la que actúa entre científicos y humanistas, debido a una estructura oficial del saber que los compartimenta y separa (López-Ocón 2003: 13) y que aquí pretenderíamos aunar ${ }^{2}$.

\subsection{EL LENGUAJE DE LA CIENCIA}

El lenguaje de la ciencia puede que sea uno de los espacios en los que los filólogos podemos optar por adentrarnos en textos científicos históricos, en primer lugar porque hay un deseo real de conocer la ciencia y el léxico de aquel entonces, ya que influye directamente en nuestro conocimiento del léxico actual. Sin embargo, con esto no podemos eludir que, a pesar del trayecto transcurrido a día de hoy, adentrarse en textos científicos y técnicos desde la formación filológica actual no deja de ser hasta cierto punto osado y, para justificar esta bienintencionada intromisión, hemos recurrido a las palabras de la Dra. Gutiérrez Rodilla, quien afirma que "el conocimiento científico se expresa, se transmite, a través de la palabra, siendo esa transmisión, además, condición indispensable para la existencia de la propia ciencia" (Gutiérrez Rodilla 2005: 9), por lo que consideramos que sí que puede ser significativa la contribución de la filología y, en concreto, de la lingüística histórica, al estudio que otros especialistas ofrecen sobre este campo ${ }^{3}$, ya que lengua y ciencia están tan estrechamente ligadas que la una sin la otra parecen no existir.

Esta relación lenguaje-ciencia nos anima a aprovechar algunas palabras otorgadas al conocimiento científico para así atribuírselas también al lenguaje científico y afirmar aquí que este, el lenguaje científico, "no viene dado,

${ }^{2}$ De acuerdo con Salvador Reguant, esto proviene, por un lado, de los problemas, en primer lugar, de comunicación de la ciencia, y, en segundo lugar, de "comunicación de la ciencia a científicos de diversos ámbitos, diversas lenguas y diversas culturas" (Reguant 2003: 94).

${ }^{3}$ No olvidamos citar aquí a Wüster (1998), que estableció la terminología como disciplina independiente, y a Cabré, "desde muchos campos la terminología es un instrumento funcional de sus especialidades, por lo tanto sin interés en sí misma" (Cabré 2003: 24). 
revelado, en jardín amurallado alguno, sino que es algo que hay que construir (y que nuestros antepasados tuvieron que construir) ${ }^{4}$. Construcción que no supone una captación inmediata, directa, de un sector de lo real, sino que, junto a los sentidos, hay que admitir elementos interpuestos" (Lorenzo 2009: 16). Construcciones que a día de hoy vienen llevándose a cabo en distintos grupos de investigación, existentes en un nutrido grupo de universidades y centros de investigación de distintos países, lugares en los que sus miembros investigadores enfocan sus intereses en el conocimiento de la lengua de la ciencia y de la técnica de nuestros antepasados.

\subsection{EL CONTEXTO: EL PROYECTO DEL DICTER}

Nuestra tesis doctoral se inserta en las líneas de investigación llevadas a cabo en el Centro de Investigaciones Lingüísticas de la Universidad de Salamanca, en el marco del proyecto El diccionario de la Ciencia y la Técnica del Renacimiento, dirigido por Doña María Jesús Mancho Duque. Este proyecto ha sido la fuente de la que han surgido varios trabajos de investigación que, en forma de trabajos del grado, tesis doctorales, participaciones en eventos científicos o artículos de investigación, se han aproximado al estudio del léxico científico-técnico renacentista.

Uno de los pilares en los que este proyecto se sustenta, material y herramienta fundamentales en el desarrollo del DICTER, es el corpus de la Ciencia y la Técnica en el Renacimiento, corpus informatizado constituido por 74 textos renacentistas especializados que, clasificados en las distintas áreas, fueron seleccionados bajo la supervisión de un grupo de historiadores de la ciencia:

\section{Arte militar}

Montes, Diego, Instrucción y regimiento de guerra, Zaragoza, George Coci, 1537.

\footnotetext{
${ }^{4}$ El contenido del paréntesis es mío.
} 
García de Palacio, Diego, Diálogos militares, México, Pedro Ocharte, 1583.

Álaba y Viamont, Diego de, El perfeto capitán instruido en la diciplina militar y nueva ciencia de la Artillería, Madrid, Pedro Madrigal, 1590.

Collado de Lebrixa, Luys, Plática manual de Artillería, Milán, Pablo Gotardo Poncio, 1592.

Mendoça, Bernardino de, Theórica y práctica de guerra, Anveres, Imprenta Plantiniana, 1596 (1. ${ }^{\text {a }}$ ed., Madrid, Viuda de P. Madrigal, 1595).

Mosquera de Figueroa, Christóval, Comentario en breve compendio de disciplina militar, Madrid, Luis Sánchez, 1596.

Ferrofino, Julián, Descrizión y tratado muy breve y lo más probechoso de Artillería, mss. 1599.

Lechuga, Cristóval, Discurso del Capitán Cristóval Lechuga, en que trata de la Artillería y de todo lo necessario a ella, Milán, Marco Tulio Malatesta, 1611.

Ufano, Diego, Tratado de la Artillería, Brusselas, Juan Momarte, 1613.

\section{Astronomía}

Nebrija, Antonio de, Tabla de la diversidad de los días y horas, s. 1. (Alcalá de Henares), s. n. (Arnao Guillén de Brocar), s. a. (1517).

Sacrobosco, Juan de, Tractado de la sphera, Sevilla, Juan de León, 1545, trad. Hierónymo de Chaves.

Anónimo, Repertorio de los tiempos, Valladolid, Francisco Fernández de Córdova, 1554.

Muñoz, Hierónimo, Libro del nuevo cometa, Valencia, Pedro de Huete, 1573.

Micón, Josepe, Diario y juyzio del grande cometa, Barcelona, Jayme Sendrat, 1578. 


\section{Construcción}

Sagredo, Diego de, Medidas del Romano, Toledo, Remon de Petras, 1526.

Alberto, León Baptista, Los diez libros de Architectura, Madrid, Alonso Gómez, 1582, trad. Francisco Loçano.

Vitruvio Pollión, Marco, De Architectura, Alcalá de Henares, Juan Gracián, 1582, trad. Miguel de Urrea.

Arphe y Villafañe, Joán de, De varia commensuración para la Esculptura y Architectura, Sevilla, Andrea Pescioni y Juan de León, 1585-87.

Vandelvira, Alonso de, Libro de traças de cortes de piedras, mss. ca. 1591.

Vignola, Jacome de, Regla de las cinco órdenes de Architectura, Madrid, en casa del autor, 1593, trad. Patritio Caxesi.

Martínez de Aranda, Xinés, Zerramientos i trazas de montea, mss. ca. 1599.

López de Arenas, Diego, Primera y sigunda parte de las reglas de la carpintería, mss. 1619.

\section{Cosmografía y geografía}

Fernández de Enciso, Martín, Suma de Geographía, Sevilla, Juan Cromberger, 1530 (1. ${ }^{\text {a }}$ ed., Sevilla, Jacobo Cromberger, 1519).

Santa Cruz, Alonso de, Libro de las longitúdines, mss. a. 1567.

Apiano, Pedro, Cosmographía, Anvers, Juan Bellero, 1575, trad. anónimo (1. ${ }^{\mathrm{a}}$ ed., Enveres, Gregorio Bontio, 1548).

Poça, Andrés de, Hydrografía, Bilbao, Mathías Mares, 1585.

Tovar, Simón de, Examen i censura del modo de averiguar las alturas de las tierras, Sevilla, Rodrigo de Cabrera, 1595.

\section{Destilación}


Valles de Covarrubias, Francisco de, Tratado de las aguas destiladas, Madrid, Luis Sánchez, 1592.

Sanctiago, Diego de, Arte separatoria, Sevilla, Francisco Pérez (por Rodrigo Cabrera), 1598.

\section{Fortificación}

Rojas, Christóval de, Teórica y práctica de fortificación, Madrid, Luis Sánchez, 1598.

González de Medina, Diego, Examen de fortificación, Madrid, Pedro Várez de Castro, 1599.

Roxas, Christóval de, Sumario de la milicia antigua y moderna, mss. 1607.

Rojas, Christóval de, Compendio y breve resolución de fortificación, Madrid, Juan de Herrera, 1613.

\section{Legislación y Comercio}

Anónimo, Ordenanças sobre el obraje de los paños, lanas, bonetes y sombreros, nuevamente hechas, Burgos, s. n., 1527.

Anónimo, Leyes, ordenanças, premáticas y declaraciones de las ordenanças antiguas que hablan del obrage de las lanas e paños, Sevilla, s. n., 1538 (1. ${ }^{a}$ ed., Toledo, s. n., 1528).

Castillo, Diego del, Tratado de cuentas, Salamanca, Juan de Junta, 1551 (1. ed., Burgos, Alonso de Melgar, 1522).

Martínez de Burgos, Andrés, Reportorio de todas las premáticas y capítulos de Cortes (1523-1551), Medina del Campo, Guillermo de Millis, 1551.

Anónimo, La premática que Su Magestad ha mandado hazer... para que ningún mercader ni tratante... no traten ni vayan a las ferias de León..., Alcalá de Henares, Joán de Mey, 1552. 
Celso, Hugo de, Reportorio universal de todas las leyes d'estos reynos de Castilla, Medina del Campo, Juan María da Terranova y Jacome de Liarcari (imprenta de Francisco del Canto), 1553, comp. Andrés Martínez de Burgos.

Anónimo, Pragmática y declaración sobre juegos, Madrid, Alonso Gómez, 1574.

Valle de la Cerda, Luys, Desempeño del patrimonio de Su Magestad por medio de los erarios públicos y montes de piedad, Madrid, Pedro Madrigal, 1600.

\section{Maquinaria}

Helt Frisio, Hugo, Declaración y uso del relox español, Salamanca, Juan de Junta, 1549, trad. Francisco Sánchez de las Broças.

Roiz, Pedro, Libro de reloges solares, Valencia, Pedro de Huete, 1575.

Lobato, Francisco, Notas, mss. a. 1585.

Besson, Diego, Teatro de los instrumentos y figuras matemáticas y mecánicas, León de Francia, Horacio Cardon, 1602.

Pseudo Juanelo Turriano, Los veinte y un libros de los yngenios y máquinas, mss. a. 1605.

\section{Matemáticas}

Ortega, Juan de, Conpusición de la arte de la Arismética y de Geometría, León de Francia, Maistro Nicolau de Benedictis (por Joannes Trinxer), 1512.

Aurel, Marco, Libro primero de Arithmética algebrática, Valencia, Joán de Mey, 1552.

Fineo, Oroncio, Los dos libros de la Geometría práctica, mss. 1553, trads. Hierónimo Girava y Pedro Juan de Lastanosa.

Pérez de Moya, Juan, Arithmética práctica y speculativa, Salamanca, Mathías Gast, 1562. 
Núñez, Pedro, Libro de Álgebra en Arithmética y Geometría, Anvers, Herederos de Arnoldo Birckman, 1567.

Herrera, Juan de, Institución de la Academia Real Mathemática, Madrid, Guillermo Droy, 1584.

Alcega, Juan de, Libro de Geometría prática y traça, Madrid, Guillermo Drouy, 1589.

Pérez de Moya, Juan, Manual de contadores, Madrid, Pedro Madrigal, 1589.

Belveder, Joán de, Libro general de las reduciones de plata y oro, Lima, Antonio Ricardo, 1597.

Molina Cano, Joán Alfonso de, Descubrimientos geométricos, Anveres, Andrea Bacx, 1598.

Molina Cano, Joán Alfonso de, Nuevos descubrimientos geométricos, Anveres, Andrea Bacx, 1599.

García de Céspedes, Andrés, Libro de instrumentos nuevos de Geometría, Madrid, Juan de la Cuesta, 1606.

\section{Metalurgia y Minería}

Pérez Vargas, Bernardo, De re metallica, Madrid, Pierres Cosin, 1568.

Arphe de Villafañe, Joán, Quilatador de la plata, oro y piedras, Valladolid, Alonso y Diego Fernández de Córdova, 1572.

Acosta, Joseph de, Historia natural y moral de las Indias. Libro IV, Sevilla, Juan de León, 1590.

Llanos, García de, Diccionario y maneras de hablar que usan en las minas, mss. ca. 1609-11.

Alonso Barba, Álbaro, Arte de los metales, Madrid, Imprenta del Reyno, 
1640.

\section{Náutica y Arquitectura naval}

Falero, Francisco, Tratado del esphera y del arte del marear, Sevilla, Juan Cromberger, 1535.

Medina, Pedro de, Arte de navegar, Valladolid, Francisco Fernández de Córdova, 1545.

Cortés de Albacar, Martín, Breve compendio de la sphera y de la arte de navegar, Sevilla, Antón Álvarez, 1556 (1. a ed., Sevilla, Antón Álvarez, 1551).

Medina, Pedro de, Regimiento de navegación, Sevilla, Simón Carpintero, 1563

Escalante, Bernardino de, Discurso de la navegación, Sevilla, Biuda de Alonso Escrivano, 1577.

García de Palacio, Diego, Instrución náuthica, México, Pedro Ocharte, 1587.

Çamorano, Rodrigo, Compendio del arte de navegar, Sevilla, Joán de León, 1588 (1. ${ }^{a}$ ed., Sevilla, Alonso de la Barrera, 1581).

Cano, Thomé, Arte para fabricar, fortificar y aparejar naos de guerra y merchante, Sevilla, Luis Estupiñán, 1611.

Anónimo, Diálogo entre un bizcaýno y un montañés sobre la fábrica de navios, mss. ca. 1631.

\section{Óptica}

Euclides, La perspectiva y especularia, Madrid, Viuda de Alonso Gómez, 1584-85, trad. Pedro Ambrosio Ondériz.

Daça de Valdés, Benito, Uso de los antojos para todo género de vistas, Sevilla, Diego Pérez, 1623. 
Como investigadora en formación en el proyecto DICTER, me fue gratamente atribuido el campo de la maquinaria, etiqueta que engloba los siguientes textos renacentistas del corpus:

Helt Frisio, Hugo, Declaración y uso del relox español, Salamanca, Juan de Junta, 1549, trad. Francisco Sánchez de las Broças.

Roiz, Pedro, Libro de reloges solares, Valencia, Pedro de Huete, 1575.

Lobato, Francisco, Notas, mss. a. 1585.

Besson, Diego, Teatro de los instrumentos y figuras matemáticas y mecánicas, León de Francia, Horacio Cardon, 1602.

Pseudo Juanelo Turriano, Los veinte y un libros de los yngenios y máquinas, mss. a. 1605.

Los dos primeros, que tratan sobre relojes solares, fueron dos de las fuentes principales de una investigación realizada anteriormente que constituyó mi trabajo de grado, El léxico de la cronometría y de los instrumentos de medición del tiempo en textos científico-técnicos del Renacimiento español ${ }^{5}$ dirigido por la Dra. $\mathrm{M}^{\mathrm{a}}$ Jesús Mancho Duque. Los tres subsiguientes son tres de los textos renacentistas fundamentales para la elaboración de de la tesis doctoral que aquí nos ocupa, y, por tanto, los presentaremos con más detalle en el capítulo correspondiente.

\subsection{INTENCIONES}

Con este trabajo de investigación nos proponemos reconstruir, en la medida de nuestras posibilidades, una parcela del lenguaje de la ciencia del Renacimiento. Se trata en este caso del léxico de la ingeniería renacentista, ámbito que quisiéramos abordar mediante el estudio de las características del léxico de esta área científico-técnica. También quisiéramos acercarnos a los elementos que participaron en la creación y construcción del lenguaje propio de

\footnotetext{
5 V. Martín Herrero (2006).
} 
esta especialidad en aquel preciso momento histórico.

La elección de los márgenes temporales del siglo XVI para el estudio del lenguaje de la ciencia y la técnica se apoya en que el Renacimiento es la época en la que se considera que nacieron tanto la ciencia como el estado modernos, ambos íntimamente relacionados y caracterizados por una serie de necesidades propias. Hemos de recordar que, durante este tiempo, el siglo XVI, el castellano se unió a otras lenguas romances en su consolidación como instrumento vehicular de divulgación científica, en decremento del latín (V. Mancho Duque 2008: 313). Este proceso de afianzamiento del castellano ${ }^{6}$ estaba inmerso en uno mayor, de extensión o renovación humanista y de recuperación del saber grecolatino. Fueron, sin embargo, los altos intereses del imperio español, que no solo precisaba de ciencia y técnica aplicadas de vanguardia, sino que además llegó a contar con ellas, lo que pudo provocar el control de la difusión textual de estas innovaciones fuera de sus dominios ${ }^{7}$ (Sánchez Ron 1999: 34), hecho que contribuiría a causar la omisión histórico-científica anteriormente comentada.

Procuramos con esta tesis doctoral, aproximarnos, en concreto, al área de la ingeniería y maquinaria, uno de los ámbitos que sufrió más transformaciones durante la época renacentista. Por un lado, debido al nuevo sistema de ordenanzas que promovía las reformas urbanas, fueron muchas las obras de ingeniería que se ejecutaron en aquel tiempo, principalmente ligadas al abastecimiento de aguas, pero también relacionadas con la navegabilidad de los ríos y el establecimiento de zonas portuarias. Por otro, fue muy significativo el singular auge de invenciones acontecido durante la época renacentista (V. Silva Suárez 20083: 293), que en el ámbito de la maquinaria se materializó en el surgimiento de una variada tipología molinera, destinada a muy distintas aplicaciones, así como una serie de máquinas necesarias para la construcción, bien para la carga y descarga de materiales, bien para su transporte. Por estos y

${ }^{6}$ V. “La cultura del Renacimiento (1480-1580): la lengua", del Dr. Frago Gracia (1999).

7 V. a este respecto las palabras de Felipe II (1563) dirigidas al Consejo de Indias a propósito de los inconvenientes de la divulgación del Libro de las longitudes de Alonso de Santa Cruz a "extranjeros y otras personas que no fuesen súbditos ni vasallos nuestros" (Vicente Maroto, 1997). 
otros motivos, consideramos que el léxico especializado de este ámbito es especialmente relevante en su tiempo y por tanto merece un estudio más detallado con las nuevas herramientas informáticas de que disponemos.

\subsection{ESTADO DE LA CUESTIÓN}

Aunque a día de hoy existe una importante bibliografía dedicada a la historia de la ingeniería y en concreto a la ingeniería del Renacimiento (V. Silva Suarez, García-Diego, González Tascón, García Tapia, etc.), contamos solamente con estudios parciales del léxico de este ámbito. En general, no son muchas las páginas que se han dedicado a aspectos terminológicos de la ingeniería y la maquinaria renacentistas, aunque podemos encontrar referencias relevantes a términos de la ingeniería en otros estudios lingüísticos más amplios. Así, señalamos el estudio de los arabismos pertenecientes al área de ingeniería hidráulica incluido en la obra Historia de la lengua española de Rafael Lapesa, o el de los aragonesismos presentes en Los Veinte y un Libros de los Ingenios y las Máquinas, realizado por Juan A. Frago. En cuanto a los repertorios lexicográficos, son muchas las obras lexicográficas generales que albergan voces de la ingeniería y la maquinaria, pero muy pocos los repertorios especializados dedicados a esta parcela. Podemos señalar El léxico de alarifes de los Siglos de Oro de García Salinero como una de las obras lexicográficas más significativas para el estudio del léxico que nos ocupa, pues contiene gran número de términos de ingeniería y numerosos ejemplos tomados de algunos de los textos que componen nuestro corpus, aunque también registra términos de otras parcelas científico-técnicas, como arquitectura, cantería y construcción en general. Asimismo, existe una obra lexicográfica dedicada a la ingeniería, El diccionario general de arquitectura e ingeniería de Clairac y Sáenz, que es de época posterior, y su utilidad para el estudio del léxico renacentista es algo limitada.

Destacamos, sin embargo, la existencia de una serie de glosarios especializados que, recogidos como apéndices en otras obras, y realizados desde una perspectiva fundamentalmente histórica, pueden servir de gran ayuda a la hora de acercarse a los distintos conceptos relacionados con los 
ingenios y máquinas del Renacimiento. Nos referimos aquí a los vocabularios contenidos en Ingeniería y arquitectura en el Renacimiento, de Nicolás García Tapia; en los Catálogos Felipe II y Ars mechanicae, de González Tascón; así como al glosario que se incluye al final de la edición de Los Ventiún libros de los ingenios y las máquinas realizada por la Fundación Juanelo Turriano. También nos han resultado útiles trabajos de terminología sobre molinología y obras hidráulicas, como los contenidos en el $\mathrm{ALEA}^{8}$, los realizados por Manuel Alvar Ezquerra ${ }^{9}$ o el Glosario de términos hidráulicos de Leonardo Icaza Lomell. Y ya para finalizar, resaltamos la utilidad de la Guía bibliográfica de la historia de la Ingeniería Civil elaborada por García García y González Tascón (2004).

\subsection{OBJETIVOS}

En la presente tesis doctoral, es nuestro objetivo llevar a cabo un estudio del léxico de los ingenios y máquinas en el siglo XVI, por ser esta una parcela del conocimiento que aún no ha sido investigada independientemente.

Para lograr este objetivo, confeccionaremos en primer lugar un glosario de la ingeniería en el Renacimiento, siguiendo la metodología de un reconocido equipo de investigación en el área de lexicografía y lexicología históricas.

Ayudados por importantes y variadas fuentes bibliográficas, obtendremos los diversos datos sobre los términos que consideramos indispensables para confeccionar un glosario lexicográfico y realizar el estudio lexicológico. Estas informaciones serán gramaticales, etimológicas, morfológicas, cronológicas, semánticas y léxicas y nos permitirán analizar diversos aspectos del léxico de esta área designativa. Nos serviremos de imágenes allí donde consideremos que estas pueden aclarar el sentido de los términos.

Es nuestro objetivo, además, ofrecer una panorámica de la ingeniería y maquinaria renacentistas y de los textos más significativos de este ámbito, para

${ }^{8}$ Atlas lingüístico y etnográfico de Andalucía.

${ }^{9}$ V. Alvar Ezquerra, 1998. 
así introducir, acercar y contextualizar nuestro estudio lexicológico.

\subsection{METODOLOGÍA}

De acuerdo con la metodología vigente en el proyecto, la selección de las voces que conforman el glosario se realiza en varias fases. En primer lugar, se selecciona un primer elenco a partir de la lectura detenida de los textos del área científico-técnica destinada a la investigación ${ }^{10}$. Además, esta selección se completa con los términos detectados por medio de búsquedas en la base de datos denominada Fichero Índice ${ }^{11}$. Posteriormente, se añaden las voces necesarias para completar las distintas familias léxicas que han surgido en esta fase selectiva, teniendo en cuenta su ligazón o pertenencia al ámbito léxico objeto de estudio.

El programa de búsquedas elegido por la dirección del proyecto, UltraEdit, consigue que el usuario obtenga con rapidez el conjunto de concordancias, halladas en el corpus, que contienen las ocurrencias de los términos buscados. De esta manera, resulta para el investigador más accesible el material necesario para el desempeño de los pasos subsiguientes, obligados para la delimitación de las entradas y acepciones del glosario especializado: observación de la categoría gramatical del término, detección de los distintos sentidos o usos de este y demarcación de las unidades léxicas complejas.

Será posteriormente una base de datos de Filemaker el formato que albergará las informaciones, de diferente tipo, registradas por los lexicógrafos del DICTER, para cuya elaboración el equipo se nutrirá de fuentes diversas que incluyen repertorios lexicográficos de distinta índole, obras filológicas o

10 Serán esta lectura y las búsquedas en el corpus algunos de los pasos utilizados en el método para la detección de tecnicismos, aunque en un primer momento domina la doble competencia o método intuitivo (V. Gutiérrez Rodilla 1993: 465).

11 Esta base de datos, configurada en las fases iniciales del diccionario, pero actualizada y corregida continuamente, alberga la macroestructura fundamental del futuro Diccionario de la Ciencia y de la Técnica del Renacimiento. Contiene la lista de los términos indispensables que figurarán como entradas en el diccionario, las variantes gráficas de éstos encontradas en los textos en la fase de transcripción de los mismos, así como el listado de textos en los que aparece cada uno de los términos, información, esta última, que facilita especialmente las búsquedas. 
manuales de historia de la ciencia, así como múltiples artículos especializados. Los contenidos introducidos en cada una de las fichas informatizadas de esta base de datos se ordenan conforme a la siguiente nomenclatura común:

Forma e historia, con los apartados: lema, variantes gráficas, sublema y estructura (en el caso de tratarse de una lexía compleja) e información gramatical (categoría, género, número, uso pronominal, etc.).

Información histórica y etimológica: recoge el origen etimológico o la clase morfológica, la cronología, la primera documentación histórica y la primera documentación en el corpus, la marca diatópica, la marca diacrónica y la familia léxica.

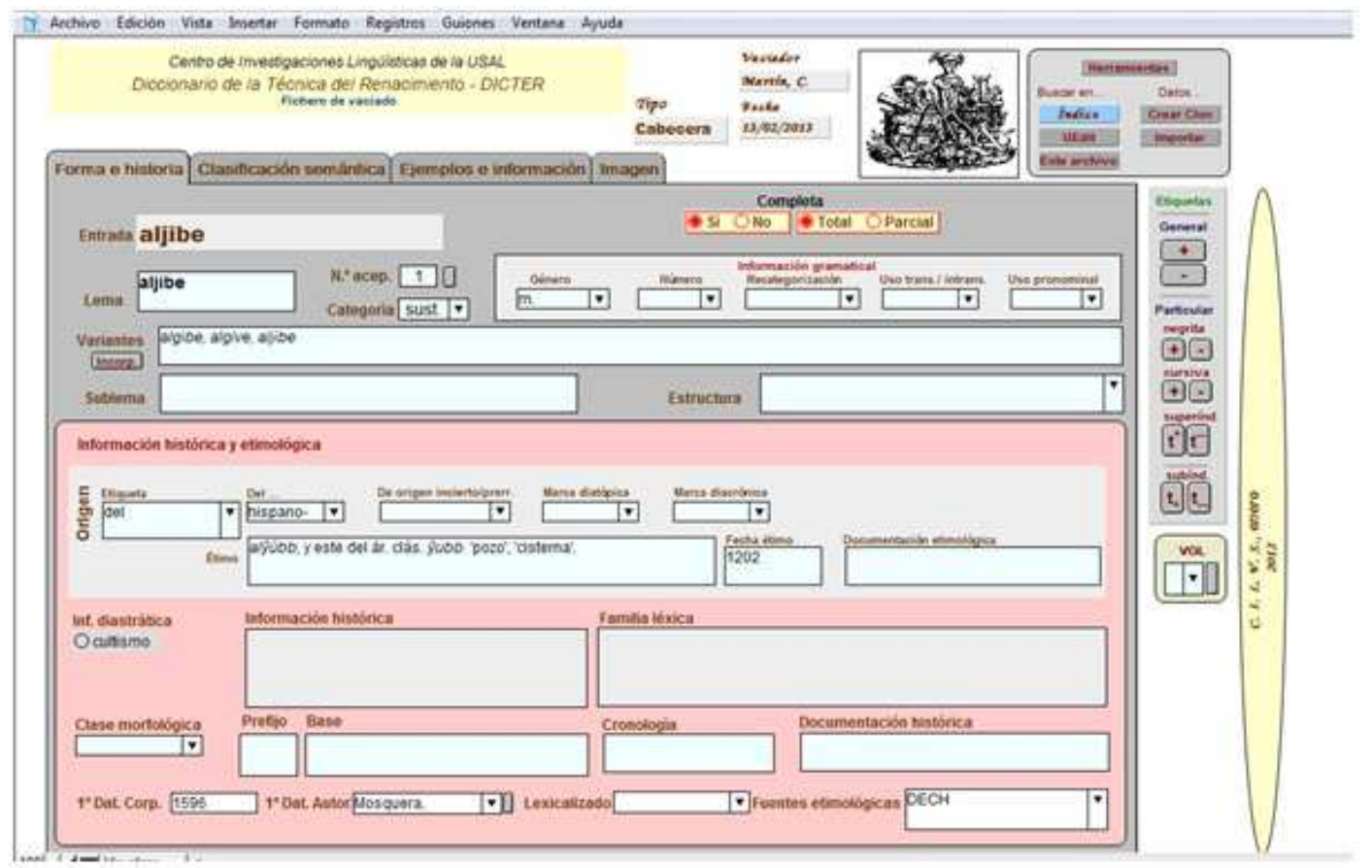

Clasificación semántica: contiene fundamentalmente el área técnica al que pertenece una palabra, la marca diatécnica, así como los sinónimos y antónimos.

Campos léxicos: incluye una serie de pestañas que abordan clasificaciones 
científico-técnicas, en torno a campos como localizaciones, profesiones, objetos, actividades, estados, etc.

Definición e información lexicográfica.

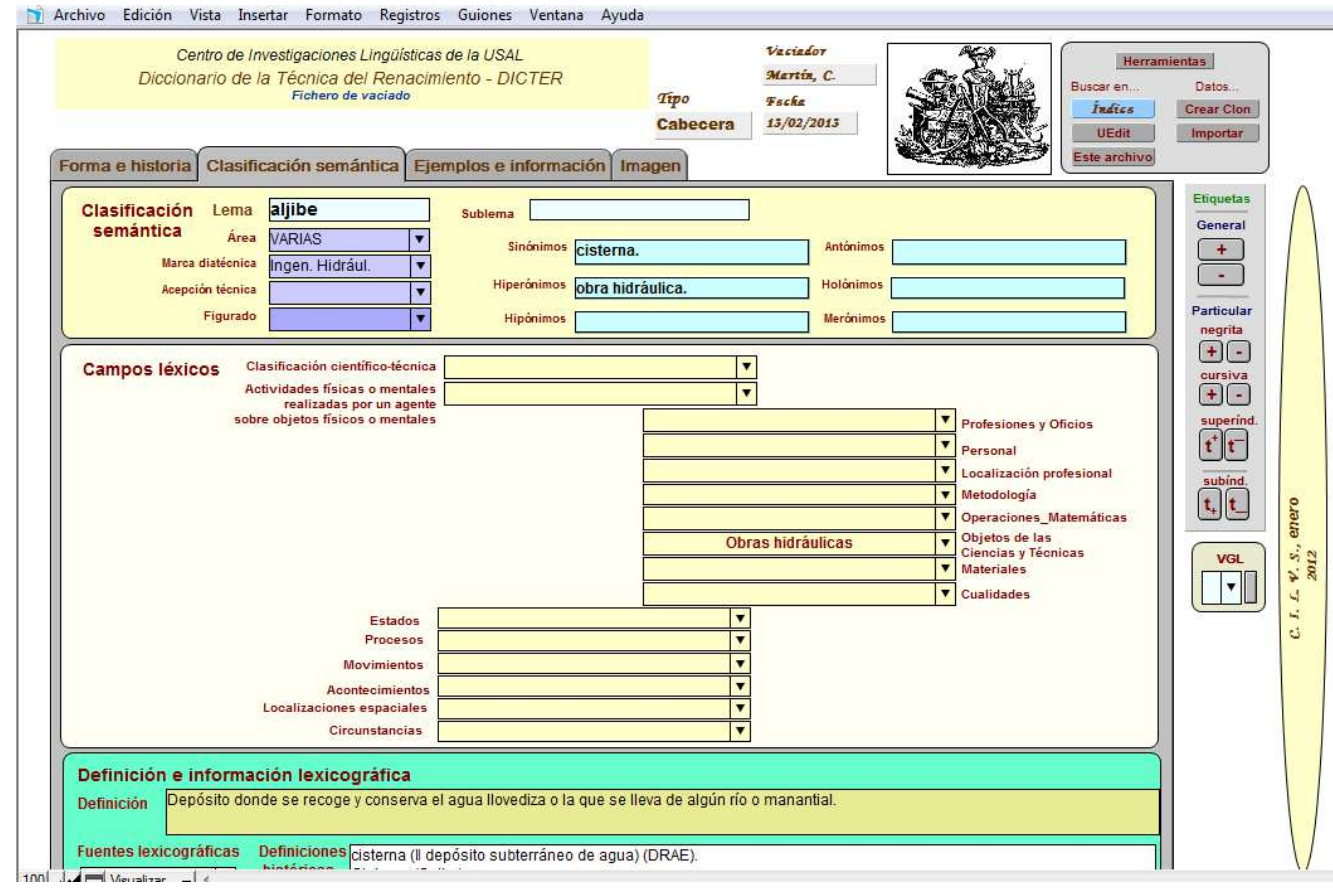

Ejemplos e informaciones (enciclopédica, semántica y otras).

Imágenes y referencias. 


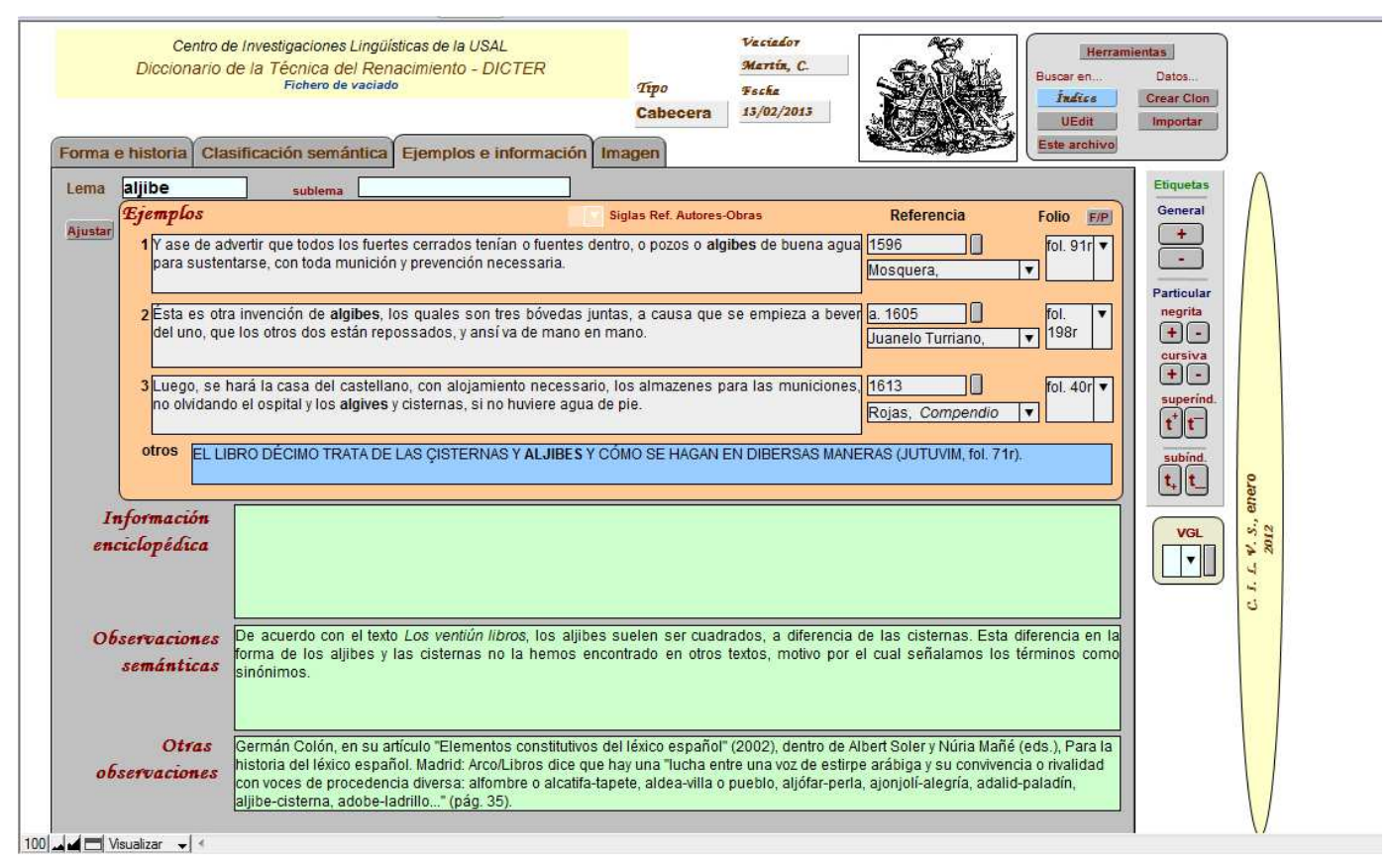

Además, en este soporte se realizan también las remisiones de las variantes gráficas y las unidades complejas, que junto al grueso de las entradas lexicográficas, acepciones y fichas de las unidades pluriverbales, constituirán el fichero parcial de cada especialidad.

Este fichero es indispensable y fundamental tanto en la configuración del repertorio lexicográfico especializado o glosario, a partir de la exportación de una selección de sus campos, como en la elaboración del estudio lexicológico, gracias a las diferentes opciones de búsqueda, por los apartados de información anteriormente señalados, que permite Filemaker.

\subsubsection{MARCACIÓN DIATÉCNICA}

La marcación diatécnica en lexicografía histórica es un asunto complejo. Como sabemos, la marca diatécnica tiene como cometido el señalar la adscripción de una palabra a una determinada ciencia o técnica (Porto Dapena 2002: 263) y, por lo tanto, esta marca indica la pertenencia de esa palabra a un lenguaje propio de una especialidad. A propósito del término especialidad, recordamos aquí que el DRAE lo define, en su tercera acepción, como 'rama de una ciencia, arte o actividad, cuyo objeto es una parte limitada de ellas, sobre la 
cual poseen saberes o habilidades muy precisos quienes la cultivan'. En cuanto a esto, en el caso del léxico técnico histórico, en concreto, del siglo XVI, y por tanto, de disciplinas "históricas", hay un agravante: "En esta época las disciplinas no tenían los márgenes tan nítidos y establecidos como en la actualidad. Así sucede, por ejemplo, en áreas de límites tan lábiles como las de Geografía, Cosmografía y Náutica; o en materias tan ampliamente concebidas como las Matemáticas" (Mancho Duque 2005: 5).

Por otro lado, el lexicógrafo ha de tener presente la nomenclatura utilizada para la marcación diatécnica en la tradición lexicográfica a la que pertenece, para evitar así confusiones con la que pudo haberse utilizado en otro lugar o momento histórico.

En cuanto al área de maquinaria, parece lógico que sea la marca Maquinaria, es decir, que sea Maquin. la marca diatécnica que señale las acepciones técnicas de esta área de conocimiento. Y aunque así lo pensamos en un primer momento, nos hizo cambiar de idea el hecho de que la marca Maquinaria no se incluye en la lista de marcas diatécnicas del DRAE y tampoco lo hace en las del TLF, el TLIO o el DHE, aunque sí que se registra, en este caso como Machinery, en el OED (Véase a este respecto el ANEXO 6 "Lista de materias de especialidad en los cinco diccionarios", en Gómez Martínez y Carriazo Ruiz 2010: 390).

Además, a pesar del gran volumen de páginas del corpus en las que se habla de máquinas, la palabra maquinaria no está recogida en los textos del DICTER. Sí que lo está, sin embargo, el cultismo maquinatoria, que aparece en su variante gráfica machinatoria, pero lo hace únicamente en 3 ocasiones y en dos de ellas es por alusión a Vitrubio, que utilizaba este término ${ }^{12}$.

12 "Y, assí, el que quisiere ser perfecto architecto, como dixo Vitrubio, conviene que tenga prática theórica, sepa Arithmética, Geometría, conozca las tres partes en que la dicha sciencia se divide, qu'es machinatoria, gnomónica y edificatoria" (Loçano 1582: fol. V). "Y el que se hallare medianamente instructo en las dichas sciencias, y principalmente en las tres que el mismo Vitruvio pone, que son: Gnomónica, Machinatoria y Edificatoria, con justa causa se le podrá dar título de Architecto" (Herrera 1584: fol. 15v). 
Los límites del área de conocimiento de Maquinaria establecidos en el corpus y los que sugiere la marca diatécnica Maquin. parecen ser muy diferentes, puesto que en el corpus hay un gran número de máquinas de guerra recogidas en los textos de arte militar que no hemos tratado por limitaciones tanto de la extensión del estudio como del léxico del área de conocimiento al que nos hemos circunscrito.

De hecho, las máquinas que forman parte de nuestra selección léxica son, en general, "Máquinas para la industria"13, por lo que es frecuente que la palabra máquina o el sintagma parte o pieza de una máquina aparezcan en la definición. También por todos estos motivos, hemos seleccionado para estos casos la marca diatécnica Mec., es decir, Mecánica, que según la segunda acepción del DRAE significa “ejecutado por un mecanismo o máquina”.

Debido a los límites de nuestro ámbito, nos hemos visto obligados a utilizar, además, la marca Ingen. Hidrául., abreviatura de Ingeniería Hidráulica, marca muy similar a la de Hidrául., que ya fuera utilizada en el DHE. Entendemos por Hidráulica lo contenido en la séptima acepción de su entrada en el DRAE “Arte de conducir, contener, elevar y aprovechar las aguas”.

Finalmente, hemos hecho uso de la marca Fís. (Física) en todas aquellas entradas especializadas relacionadas con esta "ciencia que estudia las propiedades de la materia y la energía" (DRAE).

13 "Ingenios y máquinas para la industria" fue la denominación elegida por Ignacio González Tascón para encabezar el $5^{\circ}$ capítulo del catálogo Felipe II. Los ingenios y las máquinas. Ingeniería y obras públicas en la época de Felipe II. 


\section{LOS TEXTOS DE MAQUINARIA EN EL CORPUS DEL}

\section{DICTER}

\subsection{LAS NOTAS DE FRANCISCO LOBATO}

No es mucho lo que conocemos sobre Francisco Lobato del Canto, pues prácticamente todos los datos que manejamos acerca de su figura provienen del códice, manuscrito por él, recogido en el reverso, originalmente en blanco, de una serie de mapas presentes en un ejemplar de la Geografía de Ptolomeo editado en Roma en 1508. Este volumen ptolemaico, que incluye comentarios en latín de Marco Beneventano y Juan Cotta, así como el texto del amanuense contenido en algunos de sus vacíos, es propiedad de D. Mariano G. GarcíaCañas y se halla en Valladolid en buen estado de conservación.

Son treinta y siete páginas, con un tamaño de $250 \times 415 \mathrm{~mm}$., las que contienen el legado de Lobato, conformado principalmente por un grupo de textos, hasta cierto punto heterogéneos, en letra bastarda española, y una serie de dibujos ilustrativos de distintas máquinas y piezas, presentes en casi todas las hojas del conjunto. En las páginas, que no están numeradas, el que se declara vecino de Medina del Campo recoge, entre sucesos cotidianos e índices para la historia de Medina, un nutrido grupo de explicaciones sobre el funcionamiento de algunas máquinas, así como las experiencias personales surgidas durante la invención y montaje de estos artificios.

Asimismo, Francisco Lobato del Canto introduce, a lo largo de sus escritos, varias referencias cronológicas de singular importancia, comprendidas entre 1547 y 1585. Entre estas, aparece la datación de la construcción de algunos molinos, como unos cercanos a Medina (1547), un molino de viento en Almagro (1556), y otros molinos construidos por él mismo, como el molino de sangre asentado en el corral de su tío en Medina del Campo (1557) y el molino que él denomina "de agua estancada y de regolfo", que, de acuerdo con sus notas, fue fabricado en el año 1577, aunque Lobato ya lo había ideado hacia 1559. Es precisamente este año 1577 el tiempo en el que se cree que fue escrita la mayor 
parte de sus anotaciones (García Tapia 1990: 139).

\subsubsection{ESTRUCTURA}

Las Notas de Francisco Lobato podrían estructurarse, a nuestro juicio, de la siguiente forma:

Fol. 2-7: Índice para las crónicas de Medina del Campo, poesías conmemorativas, romances, sucesos de Medina.

Fol. 9: Conducción de aguas para fuentes

Fol. 11: Pesquera

Fol. 8, fol. 12-14, fol. 16, fol. 18-19, fol. 30-35: Molinos hidráulicos de distintos tipos, explicados en mayor o menor grado, entre ellos el molino de marea (fol. 10) y el de pasaje (fol. 18).

Fol. 15 y fol. 25: Molinos de sangre, uno movido por fuerza humana (fol. 15) y otro por fuerza animal (fol. 25)

Fol. 17: Serie cronológica de molinos

Fol. 20-fol. 24: Molinos de viento

Fol. 26-28: Navegación fluvial y molinos hidráulicos para facilitarla.

Fol. 29: Serie de materiales y cantidades.

Fol. 36: Explicación y serie de piezas de molino.

\subsubsection{CARACTERÍSTICAS DEL TEXTO}

La originalidad y exclusividad del códice se fundamenta en que es uno de los escasos ejemplares manuscritos por lo que podríamos denominar un "ingeniero técnico" del Renacimiento, es decir, una persona dotada de gran intuición y curiosidad en el ámbito de los ingenios mecánicos, en este caso, de los molinos, pero cuyos cometidos no atendían a las exigencias de un cargo profesional de ingeniero o similar, puesto que presumiblemente Francisco 
Lobato, "encuadrado dentro de una burguesía acomodada de pequeños propietarios" (García Tapia 1990: 143) se dedicaría de forma oficial a otra cosa, que a día de hoy desconocemos. Sin embargo, gran parte de la frescura y especial singularidad presente en sus notas, proviene precisamente de esos márgenes de pasión, dedicación personal y experimentación en los que se inserta y que le mueven, entre otras cuestiones, a la construcción de obras exclusivas producto de su inventiva, en su mayoría hidráulicas, que, como ocurre con los resultados de todo saber científico y tecnológico que se precie, no siempre culminaron con el éxito inicialmente previsto.

No obstante, cuando su utilidad y beneficio eran probados, los inventores podían ser reconocidos por sus artificios. Tanto es así que desde tiempos de los Reyes Católicos se otorgaban en Castilla una serie de privilegios a ciertas personas a raíz de sus creaciones, inventos y descubrimientos. El caso más antiguo de este tipo del que tenemos noticia es la Cédula de Privilegio ${ }^{14}$ concedida por la Reina Isabel la Católica al médico Pedro Azlor en 1478 para la construcción, precisamente, de molinos y otros edificios para la molienda (García Tapia 2008¹: 49). De acuerdo con algunos estudios, también realizados a este respecto por Nicolás García Tapia (1990, 2008²), el número de patentes de invención otorgadas por la Corona Española a lo largo del siglo XVI fue muy elevado, probablemente superior al de la Corona Inglesa de aquel entonces y, asimismo, los privilegios con los que se dotaba a aquellos que disponían de estas patentes eran de gran importancia. Especialmente en el Renacimiento, destacaban aquellos derechos excepcionales concedidos a los inventores de máquinas destinadas tanto a procedimientos metalúrgicos como a

14 "Desde el principio quedó configurada la fórmula jurídica de lo que serían las patentes, que constaban de tres partes: una exposición de lo que era la invención y su utilidad, el tiempo por el que se concedía la exclusiva y los castigos o penas que se señalaban a los que intentasen reproducir la invención en el período en que estaba protegida. El privilegio estaba garantizado con la firma del rey, que era quien otorgaba la patente, válida en el territorio del reino y en las posesiones de ultramar y refrendada por los secretarios de la Corona. Se hacían tres copias: un ejemplar era para el inventor, otro para la administración del monarca y el tercero se archivaba, gracias a lo cual han llegado a nosotros estas primeras invenciones" (García Tapia 20082: 49). 
procedimientos molineros ${ }^{15}$ (García Tapia 20082: 676-677), circunstancia que probablemente podría haber inducido a Francisco Lobato a conservar de una forma segura sus pliegos, en tanto que se demostraba o evaluaba el funcionamiento y/o la necesidad de sus invenciones.

No estamos, por tanto, totalmente de acuerdo con las conclusiones obtenidas por García-Diego y García Tapia en relación a las circunstancias que motivaron en Lobato la inclusión de sus escritos entre las páginas del volumen de Ptolomeo:
Es muy probable que la curiosa idea de incorporar el códice a un libro sea responsable de que se haya conservado; el saber técnico de un individuo oscuro no era entonces muy apreciado, lo que hace que tales testimonios sobre máquinas y obras hidráulicas sean raros (García-Diego y García Tapia 1987: 15).

Dados los numerosos testimonios con los que contamos, tanto textuales como físicos, de la presencia de estos artificios en el Renacimiento, prevalece, en nuestra opinión, dentro de las motivaciones de un ocultamiento semejante, el hecho de que Lobato podría estar interesado en recibir alguna patente o privilegios por sus invenciones y por esto, debía mantener sus diseños en secreto.

El interés del autor de estas Notas por los inventos de esta índole se muestra de manera especial en el folio 17 del manuscrito, en el que reúne, de acuerdo con sus palabras, en el año entonces en curso 1577, un listado de los molinos hidráulicos inventados en España según Lobato, "por razón de que como cada día se van adelgazando más el ingenio de los hombres" (Lobato, c. 1585: fol. 17). Entre los dieciocho molinos que conforman la serie,

15 "Los molinos, en sus diversas modalidades, fueron objeto de numerosas patentes. Algunas se concedieron por representar una mejora en el rendimiento o en otras características de funcionamiento de la maquinaria, que permitían moler más cantidad de trigo en menos tiempo. Por ejemplo, a Pedro Ortiz de la Sobera, de Guipúzcoa, se le concedió una patente por veinte años por un molino a la manera de tahona, es decir, movido por animales, cuyo rendimiento era una molienda de cincuenta fanegas de trigo, día y noche. El documento de concesión de patente fue firmado por el príncipe, el futuro Felipe II, en Madrid, el 20 de febrero de 1552" (García Tapia 20081: 54). 
cronológicamente, tal y como afirma el propio medinense ${ }^{16}$, encontramos el "molino de bestia de Lobato", es decir, una de las invenciones de las que él mismo es autor, situado entre el "molino de regolfo" y el "molino de bestias de Antonio Martínez de Écija". Algunos folios más adelante, en concreto en el folio 25, Francisco Lobato realiza una descripción bastante minuciosa de una de sus invenciones, el "molino de bestia", acompañada de algunos datos interesantes, como la ubicación de este molino, tanto en el tiempo como en el espacio:

En el año de mil y quinientos cincuenta y siete años, yo, Francisco Lobato del Canto, vecino de esta villa de Medina del Campo, hice un molino de bestias, en que gasté harto dinero, en el corral de las casas de Francisco Lobato, mi tío, donde al presente vivía Diego Lobato, mi tío $[\ldots]$

Y también comenta los motivos por los que tuvo que desmontar el molino, que tanto gasto le había ocasionado, con la intención de aclarar este hecho a sus hijos:

\begin{abstract}
Pero, mirado lo que podía ganar cada día y lo que comía la mula y el molinero cada día, y el daño que de bestias y artificio se gastaba cada año, acordé de la deshacer, y así me hallé con más de quinientos ducados gastados en la obra y más lo que gasté con mi familia en un año que anduve perdido en hacerle. Y esto póngolo aquí para que entiendan mis hijos que por procurar ganar lo hice, y no lo jugué ni gasté en otros vicios que otros hombres lo gastan.
\end{abstract}

Disponemos asimismo, en el mismo folio, de un pasaje, a nuestro juicio, de especial relevancia. Se trata de aquel en el que Francisco Lobato aborda las diferentes medidas que fue tomando en un intento de que el funcionamiento de su invento fuera exitoso. Aunque las soluciones provisionales no alcanzaron el éxito esperado, gracias a este legado conocemos de primera mano no sólo las dificultades propias de la invención de ingenios de esta índole en la época, caracterizados por numerosas pruebas de ensayo-error, sino también el tesón y constancia, a pesar de los inconvenientes, de dicho técnico e inventor

\footnotetext{
16 "Y así iré poniendo los más de ellos (molinos de agua) de los antiguos y proseguiré con los más modernos de la manera siguiente" (Lobato, c. 1585: fol. 17).
} 
renacentista.

Así que una vuelta que daba, veinte y cuatro vueltas la piedra, mientras la bestia daba una. Y, acabado y puesto en efecto, andaba la piedra despacio si la bestia no corría. Y, visto esto, acordé de acrecentar la rueda grande, para que, teniendo más vuelo, pudiese andar la bestia más despacio y diese más vueltas la piedra, para lo cual hice la dicha rueda de noventa y seis pendazos, del mismo compás que los otros. $\mathrm{Y}$, tornada a poner en el dicho molino, andaba con buena orden la piedra para el moler, pero la bestia pasaba grande sudor y trabajo a causa de pesar todos los aparejos mucho. Y la rueda que volvía el eje había de ser mayor, para que más fácilmente se volviese (Lobato, c. 1585: 26).

Pero es el siguiente folio, el 27, el que nos da algunas pistas sobre la probable intención de Lobato de recibir quizás unos privilegios por otro de sus inventos. En esta ocasión, se trata de unos molinos hidráulicos que no precisan de aceñas o pesqueras, cuyo uso, de acuerdo con su autor, permitiría la navegación en los ríos de España. Para esto, los molinos, compuestos por torre y muralla, se situarían en los desniveles de los ríos, desniveles naturales o cavados artificialmente, y dispondrían de un sistema de trampas que podrían abrirse para el paso de las embarcaciones. Esbozamos el probable deseo de Lobato de que le fueran concedida una patente o una serie de privilegios por su invención a partir de algunas de sus afirmaciones en el texto, como su intención de llevar a cabo la propuesta del rey Maximiliano de Austria de deshacer las pesqueras que impedían la navegación fluvial o la afirmación de Lobato en la que concluye que, si su invento cumple las expectativas para las que ha sido ideado, se harían muchos molinos iguales a este, acontecimiento que en la época implicaba una serie de concesiones al autor del mismo:

Que, acabado mi molino y máquina en perfección, como se vendrán a hacer muchos molinos como él, no será menester aceñas en Duero, ni Guadalquivir, ni Tajo, ni en Águeda, ni en Tormes, ni en Pisuerga, ni en Miño, ni en todos los más ríos de España, Henares y grandes ríos, y se naveguen todos deshaciendo las pesqueras, como lo propuso el Rey 
Maximiliano [...]. Pero, después de imaginado mi molino, pareciéndome ser provechoso a todo el reino [...] (Lobato, c. 1585: 27).

Las ventajas de la navegación de los ríos, detalladas por el propio autor en el siguiente folio, vendrían a apoyar, por tanto, la importancia del uso masivo que el propio Lobato cree que debería dársele a su molino, sustituyendo así a aquellos utilizados en ese momento, que entre otras cosas, impedían la circulación regular de barcas:

\begin{abstract}
$\mathrm{Y}$, hecho esto, por estas barcas se haría un gran bien a todo lo más de España, porque, además de llevar mercaderías, llevarían y traerían muchos bastimentos de pan, leña, carbón y madera de unas partes a otras a menos costa que no con recuas y trajinería, y se gastaría mucha menos cebada que no se gasta por amor de las recuas, y, demás, que valdría más barata. Se sembraría más trigos en buenas tierras, porque en las mejores siembran cebada. $\mathrm{Y}$ porque a cualquier buen entendimiento le parecerá que lo que digo de ser gran provecho es así y lo entenderán mejor que lo sé decir, ceso (Lobato, c. 1585: 28).
\end{abstract}

Al margen de que técnicamente este molino ideado por Lobato podría tener varias deficiencias que impedirían un resultado tan exitoso, tanto en la práctica de la molienda como en la de la fluidez de la circulación fluvial, destacamos en el talante de nuestro técnico renacentista su empeño personal en pro de una mejora de la ingeniería de su época, así como la conciencia del gran alcance y beneficio que, para la población en general, podría tener la invención y ejecución de una máquina de semejantes características. Y refutamos de nuevo, la posible creencia, ya nombrada aquí y tomada de García Tapia, que podría pesar sobre él y sus ingenios, como los propios de un ser oscuro, también a partir de las afirmaciones de Ignacio González Tascón incluidas en la Presentación del catálogo Ingenios y máquinas en la época de Felipe II "hemos de señalar la relativa indiferencia que las diversas ingenierías tenían en los negocios religiosos -que llevaba a la Corona a hacer la vista gorda acerca de las creencias de los artífices que trabajaban para ella -y el prestigio, universalidad y riqueza de la casa gobernante y del propio rey Felipe II" (González Tascón 19991: 19). 
Este códice, conservado en la BNE en los cinco tomos manuscritos comprendidos entre los registros 3372 y 3376, ha suscitado especial interés entre los investigadores de la historia de la tecnología española, por varios motivos: por una parte, constituye un ejemplar único sobre la hidráulica renacentista, puesto que

se trata de la primera Architectura Hydraulica; y así, misteriosa y desconocida, es, sin embargo cabeza de una serie de ellas importantes para la ciencia, las técnicas y los oficios así como para el bienestar de los pueblos. Siguen escribiéndose ahora y continuarán en el futuro (García-Diego 1983: 9).

Y, por otro lado, ha levantado cierta turbación y revuelo la búsqueda, quizá en ocasiones un tanto apasionada, de un autor para este códice, a partir de ciertas pruebas que negaban la atribución del mismo al denominado como tal en las portadas de los manuscritos, es decir, a Juanelo Turriano.

Presente por vez primera en los índices de la Biblioteca Real de los años 1821-1833, este conjunto de libros manuscritos, cuyas hojas miden $21 \times 30$, un centímetro menos de largo que las tapas, sería encuadernado seguramente en el siglo XIX (García-Diego 1983: 18-19). Aunque existe un informe sobre el códice, redactado por Benito Bails ${ }^{17}$ en la segunda mitad del siglo XVIII (V. Llaguno 1977), fue en 1964 cuando, a partir del estudio de Ladislao Reti, se abrió una línea de investigación en torno al manuscrito ${ }^{18}$.

17 En este informe, Benito Bails, además de resumir el contenido de los distintos libros que conforman el códice, ofrece algunos datos de estudio interesantes. Por un lado, afirma que la obra está escrita "con muy poco método" y que su estilo es "bárbaro"; por otro lado, menciona que el texto "habla muchísimo de Aragón". Finalmente, comenta que "el manuscrito parece copia, porque se encuentran diferentes claros que dan a conocer que el copiante dejó lugar para las voces que no supo leer en el original que copiaba" (V. "Informe de Benito Bails sobre el códice de Juanelo Turriano", en Los ventiún libros de los ingenios y de las máquinas, V. 6, 1996: 25-29).

${ }^{18}$ Nombramos, en esta primera fase de la investigación acerca de Los ventiún libros de los ingenios y de las máquinas, a personalidades como José Antonio García-Diego, Luis Cervera Vera, Manuel Díaz-Marta, Ángel del Campo Francés, José Antonio Fernández-Ordoñez, 


\subsubsection{ESTRUCTURA DE LOS VEINTE Y UN LIBROS...}

De acuerdo con los epígrafes concurrentes en el texto, la estructura del manuscrito es la siguiente:

\section{TOMO I}

\section{LIBRO I: De las calidades de las aguas, de sus propiedades y de su} generación o nascimientos

El libro ahonda en el nacimiento y las causas del agua y hace referencia, entre otras cosas, a los vapores y exhalaciones de esta. Además, distingue el agua, más sutil, del jugo, más graso. Entre las referencias presentes en el texto hallamos a Aristóteles, según quien el agua que mana y corre es mayor que el grandor de la tierra, y a Séneca, que afirma la mutabilidad de la tierra y de todo lo que por ella corre, entre otras cosas, el agua. En el libro encontramos un capítulo titulado "De los efectos de las aguas y de las cosas que hacen dentro de la tierra", en el que cita canales, concavidades, fuentes y otros tipos de hechuras realizadas por el agua dentro de la tierra, considerando la presencia del fuego por debajo de estas canales por las que pasa el agua. Asimismo, nombra ciertos betunes y otros fluidos presentes en la tierra, para posteriormente dirigir al lector a otro capítulo titulado "De la craseça de las aguas", con un subapartado "De las señales que ay para aver de hallar agua de la que es dentro de la tierra escondida", que de nuevo contendrá el apartado "De las señales que ay para aver de hallar agua y quáles son muy verdaderos". En estos apartados, el autor de estas páginas nos habla de métodos experimentales, utilizados ya por los antiguos, para hallar agua, teniendo en cuenta la humedad y el humor de la pisada, así como las plantas e incluso los insectos allí presentes, citando para esto último a Columela.

\section{LIBRO II: De las experiencias que se an de hazer para hallar agua}

En este libro, el autor del texto nos recomienda el principio de la 
primavera o el principio del otoño como épocas idóneas para llevar a cabo la búsqueda de agua oculta bajo la tierra. Entre otros métodos, nos propone tirarnos en el suelo a lo largo y mirar en redondo buscando algún lugar del que pudieran salir vapores o exhalaciones. Será allí donde podremos ocultar un vaso de barro, cavando ocho pies de hondo, y observarlo al cabo de un tiempo, pues el hecho de que contenga humedad o no afirmará o negará la existencia de agua en ese lugar.

\section{LIBRO III: Cómo podremos conoçer la agua ser buena o no}

En un primer momento, en este libro, el autor nos guía para conocer si el agua es buena o no mediante dos sencillos métodos experimentales: por un lado, el agua buena nunca manchará un vaso o recipiente de latón o estaño, al contrario del agua mala; por otro, las legumbres siempre hervirán con rapidez en el agua buena, cosa que no ocurrirá en la mala. Además de todo esto, se tratan diversas cuestiones, como cómo reconocer las aguas simple y mixta y, en general, nos da consejos para distinguir el agua de acuerdo con su color o sus colores, por su olor $\mathrm{u}$ olores o bien por otras particularidades que tienen los jugos que se mezclan en las aguas. Citando a Hipócrates, aparecen algunas cuestiones médicas relacionadas con el agua, y diversos aspectos de las aguas que podemos conocer gracias a nuestros sentidos, entre ellos, el del tacto. Entre el texto del libro, seleccionamos como muestra una de las frases: "Dice aquella sentencia de $[\ldots]^{19}$ que aquellas aguas que una vez se han corrompido, que si se vuelven a purgarlas, que en el discurso de tiempo que ellas se vuelven buenas para beber y que jamás se vuelven a corromper" (Pseudo-Juanelo Turriano (c. 1605): fol. $44 \mathrm{v})$.

\section{LIBRO IV: De los niveles y sus formas}

En el libro recurre a Julio Frontino, a Vitrubio y a Arquímedes para hacer alusión a los niveles "por ser ello cosa de mucho más artificio de lo que el vulgo se piensa", pues dada su gran utilidad "no hay labrador que no pretenda

\footnotetext{
${ }^{19}$ En el original aparece un espacio en blanco.
} 
hacerle, ni emperador". Labradores, niveladores de aguas, fronteros, canteros, etc. precisan todos ellos de estos instrumentos que señalan la distancia o diferencia de altura entre dos puntos. Entre los tipos de niveles que aparecen en el libro, encontramos el nivel de tranco, la escala altímetra, el nivel de grados, el corbate...y sobre cada uno de ellos recogemos una descripción de sus características fundamentales. También se hallan citados "los que nivelan a borneo" y cómo han de ser sus borneaduras.

\section{LIBRO V: De los betunes de diversas maneras, el qual es el quinto} libro

Este libro contiene un subepígrafe: “Libro que enseña cómo se hagan los caños de plomo o fístulas y trompas de metal", parte que aparece al final del texto. Anteriormente, sólo se hace referencia a distintos tipos de betunes, hechos con los más diversos materiales: pez viva, alquitrán, pez de piedra, polvo de coca... En este apartado, el autor nos suministra distintas "recetas" o maneras de hacer dichos betunes y pegamentos, necesarios, entre otras funciones, para el encañado de fístulas o la pega de junturas o de piedras. En el libro se aconsejan los que están mejor destinados a los distintos fines, en especial para los arcaduces o caños de barro. En el apartado que hemos comentado sí que detalla la forma de elaborar caños de plomo, de distintas medidas, así como los materiales más apropiados de acuerdo con su forma: plomo, alambre, latón, etc.

\section{TOMO II}

\section{LIBRO VI: Del llevar aguas en diversas maneras y de aguaductos}

En el libro se muestran diversos tipos de aguaductos a través de recomendaciones sobre el tipo de construcción más indicada de acuerdo con el agua o el tipo de caudal ante el que nos encontremos. Aparecen distintos tipos de aguaductos, con diversas órdenes o número de arcadas, así como una serie de consejos para dar velocidad al agua cuando está estancada. Algunos de los aguaductos llevan armaduras con garfias y otros poseen arcadas de piedra asentadas sobre fuertes pilares. En este libro hallamos también las diversas 
formas existentes en la época para realizar minas, es decir, para minar un terreno teniendo en cuenta los inconvenientes que pudieran surgir. Además aparecen, entre otras cosas, modos para hacer una acequia navegable y otros tipos de reparaciones que se pueden llevar a cabo en canalizaciones artificiales.

\section{LIBRO VII: Para llevar aguas que passen unas por debaxo de otras}

En este libro se hacen bastantes recomendaciones sobre sifones, es decir, se explica cómo se debe construir y salvar el agua de un río con un sifón, ejercicio modesto pero práctico si queremos saber cómo poder elevar o descender unas aguas sobre otras de forma que no se mezclen. Consiste en llevar las aguas buenas por sus caños hasta el lugar donde habremos de disponer de maderos anchos o de caños o de fístulas de plomo que tendrán gran resistencia y además llevarán pesos encima. Se colocarán de forma transversal y, de este modo, podrá pasar una fuente por encima o por debajo de un río.

\section{LIBRO VIII: De las differencias que ay en el llevar de las fuentes}

Es en este libro donde el autor hace hincapié en los distintos terrenos que podríamos encontrarnos para trasladar el agua de una fuente o manantial a través de distintos cauces o bien aprovechando los desniveles naturales del terreno. Además, ofrece soluciones para adaptar esos terrenos de manera que sean más consistentes y la caída del agua más firme. En el texto, nos introduce las gavias o gaulas, que son las grúas que bien podrían aprovecharse para estos trabajos, en la carga y descarga de piedras u otros materiales necesarios para la construcción de estos cauces.

\section{LIBRO IX: Que tracta de diversos modos de azutes (o presas de ríos)}

En el libro se detalla la diversa tipología de azudes cuya construcción sería posible tanto para derivar el agua para riegos como para mover máquinas hidráulicas con la fuerza motriz de este elemento, el agua. Hemos de tener en cuenta que, dado el empuje del agua sobre los azudes, estos se han visto sometidos a constantes reconstrucciones, por lo cual es grande la importancia 
del testimonio sobre azudes que aparece en este manuscrito. Además, la traza de azudes, tal y como comenta el autor de Los Ventiún Libros..., no ha de proyectarse de forma perpendicular a la corriente, sino de forma oblicua, para afrontar con buena disposición las avenidas de agua. Entre la tipología, encontramos los azudes "de cal y canto", resistentes aunque podían ser sometidos a grandes roturas, y los "de selva" o de madera y vegetales, más flexibles a la deformación y por tanto más resistentes a roturas (V. González Tascón 19994: 228).

\section{LIBRO X: De las cisternas y algives, cómo se hagan en diversas} maneras

En primer lugar, en este libro el autor señala las diferencias existentes entre las cisternas y los pozos, pues así como las primeras se llenan manual o artificialmente, los pozos, sin embargo, albergan agua de forma natural. El texto hace referencia a los distintos tipos de cisternas que podemos encontrarnos, y a cómo debemos construirlas para que permanezcan en buen estado de conservación a lo largo del tiempo. Normalmente, estas cisternas van a tener varias paredes para sobrellevar el peso del agua e impedir su putrefacción. También encontramos en el libro diferentes formas de repararlas en caso de que se hayan obstruido o el agua se esté derramando. Entre otras cosas, hallamos de nuevo aclaraciones sobre los varios tipos de agua e impresiones sobre cuál sería el tipo más adecuado para rellenar una cisterna. Posteriormente, el texto nos habla de los aljibes, de cómo llevar a cabo su edificación y de las características particulares con las que se han de componer tanto los aljibes como las casas que los albergan. Para finalizar, el texto acude a los baños, distinguiendo sus diversas formas de construcción.

\section{TOMO III}

\section{LIBRO XI: Trata de diversas maneras de molinos}

En primer lugar, en este libro se resalta la utilidad de los molinos, 
elemento común, universal y antiguo, del que describe su variada tipología y sus partes constituyentes y ofrece instrucciones para su construcción. El primero de los molinos que aparece es el molino de canal abierta y posteriormente se detiene en los distintos tipos de canales que pueden estar presentes en los molinos para que el agua se dirija a los rodeznos. En general, el libro describe cómo construir las distintas partes del molino, como el cubo, las ruedas, de acuerdo con la cantidad de agua de la que disponga el molino. Posteriormente, el libro trata de los molinos de regolfo y de medio regolfo, de cómo han de ser sus cubetes y de las características de los rodetes que se incorporan en su interior. Recordamos aquí que este molino es el precedente de las turbinas, y que, por ese motivo, se consideran invento español. También aparecen los molinos de balsa y los de balsa y cubo, y el autor se detiene suficientemente en los distintos tipos de cubos existentes. Otro de los molinos que hallamos introducidos como novedad, como invención, tiene cuatro ruedas o muelas. En el folio 307 aparece una recopilación con gran número de tipos de molino existentes en la época, de todo género, aunque en su mayor parte son hidráulicos.

LIBRO XII: (Este libro no lleva epígrafe. Apuntamos, sin embargo, que el libro trata de diversos modos de cerner la harina)

En este breve libro hallamos formas de cerner la harina mediante una manga de burato o material semejante.

LIBRO XIII: Libro de los molinos batanes y de azeite, y de diversos géneros de artificios de la misma calidad, para sacar aguas, para hazer alumbres y salitres, y lavar lanas y paños

Tal y como el título del libro indica, en esta ocasión el autor del texto describe los mecanismos, piezas y partes de algunos molinos y otros artificios destinados a muy variados y diferentes fines. Primero aparecen los artificios dirigidos a picar pólvora, seguidos de aquellos cuyo cometido es limpiar arroces u otro tipo de cereales, como el trigo; a continuación encontramos varias 
formas de moler aceitunas y de extraer aceite, mediante la prensa de la oliva en algunas curiosas almazaras. Como otro de los componentes cuya obtención puede darse a través de artificios mecánicos es el almidón, el autor del texto se detiene en este punto; sin embargo, es la obtención de azúcar a partir de la caña el asunto al que él presta más interés y dedica más líneas, muy al contrario que al que trata sobre la materia de lavar lanas, pues considera que esta ya es muy conocida. Seguidamente el autor aborda temas variados ya recurridos en otros libros, también presentes en el título de este libro, como lo son las descripciones del modo de fabricar una serie de artificios para elevar o almacenar agua, como la bomba, la tesíbica, pozos, norias, la rueda timpanada... así como el modo de hacer minas de alumbre, calderas de plomo y agua salina.

\section{TOMO IV}

\section{LIBRO XIV: Libro de las barcas que sirven en lugar de puente para} passar los ríos y de puentes

El libro trata de las barcas que han actuado como puentes en aquellos lugares en los que construir un puente resultaba demasiado costoso. Por eso, las barcas, atadas a ambos lados de un río o canal, han servido de puentes movibles en diversos lugares. El texto afirma que conviene que la barca sea alta, construida con tablones gruesos, y que también pueden construirse puentes de varias barcas, enclavijando unas con otras. Además, el autor habla de los puentes realizados con odres, y los recomienda para su transporte por ser muy ligeros.

\section{LIBRO XV: De puentes de sólo madera}

En un primer momento, el texto aborda la importancia de la elección de un buen lugar para construir un puente y, en concreto, trata de los puentes de madera, y de la necesaria conveniencia de realizar buenas empalmaduras en estos. El texto habla de las distintas partes o piezas de dichos puentes así como de la variada tipología existente de puentes de madera. A modo de ejemplo, aparece el puente que realizó Julio César sobre el río Rin, el cual está descrito en 
sus Comentarios. Posteriormente, el libro aborda los tipos de madera más convenientes para fabricar un puente, así como las distintas armaduras. Entre los casos curiosos, aparece la descripción de un puente de madera que tiene un pie o pilar dentro del agua, pues, posteriormente, y aunque el epígrafe que da título al libro no lo indica, el texto habla de puentes de piedra, de los lugares en los que se suelen emplazar y de aquellos puentes que alternan el uso de madera con el uso de la piedra. Seguidamente, en el libro aparecen algunas máquinas con ruedas que se utilizan para limpiar superficies, como el fondo de los ríos, y que por tanto son muy útiles en la cimentación de la base de los puentes.

LIBRO XVI: De las maderas y de piedras, y cómo ellas se cortan, y cómo se arrancan las piedras, y cómo se haze la calçina y el yeso y ladrillos de diversas maneras

El libro nos habla de las mejores épocas del año para cortar árboles y divaga sobre cómo hacerlo, si es mejor de pie, o sobre sus troncos y raíces, o a la redonda, de acuerdo con las distintas opiniones que el autor tiene entendidas. También, bajo un subepígrafe, trata "de los remedios que deben hacer para que las maderas se conserven después de ser ellas cortadas" y para esto aborda fundamentalmente tipos de grasas y otros ungüentos con los que podría cubrirse la madera para así conservarse, dependiendo del tipo de madera del que se trate. Para finalizar, el libro tiene en cuenta diversos factores de todos los tipos de madera, para concluir cuáles deben o pueden utilizarse en la construcción y cuáles no, y en qué momento ha de hacerse por estar la madera más sólida o proclive para esto. Bajo otro subepígrafe, "de los árboles en suma”, el autor ofrece detalles de los árboles que deberíamos tener en cuenta, como el tipo de corteza, de madera, de ramaje, si se trata de un árbol macho o hembra, etc. Estos detalles adquieren gran importancia en los lugares en los que, por circunstancias, no se puede disponer ni de puentes ni de barcas y se ha de recurrir a entablamientos.

LIBRO XVII: Capítulo de las piedras en universal, y en qué tiempo se deben arrancar en la cantera, y en qué sazón y tiempo se deven poner en obra, 


\section{y quáles son más fáciles de quebrar y quáles son más durables en la obra}

Afirma el autor del texto que este asunto de las piedras "es muy común entre el vulgo", dejando así constancia de su interés por expresar toda aquella materia que pudiera ser de utilidad a obreros seguramente iletrados. Recurre a Catón como referencia que expresa la época del año más adecuada para tal acción, la de sacar piedras, y posteriormente describe cómo han de secarse estas piedras al sol antes de pasar a formar parte de una obra. A continuación describe distintos tipos de piedras y sus características, como la piedra blanca, la transparente, la piedra de la sal... y menciona asimismo las mejores cualidades de las vetas de las piedras. Posteriormente aparece un subepígrafe “De la calidad de las piedras, y el modo de hacer rejolas y tejas y otras cosas de barro para adornar edificios". En este apartado, el autor narra especiales peripecias logradas con piedras de gran dureza, firmeza y resistencia al fuego, como la piedra de Albano y Gabino, muy contraria a la que Julio César empleó en la edificación de los muros de Zaragoza, puesto que esta última, al fuego, se convierte en yeso. En conjunto, se describen piedras halladas en los términos de Aragón, aunque también se mencionan, en ocasiones, otros lugares, fundamentalmente italianos. En el siguiente apartado contenido en el libro, "Qué calidad de piedra es mejor para hacer calcina", el autor comenta que, aunque la calcina puede sustraerse de un gran número de piedras, la que menos le gustaba a Catón Censorino era la que procedía de guijarros, pues no podía aprovecharse para nada, pero que la calcina procedente de piedras blancas grandes tomadas en las riberas de los ríos era muy provechosa. En conjunto, señala distintos modos de proceder para fabricar calcina, indicando cómo era elaborada en los lugares a los que se remonta, con instrucciones para la mezcla de ingredientes y el manejo de las herramientas. Finalmente, en el último apartado del libro, "En qué tiempo se debe cavar la tierra para hacer ladrillos y en qué tiempo se deben labrar los ladrillos y cocerlos" encontramos el modo de hacer ladrillos que utilizaban los antiguos, preparando con tiempo la tierra y usando buen barro y arena. También comenta la necesidad de irlos agujereando con un hierro. Seguidamente, hallamos en el libro diversos modos de hacer tejas 
y las distintas formas que estas pueden tener.

LIBRO XVIII: De cómo se an de hazer las pilas de las puentes de piedra en diversas maneras

El libro aborda distintas cuestiones cuyo conocimiento es necesario a la hora de edificar un puente de piedra, y fundamentalmente estas tienen que ver con la definición del número de órdenes del puente, el número de arcadas, las pilas, los costados, las ribas y los arcos. El autor comienza su texto comentando la importancia de elegir un emplazamiento firme para asentar el puente en la ribera del río, con una buena piedra que soporte el peso del puente. Posteriormente, explica que el número de arcos ha de ser siempre nones, y el de pilas, siempre pares, debido a que de esta manera el puente tiene mayor firmeza y apariencia. Entre otras aclaraciones que hallamos en el texto, están algunas como la de que el arco de en medio de un puente ha de ser siempre mayor que los otros, la de que la obra conviene hacerla en verano, porque el río trae menos agua y así no hay crecidas. Posteriormente introduce una serie de máquinas adecuadas para la limpieza de los lugares de cimentación de los pilares de los puentes, máquinas que el autor ya había descrito en el capítulo dedicado a los puertos. Estas son la bomba o cóclea o caracol, la grúa, la cabrilla y la cigüeña. El autor del texto también comenta algunas de las características de las distintas piedras con las que se podrían edificar los puentes y en concreto, se detiene en la manera de construir un puente levadizo.

\section{LIBRO XIX: Libro de edifficios de mar y cómo se an de hazer y} acomodar en diversas maneras

Este libro trata de fortificaciones marítimas, que, de acuerdo con el autor, han de ser firmes, gruesas, sólidas y lisas, para que resistan bien el empuje del oleaje y aún mejor si son lamboradas. Posteriormente, el texto describe distintos reparos o formas de parar o frenar los reflujos del mar en distintas circunstancias, como en el monte, la arena, etc. A continuación se explica la forma de fortificar un puerto y también cómo repararlo en caso de que el muelle 
esté dentro del mar, teniendo en cuenta siempre la forma de las paredes que sería menos sensible al daño de la fuerza de las olas. Hace referencia, además, a obras de este tipo ejecutadas por los antiguos y que, aunque parecía que iban a perdurar largamente en el tiempo, esto no ocurrió así, como el puerto de Claudio, la máquina del puerto de Adriano y la fábrica de Julio César cerca de Tarragona. Seguidamente, el libro aborda de nuevo el tema de los puertos y de su importancia en una ciudad, describiendo las distintas figuras que puede tener un puerto, así como la opinión que el autor tiene sobre cada una de acuerdo con los menesteres para los que estarían más indicadas. También aparecen de nuevo las distintas partes que pueden constituir un puerto, como habíamos visto anteriormente.

\section{LIBRO XX: De hazer deffensas a puertos para que armadas no puedan} entrar

El libro se detiene en la configuración de defensas para los puertos, construidas con grandes bloques de piedra de distintas formas, tanto redondas con un hueco en medio, a modo de muela que pueda ser recogida con un hierro que la atraviese, como cuadradas o en bloque. Según comenta el libro, estas piedras también podrán embetunarse para hacerse así más resistentes. Otra forma de defensa que aparece, de acuerdo con el texto, es una armadura de palos hincados y afirma que la arena negra, que puede encontrarse en Italia, puede servir para endurecer la zona. De nuevo recurre a la descripción de instrumentos para la limpieza de la base del agua en la que podrían establecerse dichos reforzamientos. Finalmente, relata aquellas naos que pueden servir de defensa, como galeras y vasillos, y habla de la utilidad de las gavias en esas zonas en las que podría haber armaduras o intentos de entrada del enemigo. Serán máquinas útiles para levantar ruedas, pero también para limpiar los puertos, como para sacar el lodo o levantar naves pesadas u objetos perdidos en el fondo del mar. Para finalizar, describe un tipo de carretón para llevar mercaderías.

LIBRO XXI: El qual trata de divisiones de aguas, ansí de islas como de 


\section{otras cosas de agua, y de relojes de agua}

En concreto, este libro describe el modo de construir distintos relojes hidráulicos a los que acudimos como referencia anteriormente (V. Martín Herrero 2006: 35). La construcción de estos relojes era barata y sencilla, pues estaban formados por varios recipientes, uno de ellos con un agujero por el que iba pasando el agua hacia otro, y se iba calculando el tiempo que tardaba en llenarse el siguiente recipiente conociendo la cantidad de agua que albergaba mediante unas marcas o medidas que este tenía. También aparece, por ejemplo, otro tipo de reloj en el que el agua vertida hiere una rueda de molino, que al moverse va marcando las horas que están escritas en un una circunferencia. El libro contiene dibujos de estos relojes con detalles de los recipientes o vasos. Además, se centra en dar indicaciones sobre cómo hacer las líneas divisorias en estos recipientes y fundamentalmente hace hincapié en la forma de realizar las divisiones de aguas en acequias y canales, teniendo en cuenta las condiciones del terreno para designar las partes en las que se quiere dividir el caudal. Asimismo, aparecen datos que se pueden tener en consideración para calcular la cantidad de agua necesaria para mover determinadas muelas o ruedas de molino.

\subsubsection{CARACTERÍSTICAS DEL TEXTO}

Uno de los enigmas en torno al ejemplar Los Ventiún Libros... que aún no se ha desvelado es el motivo por el cual las páginas que componen sus cinco volúmenes encuadernados no aparecen ordenadas 20 . Por un lado, los investigadores piensan que pudo ser despiste del encuadernador (García-Diego 1983: 22), pero este descuido no parece ser simplemente aleatorio, sino que, al hallarse en varios libros completos, puede tratar de responder a un nuevo orden interno del texto.

20 Por ejemplo, el libro 5, presente en el primer tomo, debería continuar la paginación del libro $4 \mathrm{y}$, por tanto, comenzar en el folio $92 \mathrm{v}$. Sin embargo, comienza en el folio 274 y es el capítulo 6, que forma parte del segundo tomo, el que empieza en el folio 92v. De manera similar, no respetan el orden de foliación los libros 11, 12 y 13. 
Otra de las características del códice que ha llamado la atención a los investigadores del mismo es el hecho de que el nombre de Juanelo aparezca en las portadas de todos los volúmenes, pero que no se encuentre, sin embargo, en el cuerpo textual ${ }^{21}$, aspecto que de alguna manera refuerza la idea, muy confirmada, por otra parte, gracias a otros datos, de que la autoría del texto no corresponde a Juanelo Turriano (V. García Tapia 19971).

De lo que tenemos constancia, a pesar de que sus letras no difieren demasiado, es de que intervinieron diferentes manos en la escritura del mismo. Destacan, sin embargo, de forma evidente, las grandes diferencias en el estilo y tamaño de muchos de los dibujos que pueblan el códice.

Por otro lado, el códice que nos ocupa se ha relacionado con otros dos manuscritos: un ejemplar perteneciente a los Sres. Turner de Barcelona y el Tratatto delle acque, conservado en Florencia, códices que, de forma conjunta, están siendo estudiados por D. Manuel Silva Suárez, de la Universidad de Zaragoza.

Asimismo, han suscitado especial interés las particularidades lingüísticas del escrito, estudiadas profundamente por Juan A. Frago Gracia (V. Frago Gracia y García-Diego: 1988). Entre estas, destacamos aquí:

-El estilo, que ha recibido en ocasiones, por parte de algunos investigadores, los calificativos de pesado y farragoso, fundamentalmente por la abundancia de repeticiones ${ }^{22}$. En general, son muchos los temas que se abordan en varios capítulos, de forma que la estructura del contenido no siempre coincide con la de los títulos de los capítulos. Además, esto produce confusión o poca claridad al lector, pues en muchas ocasiones da la impresión de que el autor ha ido tratando aquello que se le ha ocurrido en ese momento.

21 “ ¿Por qué entonces esa insistencia en 'Iuanelo' a lo largo de todas las portadas del siglo XVII, cuando no aparece para nada en el interior de las páginas? Este es el primer enigma del manuscrito" (García Tapia, 1997: 24).

22 "Una curiosa peculiaridad del manuscrito de Juanelo Turriano es la insuficiencia de su idioma...¿Por qué está tan mal escrita la obra de Juanelo?" (Reti) 
-Presencia de abundantes aragonesismos ${ }^{23}$ y algunos italianismos en el texto, que analizaremos con más detalles en el apartado del estudio lexicológico correspondiente.

-Las numerosas referencias geográficas a Aragón, así como comentarios que tienen su fuente de origen el Italia.

Entre algunos argumentos que justifican estas características especiales del texto, fundamentalmente el estilo y las repeticiones, destacamos aquí la convicción de José A. García-Diego de que el códice es "un borrador puesto en limpio por los escribanos y al que se añadieron, ordenadas, las figuras, pero no dispuesto, ni mucho menos, para la imprenta" (García-Diego 1996: 54-55).

\subsubsection{LA AUTORÍA DE LOS VEINTE Y UN LIBROS}

Como hemos apuntado anteriormente, la autoría del códice es un tema controvertido, que ha animado la producción de un importante caudal de estudios, así como conferencias y mesas de discusión en torno a este asunto. Señalamos, a este respecto, la mesa redonda celebrada en la Biblioteca Nacional de Madrid el 8 de noviembre de 2007, en la que participaron el ingeniero industrial D. José María Izaga Reiner, el molinólogo D. Carlos Blázquez Herrero, D. Javier Goicolea, Vicepresidente de la Fundación Juanelo Turriano y D. Nicolás García Tapia, Académico de la Real Academia de Bellas Artes de Valladolid.

Ofrecemos a continuación una reseña de esta mesa redonda, a la que tuvimos la oportunidad de asistir y para esto resumimos, desde nuestro punto de vista, las participaciones que allí tuvieron lugar ${ }^{24}$.

23 "En su estilo es casi omnipresente el desdoblamiento de los dialectalismos o regionalismos con voces de significado idéntico o equivalente generales en el español de aquellos años, procedimiento del que abundan sobremanera casos similares a los que a continuación consigno con el término aragonés en cursiva [...]" (Frago y García-Diego 1988: $71)$.

${ }^{24}$ Puesto que es una mesa redonda que no ha sido publicada, consideramos de gran interés los datos que a continuación aparecen. Sin embargo, somos conscientes de que puede que haya algún error o algún malentendido, ya que todo el contenido procede de las notas 


\section{Javier Goicolea}

Comienza recordando la importancia de José Antonio García-Diego por sus aportaciones al análisis del manuscrito. Sabemos que García-Diego fue discípulo de Ladislao Reti, gran autoridad en el estudio de Leonardo da Vinci.

Para él, lo que conformaría el primer libro de hidráulica publicado en el mundo, anterior a los tratados franceses e italianos, sería el conjunto de tres manuscritos: por un lado, la transcripción del manuscrito de Los Ventiún Libros de los Ingenios y Máquinas de Juanelo de la Biblioteca Nacional25, después un segundo manuscrito de la misma obra en la colección privada de los Sres. Turner de Barcelona y ya el tercer manuscrito lo compondría el Tratatto delle acque, texto que se encuentra en Florencia y que en principio parece que es el más antiguo de los tres. Señala algunas de las diferencias entre los manuscritos: el texto de Madrid contiene aragonesismos, mientras que el de Florencia, italianismos. El estudio simultáneo de los tres códices lo está llevando a cabo en estos momentos Manuel Silva Suárez.

\section{Carlos Blázquez Herrero}

Carlos Blázquez recopila y ha recopilado gran cantidad de información sobre constructores aragoneses de la época ${ }^{26}$, pero aún no ha llegado a conclusiones sobre la posible autoría. Actualmente está trabajando con los tres manuscritos, sobre todo con las imágenes, y también está buscando, con su equipo, constructores en archivos notariales.

En cuanto a lo que se refiere a Aragón, sí que ha hallado un molino de regolfo de 1576 en Zaragoza. Además, en el texto aparece una imagen de una obra que se realizó en el pueblo de Arguís para llevar agua de Bonés a Arguís. Sin embargo, de acuerdo con sus palabras, muchos de los aragonesismos citados por Frago eran propios también de otros lugares (ej.: tujarón aparece

que fuimos capaces de apuntar en una libreta en ese momento. Desde aquí, mis más sinceras disculpas de antemano.

${ }^{25}$ Afirma que la transcripción del texto realizada por Rosa García Calvo en Simancas es de gran calidad.

${ }^{26}$ V. Blázquez Herrero, 1999 y 2005. 
también como vasquismo).

Respecto al texto, Blázquez dice que hay una serie de cosas que un maestro práctico no incluiría por ser demasiado simples. También cree que es posible que el libro no haya sido escrito por una sola mano, sino por bloques, y que puede que sea un manual de texto. Sin embargo, en su opinión, las figuras son perfectas, e imprescindibles para entender los molinos, por lo cual opina que estas están calcadas de un libro común.

\section{Nicolás García Tapia}

En lo que se refiere a Los Ventiún Libros..., Nicolás García Tapia comenta que el estilo farragoso de esta obra era el estilo propio del XVI y que los circunloquios son los naturales de un hombre de su tiempo, los propios del humanismo. Por otro lado, afirma que el autor de Los ventiún libros era un gran científico y que fue el copista el que no tenía ni idea de matemáticas, por lo cual hay algunos errores científicos.

A propósito de su tesis sobre la autoría de Lastanosa, recuerda que P.J. de Lastanosa estuvo en Nápoles, que era maquinario mayor de Felipe II y que un libro de esas características sólo puede estar patrocinado por este monarca. Además, Lastanosa patentó, el molino de pesas que aparece en el texto. Asimismo, Lastanosa era erasmista, lo que podría justificar las pocas y muy racionales referencias religiosas presentes en la obra. Sin embargo, comenta, por otro lado, que quizás se precipitó un tanto al otorgar la autoría de Los Ventiún libros a Pedro Juan de Lastanosa, puesto que, para proclamar la autoría de una obra de estas características con absoluta seguridad, debería existir, según él, el manuscrito original.

\section{José María Izaga Reiner}

Al igual que Blázquez, Izaga afirma que en la obra podemos rastrear diversos conceptos físicos (la pérdida de energía, a menor carga de agua, la pendiente, etc.) y que incluye principios de la física que tardarían más de cien años en admitirse, pero que, en muchas ocasiones, no llega a conclusiones. Para 
él, el autor del texto tiene un ánimo de pedagogo, habla para gente con un nivel cultural medio-bajo, constructores seguramente, y al mismo tiempo parece que no posee muy buena opinión de los constructores.

Según él, resulta extraño que en la obra no haya ninguna referencia a las ferrerías, que existían ya desde el siglo XIV en el País Vasco y que estaban muy extendidas por toda la Península Ibérica. Asimismo, nos quedamos con la duda de cuál era la mejor rueda en el siglo XVI y no menciona las ruedas de cajones (al contrario que Lobato). Sí que aparecen, como toda una novedad, los tornos de gran calibre para fabricar husillos de gran tamaño.

Izaga comenta también que a veces el autor parece que va a decir algo y después el lector se encuentra con una conclusión completamente distinta a la que en principio esperaba. Por ejemplo, describe varios procesos como la extracción de aceite, la lana, pero no queda todo claro, de forma que da la impresión de que el autor del texto buscaba el ahorro de tiempo en la construcción de los ingenios. Parece que es alguien que ha intercambiado pareceres, con un dominio de los detalles y un conocimiento muy extenso y práctico.

En cuanto a los dibujos, afirma que están realizados con sumo cuidado, trazados por otros, por varios dibujantes, pero que, a la vista de estas imágenes, el autor debió de explicar con gran precisión todos los detalles.

\section{Comentarios y preguntas}

En la ronda de sugerencias, preguntas y comentarios de la mesa redonda, el público y los conferenciantes participaron activamente, tratando las siguientes cuestiones:

-La posible relación del texto con: Leonardo Turriano, ingeniero mayor de Portugal de Felipe III; Tiburcio Spanochi, ingeniero militar que fue un gran dibujante, relación que García Tapia niega rotundamente; y Leonardo da Vinci, pues hay similitudes entre algunos de los dibujos de Los Ventiún Libros... y los 
de Leonardo da Vinci, habiendo estado estos últimos a disposición de los criados en la Corte de Felipe II'27.

-Las diferencias entre los dibujos, pues algunos son más detallados y están hechos con un trazo más firme que otros. Uno de los dibujos significativos es aquel en el que aparece un hombre empujando un cartón, dibujo que, aparentemente, no tiene sentido, pero que podría ser la representación de una manera de transportar las piedras en la época, haciéndolas rodar. García Tapia apunta la existencia de un puente de Benito Bails en París, hecho con tirantes y grapas, y contrapone los dibujos.

-El hecho de que en el códice no aparecen, como era de esperar, la valoración de la seguridad en las obras y los costes de los fallos. Se alaba la maestría de Los Ventiún Libros... en los libros de molinos, pero se recuerda el fallo garrafal del texto al hablar del puente en clave, pues es imposible que se posicione sin cerrar, sería impropio de un constructor, ya que no podrían pasar los carros.

-La existencia de un libro de Juan Francisco Sifón que comienza como Los Ventiún libros...

-Un signo de datación del original es que no aparece el artificio de Juanelo, seguramente porque el artificio original todavía estaba construyéndose.

-En el Monasterio de Rueda de Zaragoza se ha habilitado el molino de regolfo con cubeta redonda y con tapa, lo que sería, a su parecer, una turbina,

27 Se pueden encontrar ciertos parecidos entre el discurso y los dibujos de Los Ventiún Libros... y Leonardo da Vinci, en lo que se refiere al desorden de los textos y la perfección de muchos dibujos de Los Ventiún Libros...: "No puede reprochársele a Leonardo que al preguntarse preguntas acerca de la Naturaleza se detenga en la experiencia y las especulaciones teóricas, dejando a un lado el experimentar [...]. La curiosidad de Leonardo no conocía límites: observaba y dibujaba como nadie, pero no le fue dado el orden y, por tanto, la capacidad de crear una teoría. [...] Cuando Leonardo tenía cerca de 60 años comenzó un nuevo libro, uno de los muchos que había pensado escribir con la idea de darlos a publicar, con las siguientes palabras: y sea ésta una colección sin orden, escogida entre las muchas hojas que he copiado confiando en ordenarlas más adelante según las materias que tratan" (Truesdell 1975: 33). 
pero dos siglos antes de que se inventara esta. Sin embargo, García Tapia opina que no sería una turbina porque solo tenía una tapa y no estaba cerrada por abajo.

\subsubsection{Conclusiones sobre la autoría de Los Veinte y un} libros...

Aunque es mucho lo que a día de hoy se ha tratado sobre este tema, consideramos aún difícil ponerle nombre al autor del códice de Los Ventiún Libros de los Ingenios y Máquinas de Juanelo. Descartamos la ya negada autoría de Juanelo Turriano y, como muchos, nos planteamos que probablemente su nombre se utilizó simplemente en las portadas, para dar más relevancia al códice. Creemos que la tesis de García Tapia que otorga la autoría a Pedro Juan Lastanosa está muy fundamentada, pero pensamos que quizás estos fundamentos partan, no del texto en conjunto, sino de la coincidencia de algunas características del texto con los apuntes biográficos de Lastanosa. No estamos de acuerdo con García Tapia en su opinión sobre el estilo del texto "farragoso pero propio del siglo $\mathrm{XVI}$ ", pues si bien es cierto que los circunloquios eran propios en la época, el interés pedagógico animaba a los autores a clasificar, ordenar y clarificar al máximo sus textos, cosa que no ocurre en Los Ventiún Libros... pues, como hemos visto en el apartado de la estructura del texto, son varios los temas que se repiten en distintos capítulos y frecuentemente hay saltos de contenido. No hemos tenido la oportunidad de manejar y cotejar los otros textos con los que se relaciona el manuscrito, pero estamos de acuerdo con los apuntes que se ofrecieron en la mesa redonda acerca de las imágenes: imágenes tan precisas sólo pueden provenir de otros códices o textos de los que se han copiado. En cuanto a nuestra opinión sobre el texto en sí, pensamos que el tipo de discurso que contiene es más propio del discurso oral que del discurso escrito de la época, por lo que no descartamos que se trate de un compendio de notas o apuntes de clase, o algo parecido, en cuya confección o intento de perfección pudieron intervenir, de una manera o de otra, los textos a los que Los Ventiún Libros... se asemeja, y que, por supuesto, 
tiene relación con la zona de Aragón y con Italia. En qué orden, de qué manera y con qué peso ocurrieron estas cosas siguen siendo incógnitas para nosotros.

\subsection{PRESENTACIÓN DEL TEATRO DE BESSON}

Bajo la denominación Teatro encontramos en el Renacimiento frecuentemente una compilación de láminas sobre diversos temas. En el caso del Teatro de los Instrumentos y Figuras Matemáticas y Mecánicas de Jacques Besson, en las láminas aparecen representados distintos artificios o invenciones, fundamentalmente máquinas, algunas de las cuales habían sido inventadas y se utilizaban habitualmente y otras, sin embargo, estaban aún en fase de gestación, creación o “imaginación” (Uceda Antolín 2006: 4), fase que un buen número de ellas no superó, puesto que eran "máquinas irrealizables" (López García 2006: 6). Esta obra de Besson, aparecida en torno a $1570^{28}$, supone el inicio de un género de literatura técnica, “el Teatro de las Máquinas”29, género que la crítica considera que finaliza siglo y medio después, hacia 1724-1725, fecha de la publicación en Leipzig de El Theatrum Machinarum de Jacob Leupold (López García 2006: 5). En concreto, la obra de Besson es una de las primeras publicaciones sobre nuevos inventos mecánicos (Keller 1999: 38) y aunque fue reprimido en diversas ocasiones, también fue traducido a varios idiomas. Según algunos autores, una de las utilidades de este género "no específicamente tecnológico, escrito para un público culto y no especialista" (Marchis 1994: 101), sería servir de credencial al autor del Teatro, y así este podría justificar su conocimiento acerca de la materia del texto ante determinadas personas (Benito Quintana 1971: 38).

\subsubsection{JACQUES BESSON Y THEATRUM INSTRUMENTORUM}

${ }^{28}$ No está muy clara la fecha de publicación, puesto que la edición más antigua no lleva ni fecha ni lugar de edición. Existe un privilegio real a su favor fechado en 1569 en Orleans y concedido para los diez años inmediatamente posteriores a la impresión de la obra, privilegio que aún lleva la edición de 1582, por lo que la primera publicación del Teatro se realizó, como fecha más temprana, en 1582 (V. Benito Quintana 1971: 42).

${ }^{29}$ Otras obras pertenecientes a este género serían Diverse et artificiose machine (1588) de Agostino Ramelli, Novo Teatro di mchine et edifici (1607) de Vittorio Zonca y Machinae Novae de Fausto Veranzio (V. Pacey 1980: 104). 
No es mucho lo que conocemos sobre el científico y profesor de matemáticas Jacques Besson, quien estuvo al servicio del rey Francisco II. Creemos que nació a principios del siglo XVI en Grenoble (Francia) y falleció hacia 1573 en Inglaterra, donde huyó, parece ser, por motivos religiosos (López García 2006: 8).

En general, sus obras pertenecen al ámbito de las matemáticas y de la física, y tratan temas como el cosmolabio ${ }^{30} \mathrm{y}$ otros inventos (Le cosmolabe, ou instrument universal concernant toutes observationes..., publicada en 1572), el cosmógrafo $^{31}$ (Le Cosmographe, instrument adjoint..., en 1561) o el compás de Euclides (Description et usaige du compas Euclidien, aparecida, como el Theatrum instrumentorum, en París en 1572).

Son varias las ediciones e impresiones, en distintas lenguas, que existen de la obra de Besson. Además de la que se considera la primera de ellas, Theatrum instrumentorum et machinarum Jacobus Bessonus excogitavit liber primus, publicada en latín hacia 1570, encontramos traducciones al francés que incluían comentarios y adiciones (Lyon en 1578 y 1582 y Ginebra en 1584), al alemán (Nuremberg, 1585) o la versión en castellano que aquí nos ocupa, impresa en Lyon en 1602 por Horacio Cardon.

Conocemos, por obra del Profesor Keller, que la publicación de Besson “animó a otros ingenieros al servicio de Francia, como por ejemplo Agostino Ramelli, Jean Errard y Joseph Boillot a publicar sus nuevas ideas, (casi siempre ingeniosas aunque no necesariamente prácticas)" (Keller 1999: 38). Ramelli era ingeniero de Enrique III, su libro se publicó en París en 1588 y además había elaborado un manuscrito sobre su sistema de agrimensura que no llegó a ver la luz. Otro de los ingenieros que logró que varias de sus obras se publicaran fue

30 "El cosmolabio es un aparato con dos círculos graduados articulados entre sí que, mediante rótulas y tornillos, pueden adoptar diversas orientaciones. En términos más modernos diríamos que es un teodolito de usos múltiples, superior con mucho a las ballestillas o báculos de Jacob, cuadrantes, círculos y esferas que eran los instrumentos usuales en la época" (Benito Quintana 1971: 40).

31 Instrumento similar al cosmolabio, pero a diferencia de este, en vez de un círculo superior posee una escuadra articulada y graduada (V. Benito Quintana 1971: 42). 
Errard, quien publicó varios libros sobre fortificación e ingeniería que, en palabras de Keller, referidas a todas estas obras publicadas en aquel momento histórico, “creaban una sensación de progreso técnico” (Keller 1999: 38).

\subsubsection{ESTRUCTURA DEL TEXTO}

La traducción de la obra de Besson realizada por Horacio Cardon, Teatro de los instrumentos y figuras matemáticas y mecánicas, está encabezada por una dedicatoria que el traductor realiza al Duque de Lerma en la que le solicita el protectorado de la obra ${ }^{32}$.

El texto está compuesto por 60 láminas o figuras, acompañadas cada una de ellas por un texto breve conformado por tres partes: "Proposición de autor", “Declaración" y “Adición". Las planchas de los grabados que constituyeron las imágenes fueron realizadas por distintos autores, como Jacques Endrouet du Cerceau y René Boyvin; las "Proposiciones de autor", por Besson; las "Declaraciones", por Francisco Beroaldo y las "Adiciones" son, probablemente, de Julio Pascal Siculo(Benito Quintana 1971: 48 y López García 2006: 10).

En la "Proposición de autor" aparece, en una sola frase, el nombre de la máquina o instrumento que encontramos en la lámina y su utilidad principal $u$ otros datos.

En “Declaración" se describe el instrumento o máquina y las partes que lo componen y se citan algunas instrucciones de uso.

En el apartado "Adición" hallamos diferentes cuestiones relacionadas con el instrumento o máquina presentado anteriormente, que tratan, por un lado, de aclarar su funcionamiento, pero también de recordar algunos de los problemas que pueden surgir a la hora de utilizarlo. Por esto, es frecuente descubrir en esta parte algunos consejos de uso e incluso la declaración de la

32 "Reciba, pues, Vuestra Excellencia en su protección esta obra y se sirva por su humanidad de ser también protector de todas las que salieren de mi impressión, no siendo mi intención otra que de servir al público y, en particular, a Vuestra Excellencia, de quien siempre quedaré muy humilde y verdadero servidor" (Besson 1602: A2r). 
imperfección de la máquina, frecuentemente por estar "inacabada"33.

Los grabados son de gran calidad e incluyen muchos detalles, aunque se encuentran en un estado de conservación regular. Entre los instrumentos y máquinas recogidos en las láminas destacan los compases y otros instrumentos geométricos (figuras I-VI); los tornos para cortar y tornear distintos materiales (figuras VII-X); las máquinas movidas por fuerza humana, destinadas a usos variados como cortar madera, avivar fuegos o mover el martillo de un yunque (figuras XI-XIV); distintos tipos de transporte de materiales y humanos por tierra (figuras XV-XVII); mecanismos para almacenar y dosificar líquidos (figuras XVIII y XIX); varias máquinas relacionadas con la construcción en el agua, utilizadas para el dragado de los puertos, la cimentación de puentes o la carga y descarga de barcos (figuras XX-XXIV, XXXVI-XXXVIII); molinos movidos por fuerza humana, para prensar paños o moler harina (figuras XXVXXVII); la rueda hidráulica (figura XXVIII); instrumentos musicales (figura XXIX); máquinas para mover cargas (figuras XXX-XXXI y XXXV) y navíos (LIIILVIII y LX); ingenios para sacar agua de los pozos o subir el agua (figuras XLIII-XLIV y XLVI-L) y prensas para distintos materiales, como la uva, el paño o las estampas (figura LIX).

La imperfección de algunas de estas máquinas puede ser consecuencia, por un lado, de su invención por medio del papel o de maquetas, sin prueba con los materiales con los que habría de fabricarse; por otro lado, puede estar motivada por el intento de distinguir, por motivos de privilegios, a los verdaderos inventores, que sabrían como "terminar" la máquina, de los simples imitadores que, sin comprenderla, tratarían de fabricarla a partir de estos tratados (V. Benito Quintana 1971: 50).

33 "No, cierto, por culpa del pintor, ni del que ha sculpido, este instrumento queda imperfecto, sino porque el autor mesmo no lo acabó. Sea la causa qual ella fuese, empero, ha querido que fuesse puesto aquí para que, si alguno lo acabasse, se entendiesse la invención ser suya" (Besson 1602: Ir, Adición a la Figura XXIX). 


\section{INGENIERÍA Y MAQUINARIA EN EL RENACIMIENTO HISPANO}

\subsection{LA ACTIVIDAD CIENTÍFICA EN EL RENACIMIENTO}

De manera general se considera que el desarrollo científico de un lugar está estrechamente ligado a su desarrollo social y económico (López Piñero 1979: 40), de forma que los movimientos históricos y la interpretación de estos realizada por la historiografía son fundamentales a la hora de configurar la historia de la ciencia de nuestros antepasados.

Perdura, por tanto, en la historiografía de la ciencia, el establecimiento de nuevas etapas científicas coincidentes con los grandes cambios socio-políticos acontecidos (V. Maravall 1972). En las coordenadas en las que nos situamos, el siglo XVI europeo, partimos de severos conflictos bélicos tanto entre los distintos estados europeos como en el interior de los mismos, lugares en el que floreció sin embargo una nueva cosmología (Galileo, Kepler) en la que resultaba novedosa "la decisión de potenciar al máximo los beneficios, incluso en la agricultura, empleando técnicas conscientemente innovadoras" (Keller 1999: 25). En cuanto al estado español, la expansión del movimiento denominado "humanismo científico" y la paulatina supresión del escolasticismo arabizado bajomedieval coinciden con la introducción de las diversas innovaciones generadas a partir de finales del siglo XV, durante el reinado de los Reyes Católicos y el nacimiento del Estado moderno y el imperio español (V. LópezOcón 2003: 23-24).

Como es de suponer, la actividad científica demandada por la maquinaria imperial tuvo distintas concreciones de acuerdo con sus necesidades e intereses circunstanciales (López Piñero 20021: 15) y por tanto fue regulada y organizada por el poder real en pragmáticas, reales cédulas, instrucciones y ordenanzas, así como en las constituciones de las instituciones.

Señalamos, respecto a estas últimas, que durante el siglo XVI el estado español propició el surgimiento de varias academias en las que se 
institucionalizó el cultivo científico, cuyos exponentes más significativos fueron la Casa de la Contratación de Sevilla y la Academia Real Matemática.

La Casa de la Contratación de Sevilla, una de las primeras instituciones científicas europeas, cuya creación, en 1503, con fines cosmográficos, se fundamentaba en "el control de la navegación oceánica que permitía la comunicación y el ensamblaje de las diversas piezas dispersas de una monarquía universal" (López-Ocón 2003: 26), continuó con los objetivos de regulación del tráfico de mercancías que ejercía la Aduana de Cádiz, ampliándolos, entre otros, a la expedición, previa formación y examen, de licencias de pilotaje, y a la confección de cartas de navegación (Esteban Piñeiro y Vicente Maroto 2002: 35).

En cuanto a la creación de la Academia Real Matemática (1583), localizada durante treinta años en un edificio frente al Alcázar Real de Madrid, fue el fruto de la motivación que el arquitecto Juan de Herrera infundió a Felipe II, con la intención de formar a jóvenes en conocimientos científico-técnicos, puesto que, en palabras del propio Herrera en la Institución de la Academia Real Mathemática, hacía "falta en la república de artífices entendidos y perfectos para muchos usos y ministerios necesarios a la vida política" (Herrera 1584: 1v). Aunque no se cumplieron las amplias pretensiones dictadas por Herrera en cuanto a la formación de profesionales en múltiples y diversas materias especializadas (mecánicos, astrólogos, perspectivos, gnomónicos, arquitectos, músicos, artilleros, etc.), ni tampoco tuvo lugar la emisión de los títulos correspondientes que según él debían poseerse para el ejercicio profesional, sí parece que se utilizaron los textos y contenidos que en la Institución se exponían como lecturas obligatorias ${ }^{34}$, incluidos muchos cuya traducción al romance había sido encomendada por el arquitecto ${ }^{35}$ (Esteban Piñeiro y Vicente Maroto 2002: 46-47). Por estos motivos, se ha concluido que el gran prestigio de esta

${ }^{34}$ Entre estos, Geometría de Euclides, Geografía de Ptolomeo, la Esfera, las Teóricas de los planetas.

35 Como los traducidos por Ondériz, los libros X y XI de los Elementos, la Perspectiva y Especularia, los Esféricos de Teodosio y los Equiponderantes de Arquímedes. 
institución renacentista no radicó tanto en su eficaz formación de científicos y técnicos, como en la labor investigadora y difusora de conocimientos científicotécnicos que tuvo lugar en su sede (Esteban Piñeiro y Vicente Maroto 2002: 50$51)$.

Respecto al ámbito que nos interesa, la ingeniería hidráulica y la maquinaria, parece que su estudio no tuvo cabida, como tampoco lo tuvo el de otras disciplinas, en estas instituciones científico-técnicas surgidas en la España renacentista, y eso a pesar de que Herrera recogiera en su Institución, entre los profesionales destinados a ser formados en la Academia, a aquellos vinculados al ejercicio de la materia que nos ocupa (ingenieros, maquinistas, arquitectos, niveladores de aguas y fontaneros) (Herrera 1584: 2v). Se trataría, en este caso, de una cultura científica extraacadémica ${ }^{36}$, al ser la invención y construcción de máquinas y el diseño y ejecución de obras hidráulicas materias típicamente prácticas, en cuyo seno, además, "se formularon nociones teóricas sobre fenómenos físicos independientes de la filosofía natural académica" (López Piñero 20022: 222).

Sí que eran necesarias, para las ejecuciones hidráulicas, las técnicas de agrimensura y el conocimiento del manejo de los instrumentos necesarios para esta tarea, cuya presentación al alumnado se realizaba por profesores que, por lo que sabemos, en ocasiones trataban de complicar los manuales dedicados a esta materia para así alargar sus labores y ejercicios docentes en su propio beneficio (Keller 1999: 26).

Aunque en los textos científico-técnicos renacentistas podemos hallar referencias a la clasificación de las artes realizada por los antiguos ${ }^{37}$, que separaba las artes liberales de las mecánicas ${ }^{38}$ y estas últimas se despreciaban

${ }^{36}$ Tomamos la expresión cultura científica extraacadémica de López Piñero, 2002, aunque en este caso no para referirnos a las vertientes alquímica o mágico-astrológica que el señala a propósito de esta.

${ }^{37}$ V. a este respecto, por ejemplo, República de Platón, Política de Aristóteles o Biblia (Libro I de los Macabeos), así como Plotino o Cicerón.

${ }^{38} \mathrm{~V}$. acerca de este tema, Granada: 2008, especialmente las páginas 67-69 y Navascués (2008). 
por ser manuales y propias de "esclavos", lo cierto es que ya desde la Baja Edad Media esta estructura venía sustituyéndose por otra en la que las técnicas recibían una valoración positiva (López Piñero 20022: 227). Sin embargo, es en el Renacimiento cuando el desarrollo del estudio, la práctica, la divulgación y la creación de innovaciones en las distintas disciplinas técnicas permiten un nuevo acercamiento epistemológico a este ámbito de conocimiento.

\subsection{EN TORNO AL INGENIO, LOS INGENIOS Y EL INGENIERO}

De acuerdo con el Diccionario de Autoridades, el ingenio, una de las facultades del espíritu humano recurrentes en los textos renacentistas, no es sino la "facultad o potencia en el hombre, con que sutilmente discurre o inventa trazas, modos, máquinas y artificios o razones y argumentos o percibe $\mathrm{y}$ aprehende fácilmente las ciencias". Tomado del latín ĭngĕnŭum 'cualidades innatas de alguien', este cultismo está documentado a finales del siglo XV en la obra de Nebrija (DECH). De forma gratamente innovadora, esta facultad del ingenio aparece vinculada, en algunos textos renacentistas, a los oficiales y profesionales relacionados con ámbitos, el liberal y el mecánico, que habían sido repetitivamente separados en la ramificación de las artes y se articula como facultad común a todos ellos:

\footnotetext{
Aquéllos se llaman oficiales mecánicos que trabajan con el ingenio y con las manos, como son los canteros, plateros, carpenteros, cerrageros, campaneros y otros oficiales, que sus artes requieren mucho saber e ingenio. Pero liberales se llaman los que trabajan solamente con el espíritu y con el ingenio, como son los gramáticos, lógicos, retóricos, arisméticos, músicos, geométricos, astrólogos, con los quales son numerados los pintores y esculptores (Sagredo 1526: 14).
}

A nuestro modo de ver, la importancia del ingenio en la caracterización de los hombres renacentistas viene realzada desde el momento de la impronta de la observación de esta facultad en los agentes de las más variadas actividades humanas, de distinta índole. Esta acción promueve quizás uno de los puntos clave en los que anida la propuesta de la particular mirada 
humanista, que de manera singular, pretende captar dichas "cualidades innatas" en el hombre renacentista y en los diversos resultados de su trabajo, de una forma consecuentemente independiente a la idea de necesidad ${ }^{39}$ en otro tiempo promulgada y que en este momento esboza, a nuestro parecer, algunos de los vislumbres de la propuesta de aisthesis ${ }^{40}$ del siglo XVI hispano.

Por otra parte, la voz ingenio, que en palabras de Sebastián de Covarrubias equivale a la "fuerza natural del entendimiento, investigadora de lo que por razón y discurso se puede alcanzar en todo género de ciencias [...] invenciones y engaños $41 "$, señala, en otras de sus acepciones, según el Diccionario de Covarrubias, "cualquier cosa que se fabrica con entendimiento y facilita el ejecutar lo que con fuerzas era dificultoso" y "las mismas máquinas inventadas con primor". Es decir, a partir del sentido de ingenius derivado del verbo gignĕre 'engendrar, dar a luz, crear', esto es, "lo engendrado, lo creado" 42 , podemos revisar atisbos que despuntan, por un lado, a las creaciones realizadas por esta facultad propia del genius, en sus muy diferentes manifestaciones concretas, y, por otro, a su concreción particular en la invención de máquinas ${ }^{43}$. Las máquinas, por tanto, se proyectan como el fruto selecto de un trabajo en el que el primor de la facultad del ingenio es aventajadamente sobresaliente entre otros fines del uso de esta fuerza natural, cuya disposición avanza hacia el compromiso de aminorar las fuerzas empleadas en la ejecución de electas tareas

${ }^{39} \mathrm{~V}$. Aristóteles, en su libro primero de la Política y el primer capítulo del libro E de la Metafísica, donde las ciencias productivas son inferiores a las ciencias prácticas y a las ciencias teóricas (Granada 2008: 69).

40 “Típico de este período es el entrecruzarse de las artes visuales, las ciencias y la literatura que en sus expresiones más características y en su individualidad presentan factores comunes no sólo desde el punto de vista teórico, sino también práctico. De estos signos y expresiones bien tangibles me he ocupado, en cuanto testimonios de la estética del Renacimiento" (Castelli 2011: 33-34).

${ }^{41}$ Resultaría sugerente considerar aquí, respecto a engaño, los apuntes en torno a irrealidad, juego, falsedad, farsa o guiño, dentro del panorama de la creación de ingenios o artificios, cuidadosamente señalados por Alfredo Aracil en Juego y artificio (1998). 41.

42 A propósito de la aproximación etimológica a ingenio, véase Silva Suárez 20082: 32-

43 Silva Suárez ahonda en la trayectoria de estos dos sentidos del término, lo que él denomina "dualidad de concepciones", a través de su representación en dos vertientes de la ingeniería a lo largo de la historia. Por un lado, la ingeniería francesa, extensible al continente europeo, a partir del concepto de ingenio como facultad y, por otro, la ingeniería británica, desde la idea de ingenio como máquina u obra. V. Silva Suárez 20082: 53-57. 
humanas. Este enfoque de la maquinaria sustenta, desde nuestro punto de vista, uno de los pilares de la idea de invención, edificado en el transvase de lo que concierne a los lugares de manejo de las fuerzas humanas y naturales: puesto que la correcta dirección del ingenio en la fase de gestación de ingenios o máquinas conlleva, de manera natural, una reducción del esfuerzo, también humano o natural, en el desempeño del propósito para el cual esa obra fue creada, asimismo, el desaprovecho o desuso del anima geniis implica el aumento en la inversión de otras fuerzas motrices de la maquinaria en época renacentista, reducidas entonces a la fuerza de sangre, bien proceda de seres humanos o de animales, o bien a las energías sustraídas del aire, del agua o del fuego.

A la hora de clarificar nuestra aproximación conceptual al creador de estos ingenios, el ingeniero, incidimos una doble vertiente postulada ya en Covarrubias y articulada en dos de las principales metas perseguidas por los propios y más ejemplares objetos de su creación. Por una parte, responde a la voz ingeniero "el que fabrica máquinas para defenderse del enemigo y ofenderle" y, por otra, “(el que inventa) las mismas máquinas [...] (que) llamamos ingenio, como el ingenio del agua, que sube desde el río Tajo hasta el alcázar, en Toledo, que fue invención de Juanelo, segundo Arquímedes". Dentro del natural fluir del cuerpo de ingenieros renacentista, indefinido en cuanto a especializaciones producto de épocas posteriores ${ }^{44}$, creemos que resultaría legítimo, sin embargo, demarcar las lindes de un nuestro acercamiento a partir de los márgenes de aquello que "nos permitiría hablar de ingenieros para la paz e ingenieros para la guerra, aun cuando a veces fueran los mismos" (Cámara Muñoz 2008: 131). De este modo, a lo largo de los presentes investigación y trabajo doctorales, pretendemos permanecer inmersos en ese ámbito de los ingenios y máquinas cuya intención dista notablemente del fin bélico, y que, gracias a la inclinación pacífica a la que apuntan, lejos de los

${ }^{44}$ Cámara Muñoz señala, como momento de división definitiva de la arquitectura civil y la arquitectura militar, la muerte de Sabatini a finales del siglo XVIII (Cámara Muñoz 2008: 130). Véase, respecto a esta cuestión, “El ingeniero Sabatini” (Cámara Muñoz, 1993). 
contingentes de la conservatio y destructio objetos de las obras de fortificación o de arquitectura militar, creemos que regresan por rectos cauces al que acordamos principio $\mathrm{u}$ origen del verbum que nos ocupa, ingenio, esto es, genitura.

\subsection{INGENIEROS E INVENTORES DEL SIGLO XVI}

Bajo la denominación ingenieros encontramos en el Renacimiento un diáfano y heterogéneo grupo de hombres, de distintas procedencias, condiciones y ocupaciones, hecho que no es sino el reflejo, hasta cierto punto, de la ya variada actividad con la que, en muchas ocasiones, se concretaba el trabajo del ingenio de los individuos denominados ingenieros.

Por otro lado, han sido varios los hombres que, no habiendo sido inscritos en la historia del siglo XVI como ingenieros, han sido reconocidos a tal nombre a posteriori, previo análisis y estudio de sus más frecuentes y sólidos empeños.

Inclinado, por tanto, el conjunto de ingenieros, a ser materia de un intento de ajuste por medio de distintas y varias clasificaciones ${ }^{45}$, no podemos aquí sino tratar de describir, dentro de algunos parámetros de circunscripción, la variabilidad presente tanto en la figura del ingeniero como en el resultado de sus dedicaciones y trabajos.

En un primer lugar, podríamos señalar a aquellos agentes de invenciones en materia de ingenios y máquinas, que independientemente de sus profesiones $\mathrm{u}$ oficios usuales, muchas veces vinculados con ámbitos remotamente ligados a la ingeniería, ejercían como inventores (García Tapia 1990: 52-53), y así resultaba habitual o incluso a veces demasiado habitual, como interpretamos de algunas palabras de Juan de Herrera ${ }^{46}$ al respecto, que frecuentaran la corte en

45 Por ejemplo, López Piñero (1979) distingue tres grupos de ingenieros: los mecánicos, los artistas y los científicos, que García Tapia (1990) califica, respectivamente, de prácticos, arquitectos y teóricos, y añade además a la lista los ingenieros ocasionales o inventores.

${ }^{46}$ Nos referimos a una porción del contenido presente en la memoria que envía al secretario de Felipe II, Mateo Vázquez, en 1984, que aparece recogida en Llaguno y Ceán (1977[1829]: 335) e incluida en García Tapia (1990: 53), especialmente donde Juan de Herrera 
un intento de que sus inventos fueran reconocidos con méritos. Resultaría legítimo revisitar en este punto figuras como la de Francisco Lobato del Campo, del que hemos hablado más extendidamente anteriormente, pues, aunque no tenemos constancia de que acudiera a la corte de Felipe II para mostrar sus proyectos de maquinaria, y además desconocemos la fuente de ingresos del medinense, es, para nosotros, uno de los renacentistas castellanos ejemplares por su ejercicio de la facultad del ingenio enfocada hacia la experimentación en la creación de máquinas y otras obras hidráulicas, de manera aún más aventajada si valoramos su labor en las circunstancias en las que la realizó, circunstancias que atienden las coordenadas espacio-temporales, Medina del Campo en la segunda mitad del XVI, en las que este inventor de sitúa.

Resaltamos, además, la presencia en torno a la corte de muchos individuos que mostraban la uniforme y amplia cara del humanismo y sus múltiples intereses, al combinar con mucha naturalidad la invención de ingenios y máquinas entre gran número de actividades. El papel de estos ingenieros para el imperio fue fundamental, pues la alternancia de conocimientos teóricos y prácticos de diversa índole en su profesión los llevó a destacar por su ejercicio variado en ámbitos como el militar, la náutica, la metalurgia o la arquitectura (López-Ocón 2003: 28). Nos es grato citar aquí, por ejemplo, al que Lope de Vega denominaría el "Hércules español", Jerónimo de Ayanz y Beaumont (1553-1613), artista, empresario y militar de origen navarro, caballero además de la orden de Calatrava, quien, aunque no tuvo el cargo de ingeniero, recibió privilegios de Felipe III por sus invenciones en este ámbito, pues realizó innovaciones significativas en maquinaria minera, molinera, ingenios de vapor, ingenios para regar y unos originales equipos de buceo ${ }^{47}(\mathrm{~V}$. Silva Suárez 20084: 706). También podría ser preciso recoger, a este respecto, la figura del que fue llamado "ermitaño ingeniero", el napolitano Ambrosio

explica: "Y por mi causa en muchas de ellas (máquinas) no se ha puesto la mano, porque se hubiera perdido la hacienda, tiempo y reputación y el conoscimiento de estas enseñándolo a muchos, que aquí adelante podrán hacer lo que yo".

47 Encontraremos información mucho más detallada sobre Jerónimo de Ayanz en García Tapia (2001). 
Mariano Azaro de San Benito, ingeniero militar en la batalla de San Quintín, caballero de la Orden de Malta y teólogo secular en el Concilio de Trento, quien se hizo ermitaño en Andalucía y, tras conocer a Santa Teresa de Jesús, ingresó en la orden carmelitana. Entre sus trabajos de ingeniería hidráulica al servicio de Felipe II, a partir de 1570, como ingeniero sin salario, "por amor a Dios y al rey", aparecen sus intervenciones a propósito del trazado de la acequia del Colmenar, de la proyección del canal navegable de Jerez o de la conducción de aguas a Valladolid (García Tapia 1990: 58 y Silva Suárez 20084: 707).

Pero, además de todos aquellos que ejecutaron obras de ingeniería y que fueron conocidos, de acuerdo con los ámbitos en los que se movían, como militares, frailes, arquitectos o cosmógrafos, no podemos dejar de mencionar que el título de ingeniero era en el Renacimiento un título profesional que el rey otorgaba a determinadas figuras que se dedicaban, en su mayor parte, a la arquitectura militar (Cámara Muñoz 2008: 130). De manera general, se ha extendido la idea de que entre estos "ingenieros del rey" predominaban los de origen italiano, a diferencia de los ingenieros no reconocidos, que eran casi siempre españoles (García Tapia 1990: 41). Por citar algunos ejemplos de las obras de ingeniería hidráulica realizadas por estos ingenieros reales que normalmente ejercían en ámbitos militares, señalamos el diseño y la dirección de la navegación del Tajo ${ }^{48}$ entre Abrantes y Toledo llevadas a cabo por Juan Bautista Antonelli ${ }^{49}$, la actuación de Cristóbal Antonelli en la presa de Tibi y los

48 "El río Tajo, a diferencia del Ebro y del Guadalquivir, atravesaba dos reinos Castilla y Portugal- regidos por monarcas diferentes, y cuyas relaciones durante las primeras décadas del reinado de Felipe II estaban marcadas por sus recelos históricos. Un hecho inesperado pero de gran transcendencia, la muerte del joven rey Sebastián de Portugal, seguida por una breve guerra ibérica, hizo que la navegación por el Tajo fuera ya no sólo posible, sino también aconsejable. [...] La navegación por el Tajo debió de mantenerse cierto tiempo, aunque la desaparición de Antonelli y la mala situación económica de la Corona tal vez hicieron que se descuidaran las obras imprescindibles de mantenimiento (González Tascón 19992: 104 y 108).

49 En abril de 1581, las cortes de Tomar reconocen al nuevo rey con el título de Felipe I de Portugal, y ese mismo año Felipe II hace su entrada triunfal en Lisboa -cruzando el Tajo en la galera real- para asumir personalmente las tareas administrativas de su nuevo reino. [...] Pero todo ello resultaba imposible si antes no se abordaban trabajos de gran envergadura para los cuales Felipe II contó desde el primer momento con un técnico de gran valía, el ingeniero italiano Juan Bautista Antonelli, que sirvió con lealtad y entusiasmo a su rey hasta su muerte accidental en 1588" (González Tascón 19992: 104-105). 
trabajos de urbanización de Tiburzio Spannocchi en Pontevedra o en Guetaria (Silva Suárez 20082: 43).

En este punto, no hemos obviar la figura de Juanelo Turriano (V. Martín Herrero 2010), ingeniero de Carlos V y Felipe II, de origen cremonés, afamado en la época renacentista e incluso en siglos posteriores fundamentalmente por dos inventos de gran magnitud: un reloj planetario de gran tamaño, en el que trabajó más de veinte años, cuyo complicado mecanismo estaba constituido por más de 1800 ruedas y solamente tres muelles (Kiaulehn 1959-1964: 129); y un invento conocido como el artificio de Juanelo, gran máquina de engranajes construida en Toledo para subir el agua del Tajo hasta el alcázar ${ }^{50}$, por medio de un sistema de ruedas hidráulicas con cangilones en un primer nivel y a través de un acueducto con máquinas elevadoras en torres en un segundo nivel (Aracil 1998: 78).

No es casualidad que el artificio de Juanelo fuera escogido por los autores del Diccionario de Autoridades (1990[1726-1739]) para ejemplificar la segunda de las acepciones de artificio. Esa, de acuerdo con Autoridades (s. v. artificio), «obra ejecutada según arte y sus reglas, o con novedad, primor y sutileza» fue en la época una construcción de fama y culto que no pasó desapercibida en las letras hispánicas ${ }^{51}$.

Apodado el príncipe de los arquitectos, la fama y notoriedad con la que Juanelo Turriano y su artificio fueron otorgados en la tradición textual, fundamentalmente a lo largo del siglo XVI y XVII, remiten tanto a lugares en los que el nombre de Juanelo Turriano sustentaba autoridad o realce, como ocurre en las portadas de los cinco volúmenes de que constan los Ventiún libros de los ingenios y máquinas de Juanelo (c. 1605), como a referencias, en ocasiones jocosas,

50 En esta época, unos ingenieros y arquitectos italianos estudiaron la posibilidad de atravesar el Tajo con un sifón, pero la presión resultaba excesiva para la resistencia de las tuberías. Francesco di Giorgio Martín diseñó unas bombas de émbolo para salvar el desnivel del Tajo a la ciudad, pero no pudieron llevarse a efecto. A lo largo del siglo XVI se hicieron diversos intentos por ingenieros alemanes, italianos y franceses, fracasando todos ellos (Aracil 1998: 78).

51 Véase, acerca de la inclusión de referencias sobre Juanelo Turriano y su artificio en obras hispanas, Moreno Nieto y Moreno Santiago: 2006. 
a los problemas de ejecución y coste de dicha máquina en Toledo (V. Martín Herrero, 2010), problemas que conllevaron los retrasos en los pagos y el endeudamiento de este gran ingeniero:

\begin{abstract}
En estos tiempos Juanelo Turriano inventó un ingenio con que se sube la agua del río Tajo al Alcáçar de Toledo, que ay una muy gran cuesta. La máchina tiene ingenio, pero es muy violenta y de poca utilidad y así continuamente es necessario adereçalla (García de Céspedes 1606: $40 \mathrm{v})$.
\end{abstract}

Otra gran figura polifacética de la época, importante en cuanto a lo que la ingeniería y maquinaria se refiere, fue el gran arquitecto y artista Juan de Herrera (1530-1597), inventor también de varios ingenios para la carga y el transporte de pesos que fueron utilizados en la obra de El Escorial. En cuanto al ámbito de la ingeniería hidráulica, Herrera participó en varias obras importantes de su tiempo, como los riegos del Jarama, los jardines de Aranjuez, las huertas de Picotajo, la presa de Ontígola y el canal de Colmenar. También, junto a Juanelo Turriano, llevó a cabo la planificación del pantano de Tibi, el mayor construido en Europa hasta el siglo XVIII (V. Maldonado y García 2002: 112-113).

Por otro lado, afines a la profesión de ingeniero y a la ejecución de ingenios y máquinas y obras de ingeniería hidráulica, encontramos en la época otros técnicos y oficiales, con fines más específicos. Entre estos, los zahoríes, dedicados a la búsqueda de aguas subterráneas, que, de acuerdo con Los Ventiún Libros... "el vulgo llama fontaneros" (Pseudo-Juanelo Turriano, a. 1605: fol. 36r), profesaban, sin embargo, entre sus ocupaciones, y a diferencia de los fontaneros, la distinción entre aguas buenas o malas (ídem: fol. 36r y 36v) ${ }^{52}$ y eran requeridos como Maestros de obras de agua por su clara observación y localización de los orígenes y trazados que el agua realiza bajo tierra. Dados sus conocimientos sobre una materia a priori oculta al sentido de la vista, aunque $a$

52 "Aunque, en esto del conozer de las aguas la calidad, es cosa muy agena de los que professan el exercicio de fontaneros, los quales no es más su exercicio que saber nivelar un agua para saber si podrá subir o abajar para el servicio de los pueblos, o para regar o moler". 
posteriori se sirva ampliamente de la vista para la correcta lectura de las señales naturales, los zahoríes fueron tildados de adivinos, sentido hacia el que evolucionó la voz zahorí, que dista un tanto de su sentido etimológico, pues es un “derivado de zúhara 'lucero, planeta Venus' (de záhar 'brillar'), por la semejanza de procedimientos entre los zahoríes y los astrólogos" (DECH). En cualquier caso, la aún no evidente para todos, en el Renacimiento, base científica de su tarea geomántica, no impidió que los zahoríes fueran especialmente solicitados para el diseño de jardines y otros lugares en los que la intervención del agua resultaba prioritaria ${ }^{53}$ y el trabajo del zahorí eminentemente necesario.

Serían, por tanto, fontaneros y niveladores de las aguas (V. Herrera 1584: 3r) denominaciones que en nuestros textos también designan a técnicos encargados de las obras de ingeniería hidráulica, donde se ocupan, entre otras actividades, del establecimiento y arreglo de conductos de canalización de agua, encañados de fuentes o ubicaciones de acequias, acueductos y otros elementos de esta índole.

Mecánicos y maquinistas son términos que conviven en la época también para la designación de aquellos oficiales dedicados a la invención y fabricación de ingenios y máquinas, tal y como nos muestra La institución de la Academia Real Matemática (1584) de Herrera. Entre la bibliografía dictada en el texto con objeto de la formación institucional de estos técnicos se encuentran varios libros de Euclides, el libro décimo de Vitrubio, Los Equiponderantes de Arquímedes, las Mecánicas de Aristóteles, Giordano y Guidobaldo y, especialmente dedicadas a los niveladores, los Hidráulicos de Herón Alejandrino (V. Herrera 1584: fol. 10v-11r y 17r-17v).

53 Respecto a Baltasar de San Juan, zahorí que trabajó en las obras de los manantiales de Aranjuez llevadas a cabo por Felipe II hacia 1565, nos cuenta Álvarez de Quindós en su Descripción histórica del Real Bosque de Aranjuez (1804) que "por las obras que hizo entiendo que era un inteligente o Maestro de obras de agua, que con su arte y observaciones de las señales naturales descubrió unos y aclaró otros nacimientos para el mar (de Ontígola) y a esto ignorante el vulgo de semejante ciencia, lo atribuía a adivinaciones, y resultó confundir el verdadero significado de la voz zahorí" (Álvarez de Quindós: 1804, V. Cámara Muñoz 2008: 133). 
No podemos en este punto sino citar al gran ingeniero Leonardo da Vinci, precursor de la ingeniería moderna, cuyas invenciones, si bien se creía que no habían tenido demasiada influencia en otros lugares (V. Benito Quintana 1971: 20) se difundieron especialmente, en determinados círculos intelectuales, a través de sus dibujos, obras magníficas y especialmente singulares que le han llevado a ser llamado "El gran genio del Renacimiento"54.

\subsection{LAS OBRAS DE INGENIERÍA}

La nueva concepción utópica de las ciudades surgida a partir de la revisión de los textos clásicos durante el Renacimiento posibilita la introducción de reformas urbanas con arreglo a un nuevo plan urbanístico que, desde la época de los Reyes Católicos, trata de mejorar y racionalizar el anterior trazado medieval. Por este motivo, las ordenanzas promulgan sucesivamente normas que contribuyen, entre otras cosas, a la separación de los distintos espacios urbanos y a la mejora de las condiciones higiénicas (García Tapia 2002: 438).

\subsubsection{LOS PUENTES}

Respecto a algunas obras de ingeniería civil ejecutadas en el Renacimiento, destacamos la mejora y/o construcción de caminos y puentes, deseada por las cortes castellanas, tal y como Carlos V recogió en las leyes de la Novísima Recopilación. Estas obras se ampliaron con la reorganización del territorio llevada a cabo por Felipe II debido al establecimiento de la corte en Madrid, aunque el auge de la construcción de puentes en Castilla en el período 1575-1610 se explica por las crecidas hidráulicas que produjeron el derrumbe de antiguos puentes (García Tapia 2002: 451).

En general, en el Renacimiento, fueron muchos los puentes que se repararon, entre otros lugares, en Oviedo, Segovia, Trujillo, Medina, Congosto, Úbeda $^{55}$, Olivares y San Vicente de la Barquera (V. Llaguno 1977). De forma habitual, para la reparación de puentes, totales o parciales, se utilizaban

\footnotetext{
54 V. Megahey (2003).

55 En su reconstrucción participó el famoso arquitecto Andrés de Vandelvira.
} 
estructuras de madera que, normalmente, no han llegado a nosotros. Ejemplos de estos casos podrían ser los puentes de Vilanova en Orense y el de la Alhóndiga en Aranjuez ${ }^{56}$, y estas construcciones de madera solían asentarse sobre caudales fluviales arenosos (González Tascón 19992: 109). También podían utilizarse criznejas u otro tipo de sogas, como venía haciéndose en la construcción de puentes colgantes en América. Un puente importante en Madrid es el que intentó llevar a cabo Patricio Caixés hacia 1575. Hecho en madera, el puente tenía la intención de unir el Palacio del Alcázar de Madrid con la Casa de Campo, salvando el cauce del río Manzanares. También existían los puentes con barcas, puentes flotantes, bien de una sola barca con un barquero al que se le pagaba por cruzar a alguien a la otra orilla, bien de varias barcas en hilera, situadas de tal forma que podía realizarse fácilmente el traslado de una barca a otra. En cuanto a las nuevas construcciones, y con esto nos referimos a las nuevas construcciones de puentes de cantería, aparece un puente distinto al medieval, más ancho y no siempre unido a un concepto defensivo, un puente que "recupera su plena función de vínculo y pierde el carácter de frontera" (Sáenz Ridruejo 2008: 349) y que, edificado también con arcos de medio punto, es más regular y simétrico, tiende a la verticalidad y está más cuidado en sus aspectos ornamentales. En cualquier caso, se trata de puentes que requieren una sólida cimentación debido a las cargas que soportan en sus pilares y cimientos, y podían componerse tan solo de piedra o alternando piedra y ladrillo (González Tascón 19992: 115). Para su construcción se requería en varios casos de la preparación para la cimentación, bien por el vaciado de la ataguía o zona hincada de pilotes y estacas, bien por el uso de cangilones, cócleas, tornillos de Arquímedes y otras máquinas que podían contribuir en la limpieza de los cercos de cimentación. Posteriormente, tenía lugar la construcción de las pilas, con maderos longitudinales y transversales, con los que se confeccionaba un zócalo sobre el que se levantaba la sillería. Tras esto, se elaboraba la cimbra, generalmente avanzando desde los laterales hasta el centro

${ }^{56}$ Construido en la década de los 60 del siglo XVI, lo llevó a cabo Juan de Castro siguiendo las indicaciones proporcionadas por Juan Bautista de Toledo (González Tascón 19992: 109). 
y guardando la simetría. Junto a la cimbra, se utilizaban guindaletas y tornos que trataban de evitar los destrozos del viento. Las dovelas, eran talladas y colocadas con las grúas. En concreto, las grúas utilizadas en la construcción de puentes no eran muy diferentes a las empleadas en otros ámbitos de la construcción. De hecho, Juan de Herrera hizo diseños de las nuevas grúas, constituidas por dos ruedas de pisar y utilizadas masivamente en las obras del Monasterio. Estas grúas podían orientarse en la dirección más conveniente, a partir del uso de las tenazas romanas, muy al contrario de aquellas que continuaban usando el garfio con argolla (González Tascón 19992: 115-124).

De cualquier modo, es, a nuestro juicio, este, el lugar para citar ejemplos de puentes renacentistas construidos "a cal y canto" como los puentes sobre el Turia, en Valencia; los puentes de Ariza, Puente Genil y Plasencia; el puente de San Pablo, en Cuenca; y los puentes de Montalbán (Toledo) y Lerma (Burgos), entre otros. Además, tenemos noticia de que Juan de Herrera estudió los planos para una probable reparación del puente de Mérida sobre el río Guadiana (González Tascón 19992: 115). En cualquier caso, uno de los puentes renacentistas más impresionantes, por su tamaño y monumentalidad, y por su transcendencia como modelo de otros puentes, fue el puente de Almaraz sobre el río Tajo, que fundamentó las relaciones viarias entre Castilla y Extremadura gracias a su gran mole viaria constituida sobre pilares terminados por obra del artífice Pedro de Uría, en 1537 (González Tascón 19992: 124). Otro de los puentes renacentistas que creemos que en este contexto debe ser citado es el puente de Cuenca, población en la loma entre el Huécar y el Júcar, que precisaba en la época de un nuevo puente para comunicar el convento de San Pablo con el resto de la ciudad. El puente, tras pasar por las manos de distintos artífices (Juan del Pozo, Francisco de Luna) que ya habían construido sus altísimos pilares, terminó en manos del experto Andrés de Vandelvira, quien consiguió acabar las bóvedas y terminarlo completamente hacia 1589 (González Tascón 19992: 125-126).

\subsubsection{LOS PUERTOS}


Ligadas al desarrollo naval y a los descubrimientos geográficos realizados durante el siglo XVI, señalamos las estructuras portuarias como algunas de las obras hidráulicas más emblemáticas de esta época. Incluidas también en Los Ventiún libros..., en su diferente tipología, adecuada a la zona de instalación y a los fines de la obra (carga y descarga, defensa militar, etc.), las obras portuarias habían sido favorecidas ya por los Reyes Católicos y se beneficiaron de los progresos constructivos llevados a cabo en la época, aunque fueron varias las obras portuarias marítimas que fracasaron debido a los escasos conocimientos oceanográficos (Sáenz Ridruejo 2008: 381). Los conocimientos de la ingeniería portuaria de que disponemos provienen, en su mayor parte, de la obra del cosmógrafo portugués Pedro Teixera Albernas, titulada Descripción Geográphica de algunas Provincias de España y redactada un poco después de la muerte de Felipe II, entre 1622 y 1630 (González Tascón 19993: 137), que en su obra detalla con sumo cuidado las actividades portuarias de toda la península ibérica.

Sabemos que los puertos disponían, habitualmente, de lo que se ha denominado "diques de abrigo", es decir, muelles y contramuelles que definían una dársena cerrada, útil para las actividades de carga y descarga de las mercancías en los barcos. En este lugar de la tesis, simplemente tenemos espacio para citar, entre las distintas obras portuarias ejecutadas en el Renacimiento, algunos puertos del Mediterráneo, sobre costas abiertas, como los de Cartagena, Mahón, Málaga o Palma de Mallorca; los puertos del Cantábrico, como los puertos fluviales de Bilbao o Avilés o el situado en la ría de El Ferrol, o los diques convergentes de San Sebastián y Gijón (Sáenz Ridruejo 2008: 379). En general, a estos puertos llegaban navíos procedentes de Flandes, Inglaterra y Francia, y también navíos españoles. En cuanto a las mercancías que transportaban, señalamos la importancia de la exportación de ferrerías y otros objetos fabricados con hierro en el País Vasco, de las lanas de Castilla y algunos productos tintóreos, así como la fruta agria del sur (naranjas, limones) y la madera de la tierra (castaños, nogales y robles). En lo que se refiere a la importación, Asturias importaba mucho trigo, vino y aceite de oliva de los 
puertos sureños, así como paños, pero se dedicaba casi enteramente a la exportación de ballena y su grasa. Galicia también tenía un déficit de cultivo de trigo que suplía con el cultivo de mijo y centeno y, como Asturias, con la pesca de ballena en alta mar y con la pesca de truchas y salmones en sus ríos que posteriormente exportaba (González Tascón 19994: 144-153). El equivalente a la caza de ballenas del Norte era la pesca de atún del sur, comercio que se regulaba desde Sevilla tras bordear el cauce fluvial del Guadalquivir. Las instalaciones portuarias de Sevilla comprendían grandes muelles que facilitaban el atraque de barcos para la carga y descarga de mercancías, provenientes del Otro Mundo o dirigidos a Ultramar. En esta época, “Sevilla era la cabeza de un comercio internacional de gran envergadura" (González Tascón 19993: 158), donde se importaban y exportaban todo tipo de objetos y materiales procedentes de muy diversos lugares.

En cuanto a los puertos mediterráneos, en conjunto tenían rutas comerciales con Italia, y por ellos se exportaba fundamentalmente la producción agrícola de sus fértiles campos, y aquí incluimos los de Marbella, Fuengirola, Málaga, Almería, Cartagena y Valencia, conocido este último por su exportación de sedas y panes de azúcar, así como Tarragona y Barcelona, puerto este último que se vio visto en grandes dificultades para su construcción, pues por el clima se creaba una playa que continuamente alargaba la longitud del dique o muelle de abrigo que lo cobijaba.

\subsubsection{LAS PRESAS}

Si hay una obra hidráulica de envergadura en Hispania, por su transcendencia, desde la Antigüedad, son las presas, siendo las hispanoamericanas algunas de las más conocidas en el mundo por su altura y variada tipología. Entre las presas romanas presentes en Hispania más reseñables se encuentra la de Proserpina, cerca de Emérita Augusta (actual Mérida), fabricada, como otras muchas, con la técnica del "muro y espaldón", es decir, se trata de un muro vertical que lleva adosado un espaldón de tierras que actúa como muro de resistencia cuando, debido al empuje del agua, el 
muro no es suficiente para sujetarse verticalmente. Otra de las presas llevadas a cabo con esta técnica durante el Renacimiento fue La Fresneda (hoy Granjilla), cerca de El Escorial, de la cual aún se mantienen en pie dos de sus estanques (González Tascón 19994: 214).

Fue fundamentalmente en la segunda mitad del siglo XVI cuando se construyeron en España muchas presas, con la intención de acumular el agua de la lluvia para utilizarla durante el verano en los regadíos en los que fuera necesaria. La mayoría de ellas eran presas "de gravedad" (rectas) aunque también hemos encontrado planos de presas en curva o "de bóveda" 57 . Las presas más significativas en ese momento eran las de Tibi en Alicante y la de Almansa en Albacete.

La presa de Tibi, la presa más importante del mundo por su gran altura (mide más de 40 metros) fue una obra renacentista monumental que se llevó a cabo, sin ayuda económica de la Corona, entre los años 1579 y 1594 y que pretendía, con su magnitud, albergar la cantidad de agua necesaria para regar las entonces secas tierras alicantinas. Fue Pere Izquierdo, habitante de Mutxamel, quien realizó las primeras trazas, cubriendo con la presa los cerros del Mos y de la Cresta. Tras la aprobación real, desprovista de ayuda económica, comenzaron en 1579 los trabajos, que solo pudieron continuarse con préstamos o censales, aunque Felipe II también envió, para este cometido, técnicos y expertos competentes que estaban a su servicio. Tras muchas opiniones emitidas, fue Cristóbal Antonelli quien realizó el proyecto de la presa de Tibi, cuyos planos aún se conservan, y que finalizó hacia 1594. La gran mole pétrea que constituye la presa tiene un talud aguas arriba casi vertical, mientras que el de aguas abajo es escalonado. Tanto “el zócalo como los parámetros exteriores están formados por buena sillería caliza, siendo el interior un simple hormigón de mampostería gruesa" (González Tascón 19994: 220).

Por otro lado, la presa de Almansa, cuya construcción tenía por fin

\footnotetext{
${ }^{57}$ Por nuestros conocimientos, estas serían las primeras presas "de bóveda" del mundo (V. González Tascón 19994: 216).
} 
albergar las aguas del arroyo Belén la Grande, fue durante un tiempo considerada una obra islámica, pero posteriores estudios desvelaron que su capa inferior, puesto que tiene dos, es de época renacentista, mientras que la superior fue construida seguramente en el siglo XVIII. La presa del siglo XVI conservada está emplazada en el mismo lugar en el que anteriormente hubo una presa de características posiblemente similares. Por distintos avatares, la obra no comienza hasta 1584, aunque se terminó con rapidez, en tres años, gracias a las trazas y dirección de Pedro de Aguirre y posteriormente a las de su ayudante Juanes del Temple. “Tipológicamente la presa tiene una planta curva, con el paramento de aguas arriba vertical, mientras que el de aguas abajo es escalonado, definiendo un plano medio ideal que forma 45 grados con el plano horizontal" (González Tascón 19994: 222). Otras presas importantes en la época fueron las de Elche y las de la Casa de Campo y la de Ontígola, estas dos últimas también conocidas como las "nuevas presas holandesas de doble muro" (V. González Tascón 19994: 225).

\subsubsection{AZUDES Y CANALES}

A diferencia de las presas anteriormente revisadas, destinadas a la acumulación o almacenamiento de agua, los azudes sólo pretenden derivar una parte del agua de un canal o río hacia otro lugar, manteniendo cierto nivel hidráulico allá donde se emplazan (V. González Tascón 19994: 228). Los fines para los que se situaban dichos azudes podían ser los riegos, por un lado, pero también la formación de los caudales necesarios para mover ingenios y máquinas hidráulicas, como los molinos ${ }^{58}$.

Generalmente, son pilotes hincados y unidos con maderos rellenos de piedra lo que constituye la cimentación del azud, por tanto, esta es bastante

58 A pesar de esta aclaración realizada por González Tascón, en nuestros textos renacentistas encontramos el término presa para denominar a una obra hidráulica de menor tamaño empleada para usos similares a los de los azudes: "Y por ser el fundamento donde se avía de hazer la pressa (para atajar el río y encaminallo al molino) de arena y cascajo, huvo siempre dificultad en ello, porque siempre que hazían la pressa con cal y arena, por ser materia muy fuerte, socavava el agua por debaxo de la fábrica y se salía por allí" (Rojas, Teórica fortificación, 1598, fol. 96r). "Libro 9, que trata de los diversos modos de azutes (o presas de ríos)" (Juanelo Turriano, Veinte y un libros, a. 1605, fol. 153v). 
permeable y flexible. "En los azudes importantes, la toma de agua se hacía mediante un bocal de piedra reforzada y provista de tajamares para evitar la erosión" (González Tascón 1999: 229).

Los intereses en cuanto al regadío y los usos industriales produjeron en época de Felipe II un crecimiento del número de azudes con esclusas, que tuvieron que revisarse, debido a los intereses de navegación fluvial, fundamentalmente en el Tajo, por ingenieros como Juan Bautista Antonelli (V. imagen azud de piedra en Pseudo-Juanelo Turriano (c. 1605): fol. 164r).

Por lo que respecta a los azudes que derivaban agua a los molinos hidráulicos, y que, por tanto, los abastecían de su "elemento motor", hemos de constatar que se realizaban en la mayoría de las ocasiones con forma oblicua, por ser esta forma de azudes la más segura a la hora de controlar las avenidas fuertes de agua y su regularidad, comparado con las procedentes de azudes perpendiculares al río (González Tascón 19995: 242). Sin embargo, en los lugares en los que el agua frecuentemente escaseaba, como Extremadura, se establecieron azudes de cantería más notables, de contrafuertes, entre los que destaca, por su importancia y antigüedad, el de Trujillo, conocido también como Albuera de San Jorge. Aunque de manera general, a lo largo del XVI fueron muchos los caces de madera que se sustituyeron por caces de piedra, como la obra que llevó a cabo el ingeniero Aracil en el acueducto de Castillazuelo.

Respecto a los canales, acequias y otras conducciones de agua, fueron muchas las autorizadas por la Corona en aquel entonces destinadas al riego, y frecuentemente estaban ligadas a azudes para el riego de aquellos terrenos que estaban por encima del nivel del canal. Las distintas acequias provenían en ocasiones del sangrado de grandes ríos, como la acequia de Colmenar de Oreja constituida en la margen derecha del Tajo. En aquel tiempo se volvieron a construir canales subterráneos y sifones tal y como hicieran los romanos (V. González Tascón 19994: 233), como los recomendados por el ingeniero milanés Sitoni en 1578. 
En lo que se refiere a los abastecimientos de agua, llegados a fuentes públicas desde fuentes, manantiales $u$ otros cauces cercanos a las poblaciones...todos ellos se realizaban por medio de conductos, tramas de caños, arcaduces, arcas o atanores (V. imagen en Lobato (c. 1585), fol. 9), y en ocasiones gracias a la reforma de antiguas conducciones romanas ${ }^{59}$ se compusieron conducciones siguiendo distintos planes de abastecimiento, como el de Juan de Herrera en Valladolid o el de Juan del Ribero en León (García Tapia 2002: 441). En otras circunstancias, cuando el suministro de agua estaba a menor altura que la fuente a la que debía llegar, se recurría a inventores para el trazado de máquinas elevadoras de agua, como ocurrió en Toledo.

Una obra significativa destinada al abastecimiento de aguas construida durante el Renacimiento es el acueducto de los Arcos en Teruel, obra de Pierres Vedel. Compuesto por un doble nivel de arcos en su parte fundamental, el acueducto cubre un recorrido de 3 kilómetros, desde la captación de las aguas hasta su distribución por la ciudad, y aparece recogido como modelo de acueducto en Los Ventiún libros... (Sáenz Ridruejo 2008: 366-367).

Muchas veces el destino de estos abastecimientos no eran las fuentes de agua para el consumo e higiene de los habitantes de una población, sino las fuentes de los jardines, lugares de "naturaleza urbanizada", propios para el ocio y esparcimiento, como los Sitios Reales de Felipe II: Aranjuez, Casa de Campo, Segovia y El Escorial (García Tapia 2002: 442).

\subsubsection{ALJIBES, POZOS Y CISTERNAS}

En lo que respecta a los depósitos de almacenamiento y conservación de agua en las urbes, eran frecuentes los aljibes y las cisternas. Aunque Nicolás García Tapia afirma que "para conservar el agua se recurría a depósitos que recibían el nombre de cisternas cuando recogían el agua de lluvia, y aljibes si el agua procedía de una fuente o manantial", en nuestros textos ambos se utilizan

\footnotetext{
${ }^{59}$ Señalamos aquí la reparación del acueducto de Segovia encomendada a Fray Juan de Escobedo por Isabel la Católica (García Tapia 2002: 441).
} 
para los dos fines, quizá debido a que entre este par de términos, citados por Germán Colón, se da una "lucha entre una voz de estirpe arábiga y su convivencia o rivalidad con voces de procedencia diversa" (Colón 20021: 35). Por otra parte, los pozos fueron los elementos de abastecimiento no solo de viviendas individuales, monasterios y palacios, sino también de ciudades enteras, como Cádiz, que en el siglo XVI había perdido su acueducto romano y por tanto tuvo que abastecerse del agua que manaba de un único pozo (V. González Tascón 1998: 326) o La Coruña, que disponía de varios pozos en el interior de la muralla.

\subsubsection{NORIAS Y AZUDAS}

Entre las obras de ingeniería hidráulica llevadas a cabo en el siglo XVI destacan las obras de regadío, por las cuales se aumentaron las zonas de cultivo, hecho de singular importancia pues de ahí provenían tanto materias primas, tanto las agrarias como otras ligadas a la industria textil y a la tintórea. Además de la ampliación de estas zonas de cultivo de regadío, en el Renacimiento crecieron los lugares de almacenamiento de grano. En concreto, fueron dos los artificios utilizados con el objetivo de regar los terrenos próximos a las corrientes de agua: las norias y las azudas. Las norias no dejaban de ser artificios de sangre, es decir, su movimiento se debía al empuje de una bestia, mientras que las azudas, más difundidas que las norias, no precisaban de animales de tiro ni de engranajes, sino que el propio movimiento de la corriente facilitaba el giro, y además proporcionaba caudales mucho mayores que los de la noria. Entre las más famosas, las azudas de El Carpio, también conocidas como Grúas, proyectadas en 1563 por el "ingeniero ermitaño" D. Ambrosio Mariano Azaro de San Benito, que aún en el siglo XIX, como dice el Diccionario de Madoz, continuaban funcionando normalmente.

\subsection{INGENIOS Y MÁQUINAS EN PROCESOS INDUSTRIALES}

\subsubsection{EL AGUA}

Hay que reconocer en el agua dos aspectos relacionados con la materia 
que aquí nos ocupa, la ingeniería: por un lado, el agua ha sido elemento motor de gran número de ingenios hidráulicos; por otro, el agua ha sido una de las materias primas que se han utilizado en muchos de los procesos (pre)industriales, sin la cual no hubiera sido posible llevar a cabo esas tareas: curtir cueros, teñir paños, moldear barro, cocer y lavar material diverso...

Podemos resumir las técnicas empleadas con el agua como aquellas que se dedican a su captación, conducción y almacenamiento, que son las que hasta ahora hemos revisado gracias a las breves descripciones aparecidas sobre azudes, canales, acueductos, puertos, presas, etc. (V. Córdoba de la Llave 2002: 254). A partir de ahora veremos distintos usos del agua, que pueden ser agrícola, industrial o doméstico, pero en cualquier caso se tratará de un proceso preindustrial donde el agua es un elemento fundamental para el tratamiento de una materia prima, aunque, en algunos casos, el agua también pueda actuar como elemento motor.

\subsubsection{LOS MOLINOS Y OTROS INGENIOS INDUSTRIALES}

No nos detendremos demasiado en el apartado de los molinos, pues el tema ya ha sido tratado en los capítulos dedicados a las Notas (c. 1585) de Lobato y a Los Ventiún libros. El molino, una de las máquinas más importantes a lo largo de la historia, se desarrolló especialmente durante el Renacimiento, gracias a las condiciones particulares del imperio que propiciaron la aparición de una variada tipología molinera que fue utilizada, de manera general, para muy diversos fines, que abarcaban desde la preparación de harinas, hasta el encurtido de paños y el triturado de pólvoras, piedras y otros materiales.

Movidos, bien por fuerza animal o humana, bien por la fuerza del viento o del agua, los molinos han sido considerados "las máquinas más complejas y poderosas de la época y el símbolo de la era preindustrial" (García Tapia 19972: $8)$.

Los molinos hidráulicos eran muy comunes en aquel tiempo y en general se clasifican en dos tipos fundamentales, de acuerdo con la posición de la rueda 
o muela que, colocada en el interior de un cauce de agua, o movida por el agua que le llegaba desde otro lugar, producía el movimiento del molino (V. González Tascón 1987: 18). Dentro de los molinos de rueda vertical, los más habituales eran los denominados aceñas o molinos de aceña, enclavados en un determinado río o canal, aunque también existían los molinos o aceñas móviles, conocidos como molinos de barcas, que se trasladaban por los ríos, de pueblo en pueblo, tras las moliendas. Asimismo, encontramos referencias a los molinos de canal, es decir, molinos de ruedas verticales a las que el agua llegaba por medio de un canal o conducto, que podía ser abierto o cerrado. En el caso de que esta canal o conducto fuera cerrado y se fuera estrechando, estaríamos ante un saetín, pieza de uno de los denominados molinos de bomba.

\footnotetext{
Esta canal de molino de bomba va muy differente, por razón que, quanto más se va acercando a la rueda, tanto más se va estrechando, de modo que donde despide la agua no es más de medio palmo de ancho, en quadro, la salida de la agua. La qual va en esta forma que aquí está señalada (Turriano, ca. 1605: 290r).
}

En cuanto a los molinos hidráulicos de rueda horizontal o rodezno, es decir, molinos movidos por una rueda de álabes o paletas, encontramos en la época los molinos de cubo, molinos que poseían un cubo o depósito en el que se almacenaba el agua para que, al salir por uno de sus orificios, o por una saeta o saetín, lo hiciera con la presión necesaria para mover el rodezno. También hallamos en los textos los molinos de balsa, que constaban de un estanque o pesquera en el que se recogía el agua que se dirigía al saetín. Pero si hay un molino hidráulico innovador en la época renacentista, ese es el conocido como molino de regolfo, máquina que se ha considerado un precedente de las turbinas actuales. En este tipo de molino, el rodezno gira por fuerza centrífuga, pues está rodeado por una pared cilíndrica o cubete en el que entra el agua por una abertura. Cuando solamente se llenaba de agua la mitad del cubete, se denominaban molinos de medio regolfo.

Respecto a los molinos cuya fuerza motor la ejercen otras fuerzas, encontramos en el Renacimiento los molinos de sangre, que podían moverse por 
fuerza humana o animal y los molinos de bestias, que eran aquellos dirigidos por la fuerza de animales de carga. También aparecen en nuestros textos los molinos de viento, en los cuales el molinero debía afanarse para orientar su caperuza hacia la dirección del viento, molinos que en aquel tiempo eran muy habituales en Flandes.

Prestaremos sin embargo especial atención a las diversas finalidades a las que podía destinarse el uso de molinos y otros ingenios mecánicos similares: almazaras y trapiches.

En las almazaras podía molerse la aceituna para obtener aceite, y su fuerza motriz podía ser de sangre o hidráulica; en cualquier caso, las ruedas podían ser verticales $u$ horizontales, los rodeznos y su mecanismo era similar al de los molinos anteriormente revisados. Los trapiches podían cualquier elemento motor y su uso, generalizado a partir de su empleo en Latinoamérica, se debe a la importación de la caña de azúcar. Aparecido en Brasil, se trataba de un ingenio mucho más ágil, que reducía el tiempo de empleo en la obtención de azúcar, pues permitía trabajar con la caña de azúcar cortada, en vez de troceada.

En lo que respecta a los ingenios que se valían de mazos o levas, mencionamos aquí los batanes (V. Sánchez Orense, 2007) o molinos traperos. Los batanes eran máquinas antiguas, aparecidas ya en el siglo $X$ y eran una de las máquinas más populares en el siglo XVI (González Tascón 1998: 260). “A partir del siglo XI, las aceñas o molinos de rueda vertical, que hasta entonces sólo se habían utilizado para moler diversos productos (cereales, aceitunas, sal) entre dos moleras de piedra, una solera fija y una corredera móvil, encuentran nuevas aplicaciones en las industrias que requieren el uso de mazos que golpean mecánicamente gracias al aprovechamiento de la energía del agua" (González Tascón 2008: 110). Además de los batanes para enfurtir paños, este sistema de levas se utilizaba en las ferrerías para labrar hierro, industrias más pesadas propias del norte de España, en las que se forjaba el hierro de grandes dimensiones para después labrarlo en cada una de las formas que fueran 
necesarias. En el siglo XIII, en el País Vasco se dio el paso de las ferrerías masuqueras (aquellas que empleaban mazos) a las de fuelles o barquines (González Tascón 2008: 111). El auge de las ferrerías guipuzcoanas durante los siglos XV y XVI fue notable, aunque también estaban generalizadas por Cataluña, Cantabria, Asturias y Galicia. Además fue significativo el uso de fanderías, que es el término acuñado por González Tascón (1998: 280) con el que, por los datos con los que contamos, y a pesar de no encontrarse en nuestro corpus, denominaban en la época "a las factorías hidráulicas dedicadas a la transformación del hierro en bruto o tocho de forja en chapas delgadas y de gran longitud, empleando para ello medios mecánicos que sustituyen la lenta y penosa forja con el martinete" (González Tascón 1998: 280).

Otra de las máquinas que fueron accionadas mediante rueda hidráulica fueron las serrerías, documentadas a finales de la Edad Media. En ellas, el eje de la rueda solía llevar una leva que permitía el movimiento de una hoja que cortaba madera. Muchas aparecen documentadas en herencias, compras y ventas y fueron muy utilizadas en América (V. González Tascón 1998: 282). Fue también importante en la época el ingenio destinado a fabricar pólvora, que se elaboraba con tres elementos principales: salitre, cal viva y cenizas duras de madera. Esta mezcla se incorporaba a unos recipientes provistos de una apertura, por la que, pasado el tiempo necesario para ello, se canalizaba el agua salitrosa sobrante. Ese salitre se iba controlando y se acoplaba más a la mezcla siempre que era necesario.

Aunque la más conocida estuvo situada en Játiva, la industria papelera también logró adquirir gran importancia en España, fundamentalmente al sur, donde se situaron grandes factorías papeleras como las de Ceuta, Córdoba, Granada, Sevilla y Toledo. A lo largo del siglo XV se difunde también el papel de filigrana, aquel que lleva el sello del fabricante marcado con un hilo tan fino que sólo es visible en transparencia. Con esta finalidad, fue de importancia en Castilla el molino del Monasterio del Paular (cerca de Rascafría). A grandes rasgos, podríamos decir que la fabricación de papel se realizaba a partir de la 
recogida de trapos, que se separaban por colores y troceaban, para después pasarlo todo por un torno donde se le quitaba el polvo, la tierra, etc. A continuación los trapos se dejaban en remojo en un recipiente durante un par de semanas, tras las cuales se trituraban en una tinas gracias al golpeo de unos mazos; después esos trapos se molían y se homogeneizaban, para posteriormente pasar al secado del papel, colocándolo entre bayetas.

Por otra parte, fue grande el interés del monarca Felipe II por establecer una factoría de grandes dimensiones para acuñar moneda, pues esta venía acuñándose a mano en pequeños lugares como Burgos, Toledo, Segovia, La Coruña, etc. Por distintos motivos, sería Segovia el lugar elegido para emplazar el Real Ingenio, que seguiría las directrices de aquel de Hall, próximo a la ciudad de Innsbruck, puesto que el Real Ingenio fue idea del archiduque Fernando de Austria, primo de Felipe II. Será en 1583 cuando, a partir de un molino de papel existente en el lugar, que contaba con agua abundante, comenzarían las obras del ingenio, supervisadas por arquitectos y técnicos alemanes. El Real Ingenio de la Casa de la Moneda de Segovia sería una obra de cuyo buen funcionamiento se sentiría orgulloso siempre Felipe II.

\subsubsection{OTRAS INVENCIONES: LA IMPRENTA}

Aunque la invención de la imprenta, atribuida a Hans Gutenberg (c. 1400-1468) se sitúa a mediados del siglo XV, fue a finales de este siglo y principios del XVI cuando se produjo el que, en palabras de Cardwell (1996: 64) se ha considerado "uno de los inventos más poderosos de todos los tiempos": la imprenta mediante móviles. No son muchas las referencias a imprentas que encontramos en nuestros textos del corpus, a pesar de que estamos seguros de que fue de gran importancia en la época y gran parte de los textos que hemos manejado estaban impresos. La imprenta aumentó tanto la rapidez como la cantidad de las difusiones escritas, lo que supuso mayor accesibilidad, de manera general, al libro o al texto, durante el siglo XVI y también posteriormente, pero sabemos que la difusión de la imprenta en sí, es decir, de la maquinaria de la imprenta, fue bastante lenta, desde su origen en el segundo 
tercio del siglo XV (V. Verger 1999: 111).

Aunque la Imprenta Real inaugurada en Alcalá de Henares por Felipe II no comenzó a emitir trabajos, de mano de Tomás Junti, hasta 1594, fueron muchos los talleres que se instalaron en España durante la segunda mitad del siglo XVI, siendo los más significativos, quizás, los de Sevilla, Barcelona y Salamanca (V. Clair 1998: 246-249). 


\section{ESTUDIO DEL LÉXICO}

\subsection{TIPOLOGÍA DE LAS UNIDADES LÉXICAS}

De acuerdo con Porto Dapena 2002: 51, "pueden distinguirse tres tipos de lexías: la lexía simple, que coincide con la palabra; la lexía compuesta, conjunto de palabras más o menos integradas y que vienen a equivaler a la noción tradicional de 'palabra compuesta' 60 y, por último, la lexía compleja, que es una construcción fija lexicalizada, esto es, lo que aquí llamamos locución61".

El léxico de los ingenios y máquinas contenido en nuestro glosario está formado por 992 lexías simples, 47 palabras compuestas o compuestos sintagmáticos y 13 locuciones.

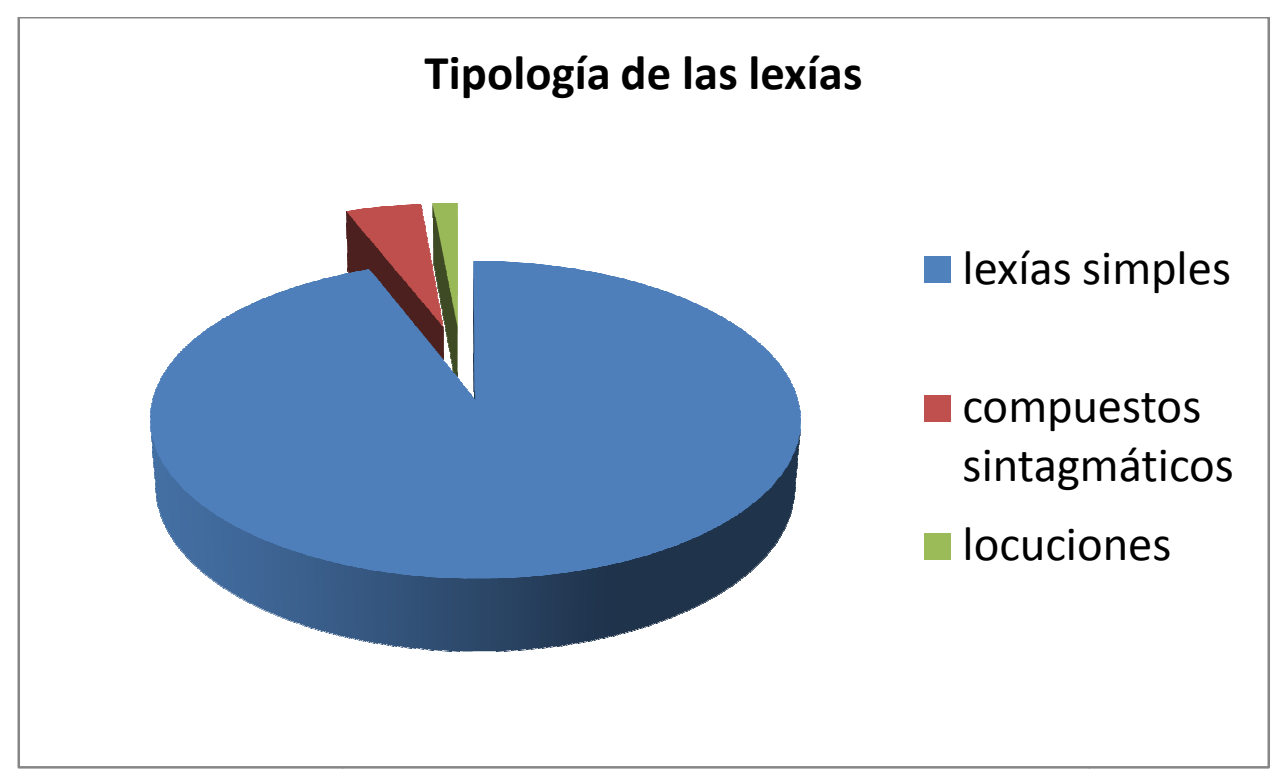

\subsection{DISTRIBUCIÓN CATEGORIAL}

El vocabulario especializado se caracteriza por un predominio de los sustantivos frente al resto de categorías gramaticales.

“El léxico (científico) está compuesto por adjetivos, verbos $\mathrm{y}$, fundamentalmente, sustantivos que, en una gran proporción, se construyen

${ }^{60}$ Equivaldría a lo que se ha denominado compuesto sintagmático.

${ }^{61}$ Porto Dapena entiende por locución "una construcción estable, fija, [...] (que ofrece) un sentido que no equivale a la suma de sus componentes" (Porto Dapena, 2002: 151). Ver también la definición de estas que hace Corpas Pastor (4.6.2.2). 
mediante la combinación de los llamados formantes clásicos, griegos y latinos, como veremos más adelante; aunque igualmente es posible, como también veremos, construir términos recurriendo a otros procedimientos" (Gutiérrez Rodilla, 2005: 28).

Entre las 992 lexías simples de nuestro fichero, registramos 698 sustantivos, 161 verbos, 122 adjetivos y 11 adverbios.

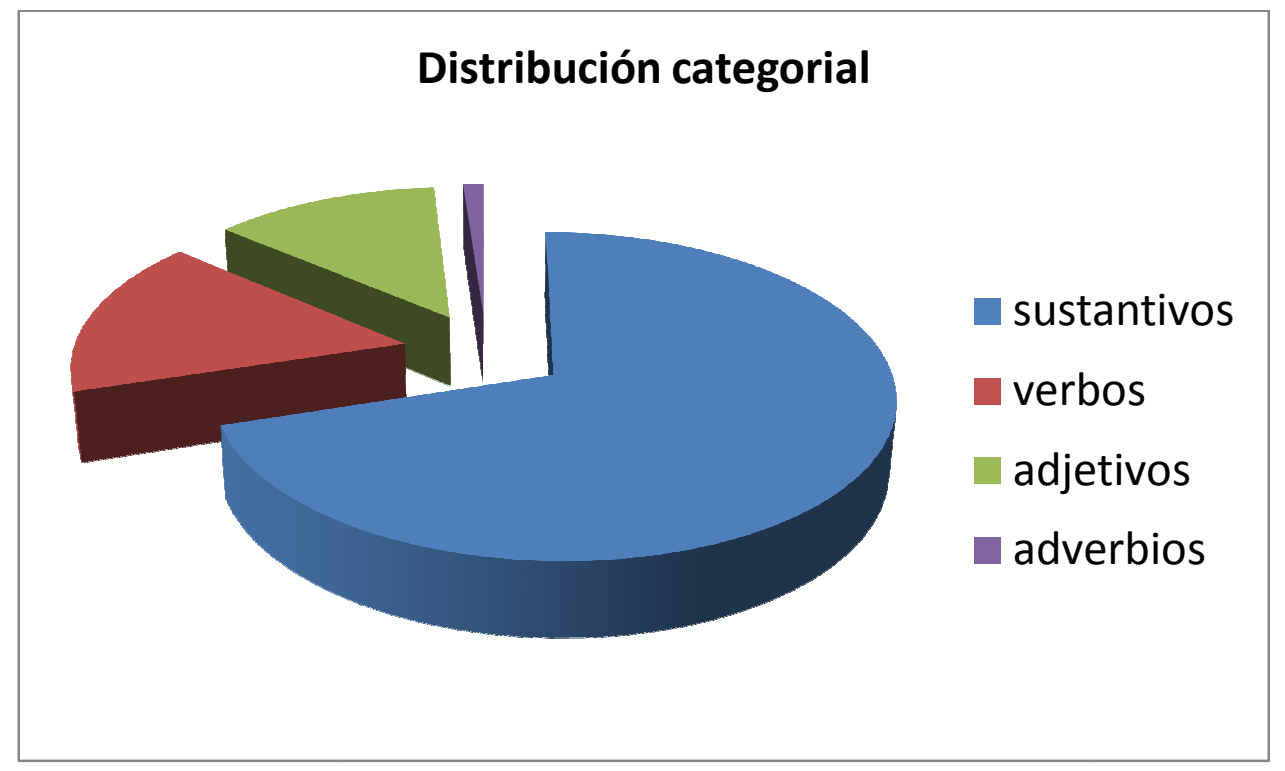

\subsection{PROCEDENCIA DE LAS VOCES}

De manera general, consideramos que el español, al igual que otras lenguas romances peninsulares, no es sino el resultado de la evolución de la lengua latina (Colón Doménech 2002¹: 19). Sin embargo, para abordar el estudio del léxico del idioma, desglosamos, por un lado, las voces patrimoniales, es decir, aquellas que proceden del uso ininterrumpido del idioma desde lo que consideramos sus orígenes, de las voces neológicas, que son aquellas que se han incorporado posteriormente, bien como préstamos, bien como creaciones morfológicas propias.

\subsubsection{ORIGEN PRERROMANO}

En el castellano, son numerosas las huellas de las lenguas paleohispánicas en el léxico común y en la onomástica de las lenguas 
peninsulares. En el léxico que nos ocupa, señalamos el origen prerromano de voces como pieza 'parte', 'fragmento', que procede del celta *pĕttı̆a 'pedazo', voz que definimos como "cada una de las partes que componen un instrumento o máquina". Otras voces registradas son balsa 'hueco en el terreno que se llena de agua', barro y barra. De acuerdo con el DECH, balsa es una voz protohispánica, probablemente ibérica, común al castellano, al catalán y a algunos dialectos occitanos. Respecto a barro, el DECH solo se atreve a señalar su origen prerromano, mientras que el DRAE concreta, además, que barro quizás sea de origen celta (cf. irl. medio broch 'basura', y galo barros 'matojo'). En cuanto a barra, tenemos informaciones muy distintas de su origen: el DECH afirma que es una voz prerromana, común a todas las lenguas romances menos el rumano y baraja la posibilidad, teniendo en cuenta su difusión geográfica, de que se trate de una voz que proceda del céltico *barros 'penacho, fronda', 'punta, cumbre'. Sin embargo, el DECH recoge también opiniones, como la de Brüch, que niegan ese origen debido a la dificultad de llegar a 'barrera, barra' partiendo de 'penacho, fronda'. Ahora bien, el DRAE sostiene el origen incierto de barra y considera además que quizás provenga del latín vulgar *barra.

En cuanto a estancar, el Diccionario de Corominas afirma que probablemente provenga del prerromano *tanko 'yo sujeto', 'yo fijo'; sin embargo, para el DRAE, estancar viene del latín vulgar *extancāre, y este del celta *ektankō 'fijar', 'sujetar'; cf. tankar.

Encontramos otras seis voces "de origen incierto, probablemente/quizás prerromano": artesa, boñiga, gancho, mota, rosca y tarugo. Artesa 'cajón cuadrilongo' (Juan Ruiz, 1221), es una voz común solamente a dos lenguas romances: el portugués y el gallego, para la que el $\mathrm{DECH}$ propone que se compare con el vasco artesia 'el agujero, la grieta' ${ }^{162}$. Boñiga, procede seguramente de una base *bunnica ${ }^{63}$ emparentada con el catalán bony 'buto, chichón', gasc.

62 El DRAE dirá de esta voz simplemente "de origen incierto", sin especificar su posible origen prerromano.

${ }^{63}$ La boñiga o excremento animal era utilizado para calentar los hornos. Aunque boñiga está en el margen del área léxica que nos ocupa, hemos decidido incluir esta voz en el 
bougno 'íd.', fr. ant. y dial. bugne 'id.'. Libro de la montería ( $1^{\mathrm{a}}$ mitad del siglo XIV). Sobre gancho (h. 1100, qanğ $\hat{u} l l u$ 'abrojo'; a. 1331, gancho), palabra antigua en castellano y portugués, el DECH sí que considera la posibilidad de que proceda del céltico *ganskjo- 'rama'64. De otro lado, de acuerdo con este diccionario, tarugo 'trozo de madera' (Lz. De Ayala, 1386) estaría emparentado con los galos tarinca 'perno o clavija' y taratrum. En cuanto a mota, es una voz que ya aparece documentada en 1218 y rosca está datada por primera vez hacia 1300.

De cualquier modo, hemos de recalcar la importancia de los préstamos de las lenguas prerromanas, porque con frecuencia designaban conceptos cuya equivalencia no existía en latín (Torrens Álvarez 2007: 126). A propósito de las voces prerromanas o probablemente prerromanas de nuestro glosario, destacamos que la mayoría de ellas están relacionadas con la naturaleza ${ }^{65}$ y designan materiales (barro, boñiga), elementos naturales (balsa, mota) ${ }^{66}$ o actividades propias del medio natural (estancar). También significan objetos de usos múltiples, con alguna forma específica, construidos con alguna materia, como la madera (artesa, tarugo), el metal (gancho, barra) o que pueden fabricarse de varios materiales (rosca) e incluso tener cualquier forma (pieza). Todas, excepto el verbo estancar, son sustantivos.

\subsubsection{PALABRAS PATRIMONIALES}

Algo más de una cuarta parte de las voces que constituyen nuestro glosario son palabras patrimoniales, es decir, contamos con unas 270 palabras que, al contrario que los préstamos ${ }^{67}$, provienen de la lengua que constituye la base fundamental del idioma $\mathrm{y}$ han sido utilizadas de forma continua $\mathrm{y}$

estudio porque solo aparece en una ocurrencia del corpus y esta pertenece a Los ventiún libros de los ingenios y máquinas.

64 Para gancho, el DRAE solo dice "de origen incierto".

65 "En cuanto a los elementos léxicos de substrato [Menéndez Pidal] advierte que se conservan en los nombres de lugar o en significaciones referidas a la vida material o a la naturaleza, ya que «las esferas superiores de la actividad humana fueron invadidas totalmente por el vocabulario latino»" (Abad Nebot 2008: 84).

66 Elementos que también pueden construirse de forma artificial, tal y como aparece en el corpus del DICTER.

67 V. Tagliavini 1973: 368. 
popular. En el caso del español, como sabemos, las palabras patrimoniales no son sino palabras latinas transformadas o modificadas con el uso oral a lo largo de los siglos.

Entre estos términos encontramos engeño, doble popular de ingenio 'máquina o artificio mecánico', del latín ingěnŭum 'íd.', y distintos tipos de ingenios o máquinas, como aquellas para levantar pesos, tales como cabra, del latín căpra 'íd.' y cabria, de căprĕa 'cabra montés' y gavia68 'andamio con forma de jaula'; otra máquina común, carro69, para transportar cargas, y algunas máquinas para moler, como lagar ${ }^{70}$, molino ${ }^{71}$ y trapiche ${ }^{72}$, que en nuestro corpus designa un 'molino para moler metales', forma que es resultado de una alteración mozárabe del latín trăpētus 'molino de aceite', que a su vez procede del griego tрanєıv. También registramos torno 'máquina para labrar piezas', voz del latín tornus 'íd.' y este del griego tópvos 'torno, instrumento de

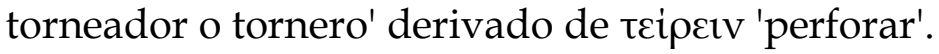

Son muchas las palabras patrimoniales que designan una parte o pieza de una máquina o instrumento, como por ejemplo árbol 'barra fija o giratoria que transmite la fuerza motriz en una máquina', bolsa 'grosor de una pieza con forma de tuerca', del latín bŭrsa 'íd.' y este del gr. ßúpor 'cuero' 'odre'; huso ${ }^{73}$ 'tornillo de gran tamaño' y pierna ${ }^{74}$ 'pieza alargada y móvil'. Entre las voces patrimoniales que señalan piezas de máquinas, destacan en número las que tienen origen zoonímico: asno y su sinónimo caballo 'tabla para elevar cargas' (también tiene este significado el término corazón $\left.{ }^{75}\right)^{76}$, cigüeña 'codo de torno $\mathrm{u}$

${ }^{68}$ Del lat. căvĕa 'jaula'.

${ }^{69}$ Del lat. carrus 'íd.'.

${ }^{70}$ Del lat. lăcŭs 'balsa o depósito de líquidos'.

${ }^{71}$ Del lat. tardío molinum 'íd.', abreviación de saxum molinum 'muela'.

72 "Los que llaman ingenios para moler los metales, son muy sabidos y usados dos modos de reduzirlos a hazerlos a harina con piedras: llaman al uno trapiche y maray al otro" (Alonso Barba 1640: 72v).

${ }^{73}$ Del lat. fusus 'íd.'.

${ }^{74}$ Del lat. pěrna 'muslo y pierna juntos, en un animal'.

${ }^{75}$ Del lat. cŏr 'íd.', que recibió probablemente los dos sufijos aumentativos -aceum y onem.

76 "Hay otros que le ponen unas tablas de madera gruessa, que tiene a los quatro ángulos quatro sortijas de hierro con quatro pedaços de cuerda que se vienen a asir con la cuerda E. Este pedaço, Q, tiene diversos nombres entre officiales; llámele cada qual como 
otros instrumentos', hembra 'pieza que, en algunos instrumentos y artificios, tiene un hueco o agujero donde se introduce o encaja otra' y macho 'pieza que entra en la hembra', langosta 77 'dispositivo formado por dos tablas unidas por un eje', lobo 'garfio de hierro para encajar piezas' y toro 'leño grueso de algunas máquinas como el ariete'.

Un gran número de voces designa una parte o pieza de un molino, tales como ala 'paleta de la hélice de un molino', badil78 'barra de hierro entre el rodete y la nanilla', cárcavo 79 'edificio donde se sitúa el rodete', cárcel 'armazón que en los molinos sujeta el árbol' , cercillo 'aro que fija la barra en el eje', cítola ${ }^{80}$ 'tabla de madera por la que se despide la cibera', levador 'viga que sube o baja la muela voladera', libra 'base en la que se asienta el caracol o árbol de un molino', linterna 'rueda pequeña y dentada', llave 'pieza que regula el paso del agua en un molino', muela y su sinónimo rueda 'disco de piedra sobre la solera', oreja 'parte lateral de la puente de un molino', rangua81 'pieza encajada en la solera, sobre la que se apoya el gorrón de un molino', rodezno 82 'rueda hidráulica con álabes', ruello 83 o solera 'muela baja', sobarbo 84 'espina gruesa que levanta los mazos en un molino', tolva ${ }^{85}$ 'caja en la que se echa el grano para que caiga en la muela', torre 'cuerpo de un molino de viento'.

Además de distintas herramientas e instrumentos, como balanza, cedazo, cribo y embudo ${ }^{86}$, entre otras, registramos un importante número de voces patrimoniales relacionadas con el ámbito de la ingeniería hidráulica, que

quisiere, porque unos le llaman el cavallo, otros asno, otros albardón, otros la zivilla de la grúa, otros coraçón, como aquél de las balanças de pesar las cosas" (Turriano a. 1605: 384r).

77 Del lat. lŏcŭsta 'saltamontes', 'langosta de mar'.

78 Del lat. vg. *batile 'paleta para mover lumbre', latín clásico bătŭllum 'paleta para mover lumbre'.

${ }^{79}$ Del lat. caccăbus 'olla', 'cazuela', procedente a su vez del gr. кaákкaßos 'íd.'.

80 Del lat. cŭthăra 'íd.'. el molino.

81 Probablemente del lat. rānula 'rana pequeña', por el gruñido de esta pieza al girar

${ }^{82}$ Del lat. vg. *rŏtĭč̆nŭus 'íd.', y este del lat. rŏta 'rueda'.

${ }^{83}$ Del lat. rŏtŭlus 'ruedecilla'.

${ }^{84}$ Del lat. sub arbŏre 'debajo del árbol'.

${ }^{85}$ Del lat. tŭbŭla 'trompetita'.

${ }^{86}$ Del lat. tardío ı̆mbūtum 'íd.', abreviación de (traiectorŭum) $\breve{m b} b \bar{u} t u m$ 'conducto lleno de líquido'. 
designan elementos propios de la conducción de aguas, como aguaducho ${ }^{87}$, canal, caña, cauce y ladrón; elementos utilizados para la contención de aguas, como aguatocho ${ }^{88}$, presa $^{89}$ y y otros destinados a su almacenamiento, como arca, pesquera ${ }^{90}$, pila 91 , pozo y vivero ${ }^{92}$.

Dentro de las palabras patrimoniales registradas en el glosario, encontramos un pequeño grupo de adjetivos y señalamos un notable número de verbos. De estos, muchos están relacionados con el agua u otros líquidos, como abrevar ${ }^{33}$ y anegar ${ }^{94}$, o con actividades cuyo objeto son las obras hidráulicas o los ingenios y máquinas o sus partes, tales como armar, cavar, cegar, clavar, ligar, pegar95, reparar 96 , serrar y soldar.

\subsubsection{PRÉSTAMOS}

A diferencia de las palabras patrimoniales, los préstamos son aquellas palabras que una lengua transfiere a otra (Gómez Capuz 1998: 19), es decir, los préstamos ponen en contacto dos lenguas distintas, de forma que se efectúa una transmisión de elementos por medio de la adopción o imitación ${ }^{97}$ (Guilbert 1975: 92-101, en Gómez Capuz 1998: 46-50). Esta transmisión se realiza, generalmente, desde una lengua distinta a la que conforma la base fundamental de la lengua receptora del préstamo. En el caso de que una palabra proceda de esa misma lengua básica -por ejemplo, del latín en el caso del español-, sólo podremos considerarla préstamo si esa palabra no se ha transmitido por vía

${ }^{87}$ Del lat. ăquaeductŭs 'conducto de agua', 'acueducto'.

${ }^{88}$ Del lat. ăquaeductŭs 'conducto de agua', 'acueducto', parece ser duplicado de aguaducho: la -t- puede deberse a aguatel que, con el mismo significado de 'compuerta', aparece en un texto jurídico aragonés de h. 1400. Aquatel está compuesto por el verbo tŏllĕre (hoy aguatiello por influjo del sufijo -ellum).

89 Del lat. prensa 'cogido, agarrado'.

${ }^{90}$ Del lat. p̌̌scārŭus, pǔscārĭa 'de pescado'.

${ }^{91}$ Del lat. pila 'mortero', 'tina de batán', derivado de pinsěre 'majar'.

92 Del lat. vĩvārŭum 'semillero', 'criadero de animales acuáticos'.

${ }^{93}$ Del lat. vg. *abbiberāre 'íd.', derivado de bibĕre, forma sustantivada del verbo que significa 'beber'.

${ }^{94}$ Del lat. èněcāre 'ahogar en agua'.

${ }^{95}$ Del lat. p̌cāere 'embadurnar o pegar con pez'.

${ }^{96}$ Del lat. rĕpărāre 'íd.'.

${ }^{97}$ André Thibault recuerda, a este respecto, que "las palabras extranjeras no se toman prestadas, sino que se imitan, dando lugar a neologismos a veces muy alejados del modelo de origen" (Thibault, en Curell 2009: VIII). 
popular y de forma oral e ininterrumpida, es decir, si ha sido tomada o recibida posteriormente (Tagliavini 1973: 368).

\subsubsection{Cultismos}

Entendemos por cultismos, aquellos préstamos de lenguas cultas -que en el caso del español son las lenguas latina y griega- que, al igual que el resto de préstamos, han sido transferidos a lo largo del tiempo y no en la base de un idioma, pero que, a diferencia de los extranjerismos, su incorporación a una lengua transluce "una continuidad histórica y cultural" (V. Herrero Ingelmo 1994-1995: 21). Son, por tanto, establecidos los orígenes grecolatinos de la lengua española como sustento de esta, considerados cultismos del español los denominados latinismos y helenismos, caracterizados estos por su falta de cambio o fidelidad formal a su lengua de procedencia y por su pertenencia, generalmente, a registros cultos, técnicos, formales o literarios (Clavería Nadal 1999-2000: 17).

\subsection{HELENISMOS}

Recordamos aquí que, aunque el español cuenta con gran número de voces de origen griego, gran parte ha pasado a formar parte de nuestra lengua a través de la lengua latina, donde eran préstamos de procedencia griega de uso habitual (V. Fernández Galiano 1967: 51) y, por tanto, los encontramos documentados tempranamente, en los orígenes de la lengua española ${ }^{98}$. Por no cumplir con las características de los cultismos, estas voces de origen griego han sido estudiadas como palabras patrimoniales en el capítulo anterior.

Consideramos voces cultas helénicas a las formas de origen griego que han llegado a nuestra lengua vernácula, normalmente por vía escrita latina (Bergua Cavero 2004: 60), aunque también por otras vías ${ }^{99}$, durante los siglos medievales o la época renacentista.

En cualquier caso, estos helenismos no son todos de la misma condición,

98 Por ejemplo, la voz cárcavo, del latín caccăbus 'olla', 'cazuela', procedente a su vez del gr. кá́kкaßos 'íd.', documentada en 1057 (DECH).

99 Señalamos, a este respecto, las que, por ejemplo, pudieron entrar por vía del francés (V. Gutiérrez Cuadrado 2006). 
puesto que, de alguno de ellos, no tenemos constancia de su existencia en latín más allá del texto latino en el que fueron recogidos; este sería el caso de

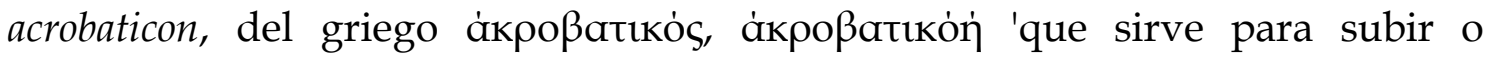
levantar', voz helénica que nunca se transvasó a la lengua latina y que pensamos que Vitrubio tomó directamente del griego y Urrea, asimismo, la utilizó sin traducirla en su traducción de De architectura ${ }^{100}$.

Señalamos al latín como lengua vehicular en la transmisión de otros 15 helenismos presentes en los textos, entre los que destaca el término máquina 'artificio para aprovechar, dirigir o regular la acción de una fuerza', tomado del latín māchùna 'íd.', 'andamio', 'artificio', 'maquinación', y este del griego dórico raxavá, documentado, de acuerdo con el DECH, en Juan de Mena en el siglo $\mathrm{XV}$.

Contenidos también en la traducción de la obra vitrubiana, como helenismos que designan máquinas, registramos anisociclo101 'máquina para elevar pesos montada sobre ruedas desiguales', voz tomada del latín ănīsŏcycli, -

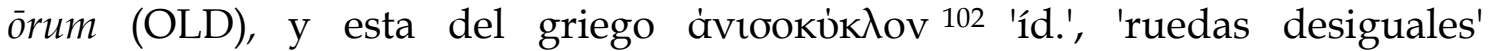
(Diccionario Histórico) y contenida en Laterculi vocum latinorum como anysocicla. Gaffiot 103 incluye la referencia a Vitrubio, y lo define como 'engrenages'; carquesio $^{104}$ 'torno de eje vertical para mover pesos', tomado del latín carchèsŭum 'cabrestante', y este del griego kapxท́oıov, 'vaso', 'íd.' (García Salinero); cóclea

100 V. Callebat y Fleury, 1995.

101 No se encuentra en el DECH ni en el DRAE.

102 Aunque existen muchas formas en griego compuestas por el adjetivo ávıoo

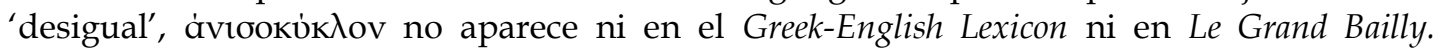
Dictionnaire Grec-Français.

${ }^{103}$ En esta ocasión se trata de Gaffiot, Félix (2000 [1934]) Le Grand Gaffiot Dictionnaire Latin Français. Nouvelle édition revue et augmentée sous la direction de Pierre Flobert. Paris: Hachette-Livre.

${ }^{104}$ No se encuentra, sin embargo ni en DECH ni en el CORDE, aunque sí en el Léxico de los alarifes de García Salinero, quien además señala la misma procedencia para carquesa. Por otro lado, Gaffiot acompaña la definición de carchēš̌um versatile 'plate-forme tournante ou mât de charge' con una referencia a Vitrubio. Le Grand Bailly define kapxńoıov como 'poulie fixée au mât et autour de laquelle s'enroulent les cordages', 'siège d'une machine de jet sur son pied', 'équerre de charpentier et de maçon'. 
'aparato para elevar el agua', tomado del latín cochlěa105 'concha', 'rosca' (DECH

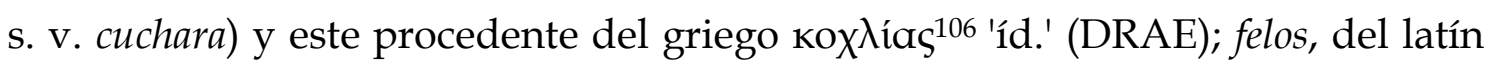

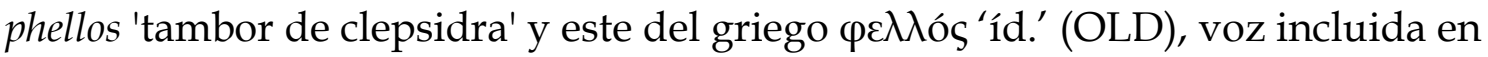
la traducción de Vitrubio realizada por Urrea como sinónimo de tímpano 'aparato de elevación del agua formado por una rueda vertical'; polispasto 'máquina formada por varias poleas para levantar pesos tirando de ellos', tomado del latín pŏlyspāston 'íd.', у este del griego по入úonaбtov 'sistema de varias poleas', voz recogida también en la traducción de Besson, como ocurre con tripasto, tomado del latín trispāstos 'íd.' y este del griego tpionaotov 'sistema de tres ruedas o poleas' (Bailly); quelonio 'cabra' 'máquina para levantar pesos formada por tres vigas', tomada del latín chĕlōnŭum 'grapa o garfio de diversos

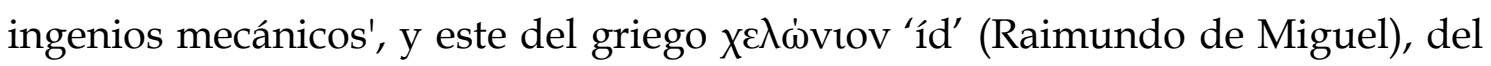
griego $\chi \varepsilon \lambda$ óon 'tortuga' (Agustín Blánquez Fraile).

También localizamos algunos helenismos, presentes tanto en Urrea como en Los Ventiún Libros..., que designan instrumentos, como corbate 'nivel de agua', tomado del latín chōrŏbătes 'instrumento para tomar el nivel del agua' y

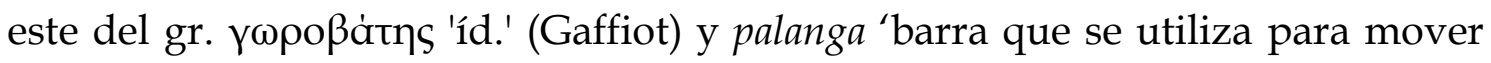
cosas de mucho peso', tomado del latín phalanga 'íd', y este tomado del griego

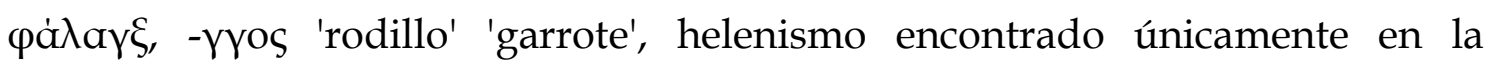
traducción de Besson y que, por tanto, debe su introducción a la lengua francesa. Aunque de poco alcance en el castellano, palanga conviviría en ese momento con la voz patrimonial palanca, del latín vulgar *palanca 'id.' (DECH).

En cuanto a los helenismos que señalan partes de una máquina, citamos émbolo 107 'órgano movible, regularmente cilíndrico, de algunas máquinas', tomado del latín embŏlus 'íd.' y este del griego ěßßoגos 'pene' (DECH) y tróclea 'polea, rueda acanalada y móvil', tomado del latín trŏchlĕa 'íd.' y este del griego

105 Gaffiot cita a Vitrubio en las acepciones 'vis de pressoir' y 'vis d'Archimède, machine à élever les eaux'.

106 Este término aparece definido en Bailly como 'coquillage en spirale, limaçon', 'escalier en espirale' 'pompe en espirale (vis d'Archimède) pour puiser de l'eau' 'vis, clou à vis'.

107 Anotamos, por tanto, una primera documentación del término émbolo anterior a la señalada por DECH (Tosca, principios del s. XVIII). 
троха入ia 'íd.' (DECH).

Destacamos asimismo en Urrea el adjetivo hidráulico, referido también a máquinas o instrumentos, 'que se mueve por la acción del agua', tomado del

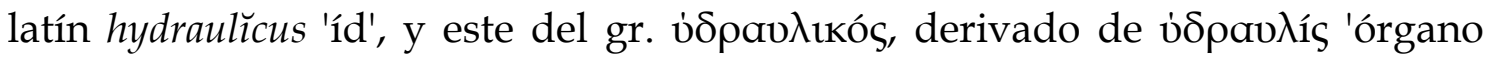
musical movido por el agua' (DECH), y el sustantivo autómato108 'máquina que se mueve por sí misma', voz que no aparece en DECH aunque sí que lo hace autómata. De autómata, el DECH dice que procede del francés automate, el cual estaría tomado del lat. automăton 'íd.', que a su vez procede del adjetivo griego aútóhatos 'espontáneo'.

\subsection{LATINISMOS}

El grupo de latinismos hallados en el léxico de ingenios y máquinas del Renacimiento es bastante numeroso, pues está conformado por 98 voces. Entre estos latinismos, destacan algunos términos fundamentales en este campo, como artificio, tomado del latín arť̌ficium 'íd.'; ingenio, tomado del latín ǐngĕnŭum 'cualidades innatas de alguien', que convive en aquel tiempo con la palabra vulgar engeño; instrumento, tomado del latín instrūmentum 'íd.' (DECH), cultismo simultáneo al uso de la forma popular estrumento; invento ${ }^{109}$ e invención, del latín inventǐ̄o, inventīōnis 'íd.'. También son importantes en el área las voces maquinación 'arte de inventar y fabricar máquinas' 'conjunto de máquinas' 'mecanismo que da movimiento a un artefacto', del latín māchĭnātǔō,

108 El DECH documenta autómata por primera vez en el Diccionario de Terreros y comenta que, si en vez de tomarse del francés, autómata se hubiera tomado directamente de las lenguas clásicas, la forma castellana sería autómato. Pero, curiosamente, es el mismo Diccionario de Terreros el que afirma que "algunos dicen en castellano autómato". Esta es precisamente la forma encontrada en la traducción de Urrea de Vitrubio, aunque el DECH no menciona esta aparición, motivo por el cual señalamos que autómato entró en el siglo XVI directamente del latín y creemos que sería suplantado posteriormente por autómata. Carecemos de datos del uso de la voz autómato, pero a primera vista parece que fueron muy limitados. El CORDE solo nos ofrece 5 ejemplos de autómato, cuatro de ellos del siglo XVIII (a partir de 1733) y uno del siglo XX, sin embargo contiene casi dos centenares de registros de autómata (a partir de 1791). aútółatos aparece definido en Le Grand Bailly. Dictionnaire Grec-Français como 'qui se meut de soi-même' y, a la luz del único ejemplo de autómato registrado en el corpus, ciertamente no demasiado esclarecedor, hemos definido esta palabra como 'máquina que se mueve por sí misma'.

109 Tomado del latín invěntum 'íd.'. 
māchünātīōnis 'íd.'; maquinatoria 110 'arte de inventar y fabricar máquinas' y mecánica ${ }^{111}$ 'arte o ciencia de los mecanismos, ingenios o máquinas', tomado del latín mēchăn ̌̌ca 'íd.'.

En cuanto a las designaciones de máquinas e artificios, señalamos los latinismos ariete 112 'máquina, generalmente usada en la guerra para batir murallas', engibato 113 'artificio hidráulico musical', escorpión, del latín scorpiō, scorpiōnis 'íd.', que en Urrea señala una 'máquina para elevar pesos' y tímpano 'aparato para la elevación del agua', tomado del latín tympănum 'pandero', 'rueda', 'grúa'. Respecto a los latinismos que designan piezas de máquinas, encontramos arbúscula 'pie de carro para llevar máquinas', tomado del latín arbuscŭla 'íd.', diminutivo de arbor, arbŏris 'árbol' (Salinero); armamento 'pieza o conjunto de piezas unidas', tomado del latín armāmentum 'íd.' (DECH), sinónimo de armazón, el cual está tomado de armatǐo, armatǐonis 'íd.'; arrectario 'madero que soporta el peso en algunas máquinas', de arrectārŭus 'madero derecho'; atelabo 'trabazón de la balanza de un torno', tomado del latín attělěbus 'langosta'; camilo 'grosor de una pieza con forma de tuerca', tomado del latín cămillum 'grosor de porquezuela'; cárdine 'hierro de algunas máquinas', del latín cardō, cardĭnis 'gozne, quicio'; catino, tomada del latín cătīnum 'fuente de loza', 'crisol', que en Urrea designa el vaso de metal que recibe el agua en una máquina tesíbica; equipondio 'pieza metálica para comparar pesos', tomado del latín ecquis pondus 'mismo peso' y su sinónimo pondos, tomado del latín pondus, eris 'peso' (OLD); ergata114 'torno vertical para mover pesos'; estípite 'eje de una

110 Creemos que este puede ser uno de los casos en los que el traductor decidió no hacer cambios en la traducción de la palabra latina y prefirió dejarla tal cual (véase, respecto a este tipo de cambios, Jiménez Ríos 2010: 255-256). Haber traducido la palabra implicaría introducir, por ejemplo, maquinaria. Pero este término no se introdujo, de acuerdo con el CORDE, hasta 1626, en un texto de Juan de Valencia y Guzmán).

111 Tomado del latín mēchănĭca 'íd.'.

112 Tomado del latín ărǔes, ăriětis 'morueco (carnero padre)', 'ariete' (DECH). Aunque en principio la voz ariete pertenece al léxico militar, hemos decidido incluirla en el glosario pues hemos hallado ejemplos en los que, en máquinas industriales, los arietes se usaban con la misma función de las vigas.

113 Tomado del latín angỉbăta, angibătorum 'pequeñas figuras huecas' (Agustín Blánquez Fraile).

114 Tomado del latín ergăta 'íd.' (incluido en Laterculi). 
puerta', tomado del latín stīpěs, stīpütis 'tronco', 'estaca', 'rama'; fíbula115 'hebilla con la que se sujeta la carga'; modiolo 'vasija', tomado del latín modiŏlus 'vasija para beber' (Gaffiot), 'vaso que forma parte de algunas máquinas'; motor116 'parte de una máquina destinada a producir un movimiento', del latín mōtŏr, mōtōris 'que mueve, movedor'; pénula117 'cubierta de una máquina'; súcula 'pieza grande con forma de tuerca' tomado del latín sŭcŭla 'cabria';

Relacionados con las obras de ingeniería hidráulica, hemos recogido los términos acueducto, tomado del latín ăquaedūctŭs 'conducto de agua', 'acueducto'; castelo 'desaguadero', tomado del latín castēllum 'depósito o arca de agua' (Raimundo de Miguel); cisterna 'depósito de agua', del latín č̆stěrna 'íd.', derivado de cista 'cesta'; conducto, tomado del bajo latín conductŭs 'íd.'; emisario, tomado del latín èmissārĭum 'conducto, canal'; especo 'cabecera de un conducto', del latín specŭs 'canal, conducción de agua' (Gaffiot); fístula 'caño, tubería', tomado del latín fistŭla 'caño de agua', 'tubo', 'flauta' (DECH), el latinismo incile $^{118}$ 'cabecera de un conducto'; premodo 'obra para regular la cantidad de agua', probablemente tomado del latín praemŏdum 'otra medida' (V. Gaffiot), sinónimo del también presente en este texto promódulo, que podría haber sido tomado de pro mŏdŭlo (ingĕnī̄) 'según su capacidad' (V. Blánquez Fraile); quinario y quinaria 'caño o fístula de cinco dedos de diámetro', tomados del latín quīnārŭus, quīnārĭa 'relativo a cinco' (Gaffiot); receptáculo 'cavidad en que se contiene cualquier sustancia', de rĕceptācŭlum 'íd.'; los cultismos senario y senaria 'caño o fístula de seis dedos de diámetro' y setinaria 'caño o fístula de cinco quinarias de diámetro'.

Pertenecientes al campo de las profesiones, incluimos los latinismos artífice 'maestro de las artes mecánicas o manuales', de arť̌fex, artǔfič̆s 'íd.'; ingeniero ${ }^{119}$ 'persona que tiene como profesión inventar ingenios y máquinas' e

\footnotetext{
115 Tomado del latín fibŭla 'hebilla' (DECH).

116 Tomado del latín mōtŏr, mōtōris 'que mueve, movedor'.

117 Tomado del latín paenŭla 'cubierta de una máquina' (Agustín Blánquez Fraile).

118 Tomado del latín incīle 'acequia, arroyo' (Segura Munguía).

119 Tomado del latín ĭngěnǔerius 'íd.' (DECH).
} 
inventor 120; y los adjetivos mecánico 'dicho de una persona: que se dedica a un oficio manual' y perito 'entendido o experimentado en una ciencia o arte', tomado de pěrĭtus 'experimentado', 'entendido' (DECH).

Hallamos en este tiempo los primeros registros de latinismos que designan acciones y efectos realizados, entre otras cosas, por el agua, como detención ${ }^{121}$ 'efecto de detener o detenerse' y división 'acción y efecto de dividir', y otros realizados con máquinas, como impresión ${ }^{122}$ 'acción de imprimir', del latín impresš̆o, -ōnis 'íd.' y moto ${ }^{123}$ 'acción y efecto de mover'; también movimientos como rotundación 'movimiento que consiste en girar en redondo', tomado del latín rŏtŭndatio, rŏtŭndationis 'íd.' (Gaffiot). También incluimos aquí, ligados al ámbito de la construcción en general, cultismos como edificación 'acción y efecto de edificar', tomado del latín aedĭficatĭo, -ōnis 'íd.', edificio 'construcción fija, hecha con materiales resistentes' y reedificación 'acción y efecto de volver a edificar', probablemente tomado del latín *rěaedĭfícātĭo 'íd.'. Asimismo, recogemos términos que designan conceptos físicos, como potencia ${ }^{124}$ 'capacidad para producir un efecto'.

Además, disponemos de varios adjetivos tomados del latín, en su mayoría aplicados a máquinas, entre los que resaltamos artificial 'hecho por mano, arte o ingenio del hombre', de artĭficiāalis 'íd.'; artificioso 'hecho o elaborado con artificio, arte, ingenio o habilidad', del latín artüficǔoosus 'íd.'; edificatorio ${ }^{125}$ 'perteneciente o relativo a la edificación'; escansorio ${ }^{126}$ 'que sirve para subir pesos'; espirital y espiritual 'que funciona con aire'; ingenioso, móvil127 'que puede moverse o se mueve por sí mismo'; potente 'que tiene poder, eficacia o virtud para algo', tomado del latín pŏtēns, pŏtèntis 'el que puede'; tractorio ${ }^{128}$

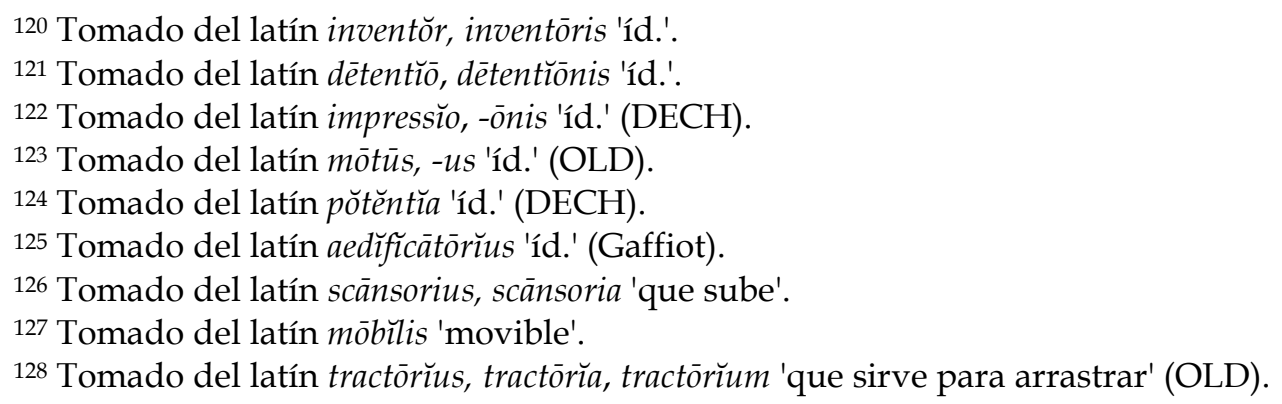


'que sirve para arrastrar cargas' y veloz'129.

Por otra parte, señalamos los verbos conducir, tomado del latín condūcĕre 'conducir juntamente, juntar'; congelar; dividir130 'dicho del agua: distribuir, repartir en varios cauces'; edificar, tomado del latín aedíficāre 'íd.', compuesto de aedes 'casa, edificio' y făcĕre 'hacer' (DECH) y reedificar131; espirar'132 'despedir gases', inventar, maquinar 'pensar, discurrir e idear medios para algún fin' 'trabajar una pieza de metal por medio de una máquina', del latín māchĭnārī 'pensar, idear', 'íd.'.

\subsubsection{Arabismos}

El árabe es, después del latín, la lengua en la que se origina el mayor número de voces del castellano hasta la época renacentista ${ }^{133}$, voces que son fundamentalmente sustantivos. En nuestro glosario hemos recogido hasta 40 arabismos. Recordamos aquí que un gran número de los arabismos del castellano no proceden del árabe clásico sino del dialecto andalusí (Corriente 2004[1999]: 188-189), así que nos referiremos al árabe hispánico o al hispanoárabe a no ser que hagamos referencia específica al árabe clásico.

Fruto del perfeccionamiento del sistema de riego romano realizado por los árabes (Lapesa 1981: 134), destaca especialmente, en el ámbito léxico del que nos ocupamos, un numeroso grupo de arabismos que designan elementos de la ingeniería hidráulica, tales como acequia134 'zanja o canal para regar' y cequia; albañal 'canal que da salida a aguas sucias', de alballáa 'tragona', del árabe clásico ballā’a 'cloaca'; alberca ${ }^{135}$ ‘depósito artificial de agua'; aljibe, del andalusí $a l \hat{y} u ́ b b$, y este del ár. $\hat{y} u b b$ 'pozo', 'cisterna'; el aragonesismo almenara 'compuerta

129 Tomado del latín vĕlox, vělōcis 'rápido, presto, veloz'.

130 Tomado del latín dĩvìdĕre 'partir', 'dividir', 'separar' (DECH).

131 Tomado del latín rěaedĭficāre 'íd.' (Segura Munguía).

132 Tomado del latín spirrāre 'soplar', 'respirar' (DECH).

133 " La Reconquista de Al-Andalus fue, naturalmente, reduciendo el ámbito de uso del árabe andalusí, incluso en los casos de permanencia bajo dominación cristiana de una población mudéjar, invirtiéndose los términos y generándose un nuevo bilingüismo, en que aquél acabaría por ceder totalmente el puesto al romance [...]" (Corriente 1992: 34).

${ }^{134}$ Del hispano-árabe assáqiya 'íd.'.

${ }^{135}$ Del ár. hisp. albírka 'estanque', 'depósito de agua' y este del ár. clás. birka. 
que distribuye el agua en una acequia', del hispano-árabe mánhar 'canal' y este del árabe manhar 'arroyo'; rambla 'lecho o suelo de de arena depositado como consecuencia de las avenidas de una corriente de agua', del hispano-árabe rámla 'arenal' y este del árabe clásico ramla 'arenal'; arcaduz 'tubería de cerámica', de alcaduz, del árabe clásico qādūs 'íd.', procedente a su vez del griego káóos 'jarro', 'caño de agua', 'cangilón de noria' y su sinónimo atanor ${ }^{136}$; azud 'presa', del hispano-árabe assudd 'obstáculo, obstrucción', 'presa' y este del árabe clásico sudd 'obstáculo, obstrucción'; azuda 'máquina hidráulica'137, en este caso del árabe súdda, nombre de unidad del anterior sudd; mandracho 'puerto abierto con pared', probablemente del árabe hispánico mádrây 'muelle, embarcadero'.

Son también abundantes los arabismos que designan máquinas o sus piezas, como aceña138 'molino hidráulico' y ceña 'noria', atahona y tahona, del hispano-árabe atțahúna, y este del ár. clás. țāhūn[a] 'molino'; tarabilla 'cítola de molino' del hispano-árabe țaráb, y este del árabe clásico țarab 'música' y el sufijo -illa; jaraíz 'lagar' 139 y zafariche 'estanque', ambos del árabe șahrî̀y 'balsa, estanque' y batán 'máquina hidráulica para enfurtir paños', probablemente del hispano-árabe *bațán 'íd', de la misma raíz que batțana 'forrar', 'batanar' y bițāna 'piel de carnero preparada'; o piezas de molinos, como dado140 'pieza cúbica en la que se apoya el árbol de los molinos' y saetía 'canal por el que se conduce el agua en los molinos' probablemente del árabe clásico šayțiyya 'íd.' (DECH).

Además encontramos en el glosario aldaba141 'pieza de hierro con forma de aro', que en nuestro corpus aparece vinculada a la hidráulica al utilizarse para atar embarcaciones o sujetar puentes; almadía del hispano-árabe alma'díyya 'barca de paso', 'almadía'; y el utensilio maroma 'cuerda', del hispano-árabe mabrúm[a], y este del ár. clás. mabrūma, 'retorcida'.

136 Del árabe hispánico attannúr y este del ár. tannūr 'boca de pozo', 'manantial', 'cañería para agua' (DRAE).

137 'Máquina con que se saca agua de los ríos para regar los campos, formada por una gran rueda afianzada por el eje en dos fuertes pilares que, movida por el impulso de la corriente, da vueltas y arroja el agua fuera' (DRAE).

138 Del ár. hisp. assánya, y este del ár. clás. sāniya 'elevadora' (DRAE).

139 Respecto al léxico castellano del lagar, V. Pascual Rodríguez, 1985.

140 Probablemente del árabe clásico $a^{\prime}$ dād 'números'.

141 Del hispano-árabe aḍḍabba, y este del ár. clás. ḍabba, literalmente, 'lagarta' (DRAE). 
Relacionados con el ámbito de la construcción en general, señalamos los arabismos que designan materiales como adobe ${ }^{142}$ y el aragonesismo adoba y zulaque 'pasta para rellenar las juntas de los caños', del hispano-árabe suláqa 'íd.', derivado de salaqa 'cocer, hacer hervir', 'embadurnar' y este del griego

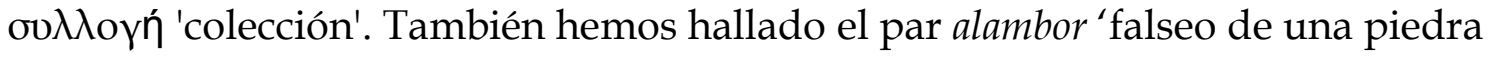
o madero', probablemente del hispano-árabe harabúl 'orla', 'borde', 'revuelta' y este derivado del verbo clásico hawwwala 'alterar'.

En cuanto a las profesiones, registramos alarife, también del hispanoárabe, en este caso de al'arif 'arquitecto', 'hombre entendido en construcción', y este del ár. clás. 'arīf 'experto'; también albañil, del hispano-árabe banní y este del árabe clásico bannā' 'constructor', 'albañil' y zahorí 'persona que tiene por oficio buscar aguas subterráneas', del andalusí *zuharí 'geomántico', 'zahorí', y este del ár. clás. zuharī 'geomántico', der. de az-zuhara 'Venus'143.

Son varias las voces de procedencia andalusí que designan herramientas e instrumentos, tales como almádena, de almáțana, y este cruce del ár. clás. mi'dan y el ár. hisp. patána 'trasto' 'cacharro' (DRAE); anafe 'hornillo', del hispano-árabe annáfij, 'hornillo portátil' y este del árabe clásico nāfij (DRAE); azuche144 'punta de hierro para asegurar los fundamentos de un edificio'; barrena ${ }^{145}$ 'herramienta para hacer agujeros'; garfa 146 'pieza de hierro para unir sillares' y roba147 'instrumento para allanar terrenos'.

\subsubsection{Occitanismos}

Dadas las semejanzas existentes entre el occitano, el francés y el catalán, resulta en muchas ocasiones complicado delimitar de cuál de estas tres lenguas fronterizas proceden algunos préstamos del castellano (Colón Doménech 19591: 161-162). A pesar de esto, podemos señalar en nuestro glosario la presencia de

142 Del hispano-árabe atțúb, este del ár. clás. țūb, y este del egipcio $d b t$.

143 Por la semejanza de procedimientos entre los zahoríes y los astrólogos.

${ }^{144}$ Del hispano-ár. zúŷŷ 'íd.' y este del ár. clás. zuŷŷy 'cuento de la lanza' (DRAE).

145 Del hispano-ár. barrína 'íd.' y este del lat. veruina 'jabalina'.

${ }^{146}$ Del hispano-ár. garfa 'puñado' 'cantidad que se coge con una mano' y este del ár. clás. gurfa, infl. por garfio (DRAE).

${ }^{147}$ Del hispano-ár. rúba 'íd.', del árabe clásico rub“ 'cuarta parte'. 
un relevante número de voces que, a la luz de la información recogida en varios repertorios lexicográficos y en los textos del corpus, creemos que son unos, galicismos, y otros, catalanismos. En cuanto a las voces transferidas al castellano desde la lengua de oc ${ }^{148}$, sólo registramos una, motón 'especie de polea utilizada en la navegación', del occitano cap de moton 'vigota, especie de motón', propiamente 'cabeza de carnero' (V. Colón Doménech 19591: 181 s. v. motón).

\subsubsection{Galicismos}

Son 28 los galicismos localizados en nuestro glosario, varios de estos relacionados con el mundo de la construcción, como mazonería 'obra de albañilería', del francés maçonnerie 'íd.'; maniobra 'obra material que se ejecuta con las manos', de manoeuvre 'íd.', montea 'dibujo de tamaño natural del todo o parte de una obra', del francés montée, derivado de monter 'subir' y pilote 'madero con punta de hierro utilizado para consolidar cimientos', del francés pilot 'íd.' (TLF). Otros tienen que ver con las obras hidráulicas, como mina 'paso artificial subterráneo que se utiliza para conducir aguas', probablemente del francés mine 'íd.' y bulsón 'cada uno de los maderos que levanta un puente levadizo', quizás del francés blouson 'blusón' o bourson 'bolsón'.

Encontramos también varios préstamos del francés que designan máquinas o piezas de máquinas, como crica 'máquina destinada a elevar grandes pesos a pequeñas alturas', del francés cric 'gato', onomatopeya imitativa del sonido del instrumento; gaula 'especie de andamio volante con forma de jaula', del francés antiguo jaole 'íd.'; marrano 'madero para asentar cimientos' del francés marrain 'íd.'149; martinete 'mazo de hierro movido por distintos mecanismos, utilizado para alzar piezas de artillería pesada', del

148 Recordamos aquí que "la influencia provenzal quedaba cronológicamente limitada a un período medieval bastante corto $\mathrm{y}$, temáticamente, a los campos religioso, cortés y comercial" (Colón Doménech 19592: 194).

149 Cabe la posibilidad de que marrano, en este caso, sea un arabismo indirecto que ha entrado en el español a través del francés (V. caso similar señalado por Colón 20022: 47, respecto al caso de estragón). 
francés martinet 'fouet' 'marteau-pilon', oc. ant. martinet 'íd. '150; visinfín 'aparato para elevar agua consistente en un tubo arrollado en hélice', del francés vis sans fin 'íd.'; guepejo 'pieza encajada en la solera, donde se apoya el gorrón de un molino', probablemente del francés guêpe 'avispa' y el sufijo -ejo; mástil 'barra fija o rotatoria que en una máquina sirve para soportar piezas rotativas o para transmitir la fuerza motriz', del francés antiguo mast 'íd', hoy mât y este del fráncico mast 'íd.'.

Otros galicismos designan instrumentos y herramientas, y este es el caso de burato, 'instrumento a modo de manga que se utiliza para cerner harina', posiblemente tomado del francés burat 'tela o tejido grueso de seda o lana' como afirma el DECH, o quizás se trate de un italianismo, de buratto (DRAE, Varela Merino); cincel 'hierro largo y redondo que se utiliza para labrar piedra', del francés antiguo cisel 'íd.' y 'tijeras'; chimenea 'conducto para dar salida al humo de la combustión', del francés cheminée 'íd.'151; hacha, tomado del francés hache 'íd.' y plancha 'lámina de metal ancha y delgada', del francés planche 'íd.'. Son también galicismos las voces gonce 'herraje articulado de dos piezas', probablemente del francés gonz, plural de gont 'gozne' y jardín, tomado del francés jardín 'íd. ${ }^{152}$

En cuanto a los galicismos que designan objetos, en este caso, destinados a contener líquidos, señalamos bacía, quizás del francés antiguo bassie 'íd.'153 y tonel, tomado del francés antiguo tonel 'íd.', diminutivo de tonne 'tonel grande' y este del lat. tardío tunna 'íd.' (DECH).

Son también varios los verbos presentes en el glosario que proceden del francés: bornear 'mirar con un solo ojo, teniendo el otro cerrado, para examinar si un cuerpo o varios están en una misma línea con otro u otros', del francés bornoyer 'íd.'; estampar 'imprimir, sacar en estampas algo', probablemente del

150150 A propósito de la voz martinete, V. Colón $2002^{3}$.

151 Y éste del lat. tardío caminata, derivado del lat. caminus 'íd' (DECH).

152 Diminutivo romance del fr. ant. jart 'huerto', y este del franco *gard 'cercado'; cf. alto alem. ant. gart 'corro', ingl. yard 'patio' (DECH).

153 Que parece ser forma dialectal correspondiente a un latín vulgar *bacceata, derivada del citado baccea $(\mathrm{DECH})$. 
francés estamper 'íd. '154; forjar, del francés forger 'dar la primera forma con el martillo a una pieza de metal'; guindar 'subir en alto alguna cosa', del francés guinder 'íd.'155; y voltar 'dar vueltas a alguien o a algo', probablemente del francés volter 'executer une volte'.

\subsubsection{Catalanismos}

De acuerdo con el DECH, "la terminología castellana de la construcción está llena de catalanismos" (DECH s. v. nivel, en Herráez 2007: 257) y así es muestra de esto el léxico que nos ocupa, que comparte una parcela designativa con el área de la construcción.

En cuanto al léxico de ingeniería hidráulica, hemos registrado 27 catalanismos, como lo son botana 'compuerta que regula el agua en las pesqueras', del catalán botana 156 'remiendo en pellejos de vino' 'tarugo que tapona las cubas'; cantimplora 'tubo o conducto por el que se pasa el agua en algunos ingenios', del catalán antiguo cantiplora (hoy cantimplora) y éste compuesto de canta i plora 'canta y llora', por el ruido que hace la cantimplora al gotear; y regata 'reguera por donde se conduce el agua a las eras', del catalán regata 'íd.', de acuerdo con el DECH, aunque en nuestros textos sólo encontramos la variante recata, quizás por similitud fónica con el verbo recatar.

Asimismo señalamos algunas máquinas, como emprenta, tomado del catalán empremta 'impresión o huella (de un sello, de un pie, etc.)'; imprenta, de ese mismo étimo; grúa 'máquina para levantar pesos', del catalán grua 'grulla' 'grúa' y prensa 'máquina para comprimir', del catalán premsa 'íd.', propiamente participio femenino del verbo prémer 'apretar'.

También son varios los catalanismos que designan piezas de máquinas, especialmente piezas de molinos: caja 'armazón sobre el que se forjan los rodeznos de los molinos', probablemente del catalán caixa ${ }^{157}$ u oc. caissa 'íd.',

\footnotetext{
154 Antiguamente 'aplastar', 'machacar', después 'estampar'.

${ }^{155} \mathrm{Y}$ este del escand. ant. vinda 'envolver', 'devanar', 'izar por medio de un guindaste'.

${ }^{156}$ El DRAE, sin embargo, afirma que proviene de bota.

157 Según el DRAE, viene del latín capsa 'íd.'.
} 
procedentes del lat. capsa 'íd'; cajal158 'diente de muela de molino' pensamos que probablemente viene del catalán caxal 'muela'(Clairac); gruenza 'tolva', del catalán engronçar o gronxar 'columpiar, mecer', por el movimiento oscilatorio a que estaban sometidas las tolvas antiguas con objeto de que el grano cayera más fácilmente; mancha, probablemente del catalán manxa 'fuelle para subir agua' y este del latín mantica 'saquito, alforja, zurrón'; polija 'polea', del catalán politja 'íd.', catalán antiguo y dialectal polija y su sinónimo roldana 'polea', del catalán antiguo rotlana 'roldana', 'rodaja', 'carro'.

En cuanto a los transportes, anotamos la procedencia catalana de carreta ${ }^{159}$, del catalán u occitano carreta 'íd.'; carretón, de carretó 'parte inferior de un mantelete'; carruaje, tomado del catalán carruatge 'conjunto de los carros de un ejército', 'vehículo de ruedas'.

Hay varias herramientas e instrumentos en nuestro glosario que provienen del catalán: gafa 'pieza de hierro para unir sillares', del catalán gafa 'íd.', derivado del verbo catalán y occitano gafar, agafar 'coger', de origen incierto, probablemente prerromano; limatón 'lima utilizada por artífices en sus oficios', que probablemente viene del catalán llimetó 'lima fina utilizada por los plateros'; nivel, del catalán nivell (o quizás de la lengua de Oc o del francés) y este del latín vulgar lỉbēllum, en latín clásico lỉbēlla, diminutivo de libra 'balanza'; perno 'pieza alargada que se usa para asegurar piezas', tomado del catalán pern 'íd.' y este del latín perna 'pierna'; própalo 'palanca', probablemente del catalán perpal 'palanca de madera o de hierro' y tascón 'cuña', del catalán tascó 'cuña en general'.

Hemos encontrado además un catalanismo que designa un oficio, pilatero 'persona que tiene por oficio asistir a las pilas del batán', del catalán pilater 'íd.'.

Finalmente destacamos algunos catalanismos relacionados con los materiales presentes en nuestra área léxica, como betún ${ }^{160}$, del catalán betum 'íd.',

\footnotetext{
158 No se encuentra ni en el DECH ni en el DRAE

159 El DRAE lo considera derivado de carreta.

160 De acuerdo con el DRAE, no es catalanismo, sino que proviene del latín bitūmen.
} 
y éste del lat. bitūmen 'íd.'; cuera161 'carcoma'; runa, del catalán runa 'íd.', de origen incierto y vesque 'masa hecha con muérdago', del catalán vesc y este del lat. visscum 'muérdago'.

\subsubsection{Italianismos}

Creemos que son 7 las voces procedentes del italiano incluidas en nuestro glosario.

En cuanto a las máquinas y sus piezas, registramos balaustre 'cada una de las columnitas en los carros de un molino', del italiano balaùstro 'columnita de barandilla'; cicleola 'ruedecilla', que probablemente procede del italiano cicleola 'íd.', diminutivo del sustantivo grecolatino cyclus; holivela 'agarrador de tres piezas para subir cargas', tomado del italiano olivella 'cierto ingenio de llave'; recamo 'polea', probablemente también del italiano recamo 'bordado', del italiano ricamare 'bordar' y este del árabe ráqam, 'tejer rayas en un paño', 'bordar'162; tromba 'conducto de metal por el que se conducen las aguas', del italiano tromba 'trompa'.

Con respecto a los transportes, encontramos carromato 'carro bajo y llano para transportar mercancías', término tomado del italiano carro matto 'carro compuesto de un fuerte suelo de tablas, sin varales, sobre cuatro ruedas muy

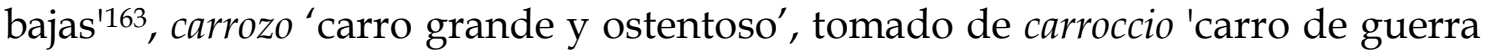
de las antiguas repúblicas italianas'.

\subsubsection{Otras procedencias}

Señalamos aquí algunas voces cuyo origen se remonta a lenguas minoritarias en nuestro glosario, es decir, a lenguas de las que son procedencia un número muy limitado de las voces registradas. Este es el caso del húngaro, lengua de la que proviene la voz coche 'carruaje de cuatro ruedas',

161 Del catalán quera 'íd.'.

162 En el caso de recamo, según el DECH cabe la posibilidad de que el catalán sirviera de intermediario.

163 Donde el adj. matto, propiamente 'loco', significa 'falso, impropio' (DECH). 
probablemente del húngaro kocsi 'carruaje'; el neerlandés, del que procede dique 164 ; y el quechua, lengua originaria de la voz cocha 'estanque que, en la extracción de metales, se separa del lavadero principal', pues procede del quechua kocha 'laguna'.

\subsubsection{ORIGEN INCIERTO}

En cuanto a nanilla y ananilla 'pieza horizontal sobre la que se asienta la muela de un molino', tenemos varias opciones: por un lado, nos planteamos si pudo ser un error de escritura y de entendimiento por parte del escribano y que el término adecuado fuera manilla; por otro lado, el error pudo ser con anadija, pues son sinónimos. A este respecto, no hemos encontrado el término *nana que pudiera servir de base de derivación, por lo que descartamos su inclusión entre las voces derivadas. Respecto a jeta165 'grifo', DECH señala que es un arabismo, cosa que Corriente ${ }^{166}$ desmiente y lo vincula a la palabra, de origen incierto también, seta. No estamos seguros de su procedencia, pero pensamos que podría tener relación con el galicismo jeter 'echar, tirar', al igual que enjeta.

\subsubsection{DiALECTALISMOS LÉXICOS}

\subsubsection{Aragonesismos}

Destacan, dentro de los términos que conforman nuestro glosario de ingenios y máquinas en el Renacimiento, el conjunto de aragonesismos, es decir, las voces, de distinta procedencia, que en el siglo XVI eran voces dialectales de la zona de Aragón y que, por lo tanto, en nuestro repertorio lexicográfico aparecen señaladas con la marcación diatópica correspondiente (arag.). En cualquier caso, hemos de tener en cuenta que

cuanto más nos alejemos en el pasado, más difícil es dar con la variación (piénsese en la reconstrucción plana del latín vulgar); no podemos aspirar, desde el comienzo, a marcar las voces como si se tratara de un hecho actual. Por eso hemos de

\footnotetext{
164 Del neerl. dijk (DRAE).

165 Del ár. jeta 'espita, grifo' y este de jeta 'hocico' (DECH).

166 V. Corriente, 2008 "false arabic loanwords".
} 
conformarnos con marcar lo posible, no todo, sino preparar la base informática para una marcación cada vez más completa (Gómez Martínez y Sánchez González de Herrero 2010: 110-111).

Todas estas voces aragonesas han sido localizadas en el códice manuscrito Los ventiún libros de los ingenios y máquinas, revisado anteriormente.

Para realizar el estudio de estos términos, han sido de gran ayuda los análisis de aragonesismos llevados a cabo por Juan A. Frago Gracia, fundamentalmente los recogidos en "Las fuentes documentales aragonesas y el diccionario etimológico español de J. Corominas" publicado en AFA ${ }^{167}$ y el capítulo VII "La incidencia del léxico dialectal aragonés”, incluido en la obra de Frago y García-Diego (1988) Un autor aragonés para los Ventiún libros de los ingenios y de las máquinas ${ }^{168}$. También nos han resultado de gran interés algunos repertorios lexicográficos del aragonés, entre los que destacamos el Diccionario aragonés de Andolz y el Vocabulario básico bilingüe de Martínez Ruiz. Además, resaltamos aquí la utilidad para este propósito del Léxico de los alarifes de García Salinero y las consultas en el CORDE.

Un numeroso grupo de las voces del aragonés halladas pertenece al ámbito léxico de las obras hidráulicas, como aguilón 'caño cuadrado de barro', de águila; almenara 'compuerta para distribuir el agua', del árabe mánhar 'canal'169; amparo y ampara en su sentido 'pared o baranda para recoger agua'; bocal 'toma de agua o desaguadero', botana 'compuerta que regula la salida de aguas en las pesqueras', canalera 'conducto formado por tejas que regula el agua en los tejados', canalón 'conducto por el que cae el trigo en una muela', de canal; chozola 'pequeño azud o presa', entibo 'represa de aguas en un río o canal', follura 'cauce por donde se da paso al agua', gallipuente y su sinónimo maripuente 'acueducto o puente sin barandas', jeta 'grifo o llave de algunos

167 Archivo de Filología Aragonesa.

168 En concreto, resaltamos aquí los apartados en los que Frago recopila una lista de términos dialectales aragoneses hallados en el códice (Frago y García-Diego 1988: 71-72).

169 A diferencia de almenara 'almenar' 'fuego' 'candelero', que procede del árabe hispánico almanára, y este del árabe clásico manārah 'lugar donde hay luz', 'faro' y que no es aragonesismo en la época. 
depósitos de líquidos', mota 'pella de tierra con la que se cierra un paso de agua', partidero 'parte de obra hidráulica que divide una conducción de agua en varios cauces', recata 'reguera pequeña', tajadera y su sinónimo tajador, ambos en su sentido 'compuerta para detener la corriente', tramada en su sentido 'espacio entre dos pilares de un puente'; veintena en su variante vintena 'caño o fístula de dieciséis quinarias de diámetro' y zafariche 'estanque'. Otra importante selección de aragonesismos estaría incluida en el vocabulario de maquinaria, puesto que estos nominan elementos, piezas o partes de algunos ingenios o máquinas. De estas voces, destacamos cajal 'diente de madera en una rueda', canalote 'conducto por el que cae el trigo en la muela', cibilla170 'tabla para izar cargas', farinal 'cajón que recibe la harina en un molino', fuella y su sinónimo mancha 'fuelle utilizado para subir agua o mover ruedas en algunas máquinas', fusto 'pieza de madera de hilo', mallo 'martillo grande de hierro utilizado para forjar metales' y ruello 'muela de molino'. Señalamos también aquí mortimiento 'lugar o zona en el que una pieza u otro objeto termina'.

Otro grupo de voces dialectales del aragonés renacentista podría clasificarse en el campo semántico de las herramientas e incluiría voces como ferramenta 'herramienta', aja 'azuela', escoda 'herramienta con forma de martillo, con corte a los dos lados, que se utiliza para labrar piedras y picar paredes', estral 'hacha pequeña', mallo 'herramienta que se utiliza para desgranar a golpes la mies', própalo 'barra para levantar pesos', rallo 'chapa con agujeros utilizada para rallar', roba 'instrumento para allanar terrenos' y ruello 'rodillo'. También señalamos aquí algunos objetos variados en cuya nomenclatura hemos apuntado la marcación aragonesa, como alguaza y su sinónimo frontiza 'bisagra', bacieta 'barreño grande', capaza 'espuerta para prensar la uva', capazo 'espuerta para transportar materiales', ligarza 'sujección del ancla en las almadías', portadera 'caja grande para transportar cosas' y pozal 'cubo con el que se saca agua de un pozo'.

170 Frago habla de cebilla en vez de cibilla, pero no hemos encontrado ejemplos al respecto en el CORDE ni en diccionarios del aragonés. Dadas las variantes gráficas existentes en nuestro corpus (cibilla, civilla, zivilla) hemos lematizado el término como cibilla. 
Entre los aragonesismos que en el siglo XVI designan materiales, simples o conglomerados, recogemos adoba 'adobe', glera 'especie de tierra que contiene cantos o guijarros', piedra caracolina 'caliza', vesque 'muérdago' y zaborra 'piedra pequeña sin labrar'. Además, registramos el aragonesismo cuera 'carcoma', puesto que el texto atribuido a Juanelo Turriano insiste en la incidencia de las larvas de la cuera sobre algunos de los materiales necesarios para la ejecución de ingenios y máquinas, y una actividad, enrunar 'revestir el suelo con escombros', en su variante gráfica enronar, ya recogida en el Ensayo de un diccionario aragonés-castellano de Mariano Peralta.

\subsection{PROCEDENCIA DE LOS ARAGONESISMOS}

En cuanto a la procedencia de estas voces dialectales del aragonés, encontramos tanto palabras patrimoniales como voces neológicas, creadas por procedimientos internos o tomadas como préstamos. En conjunto destacan las voces patrimoniales, provenientes del latín ${ }^{171}$, como aja, cibilla, estral, ferramenta, fuella, glera, rallo, ruello, zaborra; en algunas observamos rasgos propios del aragonés, como la conservación de la F- inicial latina en ferramenta y fuella o la diptongación de la vocal breve tónica latina -O- en -UE-, como ocurre en fuella. Además encontramos un gran número de voces de origen árabe ${ }^{172}$, como adoba, del árabe tûb 'ladrillos'; alguaza, del mozárabe *algruaza; almenara, del árabe mánhar 'canal'; roba, del hispanoárabe rúba 'íd.', del árabe rub 'cuarta parte' y zafariche, del árabe șahrî̆g 'balsa, estanque'. El catalán también es una de las lenguas de origen de estos aragonesismos, entre los que señalamos cajal ‘diente de madera en una rueda', probablemente del catalán caxal 'muela'; mancha, del catalán manxa 'fuelle' y este del latín mantica 'saquito, alforja, zurrón'; própalo, del catalán perpal 'palanca de madera o de hierro' y vesque, del catalán vesc y este

171 “El aragonés presenta un léxico básicamente de procedencia latina [...], aunque también existe numeroso léxico prerromano [...]. En la zona Pirenaica existe una parte de léxico coincidente con el Gascón u Occitano [...] y en la zona más oriental, léxico coincidente con el catalán, en ambos casos adaptado a la fonética y evolución propias del aragonés" (Blas 2008: 30).

172 Señalaba ya Germán Colón en su capítulo "De arabismos interhispanos" (20022: 53) que "el aspecto diatópico es muy importante" y que si hay una "asignatura pendiente" en la filología iberorrománica, esa es precisamente la del estudio léxico de los arabismos: documentación antigua, extensión, acepctación social". 
del lat. v̆sscum 'muérdago'. En cuanto a las voces de origen prerromano, aparece en nuestros textos el aragonesismo mota 'pella de tierra que cierra el paso en una acequia'. Y de origen incierto, probablemente galicismo, jeta 'grifo'.

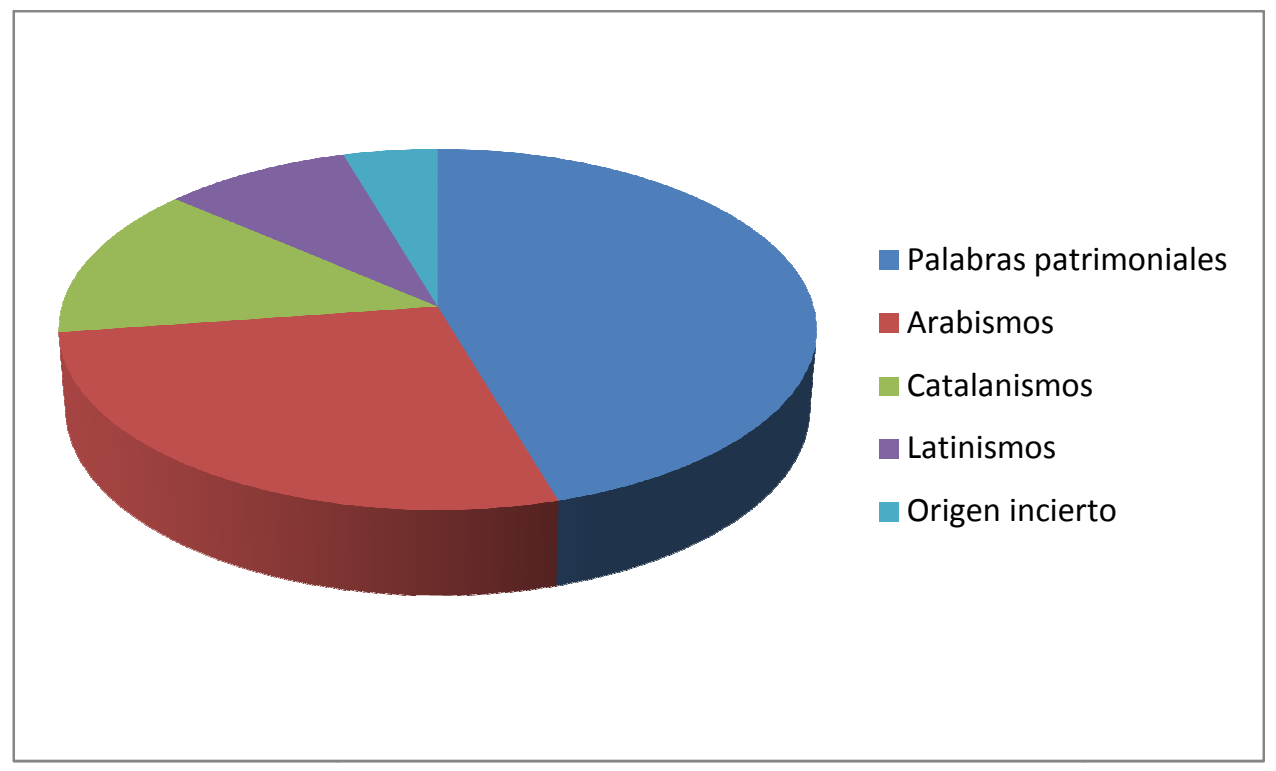

Respecto a los aragonesismos creados mediante procedimientos propios del idioma, encontramos bastantes derivados, todos ellos formados por un proceso de sufijación. Entre los denominales aparecen bacieta, bocal, canalera, capazo, chozola, canalote, fusto (de fuste), frontiza, pozal y el adjetivo farinal. Entre los deverbales, amparo, entibo, escoda, follura, partidero, portadera, tajador y tajadera. También registramos dos compuestos, dos de ellos léxicos, gallipuente y maripuente y uno sintagmático, piedra caracolina.

\subsubsection{Americanismos}

El descubrimiento de América conlleva el enriquecimiento de la lengua española con voces de origen indígena, necesarias para nombrar las nuevas realidades encontradas, tanto en materia natural (flora, fauna, geografía) como artificial (productos, herramientas y otros utensilios utilizados en el nuevo mundo) (Buesa 1959: 325-326). Señalamos, en este punto, el americanismo cocha 'estanque que, en la extracción de metales, se separa de la tina o lavadero principal', del quechua kocha 'laguna' (DRAE).

\subsubsection{CONCLUSIONES SOBRE LA PROCEDENCIA DE LAS VOCES}


En lo que respecta al origen de las voces de ingeniería en el Renacimiento, el mayor porcentaje está formado por palabras patrimoniales, cuyo número es casi tres veces superior al de latinismos. Del total de voces que constituyen el glosario, que asciende a 992, 270 son palabras patrimoniales. Así, como comentábamos en el apartado correspondiente, el número de voces de origen patrimonial alcanza más de la cuarta parte de las que componen el glosario, es decir, el número de estas es especialmente significativo en el área léxica que nos ocupa, y nos da muestras de la importancia de las vías populares en la transmisión de los conocimientos en el campo de la ingeniería hidráulica. Las voces patrimoniales aparecen en la designación tanto de máquinas y piezas como en los elementos de obras hidráulicas, así como en las herramientas utilizadas para su construcción, la mayoría de ellas comunes para múltiples usos.

Los cultismos ocupan el segundo lugar en cuanto a importancia en el origen de las voces del glosario, pues su número, 114, alcanza casi en la mitad al de las voces patrimoniales. Como era de esperar, prácticamente todos estos cultismos son de origen latino, pero hemos de señalar que el número de helenismos, aunque reducido a unas 16 voces, es notable y significativo, especialmente en comparación con el número de helenismos presentes en el léxico de otras áreas técnicas estudiadas por los miembros del equipo del DICTER. En cualquier caso, destacamos que una amplia parte de estos cultismos designa nombres de máquinas y una tercera parte de todo el conjunto, unos 37, fueron transmitidos por medio de la traducción de la obra latina de De architectura de Vitrubio realizada por Urrea, donde estaban contenidas en la tercera parte del texto, dedicada a las máquinas. Asimismo, hemos de comentar que estos nombres de máquina cultos no siempre lograron difundirse suficientemente en castellano, bien porque las máquinas que designaban no llegaron a construirse y a utilizarse de forma regular en la península, seguramente porque existían otras destinadas a esos mismos fines, bien porque existían o se crearon otros términos que las designaban. 
Las voces de origen árabe son también numerosas en este ámbito, especialmente para la designación de todo lo referente a obras hidráulicas, materia en la que los árabes destacaron históricamente y en la que realizaron obras de gran envergadura e innovación técnica durante su estancia en la península ibérica. En nuestro glosario hallamos 40 voces de origen árabe, que por su número atestiguan la importancia de la herencia árabe en el ámbito de la ingeniería renacentista hispana, fundamentalmente en la designación de todo lo referente a la canalización de las aguas y a los materiales utilizados para su ejecución.

Por otra parte, el francés y el catalán son lenguas de las que provienen un número de voces significativo, aunque menor que el reseñado en las lenguas anteriores, pues son unos 27 los términos que proceden de cada una de ellas. En general, tanto los galicismos como los catalanismos designan piezas de máquinas y herramientas, muchas de ellas comunes a otros ámbitos constructivos, como la arquitectura y la cantería, ámbitos para cuyo desarrollo en la península influyeron especialmente las técnicas aportadas por la zona catalana y el país galo. Señalamos, asimismo, que un grupo importante de los catalanismos encontrados lo conforman voces propias de Aragón, es decir, son voces dialectales aragonesas, pues, por su localización geográfica, la zona de Aragón propició la entrada de catalanismos en el castellano (V. Colón 19591: 157).

Asciende únicamente a 7 el número de italianismos registrados en el glosario, un número de voces bastante reducido en comparación con el número de préstamos anotados con otras procedencias. Entre estos italianismos, señalamos que dos de ellos designan máquinas para el transporte, carro mato y carrozo, a diferencia de otras máquinas para estos fines recogidas en el glosario, cuya nomenclatura está formada mediante mecanismos internos del castellano.

Finalmente, anotamos que son 21 las voces de origen prerromano o de origen probablemente prerromano halladas en esta área léxica, las cuales designan principalmente materiales, elementos naturales y objetos de uso 
cotidiano, conceptos cuya equivalencia en ocasiones no existía en latín.

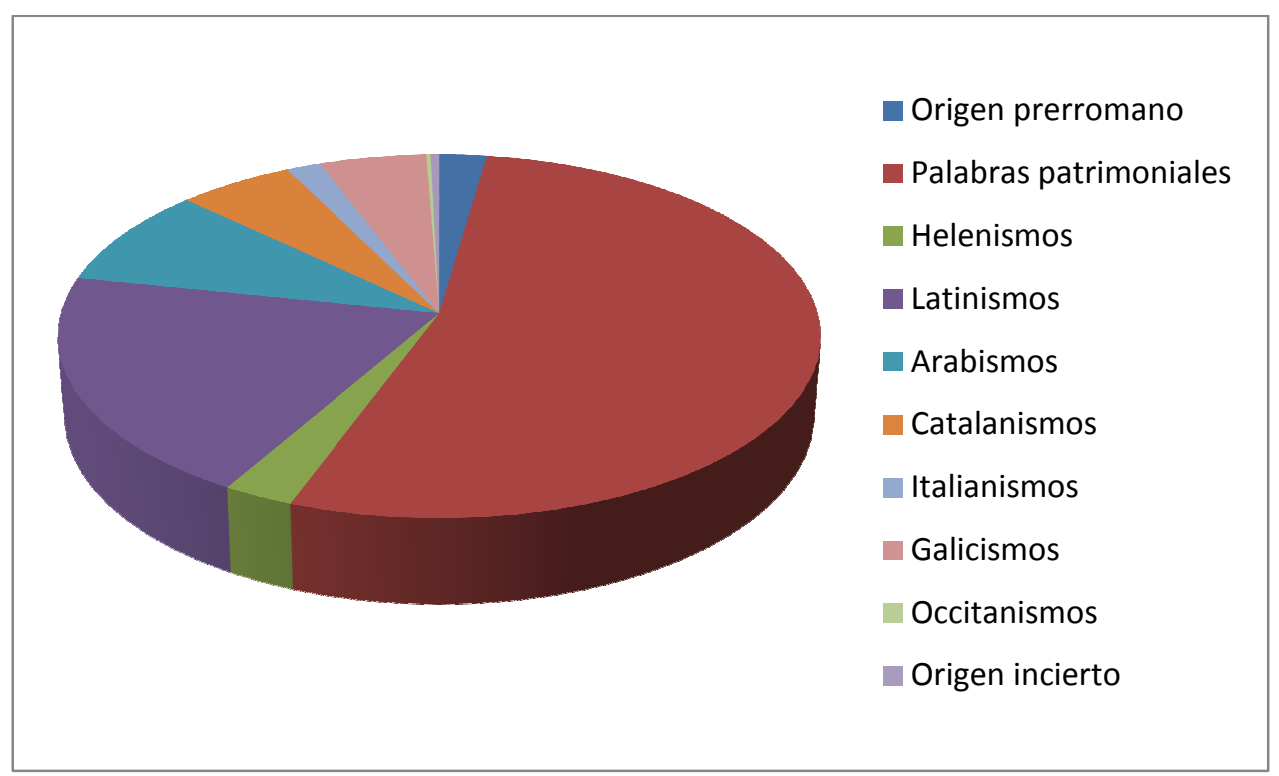

En cuanto a los dialectalismos renacentistas, registramos un número destacable de términos presentes en la zona aragonesa y propios de esta zona y no de otros lugares. La mayor parte de estas voces están documentadas en el texto Los Ventiún Libros de los Ingenios y Máquinas de Juanelo, texto al que, por este y otros motivos, se le suele atribuir una autoría de procedencia aragonesa. Muchas de estas voces pertenecen al ámbito de las obras hidráulicas y por tanto designan partes de obras o medios de canalización. Sin embargo, hallamos también algunas voces de maquinaria entre estos aragonesismos, así como voces referentes a materiales. Anteriormente nos hemos detenido más en este apartado pues lo consideramos importante, ya que "el aragonés es uno de los transmisores de arabismos indirectos al castellano" (Corriente 2004: 190) y sí que pensamos que algunos de los arabismos registrados podrían haber penetrado en el castellano por vía aragonesa. Por otro lado, sólo hemos encontrado un americanismo, cocha, en nuestro glosario.

Respecto a los neologismos renacentistas, fue importante la entrada de un grupo numeroso de voces del área de la ingeniería y la maquinaria, fundamentalmente por vía del latín para las denominaciones de máquinas y de sus piezas y partes. Muchos se encuentran en la traducción de Urrea de la obra de Vitrubio, aunque también hemos hallado varios en Los Ventiún Libros de los 
Ingenios y Máquinas de Juanelo.

\subsection{PRIMERAS DOCUMENTACIONES DE LAS VOCES}

\subsubsection{EDAD MEDIA}

En La Fazienda de Ultramar, fechada ca. 1200 en el CORDE, encontramos por vez primera el latinismo cisterna 'depósito de agua', del latín č̌stěrna 'íd.', derivado de cista 'cesta'.

En Berceo ya aparecen documentadas las voces catino, tomada del latín cătìnum 'fuente de loza', 'crisol', que en Urrea designa el vaso de metal que recibe el agua en una máquina tesíbica; escorpión, que en Urrea señala una 'máquina para elevar pesos' e instrumento, tomado del latín instrūmentum 'íd.' (DECH), cultismo simultáneo al uso de la forma popular estrumento. También hallamos en este autor los registros más antiguos de potencia 'capacidad para producir un efecto' y potente, tomado del latín pǒtèns, pŏtèntis 'el que puede'.

Hallamos en este tiempo los primeros registros de latinismos que designan acciones y efectos realizados, entre otras cosas, con el agua, como división 'acción y efecto de dividir', que aparece en el Libro de Alexandre y moto ${ }^{173}$ 'acción y efecto de mover' [1254-1256, Anónimo, Judizios de las estrellas (CORDE)].

A finales del siglo XIII datamos armamento 'pieza o conjunto de piezas unidas', tomado del latín armāmentum 'íd.' (DECH), sinónimo de armazón, el cual está tomado de armatǐo, armatǐnnis 'íd.' y documentado a finales del siglo XV (Woodbr.)

Recogeríamos la entrada en el siglo XIV de verbos como espirar ${ }^{174}$ 'despedir gases', que DECH documenta hacia 1400, en Gutierre de Toledo, pero que el CORDE ya recoge hacia 1350, en la traducción anónima de la Historia de

173 Tomado del latín mōtūs, -us 'íd.' (OLD).

174 Tomado del latín spīrāre 'soplar', 'respirar' (DECH). 
Jerusalem abreviada de Jacobo, e imprimir ${ }^{175}$, para cuya primera datación $\mathrm{DECH}$ propone mediados del siglo XV con El Corbacho, pero que aquí situamos, gracias al CORDE, en 1352, en el Anónimo Becerro de las Behetrías de Castilla.

Ya es en el siglo XV cuando datamos latinismos que designan máquinas, documentados en Alfonso de Palencia, como ariete $^{176}$ ‘máquina, generalmente usada en la guerra para batir murallas' o elementos de las obras hidráulicas como conducto, tomado del bajo latín conductŭs 'íd.' (DECH). El verbo conducir, tomado del latín condūcĕre 'conducir juntamente, juntar' se halla por vez primera en Juan de Mena $(\mathrm{DECH})^{177}$. Aunque $\mathrm{DECH}$ data divertir a finales del siglo XVI, gracias al CORDE lo hemos encontrado en el s. XV, en la Traducción y glosas de la Eneida de Enrique de Villena.

También recogemos algunas primeras documentaciones de estos latinismos en Nebrija, como es el caso de fístula 'caño, tubería', tomado del latín fistŭla 'caño de agua', 'tubo', 'flauta' (DECH).

En distintos textos de mediados del siglo $\mathrm{XV}$, de acuerdo con el DECH y con el CORDE, se documentan los cultismos invento ${ }^{178}$, inventar, inventor ${ }^{179} \mathrm{e}$ invención y mecánica ${ }^{180}$ y mecánico.

Además datamos en el siglo XV la entrada del adjetivo veloz ${ }^{181}$ [Mena, Santillana (DECH) y ya a finales de siglo el adjetivo móvil 182 'que puede moverse o se mueve por sí mismo' [1499, Hernán Núñez (DECH)]. En Enrique de Villena (1422-1425) registramos, según el CORDE, la primera aparición de impresión ${ }^{183}$.

\subsubsection{SIGLO XVI}

175 Tomado del latín imprimĕre 'hacer presión (en algo), marcar una huella'.

176 Tomado del latín ărǐes, ărǔ̌tis 'morueco (carnero padre)', 'ariete' (DECH).

177 No hemos encontrado registros de conducto y conducir anteriores a esta fecha en el CORDE.

178 Tomado del latín invěntum 'íd.'.

179 Tomado del latín inventŏr, inventōris 'íd.'.

180 Tomado del latín mēchănŭca 'íd.'.

181 Tomado del latín vĕlox, vělōcis 'rápido, presto, veloz'.

182 Tomado del latín mōbullis 'movible'.

183 Tomado del latín impresš̌o, -ōnis 'íd.' (DECH). 
En primer lugar, quisiéramos comentar que documentamos por vez primera la voz ingeniería en 1606, voz que se encuentra en nuestros textos (García de Céspedes, etc.) aunque en un número limitado de ocurrencias. Nos ha llamado la atención que ingeniería no esté recogida en diccionarios como el de Covarrubias, el Diccionario de Autoridades o el Diccionario de Terreros.

Registramos la entrada en esta época de latinismos que designan importantes elementos de ingeniería hidráulica, como acueducto, tomado del latín ăquaedūctŭs 'conducto de agua', 'acueducto', que por vez primera aparece, según los datos del CORDE, en De la antigua lengua (1587) de Andrés de Poza.

De acuerdo con el CORDE, situaríamos la primera documentación del latinismo perito 'entendido o experimentado en una ciencia o arte', tomado de pĕrĭtus 'experimentado', 'entendido' (DECH) en la primera mitad del s. XVI, en Apologética historia sumaria de Bartolomé de Las Casas.

A pesar de que hemos situado máquina en el grupo de helenismos que llegaron a través del latín, no podemos sino clasificar a otros miembros de esa familia en el apartado de latinismos, pues derivan, de acuerdo con Raimundo de Miguel, del latín māchĭna y māchĭnator. Estos son maquinación [1562, Zurita (CORDE)], maquinar [1497 (CORDE)] y maquinatoria [1582, Urrea (DICTER)], fechados por vez primera, por tanto, en torno al siglo XVI.

Conforman un nutrido grupo los latinismos que, designando máquinas y piezas de máquinas, se encuentran presentes por primera vez en la traducción de Urrea, como arbúscula 'pie de carro para llevar máquinas', tomado del latín arbuscŭla 'íd.', diminutivo de arbor, arbŏris 'árbol' (Salinero); arrectario 'madero que soporta el peso en algunas máquinas', de arrectārŭus 'madero derecho'; cárdine 'hierro de algunas máquinas', del latín cardō, cardĭnis 'gozne, quicio'; engibato 184 'artificio hidráulico musical'; equipondio 'pieza metálica para comparar pesos', tomado del latín ecquis pondus 'mismo peso'; ergata185 'torno

184 Tomado del latín angibăta, angībătorum 'pequeñas figuras huecas' (Agustín Blánquez Fraile).

185 Tomado del latín ergăta 'íd.' (incluido en Laterculi). 
vertical para mover pesos'; fibula186 'hebilla con la que se sujeta la carga'; modiolo 'vasija', tomado del latín modiŏlus 'vasija para beber' (Gaffiot), 'vaso que forma parte de algunas máquinas'; pénula187 'cubierta de una máquina'; súcula 'pieza grande con forma de tuerca' tomado del latín sŭcŭla 'cabria', que DECH documenta tardíamente, en 1843; tímpano 'aparato para la elevación del agua', tomado del latín tympănum 'pandero', 'rueda', 'grúa', voz que, de acuerdo con DECH, estaba ya presente en Juan de Mena. También encontramos en esta traducción de Urrea varios adjetivos aplicados a máquinas, como escansorio ${ }^{188}$ 'que sirve para subir pesos'; tractorio 189 'que sirve para arrastrar cargas' y espirital y espiritual 'que funciona con aire', voces presentes, con otro significado, evidentemente, desde los Orígenes. Asimismo señalamos movimientos como rotundación 'movimiento que consiste en girar en redondo', tomado del latín rŏtŭndatio, rŏtŭndationis 'íd.' (Gaffiot).

En la traducción de Besson, cuya entrada por tanto se realiza por vía del francés, hallamos el latinismo atelabo 'trabazón de la balanza de un torno', tomado del latín attĕlĕbus 'langosta'.

Es en el corpus del DICTER donde localizamos el latinismo motor ${ }^{190}$ en fecha más temprana [1590, Perfeto capitán de Álava de Viamont] a la señalada en DECH (s. XVII).

En cuanto a la traducción de Loçano de los libros de León Baptista Alberti, señalamos la presencia del latinismo incile ${ }^{191}$ 'cabecera de un conducto'.

Hallados por vez primera en Los Ventiún Libros..., recogemos los latinismos castelo 'desaguadero', tomado del latín castēllum 'depósito o arca de agua' (Raimundo de Miguel): especo 'cabecera de un conducto', del latín specu

186 Tomado del latín fibŭla 'hebilla' (DECH).

187 Tomado del latín paenŭla 'cubierta de una máquina' (Agustín Blánquez Fraile).

188 Tomado del latín scānsorius, scānsoria 'que sube'.

189 Tomado del latín tractōrǔs, tractōrŭa 'que sirve para arrastrar'.

190 Tomado del latín mōtŏr, mōtōris 'que mueve, movedor'.

191 Tomado del latín incīe 'acequia, arroyo' (Segura Munguía). 
'conducto de agua' (Gaffiot); estípite 'eje de una puerta', tomado del latín stīpěs, stīputtis 'tronco', 'estaca', 'rama', adelantando así la primera documentación de este término que ofrece DECH, que lo sitúa en el Diccionario de Autoridades; pondos, sinónimo en el texto del ya visto equipondio 'pieza metáliza para determinar un peso', tomado del latín pondus 'peso'; premodo 'obra para regular la cantidad de agua', probablemente tomado del latín praemŏdum 'otra medida' (V. Gaffiot), sinónimo del también presente en este texto promódulo, que podría haber sido tomado de pro mŏdŭlo (ingenii) 'según su capacidad' (V. Blánquez Fraile). También encontramos aquí por primera vez quinario y quinaria 'caño o fístula de cinco dedos de diámetro', tomados del latín quīnārĭus, quīnārĭa 'relativo a cinco' (Gaffiot), aunque el adjetivo quinario 'relativo a cinco' ya está documentado en Alfonso de Palencia (CORDE). Lo mismo ocurre con los cultismos senario y senaria 'caño o fístula de seis dedos de diámetro' y setinaria 'caño o fístula de cinco quinarias de diámetro'.

\subsection{CRONOLOGÍA DE ALGUNAS FAMILIAS LÉXICAS}

Observamos, por las dataciones, la introducción paulatina de los miembros de una familia de latinismos, como es la de artificio, término tomado del latín artǐfícium 'íd.', documentado ya en las Glosas de Silos (2 $2^{\mathrm{a}}$ mitad del siglo X), cuya llegada al idioma se verá seguida por la de otros miembros de esta familia de cultismos, como artificial [h. 1250, Setenario], de artüfícūālis 'íd.', artífice 'maestro de las artes mecánicas o manuales' [Celestina], de artǔfex, artǐfičs 'íd.' y artificioso [1 $1^{\mathrm{a}}$ mitad del siglo XVI, Garcilaso], del latín artǐfíč̄osus 'íd.'.

Algo similar ocurre con la familia léxica de edificar [h. 1107, BHisp.], tomado del latín aed̆̈ficāere 'íd.', compuesto de aedes 'casa, edificio' y făcĕre 'hacer' $(\mathrm{DECH})$, pues documentamos la entrada de edificio hacia 1275 en $1^{a}$ Crón. Gral. (DECH), la del adjetivo edificatorio ${ }^{192}$ en la Controversia entre Ginés de Sepúlveda y Bartolomé de las Casas (1552) (CORDE) y adelantamos la fecha registrada en el

192 Tomado del latín aedŭficātōrŭus 'íd.' (Gaffiot). 
CORDE como primera entrada de reedificar ${ }^{193}$ (1573-1581, Historia de Santa Marta de Fray Pedro de Aguado) a 1530, por su aparición en uno de los textos del DICTER, Suma de Geographía de Fernández de Enciso. Sin embargo, en el corpus del DICTER la palabra reedificación aparece datada algo después que en el DECH, pues Corominas la documenta en 1521-1543, mientras que nosotros la encontramos en Los Ventiún Libros de los Ingenios y Máquinas (a. 1605).

En cuanto a la familia de ingenio, tomado del latín ĭngĕnĭum 'cualidades innatas de alguien' [1251, Calila e Dimna (CORDE); Nebrija (DECH)], término que convive en aquel tiempo con la palabra vulgar engeño, registramos el cultismo ingenioso en Gran Crónica de España (1385) de Fernández de Heredia en fecha anterior a la señalada por el DECH (Nebrija). Además, la obra de Fernán Pérez de Oliva Razonamiento sobre la navegación del Guadalquivir (1524-1580) nos sirve para, de acuerdo con el CORDE, documentar por vez primera el cultismo latino ingeniero ${ }^{194} \mathrm{y}$ así adelantar algo la fecha recogida a ese respecto en el DECH (1585, Fray Luis de León).

\subsection{ESTUDIO MORFOLÓGICO DE LAS VOCES}

De manera general, en los estudios sobre morfología se considera que son dos los procedimientos fundamentales de formación de palabras endógenos al castellano195: la derivación y la composición (Varela 2005: 8). A su vez, la derivación consta de dos mecanismos, la prefijación y la sufijación ${ }^{196}$, y de un tipo de formación, habitualmente estudiada aparte, en la que confluyen la prefijación y la sufijación simultáneamente: la parasíntesis ${ }^{197}$.

\subsubsection{LA DERIVACIÓN}

193 Tomado del bajo latín rěaedĭficāre 'íd.' (Segura Munguía).

194 Tomado del latín ı̆ngĕňerius 'íd.'.

195 Por tanto, nos ocupamos de morfología léxica y no de morfología flexiva (Pena 2000[1999]: 4308).

196 Algunos autores, como Alvar (1995), consideran que la prefijación debería ser clasificada como un tipo de composición y no de derivación, puesto que la intervención de un prefijo sobre una base léxica no implica el cambio de la categoría gramatical de esta base. Ante este argumento, Pena (2000[1999]), entre otros morfólogos, recuerda que los sufijos apreciativos tampoco producen un cambio categorial en la palabra a la que se adjuntan, pero que no por este motivo dejan de ser considerados sufijos derivativos.

${ }^{197}$ Denominada también circunfijación, V. Pena 2000[1999]: 4332-4333. 
Para desglosar el análisis de los tipos de derivaciones que operan en el léxico que nos ocupa, hemos tenido en cuenta, por este orden de clasificación, el proceso derivativo utilizado, la categoría gramatical de la palabra derivada, la categoría gramatical de la base léxica, el afijo que ha intervenido en la formación de esa palabra y el significado o los significados que creemos que ese afijo aporta a las distintas bases léxicas ${ }^{198}$.

Destacamos, en la derivación, su capacidad creativa y su capacidad inherente de cambio, tanto de la categoría gramatical de la base léxica, como de la semántica de esta base (Varela 1996: 69-70).

\subsubsection{Sufijación (no apreciativa) en la formación de sustantivos denominales}

$-a d a$

Este sufijo se remonta al -āta latino, representación tanto de la terminación adjetival femenina $-\bar{a} t u s,-a,-u m$, como de $-\bar{a} t a,-\bar{o} r u m$, neutro plural de la forma sustantivada $-\bar{a} t u m,-\bar{\imath}$, forma que en el latín tardío incluye los nomina actionis en -ātus, -ūs (Pharies 2002: 39). Son varios los autores que argumentan las especiales características de este sufijo debido a esa procedencia de dos sufijos homófonos ${ }^{199}$. Aunque las bases con las que se puede combinar este sufijo pueden ser sustantivas o adjetivas (Santiago Lacuesta y Bustos Gisbert 2000[1999]: 4518), en nuestro glosario sólo registramos su adición a sustantivos, a los que añade distintos significados:

'Golpe que se da con' + sustantivo base: martillada 'golpe que se da con un martillo' y mazada 'golpe dado con una maza o un mazo' (DRAE).

'Contenido en' + sustantivo: carretada 'carga que lleva una carreta', cubada

198 Para un análisis más profundo de las relaciones morfológicas y las relaciones semánticas, de las asociaciones o disociaciones entre estructura formal y estructura semántica, V. Corbin, 1987: 208-260 y Rainer 1989: 330-340, cit. en Pena 2003: 506. 4518.

199 V. Lüdtke 1978: 362 y 367, cit. en Santiago Lacuesta y Bustos Gisbert 2000[1999]: 
'cantidad que cabe en una cuba', molada200 'porción de color que se muele en una moleta'.

Los ejemplos de arcada y tramada ${ }^{201}$ recogidos en nuestro corpus son una muestra de lo que consideramos una extensión del significado 'colectivo' del sufijo -ada. Pues, aunque estos términos pueden designar un conjunto, de arcos en el caso de arcada y de tramos en el de tramada, no es esto lo que significan en nuestros textos. Hemos definido arcada 202 como 'fábrica en forma de arco entre dos de los pilares de un puente' y tramada 203 como 'espacio entre dos pilares de un puente'. El sufijo -ada tendría en estos casos, en nuestra opinión, el significado de 'uno en un colectivo o conjunto'. No hemos hallado este significado del sufijo en la bibliografía consultada.

Por otro lado, tenemos un ejemplo en el que -ada sugiere un proceso y un resultado, caracterizando así a la cosa denotada por su radical (Pharies 2002: 42). Esto lo podemos observar en el término rodada 'señal que deja impresa la rueda de un vehículo por donde pasa', de rueda (DECH).

\section{-adura}

Debe distinguirse este sufijo nominal de -dura, sufijo deverbal. Con valor colectivo señalamos dentadura 204 'conjunto de dientes de una rueda' (Pena 1980: 150 nota, Rainer 1993: 393 y Moreno de Alba 1986: 52, cit. en Santiago Lacuesta y Bustos Gisbert 2000[1999]: 4546), canaladura 'conjunto de hendiduras de la muela de un molino' y encañadura 205 'conducto formado por canales o caños trabados y unidos, para conducir el agua'.

-aje

200 De muela.

201 De tramo 'cada una de las partes en que está dividida una extensión lineal'. No aparece en DECH ni DRAE. Diferénciese de trama 'conjunto de hilos', derivado de trama.

202 "La puente A es hecha llana, y todas las arcadas se van cresciendo hasta llegar a lo medio" (Turriano, a. 1605: 372r).

203 "Para saber yr repartiendo los trampos de la puente o tramadas, y quánto ha de aver de un pie al otro, para saberla hazer con orden y concierto y medida" (Turriano, a. 1605: 214r).

204 De diente.

205 De encañado (DECH). 
Este sufijo es un préstamo que se incorporó al castellano por analogía con voces de procedencia occitana, francesa y catalana que incluían esta terminación en alguna de sus variantes ${ }^{206}$ (Pharies 2002: 52). En herraje 'conjunto de piezas de hierro', de hierro, el sufijo tiene un valor colectivo, siendo este significado el más habitual e importante del sufijo (Santiago Lacuesta y Bustos Gisbert 2000[1999]: 5423).

$$
-a l /-a r
$$

De manera general, se considera que -al y -ar son alomorfos de un mismo sufijo, que habitualmente se combina con bases nominales (Santiago Lacuesta y Bustos Gisbert 2000[1999]: 4527). Este sufijo proviene del -ālis latino, que deriva adjetivos a partir de bases nominales (Pharies 2002: 57) y que significa pertenencia o relación, por un lado, y lugar, por otro, en su forma de adjetivo sustantivado. En cuanto al significado de este sufijo en los sustantivos del glosario que conforma, destacamos el locativo en arenal 'extensión grande de arena', donde para algunos autores este sufijo tiene el sentido de 'abundancia' (Almela 1999: 108).

En otras ocasiones, este sufijo tiene el sentido de 'relativo a' + base. Son casos de mayor dificultad a la hora de agruparlos semánticamente (Santiago Lacuesta y Bustos Gisbert 2000[1999]: 4529) el de bocal207 'toma de agua o desaguadero de una presa o azud', cañal 208 'cauce artificial por donde se conduce el agua para darle salida o para otros usos', cigoñal209 'pértiga que forma parte del mecanismo de distintos ingenios hidráulicos', guindal210 'cuerda

206 -age, -atge, -aie, -aje, etc.

207 De boca. "Las formas son differentes, en especial las que tienen dos bocales. Éssas se hazen muy differentes de lo que se hazían los que tienen dos vocales en un mismo açute, por causa del encaminar el agua a las dos partes" (Turriano, a. 1605: 172r).

208 De caña 'cauce artificial'. "Aquél a quien se deve la servidumbre deve mantener las acequias, o cañas, o cañales, o calçada por do corriere el agua, por manera que no haga daño a la tal heredad que deve la servidumbre" (Celso 1553: CLXIv).

209 De cigüeña. "Nueva hechura de molino a braços para prensar y aparejar paños y papel, y moler especies, y esmenuzar piedras preñadas de metales para preparallas a hundir, y también para pulir y aguzar qualesquier instrumentos soltados a cigoñales y majaderos" (Besson 1602: G4v).

210 Creemos que viene de guinda 'cosa que remata o culmina algo'. "Cien quintales de toda clavazón, áncoras y alquitrán, cuerdas a la mano, guindales, escaletas y martinetes, 
de cáñamo o de cuero, del grueso de un dedo', pozal 'cubo con el que se saca el agua de un pozo', quicial 211 'madero que asegura y afirma las puertas y ventanas' y varal 'vara muy larga y gruesa'.

El alomorfo latino -āris, del que procede -ar, se añade originariamente a las bases que contienen -l-, y así ocurre con su equivalente castellano. Este es el caso, en cuanto al léxico que conforma nuestro glosario, de sillar212.

- dor

Aunque este sufijo actúa habitualmente sobre bases verbales, tal y como veremos posteriormente, existen algunos casos, como el de aguador 213 , registrado en nuestro corpus, en el que la base de derivación es nominal (Santiago Lacuesta y Bustos Gisbert 2000[1999]: 4543). La categoría semántica del sufijo, en este sustantivo, no tendría cabida en la clasificación de Laca (1986: 271-294) 214 , realizada a partir del comportamiento sintáctico de las designaciones de seres animados formadas con -dor, aunque sí que coincide con el rasgo semántico indicativo de profesión u oficio, pues aguador designa una 'persona que tiene por oficio el llevar o vender agua'.

-era

Con respecto al sufijo -era, señalamos que, al contrario que -ero, no atiende en sus apariciones a ninguna designación de 'nombres de agente', sino que refleja, en el léxico recogido, un heterogéneo grupo semántico. Aunque estos tipos formativos no son de fácil delimitación puesto que se relacionan

faroles, turquesas o rosquillas de brea, lanternas, candelas de sebo, hachas de çera o antorchas, graso y otras menudencias" (Ufano 1613: 86).

211 De quicio. "Sobre esta juntura se levanten los postes de juntar fuera de los quiciales, de nueve pies en gruesso, por todas partes de un palmo y un pie, que disten entre sí por pie y medio" (Urrea 1582: 136r).

${ }^{212}$ De silla. "Y conviene que sea muy bien hecha y bien asentada, por razón que no se trasmine la agua por las juntas de los sillares" (Turriano, a. 1605: 314v).

${ }^{213}$ De agua. "Y mandó que hubiese pocos aguadores y leñadores y que todas las vestias de albarda se bendiesen, salvo que quedasen las forçosas" (Rojas 1607: 51r).

${ }^{214}$ Laca distingue entre sustantivos 'clasificadores' (designan a "alguien que profesionalmente + verbo base"), 'caracterizadores' (personas que se inclinan a realizar la acción de la base verbal) e 'identificadores' (personas que han llevado a cabo la acción referida por el verbo) (Santiago Lacuesta y Bustos Gisbert 2000[1999]: 4543-4544). 
entre sí (Amador 2009: 262), distinguimos fundamentalmente nombres de objetos, en los que la base léxica designa, en nuestra opinión:

La acción que provoca un objeto, como la designada por parada, base léxica de paradera 215 'compuerta con que se regula el agua' $\mathrm{o}$, dicho de otro modo, "compuerta que produce la parada de las aguas".

El contenido de ese objeto, contenido total en el caso de canal en canalera, y parcial en el de clavo en clavera 'agujero o molde en que se forman las cabezas de los clavos'. Canalera es además sinónimo de una de las acepciones de su base canal.

Creemos que en los textos tienen el mismo significado quicial y su derivado quicialera 'madero que asegura y afirma las puertas y ventanas'.

\section{-ería}

A pesar de que este sufijo se añade tanto a adjetivos como a sustantivos, todos los derivados de -ería de nuestro glosario son denominales. De acuerdo con Pharies, este sufijo es un compuesto integrado por -ero e -ía y debe considerarse una variante de -ía, puesto que comparte con él características semánticas y léxicas (Pharies 2002: 225). Sin embargo, siguiendo a Ramón Santiago Lacuesta y Eugenio Bustos Gisbert, nosotros los consideramos sufijos diferentes y los tratamos como tales.

Los sinónimos albañería, albañilería e pertenecen al grupo de voces que designan una actividad profesional, en este caso un arte $\mathrm{u}$ oficio. Son varios los miembros de este grupo que derivan de una base en -ero, y que, por tanto, se encuentran en el apartado del sufijo -ía. Observamos aquí la señalada tendencia de este sufijo a adjuntarse a sustantivos terminados en vocal tónica (albañería ${ }^{216}$ ), vocal a la que, en ocasiones, sigue -n/-1 (albañilería ${ }^{217}$ ) (NGLE: 120). Pertenecería

\footnotetext{
215 De parada (DRAE).

216 De albañí.

217 De albañil.
} 
a este grupo la voz ingeniería 218 .

Dentro de los varios subgrupos del significado colectivo de -ería que aparecen en Rainer 1993: 480, señalamos el de referencia no animada, con una base de designación "de objeto", subgrupo al que pertenecería cañería219 'pieza hueca por donde se conducen las aguas'. También otorgaría el sufijo un significado colectivo no animado, referido a lo que Rainer denomina “objetos de equipamiento" en albañilería, en un ejemplo registrado en el manuscrito de Lobato (1585), donde significa, en nuestra opinión, 'conjunto de materiales propios del arte de la albañilería, como los ladrillos, la piedra, la cal y la $\operatorname{arena}^{220:}$

-ero

Aunque originalmente este sufijo deriva adjetivos de pertenencia (Pharies 2002: 228), en nuestra selección léxica hemos comprobado que prácticamente todos los derivados en -ero son únicamente sustantivos. En estos, de acuerdo con el DRAE, este sufijo indica oficio, ocupación, profesión o cargo. Efectivamente, se trata de un conjunto de derivados que designan 'nombres de agente' (Santiago Lacuesta y Bustos Gisbert 2000[1999]: 4557). En el glosario, hemos decidido definir todas estas palabras, siempre que nos ha sido posible, como "persona que tiene como oficio el + infinitivo + complemento(s)". Tal y como afirma Laca, este grupo puede dividirse, teniendo en cuenta su base de designación, en varios subgrupos (Laca 1986: 538). Aunque entre estos subgrupos existen continuos desplazamientos semánticos, hemos realizado una pequeña clasificación de estos derivados en cuanto al significado de su base léxica:

Lugar en el que se realiza una actividad: alfar en alfarero 221 , batán en

218 De ingenio.

219 De caño.

220 "Ha de ir a salir la dicha acequia cubierta de albañilería muy baja y con gran corriente dentro de la dicha balsa, no atravesada, sino al hilo del agua, a soltar casi la tercera parte de la balsa, y al fin asentar un marco de madera cuadrado, no levantado ni echado, sino de lado" (Lobato 1585: 33).

${ }^{221}$ De alfar 'obrador de alfarero', 'arcilla'. Alfar no está en el corpus. 
batanero, jardin en jardinero, molino en molinero y torno en tornero.

Objeto resultado de esa actividad (generalmente objeto que se fabrica, arregla o vende y habitualmente varias de estas acciones simultáneamente): agua en aguacero 222 , caldera en calderero 223 , campana en campanero, cántaro en cantarero, carreta en carretero, cerraja en cerrajero 224 , escudilla en escudillero, fontana en fontanero ${ }^{225} \mathrm{y}$ vidrio en vidriero.

Mención aparte merece el caso de frontero 'persona que tiene por oficio el llevar aguas y fuentes de una parte a otra'. Creemos que viene de fronte, tal y como lo registran los repertorios lexicográficos DECH y DRAE. Sin embargo, no hemos encontrado el sentido que nos ocupa en ninguno de los diccionarios consultados. Tampoco hemos hallado un sentido de fronte del que pudiera derivar este otro de frontero, porque en DRAE y en el corpus significa 'frente', motivo por el cual no hemos incluido fronte en el glosario. Resaltamos el hecho de que, con este sentido, frontero solo aparece una vez en el corpus y lo hace en el fol. $49 \mathrm{v}$ de la obra atribuida a Juanelo Turriano, donde además se dice de esta voz que es popular 226 .

\section{-ía}

Prácticamente en todas las palabras en las que hemos hallado este sufijo, aparece concatenado a una base en -ero. En ellas tiene distintos valores, muchos de ellos afines a los de -ería, como el colectivo en carretería 'conjunto de carretas'

${ }^{222}$ Este es uno de los casos en los que aparece un interfijo, en concreto $-c$-, probablemente resultado de un hueco en la cadena derivativa aguacero (< aguaza) (V. ejemplos de este tipo en Santiago Lacuesta y Bustos Gisbert 2000[1999]: 4557).

${ }^{223}$ Proviene del femenino caldera en lugar del masculino caldero (DECH). Caldero, según el DRAE, deriva del latín caldārĭum, que no aparece en Segura Munguía sino como una forma del adjetivo caldārǔus, $-a,-u m$ 'de baño caliente'.

224 De cerraja 'cerradura'.

${ }^{225}$ Fontana no se halla en el corpus. Este es uno de los casos en los que el diptongo de la base nominal desaparece (Santiago Lacuesta y Bustos Gisbert 2000[1999]: 4557).

226 "Mas, para quien más conviene estos instrumentos son para los que professan el llevar fuentes y aguas de una parte a otra, como son aquéllos que el vulgo llama fronteros, para saber conocer la differencia que ay de una parte a otra en altura, y para saber quánto es más baja una tierra a la otra" (Turriano, a. 1605: 49v). 
o el locativo en herrería ${ }^{227}$ y pesquería, donde señala el lugar en el que algo (el hierro o los peces, respectivamente) se vende, fabrica o almacena. En mampostería, -ía creemos que designa tanto el resultado de la actividad del mampostero, es decir, la obra hecha con mampuestos 228 , como los mampuestos propiamente o el conjunto de materiales principales de esa actividad ${ }^{229}$.

\section{- ista}

Este sufijo culto deriva sustantivos a partir de bases nominales y adjetivales, sustantivos que designan, entre otras cuestiones, personas que ejercen una profesión $\mathrm{u}$ oficio, como maquinista 'inventor o fabricante de máquinas'.

$$
-i z a
$$

Aunque este sufijo deriva adjetivos, como veremos en el apartado correspondiente, encontramos un caso, seguramente aragonesismo, en el que $i z a$ deriva un sustantivo, frontiza ${ }^{230}$ 'herraje en dos piezas', a partir de una base también sustantiva, probablemente fronte 'frente'.

$-n t e$

Es un caso curioso el que registramos aquí, puesto que, como veremos posteriormente, el sufijo -nte deriva adjetivos y sustantivos deverbales, pero hemos hallado su intervención en un sustantivo con base nominal, tenazante 'tenaza de gran tamaño', donde el sufijo aporta, a nuestro modo de ver, un valor aumentativo.

227 De herrero. Pharies 2002: 227 señala, sin embargo, que en la formación de herrería participa el sufijo -ería, por lo cual, según este autor, sería derivado de hierro. DRAE, por otro lado, afirma que herrería proviene de ferrería, y esta de ferrero.

228 "Lo primero, porque las piedras de la mampostería están espessas y macizas, y assí no pueden chupar el humor de la materia de la cal, antes se conservan en humedad hasta la vejez" (Urrea 1582: 28r).

229 "Y en el medio assentarán mampostería menuda, $\mathrm{y}$, de trecho en trecho, hazer traviessas algunas piedras que sean muy largas" (Turriano, a. 1605: 432v).

230 "Y, por tanto, aquellas alguaças o frontizas han de desçendir hasta los cabos de las puntas como triángulos, para que tengan fuerça para atraher el lodo" (Turriano, a. 1605: $365 \mathrm{v})$. 


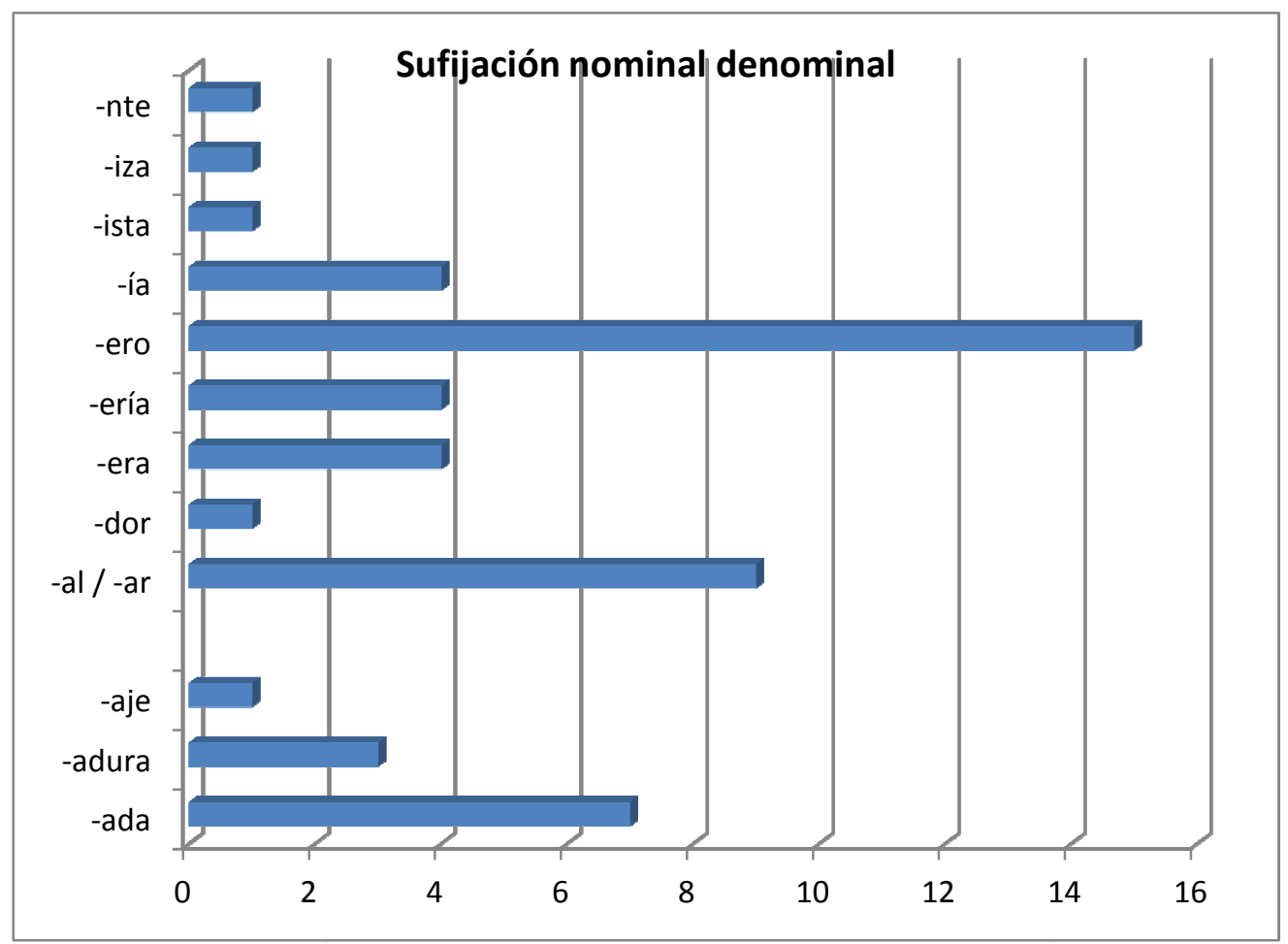

\subsubsection{Relación derivativa}

Incluimos en este apartado aquellos pares flexivos en los que los morfemas de género adquieren una interpretación como afijos derivativos y, por tanto, en estas voces la variación genérica implica también una variación semántica (Ambadiang 2000[1999]: 4880).

En nuestro registros encontramos algunos pares de este tipo. En cuanto a aquellos en los que el masculino, de acuerdo con nuestras fuentes, deriva del femenino, señalamos oposiciones semánticas de tamaño, en las que el masculino designa un objeto más grande que aquel señalado por el femenino, en pares como barreno/barrena, caño/caña y capazo/capaza; también ocurre lo contrario, que el femenino indica mayor tamaño que el masculino en cubo/cuba; la oposición semántica es de macho/hembra, en cuanto a piezas de máquinas, en caracol/caracola; por otro lado, observamos una relación metonímica en los pares huello/huella (sitio en el que se pisa/marca que se deja al pisar), así como en tranco 'nivel' (de tranca 231 'palo'). No registramos ninguna diferencia de 
significado en el par carrucho/carrucha ${ }^{232}$ ni entre resquicio/resquicia. Respecto a los pares genéricos en los que consideramos que el femenino deriva del masculino, no hemos hallado oposición semántica en cribo/criba, aunque sí que la marcamos, en cuanto a profundidad, en pozo/poza. También sería una voz de este tipo gata (de gato ${ }^{233}$ ). Sin variación genérica, puesto que ambos son masculinos, pero con alternancia alomórfica, registramos el par fuste/fusto, donde el aragonesismo fusto 'pieza de madera de hilo', deriva, de acuerdo con $\mathrm{DECH}$, de fuste 'fundamento de madera para colocar algo sobre él'.

\subsubsection{La sufijación apreciativa}

\subsection{PEYORATIVOS Y DIMINUTIVOS}

$-a j o,-a j a$

Clasificado en el grupo de los peyorativos (V. Lázaro Mora 2000[1999]: 4648 y NGLE: 627), en este sufijo convergen dos sufijos latinos, -āculum, -ī, sufijo deverbal que deriva nombres de instrumentos, de objetos y de lugares y -ālia, ium, sufijo, habitualmente nominal, que conforma colectivos (Pharies 2002: 54). ajo, -aja aparece también en rodaja 234 ' pieza plana y circular que forma parte de la polea'. Consideramos, sin embargo, palabra patrimonial a tinaja 'vasija grande de barro cocido para guardar aceite, agua', pues ahí el sufijo -ajo, -aja continua étimos documentados en $-\bar{a} c u l u m^{235}$ (del latín *tīnăcula, diminutivo de tìna, tìnae 'vasija', según Segura Munguía).

$$
-e j o,-e j a^{236}
$$

Este sufijo se remonta al latín -(i)culus, $-a$, -um, sufijo diminutivo (Pharies 2002: 195). Lo encontramos en martillejo 'martillo pequeño', donde conserva el significado original del sufijo diminutivo y en canaleja 'pieza de madera unida a

232 Este par no se encuentra recogido en los diccionarios consultados; creemos que el femenino deriva del masculino por ser este último derivado de carro.

233 No se encuentra en el corpus.

234 De rueda $(\mathrm{DECH})$.

235 Tenāculum, -ī'recipiente' <teneō, -ēre 'contener'(Pharies 2002: 54).

236 Acerca del temprano uso del sufijo -ejo, -eja, V. Rainer 2002: 98. 
la tolva, por donde pasa el grano u otro material a la muela', voz en la que ese significado apreciativo se mantiene sólo parcialmente. Registramos además guepejo 'pieza encajada en la solera, donde se apoya el gorrón de un molino', término para el cual no hemos hallado una base léxica en castellano y pensamos que, para su configuración, el sufijo se adjuntó a una base procedente probablemente del francés, en concreto creemos que puede tratarse de guêpe 'avispa' (TLF).

$$
\text { -ete, -eta }
$$

Como este sufijo apreciativo se remonta al catalano-aragonés -et, -eta, proveniente a su vez del sufijo de origen no latino -ittus (Pharies 2002: 242), tenemos constancia de un posible uso dialectal de algunos términos derivados en -ete, -eta en el léxico estudiado. A este respecto, hemos de señalar que, entre las voces formadas con este sufijo diminutivo, podemos marcar bacieta, cubete y rodete como aragonesismos, por haber sido extraídas, en todas sus ocurrencias, de Los Veinte y un libros de los yngenios y máquinas de Juanelo237. En nuestra opinión, en estos aragonesismos el significado apreciativo diminutivo del sufijo se ha perdido. Sí que se halla ese matiz semántico en gran medida en otras voces sobre las que, a la luz de su aparición en los textos, no registramos dialectalismos, como barreta, canalete y su doble femenino canaleta $^{238}$, hacheta, maceta, moleta239, molinete, palanqueta y piqueta. Creemos que ese valor no se encuentra en arqueta 240 'casilla o depósito para recibir el agua y distribuirla' y almadeneta 241 'piedra dura y pesada utilizada para moler metal', motivo por el que hemos considerado a estas voces sinónimos de $\operatorname{arca}^{242}$ y almádena ${ }^{243}$,

237 Para más detalles sobre este texto y su relación con Aragón, véase el capítulo 2.2.

238 El derivado admite las dos formas debido a que la base léxica, canal, es un nombre ambiguo.

239 De muela (DRAE).

240 "Molino de aceñuela de arquetas" (Lobato c. 1585: 17).

241 "Almadaneta llaman a otro género de piedra por su dureza y peso; es solidíssima, de color escuro, compañía de metales ricos que se crían en ella quando llega a madurar o podrir, como también los quijos" (Alonso Barba 1640: 12v).

242 "Y si este vasso está ençima de las fuentes, puede vaziar sus aguas, como hazen las arcas de las fuentes que se llevan por caños o alcaduzes, porque no hecharía más agua afuera, si una vez se ubiese vaziado" (Turriano, a. 1605: 3v). 
respectivamente. Tampoco hallamos ese matiz diminutivo en guindaleta, voz que el DRAE considera un derivado deverbal de guindar, pero que, a la luz de los datos recogidos, creemos que podría tratarse de un derivado denominal, de guindal 'cuerda de cáñamo o cuero del grueso de un dedo', su sinónimo.

$$
- \text { illo, -illa }
$$

Del sufijo latino -ĕllus, tiene varios resultados en castellano ${ }^{244}$, así como los tuvo en latín, debido a las variantes surgidas por el reajuste morfológico que

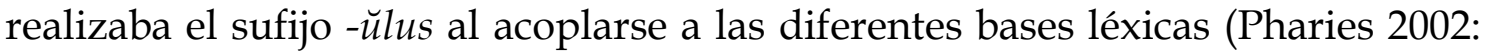
326). Este sufijo, el diminutivo más productivo en nuestra lengua a lo largo de la Edad Media, perdió vigencia a partir del siglo XV ante el uso cada vez más frecuente de -ito (Pharies 2002: 327).

-illo, -illa, única forma del sufijo encontrada en el glosario, mantiene en general en las voces seleccionadas el significado diminutivo: alcantarilla 245 'puente pequeño para algún arroyo', arenilla, bacinilla 246, cabrilla 'cabria pequeña', carretillo 247 'polea' y su sinónimo carrillo $^{248}$, carretoncillo ${ }^{249}$, furillo 250 'rosca de caracol', husillo251, parrilla252, tarabilla253 'tabla de madera por la que la tolva despide la cibera' y tornillo.

-ín

243 "Y poco después añade: «Hieren la dura peña con almádanas que tienen ciento y cincuenta libras de hierro" (Acosta 1590: 217).

244 Además de -illo, existen -iello y -ello.

245 De alcántara 'caja grande de madera'.

246 De bacina 'vasija', voz que no se encuentra en el corpus del DICTER, aunque sí que registramos bacín.

247 Probablemente de carrete 'cilindro'. "D'esta máchina usamos muy cómmodamente para levantar los pesos aplicándole poleas o carretillo" (Lechuga 1611: 346).

248 "Trochilo es otro miembro principal en la basa que, por semejar al carrillo o polea, le llamaron los griegos trochilo, que quiere dezir 'rodaja'" (Sagredo 1526: 37).

${ }^{249}$ De carretón, y este del catalán u occitano carretó 'parte inferior de un mantelete', por lo que -ón en esta voz no es un sufijo aumentativo. Como en otros casos en los que la base léxica acaba en consonante, en la formación de carretoncillo encontramos el infijo -centre la base y el sufijo apreciativo.

250 De furo 'orificio' (del latín forāre 'horadar').

251 De huso 'cilindro'.

252 De parra 'enrejado'.

253 Del árabe hispánico țaráb, y este del ár. clás. țarab 'música'. 
Este sufijo con valor diminutivo ${ }^{254}$, variante apocopada de -ino ${ }^{255}$ surgida probablemente por analogía con el aumentativo -ón (Malkiel 1988), deriva una forma en nuestro léxico, saetín ${ }^{256}$ 'canal angosto que conduce el agua a la rueda de un molino'.

$-o l o,-o l a$

Este sufijo es uno de los primeros estadios evolutivos del sufijo diminutivo latino - ŏlus y generalmente lo encontramos en préstamos (Pharies 2002: 426). En nuestro glosario, sin embargo, lo hemos hallado en una forma vernácula, derivada de polea: poleola 'polea de pequeño tamaño'.

\section{-ucho, -ucha}

Derivado de -us, -culus, este sufijo es peyorativo a día de hoy, pero en los derivados antiguos aporta un valor diminutivo (Pharies 2002: 507). Con este matiz lo encontramos en los hallados carrucho y carrucha257 'polea' y sus respectivas variantes posteriores, garrucho y garrucha.

-uelo, -uela

Este sufijo procede del también diminutivo -ŏlus latino, originalmente átono, que sufrió una larga cadena evolutiva (Pharies 2002: 517). González Ollé y Casado Velarde (1992: 108, cf. Pharies) resaltan la aparición de este sufijo en determinados contextos fonéticos, dos de los cuales coinciden con los contextos de dos de las bases léxicas a las que se añade este sufijo en nuestra selección léxica. Estos son: tras -ñ-, como en cigüeñuela 'codo del eje que realiza el movimiento rotatorio en un molinete' y tras -ch-, como ocurre en hachuela 'hacha pequeña'. Entre el gran número de interfijos con los que se combina este sufijo,

254 De acuerdo con Malkiel, este sufijo no denota diminutivos en sentido estricto, sino que da nombre a personas u objetos de poco valor o importancia (Malkiel 1988, en Pharies 2002: 331).

255 Encontramos en nuestros textos la forma barquín, apócope de la voz barquino (no incluida en el corpus). No las consideramos derivados, puesto que provienen, de acuerdo con el DECH, del latín [follis] vervecinus '[odre] de morueco)'.

256 De saeta. Obsérvese que en este caso sí que ha habido cambio de género, puesto que saeta es femenino y saetín, masculino.

257 De carro. 
destaca notablemente -(e)z-, interfijo que ha actuado en la formación de los términos herrezuelo, mazuelo y porquezuela. Observamos que, también estos casos de derivación con -uelo, -uela, prácticamente todos los términos conservan el valor diminutivo del sufijo. Supone una excepción a este respecto porquezuela ${ }^{258}$, puesto que, en el único texto en el que se recoge ${ }^{259}$, lo hace con el sentido de 'pieza grande con forma de tuerca', es decir, tiene un significado aumentativo, completamente opuesto al que denota el sufijo -uela. En este contexto léxico, se produce un curioso cruce con puerca, el término que constituye su base léxica y que denomina tanto una pieza pequeña 'tuerca, pieza para ajustar clavos y tornillos', como una grande, motivo este último por el que porquezuela y puerca, en su sentido de 'pieza grande', son extrañamente sinónimos y como tal los hemos registrado.

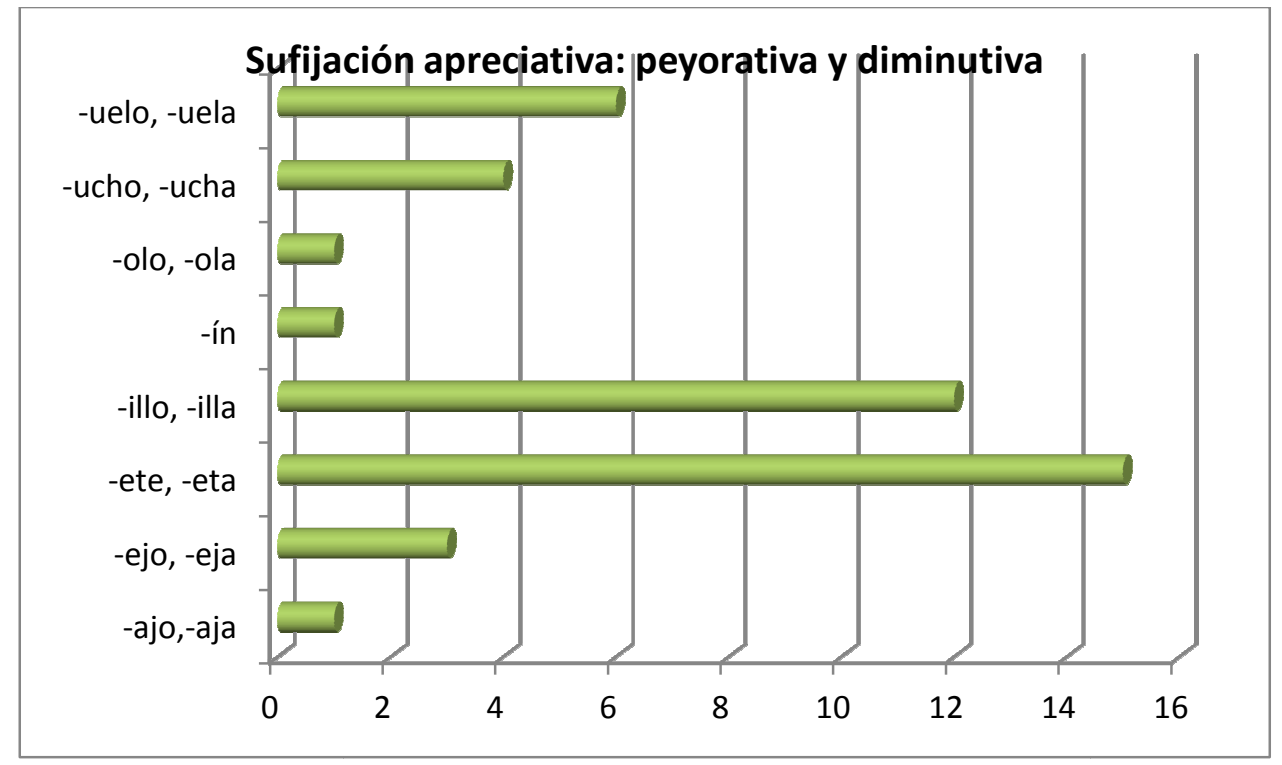

\subsection{AUMENTATIVOS}

$-a z o$

Del sufijo latino -āceus, -azo, como sufijo con valor aumentativo, interviene en la formación de marrazo 'hacha de dos bocas', de marra 'mazo para romper piedras'.

258 De puerca 'tuerca'.

259 Urrea, Miguel de (trad.) (1582): De arquitectura de Marco Vitruvio Pollión, mss. 
Procede, como sufijo nominal aumentativo, del -ō, -ōnis latino, sufijo denominal y deverbal que designaba generalmente a personas destacadas por alguna acción negativa (Pharies 2002: 429). Secundariamente, en latín se utilizaba también para designar nombres de animales. En cuanto al léxico que nos ocupa, encontramos dos términos formados con -ón cuya base léxica es zoonímica: aguilón 260 'caño cuadrado de barro' y gorrón 261 'púa fuerte o espiga recia'. Albardón, azadón, balanzón, barrón, canalón, cañón, pilón, serón, tenazón y tinajón son voces derivadas con este sufijo que conservan en gran medida el valor aumentativo. Destaca en ellas el hecho de que, en todas menos en cañón, la raíz léxica posee género femenino, pero el derivado tiene género masculino. En tinajón, además, nos llama la atención la superposición de dos sufijos apreciativos a partir del radical tina, -aja con valor diminutivo y -ón con valor aumentativo. Como este término conserva un significado aumentativo, nos sirve de muestra de la efectiva lexicalización de tinaja.

-ote

Del sufijo catalán -ot, y éste heredero del latino -ottus, este sufijo aumentativo se adapta al castellano añadiendo una -e paragógica (Pharies 2002: 454), como ocurre en los dos casos de este tipo registrados en el glosario: barrote y canalote. Así como barrote contiene un significado aumentativo, canalote, sinónimo de canalete 'conducto por el que cae el trigo a la muela' tiene, sin embargo, un valor diminutivo. Esto podría deberse a que se trata de un aragonesismo.

260 De águila.

${ }^{261}$ De guarro 'puerco'. 


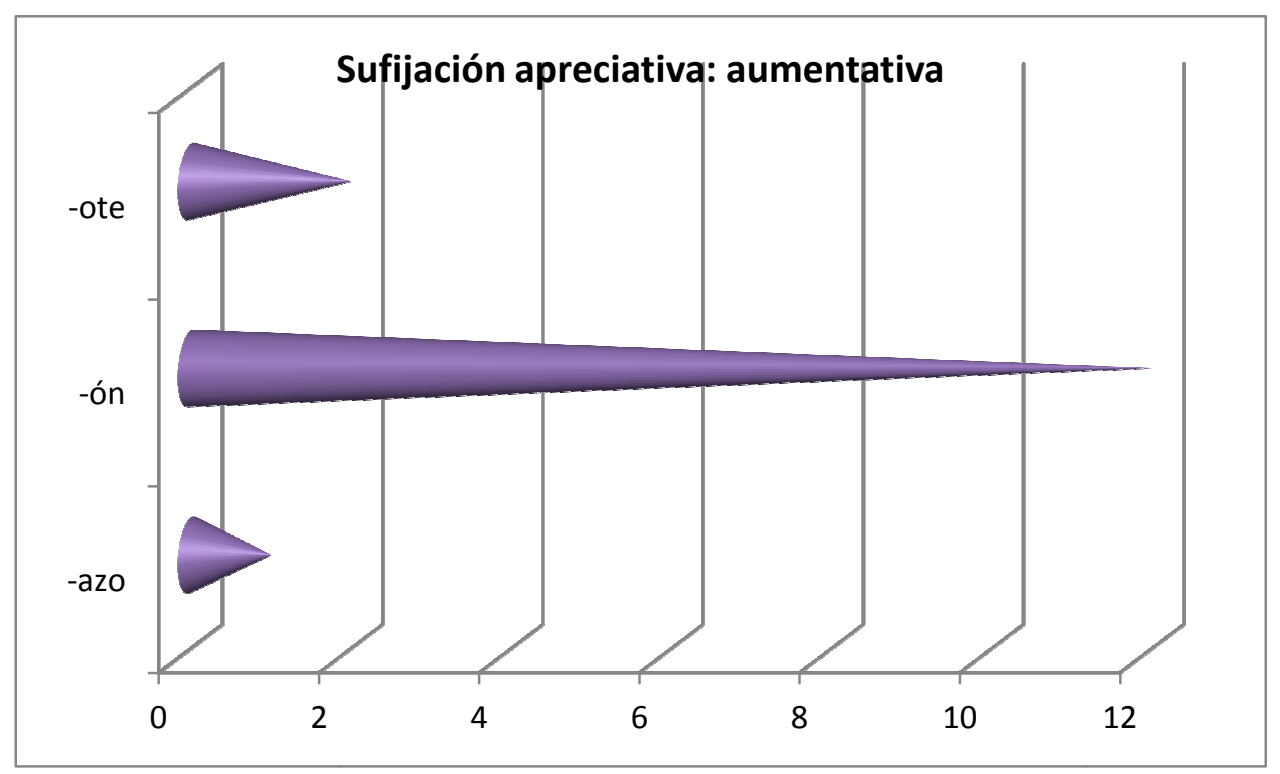

\subsubsection{Sufijación en la formación de sustantivos deadjetivales}

- dad

Este sufijo, al igual que aquellos que algunos autores consideran sus alomorfos (-idad,-edad, -tad), expresa el nombre de la cualidad del adjetivo que deriva (Santiago Lacuesta y Bustos Gisbert 2000[1999]: 4536). En nuestra selección léxica sólo registramos - $d a d$, que ha participado en la formación de dos términos, ceguedad e impetuosidad. Ceguedad, en este caso, cualidad de ciego 'dicho de un conducto o vano: obstruido, tapiado', denomina uno de los elementos comunes en las cañerías y otras obras hidráulicas 'obstrucción o taponamiento en un conducto o vano'.

-ena

Del latín tardío -ēnus, -èna, este sufijo crea, en su forma femenina, sustantivos colectivos a partir de adjetivos numerales (DRAE). Señalamos, derivada con este sufijo, la voz veintena ${ }^{262}$, que ha sufrido una extensión semántica en el campo léxico que nos ocupa, para así designar, a partir de una medida de longitud, un 'caño o fístula de dieciséis quinarias de diámetro'.

${ }^{262}$ De veinte, aunque, con ese sentido, en el corpus nosotros registramos la variante dialectal aragonesa vintena. 
Este sufijo se adjunta a adjetivos fundamentalmente bisílabos (Lang 1992: 183 y Rainer 1993: 506) para formar sustantivos abstractos que expresan cualidad (Santiago Lacuesta y Bustos Gisbert 2000[1999]: 4564), como ocurre en firmeza, graveza y ligereza.

\section{-ío}

Este sufijo castellano es el resultado, entre otras terminaciones latinas, de -ivus. Puede derivar tanto sustantivos como adjetivos, con diferentes bases. En esta ocasión, -io deriva en nuestros registros un sustantivo, regadio 'terreno que se puede regar', a partir de una base adjetiva, regado. A propósito de este término y otros parejos, Malkiel (1992) explica que, originariamente, son adjetivos que acompañan voces que designan lugares, y que posteriormente estos adjetivos se sustantivizan.

\section{$-o r$}

Reflejo del latín -or, -ōris, este sufijo deriva sustantivos a partir de bases nominales y adjetivales. Del adjetivo verbal impreso deriva impresor, donde el sufijo -or aporta un valor agente que se ha extendido al de profesión, y así impresor 'persona que tiene por oficio imprimir'.

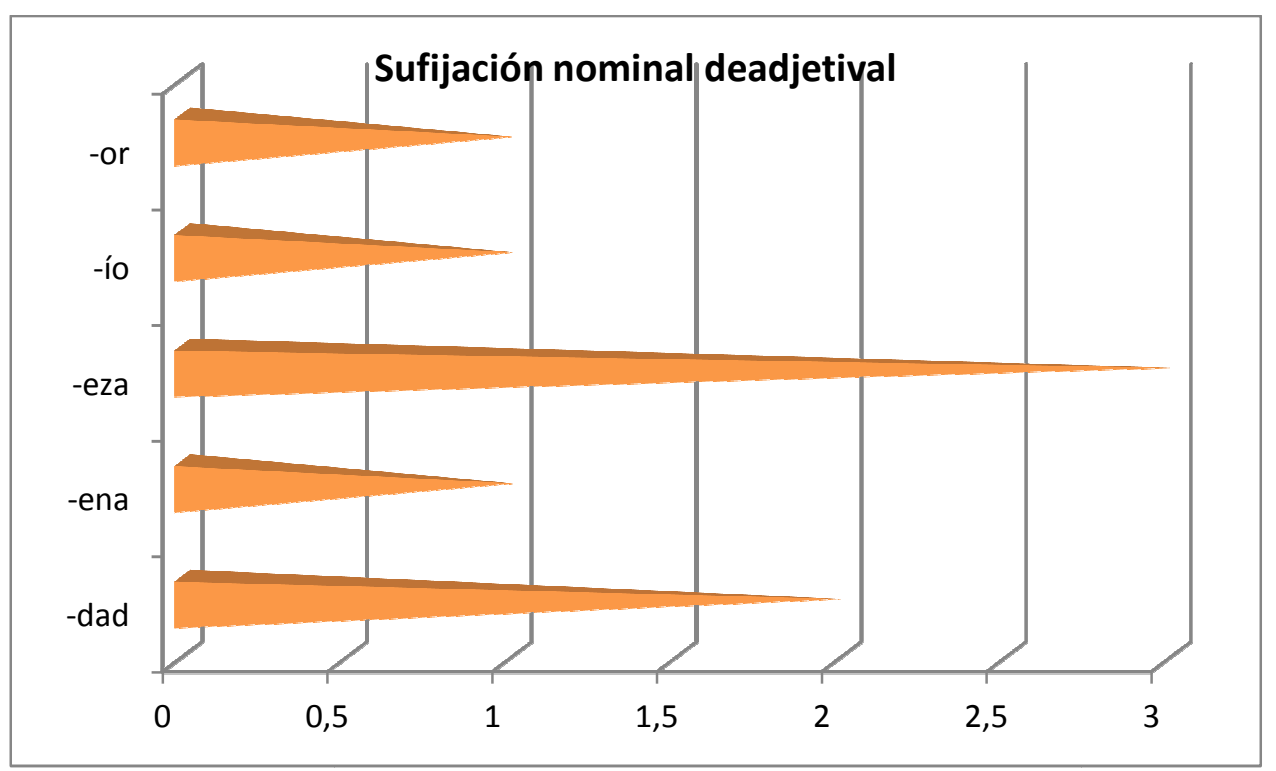




\subsubsection{Sufijación en la formación de sustantivos deverbales}

$-a$

Este sufijo átono se aplica de manera similar a los posteriormente recogidos $-e \mathrm{y}-o, \mathrm{y}$, por tanto, deriva, como estos, sustantivos a partir de verbos que suelen pertenecer a la primera conjugación. Aunque generalmente este tipo de derivación forma 'nombres de acción', como en cava ${ }_{1}^{263}$, este no es un grupo homogéneo y alberga varias extensiones de significado, como la resultativa, a la que pertenecerían estampa 'efigie o imagen impresa' (Santiago Lacuesta y Bustos Gisbert 2000[1999]: 4516) y excava 'efecto de quitar la tierra'; la instrumental, en la que incluiríamos escoda 264 'herramienta con forma de martillo utilizada para labrar piedras', estufa 265 , leva 266 y pesa; y la locativa, extensión a la que creemos que pertenecería junta 'unión de dos partes de una máquina'.

$$
\text { -ción, -zón }
$$

En general, -zón no se clasifica de forma independiente, sino como un alomorfo de -ción (Santiago Lacuesta y Bustos Gisbert 2000[1999]: 4531)267, puesto que -zón es el resultado popular del sufijo femenino latino -tȟo, -tȟonis. Encontramos un caso de derivación en -ción, derramación, sustantivo en el que el sufijo significa 'acción', de manera que el término designa 'acción de derramar'. Aunque -zón es el alomorfo que habitualmente deriva verbos de la primera conjugación, en el léxico que nos ocupa hemos hallado esta combinación tanto con -ción como con -zón. Hemos registrado un sustantivo derivado en -zón: clavazón, que designa un 'conjunto de objetos que constituyen un todo' (DRAE s. v. -azón), en conjunto, 'conjunto de clavos puestos en alguna cosa'.

263 "Si es monte o collado, más fácilmente se cava y beneficia, porque pueden hazer sangraderas para el agua, que suele ordinariamente estorvar la cava de las venas" (Pérez Vargas 1568: 54v).

${ }^{264}$ De escodar 'labrar piedras' (DRAE). Escodar no se halla en nuestro corpus.

${ }^{265}$ De estufar 'caldear, calentar' (DRAE).

266 'Paleta de una rueda hidráulica', utilizada para elevar el agua.

267 Estos autores señalan, por otro lado, que cabría tener en cuenta algunos argumentos que en cierto modo contradicen la pertenencia de -zón al grupo de alomorfos de -ción, como lo son los distintos criterios seguidos por cada sufijo para realizar la elección de la vocal temática que acompaña a la base léxica verbal, de acuerdo con la conjugación a la que esta pertenezca. 


\section{$-d a^{268}$}

Como sufijo deverbal, puede formar sustantivos a partir de verbos de las tres conjugaciones (Santiago Lacuesta y Bustos Gisbert 2000[1999]: 4540), y forma generalmente nombres de acción y efecto. Respecto a las voces cuyas bases verbales pertenecen a la primera conjugación, señalamos abrevada ${ }^{269}$. También registramos un ejemplo de sufijación en - $d a$ a partir de un verbo de la tercera conjugación, despedida, y un ejemplo a partir de la segunda conjugación verbal, caída 'efecto de caer un líquido'. En el caso de abrevada hay una extensión semántica del efecto, de manera que viene a significar 'cantidad de agua que se da a algún material'.

\section{-dera}

Este sufijo femenino, tiene el mismo significado que el masculino -dero, es decir, es un locativo o indica finalidad. En nuestro glosario registramos las voces amoladera 'piedra que se utiliza para amolar o para sacar corte o punta', desangradera 'cauce por el que se da salida a parte de las aguas de un pozo o canal', portadera 'caja grande que se utiliza para transportar cosas', regadera 'zanja o canal por donde se conduce el agua para regar', sangradera 'cauce por el que se da salida a parte de las aguas de un pozo o canal'. Tajadera 'cuchilla, a modo de media luna, que se utiliza para tajar algo' sería el ejemplo más claro de nomina instrumenti, pero en su sentido 'compuerta que se pone para detener la corriente de agua' se acerca más al nomina loci.

Con un significado cercano, pero no exacto: voladera 270 , ya que no designa un lugar en el que algo vuele, sino que se trata de una metáfora, puesto que señala la muela superior, que está al aire.

\section{-dero}

268 De manera general, se acepta la segmentación - da/-do, puesto que se supone que la vocal inicial forma parte de la raíz verbal (V. Lüdtke 1978, Pena 1980 y Rainer 1993, cit. en Santiago Lacuesta y Bustos Gisbert 2000[1999]: 4540).

269 De abrevar 'dar de beber, principalmente al ganado' (DRAE).

270 De volar. 
Se remonta a -torius, $-a$, -um, sufijo que deriva nomina loci y nomina instrumenti (Pharies 2002: 166). Como sufijo deverbal, indica normalmente una relación locativa o una finalidad (Santiago Lacuesta y Bustos Gisbert 2000[1999]: 4538). Sin embargo, no siempre es fácil determinar de cuál de los dos tipos se trata (Rainer 1993: 442). De acuerdo con el DRAE, "en los sustantivos significa, por lo común, y preferentemente en forma masculina, 'lugar donde se realiza la acción significada por el verbo base'. En cuanto al léxico que nos ocupa, se trata, en la mayoría de las ocasiones, de lugares de un mecanismo, casi siempre hidráulico, en los que ocurre algo o, visto de otra manera, piezas o partes de un ingenio hidráulico destinadas a un fin concreto: abrevadero 'lugar donde se da de beber al ganado', aliviadero 'vertedero de aguas sobrantes', batidero 'parte del cerco de las hojas de las puertas', congeladero 'depósito en el que se recogen las lejías de las calderas', derramadero 'canal o conducto que da salida a aguas inmundas', desaguadero 'conducto o canal por el que se da salida a las aguas', desviadero 'conducto por el que se desvía el agua', escurridero 'lugar por el que el agua tomada de una acequia vuelve al río', espiradero 'abertura por donde entra y sale el aire', henchidero 'lugar en el que las cantimploras se llenan de agua', majadero 'maza o pértiga para majar'271, manadero 'lugar en el que nacen las aguas', partidero 'parte de una obra hidráulica destinada a dividir una conducción de agua en varios cauces', respiradero 'abertura por donde entra y sale el aire', saltadero 'surtidor de agua', sangradero 'canalón por el que se desangra el agua de lluvia', sumidero 'conducto o canal por donde se sumen las aguas' y vertedero 'lugar por donde se vierte algo'.

\section{-dor}

Este sufijo proviene del sufijo latino de nomina agentis -tor, -ōris (Pharies 2002: 169) y se añade a bases verbales o nominales. En los casos registrados, el sufijo -dor es casi siempre deverbal. Siguiendo la clasificación de Laca (1986: 271-294) distinguimos los derivados que constituyen seres animados y los que conforman seres inanimados. Dentro del primer grupo, destacamos aquellos

271 Situados en algunos tipos de molinos. 
que designan profesiones $\mathrm{u}$ oficios (también llamados 'clasificadores'): aparejador 272 'persona que tiene por oficio el preparar los materiales y dividir las piezas en las obras de construcción', aserrador, edificador, empedrador, estampador ${ }^{273}$ y su sinónimo imprimidor 'persona que tiene por oficio el imprimir o que tiene a su cargo una imprenta', herrador 'persona que tiene por oficio el herrar las caballerías', nivelador 'persona que tiene por oficio el igualar un terreno en las obras de construcción' ${ }^{274}$ y 'persona que tiene por oficio el conducir el agua de un terreno a otro' 275 y soplador 'persona que tiene por oficio el ejercer su fuerza sobre una cuerda que, a través de una polea, ejecuta el movimiento de unos fuelles'. También pertenecen al conjunto de los seres animados aquellos sustantivos 'caracterizadores', es decir, sustantivos que “designan personas caracterizadas por su inclinación a realizar la acción designada por la base verbal" (Santiago Lacuesta y Bustos Gisbert 2000[1999]: 4544) como maquinador 276 'que maquina, piensa o discurre alguna cosa'.

Dentro de los sustantivos derivados en -dor que pertenecen al grupo de los seres inanimados, señalamos aquellos que designan 'instrumentos', que en el léxico que nos ocupa son frecuentemente partes de un mecanismo. Estos son aliviador 'palanca que en los molinos harineros sirve para levantar o bajar la piedra, de modo que la harina pueda salir más o menos fina', cernedor 'torno para cerner harina', partidor 277 'parte de una obra hidráulica destinada a dividir un cauce', soltador 'portillo o canal que se hace en un río o acequia para

272 De aparejar 'preparar, prevenir, disponer'.

273 De estampar 'imprimir, sacar en estampas algo; como las letras, las imágenes o dibujos contenidos en un molde'.

274 "De modo que el nivel o corbate a de hallarse apartado cinqüenta passos dende el de la vanderilla al mismo nivel, y otros tantos del de la regla, de modo que dende el que tiene la regla al de la vanderilla a de aver cien passos, y el nivelador está en medio de los dos" (Turriano, a. 1605: 57v).

275 “ $\mathrm{Y}$, ansimismo, fontaneros y niveladores de las aguas, para los aguaductos y regadíos que en estos reynos tan importantes y convenientes serían, y para desaguar y beneficiar las minas de ricos metales" (Herrera 1584: 3r).

276 De maquinar 'urdir, tramar algo'.

277 “Las paredes de la çequia es A. El enlosado es B. El partidor es C. Y donde se a de dividir el agua es D, que es donde están hincadas las losas D D” (Turriano, a. 1605: 467r). 
sangrarlo', surtidor, tajador 278 'compuerta que se pone para detener la corriente de agua', templador 'viga de madera que se utiliza para subir o bajar la muela voladera, controlando así la separación entre las muelas' y torcedor 'pieza que sujeta y dirige el canalón por el que el grano cae desde la tolva hasta la muela de un molino'.

\section{-dura}

Este sufijo deverbal se remonta al -tūra, -ae latino y, como él, deriva sustantivos de nomina actionis (Pharies 2002: 176) y además lo hace a partir de verbos de las tres conjugaciones (Santiago Lacuesta y Bustos Gisbert 2000[1999]: 4546). Generalmente -dura señala la acción o el efecto del verbo que deriva, como ocurre en apegadura, borneadura, cegadura, empalmadura, ligadura, pegadura y soldadura, pero también puede designar un conjunto y este es el caso en términos habitualmente usados en plural como aserraduras y serraduras 'partículas de madera que se desprenden al serrar' y también así ocurre en amoladura 'conjunto de arenillas y pedazos muy menudos que se desprenden de la piedra al tiempo de amolar', encañadura 'conducto formado por canales o caños trabados y unidos' y picadura 'conjunto de hendiduras de la muela de un molino'.

$-e$

Generalmente considerado de origen incierto, este sufijo propio del iberorromance centro-occidental podría haber adquirido la función deverbativa por analogía con las desinencias verbales (Pharies 2002: 181-182). Dentro de los matices semánticos que comporta este sufijo en los nombres de acción que deriva, está el instrumental (Santiago Lacuesta y Bustos Gisbert 2000[1999]: 4550), como sucede en engaste 279 'cerco que asegura lo que engasta', estanque 'balsa construida para recoger agua'.

278 De tajar 'dividir algo en dos partes'. "El tajador que se pone encima del cubete, se pone a fin que, como trae tanta furor la agua, que se levanta para arriva y sale del cubete" (Turriano, a. 1605: 303r).

279 De engastar 'encajar'. 
Heredero del sufijo -ia latino, forma sustantivos generalmente abstractos (DRAE). En nuestro glosario, hemos registrado un término que creemos que ha sido formado mediante sufijación deverbal en -ia. Se trata en esta ocasión de un sustantivo concreto, puesto que designa una parte de un molino de aceite, denominada imprimia 280 'conjunto de dos maderos ajustados que prensan las olivas' 281 . Esta voz no aparece recogida en ninguno de los repertorios lexicográficos consultados 282 .

\section{-ía}

De acuerdo con Lüdtke, sangría es uno de los pocos casos en los que el sufijo -ía es deverbal (Lüdtke 1978: 353, en Santiago 2000[1999]: 4565). Así, por ejemplo, entre las bases preferidas de este sufijo señaladas en Almela Pérez (1999: 111) no se encuentra el verbo, sino el adjetivo y el sustantivo. En el léxico que nos ocupa, -ía señala un lugar, como -dera en sangradera, y así sangría y sangradera 'cauce con el que se da salida a parte de las aguas de un pozo o canal' son sinónimos.

\section{$-i v a$}

Este sufijo, que analizaremos más ampliamente en el apartado de los adjetivos deverbales, deriva un solo sustantivo de los recogidos, inventiva 'capacidad para inventar' 'cosa inventada'.

\section{- miento $^{283}$}

Este sufijo, que se remonta al -mĕntum latino (Pharies 2002: 403), forma, como este, sustantivos deverbales y en ellos suele significar 'acción y efecto'

${ }^{280}$ De imprimir.

281 "Estos yerros conviene que sean como son los yerros que están en los libros de los molinos del azeyte, que están asidos a los caracoles de la imprimia que prensan la azeyte" (Turriano, a. 1605: 326r).

${ }^{282}$ No se encuentra en DECH, DRAE, ni en diccionarios italianos o latinos, entre ellos Laterculi... Puesto que el único texto en el que aparece es Los Ventiún libros de ingenios, hemos buscado imprimia, también sin éxito, en diccionarios de aragonesismos.

${ }^{283}$ No hemos hallado entre nuestras voces ningún término derivado en su variante alomórfica -mento. 
(DRAE). De manera general, deriva bases verbales de la primera conjugación y es bastante productivo con verbos parasintéticos (NGLE: 359-360). En el léxico de los ingenios y máquinas registramos anegamiento, cegamiento 'acción de cerrar o macizar algo que antes estaba hueco o abierto', congelamiento, derramamiento, despedimiento, detenimiento, movimiento y remolimiento.

En algunos sustantivos hemos hallado una extensión semántica de este sufijo, sobre la que no hemos encontrado muchas referencias en la morfología tradicional 284 . Se trata de aquellos casos en los que -miento significa conjunto, conjunto que a su vez conforma un instrumento ${ }^{285}$ o medio con el que se lleva a cabo la acción del verbo. Así ocurre en encañamiento 'conducto formado por canales o caños' y envigamiento 'conjunto de vigas de madera'. Otra de las extensiones registradas es la de 'lugar', como en mortimiento 286 'lugar de mayor estrechez en el cubo de un molino, donde este muere o termina'.

\section{$-n t e$}

Este sufijo habitualmente deriva adjetivos activos puros, que en ocasiones se sustantivizan. Adquiere las variantes -ente o -iente independientemente de la conjugación de la base verbal (Pharies 2002: 218). En nuestro glosario hemos localizado varios sustantivos derivados en -nte que no aparecen como adjetivos $^{287}$. En general, designan objetos concretos que efectúan la acción señalada por el verbo de la base léxica: batiente 'parte del cerco de las puertas en que estas se baten', rebotante 'muesca que sirve de contraempuje', tirante 'madero que soporta tensión en una armadura' y vertiente 'declive por donde corre el agua'. Además registramos un sustantivo que designa una profesión,

284 "La tendencia de los nombres en -miento a referir entidades concretas es interpretada como una especialización del significado básico de 'acción y efecto' por desplazamiento metonímico. De manera que, cuando en aparcamiento, por ejemplo, nos referimos al 'lugar donde se aparca', estamos tomando una parte en relación al todo, que es el proceso en sí de aparcar, donde se encuentra contenida una referencia locativa, puesto que siempre se aparca en algún sitio" (Amador Rodríguez 2009: 325). 2002: 403.

285 Sobre los sustantivos derivados en -mento que designan instrumento, V. Pharies

286 De morter 'desembocar, acabar algo'.

287 Encontramos también el compuesto sintagmático despidiente de agua(s), como veremos en el apartado correspondiente. 
edificante 'persona que tiene por oficio edificar'.

$-0$

Procedente del $-u s,-\bar{\imath}$ latino, el sufijo átono -o deriva, casi siempre a partir de verbos de la primera conjugación, como ocurre en aparejo 'conjunto de objetos necesarios para aparejar' y, además, son muchos los derivados de verbos terminados por la secuencia "vocal + ar" (NGLE: 371), fundamentalmente -ear, y así sucede con los términos acarreo 288 , alabeo y borneo. Este sufijo designa, en estas voces, el nombre de una acción o su efecto (acarreo, alabeo 289 , borneo, reparo, restaño 290 'estancamiento de aguas', soplo 'acción y efecto de soplar fuelles y otros artificios'), el instrumento con que se realiza esa acción (aparejo ${ }^{291}$ ) o el lugar en el que se lleva a cabo (huello 292 'sitio o terreno en el que se pisa') (Pharies 2002: 222). En acarreto, sinónimo de acarreo 'acción de acarrear', pensamos que el proceso de derivación se ha realizado también por este mismo sufijo -eo, en el cual se intercala una -t-, debido seguramente, a nuestro modo de ver, a la influencia de la voz carreta.

-ón

Aunque el sufijo - $\breve{\imath}$, -iōnis al que se remonta no fue muy frecuente en latín, en castellano son bastantes los sustantivos deverbales en -ón ${ }^{293}$ (NGLE: 396). Los dos casos que encontramos, chiflón y chirrión, eran originariamente adjetivos que marcaban una cualidad de un objeto, 'que chifla' y 'que chirría'294 respectivamente, y que, tras un proceso de sustantivación, pasaron a designar dos instrumentos concretos. Así, chiflón nombra un tipo de canal "que chifla" y chirrión, un tipo de carro "que chirría".

288 De acarrear 'transportar algo en un carro'.

289 De alabear 'combar, curvar, especialmente la madera' (DRAE). El corpus del DICTER no contiene alabear.

290 De restañar 'detener un derrame'. En el corpus sólo se encuentra referido a la sangre.

291 'Conjunto de objetos necesarios para hacer ciertas cosas', de aparejar 'preparar, prevenir, disponer'.

292 De hollar 'pisar'.

293 No hay que confundirlo con el sufijo aumentativo -ón, -ona heredero del latino -o, -ōnis.

294 "Algunos dicen que porque chirría se dijo" (Covarrubias s. v. chirrión). 
A pesar de que este sufijo es mayoritariamente deadjetival, forma también algunos sustantivos deverbales o denominales (Santiago Lacuesta y Bustos Gisbert 2000[1999]: 4590), como creemos que puede ser el caso de follura $^{295}$, donde consideramos que - ura tiene un significado locativo, puesto que follura 'cauce por donde se da paso al agua'296.

\subsubsection{Sufijación en la formación de adjetivos denominales}

-ado

Una de las formas de distinción de este tipo de adjetivos denominales derivados en -ado de los adjetivos participiales derivados en -do es la prueba de la inexistencia de una forma verbal que pudiera constituir la base léxica.

Propio de los lenguajes de especialidad, es el sentido posesivo del sufijo denominal -ado (Rainer 2000[1999]: 4625 y 4630), sentido que se solapa bastante con el relacional y el de semejanza. Ejemplos de este tipo serían alamborado 297 'que tiene alambor', clavetado 'sujeto con clavetas', clavijado 'sujeto con clavijas', dentado 'con dientes' y su sinónimo dentejado 298.

Como adjetivos de semejanza podemos señalar aspado 'con forma de aspa', caracolado 'con forma de caracol', posible aféresis del adjetivo parasintético encaracolado y gancheado 'con forma de gancho', voz derivada por el sufijo -eado.

Ya como ejemplo de adjetivo relacional de este tipo citamos quiciado 299

${ }^{295}$ No aparece ni en el DECH ni en el DRAE. Pensamos que, en este caso, sería un aragonesismo que podría derivar de follar (hollar en castellano) 'pisar, comprimir con los pies' o de fuello/a 'fuelle'. En caso de derivar de este sustantivo, estaría ausente el diptongo -ue en el derivado, como ocurre en algunos derivados deadjetivales respecto de sus bases (V. Santiago Lacuesta y Bustos Gisbert 2000[1999]: 4590).

296 " $Y$ con esta orden van rodeando todo aquel patio que han determinado de tomar, con dos órdenes d'estos maderos, con estas folluras o canales, de alto abaxo" (Turriano, a. 1605: 362v).

297 De alambor.

298 Probablemente de dentejo, diminutivo de diente.

${ }^{299}$ De quicio. 
'movido o girado en un quicial'.

$-a l$

Como ya hemos visto anteriormente, este sufijo es uno de los más importantes sufijos relacionales y resulta notablemente productivo en la formación del léxico de los lenguajes de especialidad (Rainer 2000[1999]: 4616). El único adjetivo denominal derivado en -al que no ha seguido un proceso de sustantivación es instrumental. Alguno, como farinal ${ }^{300,}$ aparece en el corpus como adjetivo, en este caso formando parte del compuesto caja farinal, y como sustantivo (el farinal) sinónimo de este compuesto sintagmático.

-ero

Señalamos un único caso de derivación adjetival en el sufijo anteriormente revisado -ero, a partir de una base sustantiva. Se trata de frontero 301 'puesto y colocado enfrente', de fronte 'frente'.

\section{$-i s c o$}

Este sufijo deriva adjetivos a partir de bases nominales, como ocurre en el único ejemplo de este tipo hallado en nuestros registros, arenisco 'que tiene arena', en el que el sufijo tiene un sentido de posesión; en otros contextos -isco también puede significar semejanza, como aparece en el esquema de Rainer 2000[1999]: 4627.

301 "El remate de las órdenes dichas en las monteas fronteras se haze con un frontispicio" (Arphe, 1585-1587: 22r). 


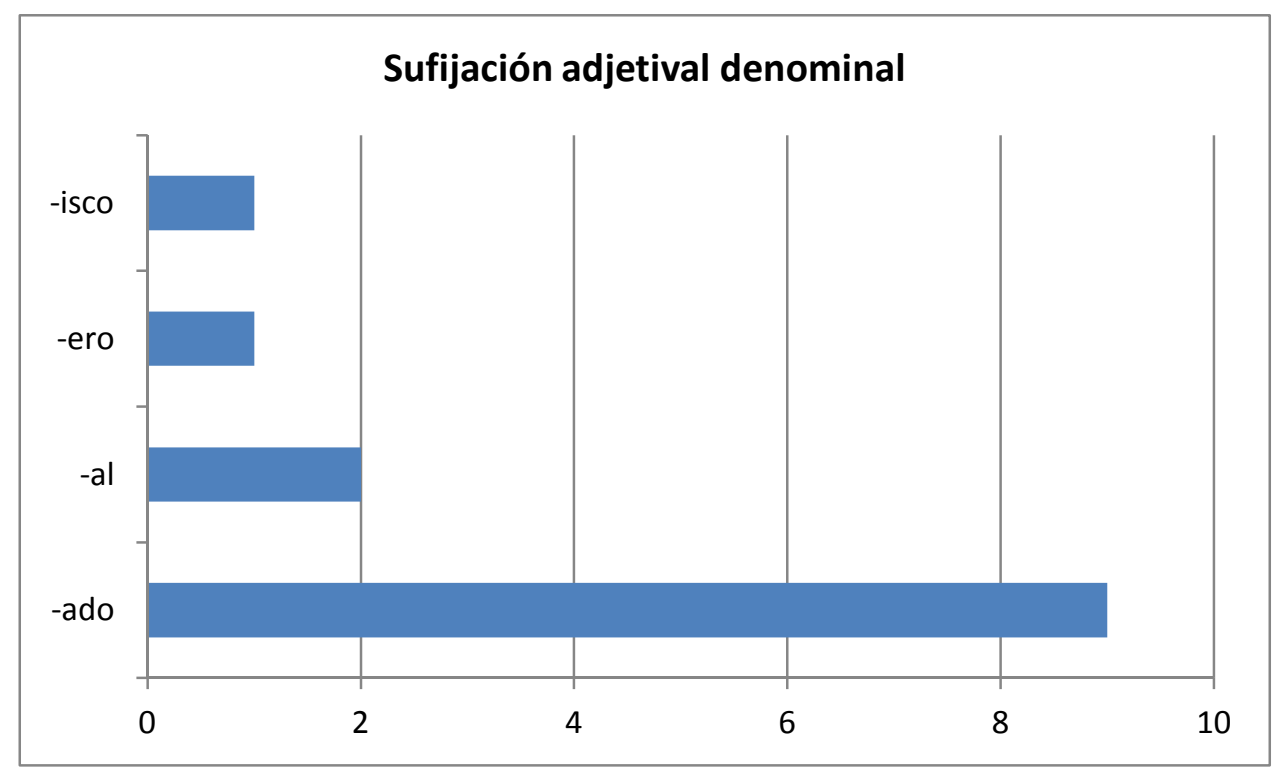

\subsubsection{Sufijación en la formación de adjetivos deadjetivales}

$-a l$

Aunque los adjetivos deadjetivales no están categorizados en Rainer 2000[1999]: 4595-4643, creemos que pertenecería a este grupo manantial, ejemplo de adjetivo derivado en -al a partir de una base adjetival, manante 'que mana', en lugar de la base nominal a la que acostumbra a adjuntarse este sufijo.

\subsubsection{Sufijación en la formación de adjetivos deverbales}

-ble

Sólo hemos hallado un caso de sufijación adjetival en -ble, sufijo heredado del latino -bülis. Se trata del adjetivo deverbal torneable, adjetivo que, de acuerdo con la clasificación de Rainer (2000[1999]), estaría incluido en el grupo de los adjetivos deverbales pasivos con sentido potencial. Respecto a esto, entendemos por adjetivos potenciales aquellos que pueden parafrasearse por "que se puede + infinitivo" 302 , como sucede con torneable 'que se puede tornear o labrar en el torno'.

-dizo/a

302 "El elemento modificado por la forma -ble designa algo que, por sus cualidades intrínsecas, puede ser afectado por la acción designada por el verbo base" (Rainer 2000[1999]: 4609). 
Este sufijo proviene del latino -īcius, y se aplica especialmente a sustantivos, aunque también deriva adjetivos y participios (Pharies 2002: 376). Es este último caso el de los tres derivados con este sufijo que encontramos en nuestro glosario, anegadizo, desapegadizo, movedizo y rodadizo, que podrían parafrasearse como "que con facilidad / frecuentemente + (se) + anega/desapega/mueve/rueda", respectivamente ${ }^{303}$.

$-d o$

Este es uno de los sufijos más productivos en la derivación de adjetivos deverbales, en concreto adjetivos deverbales pasivos participiales, que son los que pueden parafrasearse por "que ha sido/ está/ es + adjetivo participial" (Rainer 2000[1999]: 4597 y 4607). En general, podemos afirmar que son los participios que denotan estados los que actúan como adjetivos (Marín 2009: 346).

Resulta en muchas ocasiones complicado delimitar los adjetivos formados mediante la parasíntesis prefijo + base $+-d o$ de los adjetivos participiales derivados de un verbo parasintético, puesto que no siempre tenemos a nuestra disposición los materiales necesarios para distinguir los diferentes niveles de dependencia lexicogenética (V. Serrano-Dolader 1995: 156157). Por este motivo, hemos decidido clasificar aquí todos los adjetivos participiales, puesto que tenemos constancia de la existencia de la forma verbal correspondiente, parasintética o no.

Entre los adjetivos derivados de verbos de la primera conjugación señalamos acanalado, acerado, acribado, afirmado, aliviado, alvidriado, amartillado, arenado, aserrado, barnizado, cedazado 304 , cincelado, clavado, edificado, embalsado, embetunado, emboñigado, empalagado, empalmado, empedrado, enarenado, encañado, encañizado, enclavado, enclavijado, endentado, enladrillado, enroscado, estancado,

${ }^{303}$ Serían, por tanto, adjetivos clasificados dentro del grupo de los pasivos, al ser susceptibles de una paráfrasis pasiva (V. Rainer 2000[1999]: 4610). DICTER

${ }^{304}$ De cedazar, forma que no está recogida en el DRAE, pero sí en el corpus del 
firmado, gastado, maquinado 305 , martillado, majado, pesado, picado, rallado, represado, rodado, serrado, socavado, tajado, torneado, vidriado, voltado, volteado, zulacado.

Derivados de verbos de la segunda conjugación, registramos los adjetivos cernido, embebido, molido y movido.

$-i v o$

Este sufijo proviene del sufijo -īous, que en latín derivaba adjetivos a partir de participios (Pharies 2002: 370). En concreto, en latín se formó un gran número de adjetivos en -ĩous sobre bases participiales (NGLE: 547). Además, este sufijo siempre está precedido, en las formaciones en las que interviene, por las consonantes $-t-\mathrm{o}-s-$. Puede significar 'capacidad para lo significado por la base o inclinación a ello' (DRAE). En el único término derivado en -ivo presente en el glosario, inventivo ${ }^{306}$, -ivo ha actuado sobre una base verbal ${ }^{307}$, aunque este sufijo puede derivar también bases nominales.

-nte

Este sufijo, procedente de -ens, -entis, la terminación flexiva del participio de presente latino, forma adjetivos deverbales denominados activos puros (Rainer 2000[1999]: 4600), conocidos tradicionalmente como participios activos. Estos son aquellos que significan 'que ejecuta la acción denominada por la base' (DRAE). Hallamos cuatro adjetivos de este tipo, despidiente 308 , manante 'que mana', moviente 'que mueve o se mueve' y tajante 'que taja o corta'.

$-0$

Sólo marcamos un ejemplo de adjetivo deverbal en -o, excepción en el empleo de un sufijo que generalmente denomina nomina actionis, aunque tiene

305 `Regulado por la acción de alguna fuerza’.

306 ‘Que tiene disposición para inventar' (DRAE).

${ }^{307}$ Cabía la posibilidad de que derivase del sustantivo invención, pues es lo habitual en este sufijo y además el CORDE data por las mismas fechas la primera documentación de todas estas palabras (inventar, invención, inventivo). Sin embargo, por semejanza fónica, hemos decidido que derivaba del verbo. Tenemos en cuenta, sin embargo, el valor relacional existente en este sufijo (V. Santos Río 2002: 151).

${ }^{308}$ En el corpus no aparece fuera de la locución despidiente de aguas. 
otros posibles valores, como el efecto o resultado. En este caso, estanco, sinónimo de estancado 'dicho de un líquido: detenido y parado su curso', sería un adjetivo resultativo.

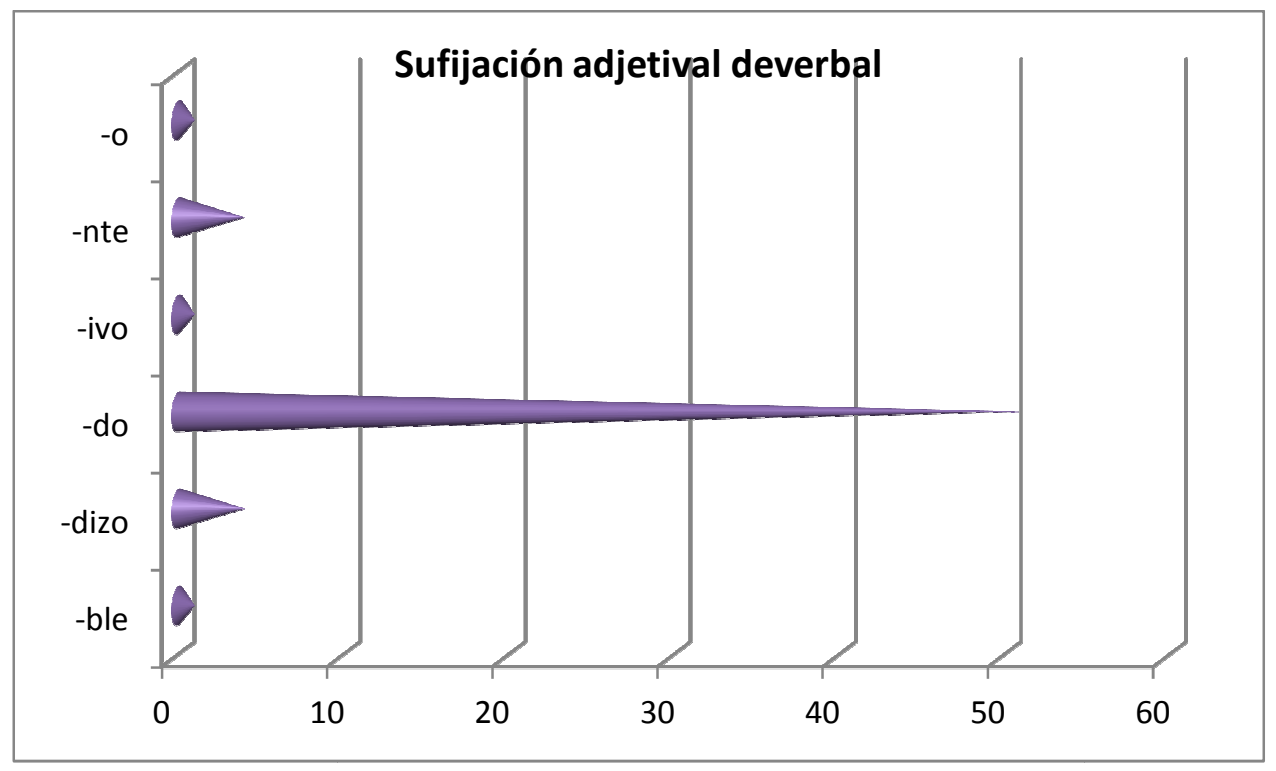

\subsubsection{Sufijación en la formación de verbos denominales}

El español es una lengua muy productiva en cuanto a los mecanismos verbalizadores de que dispone, pues consta tanto de derivación verbal, proceso formativo en el que se aplica un sufijo verbalizador al radical, como de parasíntesis verbal, procedimiento en el que se adjuntan a la base léxica un prefijo y un sufijo simultáneamente (Serrano-Dolader 2000[1999]: 4685). Antonio Rifón, sin embargo, describe los distintos procesos existentes en la formación de verbos como "adición a la base de sufijos, prefijos o circunfijos" (Rifón 1997: 9).

$$
-a r
$$

Aunque en latín no fueron muchos los verbos denominales formados por sufijación en -āre, en castellano este proceso de 'derivación inmediata'309 es muy productivo, especialmente en lenguajes especializados (NGLE: 600-601). Aunque, de acuerdo con Pena, la clasificación semántica de los verbos

${ }^{309}$ El sufijo se añade directamente a la base, frente a la 'derivación mediata', en la que el sufijo se añade a la base por medio de interfijos (Serrano-Dolader 2000[1999]: 4686). 
derivados en -ar no corresponde a la morfología, puesto que este sufijo no se distingue por ninguna particularidad semántica (Pena 1993: 233, en SerranoDolader 2000[1999]: 4688), quisiéramos presentar aquí una pequeña panorámica del significado de los verbos de este tipo presentes en el léxico estudiado.

Por una parte, constituyen un importante grupo los verbos derivados de un radical que designa un instrumento, y por lo tanto, el significado de estos verbos suele interpretarse como la actividad resultado del uso de ese instrumento para el fin que le es propio, como ocurre con: balanzar, barrenar 310 , batanar, cedazar, cincelar, contrapesar311, martillar, prensar, taladrar.

También resulta muy significativo el conjunto de verbos cuya base designa una materia y que admiten paráfrasis del tipo 'echar, dar, llenar de + sustantivo': aguar, arenar, barnizar, betunar, enrunar312, herrar, vidriar, zulacar.

Por último, localizamos los verbos denominales denominados causativos (NGLE: 604), que pueden parafrasearse por 'causar, crear, hacer + sustantivo', y así sucede en industriar313 'instruir en algún arte', ingeniar314 'discurrir con ingenio trazas y modos para conseguir algo o ejecutarlo', montear 'trazar la montea de una obra', remolinar315 'hacer o formar remolinos' y represar 316 . En voltar $^{317}$ 'dar vueltas a alguien o a algo', sinónimo de voltear ${ }^{318}$, tiene un valor iterativo.

310 De barrena.

311 De contrapeso, a nuestro juicio. DRAE señala, sin embargo, "de contra y pesar".

312 De enruna 'cascote, escombro' (DRAE).

313 "Dos cabos de esquadra, diez conservadores de la diciplina militar, cuyo oficio será industriar y emponer la gente visoña en el lenguaje y trato de la guerra y en los términos d'ella" (Álaba 1590: 28v).

314 "Mas, como el Marqués quiere que nada tenga fundamento, ansí se ingenia a divertirlo todo, y como los erarios se fundan de diversos particulares" (Valle de la Cerda 1600: 16r).

315 De remolino. "La agua va derecho a herir a la otra parte del cubo, de modo que ella no tiene lugar de yr remolinando por dentro del cubo" (Turriano, a. 1605: 299v).

316 De represa. "O haziendo presa, passada la fuerza, para que represadas y detenidas las aguas, queden las ruedas de las pistas y las de los molinos empalagadas" (Lechuga 1611: 267).

317 "La qual muela, a braços la bueltan dos obreros que empuxan los rayos, de do nace que las fuerças d'esta máquina son totalmente grandíssimas" (Besson 1602: O4v).

318 V. Sufijación en la formación de verbos denominales: -ear, 
Este sufijo de 'derivación mediata' se añade, en los casos encontrados, a bases sustantivas. Señala un proceso iterativo en voltear 'dar vueltas' (SerranoDolader 2000[1999]: 4692). En cuanto al derivado tornear 'labrar y pulir en un torno', creemos que tiene valor instrumental.

\subsubsection{Sufijación en la formación de verbos deadjetivales}

$-a r$

Sólo encontramos un verbo derivado de un adjetivo mediante sufijación, en este caso en -ar: fijar. Su paráfrasis coincide en parte con la de los verbos denominales causativos, aunque tendría que combinarse con un objeto directo: 'hacer + raíz (fijo) + (sustantivo)'.

\subsubsection{Sufijación en la formación de verbos derivados de locuciones}

$-a r$

Hallamos solamente un caso que consideramos de este tipo, el de achiflonar 'hacer un chaflán o rebajo', verbo que consideramos derivado de una locución muy utilizada en el texto en el que este término aparece: a chiflón 'formando un ángulo agudo'. Aunque no poseemos testimonios lexicogenéticos suficientes como para demostrar esta relación derivativa, creemos que las ocurrencias de esta familia léxica parecen deslindar el proceso formativo de achiflonar del grupo de verbos parasintéticos, es decir, la fuerte ligazón de la preposición $a$ al sustantivo chiflón en la locución adverbial a chiflón presupone que la derivación prefijal y la derivación sufijal en este término no fueron simultáneas, y que, por tanto, la formación de achiflonar no debería considerarse parasintética.

\subsubsection{Sufijación en la formación de adverbios -mente}


Este sufijo deriva adverbios a partir de la forma femenina de adjetivos. Proviene de mente, ablativo de mens, mentis 'mente', forma que en perífrasis adverbiales describe el estado mental de algo (Pharies 2002: 398). En el léxico de los ingenios y máquinas, son varios los adverbios en -mente que encontramos: artificiosamente, firmemente, fuertemente, inartificiosamente, industriosamente, ingeniosamente, lentamente, livianamente, mecánicamente y velozmente.

\subsubsection{Prefijación en la formación de sustantivos}

Una de las condiciones de la base a cuyo inicio se adjunta el morfema prefijal es que ésta ha de ser, bien una palabra independiente, bien un tema o raíz ligada al prefijo. Ahí, aunque la combinación con un prefijo no modifica el contenido semántico de la palabra base, pero sí que lo ajusta o fija (Varela y Martín García 2000[1999]: 4995).

con-

Creemos que este sufijo añade un significado de 'agregación' en aquel único sustantivo prefijado con con- que registramos, compuerta 'puerta móvil'.

\section{contra-}

Este prefijo tiene, en los términos localizados, un significado posicional ("junto a, frente a") y añade al sustantivo al que se adjunta, bien un valor de refuerzo (Varela y Martín García 2000[1999]: 5013) para así designar “lo que se sitúa próximo a otra cosa para protegerla o reforzarla" (NGLE: 690) como ocurre en contrabalsa 'estanque (extra, de refuerzo) en los molinos que tienen balsa', bien nombra cosas por su posición contraria u opuesta a algo, caso de contrapeso 'peso que se pone en la parte contraria de otro'.

en-

Prefijo posicional verbal (Varela y Martín 2000[1999]: 5012). Prefija también adjetivos, de acuerdo con el DRAE, y significa 'dentro de' o 'sobre'. En nuestro caso, creemos que hay alguna posibilidad, aunque no estamos seguros, de que este sufijo se halle en un sustantivo raro, cuyo origen es incierto: enjeta 
'grifo o llave que en los depósitos de líquidos regula la salida de estos'.

in-

Este prefijo, clasificado como prefijo de contrariedad, suele unirse a bases adjetivas y verbales (Varela y Martín 2000[1999]: 5022). Nosotros lo hemos hallado en la prefijación de un sustantivo, estabilidad, constituyendo así la voz inestabilidad.

re-

Este prefijo, que posee varios valores, prefija dos de nuestros sustantivos, regolfo y remolino. En regolfo 'vuelta o retroceso del agua o del viento contra su curso', creemos que aporta un significado locativo, 'detrás, hacia atrás', mientras que en remolino 'movimiento giratorio y rápido', consideramos que posee un valor reiterativo.

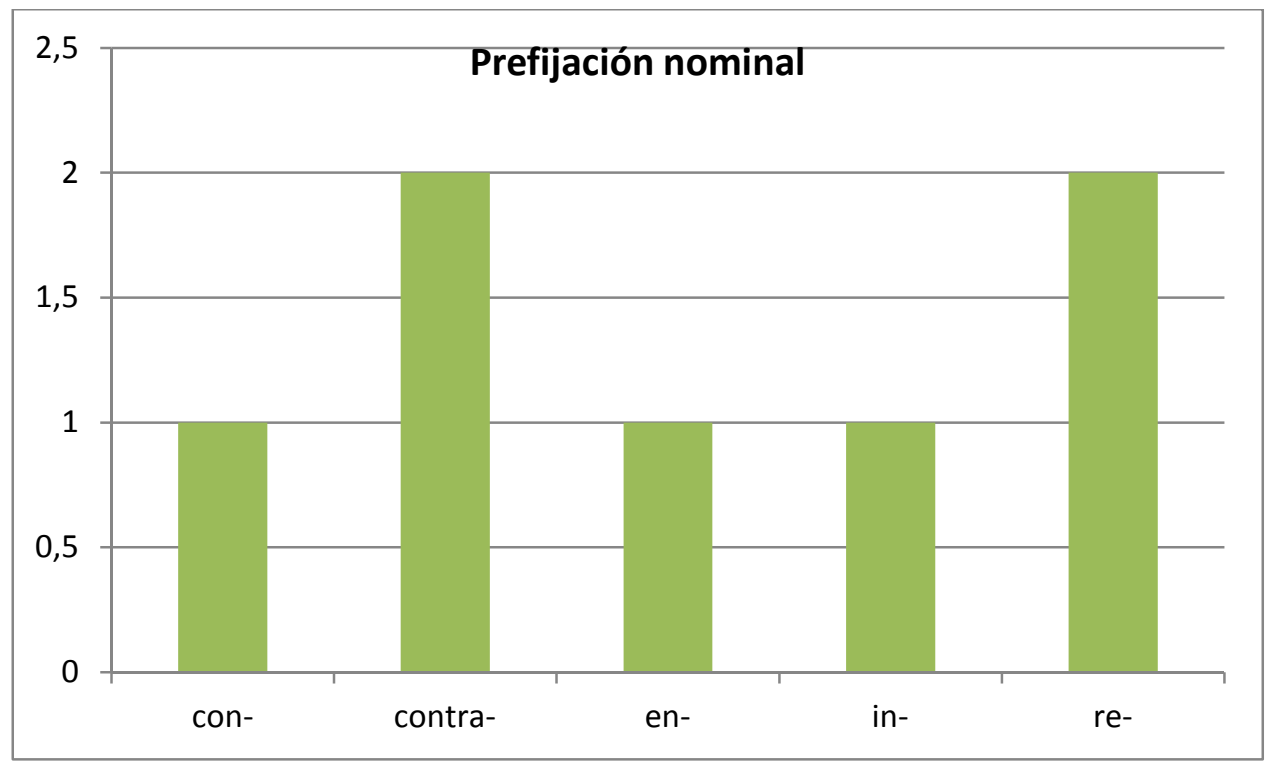

\subsubsection{Prefijación en la formación de adjetivos}

en-

Señalamos un caso dudoso, entorneado, sinónimo, a nuestro parecer, de torneado. Hemos decidido descartar la posibilidad de que este adjetivo sea deverbal, puesto que no hallamos en los textos ni en los diccionarios consultados entornear. Este prefijo, que significa, de acuerdo con el DRAE, 
'dentro de' o 'sobre', no añade un valor o significado concreto a la base léxica en este caso.

\subsubsection{Prefijación en la formación de verbos}

$a-$

Como prefijo deverbal sin significación precisa (DRAE) lo localizamos en afirmar ${ }^{319}$, apegar, arrevolver y aserrar. Son casos en los que este prefijo, originalmente con valor locativo, muestra que el resultado de su actuación no supone ningún cambio semántico en la base sin prefijación ${ }^{320}$, por lo cual podría caracterizarse con un valor meramente intensivo (Varela y Martín 2000[1999]: 5017).

des-

Son muchos los significados con los que este prefijo puede dotar a las bases léxicas sobre las que actúa (Martín García 2007: 5). En cuanto a las bases verbales que prefija en nuestro glosario, es un prefijo clasificado como negativo, y aporta un valor regresivo (Varela y Martín García 2000[1999]: 5028). Es decir, "suponen que la acción de la base se ha realizado y que además ha llegado a un estado resultado sobre el que incide la acción denotada con la forma en des-“ (Martín García 2007: 11). Ejemplos de este tipo son desapegar, desarmar, desarrevolver, desclavar, despegar y destornear 'quitar algo de un torno o cilindro' 321 .

en-

Como prefijo posicional, en- se adjunta a verbos simples y puede señalar el lugar "en donde" (Varela y Martín 2000[1999]: 5012), como creemos que

${ }^{319}$ De firmar y este del latín firmāre 'afirmar' 'dar fuerza'.

320 Respecto a la alternancia con y sin prefijo, V. Sánchez-Prieto (1992). Registramos los términos correspondientes constituidos por la base sin prefijación en todos los casos, excepto en acarrear. Sin embargo, aunque en el corpus no se halla carrear, tenemos constancia de su existencia en la época, de modo que incluimos acarrear en el apartado de prefijación en vez de en el de parasíntesis.

${ }^{321}$ En este caso no hemos hallado ejemplos de tornear con un significado antónimo; solamente recogemos tornear 'labrar y pulir algo en el torno'. 
ocurre en embeber 'dicho de un cuerpo sólido: absorber a uno líquido' y empegar 'bañar o cubrir con pez una superficie'.

re-

Este sufijo marca, entre otros valores, la iteración, es decir, la repetición de una acción por segunda vez (Varela y Martín 2000[1999]: 5029). Con este sentido señalamos rehenchir, repartir y retornear. Consideramos, sin embargo, que este prefijo apunta una gradación con marcada intensidad (NGLE: 670) en remoler 'moler mucho', resurtir 'brotar hacia arriba' y revolcar 'echar algo sobre otra cosa'.

so-

Esta es una de las variantes del prefijo $s u b-$, que señala principalmente una posición espacial de inferioridad (Varela y Martín 2000[1999]: 5014). Así, socavar 'excavar por debajo de algo'.

\section{tras-}

Este prefijo, variación de trans-, del latín trans, es uno de los que indican una posición, en concreto "más allá de, al otro lado de" (Varela y Martín 2000[1999]: 5014) o movimiento o posición “a través" (NGLE: 670), como trasminar ${ }^{322}$ y su sinónimo trasvinar 'penetrar o pasar a través de algo' o trasverter 'exceder su capacidad hasta derramar su contenido'.

${ }^{322}$ Respecto a este término, DECH no asegura totalmente que sea un derivado de minar, como sí que hace DRAE. Argumenta que podría ser originaria la forma trasmanar 'rezumar, trasminar', usual en Murcia, relacionada con manar. 


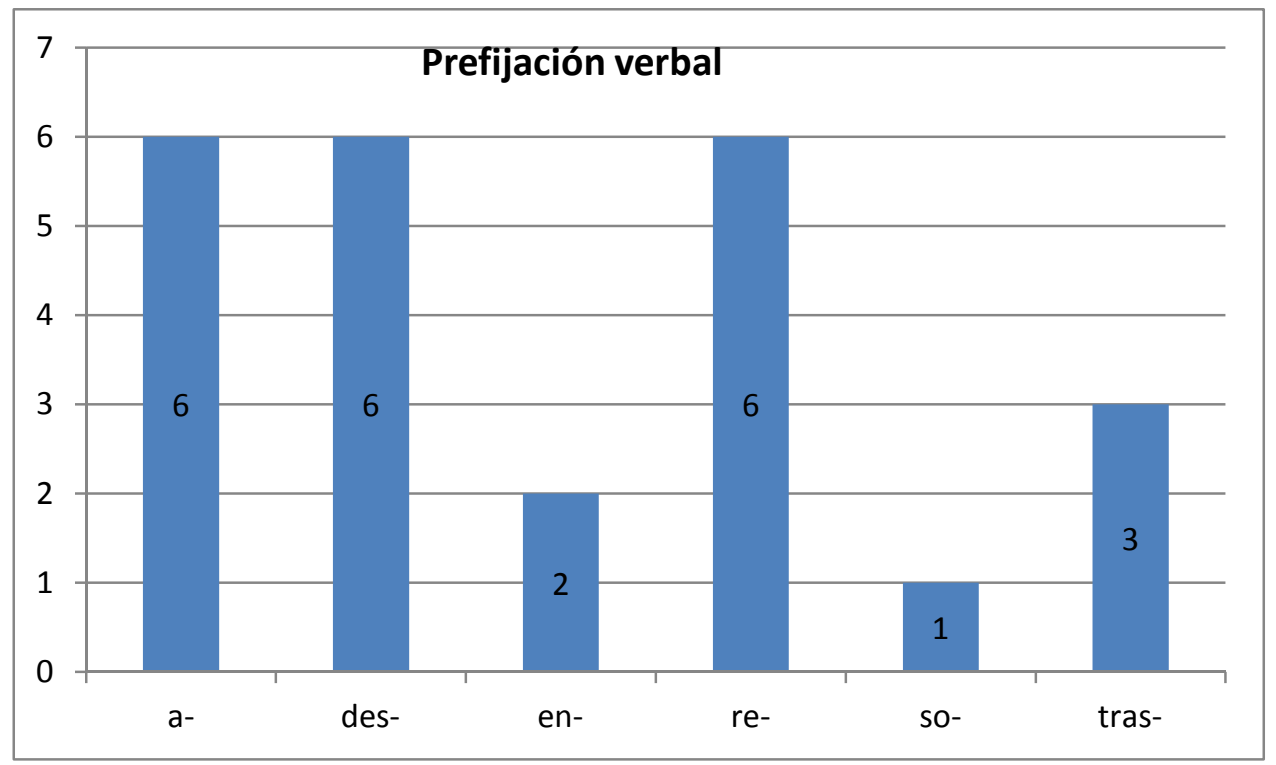

\subsubsection{Parasíntesis verbal sobre base sustantiva}

El mecanismo de formación de verbos mediante parasíntesis implica la combinación conjunta de un prefijo y de un sufijo sobre una base sustantiva o adjetiva, y supone la inexistencia de las fases intermedias (prefijo + base; base + sufijo), tanto por criterios formales, como semánticos (Serrano-Dolader 2000[1999]: 4701).

\section{$a-+$ sustantivo $+-a r$}

Conforman un grupo muy significativo los verbos parasintéticos con esta estructura, tanto con bases nominales como adjetivas, surgidos en la segunda mitad del s. XIV y en la primera mitad del s. XVI (NGLE: 605). Estos verbos denominales, frecuentemente señalan la acción realizada con el instrumento denotado por el sustantivo base, y así ocurre en los "verbos instrumentales"323 como abarrenar 'agujerear alguna cosa con una barrena', acarrear, amartillar 'dar golpes con el martillo' y amolar 324 'afilar un arma en la muela'. Otras paráfrasis posibles son "sacar" en afilar 325 'sacar filo' o "poner, echar" en alvidriar 326 'echar

${ }^{323}$ V. Serrano-Dolader 1995: 136.

${ }^{324}$ De muela $(\mathrm{DECH})$.

325 De filo $(\mathrm{DECH})$. Aunque existe filar, no procedería de ahí (y por lo tanto no se trataría de un caso de prefijación) puesto que no tiene el mismo significado, ya que filar ‘hilar'.

${ }^{326}$ Aquí tenemos al- como alomorfo de $a$ - 
barniz vidrioso'.

des- + sustantivo + -ar

En la formación de verbos parasintéticos, el prefijo des- tiene generalmente un valor privativo, es decir, indica la privación o carencia de aquello que denota la base (Varela y Martín García 2000[1999]: 5023, SerranoDolader 1995: 138-142). Así ocurre en verbos como desaguar 'dar salida a las aguas' y descerrajar 327 'arrancar una cerradura'.

en- + sustantivo + -ar

Ya que el sentido locativo (Varela y Martín García 2000[1999]: 5012) o el valor locativo-direccional (Serrano-Dolader 1995: 122) está presente en los verbos con esta estructura, el esquema en- + sustantivo + -ar produce verbos que pueden interpretarse de manera similar a algunos con la estructura $a_{-}^{-}$ sustantivo + -ar (NGLE: 609), en concreto aquellos que pueden parafrasearse por "poner + sustantivo". En este numeroso grupo, situamos los verbos embarnizar, embetunar, emboñigar, empedrar, empeguntar 328 , enarenar, enclavar, enclavijar, enladrillar, ensolar ${ }^{329}$ y envigar.

Otros verbos parasintéticos de este tipo que hemos registrado son encañar, encarar330 'señalar', endentar 'encajar en dientes', engastonar331 'encajar en engastes' y enroscar.

\section{re- + sustantivo + -ar}

Localizamos con esta estructura parasintética el verbo regolfar332 'dicho del agua: retroceder contra su corriente haciendo un remanso'.

tras- + sustantivo + -ar

\footnotetext{
327 De cerraja, *cerrajar.

${ }^{328}$ De pegunta 'señal con pez'.

329 De suelo.

330 'Apuntar o señalar hacia algún sitio'.

${ }^{331}$ De gastón 'engaste' (DECH).

332 De golfo.
} 
Señalamos el verbo trasvinar 'penetrar o pasar a través de algo', de vino (DECH).

$$
\text { en- + sustantivo + -ecer }
$$

Disponemos también únicamente de un ejemplo de este caso, empedrecer 'dicho de un material: solidificarse, convertirse en piedra'.

\subsubsection{Parasíntesis verbal sobre base adjetival}

$$
a-+ \text { adjetivo }+-a r
$$

Aunque son muchas las palabras del castellano que poseen esta estructura, no son tantas las creaciones propias del idioma, pues un gran número de ellas deriva del latín (NGLE: 605). Dentro de las que consideramos que se han formado mediante mecanismos propios del castellano, señalamos alivianar333, que puede parafrasearse por "hacer liviano" afijar334 'hincar, clavar' y aparejar335 'preparar, disponer'.

$$
e n-+ \text { adjetivo }+-a r
$$

Sólo encontramos un ejemplo de este tipo, el verbo emparejar 336 que, al igual que los verbos denominales con este esquema parasintético en-...-ar, podría parafrasearse por 'poner (algo) + adjetivo', en concreto, 'poner algo a nivel o parejo'.

\footnotetext{
333 De liviano (DRAE).

334 De fijo (DRAE).

335 De parejo (DRAE).
}

336 De parejo (DRAE). 


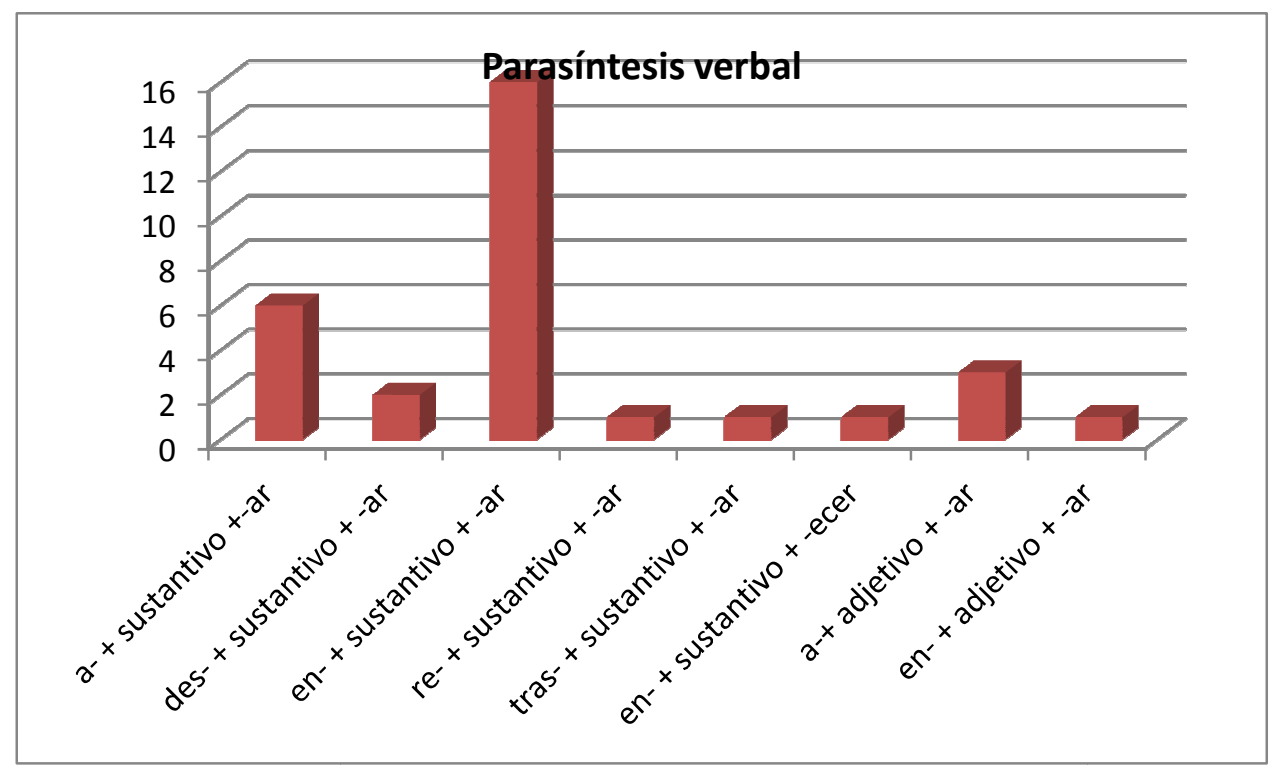

\subsubsection{Morfología regresiva}

Señalamos en este apartado la voz quicio, voz que parece haberse sacado secundariamente de resquicio 'abertura que hay entre el quicio y la puerta', que antiguamente era rescrieço 'grieta', 'rendija' y deriva de *excrepitiare 'resquebrajarse' (DECH).

\subsubsection{LA COMPOSICIÓN}

\subsubsection{Compuestos léxicos}

Consideramos compuestos léxicos u ortográficos a aquellas unidades léxicas simples que son el resultado de la concatenación ortográfica de dos palabras (Varela 2005: 74) frente a otras estructuras compositivas, formadas por dos o más unidades léxicas, denominadas unas compuestos sintagmáticos y otras compuestos sintácticos o locuciones nominales.

Los compuestos léxicos que registramos en nuestro glosario son todos sustantivos $^{337}$. De acuerdo con la estructura gramatical de las palabras que los conforman, podemos clasificarlos en los siguientes grupos:

337 “Los compuestos del español pueden pertenecer a las categorías nominal, verbal, adjetival y preposicional [...]. Entre ellas, son especialmente importantes los compuestos nominales" (Clavería y Torruella 1993: 323). 
Sustantivo + sustantivo: son tres los compuestos léxicos formados por un sustantivo antepuesto al sustantivo puente. Los tres casos contienen la vocal de enlace $-i-$, herencia de un genitivo latino ${ }^{338}$. Se trata de carripuente 'carro para transportar pertrechos de artillería', compuesto de carro y puente; gallipuente 339 'acueducto o puente sin barandas, construido de cañas cubiertas de césped', de gallón 'pedazo de tierra cubierta de césped' y puente; maripuente (V. nota de gallipuente) 'acueducto o puente colocado a gran altura', de mar y puente; además, con esta estructura gramatical de Sustantivo + Sustantivo señalamos palahierro 'pieza en la que se encaja el gorrón de un molino', compuesto léxico en el que se encuentran concatenados dos sustantivos, palo y hierro (DRAE).

Sustantivo + adjetivo: mampuesto 'piedra sin labrar que se puede colocar con la mano', compuesto de mano y puesto.

Adjetivo + sustantivo: trespuntas 'vara larga con cabeza de tres dientes', de tres y punta.

Verbo + sustantivo: cortahierro 'herramienta que se utiliza para cortar objetos de hierro', compuesto de cortar y hierro; tajamar340 'obra de cantería que se construye en una corriente para repartir las aguas', de tajar y mar.

Preposición + sustantivo: antepecho 'murete o baranda', formado por la preposición ante y el sustantivo pecho.

Teniendo en cuenta la existencia o no de un núcleo en los compuestos, y entendiendo por núcleo "el constituyente en el que radican las posibilidades distribucionales y que determina el tipo de categoría de la construcción" (Val Álvaro 2000[1999]: 4766), podemos distinguir dos grupos de compuestos, los

338 Se usa la vocal -i- como elemento de enlace en los compuestos nominales formados con las pautas N-i-N, V-i-V, A-i-A y (para algunos autores) también N-i-V" (NGLE: 751).

339 "Llámanse maripuente o gallipuente quando estos arcos tan solamente, o uno o muchos, allegan de un monte a otro, o de una parte a otra de algún barranco, de adonde la toma hasta donde la deja, aunque estos arcos sean dos o tres órdenes, unos encima de otros, y aunque sean çiento ni dozientos passos" (Turriano, ca. 1605: 88v).

340 "Al fin de esta pesquera se ha de hacer una puerta de dos arcos de ladrillo pequeños y bajos, por donde la gente pueda pasar a San Cosmes del Camino, que va de la pesquera de Carreño con una tajamar en medio pequeña y baja" (Lobato a. 1585: 31). 
endocéntricos o aquellos que sí que presentan un núcleo y los exocéntricos, que son los que carecen de éste. Serían, en nuestra opinión, compuestos endocéntricos carripuente 'carro para transportar pertrechos de artillería', gallipuente 'acueducto o puente, generalmente elevado, que sirve para hacer pasar una conducción de agua por encima de un río o arroyo' y su sinónimo maripuente. En ellos creemos que el núcleo es el segundo de los sustantivos 341 , puente, pues determina la categoría gramatical de estos términos y posee la mayor carga semántica.

Respecto al resto de compuestos, incluimos solamente cortahierro 'herramienta que se utiliza para cortar objetos de hierro' en el grupo de los endocéntricos. Pensamos que los demás compuestos son exocéntricos (palahierro 'pieza en la que se encaja el gorrón de un molino', mampuesto 'piedra sin labrar que se puede colocar con la mano', trespuntas 'vara larga con cabeza de tres dientes', tajamar 'obra de cantería que se construye en una corriente para repartir las aguas' y antepecho 'murete o baranda'), puesto que no tiene cabida una clara interpretación de lo que estos denotan a partir de sus elementos compositivos, entre otras cuestiones porque "el hiperónimo de la formación no puede identificarse directamente a través de ninguno de los miembros que la componen" (Val Álvaro 2000[1999]: 4787).

\subsubsection{Compuestos sintagmáticos}

Llamamos compuestos sintagmáticos a aquellos sintagmas nominales complejos que denominan un referente único y que se caracterizan, por tanto, por el hecho de que su significado no es el resultado de la suma de los significados de los componentes de ese sintagma (Bustos Gisbert 1986: 20). Es decir, aunque no existe una cohesión ortográfica en estos compuestos, la coherencia semántica que los caracteriza implica que posean un significado unitario y un referente único (Varela 2005: 80).

\footnotetext{
${ }^{341}$ A pesar de que "la mayor parte de los compuestos $\mathrm{N}+\mathrm{N}$ del español, y de las demás lenguas romances, tienen el núcleo a la izquierda" (NGLE: 750).
} 
Teniendo en cuenta en qué medida están fijas las distintas construcciones complejas, así como su grado de idiomaticidad ${ }^{342}$, los compuestos sintagmáticos estarían situados, en una escala de menor a mayor grado, entre las colocaciones y las locuciones (Ferrando Aramo 2002: 105). Aunque para algunos autores, como Gloria Corpas, los compuestos sintagmáticos forman parte de las locuciones, por ser construcciones con cohesión interna pero sin unión ortográfica (Corpas 1996: 93), nosotros los consideramos un grupo autónomo, pues, a diferencia de las locuciones, los compuestos sintagmáticos generalmente pluralizan sólo uno de sus elementos o componentes ${ }^{343}$ (NGLE: 741). Sin embargo, desde el plano teórico, sigue debatiéndose si esta cuestión de la variación del plural puede marcar el paradigma (NGLE: 854).

Son varias las estructuras combinatorias que distinguimos en los compuestos sintagmáticos localizados en nuestro glosario, que ascienden a 47 en total:

\section{Sustantivo + sustantivo}

Solamente encontramos un término que pueda ejemplificar un proceso de composición sintagmática en el que participen dos sustantivos. Se trata de la denominación de la pieza de una máquina, viga lagar, construcción en la que participan dos sustantivos concatenados libremente. En la propuesta de clasificación de los compuestos nominales realizada por Val Álvaro, este tipo de compuestos formado por dos nombres que no han llegado a unirse fonológicamente pertenecería a la categoría de los compuestos imperfectos (Val Álvaro 2000[1999]: 4778).

\section{Sustantivo + de + sustantivo}

342 Además del grado de fijación e idiomaticidad, otras características de los compuestos sintagmáticos, de acuerdo con Cristina Buenafuentes, serían la posibilidad de ser una unidad de denominación, la motivación pragmática y el comportamiento paradigmático (Buenafuentes 2006: 502).

343 Por ejemplo, al pluralizar el compuesto sintagmático molino de sangre, sólo el primer elemento del compuesto, molino, sufre la correspondiente modificación flexiva del plural, tal y como observamos en el ejemplo: "Los molinos de sangre, hordinariamente, se llevan con animales, y por esta causa se llaman de sangre, aunque en muchas partes los llaman de taona" (Turriano, c. 1605: 321v). 
Entre los tipos de sintagmación en los que el complemento nominal es un sintagma preposicional, aquellos formados por la preposición de son los más habituales (Val Álvaro 2000[1999]: 4827). No es sólo ese el caso en nuestros compuestos, sino que justamente, esta estructura composicional es la más abundante, y con diferencia, en el conjunto de compuestos sintagmáticos registrados.

La gran mayoría de ellos designan nombres de máquinas, fundamentalmente diferentes modelos de molinos, motivo por el cual molino es el primero de los componentes de un importante número de sintagmas de esta tipología, como por ejemplo molino de bomba, molino de canal, molino de cubo o molino de pasaje ${ }^{344}$. También registramos varios instrumentos, entre los que destacan en frecuencia los que nombran tipos de niveles, por ejemplo nivel de agua, nivel de borneo, nivel de grados, nivel de peso y nivel de tranco ${ }^{345}$; señalamos, asimismo, algunos materiales, como betún de Babilonia y piedra de amolar.

En la designación de una de las máquinas señaladas en nuestro glosario, también un tipo de molino, el molino de medio regolfo, interviene un adjetivo en la composición del sintagma. Teniendo en cuenta las particularidades con las que Soledad Varela caracteriza lo que denomina compuestos preposicionales, especialmente la carencia de independencia sintáctica de los constituyentes de estos compuestos, la estructura sustantivo + preposición + adjetivo + sustantivo no tendría cabida, pues la participación de un adjetivo o modificador implica la independencia de sus componentes (Varela 2005: 81). A pesar de que, por este motivo, la lexicalización de este sintagma es bastante dudosa, hemos decidido incluirlo porque, a la luz de los ejemplos, consideramos que son deducibles la

344 Otros compuestos sintagmáticos formados por molino + de + sustantivo hallados en el corpus son: molino de aceña, molino de agua, molino de balsa, molino de barcas, molino de bestia(s), molino de cárcavo, molino de contrapesos, molino de grúa, molino de mano, molino de marea, molino de medio regolfo, molino de regolfo, molino de tahona, molino de viento, molino de sangre. Incluimos en este grupo molino del aceite, única excepción en cuanto a la aparición de un artículo acompañando al núcleo del sintagma preposicional del compuesto sintagmático. También señalamos la máquina cóclea de Pitágoras.

345 Otros instrumentos señalados son muela de mano, peso de balanzas, peso de cruz, peso de guindaleta, uña de cabra, uña de puerco. 
referencia o el significado únicos del sintagma ${ }^{346}$.

\section{Sustantivo + preposición + sustantivo}

El único ejemplo de compuesto sintagmático con la estructura sustantivo + preposición + sustantivo en el que la preposición que encontramos no es de, es uno en el que aparece la preposición sin, en concreto el nombre de una máquina, caracol sin fin.

\section{Sustantivo + adjetivo}

Son ejemplos de esta estructura sintagmática, de adjetivo pospuesto al sustantivo en todos los $\operatorname{casos}^{347}$, los nombres de diversos materiales, como betún judaico, piedra caracolina, piedra molar, piedra moleña. También encontramos los nombres de algunas máquinas y piezas de estas: carro mato ${ }^{348}$, molino harinero, puente levadizo/a, rueda cerrada, rueda timpanada, caja farinal, caracol infinido, muela baja.

En este tipo de sintagmas, además de las características generales de los compuestos sintagmáticos anteriormente revisadas, encontramos la concordancia interna de los morfemas de género y número del sustantivo y del adjetivo (Val Álvaro 2000[1999]: 4828). Por este motivo, dado que puente es un sustantivo ambivalente en nuestros textos, encontramos el compuesto tanto en masculino, puente levadizo, como en femenino, puente levadiza ${ }^{349}$.

346 "Vengamos a tratar de otro género de molino, el qual llaman (molino) de medio regolfo, al qual molino se le quita la mitad de la agua de lo que es necessario para que ande un molino de regolfo" (Turriano, c. 1605: 302r). "De modo que al molino de medio regolfo no ha de tener saetía de tres quartos de palmo donde despide la agua, que en el molino de regolfo es palmo y medio de alto la saetía, que son veynte quatro minutos, que la metad de veynte quatro es doze, que es lo que ha de tener de alto la saetía del molino de medio regolfo" (Turriano, c. 1605: 302v).

347 Val Álvaro explica que en los compuestos sintagmáticos $\mathrm{S}+\mathrm{A}$, las construcciones con el adjetivo pospuesto son mucho más habituales que aquellas con el adjetivo antepuesto, debido a que, en español, la posición más frecuente del adjetivo es aparecer pospuesto al sustantivo (Val Álvaro 2000[1999]: 4828).

$348 \mathrm{El}$ adjetivo mato proviene del italiano matto, propiamente 'loco', 'bufón', y aquí significa 'falso, impropio'. Matto, a su vez, procede del adjetivo latino mattus, $-a,-u m$ 'mojado', 'borracho', 'embrutecido'.

349 "La segunda, que tenga su fuessa de agua en torno del muro por la parte de fuera, de hondura de una gineta y de ancho de pica y media, o de dos picas, con sus puentes 


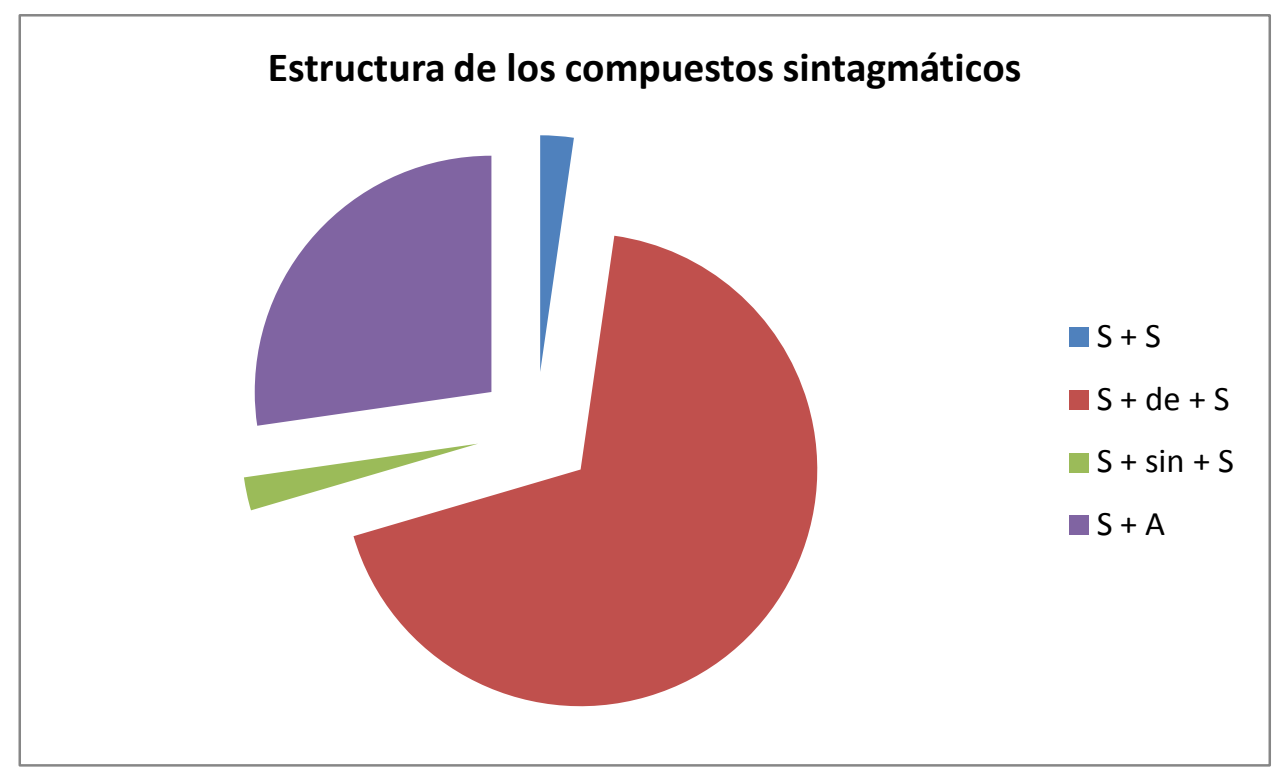

\subsubsection{LOCUCIONES}

Incluimos en este apartado aquellas unidades fraseológicas o unidades léxicas de naturaleza no composicional (NGLE: 854), caracterizadas por su fijación interna y su unidad de significado y que, además, no conforman enunciados completos, sino que funcionan como elementos oracionales (Corpas 1996: 88).

Clasificadas tradicionalmente en nominales, adjetivas, verbales $\mathrm{y}$ adverbiales, nosotros recogemos aquí locuciones adjetivas, verbales y adverbiales. En cuanto a las nominales, recordamos que sus límites con los compuestos sintagmáticos no están claramente definidos (NGLE: 854).

\subsubsection{Locuciones adjetivas}

Sólo señalamos una locución adjetiva, despidiente de agua(s) ${ }^{350}$, con la estructura adjetivo + de + sustantivo.

levadizas por donde entre y salga la gente de la ciudad; y la tercera, que tenga muchas vituallas para el mantenimiento de la gente de guerra" (Montes 1537: XVIIr). "Assimismo, se puede hazer caer rompiendo los bulsones, que son los maderos que levantan y abaxan el puente levadizo con las cadenas que asen en ellos y en él" (Loçano 1582: 214).

350 Esta locución adjetiva responde también a un posible cambio categorial, de forma que la locución adjetiva despidiente de agua(s) se usa también con función nominal. Registramos su función adjetiva en el ejemplo "y de aquí quisieron que en los lugares de muchas nieves, los techos muy despidientes de agua estuviessen hazia arriba muy levantados en ángulo agudo, para 


\subsubsection{Locuciones verbales}

Es solo una la locución verbal formada por un verbo + complemento (sintagma nominal) registrada en el glosario: dar vueltas.

\subsubsection{Locuciones adverbiales}

Hallamos en nuestro glosario 7 locuciones adverbiales, formadas todas ellas por un sintagma preposicional. 4 de estas locuciones están encabezadas por la preposición a y 3 por la preposición en, y todas ellas operan funcionalmente como complementos circunstanciales. Semánticamente, a borneo, a chiflón, a clavilla, al escarzo, en balanza, en equilibra y en fil expresan circunstancias modales.

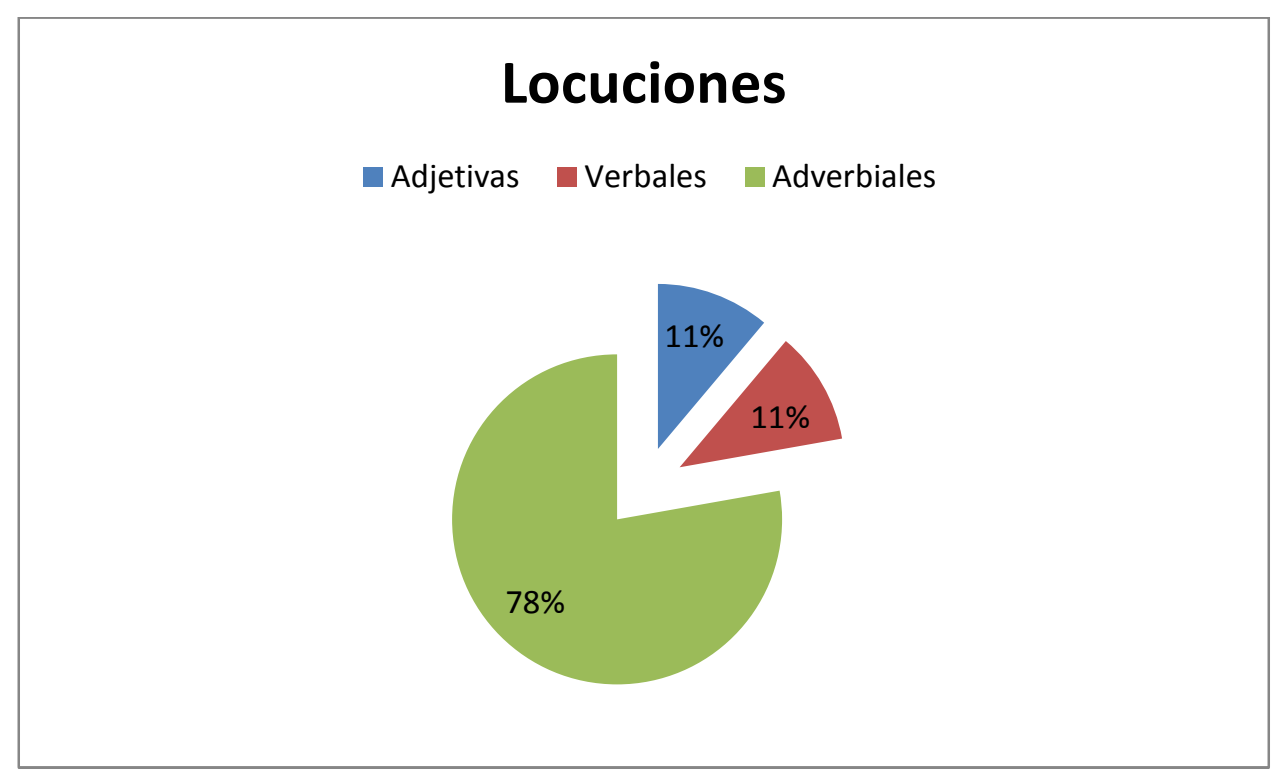

\subsubsection{CONCLUSIONES DEL ESTUDIO MORFOLÓGICO}

El análisis y estudio de los frecuentes y variados procesos morfológicos que intervienen en la formación del léxico de la ingeniería renacentista nos muestra la gran relevancia que las creaciones morfológicas constituyen en la configuración del léxico de esta área designativa. El número de voces creadas

que no creciessen mucho los augmentos de nieves y cayessen más líquidamente" (Loçano 1582: 27) y la sustantiva en "no solamente la pared y las cosas que con las paredes se levantan y consiguen, pero también las cosas que están debajo del mismo suelo no negarán aver sido halladas, como los despidientes de aguas y apartamientos que son de lluvias y albañares, y otras así" (Loçano 1582: 35). 
mediante procedimientos morfológicos es muy abundante, pues asciende a 431, casi la mitad de las que configuran el total del glosario.

Como era de esperar, el proceso morfológico que actúa con más frecuencia es la derivación, en comparación con la composición y la parasíntesis que son mucho menos recurrentes.

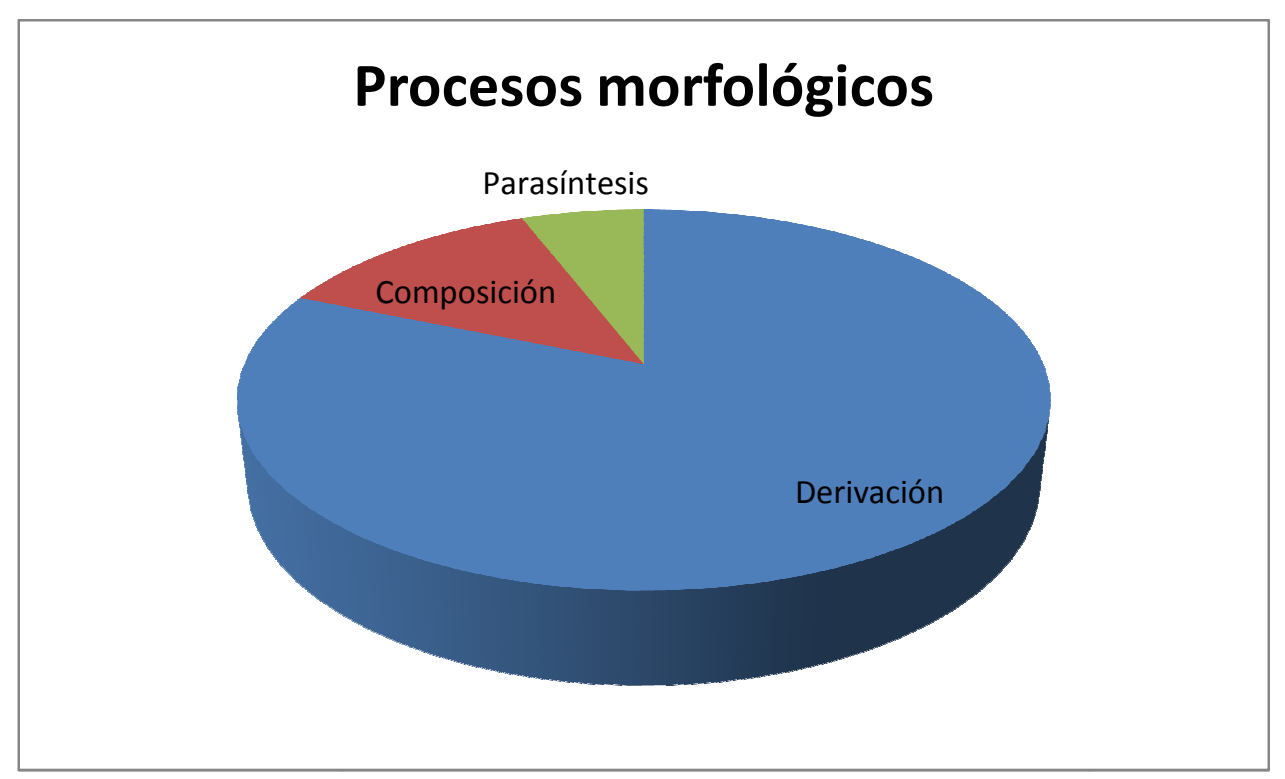

Dentro de los procesos derivativos empleados en la creación léxica, destaca notablemente el número de casos de sufijación en comparación con los de prefijación.

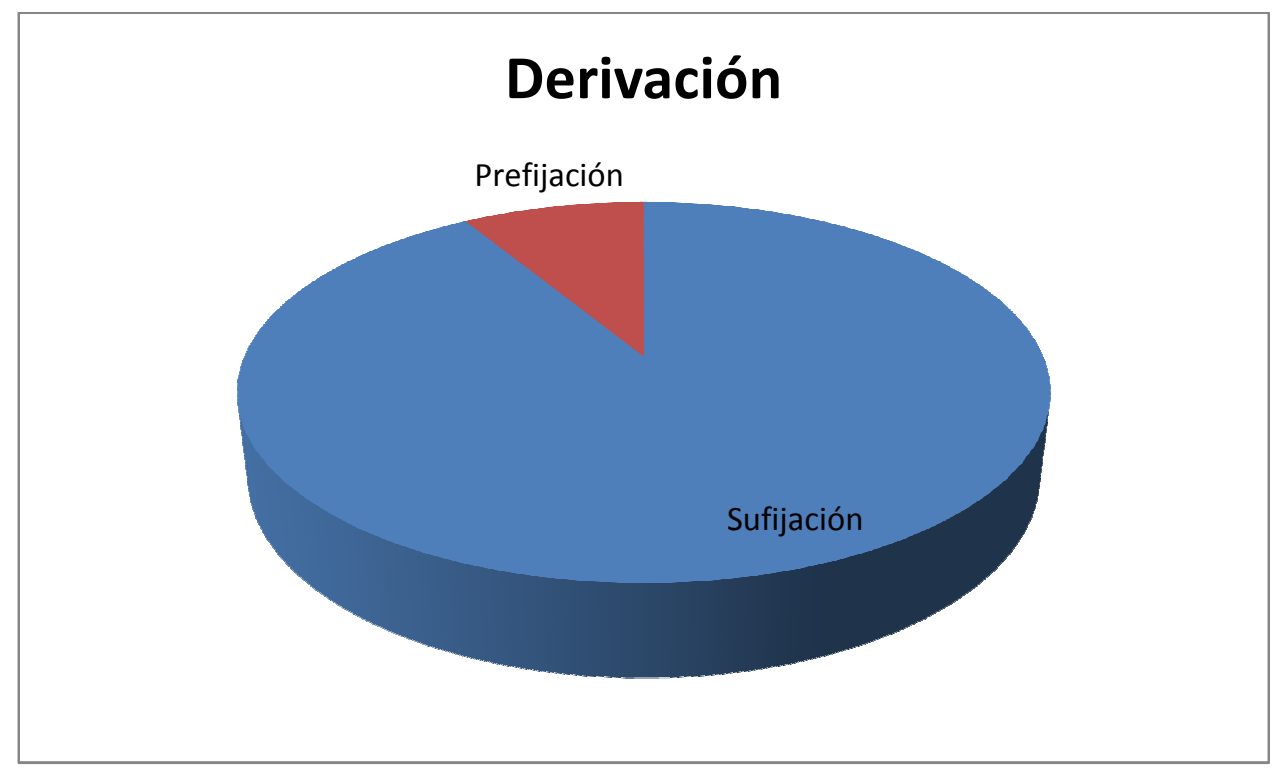

Respecto a la categoría gramatical de los términos obtenidos como 
resultado del empleo de la sufijación, el porcentaje de sustantivos es con diferencia mucho más elevado que el de otras categorías, como verbos, adjetivos y adverbios. Estos porcentajes obtenidos en el análisis de las distintas categorías de los derivados por sufijación son proporcionales a los porcentajes generales de la distribución categorial del total de los términos del glosario.

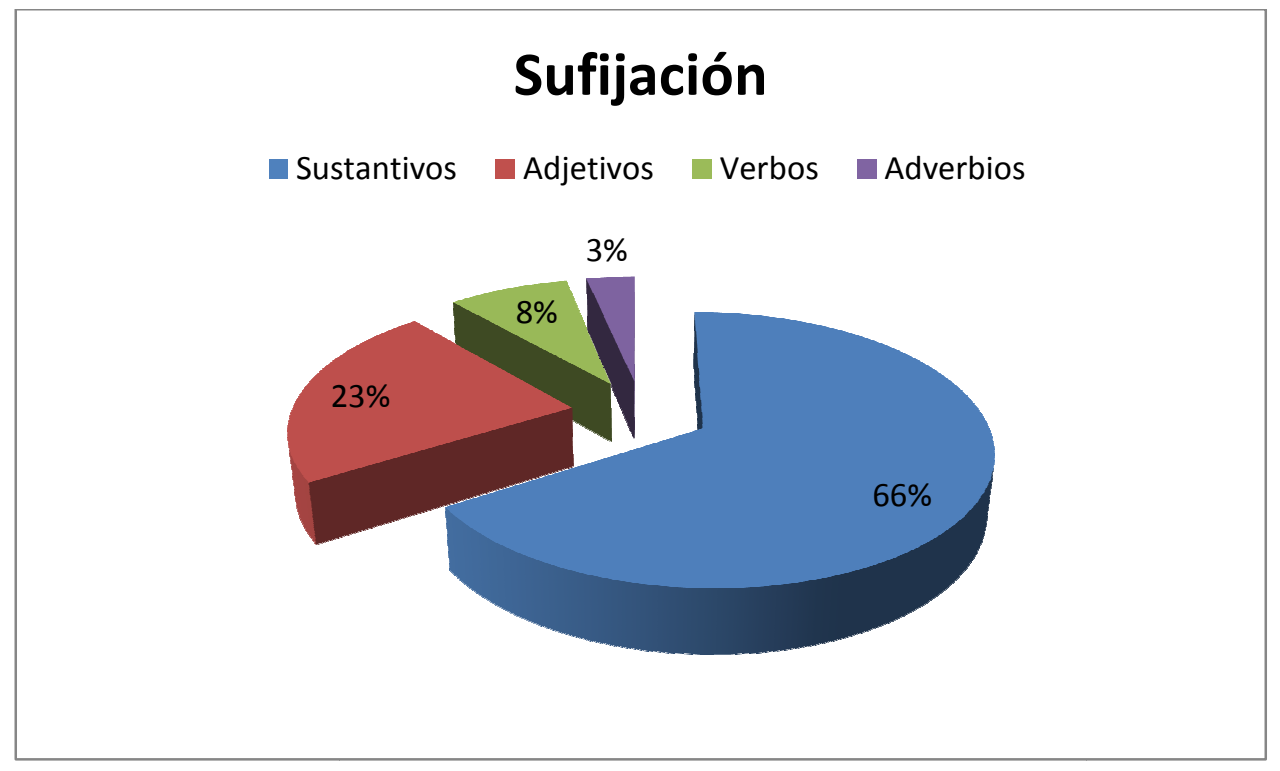

Por tanto, los sufijos más frecuentes y variados que actúan en nuestros términos son sufijos sustantivadores, los cuales intervienen a partir de bases nominales y verbales, excepto en dos de los términos, ceguedad e impetuosidad, en los que el sufijo -dad se aplica a una base adjetival.

En cuanto a la sufijación de sustantivos denominales, el 60\% es sufijación no apreciativa y el $40 \%$ apreciativa.

Este elevado porcentaje de sustantivos creados mediante sufijación apreciativa recogidos en nuestro glosario está motivado, a nuestro modo de ver, por dos razones: por una parte, se debe a la inclusión en nuestra selección léxica de un importante número de voces pertenecientes al subcampo léxico de las herramientas, ámbito en el que son numerosos los términos formados mediante sufijación apreciativa, fundamentalmente para designar distintas herramientas de acuerdo con su tamaño; por otra parte, estaría causado por la existencia de un grupo de aragonesismos, un tipo de dialectalismos en cuya morfología 
encontramos frecuentemente la sufijación apreciativa. De estos sufijos apreciativos, los más utilizados en la formación de las voces estudiadas son los sufijos diminutivos -ete, -eta e -illo, -illa.

En cuanto a los sustantivos creados por sufijación no apreciativa, más de un $60 \%$ están formados a partir de una base verbal, y el resto, excepto en dos casos, a partir de una base nominal.

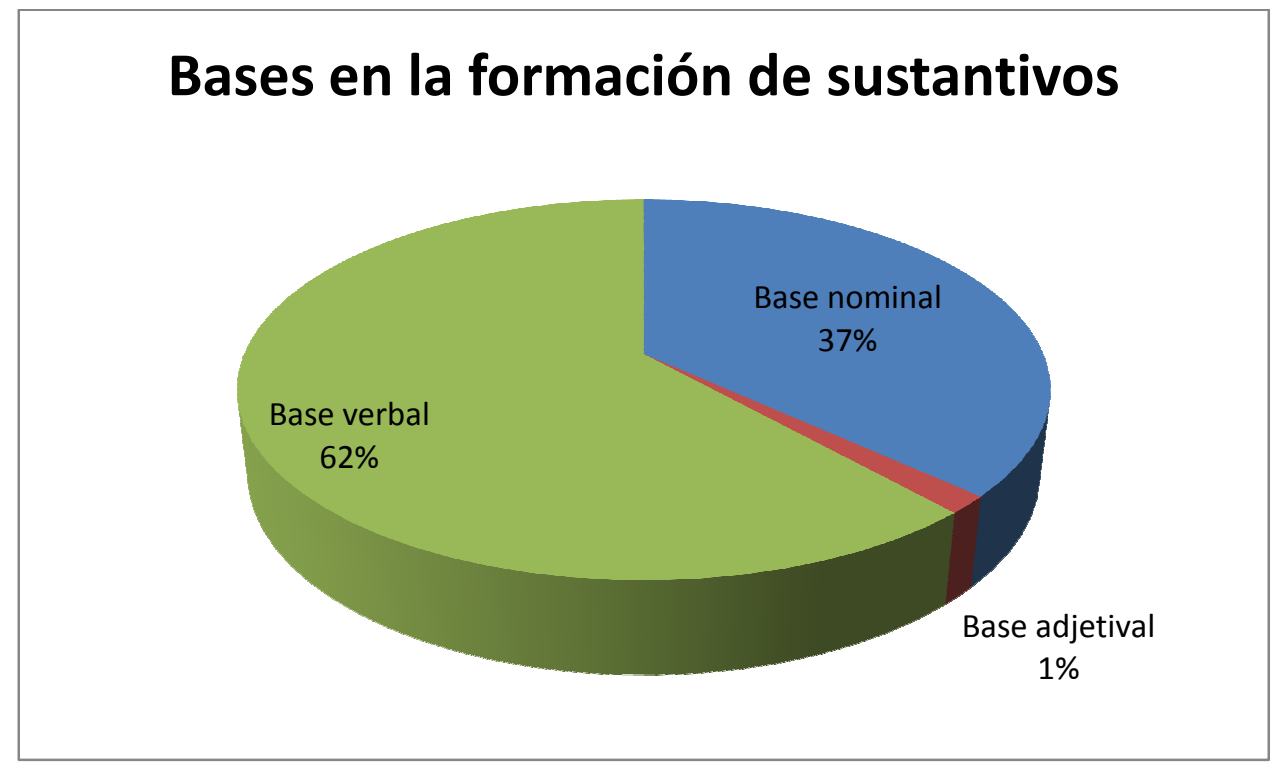

Entre los sufijos sustantivadores que se añaden a bases nominales, los más frecuentes son -ero y -al/-ar; en cuanto a los que se adjuntan a bases verbales, son más recurrentes -dero y -dor.

Los sufijos adjetivadores se adjuntan tanto a bases nominales como adjetivales o verbales, aunque destacan en número los sufijos adjetivadores aplicados a bases verbales. 


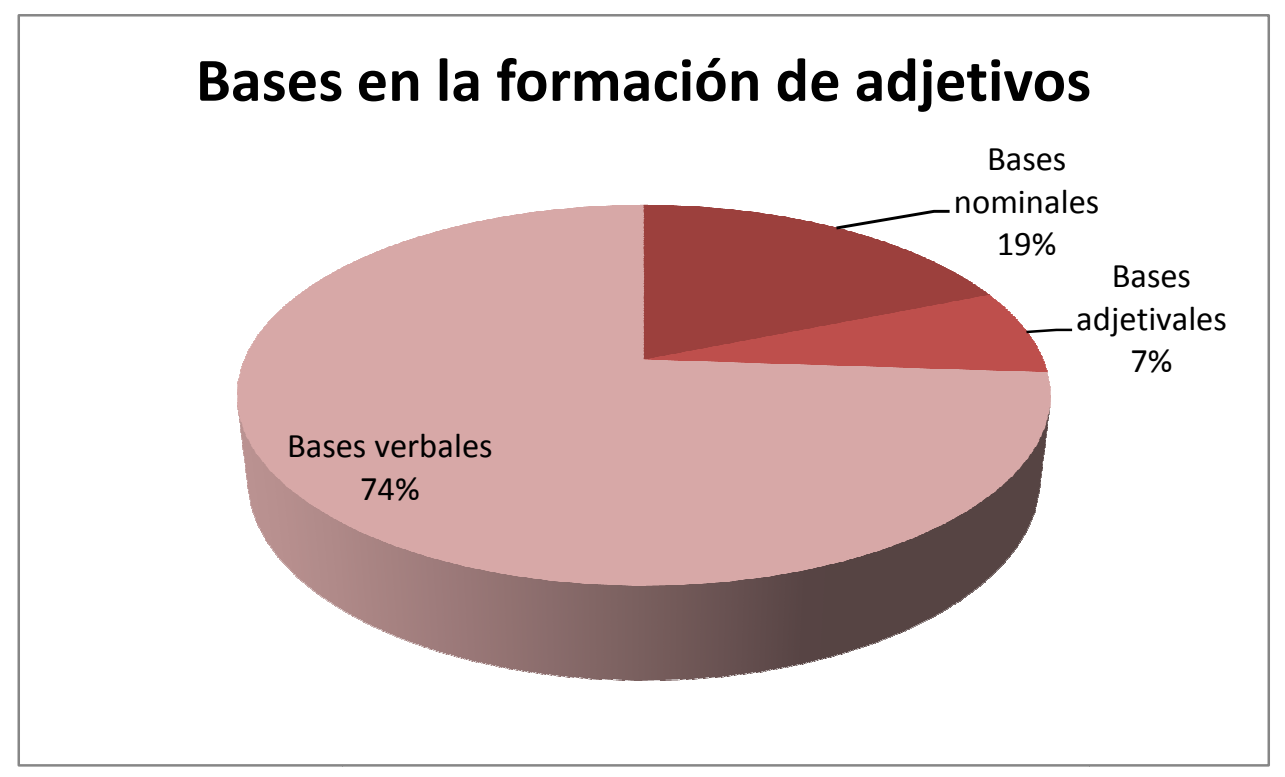

Entre los sufijos adjetivadores aplicados a bases nominales, el más recurrente es -ado; y dentro del conjunto de sufijos adjetivadores añadidos a bases léxicas verbales, sobresale y domina el sufijo -do.

Respecto a los sufijos que intervienen en la formación de verbos, registramos 23 casos de -ar, sufijo verbalizador denominal que en uno de los casos se adjunta a una base adjetival (fijar, de fijo). También hemos hallado dos verbos formados por sufijación en -ear a partir de una base nominal, y otro cuya base de sufijación está conformada por una preposición y un sustantivo.

Encontramos 11 adverbios construidos por sufijación en -mente.

Respecto a los casos de prefijación, destaca el número de términos formados con los prefijos $a-$, des-, en- y re-.

Hallamos en nuestro léxico un adjetivo parasintético y varios verbos formados por parasíntesis, entre los que domina la parasíntesis en-....-ar.

La sintagmación es uno de los recursos más empleados en los lenguajes especializados, ya que "permite crear nuevas unidades terminológicas de significado transparente" (Ferrando Aramo 2002: 99). Relacionado con esto, señalamos que hemos hallado algunas locuciones, entre las que destacan las adverbiales, que alcanzan el $60 \%$ del total. 


\subsection{NEOLOGÍA DE SENTIDO: LA ZOONIMIA}

Dentro de los procesos de creación de palabras propios de los lenguajes de especialidad, destaca la notable producción de términos llevada a cabo mediante el procedimiento de la neología de sentido. La neología de sentido "permite dotar de un nuevo significado a una palabra ya existente" (Gutiérrez Rodilla 2005: 57), bien mediante la incorporación de un nuevo sentido especializado a una palabra de uso cotidiano, proceso conocido como terminologización, bien mediante el paso de un tecnicismo de un campo del saber a otro (V. Martín Herrero 2010). Sin embargo, en muchas ocasiones los lenguajes especializados recurren a la neología de la forma, es decir, a la creación de nuevas palabras a las que asignan esos nuevos conceptos, creación que normalmente se realiza a partir de elementos lingüísticos ya existentes. La elección de este mecanismo de la neología de la forma dentro de los mecanismos neológicos de los lenguajes especializados suele estar motivada por un intento de evitar los posibles equívocos que podrían darse en el idioma con la neología de sentido (Arntz y Picht 1995: 146).

En el léxico de los ingenios y máquinas del Renacimiento son muchas las voces creadas mediante el mecanismo de la neología de sentido, aunque, en la mayoría de los casos, la neología de sentido se dio ya en latín, por lo que en castellano entraron ya como cultismos, tal es el caso de cóclea, quelonio, émbolo o autómato. En cualquier caso, nos ha llamado la atención, en el campo que nos ocupa, el gran número de términos existentes de ingeniería y maquinaria creados a partir de nombres de animales. Este es el caso de voces como aguilón, asno, atelabo, anadija, caballo, cabria, cabrilla, caracol, caracola, cigoñal, cigüeña, escorpión, gorrón, grúa, langosta, lobo, marrano, puerca y súcula.

\subsection{DISTRIBUCIÓN POR CAMPOS LÉXICO-SEMÁNTICOS}

Sabemos que las palabras no son sólo la suma de los significados parciales de los morfemas que las componen, sino que tienen un significado propio o contenido unitario, y que, además, la mayoría de las palabras son 
polisémicas, es decir, tienen varios significados. El conjunto de semas (unidad mínima de significación) de una palabra o semema, conforma, de acuerdo con Pottier (1968: 71) el semantema, es decir, el valor de una palabra en la lengua, que se realiza, bien en el discurso o en el habla, de acuerdo con sus posibilidades combinatorias (Otaola Olano 2003: 101).

Pottier propone sin embargo la terminología lexía para las unidades funcionales o de comportamiento, lugar en el que se tratan "combinaciones frecuentemente realizadas en el discurso", creadas con anterioridad y que son más o menos fijas en su empleo. Estas pueden ser simples o complejas dependiendo de las palabras que las compongan. Otros lingüistas prefieren la denominación, más ampliamente aceptada, lexema.

En el léxico renacentista del área que nos ocupa son continuos los transvases entre los términos especializados y las voces del lenguaje común, de manera que en ocasiones nos resulta más esclarecedor hablar de léxico especializado que de terminología.

Por otro lado, Coseriu considera que los campos semánticos de las terminologías organizan fenómenos definidos por las ciencias, las técnicas y objetos, formando clasificaciones objetivas en lugar de estructuraciones semánticas. Si las palabras sustituyen a las cosas, la significación coincide con la designación, al contrario de lo que ocurre en el lenguaje común (Coseriu, 1977: 196, V. Herráez Cubino 2007: 275).

Por nuestra parte, en este apartado nos detendremos en algunas de las lexías extraídas de nuestro glosario y clasificadas por bloques de significación o campos léxicos. Recordamos a este respecto que un campo léxico puede definirse como "un conjunto de lexemas relacionados por un valor significativo común, pero opuestos, al mismo tiempo, por diferencias mínimas de contenido" (Villar Díaz 2008: 232). Aunque no siempre resulta sencillo realizar la distinción semántica adecuada, señalaremos a continuación las lexías fundamentales que conforman nuestro glosario de ingenios y máquinas, de 
acuerdo con distintos subcampos léxicos y teniendo en cuenta las relaciones de hiperonimia-hiponimia y holonimia-meronimia que pudieran existir.

\subsubsection{CIENCIAS, TÉCNICAS Y OFICIOS}

En cuanto a las ciencias y técnicas del ámbito de la ingeniería y maquinaria que están presentes en nuestro corpus, echamos de menos precisamente el término maquinaria ${ }^{351}$, cuya primera documentación es algo más tardía. Sí que registramos, sin embargo, los términos ingeniería, mecánica con el sentido 'arte o ciencia de los mecanismos, ingenios o máquinas' (Salinero), maquinación, aunque son pocos los ejemplos de esta última voz y su sinónimo maquinatoria 'arte de inventar y fabricar máquinas'. Hemos de señalar que es escaso el número de voces presentes en el corpus que denominan técnicas y oficios relacionados con los ingenios y máquinas. En este caso solo podemos destacar albañería, albañilería, carretería y sillería. Por el contrario, es elevado el número de voces que designan personal que, con los oficios a los que se dedicaban y las técnicas que cultivaban, participaban, en mayor o menor medida, de la invención, creación y construcción de ingenios y máquinas. En concreto, encontramos en nuestro corpus los técnicos alarife, aparejador, balancero, edificador, edificante, estampador, impresor, imprimidor, ingeniero, inventor, maquinista, nivelador; y los oficiales aguador, albañil, alfarero, aserrador, batanero, calderero, campanero, cantarero, carretero, cerrajero, empedrador, escudillero, fontanero, frontero, herrador, herrero, jardinero, molinero, obrero, ollero, pilatero, soplador, tornero, vidriero y zahorí. Evidentemente, algunos de estos términos designan oficiales de gran importancia en la panorámica de ingenios y máquinas hallada en nuestro corpus, como molinero; otros, en cambio, son de menor importancia, como calderero o aserrador, pero también están incluidos, pues sin su trabajo no hubiera sido posible la construcción de diferentes máquinas u obras de ingeniería hidráulica. En cuanto a los términos que denominan un lugar en el que se llevaba a cabo una actividad propia de un

${ }^{351}$ De acuerdo con el CORDE, la primera documentación de maquinaria data de 1626 y se halla en Compendio historial de la jornada de Brasil, obra de Juan de Valencia y Guzmán. 
oficio, recogemos en nuestro glosario batán, herrería, imprenta, jardín, lagar y molino.

\subsubsection{CONCEPTOS FÍSICOS}

Aunque no son tantos los conceptos físicos que hemos considerado que debían incluirse en nuestro glosario, pero no por ello carecen de relevancia. Se trata de términos como fuerza, gravedad 'virtud por la cual un cuerpo grave se mueve para abajo o tiene inclinación a dicho movimiento' y su sinónimo graveza, impetu, impetuosidad, movimiento, peso y potencia 'capacidad para ejecutar algo o producir algún efecto' y del resto de miembros de las familias léxicas que conforman.

\subsubsection{PUENTES}

Uno de los subcampos que contiene mayor número de voces es el de las obras hidráulicas, aunque algunas son de mayor envergadura que otras. En lo que se refiere a puentes, citamos aquí las voces acueducto1, aguaducho2, aguaducto, alcantarilla, carripuente, gallipuente, maripuente y puente levadizo. Contenidas en nuestro glosario, son voces que designan partes o piezas de puentes antepecho, arcada, arco, bulsón, fíbula, ojo, pie, pila1, pretil, tramada y trampo.

\subsubsection{OTRAS OBRAS HIDRÁULICAS}

Voces que designan obras hidráulicas significativas en nuestro corpus son las referentes al depósito o almacenamiento de aguas, como alberca, aliviadero, albañal2, aljibe, azud, cauchil, cisterna, chozola, estanque, pesquera, pesquería, pila ${ }^{2}$ poza, pozo, presa, vertedero2 y vivero. Pero, sin duda, las que designan obras hidráulicas de mayor envergadura son, en este caso, muelle, mandracho y puerto.

\subsubsection{CONDUCTOS Y CANALES}

En lo que se refiere a los términos que designan tipos de conductos y canales, señalamos, por ejemplo, acequia, aguacero, aguaducho1, aguilón, albañal, 
arcaduz, atanor, cafia, camino, canal, canaladura, canalera, cañería, caño 2 , cañón, castelo, cauce, cequia, chimenea, derramadero, desaguadero, desangradera, desviadero, emisario, encaminamiento, encañado, encañadura, encañamiento, fístula, quinaria, quinario, regadera, regadio, sangradera, sangradero, sangría, senaria, senario, tromba, trompa y tuba. Respecto a las partes o piezas de conductos, hallamos boca, bocal, codo y nariz.

\subsubsection{MOLINOS}

Por lo que respecta a las máquinas, destaca notablemente en nuestro corpus el molino y en nuestros textos es sinónimo de este término molino el término molienda2. Como máquina más destacada, la tipología molinera presente en nuestro glosario es muy abundante. Encontramos así aceña, anoria atahona, molino batán, molino de aceña, molino de agua, molino de balsa, molino de barcas, molino de bestia(s), molino de bomba, molino de canal, molino de cárcavo, molino de contrapesos, molino de cubo, molino de grúa, molino de mano, molino de marea, molino de medio regolfo, molino de regolfo, molino del aceite, molino harinero y tahona.

También son muchas, por tanto, las voces que designan partes o piezas de los molinos, es decir, son merónimos de molino los términos ala, aliviador, anadija, ananilla, aspa 2, badil, balsa, botana 2, caja, caja farinal, canal, canaleja, canalete, canalón, canalote, capirote, cárcavo, cárcel, carro 2 , cercillo, cigüeñal, cigüeñuela, cítola, cubete, contrabalsa, cubo, dado, dedal, entruesga, farinal, grúa, gruenza, guepejo, hidraula, imprimia, levador, libra, linterna, llave, lobo, majadero, muela, muela baja, nanilla, palahierro, paradera, parahúso, peón, picadura, rangua, rodete, rodezno, rueda, ruello, saetía, saetín, sobarbo, solera, tahona2, témpano, templador, tímpano, tolva, torcedor, torre, vela y voladera.

\subsubsection{OTRAS MÁQUINAS}

Pero, además del molino, son bastantes los términos que designan máquinas que encontramos en nuestros textos. Entre estos, señalamos los que se utilizan para levantar pesos, como acrobaticon, anisociclo, balanza 1 , cabra, cabria, 
cabrilla, caracol infinido, caracol sin fin, cigüeña ${ }^{352}$, crica, grúa $a_{1}$ escorpión, quelonio 1 y trispastos; y consideradas máquinas también en nuestros textos, aunque en muchos casos son parte o piezas de las anteriores, carretillo, carrillo, carrucha, carrucho, garrucha, polea, polija, recamo, tróclea; para elevar el agua, recogemos máquinas como anoria $2, a z u d a, b_{1} b_{1}, c_{1}$ caracol $_{2}$, ceña, clea, cóclea, cóclea de Pitágoras, felos, noria, rueda cerrada, rueda timpanada, tímpano y visinfin; en cuanto a las que se utilizan para mover pesos horizontalmente, indicamos los términos árgana, árgano, cabrestante, carquesio, ergata; hallamos también autómato 'máquina que se mueve por sí misma', y, respecto a máquinas para el transporte de cargas, registramos carro1, carromato y carrozo. Destacamos notablemente el término imprenta por designar una de las máquinas más importantes del Renacimiento.

Debido a esta amplitud terminológica del área de la maquinaria, son muchos los merónimos que designan piezas de estas máquinas. En cuanto a tipos de vigas, elementos alargados o sus partes, obtenemos árbol, arista, arrectario, aspa, brazo2, cigoñal, cigüeña, gorrón, junta, manil, mástil, raposo y viga; algunas de estas piezas se utilizan también individualmente como instrumentos o herramientas, como almadeneta, barquín, fuella, mancha, martinete, palanca y palanga; respecto a los recipientes usados en algunas máquinas, hallamos términos como artesa, catino, modiolo y pandero; en lo que se refiere a tipos de canales o conductos de algunas máquinas, los términos cantimplora y chiflón; señalamos caracol, caracola, husillo, huso, porquezuela, puerca2, súcula por designar elementos de agarre o unión de las piezas. Designan piezas importantes en muchas máquinas los términos contrapeso, eje, émbolo, langosta, leva, levador, motor y móvil.

\subsubsection{INSTRUMENTOS Y HERRAMIENTAS}

En cuanto a los instrumentos utilizados en obras de ingeniería, destacan los niveles y por tanto hallamos las voces como corbate, nivel de agua, nivel de

352 También sirve para elevar agua. 
borneo, nivel de peso, nivel de tranco y tranco. Otro de los instrumentos utilizados es la balanza y así registramos voces como balanza 2 , peso de balanzas y peso de cruz; y sus piezas equipondio, pondos y pesa.

Son muchas y variadas las herramientas necesarias para realizar obras de ingeniería y máquinas. Entre los términos seleccionados que designan herramientas, algunas se utilizan para levantar objetos pesados, como alzaprima, manuela, palanca $a_{1}$, palanga $a_{1}$, própalo, uña de cabra y uña de puerco. También citamos los términos barrena, rallo, taladro, tenazante y su sinónimo tenazón; estos dos últimos designan una herramienta para romper objetos de metal.

\subsubsection{ACTIVIDADES}

En relación con las actividades que tienen que ver con la ingeniería y maquinaria, destacan en nuestro corpus todas aquellas necesarias para utilizar obras y máquinas, como afijar y fijar, afirmar y firmar, armar y desarmar, aliviar, soliviar, empalmar, emparejar, enroscar, envolver, desenvolver, reparar, y todas aquellas que deben realizarse con algún aparato, material o utensilio concreto, como apegar, desapegar, despegar y pegar, clavar, enclavar, desclavar, emboñigar, enclavijar, endentar, engastar, engastonar, envigar, forjar, guindar, herrar, ligar, aserrar y serrar y soldar.

Como acciones que realizan las propias máquinas, hemos extraído mover, pesar, rehenchir, tornear, retornear.

Relacionadas con el agua, obtenemos anegar, conducir, derivar, derramar, desviar, encaminar, detener, divertir, dividir, encauzar, estancar, partir, repartir, regar, rezumar y sangrar; y relacionadas con las cañerías, indicamos los términos betunar, embetunar, embarnizar, encañar, vidriar y zulacar.

En el campo de las tareas que se llevan a cabo en los molinos, señalamos las voces batanar, cedazar, cerner, cribar, majar, moler y remoler; en cuanto a las voces que tienen que ver con obras de ingeniería en general, destacamos arenar, enarenar, empedrar, enladrillar, enrunar, ensolar, excavar, reedificar, revolcar, 
arrevolver, desarrevolver, revolver, socavar, tajar, volcar, voltar, voltear, volver.

Otros términos que designan actividades fundamentales realizadas con ingenios y máquinas son emprimir, entornear, estampar, imprimir, industriar, inventar, maquinar y tornear. Y dentro de los que designan actividades llevadas a cabo con herramientas, destacamos las voces abarrenar y barrenar, amartillar y martillar, amolar, picar y taladrar.

\subsubsection{ACCIONES}

Respecto a los sustantivos que designan acciones, hemos incluido en nuestro glosario voces como borneadura, borneo, cava ${ }^{1}$, cegamiento, congelamiento, derramación, derramamiento, despedida, despedimiento, impresión, inmovilidad, invención, inventiva, ligamento, ligamiento, molienda, moto, movimiento, pegadura, reedificación, remolimiento, remolino y soplo.

\subsubsection{MATERIALES}

Son bastantes los materiales necesarios en la elaboración de obras de ingeniería y maquinaria. Dentro de nuestra selección, destacan en número los utilizados en la fabricación de encañamientos. En cuanto a los materiales, registramos un metal, el acero; entre los materiales de origen animal, boñiga, cuera, sangre; designa un material vegetal harina; en cuanto a los forestales, aserradura, pez, serradura y vesque. Respecto a los términos que designan tierras, arena, arenilla, barro, betumen, betún, betún de Babilonia, betún judaico, bitumen, glera, runa.

También recogemos varias voces del campo de la cantería, tipos de piedras como almadeneta, amoladera, amoladura, guija, mampostería, mampuesto, moleta, piedra caracolina, piedra de amolar, piedra molar, piedra moleña, rodado, sillar, sillería, zaborra.

\subsubsection{CUALIDADES}

Es significativo el número de términos que designan cualidades que 
recogemos. Algunas son abstractas, como las designadas por los términos artificial, artificioso, industrioso, inventivo, maquinador, perito; otras intelectuales, como ingenioso; otras designan habilidades técnicas o manuales, como artificioso; en cuanto a las relacionales, señalamos edificatorio, encaminado e instrumental.

Son varias las voces que denominan cualidades resultativas: abalanzado y balanzado, acanalado, acribado, aliviado, amartillado y martillado, arenado y enarenado, aserrado y serrado, cedazado, cernido, cincelado, clavado, enclavado, clavetado, clavijado, enclavijado, desapegadizo, edificado, embalsado, embebido, emboñigado, empalagado, empalmado, empedrado, encañado, endentado, engastado, entorneado, torneado, envuelto, estancado, estanco, excavado, fijado, afijado, firmado, afirmado, gastado, majado, molido, movido, moviente, picado, quiciado, rallado, socavado, tajado, tajante, zulacado.

En cuanto a las que designan contenido, abundancia o parecido, obtenemos los términos acerado, aguanoso, alvidriado 1 y vidriado, arenisco, arenoso, barnizado, embarnizado, betuminoso, dentado, dentejado, embetunado, enladrillado, ingenioso. Y por último, denominan cualidades formales los términos acanalado, alamborado, caracolado y encaracolado, ciego, enroscado, gancheado, parejo, voltado y volteado. Finalmente, citaríamos aquí las voces de origen zoonímico anteriormente revisadas. 


\section{CONCLUSIONES FINALES}

\subsection{LA CIENCIA Y LA TÉCNICA EN EL RENACIMIENTO}

Por lo que respecta a los parámetros en los que se ha medido la historia de la ciencia en España, apuntamos que la ciencia, la historia de la ciencia y la historiografía científica no siempre han ido de la mano, como en otro tiempo se quiso suponer, y que debemos tratar de saber diferenciar el valor de los testimonios existentes, tanto textuales como objetuales, que manejamos, para poder calibrar el estado científico y tecnológico de un país en una época concreta.

Tal y como hemos comentado en nuestra tesis, la ciencia y la técnica en la España del siglo XVI fueron de vanguardia, como propias de un estado moderno y de gran envergadura que debía medirse en conflictos bélicos tanto en Europa como en territorios de Ultramar. Consideramos, por tanto, que la labor filológica y el análisis y estudio de los textos y del léxico que contienen pueden contribuir al conocimiento de la ciencia de otras épocas, y en concreto, del Renacimiento español, ya que "el conocimiento científico se expresa, se transmite, a través de la palabra, siendo esa transmisión, además, condición indispensable para la existencia de la propia ciencia" (Gutiérrez Rodilla 2005: 9).

Con este fin, la presente tesis doctoral se apoya en un pilar que posee una amplia trayectoria en los estudios lexicográficos y lexicológicos: el proyecto del DICTER, fundamentado en un corpus de 74 textos seleccionados por especialistas en historia de la ciencia y valorados por su notable aportación histórica. La metodología del equipo se ha puesto en marcha gracias a varias herramientas informáticas, como una base de datos de FileMaker específica para la elaboración lexicográfica y un programa de búsquedas, UltraEdit. Desde nuestra experiencia, afirmamos que las herramientas informáticas son de gran utilidad en este tipo de tareas lexicográficas, pues agilizan la elaboración sistemática, coherente y rigurosa de glosarios, a la vez que permiten realizar búsquedas de términos que no podrían efectuarse sin este apoyo informatizado. 


\subsection{LOS TEXTOS RENACENTISTAS DE INGENIERÍA Y MAQUINARIA}

Dentro de las áreas que configuran el corpus del DICTER, se halla el área de maquinaria, cuyos textos fundamentales, en lo que se refiere a ingenios y máquinas, son: Las Notas, mss. a. 1585 de Francisco Lobato; el Teatro de los instrumentos y figuras matemáticas y mecánicas de Diego Besson, traducido por Horacio Cardon, 1602; y Los veinte y un libros de los yngenios y máquinas, mss. a. 1605, atribuidos a Juanelo Turriano. No obstante, las búsquedas de los términos se han realizado dentro del corpus total.

En relación con los textos señalados, apuntamos, a modo de conclusión, nuestras hipótesis sobre el ocultamiento de las Notas de Lobato en un libro de Ptolomeo, hecho que podría explicarse porque su autor quizás estuviese interesado en recibir alguna patente o privilegios por sus invenciones. Sobre Los Veinte y un Libros de los Ingenios y Máquinas de Juanelo, pensamos que quizás sea un tanto precipitado atribuírselos, como ha hecho García Tapia, a Pedro J. de Lastanosa y, dados los saltos de contenido de Los Ventiún Libros..., y las imágenes que contiene, en muchos casos, tan precisas, "no descartamos que se trate de un compendio de notas o apuntes de clase, o algo parecido, en cuya confección o intento de perfección pudieron intervenir, de una manera o de otra, los textos a los que Los Ventiún Libros... se asemeja, y que, por supuesto, tiene relación con la zona de Aragón y con Italia"353.

Respecto al ámbito que nos interesa, el de la ingeniería y maquinaria, no tenemos noticia de que hubiera un lugar concreto para su estudio en las instituciones surgidas en la España renacentista (como la Casa de Contratación de Sevilla o la Academia Real Matemática). Sin embargo, los profesionales de esta materia sí que fueron recogidos por Herrera en su Institución (ingenieros, maquinistas, arquitectos, niveladores de aguas y fontaneros). Por otra parte, fue esta disciplina, la ingeniería, una de las que sufrió más cambios, debido a las reformas urbanas renacentistas, como las realizadas en el abastecimiento de aguas, la navegabilidad de los ríos o la construcción de zonas portuarias (V. Los

353 V. Martín, presente volumen: 63. 
Ventiún Libros...). En lo que se refiere a la maquinaria, en esta época destaca fundamentalmente el auge en la creación de molinos, de variada tipología y destinados a diferentes fines, así como máquinas para la carga, descarga o transporte de materiales.

\subsection{LOS INGENIEROS}

A partir de las dos acepciones de la voz ingeniero que separa Covarrubias "el que fabrica máquinas para defenderse del enemigo y ofenderle" y, por otra, "(el que inventa) las mismas máquinas [...] (que) llamamos ingenio, como el ingenio del agua, que sube desde el río Tajo hasta el alcázar, en Toledo, que fue invención de Juanelo, segundo Arquímedes", nosotros nos hemos centrado en la segunda, en ingenieros para la paz, distándolos de ingenieros para la guerra, "aunque a veces fueran los mismos" (Cámara Muñoz 2008: 131).

En cualquier caso, bajo la denominación ingeniero hallamos hombres de muy diversa índole: por un lado, aquellos que fueron reconocidos como tales en su época, por ejemplo, Juanelo Turriano, y por otro, aquellos que, habiéndose dedicado también a otros menesteres, se les ha visto como ingenieros posteriormente, a la luz de sus trabajos. Algo muy parecido ocurría con los inventores, que acudían a la corte con la intención de que sus invenciones fueran reconocidas y retribuidas.

\subsection{INGENIOS Y MÁQUINAS EN EL SIGLO XVI}

En cuanto a las obras de ingeniería renacentistas, fueron muchos los puentes que se repararon y bastantes los que se construyeron, como los puentes sobre el Turia, en Valencia; los de Ariza, Puente Genil y Plasencia; el puente de San Pablo, en Cuenca; y los puentes de Montalbán (Toledo) y Lerma (Burgos). En algunos de ellos se vieron ayudados de nuevas grúas con ruedas de pisar (Herrera). Respecto a los puertos, se edificaron varios en el Mediterráneo, sobre costas abiertas, como los de Cartagena, Mahón, Málaga o Palma de Mallorca; también en el Cantábrico, como los puertos fluviales de Bilbao o Avilés o el 
situado en la ría de El Ferrol, o los diques convergentes de San Sebastián y Gijón. Por lo que respecta a la gran obra de envergadura en Hispania, la presa, se ejecutaron muchas en la segunda mitad del siglo XVI, especialmente presas "de gravedad" (rectas), siendo las más significativas las de Tibi y Almansa. En lo que se refiere a la conducción de aguas, fue una época en la que se potenció la construcción de azudes, pues derivaban una parte del agua para regadíos (con el uso frecuente de norias o azudas), para usos industriales, o bien para la formación del caudal necesario para mover molinos.

Los abastecimientos de agua, llegados a las poblaciones desde fuentes, manantiales o cauces, se realizaban por medio de conductos, tramas de caños, arcaduces, arcas o atanores. En ocasiones se reformaban antiguas conducciones romanas, pero también se compusieron conducciones siguiendo distintos planes de abastecimiento, como el de Juan de Herrera en Valladolid o el de Juan del Ribero en León (García Tapia 2002: 441). Cuando la altura a la que debía elevarse el agua era excesiva, hubo intentos de creación de máquinas para este fin, siendo la más famosa el artificio de Juanelo Turriano de Toledo. También pertenecen a esta época el acueducto de Teruel y las fuentes de los Sitios Reales de Felipe II: Aranjuez, Casa de Campo, Segovia y El Escorial. Respecto al almacenamiento de aguas, este se producía en aljibes, pozos o cisternas.

En lo que se refiere a los molinos y otro tipo de maquinaria para procesos industriales, el Renacimiento fue una época muy fructífera, pues fueron muchas las creaciones e invenciones que se idearon y que dieron lugar a una variada tipología de maquinaria, con uso bien agrícola, bien industrial, bien doméstico. Movidos, bien por fuerza animal o humana, bien por la fuerza del viento o del agua, los molinos han sido considerados "las máquinas más complejas y poderosas de la época y el símbolo de la era preindustrial" (García Tapia 19972: 8).

Dependiendo de la posición de la rueda o muela, los molinos hidráulicos podían denominarse aceñas o molinos de aceña, que eran aquellos a los que el agua les llegaba directamente desde el río o canal, o bien molinos de canal, 
denominados así porque en ellos el agua llegaba a la muela a través de un canal o conducto. Si el conducto era cerrado, se denominaba saetín y en ese caso el molino era un molino de bomba. Respecto a los de rueda horizontal o rodezno, fueron famosos los molinos de cubo, pues disponían de un cubo en el que se almacenaba el agua, que posteriormente salía a presión. También fueron muy significativos los molinos de balsa, pues el agua que los movía procedía de una balsa en la que se había acumulado. Incluso llegó a existir un tipo de molino que combinaba los dos anteriores, el molino de balsa y cubo. Pero si hay un molino significativo en esta época es el molino de regolfo, por lo que se conoce, invento español, que ha sido calificado como "precedente de las actuales turbinas", en el cual el rodete, rodezno o rueda horizontal, estaba rodeado por una pared cilíndrica donde el agua actuaba con fuerza centrífuga. En cualquier caso, en el Renacimiento continuaban utilizándose molinos de sangre o de bestias, y en aquellas zonas en las que no se disponía de agua suficiente, podía recurrirse a molinos de viento.

\subsection{GLOSARIO}

Para la confección del glosario hemos completado 1762 fichas en la base de datos de Filemaker. Entre estas, destaca el gran número de entradas, que ascienden a 992, mientras que solo contamos con 132 acepciones; a ellas hay que sumar 528 fichas de variantes gráficas y 50 unidades pluriverbales con sus correspondientes fichas de remisiones. Subrayamos aquí la relevancia de un número tan significativo de entradas, en comparación con los hallados en otras áreas léxicas, junto al limitado número de acepciones, pues está directamente relacionado con el tipo de léxico de nuestra área, en la que dominan las máquinas, piezas de estas, tipos de obras hidráulicas y sus partes o elementos, así como herramientas, etc., subcampos léxicos que quizás no son tan flexibles a la variabilidad de significado.

La mayor proporción de lemas está constituida por sustantivos, pues registramos 698, frente a 161 verbos, 122 adjetivos, y 11 adverbios. Este predominio de los sustantivos frente a otras categorías gramaticales es propio 
de los lenguajes de especialidad, pero, en nuestro caso, ligados a la mecánica y a la física, recogemos además una cantidad significativa de verbos.

En lo que se refiere a la marcación diatécnica, hemos utilizado la marca Mecánica encabezando a 281 términos, de los cuales 207 son cabeceras, 42 acepciones y 32 unidades pluriverbales. La marca Ingeniería Hidráulica también ha sido usada en un número significativo de ocasiones, 166, en las cuales acompañaba a cabeceras 139 veces, a acepciones 26 veces y a unidades pluriverbales en un caso. En cuanto a la marca Física, se encuentra en el glosario 57 veces, y lo hace junto a cabeceras en la mayor parte de ocasiones, 52.

La mayoría de los verbos son transitivos (133), 25 son intransitivos y solo 3 pronominales, aunque registramos dos que, siendo transitivos, pueden utilizarse también como intransitivos, y un verbo intransitivo que puede usarse como transitivo. Son bastante frecuentes los verbos que tienen también un uso ocasional pronominal, y su número alcanza a 23.

Por lo que se refiere a la clase léxica de los sustantivos, no son muchos los que, dentro de la clasificación léxico-semántica, designan conceptos abstractos tales como ciencias, técnicas o artes. Sí que encontramos, sin embargo, hasta 40 voces que designan al personal que cultiva una ciencia, técnica u oficio. Este es el caso, por ejemplo, de voces como aguador, fontanero, molinero y zahorí, voces que designan técnicos y personal de los oficios de nuestra área léxica, para las que, sin embargo, no existe o no hemos encontrado un término que designe su correspondiente técnica o profesión. Esto podría deberse a que en nuestra área léxica recogemos tanto oficios más bajos o serviles como otros cercanos a las artes liberales. En cuanto a los objetos de las ciencias y de las técnicas, 129 voces pertenecen a la subárea de las obras hidráulicas, 190 al de las máquinas, 45 al de herramientas y 45 al de instrumentos. Asimismo, 81 son objetos de los oficios, como tornillo, puerca, laña, guindal y guindaleta. Destacan, pues, en número, los elementos pertenecientes al área léxica de las obras hidráulicas y de la maquinaria, subcampos léxicos fundamentales en nuestra tesis. 
Por otro lado, hemos hallado 36 voces que designan materiales y 4 los sustantivos que denominan cualidades, como artificio, ceguedad, firmeza y velocidad. Son unas 30 las voces que designan estados, procesos y movimientos, 4 las que denominan localizaciones espaciales y 13 las que designan circunstancias.

En cuanto a los adjetivos, hemos hallado 122 que denominan cualidades. La mayor parte de ellas, 54, son resultativas, y ejemplo de estas son voces como aliviado, encañado, embalsado, endentado, entorneado y zulacado; también hemos encontrado cualidades de contenido, abundancia o parecido en voces como aguanoso, alvidriado, betuminado; formales, en acanalado, encaracolado, enroscado, voltado; además estas cualidades pueden ser abstractas, como ocurre en los términos artificial, artificioso, industrioso; intelectuales, como en ingenioso; relacionales, como, por ejemplo, mecánico y edificatorio; o espaciales, en voces como frontero.

\subsection{ASPECTOS LÉXICO-SEMÁNTICOS}

En conjunto, los campos léxico-semánticos principales de nuestra tesis son las obras hidráulicas de mayor o menor envergadura, entre las que destacan los puentes, los puertos, los conductos y las canales; y, por otro lado, las máquinas, y dentro de estas, fundamentalmente, los molinos; también subrayamos el área de los instrumentos y herramientas. Asimismo, son relevantes los campos de las actividades y de las acciones, muchas de ellas llevadas a cabo con máquinas o con el agua. También son significativos los campos, como hemos mencionado, de los materiales y de las cualidades.

Los hiperónimos más comunes son máquina, con 58 hipónimos, obra hidráulica con 47 y molino con 28. Entre los hipónimos de máquina, señalamos, por ejemplo, molino, cabria, quelonio y bomba. Son hipónimos de obra hidráulica, entre otros, a nuestro parecer, azud, canal, pesquera y vivero. Y son hipónimos de molino voces como molino de balsa, molino de cubo y tahona. Entre los holónimos más comunes destaca molino, con 65 merónimos, como, por ejemplo, muela, 
gruenza, rodezno; obra hidráulica, que tiene 64 merónimos y, entre estos, arcaduz, atanor, desaguadero; y máquina con 40, como gorrón, caracol, husillo y cigüeñal. Destacamos, por tanto, que máquina, obra hidráulica y molino son los términos utilizados con más frecuencia en el glosario, tanto como hiperónimos, como como holónimos.

\subsection{PROCEDENCIA DE LAS VOCES}

Es muy significativo, en el área léxica estudiada, el número de voces patrimoniales existentes, ya que configura más de la cuarta parte de la totalidad de voces que constituyen el glosario de los ingenios y máquinas en el Renacimiento. Por este motivo, subrayamos la importancia de la transmisión de conocimientos de ingeniería hidráulica y maquinaria por vía popular, ya que estas voces a las que nos referimos designan, tanto máquinas, como elementos de ingeniería y nombres de herramientas, destinadas generalmente a varios usos.

En segundo lugar, destacan los cultismos, pues encontramos 114, número que asciende a casi la mitad del que abarcan las voces patrimoniales. El origen de prácticamente todos estos cultismos es latino, aunque también registramos 16 helenismos, de los cuales todos salvo uno se introdujeron en nuestro idioma a través del latín. Esta proporción de helenismos es importante y significativa, fundamentalmente si la comparamos con los helenismos presentes en otras áreas léxicas del proyecto DICTER. Gran parte de estos cultismos designa nombres de máquinas $\mathrm{y}$, aproximadamente una tercera parte del conjunto, unos 37, fueron transmitidos a través de la traducción, realizada por Urrea, de la obra vitrubiana De architectura. Respecto a esto, quisiéramos comentar que estas voces cultas no siempre llegaron a integrarse y a utilizarse de forma regular en el idioma, bien porque existían otras para designar los mismos conceptos, bien porque los objetos o máquinas que designaban no alcanzaron un uso masivo.

En cuanto a las voces de origen árabe, son muy numerosas en este 
ámbito y testimonian la gran importancia histórica de de este segmento de la población en la ejecución de obras hidráulicas en la península, caracterizadas por su gran envergadura y su innovación técnica. Son 43 las voces de origen hispano-árabe o andalusí halladas en nuestro glosario, entre las que destacan, fundamentalmente, las dedicadas a la designación de elementos referidos a la canalización de las aguas o bien a los materiales empleados para su elaboración.

Por otro lado, cabe resaltar el número de voces que proceden del francés y del catalán, que en ambos casos ascienden a 27, y que muestran la importancia de las técnicas aportadas por el país galo y la zona catalana en el desarrollo del nuestra área de estudio. Las voces procedentes de estas lenguas, generalmente, están ligadas a ámbitos constructivos, como la arquitectura y la cantería. Además, señalamos que un importante número de catalanismos encontrados lo conforman voces propias de Aragón, localización geográfica que propició la entrada de catalanismos en el castellano (V. Colón 19591: 157).

Es importante el grupo de palabras de origen prerrománico o probablemente prerrománico, que en nuestro glosario está compuesto por 21 voces y que en general designan elementos naturales, materiales $u$ objetos de uso cotidiano.

En cuanto a los italianismos, sólo hemos registrado 7, número bastante reducido comparado con el número de voces de otras procedencias. Lo mismo ocurre con lenguas como el húngaro, el neerlandés y el quechua, pues de cada una de ellas procede únicamente una de las voces del glosario. En cuanto a las voces de origen incierto, señalamos nanilla y ananilla, sinónimos de anadija 'piedra horizontal sobre la que se asienta la muela de un molino'. Por lo que se refiere a jeta 'grifo', podría ser un arabismo, de acuerdo con $\mathrm{DECH}$, pero Corriente lo desmiente y lo vincula a la palabra, de origen incierto también, seta. Nosotros barajamos la posibilidad de que provenga del galicismo jeter 'echar, tirar', al igual que enjeta.

\subsection{DIALECTALISMOS LÉXICOS}


Respecto a los dialectalismos, destacamos la existencia de un nutrido grupo de aragonesismos entre los términos de ingeniería hidráulica, lo que atestigua los vínculos existentes entre esta zona geográfica y la creación y construcción de obras hidráulicas. También hemos hallado en nuestra área léxica aragonesismos que designan herramientas y materiales, simples o conglomerados. Entre estos aragonesismos hallamos tanto palabras patrimoniales como voces neológicas, además de un importante número de voces de origen árabe y catalán. En cuanto a los aragonesismos creados mediante procedimientos propios del idioma, son frecuentes los derivados, principalmente por sufijación. Solamente hemos hallado un americanismo, cocha 'estanque que, en la extracción de metales, se separa de la tina o lavadero principal'.

\subsection{ASPECTOS MORFOLÓGICOS}

El número de voces creadas mediante procedimientos morfológicos es muy elevado, pues asciende a 431, casi la mitad de las que configuran el total del glosario. Dentro de los procesos morfológicos existentes, el más habitual es la derivación, y dentro de esta, la sufijación es mucho más abundante que la prefijación.

Entre las voces formadas mediante derivación incluidas en el glosario, hay un gran porcentaje de sustantivos, un $66 \%$, en relación a otras categorías como adjetivos, verbos y adverbios. En la formación de estos sustantivos intervienen principalmente sufijos que actúan sobre bases nominales y verbales.

Respecto a la sufijación de sustantivos denominales, destacamos un alto porcentaje, un $40 \%$, de sufijación apreciativa, frente a la no apreciativa. Esto se debe, a nuestro modo de ver, a la presencia de un subcampo de herramientas y a la existencia de muchos aragonesismos entre nuestros términos, pues en ambos casos es frecuente que este tipo de sufijación se encuentre lexicalizada. En cuanto a la sufijación no apreciativa, en este caso, de sustantivos denominales, estos están formados a partir de una base verbal, siendo los 
sufijos más recurrentes -dero y -dor; prácticamente el resto son sustantivos denominales y están sufijados, de forma destacada, por -al/-ar y -ero.

Entre los sufijos adjetivadores, resaltan los que se aplican a bases verbales, que ascienden a un $74 \%$, y en conjunto sobresale y domina el sufijo do. Respecto a los sufijos verbalizadores, destaca el número de actuaciones de ar y encontramos 10 adverbios sufijados en -mente.

Por otra parte, el procedimiento de la prefijación es más habitual con los prefijos $a-$, des-, en- y re-. También hallamos en nuestro léxico varios verbos parasintéticos.

En cuanto a los compuestos, registramos 7 compuestos léxicos y señalamos que, entre los 47 compuestos sintagmáticos recogidos en el glosario, 22, es decir, casi la mitad, tienen la estructura molino + sustantivo/adjetivo / de sustantivo, etc.

\subsection{ASPECTOS HISTÓRICOS}

En lo que se refiere a las voces neológicas renacentistas, documentamos en el siglo XVI la entrada de latinismos que designan importantes elementos de ingeniería hidráulica, como acueducto, tomado del latín ăquaedūctŭs 'conducto de agua', 'acueducto', que por vez primera aparece, según los datos del CORDE, en De la antigua lengua (1587) de Andrés de Poza. En cuanto a la traducción de Loçano de los libros de León Baptista Alberti, señalamos la presencia de los latinismos incile 'cabecera de un conducto' y tímpano 'aparato para la elevación del agua'. Asimismo encontramos aquí por primera vez las voces quinario y quinaria 'caño o fístula de cinco dedos de diámetro'. Lo mismo ocurre con los cultismos senario y senaria 'caño o fístula de seis dedos de diámetro' y setinaria 'caño o fístula de cinco quinarias de diámetro'.

También conforman un nutrido grupo los latinismos que, designando máquinas y piezas de máquinas, se encuentran presentes por primera vez en la traducción de Urrea, como arbúscula 'pie de carro para llevar máquinas', arrectario 'madero que soporta el peso en algunas máquinas', cárdine 'hierro de 
algunas máquinas', engibato 'artificio hidráulico musical'; equipondio 'pieza metálica para comparar pesos'; ergata 'torno vertical para mover pesos'; fibula 354 'hebilla con la que se sujeta la carga'; modiolo 'vasija'; pénula 'cubierta de una máquina'; súcula 'pieza grande con forma de tuerca', tomado del latín sŭcŭla 'cabria', que DECH documenta tardíamente, en 1843. En la traducción de Besson, cuya entrada por tanto se realiza por vía del francés, hallamos el latinismo atelabo 'trabazón de la balanza de un torno', tomado del latín attělěbus 'langosta'. Es en el corpus del DICTER donde localizamos el latinismo motor 355 en fecha más temprana [1590, Perfeto capitán de Álava de Viamont] a la señalada en DECH (s. XVII).

Asimismo encontramos en la traducción de Urrea varios adjetivos aplicados a máquinas, como escansorio 'que sirve para subir pesos'; tractorio 'que sirve para arrastrar cargas' y espirital y espiritual 'que funciona con aire', voces presentes, con otro significado, evidentemente, desde los Orígenes.

Hallados por vez primera en Los Ventiún Libros..., señalamos los latinismos castelo 'desaguadero', especo 'cabecera de un conducto', estípite 'eje de una puerta', adelantando así la primera documentación de este término que ofrece DECH, que lo sitúa en el Diccionario de Autoridades; pondos, sinónimo en el texto del ya visto equipondio 'pieza metálica para determinar un peso'; premodo 'obra para regular la cantidad de agua', sinónimo del también presente en este texto promódulo, que podría haber sido tomado de pro mŏdŭlo (ingenii) 'según su capacidad' .

Resaltamos, finalmente, la importancia de la zoonimia en la designación de las voces que configuran el léxico de la ingeniería y la maquinaria renacentistas, puesto que son muchas las voces creadas a partir de nombres de animales ${ }^{356}$. Este hecho puede deberse a mecanismos semánticos de creación terminológica existentes en nuestra lengua, como lo son la analogía, la metáfora o la extensión metonímica, mecanismos que son muy recurrentes a partir de

\footnotetext{
354 Tomado del latín fibŭla 'hebilla' (DECH).

355 Tomado del latín mōtŏr, mōtōris 'que mueve, movedor'.

$356 \mathrm{~V}$. apartado palabras patrimoniales.
} 
todo aquello que concierne a lo cotidiano, como lo son los animales típicos de granja, de consumo y de acarreo.

En definitiva, fueron muchos los términos que fueron tomados por la lengua española durante el siglo XVI para designar elementos de ingeniería y maquinaria; fueron muchos también los que consolidaron su uso, que venía atestiguándose previamente, desde tiempos medievales o incluso anteriores; y, finalmente, registramos el abundante número de voces que se crearon mediante los procedimientos morfológicos de nuestra propia lengua. Todo esto testimonia la actividad creciente del área científico-técnica renacentista que hemos abordado y la participación notable del estado español y de sus ciudadanos en esta materia y en la constitución del lenguaje de dicha especialidad durante esta época. 


\section{RÉSUMÉ}

\subsection{INTRODUCTION}

De nos jours, dans certains cercles, on continue à interpréter l'omission historiographique de la science en Espagne comme une omission de la propre science dans notre pays. Nous pensons que cette interprétation repose sur le sentiment d'infériorité scientifique que nous avons développé, il y a de cela plusieurs siècles, à partir de la critique émise par Masson (1782):

El español tiene aptitud para las ciencias, existen muchos libros, $y, \sin$ embargo, quizás sea la nación más ignorante de Europa. ¿Qué se puede pensar de un pueblo que necesita permiso de un fraile para leer y pensar? [...] y son un miserable franciscano o un bárbaro dominico quienes deben permitir a un hombre de letras tener genio (Masson 1782, en López Piñero 1979: 21).

Certains historiens et scientifiques ont décidé, pour de diverses raisons, $\mathrm{d}^{\prime}$ accepter cette critique sans protester:

No ha sido España un lugar fácil para los científicos; no hemos estado, salvo muy honrosas excepciones, a la altura de otras naciones en este apartado (Maldonado y García 2002: 9).

Cependant, pour pouvoir définir la science en Espagne selon certains paramètres, il est nécessaire, dans les marges discursives de la «polémica de la ciencia en España » (Sánchez Ron 1999: 7), de trouver les raisons de cette omission historiographique :

Esta sorprendente omisión historiográfica, común a tantas otras obras, ¿significa que la ciencia ha carecido de importancia en el devenir de las sociedades que han configurado la España actual?, o ¿más bien es un producto de un desenfoque del pasado histórico y científico por parte de sus estudiosos: los historiadores? (López-Ocón 2003: 9-10).

Ces paramètres pourraient inclure le manque de dialogue entre les historiens et historiens de la science, l'insuffisante institutionnalisation de 
l'enseignement et de la recherche historico-scientifique (cf. López Piñero 1979: 16) qui a séparé les triomphalistes des pessimistes

consistió en una mera proyección de imágenes a priori procedentes de
ideologías que mantenían posturas opuestas en los terrenos
socioeconómico, político y cultural. Los panegiristas ensalzaron las
"glorias de la ciencia española" con la intención de justificar la misma
organización sociopolítica y el mismo sistema de valores que los
pesimistas pretendían invalidar con su negra imagen de "látigo,
hierro, sangre y rezos". Sin embargo, los excesos retóricos triunfalistas,
revestidos en ocasiones de alardes de falsa erudición, y las
lamentaciones pesimistas de sus contradictores coincidieron en un
completo rechazo por la investigación histórica del tema (López
Piñero 20022: 11).

Notre intention est de concilier, à travers notre étude et la méthodologie qui en résulte, toutes ces carences, dans la recherche de l'histoire de la science, et la carence de communication encore plus ample: celle qui agit entre scientifiques et humanistes, $d u$ fait d'une structure officielle du savoir qui les catégorise et sépare (cf. López-Ocón 2003: 13) et que nous prétendons unir ici ${ }^{357}$.

Nous ne pouvons négliger le fait que, malgré le trajet parcouru jusqu'au jour d'aujourd'hui, se plonger dans des textes scientifiques et techniques à partir la formation philologique actuelle ne cesse d'être, jusqu'à un certain point, osé et, pour justifier cette intromission bien intentionnée, nous nous référons aux mots du Dr. Gutiérrez Rodilla, qui affirme que « el conocimiento científico se expresa, se transmite, a través de la palabra, siendo esa transmisión, además, condición indispensable para la existencia de la propia ciencia » (Gutiérrez Rodilla 2005: 9). Ainsi, nous considérons que la contribution de la philologie, concrètement de la linguistique historique, peut être significative pour l'étude que d'autres spécialistes offrent dans ce domaine ${ }^{358}$. En effet, la langue et la

357 Selon Salvador Reguant, cela provient, d'une part, en premier lieu, des problèmes de communication de la science et, en second lieu, de la « comunicación de la ciencia a científicos de diversos ámbitos, diversas lenguas y diversas culturas » (Reguant 2003: 94).

358 Nous n'oublions pas de citer ici Wüster (1998), qui a établi la terminologie comme discipline indépendante, ainsi que Cabré, "desde muchos campos la terminología es un 
science étant si intimement liées, il paraît impossible qu'elles puissent exister l'une sans l'autre.

Notre thèse de doctorat s'inscrit dans les lignes des recherches menées à bien dans le Centro de Investigaciones Lingüísticas de la Universidad de Salamanca, dans le cadre du projet El diccionario de la Ciencia y la Técnica del Renacimiento, dirigé par Doña María Jesús Mancho Duque. Ce projet a donné naissance à de nombreux travaux de recherches qui, sous la forme de mémoires, de thèses de doctorat, de participations à des événements scientifiques ou d'articles de recherches, ont côtoyé l'étude du lexique scientifico-technique renaissantiste.

Un des piliers sur lequel se base ce projet, le matériel et les outils fondamentaux pour le développement du DICTER est le corpus de la Ciencia y la Técnica en el Renacimiento. Ce corpus informatisé est constitué de 74 textes renaissantistes spécialisés qui, classifiés selon leur domaine, ont été sélectionnés sous la supervision d'un groupe d'historiens de la science.

C'est pour cela qu'avec ce travail de recherche, nous proposons de reconstruire, dans la mesure de nos possibilités, une parcelle du langage de la science du temps de la Renaissance. Il s'agit, dans notre cas, du lexique de l'ingénierie renaissantiste, domaine que nous voudrions aborder à l'aide de l'étude des caractéristiques du lexique de ce domaine scientifico-technique. Nous voudrions également nous approcher des éléments qui ont participé à la création et à la construction du langage propre à cette spécialité, à ce moment précis dans l’Histoire.

Le choix du cadre temporel du XVIème siècle pour l'étude du langage de la science et de la technique s'appuie sur le fait que la Renaissance est l'époque où l'on considère que sont nés tant la science comme l'état modernes, tout deux intimement liés et caractérisés par une série de nécessités propres. Nous devons rappeler que jadis, au XVIème siècle, le castillan s'est uni à d'autres langues 
romanes dans sa consolidation comme instrument véhiculaire de divulgation scientifique, au détriment du latin (cf. Mancho Duque 2008: 313). Ce processus de consolidation du castillan ${ }^{359}$ était immergé dans un autre beaucoup plus grand: celui de l'extension ou de la rénovation humaniste ainsi que de la récupération du savoir gréco-latin. Cependant, ce sont les intérêts supérieurs de l'empire espagnol, qui non seulement avait besoin de la science et de la technique d'avant-garde mais les avait même sollicitées, qui ont pu provoquer le contrôle de la diffusion textuelle de ces innovations en dehors de leur domaine $^{360}$ (cf. Sánchez Ron 1999: 34), fait qui aurait contribué à l'omission historico-scientifique commentée plus haut.

Avec cette thèse de doctorat, nous tâchons de nous rapprocher concrètement du domaine de l'ingénierie et de la machinerie, l'un des domaines qui a souffert le plus de transformations durant l'époque renaissantiste. D'une part, suite au nouveau système de règlement qui promouvait les réformes urbaines, beaucoup de constructions d'ingénierie ont été exécutées à cette époque, la plupart servant principalement à l'adduction d'eau, mais d'autres étant aussi liées à la navigabilité des fleuves et à l'établissement de zones portuaires. D'autre part, l'essor singulier d'inventions qui a eu lieu durant l'époque renaissantiste (cf. Silva Suárez 20083: 293) a été très significatif dans le domaine de la machinerie. Celui-ci s'est matérialisé dans le surgissement d'une typologie meunière variée, destinée à des applications très différentes, sans oublier une série de machines nécessaires pour la construction, soit pour la charge et décharge de matériel, soit pour leur transport. Pour ces raisons, entre autres, nous considérons que le lexique spécialisé de ce domaine est spécialement éminent pour son époque et c'est pourquoi il mérite une étude plus détaillée à l'aide des outils informatiques dont nous disposons.

${ }^{359}$ Cf. « La cultura del Renacimiento (1480-1580): la lengua », du Dr. Frago Gracia (1999).

360 Voir à ce sujet les mots de Philippe II (1563) dirigées au Consejo de Indias au sujet des inconvénients de la divulgation du Libro de las longitudes de Alonso de Santa Cruz aux « extranjeros y otras personas que no fuesen súbditos ni vasallos nuestros » (Vicente Maroto, 1997). 


\section{2. ÉTAT DE LA QUESTION}

Bien qu'aujourd'hui il existe une importante bibliographie dédiée à l'histoire de l'ingénierie et, concrètement, à l'ingénierie de la Renaissance (cf. Silva Suarez, García-Diego, González Tascón, García Tapia, etc.), nous ne disposons que d'études partielles du lexique dans ce domaine. En général, on ne trouve que peu de pages dédiées aux aspects terminologiques de l'ingénierie et de la machinerie renaissantistes, bien que nous pouvons trouver des références à des termes de l'ingénierie dans d'autres études linguistiques plus amples. Ainsi, nous signalons l'étude des arabismes appartenant au domaine de l'ingénierie hydraulique incluse dans l'œuvre Historia de la lengua española de Rafael Lapesa ou celui des aragonismes apparaissant dans Los Veinte y un Libros de los Ingenios y las Máquinas, réalisé par Juan A. Frago. En ce qui concerne les répertoires lexicographiques, il existe beaucoup d'œuvres lexicographiques générales qui contiennent des lemmes de l'ingénierie et de la machinerie mais il y en a peu avec des répertoires spécialisés dédiés à cette parcelle. Nous pouvons signaler El léxico de alarifes de los Siglos de Oro de García Salinero comme l'une des œuvres lexicographiques les plus significatives pour l'étude du lexique qui nous occupe. En effet, il contient un grand nombre de termes de l'ingénierie et de nombreux exemples pris de certains des textes qui composent notre corpus, bien qu'il atteste également des termes d'autres parcelles scientifico-techniques, comme l'architecture, la taille de pierre et la construction en général. De plus, il existe une œuvre lexicographique dédiée à l'ingénierie, $E l$ diccionario general de arquitectura e ingeniería de Clairac et Sáenz, mais, se basant sur une époque postérieure, son utilité pour l'étude du lexique renaissantiste est quelque peu limitée.

Nous soulignons, cependant, l'existence d'une série de glossaires spécialisés qui, recueillis comme annexes dans d'autres œuvres et réalisés dans une perspective fondamentalement historique, peuvent être d'une grande aide à l'heure de s'approcher des différents concepts liés aux engins et machines de la Renaissance. Nous nous référons ici aux vocabulaires contenus dans 
Ingeniería y arquitectura en el Renacimiento, de Nicolás García Tapia; dans les Catalogues Felipe II y Ars mechanicae, de González Tascón; ainsi comme au glossaire inclus à la fin de l'édition des Los Ventiún libros de los ingenios y las máquinas réalisée par la Fundación Juanelo Turriano. Les travaux de terminologie sur les moulins et constructions hydrauliques, comme ceux contenus dans le ALEA $^{361}$, ceux réalisés par Manuel Alvar Ezquerra ${ }^{362}$ ou le Glosario de términos hidráulicos de Leonardo Icaza Lomell, nous ont également été utiles. Finalement, nous insistons sur l'utilité du Guía bibliográfica de la historia de la Ingeniería Civil élaboré par García García et González Tascón (2004).

\subsection{OBJECTIFS}

Dans la présente thèse de doctorat, notre objectif est de mener à bien une étude du lexique des engins et machines au XVIème siècle, du fait qu'elle représente une parcelle du savoir qui n'a pas encore fait l'objet de recherches de manière indépendante.

Pour atteindre cet objectif, nous confectionnerons en premier lieu un glossaire de l'ingénierie à la Renaissance, en suivant la méthodologie d'une équipe de recherche reconnue dans le domaine de la lexicographie et de la lexicologie historiques.

En nous aidant de sources bibliographiques importantes et variées, nous obtiendrons les différentes données sur les termes que nous considérons indispensables pour confectionner un glossaire lexicographique et réaliser notre étude lexicologique. Ces informations seront d'ordre grammatical, étymologique, morphologie, chronologique, sémantique et lexical, et nous permettront d'analyser divers aspects du lexique dans le domaine qui nous occupe. Nous utiliserons des images lorsque nous considérerons qu'elles peuvent éclaircir le sens des termes.

361 Atlas lingüístico y etnográfico de Andalucía.

362 Cf. Alvar Ezquerra, 1998. 
Notre objectif est également celui d'offrir un panoramique de l'ingénierie et de la machinerie renaissantiste ainsi que des textes les plus significatifs de ce domaine pour ainsi introduire, joindre et contextualiser notre étude lexicologique.

\subsection{MÉTHODOLOGIE}

Selon la méthodologie du projet en vigueur, la sélection des lemmes que contient le glosario est réalisée en différentes étapes. En premier lieu, on sélectionne une première liste à partir de la lecture approfondie des textes du domaine scientifico-technique destinée à la recherche ${ }^{363}$. De plus, on complète cette sélection avec les termes découverts à travers les recherches dans la base de données appelée Fichero Índice ${ }^{364}$. Postérieurement, on ajoute les lemmes nécessaires pour compléter les différentes familles lexicales qui ont surgi dans cette phase sélective, en tenant en compte leur rapport ou appartenance au domaine lexicale de notre objet de l'étude.

Le programme de recherches choisi par la direction du projet, UltraEdit, permet à l'utilisateur d'obtenir avec rapidité l'ensemble des concordances, trouvées dans le corpus, qui contiennent les occurrences des termes cherchés. De cette manière, le matériel nécessaire est plus accessible au chercheur pour effectuer les démarches suivantes, obligatoires pour la délimitation des entrées et acceptions du glossaire spécialisé : observation de la catégorie grammaticale du terme, détection des différents sens ou usages de ce dernier, ainsi que la démarcation des unités lexicales complexes.

${ }^{363}$ Cette lecture et les recherches dans le corpus seront l'une des démarches utilisées dans la méthode pour la détection de technicismes, bien que dans un premier temps la double compétence ou méthode intuitive soient dominantes (cf. Gutiérrez Rodilla 1993: 465).

364 Cette base de données, configurée dans les phases initiales du dictionnaire, mais continuellement actualisée et corrigée, contient la macrostructure fondamentale du futur Diccionario de la Ciencia y de la Técnica del Renacimiento. Il contient la liste des termes indispensables qui figureront comme entrées dans le dictionnaire, leurs variantes graphiques trouvées dans les textes lors de leur phase de transcription, ainsi comme le listage des textes dans lesquels apparaît chacun des termes, cette information facilitant particulièrement les recherches. 
Le format qui contiendra les informations, de différent types, recueillies par les lexicographes du DICTER, constituera postérieurement une base de données. Pour son élaboration, l'équipe puisera dans différentes sources qui incluront des répertoires lexicographiques de nature diverse, des œuvres philologiques ou des manuels d'histoire de la science ainsi que de multiples articles spécialisés. Les contenus introduits dans chacune des fichas informatisées de cette base de données seront ordonnées selon la nomenclature commune suivante :

Forme et histoire, avec les sections: lemme, variantes graphiques, sousentrée et structure (lors de lexie complexe) et information grammaticale (catégorie, genre, nombre, utilisation pronominale, etc.).

Information historique et étymologique: recueille l'origine étymologique ou la classe morphologique, la chronologie, la première documentation historique et la première documentation dans le corpus, la marque diatopique, la marque diachronique et la famille lexicale.

Classification sémantique: contient fondamentalement le domaine technique auquel appartient un mot, la marque diatechnique, ainsi que ses synonymes et antonymes.

Champs lexicaux: inclue une série d'onglets qui abordent des classifications scientifico-techniques relatives à différents champs comme les localisations, les professions, les objets, les activités, les états, etc.

Définition et information lexicographique.

Exemples et informations (encyclopédique, sémantique et autres).

Images et références. 


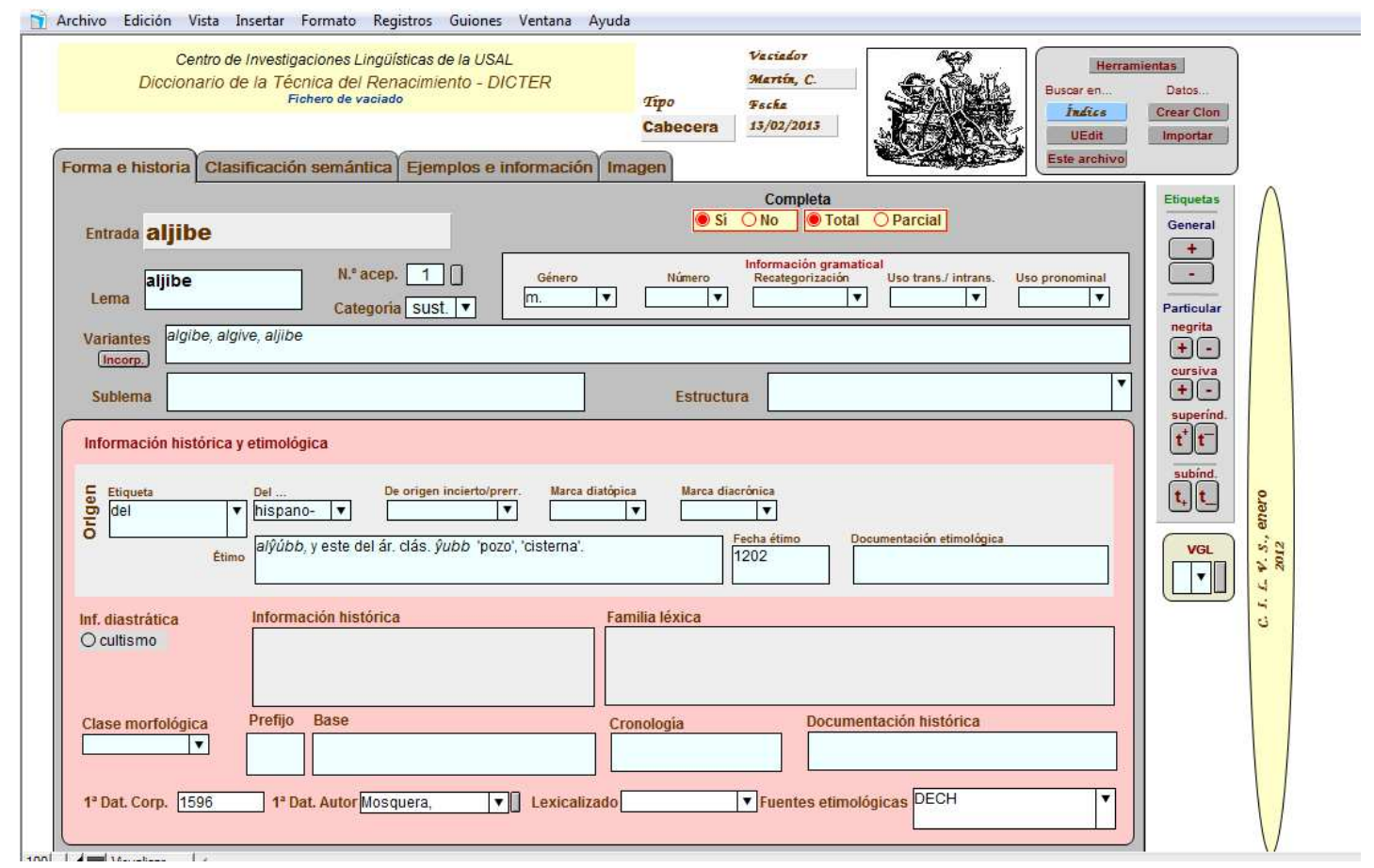

De plus, les renvois des variantes graphiques et les unités complexes seront réalisées dans ce support. Celles-ci constitueront, avec une grande partie des entrées lexicographiques, acceptions et fiches des unités pluriverbales, le fichier partiel de chaque spécialité. Ce fichier est indispensable et fondamental, tant pour la configuration du répertoire lexicographique spécialisé ou glossaire, à partir de l'exportation d'une sélection de ses champs, que pour l'élaboration de l'étude lexicologique, grâce aux différentes options de recherches, mentionnées plus haut, que permet Filemaker.

\subsection{LA MARQUE DIATECHNIQUE}

En ce qui concerne le domaine de la machinerie, il paraît logique que ce soit la marque Machinerie, c'est-à-dire, Machin., qui signale les acceptions techniques de ce domaine de connaissance. Et bien que nous le pensions ainsi dans un premier lieu, nous avons changé d'avis étant donné que la marque Machinerie n'est pas incluse dans la liste des marques diatechniques du DRAE, ni dans celle du TLF, du TLIO ou du DHE, alors qu'on le trouve sous Machinery 
dans le OED (voir à ce sujet l'Annexe 6 « Lista de materias de especialidad en los cinco diccionarios », dans Gómez Martínez y Carriazo Ruiz 2010: 390).

De plus, malgré le grand nombre de pages du corpus qui traitent de machines, le mot machinerie (maquinaria) n'est pas recueilli dans les textes du DICTER, alors qu'on trouve le mot savant maquinatoria, qui apparaît dans sa variante graphique machinatoria. Cela, cependant, à 3 occasions seulement et deux d'entre elles sont une allusion à Vitruve, qui utilisait ce terme ${ }^{365}$.

Les limites du domaine de connaissance de Machinerie établies dans le corpus et ceux que suggère la marque diatechnique Maquin. paraissent être très différentes. En effet, il y a dans le corpus un grand nombre de machines de guerre recueillies dans les textes de l'art militaire que nous n'avons pas traitées, étant limités tant par l'extension de l'étude du lexique que par le domaine de connaissances auquel nous nous sommes circonscrits.

De fait, les machines qui font partie de notre sélection lexicale sont, en général, « Máquinas para la industria »366, et c'est pourquoi il est fréquent que le mot machine ou le syntagme partie ou pièce d'une machine apparaissent dans la définition. C'est également pour ces motifs que nous avons sélectionné, pour ces cas, la marque diatechnique Méc., c'est-à-dire, Mécanique, qui, selon la deuxième acception du DRAE signifie « ejecutado por un mecanismo o máquina».

A cause des limites de notre domaine, nous nous sommes vus obligés d'utiliser, de plus, la marque Ingén. Hydraul., abréviation d'Ingénierie Hydraulique, marque très similaire à Hydraul, déjà utilisée dans le DHE. Nous

365 «Y, assí, el que quisiere ser perfecto architecto, como dixo Vitrubio, conviene que tenga prática theórica, sepa Arithmética, Geometría, conozca las tres partes en que la dicha sciencia se divide, qu'es machinatoria, gnomónica y edificatoria » (Loçano 1582: fol. V). «Y el que se hallare medianamente instructo en las dichas sciencias, y principalmente en las tres que el mismo Vitruvio pone, que son: Gnomónica, Machinatoria y Edificatoria, con justa causa se le podrá dar título de Architecto » (Herrera 1584: fol. 15v).

366 «Ingenios y máquinas para la industria » c'est ainsi qu'Ignacio González Tascón a dénominé l'en-tête du $5^{\circ}$ chapitre du Catalogue Felipe II. Los ingenios y las máquinas. Ingeniería y obras públicas en la época de Felipe II. 
entendons par Hydraulique le contenu de la septième acception de son entrée dans le DRAE « Art de conduire, contenir, élever et récupérer les eaux ».

Finalement, nous avons utilisé la marque Phys. (Physique) pour toutes les entrées spécialisées ayant un lien avec cette «science qui étudie les propriétés de la matière et de l'énergie » (DRAE).

\subsection{LES NOTAS DE FRANCISCO LOBATO}

Nous ne savons pas grand chose sur Francisco Lobato del Canto car pratiquement toutes les données que nous avons de lui proviennent du codex, écrit par lui, qui se trouve au verso, vierge à l'origine, d'une série de cartes présentes dans un exemplaire de la Geografía de Ptolémée édité à Rome en 1508. Ce volume ptoléméen, qui inclut des commentaires en latin de Marco Beneventano et Juan Cotta, ainsi que le texte du copiste joint dans certaines marges, est la propriété de D. Mariano G. García-Cañas, et se trouve à Valladolid en bon état de conservation.

L'héritage de Lobato est constitué de trente sept pages, d'une taille de 250 x 415 mm, formé principalement d'un groupe de textes, jusqu'à un certain point hétérogènes, en écriture bâtarde espagnole, et d'une série de dessins illustratifs de différentes machines et pièces, présentes sur presque toutes les feuilles de l'ensemble. Dans les pages non numérotées, celui qui se déclare voisin de Medina del Campo joint, entre succès quotidiens et indices sur l'histoire de Medina, un groupe abondant d'explications sur le fonctionnement de certaines machines, ainsi que des expériences personnelles nées durant l'invention et le montage de ces appareils.

De même, Francisco Lobato del Canto introduit tout au long de ses écrits diverses références chronologiques d'importance singulière, comprises entre 1547 et 1585. Parmi elles apparaît la datation de la construction de certains moulins, comme certains proches de Medina (1547), un moulin à vent à Almagro (1556), et d'autres moulins construits par lui-même, comme le moulin à sang édifié dans la cour de son oncle à Medina del Campo (1557) et le moulin 
qu'il appelle « de agua estancada y de regolfo » (« d'eau stagnante et de contrecourant") , qui, d'après ses notes, a été fabriqué en 1577 , bien que Lobato l'avait déjà imaginé vers 1559. C'est précisément en l'an 1577 qu'on pense qu'il a écrit la plus grande partie de ses annotations (cf. García Tapia 1990: 139).

\subsection{LOS VEINTE Y UN LIBROS DE LOS YNGENIOS Y MÁQUINAS DE}

\section{JUANELO}

Ce codex, conservé dans la BNE dans les cinq tomes manuscrits compris entre les registres 3372 et 3376, a suscité un intérêt spécial parmi les chercheurs en histoire de la technologie espagnole et ce, pour différents motifs : d'une part, il constitue un exemplaire unique sur l'hydraulique renaissantiste, du fait que

se trata de la primera Architectura Hydraulica; y así, misteriosa y
desconocida, es, sin embargo cabeza de una serie de ellas importantes
para la ciencia, las técnicas y los oficios así como para el bienestar de
los pueblos. Siguen escribiéndose ahora y continuarán en el futuro
(García-Diego 1983: 9).

Et, d'autre part, la recherche d'un auteur pour ce codex a semé un certain embarras et trouble, peut-être parfois un brin trop vif, du fait que certaines preuves niaient l'attribution de ce dernier à l'auteur nommé sur les couvertures des manuscrit, c'est-à-dire, Juanelo Turriano.

Présent pour la première fois dans les annexes de la Biblioteca Real des années 1821-1833, cet ensemble de livres manuscrits, dont les feuilles mesurent 21 x 30, un centimètre de moins que les couvertures, a sûrement été relié au XIXème siècle (cf. García-Diego 1983: 18-19). Bien qu'il existe un rapport sur le codex, rédigé par Benito Bails ${ }^{367}$ dans la deuxième moitié du XVIIIème siècle (cf.

${ }^{367}$ Dans ce rapport, Benito Bails, en plus de résumer le contenu des différents livres qui constituent le codex, offre certaines données d'études intéressantes. D’une part, il affirme que l'œuvre a été écrite « con muy poco método » et que son style est «bárbaro »; d'autre part, il mentionne que le texte «habla muchísimo de Aragón». Finalement, il commente que « el manuscrito parece copia, porque se encuentran diferentes claros que dan a conocer que el copiante dejó lugar para las voces que no encuentran diferentes claros que dan a conocer que el copiante dejó lugar para las voces que no supo leer en el original que copiaba » (cf. « Informe de Benito Bails sobre el códice de Juanelo Turriano ", dans Los ventiún libros de los ingenios y de las máquinas, V. 6, 1996: 25-29). 
Llaguno 1977), c'est l'étude Ladislao Reti en 1964, qui a déclenché une série de recherches autour du manuscrit ${ }^{368}$.

\subsection{LE TEATRO DE JACQUES BESSON}

Sous la dénomination de Teatro à la Renaissance nous trouvons fréquemment une compilation de planches sur divers thèmes. Dans le cas du Teatro de los Instrumentos y Figuras Matemáticas y Mecánicas de Jacques Besson, on trouve sur ces planches différents artifices ou inventions, principalement des machines. Certaines d'entre elles avaient été inventées et s'utilisaient habituellement; d'autres, cependant, étaient encore en phase de gestation, création ou «imagination » (Uceda Antolín 2006: 4), phase que bon nombre d'entre elles n'ont pas surmontée, du fait qu'elles étaient des «machines irréalisables » (López García 2006: 6). Cette œuvre de Besson, apparue vers 1570369, suppose le début d'un genre de littérature technique, "el Teatro de las Máquinas" 370 , genre que la critique considère s'achevant un siècle et demi plus tard, vers 1724-1725, date de parution à Leipzig de El Theatrum Machinarum de Jacob Leupold (cf. López García 2006: 5). Concrètement, l'œuvre de Besson est l'une des premières publications sur de nouvelles inventions mécaniques (cf. Keller 1999: 38) et bien qu'elle ait été censurée à diverses occasions, elle a aussi été traduite en différentes langues. Selon certains auteurs, l'une des utilités de ce genre «no específicamente tecnológico, escrito para un público culto y no especialista » (Marchis 1994: 101), serait de servir de laissez-passer à l'auteur du

368 Nous nommons, dans cette première phase de recherche sur Los ventiún libros de los ingenios y de las máquinas, les personnalités comme José Antonio García-Diego, Luis Cervera Vera, Manuel Díaz-Marta, Ángel del Campo Francés, José Antonio Fernández-Ordoñez, Carmen Bernis y David Fernández-Ordoñez (cf. présentación de l'édition de Los ventiún libros de los ingenios y de las máquinas, cf. 6, 1996: 13).

${ }^{369} \mathrm{La}$ date de publication n'est pas très claire, du fait que l'édition la plus ancienne ne précise ni date ni lieu d'édition. Il existe un privilège royal en sa faveur, daté en 1569 à Orléans, et accordé pour les dix ans postérieurs à l'impression de l'œuvre, privilège que porte encore l'édition de 1582. De ce fait, la première publication du Teatro a été réalisée, au plus tôt, en 1582 (cf. Benito Quintana 1971: 42).

370 D'autres œuvres appartenant à ce genre seraient Diverse et artificiose machine (1588) de Agostino Ramelli, Novo Teatro di mchine et edifici (1607) de Vittorio Zonca et Machinae Novae de Fausto Veranzio (cf. Pacey 1980: 104). 
Teatro, qui pourrait ainsi justifier sa connaissance au sujet du contenu du texte devant certaines personnes (cf. Benito Quintana 1971: 38).

\subsection{L'ACTIVITÉ SCIENTIFIQUE À LA RENAISSANCE}

De manière générale, on considère que le développement scientifique d'un lieu est étroitement lié à son développement social et économique (cf. López Piñero 1979: 40). Ainsi, les mouvements historiques et leur interprétation, réalisée par l'historiographie, sont fondamentaux à l'heure de configurer l'histoire de la science de nos aïeux.

Cependant, dans l'historiographie de la science perdure l'établissement de nouvelles étapes scientifiques coïncidant avec les grands changements sociopolitiques (cf. Maravall 1972). Dans les coordonnées dans lesquelles nous nous situons, le XVIème siècle européen, il faut considérer les sévères conflits belliqueux qui régnaient, tant entre les différents états européens qu'à l'intérieur des mêmes. C'est cependant dans ces lieux qu'a fleuri une nouvelle cosmologie (Galilée, Kepler), dans laquelle on jaugeait comme innovatrice « la decisión de potenciar al máximo los beneficios, incluso en la agricultura, empleando técnicas conscientemente innovadoras » (Keller 1999: 25). En ce qui concerne l'Etat espagnol, l'expansion du mouvement appelé «humanisme scientifique » et la lente suppression du scolasticisme arabisé au bas Moyen Âge coïncident avec l'introduction des diverses innovations générées à partir de la fin du XVème siècle, durant le règne des Rois catholiques et la naissance de l'Etat moderne ainsi que de l’empire espagnol (cf. López-Ocón 2003: 23-24).

Comme on peut le supposer, l'activité scientifique qu'exigeait la machinerie impériale a été concrétisée de différentes manières selon les nécessités et intérêts circonstanciels (cf. López Piñero 20021: 15). Ainsi, elle a été réglée et organisée par le pouvoir royal sous la forme de pragmatiques, brevets royaux, instructions et ordonnances, ainsi que dans les constitutions des institutions. 
Quant à ces dernières, nous signalons que durant le XVIème siècle l'Etat espagnol a favorisé la création de différentes académies dans lesquelles on a institutionnalisé la culture scientifique. Parmi leurs représentants les plus significatifs, citons la Casa de la Contratación de Sevilla et la Academia Real Matemática.

La Casa de la Contratación de Sevilla, l'une des premières institutions scientifiques européennes, dont la création, en 1503, dans un but cosmographique, était basée dans « el control de la navegación oceánica que permitía la comunicación y el ensamblaje de las diversas piezas dispersas de una monarquía universal » (López-Ocón 2003: 26), a continué avec les objectifs de régulation du trafic de marchandises qu'exerçait la Douane de Cadiz, et les a élargi, en autres, avec la délivrance, formation préalable et examen, de licences de pilotage ainsi qu'avec la confection de cartes de navigation (cf. Esteban Piñeiro y Vicente Maroto 2002: 35).

Concernant la création de l'Academia Real Matemática (1583), localisée durant trente ans dans un bâtiment en face de l'Alcázar Real de Madrid, elle a été le fruit de la motivation que l'architecte Juan de Herrera a inspiré à Philippe II, avec l'intention de former des jeunes avec des connaissances scientificotechniques, du fait que, selon les dires du propres Herrera dans l'Institución de la Academia Real Mathemática, il y avait besoin «en la república de artífices entendidos y perfectos para muchos usos y ministerios necesarios a la vida política » (Herrera 1584: 1v). Les larges prétentions dictées par Herrera concernant la formation de professionnels dans de multiples et divers domaines spécialisés (mécaniciens, astrologues, gnomoniques, architectes, musiciens, perspectivistes, artilleurs, etc.) n'ont pas été accomplies et l'émission des titres correspondants qu'on devait, selon lui, posséder pour l'exercice professionnel, n'ont pas eu lieu non plus. Cependant, on pense que les textes et contenus qui étaient exposés comme lectures obligatoires ${ }^{371}$ dans $1^{\prime}$ Institución ont bien été utilisés, ainsi que beaucoup d'autres dont la traduction vers les langues planetas.

${ }^{371}$ Entre autres, Geometría de Euclide, Geografía de Ptolémée, la Esfera, les Teóricas de los 
romances avait été confiée par l'architecte ${ }^{372}$ (cf. Esteban Piñeiro y Vicente Maroto 2002: 46-47). C'est pour ces raisons qu'on a déduit que le grand prestige de cette institution renaissantiste ne se trouve pas tant dans sa formation efficace de scientifiques et de techniciens mais dans le travail de recherche et de diffusion de connaissances scientifico-techniques qui a eu lieu dans son siège (cf. Esteban Piñeiro y Vicente Maroto 2002: 50-51).

En ce qui concerne le domaine qui nous intéresse, l'ingénierie hydraulique et la machinerie, son étude, ainsi que celle d'autres disciplines, n'a apparemment pas été admise dans ces institutions scientifico-techniques apparues dans l'Espagne renaissantiste et ce, bien qu'Herrera ait mentionné dans son Institución, parmi les professionnels destinés à être formés dans l'Académie, ceux étant liés à l'exercice de la matière qui nous occupe (ingénieurs, machinistes, architectes, niveleurs d'eau et tailleurs de pierre) (cf. Herrera 1584: 2v). Il s'agirait, dans ce cas, d'une culture scientifique extraacadémique $^{373}$. En effet, l'invention et la construction de machines ainsi que la conception et l'exécution d'œuvres hydrauliques sont des matières typiquement pratiques, au sein desquelles «se formularon nociones teóricas sobre fenómenos físicos independientes de la filosofía natural académica » (López Piñero 20022: 222).

Cependant, pour les exécutions hydrauliques, les techniques d'arpentage étaient nécessaires, de même que la connaissance du maniement des instruments pour cette tâche, dont la présentation à l'élève était réalisée par des professeurs qui, de ce que nous savons, essayaient parfois de compliquer les manuels dédiés à cette matière pour ainsi rallonger leurs travaux et exercices d'enseignement, pour leur propre bénéfice (cf. Keller 1999: 26).

372 Citons les livres traduits par Ondériz ainsi que les livres X et XI des Elementos, la Perspectiva et Especularia, les Esféricos de Théodose y les Equiponderantes d'Archimède.

${ }^{373}$ Nous reprenons l'expression cultura científica extraacadémica de López Piñero, 2002², bien que, dans ce cas, nous ne nous référions pas aux aspects alchimiques ou magicoastrologiques qu'il signale à son sujet. 
Bien que dans les textes scientifico-techniques renaissantistes nous trouvions des références à la classification des arts réalisée par les anciens ${ }^{374}$, qui séparait les arts libéraux des arts mécaniques ${ }^{375}$, ces derniers étant méprisés pour être des manuels et biens d' « esclaves », ce qui est sûr c'est que déjà depuis le bas Moyen Âge cette structure était en train d'être remplacée par une autre dont les techniques étaient plus estimées (cf. López Piñero 20022: 227). Cependant, c'est à la Renaissance que le développement de l'étude, la pratique, la divulgation et création d'innovations dans les différentes disciplines techniques permettent un nouveau rapprochement épistémologique à ce domaine de connaissance.

\subsection{GLOSSAIRE}

Le glossaire des engins et machines renaissantistes recueille les lemmes principaux du domaine lexico-sémantique trouvés dans le corpus. Le glossaire se présente sous le format que nous pouvons observer avec l'exemple de l'entrée du mot acequia:

acequia, acequia, açequia, assequia, azequia [del hispano-ár. assáqiya 'íd.' y este del ár. clás. sāqiyah 'irrigadora'. 1140 (DRAE). Fernández de Enciso, Suma de Geographía, 1530]. sust. f. Ingen. Hidrául. Zanja o canal por donde se conduce el agua, generalmente para regar tierras o para acercarla a alguna localidad.

Fernández de Enciso, Suma de Geographía, 1530, fol. XLVIIIr: E los egipcios tienen fechas ciertas acequias por donde, quando el Nilo crece, entra mucha parte del agua del Nilo en este lago. // Celso, Reportorio universal leyes Castilla, 1553, fol. CCCIXv: Quién deve mantener las acequias o caños por do passa la tal agua a la heredad a quien deve la servidumbre, dezimos de suso, capítulo heredad, versículo VIII. // Anónimo, Repertorio tiempos, 1554, fol. XXXVIIv: En este mes se hazen pocas obras del campo, empero en las huertas puédese poner las ortalizas, y en la menguante de la Luna se puede cortar la madera y cañas y mimbres. Puédense sembrar lechugas, rávanos y ajos. Puédense adovar los vallados, limpiar acequias, cerrar portillos.

SIN.: cequia $a_{1}$ regadera.

HIPER.: obra hidráulica.

FAM.: cequia.

\footnotetext{
${ }^{374} \mathrm{Cf}$. à ce sujet, par exemple, République de Platon, Politique d'Aristote ou Bible (Premier livre des Maccabées), ainsi que Plotin ou Cicéron.

375 Cf. à ce sujet, Granada: 2008, en particulier les pages 67-69 et Navascués (2008).
} 


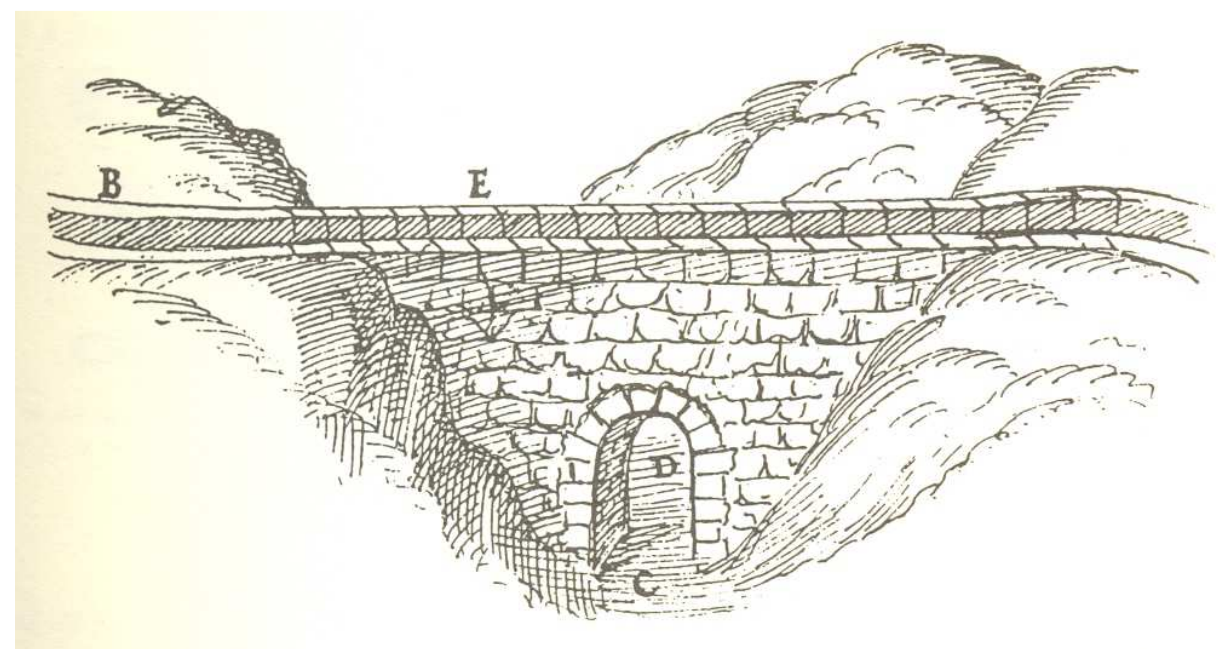

\subsection{1. ÉTUDE DU LEXIQUE}

\subsubsection{TYPOLOGIE DES UNITÉS LEXICALES}

Selon Porto Dapena 2002: 51, «pueden distinguirse tres tipos de lexías: la lexía simple, que coincide con la palabra; la lexía compuesta, conjunto de palabras más o menos integradas y que vienen a equivaler a la noción tradicional de 'palabra compuesta'376 y, por último, la lexía compleja, que es una construcción fija lexicalizada, esto es, lo que aquí llamamos locución ${ }^{377}$ ».

Le lexique des engins et machines contenu dans notre glossaire se compose de 922 lemmes simples, de 47 mots composés ou composés syntagmatiques et de 13 locutions.

376 Equivaut à ce qu'on appelle composé syntagmatique.

377 Porto Dapena définit la locution comme « una construcción estable, fija, [...] (qui offre) un sentido que no equivale a la suma de sus componentes» (Porto Dapena, 2002: 151). Voir également la définition donnée par Corpas Pastor (4.6.2.2). 


\section{Typologie des lemmes}

- lemmes simples $\quad$ composés syntagmatiques locutions

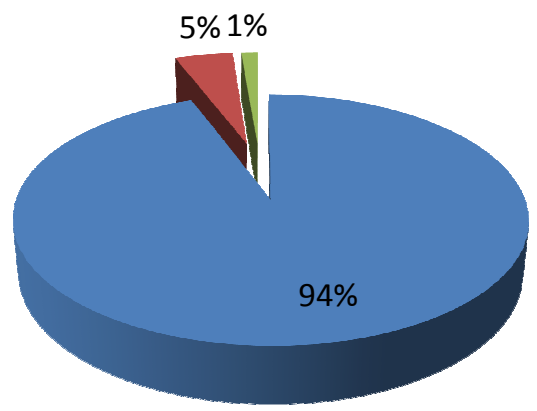

\subsubsection{DisTRIBUTION CATÉGORIELLE}

Le vocabulaire spécialisé est caractérisé par une prédominance des substantifs face au reste des catégories grammaticales.

«El léxico (científico) está compuesto por adjetivos, verbos y, fundamentalmente, sustantivos que, en una gran proporción, se construyen mediante la combinación de los llamados formantes clásicos, griegos y latinos, como veremos más adelante; aunque igualmente es posible, como también veremos, construir términos recurriendo a otros procedimientos » (Gutiérrez Rodilla, 2005: 28).

Parmi les 992 lemmes simples de notre fichier, nous comptons 698 substantifs, 161 verbes, 122 adjectifs et 11 adverbes. 


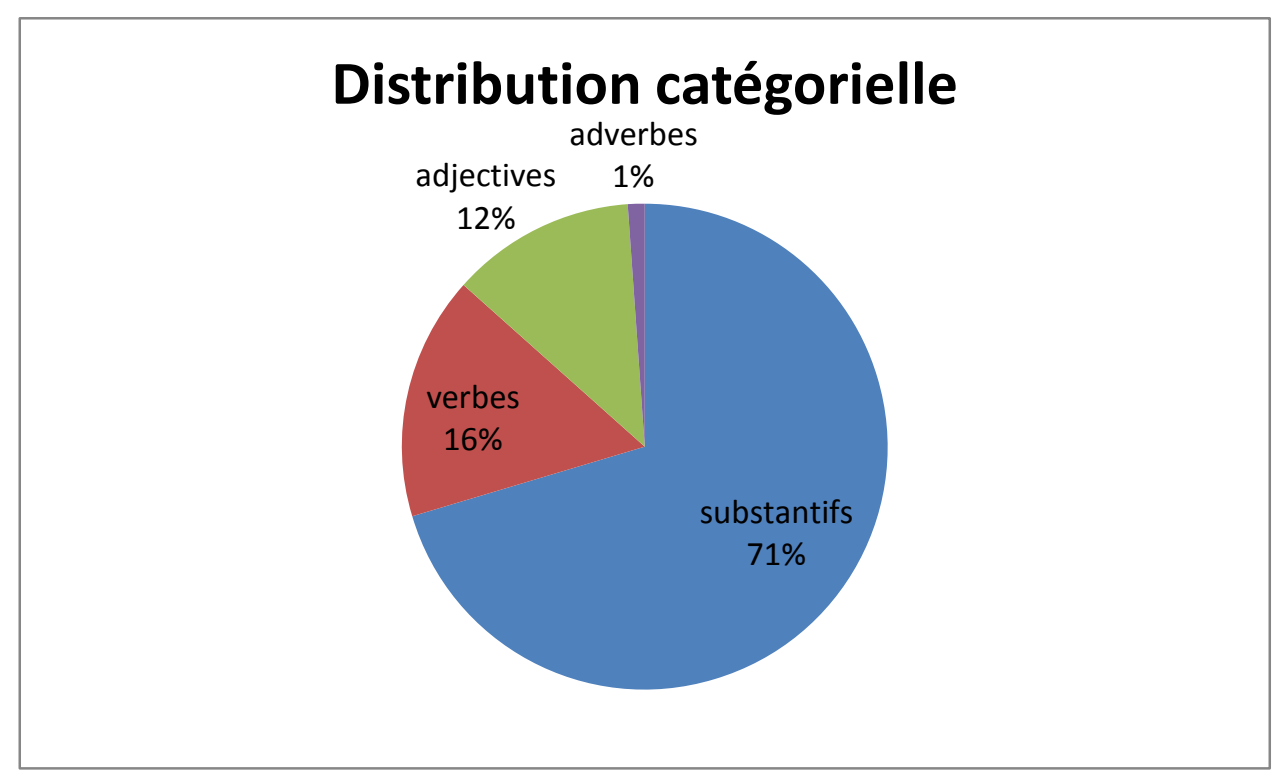

\subsubsection{ORIGINE DES MOTS}

La première observation au sujet de l'origine des mots de l'ingénierie à la Renaissance concerne le grand pourcentage que forment les mots patrimoniaux, dont le nombre est presque trois fois supérieur à celui des latinismes. Du total des mots qui constituent le glossaire et qui s'élèvent à 922, 270 sont des mots patrimoniaux. Ainsi, comme nous le commentions dans le paragraphe correspondant, le nombre de mots d'origine patrimoniale atteint plus du quart de ceux qui composent le glossaire, c'est-à-dire que leur nombre est particulièrement significatif dans le domaine lexical qui nous occupe et nous montre l'importance des voies populaires pour la transmission des connaissances, dans le domaine de l'ingénierie hydraulique. Les mots patrimoniaux apparaissent pour désigner tant des machines et des pièces constituant les éléments d'œuvres hydrauliques, comme les outils utilisés pour leur construction, la majorité d'entre eux étant communs à de multiples usages.

Les mots savants occupent la deuxième place selon leur importance relative à l'origine des mots du glossaire. En effet, leur nombre, 114, atteint presque la moitié des mots patrimoniaux. Comme on pouvait s'y attendre, presque tous les mots savants sont d'origine latine mais nous devons signaler que le nombre d'hellénismes, bien que réduit à 16 mots, est notable et significatif, spécialement en comparaison avec le nombre d'hellénismes 
présents dans le lexique d'autres domaines techniques étudiés par les membres de l'équipe du DICTER. Dans tous les cas, nous soulignons qu'une grande partie de ces mots savants désigne des noms de machines et une troisième partie de l'ensemble, 37, ont été transmis à travers la traduction de l'œuvre latine de De architectura de Vitruve réalisée par Urrea, dont la troisième partie est dédiée aux machines. De même, il nous faut commenter que ces noms de machines cultes n'ont pas toujours réussi à se diffuser de manière acceptable dans le castillan, soit parce que les machines qu'ils désignaient n'avaient pas pu être construites et utilisées de manière régulière dans la péninsule (sûrement du fait qu'il y en avait d'autres destinées au mêmes fins) soit parce que d'autres termes qui les désignaient existaient déjà ou avaient été créés.

Les mots d'origine arabe sont également nombreux dans ce domaine, en particulier pour désigner tout ce qui se réfère aux constructions hydrauliques, domaine dans lequel les arabes se sont fait remarquer historiquement et dans lequel ils ont réalisé des œuvres de grande envergure et d'innovation technique durant leur résidence dans la péninsule ibérique. Dans notre glossaire nous trouvons 40 mots d'origine arabe, nombre qui témoigne de l'importance de l'héritage arabe dans le milieu de l'ingénierie renaissantiste hispanique, principalement dans la désignation de tout ce qui se réfère à la canalisation des eaux et aux matériaux utilisés pour son exécution.

D'un autre côté, le français et le catalan sont des langues desquelles provient un nombre de mots significatif, bien qu'inférieur à celui des langues signalées auparavant. En effet, on compte 27 termes provenant de chacune d'entre elles. En général, tant les gallicismes comme les catalanismes désignent des pièces de machines et des outils, beaucoup d'entre eux étant communs à d'autres domaines de la construction comme l'architecture et la taille de pierre. Ces domaines ont, par leur développement dans la péninsule, particulièrement influencé les techniques apportées par la zone catalane et le pays gaulois. De plus, nous signalons qu'un groupe important de catalanismes est composé de mots propres d'Aragon, c'est-à-dire qu'il s'agit de mots dialectaux aragonais. 
Aragon, de par sa localisation géographique, a favorisé l'entrée de catalanismes dans le castillan (cf. Colón 19591: 157).

Le nombre d'italianismes répertoriés dans le glossaire ne s'élève qu'à 7, nombre de mots assez réduit comparé à celui d'emprunts d'autres origines. Parmi ces italianismes, nous signalons que deux d'entre eux désignent des machines pour le transport, carro mato et carrozo, contrairement à d'autres machines aux mêmes fins réunies dans le glossaire, dont la nomenclature est formée à l'aide de mécanismes internes du castillan.

Finalement, nous notons que les mots d'origine préromaine ou d'origine probablement préromaine trouvés dans notre domaine lexical s'élèvent à 21 . Ceux-ci désignent principalement des matériaux, des éléments naturels et des objets d'usage quotidien, ainsi que des concepts dont l'équivalence parfois n'existait pas en latin.

\subsubsection{DiALECTALISMES}

Concernant les dialectalismes renaissantistes, nous observons un nombre élevé de termes présents dans la zone aragonaise et propres à cette zone uniquement. La plus grande partie de ces mots est documentée dans le texte Los Ventiún Libros de los Ingenios y Máquinas de Juanelo, texte à qui, pour cette raison, on attribue une paternité littéraire d'origine aragonaise. Beaucoup de ces mots appartiennent au domaine des constructions hydrauliques et, ainsi, désignent des parties de constructions ou des moyens de canalisation. Cependant, nous trouvons également certains mots de machinerie parmi ces aragonismes, ainsi que des mots se référent à des matériaux. Antérieurement, nous nous sommes attardés plus longtemps sur ce paragraphe car nous le considérons comme très important. En effet «el aragonés es uno de los transmisores de arabismos indirectos al castellano » (Corriente 2004: 190) et c'est pourquoi nous pensons que certains arabismes pourraient avoir pénétré dans le castillan par voie aragonaise. D'un autre côté, nous n'avons trouvé qu'un seul américanisme, cocha, dans notre glossaire. 


\subsubsection{ETUDE MORPHOLOGIQUE}

L'analyse et l'étude des processus morphologiques fréquents et variés qui interviennent dans la formation du lexique de l'ingénierie renaissantiste nous montre la grande importance que les créations morphologiques constituent dans la configuration du lexique dans ce domaine. Le nombre de mots créés à travers des procédés morphologiques est très élevé ; en effet, celuici s'élève à 431, presque la moitié du total des mots dans le glossaire.

Comme on pouvait le prévoir, le processus morphologique qui agit avec le plus de fréquence est la dérivation, comparé à la composition et la parasynthèse qui sont beaucoup moins récurrents.

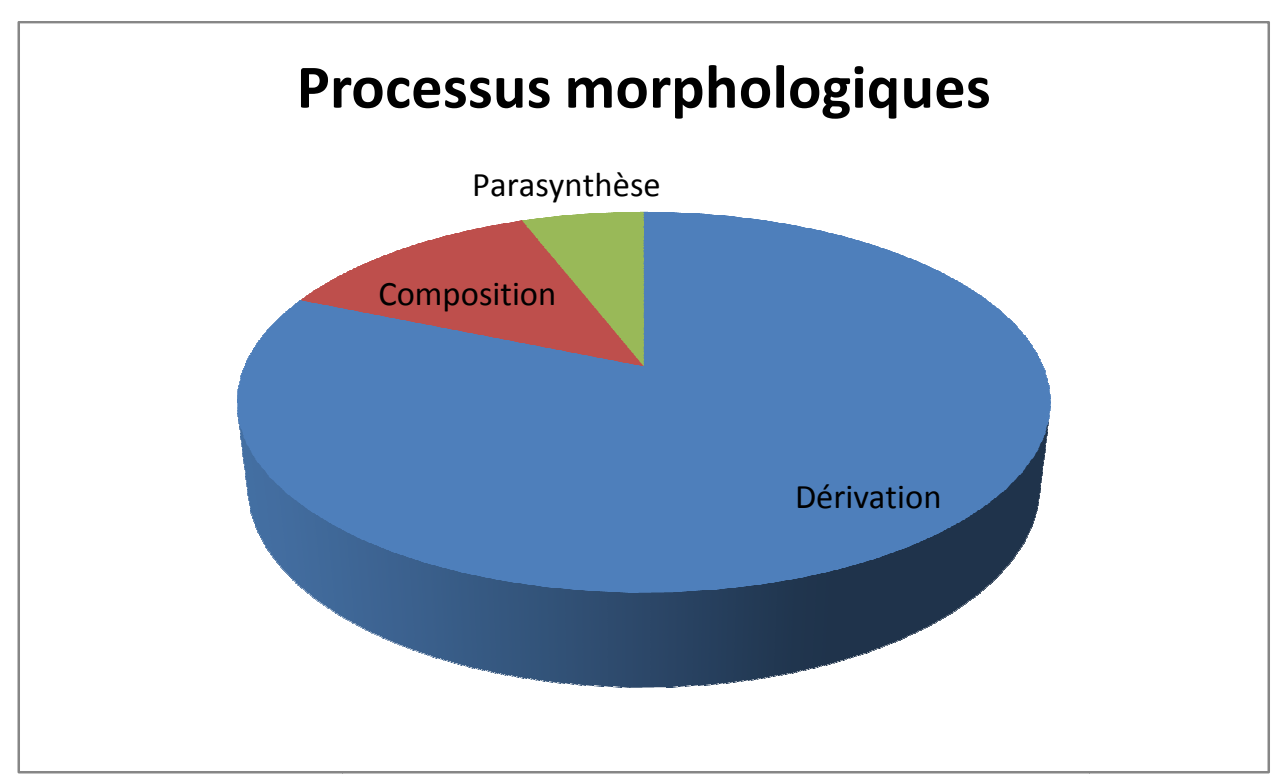

Parmi les processus de dérivation employés pour la création lexicale, le nombre de cas de suffixation se détache notablement par rapport à ceux de préfixation. 


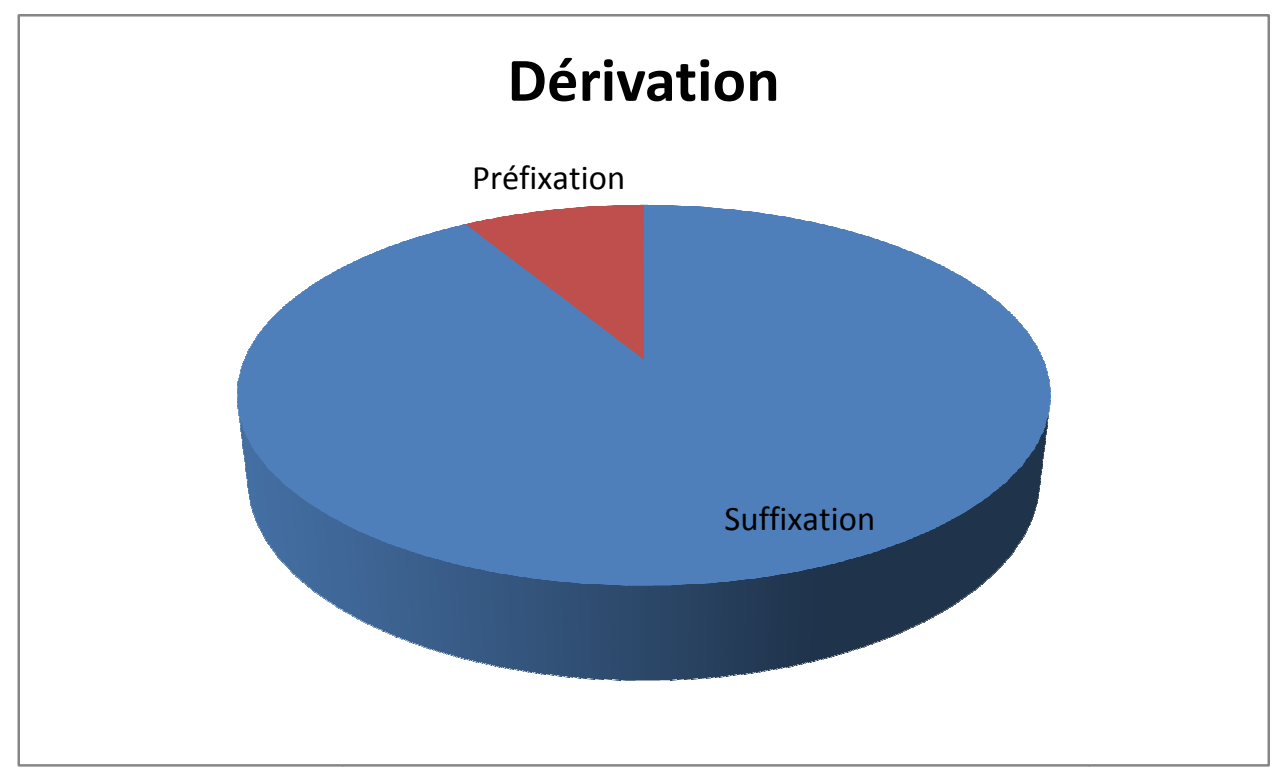

Concernant la catégorie grammaticale des termes résultant de la suffixation, le pourcentage de substantifs est beaucoup plus élevé que celui d'autres catégories comme les verbes, les adjectifs et les adverbes. Ces pourcentages obtenus dans l'analyse des différentes catégories des dérivés par suffixation sont proportionnels aux pourcentages généraux de la distribution catégorielle du total des termes du glossaire.

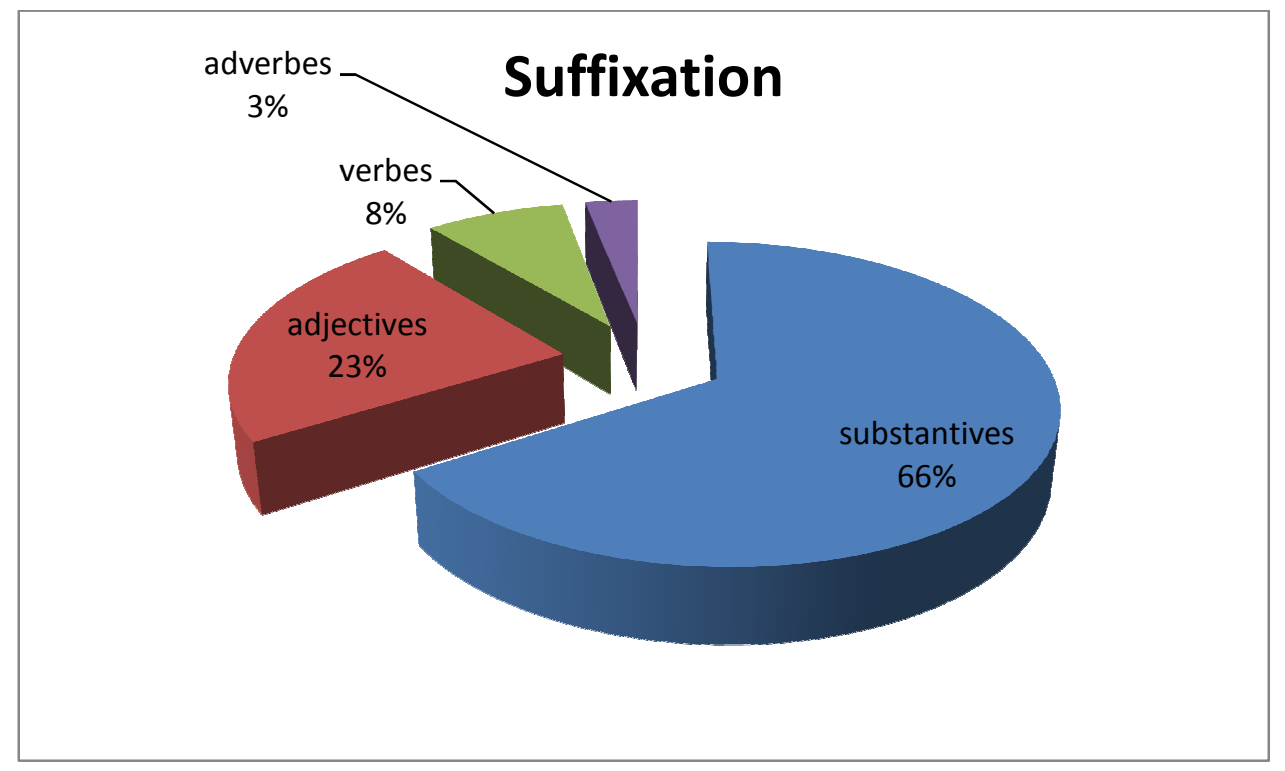

C'est pourquoi les suffixes les plus fréquents et variés qui agissent dans nos termes sont des suffixes de substantivation, lesquels interviennent à partir de bases nominales et verbales, sauf pour deux termes, ceguedad e impetuosidad, où le suffixe -dad s'applique sur une base adjectivale. 
Quant à la suffixation de substantifs dénominaux, elle est dans 60\% des cas non appréciative et dans $40 \%$ des cas appréciative.

Ce pourcentage élevé de substantifs créés par le biais d'une suffixation appréciative est motivé, selon nous, pour deux raisons: d'une part, il est dû à l'inclusion dans notre sélection lexicale d'un nombre important de mots appartenant au sous-champ lexical des outils, domaine qui compte un grand nombre de termes formés par une suffixation appréciative, principalement pour désigner différents outils selon leur taille; d'autre part, il serait causé par l'existence d'un groupe d'aragonismes, un type de dialectalismes dont la morphologie présente fréquemment une suffixation appréciative. De ces suffixes appréciatifs, les plus utilisés pour la formation des mots étudiés sont les suffixes diminutifs -ete, -eta et -illo, -illa.

En ce qui concerne les substantifs créés par suffixation non appréciative, plus de $60 \%$ sont formés à partir d'une base verbale et le reste, à l'exception de deux cas, à partir d'une base nominale.

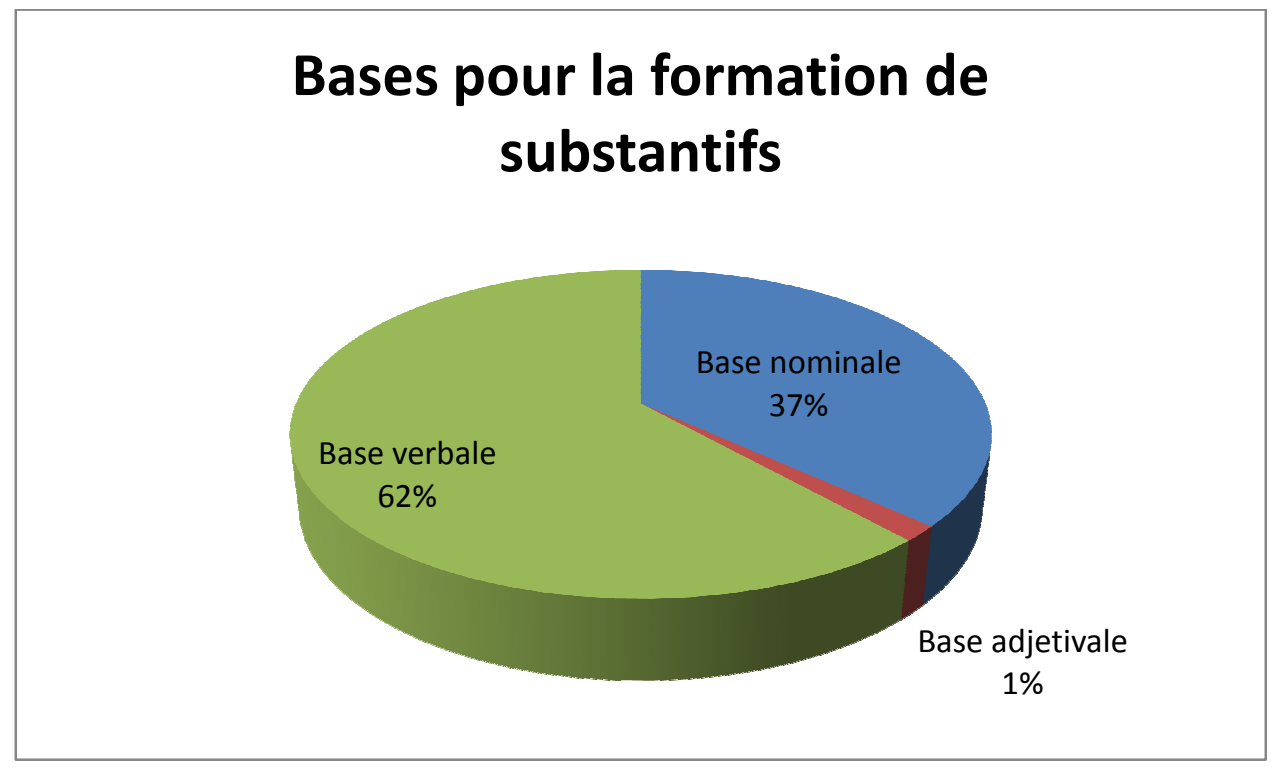

Parmi les suffixes de substantivation appliqués sur des bases nominales, les plus fréquents sont -ero et -al/-ar; quant à ceux appliqués sur des bases verbales, les plus récurrents sont dero et -dor. 
Les suffixes d'adjectivation s'appliquent tant sur des bases nominales comme adjectivales ou verbales, bien que ceux s'appliquant à des bases verbales se distinguent par leur nombre.

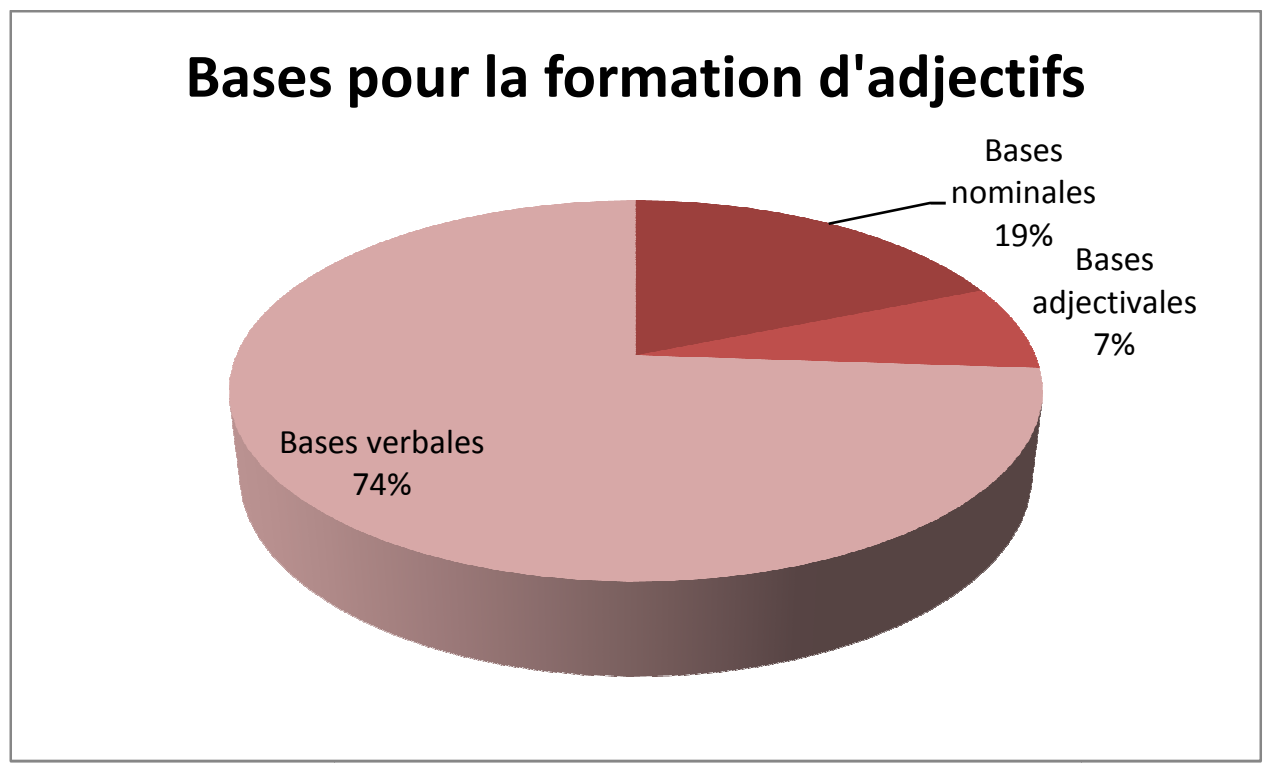

Parmi les suffixes d'adjectivation appliqués sur des bases nominales, le plus récurrent est -ado; et parmi l'ensemble des suffixes d'adjectivation appliqués sur des bases verbales, le suffixe -do ressort et domine.

Concernant les suffixes qui interviennent dans la formation de verbes, nous comptons 23 cas de -ar, suffixe de verbalisation dénominale qui, dans un des cas, s'applique sur une base adjectivale (fijar, de fijo). Nous trouvons également deux verbes formés par suffixation en -ear à partir d'une base nominale ainsi qu'une autre dont la base de suffixation est formée par une préposition et un substantif.

Nous trouvons 11 adverbes formés avec une suffixation en -mente.

A propos des cas de préfixation, le nombre de termes formés avec les préfixes $a$-, des-, en- et re- est particulièrement élevé. 
Nous trouvons dans notre lexique un adjectif parasynthétique et de nombreux verbes formés par parasynthèse, dont la plus dominante est la parasynthèse en-....-ar.

La syntagmation est l'un des recours les plus employés dans les langages spécialisés du fait qu'elle «permite crear nuevas unidades terminológicas de significado transparente » (Ferrando Aramo 2002: 99).

Nous trouvons également certaines locutions, où celles de type adverbial atteignent le $60 \%$ du total.

En ce qui concerne les néologismes renaissantistes, nous mentionnons l'importance de l'entrée d'un grand groupe de mots du domaine de l'ingénierie et de la machinerie, principalement par le biais du latin, pour les dénominations de machines ainsi que pour leurs pièces et leurs parties. En en trouve également un nombre considérable dans la traduction d'Urrea dans l'œuvre de Vitruve, bien que nous en ayons trouvé plusieurs dans Los Ventiún Libros de los Ingenios y Máquinas de Juanelo. 


\section{CONCLUSIONS FINALES}

\subsection{LA SCIENCE ET LA TECHNIQUE À LA RENAISSANCE}

En ce qui concerne les paramètres avec lesquels on a mesuré l'histoire de la science en Espagne, nous remarquons que la science, l'histoire de la science et l'historiographie scientifiques ne sont pas toujours allés main dans la main, comme on l'a supposé jadis. Nous sommes conscients de l'importance de devoir différencier la valeur des témoignages dont nous disposons, tant textuels qu'objectaux, pour pouvoir calibrer l'état scientifique et technologique d'un pays dans une époque concrète.

Ainsi que nous l'avons commenté dans notre thèse, la science et la technique dans l'Espagne du XVIème siècle étaient d'avant-garde, propres d'un état moderne et de grande envergure qui devait se mesurer dans des conflits belliqueux, tant en Europe comme dans les territoires d'outre-mer. C'est pourquoi nous considérons que le travail philologique, ainsi que l'analyse et l'étude des textes et du lexique qu'ils contiennent, peuvent contribuer à la connaissance de la science d'autres époques (dans notre cas, concrètement, de la Renaissance espagnole), du fait que "el conocimiento científico se expresa, se transmite, a través de la palabra, siendo esa transmisión, además, condición indispensable para la existencia de la propia ciencia" (Gutiérrez Rodilla 2005: 9).

La présente thèse de doctorat se base sur un pilier qui possède une ample trajectoire dans les études lexicographiques et lexicologiques: le projet du DICTER, établi sur un corpus de 74 textes sélectionnés par des spécialistes en histoire de la science et évalués d'après leur apport historique notable. La méthodologie de l'équipe a été mise en route grâce à différents outils informatiques, tels que deux bases de données de FileMaker, spécialisées pour l'élaboration lexicographique, et le programme de recherches UltraEdit. D'après notre expérience, nous affirmons que les outils informatiques sont d'une grande utilité pour ce type de tâches lexicographiques, du fait qu'ils accélèrent l'élaboration systématique, cohérente et rigoureuse de glossaires, et permettent 
également de réaliser des recherches précises qui seraient impossibles sans ce soutien informatique.

\subsection{LES TEXTES RENAISSANTISTES D'INGÉNIERIE ET DE} MACHINERIE

Dans l'ensemble des domaines qui configurent le corpus du DICTER se trouve celui de la machinerie, dont les textes fondamentaux, qui se réfèrent à des engins et des machines, sont: Les Notas, mss. a. 1585 de Francisco Lobato; le Teatro de los instrumentos y figuras matemáticas y mecánicas de Diego Besson, traduit par Horacio Cardon, 1602; et Los veinte y un libros de los yngenios y máquinas, mss. a. 1605, attribués à Juanelo Turriano. Nonobstant, les recherches lexicales ont été réalisées dans la globalité du corpus.

En ce qui concerne les textes signalés, nous notons, en guise de conclusion, nos hypothèses sur la dissimulation des Notas de Lobato dans un livre de Ptolomeo, ce qui pourrait s'expliquer par le fait que son auteur était peut-être intéressé de recevoir une patente ou des privilèges pour ses inventions. Quant aux Los Veinte y un Libros de los Ingenios y Máquinas de Juanelo, nous pensons qu'il serait quelque peu précipité de les attribuer, comme l'a fait García Tapia, à Pedro J. de Lastanosa et, d'après les sauts de contenu des Ventiún Libros..., et les images qu'il contient, souvent si précises, "no descartamos que se trate de un compendio de notas o apuntes de clase, o algo parecido, en cuya confección o intento de perfección pudieron intervenir, de una manera o de otra, los textos a los que Los Ventiún Libros... se asemeja, y que, por supuesto, tiene relación con la zona de Aragón y con Italia"378.

Concernant le domaine qui nous intéresse, celui de l'ingénierie et de la machinerie, nous n'avons pas connaissance d'un quelconque endroit concret consacré à ses études dans les institutions qui ont émergé dans l'Espagne à la Renaissance (comme la Casa de Contratación de Séville ou l'Academia Real Matemática). Cependant, les experts dans ce domaine ont bien été reçus par

378 cf. Martín, volume présent: 63. 
Herrera dans son Institution (ingénieurs, machinistes, architectes, hydrauliciens et fontainiers). D'autre part, c'est cette discipline, l'ingénierie, qui a souffert le plus de changements, du fait des réformes urbaines à la Renaissance, comme celles réalisées sur l'adduction d'eau, la navigabilité des fleuves ou la construction de zones portuaires (cf. Los Ventiún Libros...). Quant à la machinerie, cette époque est fondamentalement caractérisée par l'essor de la création des moulins, de typologie variée et destinés à différents buts ainsi comme les machines pour la charge, décharge ou le transport de matériaux.

\subsection{LES INGENIEURS}

Covarrubias donnant deux acceptions de ce mot, il sépare «celui qui fabrique des machines pour défendre l'ennemi et l'offenser» de «celui qui invente les mêmes machines, que nous appelons engins, comme l'engin de l'eau qui monde depuis le fleuve Tage jusqu'à l'alcazar à Tolède, qui fut une invention de Juanelo, second d'Archimède ». Pour cette thèse, nous nous sommes basés sur la deuxième, c'est-à-dire les ingénieurs pour la paix en opposition aux ingénieurs de guerre, «bien qu'ils soient parfois les mêmes »379 (Cámara Muñoz 2008: 131).

Dans tous les cas, nous trouvons sous la dénomination d'ingénieur des hommes de différentes natures: d'un côté, ceux qui ont été reconnus comme tels à leur époque, comme par exemple Juanelo Turriano, et, de l'autre, ceux qui se sont aussi dédiés à des nécessités et qui ont été considérés comme des ingénieurs postérieurement, à la lumière de leurs travaux. Un cas similaire est celui des inventeurs qui se présentaient à la cour avec l'intention de faire reconnaître et rétribuer leurs inventions.

\subsection{ENGINS ET MACHINES AU XVI ${ }^{\grave{E} M E}$ SIÈCLE}

Passant aux œuvres d'ingénierie à la Renaissance, notons le grand nombre de ponts qui ont été réparés ou construits comme les ponts sur le Turia, à Valence ; ceux d'Ariza, le Puente Genil y Plasencia ; le pont de San Pablo, à

379 Il s'agit d'une traduction. 
Cuenca; et les ponts de Montalbán (Tolède) et Lerma (Burgos). Pour la construction de certains d'entre eux, les nouvelles grues à tympan (cage à écureuil) ont été utilisées (Juan de Herrera). En ce qui concerne les ports, certains ont été édifiés dans la Méditerranée, sur des côtes ouvertes, comme ceux de Carthagène, Mahon, Malaga ou Palma de Majorque ; ainsi que dans la Cantabrique, comme les ports fluviaux de Bilbao ou Avilés ou celui situé sur la ria de Ferrol, ou encore les digues convergentes de Saint Sébastien et Gijón. Concernant la grande œuvre d'envergure en Hispanie, le barrage, une grande partie d'entre eux ont été exécutés dans la seconde moitié du XVIème siècle, en particulier des barrages «à gravité » (droits), les plus significatifs étant ceux de Tibi et Almansa. Pour mentionner l'adduction d'eau, cette époque a largement favorisé la construction de barrages de rivières, du fait qu'ils dérivaient une partie de l'eau pour irriguer les terres (avec l'usage fréquent de norias ou de pompes à eau), pour un usage industriel, ou bien pour la formation du débit nécessaire au fonctionnement des moulins.

L'adduction d'eau qui arrivait à la population depuis des fontaines, des sources ou des canaux, était réalisée au moyen de conduits, de tuyaux, d'aqueducs, d'arches ou d'athanors. Parfois, l'on réutilisait d'antiques constructions romaines, mais l'on a aussi composé des conductions suivant différents plans d'adduction, comme celui de Juan de Herrera à Valladolid ou celui de Juan del Ribero à León (cf. García Tapia 2002: 441). Lorsque la hauteur à laquelle devait s'élever l'eau était excessive, il y eu des essais de création de machines à ce but, la plus connue étant l'artifice de Juanelo Turriano de Toledo. Cette époque a également vu naître l'aqueduc de Teruel et les fontaines des Sitios Reales de Philippe II : Aranjuez, Casa de Campo, Segovia et El Escorial. L'emmagasinage d'eau était assuré par des citernes souterraines, des puits ou des citernes.

En ce qui concerne les moulins et les autres types de machinerie à fins industrielles, la Renaissance a été une époque très fructueuse. En effet, beaucoup de créations et d'inventions ont vu le jour et ont donné lieu à une 
typologie variée de machinerie, pour usage agricole, industriel ou domestique. Fonctionnant soit avec la force animale ou humaine, soit par la force du vent ou de l'eau, les moulins ont été considérés comme «les machines les plus complexes et puissantes de l'époque ainsi que le symbole de l'ère préindustrielle »380 (García Tapia 19972: 8).

Selon la position de la roue ou de la meule, les moulins hydrauliques pouvaient s'appeler aceñas, lesquels recevaient l'eau directement depuis la rivière ou le canal, ou bien les molinos de canal, appelés ainsi parce que l'eau de propulsion était conduite à travers un canal d'amenée ou un conduit. Si le conduit était fermé, on l'appelait saetín et, dans ce cas, il s'agissait d'un molino de bomba. Concernant ceux dont la roue était horizontale (roue à aubes), les plus connus étaient les molinos de cubo, appelés ainsi d'après le cube dont ils disposaient pour emmagasiner l'eau, qui sortait postérieurement à pression. Les molinos de marea ont également été significatifs : l'eau amenée provenait d'une mare, que l'accumulation d'eau avait produite. Il a même existé un type de moulin qui combinait les deux précédent: le molino de marea y de cubo. Mais s'il y a eu un moulin significatif en cette époque c'est le molino de regolfo qui est, à ce qu'on dit, une invention espagnole qui a été qualifiée comme "précédent les turbines actuelles", dans lequel la roue horizontales, ou à aubes, était entourée d'un mur cylindrique où l'eau agissait avec une force centrifuge. Dans tous les cas, à la Renaissance on continuait à utiliser les moulins à sang ou à bêtes et, dans les zones qui ne disposaient pas d'assez d'eau, on pouvait avoir recours aux molinos de viento.

\subsection{GLOSSAIRE}

Pour la confection du glossaire, nous avons complété 1762 fiches dans la base de données Filemaker. Celles-ci comportent un grand nombre d'entrées, qui s'élève à 992 alors que nous comptons seulement 132 acceptions, auxquelles il faut ajouter 528 fiches de variantes graphiques et 50 unités pluriverbales avec leurs fiches de renvois correspondantes. Nous soulignons ici l'importance d'un

380 Il s'agit d'une traduction. 
nombre tant significatif d'entrées, à côté du nombre limité d'acceptions, en comparaison d'autres domaines lexicaux. Cela est dû au fait que notre glossaire est directement relié au type de lexique de notre domaine dans lequel dominent les machines, leurs pièces, les types de constructions hydrauliques et leurs pièces ou éléments, ainsi que les outils, etc., sous-champs lexicaux qui ne sont peut-être pas tant flexibles à des variations de signification.

La plus grande proportion de lemmes est constituée de substantifs. En effet, ceux-ci s'élèvent à 698, par rapport aux 161 verbes, aux 122 adjectifs et aux 11 adverbes. Cette prédominance pour les substantifs, comparée à d'autres catégories grammaticales, est propre des langages de spécialité mais, dans notre cas, nous comptons également une quantité significative de verbes liés à la mécanique et à la physique.

Concernant les marques diatechniques, nous avons utilisé la marque Mécanique comme en-tête pour 281 termes, desquels 207 sont des lemmes, 42 acceptions et 32 unités pluriverbales. La marque Ingénierie Hydraulique a également été utilisée lors de nombreuses occasions, 166, dans lesquelles elle accompagnait des têtes de chapitres 139 fois, des acceptions 26 fois et des unités pluriverbales dans un cas. En ce qui concerne la marque Physique, elle apparaît dans le glossaire 57 fois et, dans la plupart des cas (52 fois), également dans des têtes de chapitres.

La plupart des verbes sont transitifs (133), 25 sont intransitifs et seulement 3 pronominaux, bien qu'il y ait deux verbes transitifs qui peuvent s'utiliser sous la forme intransitive et un verbe intransitif qui peut également s'employer sous la forme transitive. Les verbes dénotant un usage pronominal occasionnel sont assez fréquents, leur nombre s'élevant à 23.

Concernant la classe lexicale des substantifs, seul un petit nombre d'entre eux, dans la classification lexico-sémantique, désignent des concepts abstraits tels que les sciences, la technique ou l'art. Nonobstant, on trouve jusqu'à 40 lemmes qui désignent le personnel qui cultive une science, une technique ou un 
métier. Ceci est le cas, par exemple, des mots comme aguador, fontanero, molinero et zahorí, dénominations qui désignent techniciens et personnel des métiers de notre domaine lexical, pour lesquels, cependant il n'existe pas, ou nous n'avons pas trouvé, de terme qui désigne sa technique ou profession correspondante. Cela pourrait être dû au fait que dans notre domaine lexical nous englobons autant les métiers les plus bas ou serviles comme ceux touchants aux arts libéraux. En ce qui concerne les objets des sciences et de la technique, 129 lemmes appartiennent au sous-domaine des constructions hydrauliques, 190 à celui des machines, 45 à celui des outils et 45 à celui des instruments. Ainsi, 81 sont des objets de métiers, comme tornillo, puerca, laña, guindal et guindaleta. Les éléments appartenant au domaine lexical des constructions hydrauliques et de la machinerie ressortent par leur nombre, leurs sous-champs lexicaux sont fondamentaux dans notre thèse.

D'autre part, nous avons trouvé 36 lemmes qui désignent des matériaux et 4 substantifs qui dénomment des qualités: artificio, ceguedad, firmeza et velocidad. On compte également 30 lemmes qui désignent des états, des processus et des mouvements, 4 qui dénomment des localisations spatiales et 13 qui désignent des circonstances.

En ce qui concerne les adjectifs, nous en avons trouvé 122 qui dénomment des qualités. La plus grande partie d'entre eux, 54, expriment un résultat, comme par exemple aliviado, encañado, embalsado, endentado, entorneado et zulacado; nous avons également trouvé des qualités de contenu, d'abondance ou autres comme dans les lemmes aguanoso, alvidriado, betuminado; formelles dans acanalado, encaracolado, enroscado, voltado; de plus, ces qualités peuvent être abstraites, comme le montrent les termes artificial, artificioso, industrioso; intellectuelles comme dans ingenioso; relationnelles comme par exemple mecánico et edificatorio; ou spatiales, comme dans l'adjectif frontero.

\subsection{ASPECTS LEXICO-SEMANTIQUES}

Dans l'ensemble, les champs lexico-sémantiques principaux de notre 
thèse sont les constructions hydrauliques d'envergure majeure ou mineure, qui comptent les ponts, les ports, les conduits et les canaux; et, d'autre part, les machines, les moulins ayant une place prédominante. Nous soulignons également le domaine des instruments et outils. De même, les champs des activités et des actions sont importants, un grand nombre d'entre elles étant réalisées avec des machines ou à l'aide de l'eau. Comme mentionné plus haut, les champs des matériaux et des qualités jouent également un rôle prépondérant.

Les hyperonymes les plus courants sont machine, avec 58 hyponymes, construction hydraulique (47 hyponymes) et moulin (28). Parmi les hyponymes de machine, nous signalons par exemple molino, cabria, quelonio y bomba. Les lemmes suivants sont, selon nous, des hyponymes de construction hydraulique : azud, canal, pesquera et vivero. Et les lemmes suivants des hyponymes de moulin: molino de balsa, molino de cubo y tahona. Entre les holonymies les plus communes, on trouve moulin, avec 65 méronymes, comme par exemple muela, gruenza, rodezno; Construction hydraulique qui compte 64 méronymes dont, arcaduz, atanor, desaguadero; et machine 40, comme gorrón, caracol, husillo et cigüeñal. Ainsi nous constatons que machine, construction hydraulique et moulin sont les termes utilisés avec la plus grande fréquence dans le glossaire, autant comme hyperonymes que comme holonymes.

\subsection{PROVENANCE DES LEMMES}

Dans le domaine lexical, le nombre de lemmes patrimoniaux existant est très significatif. En effet, ceux-ci configurent plus du quart de la totalité des lemmes qui constituent notre glossaire des engins et machines à la Renaissance. Pour cette raison, nous soulignons l'importance de la transmission de connaissances sur l'ingénierie hydraulique et la machinerie par voie populaire, $\mathrm{du}$ fait que les lemmes auxquels nous nous référons désignent tant des machines comme des éléments d'ingénierie et un grand nombre d'outils destinés généralement à des usages divers. 
En second lieu se détachent les mots savants. En effet, nous en trouvons 114, nombre qui atteint presque la moitié des lemmes patrimoniaux. L'origine de pratiquement tous ces mots savants est latine, bien que 16 soient des hellénismes, parmi lesquels tous sauf un ont été introduits dans notre langue à travers le latin. Cette proportion d'hellénismes est importante et significative, en particulier si on la compare avec les hellénismes présents dans d'autres domaines lexicaux du projet DICTER. Une grande partie de ces mots savants désigne des noms de machines et, approximativement une troisième partie de l'ensemble, 37, ont été transmis à travers la traduction réalisée par Urrea de l'œuvre vitruvienne De architectura. En relation à celle-ci, nous voudrions commenter que ces mots savants n'ont pas toujours réussi à s'intégrer et s'utiliser da manière régulière dans la langue, soit parce qu'il en existait d'autres pour désigner les mêmes concepts, soit parce que les objets ou machines qu'ils désignaient n'ont pas atteint un usage massif.

Concernant les lemmes d'origine arabe, ceux-ci sont nombreux dans ce domaine et attestent l'importance historique de ce segment de la population dans l'exécution de constructions hydrauliques dans la péninsule, celles-ci étant caractérisées par leur grande envergure et leur innovation technique. On trouve dans notre glossaire 43 lemmes d'origine hispano-arabe ou andalouse, dont les plus importants sont ceux dédiés à la désignation d'éléments se référant à la canalisation des eaux ou aux matériaux employés pour son élaboration.

D'un autre côté, il faut mentionner le nombre de lemmes provenant du français et du catalan qui, ensemble, s'élèvent à 27 et montrent l'importance des techniques apportées par le pays gaulois et la zone catalane dans le développement de notre domaine d'étude. Les lemmes provenant de ces langues sont liés généralement à des domaines de construction comme l'architecture et la taille de pierre. De plus, nous signalons qu'un nombre important de catalanismes trouvés se réfèrent à des lemmes propres d'Aragon, localisation géographique qui a favorisé l'entrée de catalanismes dans l'espagnol (cf. Colón 19591: 157). 
Quant aux italianismes, nous n'en comptons que 7, nombre assez réduit comparé au nombre de lemmes d'autres origines. Il en va de même avec les langues comme le hongrois, le hollandais et le quechua qui sont, chacune, l'origine d'un seul lemme du glossaire. Concernant les lemmes d'origine incertaine, nous signalons nanilla et ananilla, des synonymes de anadija 'pierre horizontale sur laquelle repose la meule d'un moulin'. Quant au lemme jeta 'robinet', il pourrait s'agir d'un arabisme, selon DECH, alors que Corriente, lui, l'associe au mot d'origine également incertaine, seta. Nous avançons la possibilité qu'il provienne du gallicisme jeter, tout comme le mot enjeta.

\subsection{DIALECTALISMES LEXICAUX}

En ce qui concerne les dialectalismes, nous notons l'existence d'un groupe nombreux d'aragonismes dans les termes d'ingénierie hydraulique, ce qui témoigne des liens existant entre cette zone géographique et la création de constructions hydrauliques. Nous avons également trouvé dans notre domaine lexical des aragonismes qui désignent des outils et matériaux, simples ou agglomérés. Parmi ces aragonismes, on trouve autant de mots patrimoniaux que de néologismes, en plus d'un nombre important de lemmes d'origine arabe et catalane. Concernant les aragonismes créés à l'aide de procédés propres de la langue, les dérivations, principalement par suffixation, sont très courantes. Au total, nous n'avons trouvé qu'un seul américanisme cocha 'bassin qui, pour l'extraction de métaux, est séparé de du bac ou lavoir principal'.

\subsection{ASPECTS MORPHOLOGIQUES}

Le nombre de lemmes créés à travers des processus morphologiques est très élevé. En effet, celui-ci s'élève à 431, presque la moitié de ceux qui configurent le total du glossaire. Dans l'ensemble des processus morphologiques existant, le plus habituel est la dérivation et, à l'intérieur de celle-ci, la suffixation est beaucoup plus abondante que la préfixation.

Parmi les lemmes de notre glossaire formés à travers la dérivation, il y a un grand pourcentage de substantifs, 66\%, comparé à d'autres catégories 
comme les adjectifs, les verbes et les adverbes. Dans la formation de ces substantifs interviennent principalement les suffixes qui agissent sur les bases nominales et verbales.

Concernant la suffixation des substantifs dénominaux, un grand pourcentage, $40 \%$, présentent une suffixation appréciative, en opposition à la non appréciative. Cela est dû, selon nous, à la présence d'un sous-champ d'outils et à l'existence d'un grand nombre d'aragonismes parmi les termes. En effet, dans les deux cas il est très courant que ce type de suffixation soit lexicalisé. Quant à la suffixation non appréciative de substantifs dénominaux, ceux-ci sont formés à partir d'une base verbale, les suffixes les plus récurrents étant-dero et -dor; pratiquement tout le reste sont des substantifs dénominaux et sont suffixés, en grande majorité, par -al/-ar et -ero.

Parmi les suffixes adjectivaux, ceux d'entre eux s'appliquant à des bases verbales s'élèvent à $74 \%$ et, dans l'ensemble, le suffixe -do ressort et domine. Concernant les suffixes verbalisants, les plus courants sont -ar et nous trouvons également 10 adverbes suffixés en -mente.

D'autre part, le processus de préfixation est plus habituel avec les préfixes $a^{-}$, des-, en- et re-. Nous trouvons dans notre lexique de nombreux verbes parasynthétiques.

Concernant les composés, nous comptons 7 composés lexicaux et signalons que parmi les 47 composés syntagmatiques de notre glossaire, 22, c'est-à-dire presque la moitié, présente la structure moulin + S/A / de S, etc.

\subsection{ASPECTS HISTORIQUES}

Concernant les néologismes renaissantistes, nous documentons au XVIème siècle l'entrée de latinismes qui désignent d'importants éléments d'ingénierie hydraulique, comme aqueduc, emprunté du latin ăquaedūctŭs 'conduit d'eau'. 'Acueducto' apparait pour la première fois, selon les données du CORDE, dans De la antigua lengua (1587) d'Andrés de Poza. Quant à la traduction de Loçano des livres de León Baptista Alberti, nous signalons la 
présence des latinismes incile 'tête de conduit' et tímpano 'appareil pour l'élévation de l'eau'. De même, nous trouvons ici pour la première fois les mots quinario et quinaria 'tuyau ou fistule de cinq doigts de diamètre'. La même chose avec les mots savants senario et senaria 'tuyau ou fistule de six doigts de diamètre' et setinaria' tuyau ou fistule de cinq quinaires de diamètre'.

Les latinismes qui désignent des machines et des pièces de machines représentent également un nombreux groupe. On les trouve pour la première fois dans la traduction d'Urrea, comme arbúscula 'pied de voiture pour transporter des machines'; arrectario 'madrier qui soutien le poids dans certaines machines'; cárdine 'fer de certaines machines'; engibato 'artifice hydraulique musical' ; equipondio 'pièce métallique pour comparer des poids' ; ergata 'treuil vertical pour bouger des poids' ; fibula 381 'boucle d'attache pour une charge' ; modiolo 'pot' ; pénula 'couverture d'une machine' ; súcula 'grande pièce en forme d'écrou', emprunté du latin sŭcŭla 'grue', que DECH documente tardivement, en 1843. Dans la traduction de Besson, dont l'entrée est réalisée par le biais du français, nous trouvons le latinisme atelabo 'qui maintient la balance d'un treuil', emprunté du latin attělĕbus 'langouste'. C'est dans le corpus du DICTER que nous localisons le latinisme motor ${ }^{382}$ à une date plus précoce [1590, Perfeto capitán de Álava de Viamont] que celle signalisée par DECH (XVIIe s.).

De même, nous trouvons dans la traduction de Urrea de nombreux adjectifs relatifs aux machines, comme escansorio 'qui sert à monter des poids' ; tractorio 'qui sert à remorquer des charges' et espirital et espiritual 'qui fonctionne avec de l'air', des mots existant, évidemment, déjà bien avant, mais avec une autre signification.

Apparaissant pour la première fois dans Los Ventiún Libros..., nous signalons les latinismes castelo 'déversoir', especo 'tête de conduit', estípite 'axe d'une porte'. Ils avancent donc la première documentation de ce terme qu'offre

\footnotetext{
381 Emprunté du latin fibŭla 'boucle' (DECH).

382 Emprunté du latin mōtŏr, mōtōris 'qui bouge, en mouvement'.
} 
DECH, qui le situe dans le Diccionario de Autoridades. Mentionnons également pondos, synonyme dans le texte $\mathrm{du}$ mot equipondio 'pièce métallique pour déterminer un poids'; premodo 'construction qui régule la quantité d'eau', synonyme du mot également présent dans ce texte promódulo, qui pourrait avoir été emprunté de pro mŏdŭlo (ingenii) 'selon sa capacité'.

Nous relevons finalement l'importance de la zoonomie dans la désignation de lemmes qui configurent le lexique de l'ingénierie et de la machinerie renaissantiste, étant donné qu'un grand nombre de mots ont été créés à partir de noms d'animaux ${ }^{383}$. Ce fait est peut être dû à des mécanismes sémantiques de création terminologiques existant dans notre langue, comme le sont l'analogie, la métaphore ou l'extension métonymique, mécanismes très fréquents dans l'expression de tout ce qui touche au quotidien, comme le sont les animaux typiques de la ferme, de consommation et de transport.

En définitive, un grand nombre de termes ont été utilités dans la langue espagnole au XVIème siècle pour désigner des éléments d'ingénierie et de machinerie et beaucoup d'entre eux ont également consolidé leur usage qui avait été attesté préalablement, depuis le Moyen-âge ou même avant. Finalement, nous notons un grand nombre de mots qui ont été créés à travers des processus morphologiques de notre propre langue. Tout cela témoigne de l'activité croissante du domaine scientifico-technique renaissantiste que nous avons abordé ainsi que de la participation notable de l'Etat espagnol et de ses citoyens dans cette matière et dans la constitution du langage de cette spécialité durant cette époque.

$383 \mathrm{~V}$. paragraphe mots patrimoniaux. 


\section{GLOSARIO: INGENIERÍA Y MAQUINARIA EN EL RENACIMIENTO}




\section{a}

abalanzado, abalanzado [de abalanzar. Loçano, Alberto, Architectura, 1582]. adj. Equilibrado, nivelado.

Loçano, Alberto, Architectura, 1582, pág. 89: Y esto para que no solamente las piedras últimamente puestas en la obra reciente no naden entre la emplastadura y sustento de la cal, sino para que entre sí occupen igual assiento de sossiego con sus abalanzados pesos.

SIN.: balanzado.

FAM.: balanza, balanzado, balanzar, balanzón.

abarrenar, abarrenar [de barrena. Urrea, Vitruvio, Architectura, 1582]. v. tr. Agujerear alguna cosa con una barrena o un barreno.

Urrea, Vitruvio, Architectura, 1582, fol. 109v: Y en los baxos de la medida del vientre se ha de poner una piedra de peña roxa, que es el mismo ñudo, y esta piedra se ha de abarrenar, de manera que el último arcaduz de la corriente de agua se pegue con la piedra. 
SIN.: barrenar.

FAM.: barrena, barrenar, barreno.

abebrada, V. abrevada.

abrevada, abebrada [de abrevar. Juanelo Turriano, Veinte y un libros, a. 1605]. sust. f. Cantidad de agua que se da a algún material.

Juanelo Turriano, Veinte y un libros, a. 1605, fol. 167v: Mas es menester que en esta obra de piedra menuda, es menester poner mucha abundançia de calçina y darle sus abebradas de mortero, muy bien hechas y con abundancia de calçina.

FAM.: abrevadero, abrevar.

abrevadero, abrevadero [de abrevar. (DECH). Loçano, Alberto, Architectura, 1582]. sust. $m$. Lugar donde hay agua y acostumbra el ganado ir a beber, por ser cómodo y a propósito para ello (Autoridades).

Loçano, Alberto, Architectura, 1582, 358: Abrevaderos. 151. 2.

HIPER.: obra hidráulica.

FAM.: abrevada, abrevar.

abrevar, abrevar [del lat. vg. *abbiberāre 'íd.', derivado de bibĕre, forma sustantivada del verbo que significa 'beber'. H. 1250, Libro de Alexandre (DECH). Juanelo Turriano, Veinte y un libros, a. 1605]. v. tr. Dar de beber, principalmente al ganado (DRAE).

Juanelo Turriano, Veinte y un libros, a. 1605, fol. 19v: Según leemos en la Sagrada Escriptura cómo Abraham hizo cavar poços, y también Loth, y cómo Jacob quitó la piedra de la boca del poço para que abrevasen sus ganados las hijas de Labán.

FAM.: abrevada, abrevadero.

acanalado, acanalado [de acanalar. Lobato, Notas, c.1585]. adj. Conducido por parte estrecha como canal.

Lobato, Notas, c.1585, fol. 26: Y como el río iba por la quiebra de la pesquera acanalado, toda la arena y cascajo que el dicho río traía se vino a parar fuera de la dicha boca, en que vino a quedar allí embarazando. 
FAM.: canal, canaladura, canaleja, canalera, canaleta, canalete, canalón, canalote.

2 [Collado, Plática Artillería, 1592]. adj. De forma larga y abarquillada como la de las canales (DRAE).

Collado, Plática Artillería, 1592, fol. 58r: Hirse ha limando de largo a largo cada ochavo de aquéllos, haziendo que queden todos ellos hondos y acanalados y, d'esta manera, entre la una canal y la otra, quedará un cuchillo o esquina muy aguda.

acarrear, acarrear [de carro. H. 1220-1250, Berceo (DECH). Loçano, Alberto, Architectura, 1582]. v. tr. Transportar alguna cosa en carro o de cualquier otra manera.

Loçano, Alberto, Architectura, 1582, pág. 11: Tendrá muchas y varias entradas, por las quales en navío, y en jumento, y en jugo, assí en el estío como en el invierno, se puedan acarrear las cosas necessarias cómmodamente. // Loçano, Alberto, Architectura, 1582, pág. 192: Platón dezía que convenía que la república, bien acostumbrada y bien constituyda, guardasse por ley que los regalos de las gentes estrangeras no se acarreassen a la ciudad, y que ningún ciudadano menor de edad de quarenta años saliesse lejos fuera. // García de Palacio, Instrución náuthica, 1587, fol. 110v: Dos calderas para fogón, cien votijas o veynte varriles para hazer y acarrear agua, tina para adereçar brevaje, un funil de cobre y otro de palo.

FAM.: acarreto, acarreo, carreta, carretada, carretería, carretero, carretillo, carretón, carretoncillo, carrillo, carripuente, carro, carromato, carrozo, carrucha, carrucho, garrucha.

acarreo, acarreo [de acarrear. (DECH). Urrea, Vitruvio, Architectura, 1582]. sust. m. Acción de acarrear (DRAE).

Urrea, Vitruvio, Architectura, 1582, fol. 20v: Y entendiendo que no podía sustentarse, sino de acarreo de la otra parte del mar, Alexandre dixo a Dinócrates: "Yo entiendo esta traça. // Llanos, Diccionario minas, ca. 1609-11, pág. 32: Y así, aunque generalmente se entiende chacanear en cualquier género de trajín o acarreos en Potosí, se toma entre la gente del Cerro por lo más principal, que es el trajinar el metal de las minas a los ingenios.

SIN.: acarreto.

FAM.: acarrear, acarreto, carretada, carretería, carretero, carretillo, carretón, carretoncillo, carrillo, carripuente, carro, carromato, carrozo, carrucha, carrucho, garrucha.

acarreto, acarreto [de acarrear. 1599, Percivale (DECH). Acosta, Historia natural, 1590]. sust. m. Acción de acarrear (DRAE s. v. acarreo). 
Rojas, Teórica fortificación, 1598, fol. 91v: Porque, de venir mal desbastadas, es mucho el gasto del acarreto de los carros y se gasta el dinero dos vezes: en el acarreto y en los canteros, que buelven a desbastar lo mal desbastado.

SIN.: acarreo.

FAM.: acarrear, acarreo, carretada, carretería, carretero, carretillo, carretón, carretoncillo, carrillo, carripuente, carro, carromato, carrozo, carrucha, carrucho, garrucha.

de [Acosta, Historia natural, 1590]. loc. adj. Dicho de una cosa: que se trae de otra parte por tierra, o no es del lugar donde está, sino que ha venido a él desde otro (DRAE s. v. de acarreo).

Acosta, Historia natural, 1590, pág. 206: Y, siendo todo de acarreto, están las plaças llenas de frutas, conservas, regalos, vinos excessivos, sedas y galas tanto como donde más. // Rojas, Teórica fortificación, 1598, fol. 36v: Ni meter trincheas ni minas, esta tal se guardará con menos gente que todas las demás, aunque suele ser plaça costosa, por ser de acarreto la leña y agua y la demás munición. // Rojas, Teórica fortificación, 1598, fol. 70v: Aunque tiene otro inconviniente semejante al argamassa, que es ser obra muy costosa, especialmente si se huviesse de traer de acarreto de otra parte

aceite, V. molino del $\sim$.

aceña, aceña [del hispano-ár. assánya, y este del ár. clás. sāniyah 'elevadora' (DRAE). 945 (DECH). Lobato, Notas, c.1585]. sust. f. Mec. Molino situado dentro de un cauce de agua, cuya corriente mueve la rueda.

Lobato, Notas, c.1585, fol. 12: Y en viendo que el dicho río Ana tenía agua para moler las aceñas, luego echaban llave a la torre, y cerraban la canal y guardaban el agua que sobraba. // Lobato, Notas, c.1585, fol. 28: Y digo que si se hiciesen en las ciudades, en las pesqueras que quedasen, se podrían hacer como va dicho, $\mathrm{y}$, en subiendo y bajando, volver a tirar las trampas, y molerían las aceñas como de antes. // Lobato, Notas, c.1585, pág. 230: Esta molienda se haze con diversos ingenios: unos que traen cavallos, como atahonas, y otros que se mueven con el golpe del agua, como aceñas o molinos, y de los unos y los otros ay gran quantidad.

SIN.: anoria ${ }_{1,}$ molino de aceña, molino de agua.

HIPER.: molino.

FAM.: ceña. 
ENCICL.: "Los molinos hidráulicos (o aceñas) constituyeron durante siglos un elemento esencial en el paisaje de los ríos castellanos. [...] La Edad Media supuso el desarrollo y la generalización del molino hidráulico, en parte por tradición árabe y en parte también como producto del ingenio de los constructores españoles. Su técnica avanzada hace que tengamos que diferenciar vaios tipos de molinos de agua en función del modo de aprovechamiento de la energía hidráulica" (García Tapia 1997: 22). "Aunque a lo largo de la Edad Media aceña tuvo significados muy distintos, ya a mediados del siglo XVI equivale a molino (hidráulico) harinero de rueda vertical" (Catálogo Felipe II: 251).

aceña, V. molino de $\sim$.

acequia, acequia, açequia, assequia, azequia [del hispano-ár. assáqiya 'íd.' y este del ár. clás. sāqiyah 'irrigadora'. 1140 (DRAE). Fernández de Enciso, Suma de Geographía, 1530]. sust. f. Ingen. Hidrául. Zanja o canal por donde se conduce el agua, generalmente para regar tierras o para acercarla a alguna localidad.

Fernández de Enciso, Suma de Geographía, 1530, fol. XLVIIIr: E los egipcios tienen fechas ciertas acequias por donde, quando el Nilo crece, entra mucha parte del agua del Nilo en este lago. // Celso, Reportorio universal leyes Castilla, 1553, fol. CCCIXv: Quién deve mantener las acequias o caños por do passa la tal agua a la heredad a quien deve la servidumbre, dezimos de suso, capítulo heredad, versículo VIII. // Anónimo, Repertorio tiempos, 1554, fol. XXXVIIv: En este mes se hazen pocas obras del campo, empero en las huertas puédese poner las ortalizas, y en la menguante de la Luna se puede cortar la madera y cañas y mimbres. Puédense sembrar lechugas, rávanos y ajos. Puédense adovar los vallados, limpiar acequias, cerrar portillos.

SIN.: cequia ${ }_{1}$, regadera.

HIPER.: obra hidráulica.

FAM.: cequia.

[IMAGEN] Pseudo-Juanelo Turriano, Los ventiún libros, c. 1605, fol. 79v, fig. 45, letra E.

2 [Lobato, Notas, a. 1585]. sust. f. Ingen. Hidrául. Zanja o canal descubierto por donde se conduce el agua para que mueva máquinas hidráulicas o por donde se da salida a la que ya ha sido utilizada para este fin.

Lobato, Notas, a. 1585, fol. 26: Y que vaciase el otro brazo en una rueda de molino que luego moviese, y que después por la acequia de aquella agua podrían volver otras ruedas hasta que se volviese al dicho río. // Juanelo Turriano, Veinte y un libros, a. 1605, fol. 78r: Si acaso se sacase alguna acequia de algún río que caminase muy mansamente, se le deve dar muy más caýda de la que se a dicho, que a mill passos se le deve dar tres pies de caýda, porque con tal caýda caminará muy maravillosamente. // Juanelo Turriano, Veinte y un libros, a. 1605, fol. 464v: Digo que la assequia N llevará ventaja quanto más atrás será puesta la piedra con el agujero que mide el terçio, que su çequia vaya más ancha. 
SIN.: cequia 2 .

HIPER.: obra hidráulica.

[IMAGEN] Lobato, Notas, c. 1585, figura del folio 35.

acerado, acerado, açerado, azerado [de acerar (DRAE). Pérez Vargas, De re metallica, 1568]. adj. Que tiene acero y está templado con él.

Pérez Vargas, De re metallica, 1568, fol. 150r: Es notable secreto, y házese assí: en un hierro azerado se labra, lo más al natural que es possible, la figura y cosa que queremos a manera de punçón // Sanctiago, Arte separatoria, 1598, fol. 110v: Y con este calor despide el cobre la sulfuridad y la communica a las tales cosas densas y con ella pierden su continuo, el qual no se sugeta con picos ni otras herramientas aceradas. // Juanelo Turriano, Veinte y un libros, a. 1605, fol. 228r: Y en la pala d'esta barrena a de estar muy bien açerada a los dos costados.

FAM.: acero.

acero, acero, açero, azero, hazero [del lat. tardío ăciarium 'íd.'. H. 1220-1250, Berceo (DECH). Fernández de Enciso, Suma de Geographía, 1530]. sust. m. Metal que se cría en las venas de la tierra de la especie del hierro, pero aún más puro, más fino y fuerte que el artificial, que se hace del hierro purificado y sin escoria (Autoridades).

Fernández de Enciso, Suma de Geographía, 1530, fol. LIVr: En esta tierra ay fierro e azero e muchos oficiales ferreros, que hazen armas e todas las cosas necessarias y ferramientas de ello, de que usan como nosotros. // Martínez de Burgos, Reportorio premáticas y Cortes, 1551, fol. XXXVv: Sobre que no se saque hierro ni hazero d'estos reynos para el reyno de Francia ni para otras partes, nos avemos mandado que durante la guerra no se saque vena. // Lobato, Notas, a. 1585, fol. 34: El palo ha de ir calzado con mucho y fuerte acero, porque en mucho tiempo no sea menester desarmarle para calzarle.

FAM.: acerado.

acha, V. hacha.

achiflonar, achiflonar [de a chiflón 'formando un ángulo agudo' (DRAE). Llanos, Diccionario minas, c.1609-11]. v. tr. u. t. c. prnl. Constr. Hacer un chaflán o rebajo en declive a la extremidad de algún cuerpo plano (Bails, en Clairac s. v. achaflanar). 
Llanos, Diccionario minas, c.1609-11, pág. 4: A chiflón y achiflonarse: Es cierta manera de labrar que se dirá en la palabra labrar, $\mathrm{n}^{\circ}$ 133. // Llanos, Diccionario minas, c.1609-11, pág. 127: A chiflón y achiflonarse.

FAM.: chiflón.

achrobaticon, V. acrobaticon.

acribado, acrivado [de acribar. Collado, Plática Artillería, 1592]. adj. Limpiado por medio de la criba.

Collado, Plática Artillería, 1592, fol. 57r: A henchir de muy buena tierra acrivada pero, pudiéndose haver de la greda, será muy más provechosa. // Collado, Plática Artillería, 1592, fol. 103v: Házese, assimismo, un terrero de tierra acrivada, porque no salten piedras dando las balas en ella.

FAM.: criba, cribar, cribo.

acrivado, V. acribado.

acrobaticon, achrobaticon, acrobaticon [tomado del gr. àkpoßatıkós,

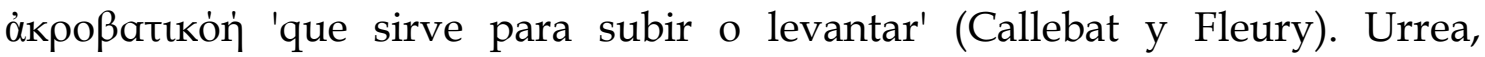
Vitruvio, Architectura, 1582]. sust. m. Mec. Máquina que sirve para levantar fardos pesados (Clairac s. v. acrobática).

Urrea, Vitruvio, Architectura, 1582, fol. 123v: Ay un género de máchinas que llaman los griegos achrobaticon, que es para subir; los latinos la llaman scansoria. // Urrea, Vitruvio, Architectura, 1582, 139r: Acrobaticon: por máchina para subir.

HIPER.: máquina.

acueducto, aquaducto, aquaeducto [tomado del lat. ăquaedūctŭs 'conducto de agua', 'acueducto' (DECH). 1587, De la antigua lengua, Andrés de Poza (CORDE). Loçano, Alberto, Architectura, 1582]. sust. m. Ingen. Hidrául. Conducto de agua que se forma o por canales y caños subterráneos o por arcos levantados (Autoridades).

Loçano, Alberto, Architectura, 1582, pág. 51: Lo mismo he visto acontecer de algunos aquaeductos antiguos, que, congelados los lados de las formas, se encostran con un cierto engomamiento de piedra. // Loçano, Alberto, Architectura, 1582, pág. 325: Y es cosa clara que a la cisterna se le embía la agua desde el río o fuente por aquaductos, y que también a cada passo acostumbraron coger las lluvias de los texados o del suelo. 
// Loçano, Alberto, Architectura, 1582, pág. 325: Y en ésta, por un aquaducto soterráneo, metía la lluvia recebida en el hoyo de arriba por arcaduzes, porque aquel hoyo era puesto en muy alto lugar.

SIN.: aguaducho 2.

HIPER.: obra hidráulica.

FAM.: agua, aguacero, aguador, aguaducho, aguaducto, aguamanil, aguanoso, aguar, aguatocho, desaguadero, desaguar.

açada, V. azada.

açadón, V. azadón.

açequia, V. acequia.

açerado, V. açerado.

açero, V. acero.

açuche, V. azuche.

açuda, V. azud.

açude, V. azud.

açuela, V. azuela.

açute, V. azud. 
adoba, adoba [del hispano-ár. ațtúb, este del ár. clás. țūb, y este del egipcio dbt. 1403, BRAE IV, 523 (DECH). Juanelo Turriano, Veinte y un libros, a. 1605]. sust. f. arag. Cuerpo regular construido con tierra arcillosa y bien batida, a la que a veces se mezcla cal y arena, o estiércol, o paja, o heno cortado para que tenga más unión, que se emplea en la construcción de paredes o muros (Clairac s. v. adobe).

Juanelo Turriano, Veinte y un libros, a. 1605, fol. 269v: Encima de madera usaron los antiguos adobas crudas o ladrillos por cozer. // Juanelo Turriano, Veinte y un libros, a. 1605, fol. 269v: Y d'esta materia hizieron muchas paredes y muchos edificios de solas tapias de tierra, sin ninguna otra mixtura, la qual invençión dura hasta hoy día, ansí de las adobas como de las tapias.

SIN.: adobe.

FAM.: adobe.

adobe, adobe, adove [del hispano-ár. atțúb, este del ár. clás. tū b, y este del egipcio $\underline{d} b t .1157$ (DRAE). Loçano, Alberto, Architectura, 1582]. sust. m. Cuerpo regular construido con tierra arcillosa y bien batida, a la que a veces se mezcla cal y arena, o estiércol, o paja, o heno cortado para que tenga más unión, que se emplea en la construcción de paredes o muros (Clairac).

Loçano, Alberto, Architectura, 1582, pág. 340: La pared que se hiziere de adobes secados, antes por dos años será la más cómmoda de todas para la salud. // González de Medina, Examen fortificación, 1599, pág. 34: Es también boníssimo terrapleno de adobes grandes, bien hechos, con su paja mezclados o con heno, crudos y assentados por orden, y ligados con cal y arena muy rala, casi como agua: házese un terrapleno como de una pieça fuerte. // Alonso Barba, Arte de los metales, 1640, fol. 63r: Hágase un horno de adoves y barro fuerte, amassado de greda, arena y estiércol con agua salada, a manera de baúl.

SIN.: adoba.

FAM.: $a d o b a$.

adove, V. adobe.

aedificado, V. edificado. 
aedificio, V. edificio.

aexe, V. eje.

affermar, V. afirmar.

affijar, V. afijar.

affirmación, V. afirmación.

affirmado, V. afirmado.

affirmar, V. afirmar.

afijado, afijado, afixado [de fijo. Urrea, Vitruvio, Architectura, 1582]. adj. Hincado, clavado, asegurado en otro cuerpo.

Urrea, Vitruvio, Architectura, 1582, 145v: C: sortija, en la qual se rebuelven los codaces o aguijones, afixados con plomo en las cabeças de la columna para tiralla. // Lobato, Notas, a. 1585, fol. 15: Digo que la entruesga tenga ciento sesenta pendazos y pueda estar pegada por más fuerte con la propia grúa afijada y clavada en un tímpano, y sería menos largo y embarazoso el eje y ella herirá con más fuerza yendo todo junto.

SIN.: fijado.

FAM.: afijar, fijado, fijar, fijo.

afijar, affixar, afijar, afixar [de fijo. Urrea, Vitruvio, Architectura, 1582]. v. tr. Hincar, clavar, asegurar un cuerpo en otro (DRAE s. v. fijar).

Urrea, Vitruvio, Architectura, 1582, fol. 50v: Después d'esto, todo lo que tenían salido afuera las vigas lo cortaron al nivel de la pared, lo qual, paresciéndoles desgraciado, affixaron unas tablillas pintadas, como agora se hazen los trigliphos, contra los cortes de las vigas. // Juanelo Turriano, Veinte y un libros, a. 1605, fol. 120r: Conviene advertir que los caños se han de afixar con calçina o yeso biscocho, o con otro material 
que los tenga muy firmemente afixados dentro de las canales de los maderos. // Juanelo Turriano, Veinte y un libros, a. 1605, fol. 140v: Los maderos que se afixarán dentro de la peña, convendrá que ellos sean dos palmos de ancho y dos de alto.

SIN.: fijar.

FAM.: afijado, fijado, fijar, fijo.

afilar, afilar [de filo. H. 1250, Libro de Alexandre (DECH). Medina, Arte de navegar, 1545]. v. tr. Sacar filo o hacer más delgado o agudo el de un arma o instrumento (DRAE).

Medina, Arte de navegar, 1545, fol. 81r: A lo tercero, si el peón está boto, subtilmente lo deve afilar, en manera que vea que la rosa no corre demasiado, ni tampoco ande muy a espacio. Y si afilándolo viere que la rosa corre mucho, toque subtilmente con algún hierro en la punta.

SIN.: aguzar.

FAM.: fil, filo.

afirmación, affirmación [tomado del lat. affirmātǐō, affirmātǐonis 'íd.'. Loçano, Alberto, Architectura, 1582]. sust. f. Efecto de afirmar o colocar algo de forma que permanezca firme.

Loçano, Alberto, Architectura, 1582, pág. 332: La qual affirmación hecha, estenderéys por arriba otros maderos atravessados, y sobre este zarço ajuntaréys cantidad de piedras, y apegaldas con cal.

FAM.: afirmado, afirmar, firmado, firmar, firme, firmemente, firmeza.

afirmado, affirmado, afirmado [de afirmar. Loçano, Alberto, Architectura, 1582]. adj. Puesto o colocado de manera que permanezca firme.

Loçano, Alberto, Architectura, 1582, pág. 177: Si no uviere en el tal peso un clavo de hierro de tres cobdos fuerte, hincareysle del todo en el suelo macizo o affirmado con troncos atravessados. // Loçano, Alberto, Architectura, 1582, pág. 115: Y para que, si acaso la continuación de las hondas con successo de las tempestades limpiare algo de la ribera, no se corte con todo esso el camino, estendida la puente azia el campo, las bóvedas y arcos, assí por las demás cosas como por los fuertes y continuos temblores de los carros, conviene que sean muy señaladamente fuertes y maravillosamente affirmados. // Juanelo Turriano, Veinte y un libros, a. 1605, fol. 227r: La maça es de carrasca, y los quatro braços $\mathrm{D}$ no passan de parte a parte, mas sólo entran quatro dedos en la maça cada uno d'ellos, y están afirmados con una clavija de madera. 
SIN.: firmado.

FAM.: afirmación, afirmar, firmado, firmar, firme, firmemente, firmeza.

afirmar, affermar, affirmar, afirmar [de firmar. Sagredo, Medidas Romano, 1526]. v. tr. Poner o colocar algo de modo que permanezca firme (DRAE s. v. asentar).

Sagredo, Medidas Romano, 1526, pág. 73: Item, los fundamentos que hizieres, penetren toda la tierra que se mostrare movediza, e si el lugar no fuere assaz sólido, o por ventura fuere cenagoso y de mala disposición para confiar tus cimientos en él, puédesle afirmar y reparar fincando en él muchas estacas de robre o de olivo. // Juanelo Turriano, Veinte y un libros, a. 1605, fol. 391r: Y donde tiene la C, es menester que de la misma pieça salga más baxo un pedaço, digo de hierro, el qual sea quadrado y que pueda entrar en la ménsula $D$, y que sea hecho un agujero quadrado para que entre el hierro C, y que se pueda affirmar en el hierro D. / / Juanelo Turriano, Veinte y un libros, a. 1605, fol. 456v: Y si el suelo fuesse de peña, agujerarse a con algún instrumento, y procurar de affirmar estos maderos muy bien y que estén muy seguros.

SIN.: firmar.

FAM.: afirmación, afirmado, firmado, firmar, firme, firmemente, firmeza.

afixado, V. afijado.

afixar, V. afijar.

agua, agua [del lat. ăqua 'íd.'. Orígenes del idioma (DECH). Ortega, Conpusición Arismética y Geometría, 1512]. sust. f. Elemento principal entre los cuatro. Los más de los filósofos sintieron era uno de los principios de la naturaleza. Divídese en dos especies, natural y artificial. La natural es la que cae de las nubes, la del mar, la de los ríos, arroyos, fuentes y pozos, y artificial la que es compuesta, como agua de azahar, agua rodada (Autoridades).

Ortega, Conpusición Arismética y Geometría, 1512, fol. 128v: Un maestro de picar piedra a fecho una fuente de piedra para tener agua, y la a fecho con cinco caños, en tal manera que si abren el un caño, que en el mayor, que toda el agua que estuviere dentro saldrá en un día. // Besson, Teatro instrumentos, 1602, fol. H3v: La rueda voluble d'éste, que está a mediodía, es equidistante a la muela de piedra, a la qual corre el agua de la parte de oriente; no, pero, importando de qué parte ella corra. // Juanelo Turriano, Veinte y un libros, c.1605, fol. 1v: Ay, o tienen duda algunos, si la agua que mana de las fuentes o poços, si el agua d'estas fuentes o poços, si ella se recoge toda ella de las aguas de las lluvias, o si tiene de la misma tierra su principio o nascimiento. 
FAM.: acueducto, aguacero, aguador, aguaducho, aguaducto, aguamanil, aguanoso, aguar, aguatocho, desaguadero, desaguar.

agua, V. despidiente de $\sim(s)$.

agua, V. molino de .

agua, V. nivel de .

aguacero, aguacero, aguaçero, aguazero [de aguaza. 1492, Woodbr. (DECH). Lobato, Notas, c.1585]. sust. m. Ingen. Hidrául. Canal de desvío en un torrente (García-Diego y García Tapia 1987).

Lobato, Notas, c.1585, fol. 13: El agua que viene a topar cuando llueve de [las] cuestas a topar en el cauce que va por la ladera o balsa del molino, ponerla en el hondo que hubiere de llevar su corriente, y luego labrar enfrente de dicho aguacero o caño un puente de uno o dos ojos, los que sean necesarios.

HIPER.: obra hidráulica.

FAM.: acueducto, agua, aguador, aguaducho, aguaducto, aguamanil, aguanoso, aguar, aguatocho, desaguadero, desaguar.

aguaçero, V. aguacero.

aguador, aguador [de agua (DECH). Roxas, Sumario milicia, 1607]. sust. m. Persona que tiene por oficio el llevar o vender agua (DRAE).

Roxas, Sumario milicia, 1607, fol. 51r: Y mandó que hubiese pocos aguadores y leñadores y que todas las vestias de albarda se bendiesen, salvo que quedasen las forçosas.

FAM.: acueducto, agua, aguacero, aguaducho, aguaducto, aguamanil, aguanoso, aguar, aguatocho, desaguadero, desaguar.

aguaduche, V. aguaducho. 
aguaducho, aguaduche, aguaducho [del lat. ăquaeductŭs 'conducto de agua', 'acueducto' (DECH). Celso, Reportorio universal leyes Castilla, 1553]. sust. m. Ingen. Hidrául. Conducto de agua que se forma generalmente por canales y caños.

Celso, Reportorio universal leyes Castilla, 1553, fol. LVIIIr: Casa, si fuere vendida, en la tal venta no solamente se comprehende la casa, mas aun los pozos, caños y canales y aguaduchos, $\mathrm{y}$ todas las otras cosas que en aquel tiempo eran para servicio de la tal casa. // Arphe, Varia Commensuración, 1585-87, fol. 17r: Están pegados uno a otro, como aguaducho de fuente, con unas ternillas, porque no se lastimen al moverse, y tiene más cada huesso de éstos siete salidas. // Besson, Teatro instrumentos, 1602, fol. Ov: Mas el pintor se ha dexado los aguaduches o canales de madera, que avían de estar cerca del pandero, más arriba, en los quales se viertan las aguas, porque malamente han sido pintadas aquí hazia el oriente.

HIPER.: obra hidráulica.

FAM.: acueducto, agua, aguacero, aguador, aguaducto, aguamanil, aguanoso, aguar, aguatocho, desaguadero, desaguar.

2 [Juanelo Turriano, Veinte y un libros, a. 1605]. sust. m. Ingen. Hidrául. Conducto de agua que se forma o por canales y caños subterráneos o por arcos levantados.

Juanelo Turriano, Veinte y un libros, a. 1605, fol. 434r: Y después podranse cavar, apartado d'este encerramiento, unos poços, los más hondos que ser pueda, y venir subiendo unos pilastrones de diez y seis pies de gruesso. Haranse los pilastrones en la manera que van señalados en los pilastrones de los aguaduchos.

SIN.: acueducto.

HIPER.: obra hidráulica.

aguaducto, aguaducto [del lat. ăquaeductŭs 'conducto de agua', 'acueducto' (DECH). Herrera, Institución Academia, 1584]. sust. m. Ingen. Hidrául. Conducto de agua que se forma generalmente por arcos levantados.

Herrera, Institución Academia, 1584, fol. $3 \mathrm{r}$ : Y, ansimismo, fontaneros y niveladores de las aguas, para los aguaductos y regadíos que en estos reynos tan importantes y convenientes serían. // Juanelo Turriano, Veinte y un libros, c.1605, fol. 78r: Y por esta causa se inventaron los aguaductos, para poder llevar el agua donde la tenían menester, y a esta causa hizieron unos grandíssimos arcos, para poderla passar de un monte a otro. // Juanelo Turriano, Veinte y un libros, c.1605, fol. 78v: De modo que los aguaductos son hedificios que mucho más se preciaron los antiguos de hazerlos, y con 
tanto gasto como los vemos hechos, y con tanto artificio, que en ellos pusieron cornisas, architraves, frisos, capiteles, basas, figuras con encassamentos,

HIPER.: obra hidráulica.

FAM.: acueducto, agua, aguacero, aguador, aguaducho, aguamanil, aguanoso, aguar, aguatocho, desaguadero, desaguar.

[IMAGEN] Pseudo-Juanelo Turriano, Los ventiún libros, c. 1605, fol. 84v, fig. 54.

aguamanil, aguamanil [del lat. tardío ăquămănīe 'íd.'. 1069, Orígenes del idioma (DECH). Urrea, Vitruvio, Architectura, 1582]. sust. m. Especie de palanca o manivela.

Urrea, Vitruvio, Architectura, 1582, fol. 122r: Que sea menor en sus quicios de torno macho y hembra, entre sí tan apretados, que el menor, a manera de aguamanil, estrecha y livianamente ande alrededor. // Urrea, Vitruvio, Architectura, 1582, fol. 132r: Encima del catino, que es un vaso de metal, está la pénula, que es a modo de aguamanil buelta y bien assentada, la qual se detiene passando un cuño por una hevillera y el catino. // Urrea, Vitruvio, Architectura, 1582, fol. 133r: Y en cada canal está un pistomio, que es una llave con aguamaniles de hierro, los quales, quando se tuercen, abren las narizes de las canales.

FАМ.: acueducto, agua, aguacero, aguador, aguaducho, aguaducto, aguanoso, aguar, aguatocho, desaguadero, desaguar.

aguanoso, aguanoso [del lat. aquānus, de aqua (DRAE). 1535 (DRAE). Pérez Vargas, De re metallica, 1568]. adj. Lleno de agua o demasiado húmedo (DRAE). Pérez Vargas, De re metallica, 1568, fol. 11r: Pues, como la mezcla de todos los metales sea de un seco terrestre sulphúreo y del húmido radical aguanoso, el qual a sido purificado de su untuosidad azeytosa y superfluo humor. // Mendoça, Theórica y práctica, 1596, pág. 95: Y quando es aguanoso el terreno, se han valido algunos de caxas de madera, llenándolas de tierra.

FAM.: acueducto, agua, aguacero, aguador, aguaducho, aguaducto, aguamanil, aguar, aguatocho, desaguadero, desaguar.

aguar, aguar [de agua. Lobato, Notas, c.1585]. v. prnl. Ingen. Hidrául. Dicho de un sitio o de un terreno: llenarse de agua (DRAE).

Lobato, Notas, c.1585, fol. 35: Y conforme al agua que dejare estar en el pozo moliendo sin aguarse se ha de hacer la salida, para que vuelva. // Lobato, Notas, c.1585, fol. 18: El de arriba es molino de pasaje de agua. Hemos puesto cubierta la casa con crecida de agua para mostrar por qué razón muele y no se agua aunque esté debajo del agua.

ANT.: desaguar. 
FAM.: acueducto, agua, aguacero, aguador, aguaducho, aguaducto, aguamanil, aguanoso, aguatocho, desaguadero, desaguar.

aguatocho, aguatocho [del lat. ăquaeductŭs 'conducto de agua', 'acueducto', parece ser duplicado de aguaducho: la -t- puede deberse a aguatel que, con el mismo significado de 'compuerta', aparece en un texto jurídico aragonés de h. 1400. Aquatel está compuesto por el verbo tŏllĕre (hoy aguatiello por influjo del sufijo -ellum) (DECH). Loçano, Alberto, Architectura, 1582]. sust. m. Ingen. Hidrául. Compuerta que en los molinos y canales permite la entrada y salida de agua.

Loçano, Alberto, Architectura, 1582, pág. 335: Y después disponed en los lugares convenientes y oportunos sumideros de agua, aguatochos y herradas, y todo instrumento para secar. // Lobato, Notas, c.1585, fol. 31: Todo lo cual y muy más bajo se puede hacer, por razón que para el ingenio que yo he imaginado se ha de bajar la balsa del molino más de cuatro pies, a par de las canales, y aún más, de manera que desde la peñuela que está entre el molino y San Cosmes acabe la balsa y tenga 10 pies de agua a los aguatochos, o 9 por lo menos. // Lobato, Notas, c.1585, fol. 32: Y, así como la balsa se baje junto a los aguatochos, ella dirá la hondura que el cauce ha de tener.

SIN.: trampa.

HOL.: obra hidráulica.

FAM.: acueducto, agua, aguacero, aguador, aguaducho, aguaducto, aguamanil, aguanoso, aguar, desaguadero, desaguar.

aguazero, V. aguacero.

aguçar, V. aguzar.

agudo, agudo [del lat. ăcūtus 'íd.', participio pasivo de acuēre 'aguzar'. H. 1140, Cid (DECH). Fernández de Enciso, Suma de Geographía, 1530]. adj. Puntiagudo, punzante, afilado (DRAE).

Fernández de Enciso, Suma de Geographía, 1530, fol. IVv: Y d'esta manera cada parte será aguda en lo que anda y está junto con el exe, e los cabos que están cabo los polos serán agudos. // Juanelo Turriano, Veinte y un libros, a. 1605, fol. 229r: Y para ver esto conviene hazer un hierro, el qual sea muy largo y agudo y delgado, puntiagudo, en tal manera hecho que, calándole dentro, tenga una hasta muy larga. // Juanelo Turriano, Veinte y un libros, a. 1605, fol. 439r: El vasillo, quanto más tendrá la punta levantada y aguda, tanto más serán ligeros para navegar.

FAM.: aguzar. 
aguilón, aguilón [de aguila. 1572, AFA (Frago). (DECH). Juanelo Turriano, Veinte y un libros, a. 1605]. sust. m. Ingen. Hidrául. arag. Caño cuadrado de barro (DRAE).

Juanelo Turriano, Veinte y un libros, a. 1605, fol. 283v: Ay otro modo de alcaduzes, los quales llaman aguilones, los quales son quadrados, a modo de canales de madera, mas ellos no son más largos de tres palmos y medio. / Juanelo Turriano, Veinte y un libros, a. 1605, fol. 283v: Y estas paredes yvan, de la una a la otra, unas losas atravesadas con tierra encima, y ansí estavan en vazío estos aguilones.

HIPER.: obra hidráulica.

aguzar, aguçar, aguzar [del lat. vg. *acutiare 'íd.', (lat. clas. ăcŭĕre 'hacer agudo'), derivado de ăcūtus 'agudo'. H. 1220-1250, Berceo (DECH). Urrea, Vitruvio, Architectura, 1582]. v. tr. Sacar filo o hacer más delgado o agudo el de un arma o instrumento (DRAE s. v. afilar).

Urrea, Vitruvio, Architectura, 1582, fol. 96v: Y en el nivel más alto con amoladura de piedra de aguzar herramienta, quitada la espuma, se da forma de suelo negro. // Besson, Teatro instrumentos, 1602, fol. G4v: Nueva hechura de molino a braços para prensar y aparejar paños y papel, y moler especies, y esmenuzar piedras preñadas de metales para preparallas a hundir, y también para pulir y aguzar qualesquier instrumentos soltados a cigoñales y majaderos. // Ufano, Tratado de la Artillería, 1613, pág. 421: Más, le toca traer una lima o dos, para limar y aguçar los çoquetes, cucharas y otras cosas que ympidan el ladino entrar en la pieça;

SIN.: afilar.

FAM.: agudo.

aja, axa [del lat. ascia 'íd.' (DECH). Juanelo Turriano, Veinte y un libros, a. 1605]. sust. f. arag. Herramienta formada por una plancha de hierro y un mango corto, que se utiliza para labrar la madera.

Juanelo Turriano, Veinte y un libros, a. 1605, fol. 248r: En la figura: Segur o estral. Açuela. Axa. Tintero de almagra. Compás.

SIN.: azuela.

HIPER.: herramienta.

[IMAGEN] Pseudo-Juanelo Turriano, Los ventiún libros, c. 1605, fol. 248r, fig. 316. Está situada en la parte de arriba de la imagen, a la derecha.

al, V. escarzo. 
ala, ala [del lat. āla 'íd'. H. 1220-1250, Berceo (DECH). Lobato, Notas, a. 1585]. sust. f. Mec. Cada una de las paletas que forman la hélice de un molino.

Lobato, Notas, a. 1585, fol. 20: Lo cual se ha de mover junto todo a la redonda, para amurar el dicho molino al viento que lo corriere. Y no ha de cubrir sino el redondo de la torre, dejando las alas por de fuera. // Besson, Teatro instrumentos, 1602, fol. H3v: La muela d'este molino está asida con la rueda en el mesmo árbol, lo que se avía de notar. Y ahunque la manera de hazerla sea, en Tolosa y en otras partes, común, empero, nuestro autor la ha mejorado, a lo menos en esto: que las alas de la rueda se van girando.

HOL.: molino.

álaba, V. álabe.

álabe, álaba, álabe, álava [del latín alăpa 'bofetada', 'golpe' > 'vuelo', 'ala'; probablemente con influjo de ala (Diccionario Histórico). S. XIII (DECH). Lobato, Notas, c.1585]. sust. f. Mec. Cada una de las paletas de una rueda hidráulica (Salinero).

Lobato, Notas, c.1585, fol. 36: Este rodezno de madera ha de tener tres pies y medio de ancho y un pie de alto, y en él cavadas seis álabes al modo de cuchares que la una desagüe por debajo de las otras y ha de llevar el cuadrado en medio en proporción. // Juanelo Turriano, Veinte y un libros, c.1605, fol. 290r: Y en E vierte esta canal la agua, en las álabas de la rueda, la qual está hecha a bueltas, las quales bueltas son veynte y quatro. // Juanelo Turriano, Veinte y un libros, c.1605, fol. 300r: Y en la parte baxa está asentada la rueda $\mathrm{L}$ o rodete con sus álabas.

SIN.: calcaño.

HOL.: rodete, rodezno.

FAM.: alabeo.

[IMAGEN] Pseudo-Juanelo Turriano, Los ventiún libros, c. 1605, fol. 290r, fig. 179.

alabeo, alabeo [de alabear (DRAE). Lobato, Notas, c.1585]. sust. m. Curvatura que aparece en las piezas de madera labrada.

Lobato, Notas, c.1585, fol. 35: Ha de tener el rebajo de alto lo que tuviere el rodezno y un dedo más, y aun dos, porque no tope el alabeo que hiciere el rodezno.

FAM.: álabe. 
alambor, alambor, lambor [probablemente del hispano-ár. harabúl 'orla', 'borde', 'revuelta' y este derivado del verbo clásico hawwwala 'alterar' (DRAE). 1583 (DECH). Juanelo Turriano, Veinte y un libros, a. 1605]. sust. m. Falseo de una piedra o madero (DRAE).

Juanelo Turriano, Veinte y un libros, a. 1605, fol. 172r: Y este alambor ha de ser, a las dos partes, conforme a esta figura aquí, que es $\mathrm{V}$, arriba, encima del açute, y lo quadrado es fundamento del azute. // Juanelo Turriano, Veinte y un libros, a. 1605, fol. 172r: Y este alambor ha de ser, a las dos partes, conforme a esta figura aquí, que es $\mathrm{V}$, arriba, encima del açute, y lo quadrado es fundamento del azute. // Juanelo Turriano, Veinte y un libros, a. 1605, fol. 416r: La M es lambor del redondo. La $\mathrm{N}$ es un llano que haze arriba, antes del antepecho.

FAM.: alamborado.

alamborado, alamborado, lamborado [de alambor (DECH). Juanelo Turriano, Veinte y un libros, a. 1605]. adj. Que tiene alambor (DRAE).

Juanelo Turriano, Veinte y un libros, a. 1605, fol. 135r: Y estas gradas an de yr alamboradas, a modo de barbacana, como se acostumbran a hazer en las murallas de los castillos. / / Juanelo Turriano, Veinte y un libros, a. 1605, fol. 296v: El cubo A B C es redondo y va lamborado desde el principio hasta la fin, que es en D. // Juanelo Turriano, Veinte y un libros, a. 1605, fol. 306r: Y porque las álabas están lamboradas de tal manera, que antes yrá la agua en alto que no herirá en firme en la álaba $C$.

FAM.: alambor.

alarife, alarife [del hispano-ár. al'arîf 'arquitecto', 'hombre entendido en construcción', y este del ár. clás. 'arîf 'experto' (DRAE). Entre 1493 y 1495, Nebrija (DECH). Loçano, Alberto, Architectura, 1582]. sust. m. Persona que tiene el cargo público de dirigir obras de construcción.

Loçano, Alberto, Architectura, 1582, VII: Los diez libros de León Baptista Alberto, que compuso de Architectura, los quales ha hecho traduzir Francisco Loçano, alarife d'esta villa de Madrid, de latín en romance. // Rojas, Teórica fortificación, 1598, fol. 92r: Sin considerar el mucho daño de las fábricas, nombran de su mano alarifes bárbaros en el oficio, sin ningunos principios de Arquitectura, sólo fundados en sus interesses particulares. // Rojas, Teórica fortificación, 1598, fol. 92r: Mirar muy bien a quién nombran por veedores y alarifes, escogiendo hombres de ciencia y conciencia.

ENCICL:: Término de origen árabe que en España ha venido a significar, frecuentemente, maestro de albañilería, pero que, a veces, puede referirse también a algunas de las artes auxiliares de la construcción e, incluso, a los canteros que levantaban una fábrica (Elucidario).

álava, V. álabe. 
albañal, albañar, alvañar [del hispano-ár. alballáa literalmente, 'tragona' y este del ár. clás. ballā'a 'cloaca', de la raíz báli' 'tragar' (DRAE). Fin s. XIII, Opúsculos legales de Alfonso X (DECH). Loçano, Alberto, Architectura, 1582]. sust. m. Ingen. Hidrául. Canal o conducto que da salida a las aguas sucias o llovedizas.

Loçano, Alberto, Architectura, 15 82, fol. 14: La cual agua se va por un albañar a sacar por bajo del rodezno. // Loçano, Alberto, Architectura, 1582, pág. 117: De los alvañares, unos son los que yo llamo derramaderos, porque vazían las aguas metidas en ellos al río, o a la laguna o a la mar. // Lobato, Notas, a. 1585, pág. 32: Pero, en qualquier parte de la casa que, o se caven poços, o se guiaren albañares, o se derramare agua y humedad, conviene que allí estén las aberturas, de tal suerte que respire por allí mucho ayre, con el qual se expelan y limpien las exalaciones húmedas del suelo con el soplo de los vientos o empujón del ayre.

SIN.: derramadero.

HIPER.: obra hidráulica.

ENCICL.: De los alvañares, unos son los que yo llamo derramaderos, porque vazían las aguas metidas en ellos al río, o a la laguna o a la mar; otros, al descubierto, en los quales, recogidas las suciedades de las aguas, no son hechadas a otra parte, sino, como embevidas en la madre de la tierra, assentándose, se deshazen (Loçano, Alberto, Architectura (1582), pág. 117).

2 [Loçano, Alberto, Architectura, 1582]. sust. m. Ingen. Hidrául. Depósito de aguas sucias o llovedizas.

Loçano, Alberto, Architectura, 1582, pág. 66: Allégase también que por aquí, abierta respiración, dará al edificio firmeza segura y no dañada por movimientos soterraños de las exhalaciones, así que, o con poço, o con cisterna, o albañar, o con otro cavar más profundo reconocida, y las cortezas que debajo de tierra estavan abscondidas, se ha de escoger la más acommodada para cometerle la obra. // Loçano, Alberto, Architectura, 1582, pág. 259: Demás d'esto en los theatros, por techo se encostran suelos y se hazen algo cuesta abajo, de suerte que las aguas corran azia las gradas, pero los arroyuelos de las aguas recogidas se sorverán por canales entre los ángulos de las paredes, y serán echados abajo por canales occultas azia los alvañares cerrados. // Lobato, Notas, a. 1585, pág. 117: Dizen la ciudad de Smirna, en la qual Dolobella libró del cerco a Trebonio, aver sido muy hermosa por tener las calles derechas, y por los ornamentos de las obras, pero que, por no aver albañares donde se recogiessen las inmundicias hechadas, se offendían los huéspedes y aun los habitadores con el hedor.

SIN.: vertedero ${ }_{2 .}$

HIPER.: obra hidráulica.

albañar, V. albañal. 
albañería, alvañería [de albañi. 1268 (DECH). Caxesi, Vignola, Regla cinco órdenes, 1593]. sust. f. Arte de construir edificios u obras en que se empleen, según los casos, ladrillos, piedra, cal, arena, etc. (DRAE s. v. albañilería).

Caxesi, Vignola, Regla cinco órdenes, 1593, III: Por ser muy útil y provechoso para la obra y fábrica de todas las artes de cantería, alvañería y carpintería y otras cosas, en lo qual avíades puesto mucho trabajo y ocupación.

SIN.: albañilería $a_{1}$

FAM.: albañil, albañilería.

albañí, V. albañil.

albañil, albañí, albañil, albañir [del hispano-ár. banní y este del árabe bannā' 'constructor', 'albañil' (DRAE). H. 1400, Glos. de Toledo (DECH). Pérez Vargas, De re metallica, 1568]. sust. $m$. Persona que tiene por oficio el construir edificios. Pérez Vargas, De re metallica, 1568, fol. 82v: El hazer de los hornos es cosa tan común que pocos albañires ay en las tierras donde se tracta que no lo sepan, quanto más que, ya que se ha ensayado la mina y se sabe que se puede labrar. // Collado, Plática Artillería, 1592, fol. 103r: Y, por quanto el arte en sí es de muchas otras artes menesterosa, conviene que hombres de muchas artes y officios se hallen a exercitarla, como son herreros, canteros, carpinteros, carreteros, arcabuzeros, albañires, marineros, polvoristas y refinadores de salitre. // Lechuga, Discurso de la Artillería, 1611, pág. 277: Esto sin puntillos ni fantasías vanas, pues la experiencia de fábricas políticas la alcanzan los ingenieros, aunque sepan todo lo que dizen, de los maestros albañires y de los carpinteros, que, en effecto, aunque mudos maestros, son los que saben obrar aunque les falte ciencia.

FAM.: albañería, albañilería.

albañilería, albañilería, alvañilería [de albañil (DECH). Celso, Reportorio universal leyes Castilla, 1553]. sust. f. Arte de construir edificios u obras en que se empleen, según los casos, ladrillos, piedra, cal, arena, etc. (DRAE).

Celso, Reportorio universal leyes Castilla, 1553, fol. CCVr: Maestros de carpintería y alvañilería, y otros officiales, no pueden alegar que fueron engañados en más de la meytad del justo precio. Petición CX, en Segovia, año de XXXII; y en Valladolid, año de XXXVIII, ley ochenta y cinco. // Lobato, Notas, c.1585, fol. 33: Hice el de Zapardiel, que le empecé a 10 de setiembre del dicho año la albañilería y a 26 de marzo 1576 a cavar. // Lobato, Notas, c.1585, fol. 33: Ha de ir a salir la dicha acequia cubierta de albañilería muy baja y con gran corriente dentro de la dicha balsa, no atravesada, sino 
al hilo del agua, a soltar casi la tercera parte de la balsa, y al fin asentar un marco de madera cuadrado, no levantado ni echado, sino de lado.

SIN.: albañería.

FAM.: albañería, albañil.

2 [Lobato, Notas, c.1585]. sust. f. Conjunto de materiales propios del arte de la albañilería, como los ladrillos, la piedra, la cal y la arena.

Lobato, Notas, c.1585, fol. 33: Ha de ir a salir la dicha acequia cubierta de albañilería muy baja y con gran corriente dentro de la dicha balsa, no atravesada, sino al hilo del agua, a soltar casi la tercera parte de la balsa, y al fin asentar un marco de madera cuadrado, no levantado ni echado, sino de lado.

albañir, V. albañil.

albardón, albardón [de albarda. 1438, Cortés (DECH). Juanelo Turriano, Veinte y un libros, a. 1605]. sust. m. Mec. Tabla plana de madera, de forma rectangular, sobre la que se colocan materiales o cargas para que sean izados o transportados.

Juanelo Turriano, Veinte y un libros, a. 1605, fol. 384r: Llámele cada qual como quisiere, porque unos le llaman el cavallo, otros asno, otros albardón, otros la zivilla de la grúa, otros coraçón, como aquél de las balanças de pesar las cosas.

SIN.: asno, caballo, cibilla, corazón.

[IMAGEN] Pseudo-Juanelo Turriano, Los ventiún libros, c. 1605, fol. 383v, fig. 378, letra Q.

alberca, alberca, alverca [del hispano-ár. albírka 'estanque', 'depósito de agua' y este del ár. clás. birka. 1253, Libro de los engaños (DECH). Pérez Vargas, De re metallica, 1568]. sust. f. Ingen. Hidrául. Depósito artificial de agua.

Pérez Vargas, De re metallica, 1568, fol. 79r: Todas estas canales y albercas o eras donde se lava el metal, se hinchen de agua, y se echa dentro el metal molido y con unos rodillos se meçe; // Urrea, Vitruvio, Architectura, 1582, fol. 20v: En la mano yzquierda del qual figuré el assiento de una grande ciudad, y en la mano derecha figuré una alverca, la qual recibiesse el agua de todos los ríos que están en aquel monte, // Juanelo Turriano, Veinte y un libros, a. 1605, fol. 345v: Abrase de hazer una alberca a cada anoria, para que tenga buena cantidad de agua.

HIPER.: obra hidráulica. 
alcantarilla, alcantarilla [de alcántara 'caja grande de madera'. 1202, F. de Madrid (DECH). Rojas, Teórica fortificación, 1598]. sust. f. Ingen. Hidrául. Puente pequeño para algún arroyo (Salinero).

Rojas, Teórica fortificación, 1598, fol. 84v: Y si se ofreciere algún arroyo o río, se harán alcantarillas o puentes conforme el sitio lo pidiere, guardando en todo la buena prática que se ha de tener en hazer el zulaque para juntar los caños.

HIPER.: puente.

alcayata, alcayata [del mozár. cayada 'cayado, bastón de pastor con gancho en la punta'. 1585, López Tamarid (DECH). Lobato, Notas, a. 1585]. sust. f. Clavo grande ganchudo (Salinero).

Lobato, Notas, a. 1585, fol. 21: Por de dentro, en el contorno de la torre, a trabarlas en gordas, veinticuatro alcayatas o garfios, en que las asían cuando estaba ya amurado el molino al viento con que había de moler. // Ufano, Tratado de la Artillería, 1613, pág. 322: Donde, con él y la alcayata de la madera, se ase y coliga la cadenilla, como se muestra en la figura.

alco, V. arco.

alçaprima, V. alzaprima.

alçaprime, V. alzaprima.

aldaba, aldava [del hispano-ár. aḍdabba, y este del ár. clás. ḍabba, literalmente, 'lagarta'. J. Ruiz (DRAE). Collado, Plática Artillería, 1592]. sust. f. Ingen. Hidrául. Pieza de hierro fija a cada lado de un río, en la que se atan las cuerdas de algunos puentes.

Collado, Plática Artillería, 1592, fol. 89r: Si la ribera será alta y de peña dura, conveniente cosa será, y aun necessaria, el hincar gruessas aldavas o sortijones de hierro engastados con plomo derretido en la peña misma, para de aquéllos atar las cuerdas de la puente. // Collado, Plática Artillería, 1592, fol. 89r: Como yo lo hize el 
año 1580, quando vino de Flandes el exército de la Magestad Cathólica, donde en la orilla del río Ródano, que era de peña biva, hinqué las aldavas dichas, que tenían un palo de hierro tan largo casi como un braço, el qual entrava dentro de la peña todo y después le henchí el agugero de plomo derretido, remedio bien importante y provechoso en aquel caso. // Collado, Plática Artillería, 1592, fol. 90v: Los quales pedaços son tan portátiles que quatro soldados llevan cada uno d'ellos y, siendo llegados al lugar donde se ha de armar el puente, van juntando los pedaços o troços de barca el uno con el otro y aquéllos asen con ciertas aldavas de hierro, como en la primera figura se vee manifiesto.

HOL.: puente.

2 [Juanelo Turriano, Veinte y un libros, a. 1605]. sust. f. Ingen. Hidrául. Pieza de hierro y de varias hechuras, fija en la pared de los puertos o muelles, en la que se atan las embarcaciones.

Juanelo Turriano, Veinte y un libros, a. 1605, fol. 412v: La H es la pared con las aldavas, que son G. La I, la barbacana o lambor. // Juanelo Turriano, Veinte y un libros, a. 1605, fol. 413v: Y tener cuenta de poner aldavas por las paredes, muy bien hechas de hierro, o sortijas o argollas. // Juanelo Turriano, Veinte y un libros, a. 1605, fol. 414r: La C es donde se atan las naos. La D es tres gradas. La G es el antepecho o pared. Y donde hay las aldavas es E. La escalera F entra dentro del puerto.

HOL.: obra hidráulica.

aldava, V. aldaba.

alfaharero, V. alfarero.

alfarero, alfaharero [de alfar 'obrador de alfarero', 'arcilla'. Lope (DECH). Pérez Vargas, De re metallica, 1568]. sust. m. Persona que tiene por oficio el fabricar vasijas de barro cocido.

Pérez Vargas, De re metallica, 1568, fol. 46r: Los vidrieros y alfahareros se aprovechan y usan d'estos medios minerales. // Pérez Vargas, De re metallica, 1568, fol. 91r: Fúndese también el plomo muy bien en horno de reberbero, que es de la manera del que hazen los olleros o alfahareros para hazer cal y quemar el plomo.

algibe, V. aljibe. 
algive, V. aljibe.

alguaça, V. alguaza.

alguaza, alguaça [del mozár. *algruaza, y este equivalente del val. gronça 'parte de la bisagra que lleva el pasador de la misma'. 1675 (DECH). Juanelo Turriano, Veinte y un libros, a. 1605]. sust. f. arag. Herraje articulado de dos piezas, enlazadas una con otra en un mismo eje, que, al moverse, cierran o abren aquello a lo que están unidas.

Juanelo Turriano, Veinte y un libros, a. 1605, fol. 120r: Y ansí tendrás tu intento, puniendo los maderos derechos con sus alguaças de metal, para que puedan jugar. // Juanelo Turriano, Veinte y un libros, a. 1605, fol. 365v: Y, por tanto, aquellas alguaças o frontizas han de desçendir hasta los cabos de las puntas como triángulos. / / Juanelo Turriano, Veinte y un libros, a. 1605, fol. 391v: Y las alguaças las hazen que ellas sean muy rezias y muy bien enclavadas en la puente de madera.

SIN.: frontiza, gonce, gozne.

aliviadero, aliviadero [de aliviar (DRAE). Lobato, Notas, c.1585]. sust. m. Ingen. Hidrául. Vertedero de aguas sobrantes embalsadas o canalizadas (DRAE). Lobato, Notas, c.1585, fol. 33: Y el aliviadero estará por la parte de hacia la cuba, a la parte que quisieren, y de la otra parte otro pequeño que vaya dentro del lobo. // Lobato, Notas, c.1585, fol. 34: El aliviadero ha de ir con la puente, puesto como parece en la plana de enfrente, en el cuadro alto. // Lobato, Notas, c.1585, fol. 35: Si se hubiere de poner puente o aliviadero, o marranos o rangua, o rodezno o cuba, estando hecha como pozo de 12 pies de hondo, no se podrá hacer si no es sacando el agua del dicho pozo.

HIPER.: obra hidráulica.

FAM.: aliviado, aliviador, alivianar, aliviar, alivio, leve, livianamente, liviano, soliviar.

aliviado, aliviado [de aliviar Urrea, Vitruvio, Architectura, 1582]. adj. Aligerado. Loçano, Alberto, Architectura, 1582, pág. 336: Después descargaréys la carga del navío, y vendrá a ser que, levantándose el navío aliviado, arrancará de raýz lo que se estuviere atado. // Lobato, Notas, a. 1585, fol. 36: Las piedras que este molino ha menester, además de piedras y tolva y demás aparejos de moler, son las vigas sobre las que se 
asienta la cuba y la dicha cuba y puente aliviada, canal y rangua, rodeznos y parahúsos, y todas estas piezas irán aquí pintadas, como se ve, cada cosa por sí, y arcos de hierro.

FAM.: aliviadero, aliviador, alivianar, aliviar, alivio, leve, livianamente, liviano, soliviar.

aliviador, aliviador [de aliviar Lobato, Notas, c.1585]. sust. m. Mec. Palanca que en los molinos harineros sirve para levantar o bajar la piedra, de modo que la harina pueda salir más o menos fina (DRAE).

Lobato, Notas, c.1585, fol. 36: Puente de roble o encina fuerte, para tener el rodezno y piedra, con el aliviador del alto que sea necesario con el guepejo o rangua. // Lobato, Notas, c.1585, fol. 36: Aliviador... 6.

HOL.: molino

FAM.: aliviadero, aliviado, alivianar, aliviar, alivio, leve, livianamente, liviano, soliviar.

[IMAGEN] Lobato, Notas, c. 1585, fol. 35. Está señalado con el número 6.

alivianar, alivianar [de liviano. Entre 1493 y 1495, Nebrija (DECH). García de Palacio, Instrución náuthica, 1587]. v. tr. Hacer ligero o menos pesado (DRAE s. v. aligerar).

García de Palacio, Instrución náuthica, 1587, fol. 129v: Alixar: es alivianar y hechar a la mar, quando ay tormenta, lo que la nao lleva, o si lleva carga demasiada. // García de Céspedes, Instrumentos nuevos, 1606, fol. 31v: Ay otra cosa que advertir: que si la cantidad de la agua fuere mucha, se lleve por dos caños, porque se reparta el peso, y los caños no tengan más hueco de quanto fuere menester para que descansadamente pueda caber la agua; que todo esto se haze para alivianar el peso de la agua.

SIN.: aliviar.

FAM.: aliviadero, aliviado, aliviador, aliviar, alivio, leve, livianamente, liviano, soliviar.

aliviar, aliviar [del lat. tardío alleviăre 'aligerar'. Entre 1493 y 1495, Nebrija (DECH). Loçano, Alberto, Architectura, 1582]. v. tr. Hacer ligero o menos pesado (DRAE s. v. aligerar).

Loçano, Alberto, Architectura, 1582, pág. 88: Y aplácenme los que, por causa de aliviar la carga, entremetieron ollas vacías hendidas y vueltas azia abajo, por las grossezas de los muslos, para que no pesen con la humedad de allí cogida. // Urrea, Vitruvio, Architectura, 1582, fol. 89r: Assimismo, se ha de tener cuenta que las bóvedas o arcos sustenten y alivien la carga de las paredes con divisiones de bóvedas. // Juanelo Turriano, Veinte y un libros, a. 1605, fol. 141r: Y que causan muy grande ayuda para aliviar la carga y pesso a los hierros y a todo lo demás.

SIN.: alivianar. 
FAM.: aliviadero, aliviado, aliviador, alivianar, alivio, leve, livianamente, liviano, soliviar.

2 [Ufano, Tratado de la Artillería, 1613]. v. tr. Ayudar a levantar algo por debajo (DRAE s. v. soliviar).

Ufano, Tratado de la Artillería, 1613, pág. 324: La qual ynvención es muy cómoda y buena para sacar o meter alguna rueda o para aliviar la pieça y desahogar la rueda del fango y graso terreno, de modo que, calçada con tablas o faxina, fácilmente se pueda sacar fuera.

SIN.: soliviar.

alivio, alivio [de aliviar. (DECH). Ufano, Tratado de la Artillería, 1613]. sust. m. Acción y efecto de aliviar (DRAE).

Ufano, Tratado de la Artillería, 1613, pág. 92: Demás d'esto, se deve considerar la diferençia de alivio que ay llevando un cañón de batería sobr'el carro mato o sobre su mismo afuste encabalgado, y la ligereza y descanso con que los caballos le tiran, por ser sus ruedas más altas y subtiles que las del afuste.

FAM.: aliviadero, aliviado, aliviador, alivianar, aliviar, leve, livianamente, liviano, soliviar.

aljibe, algibe, algive, aljibe [del hispano-ár. alŷúbb, y este del ár. clás. ŷubb 'pozo', 'cisterna'. 1202 (DECH). Mosquera, Comentario disciplina militar, 1596]. sust. m. Ingen. Hidrául. Depósito donde se recoge y conserva el agua llovediza o la que se lleva de algún río o manantial.

Mosquera, Comentario disciplina militar, 1596, fol. 91r: $\mathrm{Y}$ ase de advertir que todos los fuertes cerrados tenían o fuentes dentro, o pozos o algibes de buena agua para sustentarse, con toda munición y prevención necessaria. // Juanelo Turriano, Veinte y un libros, a. 1605, fol. 198r: Ésta es otra invención de algibes, los quales son tres bóvedas juntas, a causa que se empieza a bever del uno, que los otros dos están repossados, y ansí va de mano en mano. // Rojas, Compendio fortificación, 1613, fol. 40r: Luego, se hará la casa del castellano, con alojamiento necessario, los almazenes para las municiones, no olvidando el ospital y los algives y cisternas, si no huviere agua de pie.

SIN.: cisterna.

HIPER.: obra hidráulica.

[IMAGEN] Pseudo-Juanelo Turriano, Los ventiún libros, c. 1605, fol. 184v, fig. 161. Aljibes o caños cuadrados.

almádana, V. almádena. 
almadaneta, V. almadeneta.

almádena, almádana, almádena [del hispano-ár. almátana, y este cruce del ár. clás. mi'dan y el ár. hisp. patána 'trasto' 'cacharro' (DRAE). H. 1300, Gran Conquista de Ultramar (DECH). Acosta, Historia natural, 1590]. sust. f. Mazo de hierro con mango largo que se utiliza para romper piedras (DRAE).

Acosta, Historia natural, 1590, pág. 217: Y poco después añade: «Hieren la dura peña con almádanas que tienen ciento y cincuenta libras de hierro. // Acosta, Historia natural, 1590, pág. 217: Con cuños de hierro y con almádanas rompen las peñas y pedernales, por rezios y duros que sean, porque, en fin, es más rezia y más dura la hambre del dinero». // Ufano, Tratado de la Artillería, 1613, pág. 106: En pos de este troço, seguirán todas las municiones y aparatos de guerra que tocaren a la mitad de la provisión y conducta de todo el exérçito, assí de puentes, tablones, puntales y otras qualesquier máquinas, como de pólvora, balas y cuerda, çapas, palas, picos, uñas de cabra, almádenas, cuñas de hierro, marraços, hachas de mano y de golpe, sierras, herrerías y carpinterías.

SIN.: almadeneta ${ }_{2}$.

HIPER.: herramienta.

FAM.: almadeneta.

almadeneta, almadaneta [de almádena. Llanos, Diccionario minas, c.1609-11]. sust. f. Piedra dura y pesada utilizada para moler metal.

Llanos, Diccionario minas, c.1609-11, pág. 82: Almadaneta: De los metales pobres de vetas es la almadaneta, y se dice así por lo mucho que pesa, y es pedernal y algunos tan finos, que no pueden ser más, aunque son los de menos ley éstos tan buenos. // Llanos, Diccionario minas, c.1609-11, pág. 82: Las almadanetas que más tienen son pardas con manchas lagartadas, que las suele haber en los Altos del Estaño, Santa Cruz, Santa Bárbara y Ciegos Altos más ordinariamente que en otras partes del Cerro. // Alonso Barba, Arte de los metales, 1640, fol. 12v: Almadaneta llaman a otro género de piedra por su dureza y peso; es solidíssima, de color escuro, compañía de metales ricos que se crían en ella quando llega a madurar o podrir, como también los quijos.

FAM.: almádena.

2 [Llanos, Diccionario minas, ca. 1609-11]. sust. f. Mec. Mazo de hierro con mango largo que se utiliza para romper piedras (DRAE s. v. almádena).

Llanos, Diccionario minas, c.1609-11, pág. 29: El mortero es de madera muy fuerte, prolongado y guarnecido por lo alto con tejos de hierro en que hacen golpe las almadanetas para moler el metal. // Llanos, Diccionario minas, c.1609-11, pág. 121: 
Tejos: Son de hierro y sobre que hacen el golpe las almadanetas para moler el metal. Dijose en la palabra ingenio, $\mathrm{n}^{\mathrm{o}} 131$.

SIN.: almádena $a_{2}$

HOL.: herramienta.

ENCICL.: En la época era frecuente que las almadenetas se utilizaran en ingenios para moler metales.

almadía, almadía, almedía [del hispano-ár. alma'díyya 'barca de paso', 'almadía'. 1492-1493, Relación del primer viaje de Colón (DECH). Juanelo Turriano, Veinte y un libros, c.1605]. sust. f. Ingen. Hidrául. Conjunto de maderos unidos entre sí para facilitar el transporte por el agua, especialmente por los ríos (Diccionario Histórico).

Juanelo Turriano, Veinte y un libros, c.1605, fol. 247r: [...] sin estos vassos no podíamos saber, ni tantas armadas de mar que se hazen en diversas partes, si no fuese por la madera que de los montes nos viene, por vía de las almadías que nos trahen las maderas por los ríos abajo. // Juanelo Turriano, Veinte y un libros, c.1605, fol. 247v: Ay en algunas partes que los llevan los maderos sueltos, hasta allegar adonde ay cantidad de agua, y entonçes las hazen almadías. $Y$ donde no ay ríos no puede sacarse maderas muy largas, por causa del trabajo que ay en irlas arrastrando hasta llevarla en lugares cómodos para cargarla en carros. // Juanelo Turriano, Veinte y un libros, c.1605, fol. 248r: Las almadías las ligan con cosas de madera de avellano torcidas, que sirven como cuerdas, y les ponen remos. Mas estos remos que ponen a las almadías no es para que ellas caminen, mas sólo para yrlas guiando, que vayan en el corriente del agua, y de apartarlas de algún enqüentro.

2 [Collado, Plática Artillería, 1592]. sust. f. Balsa, especie de plancha formada por maderos ensamblados, que se emplea para navegar o transportar cosas por agua, especialmente por los ríos (Diccionario Histórico).

Collado, Plática Artillería, 1592, fol. 89r: Acostumbraron otros de passar las aguas de corriente rápida con almadías, que assí se llaman una composición de maderos muy gruessos, encadenados los unos con los otros y sobre ellos pueden hir muchos soldados, a la qual almadía llaman zátara en Italia. // Juanelo Turriano, Veinte y un libros, c.1605, fol. 248r: En Italia he visto ríos que trahen tres órdenes de maderos, unos sobre otros, y tres tramadas de largo. En unas partes de Italia he visto traher mercadurías encima de las almadías, como es hierro, alambre, plomo, y también traherlas cargadas de leña para el fuego, y en otras partes diversas cosas. // Juanelo Turriano, Veinte y un libros, a. 1605, fol. 456r: Porque no tiene ningún detenimiento de agua más de hazer; que como la agua tiene caída, que ella se va levantando hasta llegar al lugar conveniente de poder subir por este puerto, que a de ser muy largo y ancho, por la subida de las barcas y almedías.

SIN.: zátara. 
almedía, V. almadía.

almenara, almenara [del hispano-ár. mánhar 'canal' y este del árabe clásico manhar 'arroyo'. Ordenanza de Huertas de Zaragoza (DECH). Juanelo Turriano, Veinte y un libros, c.1605]. sust. f. Ingen. Hidrául. arag. Compuerta que distribuye el agua de una acequia.

Juanelo Turriano, Veinte y un libros, c.1605, fol. 108v: Donde es la A es la boca de la azequia. $\mathrm{Y}$ donde es la $\mathrm{B}$ es donde se pone el almenara de madera para çerrar, que no pueda entrar agua. // Juanelo Turriano, Veinte y un libros, c.1605, fol. 161r: Y convendrá hazer junto al açute la boca del acequia y, en tal modo, que se puede cerrar la acequia con su almenara de madera, a causa que, quando vienen los ríos crecidos, para que no pueda entrar más agua de lo que es neçessario. // Juanelo Turriano, Veinte y un libros, c.1605, fol. 454v: La fuerça d'esta máquina está en que se assegure muy bien el edificio, y que se vea cómo se abren y cierran las almenaras o puertas.

HOL.: obra hidráulica.

[IMAGEN] Pseudo-Juanelo Turriano, Los ventiún libros, c. 1605, fol. 108v, fig. 76. La letra B marca el lugar en el que se incorporaría una almenara en una acequia.

alnafe, V. anafe.

alvañar, V. albañal.

alvañería, $V$. albañería.

alvañilería, V. albañilería.

alvedriado, V. alvidriado. 
alvedriar, V. alvidriar.

alverca, V. alberca.

alvidriado, alvedriado, alvidriado [de alvidriar. Juanelo Turriano, Veinte y un libros, a. 1605]. adj. Que tiene un barniz transparente y esplendoroso como el vidrio (DRAE).

Juanelo Turriano, Veinte y un libros, a. 1605, fol. 275v: Y ponerle dentro de un vaso alvedriado, y ponerle al fuego, y irle meneando muy bien, a causa que se encorpore todo junto los materiales. // Juanelo Turriano, Veinte y un libros, a. 1605, fol. 283v: Ay otro modo de alcaduzes, los quales llaman aguilones, los quales son quadrados, a modo de canales de madera, mas ellos no son más largos de tres palmos y medio. Y éstos los hazen alvedriados. // Juanelo Turriano, Veinte y un libros, a. 1605, fol. 283v: Mas, cierto, ellos no valen ninguna cosa, ni alvidriados ni por alvedriar, porque ay tanto trabajo en ellos, en buscar dónde se pierde la agua, como en los redondos.

SIN.: vidriado.

FAM.: alvidriar, vidriado, vidriar, vidriero, vidrio.

2 [Juanelo Turriano, Veinte y un libros, a. 1605]. sust. m. Barniz transparente y esplendoroso como el vidrio.

Juanelo Turriano, Veinte y un libros, a. 1605, fol. 267r: Dévense de hazer los ladrillos de muy buena tierra, y la tierra, que ella no sea muy flaca, ni muy grassosa ni muy seca, porque se embeven el alvedriado.

alvidriar, alvedriar, alvidriar [de vidrio. Juanelo Turriano, Veinte y un libros, a. 1605]. v. tr. Dar al barro un género de barniz que tiene la transparencia y el esplendor del vidrio (Autoridades s. v. vidriar).

Juanelo Turriano, Veinte y un libros, a. 1605, fol. 283v: Mas, cierto, ellos no valen ninguna cosa, ni alvidriados ni por alvedriar, porque ay tanto trabajo en ellos, en buscar dónde se pierde la agua, como en los redondos. // Juanelo Turriano, Veinte y un libros, a. 1605, fol. 267r: Conviene hazer delgados los ladrillos que se alvidrian, por causa que se cuezen mejor que no los muy gruessos.

SIN.: vidriar.

FAM.: alvidriado, vidriado, vidriar, vidriero, vidrio. 
alzaprima, alçaprima, alçaprime, alzaprime [del ant. *alzaprime 'palanca o cuña para levantar algo'. 1535, Fz. de Oviedo (DECH). Ferrofino, Descrizión Artillería, 1599]. sust. f. Barra que se utiliza para mover o levantar cosas de mucho peso.

Ferrofino, Descrizión Artillería, 1599, fol. 73r: Para que sepa que, sin el ayuda y socorro de dos ayudantes o largos espeches o alçaprimas, no podrá ser dueño de servir a semejantes pieças. // Ufano, Tratado de la Artillería, 1613, pág. 321: Al guindal sigue la escaleta, con su uña o alçaprime, la qual sirbe para alçar el afuste con la pieça en alto, para sacarle una rota y mala rueda y meterle otra mejor. // Alonso Barba, Arte de los metales, 1640, fol. 96v: Sácanse las escorias por boca que para ello tiene el horno, y, acabada la fundición y frío el hierro, se saca afuera con unas levas o alçaprimas.

SIN.: leva $a_{2}$, manuela, palanca, palanga, própalo, uña de cabra, uña de puerco.

HIPER.: herramienta.

alzaprime, V. alzaprima.

amartillado, amartillado [de amartillar. Collado, Plática Artillería, 1592]. adj. Golpeado con el martillo.

Collado, Plática Artillería, 1592, fol. 9v: Sea comoquiera, que yo torno a dezir que de la pieça amartillada siempre se puede tener sospecha.

SIN.: martillado.

FAM.: amartillar, martillada, martillado, martillar, martillejo, martillo.

amartillar, amartillar [de martillo. Collado, Plática Artillería, 1592]. v. tr. Batir y dar golpes con el martillo (DRAE s. v. martillar).

Collado, Plática Artillería, 1592, fol. 9v: Y por eso procura de amartillar la pieça toda, dende la boca a la culata, sobre del qual amartillar por defuera no pocas vezes he contrastado. // Collado, Plática Artillería, 1592, fol. 9v: Torno a dezir que de la pieça amartillada siempre se puede tener sospecha, por quanto, si ella saliera de la fundición sana, no tenía el fundidor que tomar aquel trabajo de amartillarla, pues sin hazer aquella fatiga se la admitieran por buena, no hallándose en ella magaña alguna y resistiendo el día de la prueva.// Collado, Plática Artillería, 1592, fol. 45r: Y aun para más assegurarse, tomar un martillo y hirla amartillando del un cabo al otro para oýr de este modo si ella tiene claro y puro el sonido, por quanto, si ella fue mal fundida y tiene alguna magaña secreta, en el sonido lo manifiesta.

SIN.: martillar. 
FAM.: amartillado, martillada, martillado, martillar, martillejo, martillo.

ambudo, V. embudo.

amoladera, amoladera [de amolar (Correas). Llanos, Diccionario minas, c.1609-11]. sust. f. Piedra que se utiliza para amolar o para sacar corte o punta. Llanos, Diccionario minas, c.1609-11, pág. 83: Amoladera: Es un metal que parece piedra de amolar, y así se le dio el nombre. // Alonso Barba, Arte de los metales, 1640, fol. 12v: Amoladera es la piedra ordinaria, que por el uso de su nombre conocen todos. Ay metales muy ricos sobre ella, llenos de anco o plomería, y a los que más ordinariamente acompaña son los cobriços. // Alonso Barba, Arte de los metales, 1640, fol.

74r: Las piedras blandas y que no tienen venas son las que resisten más al fuego, y entre éstas son las mejores las que llaman amoladeras.

SIN.: piedra de amolar.

FAM.: amoladura, amolar, moler, moleta, molido, molienda, molinero, molino, molinete, muela, remoler, remolimiento, remolinar, remolino.

amoladura, amoladura [de amolar. Llanos, Diccionario minas, ca. 1609-11]. sust. f. u. t. c. pl. Conjunto de arenillas y pedazos muy menudos que se desprenden de la piedra al tiempo de amolar (DRAE).

Urrea, Vitruvio, Architectura, 1582, fol. 96v: Y en el nivel más alto con amoladura de piedra de aguzar herramienta, quitada la espuma, se da forma de suelo negro. // Llanos, Diccionario minas, ca. 1609-11, pág. 40: Donde está el agua en que la piedra se moja (como se hace en las ordinarias de amolar), de donde se saca como amoladuras, revuelto el hierro con la arena de la piedra. // Llanos, Diccionario minas, ca. 1609-11, pág. 40: Las libras que faltan se hace cuenta están en el pilón deshechas, y porque lo que está en él es hierro deshecho y arena de la piedra, y en realidad de verdad amoladuras, y no se puede apartar lo que es hierro para pesarse solo.

FAM.: amoladera, amolar, moler, moleta, molido, molienda, molinero, molino, molinete, muela, remoler, remolimiento, remolinar, remolino.

amolar, amolar [de muela. H.1300 (DECH). Urrea, Vitruvio, Architectura, 1582]. v. tr. Afilar un arma o un instrumento en la muela (Glosario Los Ventiún Libros).

Urrea, Vitruvio, Architectura, 1582, fol. 25v: [...] allí la potencia de la materia es más blanda que el topho, que es piedra arenisca como de las muelas de amolar herramientas o como toba, que es más maciza que tierra [...]. // Juanelo Turriano, Veinte y un libros, c.1605, fol. 177r: Porque, levantada el agua encima del açute, puede después servir para qualquier exercicio que será neçessario, como para batán, como para herrería, de hazer andar machos y mallo, como en tales hedificios se acostumbran 
servir, y para amolar y para alimpiar armas. // Lechuga, Discurso de la Artillería, 1611, pág. 188: Una dozena de muelas para amolar todas las cosas que fueren menester.

FAM.: amoladera, amoladura, moler, moleta, molido, molienda, molinero, molino, molinete, muela, remoler, remolimiento, remolinar, remolino.

amolar, V. piedra de .

ampara, ampara [de amparo. Juanelo Turriano, Veinte y un libros, a. 1605]. sust. Ingen. Hidrául. arag. Pared o baranda hecha para levantar o recoger agua.

Juanelo Turriano, Veinte y un libros, a. 1605, fol. 337v: El que da fuego a las calderas es N. Los que escaldan la lana son $P$. Donde es $Q$, es una ampara para conservar la lana que sale de los cestos, para que no se pierda la agua baxo.

SIN.: amparo.

HOL.: obra hidráulica.

FAM.: amparo.

amparo, amparo [de amparar. 1490, Alonso de Palencia (DECH). Juanelo Turriano, Veinte y un libros, a. 1605]. sust. m. Ingen. Hidrául. arag. Pared o baranda hecha para levantar o recoger agua.

Juanelo Turriano, Veinte y un libros, a. 1605, fol. 157r: Donde se hazen estos amparos para levantar agua de un río, para aver de regar y también para aver de bolver algún río, por raçón que por donde camina no sirve. // Juanelo Turriano, Veinte y un libros, a. 1605, fol. 326v: Y lo mismo ará en este amparo, para traer más acumulada a la rueda la agua. Y quanto será más largo y ancho en la parte donde entra la agua, tanto mejor será. // Juanelo Turriano, Veinte y un libros, a. 1605, 326v: Y quanto más estrecha será la salida de la agua, será mucho mejor, por causa que aprovechará para hazer moler mucho más de lo que haría sin este amparo o recogimiento de agua.

SIN.: ampara.

HOL.: obra hidráulica.

FAM.: ampara.

anadija, anadija [del lat. ănătĭcŭla 'pato pequeño'. S. XII (Diccionario Histórico). Lobato, Notas, c.1585]. sust. f. Mec. Pieza horizontal sobre la que se asienta la muela de un molino.

Lobato, Notas, c.1585, fol. 36: Palo y anadija de hierro cuadrado de tabla por abajo y de hierro por arriba, el largo necesario según subiere el molino. / / Lobato, Notas, c.1585, fol. 36: Anadija... 4 
SIN.: ananilla, nanilla.

HOL.: molino.

[IMAGEN] Lobato, Notas, c. 1585, fol. 36. Está señalada con el número 4.

Pseudo-Juanelo Turriano, Los ventiún libros, c. 1605, fol. 299v, fig. 200.

anafe, alnafe [del hispano-ár. annáfihh, 'hornillo portátil' y este del árabe clásico nâfih̆ (DRAE). 1475, Guillén de Segovia (DECH). Pérez Vargas, De re metallica, 1568]. sust. m. Hornillo, generalmente portátil, utilizado en la fundición de metales (DRAE).

Pérez Vargas, De re metallica, 1568, fol. 96r: Los minerales que son de plata pura, sin mezcla de metal, no se deven fundir en los hornos primeros, sino en unos crisoles o alnafes de hierro calentados, como en su lugar se dirá. / / Pérez Vargas, De re metallica, 1568, fol. 106v: Otros lo funden en unos alnafes o catinos de hierro d'esta manera: hazen dos pilarejos de ladrillo, apartado el uno del otro pie y medio, y dentro componen un lecho de leña seca menuda. // Pérez Vargas, De re metallica, 1568, fol. 106r: Y poniendo fuego a la leña, encima assientan unos alnafes de hierro llenos de metal molido, embarrados primero por dedentro.

ananilla, ananilla [de origen incierto Juanelo Turriano, Veinte y un libros, a. 1605]. sust. f. Mec. Pieza horizontal sobre la que se asienta la muela de un molino.

Juanelo Turriano, Veinte y un libros, c.1605, fol. 309r: Y el ananilla que va encima de la cigüeña de yerro es $M$.

SIN.: anadija, nanilla.

HOL.: molino.

FAM.: nanilla.

[IMAGEN] Pseudo-Juanelo Turriano, Los ventiún libros, c. 1605, fol. 308v, fig. 212. Aunque el texto nos informa de que se corresponde a la letra $\mathrm{M}$, esta letra no aparece en el dibujo. Por la descripción, creemos que se ajusta a la pieza situada en la parte izquierda de la imagen, situada justo encima de la bola que lleva la letra $\mathrm{H}$.

Pseudo-Juanelo Turriano, Los ventiún libros, c. 1605, fol. 299v, fig. 200.

andamio, andamio [de andar. Glosas de Silos (DECH). Loçano, Alberto, Architectura, 1582]. sust. m. Armazón de tablones que se hace junto a la obra para su construcción o reparación (Salinero).

Loçano, Alberto, Architectura, 1582, pág. 82: No los architectos d'este tiempo, que para hazer los andamios dexan en las paredes muy anchos rompimientos de agujeros, por donde, acabada la pared, metan las cabeças de las vigas. // Juanelo Turriano, Veinte y 
un libros, a. 1605, fol. 231v: De manera que si fuere muy alta la catarata, convendrá hazer un andamio o entablado, para que con una cavalgadura o cavalgaduras muevan los instrumentos para sacar el agua. // Llanos, Diccionario minas, ca. 1609-11, pág. 12: Y se labra todo él de alto a bajo por parejo, en que están los indios para poder trabajar, de la misma manera que se hacen los andamios para edificar, estando en ellos los oficiales.

FAM.: andar.

andar, andar, handar [del romance *amlare 'íd.'. 2 $2^{a}$ mitad S. X, Glosas de Silos, 198 (DECH). Loçano, Alberto, Architectura, 1582]. v. intr. Mec. Dicho de un artefacto o de una máquina: moverse para ejecutar sus funciones (DRAE). Loçano, Alberto, Architectura, 1582, 378: Pueden los ciegos servir para andar los tornos. // Lobato, Notas, c.1585, fol. 8: La cual rueda que mueve el agua ha de estar asentada por debajo del boleo que hace la dicha entruesga del husillo, para que la haga andar a la redonda. Y mientras le moviere, andará echando agua en otra balsa que ha de estar hecha, que tenga siempre cinco pies de agua. // Juanelo Turriano, Veinte y un libros, c.1605, fol. 330r: Y también éstos son molinos que andan con ruedas y con agua, los quales son muy necessarios en las repúblicas, que, sin ellos, con grande travajo nos serviríamos de vestidos de lana.

FAM.: andamio.

anegadizo, anegadizo [de anegar. Fernández de Enciso, Suma de Geographía, 1530]. adj. u. t. c. sust. Que frecuentemente se anega (DRAE).

Fernández de Enciso, Suma de Geographía, 1530, fol. LXIXr: En las riberas d'este río ay muchos anegadizos, y en ellos ay muchos indios, e tienen las casas e las abitaciones encima de los árboles, porque debaxo es todo agua, e biven de pescadores. // Acosta, Historia natural, 1590, pág. 204: De los lugares donde se quaja y engendra el oro algo se ha dicho, que son, o piedras en lo profundo de los montes y senos de la tierra, o arena de los ríos y lugares anegadizos, o cerros muy altos, de donde los polvos de oro se deslizan con el agua.

FAM.: anegamiento, anegar.

anegamiento, anegamiento [de anegar. 1381-1418, Sevillana medicina, de Juan Aviñón (CORDE). Lobato, Notas, c.1585]. sust. m. Efecto de anegar o anegarse.

Lobato, Notas, c.1585, fol. 13: Y así quedará libre del rompimiento y anegamiento el dicho molino. Y no servirá la dicha puente de pasaje mientras no lloviere.

FAM.: anegadizo, anegar. 
anegar, anegar [del lat. ènĕcāre 'ahogar en agua'. H. 1260, Bocados de Oro (DECH). Fernández de Enciso, Suma de Geographía, 1530]. v. tr. u. t. c. prnl. Dicho del agua: cubrir los terrenos (DRAE).

Fernández de Enciso, Suma de Geographía, 1530, fol. XLVIIr: E porque le dixeron a Tolomeo que si se juntava el Mediterráneo y el Bermejo, que se anegaría la tierra de Egypto, que por aquello dexó la obra. // Lobato, Notas, c.1585, fol. 13: Hay muchos molinos que, por no saber sus amos dar remedio a daños que se les ofrecen, los dejan perder, unos por ruines pesqueras, otros por en anegársele la balsa con lluvias, y otros porque bajan las piedras y arena de cuestas y le hinchen la balsa de piedra y arena, que le vienen a anegar y aun a romper la balsa. // Juanelo Turriano, Veinte y un libros, c.1605, fol. 110r: Vese en Italia el río Po, el qual río va casi puesto en el ayre, porque de suyo no tiene ribas, porque en las más partes son hechas a mano; que, cierto, que si no fuese por essas motas, anegaría muchíssima tierra.

FAM.: anegadizo, anegamiento.

ánima, ánima [tomado del lat. ănı̆ma 'aire, aliento', 'alma' este del gr. ơveนos 'soplo'. Orígenes del Idioma (DECH). Juanelo Turriano, Veinte y un libros, a. 1605]. sust. f. Mec. Barra que, sujeta al centro de una de las dos caras del émbolo, sirve para darle movimiento o transmitir el suyo en una bomba de agua.

Juanelo Turriano, Veinte y un libros, a. 1605, fol. 337v: La bomba es A. La canal, B. La ánima de la bomba es C. Las calderas es D y E. La chimenea es G. / / Juanelo Turriano, Veinte y un libros, a. 1605, fol. 351r: Y el redondo B es lo que ha de tener la ánima de la cóclea, y lo que ha de yr de vazío las canales de las cócleas. // Juanelo Turriano, Veinte y un libros, a. 1605, fol. 364r: Y esta ánima va adentro de la bomba F, que es en I, la qual bomba es de dos pieças cavadas a medida de la G.

HOL.: bomba, cóclea.

[IMAGEN] Pseudo-Juanelo Turriano, Los ventiún libros, c. 1605, fol. 364r, fig. 339. Observamos el ánima de una bomba.

anisociclo, anisociclos [tomado del lat. ănīsŏcycla, -ōrum 'sistema de

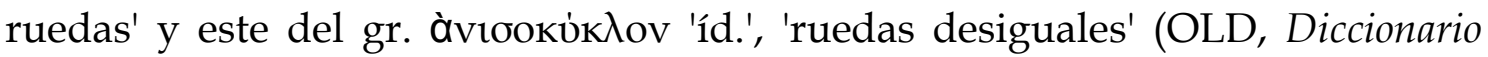
Histórico). Urrea, Vitruvio, Architectura, 1582]. sust. m. Mec. Máquina para elevar pesos, montada sobre ruedas desiguales (Salinero).

Urrea, Vitruvio, Architectura, 1582, fol. fol. 123v: Como se ve los que llaman escorpiones y los anisociclos, que son instrumentos que se mueven en rededor. // Urrea, Vitruvio, Architectura, 1582, fol. 139r: Anisociclos: máchinas que se mueven alrededor; dízense escorpiones. // Urrea, Vitruvio, Architectura, 1582, fol. 140r: Escorpiones: máchinas e instrumentos que se mueven en rededor; lo mesmo es anisociclos.

SIN.: escorpión.

HIPER.: máquina. 


\section{anisociclos, V. anisociclo.}

anoria, anoria [alteración del antiguo (a)nora por influjo de acenia y acequia; (a)nora viene del ár. nā. ûra 'íd.', derivado de ná،ra 'gruñir'. S. XII (DECH). Pérez Vargas, De re metallica, 1568]. sust. f. Mec. Molino situado dentro de un cauce de agua, cuya corriente mueve la rueda.

Pérez Vargas, De re metallica, 1568, fol. 78r: Este moler de los metales se haze differentemente mediante algunos ynstrumentos y máchinas de martillos, y maços de hierro, y palos clavados y ruedas que se traen a braço y otras con agua, como açudas y anorias, que, porque son cosas diffíciles y que cada uno las ha de ver con los ojos.

SIN.: aceña, molino de aceña, molino de agua.

HIPER.: molino.

FAM.: noria.

ENCICL.: "Los molinos hidráulicos (o aceñas) constituyeron durante siglos un elemento esencial en el paisaje de los ríos castellanos. [...] La Edad Media supuso el desarrollo y la generalización del molino hidráulico, en parte por tradición árabe y en parte también como producto del ingenio de los constructores españoles. Su técnica avanzada hace que tengamos que diferenciar vaios tipos de molinos de agua en función del modo de aprovechamiento de la energía hidráulica" (García Tapia 1997: 22).

2 [Escalante, Discurso de la navegación, 1577]. sust. f. Mec. Máquina compuesta de dos o más ruedas, que se utiliza para subir y sacar agua de los pozos, acequias, etc.

Escalante, Discurso de la navegación, 1577, fol. 58r: Usan de una suerte de bombas hechas de muchas pieças a la manera de anorias, puestas al largo de los costados de los juncos por la parte de dentro, con tal artificio que un hombre solo assentado meneando continuamente los pies como quien sube gradas desagotará un gran navío en poco tiempo, por mucho agua que haga. // Juanelo Turriano, Veinte y un libros, a. 1605, fol. 344r: Puédese hazer otras invenciones para subir agua por otro modo, que son las anorias o ceñas, las quales andan con el movimiento de la misma agua donde ellas están asentadas. // Juanelo Turriano, Veinte y un libros, a. 1605, fol. 345v: Y quando fuere tanta la cantidad de la tierra, que se uviesse de acomodar tres o quatro ruedas juntas para subir mucha cantidad de agua, yo he visto una sola anoria que subía tanta agua, que regava una legua de tierra en largo y un quarto de ancho.

SIN.: ceña, noria.

HIPER.: máquina.

[IMAGEN] Pseudo-Juanelo Turriano, Los ventiún libros, c. 1605, fol. 349r, fig. 266. 
antepecho, antepecho [cmpt. de ante y pecho. S. XVI, Ercilla (DECH). Juanelo Turriano, Veinte y un libros, a. 1605]. sust. m. Ingen. Hidrául. Murete o baranda que se coloca en los puentes y otros lugares para prevenir caídas.

Juanelo Turriano, Veinte y un libros, a. 1605, fol. 214v: Dévesele a toda puente de madera hazer su antepecho a las dos partes. // Juanelo Turriano, Veinte y un libros, a. 1605, fol. 222r: Este antepecho sube muy más alto que no es los antepechos que se hazen ordinarios en las puentes. / / Juanelo Turriano, Veinte y un libros, a. 1605, fol. 377v: Dévese levantar un antepecho, que passe de una parte a la otra de toda la puente, de unas losas [o] piedras muy grandes, y asir las unas con las otras con sus gafas de hierro y emplomarlas muy bien.

SIN.: pretil.

HOL.: puente.

[IMAGEN] Pseudo-Juanelo Turriano, Los ventiún libros, c. 1605, fol. 214v, fig. 287, letra F. Antepecho en un puente de madera.

aparejador, aparejador [de aparejar. H. 1600, J. de Sigüenza (DECH). Juanelo Turriano, Veinte y un libros, a. 1605]. sust. m. Persona que tiene por oficio el preparar los materiales y dividir las piezas en las obras de construcción. Juanelo Turriano, Veinte y un libros, a. 1605, fol. 369r: Y que se labren igualmente los sillares a toda parte, y que jamás assiente piedra el assentador ni el aparejador que primero el prudente artífiçe no passe los ojos por ella. // Roxas, Sumario milicia, 1607, fol. 23v: Y, fuera d'esto, avía también en la lejión carpinteros, aparejadores, carreteros, herreros, pintores y los demás artífiçes para edificar un gran edifiçio de máchinas o torres de madera o piedra.

FAM.: aparejar, aparejo, emparejar, parejo.

aparejar, aparejar [de parejo. H. 1140, Cid (DECH). Sagredo, Medidas Romano, 1526]. v. tr. Preparar, prevenir, disponer (DRAE).

Sagredo, Medidas Romano, 1526, pág. 75: Léese de David y Salomón que, como quisiessen edificar el templo de Jerusalén, aparejaron primero mucha copia de oro y de plata y de otros metales, madera, piedra y todos los otros pertrechos necessarios. // Loçano, Alberto, Architectura, 1582, pág. 123: Finalmente, hase de aparejar de tal manera toda la obra y edificio d'estas cosas, que sólo el que mandare possea todas las cosas altas, y a los suyos nadie les quite la facultad de correr de acá para allá por toda la ciudad. // Besson, Teatro instrumentos, 1602, fol. G4v: Nueva hechura de molino a braços para prensar y aparejar paños y papel, y moler especies, y esmenuzar piedras preñadas de metales para preparallas a hundir.

FAM.: aparejador, aparejo, emparejar, parejo. 
aparejo, aparejo [de aparejar. H. 1300, Gran Conquista de Ultramar (DECH). Anónimo, Premática ferias de León..., 1552]. sust. m. Conjunto de objetos necesarios para hacer ciertas cosas (DRAE).

Anónimo, Premática ferias de León..., 1552, fol. 1v: So pena que la persona o personas que sin tener vuestro poder para ello lo imprimieren o vendieren, o los moldes y aparejo con que la fizieren, e yncurran más, cada uno d'ellos, por cada vez que lo contrario fizieren, en pena de cien mil maravedís. // Lobato, Notas, a. 1585, fol. 12: Y viendo aparejo en las montañas de Alhanje para hacer una detención o detenimiento de aguas de las lluvias del invierno. // Juanelo Turriano, Veinte y un libros, a. 1605, fol. 316v: Conviene tener muy buen aparejo el que quiere picar muy bien una muela, y que tenga una regla muy fina y muy derecha, que a lo menos sea tan larga quanto es ancha la muela.

FAM.: aparejador, aparejar, emparejar, parejo.

2 [Montes, Instrucción y regimiento, 1537]. sust. m. pl. Instrumentos y cosas necesarias para cualquier oficio o maniobra (DRAE).

Montes, Instrucción y regimiento, 1537, fol. IIIr: Y el estilo que se deve tener en el principiar de la guerra, y los aparejos que son menester para la hazer. // Lobato, Notas, a. 1585, fol. 25: Y, tornada a poner en el dicho molino, andaba con buena orden la piedra para el moler, pero la bestia pasaba grande sudor y trabajo a causa de pesar todos los aparejos mucho. // Lobato, Notas, a. 1585, fol. 36: Las piedras que este molino ha menester, además de piedras y tolva y demás aparejos de moler, son las vigas sobre las que se asienta la cuba y la dicha cuba y puente aliviada.

apegadura, apegadura [de apegar (DECH). Loçano, Alberto, Architectura, 1582]. sust. f. Unión física que resulta de haberse pegado algo con otra cosa (DRAE s. v. pegadura).

Loçano, Alberto, Architectura, 1582, pág. 85: En todo el arco harás que las apegaduras de las junturas y los encerramientos se enderecen a su centro.

SIN.: pegadura 3.

FAM.: apegar, desapegadizo, desapegar, despegar, empegar, empeguntar, pegadura, pegar, pez.

apegar, apegar [de pegar. Med. S. XIV, Montería de Alf. XI (DECH). Cortés de Albacar, Breve compendio sphera, 1556]. v. tr. Juntar o unir una cosa con pez, betún $\mathrm{u}$ otro material adherente.

Cortés de Albacar, Breve compendio sphera, 1556, fol. LXXr: Estos fierros se han de apegar por la parte baxa de la brúxola, de manera que sus extremidades o puntas vengan precisamente por la línea del Norte Sur y, para fixarlos así, se han de cobrir con un papel delgado engrudado. // Juanelo Turriano, Veinte y un libros, a. 1605, fol. 274r: Y éste es un betún maravilloso para apegar madera, mas conviene servirse d'él luego, porque se seca presto. // Juanelo Turriano, Veinte y un libros, a. 1605, fol. 275r: Y luego 
que avrás mezclado estos polvos con la leche, enmediate, as de apegar la cosa que quieres apegar.

SIN.: pegar.

ANT.: desapegar, despegar.

FAM.: apegadura, desapegadizo, desapegar, despegar, empegar, empeguntar, pegadura, pegar, pez.

aprensar, aprensar [de prensa. Lope (DECH). Pérez Vargas, De re metallica, 1568]. v. tr. Mec. Apretar algo en la prensa, o mediante otro procedimiento, para compactarlo (DRAE s. v. prensar).

Pérez Vargas, De re metallica, 1568, fol. 187v: Y quando se escalientan, se rocíen con agua rosada y luego se aprensen. // Pérez Vargas, De re metallica, 1568, fol. 187v: Y, ansí, se aprensen hasta que las flores no huelan, y después se aprensen las almendras.

SIN.: prensar.

FAM.: prensa, prensar.

aquaducto, V. acueducto.

aquaeducto, V. acueducto.

arado, arado [del ant. aradro y este del lat. ărātrum 'íd.'. Princ. S. XV, Cancionero de Baena (DECH). Sánchez de las Broças, Helt Frisio, Relox español, 1549]. sust. m. Instrumento de agricultura que sirve para labrar la tierra abriendo surcos en ella (DRAE).

Sánchez de las Broças, Helt Frisio, Relox español, 1549, fol. 27r: De las quales salen otras tres de ygual claridad, como en arco, a manera de esteva o mancera del arado, de las quales la de medio, digo la que está más alta, tiene sobre sí otra estrella pequeña. // Urrea, Vitruvio, Architectura, 1582, fol. 124r: Tampoco tuviéramos abundancia de manjar si los yugos, los arados para los bueyes y los demás jumentos no se ovieran hallado // Besson, Teatro instrumentos, 1602, fol. I4v: Artificio no vulgar para arar la tierra, con maravilloso atajo, con tres rejas, juntamente ligadas dos cuerdas a la carreta del arado, y que por sus vezes se desencogen y encogen sobre la carreta o en los términos del campo que se ara. 
arar, arar, harar [del lat. ărāre 'íd.'. H. 1295, Crón. Gral. (DECH). Cortés de Albacar, Breve compendio sphera, 1556]. v. tr. Remover la tierra haciendo en ella surcos con el arado (DRAE).

Celso, Reportorio universal leyes Castilla, 1553, fol. CXXXIXv: Estiéndese lo que diximos de suso de los bueyes a las otras bestias de lavor o arar para un par. // Anónimo, Repertorio tiempos, 1554, fol. XXXVv: Agora se aran las tierras para prados y se alimpian y estercolan con nuevo estiércol. // Apiano, Cosmographía, 1575, 78r: Aprovéchanse de aquestos animales para arar y labrar la tierra y traer qualquiera carga, y la carne es la mejor que se pueda comer.

FAM.: arado.

árbol, árbol [del lat. arbŏr, arbŏris, 'íd.'. 1197, Berceo (DECH). Besson, Teatro instrumentos, 1602]. sust. m. Mec. Barra fija o giratoria que en una máquina sirve para soportar piezas rotativas o para transmitir fuerza motriz de unos órganos a otros (DRAE).

Besson, Teatro instrumentos, 1602, fol. H3v: La muela d'este molino está asida con la rueda en el mesmo árbol, lo que se avía de notar. // Juanelo Turriano, Veinte y un libros, a. 1605, fol. 291r: El árbol de la rueda o mástil requiere ser de alto ocho palmos, poco más o menos, según el lugar. // Juanelo Turriano, Veinte y un libros, (a. 1605), 1602, fol. 331r: La canal que trae la agua a la rueda es A. La rueda es B. Las palas es C. El árbol de la rueda es D. Y en ello van asentados dos levadores, que es E E.

SIN.: mástil.

FAM.: arbúscula.

HOL.: máquina.

[IMAGEN] Pseudo-Juanelo Turriano, Los ventiún libros, c. 1605, fol. 383v, fig. 378, letra F. Árbol de una grúa.

arbúscula, arbúscula [tomado del lat. arbuscŭla 'íd.', diminutivo de arbor, arbŏris 'árbol' (Salinero). Urrea, Vitruvio, Architectura, 1582]. sust. f. Mec. Pie de carro para llevar otra máquina de un lugar a otro (Salinero).

Urrea, Vitruvio, Architectura, 1582, fol. 136r: Pero éstos sean contenidos de otros dos gruessos E S y anchos S, y los atravessaños disten el uno del otro cerca de pie y S, y en cada espacio se pongan sus arbúsculas, que en griego se llaman amasopodes, en los quales los exes de las ruedas se arrebuelven, cubiertas con planchas de hierro.

FAM.: árbol.

HOL.: carro $_{1 .}$ 
arca, arca [del lat. arca 'íd'. H. 1140, Cid (DECH). Loçano, Alberto, Architectura, 1582]. sust. f. Ingen. Hidrául. Depósito para recibir el agua y distribuirla (DRAE s. v. arqueta).

Loçano, Alberto, Architectura, 1582, pág. 322: Después, por el aquaducto, se entreponen las arcas de el agua; pero donde topan el suelo un poco levantado, se causa una cueva. // Juanelo Turriano, Veinte y un libros, a. 1605, fol. 3v: Y si este vasso está ençima de las fuentes, puede vaziar sus aguas, como hazen las arcas de las fuentes que se llevan por caños o alcaduzes, porque no hecharía más agua afuera, si una vez se ubiese vaziado. // García de Céspedes, Instrumentos nuevos, 1606, fol. 39r: Quanto más espessas estuvieren estas arcas es mejor, assí para facilitar la corriente de la agua como para adereçar la cañería, si alguna vez se rompiere, y también para limpiarla (que la suziedad suele ser causa de romper el edificio).

HIPER.: obra hidráulica.

FAM.: arqueta.

arcada, arcada [de arco. 1533, Morgante (DECH). Juanelo Turriano, Veinte y un libros, a. 1605]. sust. f. Arq. Fábrica en forma de arco entre dos de los pilares de un puente.

Juanelo Turriano, Veinte y un libros, a. 1605, fol. 360r: Quando se havrán de hazer las puentes de piedra, converná dar el orden como se han de hazer, y con quántas arcadas se han de repartir, y qué modo de pilas se deven hazer. // Juanelo Turriano, Veinte y un libros, a. 1605, fol. 361v: Y ver quántas pilas son menester hazer, teniendo cuenta que siempre la arcada de en medio requiere ser la quarta parte más ancha que ninguna de las otras. // Juanelo Turriano, Veinte y un libros, a. 1605, fol. 372r: La puente A es hecha llana, y todas las arcadas se van cresciendo hasta llegar a lo medio.

SIN.: arco.

HOL.: puente.

FAM.: $\operatorname{arco.}$

arcaduz, alcaduz, arcaduz [del ár. qādûs 'íd.', procedente a su vez del gr. кáठos 'jarro', 'caño de agua', 'cangilón de noria'. 1256-1263, Partidas (DECH). Loçano, Alberto, Architectura, 1582]. sust. m. Ingen. Hidrául. Conducto o cañería, generalmente de barro, piedra o cerámica, que sirve para conducir el agua a las fuentes o a otra parte.

Loçano, Alberto, Architectura, 1582, pág. 316: Columella dize que la agua llovediza será no mala, si se guía cubierta a la cisterna por arcaduzes de barro, porque al sereno y con los soles fácilmente se podrece, y guardada en vaso de madera está subjecta a vicios. // Urrea, Vitruvio, Architectura, 1582, fol. 109v: Si a menos costa queremos guiar el agua, se hará assí: háganse arcaduzes gruessos, no menos que de dos dedos, y háganse de tierra; pero sean de tal arte, que por una parte cada uno sea delgado a manera de lengua, porque el uno pueda encaxarse en el otro. // Juanelo Turriano, Veinte y un 
libros, c.1605, fol. 3v: Y si este vasso está ençima de las fuentes, puede vaziar sus aguas, como hazen las arcas de las fuentes que se llevan por caños o alcaduzes, porque no hecharía más agua afuera, si una vez se ubiese vaziado.

SIN.: atanor.

HIPER.: obra hidráulica.

[IMAGEN] Lobato, Notas, c. 1585, fol. 9.

[IMAGEN] Pseudo-Juanelo Turriano, Los ventiún libros, c. 1605, fol. 283v, fig. 30.

arco, alco, arco [del lat. arcŭs 'íd.'. 1136 (DECH). Juanelo Turriano, Veinte y un libros, a. 1605]. sust. m. Ingen. Hidrául. Fábrica en forma de arco entre dos de los pilares de un puente.

Juanelo Turriano, Veinte y un libros, a. 1605, fol. 360v: Dévese siempre hazer el arco d'en medio de qualquier puente muy mayor que ninguno de los otros, a causa que, ordinariamente, las cosas que consigo suelen traher las aguas es en medio del río, y muy pocas vezes a las orillas. // Juanelo Turriano, Veinte y un libros, a. 1605, fol. 376r: Lo que hay entre el un arco y el otro se deve ir hinchendo de piedra, de tal modo que todo sea muy firme, ni se halle en toda la obra cosa más firme. // Juanelo Turriano, Veinte y un libros, a. 1605, fol. 388r: Este arco ha de estar abierto en medio, y las dos partes d'él se han de sustentar en el ayre, assí de la una parte como la otra, a donde está todo el artificio de la fábrica.

SIN.: arcada.

HOL.: puente.

FAM.: arcada.

arena, arena [del lat. ărēna 'íd.'. H. 1140, Cid (DECH). Fernández de Enciso, Suma de Geographía, 1530]. sust. f. Tierra menuda, casi polvo, que se halla en los caminos, ríos y particularmente en las orillas y en el fondo del mar.

Fernández de Enciso, Suma de Geographía, 1530, fol. XLr: E passando los macedones por aquella tierra de arena, hizieron un pozo para sacar agua e sacaron agua de licor de azeyte. // Lobato, Notas, a. 1585, fol. 13: Hay muchos molinos que, por no saber sus amos dar remedio a daños que se les ofrecen, los dejan perder, unos por ruines pesqueras, otros por en anegársele la balsa con lluvias, y otros porque bajan las piedras $\mathrm{y}$ arena de cuestas y le hinchen la balsa de piedra y arena, que le vienen a anegar y aun a romper la balsa. // Juanelo Turriano, Veinte y un libros, a. 1605, fol. 262r: La qual arena, puesta dentro de un vasso que tenga agua, y meneando el agua, y no se enturbeziere el agua, es buena, y si el agua enturbeziere, será muy mala arena, que participa de mucha tierra.

FAM.: arenado, arenal, arenar, arenilla, arenisco, arenoso, enarenado, enarenar. 
arenado, arenado [de arenar. Urrea, Vitruvio, Architectura, 1582]. adj. Cubierto o mezclado con arena.

Urrea, Vitruvio, Architectura, 1582, fol. 97v: Y la parte que fuere más gruessa, assí como está escripto arriba, se mezcla con la cal arenada.

SIN.: enarenado.

FAM.: arena, arenal, arenar, arenilla, arenisco, arenoso, enarenado, enarenar.

arenal, arenal [de arena (DECH). Fernández de Enciso, Suma de Geographía, 1530]. sust. m. Extensión grande de terreno arenoso (DRAE).

Fernández de Enciso, Suma de Geographía, 1530, fol. LXVIIIv: Los lagartos en el mes de enero y febrero crían en esta manera: quando más hierve el sol en el día, ellos se salen del agua a los arenales e hazen con las manos un hoyo, e allí ponen los huevos. // Loçano, Alberto, Architectura, 1582, pág. 129: Terminaranse muy bien en algún albañar, o en algún arenal desierto y no sabido, o en capillas de yglesias, o sepulturas, y, demás d'esto, si en alguna manera conviene tener en poco los acaecimientos humanos. // Juanelo Turriano, Veinte y un libros, a. 1605, fol. 104r: Conviene escoger un lugar que sea cómodo para poder tomar esta agua, y harto apartado del río, quarenta passos o más, y después cavar en el suelo del arenal.

FAM.: arena, arenado, arenar, arenilla, arenisco, arenoso, enarenado, enarenar.

arenar, arenar [de arena (DECH). Pérez Vargas, De re metallica, 1568]. v. tr. Cubrir de arena una superficie (DRAE s. v. enarenar).

Pérez Vargas, De re metallica, 1568, fol. 166r: Y se eche en orinas, después de frío, y se limpie con un gratagujas de cobre, y se arene, y sedee y limpie con un paño de lino delgado. // Pérez Vargas, De re metallica, 1568, fol. 166v: Luego se grate, y arene, y sedee, y bruña y se limpie con una toca o lino delgado. // Pérez Vargas, De re metallica, 1568, fol. 167v: Después de blanqueada, se grate otra vez, y se bruña, y se le dé un poco de color de çufre, hervida en agua, bien molida, y se arene, y sedee y limpie con una toca.

SIN.: enarenar.

FAM.: arena, arenado, arenal, arenilla, arenisco, arenoso, enarenado, enarenar.

arenilla, arenilla [de arena (DECH). Ferrofino, Descrizión Artillería, 1599]. sust. f. Arena menuda.

Ferrofino, Descrizión Artillería, 1599, fol. 143r: Y, estando echo como gachas, se yrá mezclando muy bien con una chuchara hasta que se aga arenilla y se enjugue el agua y toda la umedad. Y se tendrá cuydado de no dejarle pegar a la caldera después d'echo arenillas. // Daça de Valdés, Uso de los antojos, 1623, fol. 82v: Aunque algunas vezes lo parecen unas arenillas o terrezuelas que se ven en el cuerpo de el cristal, a modo de manchas, pero éstas son naturales como lo es el mismo cristal. 
FAM.: arena, arenado, arenal, arenar, arenisco, arenoso, enarenado, enarenar.

arenisco, arenisco [de arena. 1490, Alonso de Palencia (DECH). Urrea, Vitruvio, Architectura, 1582]. adj. Que tiene mezcla de arena (DRAE).

Urrea, Vitruvio, Architectura, 1582, fol. 25r: Y assí, el fuego y el vapor de la llama, caminando por las entrevenas de la tierra ardiendo, haze ligera aquella tierra, y el polvo que nace allí es topho arenisco seco y sin jugo. // Loçano, Alberto, Architectura, 1582, pág. 67: Lo mismo se ha de hazer en el suelo arenisco, quanto convenga.

FAM.: arena, arenado, arenal, arenar, arenilla, arenoso, enarenado, enarenar.

arenoso, arenoso [del lat. arenōsus 'íd.' (DRAE). Pérez Vargas, De re metallica, 1568]. adj. Que tiene arena, o abunda en ella (DRAE).

Pérez Vargas, De re metallica, 156877v, fol. 17r: El qual se ahoga y digere entre la materia arenosa, porque, como en sí está tupida y apretada con la frialdad del agua y freqüencia, es naturalmente dispuesto el suelo arenoso para detener y quajar este vapor, y por esso es el oro muy escogido. // Loçano, Alberto, Architectura, 1582, pág. 177: Pero, si el suelo fuere arenoso, estenderéys vigas largas enteras, en que se compongan los planos, y por las cabeças ligaréys las ataduras al clavo. // Juanelo Turriano, Veinte y un libros, a. 1605, fol. 366v: Esto queda en el buen juizio del artífice, por causa que hallará un suelo muy floxo, otro muy çenoso, otro que será todo arenoso; otro será de peña, otro de muy excelente para tierra.

FAM.: arena, arenado, arenal, arenar, arenilla, arenisco, enarenado, enarenar.

argamasa, argamasa, argamassa [del lat. massa y otro elem. de origen incierto. 1190, Doc. de San Román de Entrepeñas (DECH). Pérez Vargas, De re metallica, 1568]. sust. f. Compuesto o mezcla de cal, arena y agua que se emplea en obras de albañilería (DECH).

Pérez Vargas, De re metallica, 1568, fol. 5r: Después de elada y concreta resultara tal manera de metal empedernido, hecho argamasa, que a golpes se partiera sin consentir el martillo. // Lobato, Notas, a. 1585, fol. 29: Y, pues se han de henchir de piedra, me parece que se hinchan de argamasa, que será mejor, como vaya toda de una vez. // Urrea, Vitruvio, Architectura, 1582, fol. 72v: Si estos camaramientos o bóvedas fuessen hechas con argamasa, serían más provechosas.

argamassa, V. argamasa.

árgana, árgana [del lat. vg. *argana 'íd.' y este del gr. täpүava, contracción de tà őpyava, plural de tò ôpyavov 'el instrumento'. 1612 (DECH). Ufano, Tratado de la Artillería, 1613]. sust. f. Mec. Torno de eje vertical que se emplea para 
mover grandes pesos arrastrándolos horizontalmente por medio de una maroma o cable que se va arrollando en él a medida que gira.

Ufano, Tratado de la Artillería, 1613, fol. 426: 29 lición. De una árgana de fuego artificial con la de un castillo. Folio 396.

SIN.: árgano, cabrestante, carquesio, ergata.

HIPER.: máquina.

FAM.: árgano.

árgano, árgano, árgueno [del lat. vg. *arganum 'íd.' y este del gr. tò őpyavov 'el instrumento'. 1526, C. de Arcos (DECH). Loçano, Alberto, Architectura, 1582]. sust. m. Mec. Torno de eje vertical que se emplea para mover grandes pesos arrastrándolos horizontalmente por medio de una maroma o cable que se va arrollando en él a medida que gira.

Loçano, Alberto, Architectura, 1582, pág. 174: Pero todas estas cosas, d'esta manera, qualesquiera que sean, ahora sean grandes ruedas, las quales muevan al derredor hombres metidos dentro pisando, ahora sean árganos o poleas, en las quales el exe principalmente vale, o cicleolas y otras cosas assí del mismo género. // Collado, Plática Artillería, 1592, fol. 71v: He querido traer en demostración el effecto del árgano y polijas dicho, por tan largo camino como en la siguiente pieça y figura se demuestra, para dar a entender la potencia del árgano y lo que con él se puede hobrar siendo bien entendido. // Lechuga, Discurso de la Artillería, 1611, pág. 189: Quatro cabestrantes o árguenos.

SIN.: árgana, cabrestante, carquesio, ergata.

HIPER.: máquina.

FAM.: árgana.

árgueno, V. árgano.

ariete, ariete [tomado del lat. ărĭes, ărụ̌tis 'morueco (carnero padre)', 'ariete'. 1490, Alfonso de Palencia (DECH). Urrea, Vitruvio, Architectura, 1582]. sust. m. Mil. Máquina, generalmente empleada en las guerras para batir murallas, consistente en una viga grande armada de hierro en la punta.

Urrea, Vitruvio, Architectura, 1582, fol. 135r: Primeramente, el ariete, que es máchina para batir, dizen que se halló d'esta manera. // Collado, Plática Artillería, 1592, fol. 4v: La máquina llamada ariete, que quiere dezir 'carnero', se aplicava, assimismo, al combatir las fortalezas y derribar las murallas; llamáronla de este nombre y aun diéronle la figura y forma de aquel animal por el effecto que con ella se hazía y modo como se exercitava. // Besson, Teatro instrumentos, 1602, fol. Gv: En esta última parte 
se muestran dos caracoles, en cuyas partes de fuera están asidas unas cuerdas (y cógelas a estas partes exteriores la abertura de las vigas), las quales cuerdas después son atadas a dos máquinas que llaman en latín arietes, y las levantan, las quales máquinas están hazia mediodía.

HIPER.: máquina.

arina, V. harina.

arista, arista [del lat. vg. *ăresta 'íd.', lat. ărista 'arista de la espiga' 'espina de pescado'. J. Ruiz (DECH). Juanelo Turriano, Veinte y un libros, a. 1605]. sust. f. Mec. Cada uno de los maderos largos que frena el movimiento torcido de la maza de una máquina utilizada para clavar maderos en el río.

Juanelo Turriano, Veinte y un libros, a. 1605, fol. 226v: Las aristas I I son movibles, las quales sirven para quando la maça va hiriendo el madero y se tuerce. // Juanelo Turriano, Veinte y un libros, a. 1605, fol. 227r: Las aristas I I K están asidas a las piernas C C con unas clavijas de yerro, que juegan en las dichas piernas de la máchina.

HOL.: máquina.

[IMAGEN] Pseudo-Juanelo Turriano, Los ventiún libros, c. 1605, fol. 224r, fig. 303, letra I.

armaçón, V. armazón.

armadura, armadura [del lat. armātūra 'íd.'. Princ. S. XIV, Juan Manuel (DRAE). Juanelo Turriano, Veinte y un libros, a. 1605]. sust. f. Constr. Pieza o conjunto de piezas unidas que presta estructura o sostén a una máquina u obra hidráulica (DRAE s. v. armazón).

Juanelo Turriano, Veinte y un libros, a. 1605, fol. 81r: Y que en essa distancia no sea mucha, podrase hazer una armadura de madera por huyr gasto, la qual pondré aquí abajo el modo d'ello. // Juanelo Turriano, Veinte y un libros, a. 1605, fol. 82r: Esta invención es harto differente de la anterior d'ésta, y es muy segura, y de tres maderos, puestos uno ante otro, que es A B C. Esta armadura no es muy dificultosa de hazer, por raçón que no van maderos ligados los unos con los otros. // Juanelo Turriano, Veinte y un libros, a. 1605, fol. 145v: El ergate A es el que se buelve a la redonda, andando alrededor, el qual coje y descoje a un mismo tiempo la sirga E. Y donde se buelve es B. La armadura es D, que tiene el ergate.

SIN.: armamento, armamiento, armazón.

FAM.: armamento, armamiento, armar, armazón, desarmar. 
[IMAGEN] Pseudo-Juanelo Turriano, Los ventiún libros, c. 1605, fol. 294r, fig. 186, letra M.

armamento, armamento [tomado del lat. armāmentum 'íd.'. 1295-1317 (DECH). Juanelo Turriano, Veinte y un libros, a. 1605]. sust. m. Constr. Pieza o conjunto de piezas unidas que presta estructura o sostén a una máquina u obra hidráulica (DRAE s. v. armazón).

Juanelo Turriano, Veinte y un libros, a. 1605, fol. 159r: Y también ay açutes que no se les pone más de sólo el armamento, y se entablan con tablas que se juntan muy bien, que por debajo se puede passar de una parte a la otra del açute.

SIN.: armadura, armamiento, armazón.

FAM.: armadura, armamiento, armar, armazón, desarmar.

armamiento, armamiento [del lat. armāmentum 'íd.' (DECH). Juanelo Turriano, Veinte y un libros, a. 1605]. sust. m. Constr. Pieza o conjunto de piezas unidas que presta estructura o sostén a una máquina u obra hidráulica (DRAE s. v. armazón).

Juanelo Turriano, Veinte y un libros, a. 1605, fol. 151r: Y si por caso no ubiese modo para poder hazer arcos, por raçón del mucho gasto que para ello se offrecía, podrase hazer de madera un armamiento, la qual será cosa muy fuerte y muy segura y que durará mucho tiempo. // Juanelo Turriano, Veinte y un libros, a. 1605, fol. 151v: Y todas estas pieças d'este armamiento convendrá que fuesen de roble, por causa que duran mucho más tiempo sin corromperse, y porque no se podría conservar en sí mesma tanta máquina.

SIN.: armadura, armamento, armazón.

FAM.: armadura, armamento, armar, armazón, desarmar.

armar, armar [del lat. armāre 'íd.'. H. 1140, Cid (DECH). Collado, Plática Artillería, 1592]. v. tr. Mec. Concertar y juntar entre sí las piezas de que se compone una máquina o instrumento.

Collado, Plática Artillería, 1592, fol. 16r: Sirve, como digo, esta escalera para armar sobr'ella un caracol, ya sea de la una manera, aprobechándose de las paredes para alguna suvida corta, ya sea caracol entero para suvida más alta. // Juanelo Turriano, Veinte y un libros, a. 1605, fol. 158v: Éste es el modo del açute, cómo se ha de hazer; digo, el armarlo. // Juanelo Turriano, Veinte y un libros, a. 1605, fol. 209r: Y ansí se van armando de pieza en pieza. Y para armar esta puente no es menester barcos, que con solas [las] mismas piezas se pueden armar, que con unas cuerdas que la vaya detiniendo.

ANT.: desarmar.

FAM.: armadura, armamento, armamiento, armazón, desarmar. 
armazón, armaçón, armazón [tomado del lat. armať̌o, armatǐōnis 'íd.'. 1492, Woodbr. (DRAE). Collado, Plática Artillería, 1592]. sust. f. Constr. Pieza o conjunto de piezas unidas que presta estructura o sostén a una máquina u obra hidráulica (DRAE).

Collado, Plática Artillería, 1592, fol. 4r: Acostumbravan, assimismo, Cathólica Magestad, otra máquina los antiguos, [...]. Era una armazón hecha de madera, a modo de un galápago y en la manera misma que aquí se vee en dibuxo. // Besson, Teatro instrumentos, 1602, fol. M3v: Encima, pues, de la boca del pozo que muestra la figura, está levantada una armazón de quatro columnas que sostienen el tejado de aquélla y están asidas entre sí con unos maderos atravesados. // Besson, Teatro instrumentos, 1602, fol. Pv: En la qual armazón de leños, más arriba, se veen cinco maderos de mediodía a tramontana, en el primero de los quales hay un mango que rueda, con que son movidas todas las poleas de los caracoles sin fin.

SIN.: armadura, armamento, armamiento.

FAM.: armadura, armamento, armamiento, armar, desarmar.

[IMAGEN] Pseudo-Juanelo Turriano, Los ventiún libros, c. 1605, fol. 158v, fig. 129, armazón de madera de un azud.

arnero, V. harnero.

arqueta, arqueta [de arca (DECH). Lobato, Notas, c.1585]. sust. f. Ingen. Hidrául. Casilla para recibir el agua y distribuirla (DRAE).

Lobato, Notas, c.1585, fol. 17: Molino de aceñuela de arquetas.

HOL.: obra hidráulica.

FAM.: arca.

arrectario, arrectario [tomado del lat. arrectārŭus 'madero derecho'. Urrea, Vitruvio, Architectura, 1582]. sust. m. Mec. Madero derecho y alto que soporta el peso en algunas máquinas.

Urrea, Vitruvio, Architectura, 1582, fol. 135r: Pero un cirra de Calcedonia hizo primeramente una basa de madera con unas ruedas puestas debaxo, y encima unos arrectarios, que son maderos derechos y altos, y juntolos. // Urrea, Vitruvio, Architectura, 1582, fol. 135r: Los arrectarios, en lo baxo de la torre, sean de nueve partes; en lo alto, de medio pie. // Urrea, Vitruvio, Architectura, 1582, fol. 135r: El remate de lo alto de la quinta parte * los arrectarios en lo baxo de un pie y lo alto de medio pie, y dava a esta torre $\mathrm{XX}$ suelos, y cada suelo de anchura de tres cobdos en redondo

HOL.: máquina. 
arrevolber, V. arrevolver.

arrevolver, arrevolber [de revolver. Pérez Vargas, De re metallica, 1568]. v. tr. Menear algo de un lado a otro, moverlo alrededor o de arriba abajo (DRAE s. v. revolver).

Pérez Vargas, De re metallica, 1568, fol. 69r: Luego, tomamos el azogue y lo echamos en un lienço crudo de cáñamo, o en fieltro delgado, o en una bolsa de cuero de ciervo, y lo atamos muy bien con un hilo o cordel encerado y rezio, y con fuerça vamos arrebolviendo el metal con el cordel, y exprimiéndolo.

SIN.: revolver.

ANT.: desarrevolver.

FAM.: desarrevolver, desenvolver, envolver, envuelto, revolver, volteado, voltear, volver, vuelta.

arteça, V. artesa.

artéfice, V. artífice.

artesa, arteça, artesa, arteza [de origen incierto probablemente prerromano, compárese el vasco artesia 'el agujero, la grieta'. 1221, J. Ruiz (DECH). Juanelo Turriano, Veinte y un libros, a. 1605]. sust. f. Mec. Cajón de madera, generalmente cuadrado y alargado, que posee un agujero, que recoge y cuela el agua $u$ otros materiales en algunas máquinas.

Juanelo Turriano, Veinte y un libros, a. 1605, fol. 334v: Y después se va tomando, poco a poco, dentro de una artesa que sea grande, de madera como los que pisan las uvas. // Juanelo Turriano, Veinte y un libros, a. 1605, fol. 334v: Y esta arteza tiene un agujero al un cabo, y ansí van pisando y hechando agua. Y esa agua va a dar dentro de otro vaso limpio con la flor de la arina que sale del trigo. / / Juanelo Turriano, Veinte y un libros, a. 1605, fol. 342r: Y la canal que yrá inchendo las caxas, que yrá de las unas a las otras. Y por donde ellas han de colar por sus canales es D. Y las caxas o arteças, C. El recetáquulo o tino que recive las lexías de las canales es E.

HOL.: máquina.

arteza, V. artesa. 
artíffice, $\mathrm{V}$. artífice.

artifficial, V. artificial.

artifficio, V. artificio.

artifficioso, V. artificioso.

artíffiçe, $\mathrm{V}$. artífice.

artiffiçial, V. artificial.

artiffiçio, V. artificio.

artiffiçioso, V. artificioso.

artífice, artéfice, artíffice, artíffiçe, artífice, artífiçe [tomado del lat. artǔfex, artǐfič̌s, 'íd.', compuesto con el verbo facere 'hacer'. 1499, Celestina (DECH). Sagredo, Medidas Romano, 1526]. sust. m. Maestro de las artes mecánicas o manuales, como maestro de escultura, de arquitectura (Autoridades).

Sagredo, Medidas Romano, 1526, pág. 9: De la qual opinión es maestre Phelipe de Borgoña, singularíssimo artífice en el arte de esculptura y estatuaria, varón, assimesmo, de mucha experiencia e muy general. // Urrea, Vitruvio, Architectura, 1582, fol. 3r: Y como restaurador de la Architectura, illustrará al auctor d'ella, y, finalmente, como único amparo de los artífices, hará merced a quien dessea tanto por su parte ayudarle. // Juanelo Turriano, Veinte y un libros, a. 1605, fol. 369r: De modo que conviene sea el artífice un hombre prudente y que sepa discernir qué piedras y quáles sean las mejores, y conoscer la calidad d'ellas y sus effectos, porque después de haver hecho la obra no se arrepienta de haver assentado tales piedras en la obra. 
FAM.: artificial, artificio, artificiosamente, artificioso.

2 [Núñez, Álgebra en Arithmética, 1567]. sust. m. Inventor de muchas cosas que no caen debajo del objeto de las artes, el que las traza, dispone y ejecuta (Autoridades).

Núñez, Álgebra en Arithmética, 1567, fol. 114v: Y no, como Aristóteles dize en la Mechánica, de los artífices, que nos muestran de la máchina que tienen hecha lo de fuera y esconden el artificio, por parescer admirables. // Herrera, Institución Academia, 1584, fol. 7v: Platican los alarifes, los arqueadores de navíos, niveladores de aguas, ingenieros, artilleros, fundidores y otros artífices muchos, que usan estas divinas Mathemáticas por beneficio y medio de quantidad continua o discreta. // Mosquera, Comentario disciplina militar, 1596, fol. 5v: Y subiolo en más alto grado que ningún español ni otra nación el conde Pedro Navarro, bravo artífice de máquinas y minas de fuego.

artífiçe, V. artífice.

artificial, artifficial, artiffiçial, artificial, artifiçial [tomado del lat. artǐfičălis 'íd.'. H. 1250, Setenario (DECH). Sagredo, Medidas Romano, 1526]. adj. Hecho por mano, arte o ingenio del hombre.

Sagredo, Medidas Romano, 1526, pág. 51: Estos tallos han de ser diziséys, y los ocho se juntan de dos en dos debaxo de los cornijales del tablero, donde hazen sus retorcijos y bueltas hélycas; los otros ocho se siembran por las paredes del vaso y hazen, assimesmo, sus retorcijos respondientes los unos a los otros con ataduras artificiales de mucha ygualdad. // Fernández de Enciso, Suma de Geographía, 1530, fol. LXVIIr: E como son las colores naturales e propias, parescen tanto bien, que ninguna obra artificial de las que acá obran es tan buena ni tan agradable a la vista. // Juanelo Turriano, Veinte y un libros, a. 1605, fol. 105r: Ansí que realmente podemos llamar esta fuente artificial, pues que con industria humana se a hecho.

FAM.: artífice, artificio, artificiosamente, artificioso.

artificie, V. artificio.

artificio, artifficio, artiffiçio, artificie, artificio, artifiçio [tomado del lat. artíficium 'íd.'. 2 ${ }^{\mathrm{a}}$ mitad del s. X, Glosas de Silos (DECH). Chaves, Sacrobosco, 
Sphera, 1545]. sust. m. Primor, modo, arte con que está hecha alguna cosa (Autoridades).

Nebrija, Tabla días y horas, 1517, IIr: Muchas cosas están puestas en la común opinión del pueblo ignorante, que la razón y artificio muestran ser de otra manera, como aquello que todos comúnmente piensan que el crecer y menguar de los días se haze igualmente. // Collado, Plática Artillería, (1592), 1592, fol. 10v: Quando, por ahorrarse el fundidor el metal bueno y escogido que para la fundición del artillería le fue dado, lo trueca para fundir de él otras cosas de más artificio, las pieças salen con magañas o concavidades, esponjosas, o con otro qualquier deffecto, meresce ser muy bien castigado. // Juanelo Turriano, Veinte y un libros, a. 1605, fol. 64v: Puédese hazer esto en otra manera, con más artificio, como la figura lo demuestra.

FAM.: artífice, artificial, artificiosamente, artificioso.

2 [Sagredo, Medidas Romano, 1526]. sust. m. Obra ejecutada según arte y sus reglas, o con novedad, primor y sutileza, como el artificio del reloj, el de Juanelo (Diccionario Histórico).

Sagredo, Medidas Romano, 1526, pág. 13: De Archímedes se escribe, según cuenta Plutarco, que hizo un artificio ordenado por arte de Geometría contra Marcello, capitán de los romanos, quando tenía cercada la cibdad de Syracusa, en Cecilia, con el qual prendía las naos del dicho Marcello, y las levantava y sacava del agua y las metía dentro de la cibdad. // Besson, Teatro instrumentos, 1602, pág. I4v: Artificio no vulgar para arar la tierra, con maravilloso atajo, con tres rejas, juntamente ligadas dos cuerdas a la carreta del arado, y que por sus vezes se desencogen y encogen sobre la carreta o en los términos del campo que se ara. // García de Céspedes, Instrumentos nuevos, 1606, fol. 40r: En este caso es necessario de algún artificie para que aya efeto lo que se pretende, porque naturalmente la agua no puede subir de parte baxa a parte alta.

artificiosamente, artificiosamente [de artificioso. Chaves, Sacrobosco, Sphera, 1545]. adv. Ingeniosamente, con industria y artificio (Terreros).

Chaves, Sacrobosco, Sphera, 1545, fol. XCIIr: Fue necessario que los astrólogos artificiosamente hiziessen los días yguales, para lo qual constituyeron la tabla que anda de las equationes de los días. / / Sánchez de las Broças, Helt Frisio, Relox español, 1549, fol. 18r: Porque paresce que concuerda con razón que, pues ya sabemos sacar el día por el instrumento, sepamos también distinguir y cognoscer artificiosamente sus partes. // Arphe, Varia Commensuración, 1585-87, fol. Vv: Pues lo que yo en mi obra pretendo es solamente juntar, de todos los autores que mejor acertaron estas artes, solas las reglas necessarias para labrar artificiosamente la plata, y oro y otros metales.

FAM.: artífice, artificial, artificio, artificioso. 
artificioso, artifficioso, artiffiçioso, artificioso [tomado del lat. artǐfič̌osus

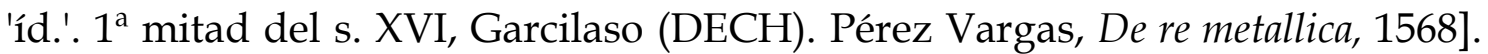
adj. Hecho o elaborado con artificio, arte, ingenio o habilidad.

Pérez Vargas, De re metallica, 1568, fol. 35v: Y ay algunos tan artificiosos que en cierta secreta manera le sacan cierta parte de oro que es inseparable por fuzión, y dizen nascer y estar siempre con él mezclada. // Apiano, Cosmographía, 1575, fol. 75v: El oficio de los plateros es el más primo y el más artificioso de todos, y tienen tanta habilidad en el labrar, que qualquiera cosa natural imitan al vivo. // Collado, Plática Artillería, 1592, fol. 83v: Otro muy más artificioso modo de dar fuego a tiempo se ha inventado en Alemaña, que es un instrumento a manera de un despertador de la noche que dispara un resurte y toca un pedernal, y saca fuego y dalo a la mixtura del saquillo;

FAM.: artífice, artificial, artificio, artificiosamente.

artifiçial, V. artificial.

artifiçio, V. artificio.

aserrado, aserrado, asserrado [de aserrar (DECH). Urrea, Vitruvio, Architectura, 1582]. adj. Cortado o dividido con la sierra.

Urrea, Vitruvio, Architectura, 1582, fol. 32r: La parte baxa, cortada y asserrada en quatro quartos. // Urrea, Vitruvio, Architectura, 1582, fol. 110v: D'esto se harán las paredes con el peso a nivel del altura que ha de aver, y písese con pisones de madera asserrados. // Juanelo Turriano, Veinte y un libros, a. 1605, fol. 229r: Y después de visto la hondura, conviene tener aparejado mucha madera aserrada, que es el principio de la obra.

SIN.: serrado.

FAM.: aserrador, aserradura, aserrar, serrado, serradura, serrar, sierra.

aserrador, aserrador [de aserrar (DECH). Lechuga, Discurso de la Artillería, 1611]. sust. $m$. Persona que tiene por oficio el aserrar (DRAE).

Lechuga, Discurso de la Artillería, 1611, pág. 191: Dos aserradores continuos en la artillería. // Lechuga, Discurso de la Artillería, 1611, pág. 227: A cada aserrador, otros tantos. // Lechuga, Discurso de la Artillería, 1611, pág. 234: Item, avrá de toda suerte de trabaxadores en la artillería, como carpinteros, herreros, herradores, aserradores, toneleros, canastreros, cañameros.

FAM.: aserrado, aserradura, aserrar, serrado, serradura, serrar, sierra. 
aserradura, aserradura, asserradura [de aserrar (DECH). Collado, Plática Artillería, 1592]. sust. f. u. t. c. pl. Partículas de madera que se desprenden al serrar (DRAE s. v. serraduras).

Collado, Plática Artillería, 1592, fol. 87v: Toma una cantidad de asserraduras de pino y que sea del más grasso de tea que se pueda hallar, porque arderá mejor. // Collado, Plática Artillería, 1592, fol. 81r: Y nota que si a mezcla de la estopa dicha querrás meter asserradura de pino o de laurel, harán flama maravillosa. // Ufano, Tratado de la Artillería, 1613, pág. 402: Rastreros y petares con una nuvada de fuego esparcida por el ayre de aserraduras gruesas de pino, en açufre, pólvora y aguardiente bañadas.

SIN.: serradura.

FAM.: aserrado, aserrador, aserrar, serrado, serradura, serrar, sierra.

aserrar, aserrar, asserrar [de serrar. 1251, Calila (DECH). Loçano, Alberto, Architectura, 1582]. v. tr. Cortar o dividir con la sierra (DRAE s. v. serrar).

Loçano, Alberto, Architectura, 1582, pág. 55: D'éste mande asserrar, con sierra de dientes, tablas muy acommodadas para entabladuras. // Juanelo Turriano, Veinte y un libros, a. 1605, fol. 235v: Y aún dizen más a esto: que las maderas que se han de aserrar y hazer tablas. // Juanelo Turriano, Veinte y un libros, a. 1605, fol. 239r: Y no se deven aserrar estos maderos antes que primero no sean enjutos.

SIN.: serrar.

FAM.: aserrado, aserrador, aserradura, serrado, serradura, serrar, sierra.

asno, asno [del lat. ăš̌nus 'íd.'. 1076 Juanelo Turriano, Veinte y un libros, a. 1605]. sust. $\mathrm{m}$. Mec. Tabla plana de madera, de forma rectangular, sobre la que se colocan materiales o cargas para que sean izados o transportados.

Juanelo Turriano, Veinte y un libros, a. 1605, fol. 384r: Llámele cada qual como quisiere, porque unos le llaman el cavallo, otros asno, otros albardón, otros la zivilla de la grúa, otros coraçón, como aquél de las balanças de pesar las cosas.

SIN.: albardón, caballo, cibilla, corazón.

[IMAGEN] Pseudo-Juanelo Turriano, Los ventiún libros, c. 1605, fol. 383v, fig. 378, letra Q.

aspa, aspa, haspa [del gót. *haspa 'aspa de aspar hilo'. 1256-76 (DECH). Lobato, Notas, c.1585]. sust. f. u. t. c. pl. Conjunto de dos maderos o palos atravesados el uno sobre el otro de modo que formen la figura de una $X$ (DRAE).

Juanelo Turriano, Veinte y un libros, a. 1605, fol. 52v: Ay otro instrumento, el qual instrumento Junior Columela, en su obra De re rustica, le llama çiconia, el qual es hecho en una manera de aspa o de $\mathrm{X}$, letra del abecedario, y encima d'esta aspa se le 
asienta una otra pieza como es la letra T latina. // Juanelo Turriano, Veinte y un libros, a. 1605, fol. 222r: Las aspas $\mathrm{K}$ y $\mathrm{O}$ van cruzando todo el antepecho y líganse con aquellos pies derechos que caen a pesso. // Juanelo Turriano, Veinte y un libros, a. 1605, fol. 225r: Sólo consiste la fuerça en las dos pilas, de modo [que], aunque fuese algún río muy anchíssimo, que se les podría hazer tres d'estas puentes, o cinco, con este modo de arcos de madera, que van ansí, con estas aspas y con aquellos pilares, que las sustentan las aspas o cruces.

HIPER.: pieza.

FAM.: aspado.

[IMAGEN] Pseudo-Juanelo Turriano, Los ventiún libros, c. 1605, fol. 221v, fig. 296, letras K y O, son las aspas que cruzan el antepecho de un puente.

2 [Lobato, Notas, a. 1585]. sust. f. pl. Mec. Aparato exterior del molino de viento, que parece una cruz o aspa, en cuyos brazos se ponen unos lienzos a manera de velas, y el cual, girando a impulso del viento, mueve el molino (DRAE).

Lobato, Notas, a. 1585, fol. 20: Es un ingenio poco costoso y muy vistoso y provechoso para la molienda. Y muele en lo bajo, que no ha necesidad de aspas grandes que circunden la torre, porque el viento le toma en la superficie de la torre. // Lobato, Notas, a. 1585, fols. 23 y 24: Y en él injerir de fuertes maderos el eje principal del molino de viento, solamente para sostener las aspas que han de ir en el dicho eje puestas, que entren y vengan a entrar en el agua que está a la redonda de la torre cuatro o cinco pies de hondo.

HOL.: molino.

[IMAGEN] Lobato, Notas, c. 1585, figuras 19 y 20.

aspado, aspado [de aspa (DRAE). Anónimo, Ordenanças paños, 1527]. adj. Con forma de aspa (DRAE).

Anónimo, Ordenanças paños, 1527, fol. IIv: Assí de trama como de estambre, en madexas aspadas, y que no las peynen ni alisen, so la dicha pena.

FAM.: aspa.

assequia, V. acequia.

asserrado, V. aserrado.

asserradura, V. aserradura. 
asserrar, V. aserrar.

asta, asta, hasta [del lat. hasta 'palo de lanza o pica', 'pica'. H. 1140, Cid (DECH). Fernández de Enciso, Suma de Geographía, 1530]. sust. f. Palo largo donde se ponen los hierros de algunas armas y herramientas.

Fernández de Enciso, Suma de Geographía, 1530, fol. XXVIv: Labran en ella muchas armas e arneses de todas suertes, e muy buenas, tienen muchos árboles de que hazen las astas de lanças e dardos e saetas en quantidad. // Alcega, Geometría prática, 1589, fol. 77r: El qual cordón ha de yr atado en la punta de la dicha asta después que esté puesta la vandera y un hierro de lança que lleva en la punta de la dicha asta. // Roxas, Sumario milicia, 1607, fol. 50v: Dicen hoz a un hierro muy agudo, encorvado a manera de hoz de segar el trigo, el qual puesto en una asta luego en un ystante corta las cuerdas que llaman cimntes.

FAM.: astil.

2 [Lobato, Notas, a. 1585]. sust. f. Hilada de ladrillos (DRAE).

Lobato, Notas, a. 1585, fol. 13: El agua que viene a topar cuando llueve de [las] cuestas a topar en el cauce que va por la ladera o balsa del molino, ponerla en el hondo que hubiere de llevar su corriente, y luego labrar enfrente de dicho aguacero o caño un puente de uno o dos ojos, los que sean necesarios, de un asta de ladrillo de grueso y del ancho que fuere menester para pasar el agua del arroyo de la avenida. // Lobato, Notas, a. 1585, fol. 30: La casica donde ha de ir esta escalera de torno, arriba dicha, ha de ser cuadrangular, de 4 pilares de ladrillo gruesos, y lo demás de una asta, o toda ella de asta y media, con su cobertor de una bobedica de ladrillo de una frente de grueso por tejado y enladrillada por encima muy corriente y fuerte.

astil, astil, hastil [del lat. hastīle 'íd.', derivado de hasta. H. 1140, Cid (DECH). Loçano, Alberto, Architectura, 1582]. sust. m. Varilla o regla en la que se realizan mediciones en algunos niveles y otros instrumentos.

Loçano, Alberto, Architectura, 1582, pág. 321: En el centro del círculo fixaréys un hastil que esté enhiesto a plomo. Esto hecho, el maestro que dirige las aguas, por de fuera rodeará el círculo, buscando en qué lugar la línea de la vista extendida al otro término del agua que se ha de guiar vaya al mismo término, y por abajo toque a aquel hastil fixado en el centro. // Juanelo Turriano, Veinte y un libros, a. 1605, fol. 54v: De modo que es muy más alto el monte que no es el asiento del nivel, porque dende el peso hasta la línea de la planiçie ay quatro palmos, como por las líneas y números se puede ver el valor del instrumento. El suelo adonde está asentado el instrumento es K. Y el pie, que es un triángulo, es A. Y el astil o regla derecha es B. // Juanelo Turriano, Veinte y un libros, a. 1605, fol. 460v: Y donde salle la agua es G. Y después de haver hinchido el vaso de agua, señalar en el hastil dónde llegó el agua; dende aý, tomar aquella distançia de espacio y repartirla en espacios iguales con sus números. 
HOL.: nivel.

2 [Juanelo Turriano, Veinte y un libros, a. 1605]. sust. Mango, ordinariamente de madera, que tienen las hachas, azadas, picos y otros instrumentos semejantes (DRAE).

Juanelo Turriano, Veinte y un libros, a. 1605, fol. 228r: Convendrá encaxar el astil de la barrena en un madero que sea muy largo, y después de puesto, es menester volver a poner un pedazo de madera que hincha lo vazío que queda, y ponerle dos cercillos de hierro muy bien asentados. // Juanelo Turriano, Veinte y un libros, a. 1605, fol. 252r: Los astiles de los picos y maças conviene que sean delgados, a causa que, siendo delgados, dan mayor golpe.

HOL.: herramienta.

atahona, atahona [del hispano-ár. atṭahúna, y este del ár. clás. țāhūn [ah], 'molino'. (DRAE). Escalante, Discurso de la navegación, 1577]. sust. f. Mec. Molino harinero cuya rueda se mueve por fuerza humana o animal.

Escalante, Discurso de la navegación, 1577, fol. 49r: A los ciegos, quando son pobres, ordénanles que trabajen y ganen de comer en moler en atahonas trigo y arroz en lugar de mulas. // Acosta, Historia natural, 1590, pág. 230: Esta molienda se haze con diversos ingenios: unos que traen cavallos, como atahonas, y otros que se mueven con el golpe del agua, como aceñas o molinos, y de los unos y los otros ay gran quantidad. // Alonso Barba, Arte de los metales, 1640, fol. 72v: Consta qualquiera d'ellos de dos piedras grandes y duras, [...] en forma de rueda o queso entero la de arriba, en los trapiches que mueven cavalgaduras, como en las atahonas o molinos de azeitunas.

SIN.: molino de bestia(s), molino de sangre, molino de tahona, tahona 1.

HIPER.: molino.

FAM.: tahona.

ENCICL.: En las Antiguas Grecia y Roma, era a los esclavos a quien se encargaba la dura tarea de mover el molino, y aunque durante la Edad Media y el Renacimiento se recurrió a animales de tiro para realizar este propósito, continuaron proliferando molinos, como los de rueda de pisar o grúa, que precisaban de la fuerza humana para su funcionamiento. En cualquier caso, los molinos movidos por animales se vieron favorecidos por el invento de la collera y el atalaje, que facilitaron el empleo de la fuerza animal en maquinaria diversa (García Tapia 1997: 12-14).

2 [Juanelo Turriano, Veinte y un libros, a. 1605]. sust. f. Mec. Barcaza de fondo plano, provista de una trampilla abatible, sobre la que se deposita el material extraído al ahondar y limpiar puertos y canales. 
Juanelo Turriano, Veinte y un libros, a. 1605, fol. 382r: Ella ha de estar como el govierno de un cópulo o barco, y hásele de accomodar un otro barquillo junto el qual pueda recebir el lodo que con la palaça se va secando, y ponerle dentro del otro barco en una atahona que estará assentada en el medio del barco. // Juanelo Turriano, Veinte y un libros, a. 1605, fol. 382r: Y encima d'esta atahona ha de haver un madero que juegue, $y$ ha de tener una cuerda que vaya desde el madero hasta la portezuela, y ha de jugar esse madero para recoger la cuerda y para soltarla. // Juanelo Turriano, Veinte y un libros, a. 1605, fol. 382v: Y en esta atahona se ha de hechar el lodo, y quando está llena, vaziarla afuera.

SIN.: tahona 3.

atanor, atanor, atenor [del hispano-ár. attannúr y este del ár. clás. tannūr 'boca de pozo', 'manantial', 'cañería para agua'. Entre 1493 y 1495, Nebrija (DECH). Lobato, Notas, c.1585]. sust. m. Ingen. Hidrául. Conducto o cañería, generalmente de barro, piedra o cerámica, aunque también puede fabricarse de metal, que sirve para conducir el agua a las fuentes o a otra parte.

Lobato, Notas, c.1585, fol. 9: De donde sale la dicha fuente se ha de hundir el agua, que caiga directamente hacia abajo de toda aquella altura que nace a plomo por un arcaduz o atanor que vaya cuatro o cinco pies debajo de la superficie de la tierra. // Sanctiago, Arte separatoria, 1598, fol. 49r: Lo qual se demuestra porque vemos que en los condutos $\mathrm{y}$ atenores del agua se hazen y engendran sarros y tovas, que muchas vezes suelen cerrarse los dichos condutos, lo qual se le comunica de las partes gruesas y viciosas por donde ella pasa. // Besson, Teatro instrumentos, 1602, fol. M2v: Envención nueva, no de tener en poco, con que, sin atanores y respiraderos, se puede sacar agua de un pozo muy hondo, con solamente dos poleas, de manera que el que tira el jugo sienta tan solamente la metad del peso.

SIN.: arcaduz.

HOL.: obra hidráulica.

[IMAGEN] Lobato, Notas, c. 1585, fol. 9.

atelabo, attelabo [tomado del lat. attĕlěbus 'langosta' (Laterculi). Besson, Teatro instrumentos, 1602]. sust. m. Mec. Trabazón de la balanza de un torno.

Besson, Teatro instrumentos, 1602, fol. Dv: Al cabo de la balança están asidos dos arcos, en el fin de los quales están cruzados otros palos, entre sí oppuestos, cuya travazón, por la semejança de los pies de la langosta, me plaze llamar attelabo. // Besson, Teatro instrumentos, 1602, fol. Dv: De los quales tres maderos, el uno se vee cerca del obrero, los otros dos están juntos al cabo de aquellos palos puestos a manera de cruz, que el intérprete les llama attelabo. // Besson, Teatro instrumentos, 1602, fol. Dv: Y assí, acaece que, acercándose la balança al obrero, se apriete el attelabo, y, ella retirándose, éste, por el contrario, se estienda.

HOL.: torno.

[IMAGEN] Besson, Diego, Teatro de los instrumentos, Horacio Cardon (trad.), 1602, pág. D2r, figura 10. 
atenor, V. atanor.

attelabo, V. atelabo.

autómato, autómato [tomado del lat. automăton 'íd.' y éste del adj. gr. av̉ó́patos 'espontáneo'. Terr. (autómata) (DECH s. v. autómata). Urrea, Vitruvio, Architectura, 1582]. sust. m. Mec. Máquina que se mueve por sí misma (Terreros). Urrea, Vitruvio, Architectura, 1582, fol. 121r: Pues quando Cthesibio consideró que el espíritu y voz nacía del tocar el ayre y exprimirlo, aprovechándose d'estos principios, inventó las máchinas hidráulicas, que son instrumentos músicos de agua, y el exprimir de las aguas, y los autómatos del porrecto, y las máchinas pintadas, y otros muchos géneros de passatiempos.

HIPER.: máquina.

axa, V. aja.

ayunque, ayunque [del ant. iuncue 'íd.', procedente, con probabilidad, de un lat. vg. incude (DECH s. v. yunque). Pérez Vargas, De re metallica, 1568]. sust. $\mathrm{m}$. Prisma de hierro acerado, de sección cuadrada, a veces con punta en uno de los lados, encajado en un tajo de madera fuerte, que utiliza el herrero para trabajar a martillo los metales.

Pérez Vargas, De re metallica, 1568, fol. 102r: Y, puesto en un ayunque, con unos maços o martillos grandes, pesados, que se muevan con el yngenio del agua, y con unos dientes que tiene el exe de la rueda con un batán se bata y corte en quatro o cinco pedaços // Ufano, Tratado de la Artillería, 1613, pág. 82: Dos fraguas con sus ayunques y todo su adereço y serviçio. // Lechuga, Discurso de la Artillería, 1611, pág. 202: Ayunques... 8.

SIN.: yunque.

FAM.: yunque.

azada, açada, azada, hazada [del lat. vg. *asciata 'herramienta provista de una ascia'. H. 1220-1250, Berceo (DECH). Álaba, Perfeto capitán, 1590]. sust. f. Herramienta formada por una pala cuadrangular de hierro y un mango y que se utiliza, entre otros usos, para cavar tierras blandas.

Álaba, Perfeto capitán, 1590, fol. 75r.: Yendo prevenidos de açadas, picos, hachas de hierro, palas, hozinos, sierras, machos de hierro y vinagre para que con celeridad 
gasten las piedras. // Collado, Plática Artillería, 1592, fol. 91v: Primeramente, harás una buena provisión de hachas, açadas, palas de hierro, çarandas o crivas grandes hechas de mimbres o de cuerdas de cáñamo o de esparto. // Juanelo Turriano, Veinte y un libros, a. 1605, fol. 172v: Mucha piedra, cal, arena, clavazones, qüerdas, anillas portaderas, espuertas de mimbre, bacietas o gamellas, açadas, palas, ligones, garruchas, carros, sierras, martillos, picos y otras infinitas cosas que para ello es menester.

HIPER.: herramienta.

FAM.: azadón, azuela.

[IMAGEN] Pseudo-Juanelo Turriano, Los ventiún libros, c. 1605, fol. 252r, fig. 318, situada en la parte inferior de la imagen, a la izquierda.

azadón, açadón, azadón, hazadón [de azada. Entre 1493 y 1495, Nebrija (DECH). Collado, Plática Artillería, 1592]. sust. m. Herramienta formada por una pala más curva y larga que la de la azada, y que se utiliza, entre otros usos, para romper tierras duras.

Collado, Plática Artillería, 1592, fol. 48v: Torné a cargar la pieça y hízele hazer con un açadón un hoyo de un palmo de hondo debaxo de la rabera o cola de la caxa. // González de Medina, Examen fortificación, 1599, pág. 42: Y no porque no sea bueno, y se contentan como ella se sale peynada del terreno con el açadón, perpendicularmente. // Alonso Barba, Arte de los metales, 1640, fol. 55r: Estando para lavar el metal, se le echa agua en abundancia y se abra con el açadón por muchas partes para que mejor lo penetre

HIPER.: herramienta.

FAM.: azada, azuela.

azequia, $V$. acequia.

azerado, V. acerado.

azero, V. acero.

azuche, açuche, azuche [del hispano-ár. zúğğ 'íd.' y este del ár. clás. zuğğ 'cuento de la lanza' (DRAE). 1772, Bails (DRAE). Juanelo Turriano, Veinte y un libros, a. 1605]. sust. m. Punta de hierro que va al extremo del piloto o palo que se clava en el suelo para asegurar los cimientos de un edificio (Salinero). 
Juanelo Turriano, Veinte y un libros, a. 1605, fol. 158r: Y para que muy mejor se hinquen estos maderos dentro del suelo, convendrá ponerles en la punta que se a de hincar unos açuches de yerro, que estén muy bien asentados en la punta del madero, que es el que tiene la P. // Juanelo Turriano, Veinte y un libros, a. 1605, fol. 216r: Nunca se hincarán bien, por causa que, no teniendo azuches, la madera, tocando en cosa dura, luego sehaze estopa y, quanto más golpes le dan, tanto más se embota y menos entra. // Juanelo Turriano, Veinte y un libros, a. 1605, fol. 427r: Y conviene hincar maderas de punta, y que tengan sus azuches a los cabos, y después hazer dos armaduras de maderos, que liguen todo el patio que se a de hazer.

azud, açude, açute, azute [del hispano-ár. assudd y este del árabe clásico sudd 'obstáculo, obstrucción', 'presa', que a su vez proviene del verbo sadd 'cerrar'. 1128 (DECH). Juanelo Turriano, Veinte y un libros, c.1605]. sust. m. Ingen. Hidrául. Presa hecha en los ríos a fin de tomar agua para regar y para otros usos (DRAE).

Juanelo Turriano, Veinte y un libros, c.1605, fol. 107r: De modo que, quando se trahe agua por azequias grandes, y esta agua se saca ordinariamente de los ríos grandes, y también de los pequeños, y en algunos se saca azequias sin açutes, que de suyo mismo se entra el agua en la acequia sin ningún artificio de hazerla levantar. // Juanelo Turriano, Veinte y un libros, c.1605, fol. 117v: Mas para avelle de resistir a todo el peso del agua del río, estos reparos se devían de hazer en el verano, quando las aguas son muy baxías, y hazer una mota o açute que atraviese. // Juanelo Turriano, Veinte y un libros, c.1605, fol. 153v: El más fácil y más simple es el que sigue, y es que en esta forma de azute no se haze más que yr puniendo de las piedras del mismo río, puestas amontonadas, y después, con unos çéspedes de tierra yr puniendo a la parte donde viene el río.

HIPER.: obra hidráulica.

FAM.: azuda.

[IMAGEN] Pseudo-Juanelo Turriano, Los ventiún libros, c. 1605, fol. 164r, fig. 138.

azuda, açuda, azuda [del hispano-ár. súdda, nombre de unidad de sudd 'obstáculo, obstrucción', 'presa' y este del verbo sadd 'cerrar'. 1221 (DECH). Pérez Vargas, De re metallica, 1568]. sust. f. Mec. Máquina con que se saca agua de los ríos para regar los campos, formada por una gran rueda afianzada por el eje en dos fuertes pilares que, movida por el impulso de la corriente, da vueltas y arroja el agua fuera (DRAE s. v. azud).

Pérez Vargas, De re metallica, 1568, fol. 78r: Este moler de los metales se haze differentemente mediante algunos ynstrumentos y máchinas de martillos, y maços de hierro, y palos clavados y ruedas que se traen a braço y otras con agua, como açudas y anorias, que, porque son cosas diffíciles y que cada uno las ha de ver con los ojos, no diremos otra cosa sino que el señor de la mina busque tales maestros y artífices que tengan experiencia. // Lobato, Notas, c.1585, fol. 26: Y, visto esto, dimos orden cómo se podría volver el agua, y parecionos que con una rueda o azuda como las de Toledo la volveríamos, la cual hicimos, y volvería la doceava parte, y aún no tanto como lo que 
salía. / / García de Céspedes, Instrumentos nuevos, 1606, fol. 40r: Los antiguos para este efeto imaginaron algunas máchinas, como son norias de diferentes suertes, bombas, azudas, cócleas y la tesibica que pone Vitruvio, la qual dize que sube la agua muy alto, pero es poca y con mucha violencia.

HIPER.: máquina.

FAM.: $a z u d$.

azuela, açuela, azuela [del hispanolatino asciŏla 'íd.', diminutivo del lat. asč̆a 'azuela', 'hacha'. 1351, Cortes (DECH). Pérez Vargas, De re metallica, 1568]. sust. f. Herramienta formada por una plancha de hierro y un mango corto, que se utiliza para labrar la madera.

Pérez Vargas, De re metallica, 1568, fol. 9v: Que explica todas las formas juntamente con los elementos quatro, assí como el artífice y official, con el martillo, con el açuela, con la sierra y con el cinzel compone y perficiona las formas de su arte. // Collado, Plática Artillería, 1592, fol. 111v: Una hacheta o una açuela, un martillo de orejas, una hacha grande, limas y raspas de azero de todas suertes. // Rojas, Teórica fortificación, 1598, fol. 73v: Y mucho género de herramientas, como son: picos, palas, hazadas, hazadones, hachas, azuelas, barras de hierro, barrenas chicas y grandes

SIN.: aja.

HIPER.: herramienta.

FAM.: azada, azadón.

[IMAGEN] Pseudo-Juanelo Turriano, Los ventiún libros, c. 1605, fol. 248r, fig. 316. La azuela es la herramienta situada en la parte de arriba de la imagen, en el centro.

azute, V. azud. 


\section{Babilonia, V. betún de .}

bacía, bacía, vacía [quizás del fr. antic. bassie 'íd.'. 1368, Fuentes aragonesas. (DECH). Urrea, Vitruvio, Architectura, 1582]. sust. f. Pieza cóncava y pequeña, de barro $\mathrm{u}$ otra materia, que sirve para contener especialmente líquidos (DRAE s. v. vasija).

Urrea, Vitruvio, Architectura, 1582, fol. 102r: Y en aquellos lugares donde estas señales no parecieren, experimentarse ha d'esta manera si ay agua: cávese hazia todas partes en lugar ancho de cinco pies, y allí se ponga al poner del sol un baso de açófar o de plomo, o una bacía, lo que se hallare d'estas cosas, y por dentro úntese con azeyte y póngase hazia baxo, y lo de arriba cúbrase de cañas so tierra. // Mosquera, Comentario disciplina militar, 1596, fol. 30v: La moneda es de cobre la mayor parte, y para la fabricar han deshecho quantas bacías y vasos de cobre ay en las islas y ahora lo esperan de Flandes para hazer moneda d'ello. // Alonso Barba, Arte de los metales, 1640, fol. 106v: Molidos y mezclados los polvos de que se ha de hazer el agua fuerte, según las proporciones dichas, se echarán en la vacía o orinal los que cupieren hasta el tercio y, quando mucho, la mitad d'él y no más.

SIN.: bacín.

FAM.: bacieta, bacín, bacinilla. 
[IMAGEN] Pseudo-Juanelo Turriano, Los ventiún libros, c. 1605, fol. 265v, fig. 322. La bacía está situada en la parte inferior derecha de la imagen.

bacieta, bacieta [de bacía. 1331, Inv. arag. (DECH). Juanelo Turriano, Veinte y un libros, a. 1605]. sust. f. arag. Barreño grande, por lo común de madera, que sirve para varios usos domésticos o industriales (Clairac s. v. gamella).

Juanelo Turriano, Veinte y un libros, a. 1605, fol. 172v: Espuertas de mimbre, bacietas o gamellas, açadas, palas, ligones, garruchas, carros, sierras, martillos, picos y otras infinitas cosas que para ello es menester. // Juanelo Turriano, Veinte y un libros, a. 1605, fol. 430r: Maças de hierro, bacietas o gamellas de madera grandes y pequeñas, de toda suerte muchas tablas. // Juanelo Turriano, Veinte y un libros, a. 1605, fol. 359v: En la figura: Poçal. Bacioncillo. Bacieta o gamella. Baciete. Mortero de cal y arena. Fosa para matar la calcina.

SIN.: gamella.

FAM.: bacía, bacín, bacinilla.

[IMAGEN] Pseudo-Juanelo Turriano, Los ventiún libros, c. 1605, fol. 265v, fig. 322, situada en el centro, en la parte superior de la imagen.

bacín, bacín, bazín [del lat. tardío bacchīnon, de origen desconocido. S. XIII (DECH). Anónimo, Repertorio tiempos, 1554]. sust. m. Pieza cóncava y pequeña, de barro $u$ otra materia, que sirve para contener especialmente líquidos (DRAE s. v. vasija).

Anónimo, Repertorio tiempos, 1554, fol. XLIIIr: Y devéys de notar que quando havéys de sangrar del pie, o mano, o piernas, o de alguna parte d'estos miembros, devéys henchir un bazín de agua caliente de manera que se pueda buenamente suffrir. // Collado, Plática Artillería, 1592, fol. 68r: Otros, para el effecto dicho de saber si el enemigo mina o viene contraminando, procuran de saberlo en otro modo no menos importante y cierto qu'el passado: toman vasos de alatón, como son bacines de barbero o otros semejantes, y aquéllos hinchen de agua clara y pónenlos llanos en el suelo de la mina.

SIN.: bacía.

FAM.: bacía, bacieta, bacinilla.

bacinilla, bacinilla [de bacina. (DRAE). Lobato, Notas, a. 1585]. sust. f. Bacía pequeña con varios usos.

Lobato, Notas, a. 1585, fol. 37: Y cuando orinaba no sonaba sino como si cayera miel, y después se cuajaba como quesos en la bacinilla. // Collado, Plática Artillería, 1592, fol. 88v: Y estando assí, henchirás una bacinilla de agua clara, qu'el pan de cera pueda estar dentro d'ella sin hundirse.

FAM.: bacía, bacieta, bacín. 
badil, badil [del lat. vg. *batile 'paleta para mover lumbre', latín clásico bătŭllum 'paleta para mover lumbre'. A. 1289, Doc. de la Rioja Baja (DECH). Juanelo Turriano, Veinte y un libros, c.1605]. sust. m. Mec. Barra de hierro que está encajada entre el árbol del rodete y la nanilla de algunos molinos harineros. Juanelo Turriano, Veinte y un libros, c.1605, fol. 300r: Y la muela que anda es H, la qual va asentada encima de la nanilla, la qual va asentada encima de aquella barra de yerro, la qual llaman badil, el qual es I. // Juanelo Turriano, Veinte y un libros, c.1605, fol. 300r: El árbol del rodete es K, donde está encaxado el badil, en la parte de arriva. // Juanelo Turriano, Veinte y un libros, c.1605, fol. 300r: Al costado va señalado la nanilla y el badil y el árbol del rodete.

HIPER.: herramienta.

HOL.: molino.

[IMAGEN] Pseudo-Juanelo Turriano, Los ventiún libros, c. 1605, fol. 259v, fig. 319. Está situado en la parte baja de la imagen, a la izquierda.

baja, V. muela .

balaçón, V. balanzón.

balança, V. balanza.

balançar, V. balanzar.

balançón, V. balanzón.

balanza, balança, balanza, valança, valanza [del lat. vg. *bülancia 'íd.', supuesto por todos los romances, y seguramente derivado adjetivo de bilanx, büilancis 'íd.'. Orígenes del idioma (DECH). Sagredo, Medidas Romano, 1526]. sust. f. Cada uno de los vasos o platos cóncavos que penden de los extremos de los brazos del peso, con algunos cordones o cadenillas y sirven para poner en el uno lo que se ha de pesar y en el otro las pesas con que se ha de hacer el peso (Autoridades).

Sagredo, Medidas Romano, 1526, pág. 46: Los primeros que assentaron capiteles sobre las colunas fueron los doros, y su capitel era un vaso redondo, a manera de taçón o balança, cubierto con un tablero quadrado, a semejança de plinto // Sagredo, Medidas Romano, 1526, pág. 50: El vaso de los otros es como taçón o balança, el del corinthio es como cuvo o errada con que sacan agua. 
FAM.: abalanzado, balanzado, balanzar, balanzón.

2 [Sagredo, Medidas Romano, 1526]. sust. f. Instrumento que sirve para pesar o, más propiamente, para medir masas. (DRAE).

Fernández de Enciso, Suma de Geographía, 1530, fol. XXXVr: Y que hizo hacer un peso muy grande, y que le hizo a Alexandre que pusiese en la una balanza cuantas joyas ricas y tesoro tenía. // Juanelo Turriano, Veinte y un libros, a. 1605, fol. 123r: Y esto nos lo averiguan las balanzas, que, quando el pesso es ygual, vemos que la balança está en la línea de la ygualdad.

3 [Besson, Teatro instrumentos, 1602]. sust. f. Mec. Máquina con forma de balanza que sirve para levantar cargas o para mover otros instrumentos.

Besson, Teatro instrumentos, 1602, fol. Dv: Y a la parte oppuesta la balança, que tira a sí con la mano isquierda el obrero por medio de la cuerda en ella atada, contadas del cabo de la balança, que está hazia tramontana, una mesura y seys partes. // Besson, Teatro instrumentos, 1602, fol. Dv: Al cabo de la balança están asidos dos arcos, en el fin de los quales están cruzados otros palos, entre sí oppuestos, cuya travazón, por la semejança de los pies de la langosta. // Besson, Teatro instrumentos, 1602, fol. D2v: Nueva manera de balança, la qual, movida a mano de dos, a guisa de campana que se buelve, tiene tanta fuerça a mover dos fuelles.

HIPER.: máquina.

[IMAGEN] Besson, Diego, Teatro de los instrumentos, Horacio Cardon (trad.), 1602, pág. D3r, figura 11.

en [Collado, Plática Artillería, 1592]. loc. adv. En un plano horizontal (DRAE s. v. a nivel).

Collado, Plática Artillería, 1592, fol. 4r: Era sustentada en el ayre ésta tirante y con cadenas colgada del cielo de la máquina, acomodada en tal manera que siempre estava en equilibra o en balança. // Collado, Plática Artillería, 1592, fol. 74v: Que, estando ya ella alta y llegada al término que digo, con poco tirar de las cuerdas de la boca, la trastornarán dentro, por quanto, si bien se considera, ya ella entonces está quasi en equilibra o en balança. // Ufano, Tratado de la Artillería, 1613, pág. 411: Encaxados en las lunetas o muñoneras, y cerrados y abraçados con las visagras o platinas, facilitan en gran manera el manejo y movimiento de la pieça, por estar quasi en balança y equilibra.

SIN.: en equilibra.

balanza, V. peso de $\sim$ s. 
balanzado, valançado, valanzado [de balanzar. Loçano, Alberto, Architectura, 1582]. adj. Equilibrado, nivelado.

Loçano, Alberto, Architectura, 1582, pág. 75: Pero, con qualquiera piedra que instituyeres de hinchir aquel vacío entre las cortezas, procurarás, quanto el negocio lo suffriere, que enlazen las órdenes valanzadas con trazo igualado. // Loçano, Alberto, Architectura, 1582, pág. 327: Y, por el contrario, en collado y en seco harás prado assí: haréys una çanja larga y no correntía, sino que se estanque en la parte más alta, con el lado igualado y valançado con nivel.

SIN.: abalanzado.

FAM.: abalanzado, balanza, balanzar, balanzón.

balanzar, balançar, valançar, valanzar [de balanza. 1595 (DECH). Loçano, Alberto, Architectura, 1582]. v. tr. Poner en equilibrio, igualar y contrapesar (Autoridades).

Loçano, Alberto, Architectura, 1582, pág. 67: Demás de esto, el hondo de todo cavamiento se ha de igualar llanamente con nivel, de tal manera que por ninguna parte esté cuesta abajo, para que las cosas que se uvieren de poner estén valanzadas con pesos iguales.

FAM.: abalanzado, balanza, balanzado, balanzón.

balanzón, balaçón, balançón [de balanza (DRAE). Pérez Vargas, De re metallica, 1568]. sust. m. Vasija, por lo común de cobre, esférica u oval, con mango de hierro, que usan los plateros para blanquecer o limpiar la plata o el oro (DRAE).

Pérez Vargas, De re metallica, 1568, fol. 163v: Y luego se quita el crisol y se vazía en una concha o balançón de agua fría. // Pérez Vargas, De re metallica, 1568, fol. 166v: Muélense yguales partes de rasuras y sal, y echánse en un balaçón de agua caliente y pónese a hervir. // Pérez Vargas, De re metallica, 1568, fol. 166v: Todo molido mezclado, se eche en un quartillo de agua en un balançón y hierva hasta que se consuma la mitad del agua; y guardarlo en una redoma.

FAM.: abalanzado, balanza, balanzado, balanzar.

balaustre, balaustre [del it. balaùstro 'columnita de barandilla' (DECH). 1526 (CORDE). Lobato, Notas, a. 1585]. sust. m. Mec. Cada una de las barritas de los carros de un molino.

Lobato, Notas, a. 1585, fol. 20: $\mathrm{Y}$ al fin de la parte baja ha de estar una rueda de 200 dientes cuadrados que tenga más de sesma de un grueso a otro, y esta rueda ha de herir en un carro de doce balaustres y en el palo de hierro que mueve la piedra. 
balsa, balsa [de origen prerrom. voz protohispánica, probablemente ibérica, común al castellano, al catalán y a algunos dialectos occitanos. Fin. S. XIII (DECH). Loçano, Alberto, Architectura, 1582]. sust. f. Ingen. Hidrául. Especie de estanque donde se recoge agua para usarla en los molinos.

Lobato, Notas, c.1585, fol. 16: Y huelga la mitad del tiempo y muele mucho más ferozmente que no el de arriba, mientras le dura el agua, y no ocupa tanto tiempo al molinero, que, entretanto que se hinche la balsa, puede cavar una viña o huerta. // Juanelo Turriano, Veinte y un libros, c.1605, fol. 293v: Esto se entiende en los molinos de regolfo. Y la balsa que subiere ocho o nueve palmos de agua encima de la saetía, en molino de regolfo molerá un caýz cada ora, y aun más. // Juanelo Turriano, Veinte y un libros, c.1605, fol. 312r: De modo que, caso que tenga mucha agua la balsa, ellos muelen arto poco. La balsa, conviene que ella sea, a lo menos, ocho palmos de ondo, ordinariamente, para aver de moler mucho.

HOL.: molino.

FAM.: contrabalsa, embalsado.

[IMAGEN] Lobato, Notas, c. 1585, fol. 16.

balsa, V. molino de $\sim$.

bambalear, V. bambolear.

bambanear, bambanear [voz de creación expresiva. S. XVI, Nebrija (DECH). Juanelo Turriano, Veinte y un libros, a. 1605]. v. intr. Oscilar con un movimiento de vaivén.

Juanelo Turriano, Veinte y un libros, a. 1605, fol. 142v: Y con estas quatro piezas de los cantones, en lo bajo y en lo alto, se le a de afixar unas anillas de hierro muy bien puestas, por causa que en las bajas se le puede colgar un peso que tenga quieta essa gata, que no ande bambaneando, el qual ha de ser una grande bola de plomo.

SIN.: bambolear.

bambolear, bambalear, bambolear, banbolear ['oscilar', voz de creación expresiva. 1550 (DECH). Loçano, Alberto, Architectura, 1582]. v. intr. Oscilar con un movimiento de vaivén. 
Loçano, Alberto, Architectura, 1582, pág. 345: Pondréys unas palancas, y lo estendido d'ellas cargaldo con espuertas de arena; levantarán el peso poco a poco sin bambalear muy ygualmente. // Juanelo Turriano, Veinte y un libros, a. 1605, fol. 143r: El peso, conviene que pesse mucho para tener que no se ande bamboleando la gata, gavia o gaula, las quales han de yr enclavadas. // Juanelo Turriano, Veinte y un libros, a. 1605, fol. 147v: Y si fuera más pesso, tanto más firme la tendrá, que no se vaya banboleando esta gata o meneándose mucho.

SIN.: bambanear.

banbolear, V. bambolear.

baño, baño [del lat. balněum 'íd.'. 1048, Orígenes del idioma (DECH). Celso, Reportorio universal leyes Castilla, 1553]. sust. m. u. t. c. pl. Ingen. Hidrául. Obra hidráulica colocada en tierra, generalmente con gradas, que se utiliza para distintos fines, como contener aguas medicinales (DRAE).

Celso, Reportorio universal leyes Castilla, 1553, fol. CIVv: Páguese diezmo de las tierras, viñas y huertas, prados, dehesas, montes donde sacan madera e leña para quemar, y de las pesquerías, y de los molinos, hornos e baños, lagares de las casas, y de todos los otros fructos y rentas que los hombres sacaren d'estas cosas. // Urrea, Vitruvio, Architectura, 1582, fol. 108v: Y assí, en medio se pondrán sus caños en todos los lagos y corrientes; del otro yrán a los baños, para que cada año dé renta a la ciudad; el tercero yrá a las casas particulares, de suerte que no falte al público. // Juanelo Turriano, Veinte y un libros, a. 1605, fol. 199v: Ay baños para diversos effectos, los quales son en diversas maneras hechos para diversas dolencias.

HIPER.: obra hidráulica.

[IMAGEN] Pseudo-Juanelo Turriano, Los ventiún libros, c. 1605, fol. 203v, fig. 175.

bara, V. vara.

barca, V. molino de $\sim$ s.

barca, barca, varca [del lat. tardío barca 'íd.', quizá de origen hispánico. Cid (DECH). Apiano, Cosmographía, 1575]. sust. f. Embarcación pequeña para pescar o para traficar en las costas del mar, o para atravesar los ríos (DRAE).

Lobato, Notas, a. 1585, fol. 27: Pues, pongo caso que en lo que dicho tengo del largo de estos ríos, después de deshechas las pesqueras y hecha hondura conveniente para pasar las barcas, quedasen algunos saltos o corrientes tan recias que no se pudiesen 
subir. // Besson, Teatro instrumentos, 1602, fol. K3v: Nueva suerte de engeño con que las barcas, llegadas al puerto llenas y cargadas de agua o de otra qualquier cosa, sean con poca fatiga descargadas. // Juanelo Turriano, Veinte y un libros, a. 1605, fol. 204v: Ay otra invençión de barca, la qual es muy differente de la varca que avemos dicho arriba.

FAM.: barquín.

barena, V. barrena.

bareno, V. barreno.

barniz, barniz, barnyz, berniz, varniz, vernís, verniz [del lat. veronix, veronīis 'sandáraca, resina olorosa'. S. XIII, Guillén de Segovia (DECH). Pérez Vargas, De re metallica, 1568]. sust. m. Licor compuesto de gomas y aguas espiritosas liquidado a fuego lento o al sol, para bañar y dar lustre y esplendor a las cosas, como a la pintura, al hierro (Autoridades).

Pérez Vargas, De re metallica, 1568, fol. 177r: Varniz excelente para pintar se haga assí: tómense diez adarmes de agua ardiente y dos de menjuý muy molido entre dos papeles // Ferrofino, Descrizión Artillería, 1599, fol. 150v: El barniz común es una conpusiçión el qual se haçe de tres partes de haceyte y una de pez griega. // Juanelo Turriano, Veinte y un libros, a. 1605, fol. 274v: Para apegar piedras que sean húmedas. Toma vernís de pintores y blanquete y blerniza, y todo hecho polvo, y mescla con el verniz.

FAM.: barnizado, embarnizado, embarnizar.

barnizado, barnizado [de barnizar. Escalante, Discurso de la navegación, 1577]. adj. Cubierto o bañado de barniz.

Escalante, Discurso de la navegación, 1577, fol. 51v: Ay plateros, que labran oro y plata curiosamente, y maravillosos entalladores, que tienen grandes tiendas llenas de escritorios y caxones pintados y barnizados. // Escalante, Discurso de la navegación, 1577, fol. 89v: Los otros traen el cabello largo y rematado por divisa en lo alto de la cabeça, con un palo muy curioso barnizado de negro de la hechura de una mano cerrada.

SIN.: embarnizado.

FAM.: barniz, embarnizado, embarnizar.

barnyz, V. barniz. 
barquín, barquín [de barquino y este del latín [follis] vervecinus, '[odre] de morueco' (DECH). 1520 (CORDE). Juanelo Turriano, Veinte y un libros, a. 1605]. sust. m. Mec. Especie de fuelle utilizado para subir agua o mover ruedas en algunas máquinas hidráulicas.

Juanelo Turriano, Veinte y un libros, a. 1605, fol. 232v: Puédese servir para este mismo efecto, para sacar agua, del instrumento de la mancha o barquín o fuellas, el qual es en la misma forma, sin faltar un punto de los que se sirven los herreros. El qual instrumento sube harta cantidad de agua. // Alonso Barba, Arte de los metales, 1640, fol. 82v: Los castellanos han sido menos usados, y por esta causa se han platicado menos los que llaman barquines o otros fuelles grandes, que se traen con ruedas de agua $\mathrm{u}$ otros instrumentos, aunque en Collquiri, mineral famoso de estaño, en la provincia de Paria, junto a Oruro, están en uso. // Alonso Barba, Arte de los metales, 1640, fol. 96v: Llénase este catino o receptáculo de carbón; sobre él se pone metal, luego carbón otra vez, y más metal encima, con que se forma un montón; dásele fuego muy recio con barquines grandes, que menean ruedas que trae el agua.

SIN.: fuella, mancha.

HIPER.: instrumento.

FAM.: barca.

[IMAGEN] Pseudo-Juanelo Turriano, Los ventiún libros, c. 1605, fol. 233r, fig. 314, letra C.

barra, barra, varra [de origen prerrom. voz común a todas las lenguas romances menos el rumano. 1283, Libros del Acedrex (DECH). Fernández de Enciso, Suma de Geographía, 1530]. sust. f. Pieza de metal u otra materia, de forma generalmente prismática o cilíndrica y mucho más larga que gruesa (DRAE).

Fernández de Enciso, Suma de Geographía, 1530, fol. XLIIv: En el qual si echan algún palo se hunde y va al suelo como piedra, e si echan una barra de fierro se tiene sobre el agua, que es contra natura. // Urrea, Vitruvio, Architectura, 1582, fol. 128r: Como la barra de hierro junta a la carga, lo que muchas manos no pueden mover, puesta debaxo de la carga como centro. // Juanelo Turriano, Veinte y un libros, a. 1605, fol. 291r: La barra que se pone dentro d'este árbol o mástil, conviene que ella sea quadrada, y que sea de seys palmos, y entra en el mástil de madera dos palmos

FAM.: barreta, barrón, barrote.

barrena, barena, barrena, varrena [del hispano-ár. barrína 'íd.' y este del lat. veruina 'jabalina'. Princ. S. XV, J. A. de Baena (DECH). Anónimo, Repertorio tiempos, 1554]. sust. f. Instrumento de acero con una rosca en espiral en su punta y una manija en el extremo opuesto, que sirve para taladrar o hacer agujeros en madera, metal, piedra u otro cuerpo duro (DRAE). 
Anónimo, Repertorio tiempos, 1554, fol. LXVIIIv: Y después, con una varrena pequeña o con un delgado taladro horada la dicha vara por los puntos que havías compassado, y los agujeros han de ser muy parejos y derechamente horadados. // Pérez Vargas, De re metallica, 1568, fol. 79v: La laguna se haze d'esta manera: es un canal largo de doze pies, hecho de madera, descubierto por lo alto, la qual tiene tres pies de ancho, el suelo agujereado con una barrena. // Juanelo Turriano, Veinte y un libros, a. 1605, fol. 228r: La manera o forma de barrena es la que se sigue: con aquellas dos puntas, y en los costados ha de tener una poquita de buelta, y el canto ha de tener corte como tienen las barrenas.

HIPER.: herramienta.

FAM.: barrena, barrenar, barreno.

[IMAGEN] Pseudo-Juanelo Turriano, Los ventiún libros, c. 1605, fol. 248r, fig. 316. La barrena está situada en el centro de la parte inferior de la imagen.

barrenar, barrenar [de barrena. Entre 1493 y 1495, Nebrija (DECH). Cortés de Albacar, Breve compendio sphera, 1556]. v. tr. Agujerear alguna cosa con una barrena o barreno.

Cortés de Albacar, Breve compendio sphera, 1556, fol. LXXr: Ésta se haze redonda o ochavada como mejor paresce, y por lo baxo o ancho se ha de barrenar con un taladro, y el barreno ha de ser de forma piramidal y ha de entrar en el piramide hasta medio o algo más. // Juanelo Turriano, Veinte y un libros, a. 1605, fol. 228v: Y barrenarase, si es piedra arenisca, en tres o quatro horas un agujero, y si es otra calidad de piedra, o más o menos, según la dureza de la piedra. / / Juanelo Turriano, Veinte y un libros, a. 1605, fol. 228v: Esta barrena, quando se quiere barrenar, no es en ello ninguna más invención, que el mismo peso de la barrena la haze decender abajo y aun ayuda a barrenar muy más presto.

SIN.: abarrenar.

FAM.: abarrenar, barrena, barreno.

barreno, bareno, barreno, varreno [de barrena. Nebrija (DECH). Fernández de Enciso, Suma de Geographía, 1530]. sust. m. Barrena de gran tamaño.

Lobato, Notas, a. 1585, fol. 31: Y la dicha pesquera se había de hacer de pinos verdes encajados o clavados con tarugos de roble en lugar de clavos, con barreno de carretero gordo y con dos vertientes.

FAM.: abarrenar, barrena, barrenar.

barreta, barreta [de barra. Loçano, Alberto, Architectura, 1582]. sust. f. Barra o palanca pequeña de hierro que usan los mineros, los albañiles, etc. (DRAE).

Loçano, Alberto, Architectura, 1582, pág. 114: Y aplicarse han pernos de cobre y barretas muy a menudo. // García de Palacio, Instrución náuthica, 1587, fol. 149v: Pie de cabra: 
es una barreta común de hierro con dos orejas al remate, como martillo con que se sirve la nao para sacar clavos, pernos y otras cosas. // Acosta, Historia natural, 1590, pág. 216: El metal es duro commúnmente y sácanlo a golpes de barreta, quebrantándole, que es quebrar un pedernal.

FAM.: barra, barrón, barrote.

barro, barro, varro [de origen prerrom. quizás de origen celta (cf. irl. medio broch 'basura', y galo barros 'matojo'). S. XIII, L. del Saber de Astronomía (DRAE). Sagredo, Medidas Romano, 1526]. sust. m. Tierra mezclada con el agua hecha lodo, ya sea en el campo causado de las lluvias o mezclada expresamente para diferentes usos, como son hacer tapias, ladrillos, tejas, ollas, adobes y otras cosas (Autoridades).

Sagredo, Medidas Romano, 1526, pág. 74: Pero si el arena era cavadiza, le davan quatro, e quando la querían hazer tenacíssima y de mucha resistencia, acrecentavan en el arena la tercia parte de pedaços menudos de ladrillo o teja o otro barro cozido. // Juanelo Turriano, Veinte y un libros, a. 1605, fol. 275r: Betún, el qual sirve para pegar toda cosa de barro, en especial alcaduces de varro, y también sirve a pegar cosas de barro rompidas. // Juanelo Turriano, Veinte y un libros, a. 1605, fol. 285r: Ellos se han de hazer como los de barro, y conviene enbetunarlos como los de barro o con otro modo de betún.

barrón, barrón [de barra (DRAE). Pérez Vargas, De re metallica, 1568]. sust. m. Barra grande con distintos usos.

Pérez Vargas, De re metallica, 1568, fol. 83v: Y lo mismo se ha de hazer en el suelo y fondo del horno principal, sacando por el agujero, con garfios de hierro y barrones, las escorias, si algunas se espessaren, antes que cuajen y cierren la puerta. // Juanelo Turriano, Veinte y un libros, c.1605, fol. 290v: En este género de rueda no ay menester de linterna para hazer andar la muela, mas que en el exe de la rueda va una barra de yerro muy gruesa, la qual va fixada con unos cercillos de yerro, y encima de este barrón va la muela. / / Juanelo Turriano, Veinte y un libros, c.1605, fol. 443v: Hay una linterna en el exe $\mathrm{E}$, que es movida de la rueda $\mathrm{M}$, y muévenla dos hombres dentro de la rueda, que la mueven con los pies en aquellos barrones $\mathrm{N}$.

SIN.: barrote.

HIPER.: herramienta.

FAM.: barra, barreta, barrote.

barrote, barrote [de barra. 1535 (DECH). Medina, Regimiento de navegación, 1563]. sust. m. Barra grande con distintos usos.

Medina, Regimiento de navegación, 1563, fol. 70r: Háganse dos barrotes del anchor de la medida, y por encima d'ellos se claven sus tablas hasta el medio altor de la medida y tenga el ancho de la misma medida. // Lobato, Notas, a. 1585, fol. 34: Y después en cada una forjarse dos barrotes de hierro, vara de medio largo de largo de la forma del 
que está la letra O. // Lobato, Notas, a. 1585, fol. 36: Y la cuba conforme el peso del agua la misma altura ha de alto tanto por arriba como por abajo, con unos barrotes que la tengan por arriba.

SIN.: barrón.

FAM.: barra, barreta, barrón.

baso, V. vaso.

basso, V. vaso.

batán, batán [probablemente del hispano-ár. *baț́n 'íd', de la misma raíz que bátțan 'forrar', 'batanar' y bițāna 'piel de carnero preparada'. S. XV, Cancionero de Montoro (DECH). Anónimo, Ordenanças paños, 1527]. sust. m. Mec. Máquina generalmente hidráulica, compuesta de gruesos mazos de madera, movidos por un eje, para golpear, desengrasar y enfurtir los paños (DRAE).

Anónimo, Ordenanças paños, 1527, fol. VIr: Y, esto hecho, le entreguen al perayle para que le adobe de batán, so pena que el que de otra manera lo diere pague de pena, por cada paño, veynte maravedís. // Santa Cruz, Libro de las longitúdines, c.1567, pág. 113: [...] dixo que tenía consideraçión a un batán que se movía igualmente con agua de una fuente que no creçía ni menguava, por manera que le hazía dar muy a compás las maçadas, de las quales él avía esperimentado quántas dava en cada una hora [...]. // Juanelo Turriano, Veinte y un libros, c.1605, fol. 177r: Porque, levantada el agua encima del açute, puede después servir para qualquier exercicio que será neçessario, como para batán, como para herrería, de hazer andar machos y mallo,

SIN.: molino batán.

HIPER.: máquina.

FAM.: batanar, batanero.

ENCICL.: También puede ser de sangre, es decir, movido por fuerza humana o animal.

[IMAGEN] Pseudo-Juanelo Turriano, Los ventiún libros, c. 1605, fol. 331v, fig. 241.

2 [Anónimo, Ordenanças paños, 1527]. sust. m. Edificio en que funciona esta máquina (DRAE).

Anónimo, Ordenanças paños, 1527, fol. VIv: Y porque mejor se pueda hazer, permito que puedan cardar de escuramente en los batanes, contando que sean officios distintos e apartados el pilatero del perayle que los cardare. // Anónimo, Leyes lanas e paños, 1538, fol. 5r: Declaramos e mandamos que los dichos paños velartes se puedan teñir prietos, aunque quando vengan del batán les falte algo del azul e no llegue a la muestra, con tanto que a los tales paños les cumplan del azul, conforme a la muestra de 
dos celestres. // Celso, Reportorio universal leyes Castilla, 1553, fol. CCXLVv: No haya en estos reynos tirador alguno en que se tiren los paños, salvo solamente para ygualarlos quando los traen del batán.

batán, V. molino .

batanar, batanar [de batán. SS. XVI-XVII (DECH). Anónimo, Ordenanças paños, 1527]. v. tr. Mec. Golpear o batir con los mazos del batán los paños u otros géneros para que se limpien del aceite y se incorporen y cierren (Autoridades).

Anónimo, Ordenanças paños, 1527, fol. VIIr: Otrosí, mando que los dichos perayles e bataneros adoben y batanen las dichas bernias y guirnaldas, e las carden de escuramente y enfurtan bien e legítimamente [...]. // Anónimo, Ordenanças paños, 1527, fol. Xr: En esta manera: que el perayle o batanero no batane sin el sello del texedor, y el tintorero sin el sello del perayle, y el tondidor sin el sello del tintorero, si fuere paño que oviere de teñir.

FAM.: batán, batanero.

batanero, batanero [de batán (DECH). Anónimo, Ordenanças paños, 1527]. sust. m. Persona que tiene por oficio el batanar o que trabaja en el batán (Autoridades).

Anónimo, Ordenanças paños, 1527, fol. VIr: Y que el tal batanero no pueda fazer ni haga partido con el dueño del tal paño para le dar tantas varas [...]. // Anónimo, Ordenanças paños, 1527, fol. VIv: Otrosí, mando que ningún batanero ni pilatero no sea osado de echar ni eche a los paños que adobare la greda que oviere de echar [...]. // Anónimo, Ordenanças paños, 1527, fol. VIIr: Otrosí, mando que los dichos perayles e bataneros adoben y batanen las dichas bernias y guirnaldas, e las carden de escuramente y enfurtan bien e legítimamente [...].

FAM.: batán, batanar.

batedero, V. batidero.

batidero, batedero, batidero [de batir (DRAE). Juanelo Turriano, Veinte y un libros, a. 1605]. sust. m. Parte del cerco de las hojas de puertas, ventanas y otras cosas semejantes, en que se detienen y baten cuando se cierran (DRAE s. v. batiente).

Juanelo Turriano, Veinte y un libros, a. 1605, fol. 455v: La parte H I se buelve al corriente de la agua. $Y$ tienen sus batideros, y también se abren de otro modo; que tengan asido 
al medio, donde es K L. // Juanelo Turriano, Veinte y un libros, a. 1605, fol. 456v: Las puertas de la catarata, in quarto modo, son las que se siguen. La A B se junta en G, que juegan en el perne H I. Y los dos cabos, C D, hieren en los batederos, E F.

SIN.: batiente.

FAM.: batiente, batir.

batiente, batiente [de batir. Entre 1493 y 1495, Nebrija (DECH). Lobato, Notas, a. 1585]. sust. m. Parte del cerco de las hojas de puertas, ventanas y otras cosas semejantes, en que se detienen y baten cuando se cierran (DRAE).

Lobato, Notas, a. 1585, fol. 36: Pero la del desaguadero de la acequia, ha de ser a la manera que aquí va pintada que abra hacia el río y cierre hacia la acequia con batientes muy ajustados. // Martínez de Aranda, Zerramientos montea, ca. 1599, pág. 123: La distançia que ubiere entre las linias C F es el batiente del dintel donde baten las puertas. // Martínez de Aranda, Zerramientos montea, ca. 1599, pág. 169: El largo de las caras de las plantas por lechos, desde adonde tocaren los plomos que baxaron de la linia $\mathrm{G}$ en la linia que sirbe de batiente $\mathrm{H}$.

SIN.: batidero.

FAM.: batidero, batir.

batir, batir [del lat. battuěre 'íd.'. H. 1140, Cid (DECH). Fernández de Enciso, Suma de Geographía, 1530]. v. tr. u. t. c. sust. Dar un golpe o golpes repetidos (DRAE s. v. golpear).

Fernández de Enciso, Suma de Geographía, 1530, fol. XLVIIv: Has de tener lo primero, que del batir del agua en la tierra, que es bermeja. // Besson, Teatro instrumentos, 1602, fol. Dv: Lo que prohibiéndoselo la diligencia súbita del maestro en tirar, assí suspendida en alto, la bate, que el hierro, que pule o corta por medio de la langosta, ágilmente tire y retire. // Alonso Barba, Arte de los metales, 1640, fol. 67r: El mayor daño que los fondos reciben es en la circunferencia que señala la superficie del açogue, causado por el batir continuo de los hervores y la junta del metal y agua.

FAM.: batidero, batiente.

bazín, V. bacín.

berina, berina [probablemente del lat. věrŭina 'jabalina' (Pascual Rodríguez). Lobato, Notas, c.1585]. sust. f. Mec. Cada uno de los maderos paralelos verticales que guían el movimiento de la viga de un lagar.

Lobato, Notas, c.1585, fol. 33: En las paredes del dicho molino se encajarán unos lobos para que la puente no se pueda ir a una parte ni a otra, que serán como las berinas de 
un lagar en sano horadadas en cuadrado, y en aquel cuadrado entrarán las orejas de la dicha puente.

HOL.: lagar.

berniz, V. barniz.

besque, $V$. vesque.

bestia, V. molino de $\sim(s)$.

betum, V. betún.

betúm, V. betún.

betumar, V. betunar.

betumen, betumen, vetumen [del lat. bütūmĕn 'íd.'. Loçano, Alberto, Architectura, 1582]. sust. m. Especie de barro de su naturaleza fluido, tenaz y pegajoso, que tiene parte de azufre y nace o mana del lago Alphastite, que está en la Judea (Autoridades s. v. betún).

Loçano, Alberto, Architectura, 1582, pág. 58: En toda Italia, por la parte que cae al Mediodía, testifican que se halla arena de fossas, y que desde el Apennino a esta parte no se halla. Los de Babylonia, dize Plinio, que usan de betumen y los carthagineses del lodo. // Loçano, Alberto, Architectura, 1582, pág. 247: De aquél que escrivió la vida de Appollonio hallé una vida digna de memoria, porque dize que una muger de Media, en Babylonia, guió una calle, fabricada de piedra y vetumen ancha, por debajo de la madre del río, por la qual se fuesse a pie enjuto desde la casa real hasta otra casa puesta enfrente de la otra parte del río. 
SIN.: betún, betún de Babilonia, betún judaico, bitumen.

FAM.: betumar, betuminoso, betún, betunar, bitumen, embetunar.

betuminoso, betuminoso, bituminoso, vituminoso [del lat. bìtūmĭnōsus 'íd.' (DECH). Pérez Vargas, De re metallica, 1568]. adj. Que tiene betún o semejanza con él (DRAE).

Pérez Vargas, De re metallica, 1568, fol. 78v: Y el metal duro y bituminoso, y que tiene açufre, conviene molerse menudo; // Loçano, Alberto, Architectura, 1582, pág. 333: Y es traýda en tal grosseza que, si alguna vez la mar sosiega algún tanto, poco a poco pone por cima corteza mohosa y muy vituminosa. // Juanelo Turriano, Veinte y un libros, a. 1605, fol. 15v: Las piedras, como escrive Plinio, que son en los montes de la Liçia, que de dentro del agua queman, créese que ellas sean betuminosas, y lo mesmo haze las arenas.

FAM.: betumar, betumen, betún, betunar, bitumen, embetunar.

betún, betum, betúm, betún, vetún [del cat. betum 'íd.', y éste del lat. bitūmen 'íd.'. 1475, Guillén de Segovia (DECH). Pérez Vargas, De re metallica, 1568]. sust. $\mathrm{m}$. Especie de barro de su naturaleza fluido, tenaz y pegajoso, que tiene parte de azufre y nace o mana del lago Alphastite, que está en la Judea (Autoridades). Pérez Vargas, De re metallica, 1568, fol. 30r: También se cría en cierta tierra como betún, pegajosa, que paresce arzilla, la qual tierra es pesada, con algún olor de piedra açufre. // Urrea, Vitruvio, Architectura, 1582, fol. 104v: En Babylonia ay un lago de grandeza estraña, que se llama Lanne Aphaltes, encima del qual nada un betún líquido, con el qual, y con ladrillos, Semíramis cercó a Babylonia.

FAM.: betumar, betumen, betuminoso, betunar, bitumen, embetunar.

ENCICL.: Sustancia de color negro que constituye la fracción más pesada del petróleo crudo. Se encuentra a veces en grandes depósitos naturales, como en el lago Asfaltites o mar Muerto, lo que se llamó betún de Judea. Se utiliza mezclado con arena o gravilla para pavimentar caminos y como revestimiento impermeable de muros y tejados (DRAE s. v. asfalto).

2 [Juanelo Turriano, Veinte y un libros, a. 1605]. sust. m. Pasta hecha con estopa, cal, aceite, escorias, vidrios molidos u otros materiales, que se utiliza para tapar las juntas de los arcaduces en las cañerías de aguas y para otras obras hidráulicas.

Juanelo Turriano, Veinte y un libros, a. 1605, fol. 274v: Betún para enbetunar xetas de fuentes o de çaariches que sea de agua. // Juanelo Turriano, Veinte y un libros, a. 1605, fol. 277v: Esta invención de betún es para enbetunar alcaduces, fístulas o caños de metal o de barro o de piedra y de madera. // Juanelo Turriano, Veinte y un libros, a. 1605, fol. 277v: Otro modo de betún para enbetunar caños y alcaduces de barro. 
Tomarás calcina viva y hazerla polvo. Y tomarás ladrillo molido, y escoria de yerro molido, y claras de huevos muy bien batidas.

SIN.: zulaque.

HOL.: obra hidráulica.

3 [Juanelo Turriano, Veinte y un libros, a. 1605]. sust. m. Pasta hecha con estopa, cal, aceite, escorias, vidrios molidos $u$ otros materiales, que se utiliza para pegar o ligar piedra, madera, hueso, etc.

Juanelo Turriano, Veinte y un libros, a. 1605, fol. 274r: Betún para pegar madera, que sirve en lugar de cola. Toma quezo tierno, del que tiene unos ojos en él, y córtale a tajadas que sean delgadas, y ponlas a remojo con lexía que no seafuerte, que sea hecha de zenisa de sarmientos, o en agua caliente, aunque es muy mejor la lexía. / / Juanelo Turriano, Veinte y un libros, a. 1605, fol. 274r: Este betún es muy excellente para pegar madera y hueso juntos. Toma idrocolon, dos onças, y leche de figuera, y leche de titimios y yerva lechera, yguales partes, una onça. $Y$ estas leches y el idrocolon, los quales mesclarás juntos y los coserás con una poca de goma arábica. Y éste es un betún maravilloso y bueno para lo dicho. // Juanelo Turriano, Veinte y un libros, a. 1605, fol. 278r: Betún para apegar qualquier cosa de piedras, de qualquier género que ellas sean. Toma almástique, y cera vieja que aya servido, y açufre, y un poco de polvo de la misma piedra y una poca de pez líquida, y poner todos estos materiales juntos en un vaso nuevo alvedriado, y ponerle al fuego.

SIN.: ligadura, pegadura.

$\sim$ de Babilonia [Juanelo Turriano, Veinte y un libros, a. 1605]. comp. sintag. Especie de barro de su naturaleza fluido, tenaz y pegajoso, que tiene parte de azufre y nace o mana del lago Alphastite, que está en la Judea (Autoridades s. v. betún).

Juanelo Turriano, Veinte y un libros, a. 1605, fol. 35r: El betún de Babylonia es muy provechoso para el mal de los ojos quando es causado por sangre que está derramado por la persona, o que se haze algunas manchas por el cuerpo, que es un cierto mal que se haze en la barba o que empieza a naçer en ella, y de aý se va derramando y se hazen llagas.

SIN.: betumen ${ }_{1}$, betún, betún judaico, bitumen.

ENCICL.: Sustancia de color negro que constituye la fracción más pesada del petróleo crudo. Se encuentra a veces en grandes depósitos naturales, como en el lago Asfaltites o mar Muerto, lo que se llamó betún de Judea. Se utiliza mezclado con arena o gravilla para pavimentar caminos y como revestimiento impermeable de muros y tejados (DRAE s. v. asfalto). 
judaico [Loçano, Alberto, Architectura, 1582]. comp. sintag. Especie de barro de su naturaleza fluido, tenaz y pegajoso, que tiene parte de azufre y nace o mana del lago Alphastite, que está en la Judea (Autoridades s. v. betún).

Loçano, Alberto, Architectura, 1582, pág. 91: Y offréceseme que refiera aquello que leemos acerca de Diodoro, historiador, aver sido hecho para que los huertos celebrados de Siria con invención nueva no inútil, porque pusieron cañas en las vigas untadas con vetún judayco, y en ellas encaxaron piedras cozidas ligadas con yesso con dos lechadas // Loçano, Alberto, Architectura, 1582, pág. 331: Semýramis, no contentándose con vallado de ladrillo, echó por cima vetún judayco en quatro cobdos de gruesso, y aun puso paredes por muchos estadios, tan altas que ygualavan con las murallas.

SIN.: betumen betún$_{1}$ betún de Babilonia, bitumen.

betunar, betumar, betunar, vetunar [de betún. 1475, Guillén de Segovia (DECH). García de Palacio, Diálogos militares, 1583]. v. tr. Cubrir algo con betún (DRAE s. v. embetunar).

García de Palacio, Diálogos militares, 1583, fol. 134v: Brea: es con que se embrean y betuman los navíos. // Cano, Arte para fabricar naos, 1611, fol. 53r: Maceándolos con maços de palo y después vetunándolos con brea mesclada con azeyte.

SIN.: betumar, embetunar.

FAM.: betumar, betumen, betuminoso, betún, bitumen, embetunar.

bidrio, V. vidrio.

biga, V. viga.

bitumen, bitumen [tomado del lat. bŭtūmĕn 'íd.'. Alonso Barba, Arte de los metales, 1640]. sust. Especie de barro de su naturaleza fluido, tenaz y pegajoso, que tiene parte de azufre y nace o mana del lago Alphastite, que está en la Judea (Autoridades s. v. betún).

Alonso Barba, Arte de los metales, 1640, fol. 40v: Éstos son: sales, alumbres, caparrosas, açufre, oropimente, sandáraca, antimonio o alcohol, bitumen, que llaman grassa, blanco o negro y margagitas.

SIN.: betumen, betún, betún de Babilonia, betún judaico.

FAM.: betumar, betumen, betuminoso, betún, betunar, embetunado, embetunar. 


\section{bituminoso, V. betuminoso.}

boca, boca, voca [del lat. bŭcca 'mejilla'. H. 1140, Cid (DECH). Sánchez de las Broças, Helt Frisio, Relox español, 1549]. sust. f. Ingen. Hidrául. Entrada o salida, generalmente con forma redonda, de una obra hidráulica.

Sánchez de las Broças, Helt Frisio, Relox español, 1549, fol. 32v: Pues, sabido el diámetro de la boca del pozo (que pongo que es de 10 pies), pondremos el instrumento sobre el pozo, de manera que la orilla baxa del instrumento cargue sobre la orilla alta del pozo muy poquito. // Besson, Teatro instrumentos, 1602, fol. F2v: Se le meta un tapón, el qual tape todas las tres por medio de tres clavijas de madera, que entran en los tres agujeros que están en la boca que cierra, y responden totalmente a las bocas de los cañales. // Juanelo Turriano, Veinte y un libros, a. 1605, fol. 172v: Y por esta causa son ellos muy differentíssimos en toda manera, porque los que tienen dos bocas en un mismo açute, por causa del encaminar el agua a las dos partes, y por esta causa son ellos muy differentíssimos en toda manera.

SIN.: ojo $_{3}$.

HOL.: obra hidráulica.

FAM.: bocal.

[IMAGEN] Pseudo-Juanelo Turriano, Los ventiún libros, c. 1605, fol. 108v, fig. 76, letra A.

bocal, bocal, vocal [de boca (DECH). 1325, Venta al monasterio de un derecho a riego en Ymas (CORDE). Juanelo Turriano, Veinte y un libros, c.1605]. sust. $\mathrm{m}$. Ingen. Hidrául. arag. Toma de agua o desaguadero por donde entra o sale el agua en una presa, acequia o azud (Glosario Los Ventiún libros).

Juanelo Turriano, Veinte y un libros, c.1605, fol. 108r: Por causa que conviene yr más arriba a buscar el remedio, río arriba, de modo que será necessario hazer bocal de piedra, de tal arte que el río no rompa la entrada a la agua. // Juanelo Turriano, Veinte y un libros, c.1605, fol. 172r: Las formas son differentes, en especial las que tienen dos bocales. Éssas se hazen muy differentes de lo que se hazían los que tienen dos vocales en un mismo açute, por causa del encaminar el agua a las dos partes.

HOL.: obra hidráulica.

FAM.: boca.

2 [Juanelo Turriano, Veinte y un libros, a. 1605]. sust. m. Boca o abertura por la que entra el agua $u$ otro líquido en un aljibe o cisterna.

Juanelo Turriano, Veinte y un libros, a. 1605, fol. 182r: Y bolver, en este patio que se avrá cavado, una bóbeda redonda, a modo de una media naranja, y en el medio dejar, en lugar de la llave, un agujero redondo para poner un bocal a la cisterna para sacar agua. 
// Juanelo Turriano, Veinte y un libros, a. 1605, fol. 182v: Esta manera de la planta de la cisterna B. Y la entrada es donde es la A; aý entra el agua en aquella capacidad. Y el bocal de la cisterna es C. La escala es $\mathrm{D}$. Y el perfil de la cisterna es, en ella, las mismas letras, aunque en la bóbeda es $\mathrm{H}$ y lo baxo es I, que la G es donde la arena. // Juanelo Turriano, Veinte y un libros, a. 1605, fol. 197v: Este algive es para dentro de casa, por causa que se saca el agua por el bocal A, el qual bocal va asentado encima de la bóveda B. Y la una caveça es C.

HOL.: aljibe.

[IMAGEN] Pseudo-Juanelo Turriano, Los ventiún libros, c. 1605, fol. 198r, fig. 169, letra A.

boladera, V. voladera.

bolcar, V. volcar.

bolsa, bolsa [del lat. bŭrsa 'íd.' y este del gr. ßúpor 'cuero' 'odre'. Med. S. XIII, F. Juzgo, Libro de Alexandre (DECH). Urrea, Vitruvio, Architectura, 1582]. sust. f. Mec. Grueso o grosor de una porquezuela o una pieza grande con forma de tuerca utilizada en algunas máquinas.

Urrea, Vitruvio, Architectura, 1582, 139v: Camilo: gruesso de la súcula, o se dize bolsa. // Urrea, Vitruvio, Architectura, 1582, 143r: Súcula: porquezuela de máchinas; su gruesso se dize camilo o bolsa. Pónese asida en los chelonios, que son las sortijas como ombligos en que se rebuelve con su exe.

SIN.: camilo.

HOL.: porquezuela.

boltado, V. voltado.

boltar, V. voltar.

bolteado, V. volteado. 
boltear, V. voltear.

bolver, V. volver.

bomba, bomba, bonba [del lat. bŏmbus, bŏmbi 'ruido, zumbido' (gr. bombós). Entre 1493 y 1495, Nebrija (DECH). Urrea, Vitruvio, Architectura, 1582]. sust. f. Mec. Máquina hidráulica o parte de esta destinada a elevar el agua y darle impulso en una dirección determinada.

Urrea, Vitruvio, Architectura, 1582, fol. 75v: Quando fueren bien calçadas y muy espesamente, entonces, con cleas, que son engeños para sacar agua, y con ruedas y tímpanos, que son las bombas o maças de las ruedas, puestos y assentados. // Juanelo Turriano, Veinte y un libros, a. 1605, fol. 231v: Y conviene tener mucha qüenta en la cantidad, por causa de saber acomodar los instrumentos que para ello son menester; que si ubiere mucha hondura de agua, convendrá servirse de unos instrumentos, como es la cóclea, como la tesíbica, con bombas. // Juanelo Turriano, Veinte y un libros, a. 1605, fol. 364r: Hecha esta defensa, conviene accommodar, dentro del encerramiento donde se ha de hazer la pila, muchos instrumentos para sacar la agua, que será con bombas, o con la rueda timpanada, o con la cóclea o caracol, y con otros infinitos instrumentos que hay para ello.

HIPER.: máquina.

ENCICL.: "Cuando había que abastecer a una población numerosa, lo primero que se hacía era busca la forma de elevar el agua desde el río hasta la ciudad por medio de algún mecanismo hidráulico. Uno de los más famosos era la torre de Augsburgo; esta torre, construida en la década de 1540, probablemente sirvió de inspiración, gracias a los relatos de otros viajeros, a otras torres en que una o dos bombas elevaban el agua hasta la cubeta, desde la cual una segunda bomba la elevaba aún más, de manera que, tras tres o cuatro etapas, el agua estaba lo bastante alta como para fluir por gravedad en dirección a las fuentes públicas y a las tinajas y aljibes de los consumidores privados" (Catálogo Felipe II: 28).

Otras bombas famosas en la época fueron la de Peter Merris a orillas del Támesis, la de Jan Lintlaer, conocida como la Samaritaine del Pont Neuf a orillas del Sena.

Las tesíbicas o bombas se utilizaban también en el achique de terrenos fanganosos, "sobre todo en la primera fase, ya que cuando el agua arrastraba cienos y fangos, dejaban de ser eficaces, pues se obstruían con gran facilidad" (González Tascón 19993: 196).

2 [Juanelo Turriano, Veinte y un libros, c.1605]. sust. f. Mec. En los molinos, canal angosto por donde se conduce el agua hasta la rueda hidráulica (Salinero s. v. saetía, saetín).

Juanelo Turriano, Veinte y un libros, c.1605, fol. 290r: Aunque esta bomba o canal se asienta muy más llana, por causa que el herir que haze en el carcaño o en la rueda, la qual está differentemente asentada y de otra forma. // Juanelo Turriano, Veinte y un 
libros, c.1605, fol. 291r: La canal que se hiziere cubierta, que llaman bomba, conviene que sea muy más ancha en la parte donde entra la agua que no en la otra parte que la vierte. // Juanelo Turriano, Veinte y un libros, c.1605, fol. 292r: La tercera canal o bomba o saetía, que su quadro es K L M N, la qual su perpendicular es doze y su basa es quinze, que es $\mathrm{MN}$, de modo que su basa es tres más que no es su altariala diagonal del paralelogramo, y esto causa el tener mucha más agua que no tiene la segunda.

SIN.: canal $_{3}$, saetía, saetín.

HOL.: molino.

ENCICL.: "De la parte inferior del cubo arranca la saetía -llamada a veces saetín o bombaque conducía el agua a gran velocidad a los rodeznos" (Catálogo Felipe II).

[IMAGEN] Pseudo-Juanelo Turriano, Los ventiún libros, c. 1605, fol. 364r, fig. 339.

bomba, V. molino de $\sim$.

bonba, V. bomba.

boñiga, boñiga [de origen incierto al parecer, prerromano. Seguramente de una base *bunnica emparentada con el cat. bony 'buto, chichón', gasc. bougno 'íd.', fr. ant. y dial. bugne 'id.'. $1^{\text {a }}$ mitad s. XIV, Libro de la Montería (DECH). Juanelo Turriano, Veinte y un libros, a. 1605]. sust. f. Escremento de ganado, generalmente vacuno.

Juanelo Turriano, Veinte y un libros, a. 1605, fol. 263r: En Egypto hazen fuego con estiércol, como lo acostumbran hazer oy día en muchas partes, en particular en Tierra de Campos, que no queman otro si no es boñiga de buey y paja, y con esto calientan sus hornos.

FAM.: emboñigado, emboñigar.

borneadura, borneadura [de bornear (DRAE). Juanelo Turriano, Veinte y un libros, a. 1605]. sust. f. Acción de bornear (DRAE s. v. borneo).

Juanelo Turriano, Veinte y un libros, a. 1605, fol. 68r: Los que nivelan a borneo, quanto más cortas harán sus borneaduras, tanto menos herror harán en su nivelaçión.

SIN.: borneo.

FAM.: bornear, borneo.

bornear, bornear [del fr. bornoyer 'íd.'. Nebrija (DECH). Anónimo, Repertorio tiempos, 1554]. v. tr. u. t. c. sust. Constr. Mirar con un solo ojo, teniendo el otro 
cerrado, para examinar si un cuerpo o varios están en una misma línea con otro $\mathrm{u}$ otros, o si una superficie tiene alabeo (DRAE).

Anónimo, Repertorio tiempos, 1554, fol. LXIXr: Y pongo el cabo de la vara, h, junto al ojo, y el cabo i hazia la torre, y allégome o apártome de la torre hasta que vea que bornea $\mathrm{o}$ empareja la punta alta del junco con la cima de la torre. // Roiz, Reloges solares, 1575, pág. 71: Para bornear, para medir quanto al ojo viéremos, tomar alturas del Sol y estrellas. // Juanelo Turriano, Veinte y un libros, a. 1605, fol. 57v: Mas conviene tener muy buena vista y muy buen objeto en saber bornear, porque conviene tener muy grande cuenta en el bornear, por no se abajar mucho con la vista, que señalan muy más alto de lo necessario

FAM.: borneadura, borneo.

borneo, borneo [de bornear (Salinero). Álaba, Perfeto capitán, 1590]. sust. m. Acción de bornear (DRAE).

Álaba, Perfeto capitán, 1590, fol. 189r: Fiado en lo que ellos llaman borneo del ojo y en un poco más o menos, que suele tener de error la mitad del camino. // Juanelo Turriano, Veinte y un libros, a. 1605, fol. 60r: Otro instrumento se acostumbra entre los agrimensores, que, nivelando, pueda saber quántos passos haze cada borneo. // Juanelo Turriano, Veinte y un libros, a. 1605, fol. 65r: Pasando el rayo visual por las pínulas, como la figura lo demuestra la diferencia del camino de un borneo al otro o de una línea a otra, por raçón de los grados del planisferio.

SIN.: borneadura.

FAM.: borneadura, bornear.

a [Vandelvira, Traças de cortes, ca. 1591]. loc. adv. Mediante la mirada de un solo ojo.

Vandelvira, Traças de cortes, ca. 1591, fol. 14r: Por la parte de afuera, quisiesen en los rincones sacar quatro balcones, que correspondiesen a borneo con las paredes. // Juanelo Turriano, Veinte y un libros, a. 1605, fol. 57r: Y a los dos cabos ay dos traviessas con dos frontispicios, que son $G \mathrm{G}$, en los quales van colgados dos pesicos en el medio, que es H. Y con este instrumento se nivela a borneo. // Juanelo Turriano, Veinte y un libros, a. 1605, fol. 68r: Los que nivelan a borneo, quanto más cortas harán sus borneaduras, tanto menos herror harán en su nivelaçión.

borneo, V. nivel de $\sim$.

botana, botana [del cat. botana 'remiendo que se pone en los agujeros de los pellejos de vino', 'tarugo que tapona un agujero en las cubas'. S. XV (DECH). Juanelo Turriano, Veinte y un libros, c.1605]. sust. f. Ingen. Hidrául. arag. Compuerta que regula la salida de agua en las pesqueras. 
Juanelo Turriano, Veinte y un libros, c.1605, fol. 137v: Y asiéntasele una portezuela, en tal modo que no pueda salir el agua, la qual llaman botana, que viene a encaxar dentro de unas piedras muy justíssimamente, en lo alto.

HOL.: obra hidráulica.

2 [Juanelo Turriano, Veinte y un libros, a. 1605]. sust. f. Mec. Parte final o cierre de la saetía del cubo de algunos molinos.

Juanelo Turriano, Veinte y un libros, a. 1605, fol. 295v: Y la C es la saetía. Y donde es la D es la botana. La saetía conviene que se haga quan más baxa fuere possible hazerla, y aun hazer el suelo del cubo algún tanto declinado asia la saetía. // Juanelo Turriano, Veinte y un libros, a. 1605, fol. 295v: Y como el lugar es mucho menor que es en la parte de arriba, va haziendo toda la fuerça que puede para caber; es de necessidad que la agua salga de la botana con muy grande furor para dar lugar a la que viene. // Juanelo Turriano, Veinte y un libros, (a. 1605), a. 1605, fol. 302r: Convendrá tener cerradas las botanas, asta ver que las saetías están llenas de agua, que después siempre estarán llenas; aunque vaya saliendo la agua, siempre se conservarán llenas.

HOL.: cubo.

[IMAGEN] Pseudo-Juanelo Turriano, Los ventiún libros, c. 1605, fol. 295r, fig. 188, letra D.

braço, V. brazo.

brazo, braço, brazo [del lat. brācchĭum 'íd.'. 1044, Orígenes (DECH). Núñez, Álgebra en Arithmética, 1567]. sust. m. En la balanza, cada una de las dos mitades de la barra horizontal, de cuyos extremos cuelgan o en los cuales se apoyan los platillos (DRAE).

Núñez, Álgebra en Arithmética, 1567, fol. 68v: Demuestra entonces en la segunda proposición del primero libro que, si la balança tuviere braços yguales y d'ellos colgáremos pesos yguales, para ninguna parte podrá aver inclinación.

HOL.: balanza.

2 [Besson, Teatro instrumentos, 1602]. sust. m. Mec. Apéndice o parte saliente de una pieza de una máquina, que tiene un movimiento de rotación sobre un eje o descansa en un punto de apoyo.

Lobato, Notas, a. 1585, fol. 26: Meter una cantimplora metida entre unas paredes muy fuertes, que crecida no las llevase, o en las riberas del río hecho un pozo por donde llegase el brazo a tomar el agua, y después, pasando por encima de cierta parte de la barranca la vuelta de la cantimplora, y que vaciase el otro brazo en una rueda de molino que luego moviese. // Besson, Teatro instrumentos, 1602, fol. D4v: De la parte 
oriental de los braços cuelgan las sierras, y la parte d'ellas do los braços están fixos tiene el movimiento libre en derredor d'ellos. // Besson, Teatro instrumentos, 1602, fol. G4v: Nueva hechura de molino a braços para prensar y aparejar paños y papel, y moler especies, y esmenuzar piedras preñadas de metales para preparallas a hundir, y también para pulir y aguzar qualesquier instrumentos soltados a cigoñales y majaderos.

HOL.: máquina.

buelta, V. vuelta.

bulsón, bulsón [probablemente del fr. blouson 'blusón' o bourson 'bolsón' (Trésor de la Langue Française). Lechuga, Discurso de la Artillería, 1611]. sust. m. Ingen. Hidrául. Cada uno de los maderos que levanta un puente levadizo.

Lechuga, Discurso de la Artillería, 1611, pág. 214: Assimismo, se puede hazer caer rompiendo los bulsones, que son los maderos que levantan y abaxan el puente levadizo con las cadenas que asen en ellos y en él.

HOL.: puente.

burato, burato [tomado del fr. burat 'tela o tejido grueso de seda o lana'. 1595, Doc. oscense (DECH). Alcega, Geometría prática, 1589]. sust. m. Instrumento a modo de manga, hecho de tela de burato, que sirve para cerner harina.

Alcega, Geometría prática, 1589, fol. 328r: De modo que este burato, que ansí le llaman en Italia, donde ello se ha inventado esta invención para serner arina, y donde se haze mucho excercisio de masar, éste es un estrumento de mucho provecho y de muy grande descanço. // Juanelo Turriano, Veinte y un libros, a. 1605, fol. 329r: La caxa es D. La taona es A. Donde cae la arina para cerner es B. La armadura donde es asentada la taona es $\mathrm{C}$. La manga o burato, que es lo que recive dentro de sí la arina para cerner, es E. // Juanelo Turriano, Veinte y un libros, a. 1605, fol. 330r: El yerro que va de un mástil a otro es $\mathrm{F}$, asido en $\mathrm{E} \mathrm{H}$. Y H es el manil de la aspa que mueve el burato que cierne.

[IMAGEN] Pseudo-Juanelo Turriano, Los ventiún libros, c. 1605, fol. 328v, fig. 239 
caba, V. cava.

cabadura, V. cavadura.

caballo, caballo, cavallo [del lat. căballus 'caballo castrado', 'caballo de trabajo', 'caballo malo, jamelgo'. 932, Oelschl. (DECH). Juanelo Turriano, Veinte y un libros, a. 1605]. sust. m. Mec. Tabla plana de madera, de forma rectangular, sobre la que se colocan materiales o cargas para que sean izados $o$ transportados.

Juanelo Turriano, Veinte y un libros, a. 1605, fol. 384r: Llámele cada qual como quisiere, porque unos le llaman el cavallo, otros asno, otros albardón, otros la zivilla de la grúa, otros coraçón, como aquél de las balanças de pesar las cosas. // Juanelo Turriano, Veinte y un libros, a. 1605, fol. 458v: El carretón que ha de llevar la barca a de ser de otro modo hecho, y las ruedas han de ir abaxo del carretón, el qual le llaman cavallo, por la carga que lleva. / / Juanelo Turriano, Veinte y un libros, a. 1605, fol. 459r: Puédese hazer este carretón o cavallo en otra manera, que le jueguen debaxo unas ruedas, y ansí irá muy cómmodamente. 
SIN.: albardón, asno, cibilla, corazón.

[IMAGEN] Pseudo-Juanelo Turriano, Los ventiún libros, c. 1605, fol. 383v, fig. 378, letra Q.

cabar, V. cavar.

cabeca, V. cabeza.

cabeça, V. cabeza.

cabesa, V. cabeza.

cabestante, V. cabrestante.

cabestrante, V. cabrestante.

cabeza, cabeca, cabeça, cabesa, cabeza, caveça, cavesa, caveza [del lat. vg. hispánico căpŭtĭa, forma que sustituyó a căput, căpütis 'íd.' en el latín vulgar hispánico. 957, M. P. (DECH). Urrea, Vitruvio, Architectura, 1582]. sust. f. Parte superior de la balanza de la cual cuelga el peso.

Urrea, Vitruvio, Architectura, 1582, fol. 128v: Esto se puede considerar en las balanças y peso de pesar, quando el asa más cercana a la cabeça, de la qual está colgada la balança como centro, el ecquipondio por la otra parte del peso, andando por sus puntos.

HOL.: balanza.

2 [Juanelo Turriano, Veinte y un libros, a. 1605]. sust. f. Ingen. Hidrául. Parte alta del aljibe, sobre la que se asienta la bóveda y el bocal.

Juanelo Turriano, Veinte y un libros, a. 1605, fol. 198r: Este algive es para dentro de casa, por causa que se saca el agua por el bocal A, el qual bocal va asentado encima de la bóveda B. Y la una caveça es C. En este algive no hay gradas en él, mas donde ay E es 
una pila para recoger agua en ella, y donde es la D ay una xeta para sacar agua del algive.

HOL.: aljibe.

[IMAGEN] Pseudo-Juanelo Turriano, Los ventiún libros, c. 1605, fol. 198r, fig. 169, letra C.

cabra, cabra [del lat. căpra 'íd.'. 965 (DECH). Loçano, Alberto, Architectura, 1582]. sust. f. Mec. Máquina para levantar pesos formada por tres vigas de madera ensambladas por la parte superior, de donde cuelga una garrucha con su maroma.

Loçano, Alberto, Architectura, 1582, pág. 346: La cabra es un instrumento naval de tres leños, cuyas más altas cabeças, en uno ajuntadas, se enlazan y añudan; pero los pies se assientan en triángulo. // Urrea, Vitruvio, Architectura, 1582, fol. 125r: Esta máchina es común a los marineros, y llámanla cabra, y es, assimismo, muy común en los pozos, para sacar agua, que es el carrillo con su rodaxa de metal o de madera. // Urrea, Vitruvio, Architectura, 1582, 139v: Chelonio: máchina que llaman cabra; tiene dos sortijas o assas como ombligos en que se rebuelven las rodezuelas o carrillos.

SIN.: cabria, cabrilla, quelonio . $_{\text {. }}$

HIPER.: máquina.

FAM.: cabria, cabrilla, cabrio.

cabra, V. uña de $\sim$.

cabrestante, cabestante, cabestrante, cabrestante [de origen incierto palabra propia del inglés, francés, castellano y portugués. 1518, Woodbr. (DECH). García de Palacio, Instrución náuthica, 1587]. sust. m. Mec. Torno de eje vertical que se emplea para mover grandes pesos arrastrándolos horizontalmente por medio de una maroma o cable que se va arrollando en él a medida que gira.

García de Palacio, Instrución náuthica, 1587, fol. 137r: Cabestrante: es un terno de madero gruesso con que se cogen las áncoras y los cabos para tirar, e hiçan las belas y se suben y baxan maderos y otra qualquier cosa pessada, y éste gana una soldada de marinero. // Ufano, Tratado de la Artillería, 1613, pág. 223: Y, siendo país montañoso, para subir y baxar artillería con toda comodidad será menester un árgano o cabestante con su torno y los demás adereços de cuerdas de ligamen. // Ufano, Tratado de la Artillería, 1613, pág. 236: Y, conçertados, el yngenio que para tal operaçión hizieron fue armar dentro de un pontón un cabrestante con una garrucha, haziendo para cada uno un ynstrumento a manera de alquitara. 
SIN.: árgana, árgano, carquesio, ergata.

HIPER.: máquina.

cabria, cabria [del lat. căprĕa 'cabra montés'. 1587, García de Palacios (DECH). Loçano, Alberto, Architectura, 1582]. sust. f. Mec. Máquina para levantar pesos formada por tres vigas de madera ensambladas por la parte superior, de donde cuelga una garrucha con su maroma.

García de Palacio, Diálogos militares, 1583, fol. 137v: Cabria: es la que arman los marineros para mastear los navíos y subir por ella cosas pessadas, y ésta la hazen ordinariamente de tres palos grandes, distantes por baxo en triángulo y juntos por las cabeças de arriba. / / Collado, Plática Artillería, 1592, fol. 72v: La cabria y el martinete son, assimismo, instrumentos comodíssimos y apropriados a alçar qualquiera gran peso $\mathrm{y}$, señaladamente, para encavalgar y desencavalgar el artillería. Es, finalmente, la cabria compuesta de tres maderos de 6 varas poco menos de alto cada uno y a las puntas de arriba los traspassa un gruesso perno de hierro, como se veerá en la siguiente primera figura en dibuxo.

SIN.: cabra, cabrilla, quelonio . $_{\text {. }}$

HIPER.: máquina.

FAM.: cabra, cabrilla, cabrio.

[IMAGEN] Vitruvio, Architectura. Traducción de Lázaro de Velasco, folio 124v, figura 120.

cabrilla, cabrilla [de cabra (DECH). Chaves, Sacrobosco, Sphera, 1545]. sust. f. Mec. Máquina para levantar pesos formada por tres vigas de madera ensambladas por la parte superior, de donde cuelga una garrucha con su maroma.

Mendoça, Theórica y práctica, 1596, pág. 77: En semejantes ocasiones suele passar el carruaje a vado y la artillería, quando no es mucha, la he visto passar desencavalgándola con las cabrillas, martinetes o otros instrumentos, que se traen para el efecto a la misma orilla del agua. // Juanelo Turriano, Veinte y un libros, a. 1605, fol. 383r: El instrumento más ordinario es la grúa y la cabrilla y el ergate. // Juanelo Turriano, Veinte y un libros, a. 1605, fol. 383v: La cabrilla es un instrumento de madera, el qual tiene tres pies, por donde se levantan pesos con ella, mas no muy en alto.

SIN.: cabra, cabria, quelonio ${ }_{1}$.

HIPER.: máquina.

FAM.: cabra, cabria, cabrio.

[IMAGEN] Pseudo-Juanelo Turriano, Los ventiún libros, c. 1605, fol. 384v, fig. 380. 
cabrio, cabrio [del lat. vg. *caprěus 'madero que forma parte de la armadura de un tejado, viga'. H. 1220-1250, Berceo (DECH). Urrea, Vitruvio, Architectura, 1582]. sust. $\mathrm{m}$. Especie de viga o madero grande (Terreros).

Urrea, Vitruvio, Architectura, 1582, fol. 58v: Sobre este frontispicio se assiente la hilera y los maderos y cabrios, de manera que las canales y el agua que d'ellas cayga del tejado correspondan al terciario. // Urrea, Vitruvio, Architectura, 1582, fol. 136r: Encima d'ellas se pongan los cabrios, metido uno en otro en los quiciales, que estén levantados nueve pies. // Urrea, Vitruvio, Architectura, 1582, fol. 136r: Sobre los cabrios se ponga una viga quadrada, con la qual se junten los cabrios.

FAM.: cabra, cabria, cabrilla.

caeer, V. caer.

caer, caeer, caer, caher [del lat. cădĕre 'íd.'. Med. s. X, Glosas de San Millán $(\mathrm{DECH})$. Medina, Arte de navegar, 1545]. v. intr. Fís. Dicho de un cuerpo: moverse de arriba abajo por la acción de su propio peso (DRAE).

Medina, Arte de navegar, 1545, fol. 17v: Este vapor es caliente y seco y por su subtilidad trasciende el ayre (porque, como sea de vapor subtil en su género y de lo subtil naturalmente es subir, assí sube, porque de lo subtil de la tierra es hecho) y de allí cae o desciende y en su descendida se señala que el vapor se mueve a lo alto. // Juanelo Turriano, Veinte y un libros, a. 1605, fol. 35r: Esta calidá de agua va goteando por los resquizios de las peñas y luego se va a convertir en piedra; antes que vayan a caer en tierra, se van endureziendo y se hazen piedra. // Juanelo Turriano, Veinte y un libros, a. 1605, fol. 111r: De modo que el agua, en aquel lugar, viene a caeer de alto y haze entonçes grandes piélagos o remolinos tan impetuosos, que pareze que cae de una grandíssima altura.

FAM.: caída.

cafia, cafia [de origen incierto quizás del árabe qáf'a 'contraida, encogida, enroscada'. (DECH s. v. gafa). Urrea, Vitruvio, Architectura, 1582]. sust. f. Ingen. Hidrául. Pieza hueca de metal, generalmente cilíndrica, por donde se conducen las aguas.

Urrea, Vitruvio, Architectura, 1582, fol. 121: B: dízese plato en la máchina, catinus; C: cobertura, tiene forma de la tolva buelta al revés, lo de abaxo arriba; D: dízese fístula o cafia; E: los émbolos machos.

SIN.: fístula, tromba, trompa ${ }_{2}$, tuba.

HOL:: obra hidráulica.

caher, V. caer. 
caída, caída, caýda [de caer. Juanelo Turriano, Veinte y un libros, a. 1605]. sust. f. Ingen. Hidrául. Dicho de un líquido: el curso que lleva sobre alguna superficie. Juanelo Turriano, Veinte y un libros, a. 1605, fol. 67v: Es cierta cosa que agua que camine en açequia abierta, que essa cantidad de caýda que no es bastante a poder caminar en ninguna manera, que le conviene, a lo menos, a mill passos dos pies de caýda. // Juanelo Turriano, Veinte y un libros, a. 1605, fol. 77r: La caýda que se le da al agua que se lleva encerrada dentro de los alcaduzes: que a cada mill passos se le da un pie de caýda; que los mill passos son ocho estadios, y cada estadio es ciento y veynte passos. // Juanelo Turriano, Veinte y un libros, a. 1605, fol. 456r: Puédese hazer otra invençión para subir y baxar alguna caída de agua; la qual inventión es muy differente de la catarata, aunque es más trabajoso, porque se puede ir levantando de poco en poco.

FAM.: caer.

caja, caja, caxa [probablemente del cat. caixa u oc. caissa 'íd.', procedentes del lat. capsa 'íd'. 1251, Calila. (DECH). Juanelo Turriano, Veinte y un libros, a. 1605]. sust. f. Mec. Armazón de madera con un hueco en medio sobre el que se forjan los rodeznos de los molinos.

Lobato, Notas, a. 1585, fol. 34: Así, da el agua primero en tres chapas que en la cuba, y la hechura de estas álabes es que se han de forjar en la caja del palo, las que han de ser fuertes cuadrados de largo que ha de tener. // Lobato, Notas, a. 1585, fol. 34: La caja sobre que se forjará mejor este rodezno me parece que será mejor redonda, porque con el redondo no hará embarazo ni tope en el agua, y el herrero la forjará mejor, que no tendrá más de tenderla en redondo. // Lobato, Notas, a. 1585, fol. 35: Si éste de seis se puede forjar en la caja cuadrada de hierro, será mejor y con menos agua molerá.

HOL.: molino.

FAM.: cajal.

$\sim$ farinal [Juanelo Turriano, Veinte y un libros, c.1605]. comp. sintag. Mec. arag. Cajón que recibe la harina en un molino.

Juanelo Turriano, Veinte y un libros, c.1605, fol. 308v: Y su mástil es de yerro, que es I, que mueve la muela $Q$, que está encima de la muela $P$, las quales están encima del banco O. La caxa farinal es R. La taona es S. Su canalón es V. // Juanelo Turriano, Veinte y un libros, c.1605, fol. 310r: La qual lanterna, en el mismo exe, está una rueda grande, que es $\mathrm{E}$, la qual tiene unos caxales al costado, los quales mueven una lanterna, que es $\mathrm{F}$, la qual tiene su mástil, que se va a encaxar en la muela G. Y tiene encima su taona, gruença, y la caxa farinal es donde I. // Juanelo Turriano, Veinte y un libros, c.1605, fol. 310v: Y la taona es $\mathrm{H}$. La caxa farinal es I. La tabla en que templa la agua es K. Y el palo con que la abaxan y suben es L. 
SIN.: harinal.

HOL.: molino.

[IMAGEN] Pseudo-Juanelo Turriano, Los ventiún libros, c. 1605, fol. 308r, fig. 211, letra R.

cajal, caxal [probablemente del cat. caxal 'muela' (Clairac). Juanelo Turriano, Veinte y un libros, a. 1605]. sust. m. Mec. arag. Diente de madera en una rueda, situado normalmente a su plano, para engranar, por lo regular, con una linterna (Clairac).

Juanelo Turriano, Veinte y un libros, a. 1605, fol. 294r: De modo que en el mismo exe ay otra rueda con unos caxales de madera, las quales es la rueda $\mathrm{E}$ y los caxales $\mathrm{F}$, y la linterna es G, la qual está asentada sobre un perne. // Juanelo Turriano, Veinte y un libros, a. 1605, fol. 298v: Acomódasele dos linternas a los dos costados, que ellos estén muy bien proporcionados, las dos, con los caxales de la rueda que recive el golpe de la agua. // Juanelo Turriano, Veinte y un libros, a. 1605, fol. 322v: La rueda más alta, que es A, la qual es para picar pólvora. Sus caxales es B. El exe es C.

HOL.: rueda.

FAM.: caja.

[IMAGEN] Pseudo-Juanelo Turriano, Los ventiún libros, c. 1605, fol. 308r, fig. 211, letra G.

calcaño, calcaño, carcaño [del lat. calcānĕum 'talón', derivado de calcare 'pisar'. H. 1250, Libro de Alexandre (DECH). Juanelo Turriano, Veinte y un libros, c.1605]. sust. m. Mec. Cada una de las paletas de una rueda hidráulica.

Juanelo Turriano, Veinte y un libros, c.1605, fol. 290r: Aunque esta bomba o canal se asienta muy más llana, por causa que el herir que haze en el carcaño o en la rueda, la qual está differentemente asentada y de otra forma.

SIN.: álabe.

HOL.: rodete, rodezno.

caldera, caldera [del lat. caldārĭa 'íd.' (DECH). Fernández de Enciso, Suma de Geographía, 1530]. sust. f. Recipiente de metal, grande y semiesférico, que sirve comúnmente para poner a calentar o cocer algo dentro de él (DRAE).

Fernández de Enciso, Suma de Geographía, 1530, fol. LXVIIr: D'esta misma harina de maýz, cozida en calderas e tinajas grandes en mucho agua, hazen vino para bever. // Juanelo Turriano, Veinte y un libros, a. 1605, fol. 337r: Conviene que la caldera sea muy grande, aunque se podría hazer una caldera de madera con sólo que tuviesse el suelo de alambre. // Juanelo Turriano, Veinte y un libros, a. 1605, fol. 355r: Después se haze un hornico, que es $\mathrm{V}$, el qual tiene asentadas dos calderas, que cada una d'ellas cabe seys cántaras de agua.

FAM.: calderero, caldero. 
[IMAGEN] Pseudo-Juanelo Turriano, Los ventiún libros, c. 1605, fol. 337v, fig. 249, letras D y E. Calderas grandes en un ingenio para lavar lanas.

calderero, calderero [de caldera (DECH). Martínez de Burgos, Reportorio premáticas y Cortes, 1551]. sust. $\mathrm{m}$. Persona que tiene por oficio el hacer calderos y calderas.

Collado, Plática Artillería, 1592, fol. 22v: Y aquella hoja la martillarás con un martillejo, como haze el calderero a las calderas. // Alonso Barba, Arte de los metales, 1640, fol. 61v: Y en no aviendo de crecer más, se le pondrá por arriba un cerco de cobre o hierro, como es costumbre entre los caldereros.

FAM.: caldera, caldero.

2 [Martínez de Burgos, Reportorio premáticas y Cortes, 1551]. sust. m. Persona que anda vendiendo por las calles sartenes, badiles y otros instrumentos caseros de cobre o hierro sin tener tienda pública, que de ordinario está reputado por gitano o vagamundo (Autoridades).

Martínez de Burgos, Reportorio premáticas y Cortes, 1551, fol. XLIIr: Porque los caldereros de fuera d'estos reynos hazen obras inútiles y llevan d'estos reynos la moneda, quitando el provecho a los nuestros súbditos y naturales, es nuestra merced. // Martínez de Burgos, Reportorio premáticas y Cortes, 1551, fol. XLVIIr: Caldereros: que no estén ni entren en estos reynos, si no estuvieren aliados o fueren vezinos antiguos en ellos. Ley IV, título X, libro VIII. / / Celso, Reportorio universal leyes Castilla, 1553, fol. LIv: Caldereros, no entren en estos reynos. Petición XXV, en Valladolid, año de treynta y siete.

caldero, caldero [del lat. caldārŭum 'íd.' (DRAE). Castillo, Tratado de cuentas, 1551]. sust. $\mathrm{m}$. Caldera pequeña de suelo casi semiesférico, y con asa sujeta a dos argollas en la boca (DRAE).

Castillo, Tratado de cuentas, 1551, fol. XXXIIv: Yo juzgaría que la división fue bien y justamente hecha, y que fue entre los compañeros hecha la estimación y tasación, como está dicho, pues que entre ellos se hizo división hasta los perros, caldero y todo lo que más tenían en el hato del dicho ganado, y así es de presumir que se hizo (r). // Pérez Vargas, De re metallica, 1568, fol. 200v: Después de averse assentado el agua y aclarado, se vazíe en unos calderos de plomo quadrados, de ocho pies de largo y hueco cada uno, y de tres de hondo, como una sepultura; y allí se cueza hasta que se espesse. // Juanelo Turriano, Veinte y un libros, a. 1605, fol. 452r: Y tomar dos pedaços de soga que sean gruessos, y bolver el caldero o herrada hazia baxo, y cruzalle las sogas en la boca, muy bien añudadas, y que hagan cruz en el suelo de la herrada.

FAM.: caldera, calderero. 
camilo, camilo [tomado del lat. cămillum 'grosor de porquezuela' (Salinero). Urrea, Vitruvio, Architectura, 1582]. sust. m. Mec. Grueso o grosor de una porquezuela o una pieza grande con forma de tuerca utilizada en algunas máquinas.

Urrea, Vitruvio, Architectura, 1582, fol. 139v: Camilo: gruesso de la súcula, o se dize bolsa. // Urrea, Vitruvio, Architectura, 1582, fol. 143r: Súcula: porquezuela de máchinas; su gruesso se dize camilo o bolsa. Pónese asida en los chelonios,que son las sortijas como ombligos en que se rebuelve con su exe.

SIN.: bolsa.

HOL:: porquezuela.

caminar, caminar [de camino. H. 1220-1250, Berceo (DECH). ]. v. intr. Fís. Dicho de una cosa inanimada: seguir su curso (DRAE).

Lobato, Notas, a. 1585, fol. 33: Y, así, hice esta traza para dar a entender que, cuando haya empezado a moler el molino y haya menguado dos pies de la parte alta, no ha menguado cosa de abajo y el agua viene ya caminando por la acequia, y como haya huidos los dos pies de agua en aquella altura, puede vaciar su acequia muy bien. // Juanelo Turriano, Veinte y un libros, a. 1605, fol. 465v: Y la otra razón: que como sallen estas dos çequias de los costados d'esta grande çequia, y ansí como viene la agua a herir en el costado d'ella, haze algún detenimiento, donde no camina con tanta veloçidad como haze la agua de la çequia de medio. // Juanelo Turriano, Veinte y un libros, a. 1605, fol. 468r: Bien sé que me dirán que la agua camina con mayor fuerça quando tiene mayor cantidad de agua, que no quando tiene poca.

FAM.: camino, encaminado, encaminamiento, encaminar.

camino, camino [del lat. vg. camminus 'íd.', de origen céltico (comp. irl. céimm, galés cam 'paso'. 1084 (DECH). Juanelo Turriano, Veinte y un libros, a. 1605]. sust. m. Ingen. Hidrául. Conducto o canal por el que discurre el agua.

Juanelo Turriano, Veinte y un libros, a. 1605, fol. 11r: De manera que estas aguas caminan por debajo de tierra con tanta furia y ímpetu, que todas las vezes que estas aguas se ençierran o se van apartando de su camino o canales por donde caminan, abren tan presto otros caminos de nuevo. // Juanelo Turriano, Veinte y un libros, a. 1605, fol. 64v: De modo que vese que el camino que haze esta fuente, que es caminar dende la D hazia la $\mathrm{C}$ y de la $\mathrm{B}$ hazia la $\mathrm{A}$, ansí que viene hazer ángulo, como por las líneas se puede ver el camino que haze, que las dos líneas no corresponden en una. // Juanelo Turriano, Veinte y un libros, a. 1605, fol. 79r: El camino del agua es A. Y el valle es $\mathrm{B}$. La mota de tierra es $\mathrm{C}$, la qual ha ygualado el camino, como se vee.

SIN.: encaminamiento.

HIPER.: obra hidráulica.

FAM.: caminar, encaminado, encaminamiento, encaminar. 
campanero, campanero [de campana (DECH). Sagredo, Medidas Romano, 1526]. sust. $m$. Persona que tiene por oficio el fabricar campanas.

Sagredo, Medidas Romano, 1526, pág. 14: Aquéllos se llaman oficiales mecánicos que trabajan con el ingenio y con las manos, como son los canteros, plateros, carpenteros, cerrageros, campaneros y otros oficiales, que sus artes requieren mucho saber e ingenio.

canal, canal [del lat. cănālis 'íd.'. 1107 (DECH). Celso, Reportorio universal leyes Castilla, 1553]. sust. u. t. c. m. Ingen. Hidrául. Cauce artificial por donde se conduce el agua para darle salida o para otros usos (DRAE).

Celso, Reportorio universal leyes Castilla, 1553, fol. LVIIIr: Casa, si fuere vendida, en la tal venta no solamente se comprehende la casa, mas aun los pozos, caños y canales y aguaduchos, y todas las otras cosas que en aquel tiempo eran para servicio de la tal casa, quier fuessen dentro, quier fuera d'ella. // Collado, Plática Artillería, 1592, fol. 63v: Y si la concurrencia de las aguas será mucha y siendo a nivel el suelo de la mina, entonces él deve de provar de sacar el agua, guyándola por una canal estrecha del un hoyo al otro hasta traherla a aquél que a la boca está más propinquo, y de aquél hirla sacando. // Juanelo Turriano, Veinte y un libros, a. 1605, fol. 80r: La agua es B. Y el barranco es $\mathrm{C}$. Y donde ha de pasar la agua, $\mathrm{D}$, que es la pared de piedra seca. E es la azequia o canal por donde ha de passar el agua.

SIN.: canaladura 2 , caña, cañal

HIPER.: obra hidráulica.

FAM.: acanalado, canaladura, canaleja, canalera, canaleta, canalete, canalón, canalote.

[IMAGEN] Pseudo-Juanelo Turriano, Los ventiún libros, c. 1605, fol. 81r, fig. 48.

2 [Pérez de Moya, Arithmética práctica, 1562]. sust. f. Ingen. Hidrául. Conducto formado por tejas delgadas y combadas por el que corre el agua en los tejados. Celso, Reportorio universal leyes Castilla, 1553, fol. CCXXXIVv: Deve, ansimesmo, el juez mandar derribar las canales que hiziere alguno en su edificio por las paredes y otros edificios, quando por las tales obras haze daño a los edificios vezinos contra derecho, no teniendo el que haze las tales obras servidumbre alguna sobre los otros edificios, por la qual puede hazer las dichas obras. // Pérez de Moya, Arithmética práctica, 1562, pág. 723: Quanto a lo primero que dezís, de saber las tejas que un tejado tiene, no es cosa de mucha difficultad, y házese la cuenta multiplicando las tejas que tuviere una canal por todas las canales del tal tejado, y lo que saliera de la tal multiplicación es el número de tejas que el tal tejado tiene. // Pérez de Moya, Arithmética práctica, 1562, pág. 723: Y esto tiene lugar de verdad quando unas canales tienen tantas tejas como otras, y porque no todas están iguales en tejas, digo que no se puede saber quántas ay justamente, mas mi parecer es que, pues se ha de subir a contar quántas tejas tiene una canal y quántas canales tiene, que las contéys una a una y no erraréys.

SIN.: canalera. 
3 [Lobato, Notas, a. 1585]. sust. f. Mec. Vía a modo de media caña por la que se conduce el agua que mueve el rodezno de un molino.

Lobato, Notas, a. 1585, fol. 19: Molino saetino que con una canal mueve dos rodeznos. // Lobato, Notas, a. 1585, fol. 36: Y el que yo he imaginado molerá levantado y con mayor violencia volverá, por la razón siguiente: la canal de 10 pies de alto, pongo caso que no entre en la cuba más de seis pies de alta el agua, no teniendo el rodezno de madera más de dos pies y medio donde le golpee el agua que más alta va. // Juanelo Turriano, Veinte y un libros, a. 1605, fol. 331v: La canal es la A, que encamina la agua a la rueda $\mathrm{B}$, la qual tiene cerrados los dos costados de las palas donde yere la agua, a causa que con más presteza pueda andar y bolver aquel árbol o exe $\mathrm{C}$, el qual tiene encaxados unos levadores.

SIN.: bomba $a_{2}$ saetía, saetín.

HOL.: molino.

ENCICL.: "De la parte inferior del cubo arranca la saetía -llamada a veces saetín o bombaque conducía el agua a gran velocidad a los rodeznos" (Catálogo Felipe II).

[IMAGEN] Lobato, Notas, c. 1585, fol. 36.

canal, V. molino de .

canaladura, canaladura [de canal (DECH). Juanelo Turriano, Veinte y un libros, c.1605]. sust. f. Mec. Conjunto de hendiduras de la muela de un molino. Juanelo Turriano, Veinte y un libros, c.1605, fol. 316v: Y esto lo a de ver poniendo la regla encima de la muela: verá en qué parte convendrá abaxar o levantar la canaladura de la muela.

SIN.: picadura.

HOL.: muela.

FAM.: acanalado, canal, canaleja, canalera, canaleta, canalete, canalón, canalote. 
2 [Juanelo Turriano, Veinte y un libros, a. 1605]. sust. f. Ingen. Hidrául. Cauce artificial por donde se conduce el agua para darle salida o para otros usos (DRAE s. v. canal).

Juanelo Turriano, Veinte y un libros, a. 1605, fol. 363r: Y con esta orden van rodeando todo aquel patio que han determinado de tomar, con dos órdenes d'estos maderos, con estas folluras o canales, de alto abaxo. Y después se van puniendo tablas por aquellas canaladuras, las quales son de gruesso de dos dedos, y hanse de labrar por los cantos, con el cimiento, que ellas estén drechas y que junten muy bien la una con la otra, a causa que no entre la agua.

SIN.: canal $_{1}$ caña, cañal.

HIPER.: obra hidráulica.

canaleja, canaleja [de canal (DECH). Lobato, Notas, c.1585]. sust. f. Mec. Pieza de madera unida a la tolva, por donde pasa el grano u otro material a la muela.

Lobato, Notas, c.1585, fol. 20: Y entre una canaleja de madera por donde ande y se pueda menear a la redonda por debajo, por de dentro de la torre. // Llanos, Diccionario minas, c.1609-11, pág. 44: Y cuando parece se habrá juntado alguno o se acaba el día, quitan los costales y lávanlos en bateas o tinas, y recogen lo que se ha juntado, y esto se dice echar relaves por canaleja. // Llanos, Diccionario minas, c.160911, pág. 112: No se despachan tanto de esta manera como por canaleja, mas sácaseles mejor el azogue y plata.

HOL.: molino.

FAM.: acanalado, canal, canaladura, canalera, canaleta, canalete, canalón, canalote.

canalera, canalera [de canal (DECH). Urrea, Vitruvio, Architectura, 1582]. sust. f. Ingen. Hidrául. arag. Conducto formado por tejas delgadas y combadas por el que corre el agua en los tejados.

Urrea, Vitruvio, Architectura, 1582, fol. 30v: Sobre lo alto de la pared se edificará de ladrillo y teja; debaxo de las tejas o canaleras, su tejaroz o cornija, que tenga de alto cerca de pie y medio, con su salida de la corona afuera.

SIN.: canal $_{2 . .}$

HIPER.: obra hidráulica.

FAM.: acanalado, canal, canaladura, canaleja, canaleta, canalete, canalón, canalote.

canaleta, canaleta [de canal (DECH). Llanos, Diccionario minas, c.1609-11]. sust. f. Mec. Canal por el que entra el agua en las tinas para lavar el metal.

Llanos, Diccionario minas, c.1609-11, pág. 68: Luego echan el agua a la tina por su canaleta $y$, juntamente con ella, van echando metal, hasta veinticinco bateas de una vez 
poco más o menos. // Llanos, Diccionario minas, c.1609-11, pág. 68: Y, teniendo este punto, la dejan llenar de agua hasta que sobrepuja por el borde de ella y rebosa, de suerte que toda la que por la canaleta va entrando vuelve a salir por encima, llevándose consigo la lama del metal, que es lo más sutil y molido de la harina.

SIN.: canalete $_{2}$.

HOL.: tina.

FAM.: acanalado, canal, canaladura, canaleja, canalera, canalete, canalón, canalote.

canalete, canalete [de canal. Juanelo Turriano, Veinte y un libros, c.1605]. sust. m. Mec. Conducto por el que cae el trigo en la muela.

Juanelo Turriano, Veinte y un libros, c.1605, fol. 311v: La taona o gruença donde se pone el trigo es E. El canalete donde cae el trigo en la muela es F.

SIN.: canalón, canalote.

HOL.: molino.

FAM.: acanalado, canal, canaladura, canaleja, canalera, canaleta, canalón, canalote.

2 [Llanos, Diccionario minas, ca. 1609-11]. sust. m. Mec. Canal por el que entra el agua en las tinas para lavar el metal.

Llanos, Diccionario minas, ca. 1609-11, pág. 10: La canal de paso por donde entra el agua a las tinas se dice canalete.

SIN.: canaleta.

canalón, canalón [de canal. 1585, AFA (Frago) (DECH). Juanelo Turriano, Veinte y un libros, c.1605]. sust. m. Mec. arag. Conducto por el que cae el trigo en la muela.

Juanelo Turriano, Veinte y un libros, c.1605, fol. 308v: La caxa farinal es R. La taona es S. Su canalón es V. El torcedor, T. La cítola es X. Donde firma el exe E, es K. Y donde firma el árbol de la muela es L. // Juanelo Turriano, Veinte y un libros, c.1605, fol. 309r: Y los caxales mueven una linterna, I. Y su mástil es $\mathrm{K}$, que mueve la muela L. Y la taona es M. Y el canalón es $\mathrm{N}$. El torcedor es $\mathrm{O}$. La caxa que recoje la arina es $\mathrm{P}$.

SIN.: canalete ${ }_{1}$, canalote.

HOL.: molino.

FAM.: acanalado, canal, canaladura, canaleja, canalera, canaleta, canalete, canalote.

[IMAGEN] Pseudo-Juanelo Turriano, Los ventiún libros, c. 1605, fol. 308r, fig. 211, letra V. 
canalote, canalote [de canal. Juanelo Turriano, Veinte y un libros, a. 1605]. sust. m. Mec. arag. Conducto por el que cae el trigo en la muela.

Juanelo Turriano, Veinte y un libros, a. 1605, fol. 312r: El templador es H, el qual es para hazer que cayga el grano dentro de la muela, o muy apriesa o muy a espacio. Y el canalote es el que guía el grano a la muela. Y el farinal es I, donde se recoje la arina molida. Y esto es quanto a esta manera de molino. // Juanelo Turriano, Veinte y un libros, a. 1605, fol. 317r: La taona es A. El templador, B. El canalote, C. La taravilla, D. La armadura es E, hecha aochavada, y otras ay redondas. El farinal es F. La pala, G. La escova es $\mathrm{H}$.

SIN.: canalete 1 , canalón.

HOL.: molino.

FAM.: acanalado, canal, canaladura, canaleja, canalera, canaleta, canalete, canalón.

cangilón, cangilón, canjilón [de origen incierto acaso de *congilón, aumentativo en -on 'medida de líquidos equivalente a seis sextarios' de un derivado del lat. congius 'medida de líquidos equivalente a seis sextarios'. Entre 1493 y 1495, Nebrija (DECH). Santa Cruz, Libro de las longitúdines, 1567]. sust. m. Vasija de barro o metal utilizada para contener líquidos (Salinero).

Santa Cruz, Libro de las longitúdines, 1567, pág. 59: Otras personas han inventado otros reloxes de agua de más primor, y es metiendo en una pila o barreñón grande lleno de agua un vaso como cangilón huradado por abaxo y asido por lo alto con un cordel, el qual estuviese rebuelto a çierto palo redondo que sirviese de exe, cuyo cabo pudiese estar metido por una tabla donde estuviesen repartidas 24 horas // Santa Cruz, Libro de las longitúdines, 1567, pág. 63: Y a esta causa el agua no podrá entrar igualmente por el agujero del vaso o cangilón, en el qual entrará por el agujero más o menos agua conforme como estuviere vazío o lleno y tuviere mayor o menor peso y assí las horas no serán iguales. // Santa Cruz, Libro de las longitúdines, 1567, pág. 63: Y a esta causa el agua no podrá entrar igualmente por el agujero del vaso o cangilón, en el qual entrará por el agujero más o menos agua conforme como estuviere vazío o lleno y tuviere mayor o menor peso y assí las horas no serán iguales.

2 [Llanos, Diccionario minas, ca. 1609-11]. sust. m. Mec. Vasija de barro o metal que sirve para sacar agua de los pozos y ríos, atada con otras a una maroma doble que descansa sobre la rueda de la noria (DRAE).

Llanos, Diccionario minas, ca. 1609-11, pág. 29: Cimbas: dícese de cimpa, que en la general quiere decir 'crizneja', cuales son las que se usan en España en las anorias a manera de empleita de mimbre y de otras cosas acomodadas para lo mismo, en que se atan los canjilones para sacar el agua.

HOL.: noria. 
canjilón, V. cangilón.

cantarero, cantarero [de cántaro (DECH). Juanelo Turriano, Veinte y un libros, a. 1605]. sust. $m$. Persona que tiene por oficio el fabricar cántaros.

Juanelo Turriano, Veinte y un libros, a. 1605, fol. 307r: Ay otro género de molino, el qual se llama de bomba, que tiene la canal cubierta y tiene rodete, que anda llana la rueda como la de los escudilleros o cantareros.

FAM.: cántaro.

cántaro, cántaro [del lat. canthărus 'especie de copa grande, de dos asas'. 1272-84, General Estoria (DECH). Anónimo, Ordenanças paños, 1527]. sust. m. Vasija grande de barro o metal, angosta de boca, ancha por la barriga y estrecha por el pie y por lo común con una o dos asas (DRAE).

Acosta, Historia natural, 1590, pág. 200: Os ingas del Pirú no se contentaron de tener vasijas mayores y menores de oro, jarros, y copas, y taças, y frascos, y cántaros y aun tinajas, sino que también tenían sillas y andas o literas de oro maciço y en sus templos colocaron diversas estatuas de oro maciço. // Ferrofino, Descrizión Artillería, 1599, fol. 173r: En un cántaro o garrafa, encendiéndose estopa, y prestamente puesta su boca sobre el agua, se levantan hacia arriva grande copia de agua o otro liquor, porque no se dé vaçío.

FAM.: cantarero.

cantimplora, cantimplora, cantinplora, cantiplora [tomado del cat. ant. cantiplora (hoy cantimplora) y éste compuesto de canta i plora 'canta y llora', por el ruido que hace la cantimplora al gotear. 1495 (DECH). Lobato, Notas, c.1585]. sust. f. Mec. Canal encorvado a través del que, en algunas obras e ingenios hidráulicos, se pasa el agua de un punto a otro.

Lobato, Notas, c.1585, fol. 26: Y así hicimos el ingenio que abajo irá dibujado, el cual pretendía el licenciado que, donde está llena el agua, el río o corriente sin pesquera ninguna, que estando así llana la superficie, meter una cantimplora metida entre unas paredes muy fuertes, que crecida no las llevase [...]. // Juanelo Turriano, Veinte y un libros, c.1605, fol. 122r: Y esto lo sacaremos de las cantiploras de vidrio, que la agua jamás no sube tan alta como abaja. // Juanelo Turriano, Veinte y un libros, c.1605, fol. 122v: Digo, que tomando el vidrio y puniendo dentro agua, que si el vidrio fuere tan alto en B como es en A, que jamás verterá el agua, salvo, si hechando la agua dentro de la cantinplora, viene de más alto; entonces verterá.

HOL.: máquina.

[IMAGEN] Lobato, Notas, c. 1585, fol. 26. 
2 [Juanelo Turriano, Veinte y un libros, a. 1605]. sust. Tubo encorvado que sirve para sacar líquidos del vaso que los contiene, haciéndolos pasar por un punto superior a su nivel (DRAE s. v. sifón).

Juanelo Turriano, Veinte y un libros, a. 1605, fol. 122r: El vaso que es lleño de agua es A. La cantinplora es B. El qual es B puesto dentro del vaso A, y toma el agua y la sube en $\mathrm{C}$, que es lo más alto de la cantinplora, y vierte el agua en $\mathrm{D}$. Y si la D no estuviese muy más baja que no es la $B$, no subiría tan sólo una gota, quanto y más que si el fin de la cantinplora fuese en $\mathrm{E}$.

[IMAGEN] Pseudo-Juanelo Turriano, Los ventiún libros, c. 1605, fol. 122r, fig. 91. Cantimplora dentro de una vasija.

cantinplora, V. cantimplora.

cantiplora, V. cantimplora.

caña, caña [del lat. canna 'íd.'. 1070, Oelschl. (DECH). Celso, Reportorio universal leyes Castilla, 1553]. sust. f. Ingen. Hidrául. Cauce artificial por donde se conduce el agua para darle salida o para otros usos.

Celso, Reportorio universal leyes Castilla, 1553, fol. CLXIv: Aquél a quien se deve la servidumbre deve mantener las acequias, o cañas, o cañales, o calçada por docorriere el agua, por manera que no haga daño a la tal heredad que deve la servidumbre.

SIN.: canal 1 , canaladura 2 , cañal .

HIPER.: obra hidráulica.

FAM.: cañal, cañería, caño, cañón, encañado, encañadura, encañamiento, encañar, encañizado.

cañal, cañal [de caña 'cauce artificial' (DRAE). Celso, Reportorio universal leyes Castilla, 1553]. sust. m. Ingen. Hidrául. Cauce artificial por donde se conduce el agua para darle salida o para otros usos.

Celso, Reportorio universal leyes Castilla, 1553, fol. CLXIv: Aquél a quien se deve la servidumbre deve mantener las acequias, o cañas, o cañales, o calçada por do corriere el agua, por manera que no haga daño a la tal heredad que deve la servidumbre. // Celso, Reportorio universal leyes Castilla, 1553, fol. CCCXXXIIv: Vendiéndose alguna casa o heredad o otra morada, en la tal venta todas las cosas que pertenescen a ella o le son ayuntadas entran en la venta, ansí como pozos, cañales, caños, aguaduchos y las otras casa que solían ser para servicio de la dicha casa, quier sean dentro, quier de fuera.

SIN.: canal canaladura $_{2}$, caña. 
HIPER.: obra hidráulica.

FAM.: caña, cañería, caño, cañón, encañado, encañadura, encañamiento, encañar, encañizado.

2 [Besson, Teatro instrumentos, 1602]. sust. m. Ingen. Hidrául. Tubo o agujero por donde sale un chorro de agua u otro líquido.

Besson, Teatro instrumentos, 1602, fol. F2v: Por un agujero, digo aquél con que el vaso se cierra, es este vaso hinchido, y por otro, digo el cañal, es vasiado. // Besson, Teatro instrumentos, 1602, fol. F2v: Mas su agujero en esta manera se haze: de qualquiera parte d'él (porque en tres se divide, como poco ha se dixo) salen sendos cañales, que tocan aquel leño cóncavo y redondo que se vee debaxo, al lado de oriente. // Besson, Teatro instrumentos, 1602, fol. F2v: Se estienden a la parte delantera d'él y fenecen en el cañal, el qual después se descarga, sacando fuera sus liquores, en espacio de dos dedos, a l'otra parte de las bocas de los cañales, para que assí, firmemente, se le meta un tapón, el qual tape todas las tres por medio de tres clavijas de madera, que entran en los tres agujeros que están en la boca que cierra, y responden totalmente a las bocas de los cañales.

HOL.: obra hidráulica.

[IMAGEN] Besson, Diego, Teatro de los instrumentos, Horacio Cardon (trad.), 1602, pág. F3r, figura 19.

cañería, cañería [de caño (DECH). Mosquera, Comentario disciplina militar, 1596]. sust. f. Ingen. Hidrául. Conducto formado de caños por donde se distribuyen las aguas (DRAE).

Mosquera, Comentario disciplina militar, 1596, fol. 89r: Harto mayor crueldad que la de Olofernes, que quando cercó la ciudad de Betulia mandó cortar la cañería por donde entrava el agua a la ciudad. // Rojas, Teórica fortificación, 1598, fol. 83r: Después que el ingeniero sepa todas las partes y requisitos dichos, será muy necessario que también sepa encaminar las aguas al castillo o fortaleza que huviere hecho, encaminándola por alguna cañería de barro, o por alguna atalxea de ladrillo y cal. / García de Céspedes, Instrumentos nuevos, 1606, fol. 31r: Y, siendo la baxada y subida muy larga y toda la cañería está llena de agua, es grande el peso de una y otra parte y, cargando sobre la cañería que está en lo más hondo y no pudiendo sufrir tanto peso, viene a rebentar.

HOL.: obra hidráulica.

MER.: $c a \tilde{n} o_{2}$.

FAM.: caña, cañal, caño, cañón, encañado, encañadura, encañamiento, encañar, encañizado. 
caño, caño [de caña (DECH). Ortega, Conpusición Arismética y Geometría, 1512]. sust. m. Ingen. Hidrául. Tubo por donde sale un chorro de agua u otro líquido, principalmente el de una fuente (DRAE).

Ortega, Conpusición Arismética y Geometría, 1512, fol. 128v: Un maestro de picar piedra a fecho una fuente de piedra para tener agua, y la a fecho con cinco caños, en tal manera que si abren el un caño, que en el mayor, que toda el agua que estuviere dentro saldrá en un día. // Ortega, Conpusición Arismética y Geometría, 1512, fol. 129r: Agora, pues has sabido que, abriendo todos 5 caños juntamente, quántos cántaros saldrá de agua por cada caño, réstate saber en quánto tiempo.

HOL.: fuente.

FAM.: caña, cañal, cañería, cañón, encañado, encañadura, encañamiento, encañar, encañizado.

2 [Urrea, Vitruvio, Architectura, 1582]. sust. m. Ingen. Hidrául. Tubo corto, particularmente el que forma, junto a otros, las cañerías.

Loçano, Alberto, Architectura, 1582, pág. 324: Estos caños (si nos es lícito hablar assí) los encaxaréys uno en otro en los arcaduzes, y con cal con azeyte sobada enlodaréys las junturas, y las affirmaréys con enlazamientos de cobre. // Rojas, Teórica fortificación, 1598, fol. 62r: En semejante ocasión, servirá bien esta regla para hazer los caños con que se ha de medir la dicha agua, dándole al diámetro el primer caño de dos reales, y al segundo diámetro de quatro, y todo lo demás que se sigue, guardando la regla dicha, porque es general para multiplicar caños y círculos para el agua. // Juanelo Turriano, Veinte y un libros, a. 1605, fol. 141r: Podríase hazer caños de madera redondos, los quales fuesen barrenados, como acostumbran barrenar las escopetas los escopeteros. Y conviene barrenar estos caños con un mismo modo de artificio, ecepto que todo a de ser mayor, ansí el artificio como las barrenas, que estos caños han de ser de doze hasta catorze palmos.

SIN.: vaso $_{2}$.

HOL.: cañería.

[IMAGEN] Pseudo-Juanelo Turriano, Los ventiún libros, c. 1605, fol. 283v, fig. 30.

cañón, cañón [de caño (DRAE). ]. sust. m. Ingen. Hidrául. Pieza hueca y larga, a modo de caña, utilizada para conducir agua.

Pérez Vargas, De re metallica, 1568, fol. 134v: Y para excusar que no saliesse a bueltas del almártaga algún metal, hazían un cilindro o cañón de barro, el qual ponían en la punta del assador, a la boca del caño de la cendra, por donde corría el almártaga, y con él detenían el buen metal. // Urrea, Vitruvio, Architectura, 1582, fol. 108r: De tres maneras se guía el agua: por arroyos, por canales fabricadas, por cañones de plomo o arcaduzes. // Juanelo Turriano, Veinte y un libros, a. 1605, fol. 233r: Y es levantada la 
mancha en D. Y ansí va moviendo alternativamente las manchas. Y en el cañón E ay unos agujeros en F, por donde entra el agua en el caño.

HOL.: obra hidráulica.

FAM.: caña, cañal, cañería, caño, encañado, encañadura, encañamiento, encañar, encañizado.

capaça, V. capaza.

capaço, V. capazo.

capaza, capaça [de capazo (DRAE). Juanelo Turriano, Veinte y un libros, a. 1605]. sust. f. arag. Especie de espuerta, con un agujero pequeño por abajo, en la que se prensa la uva o la caña en los molinos.

Juanelo Turriano, Veinte y un libros, a. 1605, fol. 334r: Las pilas donde reciven l'aceyte y donde se pone limpio, apartado de la agua, V Y Z X, de modo que V X son las pilas que reciven el azeyte que salle de las capaças. // Juanelo Turriano, Veinte y un libros, a. 1605, fol. 335r: Y después de molida la caña, se pone dentro de unas capaças de esparto, y se prensan como se haze las olivas. // Juanelo Turriano, Veinte y un libros, a. 1605, fol. 335v: Y después de molida, la van poniendo de unos vasos, y de aquí la ponen en unas capaças de esparto, casi como las que acostumbran poner las olivas.

FAM.: capazo.

capazo, capaço [del lat. vg. *capaceum 'íd.', derivado de căpĕre 'contener' y de su derivado căpāx , căpācis 'que tiene cabida'. 1331, Invent. arag. (DECH). Juanelo Turriano, Veinte y un libros, a. 1605]. sust. m. arag. Capacho o espuerta que se utiliza para transportar materiales.

Juanelo Turriano, Veinte y un libros, a. 1605, fol. 430r: Como es clavazón, cuerdas, capaços, espuertas de mimbres, palas de madera, de hierro, açadas, picas, própalos de hierro, maças de hierro, bacietas o gamellas de madera grandes y pequeñas. // Juanelo Turriano, Veinte y un libros, a. 1605, fol. 359v: Espuerta. Própalo de yerro. Cuña. Maça de yerro. Açada estrecha. Algadera. Pico caçudo. Açada. Capaço. Furicón para atizar el horno. // Juanelo Turriano, Veinte y un libros, a. 1605, fol. 359v: En la figura: Ruello para moler yesso. Bacieta. Ruello para moler yesso. Algiño. Raedera. Poçal. Capaço de yesso. Cernedor de yesso. Arnero. Bacía de amasar yesso. Pala de madera.

FAM.: capaza. 
capirote, capirote [del gasc. capirot 'capucho' (Palay), derivado de capa. $\mathrm{H}$. 1300, Gran Conquista de Ultramar (DECH). Lobato, Notas, c.1585]. sust. m. Mec. Cornisa que corona un molino.

Lobato, Notas, c.1585, fol. 21: Tenía cuarenta pies de altura hasta donde estaba el eje y entruesga, y más el tejado y capirote, el cual tenía veinticuatro cadenas de hierro por de dentro de doce pies de largo.

HOL.: molino.

[IMAGEN] Lobato, Notas, c. 1585, fol. 21.

caracol, caracol, coracol [de origen incierto voz común a los tres romances hispánicos y a la lengua de Oc, quizá de una raíz expresiva cacar-, como nombre de la cáscara del caracol. H. 1400, Glosarios de Palacio (DECH). Sagredo, Medidas Romano, 1526]. sust. m. Mec. Tornillo de gran tamaño, generalmente de madera, que se usa para el movimiento de las prensas y otras máquinas.

Besson, Teatro instrumentos, 1602, fol. C4v: A más d'esto, la parte interior del caracol tiene su puesto en una conveniente viga, seguidamente agujerada, con la qual es de toda parte sostenida, y en cuyo medio se vee fixo el caracol exterior, lo que nuestro intérprete apenas nos ha advertido, mas no se avía ello aquí de dexar. // Juanelo Turriano, Veinte y un libros, a. 1605, fol. 325v: Las maderas que han de servir para los caracoles o fusillos quieren ser de serval o de olmo, aunque para la humedad es mejor el serval. Y las hembras, por donde pasan los caracoles, serán muy buenas de enzina, y de roble o de serval, por ser madera muy sólida y tiene muy pocos poros en sí. // Juanelo Turriano, Veinte y un libros, a. 1605, fol. 326r: Conviene que aya un agugero en el medio, por donde pueda pasar la clavija de yerro, para que pueda jugar libremente quando se va bolviendo el caracol.

SIN.: husillo, huso.

HOL.: máquina.

FAM.: caracola, caracolado, encaracolado.

2 [Juanelo Turriano, Veinte y un libros, a. 1605]. sust. m. Mec. Aparato para elevar agua, consistente en un tubo arrollado en hélice alrededor de un cilindro giratorio sobre su eje, oblicuo al horizonte, y cuya base se sumerge en el depósito (DRAE s. v. rosca de Arquímedes).

Juanelo Turriano, Veinte y un libros, a. 1605, fol. 365r: La B es el segundo modo de la cóclea o caracol.

SIN.: clea, cóclea, cóclea de Pitágoras, visinfin.

HIPER.: máquina. 
infinido [Besson, Teatro instrumentos, 1602]. comp. sintag. Mec. Máquina para elevar grandes pesos, consistente en un tubo arrollado en hélice alrededor de un cilindro giratorio sobre su eje.

Besson, Teatro instrumentos, 1602, fol. Gv: Y si no bastasse para levantar los arietes, entonces se ha de añadir el mango, con que la rueda mayor se buelve en derredor el caracol infinido, que llaman trispasto. // Besson, Teatro instrumentos, 1602, fol. I2v: Mas a este torno da ayuda el trispasto, puesto al término d'él, a tramontana, y es aquel instrumento que vulgarmente llamamos caracol infinido, cuya figura está en la figura treynta y nueve, buelta hazia el ángulo de ocidente y tramontana.

SIN.: caracol sin fin, trispastos.

HIPER.: máquina.

[IMAGEN] Besson, Diego, Teatro de los instrumentos, Horacio Cardon (trad.), 1602, pág. G2r, figura 22.

$\sim$ sin fin [Besson, Teatro instrumentos, 1602]. comp. sintag. Mec. Máquina para elevar grandes pesos, consistente en un tubo arrollado en hélice alrededor de un cilindro giratorio sobre su eje.

Besson, Teatro instrumentos, 1602, fol. L2v: Toda la fuerça d'esta máquina está puesta en el caracol sin fin y en los panderos antedichos. // Besson, Teatro instrumentos, 1602, fol. M4v: Nadie ha experimentado la fuerça del caracol sin fin que dude poderse hazer esto que se propone. // Besson, Teatro instrumentos, 1602, fol. P2v: Un artificio hasta agora no hallado, con el qual, con el ayuda del caracol sin fin, con poca fatiga de obreros, navíos no demasiadamente grandes se puedan tirar a la ribera y rehazer.

SIN.: caracol infinido, trispastos 2 .

HIPER.: máquina.

[IMAGEN] Besson, Diego, Teatro de los instrumentos, Horacio Cardon (trad.), 1602, pág. G2r, figura 22.

caracola, caracola [de caracol (DECH). Juanelo Turriano, Veinte y un libros, a. 1605]. sust. f. Mec. Pieza grande con forma de tuerca utilizada en algunas máquinas.

Juanelo Turriano, Veinte y un libros, a. 1605, fol. fol. 455r: El caracol ha de tener una linterna, con su puerta o caracola, por donde passe el furillo o rosca del caracol.

SIN.: porquezuela, puerca, súcula.

HOL.: máquina.

FAM.: caracol, caracolado, encaracolado. 
caracolado, caracolado [de caracolar (DECH). Besson, Teatro instrumentos, 1602]. adj. Con forma de caracol.

Besson, Teatro instrumentos, 1602, fol. O4v: Empero, hase también de notar que la muela está en medio de los dos maderos, puestos en igual distancia, ya notados, y los dos que tienen agujeros, por dezir assí, caracolados.

SIN.: encaracolado.

FAM.: caracol, caracola, encaracolado.

caracolina, V. piedra $\sim$.

carcaño, V. calcaño.

cárcavo, cárcavo [del lat. caccăbus 'olla', 'cazuela', procedente a su vez del gr. кaákкaßos 'íd.'. Doc. de 1057 (DECH). Juanelo Turriano, Veinte y un libros, c.1605]. sust. m. Mec. Hueco abovedado donde se sitúa el rodete de algunos molinos.

Juanelo Turriano, Veinte y un libros, c.1605, fol. 299v: Éste es el modo como está asentado el rodete dentro del cárcavo y como tiene las muelas encima. // Juanelo Turriano, Veinte y un libros, c.1605, fol. 300v: Este cubo ha de tener veynte cinco palmos de saetía, por donde cae la agua al rodete y en el cárcavo. // Juanelo Turriano, Veinte y un libros, c.1605, fol. 301v: Y en esa pared haze de hazer una escala para baxar abaxo, al cárcavo, para aderesar el rodete o para otras cosas necessarias: que es $\mathrm{K}$ donde es la saetía del rodete $\mathrm{M}$, y su muela es $\mathrm{L}$.

HOL.: molino.

cárcavo, V. molino de $\sim$

cárcel, cárcel [del lat. carcĕr, carcĕris 'íd.'. H. 1140, Cid (DECH). Lobato, Notas, a. 1585]. sust. f. Mec. Armazón de tablas que sirve para sujetar algunas piezas de los molinos, como el árbol, el caracol o la cuba.

Lobato, Notas, a. 1585, fol. 36: La cuba ha de tener de alto al justo con la canal, y las tablas han de ir clavadas por de dentro en la cárcel de abajo, y han de ser de cuatro dedos de grueso. // Lobato, Notas, a. 1585, fol. 36: Esta cárcel me parece que clavará bien con cuatro tornillos gordos de hierro, porque se desarmen cuando quisieren, sin romper la madera por los agujeros que van señalados. // Juanelo Turriano, Veinte y un 
libros, a. 1605, fol. 334r: Los caracoles o árboles, con sus libras, que es 10 11, las cárceles donde están puestas, dentro de tierra, las libras.

HOL.: molino.

[IMAGEN] Lobato, Notas, c. 1585, fol. 36.,señalada con el número 8.

carchesio, V. carquesio.

cárdine, cárdine [tomado del lat. cardō, cardìnis 'gozne, quicio' (Segura Munguía). Urrea, Vitruvio, Architectura, 1582]. sust. m. Barra de hierro con distintos usos.

Urrea, Vitruvio, Architectura, 1582, fol. 139v: Cárdines: hierros de la máchina catapulta. // Juanelo Turriano, Veinte y un libros, a. 1605, fol. 392r: Y donde juegan estas alguaças, que son unos cárdines de hierro muy rezios y muy bien assentadas en las piedras.

carquesio, carchesio, charchesio [tomado del lat. carchēsìum 'cabrestante' y este del gr. кapxฑ́бıo, 'vaso', 'íd.' (Salinero). Urrea, Vitruvio, Architectura, 1582]. sust. m. Mec. Torno de eje vertical que se emplea para mover grandes pesos arrastrándolos horizontalmente por medio de una maroma o cable que se va arrollando en él a medida que gira.

Urrea, Vitruvio, Architectura, 1582, fol. 126r: Sirven estas máchinas de que arriba emos escripto, no sólo para el effecto dicho, sino también para cargar y descargar las naos, unas derechas y otras llanas, y assentadas en los charchesios, que son versátiles lugares altos, como la gavia. // Urrea, Vitruvio, Architectura, 1582, fol. 136v: De las escalas y carchesios y de las demás máchinas que son fáciles de hazer, no tuve necessidad de escrevir, porque éstas los soldados las suelen hazer. // Urrea, Vitruvio, Architectura, 1582, fol. 137r: Y hizo una pública junta, y declaró el exemplo del muro, y sobre él puso una máchina en el carchesio que se bolvía, con la qual arrebató el helópolis que se allegava al muro y le metió dentro del muro.

SIN.: árgana, árgano, cabrestante, ergata.

HIPER.: máquina.

carreta, carreta [tomado del cat. u oc. carreta 'íd.'. 1200 (DECH). Anónimo, Repertorio tiempos, 1554]. sust. f. Carro de dos ruedas, largo, angosto y más bajo que el ordinario, con un madero largo que sirve de lanza, donde se sujeta el yugo (Salinero).

Anónimo, Repertorio tiempos, 1554, fol. LXXIv: Josué passó a los hebreos el río Jordán en seco por doze carretas, y mandó detener el Sol hasta vengarse de sus enemigos. // Urrea, Vitruvio, Architectura, 1582, fol. 124r: Ay también innumerables maneras de máchinas, de las quales no parece para qué disputar, porque cada día las tenemos en las manos, como las ruedas y fuelles de herreros, las carretas y carros de posta, los 
tornos y las demás cosas, que, por la costumbre, traen para el uso público provecho. // Besson, Teatro instrumentos, 1602, fol. E2v: Nueva manera de carreta, la qual, con fatiga de un hombre solo, en lugar llano o cuesta arriba, puede traher tanta carga quanta dos o tres con otro qualquier instrumento.

FAM.: acarrear, acarreo, acarreto, carretada, carretería, carretero, carretillo, carretón, carretoncillo, carrillo, carripuente, carro, carromato, carrozo, carrucha, carrucho, garrucha.

ENCICL.: Su introducción en el Nuevo Mundo tuvo gran repercusión, "fue una revolución silenciosa y generalmente anónima" (Catálogo Felipe II: 88). "Tenemos noticias de que, ya en 1533, Sebastián de Aparicio, fraile gallego precursor del tráfico rodado, se encontraba establecido en Puebla de los Ángeles, donde construyó las primeras carretas para el transporte de mercancías entre esta ciudad y la capital del Virreinato, México. [...] En 1575, tras una fructífera vida profesional dedicada al transporte, tomó el hábito franciscano, aunque sin abandonar su oficio de constructor de carretas (Catálogo Felipe II: 88).

carretada, carretada [de carreta. H. 1300, Gran Conquista de Ultramar (DECH). Rojas, Teórica fortificación, 1598]. sust. f. Carga que lleva una carreta o un carro (DRAE).

Rojas, Teórica fortificación, 1598, fol. 96r: Para lo qual hize tener prevenidas más de 2.500 estacas de medio pie de gruesso y a 10 y 12 pies de largo, y juntamente más de 3.000 carretadas de piedra menuda y gruessa.

FAM.: acarrear, acarreo, acarreto, carreta, carretería, carretero, carretillo, carretón, carretoncillo, carrillo, carripuente, carro, carromato, carrozo, carrucha, carrucho, garrucha.

carretería, carretería [de carretero (DECH). Mendoça, Theórica y práctica, 1596]. sust. f. Conjunto de carretas (DRAE).

Mendoça, Theórica y práctica, 1596, pág. 120: Para estas dos cosas es buen aviso guarnecer los costados del campo con la carretería del bagaje, si la ay, que viene a servir de trincheas. // Ufano, Tratado de la Artillería, 1613, pág. 143: Los charlieres, que son maestros de carpintería de la carretería, ayudan en su offiçio a labrar y acomodar exes, hazer las ruedas y remendarlas de rayos y corbas quando fuere menester, así de los afustes como de carros matos y abentrenes.

FAM.: acarrear, acarreo, acarreto, carretada, carretero, carretillo, carretón, carretoncillo, carrillo, carripuente, carro, carromato, carrozo, carrucha, carrucho, garrucha.

2 [Ufano, Tratado de la Artillería, 1613]. sust. f. Oficio que consiste en fabricar y reparar carretas, así como guiar las caballerías que tiran de estas. 
Lechuga, Discurso de la Artillería, 1611, pág. 199: Y que obedecerán al capitán de la artillería y officiales que en ella uviere y harán todo aquello que les ordenaren, conviniente a la artillería y carretería, so pena de la vida. // Ufano, Tratado de la Artillería, 1613, pág. 99: A los maestros de carretería, un carro 1. // Ufano, Tratado de la Artillería, 1613, pág. 101: A todos estos maestros se les da ayudantes: çinqüenta minadores con su cabo y artíffiçe; dos maestros de carretería; dos toneleros; más, otros treinta carpinteros extraordinarios con su maestro yngeniero.

carretero, carretero [de carreta. 1157, Oelschl. (DECH). Montes, Instrucción y regimiento, 1537]. sust. $\mathrm{m}$. Persona que tiene como oficio el fabricar y reparar carretas, así como guiar las caballerías que tiran de estas.

Montes, Instrucción y regimiento, 1537, pág. 67: Y los carreteros sean pláticos: que sepan adereçar los carretones, y cinchos, y collares, porque, si se quiebran, los sepan adereçar. // Collado, Plática Artillería, 1592, fol. 32v: Pero no dexaré de tocar una dubda que no pocas vezes he oýdo disputar entre carpinteros o carreteros en las maestranças de la Magestad Cathólica, que los unos quieren que la rueda tenga los rayos derechos en el cubo y otros los ponen torcidos hazia un lado. // Besson, Teatro instrumentos, 1602, fol. E2v: Mas, mal ha hecho el pintor en poner el carretero de espaldas a la carreta, siendo que la menor rueda ha de yr delante y él le haya de estar de cara.

FAM.: acarrear, acarreo, acarreto, carretada, carretería, carretillo, carretón, carretoncillo, carrillo, carripuente, carro, carromato, carrozo, carrucha, carrucho, garrucha.

carretillo, carretillo [de carreta. Lechuga, Discurso de la Artillería, 1611]. sust. m. Mec. Rueda acanalada y móvil alrededor de un eje que se utiliza para subir pesos por medio de una cuerda o maroma.

Lechuga, Discurso de la Artillería, 1611, pág. 346: D’esta máchina usamos muy cómmodamente para levantar los pesos aplicándole poleas o carretillo.

SIN.: carrillo, carrucha, carrucho, garrucha 2 , polea, polija, recamo, tróclea.

HIPER.: máquina.

FAM.: acarrear, acarreo, acarreto, carretada, carretería, carretero, carretón, carretoncillo, carrillo, carripuente, carro, carromato, carrozo, carrucha, carrucho, garrucha.

carretón, carretón [del cat. u oc. carretó 'parte inferior de un mantelete'. H. 1300, Gran Conquista de Ultramar (DECH). Montes, Instrucción y regimiento, 1537]. sust. m. Carro pequeño a modo de un cajón abierto, con dos o cuatro ruedas, que puede ser arrastrado por una caballería (DRAE).

Montes, Instrucción y regimiento, 1537, fol. VIv: Y para la llevar más a plazer, haga los carretones a la francesa, las ruedas altas, porque caminará más con él. // Juanelo 
Turriano, Veinte y un libros, a. 1605, fol. 273r: Muy differentemente hazen las rejolas, porque ellos tienen un grande carretón, el qual tiene quatro ruedas, y está cubierto y biene ençima del barro. // Besson, Teatro instrumentos, 1602, fol. E3v: Las ruedas d'este carretón tienen entre sí la mesma proporción que tiene la precedente carreta; por donde, aquélla entendida, la razón d'éste es manifiesta.

FAM.: acarrear, acarreo, acarreto, carretada, carretería, carretero, carretillo, carretoncillo, carrillo, carripuente, carro, carromato, carrozo, carrucha, carrucho, garrucha.

[IMAGEN] Pseudo-Juanelo Turriano, Los ventiún libros, c. 1605, fol. 458v, fig. 467.

carretoncillo, carretoncillo [de carretón (DECH). Rojas, Teórica fortificación, 1598]. sust. m. Carro muy pequeño (DRAE).

Rojas, Teórica fortificación, 1598, fol. 73v: Y que tengan muchas sierras de mano, machos de hierro, martillos, maços de hincar estacas, carros y carretoncillos para la tierra y muchos saquillos de lienço. // Rojas, Teórica fortificación, 1598, fol. 105v: Y por otra parte, se yrán haziendo algunas mantas sobre carretoncillos, que sean a prueva de mosquete. // Anónimo, Diálogo fábrica de navíos, ca. 1631, fol. 20r: A modo de las piezas que se usan en Flandes, del Conde Masfelte, con un carretoncillo de dos ruedas cada uno, y es muy perjudicial que aya más que tres calibos en un galeón,

FAM.: acarrear, acarreo, acarreto, carretada, carretería, carretero, carretillo, carretón, carrillo, carripuente, carro, carromato, carrozo, carrucha, carrucho, garrucha.

carrillo, carrillo [de carro (DECH). Sagredo, Medidas Romano, 1526]. sust. m. Mec. Máquina que sirve para mover y levantar con facilidad piedras y otras cosas de mucho peso, y consta de una o muchas rodajas o ruedas pequeñas que se mueven circularmente sobre sus ejes y por quienes pasa la cuerda que trae o mueve el peso (Autoridades s. v. garrucha).

Sagredo, Medidas Romano, 1526, pág. 37: Trochilo es otro miembro principal en la basa que, por semejar al carrillo o polea, le llamaron los griegos trochilo, que quiere dezir 'rodaja'. // Urrea, Vitruvio, Architectura, 1582, fol. 125r: Esta máchina es común a los marineros, y llámanla cabra y es, assimismo, muy común en los pozos, para sacar agua, que es el carrillo con su rodaxa de metal o de madera. // Besson, Teatro instrumentos, 1602, fol. M2v: Después, hazia mediodía, se vee una herrada, que tiene en la cima el polypasto de dos carrillos o poleas, en derredor de las quales, assí como en derredor de las de más arriba, da bueltas una cuerda.

SIN.: carretillo, carrucha, carrucho, garrucha 2 , polea, polija, recamo, tróclea.

HIPER.: máquina.

FAM.: acarrear, acarreo, acarreto, carretada, carretería, carretero, carretillo, carretón, carretoncillo, carripuente, carro, carromato, carrozo, carrucha, carrucho, garrucha. 
carripuente, carripuente [cmpt. de carro y puente. Ufano, Tratado de la Artillería, 1613]. sust. m. Pequeño carro para transportar pertrechos de artillería. Ufano, Tratado de la Artillería, 1613, pág. 280: La forma del petar o cámara es como se muestra por la figura A B. La A muestra la boca y la B, la culata, y al transferirlo de una a otra parte se lleva sobre el carripuente, signifficado C D; // Ufano, Tratado de la Artillería, 1613, pág. 280: Y también sobre el dicho carripuente se lleva el tablón o planchada, E A F, el qual al armarle se encaxa la boca del petar en el encaxe A del dicho tablón.

FAM.: acarrear, acarreo, acarreto, carretada, carretería, carretero, carretillo, carretón, carretoncillo, carrillo, carro, carromato, carrozo, carrucha, carrucho, gallipuente, garrucha, maripuente, puente.

carro, carro [del lat. carrus 'íd.'. H. 1220-1250, Berceo (DECH). Montes, Instrucción y regimiento, 1537]. sust. $\mathrm{m}$. Vehículo de madera que se utiliza para llevar cargas y está formada generalmente por un armazón de tablas alargado colocado sobre un eje con dos ruedas del que tiran bueyes, mulas u otros animales.

Montes, Instrucción y regimiento, 1537, fol. VIv: Haga llevar sus carros de municiones, de collares, exes, y ruedas, y clavaçones, porque, si se quebraren, se provea de presto. // Pérez de Moya, Arithmética práctica, 1562, pág. 708: Assimismo, pongamos que un carro lleva seys cahízes de trigo, que montan estos 103680000 granos; pues, a este respecto, ¿quántos carros llevarán los granos de trigo que montan las sesenta y quatro casas del axedrez? // Juanelo Turriano, Veinte y un libros, a. 1605, fol. 329v: Porque todos los molinos no van con ruedas, como van la de los carros, que ellas van levantadas, y porque muchos molinos van con las ruedas llanas.

FAM.: acarrear, acarreo, acarreto, carretada, carretería, carretero, carretillo, carretón, carretoncillo, carrillo, carripuente, carromato, carrozo, carrucha, carrucho, garrucha.

ENCICL.: Según Covarrubias, era frecuente en el siglo XVI el empleo del refrán "lo que ha de cantar el carro, canta la carreta".

$\mathrm{Su}$ introducción en el Nuevo Mundo tuvo gran repercusión, "fue una revolución silenciosa y generalmente anónima" (Catálogo Felipe II: 88).

2 [Lobato, Notas, a. 1585]. sust. m. Mec. Pieza de molino que translada su movimiento giratorio a la muela.

Lobato, Notas, a. 1585, fol. 15: Y encima del carro esté una rueda que tenga sesenta y cuatro pendazos, hiriendo de punta en un carro de ocho palos o nueve. // Lobato, Notas, a. 1585, fol. 20: Y al fin de la parte baja ha de estar una rueda de 200 dientes cuadrados que tenga más de sesma de un grueso a otro, y esta rueda ha de herir en un carro de doce balaustres y en el palo de hierro que mueve la piedra. // Lobato, Notas, a. 1585, fol. 25: Y al fin de él, cuatro pies adentro de él, estaba asentada una entruesga de encina, como las de las aceñas de Salamanca, y tenía veinte y cuatro pendazos; ésta 
andaba levantada y hería en un carro de cuatro palos de hierro redondos y gruesos casi como la muñeca.

HOL.: molino.

[IMAGEN] Lobato, Notas, c. 1585, fol. 20.

carro mato, V. carromato.

carromato, carromato, carro mato [del it. carro matto 'carro compuesto de un fuerte suelo de tablas, sin varales, sobre cuatro ruedas muy bajas', donde el adj. matto, propiamente 'loco', significa 'falso, impropio'. 1583 (DECH). Collado, Plática Artillería, 1592]. sust. m. Carro bajo, llano y ligero de dos ruedas, que tirado por dos caballerías, se utiliza para llevar cargas.

Collado, Plática Artillería, 1592, fol. 70r: Los que para trasportarla y conduzirla, son: la estruja, el carro mato, el árgano y el torno. // Collado, Plática Artillería, 1592, fol.

100v: Tirarla y conduzirla, las quales, como en la quarta siesta tratamos, son los árganos con sus estangas, tallas o polijas, carromatos, carrines, la struja, la cabria, la bancaza, los martinetes, escaletas con sus pernos, calastras, corlones y banquillos. // Ufano, Tratado de la Artillería, 1613, pág. 95: Bien se echa de ver en su composiçión y postura ser de gran provecho, mas me parece que lo que es timones o limones, exes y ruedas, a falta de los carromatos, podrían hazer los maestros de la carpintería en los caminos, como faltassen, cortando árboles para ello.

HIPER.: carro.

FAM.: acarrear, acarreo, acarreto, carretada, carretería, carretero, carretillo, carretón, carretoncillo, carrillo, carripuente, carro, carrozo, carrucha, carrucho, garrucha.

carrozo, carrozo [tomado del it. carroccio 'carro de guerra de las antiguas repúblicas italianas' (Herder). Mosquera, Comentario disciplina militar, 1596]. sust. m. Carro de cuatro ruedas grande, ostentoso y ricamente adornado, que generalmente se utiliza en funciones públicas y solemnes.

Mosquera, Comentario disciplina militar, 1596, fol. 128v: Han hecho memoria del oficio del Auditor General, colocándolo en el carrozo, que es aquel magnificentíssimo carro, acompañado con su guardia de gente de guerra.

HIPER.: carro.

FAM.: acarrear, acarreo, acarreto, carretada, carretería, carretero, carretillo, carretón, carretoncillo, carrillo, carripuente, carro, carromato, carrucha, carrucho, garrucha.

carruage, V. carruaje. 
carruaje, carruage, carruaje [tomado del cat. carruatge 'conjunto de los carros de un ejército', 'vehículo de ruedas'. 1574 (DECH). Montes, Instrucción y regimiento, 1537]. sust. $\mathrm{m}$. Conjunto de carros, coches, calesas y otros aparejos de ruedas que se previene para un viaje y llevar lo necesario (Autoridades).

Álaba, Perfeto capitán, 1590, fol. 75r.: Y porque el gran peso d'estas pieças no da comodidad de poderse llevar sin carruage y para él no ay siempre caminos llanos. // Álaba, Perfeto capitán, 1590, fol. 150v: Era el que tenía a cargo el assiento del campo y su fortificación, las tiendas y pavellones de los soldados y el carruaje, enfermos y los que los curavan, todos los instrumentos de los gastadores // Mendoça, Theórica y práctica, 1596, pág. 72: Cubriendo los esquadrones el carruaje, que ha de yr en ocho o diez hileras de frente, porque sean más chicas y se camine con menos embaraço.

MER.: carro.

carrucha, carrucha [de carro (DECH). Collado, Plática Artillería, 1592]. sust. f. Mec. Rueda acanalada y móvil alrededor de un eje que se utiliza para subir pesos por medio de una cuerda o maroma.

Collado, Plática Artillería, 1592, fol. 71v: Se presupone que la struja con la pieça se hallava lexos de la primera polija o carrucha, que con la letra A se veerá notada, y que la virtud del movimiento del árgano la ha traýdo hasta aquel punto. // Juanelo Turriano, Veinte y un libros, a. 1605, fol. 384r: La rueda, A, que su exe es B, el qual juega ha los dos cabos sobre dos pies C. Y este exe recoge la cuerda de la grúa, que es E, la qual passa por la carrucha H. // Juanelo Turriano, Veinte y un libros, a. 1605, fol. 472r: $\mathrm{Y}$ en la otra parte del río hincarse a otra estaca, y atalle an una poleola o carrucha, y passar la cuerda por ella y estirarla quanto se pudiere

SIN.: carretillo, carrillo, carrucho, garrucha ${ }_{2}$, polea, polija, recamo, tróclea.

HIPER.: máquina.

FAM.: acarrear, acarreo, acarreto, carretada, carretería, carretero, carretillo, carretón, carretoncillo, carrillo, carripuente, carro, carromato, carrozo, carrucho, garrucha.

[IMAGEN] Pseudo-Juanelo Turriano, Los ventiún libros, c. 1605, fol. 383v, fig. 378, letra H. Carrucha de una grúa.

carrucho, carrucho [de carro. Juanelo Turriano, Veinte y un libros, a. 1605]. sust. m. Mec. Rueda acanalada y móvil alrededor de un eje que se utiliza para subir pesos por medio de una cuerda o maroma.

Juanelo Turriano, Veinte y un libros, a. 1605, fol. 323v: Encima de estos dos maderos se asienta un torno de madera con dos carruchas, que vienen encima de los dos maderos $\mathrm{K} L$, los quales carruchos tiene cada uno de ellos una buena cuerda afirmada en el 
carrucho $\mathrm{O}$ y T. // Juanelo Turriano, Veinte y un libros, a. 1605, fol. 323v: $\mathrm{Y}$ en el madero $\mathrm{P}$, que tiene los dos carruchos, ay en el medio puesto unos palos, que es $\mathrm{Q}$, los quales hazen una cruz. // Juanelo Turriano, Veinte y un libros, a. 1605, fol. 324v: El otro modo es muy differente d'éste, para aver de levantar estas ruedas; el qual se señalará en figura, aunque este exe tiene los dos carruchos para levantar.

SIN.: carretillo, carrillo, carrucha, garrucha 2 , polea, polija, recamo, tróclea.

HIPER.: máquina.

FAM.: acarrear, acarreo, acarreto, carretada, carretería, carretero, carretillo, carretón, carretoncillo, carrillo, carripuente, carro, carromato, carrozo, carrucha, garrucha.

castelo, castelo [tomado del lat. castēllum 'depósito o arca de agua' (Raimundo de Miguel). Juanelo Turriano, Veinte y un libros, a. 1605]. sust. m. Ingen. Hidrául. Desaguadero o conducto para dar salida a las aguas de un estanque o de un lago (DRAE s. v. emisario).

Juanelo Turriano, Veinte y un libros, a. 1605, fol. 77r: También se llama castelo el lugar donde se vierte la agua por los caños, que es el fin de la fuente, según es llamado de Vitruvio. // Juanelo Turriano, Veinte y un libros, a. 1605, fol. 77v: Y León Baptista, De re edificandi, le llama inçile, el principio, o especo, y al fin d'ella emissario o castelo.

SIN.: emisario.

HOL.: obra hidráulica.

catino, catino [tomado del lat. cătinum 'fuente de loza', 'crisol'. H. 1220-1250, Berceo (DECH). Pérez Vargas, De re metallica, 1568]. sust. m. Mec. Vaso de metal con forma de plato que recibe el agua en la máquina tesíbica.

Urrea, Vitruvio, Architectura, 1582, fol. 132r: Los quales tienen sus cañones, que hazen figura de tenazas, pegados también, y concurren todos en medio del catino, en el qual se hazen los exes, en las aberturas de encima de los caños, pegados subtilmente. // Urrea, Vitruvio, Architectura, 1582, fol. 132r: Encima del catino, que es un vaso de metal, está la pénula, que es a modo de aguamanil buelta y bien assentada, la qual se detiene passando un cuño por una hevillera y el catino, porque la fuerça del agua no la levante. // Urrea, Vitruvio, Architectura, 1582, 139v: Catino: baso de la máchina cthesíbica; como plato.

HOL.: máquina tesíbica.

cauce, cauce, cauz [del lat. călix, călŭcis, 'vaso para beber', 'tubo de cobre o bronce en las conducciones de agua'. H. 1140 (DECH). Lobato, Notas, c.1585]. sust. m. Ingen. Hidrául. Conducto descubierto o acequia por donde corren las aguas para riegos $u$ otros usos (DRAE). 
Lobato, Notas, c.1585, fol. 13: El agua que viene a topar cuando llueve de [las] cuestas a topar en el cauce que va por la ladera o balsa del molino, ponerla en el hondo que hubiere de llevar su corriente, // Rojas, Teórica fortificación, 1598, fol. 96r: Y assí, por huyr d'este inconveniente, abaxé las canales dos pies de alto y desde allí hize abrir el cauz la mitad más ancho que solía ser primero, de manera que solía ser de 10 pies de ancho, y lo hize ensanchar de 20. // Rojas, Teórica fortificación, 1598, fol. 96v: Y luego, desde la orilla del cauz, hize començar a echar mucha piedra menuda y gruessa, de tal forma que se cegó toda la estacada y quedó hecho un muelle o dique de piedra seca, sin otra mezcla.

HIPER.: obra hidráulica.

cauchil, cauchil [del mozár. y árabe clásico *qawčíl, dim. del mozár. *káwč, y este del latín calix,-̌̌cis, 'cauce'. Rojas, Teórica fortificación, 1598]. sust. m. Ingen. Hidrául. Depósito de agua de unas dos arrobas de capacidad.

Rojas, Teórica fortificación, 1598, fol. 84v: Y, assimesmo, de una arca a otra se harán cauchiles, que se entiende un barreñón o librillo que haga de dos arrobas de agua. // Rojas, Teórica fortificación, 1598, fol. 84v: Y avrá de distancia de un cauchil a otro 100 passos, los quales sirven para hallar la quiebra que huviere en algún tiempo en la cañería, porque, en hallando falta de agua en un arca y en la de más adelante, hazia el nacimiento, estando cabal, se entiende estar la quiebra en aquel tramo de entre aquellas dos arcas, y luego por los cauchiles verán dónde está la quiebra, y d'esta suerte se hallará sin desembolver la fábrica.

HOL.: obra hidráulica.

cauz, V. cauce.

cava1 $^{1}$, caba, cava [de cavar (DRAE). Pérez Vargas, De re metallica, 1568]. sust. f. Acción de cavar $\mathrm{y}$, más comúnmente, la labor que se hace a las viñas, cavándolas (DRAE).

Pérez Vargas, De re metallica, 1568, fol. 54v: Si es monte o collado, más fácilmente se cava y beneficia, porque pueden hazer sangraderas para el agua, que suele ordinariamente estorvar la cava de las venas.

FAM.: cavadura, cavar, encavadura, excava, excavar, socavado, socavar.

cava $^{2}$, caba, cava [del lat. căva, 'zanja', 'cueva' (DRAE). Loçano, Alberto, Architectura, 1582]. sust. f. Cueva u hoyo (DRAE).

Loçano, Alberto, Architectura, 1582, pág. 139: Hazerse ha una cava tan ancha que no pueda ser igualada, sino con gran cantidad de vallado y en mucho tiempo, o se cavarán dos cavas con espacio entrepuesto. // Loçano, Alberto, Architectura, 1582, pág. 141: Hizo una cava de cinqüenta y seys estadios estendida hasta el Tibre, ancha y honda de 
treynta pies. // Juanelo Turriano, Veinte y un libros, a. 1605, fol. 110v: Havrá hecho una cava y avrá socavado la mota, hasta tanto que del todo sea arruynada.

cavadura, cabadura, cavadura [de cavar. 1118 (DECH). Juanelo Turriano, Veinte y un libros, a. 1605]. sust. f. Ingen. Hidrául. Zanja o cavidad en la que pueden asentarse los caños, fístulas o cañerías.

Juanelo Turriano, Veinte y un libros, a. 1605, fol. 303v: Y para remediar esta falta conviene hazer una otra cavadura en el medio, como se verá en la forma; que si esta picadura fuese como se hazen en las muelas de los molinos de canal ho de cárcavo, que no es más honda que un caço de cuchillo, con facilidad se remediaría.

SIN.: encavadura.

HOL.: obra hidráulica.

FAM.: cava, cavadura, encavadura, excava, excavar, socavado, socavar.

cavallo, V. caballo.

cavar, cabar, cavar [del lat. căvāre 'ahuecar', 'cavar'. H. 1220-1250, Berceo (DECH). Fernández de Enciso, Suma de Geographía, 1530]. v. tr. Ingen. Hacer en el terreno hoyos, zanjas, desmontes, pozos o galerías subterráneas (DRAE s. v. excavar).

Fernández de Enciso, Suma de Geographía, 1530, fol. LXIv: Y en esta tierra que sacan sale mucho oro e muy fino y estas formigas defienden que los hombres no vayan a tomar de aquella tierra ni a cavar en otras partes de aquel monte para buscar el oro. // Juanelo Turriano, Veinte y un libros, a. 1605, fol. 10r: En las partes donde llueve ordinariamente a menudo, no es menester cavar muy hondos los poços para aver de hallar agua. // Juanelo Turriano, Veinte y un libros, a. 1605, fol. 130r: El modo como se a de cavar y desviar el agua para hazer este hedificio, conviene que ella se haga en enxuto.

SIN.: excavar.

FAM.: cava, cavadura, encavadura, excava, excavar, socavado, socavar.

2 [Sagredo, Medidas Romano, 1526]. v. tr. Constr. Ahuecar o labrar una superficie curva que presente a la vista su parte cóncava (Clairac). 
Sagredo, Medidas Romano, 1526, pág. 29: Cómo se deven cavar las estrías, siquier canales, en las colunas. // García de Palacio, Instrución náuthica, 1587, fol. 116v: Para todo lo qual conviene que también venga proveýdo de una sierra de dos manos, y otra de mano y media, y otra de una, y otra pequeña, quatro hachas, quatro açuelas, tres llanas, y una cóncaba para cabar ximelgas, y vergas, y calcetes y otras cosas. // Besson, Teatro instrumentos, 1602, fol. C3v: Otro género de torno, nacido d'éste de cerca, para tornear, cavar y ornar, a guisa de huevo, taças y jarros de qualquier materia que sufra hierro.

caveça, V. cabeza.

cavesa, V. cabeza.

caveza, V. cabeza.

caxa, V. caja.

caxal, V. cajal.

caýda, V. caída.

cedaçado, V. cedazado.

cedaçar, V. cedazar. 
cedaço, V. cedazo.

cedazado, cedaçado, çedaçado [de cedazar. Álaba, Perfeto capitán, 1590]. adj. Separado con el cedazo.

Álaba, Perfeto capitán, 1590, fol. 95v: Tomarse han tres libras de pólvora gruessa passada por cedazo, de berniz en grano dos onças, de açufre cedaçado quatro onças, de salitre molido y passado por cedaço tres onças. // Álaba, Perfeto capitán, 1590, fol. 97v: Se henchirán d'esta mistura: una libra de pólvora gruessa cedaçada, salitre cernido, tres onças, todo bien rebuelto y atado con hilo bramante. // Ferrofino, Descrizión Artillería, 1599, fol. 154v: Agua ardiente de cabeças, 2; aserraduras de pino, 4; oropimiente, dos; alcanfor molido y çedaçado, 4; carbón de salçe, 2; haceyte de henebro, 4; caparrosa, 1.

SIN.: cernido.

FAM.: cedazar, cedazo.

cedazar, cedaçar, çedaçar [de cedazo. Álaba, Perfeto capitán, 1590]. v. tr. Apartar, separar con el cedazo la harina del salvado, $u$ otra cualquier materia reducida a polvos, de suerte que lo más grueso quede sobre la tela, y lo sutil caiga abajo al sitio para recogerlo (Autoridades s. v. cerner).

Álaba, Perfeto capitán, 1590, fol. 179v: Y aviéndose secado muy bien, para cedaçallo, tomarse a el salitre refinado quando estuviere morado y echarse a en una caldera. // Ferrofino, Descrizión Artillería, 1599, fol. 146v: Ruciada medianamente con agua purísima y clara, se pondrá entre ella, en el çedaço, media docena de piedras linpias, y çedaçando la pólvora, cayga ençima de unos papeles linpios.

SIN.: cerner.

FAM.: cedazado, cedazo.

cedazo, cedaço, cedazo, çedaço, çedazo, sedaço, zedaço [del lat. vg. (crībrum) saetacěum 'criba hecha de cerdas', derivado del lat. saeta 'cerda, crin'. 1379, Invent. arag. (DECH). Celso, Reportorio universal leyes Castilla, 1553]. sust. m. Instrumento compuesto de un aro y de una tela, por lo común de cerdas, que sirve para separar las partes sutiles de las gruesas de la harina y algunos materiales (DRAE).

Celso, Reportorio universal leyes Castilla, 1553, fol. CCCIIIv: Que no entre seda de capullo ni madexa en estos reynos, excepto en las telas de cedaços. // Loçano, Alberto, Architectura, 1582, pág. 68: Últimamente, adonde según la naturaleza y qualidad de las piedras, como luego diremos, aya de ser la materia más líquida y blanda, se colará la arena por cedazos. // Juanelo Turriano, Veinte y un libros, a. 1605, fol. 328r: Y ésta es una manga, larga cinco palmos, la qual manga es de burato o de las telas de los sedaços. 
FAM.: cedazado, cedazar.

cegadura, çegadura [de cegar. Ufano, Tratado de la Artillería, 1613]. sust. f. Conjunto de elementos que sirven para cerrar o macizar algo que antes estaba hueco o abierto.

Ufano, Tratado de la Artillería, 1613, 13: Y, asimismo, usar de ynumerables suertes de máquinas, fuegos artifiçiales, puentes, çegaduras de fosos, y minas, y contraminas y ornillos.

FAM.: cegamiento, cegar, ceguedad, ciego.

cegamiento, çegamiento [de cegar (DECH). Ufano, Tratado de la Artillería, 1613]. sust. m. Acción de cerrar o macizar algo que antes estaba hueco o abierto. Ufano, Tratado de la Artillería, 1613, pág. 260: Y porque son propios a semejante servicio y provechossíssimos a qualquier útil de guerra, las llaman algunas vezes salchichas de guerra, las quales particularmente serán aplicadas al sitiar de las tierras marítimas o çegamiento de fossos de çiudades y fortalezas de agua corriente y fuerte.

FAM.: cegadura, cegar, ceguedad, ciego.

cegar, cegar, çegar [del lat. caecāre 'íd.'. H. 1220-1250, Berceo (DECH). Urrea, Vitruvio, Architectura, 1582]. v. tr. Cerrar, macizar algo que antes estaba hueco o abierto (DRAE).

Urrea, Vitruvio, Architectura, 1582, fol. 136r: La testudo que se haze para cegar los fossos, en la qual bien se puede también allegar al muro, se hará assí: aderécese una basa quadrada, que en griego se llama eschara, la qual tenga en cada lado veynte y cinco pies y quatro de traviessa. // González de Medina, Examen fortificación, 1599, pág. 101: En este tiempo, si el fosso es seco, se reconocen las cañoneras y casamatas que tienen en él y pie que haze la ruyna de la batería $y$, teniendo agua, se trata de sangralle, si el terreno da lugar, o agotalle con ingenios que ay para el efecto, o cegalle con faxinas o llenarle de tierra. // Roxas, Sumario milicia, 1607, fol. 109r: Ha muchos años que los romanos lo husavan en la guerra para çegar los fosos de agua, que echavan mucha piedra seca, que llaman perdida, dentro en el agua del foso, hasta ganar el agua, y luego allí ençima armavan su trinchera.

FAM.: cegadura, cegamiento, ceguedad, ciego.

ceguedad, ceguedad [de ciego (DECH). Loçano, Alberto, Architectura, 1582]. sust. f. Obstrucción o taponamiento en un conducto o vano. 
Loçano, Alberto, Architectura, 1582, pág. 293: Los vazíos de las aberturas, si recibieren vientos malsanos, lluvias molestas, soles importunos, o, por el contrario, los hiziéredes tan cerrados que acarreen ceguedad aborrecible.

FAM.: cegadura, cegamiento, cegar, ciego.

ceña, ceña [del ár. sâniya 'molino harinero', 'noria'. Juanelo Turriano, Veinte y un libros, c.1605]. sust. f. Mec. Máquina compuesta de dos o más ruedas, que sirve para sacar agua y regar con ella los campos, jardines, etc.

Juanelo Turriano, Veinte y un libros, c.1605, fol. 344r: Puédese hazer otras invenciones para subir agua por otro modo, que son las anorias o ceñas, las quales andan con el movimiento de la misma agua donde ellas están asentadas. // Juanelo Turriano, Veinte y un libros, c.1605, fol. 345r: El acomodar estas ceñas que suban agua en alto, una en pos de la otra, convendrá ponerlas en la manera que aquí abaxo las señalaremos, por horden, como conviene que ellas estén, en el modo que aquí están. // Juanelo Turriano, Veinte y un libros, c.1605, fol. 348v: Las ceñas, que el vulgo llama, las quales otros las suelen llamar anorias, las quales máquinas se acostumbran acomodar para regar y sacar agua de los poços, para bever, para regar huertas.

SIN.: noria.

HIPER.: máquina.

FAM.: aceña.

cequia, cequia, secha [del ár. sâqiya 'íd.'. Juanelo Turriano, Veinte y un libros, a. 1605]. sust. f. Ingen. Hidrául. Zanja o canal por donde se conduce el agua, generalmente para regar tierras o para acercarla a alguna localidad.

Juanelo Turriano, Veinte y un libros, a. 1605, fol. 279v: Y porque conviene que dé el orden cómo se an de hazer las cequias, las quales sirven de vasos para tener las tales aguas. // Juanelo Turriano, Veinte y un libros, a. 1605, fol. 283r: Y a más d'esto, quando se cavan las cequias conviene apartar un trecho de la cequia la tierra, por razón, como es cosa movida, luego buelve a caer dentro de la misma cequia quando llueve, y ansí se va enronando. // Ufano, Tratado de la Artillería, 1613, pág. 207: Y para las pieças sospechosas se terná una secha de agua junto de cada una para, en tirando, moxar la lanada del limpiador, porque, al limpiarla para bolverla a cargar, mate el fuego que de las filazas del bocado quedare vibo.

SIN.: acequia ${ }_{1}$, regadera.

HIPER.: obra hidráulica.

FAM.: acequia. 
2 [Juanelo Turriano, Veinte y un libros, a. 1605]. sust. f. Ingen. Hidrául. Zanja o canal descubierto por donde se conduce el agua para que mueva máquinas hidráulicas o por donde se da salida a la que ya ha sido utilizada para este fin. Juanelo Turriano, Veinte y un libros, a. 1605, fol. 288r: Por razón de la mucha o poca agua, ansí se acomoda el artificio para que pueda moler, y también según la disposición del lugar y de la caýda de los ríos o cequias, por donde se supropone de acomodarlos o hazerlos, estos edificios, los quales se hazen en diversos modos, como se verá en el discurso de esta materia. // Juanelo Turriano, Veinte y un libros, a. 1605, fol. 298v: Puédese acomodar tres cubos, y quatro, juntos en una regla, y que todos quatro muelan juntos, con tal que aya tanta cantidad de agua, que ella sea bastante ha poder hazer andar todos quatro rodetes. $Y$ estos cubos se hinchen de una cequia, y empieça a entrar por el primero, y después por el segundo, tercero y quarto, y así se acaban de hinchir hordinariamente todos quatro. / / Juanelo Turriano, Veinte y un libros, a. 1605, fol. 310v: A estos molinos, algunas vezes, suélenle hazer una balsa de agua antes de la canal, aunque las más vezes no la hazen, la balsa, a estos molinos; sólo cequia y canal junto, que luego entra la agua en la canal.

SIN.: acequia $_{2}$.

HIPER.: obra hidráulica.

cercillo, cercillo, çercillo, çerçillo [del lat. circěllus 'circulito'. 1256-76, Libros del Saber de Astronomía (DECH). Juanelo Turriano, Veinte y un libros, a. 1605]. sust. m. Mec. Aro de hierro que fija la barra del eje en los molinos.

Juanelo Turriano, Veinte y un libros, a. 1605, fol. 290v: Mas que en el exe de la rueda va una barra de yerro muy gruesa, la qual va fixada con unos cercillos de yerro, y encima de este barrón va la muela. // Juanelo Turriano, Veinte y un libros, a. 1605, fol. 290v: Y en la parte que firma en el suelo se le pone un cercillo de yerro, con su gorrón muy bien acerado y aun templado. // Juanelo Turriano, Veinte y un libros, a. 1605, fol. 303v: Los cercillos d'estas muelas, conviene que ellos sean gruessos, por razón del mucho trabajo que pasan en el bolver y de la grandíssima fuerça que hazen la una muela con la otra.

HOL.: molino.

2 [Juanelo Turriano, Veinte y un libros, a. 1605]. sust. m. Ingen. Hidrául. Argolla que se clava en la parte alta de los maderos en algunas obras hidráulicas.

Juanelo Turriano, Veinte y un libros, a. 1605, fol. 229v: Y ase de acomodar en tal modo en el madero, que dando con la maça en el madero, que siempre dé solamente en el cerquillo de hierro y no en el madero. $Y$ haziendo esto los maderos se hincan muy mejor y no se atormenta el madero. Y la argolla o çercillo ha de ser en la forma C, para este effecto.

SIN.: cerquillo.

HOL.: obra hidráulica. 
cernedor, cernedor [de cerner (DECH). Juanelo Turriano, Veinte y un libros, a. 1605]. sust. m. Mec. Torno para cerner harina (DRAE).

Juanelo Turriano, Veinte y un libros, a. 1605, fol. 359v: En la figura: Ruello para moler yesso. Bacieta. Ruello para moler yesso. Algiño. Raedera. Poçal. Capaço de yesso. Cernedor de yesso. Arnero. Bacía de amasar yesso. Pala de madera.

FAM.: cerner, cernido.

[IMAGEN] Pseudo-Juanelo Turriano, Los ventiún libros, c. 1605, fol. 265v, fig. 322. Situado en la parte inferior de la imagen, a la izquierda.

cerner, cerner, cernir, çerner, serner, zerner [del lat. cĕrnĕre 'separar', 'distinguir', 'mirar' 'comprender'. H. 1236, Santo Domingo, Berceo (DECH). Pérez Vargas, De re metallica, 1568]. v. tr. Apartar, separar con el cedazo la harina del salvado, u otra cualquier materia reducida a polvos, de suerte que lo más grueso quede sobre la tela, y lo sutil caiga abajo al sitio para recogerlo (Autoridades).

Pérez Vargas, De re metallica, 1568, fol. 157r: El arena de Toledo, quemada y molida, y cernida y tornada a moler y cerner, es excelente arena para vaziar, aunque sean cosas sutiles. // Pérez Vargas, De re metallica, 1568, fol. 156v: Háganse panes y déxense secar; después se muelan y ciernan y se amassen con sal maestra, que arriba diximos, y se cuezan al fuego en un horno y se tornen a moler y cernir. // Juanelo Turriano, Veinte y un libros, a. 1605, fol. 328r : Paréceme que no será cosa fuera de propósito tratar cómo se pueda cerner la arina después de molida y, aún más, que, moliéndose ansí, se vaya cerniendo la arina con el mismo movimiento de la rueda que haze andar la muela.

SIN.: cedazar.

FAM.: cernedor, cerner, cernido.

cernido, cernido, çernido [de cerner. Anónimo, Ordenanças paños, 1527]. adj. Separado con el cedazo.

Anónimo, Ordenanças paños, 1527, fol. VIv: Otrosí, mando que ningún batanero ni pilatero no sea osado de echar ni eche a los paños que adobare la greda que oviere de echar, si no fuere molida e cernida, so pena que, si por no echar la dicha grada molida e cernida algún paño se dañare. // Urrea, Vitruvio, Architectura, 1582, fol. 24v: Y si alguno de tejas molidas y cernidas echare una tercia parte, que si ha de ser tres partes de arena, la una d'ellas sea de tejas molidas. / / Álaba, Perfeto capitán, 1590, fol. 100r: Y molido y incorporado todo con azeyte de linosa, hazerse a una massa que esté algo blanda y con estopa y cañamaço haranse balas embueltas en pólvora cernida, las quales serán de mucha importancia. 
SIN.: cedazado.

FAM.: cernedor, cerner.

cernir, V. cerner.

cerquillo, cerquillo [de cerco (DECH). Juanelo Turriano, Veinte y un libros, a. 1605]. sust. m. Ingen. Hidrául. Aro que se clava en la parte alta de los maderos en algunas obras hidráulicas.

Juanelo Turriano, Veinte y un libros, a. 1605, fol. 229v: Y ase de acomodar en tal modo en el madero, que dando con la maça en el madero, que siempre dé solamente en el cerquillo de hierro y no en el madero. $Y$ haziendo esto los maderos se hincan muy mejor y no se atormenta el madero. Y la argolla o çercillo ha de ser en la forma C, para este effecto.

SIN.: cercillo ${ }_{2}$

HOL.: obra hidráulica.

cerrada, V. rueda $\sim$

cerragero, V. cerrajero.

cerraja, cerraja [del lat. serrācŭlum 'íd.', de serāre 'cerrar'. H. 1220-1250, Berceo (DECH). Lechuga, Discurso de la Artillería, 1611]. sust. f. Mecanismo de metal que se fija en puertas, tapas de cofres, arcas, cajones, etc., y sirve para cerrarlos por medio de uno o más pestillos que se hacen jugar con la llave (DRAE s. v. cerradura).

Lechuga, Discurso de la Artillería, 1611, pág. 202: Tenazas... 34 / Limas... 44 / Cerrajas... 3 / Cuerda para la cabra.

FAM.: cerrajero, descerrajar.

cerrajero, cerragero, cerrajero, zerrajero [de cerraja. 1351, Cortes (DECH). Sagredo, Medidas Romano, 1526]. sust. m. Persona que tiene por oficio el fabricar cerraduras, llaves, candados, cerrojos y otras cosas de hierro (Autoridades).

Sagredo, Medidas Romano, 1526, pág. 14: Aquéllos se llaman oficiales mecánicos que trabajan con el ingenio y con las manos, como son los canteros, plateros, carpenteros, 
cerrageros, campaneros y otros oficiales. // Pérez Vargas, De re metallica, 1568, fol. 172v: De los secretos del officio del herrero y cerrajeros. // Juanelo Turriano, Veinte y un libros, a. 1605, fol. 358v: 20 Zerrajero.

FAM.: cerraja, descerrajar.

charchesio, V. carquesio.

chelonio, V. quelonio.

chiflón, chiflón [de chiflar (DECH). Llanos, Diccionario minas, c.1609-11]. sust. m. Mec. Canal o tubo por donde cae el agua en la rueda de algunos ingenios. Llanos, Diccionario minas, c.1609-11, pág. 34: Dícese chiflón el del ingenio por donde cae el agua de la canal para herir en la rueda. // Llanos, Diccionario minas, c.1609-11, pág. 67: Esto hacen algunos, mas otros, que son más aprovechados y que tienen más comodidad en los suyos, arriman los lavaderos a las mismas ruedas de ellos, tanto que, después de haber caído el agua del chiflón, herido en la rueda y hecho su efecto.

HOL.: máquina.

FAM.: achiflonar.

a [Llanos, Diccionario minas, c.1609-11]. loc. adv. Formando un ángulo agudo. Llanos, Diccionario minas, c.1609-11, pág. 53: Esta diligencia de harcar se hace más cómodamente por lo más alto de las minas, si se labra a frontón, dejándose caer a chiflón sobre las que se pretenden atajar en habiéndose ganado la delantera. // Llanos, Diccionario minas, c.1609-11, pág. 63: Labrar a chiflón se dice cuando se sigue la labor por medio, ni a pique ni a frontón, como apunta el chiflón de los ingenios, de donde tomó nombre y como señala el brazo en ángulo agudo. // Llanos, Diccionario minas, c.1609-11, pág. 64: En estas diferencias se incluyen todas las que hay de labrar, y cuando se nombren otras (que no sucederá), serán derivadas de ellas y se dejarán bien entender, como si se dijese que con una labor se van achiflonando, se echará de ver que yendo con ella a socavón o frontón, se dejaron descaecer y caer un poco abajo como a chiflón, y no de todo punto.

chimenea, chimenea, chiminea [del fr. cheminée 'íd.' y y éste del lat. tardío caminata, derivado del lat. caminus 'íd.'. H. 1400, Glos. del Escorial (DECH). 
Pérez Vargas, De re metallica, 1568]. sust. f. Conducto para dar salida al humo de la combustión (Salinero).

Pérez Vargas, De re metallica, 1568, fol. 101r: En el suelo de la cámara el metal, excepto que este horno o cámara ha de tener dos chimeneas a los lados y dos ventanas que han de estar siempre abiertas. // Besson, Teatro instrumentos, 1602, fol. L4v: Nuevo instrumento y infalible para hazer chimineas en lugar, ahunque sea baxo, de las quales y los rayos del sol y soplos de vientos son echados y apartados, de manera que en las cámaras ninguno es offendido del humo. // Juanelo Turriano, Veinte y un libros, c.1605, fol. 334r: La U es un llano entre las dos imprimias. La caldera donde se calienta la agua es $R$, y su chimenea es I.

[IMAGEN] Pseudo-Juanelo Turriano, Los ventiún libros, c. 1605, fol. 337v, fig. 249, letra G. Chimenea en un ingenio para lavar lanas.

chiminea, V. chimenea.

chirrión, chirrión [de chirriar (DECH). Urrea, Vitruvio, Architectura, 1582]. sust. m. Mec. Carro común, cerrado, como un cajón con dos ruedas, tirado por una caballería, que se empleaba en las obras para el acarreo de materiales (Salinero).

Urrea, Vitruvio, Architectura, 1582, fol. 124r: Ni se pudiera acarrear, si no oviera carros, chirriones o carretas por la tierra, y naves y barcos para el agua con tantas máchinas.

HIPER.: carro.

choçola, V. chozola.

chozola, choçola [de choza y esta de chozo 'choza pequeña', que a su vez procede probablemente del latín plŭteŭs 'armazón de tablas' (DECH). Juanelo Turriano, Veinte y un libros, a. 1605]. sust. f. Ingen. Hidrául. arag. Pequeño azud o presa que forma meandros artificiales para derivar, contener o tomar el agua (Salinero).

Juanelo Turriano, Veinte y un libros, a. 1605, fol. 111v: Al qual le hizo yr haziendo bueltas y bolviéndole tan torzido, a modo de una choçola, de manera que caminava el agua, agora a una parte, agora a la otra. // Juanelo Turriano, Veinte y un libros, a. 1605, fol. 112r: Ésta es una choçola de las que se comprehende que hizo el rey Nicatrixe en el río Éuphrates. Comprehéndense en diversas maneras estas choçolas, aunque en solas tres. // Juanelo Turriano, Veinte y un libros, a. 1605, fol. 112r: Ésta es la segunda manera de choçola, aunque a mi juycio no podía estar bien, por causa de las puntas que haze la choçola.

HIPER.: obra hidráulica. 
chuchara, V. cuchara.

chuchillo, V. cuchillo.

cibilla, cibilla, civilla, zivilla [del lat. ç̌billa 'mesa para comer'. Alfonso de Palencia, Universal vocabulario en latín y romance (Raimundo de Miguel). Juanelo Turriano, Veinte y un libros, a. 1605]. sust. f. Mec. arag. Tabla plana de madera, de forma rectangular, sobre la que se colocan materiales o cargas para que sean izados o transportados.

Juanelo Turriano, Veinte y un libros, a. 1605, fol. 242v: Catón dezía que los braços de las civillas, que se devían hazer de la madera del árbol agrifolio, o de laurel, o de olmo. // Juanelo Turriano, Veinte y un libros, a. 1605, fol. 384r: Llámele cada qual como quisiere, porque unos le llaman el cavallo, otros asno, otros albardón, otros la zivilla de la grúa, otros coraçón, como aquél de las balanças de pesar las cosas.

SIN.: albardón, asno, caballo, corazón.

[IMAGEN] Pseudo-Juanelo Turriano, Los ventiún libros, c. 1605, fol. 383v, fig. 378, letra Q.

cicleola, cicleola [probablemente del it. cicleola 'íd.', diminutivo del sustantivo grecolatino cyclus (Salinero). Loçano, Alberto, Architectura, 1582]. sust. f. Mec. Ruedecilla (Salinero).

Loçano, Alberto, Architectura, 1582, pág. 174: Las cicleolas son pequeñas ruedas. // Loçano, Alberto, Architectura, 1582, pág. 174: Pero todas estas cosas, d'esta manera, qualesquiera que sean, ahora sean grandes ruedas, las quales muevan al derredor hombres metidos dentro pisando, ahora sean árganos o poleas, en las quales el exe principalmente vale, o cicleolas y otras cosas assí del mismo género, ciertamente la razón de todas es sacada de los principios de la valança.

HIPER.: máquina.

ciego, ciego, çiego [del lat. caecus 'íd.'. Cid (DECH). Rojas, Teórica fortificación, 1598]. adj. Ingen. Dicho de un conducto o de un vano: obstruido o tapiado (DRAE).

Rojas, Teórica fortificación, 1598, fol. 106r: Y aun para que de la muralla con fuegos no quemen la dicha fagina y madera, es bien tener qüeros de vaca para cubrirlo, y teniéndole ciego hasta el ras del agua, de suerte que esté hecho un dique o passo mazizo de 30 o quarenta pies de gruesso por lo menos. // Roxas, Sumario milicia, 1607, fol. 103v: Y estando ya el foso çiego y hecho ya en él un dique de quarenta o çinqüenta 
pies de ancho, se yrá haçiendo ençima un trincherón muy grueso, que tenga 20 pies de groseça, para resistir el artillería que le tiraren de la casamata. // Llanos, Diccionario minas, c.1609-11, pág. 33: Hay necesidad de sacar afuera mucho desmonte, piedra y tierra del hundimiento para desembarazar y abrir lo que con él quedó ciego y hundido.

FAM.: cegadura, cegamiento, cegar, ceguedad.

cigoñal, cigoñal [de cigüeña (DECH). Besson, Teatro instrumentos, 1602]. sust. m. Mec. Pértiga o palanca con un contrapeso a un extremo que forma parte del mecanismo de algunas máquinas.

Besson, Teatro instrumentos, 1602, fol. G4v: Nueva hechura de molino a braços para prensar y aparejar paños y papel, y moler especies, y esmenuzar piedras preñadas de metales para preparallas a hundir, y también para pulir y aguzar qualesquier instrumentos soltados a cigoñales y majaderos. // Besson, Teatro instrumentos, 1602, fol. N3v: Y el tal leño está fixo en ella; empero, en las extremidades d'este leño hay dos agujeros, en los quales se mueven dos braços que hazen el cigoñal, el cabo meridional de los quales está apartado de la línea meridional una mesura, y de la ocidental diez y siete partes, do está el exe, en derredor del qual se mueven. // Besson, Teatro instrumentos, 1602, fol. N4v: Más otra forma y firme de sacar agua, con la qual, por razón de cigoñal y de contrapeso, el agua, tirándola y empuxándola con artificio de bolsas, viene a alçarse tanto que a fuerça de braços no podría alçarse.

HOL.: máquina.

FAM.: cigüeña, cigüeñuela.

[IMAGEN] Besson, Diego, Teatro de los instrumentos, Horacio Cardon (trad.), 1602, pág. N4r, figura 48.

cigüeña, cigüeña [del lat. č̆cōnŭa 'íd.'. Biblia Escarialense (DECH). Anónimo, Leyes lanas e paños, 1538]. sust. f. Mec. Codo que tienen los tornos y otros instrumentos y máquinas en la prolongación del eje, por cuyo medio se les da con la mano movimiento rotatorio (DRAE).

Anónimo, Leyes lanas e paños, 1538, fol. 7r: E que en el tal torno los dichos torneros pongan las manezuelas de fierro bien guarnecidas y esquinadas de dentro en el cubo, de manera que no se quiebren, ni anden a la redonda; e que la mesa del dicho torno tenga de largo, desde las cigüeñas fasta los fraylezillos, una vara e una ochava, poco más o menos. // Collado, Plática Artillería, 1592, fol. 11r: El torno con su rueda y su cigüeña, y dos bancos altos y fuertes sobre los quales está la pieça mientras que se va barrenando, o otro qualquiera ingenio que sirva para el effecto del barrenar dicho, qualesquiera de estos ingenios Su Magestad provee y los paga todos. // Juanelo Turriano, Veinte y un libros, c.1605, fol. 329v: Quando estos maniles o cigüeñas van ansí bueltos, buelven con mayor presteza que no hazen los derechos.

SIN.: manil.

HOL.: máquina. 
FAM.: cigoñal, cigüeñuela.

[IMAGEN] Pseudo-Juanelo Turriano, Los ventiún libros, c. 1605, fol. 308v, fig. 212, letra K.

2 [Juanelo Turriano, Veinte y un libros, a. 1605]. sust. Mec. Máquina compuesta por una pértiga que, con un contrapeso en un extremo, y apoyada en una horquilla, se utiliza para levantar pesos o sacar agua de los pozos.

Juanelo Turriano, Veinte y un libros, a. 1605, fol. 384v-385r: Para levantar un peso y baxarlo de presto no hay instrumento tan prompto como es el instrumento que llaman cigüeña, el qual tiene muy poco artificio [...]. Y este artifiçio lo usan los labradores para sacar agua de los poços.

HIPER.: máquina.

[IMAGEN] Pseudo-Juanelo Turriano, Los ventiún libros, c. 1605, fol. 384v, fig. 381.

cigüeñuela, cigüeñuela [de cigüeña (DECH). Llanos, Diccionario minas, ca. 1609-11]. sust. f. Mec. Codo del eje que realiza el movimiento rotatorio en un molinete.

Llanos, Diccionario minas, ca. 1609-11, pág. 9: El principal instrumento que en ellas sirve para lavar el metal es el molinete, que, a manera casi de rodezno, se trae a la redonda dentro de ellas; y los anexos a él son: cigüeñuela, peón y dedal, que sirven para el mismo movimiento, que se hace a fuerza de brazos en las tinas de mano.

HOL.: molinete.

FAM.: cigoñal, cigüeñuela.

cincel, cincel, cinçel, cinzel, sinzel, zinzel [del fr. ant. cisel 'íd.' y 'tijeras'. 1475, G. de Segovia (DECH). Pérez Vargas, De re metallica, 1568]. sust. m. Hierro largo y redondo, de punta ancha y muy delgada, que, golpeado en su cabeza, se utiliza para labrar la piedra.

Pérez Vargas, De re metallica, 1568, fol. 9v: Y de los cuerpos luminosos que en él ay, que explica todas las formas juntamente con los elementos quatro, assí como el artífice y official, con el martillo, con el açuela, con la sierra y con el cinzel compone y perficiona las formas de su arte. // Juanelo Turriano, Veinte y un libros, a. 1605, fol. 285r: Y ellos se hazen quadrados. Y con el pico o con el cinzel agujéranse lo más bajo que pueda la piedra. // Alonso Barba, Arte de los metales, 1640, fol. 83v: Tenazas grandes para assir las planchas; martillos y sinceles para sacudirlas de la tierra y cortarlas.

FAM.: cincelado, cincelar. 
cincelado, cinzelado, sinzelado [de cincelar (DECH). Pérez Vargas, De re metallica, 1568]. adj. u. t. c. sust. Labrado o grabado a cincel.

Pérez Vargas, De re metallica, 1568, fol. 151v: Derrítase todo en un escudilla vedriada limpia y, assí derretido, se trayga a una mano un poco; d'esta massa se cargue un poco con un hierro en lo tallado o sinzelado de la plata. // Arphe, Varia Commensuración, 1585-87, fol. 32r: Estas cruces se hazen en diversos modos, porque unos las hazen de chapas cinzeladas y clavadas sobre madera, y ésta es obra muy frágil.

FAM.: cincel, cincelar.

cincelar, sinzelar [de cincel (DECH). Juanelo Turriano, Veinte y un libros, a. 1605]. v. tr. Labrar, grabar con cincel en piedras o metales (DRAE). Juanelo Turriano, Veinte y un libros, a. 1605, fol. 278v: Ay otro betún que sirve para los plateros, para tener sus pieças, para poder tener firmes, para sinzelarlas y hazer lavores en ellas.

FAM.: cincel, cincelado.

cinçel, V. cincel.

cinzel, V. cincel.

cinzelado, V. cincelado.

cisterna, cisterna, çisterna [tomado del lat. čsstěrna 'íd.', derivado de čssta 'cesta'. H. 1350, Poema de Alfonso XI (DECH). Fernández de Enciso, Suma de Geographía, 1530]. sust. f. Ingen. Hidrául. Depósito donde se recoge y conserva el agua llovediza o la que se lleva de algún río o manantial.

Fernández de Enciso, Suma de Geographía, 1530, fol. 28r: Entre todas las aguas, se tiene por mejor la llovediza, aviendo estado reposada en la cisterna. // Loçano, Alberto, Architectura, 1582, pág. 324: La cisterna es un vaso algo grande de aguas, no dessemejante al arca. // Juanelo Turriano, Veinte y un libros, c.1605, fol. 183r: Después que se tiene hecha una çisterna, conviene lavarla en esta manera: tómase de la escoria que queda de la mina del hierro y pícase muy menudamente, para que con ella se pueda embetunar la cisterna.

SIN.: aljibe.

HIPER.: obra hidráulica.

[IMAGEN] Pseudo-Juanelo Turriano, Los ventiún libros, c. 1605, fol. 181v, fig. 158. 
cítola, cítola [del lat. cĭthăra 'íd.'. Berceo (DRAE). Juanelo Turriano, Veinte y un libros, a. 1605]. sust. f. Mec. Tabla de madera, pendiente de una cuerda sobre la piedra del molino harinero, para que la tolva vaya despidiendo la cibera, y para conocer que separa el molino, cuando deja de golpear (DRAE).

Juanelo Turriano, Veinte y un libros, a. 1605, fol. 308v: La taona es S. Su canalón es V. El torcedor, T. La cítola es X. Donde firma el exe E, es K. Y donde firma el árbol de la muela es L. // Juanelo Turriano, Veinte y un libros, a. 1605, fol. 309r: La cítola o taravilla es E. La caxa que recoje la arina es F. La armadura donde está asentado, encima las muelas, es G.

SIN.: tarabilla.

HOL.: molino.

[IMAGEN] Pseudo-Juanelo Turriano, Los ventiún libros, c. 1605, fol. 308v, fig. 212, letra E (arriba a la derecha).

civilla, V. cibilla.

clabaçón, V. clavazón.

clabado, V. clavado.

clabazón, V. clavazón.

clabo, V. clavo.

clavaçón, V. clavazón.

clavado, clabado, clavado [de clavar (DECH). Medina, Arte de navegar, 1545]. adj. Sujeto con clavos. 
Medina, Arte de navegar, 1545, fol. 14r: Pero éstos no alcançaron más de juntar unas vigas con otras $\mathrm{y}$, muy clavadas y calafeteadas, navegavan en ellas, no apartándose mucho de la tierra. // Pérez Vargas, De re metallica, 1568, fol. 78r: Este moler de los metales se haze differentemente mediante algunos ynstrumentos y máchinas de martillos, y maços de hierro, y palos clavados y ruedas que se traen a braço y otras con agua. // Besson, Teatro instrumentos, 1602, fol. Hv: Las quales buelven al enderredor dos panderos o barrilejos clavados, puestos en la parte más baxa de las vigas; en lo más alto de la qual están las muelas.

SIN.: enclavado.

FAM.: clavar, clavazón, clavera, clavetado, clavo, desclavar, enclavado, enclavar.

clavar, clavar [del lat. tardío clāvāre 'íd.'. Entre 1493 y 1495, Nebrija (DECH). Celso, Reportorio universal leyes Castilla, 1553]. v. tr. Asegurar con clavos algo (DRAE s. v. enclavar).

Celso, Reportorio universal leyes Castilla, 1553, fol. CXIv: Salvo las tachuelas que se hizieren para clavar las coraças, las cabeças de las quales pueden ser doradas o plateadas. // Medina, Regimiento de navegación, 1563, fol. 70r: Háganse dos barrotes del anchor de la medida, y por encima d'ellos se claven sus tablas hasta el medio altor de la medida y tenga el ancho de la misma medida.

SIN.: enclavar.

ANT.: desclavar.

FAM.: clavado, clavazón, clavera, clavetado, clavo, desclavar, enclavado, enclavar.

clavazón, clabaçón, clabazón, clavaçón, clavazón [de clavar (DECH). Montes, Instrucción y regimiento, 1537]. sust. f. Conjunto de clavos puestos en alguna cosa, o preparados para ponerlo (DRAE).

Montes, Instrucción y regimiento, 1537, fol. VIv: Haga llevar sus carros de municiones, de collares, exes, y ruedas, y clavaçones, porque, si se quebraren, se provea de presto, que muchas vezes, por no llevar los aparejos necessarios, se queda una pieça en el camino. / / Martínez de Burgos, Reportorio premáticas y Cortes, 1551, fol. XXXv: Hemos sido informados que las premáticas de nuestros reynos, hechas por los Reyes Cathólicos, nuestros Señores padres y abuelos, que hablan sobre el herraje y clavazón de los herradores. // Castillo, Tratado de cuentas, (1551), 1551, fol. XXVr: Los que vieren la casa y saben quánto cuesta en aquella tierra la madera, cal, y piedra y clavazón, y los jornales de los officiales de aquel officio de cantería y carpintería y otras cosas que en la casa están gastadas.

FAM.: clavado, clavar, clavera, clavetado, clavo, desclavar, enclavado, enclavar. 
clavera, clavera [de clavo (DECH). Martínez de Burgos, Reportorio premáticas y Cortes, 1551]. sust. f. Agujero o molde en que se forman las cabezas de los clavos (DRAE).

Martínez de Burgos, Reportorio premáticas y Cortes, 1551, fol. XXXv: Y de cabeça de dado, o llano de dos golpes, tanto de uno como de otro, metida en clavera, ansí lo uno como lo otro. // Martínez de Burgos, Reportorio premáticas y Cortes, 1551, fol. Lv: Que las premáticas d'estos reynos que hablan sobre los herradores y herraje se guarden y cumplan, y que los clavos sean, conforme a ellas, hechos en clavera, de cabeça de dado o dos golpes. // Celso, Reportorio universal leyes Castilla, 1553, fol. CLXIXv: Y la cabeça del tal clavo deve ser de la gordura de un dado o llano de dos golpes, tanto de uno como de otro, metido en la clavera, ansí lo uno como lo otro.

FAM.: clavado, clavar, clavazón, clavetado, clavo, desclavar, enclavado, enclavar.

clavetado, clavetado [de claveta (DECH). Anónimo, Diálogo fábrica de navios, ca. 1631]. adj. Sujeto con clavetas.

Anónimo, Diálogo fábrica de navios, ca. 1631, fol. 7v: Llevará su tamborete o un cincho de fierro clavado con dos pernos de fierro clavetados en el bao primero de la entrada de la cámara, con que quedará fuerte.

FAM.: clavado, clavar, clavazón, clavera, clavo, desclavar, enclavado, enclavar.

clavija, clavija, clavixa [del lat. clāvǐcŭla 'llavecita'. 1490, Alonso de Palencia (DECH). Besson, Teatro instrumentos, 1602]. sust. f. Barrita de hierro con forma redonda que, encajada en un agujero, se utiliza para asegurar y fijar algunas piezas de máquinas.

Besson, Teatro instrumentos, 1602, fol. D3v: El qual exe, siendo de la una y de la otra banda impelido por los obreros, muévense las ruedas para que las clavijas fixas en el exe, topando con los braços del mango del martillo, se alce el martillo. // Juanelo Turriano, Veinte y un libros, a. 1605, fol. 52r: El redondo pequeño es E y su índize es F, los quales van fixados con una clavija de yerro que los tiene muy firmes, que es G. // Juanelo Turriano, Veinte y un libros, a. 1605, fol. 321r: La qual es A, que entra dentro de la agua, y B C es donde se haze con unas clavijas, para que la tenga firme en el lugar que se quiere que esté.

FAM.: clavijado, enclavijado, enclavijar.

2 [Valle de la Cerda, Desempeño patrimonio, 1600]. sust. f. Barrita de madera o hierro de la que se prenden las cuerdas en los instrumentos musicales.

Valle de la Cerda, Desempeño patrimonio, 1600, fol. 128r: Por sólo ver tantas cuerdas, teclas y clavijas, pero después se desengañaría viendo con solas dos manos poner en armonía y consonancia aquella variedad y diferencia. 
clavijado, clavijado [de clavija. Juanelo Turriano, Veinte y un libros, a. 1605]. adj. Trabado o unido con clavijas.

Juanelo Turriano, Veinte y un libros, a. 1605, fol. 207r: Las quales varcas van muy bien clavijadas las unas con las otras, y que puedan jugar quando passan carros cargados.

SIN.: enclavijado.

FAM.: clavija, enclavijado, enclavijar.

clavilla, clavilla sust. f.

a [Anónimo, Ordenanças paños, 1527]. loc. adv. Mediante un movimiento de meneo realizado manualmente.

Anónimo, Ordenanças paños, 1527, fol. VIIv: No sean osados de dar a paño alguno, ni cordellate, ni frisa, ni estameña, con torno, ni a pala, ni con otro artificio en la tina, sino a clavilla, meneando los paños como es costumbre.

clavixa, V. clavija.

clavo, clabo, clavo [del lat. clāvus 'íd.'. H. 1140, Cid (DECH). Medina, Arte de navegar, 1545]. sust. m. Pieza de hierro, larga, delgada, con cabeza y punta, que se utiliza para fijar y asegurar una cosa con otra.

Medina, Arte de navegar, 1545, fol. 9v: Si alguna cosa son en aquel modo, sean como los clavos en la rueda, que muy poco o nada impiden su redondez. // Sánchez de las Broças, Helt Frisio, Relox español, 1549, fol. 13v: Hecho esto, tomaremos la dioptra y, por medio d'ella, hincaremos un clavo bien redondo y derecho. // Besson, Teatro instrumentos, 1602, fol. Cv: Finalmente, aquellos dos clavos pequeños encaracolados que están en la arca a oriente no sirven a otro que a tener firme la rueda pequeña dentada, que está a oriente.

FAM.: clavado, clavar, clavazón, clavera, clavetado, clavija, desclavar, enclavado, enclavar.

clea, clea [probablemente del lat. cochlĕa 'concha'. Urrea, Vitruvio, Architectura, 1582]. sust. f. Mec. Aparato para elevar agua, consistente en un tubo arrollado en hélice alrededor de un cilindro giratorio sobre su eje, oblicuo al horizonte, y cuya base se sumerge en el depósito (DRAE s. v. rosca de Arquímedes).

Urrea, Vitruvio, Architectura, 1582, fol. 75v: Quando fueren bien calçadas y muy espesamente, entonces, con cleas, que son engeños para sacar agua, y con ruedas y tímpanos, que son las bombas o maças de las ruedas, puestos y assentados.

SIN.: caracol $_{2}$, cóclea, cóclea de Pitágoras, visinfin. 
HIPER.: máquina.

[IMAGEN] Pseudo-Juanelo Turriano, Los ventiún libros, c. 1605, fol. 350v, fig. 268.

clóclea, V. cóclea.

cobertor, cobertor, covertor, cubertor [del lat. cŏŏpertorĭum 'cubierta' (DRAE). Pérez Vargas, De re metallica, 1568]. sust. m. Cosa que se pone encima de otra para taparla o resguardarla (DRAE s. v. cubierta).

Lobato, Notas, a. 1585, fol. 6: Y plugo al Señor que cayó una teja, que era el cobertor de la canal, y me dio a mí, Francisco Lobato, en la cabeza, al lado izquierdo, sobre el sombrero. // Lobato, Notas, a. 1585, fol. 30: La casica donde ha de ir esta escalera de torno, arriba dicha, ha de ser cuadrangular, de 4 pilares de ladrillo gruesos, y lo demás de una asta, o toda ella de asta y media, con su cobertor de una bobedica de ladrillo de una frente de grueso por tejado y enladrillada por encima muy corriente y fuerte. // Juanelo Turriano, Veinte y un libros, a. 1605, fol. 353v: Y ha de aver encima dos pedaços de cuero de vaca, los quales han de estar afixados junto con la plancha, de modo que no se puedan quitar de aquel lugar, mas que se puedan levantar y abaxar como haze un cubertor de una caxa.

2 [Juanelo Turriano, Veinte y un libros, a. 1605]. sust. m. Ingen. Hidrául. Compuerta que se pone para detener la corriente de agua (Salinero s. v. tajadera). Juanelo Turriano, Veinte y un libros, a. 1605, fol. 305r: Y el covertor o tajador es la B, que es de dos pedaços, aunque en él no ay puntales para tenerle firme.

SIN.: tajadera 2 , tajador.

HOL.: obra hidráulica.

cocha, cocha [del quechua kocha 'laguna' (DRAE). Llanos, Diccionario minas, ca. 1609-11]. sust. f. hisp-am. Estanque que, en la extracción de metales, se separa de la tina o lavadero principal.

Llanos, Diccionario minas, ca. 1609-11, pág. 20: Dásele este nombre de cocha a cualquiera agua detenida que no corra, y así es el que los indios de este Reino dieron al mar. // Llanos, Diccionario minas, ca. 1609-11, pág. 66: Las cuales se benefician sacándolas primero de las cochas o albercas donde se recogen y de donde salen en pedazos, a manera de céspedes, como las van cavando. // Alonso Barba, Arte de los metales, 1640, fol. 72r: Recógense estas lamas en su cocha y se benefician después por açogue como queda dicho, y rinden muy considerable provecho. 
coche, coche [probablemente del húng. kocsi 'carruaje'. 1548, Luis de Ávila (DECH). Escalante, Discurso de la navegación, 1577]. sust. m. Mec. Carruaje de cuatro ruedas que, tirado por caballerías, se utiliza para el transporte de personas dentro de una caja en la cual hay asientos.

Escalante, Discurso de la navegación, 1577, fol. 49v: Y de gran biveza e ingenio natural, y tan inventivos en todas las artes que, con aver muchos coches y carros de cavallos, usan en los lugares de campiña de carros que son llevados a vela con el viento. // Loçano, Alberto, Architectura, 1582, pág. 152: Y avrá delante de la puerta espacios grandes para los coches y carreras de los cavallos, que sean más largas que un tiro de dardo o saeta de los mancebos. // Besson, Teatro instrumentos, 1602, fol. E4v: Dos vezes se offrece en este nuestro coche, es a saber: en la parte delantera y postrera del coche, do se veen los cuerpos de las donzellas de pies de culebras topar con sus frentes.

HIPER.: carro.

cóclea, clóclea, cóclea [tomado del lat. cochlěa 'concha', 'rosca', 'íd.' y este del gr. кох入ías 'íd.' (DRAE). Urrea, Vitruvio, Architectura, 1582]. sust. f. Mec. Aparato para elevar agua, consistente en un tubo arrollado en hélice alrededor de un cilindro giratorio sobre su eje, oblicuo al horizonte, y cuya base se sumerge en el depósito (DRAE s. v. rosca de Arquímedes).

Urrea, Vitruvio, Architectura, 1582, fol. 131r: Ay también una manera de máchina que llaman cóclea, que es instrumento que saca mucha agua, pero no la echa tan alto como la rueda. // Juanelo Turriano, Veinte y un libros, c.1605, fol. 350v: Ay otra máquina para sacar agua de un poço o de un río, la qual máquina o invención es de Pitágoras, la qual se llama la clóclea. // Juanelo Turriano, Veinte y un libros, c.1605, fol. 351v: Puédense acomodar muchas cócleas para subir mucha agua en alto, en esta manera: que se pueden acomodar tres o quatro cócleas, una encima de la otra, y que coixgan la agua de la una a la otra.

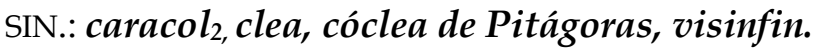

HIPER.: máquina.

[IMAGEN] Pseudo-Juanelo Turriano, Los ventiún libros, c. 1605, fol. 350v, fig. 268.

$\sim$ de Pitágoras [Juanelo Turriano, Veinte y un libros, a. 1605]. comp. sintag. Mec. Aparato para elevar agua, consistente en un tubo arrollado en hélice alrededor de un cilindro giratorio sobre su eje, oblicuo al horizonte, y cuya base se sumerge en el depósito (DRAE s. v. rosca de Arquímedes).

Juanelo Turriano, Veinte y un libros, a. 1605, fol. 364v: Podrásele accommodar la cóclea de Pithágoras, el qual instrumento sube mucha cantidad de agua, mas no la sube muy en alto.

SIN.: caracol $_{2,}$ clea, cóclea, visinfin.

HIPER.: máquina. 
codaz, codaz [del lat. cōdex 'tronco', del ant. caudex, 'tronco de árbol despojado de sus ramas' (Salinero). Urrea, Vitruvio, Architectura, 1582]. sust. m. Mec. Eje pequeño de hierro situado en algunas ruedas.

Urrea, Vitruvio, Architectura, 1582, fol. 126v: Tomó quatro leños gruessos, la tercera parte de un pie largos, quan larga era la basta de la columna, y los dos pusso atravessados y, entrepuestos a los otros dos, que tenían el largo de la columna, y travados, ajuntó también unos codaces, que son como exezillos de hierro, y púsolos como puños, y en las cabeças de las maderas los aplomó. // Urrea, Vitruvio, Architectura, 1582, fol. 126v: Y puso también sus velortas rodeadas a manera de los codaces, y ató en los capiteles palos de maderos. // Urrea, Vitruvio, Architectura, 1582, fol. 127r: Metágenes, hijo de Cthesiphón, hizo que, como se avían tra do las columnas, se llevassen en los capiteles, porque hizo unas ruedas de casi doze pies y metió las cabeças de los capiteles en medio de las ruedas con sus codaces y armillas de hierro.

HOL.: rueda.

codo, codo [del lat. cŭbŭtus 'íd.'. H. 1140, Cid (DECH). García de Céspedes, Instrumentos nuevos, 1606]. sust. m. Ingen. Hidrául. Pieza que formando ángulo varía la dirección de un conducto, tubo o cañería (Clairac).

García de Céspedes, Instrumentos nuevos, 1606, fol. 30v: Mas, si acaso es necessario que el agua venga dando bueltas, se guardará esta orden: en cada codo que hiziere la cañería se deve de hazer una arca en que descanse el agua, porque de otra manera, si el camino fuesse largo, serían causa los codos de que rebentasse la cañería. / / García de Céspedes, Instrumentos nuevos, 1606, fol. 30v: Mas, si acaso es necessario que el agua venga dando bueltas, se guardará esta orden: en cada codo que hiziere la cañería se deve de hazer una arca en que descanse el agua. // García de Céspedes, Instrumentos nuevos, 1606, fol. 31r: Pues para prevenir a este inconveniente, se tomará el siguiente remedio: también en este caso se tiene de considerar si la cañería ha de hazer bueltas, como se dixo en el caso passado, porque en el codo donde haze la buelta es necessario se haga una torre tan alta, poco menos, que el nacimiento de la agua.

HOL.: conducto, cañería, caño.

compuerta, compuerta [de puerta. Entre 1493 y 1495, Nebrija (DECH). Loçano, Alberto, Architectura, 1582]. sust. f. Ingen. Hidrául. Puerta o barrera móvil que se utiliza para regular la corriente del agua.

Loçano, Alberto, Architectura, 1582, pág. 336: Pero la más cómmoda compuerta de todas será la que en su medio tiene un huso puesto a plomo y que se buelva. // Loçano, Alberto, Architectura, 1582, pág. 337: Pero los braços de esta compuerta no serán iguales, sino que el uno será más corto que el otro hasta tres dedos // Acosta, Historia natural, 1590,: Y son siete, con sus compuertas, y, quando es menester usar de alguna, la alçan y sale un cuerpo de agua, y las fiestas las cierran. 
FAM.: puerta.

conducir, conducir, conduzir [tomado del lat. condūcĕre 'conducir juntamente, juntar'. S. XV, Juan de Mena (DECH). García de Céspedes, Instrumentos nuevos, 1606]. v. tr. Ingen. Hidrául. Dicho del agua: llevarla, transportarla de un lugar a otro o dirigirla hacia un lugar determinado mediante canales o conductos.

García de Céspedes, Instrumentos nuevos, 1606, Ir: Demás d'esto se ponen otros tratados, como es uno de conduzir aguas, y otro una qüestión de artillería, en donde se ponen algunas demostraciones curiosas. // García de Céspedes, Instrumentos nuevos, 1606, IVr: Contiene también este libro un tratado de conduzir agua, donde se declaran las dificultades que acerca d'esta materia se pueden ofrecer, y el remedio d'ellas es de importancia para semejante efeto. // García de Céspedes, Instrumentos nuevos, 1606, fol. 25r: Síguese un tratado de conduzir aguas de un lugar a otro, cosa bien importante para los que tratan de semejante oficio.

SIN.: encaminar.

FAM.: conducto.

conducto, conducto, conduto [tomado del lat. tardío conductŭs 'íd.'. 1490, Alfonso de Palencia (DECH). Loçano, Alberto, Architectura, 1582]. sust. m. Ingen. Hidrául. Canal, comúnmente tapado, que sirve para dar paso y salida a las aguas y otras cosas (DRAE).

Loçano, Alberto, Architectura, 1582, pág. 322: Al principio començaron a fabricar conductos debajo de tierra, y esso tuvo sus provechos; porque, estando la obra ascondida, menos estava subjecta a las injurias. // Collado, Plática Artillería, 1592, fol. 62v: La primera es quando alrededor de el hornillo donde se encierra la pólvora se hallasse, acaso, algún pozo antiguo o conducto de aguas de otro tiempo, o alguna contramina de las que, comúnmente, se hazen alrededor de la muralla. // González de Medina, Examen fortificación, 1599, pág. 218: Los condutos para salir el agua y echar las inmundicias han de ser de quatro pies de ancho y siete de alto.

HOL:: obra hidráulica.

FAM.: conducir.

conduto, V. conducto. 
congeladero, congeladero [de congelar. Juanelo Turriano, Veinte y un libros, c.1605]. sust. m. Mec. Depósito en el que se recogen las lejías de las calderas. Juanelo Turriano, Veinte y un libros, c.1605, fol. 342r: Y el otro es para tener las lexías que quedan en los congeladeros, que es G. Los congeladeros son L, las calderas son I y las chimeneas son $\mathrm{K}$. El tino $\mathrm{H}$ es para poner las espumas que se sacan de las calderas.

HOL.: caldera.

FAM.: congelamiento, congelar.

congelamiento, congelamiento [de congelar (DECH). Loçano, Alberto, Architectura, 1582]. sust. m. Acción y efecto de congelar (DRAE s. v. congelación). Loçano, Alberto, Architectura, 1582, pág. 51: En bajo de la Basilicata, no lexos de el río Sílari, por la parte donde caen de las altas rocas las aguas azia el Oriente, podréys ver cada día crecer grandes congelamientos de piedra, pendientes en grandeza, que alguna de ellas es de peso de muchos carros. // Juanelo Turriano, Veinte y un libros, c.1605, fol. 32v: Y porque estas aguas toman muy poco o nada del sabor, digo de aquel congelamiento d'estas piedras, son casi simples y puras.

FAM.: congeladero, congelar.

congelar, congelar [tomado del lat. congelāre 'íd' (DECH). Fernández de Enciso, Suma de Geographía, 1530]. v. tr. u. t. c. prnl. Helar algo o ponerlo sumamente frío.

Fernández de Enciso, Suma de Geographía, 1530, fol. IXr: E son tan prestos e tan furiosos que los mareantes tienen necessidad de amaynar las velas en viendo congelarse las nuves de los vapores, porque si esperan al topamiento d'ellos, las tempestades son tan prestas y tan furiosas que no les dan lugar a que las abaxen. // Pérez Vargas, De re metallica, 1568, fol. 5v: La ceniza se funde y haze vidro, a manera de metal; porque, según razón, aquellas cosas que se funden y desatan por una manera y se congelan paresce ser su natura una. // Juanelo Turriano, Veinte y un libros, a. 1605, fol. 343r: No se den ha entender que toda la agua no se congela, que si eso fuera, de muy poca agua abría arto, mas no se congela más de la que está encima de la superficie de la agua.

FAM.: congeladero, congelamiento.

contrabalsa, contrabalsa [de balsa. Juanelo Turriano, Veinte y un libros, c.1605]. sust. f. Mec. Estanque de agua de donde sale el agua que mueve los rodeznos en los molinos que tienen balsa.

Juanelo Turriano, Veinte y un libros, c.1605, fol. 312v : El molino que llaman de carreo, el qual molino es invención muy differente de todo otro género de molino, por razón que 
tiene balsa y contrabalsa, que muy pocos molinos se hallarán d'esta hechura. // Juanelo Turriano, Veinte y un libros, c.1605, fol. 312v: Y esta invención muele asta tener gota de agua en la contrabalsa, y verase toda la saetía, y siempre yrá moliendo. // Juanelo Turriano, Veinte y un libros, c.1605, fol. 312v: La balsa es A, la qual es un cavo. Donde es B entra la agua, y es de ondo diez palmos, y en $C$ es doze, asta catorze. Y la contrabalsa es ancha de doze palmos y de alto es diez y seys. La pared de la saetía es de grueso quinze palmos. La contrabalsa sirve de cubo. Cierto, a sido una muy galana consideración esto de la contrabalsa. De modo que $\mathrm{D}$ es lo alto de la contrabalsa y la $\mathrm{E}$ es lo ancho d'ella.

HOL.: molino de balsa.

FAM.: balsa, embalsado.

contrapesar, contrapesar [de contrapeso. Entre 1493 y 1495, Nebrija (DECH). Pérez de Moya, Arithmética práctica, 1562]. v. tr. Mec. Igualar y poner en equilibrio las cosas poniendo la carga proporcionada en la parte contraria.

Pérez de Moya, Arithmética práctica, 1562, pág. 747: Y házese tomando en vuestra mano tantas piedras como las que os dixeren que las cumpláys, y tendréys aviso de fingir al tomar las piedras que se haze por tiento de peso, contrapesando la mano en que la tal persona tuviere las piedras con la vuestra.

FAM.: contrapeso, pesa, pesado, pesadumbre, pesar, peso.

contrapeso, contrapeso, contrapesso [de peso. A. Palencia (DECH). Celso, Reportorio universal leyes Castilla, 1553]. sust. m. Mec. Peso que en algunas máquinas se pone en la parte contraria de otro para que queden en equilibrio.

Besson, Teatro instrumentos, 1602, fol. Ev: Porque este movimiento le causa el trabajador tirando a sí la çoga atada al braço fixo al exe de la parte interior del caracol hazia poniente, estando en la otra parte el contrapeso, de do cuelga toda la fuerça del movimiento. // Besson, Teatro instrumentos, 1602, fol. K4v: Es tal y tanta la fuerça de la balança, que con la ayuda de un solo contrapeso una muy grande carga viene a ser levantada, lo que ahún se haze más fácilmente con los caracoles. // Juanelo Turriano, Veinte y un libros, a. 1605, fol. 307r: Ay otro género de molino que se haze andar, como andan los reloxes, con contrapesos.

HOL.: máquina.

FAM.: contrapesar, pesa, pesado, pesadumbre, pesar, peso.

contrapeso, V. molino de $\sim$ s. 
contrapesso, V. contrapeso.

coracol, V. caracol.

coraçón, V. corazón.

corazón, coraçón, corazón [del lat. cŏr 'íd.', que recibió probablemente los dos sufijos aumentativos -aceum y -onem. H. 1140, Cid (DECH). Juanelo Turriano, Veinte y un libros, a. 1605]. sust. m. Mec. Tabla plana de madera, de forma rectangular, sobre la que se colocan materiales o cargas para que sean izados o transportados.

Juanelo Turriano, Veinte y un libros, a. 1605, fol. 384r: Llámele cada qual como quisiere, porque unos le llaman el cavallo, otros asno, otros albardón, otros la zivilla de la grúa, otros coraçón, como aquél de las balanças de pesar las cosas.

SIN.: albardón, asno, caballo, cibilla.

[IMAGEN] Pseudo-Juanelo Turriano, Los ventiún libros, c. 1605, fol. 383v, fig. 378, letra Q.

corbate, corbate, corobate [tomado del lat. chōrŏbătes 'instrumento para

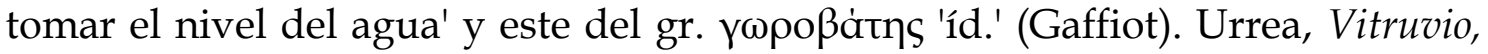
Architectura, 1582]. sust. m. Constr. Tipo de nivel utilizado para hallar la diferencia de altura entre dos puntos (DICTER).

Urrea, Vitruvio, Architectura, 1582, fol. 107v: Corobate es regla larga de veynte pies, que tiene en las cabeças extremas unos que llaman ancones, que son como reglas, ygualmente perfectos. // Juanelo Turriano, Veinte y un libros, a. 1605, fol. 56r: El corbate, que ansí es llamado de Vitruvio, y el vulgo le llama nivel de agua o pesso, el qual se haze en la forma que se sigue. // Juanelo Turriano, Veinte y un libros, a. 1605, fol. 57v: De modo que el nivel o corbate a de hallarse apartado cinqüenta passos dende el de la vanderilla al mismo nivel, y otros tantos del de la regla

SIN.: nivel de agua, nivel de peso.

ENCICL.: "Consistía según dicho autor (Vitrubio, Libro VIII, 6) en una regla larga de veinte pies con unos apéndices en sus extremos, puestos a escuadra con ella: entre las reglas y dichos apéndices había unos travesaños donde estaban señaladas líneas a plomo y unas plomadas colgadas de los travesaños servían para comprobar si el terreno era horizontal cuando las plomadas coincidían con las líneas de fe. Añade que tenía una canalita central para llenarla de agua y nivelar con ella cuando por causa del viento no se podía con los perpendículos. Era, pues, un nivel de perpendículo y de agua. Juanelo en sus obras (Lib. IV) con el nombre de corbate, lo describe y pinta como instrumento portátil sobre un trípode, y consistente en una regla con dos niveles de perpendículo en sus extremos" (Clairac). 
corobate, V. corbate.

correa, correa [del lat. corrĭğ̌a 'íd.'. H. 1220-1250, Berceo (DECH). Juanelo Turriano, Veinte y un libros, a. 1605]. sust. f. Ingen. Hidrául. Tira de cuero utilizada para asir piezas en algunos puentes.

Juanelo Turriano, Veinte y un libros, a. 1605, fol. 211r: Y que es menester madera, como en las demás puentes. Ansí que conviene assir los odres, los unos con los maderos, con correas, después de averlos hinchado. // Juanelo Turriano, Veinte y un libros, a. 1605, fol. 211v: Pónense tres órdenes de odres y juntos, como van aquí abajo dibujados, y ellos se atan con unas correas a los maderos. El odre es A. Tiene dos correas: la una, B; la evilla, C; y la otra correa es D, y la evilla, E.

HOL.: obra hidráulica.

cortahierro, cortayerro [cmpt. de cortar y hierro. Anónimo, Diálogo fábrica de navíos, ca. 1631]. sust. m. Herramienta que se utiliza para cortar objetos de hierro.

Anónimo, Diálogo fábrica de navíos, ca. 1631, fol. 27v: Un terno de toda suerte de barrenas, un cortayerro para cortar pernos, cuatro cuñas de fierro.

cortayerro, V. cortahierro.

covertor, V. cobertor.

criba, criba, criva [de cribo. 1490, Alonso de Palencia (DECH). Pérez Vargas, De re metallica, 1568]. sust. f. Utensilio de cuero o metálico agujereado para cerner o seleccionar materiales (Salinero).

Pérez Vargas, De re metallica, 1568, fol. 16r: De suerte que, como por una criva, sale sin impedimento afuera, y, llevando consigo las materias vaporosas en el ayre. // Collado, Plática Artillería, 1592, fol. 91v: Primeramente, harás una buena provisión de hachas, açadas, palas de hierro, çarandas o crivas grandes hechas de mimbres o de cuerdas de cáñamo o de esparto. // González de Medina, Examen fortificación, 1599, pág. 134: D'esta manera, sacar la tierra y, quebrantada y molida, cribándola por cribas primero, y después por cedaços de cerdas no muy espesos, passarla otra vez para que se limpie de qualquier piedrecilla o cosa que no sea tierra.

SIN.: cribo, harnero. 
HIPER.: instrumento.

FAM.: acribado, cribar, cribo.

cribar, cribar [del lat. crībrāre 'íd.'. Entre 1493 y 1495, Nebrija (DECH). González de Medina, Examen fortificación, 1599]. v. tr. Pasar o limpiar el trigo u otra semilla por el cribo o la criba (Autoridades).

González de Medina, Examen fortificación, 1599, pág. 134: D’esta manera, sacar la tierra y, quebrantada y molida, cribándola por cribas primero, y después porcedaços de cerdas no muy espesos.

FAM.: acribado, criba, cribo.

cribo, cribo, crivo [del lat. crïbrum 'íd.'. H. 1400, Cancionero de Baena (DECH). Loçano, Alberto, Architectura, 1582]. sust. m. Utensilio de cuero o metálico agujereado para cerner o seleccionar materiales (Salinero s. v. criba).

Loçano, Alberto, Architectura, 1582, pág. 64: A imitación de aquéllos que en los Alpes de la Toscana andan por las nieves, porque éstos aplican a los pies unos crivos de soguillas texidas para este uso. // Álaba, Perfeto capitán, 1590, fol. 176r: Y, después, se tornará a ruziar con agua común, para que se pueda granujar, y, en sacándola, passarse a por un crivo que tenga los agujeros estrechos o anchos, conforme fuere el grossor que se le quisiere dar a la pólvora. // Llanos, Diccionario minas, ca. 1609-11, pág. 51: Y son los cedazos con que se cierne a manera de cribos con agujeros grandes. Y cuando, asimismo, se acaba de moler alguna partida de metal, es fuerza quede alguno mal molido

SIN.: criba, harnero.

HIPER.: instrumento.

FAM.: acribado, criba, cribar.

crica, crica [del fr. cric 'gato', onomatopeya imitativa del sonido del instrumento (DECH). Ufano, Tratado de la Artillería, 1613]. sust. f. Mec. Máquina destinada a elevar grandes pesos a pequeñas alturas (Clairac s. v. cric).

Ufano, Tratado de la Artillería, 1613, pág. 81: Quatro guindalas con todo su serviçio y adreço. Quatro cricas o martinetes. Seis cuerdas a la mano. // Ufano, Tratado de la Artillería, 1613, pág. 142: Los braços de los exes de los afustes y carros matos, con el buen adreço de la crica, o cabrilla, y, asimismo, los ojales y mangas del hueco de las ruedas. // Ufano, Tratado de la Artillería, 1613, pág. 319: La escaleta con su uña o alzaprime y la crica o martinete sirven para levantar afuste y pieça en alto al tiempo del sacar una mala y rompida rueda y meter otra mejor y más fuerte al dicho afuste;

HIPER.: máquina. 
criva, V. criba.

crivo, V. cribo.

crizneja, crizneja [probablemente del lat. vg. *crīnı̆cŭla (lat. crīnŭcŭlus), diminutivo de crīn ̌s 'cabello', 'cabellera', 'trenza'. 1505, PAlc. (DECH). Llanos, Diccionario minas, ca. 1609-11]. sust. f. Soga de esparto trenzada en varios ramales utilizada para la sujeción de los cangilones y la fabricación de algunos puentes y escaleras.

Llanos, Diccionario minas, ca. 1609-11, pág. 29: 68 cimbas: Dícese de cimpa, que en la general quiere decir 'crizneja', cuales son las que se usan en España en las anorias a manera de empleita de mimbre y de otras cosas acomodadas para lo mismo, en que se atan los canjilones para sacar el agua. // Llanos, Diccionario minas, ca. 1609-11, pág. 29: De estas criznejas se han usado y usan puentes en este Reino que toman nombre de ellas, y se usó asimismo en el Cerro de Potosí para bajar al fondo de las minas.

cruz, V. peso de $\sim$.

cuba, cuba [del lat. cūpa 'íd.'. 1092, Oelschl. (DECH). Anónimo, Ordenanças paños, 1527]. sust. f. Vaso grande de madera, formado de dos círculos de tabla, que se unen con costillas un poco curvas y que sirve para echar en ella líquidos, como el mosto para hacer el vino.

Anónimo, Ordenanças paños, 1527, fol. 107v: Si quisieres saber, si una cuba que tiene de alto por el un témpano 7 palmos, y por el otro ténpano 8 palmos, y por el medio 10 palmos, y de largo 6 palmos, quántas cántaras de vino cabrá en ella. // Sanctiago, Arte separatoria, 1598, fol. 112v: Lo qual se demuestra que, tomando las hezes de dos tinajas de vino, o cubas, que la una tenga yeso y la otra no. // Sanctiago, Arte separatoria, 1598, fol. 121r: Y, ansí, conviene lutar y cerrar bien las bocas de las cubas, y tinajas y otras vasijas que tuvieren vino.

FAM.: cubada, cubete, cubo.

2 [Lobato, Notas, a. 1585]. sust. f. Depósito de agua que en los molinos contiene el agua que llega de la canal y va a parar al rodezno.

Lobato, Notas, a. 1585, fol. 34: Así, da el agua primero en tres chapas que en la cuba, y la hechura de estas álabes es que se han de forjar en la caja del palo, las que han de ser 
fuertes cuadrados de largo que ha de tener. // Lobato, Notas, a. 1585, fol. 36: La cuba ha de tener de alto al justo con la canal, y las tablas han de ir clavadas por de dentro en la cárcel de abajo. // Juanelo Turriano, Veinte y un libros, a. 1605, fol. 211r: Las cubas, $A \mathrm{~B}, \mathrm{y}$ así se van puniendo de mano en mano, y puniéndolas encima de los maderos $\mathrm{F}$ G. Y puestas aquellas clavijas $H$ para tener las cubas, y encima d'ellas los maderos C D.

[IMAGEN] Lobato, Notas, c. 1585, fol. 36, número 9.

cubada, cubada [de cuba. Juanelo Turriano, Veinte y un libros, a. 1605]. sust. f. Cantidad de líquido u otra cosa que cabe en una cuba (DRAE s. v. cuba). Juanelo Turriano, Veinte y un libros, a. 1605, fol. 293v: De la qual agua se podrá hazer dos cubadas, entre día y noche, que durará tres oras en vaziar, y enchirase en doze, de modo que cada ora podrá moler un caýz, de modo que en dos cubadas se molerá seys caýzes. // Juanelo Turriano, Veinte y un libros, a. 1605, fol. 295r: Y se a dicho lo que muele una cuba cubada, y en quánto tiempo se inche el cubo, y con quánta cantidad de agua, y quánto suelen moler en cada cubada. // Juanelo Turriano, Veinte y un libros, a. 1605, fol. 301v: Aunque molerá mucho este género de molinos el rato que les durare la agua, porque se a de moler a cubadas, y molerá mucho más en este género de molinos que en ningún otro horden de molino.

FAM.: cuba, cubete, cubo.

cubertor, V. cobertor.

cubete, cubete, qubete, quubete [de cubo. Juanelo Turriano, Veinte y un libros, c.1605]. sust. m. Mec. Cámara cilíndrica de los molinos de regolfo y medio regolfo en cuyo interior se sitúa el rodete.

Juanelo Turriano, Veinte y un libros, c.1605, fol. 302v: El cubete, así de medio regolfo como de regolfo entero, conviene que por la parte de dentro sea muy redondo y muy liso, que no tenga ninguna raya o cosa cavada, porque sería parte para enterromper el movimiento de la agua, por donde sería parte que no moliese tanto. // Juanelo Turriano, Veinte y un libros, c.1605, fol. 305v: Y la saetía C es donde entra la agua en el cubete, la qual saetía es a dos palmos de la boca del quubete. // Juanelo Turriano, Veinte y un libros, c.1605, fol. 315r: Quarto: que conviene que la agua que viene a herir dentro del cubete, y yere en el rodete, conviene que entre en el cubete, en el costado, como va aquí dibuxado A (aunque la saetía es del capítulo de arriva, del tercero).

HOL.: molino.

FAM.: cuba, cubada, cubo. 
cubo, cubo [1490, Alfonso de Palencia de cuba. (DRAE). Lobato, Notas, c.1585]. sust. m. Mec. Depósito de agua de cuya parte inferior sale el agua que mueve los rodeznos de los molinos.

Lobato, Notas, c.1585, fol. 16: Este molino muele con agua de una fuente pequeña, y no gasta más del agua que entra en el cubo, y siempre está moliendo. // Juanelo Turriano, Veinte y un libros, c.1605, fol. 294v-fol. 295r: Estos molinos muelen mucho, por razón de la mucha agua que tiene la balsa y el cubo, y porque estos molinos se suelen hazer en esta manera: porque, donde ay poca agua, para que se vaya recojendo en el cubo, y quando está lleno, entonces abren el cubo y muele el molino mientras dura la agua en el cubo. // Juanelo Turriano, Veinte y un libros, c.1605, fol. 295r: Buelvo a advertir que los cubos para los molinos, que se agan muy altos, lo más que fuere posible.

HOL:: molino.

FAM.: cuba, cubada, cubete.

ENCICL.: "Cuando los cubos eran muy altos, se recurría en algunas ocasiones a construirlos parcial o totalmente enterrados -para conseguir que el empuje exterior de las tierras ayude a resistir la presión interior del agua-, procedimiento que se utiliza en el diseño de uno de los molinos más monumentales y próximos al rey, en el Monasterio del Escorial" (Catálogo Felipe II).

[IMAGEN] Lobato, Notas, c. 1585, fol. 16.

Pseudo-Juanelo Turriano, Los ventiún libros, c. 1605, fol. 295r, fig. 188.

cubo, V. molino de .

cuchar, V. cuchara.

cuchara, chuchara, cuchar, cuchara [del ant. y dialectal cuchar y éste del lat. cochleār, cochleāris 'íd.'. Entre 1493 y 1495, Nebrija (DECH). Lobato, Notas, a. 1585]. sust. f. Mec. Especie de álabes cóncavos con agujero de vaciado situados en los rodeznos de los molinos.

Lobato, Notas, a. 1585, fol. 16: Y hiere el saetín en la rueda del témpano echado en unas cuchares cavadas en arco y que pasan a la parte baja los agujeros de las cuchares, como se muestran en la traza. // Lobato, Notas, a. 1585, fol. 36: Este rodezno de madera ha de tener tres pies y medio de ancho y un pie de alto, y en él cavadas seis álabes al modo de cuchares que la una desagüe por debajo de las otras y ha de llevar el cuadrado en medio en proporción.

HOL.: rodezno, rodete.

[IMAGEN] Lobato, Notas, c. 1585, fol. 16. 
cuchillo, chuchillo, cuchillo [del lat. cŭltěllus 'cuchillito'. H. 1220-1250, Berceo (DECH). Lobato, Notas, a. 1585]. sust. m. Ingen. Hidrául. Obra de cantería que se construye en la corriente de las aguas en forma angular para que corte el agua y se reparta igualmente por la madre del río (Autoridades).

Lobato, Notas, a. 1585, fol. 34: Quiero decir que estos brazos de delante, por donde hiere el agua, tengan su grueso, y por detrás le tengan disminuido a manera de un cuchillo, y tendida su fuerza hacia atrás y no hacia abajo, porque su fuerza es hacia atrás. // Juanelo Turriano, Veinte y un libros, a. 1605, fol. 326v: Y esto se ve manifiestamente, que la agua que va a topar en los cuchillos de las puentes de piedra, que en aquella parte se levanta mucho más la agua que no haze en ninguna otra parte de todo el río. // Juanelo Turriano, Veinte y un libros, a. 1605, fol. 217r: Estos maderos han de ser rezios, los que sustentan los corrientes, G G H H, los quales van ligados con aquellos pedaços de maderos $\mathrm{N} \mathrm{N}$ al cavo $\mathrm{B} E$, y los otros dos $\mathrm{C} F$, que es $\mathrm{O} O$. Y éstos tienen coligados toda esta máchina en estos esperones o cuchillos de madera para defensa del agua, que no haga daño en los pies de la puente.

HOL.: obra hidráulica.

cuera, V. quera.

cuera, cuera, qüera [del cat. quera 'íd.' Borao (DECH). Juanelo Turriano, Veinte y un libros, a. 1605]. sust. f. arag. Conjunto de insectos, pequeños y oscuros, cuyas labras roen la madera y otros materiales.

Juanelo Turriano, Veinte y un libros, a. 1605, fol. 439v: El betún es muy más liso y defiende muy mejor la madera que la pez sola, y impide que no entre la cuera en la madera. // Juanelo Turriano, Veinte y un libros, a. 1605, fol. 268r: Hechas con pulimiento, que mucho más se defienden contra los trabajos y no son consummidas del salitre, ni de la qüera de las piedras o llorín. 


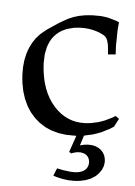

çaariche, V. zafariche.

çaborra, V. zaborra.

çanja, V. zanja.

çaorí, V. zahorí. 
çaranda, V. zaranda.

çatara, V. zátara.

çedaçado, V. cedazado.

çedaçar, V. cedazar.

çedaço, V. cedazo.

çedazo, V. cedazo.

çegadura, V. cegadura.

çegamiento, V. cegamiento.

çegar, V. cegar. 
çercillo, V. cercillo.

çerçillo, V. cercillo.

çerner, V. cerner.

çernido, V. cernido.

çiego, V. ciego.

çisterna, V. cisterna.

çoga, V. soga.

çulacado, V. zulacado.

çulacar, V. zulacar.

çulaque, V. zulaque. 
dado, dado [probablemente del ár. a'dād 'números'. H. 1250, Libro de Alexandre (DRAE). Juanelo Turriano, Veinte y un libros, a. 1605]. sust. m. Mec. Pieza cúbica de metal u otra materia dura, que se usa en las máquinas para servir de apoyo a los tornillos, ejes, etc., y mantenerlos en equilibrio (DRAE). Juanelo Turriano, Veinte y un libros, a. 1605, fol. 302v: El árbol que lleva el rodete, que va en medio del rodete, va puesto encima de un dado de metal, donde juega encima de aquél, como se verá en la materia anterior d'ésta. // Juanelo Turriano, Veinte y un libros, a. 1605, fol. 302v: El qual madero tiene el dado de metal donde firma, encima, el gorrón del rodete. // Juanelo Turriano, Veinte y un libros, a. 1605, fol. 305r: Y el madero donde está asentado el dado, que encima de aquél anda el rodete, el qual madero lo llaman levador, por razón que, quando quieren abaxar o subir la muela, ése le suelen abaxar o levantar algún tanto, y éste se llama templador.

HOL.: molino.

dar, V. vueltas. 
decerrajar, V. descerrajar.

dedal, dedal [del lat. dĭğ̌tāle 'íd.', probablemente neutro de d̆̌ğitālis 'perteneciente al dedo'. Entre 1493 y 1495, Nebrija (DECH). Llanos, Diccionario minas, ca. 1609-11]. sust. m. Base cónica y hueca sobre la que se realiza el movimiento rotatorio en un molinete.

Llanos, Diccionario minas, ca. 1609-11, pág. 9: El principal instrumento que en ellas sirve para lavar el metal es el molinete, que, a manera casi de rodezno, se trae a la redonda dentro de ellas; y los anexos a él son: cigüeñuela, peón y dedal, que sirven para el mismo movimiento, que se hace a fuerza de brazos en las tinas de mano.

HOL.: molinete.

dentado, dentado [de diente. Entre 1493 y 1495, Nebrija (DECH). Urrea, Vitruvio, Architectura, 1582]. adj. Con dientes o puntas parecidas a ellos (DRAE). Urrea, Vitruvio, Architectura, 1582, fol. 133v: Al lado del superior tímpano se fixe otro dentezillo que salga más que los otros y encima del tercer tímpano llano, de la misma manera dentado y metido en otra caxa con dientes yguales al diente que estuviere fixado. // Juanelo Turriano, Veinte y un libros, a. 1605, fol. Cv: A más d'esto, en el centro de la rueda pequeña de levante, cuya orilla es dentada, está hincada la extremidad quadrada de la parte de dentro del caracol. // Juanelo Turriano, Veinte y un libros, a. 1605, fol. Kv: A mediodía está la rueda mayor dentada, como es fácil de ver en los molinos, y ésta mete sus dientes en las aberturas de los panderos o barrilejos.

SIN.: dentejado.

FAM.: dentadura, dentejado, diente, endentado, endentar.

dentadura, dentadura [de diente. 1581, Fragoso (DECH). Collado, Plática Artillería, 1592]. sust. f. Mec. Conjunto de dientes de una rueda.

Collado, Plática Artillería, 1592, fol. 72v: Por quanto aquellos aldabones de hierro que se veen encaxar en la dentadura de la rueda de el torno fixan el torno y no lo dexan tornar atrás con su movimiento.

HOL.: rueda.

FAM.: dentado, dentejado, diente, endentado, endentar.

dentejado, dentejado [de *dentejo. Besson, Teatro instrumentos, 1602]. adj. Con dientes o puntas parecidas a ellos. 
Besson, Teatro instrumentos, 1602, fol. M3v: Assí, dos ruedas dentejadas, por medio del movimiento de la balança, hazen que las ruedas armadas por la metad de uñezuelas las metan y enclavijen entrecambiadamente.

SIN.: dentado.

FAM.: dentado, dentadura, diente, endentado, endentar.

derivar, derivar, dirivar [tomado del lat. derivāre 'desviar una corriente de agua', 'derivar'. H. 1220-1250, Berceo (DECH). Pérez Vargas, De re metallica, 1568]. v. tr. Dicho del agua: encaminarla, conducirla de una parte a otra.

Pérez Vargas, De re metallica, 1568, fol. 190v: Guiados por razón natural y prudente yndustria, hazían sus caños y las llevavan y dirivavan, hinchendo ciertas pozas, eras y hoyos, donde fácilmente los rayos del sol las penetrassen y hiziessen espessas. // Loçano, Alberto, Architectura, 1582, pág. 319: Finalmente, hallada y aprovada la agua, se ha de proveer de guiarla muy bien y que se dé a los usos acommodadamente. La razón de guiar al agua, en dos maneras: porque, o se deriva por çanja de agua, o se recoge por arcaduzes. // Loçano, Alberto, Architectura, 1582, pág. 323: Hemos, pues, dicho hasta aquí en qué manera se derive el agua por obra de fossa o por obra de fábrica.

derramación, derramación [de derramar. Juanelo Turriano, Veinte y un libros, a. 1605]. sust. f. Acción de derramar o derramarse (DRAE s. v. derramamiento).

Juanelo Turriano, Veinte y un libros, a. 1605, fol. 186v: Mas, al fin, no se puede remediar esta derramación de agua.

SIN.: derramamiento.

FAM.: derramadero, derramamiento, derramar.

derramadero, derramadero [de derramar (DECH). Loçano, Alberto, Architectura, 1582]. sust. m. Ingen. Hidrául. Canal o conducto que da salida a las aguas inmundas (DRAE s. v. albañal).

Loçano, Alberto, Architectura, 1582, pág. 117: De los alvañares, unos son los que yo llamo derramaderos, porque vazían las aguas metidas en ellos al río, o a la laguna o a la mar. // Loçano, Alberto, Architectura, 1582, pág. 118: Los derramaderos conviene que estén ensolados con suelo cuesta abajo e inclinado y macizo, por donde corra muy libremente, y que las cosas que allí estuvieren fabricadas no se curtan con la continua humedad.

SIN.: albañal

HOL.: obra hidráulica.

FAM.: derramación, derramamiento, derramar. 
derramamiento, derramamiento [de derramar. Juanelo Turriano, Veinte y un libros, a. 1605]. sust. m. Acción de derramar o derramarse (DRAE).

Juanelo Turriano, Veinte y un libros, a. 1605, fol. 47r: Y siempre que se hallará agua en esta manera, tenga por muy cierto que no tiene muy bajo el derramamiento; mas no confíe tanpoco de hallarle tan cerca como lo piensas, porque, si fuese muy hondo su nascimiento, no se derramaría en muchas partes, como haze esta tal agua que aquí vamos pintando. // Juanelo Turriano, Veinte y un libros, a. 1605, fol. 47r: Es cosa muy ordinaria que el agua camina siempre por debajo de tierra, $y$, no hallando impedimento que le interrumpa el camino, ella se va por su camino, y, hallando cosa que le empida, entonçes ella se va derramando según la disposición halla el lugar, y de la tierra ser floxa o bien densa. Y ansí tiene muy aparte su principio de su derramamiento, como se a dicho.

SIN.: derramación.

FAM.: derramación, derramadero, derramar.

derramar, derramar [del lat. vg. *diramare 'separarse las ramas de un árbol', de donde 'dispersar, desparramar' y después 'verter, derramar'. H. 1140, Cid (DECH). Pérez Vargas, De re metallica, 1568]. v. tr. u. t. c. prnl. Verter, esparcir cosas líquidas o menudas (DRAE).

Pérez Vargas, De re metallica, 1568, fol. 113r: La qual agua algunos echan en un hornillo de cobre y le hinchen de agua fría, la qual cuaja la plata; $y$, derramando el agua, ponen la plata a enxugar y la funden, después de enxuta, en un crisol y la hazen rieles. // Urrea, Vitruvio, Architectura, 1582, fol. 103v: O de alumbre o que tengan algún betún, porque, entonces, se mudan $y$, entonces, las fuentes derraman aguas calientes o frías y de mal olor y sabor. // Juanelo Turriano, Veinte y un libros, a. 1605, fol. 199r: Y para no los aver de embetunar, convendrá poner de greda muy maçeada por la parte de defuera del algive, que será a la redonda del algive, y con esta greda se conserva el agua, que no se derrame o trasmine por las paredes.

FAM.: derramación, derramadero, derramamiento.

2 [Urrea, Vitruvio, Architectura, 1582]. v. intr. u. t. c. tr. prnl. Dicho de un arroyo o de una corriente de agua: desaguar, desembocar (DRAE).

Urrea, Vitruvio, Architectura, 1582, fol. 20v: En la mano yzquierda del qual figuré el assiento de una grande ciudad, y en la mano derecha figuré una alverca, la qual recibiesse el agua de todos los ríos que están en aquel monte, para que desde allí se derramasse el agua en la mar». // Loçano, Alberto, Architectura, 1582, pág. 309: Ay algunos que affirman que las aguas que perpetuamente corren no se derraman como recogidas en vaso, sino que, por continuos momentos, son engendradas en los lugares de donde mana el ayre. / / Juanelo Turriano, Veinte y un libros, a. 1605, fol. 9r: Pues que la mar se estiende y se derrama sus aguas tan anchíssimamente por las canales de la tierra, quanto la raçón y la natura del globo terrestre lo permite que las estiendan. 
desaguadero, desaguadero [de desaguar (DECH). Apiano, Cosmographía, 1575]. sust. m. Ingen. Hidrául. Boca, canal o compuerta por donde se da salida a las aguas (Autoridades).

Lobato, Notas, a. 1585, fol. 36: Que desde el pozo donde ha de estar el dicho molino y casa se haga un albañar secreto que por partes de fuera se pueda abrir, que salga el agua que de él saliere al desaguadero del otro molino por un albañar que yo aquí pintaré, el cual ha de ir por bajo más hondo que el suelo del dicho. // Lobato, Notas, c.1585, fol. 36: Las trampas: la del agua por donde entra en la canal, no es necesario pintarla que ha de ser como las que se usan con su torno, pero la del desaguadero de la acequia, ha de ser a la manera que aquí va pintada que abra hacia el río y cierre hacia la acequia con batientes muy ajustados. // Juanelo Turriano, Veinte y un libros, c.1605, fol. 137v: Por causa que se quiere agotar toda el agua, se deve acomodar en el desaguadero una plancha de alambre o de latón, la qual sea agujereada de unos agujeros que sean muy menudos, para que pueda salir el agua y no los peçes.

HOL.: obra hidráulica.

FAM.: acueducto, agua, aguacero, aguador, aguaducho, aguaducto, aguamanil, aguanoso, aguar, aguatocho, desaguar.

[IMAGEN] Pseudo-Juanelo Turriano, Los ventiún libros, c. 1605, fol. 312r, fig. 219, letra B.

desaguar, desaguar [de agua (DECH). Lobato, Notas, a. 1585]. v. intr. u. t. c. tr. u. t. c. prnl. Ingen. Hidrául. Dicho de un recipiente o de una concavidad: Dar salida a las aguas que contiene (DRAE).

Lobato, Notas, a. 1585, fol. 36: Que salga el agua que de él saliere al desaguadero del otro molino por un albañar que yo aquí pintaré, el cual ha de ir por bajo más hondo que el suelo del dicho, poco o en aquel nivel, porque puedan trabajar en desaguarlo, que ha de ser hecho de esta manera: un albañar cuadrado de piedra que salga fuera del grueso de la tapia de ladrillo del dicho pozo de cuadrado [...]. / / Lobato, Notas, a. 1585, fol. 36: Digo, que no del grueso, que tenga un pie de grueso, y en ella hecho una hembra como de lagar en la misma piedra, y en el cobertor del dicho albañar otra piedra por donde entre un husillo que sirve de tapón para la de abajo y de arriba, y por allí se desaguará; y cuando moliere, no se irá gota de agua. // Lobato, Notas, a. 1585, fol. 36: Embornales: son los Este rodezno de madera ha de tener tres pies y medio de ancho y un pie de alto, y en él cavadas seis álabes al modo de cuchares que la una desagüe por debajo de las otras y ha de llevar el cuadrado en medio en proporción.

ANT.: aguar.

FAM.: acueducto, agua, aguacero, aguador, aguaducho, aguaducto, aguamanil, aguanoso, aguar, aguatocho, desaguadero. 
desangradera, desangradera [de desangrar. Llanos, Diccionario minas, c.1609-11]. sust. f. Ingen. Hidrául. Cauce con el que se da salida a parte de las aguas de un pozo o canal.

Llanos, Diccionario minas, c.1609-11, pág. 67: El orden que se tiene en proveerlos de agua para su molienda en la ribera de Potosí, donde se da por cuenta y la que tasadamente es menester para los ingenios, es quitarles la necesaria para el efecto por una desangradera que hacen en la canal, y eso menos muele el ingenio mientras anda el lavadero (que no es siempre).

SIN.: sangradera, sangría.

HOL.: obra hidráulica.

FAM.: desangrar, sangradera, sangradero, sangrar, sangre, sangría.

desangrar, desangrar [del lat. desanguĭnāre 'íd.' (DRAE). Rojas, Teórica fortificación, 1598]. v. tr. Ingen. Hidrául. Sacar el agua de un lago, estanque, etc.

Rojas, Teórica fortificación, 1598, fol. 106r: Y, llegado al arcen del fosso, se hará una surtida o mina por debaxo d'él, entiéndese siendo seco, que quando fuesse con agua será necessario procurar desangrarlo y quitársela, y quando no pudiere ser, se cegará con mucha abundancia de fagina, tierra y madera.

FAM.: desangradera, sangradera, sangradero, sangrar, sangre, sangría.

desapegadizo, desapegadizo [de desapegar. Juanelo Turriano, Veinte y un libros, a. 1605]. adj. Que con facilidad se despega de algo a lo que estaba pegado o junto.

Juanelo Turriano, Veinte y un libros, a. 1605, fol. 261v: Es cosa muy cierta y averiguada que entre las arenas ay grande differencia. Porque la arena de la mar se enjuga con mucha difficultad, y ella es desapegadiza de suyo y siempre está húmeda, y escúrresse por causa de lo salado que tiene.

FAM.: apegadura, apegar, desapegar, despegar, empegar, empeguntar, pegadura, pegar, pez.

desapegar, desapegar, dessapegar [de apegar 'pegar'. Loçano, Alberto, Architectura, 1582]. v. tr. u. t. c. prnl. Apartar, desasir y desprender algo de otra cosa a la que estaba pegado o junto (DRAE s. v. despegar).

Loçano, Alberto, Architectura, 1582, pág. 181: En una pared derecha están bien las de todo el relieve, pero en un cielo de bóvedas convendrán más las de bajo relieve, porque las de todo el relieve, si están pendientes con su peso, fácilmente se dessapegan, y con el caerse son peligrosas a los moradores. / Juanelo Turriano, Veinte y un libros, a. 1605, fol. 279r: Y este betún tiene dentro de la agua y nunca se desapega. // Juanelo Turriano, Veinte y un libros, a. 1605, fol. 258r: Los que entenderán en esta máquina tengan cuenta que, en siendo desapegada la nave del suelo de la mar, que entonçes no 
se vazíe más agua de los barcos o naves que sirven para sacalla, sino que, poco a poco, la vayan sacando hasta subilla encima de la agua.

SIN.: despegar.

ANT.: apegar, pegar.

FAM.: apegadura, apegar, desapegadizo, despegar, empegar, empeguntar, pegadura, pegar, pez.

desarmar, desarmar [de armar. Entre 1493 y 1495, Nebrija (DECH). Lobato, Notas, a. 1585]. v. tr. Desunir o separar las piezas de que se compone una máquina o instrumento (DRAE).

Lobato, Notas, a. 1585, fol. 36: Y si se hubiere de desarmar la cuba, han de estar los dos cortos, que carguen sobre los otros porque los desclaven y lleven consigo las tablas que estuvieren clavadas en cada una. // Collado, Plática Artillería, 1592, fol. 71v: Compónese de diversas pieças o partes y tórnase a juntar todo, se arma y se desarma, se planta y se muda según la occasión y necessidad lo demanda. // Juanelo Turriano, Veinte y un libros, a. 1605, fol. 50v: Algunos los hazen unos tornillos de yerro para poderle desarmar y llevarle muy más cómodamente este instrumento.

ANT.: armar.

FAM.: armadura, armamento, armamiento, armar, armazón.

desarrebolver, V. desarrevolver.

desarrevolver, desarrebolver [de arrevolver (DRAE). Urrea, Vitruvio, Architectura, 1582]. v. tr. u. t. c. prnl. Deshacer un movimiento en derredor o de arriba a abajo.

Urrea, Vitruvio, Architectura, 1582, fol. 127v: Luego rebolvió la maroma a los husos, y los bueyes yuncidos tiravan la maroma. Y assí como se desarrebolvía, bolvía las ruedas, pero no podía yr por camino derecho, sino a una parte y a otra, y algunas vezes bolvía atrás.

ANT.: arrevolver, revolver.

FAM.: arrevolver, desenvolver, envolver, envuelto, revolver, volteado, voltear, volver, vuelta.

desbiar, V. desviar. 
descerrajar, decerrajar [de cerraja (DRAE). Celso, Reportorio universal leyes Castilla, 1553]. v. tr. Arrancar o violentar la cerradura de una puerta, cofre, escritorio, etc. (DRAE).

Celso, Reportorio universal leyes Castilla, 1553, fol. XIVr: Dízese ayudar al ladrón el que le ayudasse a subir, o le diesse escalera, o le prestasse herramienta, o le demostrasse arte con que él pudiesse decerrajar o abrir alguna puerta o arca, e para horadar pared e en otra qualquier manera semejante. // Celso, Reportorio universal leyes Castilla, 1553, fol. LXVIIr: Y los que hovieren las llaves del sello deven venir al sello los días que se devieren sellar, e si no vinieren, puede el chanciller decerrajar la cerradura de aquél que no viniere; en los quales días el chanciller, sobre todos, no deve faltar.

FAM.: cerraja, cerrajero.

desclavar, desclavar [de clavar (DECH). García de Palacio, Diálogos militares, 1583]. v. tr. Quitar o desprender algo del clavo o clavos con que está asegurado (DRAE).

Lobato, Notas, a. 1585, fol. 36: Y si se hubiere de desarmar la cuba, han de estar los dos cortos, que carguen sobre los otros porque los desclaven y lleven consigo las tablas que estuvieren clavadas en cada una, para hacer lo que fuere menester.

ANT.: clavar.

FAM.: clavado, clavar, clavazón, clavera, clavetado, clavo, enclavado, enclavar.

desembolver, $\mathrm{V}$. desenvolver.

desenvolver, desembolver [de envolver. Entre 1493 y 1495, Nebrija (DECH). Besson, Teatro instrumentos, 1602]. v. Extender lo que está envuelto o enroscado. Besson, Teatro instrumentos, 1602, fol. Kv: Y, assí, afloxándose las unas cuerdas, las otras, por el contrario, tiran del otro lado, y quando o éstas o aquéllas vienen a desembolverse d'ellas y dexarlas vazías de nuevo, más, por el contrario, se embuelven en los mesmos panderos. // Besson, Teatro instrumentos, 1602, fol. K2v: Aquél que está cerca del torno, a mediodía, tiene una cuerda en la mano, que diximos era embuelta en la rueda más grande, la qual tirando, va desembolviendo y tira hazia sí el palo que trahe las herradas y las cestas, lo que es fácil.

ANT.: enroscar 2 , envolver.

FAM.: arrevolver, desarrevolver, envolver, envuelto, revolver, volteado, voltear, volver, vuelta. 
despedida, despedida [de despedir (DECH). Juanelo Turriano, Veinte y un libros, a. 1605]. sust. f. Acción y efecto de despedir algo.

Juanelo Turriano, Veinte y un libros, a. 1605, fol. 481v: Y esso lo declaran las dos líneas, que son $\mathrm{E}$ y $\mathrm{F}$, de los mismos partideros, quanto más que la agua le viene con gran despedida, que no se detiene en los ángulos de los partideros para haverse de entrar en su çequia, y porque camina mucho más por línea recta que por ninguna otra línea.

SIN.: despedimiento.

FAM.: despedir, despedimiento, despidiente.

despedimiento, despedimiento, despidimiento [de despedir. H. 1295, 1 a Crónica General (DECH). Urrea, Vitruvio, Architectura, 1582]. sust. m. Acción y efecto de despedir algo.

Urrea, Vitruvio, Architectura, 1582, fol. 110r: Assimismo, en esta dicha piedra se trave y pegue el primer arcaduz del despedimiento del agua para arriba, desde el cabo del vientre, nivelada d'esta manera: de los arcaduzes y corriente y de la expresión no se levantará, porque en el levar de las aguas suelen hazer algún espíritu furioso. // Ufano, Tratado de la Artillería, 1613, pág. 126: Por la qual causa, se deve dar más amplitud de plaça a la pieça más gruesa, porque haze tanta más fuerça al despedimiento [la] espulsión de la bala que, si no hallase aquella anchura más, el rebufo y soplo de la pieça la arruynaría y desbarataría toda su tronera.

SIN.: despedida.

FAM.: despedida, despedir, despidiente.

despedir, despedir [del lat. expětěre 'reclamar, reivindicar', derivado de petĕre 'pedir'. H. 1220-1250, Berceo (DECH). Sagredo, Medidas Romano, 1526]. v. tr. Soltar, desprender, arrojar algo (DRAE).

Sagredo, Medidas Romano, 1526, pág. 71: E assí, la mayor parte de sus molduras se toman de la basa de la coluna, y otras que se añaden se toman de la cornixa, con tanto que sean aquéllas que menos polvo o agua pueden sostener y que mejor despidan lo que sobre ellas se assentare. // Loçano, Alberto, Architectura, 1582, pág. 21: Finalmente, conviene igualar con nivel todas las áreas que hizieres cubiertas con techo, pero las que se dexaren al descubierto se declinarán del nivel, no más de que despidan las corrientes de las lluvias. // Juanelo Turriano, Veinte y un libros, a. 1605, fol. 135v: EI vasso $\mathrm{A}$ es donde se recoge el agua, y la despide por aquellas cabezas de león, $\mathrm{B}$. Y van a dar aquellos caños de agua en una canal antes de yr a dar por las gradas $\mathrm{C}, \mathrm{y}$ de aý va decendiendo por las gradas de mano en mano.

FAM.: despedida, despedimiento, despidiente. 
despegar, despegar [de pegar. H. 1220-1250, Berceo (DECH). Cortés de Albacar, Breve compendio sphera, 1556]. v. tr. Apartar, desasir y desprender algo de otra cosa a la que estaba pegado o junto (DRAE).

Cortés de Albacar, Breve compendio sphera, 1556, fol. LXIIIr: Bien fixado el papel sobre el padrón con plomos o apegados con una poca de cera, que fácilmente se puede despegar, señalan en el papel transparente con una pluma delgada un Leste Oeste y un Norte Sur. // Sanctiago, Arte separatoria, 1598, fol. 64v: El paño que está sobre ella, que se calentó en la escudilla, y con unas hilas o lana yrán fomentando con la dicha agua por cima del dicho paño, sin despegarle de la parte. // Llanos, Diccionario minas, ca. 1609-11, pág. 12: Se dicen barrigas aquello que excede y sobrepuja por la semejanza, las cuales se suelen despegar con su propio peso y hacer daño.

SIN.: desapegar.

ANT.: apegar, pegar.

FAM.: apegadura, apegar, desapegadizo, despegar, empegar, empeguntar, pegadura, pegar, pez.

despidiente, despidiente [de despedir. ]. adj.

FAM.: despedida, despedimiento, despedir.

$\sim$ de agua(s) [(DECH). Loçano, Alberto, Architectura, 1582]. loc. adj. u. t. c. sust. Dicho de un tejado o cubierta: que separa o despide el agua llovediza.

Loçano, Alberto, Architectura, 1582, pág. 27: Y de aquí quisieron que en los lugares de muchas nieves, los techos muy despidientes de agua estuviessen hazia arriba muy levantados en ángulo agudo, para que no creciessen mucho los augmentos de nieves y cayessen más líquidamente. // Loçano, Alberto, Architectura, 1582, pág. 35: No solamente la pared y las cosas que con las paredes se levantan y consiguen, pero también las cosas que están debajo del mismo suelo no negarán aver sido halladas, como los despidientes de aguas y apartamientos que son de lluvias y albañares, y otras assí. // Loçano, Alberto, Architectura, 1582, pág. 84: Porque, como viessen dos vigas juntadas las cabeças, y apartados los pies de abajo, poderse affirmar, de tal suerte que con el forcejear de ambas resistiessen a los pesos contra ellas puestos, agradoles la invención y començaron con esta obra a poner techos despidientes de aguas a los edificios.

despidimiento, V. despedimiento.

desquiciar, desquiciar [del lat. *excrepitiare 'abrir una hendedura entre la puerta y la pared' (DECH). Álaba, Perfeto capitán, 1590]. v. tr. Desencajar o sacar algo de su quicio (DRAE). 
Álaba, Perfeto capitán, 1590, fol. 86v: Y si por este camino entraren dentro es necessario el desquiciar las puertas o impedir con piedras o otras cosas que de alguna suerte se puedan cerrar, porque los enemigos no los hagan encerrar dentro.

FAM.: quiciado, quicial, quicialera, quicio, resquicia, resquicio.

dessapegar, V. desapegar.

destornear, destornear [de tornear. Besson, Teatro instrumentos, 1602]. v. tr. Desenroscar algo de un torno o cilindro.

Besson, Teatro instrumentos, 1602, fol. I3v: A la rahíz del árbol están dos obreros, que rigen con sus manos los cabos de cuerdas, a fin que vayan poco a poco, para moderar el movimiento del navío y para destornear las cuerdas de los tornos quando ellos estuvieren llenos.

FAM.: entorneado, retornear, torneable, torneado, tornear, tornero, tornillo, torno.

desviadero, desviadero [de desviar. Juanelo Turriano, Veinte y un libros, c.1605]. sust. m. Ingen. Hidrául. Conducto por el que se desvía el agua hacia otro lugar.

Juanelo Turriano, Veinte y un libros, c.1605, fol. 74r: D es una portezuela para desaguadero, que es para limpiar el arca quando viniere en ella mucha materia del cieno. Y E es un desviadero para hazer passar el agua para poder trabajar mientras se alimpiare.

SIN.: desviador.

HOL.: obra hidráulica.

FAM.: desviador, desviar.

desviador, desviador [del lat. dēvĭatōr, dēviatōoris 'íd.' (DRAE). Juanelo Turriano, Veinte y un libros, c.1605]. sust. m. Ingen. Hidrául. Conducto por el que se desvía el agua hacia otro lugar.

Juanelo Turriano, Veinte y un libros, c.1605, fol.311v: Y, a más d'esto, tiene a cada rodete su desviador de la agua, que es para apartar la agua, que no dé en el rodete; aunque descienda la agua por la canal, que no hyera en el rodete.

SIN.: desviadero.

HOL.: obra hidráulica. 
desviar, desbiar, desviar [del lat. deviäre, común a todos los romances de Occidente. H. 1200, Sta. M. Egipc. (DECH). Loçano, Alberto, Architectura, 1582]. v. tr. Apartar, alejar a alguien o algo del camino que seguía (DRAE).

Loçano, Alberto, Architectura, 1582, pág. 299: No me trabajo, porque el que dixere que conviene que el architecto sea jurisconsulto, porque en el entretanto que se edifica se tratan los derechos de desviar las aguas y de regir los términos, de anunciar las obras y otras muchas cosas que con derechos se diffinen, a éstos no les escucharé yo. // Juanelo Turriano, Veinte y un libros, a. 1605, fol. 108r: Después de aver hecho la acequia y averla nivelado con el suelo del río, ya después de aver hecho eleción del lugar, que él sea tal y tan seguro que el agua no se le pueda mudar ni apartar por ninguna parte, ni que se le pueda desviar por causa de yr comiendo la agua el suelo. // Juanelo Turriano, Veinte y un libros, a. 1605, fol. 423r: Mas, si es que se pueda hincar, harase en el modo como havemos dado para los reparos, para que se pueda desviar la agua.

FAM.: desviadero, desviador.

detención, detención, detençión [tomado del lat. dētentì̄o dētentīōnis 'íd.' (DRAE). Lobato, Notas, c.1585]. sust. m. Efecto de detener o detenerse (DRAE). Lobato, Notas, c.1585, fol. 12: Y es así que, considerando que el río Ana, que a par de la ciudad pasa, le veían que con las calmas del verano se venía a secar y no tenían dónde moler el trigo que era necesario en el verano, y viendo aparejo en las montañas de Alhanje para hacer una detención o detenimiento de aguas de las lluvias del invierno, para que con ellas moliesen los molinos en el verano. // Juanelo Turriano, Veinte y un libros, c.1605, fol. 77v: Y caminando l'agua ençerrada, tiene muy mayor fuerça que no tiene en azequia abierta, porque en azequia siempre va topando en alguna cosa que le causa detención, que dentro de los caños no ay en qué topar, porque siempre va de un mismo modo sin ensancharse ni estrecharse. // Juanelo Turriano, Veinte y un libros, c.1605, fol. 164r: Y como el agua no halla cosa que le haga detención, ella passa y no cura más de lo que consigo traýa.

SIN.: detenimiento.

FAM.: detener, detenimiento.

detençión, V. detención.

detener, detener [del lat. detīnēre 'íd.'. H. 1140, Cid (DECH). Urrea, Vitruvio, Architectura, 1582]. v. tr. u. t. c. prnl. Interrumpir o parar algo en su movimiento o acción. 
Urrea, Vitruvio, Architectura, 1582, fol. 72v: Los colgaderos de los calderos se han de hazer de manera que, lo primero, se allane el suelo con tejas de pie y medio, y tan inclinado hazia el vaño que, si echasse una pelota, no pudiesse detenerse dentro, sino que otra vez bolviesse ella por sí a la boca del horno. / / Juanelo Turriano, Veinte y un libros, a. 1605, fol. 158r: Y encima de la armadura, convendrá cargarla muy bien de unas piedras que sean muy grandes, que se puedan poner. $\mathrm{Y}$ poner achos de ramas de enebro debajo de las piedras, y es una cosa muy buena para detener el agua. // Juanelo Turriano, Veinte y un libros, a. 1605, fol. 221r: De modo que ella es cosa de mucho artifiçio, ultra de las dos piezas F F, que sustentan mucho, en dos maneras, que las dos piezas ayudan en detener derechos las dos piezas $\mathrm{E} E$, que es una muy grandíssima ayuda a los pies C D.

FAM.: detención, detenimiento.

detenimiento, detenimiento, detinimiento [de detener (DECH). Loçano, Alberto, Architectura, 1582]. sust. m. Efecto de detener y detenerse (DRAE).

Loçano, Alberto, Architectura, 1582, pág. 325: Algunos ay que piensan que si un vaso de vidrio, lleno de sal, le tapáredes con tal massada con azeyte, para que el agua no penetre en el vaso, y le metiéredes, de suerte que esté pendiente en medio de las aguas de la cisterna, vendrá a ser que las aguas allí con ningún detenimiento no se podrezcan. // Juanelo Turriano, Veinte y un libros, c.1605, fol. 123v: Dévense hazer las arcas para reconocer el agua en lugar llaño y no enhiesto, por las causas ya dichas y porque en los tales lugares recogerase muy grandíssimo ayre, y entonces causa un cierto detinimiento al agua, que no la deja caminar. // Juanelo Turriano, Veinte y un libros, c.1605, fol. 456r: Hase de considerar quánta es la caída, para hazer mejor la subida o baxada, aunque será algo más trabajoso el subir que la subida de la catarata, la qual sube mejor y con más facilidad que no esta subida, porque no tiene ningún detenimiento de agua más de hazer.

SIN.: detención.

FAM.: detención, detener.

detinimiento, V. detenimiento.

devidir, V. dividir.

devidir, V. dividir.

dibidir, V. dividir. 
dibidir, V. dividir.

dibisión, V. división.

dibisión, V. división.

diente, diente [del lat. dens, dentis 'íd.'. H. 1140, Cid (DECH). Pérez Vargas, De re metallica, 1568]. sust. m. Mec. Cada una de las puntas o resaltos que presentan algunas cosas y en especial ciertos instrumentos o herramientas (DRAE).

Pérez Vargas, De re metallica, 1568, fol. 102r: Y, puesto en un ayunque, con unos maços o martillos grandes, pesados, que se muevan con el yngenio del agua, y con unos dientes que tiene el exe de la rueda con un batán se bata y corte en quatro o cinco pedaços, los quales se caldeen y formen con los mesmos maços de la rueda unas barras quadradas. // Besson, Teatro instrumentos, 1602, fol. P4v: Quanto a la disposición de las ruedas, la entiendo, mas el número de los dientes, quánto sea menester, ahún no lo he experimentado. // Juanelo Turriano, Veinte y un libros, a. 1605, fol. 379r: La puente C estava hecha a modo de los dientes de una sierra.

FAM.: dentado, dentadura, dentejado, endentado, endentar.

dique, dique [del neerl. dijk (DRAE). Pérez Vargas, De re metallica, 1568]. sust. m. Ingen. Hidrául. Muro o construcción para contener las aguas (DRAE).

Rojas, Teórica fortificación, 1598, fol. 96v: Y luego, desde la orilla del cauz, hize començar a echar mucha piedra menuda y gruessa, de tal forma que se cegó toda la estacada y quedó hecho un muelle o dique de piedra seca, sin otra mezcla. / / Ufano, Tratado de la Artillería, 1613, pág. 41: La de Bolduque aun digo que pudo ser, porque por el tránsito de línea reta que hazía la bala abreviava la mitad del camino, de modo que si por bueltas y rodeos de los diques, riberas y malos passos de la una a otra villa ay tres leguas de distançia, su tránsito por la región del ayre vernía a ser de legua y media. // Ufano, Tratado de la Artillería, 1613, pág. 257: Estando Su Alteza en el sitio de Ostende se presentó a tal ocasión un hombre bassallo suyo, cuyo nombre era Adrián Hermansen, muy yngenioso de la maestrança de diques y poldrages, el qual propuso a $\mathrm{Su}$ Alteza ser muy buena y provechosa la ynvençión de la salchicha de guerra para atajar las aguas, hazer y fortifficar los diques con bastante fuerça contra la furiosa corriente y cresçimiento d'ellas. 
divertir, divertir, divirtir [tomado del lat. dìvertĕre 'apartarse'. Finales S. XVI, Mendoza, Santa Teresa (DECH). Collado, Plática Artillería, 1592]. v. tr. u. t. c. prnl. Apartar, desviar, alejar (DRAE).

Collado, Plática Artillería, 1592, fol. Vr: Cómo se da principio a la fábrica de la mina y cómo se divertirán las aguas que se hallan en ella. // Juanelo Turriano, Veinte y un libros, a. 1605, fol. 75r: $\mathrm{Y}$ estas tales aguas no le toquen en su nascimiento, porque sería posible perderla o aconteçer algún siniestro, y ya que no se perdiese del todo, se podría diminuyr mucha parte d'ella, por causa de divirtirle el camino que primero tenía. // Juanelo Turriano, Veinte y un libros, a. 1605, fol. 178v: Ansí que este açute tiene dos bocales, y por essa causa es hecho sobre essa forma, para que, dando el agua en $\mathrm{A}$, se divierta a las dos partes; de modo como va resvalando dende $A$ hasta la $C$, se viene a entrar con mucha facilidad por los bocales.

FAM.: reverter, trasverter, vertedero, verter, vertiente.

dividir, devidir, dibidir, dividir [tomado del lat. dīvı̆dĕre 'partir', 'dividir', 'separar'. 1423, E. de Villena (DECH). Juanelo Turriano, Veinte y un libros, a. 1605]. v. tr. Ingen. Hidrául. Distribuir, repartir en varios cauces.

Juanelo Turriano, Veinte y un libros, a. 1605, fol. 176v: Y d'este modo se avría lo que se dessea quanto en esto, por donde en qualquier lugar se podría hazer açutes con esta orden de yr dividiendo el agua en muchas canales, porque quantas más divisiones, muy más cómodamente se hará la obra. // Juanelo Turriano, Veinte y un libros, a. 1605, fol. 179r: Digo que este tal se deve tener, o le deven tener, en mucho. De modo que, offreciéndose que de un grande río averle de dividir en dos, para que él fuese a dar dentro de la mar, convendrá tomar muy más atrás, media legua a lo menos. // Juanelo Turriano, Veinte y un libros, a. 1605, fol. 465r: Pongamos por caso que se a de dividir una çequia en tres partes iguales, y las dos partes se an de sacar por el costado y la otra viene a sallir en el medio.

FAM.: división.

divirtir, V. divertir.

división, dibisión, división, divissión [tomado del lat. divišo, -ōnis 'íd.'. H. 1250, Libro de Alexandre (DECH). Falero, Tratado del espera, 1535]. sust. f. Ingen. Hidrául. Acción y efecto de dividir o distribuir las aguas (DRAE).

Juanelo Turriano, Veinte y un libros, a. 1605, fol. 77v: Y este pie conviene que se divida en veynte partes, para que a cada cinqüenta passos se le dé de abajada una de aquellas divisiones o parte, que será una veyntena parte, para que el agua tenga corriente . // 
Juanelo Turriano, Veinte y un libros, a. 1605, fol. 176v: Y d'este modo se avría lo que se dessea quanto en esto, por donde en qualquier lugar se podría hazer açutes con esta orden de yr dividiendo el agua en muchas canales, porque quantas más divisiones, muy más cómodamente se hará la obra // Juanelo Turriano, Veinte y un libros, a. 1605, fol. 463r: Quando se offresciere hazer alguna division de agua que aya de servir para algún término particular, y de una quantidad de agua a de haver un terçio de toda aquélla. Y el saber repartir no le sabrá todo labrador ni cantero, si no fuere geómetra y harto diestro.

FAM.: dividir.

divissión, V. división.

divissión, V. división. 
ecquipondio, V. equipondio.

edeficio, V. edificio.

edifficar, V. edificar.

edifficio, V. edificio.

ediffiçio, V. edificio. 
edificación, edificación, edificaçión [tomado del lat. aedǐficatĭo, -ōnis 'íd.'. Berceo (DECH). Micón, Diario grande cometa, 1578]. sust. f. Proceso de fábrica o construcción de un edificio.

Micón, Diario grande cometa, 1578, pág. 16: Y día que en esta Yglesia Mayor d'esta insigne ciudad de Barcelona, hecha con tan gran architectura, se puso la primera piedra y se celebra la fiesta de su edificación con grande devoción, assistiendo a los officios divinos con algunos cavalleros. // Loçano, Alberto, Architectura, 1582, pág. 204: En toda edificación diximos que se havía de advertir que las cosas que se ponen encima de otras assienten en macizo. // Sanctiago, Arte separatoria, 1598, fol. 57v: Y, conforme a esto, deve considerar el artífice que pretende imitar a la naturaleza, y no buscar más medios de aquellos con que ella obra, ni más materiales de los que ella tiene para su edificación y conservación, los quales son quatro y son conocidos.

FAM.: edificado, edificador, edificante, edificar, edificatorio, edificio, reedificación, reedificar.

2 sust. f. Construcción fija, hecha con materiales resistentes, para habitación humana o para otros usos (DRAE s. v. edificio).

Urrea, Vitruvio, Architectura, 1582, fol. 95v: Pero si se edificare hazia lo alto, déxense respiraderos, porque si el humor no tuviere salidas por las narizes abaxo y arriba, destruyrase en la nueva edificación. // Loçano, Alberto, Architectura, 1582, pág. 3: Quán ordinariamente aviene que, aun occupados en otras cosas, no podemos hazer que con el entendimiento y ánimo no imaginemos algunas edificaciones [...].

SIN.: edificio.

edificaçión, [Urrea, Vitruvio, Architectura, 1582]. V. edificación.

edificado, aedificado, edificado [de edificar. Celso, Reportorio universal leyes Castilla, 1553]. adj. Fabricado, construido, hecho.

Loçano, Alberto, Architectura, 1582, pág. 194: Querría yo que las piedras estén de tal suerte juntas, con ángulos y líneas trocadas, que las cosas edificadas en ninguna parte estén dessadornadas con hendeduras.

FAM.: edificación, edificador, edificante, edificar, edificatorio, edificio, reedificación, reedificar.

edificador, edificador [de edificar. 1490, Alonso de Palencia Sagredo, Medidas Romano, 1526]. sust. m. Persona que tiene por oficio el edificar. 
Sagredo, Medidas Romano, 1526, pág. 21: La gente d'estos pueblos fueron los primeros edificadores de templos, y el primer templo que edificaron fue en la cibdad de Argos, y después otros muchos por la provincia de Acaya. // Loçano, Alberto, Architectura, 1582, pág. 64: Y, cierto, conviene assí en todo el edificio, como principalmente en los fundamentos, que no menospreciéys cosa en que se pueda echar menos la razón y diligencia de un cauto y bien mirado edificador.

SIN.: edificante.

FAM.: edificación, edificado, edificante, edificar, edificatorio, edificio, reedificación, reedificar.

edificante, edificante [de edificar. Juanelo Turriano, Veinte y un libros, a. 1605]. sust. m. Persona que tiene por oficio el edificar.

Juanelo Turriano, Veinte y un libros, a. 1605, fol. 232r: Se pueden acomodar bien, que muchas otras particularidades se podrían poner para tales cosas, las quales se dejan al arbitrio del edificante, que con su buen juycio se sabrá acomodar en tales necessidades.

SIN.: edificador.

FAM.: edificación, edificado, edificador, edificar, edificatorio, edificio, reedificación, reedificar.

edificar, edifficar, edificar, hedificar [tomado del lat. aedíficāre 'íd.', compuesto de aedes 'casa, edificio' y făcĕre 'hacer'. 1107, BHisp. (DECH). Sagredo, Medidas Romano, 1526]. v. tr. Fabricar, hacer un edificio o mandarlo construir (DRAE).

Sagredo, Medidas Romano, 1526, pág. 75: Pero de mi consejo, quando algo quisieres edificar, procura por haver buenos maestros que te informen primeramente del gasto que puedes despender y la materia que has menester. // Juanelo Turriano, Veinte y un libros, a. 1605, fol. 318r: La causa de hazer los molinos encima de las barcas es en dos maneras: la primera es quando los ríos van por tierra llana, que no ay lugar de poder sacar cequias para poder edificar en ellas, por causa que no puede aver caýda para que pueda la agua hazer fuerça en las ruedas. // Juanelo Turriano, Veinte y un libros, a. 1605, fol. 360r: Para haver de edificar una puente de piedra conviene ir buscando por las riberas del río, assí de una parte como de otra, un buen assiento, y que en aquella parte, que tenga muy buenas ribas y costados, y que sean de muy buena tierra.

FAM.: edificación, edificado, edificador, edificante, edificatorio, edificio, reedificación, reedificar. 
edificatorio, edificatorio [tomado del lat. aedíficātōrius 'íd.' (Segura Munguía). 1554, Controversia entre Fray Bartolomé de Las Casas y Ginés de Sepúlveda (CORDE). Caxesi, Vignola, Regla cinco órdenes, 1593]. adj. Perteneciente o relativo a la edificación (DRAE).

Caxesi, Vignola, Regla cinco órdenes, 1593, p. 0: Se vee que Vuestra Alteza, assimismo, gusta de uno de los fundamentos de la Architetura, que según Vitruvio es el dibuxo, heme determinado dirigir a Vuestra Alteza el libro de Viñola, que trata de la parte edificatoria de las cinco órdenes muy curiosa y cumplidamente.

FAM.: edificación, edificado, edificador, edificante, edificar, edificio, reedificación, reedificar.

2 [Loçano, Alberto, Architectura, 1582]. sust. f. Constr. Arte de proyectar y construir edificios (DRAE s. v. arquitectura).

Loçano, Alberto, Architectura, 1582, V: Y, assí, el que quisiere ser perfecto architecto, como dixo Vitrubio, conviene que tenga prática theórica, sepa Arithmética, Geometría, conozca las tres partes en que la dicha sciencia se divide, qu'es machinatoria, gnomónica y edificatoria. // Herrera, Institución Academia, 1584, fol. 15v: Y el que se hallare medianamente instructo en las dichas sciencias, y principalmente en las tres que el mismo Vitruvio pone, que son: Gnomónica, Machinatoria y Edificatoria, con justa causa se le podrá dar título de Architecto. // Herrera, Institución Academia, 1584, fol. 15v: Leeranse públicamente en la Edificatoria algunos de los diez libros de Vitruvio, y de lo que d'esto escrivió León Baptista Alberti.

edificio, aedificio, edeficio, edifficio, ediffiçio, edificio, edifiçio, edifisio, hedificio, hedifiçio [tomado del lat. aedífičùm 'íd.'. H. 1275, 1 ${ }^{a}$ Crón. Gral. (DECH). Sagredo, Medidas Romano, 1526]. sust. m. Construcción fija, hecha con materiales resistentes, para habitación humana o para otros usos (DRAE).

Sagredo, Medidas Romano, 1526, pág. 70: Mucha parte d'esto que avemos dicho, podrías ver, si quisiesses, en edificios antiguos que se hallan en algunos pueblos de España, e principalmente en Mérida, donde los romanos edificaron con mucha diligencia edificios muy maravillosos, que después fueron por los godos destruydos, según que de lo que agora parece colegimos. // Juanelo Turriano, Veinte y un libros, a. 1605, fol. 19v: Pues que determiné de tractar materia de agua, aunque mi intento no fue de tractar del nascimiento de las aguas, ni menos de sus calidades, ni tanpoco de las causas de la calor d'ellas, ni de sus sabores, ni la causa d'ello, mas sólo fue mi intençión de tractar cosas de hedificios de agua, y esso fue mi principal intento de tractar, y no en ninguna otra cosa de las aguas. // Juanelo Turriano, Veinte y un libros, a. 1605, fol. 199r: Los algives suelen servir para toda una república. Estos edificios se hazen muy grandes y muy sólidos. Para el servicio de un pueblo se deven hazer muy capacíssimos, de muy grande cantidad de agua.

SIN.: edificación ${ }_{2}$.

FAM.: edificación, edificado, edificador, edificante, edificar, edificatorio, reedificación, reedificar. 
edifiçio, V. edificio.

edifisio, V. edificio.

eje, aexe, eje, exe, hexe [del lat. axis 'íd.'. H. 1220-1250, Berceo (DECH). Pérez Vargas, De re metallica, 1568]. sust. m. Mec. Pieza mecánica que transmite el movimiento de rotación en una máquina (DRAE).

Pérez Vargas, De re metallica, 1568, fol. 102r: Y, puesto en un ayunque, con unos maços o martillos grandes, pesados, que se muevan con el yngenio del agua, y con unos dientes que tiene el exe de la rueda con un batán se bata y corte en quatro o cinco pedaços, los quales se caldeen y formen con los mesmos maços de la rueda unas barras quadradas. // Urrea, Vitruvio, Architectura, 1582, fol. 122r: En la postrera parte, en medio del tímpano, ay un exe que se rebuelve, y assida con él, una cadena de hierro rebuelta, de la qual está colgado el felos o tímpano, al qual alivia el agua. // Lobato, Notas, a. 1585, fol. 15: Asentado en un eje fuerte, a la punta del cual tenga seis guijos de hierros, y en el eje injerida una entruesga que tenga la mitad menos del círculo que la grúa con sus pendazos, la cual dé en un carro de 16 palos.

HOL.: máquina.

[IMAGEN] Pseudo-Juanelo Turriano, Los ventiún libros, c. 1605, fol. 308r, fig. 211, letra E.

embalsado, embalsado [de embalsar. Urrea, Vitruvio, Architectura, 1582]. adj. Recogido en balsa o embalse.

Urrea, Vitruvio, Architectura, 1582, fol. 13r: Pero los edificios que están en lagunas y no tienen desaguaderos, ni por ríos ni por acequias, assí como las lagunas Pontinas, estando quedas y embalsadas las tales aguas se pudren, y assí echan humores pesados y pestilenciales en los tales lugares. // Lobato, Notas, c.1585, fol. 35: Y mientras más alta subiere y pudiera salir, mejor volverá a la balsa grande, que es esta máquina y traza para poder moler con agua embalsada en la balsa de diez pies.

FAM.: balsa, contrabalsa.

embarnizado, embarnizado, envernizado [de embarnizar. Alonso Barba, Arte de los metales, 1640]. adj. Cubierto o bañado de barniz.

Alonso Barba, Arte de los metales, 1640, fol. 70r: Algo pudiera hazerse en calderas de cobre o hierro, embarnizadas todas como queda dicho, o repassando muchas vezes el negrillo con estos materiales, como también se advirtió. 
FAM.: barniz, barnizado, embarnizar.

embarnizar, embarnizar, envernizar [de barniz. Entre 1493 y 1495, Nebrija (DECH). Juanelo Turriano, Veinte y un libros, a. 1605]. v. tr. Dar un baño de barniz (DRAE s. v. barnizar).

Juanelo Turriano, Veinte y un libros, a. 1605, fol. 267r: Hay algunos que tienen opinión que los ladrillos se envernizassen por los cantos para hazer las paredes de las delanteras de las casas. // Juanelo Turriano, Veinte y un libros, a. 1605, fol. 267v: Los que suelen envernizar los ladrillos suelen dar un baño con una greda blanca. // Juanelo Turriano, Veinte y un libros, a. 1605, fol. 270v: La teja, C D son tejas, aunque otros las llaman de otros nombres, según los lugares, las quales son envernizadas de diversos colores, como dixe.

FAM.: barniz, barnizado, embarnizado.

embeber, embeber, embever, enbever [de beber. H. 1220-1250, Berceo (DECH). Pérez Vargas, De re metallica, 1568]. v. tr. u. t. c. prnl. Dicho de un cuerpo sólido: absorber a otro líquido (DRAE).

Pérez Vargas, De re metallica, 1568, fol. 62v: Pero la margaxita tiene principalmente virtud de embever en sí el metal y defender del fuego. // Loçano, Alberto, Architectura, 1582, pág. 311: Demás de esto, averiguaron que las cortezas entre sí eran de varia y diversa natura para embever las aguas o vomitarlas. // Juanelo Turriano, Veinte y un libros, a. 1605, fol. 253v: Ay d'esta calidad piedra que se embeve toda la humedad de la calçina y la dexa como polvo.

FAM.: embebido.

embebido, embevido [de embeber. Pérez Vargas, De re metallica, 1568]. adj. Empapado, absorbido.

Pérez Vargas, De re metallica, 1568, fol. 133r: Algunos, después de assentada la cendra, la untan con clara de huevos embevida en un esponja y tornada a exprimir; la clara de huevo deve estar mezclada con sebo o sangre de toro. // Juanelo Turriano, Veinte y un libros, a. 1605, fol. 29v: Las aguas que participan de mucho jugo son aquéllas que se hallan embevidas o mezcladas de muchos jugos, el qual jugo tiene calidad de se poder convertir en piedra. // Juanelo Turriano, Veinte y un libros, a. 1605, fol. 33r: Las aguas que son tiñidas o embevidas o enpapadas de piedra judayca, o de belenite, o de trochite, estas tales aguas rompen la piedra que se halla dentro del cuerpo humano, en la vexiga o en otra parte.

FAM.: embeber.

2 [Collado, Plática Artillería, 1592]. adj. Encajado, incorporado, embutido. 
Collado, Plática Artillería, 1592, fol. 80v: Hecho esto, enpapa en aquella mixtura tanta de estopa de cáñamo o de lino quanta bastará a hazer que quede toda embevida y dura. // Collado, Plática Artillería, 1592, fol. 103v: Las balas, señor, se cobran todas, por quanto se quedan en el terrero embevidas y a cierto tiempo se sacan y se tornan mill vezes a servir de ellas.

embetunado, embetunado [de embetunar. Juanelo Turriano, Veinte y un libros, a. 1605]. adj. Cubierto con betún.

Juanelo Turriano, Veinte y un libros, a. 1605, fol. 186r: Acaeze muchas vezes que se suelen gastar o perder, por causa de ser ellas mal embetunadas. // Juanelo Turriano, Veinte y un libros, a. 1605, fol. 439r: Las naves, para que duren, sean hechas de buena madera, bien enclavadas y embetunadas, y que se ponga dentro buena cantidad de çufre, que esto la haze lúbrica en el camino y que no tenga necessidad de espalmarse a menudo.

FAM.: betumar, betumen, betuminoso, betún, betunar, bitumen, embetunar.

embetunar, embetunar, enbetunar [de betún (DECH). Juanelo Turriano, Veinte y un libros, a. 1605]. v. tr. Cubrir algo con betún (DRAE).

Juanelo Turriano, Veinte y un libros, a. 1605, fol. 274r: Para enbetunar todo género de alcaduces, ansí de fuentes o qualquier otra cosa, que por él aya de pasar alguna licor, para que le detenga, que no salga por las juntas. // Juanelo Turriano, Veinte y un libros, a. 1605, fol. 274v: Betún para enbetunar xetas de fuentes o de çaariches que sea de agua. // Juanelo Turriano, Veinte y un libros, a. 1605, fol. 183r: Después que se tiene hecha una çisterna, conviene lavarla en esta manera: tómase de la escoria que queda de la mina del hierro y pícase muy menudamente, para que con ella se pueda embetunar la cisterna.

SIN.: betunar.

FAM.: betumar, betumen, betuminoso, betún, betunar, bitumen, embetunado.

embever, V. embeber.

embevido, V. embebido.

émbolo, émbolo, émbulo [tomado del lat. embŏlus 'íd.', y este del gr. ¿̌ $\mu \beta o \lambda$ os 'pene'. Princ. S. XVIII, Tosca (DECH). Urrea, Vitruvio, Architectura, 
1582]. sust. m. Mec. Órgano movible de algunas máquinas, de forma regularmente cilíndrica y poca altura, que se mueve en el interior de un receptáculo también cilíndrico (Salinero).

Urrea, Vitruvio, Architectura, 1582, fol. 121: A: son los dos basos de bronce o de otro metal, de donde se embía el agua compelida y apretada con los émbolos machos a subir arriba. // Juanelo Turriano, Veinte y un libros, a. 1605, fol. 352v: Y en los modiolos ha de aver dos palos torneados, los quales se llaman émbulos. // Juanelo Turriano, Veinte y un libros, a. 1605, fol. 354r: Y la D donde recive la agua dentro de sí. El émbulo es $F$, que entra dentro en $A$ y llega hasta encima del cuero $B$, y haze que entre la agua en el caño $\mathrm{H}$, que passa por la ventícula I M; entonces entra en la $\mathrm{N}$, en la caxa.

HOL.: máquina.

[IMAGEN] Pseudo-Juanelo Turriano, Los ventiún libros, c. 1605, fol. 353v, fig. 273, letra F.

embolver, V. envolver.

emboñigado, enboñigado [de emboñigar. Juanelo Turriano, Veinte y un libros, a. 1605]. adj. Untado con boñiga.

Juanelo Turriano, Veinte y un libros, a. 1605, fol. 238v: Agora sean las maderas dentro del agua, o dentro de la tierra, o dentro del lodo, o enboñigadas, o emplastadas, o enbetunadas por encima, o conservadas en los bosques o en las selvas.

FAM.: boñiga, emboñigar.

emboñigar, enboñigar [de boñiga. Juanelo Turriano, Veinte y un libros, a. 1605]. v. tr. Untar o bañar con boñiga (DRAE).

Juanelo Turriano, Veinte y un libros, a. 1605, fol. 237r: Y por esta causa algunas maderas suélenlas enboñigar, para que ellas se conserven, que no se hiendan.

FAM.: boñiga, emboñigado.

embra, V. hembra.

embudo, ambudo, embudo, enbudo [del lat. tardío ı̆mbūtum 'íd.', abreviación de (traiectorŭum) ìmbūtum 'conducto lleno de líquido'. J. Ruiz. (DECH). Sanctiago, Arte separatoria, 1598]. sust. m. Instrumento hueco, ancho por arriba y estrecho por abajo, en forma de cono y rematado en un canuto, que sirve para transvasar líquidos (DRAE). 
Sanctiago, Arte separatoria, 1598, fol. 91v: Sepárenlo de la dicha agua en esta manera: el que estuviere encima se separa echando el agua en un enbudo - y para este efecto conviene que sea de vidro - , y atápese con el dedo el enbudo y váyasse sacando poco a poco el agua, y, desque a salido, se vee el aceyte solo y se echa en otra redoma, y d'esta manera se separa el que viene encima del agua. // Besson, Teatro instrumentos, 1602, fol. F2v: Aparte, pues, poniendo el embudo por vezes en los cañales, infundiré essos liquores, los quales, para que se saquen del vaso. // Juanelo Turriano, Veinte y un libros, a. 1605, fol. 295r: Ay otro modo de cubo que es redondo, el qual viene estrechamente para baxo, a modo de un ambudo, el qual a de ser muy liso por la parte de dentro.

embuelto, V. envuelto.

émbulo, V. émbolo.

emisario, emissario [tomado del lat. èmissārĭum 'conducto, canal'. (Raimundo de Miguel). Juanelo Turriano, Veinte y un libros, a. 1605]. sust. $\mathrm{m}$. Ingen. Hidrául. Desaguadero o conducto para dar salida a las aguas de un estanque o de un lago (DRAE).

Juanelo Turriano, Veinte y un libros, a. 1605, fol. 77r: Conviene yr dende el inçile midiendo hasta el emissario, que es de donde empezamos hasta donde se a de acabar. // Juanelo Turriano, Veinte y un libros, a. 1605, fol. 77v: Y León Baptista, De re edificandi, le llama inçile, el principio, o especo, y al fin d'ella emissario o castelo.

SIN.: castelo.

HOL.: obra hidráulica.

emissario, V. emisario.

empalagado, empalagado [de empalagar. Lechuga, Discurso de la Artillería, 1611]. adj. Mec. Dicho de una pieza de molino hidráulico: que ha quedado sin movimiento por la fuerza del agua. 
Lechuga, Discurso de la Artillería, 1611, pág. 267: O haziendo presa, passada la fuerza, para que represadas y detenidas las aguas, queden las ruedas de las pistas y las de los molinos empalagadas, sin poder servir.

empalmado, empalmado [de empalmar. Loçano, Alberto, Architectura, 1582]. adj. Junto, acoplado o entrelazado.

Loçano, Alberto, Architectura, 1582, pág. 271: Las quales representassen troncos de árboles cortados los nudos, o hazes atados con cuerda, o que estuviessen rebueltas o empalmadas, y ásperas, llenas de hojas, y avezillas y arroyuelos. // Juanelo Turriano, Veinte y un libros, a. 1605, fol. 81r: La qual pondré aquí abajo el modo d'ello, con tal que el trecho sea que dos maderos empalmados puedan alcanzar de una parte a otra. // Juanelo Turriano, Veinte y un libros, a. 1605, fol. 222r: Y estos tirantes van empalmados.

FAM.: empalmadura, empalmar.

empalmadura, empalmadura, enpalmadura [de empalmar (DECH). Juanelo Turriano, Veinte y un libros, a. 1605]. sust. f. Efecto de empalmar o juntar dos maderos, sogas, tubos $\mathrm{u}$ otras cosas, acoplándolas o entrelazándolas (DRAE).

Juanelo Turriano, Veinte y un libros, a. 1605, fol. 156v: La G es la segunda manera de empalmadura, la qual es hecha para poner dos tascones o cuñas, que es $\mathrm{M}$ y $\mathrm{N}$, que van dobladas las enpalmaduras. // Juanelo Turriano, Veinte y un libros, a. 1605, fol. 157r: $\mathrm{Y}$ donde ha de aver pesso encima d'estas empalmaduras, conviene poner unos cercillos de yerro, a causa que esté muy más fuerte, que estará tan firme como si fuese de una sola pieza. // Juanelo Turriano, Veinte y un libros, a. 1605, fol. 222v: Esta puente requiere que sean muy apartados los pies, por causa de las empalmaduras, que es menester que sea más de cinqüenta pies apartados los unos de los otros.

FAM.: empalmado, empalmar.

empalmar, empalmar [de empalomar 'atar con bramante', y este probablemente del cat. empalomar, derivado de paloma 'amarra que se lanzaba desde la embarcación para unir a esta con la playa'. 1587, G. de Palacio (DECH). García de Palacio, Instrución náuthica, 1587]. v. tr. Juntar dos maderos, sogas, tubos u otras cosas, acoplándolas o entrelazándolas (DRAE).

García de Palacio, Instrución náuthica, 1587, fol. 140v: Durmentes: son los que se hechan en los navíos por la parte de dentro para, sobre ellos, empalmar las latas que hazen las cubiertas y sobrados de los navíos. // Juanelo Turriano, Veinte y un libros, a. 1605, fol. 214v: Éstos no se an de empalmar, por causa que el trecho no ha de ser más largo de lo que es el madero o los maderos ordinarios. // Juanelo Turriano, Veinte y un libros, a. 1605, fol. 221v: Y cruzan por los pies aquellas aspas E E F F, las quales se han de empalmar en los pies $\mathrm{G}$ a media muesca, ansí los unos como los otros, aunque aver de asentar las otras piezas juntas.

FAM.: empalmado, empalmadura. 
emparejar, emparejar, emparexar, enparejar, enparexar [de parejo. 1241, Fuero Juzgo (DECH). Vandelvira, Traças de cortes, ca. 1591]. v. tr. Poner algo a nivel con otra cosa (DRAE).

Vandelvira, Traças de cortes, ca. 1591, fol. 53r: Después de çerrado el arco, lo podrás emparexar por su suelo y echalle gradas, si te pareçiere, y porque en el caracol de emperadores me declararé más, no trataré más aquí d'ello. // Juanelo Turriano, Veinte y un libros, a. 1605, fol. 424r: Assí conviene que se hincha de piedra muerta hasta llegar a la cara de la agua y, entonces, ir emparejando con la piedra y cal, hasta poder ir levantando las paredes. // Alonso Barba, Arte de los metales, 1640, fol. 79v: El cuello de la mufla llegue ajustadamente a emparejar con la puerta grande del tocochimpo y, si se huviere de usar de fuelle, ha de tener la dicha mufla dos cuellos que lleguen por la una y otra parte a las dos puertas.

FAM.: aparejador, aparejar, aparejo, parejo.

emparexar, V. emparejar.

empedrado, empedrado [de empedrar (DECH). Escalante, Discurso de la navegación, 1577]. adj. Cubierto con piedras (Autoridades).

Escalante, Discurso de la navegación, 1577, fol. 35v: Las calles son muy bien empedradas y derechas, sin torcedero ninguno, estendidas de una puerta a otra y tan anchas, que en las más pueden yr diez y quinze ombres a cavallo juntos.

FAM.: empedrador, empedrar, empedrecer, piedra.

2 [Juanelo Turriano, Veinte y un libros, a. 1605]. sust. m. Pavimento formado artificialmente de piedras.

Juanelo Turriano, Veinte y un libros, a. 1605, fol. 373v: Por causa de la ordinaria freqüentaçión, suéleseles hechar encima del empedrado un suelo de cascajo gruesso, más de un palmo, o de una arena muy gruessa o grava. / / Juanelo Turriano, Veinte y un libros, a. 1605, fol. 378r: Y en el medio del camino hase de levantar el empedrado, a modo de lomo del pescado, que es más alto en medio que no a los costados. // Lechuga, Discurso de la Artillería, 1611, pág. 254: Que los puentes firmes que uviere en los fossos sean de madera buena, encima de pilares de muro, cubiertos por encima de tanta alteza de tierra que pueda aver su empedrado de piedras o ladrillos.

empedrador, empedrador [de empedrar (DECH). Juanelo Turriano, Veinte y un libros, a. 1605]. sust. m. Persona que tiene por oficio empedrar calles, casas, etc. 
Juanelo Turriano, Veinte y un libros, a. 1605, fol. 304v: Y después de aver puesto esta lechada, convendrá yrla maceando con un pisón, como hazen los empedradores de calles, que, después que an empedrado, van maceando para asentar las piedras, que estén ygualmente asentadas. // Juanelo Turriano, Veinte y un libros, a. 1605, fol. 477v: Y después poner un suelo de carbón que sea menudo en el principio y después gruesso, y después irle assentando, como lo hazen los empedradores las piedras, con una maça de madera irle igualando muy bien.

FAM.: empedrado, empedrar, empedrecer, piedra.

empedrar, empedrar [de piedra. H. 1410, Gz. de Clavijo (DECH). Loçano, Alberto, Architectura, 1582]. v. tr. Cubrir el suelo con piedras ajustadas unas con otras de modo que no puedan moverse (DRAE).

Loçano, Alberto, Architectura, 1582, pág. 247: Leemos que Heliogábalo, estas más anchas y dignas calles, las empedró de piedra macedónica y pórphido. // Loçano, Alberto, Architectura, 1582, pág. 249: Estarán levantadas con una y otra grada más que la calle de en medio, la qual se empedrará de pedernal por causa de las bestias. // Juanelo Turriano, Veinte y un libros, a. 1605, fol. 377r: Las piedras con que se han de empedrar las puentes han de ser como el puño, y hase de allanar todo lo que hay de un arco a otro, como con losas.

FAM.: empedrado, empedrador, empedrecer, piedra.

empedrecer, enpedrezer [de piedra. Juanelo Turriano, Veinte y un libros, a. 1605]. v. prnl. Dicho de un material: solidificarse o convertirse en piedra.

Juanelo Turriano, Veinte y un libros, a. 1605, fol. 35r: El jugo que es apto a enpedrezerse o convertirse en piedra. Esta calidá de agua va goteando por los resquizios de las peñas y luego se va a convertir en piedra.

FAM.: empedrado, empedrador, empedrar, piedra.

empegar, empegar [de pegar. Entre 1493 y 1495, Nebrija (DECH). Loçano, Alberto, Architectura, 1582]. v. tr. Bañar o cubrir con pez derretida u otra sustancia semejante una superficie.

Loçano, Alberto, Architectura, 1582, pág. 346: Y si ello no pudieres, affirmaréys en el suelo firme con el fortalecimiento de vigas, y empegaréys bien las vías con pez y con azeyte, porque no se dañen con el tocamiento de la cal // Urrea, Vitruvio, Architectura, 1582, fol. 131v: Y las tablas se empegan y atan con planchas de hierro, porque la fuerça del agua no las rompa. // Álaba, Perfeto capitán, 1590, fol. 95r: Y el cañón se henchirá de la mezcla que adelante diré, y cubrirse a toda la alcancía con un cañamazo, y empegarse a muy bien para que tenga más fuerça.

SIN.: empeguntar.

FAM.: apegadura, apegar, desapegadizo, desapegar, despegar, empeguntar, pegadura, pegar, pez. 
empeguntar, empeguntar, enpeguntar [de pegunta 'señal con pez' (DECH). Juanelo Turriano, Veinte y un libros, a. 1605]. v. tr. Bañar o cubrir con pez derretida $u$ otra sustancia semejante una superficie.

Juanelo Turriano, Veinte y un libros, a. 1605, fol. 277r: Toma pez líquida, de la que enpegunta las naos, y calcina viva, y ir mezclando la cal con la pez. // Juanelo Turriano, Veinte y un libros, a. 1605, fol. 277r: Y después de fundidos, pon dentro un poco de cevo, que a cien libras de pez pon cinco de sevo. Y con esta mistura puedes enpeguntar qualquier cosa. Y este betún resiste al agua muy maravillosamente. // Juanelo Turriano, Veinte y un libros, a. 1605, fol. 365r: Y después de haver hecho las canales, conviene tomar tablas y ir cubriendo todos los ochavos, y empeguntar muy bien las juntas, y ponerle sus cerçillos de hierro de alto abaxo.

SIN.: empegar.

FAM.: apegadura, apegar, desapegadizo, desapegar, despegar, empegar, pegadura, pegar, pez.

emprenta, V. imprenta.

emprimir, emprimir [del lat. imprĭměre 'íd.'. Anónimo, Premática ferias de León..., 1552]. v. tr. Confeccionar una obra impresa (DRAE s. v. imprimir).

Anónimo, Premática ferias de León..., 1552, fol. 1r: Fueron emprimidas en la muy noble y muy leal cibdad de Sevilla, a XV díasdel mes de diziembre, de mil y quinientos y treynta y ocho años. // Anónimo, Premática ferias de León..., 1552, fol. 1v: La persona o personas que vuestro poder para ello oviere, e no otras algunas, puedan imprimir y empriman, e vender e vendan en estos nuestros reynos e señoríos las dichas declaratorias y ordenanças de los paños que assí agora nuevamente se an fecho por nuestro mandado.

SIN.: imprimir.

FAM.: imprenta, impresión, impresor, imprimia, imprimidor, imprimir.

enarenado, enarenado [de enarenar. Urrea, Vitruvio, Architectura, 1582]. adj. u. t. c. sust. Cubierto o mezclado con arena.

Urrea, Vitruvio, Architectura, 1582, fol. 95v: Las segundas, se affierren levantadas, y encima se haga lo enarenado y encalado con su mármol.

SIN.: arenado.

FAM.: arena, arenado, arenal, arenar, arenilla, arenisco, arenoso, enarenar. 
enarenar, enarenar [de arena (DECH). Lobato, Notas, a. 1585]. v. tr. Cubrir de arena una superficie (DRAE).

Lobato, Notas, a. 1585, fol. 13: A otros, por venidas que les vienen de avenidas de lluvias por delante, le enarenan el caño delante de los rodeznos, $\mathrm{y}$, cuando no se catan, es menester cada año gastar en limpiarlo mucho.

SIN.: arenar.

FAM.: arena, arenado, arenal, arenar, arenilla, arenisco, arenoso, enarenado.

enbetunar, V. embetunar.

enbever, V. embeber.

enbolver, V. envolver.

enboñigado, V. emboñigado.

enboñigar, $V$. emboñigar.

enbra, V. hembra.

enbudo, V. embudo. 
encaminado, encaminado [de encaminar. Juanelo Turriano, Veinte y un libros, a. 1605]. adj. Ingen. Hidrául. Dicho del agua: llevada, transportada, dirigida de un lugar a otro mediante canales o conductos.

Juanelo Turriano, Veinte y un libros, a. 1605, fol. 177v: Y donde ay la $\mathrm{N}$ es donde se toma el agua y encaminada por cequia. // Juanelo Turriano, Veinte y un libros, a. 1605, fol. 480r: Y por la mesma razón es lo de C, que tiene muy más largo su partidor que no haze $\mathrm{D}$, porque la agua viene encaminada para $\mathrm{C}$ mucho más que no haze en $\mathrm{D}$. // Juanelo Turriano, Veinte y un libros, a. 1605, fol. 481r: Y mucha más entrará en B que no en $D$, por venir la agua encaminada más drechamente a la $B$ que a ninguna otra parte, mas como sea más atrás la $\mathrm{C}$ que ninguna de las otras dos.

FAM.: caminar, camino, encaminamiento, encaminar.

encaminamiento, encaminamiento [de encaminar (DECH). Urrea, Vitruvio, Architectura, 1582]. sust. m. Ingen. Hidrául. Conducto o canal por el que discurre el agua.

Urrea, Vitruvio, Architectura, 1582, fol. 108v: Y assí todos ternán agua y no se lo podrán estorvar, como lo tengan de sus principios y por sus proprias vías y encaminamientos. // Urrea, Vitruvio, Architectura, 1582, fol. 108v: La causa por que yo divido estas cosas es ésta: porque los que particularmente llevan a las casas el agua sean libres de las alcavalas por los arrendadores de los encaminamientos del agua.

SIN.: camino.

HIPER.: obra hidráulica.

FAM.: caminar, camino, encaminado, encaminar.

ENCICL.: En general, en la época, ni la Corona ni los ayuntamientos estaban muy "dispuestos a invertir sumas considerables en la construcción de caminos, ya que, a diferencia de otras obras públicas, su financiación no resultaba nada fácil $\left[{ }_{\prime \prime \prime}\right\}$. En la práctica. preferían hacer obras de regadío (presas, azudes, canales) que se financiaban con los nuevos impuestos sobre el aumento de la producción agrícola una vez que entraban en servicio, construir abastecimientos de agua que se podían financiar cobrando tasas a los nuevos consumidores o haciendo una derrama sobre los vecinos (Catálogo Felipe II: 86).

encaminar, encaminar [de camino. Entre 1493 y 1495, Nebrija Urrea, Vitruvio, Architectura, 1582]. v. tr. u. t. c. prnl. Ingen. Hidrául. Dicho del agua: llevarla, transportarla de un lugar a otro o dirigirla hacia un lugar determinado mediante canales o conductos.

Urrea, Vitruvio, Architectura, 1582, fol. 109v: Después, quando viniere a la cuesta contraria, porque en el largo espacio el arco poco a poco se levanta, entonces se encamine el agua a lo alto del collado. // Juanelo Turriano, Veinte y un libros, a. 1605, fol. 92v: También, si ellas viniesen a un mismo pesso o nivel, se podrían hazer passar juntas, con tal que la una fuese encaminada dentro de unos alcaduzes. // Juanelo Turriano, Veinte y un libros, a. 1605, fol. 331v: La canal es la A, que encamina la agua a 
la rueda B, la qual tiene cerrados los dos costados de las palas donde yere la agua, a causa que con más presteza pueda andar y bolver aquel árbol o exe $\mathrm{C}$.

SIN.: conducir.

FAM.: caminar, camino, encaminado, encaminamiento.

ENCICL.: "Adereçar el camino, limpiarle, quitarle tropiezos y guiarle por lo más derecho" -según Covarrubias, ha sido, hasta hoy, una preocupación compartida por gobernantes, comerciantes y viajeros que, en el periodo temporal aquí estudiado sólo se llevó a cabo tímidamente allí donde era imprescindible (Catálogo Felipe II: 85).

encañado, encañado [de encañar. Herrera, Institución Academia, 1584]. adj. Ingen. Hidrául. Dicho del agua: Conducida por caños o conductos.

Herrera, Institución Academia, 1584, fol. 17r: Los que hizieren professión d'este officio de nivelar las aguas, y encañar las fuentes, y de hazer azequias y conductos de agua, ora sea cubierta y encañada, o no encañada, ora sea descubierta, ora por la superficie de la tierra, ora por arcos y de qualquier otra manera que se pueda ofrece.

FAM.: caña, cañal, cañería, caño, cañón, encañadura, encañamiento, encañar, encañizado.

2 [Pérez Vargas, De re metallica, 1568]. sust. m. Ingen. Hidrául. Conducto formado por canales o caños trabados y unidos, para conducir el agua.

Pérez Vargas, De re metallica, 1568, fol. 136: Concavidad que se dize displuviato, porque d'ella se echa fuera el agua de las canales por ciertos encañados. // Herrera, Institución Academia, 1584, fol. 18r: Ha de tener el nivelador práctica de hazer las composiciones de betumes para sus encañados, y, ] finalmente, todo lo a este ministerio perteneciente. // García de Céspedes, Instrumentos nuevos, 1606, fol. 30r: Teniendo la agua la corriente tan conocida, no ay sino hazer su encañado que, si en la cuesta no ay algunos inconvenientes, que sea necessario que la cañería venga dando bueltas.

SIN.: encañadura, encañamiento.

encañadura, encañadura [de encañado (DECH). García de Céspedes, Instrumentos nuevos, 1606]. sust. f. Ingen. Hidrául. Conducto formado por canales o caños trabados y unidos, para conducir el agua.

García de Céspedes, Instrumentos nuevos, 1606, fol. 31r: Hase de usar de artificio porque con la encañadura ordinaria no vendrá la agua al manadero, aunque esté más baxo que el nacimiento, sino que rebentarán los caños por muchas partes.

SIN.: encañado, encañamiento.

HOL.: obra hidráulica.

FAM.: caña, cañal, cañería, caño, cañón, encañado, encañamiento, encañar, encañizado. 
encañamiento, encañamiento [de encañar. Urrea, Vitruvio, Architectura, 1582]. sust. m. Ingen. Hidrául. Conducto formado por canales o caños trabados y unidos, para conducir el agua.

Urrea, Vitruvio, Architectura, 1582, fol. 81v: Estos edificios hazen en los refitorios grande molestia, porque cerca de las paredes tienen unos encañamientos, los quales reciben el agua que cae de las canales tardamente. // Urrea, Vitruvio, Architectura, 1582, 140v: Cerca de las paredes, reciben el agua de las canales en unos encañamientos.

SIN.: encañado 2 encañadura.

HOL.: obra hidráulica.

FAM.: caña, cañal, cañería, caño, cañón, encañado, encañadura, encañar, encañizado.

encañar, encañar [de caño. Herrera, Institución Academia, 1584]. v. tr. Ingen. Hidrául. Hacer pasar el agua por caños y conductos (DRAE).

Herrera, Institución Academia, 1584, fol. 17r: Los que hizieren professión d'este officio de nivelar las aguas, y encañar las fuentes, y de hazer azequias y conductos de agua, ora sea cubierta y encañada, o no encañada, ora sea descubierta, ora por la superficie de la tierra, ora por arcos y de qualquier otra manera que se pueda ofrecer. // García de Céspedes, Instrumentos nuevos, 1606, fol. 39v: Y quando, viniendo encañando con sus arcas y anivelando la agua (como está dicho), aconteciere que los caños manaderos de las arcas vienen a apegar con la tierra.

FAM.: caña, cañal, cañería, caño, cañón, encañado, encañadura, encañamiento, encañizado.

encañizado, encañizado [de encañizar. Juanelo Turriano, Veinte y un libros, c.1605]. sust. m. Enrejado o celosía de cañas que se pone en los jardines para enredar y defender las plantas o para hacer divisiones (DRAE s. v. encañado). Juanelo Turriano, Veinte y un libros, c.1605, fol. 135v: La E es una de las dos escalas para abajar y subir a la fuente. Donde es la F es un respaldo, hecho de murta o de arrayán o de xazmín, con sus encañizados.

FAM.: caña, cañal, cañería, caño, cañón, encañado, encañadura, encañamiento, encañar.

encaracolado, encaracolado [de caracol. Besson, Teatro instrumentos, 1602]. adj. Con forma de caracol.

Besson, Teatro instrumentos, 1602, fol. B4v: Queda, pues, esto a notar: aquel clavo pequeño, encaracolado, que en la tablilla se vee, no servir aquí de nada. // Besson, Teatro instrumentos, 1602, fol. B4v: Finalmente, la regla perpendicular que está hazia poniente, sea quadrada y con una clavija encaracolada hínquese por su parte de baxo al braço de mediodía, de la manera que por la parte de arriba se vee, ya annexa al braço de tramontana. // Besson, Teatro instrumentos, 1602, fol. Cv: Finalmente, aquellos dos 
clavos pequeños encaracolados que están en la arca a oriente no sirven a otro que a tener firme la rueda pequeña dentada.

SIN.: caracolado.

FAM.: caracol, caracola, caracolado.

encarar, encarar [de cara (DECH). Roiz, Reloges solares, 1575]. v. tr. Apuntar o señalar algo o hacia algún sitio.

Roiz, Reloges solares, 1575, pág. 54: Dize más: que la fuerça y virtud d'esta piedra, no solamente es encarar hazia el Norte, en que todos concordan, pero también hazia Mediodía. // Roiz, Reloges solares, 1575, pág. 55: Sea AB un pedaço de piedra ymán: A sea la parte que tiene virtud de encarar hazia el Norte y B hazia Mediodía. // Roiz, Reloges solares, 1575, pág. 57: No quiero tratar aquí de la causa d'esto, porque unos dizen que realmente la fuerça de la piedra ymán es encarar un poco apartándose del Norte, y entonces esta differencia en las agugitas vernía de la misma piedra.

2 [Muñoz, Libro nuevo cometa, 1573]. v. tr. Dirigir la vista hacia algún sitio. Muñoz, Libro nuevo cometa, 1573, fol. 17r: Y dos mathemáticos que se concertassen podrían en un mismo momento encarar con astrolabios a alguna nuvezilla queda y muy notable, y pues ternían los ángulos que se harían en sus ojos // Álaba, Perfeto capitán, 1590, fol. 192r: Hará que le pongan a sus pies a plomo la dicha vara y verá si puede, estando en aquella postura, encarar a lo alto de la torre, de suerte que su ojo y lo alto de la vara y de la torre vengan a caer en una mesma línea, que sea ECB; // Álaba, Perfeto capitán, 1590, fol.

211r: Encararé, lo primero, en el lugar donde me hallo, con el astrolabio a lo alto de la muralla o torre, y si la alidada cayere sobre la umbra versa, notaré qué puntos corta d'ella y partiré los doze que vale todo aquel lado de la escala y notaré el número que saliere de la partición.

encavadura, encavadura [de encavar. Juanelo Turriano, Veinte y un libros, a. 1605]. sust. f. Ingen. Hidrául. Zanja o cavidad en la que pueden asentarse los caños, fístulas o cañerías.

Juanelo Turriano, Veinte y un libros, a. 1605, fol. 286v: Y que la encavadura, que ella no se enbeve nada, como dize Frontino, principalmente en los quinarios que están fundidos encima de cuero muy delgado. // Juanelo Turriano, Veinte y un libros, a. 1605, fol. 287v: Y házele de hatar al cabo de arriba una encavadura donde asiente el caño, por razón que la agua no tope en el caño o alcaduz al tiempo que sube para arriba, que podría hazerle tal fuerça que la levantase en alto.

SIN.: cavadura.

HOL.: obra hidráulica.

FAM.: cava, cavadura, cavar, excava, excavar, socavado, socavar. 
enchir, V. henchir.

enclabar, V. enclavar.

enclavado, enclavado [de enclavar. Urrea, Vitruvio, Architectura, 1582]. adj. Sujeto con clavos.

Urrea, Vitruvio, Architectura, 1582, fol. 129v: Y tendrán sus arcaduzes de metal de açumbre enclavados d'esta manera: bolviéndose la rueda, rebuelve la cadena en el exe y sube arriba los arcaduzes, los quales, subidos sobre el exe, se trastornan y derraman el agua en el lugar que para ello está hecho. // Juanelo Turriano, Veinte y un libros, a. 1605, fol. 144v: Toda esta máchina a de estar guarnecida de sus lañas de hierro, que coja todas las piezas de la dicha máchina de la una parte a la otra y muy bien enclavadas. // Juanelo Turriano, Veinte y un libros, a. 1605, fol. 391v: Y en las anillas, aý dentro juegan las otras pieças, que es D E F, las quales van fixas en la puente de madera, y muy bien enclavadas, con sus llañas de hierro muy bien assentadas, ansí a la una parte y a otra.

SIN.: clavado.

FAM.: clavado, clavar, clavazón, clavera, clavetado, clavo, desclavar, enclavar.

enclavar, enclabar, enclavar [de clavo. H. 1250, Libro de Alexandre (DECH). Girava, Fineo, Geometría práctica, trads., 1553 ]. v. tr. Asegurar con clavos algo (DRAE).

Girava, Fineo, Geometría práctica, trads., 1553, pág. 63: Apparejada ya esta regla, se ha de enclavar de una parte sobre el punto A, de tal suerte que, sin ninguna difficultad, se rebuelva sobre la llana superficie del instrumento, // Juanelo Turriano, Veinte y un libros, a. 1605, fol. 320r: Y en los ángulos se ponen otros maderos de punta para arriva, a causa que tenga donde poder enclavar los clavos de las tablas, ansí en la parte delantera como en la parte postrera. // Juanelo Turriano, Veinte y un libros, a. 1605, fol. $222 \mathrm{v}$ : Toda esta máquina conviene empalmarla muy bien y, después, enclavarla con su clavazón muy buena, que sea muy larga, en especial clavijas de hierro y clavos y otras infinitas clavazones que para ello es menester.

SIN.: clavar.

ANT.: desclavar.

FAM.: clavado, clavar, clavazón, clavera, clavetado, clavo, desclavar, enclavado. 
enclavijado, enclavijado [de enclavijar (DECH). Urrea, Vitruvio, Architectura, 1582]. adj. Trabado o unido con clavijas.

Besson, Teatro instrumentos, 1602, fol. M3v: El de en medio está apartado de la raya de mediodía dos mesuras veynte y dos partes, en el qual está a oriente el pandero ya dicho y otro también a ocidente enclavijado. // Juanelo Turriano, Veinte y un libros, a. 1605, fol. 147r: Muy bien ensamblados con otros dos o tres traviesas que los tengan muy bien asidos los unos con los otros, encaxados y muy bien enclavijados, como conviene que ellos estén para un tal effecto. // Juanelo Turriano, Veinte y un libros, a. 1605, fol. 147r: Las quales dos piezas, que suben derechas, han de yr encaxadas dentro de los maderos y an de yr enclavijadas muy bien.

SIN.: clavijado.

FAM.: clavija, clavijado, enclavijar.

enclavijar, enclavijar [de clavija (DECH). Besson, Teatro instrumentos, 1602]. v. tr. Trabar una cosa con otra uniéndolas entre sí y en cierto modo enjiriéndolas (Autoridades).

Besson, Teatro instrumentos, 1602, fol. M3v: Assí, dos ruedas dentejadas, por medio del movimiento de la balança, hazen que las ruedas armadas por la metad de uñezuelas las metan y enclavijen entrecambiadamente // Juanelo Turriano, Veinte y un libros, a. 1605, fol. 207v: De modo que, quando las crecidas vienen, suélese hazer dividir la puente en dos partes, que vaya [a] arrimarse a la orilla del río, hasta tanto que aya passado la corriente o la creçida; se buelve a tornar a juntar y tórnase a enclavijar como de primero. // Juanelo Turriano, Veinte y un libros, a. 1605, fol. 209r: Se juntan y se enclavijan con muy buenas clavijas de yerro, con sus chavetas.

FAM.: clavija, clavijado, enclavijado.

endentado, endentado [de endentar (DECH). Cano, Arte para fabricar naos, 1611]. adj. Encajado como los dientes de una rueda.

Cano, Arte para fabricar naos, (1611), 1611, fol. 34v: Sobre el bao a de llevar, assimismo, un corbatón endentado en él y con su entremiche, que endiente con el otro corbatón que viene de la otra cabeça del bao. // Cano, Arte para fabricar naos, 1611, fol. 134v: Los palmejares yrán corriendo por las junturas de los henchimientos de cabeças con los virotes hasta llegar a proa y popa bien endentados y clavados.

FAM.: dentado, dentadura, dentejado, diente, endentar.

endentar, endentar [de diente (DECH). García de Palacio, Instrución náuthica, 1587]. v. u. t. c. prnl. Encajar algo en otra cosa, como los dientes y los piñones de las ruedas (DRAE).

García de Palacio, Instrución náuthica, 1587, fol. 138r: Caperol: es lo que paresce y descubre de la roda de para donde suele endentarse la madre del espolón. // Cano, Arte para fabricar naos, 1611, fol. 34v: Sobre el bao a de llevar, assimismo, un corbatón endentado en él y con su entremiche, que endiente con el otro corbatón que viene de la 
otra cabeça del bao. // Cano, Arte para fabricar naos, 1611, fol. 54r: Entremiche: es un madero que endienta en los curbatones, que atraviesan de una parte a otra.

FAM.: dentado, dentadura, dentejado, endentado, diente.

engastado, engastado [de engastar. Arphe, Quilatador de la plata, 1572]. adj. Encajado y embutido en otra cosa .

Arphe, Quilatador de la plata, 1572, fol. 70v: Pero entre todos son los mejores los verdes que tienen venas coloradas, porque dizen tener virtud contra las calenturas y contra la hidropesía, y que reprime el fluxo de la sangre y, engastado en plata, ayuda a su virtud. // Apiano, Cosmographía, 1575, 76r: Y en la guerra son más expertos y tiene armas de fierro, lo que antes no tenían, sino eran de madera y pedernal verdinegro, que es la piedra más fuerte de todas engastada en madera. // Juanelo Turriano, Veinte y un libros, a. 1605, fol. 278v: Y también sirve a tener otras cosas firme que estén engastadas en yerro o en otra cosa.

FAM.: engastar, engaste, engastonar.

engastar, engastar [del lat. vg. *incastrare 'insertar, articular', de origen incierto. 1490, Alonso de Palencia (DECH). Collado, Plática Artillería, 1592]. v. tr. Encajar y embutir algo en otra cosa (DRAE).

Collado, Plática Artillería, 1592, fol. 50r: Procure de haver de la cera colorada de sellar cartas o, a falta de ésta, de otra qualquiera y engaste cada cabillo de los dichos encendidos en una poquita de cera.

SIN.: engastonar.

FAM.: engastado, engaste, engastonar.

engaste, engaste, engasto [de engastar. 1490, Alonso de Palencia (DECH). Collado, Plática Artillería, 1592]. sust. m. Cerco o guarnición de metal que abraza $\mathrm{y}$ asegura lo que se engasta (DRAE).

Collado, Plática Artillería, 1592, fol. 91v: Cruzados los unos sobre los otros, queden engastados en sus engastos hechos con la sierra y con largos y fuertes clavos enclavados por encima. // Juanelo Turriano, Veinte y un libros, a. 1605, fol. 141v: Como aquí abajo yrán señalados cómo han de ser hechos los engastes, que entran del uno al otro, y quándo se avían de encaxar el uno dentro del otro. // Juanelo Turriano, Veinte y un libros, a. 1605, fol. 323v: Y conviene que tengan unos engastes, a causa que, con la fuerça de la agua, no los pueda sacar de su lugar.

FAM.: engastado, engastar, engastonar.

engasto, $V$. engaste. 
engastonar, engastonar [de gastón 'engaste' (DECH). Celso, Reportorio universal leyes Castilla, 1553]. v. tr. Encajar y embutir algo en otra cosa (DRAE s. v. engastar).

Celso, Reportorio universal leyes Castilla, 1553, fol. CCLXIv: El platero que engastonare una piedra preciosa en un joyel o en añillo, si la quebrantare o dañare por su culpa o por falta de sabiduría, cúyo es el peligro, dezimos de suso, capítulo culpa, versículo III;

SIN.: engastar.

FAM.: engastado, engastar, engaste.

engeño, engeño [del lat. ingěnŭum 'íd.' (DRAE). Urrea, Vitruvio, Architectura, 1582]. sust. m. Mec. Máquina o artificio mecánico (DRAE s. v. ingenio).

Urrea, Vitruvio, Architectura, 1582, fol. 75v: Quando fueren bien calçadas y muy espesamente, entonces, con cleas, que son engeños para sacar agua, y con ruedas y tímpanos, que son las bombas o maças de las ruedas, puestos y assentados. // Besson, Teatro instrumentos, 1602, fol. D4v: Nuevo engeño para cortar árboles, por el qual, con sólo el movimiento de dos trabajadores, se haze tanta obra quanta podrán hazer ocho, por vía ordinaria. // Besson, Teatro instrumentos, 1602, fol. K3v: Nueva suerte de engeño con que las barcas, llegadas al puerto llenas y cargadas de agua o de otra qualquier cosa, sean con poca fatiga descargadas.

SIN.: ingenio ${ }_{2}$.

FAM.: ingeniar, ingeniería, ingeniero, ingenio, ingeniosamente, ingenioso.

engibato, engibato [tomado del lat. angỉbăta, angỉbătorum 'pequeñas figuras huecas' (Agustín Blánquez Fraile). Urrea, Vitruvio, Architectura, 1582]. sust. m. Mec. Artificio hidráulico musical que contiene figuras cuyo movimiento es accionado por la fuerza del agua.

Urrea, Vitruvio, Architectura, 1582, fol. 132v: No solamente halló Cthesibio esta razón, sino también otras muchas y de diversas maneras, las quales, forçadas con el agua apretada, hazen su effecto en el ayre, como las mierlas, que las llamamos nosotros pajarillas, hechas de barro; las quales, movida el agua, dan cierta boz; y los engibatos, que son ciertos artificios para sonar, hechos de agua maravillosos que mueven los sellos, que son ciertas figuras pequeñas, soplando, hazen que beban en aquel agua. // Urrea, Vitruvio, Architectura, 1582, fol. 140v: Engibatos: artificios en agua para sonar.

HIPER.: artificio $_{2}$. 
enjeta, enxeta [de jeta. Besson, Teatro instrumentos, 1602]. sust. f. Ingen. Hidrául. Grifo o llave que en los depósitos de líquidos regula la salida de estos. Besson, Teatro instrumentos, 1602, fol. F2v: Quando, pues, alguno ordenare infundir éste o aquel liquor, se ha tan solamente de sacar la enxeta de aquel cañal que más quisiere, do después ponga el embudo, y en él infunda comodíssimamente el liquor. // Besson, Teatro instrumentos, 1602, fol. F2v: Lo mesmo totalmente se ha de hazer, sino que no ha hombre de servirse de embudo, si quisieres sacar fuera d'este vaso uno, o dos, o todos los liquores. Entonces, digo que deves sacar aquella o esta enxeta, como quisieres.

SIN.: jeta.

HOL.: depósito.

FAM.: jeta.

[IMAGEN] Besson, Diego, Teatro de los instrumentos, Horacio Cardon (trad.), 1602, pág. F3r, figura 19.

enladrillado, enladrillado [de enladrillar (DECH). Lobato, Notas, a. 1585]. adj. u. t. c. sust. Cubierto con ladrillos.

Loçano, Alberto, Architectura, 1582, pág. 277: Hemos visto por lo enladrillado pintada la yerva campanilla, con sus vástigas hondeando, tendidas anchamente a la redonda. // Lobato, Notas, a. 1585, fol. 30: Con su cobertor de una bobedica de ladrillo de una frente de grueso por tejado y enladrillada por encima muy corriente y fuerte.

FAM.: enladrillar, ladrillo.

enladrillar, enladrillar [de ladrillo (DECH). Pérez de Moya, Arithmética práctica, 1562]. v. tr. Cubrir con ladrillos una superficie.

Pérez de Moya, Arithmética práctica, 1562, pág. 318: Es una sala que tiene de largo 14 pies y de ancho 10; hase de enladrillar con unas piedras o ladrillos, que cada uno tiene de largor 2 tercios de pie. // Loçano, Alberto, Architectura, 1582, pág. 53: Y, por dexar lo demás, vi unos ladrillos largos, no más que seys dedos; gruessos, uno; anchos, tres, pero con éstos, principalmente, enladrillavan los suelos espigadamente. // Juanelo Turriano, Veinte y un libros, a. 1605, fol. 272r: Házense ladrillos para calles, digo para enladrillarlas, los quales se ponen de canto.

FAM.: enladrillado, ladrillo.

enpalmadura, V. empalmadura.

enparejar, V. emparejar. 
enparexar, V. emparejar.

enpedrezer, V. empedrecerse.

enpeguntar, V. empeguntar.

enronar, V. enrunar.

enroscado, enroscado [de enroscar. Sagredo, Medidas Romano, 1526]. adj. Con forma de rosca.

Sagredo, Medidas Romano, 1526, pág. 23: Que semejavan los cabellos que las señoras y donzellas usavan traer liados, compuestos y enroscados sobre las orejas. // Urrea, Vitruvio, Architectura, 1582, fol. 117v: Y otra alrededor de la cabeça de la Cynosura está echada hasta sus pies, y retorcida y enroscada, se levanta desde la cabeça de la Ossa Menor a la Mayor. // Arphe, Varia Commensuración, 1585-87, fol. 8r: El galgo es perro ligero y que corre mucho; tiene la cola larga y enroscada y los pies de tras largos; el cuerpo, delgado; su altura, tres quartas de vara; es mortal enemigo de las liebres.

FAM.: enroscar, rosca.

enroscar, enroscar [de rosca. Entre 1493 y 1495, Nebrija (DRAE). Sagredo, Medidas Romano, 1526]. v. tr. u. t. c. prnl. Dar vueltas a modo de caracol o en espiral (Terreros s. v. enroscar).

Sagredo, Medidas Romano, 1526, pág. 16: Línea espiral, que por los griegos se dize línea hélyca, es la que sobre uno de sus cabos se rebuelve y enrosca a manera de caracol, sin jamás tocarse. // Sagredo, Medidas Romano, 1526, pág. 51: Como no pudiessen de allí passar, se tornavan a inclinar y bolver hazia baxo y se enroscavan, y otros más pequeños que d'ellos mesmos salían.

FAM.: enroscado, rosca.

2 [Besson, Teatro instrumentos, 1602]. v. tr. Dar vueltas en un mismo sentido a una cuerda para fijarla sobre un carrete o torno.

Besson, Teatro instrumentos, 1602, fol. Q3v: Hay una pértiga, de cuyo cabo cuelgan las cuerdas que se veen en la nave mayor, las quales enrosca un torno. 
enrunar, enronar [de enruna 'cascote, escombro' (DECH). Juanelo Turriano, Veinte y un libros, a. 1605]. v. tr. arag. Revestir el suelo con escombros.

Juanelo Turriano, Veinte y un libros, a. 1605, fol. 283r: Y a más d'esto, quando se cavan las cequias conviene apartar un trecho de la cequia la tierra, por razón, como es cosa movida, luego buelve a caer dentro de la misma cequia quando llueve, y ansí se va enronando.

ensolar, ensolar [de suelo. H. 1140, Cid (DECH). Loçano, Alberto, Architectura, 1582]. v. tr. Revestir el suelo con ladrillos, losas u otro material (DRAE s. v. solar).

Loçano, Alberto, Architectura, 1582, pág. 116: Síguese que se ensuele essa obra. // Loçano, Alberto, Architectura, 1582, pág. 116: Con tal que se escojan las muy duras con que se ensuele señaladamente aquella parte del camino.

FAM.: solera, suelo.

entibo, entivo [de entibar. Juanelo Turriano, Veinte y un libros, a. 1605]. sust. m. Ingen. Hidrául. arag. Represa de aguas en un río o canal para aumentar el salto o nivel de las mismas.

Juanelo Turriano, Veinte y un libros, a. 1605, fol. 123r: O pensar que con esso la levantará, porque es grandíssimo herror pensar esso, que con dezir que haziéndola hazer restaño o tesón o entivo o regolpho, que por esso se levantará en grande cantidad en alto el agua.

HIPER.: obra hidráulica.

entivo, V. entibo.

entorneado, entorneado [de entornear. Besson, Teatro instrumentos, 1602]. adj. Labrado en redondo.

Besson, Teatro instrumentos, 1602, fol. F3v: Finalmente, las pértigas de la barca, que se veen pendientes sobre el agua, tienen tres puntas entorneadas por la parte de arriba, de tres maderos travados entre sí, a forma de cruz, para que assí siempre impelan, ni jamás buelvan hazia atrás.

SIN.: torneado.

FAM.: destornear, retornear, torneable, torneado, tornear, tornero, tornillo, torno. 
entruesga, entruesga [de origen incierto quizá emparentado con el latín torques 'collar'. Lobato, Notas, c.1585]. sust. f. Mec. Rueda dentada de un molino. Lobato, Notas, c.1585, fol. 8: La cual rueda que mueve el agua ha de estar asentada por debajo del boleo que hace la dicha entruesga del husillo, para que la haga andar a la redonda. // Lobato, Notas, c.1585, fol. 15: Asentado en un eje fuerte, a la punta del cual tenga seis guijos de hierros, y en el eje injerida una entruesga que tenga la mitad menos del círculo que la grúa con sus pendazos, la cual dé en un carro de 16 palos. // Lobato, Notas, c.1585, fol. 20: Un molino de viento, sin velas y sin entruesga, hecho sobre una torre redonda, alta de treinta pies.

HIPER.: rueda.

HOL.: molino.

[IMAGEN] Lobato, Notas, c. 1585, fol. 21.

envención, envención, envinción [del lat. inventīō, inventǐonis 'íd.'. Besson, Teatro instrumentos, 1602]. sust. m. Cosa inventada.

Besson, Teatro instrumentos, 1602, fol. M2v: Envención nueva, no de tener en poco, con que, sin atanores y respiraderos, se puede sacar agua de un pozo muy hondo, con solamente dos poleas, de manera que el que tira el jugo sienta tan solamente la metad del peso. // Juanelo Turriano, Veinte y un libros, a. 1605, fol. 122v: Quiriendo tomar en ello una poca de especulaçión, vendrá a verificarse esta materia. Y esto he querido demostrar antes de enseñar el modo como se a de hazer esta envención. // Juanelo Turriano, Veinte y un libros, a. 1605, fol. 323v: Convendrá hazer una otra pared, o de piedra o de madera, la qual servirá con la otra pared de la pila para asentar las ruedas. La qual envinción es en la manera que va aquí abaxo señalado.

SIN.: invención ${ }_{2}$, inventiva $a_{2}$.

FAM.: invención, inventar, inventiva, inventivo, invento, inventor.

enventar, $V$. inventar.

envernizado, V. embarnizado.

envernizar, V. embarnizar. 
envigamiento, envigamiento [de envigar. Loçano, Alberto, Architectura, 1582]. sust. $\mathrm{m}$. Conjunto de vigas de madera que forman la estructura de un suelo o de una cubierta (Elucidario Arquitectura).

Loçano, Alberto, Architectura, 1582, pág. 25: Y no dudo sino que adelante, con liviano empujón o haziendo pequeño movimiento, se caerá, y si no fuesse detenida con los envigamientos de los techos, sin duda que de suyo, con la començada obliqüidad, se uviera caýdo. // Loçano, Alberto, Architectura, 1582, pág. 44: Para envigamientos en descubierto prefieren el enebro; y ésta, dize Plinio que tiene la misma natura que el cedro, aunque es más maciza. // Loçano, Alberto, Architectura, 1582, pág. 91: Vengo a los suelos, pues que ellos también imitan la naturaleza de los techos. De éstos, unos están al descubierto, otros en los envigamientos, y otros no están en los envigamientos.

FAM.: envigar, viga.

envigar, envigar [de viga (DRAE). Loçano, Alberto, Architectura, 1582]. v. tr. Asentar las vigas de un edificio (DRAE).

Loçano, Alberto, Architectura, 1582, pág. 43: Theophrasto piensa que para maderamientos y envigar es apto el nogal de Negroponte, porque, antes que se quiebre, da señal con sonido. // Loçano, Alberto, Architectura, 1582, pág. 44: Dizen que son inútiles, para envigar, los robles y la oliva, por ser pesados y porque dan lugar al peso, y casi de suyo se doblan.

FAM.: envigamiento, viga.

envinción, $V$. envención.

envolver, embolver, enbolver [del lat. ĭnvŏlvĕre 'íd.'. H. 1140, Cid (DECH). ]. v. tr. u. t. c. prnl. Dar vueltas en un mismo sentido a un hilo, alambre, papel, cuerda, etc., para fijarlo sobre un eje o carrete (DRAE s. v. arrollar).

Besson, Teatro instrumentos, 1602, fol. M2v: Se buelva al carrillo oriental de más arriba, después al ocidental de más arriba, y de allí al ocidental de más abaxo, para que, finalmente, se junten ambas en el torno al embolverse. // Besson, Teatro instrumentos, 1602, fol. P2v: Conviene, a más d'esto, notar que el polypasto está hecho de seys ruedezuelas, y que la cuerda que entra en él se estiende del torno del trispasto, y que su postrer cabo viene a embolverse y a atarse con el cabo de cuerda, de do pende el polypasto. // Juanelo Turriano, Veinte y un libros, a. 1605, fol. 148r: Y la regla tenga aquel cordel como tengo dicho, en tal modo que, enbolviendo en una clavija de yerro que esté puesta en un cavo del armadura o gata, que enbolviendo aquella clavija de yerro que esté puesta en un cavo de la armadura o gata, que enbolviendo aquella clavija de yerro, que suba o abaje hasta estar como conviene la regla con el nivel. 
FAM.: arrevolver, desarrevolver, desenvolver, envuelto, revolver, volteado, voltear, volver, vuelta.

envuelto, embuelto [del lat. vg. *involtus 'íd.' (DRAE). Besson, Teatro instrumentos, 1602]. adj. Dicho de una cuerda u otro objeto largo y flexible: enroscado, fijado mediante vueltas sobre algo.

Besson, Teatro instrumentos, 1602, fol. Hv: Dos ruedas y un pandero o barrilejo en medio, al enderredor del qual hay una cadena embuelta, que circuye la redondez de la rueda mayor, de la suerte que entre nosotros están las cuerdas en los tornos de las mugeres. // Besson, Teatro instrumentos, 1602, fol. K2v: Debaxo, hazia mediodía, están dos tornos: el uno menor, que tiene una cuerda embuelta y lo rueda un hombre. // Juanelo Turriano, Veinte y un libros, a. 1605, fol. 364v: Podrase tomar un madero que sea muy gruesso y ochavarle a la redonda, y en estos ochavos se le ha de ir cavando una canal que vaya embuelta como caracol.

FAM.: arrevolver, desarrevolver, desenvolver, envolver, revolver, volteado, voltear, volver, vuelta.

enxeta, V. enjeta.

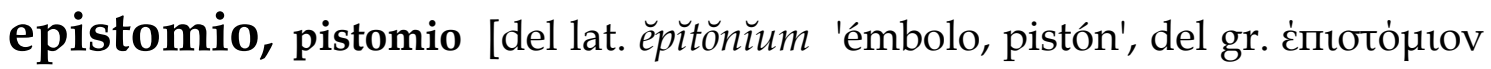
'íd.' (Lewis Short). Urrea, Vitruvio, Architectura, 1582]. sust. m. Ingen. Hidrául. Grifo, espita o llave para abrir o cerrar conductos de agua.

Urrea, Vitruvio, Architectura, 1582, fol. 133r: Y en cada canal está un pistomio, que es una llave con aguamaniles de hierro, los quales, quando se tuercen, abren las narizes de las canales.

HOL.: conducto.

equilibra, equilibra [tomado del lat. aequilibra 'íd.'. ]. sust. f.

en [Collado, Plática Artillería, 1592]. loc. adv. En un plano horizontal (DRAE s. v. a nivel).

Collado, Plática Artillería, 1592, fol. 4r: Era sustentada en el ayre ésta tirante y con cadenas colgada del cielo de la máquina, acomodada en tal manera que siempre estava en equilibra o en balança. // Collado, Plática Artillería, 1592, fol. 18v: El segundo officio es que los orejones sirven de polo o fiel que rige y govierna la pieça de artillería, assí como haze el fiel del peso o de la balança, el qual la haze estar en equilibra, mediante la qual suspensión de los orejones. // Collado, Plática Artillería, 1592, fol. 43r: Y, estando assí, colgarás el un plomillo de una parte y el otro de la otra, haziendo que 
por cada lado toquen los hilos el metal de la pieça y que quede la regla a nivel, en equilibra o en balança.

SIN.: en balanza.

equipondio, ecquipondio [tomado del lat. ecquis pondus 'mismo peso'. Urrea, Vitruvio, Architectura, 1582]. sust. m. Pieza metálica que se utiliza como término de comparación para determinar el peso de un cuerpo (DRAE s. v. pesa). Urrea, Vitruvio, Architectura, 1582, fol. 128v: Esto se puede considerar en las balanças y peso de pesar, quando el asa más cercana a la cabeça, de la qual está colgada la balança como centro, el ecquipondio por la otra parte del peso, andando por sus puntos. // Urrea, Vitruvio, Architectura, 1582, fol. 128v: Assí, la brevedad del ecquipondio o pesa, siendo más flaca, alçando mayor carga blandamente y sin vehemencia, haze que suba de baxo arriba.

SIN.: pesa, pondos.

HOL.: balanza.

ergata, ergata, ergate, hergate [tomado del lat. ergăta 'máquina para subir pesos'. (Laterculi). Urrea, Vitruvio, Architectura, 1582]. sust. f. Mec. Torno de eje vertical que se emplea para mover grandes pesos arrastrándolos horizontalmente por medio de una maroma o cable que se va arrollando en él a medida que gira.

Urrea, Vitruvio, Architectura, 1582, fol. 126r: Demás d'esto, otra soga rebuelta alrededor del tímpano se lleva a la que llaman ergata, que es un madero a que se rebuelve la maroma, y está rebolviendo el tímpano y exe. // Juanelo Turriano, Veinte y un libros, a. 1605, fol. 145r: Para aver de bajar esta máchina, convendrá tener en lo alto de la peña asentado un ergate o torno, aunque es differente el ergate del torno, aunque los dos sirven a una misma cosa y hazen un mismo effecto. // Juanelo Turriano, Veinte y un libros, a. 1605, fol. 383r: El hergate es instrumento que lleva los pesos en alto, y aun pesos muy grandíssimos. Como se les sepa accomodar las poleolas y saber ir doblando las cuerdas por ellas, llevará en alto peso, por grande que sea.

SIN.: árgana, árgano, cabrestante, carquesio.

HIPER.: máquina.

[IMAGEN] Pseudo-Juanelo Turriano, Los ventiún libros, c. 1605, fol. 146r, fig. 112.

ergate, V. ergata. 
erir, V. herir.

errada, V. herrada.

erramienta, V. herramienta.

escala, escala, scala [del lat. scāla 'escalón', 'escala', escalera'. 1490, Alonso de Palencia (DECH). Ortega, Conpusición Arismética y Geometría, 1512]. sust. f. Escalera de mano, hecha de madera, de cuerda o de ambas cosas.

Ortega, Conpusición Arismética y Geometría, 1512, fol. 202r: Un cavallero tiene una torre, la qual tiene 50 canas de alto, y quiere fazer una escala que se aparte 40 canas desde el cimiento de la torre. // Lobato, Notas, a. 1585, fol. 12: Y, vista su postura, determinaron de a la salida del dicho valle hacer una muy fuerte muralla de ciento y cincuenta pies de altura, y que llegase a cerrar de una sierra a otra con fuerte prendedero, la cual tiene 100 pies de grueso, y por parte de fuera una torre en el medio que sirve de estribo y de escala para subirla y bajarla. // Besson, Teatro instrumentos, 1602, fol. H2v: La scala que se vee sirve solamente a subir y a baxar de la muela, como también la barra de hierro, para que se tenga a ella el que, cargado, sube o baxa.

escansorio, escansorio, scansorio [tomado del lat. scānsorius, scānsoria 'que sube'. Urrea, Vitruvio, Architectura, 1582]. adj. u. t. c. sust. Mec. Dicho de una máquina: que sirve para subir cargas.

Urrea, Vitruvio, Architectura, 1582, fol. 123v: La escansoria es quando las máchinas están tan bien puestas, que se pueda subir sin peligro a la altura para la vista del aparato, después de fortalecidas las maderas y las que traviessan de una parte a otra bien enclavadas. // Urrea, Vitruvio, Architectura, 1582, fol. 123v: La que llaman escansoria no se alaba por el arte, sino por la osadía; ésta consta de cadenas y atravesaños y juntas dobladas, y con sustentáculos de erismas, que son guardas o escalas para subir. // Herrera, Institución Academia, 1584, fol. 10v: Y para se hazer versado en la práctica de muchas máchinas y saber qué es máchina, lea a Vitruvio, en el 10 libro, el qual la divide en tres: scansoria, spirital y tractoria, a las quales se ayunta la tormentaria.

HIPER.: máquina.

escarço, V. escarzo. 
escarzo, escarço [de escarzar. ]. sust. m.

al [Juanelo Turriano, Veinte y un libros, a. 1605]. loc. adv. Por panales o diferentes capas.

Juanelo Turriano, Veinte y un libros, a. 1605, fol. 355v: Y quando se prensa, se va poniendo al escarço, a suelos, y entre el un suelo y el otro se pone entre medias unas estericas hechas de esparto texido, de dos palmos de ancho.

escava, V. excava.

escavar, V. excavar.

escoda, escoda [de escodar. 1490, Alonso de Palencia (DECH). Juanelo Turriano, Veinte y un libros, a. 1605]. sust. f. arag. Herramienta con forma de martillo, con corte en ambos lados, que se utiliza para labrar piedras y picar paredes.

Juanelo Turriano, Veinte y un libros, a. 1605, fol. 409r: Pico de dos puntas. Escoda martillo. Maça. Açada martillo.

HIPER.: herramienta.

[IMAGEN] Pseudo-Juanelo Turriano, Los ventiún libros, c. 1605, fol. 252r, fig. 318, situada en el centro de la imagen, a la derecha.

escorpión, escorpión, scorpión [tomado del lat. scorpiō, scorpiōnis 'íd.'. H. 1220-1250, Berceo (DECH). Urrea, Vitruvio, Architectura, 1582]. sust. m. Mec. Máquina para elevar pesos, montada sobre ruedas desiguales (Salinero s. v. anisociclo).

Urrea, Vitruvio, Architectura, 1582, fol. 123v: Hazen aquello para que son puestos, como se ve los que llaman escorpiones y los anisociclos, que son instrumentos que se mueven en rededor. // Urrea, Vitruvio, Architectura, 1582, fol. 139r: Anisociclos: máchinas que se mueven alrededor; dízense escorpiones. // Urrea, Vitruvio, Architectura, 1582, fol. 140v: Escorpiones: máchinas e instrumentos que se mueven en rededor; lo mesmo es anisociclos.

SIN.: anisociclo.

HIPER.: máquina. 
escorrer, escorrer [del lat. vg. *excorrı̆gĕre 'íd.', derivado de corrĭgĕre 'enderezar', 'corregir', 'rectificar el curso (de alguien o de algo)'. H. 1140, Cid (DECH). Juanelo Turriano, Veinte y un libros, a. 1605]. v. intr. u. t. c. prnl. Dicho de un objeto: destilar y dejar caer gota a gota el líquido que contiene.

Juanelo Turriano, Veinte y un libros, a. 1605, fol. 339r: Y toda aquella agua que se escorre de la piedra los postreros días, dévese hazer yr a algún recetáculo para donde se recoixca. // Juanelo Turriano, Veinte y un libros, a. 1605, fol. 343r: Congélase la agua en tres o quatro días, según los soles hazen fuertes, y después de congelada, la cogen y la ponen en unas cosas que tiene al fin de las eras, hechas de mimbres, para que se acave de escorrer la agua que le tocava. // Juanelo Turriano, Veinte y un libros, a. 1605, fol. 478r: Hecho esso, hase de sacar la figura y dexarla escorrer encima del vaso.

SIN.: escurrir.

FAM.: escurridero, escurrido, escurrir.

escudilla, escudilla [del lat. scutělla 'copita', 'bandeja'. S. XIII, Aranceles santanderinos. (DECH). Sagredo, Medidas Romano, 1526]. sust. f. Vasija ancha y de forma de una media esfera, que se usa comúnmente para servir en ella la sopa y el caldo (DRAE).

Sagredo, Medidas Romano, 1526, pág. 29: Parece mayor de lo que es, como por experiencia lo puedes ver, metiendo en una escudilla vazía una sortija o moneda. Si te apartares hazia tras tanto que la pierdas de vista, y entonces te fuere echado del agua en la escudilla, verás la joya que primero no veýas, e aun te puedes retraer más, y no perderla de vista. // Besson, Teatro instrumentos, 1602, fol. Ov: Al enderredor de estos dos va una cadena sin fin, que trahe fixas ciertas escudillas, entre sí oppuestas, para que siempre, a qualquier movimiento, la una se hincha de agua. // Juanelo Turriano, Veinte y un libros, a. 1605, fol. 274r: El qual betún se haze en esta manera: tómase calcina viva, ladrillo molido, pedaços de platos y de escudillas de barro, y molerlas.

FAM.: escudillero.

escudillero, escudillero [de escudilla. Juanelo Turriano, Veinte y un libros, a. 1605]. sust. $m$. Persona que tiene por oficio el fabricar escudillas.

Juanelo Turriano, Veinte y un libros, a. 1605, fol. 307r: Ay otro género de molino, el qual se llama de bomba, que tiene la canal cubierta y tiene rodete, que anda llana la rueda como la de los escudilleros o cantareros.

FAM.: escudilla.

escurridero, escurridero [de escurrir (DECH). Juanelo Turriano, Veinte y un libros, a. 1605]. sust. m. Ingen. Hidrául. Lugar por el que el agua tomada de una acequia vuelve al río. 
Juanelo Turriano, Veinte y un libros, a. 1605, fol. 108v: Y donde es la C es para escurridero, que ordinariamente se haze en qualquier azequia, que buelve al mismo río quando quiere.

HOL.: obra hidráulica.

FAM.: escorrer, escurrido, escurrir.

[IMAGEN] Pseudo-Juanelo Turriano, Los ventiún libros, c. 1605, fol. 108v, fig. 76. La letra C marca el lugar en el que se pondría el escurridero.

escurrir, escurrir [del lat. vg. *excorrŭgĕre 'íd.', derivado de corrĭgĕre 'enderezar', 'corregir', 'rectificar el curso (de alguien o de algo)'. Pérez Vargas, De re metallica, 1568]. v. intr. u. t. c. prnl. Despedir el líquido contenido.

Pérez Vargas, De re metallica, 1568, fol. 200r: Y se despega y enxuga en unas tablas puestas acostadas y pendientes, a manera de tejado, porque el humor se escurra. // Loçano, Alberto, Architectura, 1582, pág. 66: Los lados de la fossa se han de fortalecer por una y otra parte con palos, çarzos, tabla, céspedes, lama y semejantes cosas, para que el agua no escurra. // Collado, Plática Artillería, 1592, fol. 84r: Hecho esto, ponla al fuego y hierva tanto que quede en el tercio y, estando assí, sácala del fuego, dexa la cuerda escurrir sobre la caldera misma y enxúgala al sol, que será perfectíssima, después de bien maçeada, como se usa.

SIN.: escorrer.

FAM.: escorrer, escurridero, escurrido.

especo, especo [tomado del lat. specŭs 'canal, conducción de agua' (Segura Munguía). Juanelo Turriano, Veinte y un libros, a. 1605]. sust. m. Ingen. Hidrául. Captación o cabecera de una conducción de agua.

Juanelo Turriano, Veinte y un libros, a. 1605, fol. 77r: Los legistas le llaman a esse lugar inçile y Vitruvio le llama especo. Llamáronle ansí por causa de la incissión que se haze en el suelo o en la peña. / / Juanelo Turriano, Veinte y un libros, a. 1605, fol. 77v: Y León Baptista , De re edificandi, le llama inçile, el principio, o especo, y al fin d'ella emissario o castelo.

SIN.: incile.

HOL.: obra hidráulica.

espiradero, espiradero [de espirar (DECH). Montes, Instrucción y regimiento, 1537]. sust. m. Ingen. Hidrául. Abertura por donde entra y sale el aire en las obras de ingeniería hidráulica.

Juanelo Turriano, Veinte y un libros, a. 1605, fol. 95r: Y con estos espiraderos se sacará la tierra con muy menos gasto. // Juanelo Turriano, Veinte y un libros, a. 1605, fol. 197r: A los que están en el campo y son cubiertos de bóbeda, que se le haze una entrada y a 
la parte opuesta se le haze un espiradero, a causa que pueda entrar el ayre y mover el que está ençerrado dentro. // Juanelo Turriano, Veinte y un libros, a. 1605, fol. 197v: Donde es la A es la entrada para el algive. La F es la escala para bajar. La B es los costados. La C es un espiradero del ayre. La D es la parte de dentro. Donde es la E es donde entra la agua.

SIN.: respiradero.

HOL.: obra hidráulica.

FAM.: espirar.

[IMAGEN] Pseudo-Juanelo Turriano, Los ventiún libros, c. 1605, fol. 312v, fig. 220, letra G.

espirar, espirar, expirar [tomado del lat. spìrāre 'soplar', 'respirar'. H. 1400, Gutierre de Toledo (DECH). Loçano, Alberto, Architectura, 1582]. v. intr. Exhalar, despedir de sí gases, vapores u olores.

Loçano, Alberto, Architectura, 1582, pág. 342: Aprovechará mucho si por debajo del suelo espirare el ayre. // Juanelo Turriano, Veinte y un libros, a. 1605, fol. 127r: Y caso que se cavase dos o más en tal aposento, no sentirían punto de ayre espirar en el tal aposento. // Juanelo Turriano, Veinte y un libros, a. 1605, fol. 435r: Y en la parte más alta ha de haver un corcho, para que sustente el cuero encima del agua. Y por esta trompa podrá expirar y respirar.

FAM.: espiradero.

espirital, spirital [tomado del lat. spīritālis 'espiritual, inmaterial'. H. 12201250, Berceo (DECH). Herrera, Institución Academia, 1584]. adj. u. t. c. sust. Mec. Dicho de una máquina: que funciona con aire.

Herrera, Institución Academia, 1584, fol. 10v: Y para se hazer versado en la práctica de muchas máchinas y saber qué es máchina, lea a Vitruvio, en el 10 libro, el qual la divide en tres: scansoria, spirital y tractoria, a las quales se ayunta la tormentaria.

SIN.: espiritual.

HIPER.: máquina.

FAM.: espiritual.

espiritual, espiritual, spiritual [tomado del lat. spīrŭtŭālis 'espiritual, inmaterial'. XIV, Juan Manuel (DECH). Urrea, Vitruvio, Architectura, 1582]. adj. u. t. c. sust. Mec. Dicho de una máquina: que funciona con aire.

Urrea, Vitruvio, Architectura, 1582, fol. 123v: Ay un género de máchinas que llaman los griegos achrobaticon, que es para subir; los latinos la llaman scansoria. Otra que llama el griego pneumáticon, que es espiritual. La tercera, es tractoria, para traer arrastrando, 
y llámase en griego banacison. // Urrea, Vitruvio, Architectura, 1582, fol. 123v: La espiritual es quando el espíritu, impedido con apretarle, da vozes orgánicas.

SIN.: espirital.

HIPER.: máquina.

FAM.: espirital.

espuerta, espuerta [del lat. sporta 'íd.'. 1331, Invent. Arag. (DECH). Pérez Vargas, De re metallica, 1568]. sust. f. Especie de cesta de esparto, palma u otra materia, con dos asas, que sirve para llevar de una parte a otra escombros, tierra $\mathrm{u}$ otras cosas semejantes (DRAE).

Loçano, Alberto, Architectura, 1582, pág. 345: Pondréys unas palancas, y lo estendido d'ellas cargaldo con espuertas de arena; levantarán el peso poco a poco sin bambalear muy ygualmente. // Collado, Plática Artillería, 1592, fol. 64v: Los gastadores han de estar assentados todos, arrimadas las espaldas a las paredes de la mina y tan lexos el uno del otro que cómodamente se puedan dar las espuertas de mano en mano, las quales, por la una parte, salen las llenas y por la otra entran las vazías, pero mudándose de hora en hora porqu'el trabajo se reparta. // Juanelo Turriano, Veinte y un libros, a. 1605, fol. 172v: Para hazer estas obras es necessario proveer de barcos pequeños y grandes, y de mucha madera gruessa y delgada, mucha piedra, cal, arena, clavazones, qüerdas, anillas portaderas, espuertas de mimbre, bacietas o gamellas, açadas, palas, ligones, garruchas, carros, sierras, martillos, picos y otras infinitas cosas que para ello es menester.

estabilidad, estabilidad, stabilidad [tomado del lat. stabilĭtas, stabilìtātis 'íd.' (DRAE). García de Palacio, Instrución náuthica, 1587]. sust. f. Fís. Cualidad de estable (DRAE).

García de Palacio, Diálogos militares, 1583, fol. 131v: Manifiesta cosa es que, quanta más fuerça y estabilidad halla la bala en el resistente, haze más effecto. $Y$, assí, porque la muralla es más sólida, stable y firme, y que más impide al movimiento de la bala tirada por alguna pieça de artillería, padesce mayor daño de lo que haze un navío o galera, que consiente algún tanto al golpe de la bala. / / Collado, Plática Artillería, 1592, fol. 40r: El motu natural puro es quando qualquier cuerpo grave y pesado se parte del lugar de su stabilidad y reposo y, naturalmente cayendo, busca otro nuevo lugar donde reposarse, qu'es el centro, como lo haría la bala que en la alteza de una torre fuesse detenida. // Collado, Plática Artillería, 1592, fol. 40r: En el qual motu natural, quanto mayor será la alteza de donde aquel peso se parte, tanto mayor velocidad y ligereza se adquiere; digo que, quanto más del lugar de su stabilidad se alexa, tanto más velocemente camina.

ANT.: inestabilidad.

FAM.: estable, inestabilidad. 
estable, estable, stable [del lat. stabĭlis ''íd'. Doc. de 1200 (DECH). Medina, Arte de navegar, 1545]. adj. Fís. Que se mantiene sin peligro de cambiar, caer o desaparecer (DRAE).

Medina, Arte de navegar, 1545, fol. 84r: Assí que todos estos vientos siempre están fixos y estables en sus mismos puntos, sin hazer variación ni differencia ninguna, y assí todo lo que con el aguja se situare por razón de su diferencia no corresponderá con el punto cierto conforme a los vientos que en a carta están. // García de Palacio, Diálogos militares, 1583, fol. 131v: Y, assí, porque la muralla es más sólida, stable y firme, y que más impide al movimiento de la bala tirada por alguna pieça de artillería, padesce mayor daño de lo que haze un navío o galera, que consiente algún tanto al golpe de la bala, por ser menos sólida y firme. // Collado, Plática Artillería, 1592, fol. 88v: La tercera consideración es si la puente ha de ser stable y permanescer por algún tiempo hecha, o si, acabado de passar un exército, ha de ser desarmada.

FAM.: estabilidad, inestabilidad.

estampa, estampa, stampa [de estampar. Garcilaso (DECH). Pérez de Moya, Arithmética práctica, 1562]. sust. u. t. c. m. Efigie o imagen impresa, mediante la invención del torno, con molde o lámina grabada y abierta a burí (Autoridades). Pérez de Moya, Arithmética práctica, 1562, pág. 452: En el qual se declaran algunos characteres que yo uso, por no aver en la stampa otros. // Pérez Vargas, De re metallica, 1568, fol. 151r: Y la plata occupa las concavidades del dibuxo en el estampa y queda en la plancha el mesmo dibuxo señalado, con el qual se haze la mesma obra que se ha dicho de sobrepuestos. // Lechuga, Discurso de la Artillería, 1611, IX: Item, que si las escalas en las figuras no dieren lo justo en ellas, entiendan es defecto de las estampas, hecho por el que las labró, y que para remedio de esto miren lo que digo.

FAM.: estampador, estampar.

estampador, stampador [de estampar (DECH). Collado, Plática Artillería, 1592]. sust. $\mathrm{m}$. Persona que tiene por oficio el imprimir o que tiene a su cargo una imprenta.

Collado, Plática Artillería, 1592, Ir: En Milán, por Pablo Gotardo Poncio, stampador de la Real Cámara, el año 1592. // Besson, Teatro instrumentos, 1602, fol. Q2v: La qual es differente de las ordinarias de los stampadores en esto: que, ahunque se dexe, ni haya quien prense, con todo, ella siempre apriete, lo que no sucede en las otras.

SIN.: impresor, imprimidor.

FAM.: estampa, estampar.

estampar, estampar, stampar [probablemente del fr. estamper 'íd.', antiguamente 'aplastar', 'machacar', después 'estampar'. 1503-1536, Garcilaso 
(DECH). Pérez de Moya, Arithmética práctica, 1562]. v. tr. Imprimir, sacar en estampas algo; como las letras, las imágenes o dibujos contenidos en un molde (DRAE).

Pérez de Moya, Arithmética práctica, 1562, pág. 635: Esta moneda tenía estampada una ave dicha noctua. // Besson, Teatro instrumentos, 1602, fol. Q2v: Aquí, finalmente, damos una nueva manera de prensa y angosta compuesta de tres caracoles, la qual podrá servir a la vendimia, y a prensar paños, y para stampar cartas geográphicas y tapicerías encima de cuero o tela. // Juanelo Turriano, Veinte y un libros, a. 1605, fol. 276v: Puedes hazer qualquier molde para estampar en él qualquier cosa.

FAM.: estampa, estampador.

estancado, estancado [de estancar. Loçano, Alberto, Architectura, 1582]. adj. Dicho de un líquido: detenido y parado su curso.

Loçano, Alberto, Architectura, 1582, pág. 172: Y, demás d'esto, está también en la mano que los grandes pesos de los navíos son movidos con liviano empujón por las aguas estancadas, si perseveráys en el traer. // Loçano, Alberto, Architectura, 1582, pág. 337: Junto a Larissa de Thessalia estava el campo cubierto con agua estancada y perezosa, y por essa causa tenían el ayre gruesso y muy caliente. // Lobato, Notas, a. 1585, fol. 33: Yo, Francisco Lobato del Canto, imaginé una máquina de molino de agua estancada y de regolfo, y no le puse en efecto hasta el año 1576 años.

SIN.: estanco.

FAM.: estanca, estancar, estanque.

estancar, estancar [probablemente del prerrom. *tanko 'yo sujeto', 'yo fijo'. S. XIII, Libro de los Cavallos (DECH). Pérez Vargas, De re metallica, 1568]. v. tr. u. t. c. prnl. Detener y parar el curso y corriente de un líquido (DRAE).

Pérez Vargas, De re metallica, 1568, fol. 35r: Después d'esto, considerar los arroyos y lagunas que corren por los montes, si paresce el agua verde y tienen sabor de metal, y si en el estío son muy frías y el invierno muy calientes o tibias, y si donde se estancan y reposan las aguas hazen y dexan un asiento con cierta putrefactión verde, pegajosa y gruessa. // Loçano, Alberto, Architectura, 1582, pág. 305: Junto a Tempe se estancava la agua muy ancha, y Hércules, haziendo una fossa, la limpio y quemó la hydra; desde el qual lugar los acometimientos de las aguas destruýan la ciudad propinqua, como dizen. // Poça, Hydrografía, 1585, fol. 36r: Bien sé que no faltará quien ponga dolencias en esta invención diziendo que la arena se enhumudece, que se estanca, o que no yguala a su curso en la bonança y tormenta.

FAM.: estanca, estancado, estanque.

estanco, estanco [de estancar. 1241, Fuero Juzgo (DRAE). Pérez Vargas, De re metallica, 1568]. adj. Dicho de un líquido: detenido y parado su curso. 
Pérez Vargas, De re metallica, 1568, fol. 6r: Antes el agua siempre la penetra y no para en ella, aviéndose de quajar y convertir en metal, convenía qu'el agua en ella se detuviesse estanca por mucho tiempo.

SIN.: estancado.

FAM.: estancado, estancar, estanque.

estanque, estanque [de estancar. 1490, Alonso de Palencia, Nebrija (DECH). Pérez Vargas, De re metallica, 1568]. sust. m. Ingen. Hidrául. Balsa construida para recoger el agua, con fines utilitarios, como proveer al riego, criar peces, etc., o meramente ornamentales (DRAE).

Pérez Vargas, De re metallica, 1568, fol. 90v: En Carnia hazen un cierto lugar pendiente, ynclinado hazia una parte, como una haz de un estanque que lleva corriente. // Lobato, Notas, a. 1585, fol. 8: Y el agua con que moliere se ha de volver al pozo o estanque de donde salió por su pie. // Juanelo Turriano, Veinte y un libros, a. 1605, fol. 191v: Antes que se tracte de los lagos y de los estanques y de los almarchales, conviene que tractemos primero de las aguas de las lluvias, por causa que la más parte de las aguas de los lagos y de los estanques son mucha parte de las lluvias o de las nieves que se derriten en la primavera.

HIPER.: obra hidráulica.

FAM.: estanca, estancado, estancar.

estípite, estípite [tomado del lat. stīpěs, stīprtis 'tronco', 'estaca', 'rama'. 17261739, Autoridades (DECH). Juanelo Turriano, Veinte y un libros, a. 1605]. sust. $\mathrm{m}$. Eje de una puerta.

Juanelo Turriano, Veinte y un libros, a. 1605, fol. 242v: Theophrasto dize que los antiguos acostumbravan a hazer sus puertas de latonero o de lecio, y de box y de olmo, por raçón que conservan estas maderas mucho tiempo su dureza, y que son maderas muy excelentes para hazer estípites de puertas.

estral, estral [del latín hispánico dextralis 'íd.' (DECH). Juanelo Turriano, Veinte y un libros, a. 1605]. sust. $m$. arag. Hacha pequeña que se maneja por lo general con una sola mano (DRAE s. v. destral).

Juanelo Turriano, Veinte y un libros, a. 1605, fol. 248v: Llevan sólo barrena para agujerear las maderas, y el estral para cortar, para hacer remos y para cortar ligarças, y palos para empuxar las almadías y para travarlas con las ligarças. // Juanelo Turriano, Veinte y un libros, a. 1605, fol. 359v: En la figura: Segur o estral. Açuela. Axa. Tintero de almagra. Compás. Liña. Palanca. Ruello. Barrena. Ruello.

HIPER.: herramienta.

[IMAGEN] Pseudo-Juanelo Turriano, Los ventiún libros, c. 1605, fol. 248r, fig. 316. 
estrumento, estrumento [del lat. instrümentum 'íd.'. Juanelo Turriano, Veinte y un libros, a. 1605]. sust. m. Ingenio o artificio, generalmente de pequeñas dimensiones, que sirve para hacer algo.

Juanelo Turriano, Veinte y un libros, a. 1605, fol. 285v: El asentar de los caños, conviene tener un estrumento que señale la declinación de lo que a de yr declinando, el qual a de ser una regla de veynte pies en largo y que tenga a los cabos dos pedaços de madera afixados. // Juanelo Turriano, Veinte y un libros, a. 1605, fol. 328r: De modo que este burato, que ansí le llaman en Italia, donde ello se ha inventado esta invención para serner arina, y donde se haze mucho excercisio de masar, éste es un estrumento de mucho provecho y de muy grande descanço, que qualquiera puede cerner sin tener qüenta a más de cerner. // Juanelo Turriano, Veinte y un libros, a. 1605, fol. 352v: La qual máquina es hecha en esta manera: acomódase dentro de un poço este estrumento, o dentro de un río, para sacar agua para el servicio humano, y esto es tan sólo agua de bever, ya que ella sea para regar algún vergel de algunas flores o para algún otro servicio.

SIN.: instrumento.

FAM.: instrumental, instrumento.

estufa, estufa [de estufar 'caldear'. 1490, Alonso de Palencia (DECH). Apiano, Cosmographía, 1575]. sust. f. Aposento recogido y abrigado, al cual se le da calor artificiosamente con fuego por la parte exterior (Autoridades).

Apiano, Cosmographía, 1575, fol. 48r: Ay en la cumbre d'él una boca de continuo fuego. Es el territorio d'él de tofo, que es una piedra negra de que usan en las estufas. // Juanelo Turriano, Veinte y un libros, a. 1605, fol. 14v: No en otra manera de como se haze en las estufas, se haga aquel vapor caliente que se haze de las muy ardentíssimas fornazas que son hechos por el medio de los caños o fístulas o de algunas piedras toscas. // Lechuga, Discurso de la Artillería, 1611, pág. 263: Respecto que un hombre solo no puede dar recado a hazer la pólvora que es menester, ni muchos, por los defectos que puede aver de las pistas, molinos, falta de sol, y por ésta, de calderas, estufas y otras cosas que no conocen los que no están sitiados, aunque lo ayan estado.

excava, escava [de excavar (DECH). Anónimo, Repertorio tiempos, 1554]. sust. f. Efecto de quitar la tierra alrededor de una planta (DRAE).

Anónimo, Repertorio tiempos, 1554, fol. XXIXr: Y en las tierras tempranas se pueden castrar los ganados; y es bien echar el estiércol podrido en las escavas de los árboles que son tardíos; hazer valladares, arar los campos que han de sembrar. // Anónimo, Repertorio tiempos, 1554, fol. XXXr: Es bueno en las tierras frías desmochar las olivas; echar alpechín no salado y aguado en las escavas de los olivos. // Anónimo, Repertorio tiempos, 1554, fol. XXXIv: En las tierras calientes es bien en esta menguante cubrir los árboles, es a saber, las escavas, y lo mismo a las vides.

FAM.: cava, cavadura, cavar, encavadura, excavar, socavado, socavar. 
excavado, excavado [de excavar. Roiz, Reloges solares, 1575]. adj. Cavado, horadado o labrado (DRAE).

Roiz, Reloges solares, 1575, pág. 94: Harase en una piedra, o en otra cosa sólida, un semicírculo excavado del modo del círculo precedente, como si dixéssemos en un medio cedaço. // Roiz, Reloges solares, 1575, pág. 124: En la figura: Figura de un relox equinocial traçado en un redondo excavado por la parte de dentro, cuya superficie mixta representa la equinocial. // Roiz, Reloges solares, 1575, pág. 124: En la figura: Figura de un relox equinocial, traçado en el gruesso de un medio redondo perfectamente excavado.

FAM.: cava, cavadura, cavar, encavadura, excava, excavar, socavado, socavar.

excavar, escavar [del lat. excavāre 'íd.'. 1235, Menéndez Pidal (DECH). Juanelo Turriano, Veinte y un libros, a. 1605]. v. tr. Hacer en el terreno hoyos, zanjas, desmontes, pozos o galerías subterráneas (DRAE).

Juanelo Turriano, Veinte y un libros, a. 1605, fol. 169r: Y esto es por causa de la caýda del agua, que escava el suelo, por causa del grande ímpetu con que cae, con tanto rigor, que allega hasta el suelo.

SIN.: cavar.

FAM.: cava, cavadura, cavar, encavadura, excava, excavado, socavado, socavar.

exe, V. eje.

expirar, V. espirar. 


\section{farina, V. harina.}

farinal, farinal [de farina. Juanelo Turriano, Veinte y un libros, c.1605]. sust. m. arag. Cajón que recibe la harina en un molino.

Juanelo Turriano, Veinte y un libros, c.1605, fol. 311v: Y el cubo es B. El rodete es C. Y la muela D. La taona o gruença donde se pone el trigo es E. El canalete donde cae el trigo en la muela es F. Y el templador es G. El farinal es H. La saetía es I. Y en este género de molino no ay más invención, más de serle añadida la balsa. // Juanelo Turriano, Veinte y un libros, c.1605, fol. 312r: La taona es G. El templador es H, el qual es para hazer que cayga el grano dentro de la muela, o muy apriesa o muy a espacio. Y el canalote es el que guía el grano a la muela. Y el farinal es I, donde se recoje la arina molida. Y esto es quanto a esta manera de molino. // Juanelo Turriano, Veinte y un libros, c.1605, fol. 317r: Y en ella no se dexa cosa abierta, eccepto un agujero en el medio, por donde ha de caer la arina en el farinal, que es una caxa de madera grande, que caben dos caýzes de arina, y tres, y más, según la freqüentación del molino.

SIN.: caja farinal.

HOL.: molino.

FAM.: harina, harnero. 
farinal, V. $\sim$ farinal.

felos, felos, phelos [tomado del lat. phellos 'tambor de clepsidra' y este del gr.

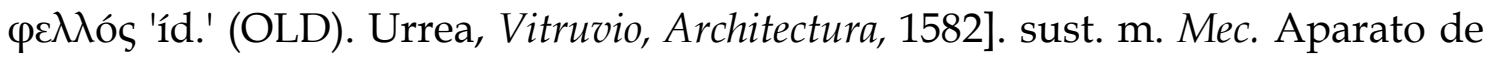
elevación del agua, formado por una rueda vertical giratoria que posee una serie de compartimentos radiales en los que voltea el agua para su elevación.

Urrea, Vitruvio, Architectura, 1582, fol. 121v: Porque el agua, cayendo por aquella concavidad, ygualmente levanta la barquilla trastornada, a la qual los artífices llaman phelos o tímpano, en el qual está puesta la regla que se rebuelve al tímpano con unos dentezillos yguales. // Urrea, Vitruvio, Architectura, 1582, fol. 122r: En la postrera parte, en medio del tímpano, ay un exe que se rebuelve, y assida con él, una cadena de hierro rebuelta, de la qual está colgado el felos o tímpano, al qual alivia el agua. // Urrea, Vitruvio, Architectura, 1582, fol. 142r: Phelos: máchina de agua que se dize tímpano.

SIN.: rueda cerrada, rueda timpanada, tímpano 1.

HIPER.: máquina.

ferir, V. herir.

ferramenta, ferramenta [tomado del lat. fẽrrämenta, plural de fẽrrāmentum 'íd.'. Juanelo Turriano, Veinte y un libros, a. 1605]. sust. f. arag. Instrumento, por lo común de hierro o acero, con que trabajan los artesanos (DRAE s. v. herramienta).

Juanelo Turriano, Veinte y un libros, a. 1605, fol. 391r: Y el hierro A passa por el hierro E y por $\mathrm{F}$, y va a firmar en el hierro $\mathrm{G}$, el qual [tiene] un foyo en el medio, donde entra la punta del hierro I para poder jugar en dos hierros. Y assí se harán, de las dos partes, estas ferramentas. // Juanelo Turriano, Veinte y un libros, a. 1605, fol. 445v: Este instrumento no difiere de la rova, excepto que no va puesto con ferramentas, como éste que se exercita en llevar la tierra de la una parte a la otra.

SIN.: herramienta.

FAM.: herrada, herrador, herramienta, herrar, herrería, herrero, herrezuelo.

ferramienta, V. herramienta. 
ferrar, V. herrar.

ferrero, V. herrero.

fíbula, fíbula [tomado del lat. fibŭla 'instrumento para clavar o sujetar' (DECH). Urrea, Vitruvio, Architectura, 1582]. sust. f. Mec. Especie de hebilla o garfio con la que se sujeta la carga que se levanta en algunas máquinas, como en las poleas.

Urrea, Vitruvio, Architectura, 1582, fol. 124r: Aderéçanse tres maderos en su razón y cuenta, según la grandeza de la carga, y desde la cabeça, se juntan con la fíbula, que es un hierro para levantar las vigas. // Urrea, Vitruvio, Architectura, 1582, 141r: Fíbula: un hierro para levantar carga con sogas y tenerla en alto.

HOL.: polea.

[IMAGEN] Urrea, Vitruvio, Architectura (1582), fol. 124v, figura 120.

2 [Juanelo Turriano, Veinte y un libros, a. 1605]. sust. f. Ingen. Hidrául. Pieza de madera, con forma de hebilla, utilizada en la sujeción del armazón de los puentes.

Juanelo Turriano, Veinte y un libros, a. 1605, fol. 215v: La puente que hizo Julio César sobre el río Rin, la qual descrive en sus Comentarios, muchos la han querido glosar, mas, al fin, a muy pocos la veo acertar, en especial en la fíbula, la qual es muy dificultosa de entender. // Juanelo Turriano, Veinte y un libros, a. 1605, fol. 215v: La qual fíbula me pareze que se entiende que ha de ser una cosa a modo de una evilla, por hazer casi el mismo effecto que haze la evilla en la correa.

HOL.: puente.

[IMAGEN] Pseudo-Juanelo Turriano, Los ventiún libros, c. 1605, fol. 215v, fig. 289, letra H.

fiel, fiel [del lat. filum 'hilo'. 1490, Alonso de Palencia (DECH). Urrea, Vitruvio, Architectura, 1582]. sust. m. Aguja de las balanzas que se pone vertical cuando hay perfecta igualdad en los pesos.

Urrea, Vitruvio, Architectura, 1582, fol. 128v: Quando está más apartado o llegado al extremo con ygual peso, un poco más grande, acaba el ygual apesgamiento por el peso de la cabeça y por el fiel que se aparta más del centro.

HOL.: balanza.

fijado, fijado, fixado [Cortés de Albacar, Breve compendio sphera, 1556]. adj. Hincado, clavado, asegurado en otro cuerpo. 
Cortés de Albacar, Breve compendio sphera, 1556, fol. XLVIv: Y numerarlos has en lo ancho del mismo medio círculo y este medio círculo fixarás por la parte baxa del instrumento como sus extremos estén fixados en las extremidades de la línea meridiana. // Urrea, Vitruvio, Architectura, 1582, fol. 134v: Luego, quando las pinas ovieren buelto las ruedas quatrocientas vezes, avrán hecho que se buelva alrededor una vez el tímpano llano con el ímpetu del diente, que está fixado al lado del tímpano que está también al lado. // Juanelo Turriano, Veinte y un libros, a. 1605, fol. 290v: En este género de rueda no ay menester de linterna para hazer andar la muela, mas que en el exe de la rueda va una barra de yerro muy gruesa, la qual va fixada con unos cercillos de yerro, y encima de este barrón va la muela.

FAM.: afijado, afijar, fijar, fijo.

fijar, fijar, fixar [de fijo. 1570, C. de las Casas (DECH). Cortés de Albacar, Breve compendio sphera, 1556]. v. tr. Hincar, clavar, asegurar un cuerpo en otro (DRAE).

Cortés de Albacar, Breve compendio sphera, 1556, fol. XLVIv: Y numerarlos has en lo ancho del mismo medio círculo y este medio círculo fixarás por la parte baxa del instrumento como sus extremos estén fixados en las extremidades de la línea meridiana. // Urrea, Vitruvio, Architectura, 1582, fol. 133v: Demás d'esto, al lado del superior tímpano se fixe otro dentezillo que salga más que los otros y encima del tercer tímpano llano.

SIN.: afijar.

FAM.: afijado, afijar, fijado, fijo.

fijo, fijo, fixo [tomado del lat. fixus 'clavado', 'fijo'. 1256, Aben Ragel, Libro Complido (DECH). Santa Cruz, Libro de las longitúdines, 1567]. adj. Firme, asegurado (DRAE).

Santa Cruz, Libro de las longitúdines, 1567, pág. 41: Y por qué, como su instrumento consistía en preçisar cosas por vía de sombras de astil, por poco balançe que el navío hiziese, se cometía gran yerro en la sombra, no obstante que hazían el instrumento de marfil, porque no se torçiese, y con gran peso de plomo debaxo para que estuviese más fixo y tomase menos balançe al hazer de las consideraçiones. // Besson, Teatro instrumentos, 1602, fol. B2v: En éste se mueven quadradamente dos braçuelos equidistantes a la pierna, en cuyo medio se mueve una ruedezuela quadrada, larga, en cuya extremidad oriental está fixo el centro de la ruedezuela. // Juanelo Turriano, Veinte y un libros, a. 1605, fol. 206r: De modo que el poner de las barcas en esta obra a sido por ser ellas unas puentes movibles, hechas al revés de las otras puentes de madera y de piedra, que aquéllas están fixas en un lugar y los que passan por ellas conviene que anden.

FAM.: afijado, afijar, fijado, fijar. 
fil, fil [del lat. filum 'hilo'. APal. (DECH). ]. sust. m.

FAM.: afilar, filo.

en [Celso, Reportorio universal leyes Castilla, 1553]. loc. adv. Con igualdad de peso, o sin inclinarse las balanzas, ni el fiel del peso, ni la lengüeta de la romana, a un lado ni a otro (DRAE).

Celso, Reportorio universal leyes Castilla, 1553, fol. CCXXIv: El maestro de la balança reciba en fil y dé en fil la dicha obra, ansí a los obreros como a los que vienen a hazer labrar la dicha moneda.

filo, filo [del lat. filum 'íd.'. S. XIII, Ms. bíblico escurialense (DECH). Cortés de Albacar, Breve compendio sphera, 1556]. sust. m. Arista o borde agudo de un instrumento cortante (DRAE).

Mosquera, Comentario disciplina militar, 1596, fol. 118v: Y con el filo dar cuchillada como una çimitarra, que, por estar del braço, que es el centro, tan distante, rasga con excessiva fuerça. // Alonso Barba, Arte de los metales, 1640, fol. 83v: Otra como barreta de dos varas y media de largo y dos dedos de gruesso, que por la una parte remate en punta, que se calçará de acero; por la otra, en filo de tres dedos de largo.

FAM.: afilar, fil.

HOL.: instrumento.

fin, V. caracol $\sin \sim$.

firmado, firmado [de firmar. Juanelo Turriano, Veinte y un libros, a. 1605]. adj. Puesto o colocado de manera que permanezca firme.

Juanelo Turriano, Veinte y un libros, a. 1605, fol. 82r: Y también se podría acomodar otra invención: que sin tener ningún pie firmado en los costados d'este valle, que sea hasta ciento y veynte pies.

SIN.: afirmado.

FAM.: afirmación, afirmado, afirmar, firmar, firme, firmemente, firmeza.

firmar, firmar [del lat. firmāre 'afirmar' 'dar fuerza'. $2^{\mathrm{a}}$ mitad S. X, Glosas de Silos (DECH). Loçano, Alberto, Architectura, 1582]. v. tr. Poner o colocar algo de modo que permanezca firme (DRAE s. v. asentar).

Loçano, Alberto, Architectura, 1582, pág. 177: Porque a la cabeça de la viga y al mismo peso se les aplicarán poleas, y junto al pie se firmará el árgano o otra cosa qualquiera 
de esta manera en que quieres que esté puesto el exe. // Besson, Teatro instrumentos, 1602, fol. O3v: La qual basa, a la banda de tramontana, tiene unas parrillas para firmar la máquina. // Juanelo Turriano, Veinte y un libros, a. 1605, fol. 209r: Y para armar esta puente no es menester barcos, que con solas [las] mismas piezas se pueden armar, que con unas cuerdas que la vaya detiniendo. Conviene firmar muy bien la primera pieza, asegurarla, que esté muy firme.

SIN.: afirmar.

FAM.: afirmación, afirmado, afirmar, firmado, firme, firmemente, firmeza.

firme, firme [del lat. vg. firmis, lat. firmus 'íd.'. Doc. de 1100 (DECH). Sánchez de las Broças, Helt Frisio, Relox español, 1549]. adj. Dicho de un objeto: estable, que no se mueve ni vacila.

Sánchez de las Broças, Helt Frisio, Relox español, 1549, fol. 28v: Esta hora, rodeando la rueda, la pondremos en derecho del centro de la otra estrella que está entre la tercera y quarta classes en el instrumento pintada, y allí, teniendo firme la rueda movible, buscaremos en el calendario el día en que esto quesimos saber. // Besson, Teatro instrumentos, 1602, fol. E4v: Empero, importa que sean las ruedas baxas para que no toquen el cuerpo de las andas, maçicas juntamente y firmes para sostener el peso. // Juanelo Turriano, Veinte y un libros, a. 1605, fol. 321r: Esta tajadera es en la forma que aquí abaxo yrá formada. La qual es A, que entra dentro de la agua, y B C es donde se haze con unas clavijas, para que la tenga firme en el lugar que se quiere que esté.

FAM.: afirmación, afirmado, afirmar, firmado, firmar, firmemente, firmeza.

en $\sim$ [Lobato, Notas, a. 1585]. loc. adv. Con firmeza.

Lobato, Notas, a. 1585, fol. 34: La caja sobre que se forjará mejor este rodezno me parece que será mejor redonda, porque con el redondo no hará embarazo ni tope en el agua, y el herrero la forjará mejor, que no tendrá más de tenderla en redondo, y llevará abierto en firme el cuadro del palo. // Juanelo Turriano, Veinte y un libros, a. 1605, fol. 150r: Y supongamos que el agua viene traýda en firme hasta el primer arco, y hasta aý allegó el agua, que es A, y de aý no puede passar más dentro de tierra. // Juanelo Turriano, Veinte y un libros, a. 1605, fol. 229v: Y como se haze una estopa en la punta, no da el golpe de la maça en firme, y por esta causa no se hinca el madero como conviene.

SIN.: firmemente.

firmeça, V. firmeza.

firmemente, firmemente [de firme. Loçano, Alberto, Architectura, 1582]. adv. Con firmeza (DRAE). 
Loçano, Alberto, Architectura, 1582, pág. 336: Y si por ventura alguna cosa çabullida o fixada impidiere fuera de las máchinas que los officiales se saben, es aquélla muy aparejada que metáys un navío cargado, y enlazaréys muy firmemente aquello, ahora sea palo o otra cosa qualquier que ayáys de sacar. // Besson, Teatro instrumentos, 1602, fol. F2v: Y allí dos vezes torciéndose a guisa de codo, se estienden a la parte delantera d'él y fenecen en el cañal, el qual después se descarga, sacando fuera sus liquores, en espacio de dos dedos, a l'otra parte de las bocas de los cañales, para que assí, firmemente, se le meta un tapón, el qual tape todas las tres por medio de tres clavijas de madera. / / Juanelo Turriano, Veinte y un libros, a. 1605, fol. 120r: Conviene advertir que los caños se han de afixar con calçina o yeso biscocho, o con otro material que los tenga muy firmemente afixados dentro de las canales de los maderos.

SIN.: en firme.

FAM.: afirmación, afirmado, afirmar, firmado, firmar, firme, firmeza.

firmeza, firmeça, firmeza [de firme. H. 1250, Setenario (DECH). Sagredo, Medidas Romano, 1526]. sust. Cualidad de firme, estable e inmóvil.

Sagredo, Medidas Romano, 1526, pág. 26: Claro está que todas las partes de la coluna retraýda estrivan hazia dentro y socorren al tuétano de la coluna, donde consiste toda la fuerça, y aploman siempre sobre lleno, que es causa de mucha firmeza. // Besson, Teatro instrumentos, 1602, fol. B4v: La otra regla sirve para la firmeza de la máquina, pues si cosas volubles al entorno de una no movediza son tiradas, harase figura oval, disponiéndose assí los cercos pequeños. // Juanelo Turriano, Veinte y un libros, a. 1605, fol. 151r: De modo que convendrá hazer dos d'estas armaduras, que vayan algún tanto apartadas la una de la otra, por causa que tenga mayor firmeza.

FAM.: afirmación, afirmado, afirmar, firmado, firmar, firme, firmemente.

fístola, V. fístula.

fístula, fístola, fístula [tomado del lat. fistŭla 'caño de agua', 'tubo', 'flauta'. Entre 1493 y 1495, Nebrija (DECH). Urrea, Vitruvio, Architectura, 1582]. sust. f. Ingen. Hidrául. Pieza hueca de metal, generalmente cilíndrica, por donde se conducen las aguas.

Urrea, Vitruvio, Architectura, 1582, fol. 132r: La fístula o tuba, que es el caño, se tiene de refirmar y levantar en alto. // Juanelo Turriano, Veinte y un libros, a. 1605, fol. 14v: Pues, concluyamos que la agua que sale de una misma fuente grandes tiempos del siglo no pueden en los canales, ansí de tierra, como haze en las fístulas o caños de metal o de bronze, sustentarse, por causa del fuego tan caliente que tiene debajo d'ella. // Juanelo Turriano, Veinte y un libros, a. 1605, fol. 286r: Agora fuesen lo caños o 
fístulas o trompas de plomo como de alambre, como de bronze, o alcaduces de barro, o de qualquier otra materia que ellos fuesen, los llamavan quinaria, por razón del diámetro, el qual era compuesto de cinco partes de un dedo.

SIN.: cafia, tromba, trompa $a_{2}$ tuba.

HOL.: obra hidráulica.

fixado, V. fijado.

fixar, V. fijar.

fixo, V. fijo.

follura, follura [de follar (hollar) 'pisar, comprimir con los pies'. Juanelo Turriano, Veinte y un libros, a. 1605]. sust. f. Ingen. Hidrául. arag. Cauce por donde se da paso al agua.

Juanelo Turriano, Veinte y un libros, a. 1605, fol. 362v: Y con esta orden van rodeando todo aquel patio que han determinado de tomar, con dos órdenes d'estos maderos, con estas folluras o canales, de alto abaxo.

HOL.: obra hidráulica.

FAM.: hollar, huella, huello.

fontanero, fontanero [de fontana (DECH). Herrera, Institución Academia, 1584]. sust. m. Ingen. Hidrául. Persona que tiene por oficio el fabricar y cuidar fuentes artificiales, así como encañar y conducir las aguas.

Herrera, Institución Academia, 1584, fol. 3r: Y, ansimismo, fontaneros y niveladores de las aguas, para los aguaductos y regadíos que en estos reynos tan importantes y convenientes serían, y para desaguar y beneficiar las minas de ricos metales que ay en estos reynos y en los de entrambas las Indias; // Juanelo Turriano, Veinte y un libros, c.1605, fol. 36r: Sólo para [que] los que tractan o hazen professión d'esta materia de llevar aguas, que el vulgo llama fontaneros o çaorises, tubiesen alguna notiçia de las calidades de las aguas, y para que sepan discernir y hazer eleción de la buena a la mala. // Juanelo Turriano, Veinte y un libros, c.1605, fol. 36v: Aunque, en esto del conozer de las aguas la calidad, es cosa muy agena de los que professan el exercicio de fontaneros, los quales no es más su exercicio que saber nivelar un agua para saber si podrá subir o abajar para el servicio de los pueblos, o para regar o moler. 
FAM.: fuente.

forjar, forjar [del fr. forger 'dar la primera forma con el martillo a una pieza de metal'. 1406, Invent. arag. (DECH). Pérez Vargas, De re metallica, 1568]. v. tr. Dar la primera forma con el martillo a cualquier pieza de metal (DRAE).

Pérez Vargas, De re metallica, 1568, fol. 149r: La segunda, en bien fundir, forjar y sacar un vaso gracioso del martillo, de bueno garbo, talla y hechura. // Lobato, Notas, a. 1585, fol. 34: Y luego forjar tres barras de hierro cuadradas para que hagan la casa, y quede el un cuadro de la tabla por donde entre el palahierro. // Lobato, Notas, a. 1585, fol. 34: La caja sobre que se forjará mejor este rodezno me parece que será mejor redonda, porque con el redondo no hará embarazo ni tope en el agua, y el herrero la forjará mejor.

2 [Lobato, Notas, a. 1585]. v. tr. Especialmente entre albañiles, fabricar y formar (DRAE).

Lobato, Notas, a. 1585, fol. 34: Luego irá quebrado las esquinas, porque no embarace al agua, que así quede en ochavo, hasta donde se ha de forjar la caja, que será de esta manera: la punta de arriba puesta al justo del cuadrado que tuviere el palo más alto. // Lobato, Notas, a. 1585, fol. 34: La caja sobre que se forjará mejor este rodezno me parece que será mejor redonda, porque con el redondo no hará embarazo ni tope en el agua. // Lobato, Notas, a. 1585, fol. 36: Este rodezno de madera ha de tener tres pies y medio de ancho y un pie de alto, y en él cavadas seis álabes al modo de cuchares que la una desagüe por debajo de las otras [...]. Si éste de seis se puede forjar en la caja cuadrada de hierro, será mejor y con menos agua molerá.

fraylezillo, V. frailecillo.

frontero, frontero [de fronte (DRAE). ]. adj. Puesto y colocado enfrente (DRAE).

Arphe, Varia Commensuración, 1585-87, fol. 5r: Los morzillos de sobre las ancas, señalados con la $\mathrm{C}$, tienen de alto dos tercios y de ancho, por la parte frontera, un tercio y un sexto. // Arphe, Varia Commensuración, 1585-87, fol. 22r: El remate de las órdenes dichas en las monteas fronteras se haze con un frontispicio.

FAM.: frontiza.

2 [Juanelo Turriano, Veinte y un libros, a. 1605]. sust. m. Ingen. Hidrául. Persona que tiene por oficio el llevar aguas y fuentes de una parte a otra. 
Juanelo Turriano, Veinte y un libros, a. 1605, fol. 49v: Mas, para quien más conviene estos instrumentos son para los que professan el llevar fuentes y aguas de una parte a otra, como son aquéllos que el vulgo llama fronteros, para saber conocer la differencia que ay de una parte a otra en altura, y para saber quánto es más baja una tierra a la otra.

frontiza, frontiza [de fronte Juanelo Turriano, Veinte y un libros, a. 1605]. sust. f. arag. Herraje articulado de dos piezas, enlazadas una con otra en un mismo eje, que, al moverse, cierran o abren aquello a lo que están unidas.

Juanelo Turriano, Veinte y un libros, a. 1605, fol. 365v: Y, por tanto, aquellas alguaças o frontizas han de desçendir hasta los cabos de las puntas como triángulos, para que tengan fuerça para atraher el lodo.

SIN.: alguaza, gonce, gozne.

FAM.: frontero.

fuella, fuella [del lat. fŏllis 'fuelle para el fuego', 'odre hinchado', 'bolsa de cuero' (Salinero). Juanelo Turriano, Veinte y un libros, a. 1605]. sust. f. Mec. arag. Especie de fuelle utilizado para subir agua o mover ruedas en algunas máquinas hidráulicas.

Juanelo Turriano, Veinte y un libros, a. 1605, fol. 232v: Puédese servir para este mismo efecto, para sacar agua, del instrumento de la mancha o barquín o fuellas, el qual es en la misma forma, sin faltar un punto de los que se sirven los herreros.

SIN.: barquín, mancha.

HIPER.: instrumento.

FAM.: fuelle.

[IMAGEN] Pseudo-Juanelo Turriano, Los ventiún libros, c. 1605, fol. 233r, fig. 314, letra C.

fuelle, fuelle [del lat. follis 'fuelle para el fuego', 'odre hinchado', 'bolsa de cuero'. H. 1250, Libro de Alexandre (DECH). Pérez Vargas, De re metallica, 1568]. sust. u. t. c. f. Mec. Instrumento para recoger aire y lanzarlo, utilizado en algunas máquinas y por los herreros para avivar el fuego de la fragua.

Pérez Vargas, De re metallica, 1568, fol. 83r: Unos hornos ay que con un par de fuelles se contentan; otros con dos, otros con tres y más, los quales fuelles se menean a braços de hombres, o con ruedas y yngenios de agua que para el effecto se inventaron curiosamente. // Urrea, Vitruvio, Architectura, 1582, fol. 124r: Ay también innumerables maneras de máchinas, de las quales no parece para qué disputar, porque cada día las tenemos en las manos, como las ruedas y fuelles de herreros, las carretas y carros de posta, los tornos y las demás cosas, que, por la costumbre, traen para el uso público provecho. // Besson, Teatro instrumentos, 1602, fol. D2v: Nueva manera de balança, la qual, movida a mano de dos, a guisa de campana que se buelve, tiene tanta 
fuerça a mover dos fuelles, y aquéllos muy grandes en las minas, que pueden igualar con aquéllos que, o con fuerça de aguas o de cavallos que rodean, son movidos.

HIPER.: instrumento.

FAM.: fuella.

fuente, fuente [del lat. föns, fōntis 'íd.'. Orígenes del Idioma (DECH). Fernández de Enciso, Suma de Geographía, 1530]. sust. f. Manantial de agua que surte en la superficie de la tierra, a quien regularmente deben su origen los ríos (Autoridades).

Fernández de Enciso, Suma de Geographía, 1530, fol. IIv: Y señalé cada provincia adónde cae por sus límites, e adónde entran los ríos en la mar, e las fuentes e sierras de donde proceden, e las provincias por donde passan, porque me paresció que esto era lo más útile y necessario a Vuestra Magestad. // Pérez Vargas, De re metallica, 1568, fol. 41r: Conóscese su mina por el olor grave que tiene y por baños y fuentes de agua caliente que en ellos mana. // Juanelo Turriano, Veinte y un libros, a. 1605, fol. 1v: Si la agua que mana de las fuentes o poços, si el agua d'estas fuentes o poços, si ella se recoge toda ella de las aguas de las lluvias.

FAM.: fontanero.

2 [Ortega, Conpusición Arismética y Geometría, 1512]. sust. f. Ingen. Hidrául. Artificio con que se hace correr el agua en los jardines y otras partes de las casas, calles o plazas, para diferentes usos, trayéndola encañada desde los manantiales de donde nace naturalmente (Autoridades).

Ortega, Conpusición Arismética y Geometría, 1512, fol. 128v: Un maestro de picar piedra a fecho una fuente de piedra para tener agua, y la a fecho con cinco caños, en tal manera que si abren el un caño, que en el mayor, que toda el agua que estuviere dentro saldrá en un día. // Loçano, Alberto, Architectura, 1582, V: Demás de que también inventaron el modo de hazer las puentes y fuentes, con tanta variedad, que assí esto como las demás partes d'ella, que dexo de dezir por abreviar, que causan admiración, vinieron con esto a illustrarla tanto, que casi todas las demás artes se comprehenden en ella. // Juanelo Turriano, Veinte y un libros, c.1605, fol. 72r-fol. 72v: Y por esta causa estas fuentes se tienen cerradas ordinariamente, por causa que el agua no se pierda y se conserve ansí recogida, uniendo la de diversas vetas, que de muchas se han hecho una, para que de muchas pueda correr.

HIPER.: artificio, obra hidráulica.

fuerça, V. fuerza. 
fuersa, V. fuerza.

fuerte, fuerte [del lat. fŏrtı̌s 'íd.'. Orígenes del Idioma. Fernández de Enciso, Suma de Geographía, 1530]. adj. Fís. Que tiene gran resistencia (DRAE).

Sagredo, Medidas Romano, 1526, pág. 73: Y con este tal instrumento meterás tus estacas todo lo que conviene, cuyas cabeças encarcelarás unas con otras, con vigas muy fuertes, y, entremedias, echarás carbón bien tapiado. // Lobato, Notas, a. 1585, fol. 8: Y si el pozo en su centro no diere lugar, por la mucha agua, a que se haga [en] la dicha laguna [el pilar] de piedra, se haga de madera fuerte bien empotrada, la cual ha de quedar hundida debajo de la superficie del agua gran cantidad, para que el ingenio cargue sobre ella y pueda coger el agua que se ha de subir. // Juanelo Turriano, Veinte y un libros, a. 1605, fol. 84v: Esta invención de aguaducto es una invención muy seguríssima y fuerte, por raçón de la diminución que hazen los arcos en el yr en alto.

FAM.: fuertemente, fuerza.

2 [Fernández de Enciso, Suma de Geographía, 1530]. adj. Fís. Dicho de una cosa: que tiene gran fuerza.

Fernández de Enciso, Suma de Geographía, 1530, fol. VIIIv: E porque estos vientos y tempestades y relámpagos son más fuertes e más rezios e más peligrosos debaxo de la tórrida dentro de los trópicos que no en otras partes, has de saber que estas tempestades se causan de los vapores de la tierra que son úmedos e fríos. / Celso, Reportorio universal leyes Castilla, 1553, fol. CCXXVIIIr: El qual sería en culpa si él navegasse sin voluntad de los mercaderes desde el onzeno día de noviembre hasta a diez andados del mes de março, porque en estos tiempos son las noches y los ayres y vientos muy fuertes, y la mar muy turbada por la fortaleza del invierno.

fuertemente, fuertemente [de fuerte. Medina, Arte de navegar, 1545]. adv. Fís. Con gran fuerza.

Medina, Arte de navegar, 1545, fol. 17v: De lo qual digo que el viento es vapor de la tierra que sube y trasciende hasta lo alto del ayre y fuertemente hiere o rempuxa al ayre. // Besson, Teatro instrumentos, 1602, fol. N4v: Ordenadas todas cosas assí como han sido ya declaradas, tirando a sí el obrero la balança, el contrapeso fuertemente le resiste, retirándola así, de suerte que otro ningún trabajo quasi queda a él que de tirar. // Juanelo Turriano, Veinte y un libros, a. 1605, fol. 274v: Y después que serán secos, tomarás un poco de almástique con un yerro caliente y le yrás asentando el almástique por encima de la junta. Y buélvele a ligar muy fuertemente asta que sea seco, y estará muy firmísimo.

FAM.: fuerte, fuerza. 
fuerza, fuerça, fuersa, fuerza [del lat. tardío fortťa 'íd.'. H. 1140, Cid (DECH). Falero, Tratado del espera, 1535]. sust. f. Fís. Vigor, robustez y capacidad para mover algo o a alguien que tenga peso o haga resistencia (DRAE).

Falero, Tratado del espera, 1535, fol. 31v: Assí como si el viento tuviere menos fuerça que la corriente, el surco será hazia la parte del viento. // Besson, Teatro instrumentos, 1602, fol. H2v: Nueva manera de moler, con que, con fatiga de dos hombres, sin fuerça de aguas o vientos, se saca tanta harina de trigo, quanta se suele sacar en un lugar de aguas o vientos do corran y soplen abundantemente. // Juanelo Turriano, Veinte y un libros, a. 1605, fol. 128r: Conviene siempre hazer passar la poca por debajo de la mucha, por causa que la mucha cantidad de agua tiene mucha más fuerça que no tiene la poca.

FAM.: fuerte, fuertemente.

furillo, furillo [de furo 'orificio'. Juanelo Turriano, Veinte y un libros, c.1605]. sust. m. Mec. Rosca del caracol.

Juanelo Turriano, Veinte y un libros, c.1605, fol. 455r: El caracol ha de tener una linterna, con su puerta o caracola, por donde passe el furillo o rosca del caracol. A d'estar puesto en las puertas, como lo iré enseñando.

HOL.: caracol.

fusillo, V. husillo.

fuso, V. huso.

fuste, fuste [del lat. füstis 'bastón, garrote'. 1131, Doc. de Calatayud (DECH). Juanelo Turriano, Veinte y un libros, a. 1605]. sust. m. Fundamento de madera para colocar o formar algo sobre él (Terreros).

Juanelo Turriano, Veinte y un libros, a. 1605, fol. 50v: Para aver de hazer este instrumento conviene tener aparejado un fuste de pino, el qual sea muy bien cuadrada y seca y sin ñudo. // Juanelo Turriano, Veinte y un libros, a. 1605, fol. 50v: Y es menester que sea tres dedos de gruesso, y que sea muy bien cimentado, y que este fuste de beta derecha sea, a causa que no se tuerçan los dos brazos, AB, AC.

FAM.: fusto. 
2 [Pérez Vargas, De re metallica, 1568]. sust. m. Instrumento que usan los plateros para asentar una pieza, por medio del betún que echan para esto en el fuste mismo (Terreros).

Pérez Vargas, De re metallica, 1568, fol. 153r : Después de forjada la plata, para averla de labrar en fuste se deve hazer betum semejante.

HIPER.: instrumento.

fusto, fusto [de fuste (DECH). Juanelo Turriano, Veinte y un libros, a. 1605]. sust. m. Mec. arag. Pieza de madera de hilo (DECH).

Juanelo Turriano, Veinte y un libros, a. 1605, fol. 279r: Y después, ponerle el queso encima de una tabla o encima de una losa, y irle moliendo con un manil de fusto de tabla que sea redondo la parte baxa.

FAM.: fuste. 
gabia, V. gavia.

gafa, gafa, gaffa [del cat. gafa 'íd.', derivado del verbo cat. y oc. gafar, agafar 'coger', de origen incierto, probablemente prerromano (DECH). Juanelo Turriano, Veinte y un libros, a. 1605]. sust. f. Pieza de hierro u otro metal, cuyos dos extremos, doblados y aguzados, se clavan para unir o sujetar piedras y sillares.

Juanelo Turriano, Veinte y un libros, a. 1605, fol. 370v: Házense las gafas commúnmente d'esta hechura: hanse de assentar las unas y las otras dentro de la piedra, de suerte que encaxen del todo dentro de los sillares y no suban encima punto de los dichos sillares. // Juanelo Turriano, Veinte y un libros, a. 1605, fol. 377v: Dévese levantar un antepecho, que passe de una parte a la otra de toda la puente, de unas losas [o] piedras muy grandes, y asir las unas con las otras con sus gafas de hierro y emplomarlas muy bien, porque no se caigan en el río o no las hagan caher. // Juanelo Turriano, Veinte y un libros, a. 1605, fol. 389v: Las gaffas que en esta obra se pondrán han de ser anchas y gruessas, y lo que entra dentro de las piedras que sea quatro dedos de largo.

gaffa, V. gafa. 
gallipuente, gallipuente [cmpt. de gallón y puente (DRAE). Juanelo Turriano, Veinte y un libros, c.1605]. sust. m. Ingen. Hidrául. arag. Acueducto o puente, generalmente elevado, que sirve para hacer pasar una conducción de agua por encima de un río o arroyo.

Juanelo Turriano, Veinte y un libros, c.1605, fol. 83r: Y para hazer este gallipuente que pueda resistir al trabajo de la mucha agua que se le acumula, conviene que en el hazerlos, que se haga en el medio un ángulo obtuso, a causa que es de mayor fuerça que ningún otro ángulo. // Juanelo Turriano, Veinte y un libros, c.1605, fol. 88v: Y el llamarse aguaductos los unos, y los otros maripuente o gallipuente los aguaductos, es por raçón que estos arcos caminan grandes trechos de tierra para aver de traher la agua que por ellos se lleva o trahe. // Juanelo Turriano, Veinte y un libros, c.1605, fol. 88v: Llámanse maripuente o gallipuente quando estos arcos tan solamente, o uno o muchos, allegan de un monte a otro, o de una parte a otra de algún barranco, de adonde la toma hasta donde la deja, aunque estos arcos sean dos o tres órdenes, unos encima de otros, y aunque sean çiento ni dozientos passos.

SIN.: maripuente.

HIPER.: puente.

FAM.: carripuente, maripuente, puente.

gamella, gamella [del lat. camèlla 'escudilla, íd.'. 1081, San Millán (DECH). Celso, Reportorio universal leyes Castilla, 1553]. sust. f. Barreño grande, por lo común de madera, que sirve para varios usos domésticos o industriales (Clairac).

Celso, Reportorio universal leyes Castilla, 1553, fol. XXIr: Es franco el regatón de Su Alteza del pescado remojado y de las otras cosas que él, y su muger y criados vendieren en la Corte y rastro, en una gamella o en una tienda. // Collado, Plática Artillería, 1592, fol. $76 \mathrm{v}$ : La qual es tanta que por todas las villas y ciudades van hombres con una escobilla y una gamella barriendo las paredes para coger el salitre de casa en casa. // Juanelo Turriano, Veinte y un libros, a. 1605, fol. 172v: Mucha piedra, cal, arena, clavazones, qüerdas, anillas portaderas, espuertas de mimbre, bacietas o gamellas, açadas, palas, ligones, garruchas, carros, sierras, martillos, picos y otras infinitas cosas que para ello es menester.

SIN.: bacieta.

gancheado, gancheado [de *ganchear. Juanelo Turriano, Veinte y un libros, a. 1605]. adj. Con forma de gancho.

Juanelo Turriano, Veinte y un libros, a. 1605, fol. 305r: De modo que la barra F tiene al cabo un yerro gancheado y también tiene una punta para abaxarle o subirle con aquel gancho. // Juanelo Turriano, Veinte y un libros, a. 1605, fol. 353r: Estos émbulos van 
asidos ha dos barras que descienden de alto abaxo del poço, las quales les van azidos en un manil gancheado, el qual manil va dentro un exe que tiene una linterna, la qual linterna la mueve una rueda que lleva un animal.

FAM.: gancho.

gancho, gancho [de origen incierto probablemente prerromano. Puede venir del céltico *ganskjo- 'rama'. A. 1331 (DECH). García de Palacio, Instrución náuthica, 1587]. sust. $\mathrm{m}$. Instrumento corvo y por lo común puntiagudo en uno o ambos extremos, que sirve para prender, agarrar o colgar algo (DRAE).

García de Palacio, Instrución náuthica, 1587, fol. 144v: Gata de arronçar: es un gancho de hierro con un ojo al cabo con que se afixa una guindalesa para subir el áncora con ella de la mar a la nao. // Ufano, Tratado de la Artillería, 1613, pág. 415: El un gancho, garfio o bioche lagartino es aquel garabato del testerón que, por defuera de cada pierna, está clavado en el afuste para asir d'él las cuerdas a la mano o de retenida // Juanelo Turriano, Veinte y un libros, a. 1605, fol. 147v: Podrase bajar dentro d'este instrumento un gancho con su vara, que sea muy larga, para poderse assir a alguna mata o alguna resquizia o agujero de la peña.

FAM.: gancheado.

garabato, garabato, garavato [del ast. y santand. gárabu, gáraba 'palito'. J. Ruiz (DECH). Collado, Plática Artillería, 1592]. sust. m. Instrumento de hierro, con punta en forma de semicírculo, que se utiliza para colgar o agarrar cosas.

Collado, Plática Artillería, 1592, pág.

86: Y puesto en lo baxo del meridiano un peso de hierro o de plomo con su garavato, como el que se pone en la romana para saber el peso que alguna cosa tiene. // Roxas, Sumario milicia, 1607, fol. 28r: También ha de aver lobos, que son unos garabatos de hierro. // Alonso Barba, Arte de los metales, 1640, fol. 93v: Sácanse las escorias de la hornilla con un garabato de hierro y se echa en ella baño de plomo pobre, si el metal que se funde lo requiere.

HIPER.: instrumento.

garavato, V. garabato.

garfa, garfa [del hispano-ár. garfa 'puñado' 'cantidad que se coge con una mano' y este del ár. clás. garfa, infl. por garfio (DRAE). Juanelo Turriano, Veinte y un libros, a. 1605]. sust. f. Pieza de hierro con los extremos doblados que se utiliza para aferrar algún objeto. 
Juanelo Turriano, Veinte y un libros, a. 1605, fol. 166v: Y estas obras se avrán de ligar con garfas de hierro o de bronze, por raçón que el agua le hará muy grande molestia.

SIN.: garfia.

FAM.: garfia, garfio.

garffio, V. garfio.

garfia, garfia [del lat. graphŭum 'punzón para escribir', 'estilete', y este del gr.

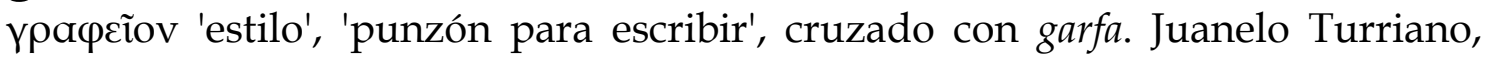
Veinte y un libros, a. 1605]. sust. f. Pieza de hierro con los extremos doblados que se utiliza para aferrar algún objeto.

Juanelo Turriano, Veinte y un libros, a. 1605, fol. 82r: Donde va la B convendrá poner unas garfias de hierro con unas gruessas clavijas.

SIN.: garfa.

garfio, garffio, garfio, grafio [del lat. graphŭum 'punzón para escribir',

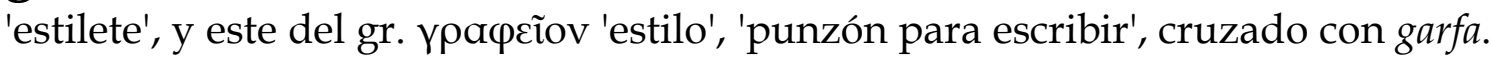
S. XVIII (DECH). Pérez Vargas, De re metallica, 1568]. sust. m. Hierro curvo y puntiagudo que sirve para aferrar algún objeto (DRAE).

Pérez Vargas, De re metallica, 1568, fol. 149v: Después d'este exercicio, se puede dibuxar en planchas de cobre lisas con grafio de hierro. // Lobato, Notas, a. 1585, fol. 21: Por de dentro, en el contorno de la torre, a trabarlas en gordas, veinticuatro alcayatas o garfios, en que las asían cuando estaba ya amurado el molino al viento con que había de moler. // Besson, Teatro instrumentos, 1602, fol. I2v: Las demás cosas apegadas a la punta de la pyrámide más baxa son manos y garfios para asir la carga.

SIN.: mano.

garrucha, garrucha [del ant. y dial. carrucha 'íd.'. 1375, Invent. arag. (DECH). Juanelo Turriano, Veinte y un libros, a. 1605]. sust. f. Mec. Pieza circular y plana, de madera, metal $\mathrm{u}$ otra materia, que forma parte de una polea.

Juanelo Turriano, Veinte y un libros, a. 1605, fol. 142v: Y en esta sortija a de estar asido una polea, la qual polea a de tener dos garruchas dentro de sí. // Juanelo Turriano, Veinte y un libros, a. 1605, fol. 144v: Y a la anilla A está colgada a la polea B, la qual tiene dentro de sí dos garruchas, por donde passan las dos qüerdas que van dobladas, que es K K K K.

SIN.: rodaja, roldana. 
HOL.: polea.

FAM.: carrillo, carrucha, carrucho.

2 [Urrea, Vitruvio, Architectura, 1582]. sust. f. Mec. Rueda acanalada y móvil alrededor de un eje que se utiliza para subir pesos por medio de una cuerda o maroma.

Urrea, Vitruvio, Architectura, 1582, fol. 7v: En los capiteles de la catapulta, en la parte derecha y en la yzquierda, ay unos agujeros redondos por donde las maromas retorcidas se estienden con los tornos y garruchas y cerrojos, las quales maromas no se assen ni las atan sin que hagan ciertos sonidos yguales y conformes al oýdo del artífice. // Juanelo Turriano, Veinte y un libros, c.1605, fol. 53r: Y esta traviessa ha de tener a los dos cabos dos poleas o garruchicas que jueguen, y por ella ha de passar un cordel con un pesso al un cabo y el otro esté afixado en el pie derecho. // Juanelo Turriano, Veinte y un libros, a. 1605, fol. 184r: En las más cisternas se saca el agua por arriba, con garruchas o con otros instrumentos, en la misma manera que se saca de los poços.

SIN.: carretillo, carrillo, carrucha, carrucho, polea, polija, recamo, tróclea.

HIPER.: máquina.

gastado, gastado [de gastar (DECH). Juanelo Turriano, Veinte y un libros, a. 1605]. adj. Deteriorado por el uso.

Juanelo Turriano, Veinte y un libros, a. 1605, fol. 15v: Porque si ella viene muy de parte caliente por su camino o canales, y aunqu'ella se enfríe, le queda siempre algún mal sabor, y aun su maglino olor, y aun tiene gastado el color. // Juanelo Turriano, Veinte y un libros, a. 1605, fol. 39v: Se sabe discerner, por causa del olor que el agua tiene, por ser gastada y corrompida. // Juanelo Turriano, Veinte y un libros, a. 1605, fol. 404v: Dévense hazer, a los costados de los puertos, otros puertos pequeños para tener vasillos gastados o viejos.

FAM.: gastar.

gastar, gastar [del lat. vastāre 'devastar, arruinar'. S. XIII, Lib. Reg. aragonés (DECH). Pérez Vargas, De re metallica, 1568]. v. tr. u. t. c. prnl. Deteriorar con el uso (DRAE).

Pérez Vargas, De re metallica, 1568, fol. 3v: Y assí, acontesse que los metales en cuya materia lo húmido y seco no están perfetamente incorporados, como el hierro, y cobre y el plomo, apartándose alguna parte de lo terrestre de la compañía de su húmido, y por no poder ampararlo todo el fuego, requema alguna parte terrestre y la gasta y buelve en escama, a quien los artífices llaman flor a manera de caspa. // Juanelo Turriano, Veinte y un libros, a. 1605, fol. 290v: Conviene que este rodete esté asentado muy a peso, porque, no lo estando, se gastan las muelas y no muele tanto. // Juanelo Turriano, Veinte y un libros, a. 1605, fol. 250v: Y la piedra que tiene manchas, agora de 
blanco, agora de color de yerba, por toda, será de la misma calidad de la piedra dicha arriba, que se gasta con mucha facilidad.

FAM.: gastado.

gata, gata [de gato. H. 1300, Gran Conquista de Ultramar (DECH). García de Palacio, Instrución náuthica, 1587]. sust. f. Mec. Aparato en forma de caja en esqueleto que servía para colocarse un operario y trabajar colgado en una escarpa, pared o sitrio de elevación, haciendo de andamio volante (Clairac).

Juanelo Turriano, Veinte y un libros, a. 1605, fol. 142r: Las lañas del suelo han de travesar de parte a parte, y que cojan los dos ángulos del suelo de la gata o gavia. // Juanelo Turriano, Veinte y un libros, a. 1605, fol. 144v: Esta máchina, la qual algunos la llaman gata, otros la llaman gaula y otros gavia, cada uno le ponga el nombre que mandaren, pues ellos la sepan acomodar para que haga el effecto por lo que ella a de servir. // Juanelo Turriano, Veinte y un libros, a. 1605, fol. 144v: La L es la maroma en que cuelga la gata. $Y$ donde es la primera sortija es $A$, la qual está assida en un ñudo de la maroma L. Y a la anilla A está colgada a la polea B, la qual tiene dentro de sí dos garruchas.

SIN.: gavia, gaula.

HIPER.: aparato.

[IMAGEN] Pseudo-Juanelo Turriano, Los ventiún libros, c. 1605, fol. 143v, fig. 110.

gaula, gaula [probablemente del fr. ant. jaole 'íd.', procedente del latín caveola, diminutivo de cavea 'jaula' (DECH s. v. jaula). Juanelo Turriano, Veinte y un libros, a. 1605]. sust. f. Mec. Aparato en forma de caja en esqueleto que servía para colocarse un operario y trabajar colgado en una escarpa, pared o sitrio de elevación, haciendo de andamio volante (Clairac s. v. gata).

Juanelo Turriano, Veinte y un libros, a. 1605, fol. 142r: Y esta máchina, que el vulgo llama gavia o gaula, la qual a de ser muy bien ensamblada. // Juanelo Turriano, Veinte y un libros, a. 1605, fol. 142v: En la parte de arriba se le ha de poner otras quatro anillas de yerro, con sus lañas muy reçias, para que se pueda tener colgada esta gata o gaula o gavia, como el vulgo la llama. // Juanelo Turriano, Veinte y un libros, a. 1605, fol. 144v: Esta máchina, la qual algunos la llaman gata, otros la llaman gaula y otros gavia, cada uno le ponga el nombre que mandaren, pues ellos la sepan acomodar para que haga el effecto por lo que ella a de servir.

SIN.: gata, gavia.

HIPER.: aparato.

[IMAGEN] Pseudo-Juanelo Turriano, Los ventiún libros, c. 1605, fol. 143v, fig. 110.

gavia, gabia, gavia [del lat. căvĕa 'jaula' (DECH). Juanelo Turriano, Veinte y un libros, a. 1605]. sust. f. Mec. Aparato en forma de caja en esqueleto que servía 
para colocarse un operario y trabajar colgado en una escarpa, pared o sitrio de elevación, haciendo de andamio volante (Clairac s. v. gata).

Juanelo Turriano, Veinte y un libros, a. 1605, fol. 139r: Y para aver de hazer este remedio, quando ello no fuesse tanto ni tan descómodo que no se pudiese hazer, convendrá hazer una o dos gavias de las que acostumbran para limpiar las yglesias, o más, según se oviere de hazer mucha o poca obra. // Juanelo Turriano, Veinte y un libros, a. 1605, fol. 142r: Y esta máchina, que el vulgo llama gavia o gaula, la qual a de ser muy bien ensamblada. Las pieças han de ser de tres dedos de gruesso, con muchas traviesas de las unas piezas a las otras. Y en el suelo a de ser todo de tablas, y en los ángulos ha de aver sus lañas de hierro, que cojen las dos partes. // Juanelo Turriano, Veinte y un libros, a. 1605, fol. 144v: Esta máchina, la qual algunos la llaman gata, otros la llaman gaula y otros gavia, cada uno le ponga el nombre que mandaren, pues ellos la sepan acomodar para que haga el effecto por lo que ella a de servir.

SIN.: gata, gaula.

HIPER.: aparato.

[IMAGEN] Pseudo-Juanelo Turriano, Los ventiún libros, c. 1605, fol. 143v, fig. 110.

glera, glera [del lat. glārěa 'íd.'. H. 1140, Cid (DECH). Juanelo Turriano, Veinte y un libros, a. 1605]. sust. f. arag. Especie de tierra que contiene cantos y guijarros. Juanelo Turriano, Veinte y un libros, a. 1605, fol. 115r: De modo que en aquellos senos que ay, donde es la A B C D, va cargando de arena y glera, de modo que la misma agua va fortificando este reparo. // Juanelo Turriano, Veinte y un libros, a. 1605, fol. 261r: Y después d'ésta, es en el segundo lugar la arena de los ríos, quitándole de ençima aquella capa que tiene de glera.

gonce, gonce, gonze [probablemente del fr. gonz, plural de gont 'gozne'. 1438, Juan de Mena (DECH). Escalante, Discurso de la navegación, 1577]. sust. $m$. Herraje articulado de dos piezas, enlazadas una con otra en un mismo eje, que, al moverse, cierran o abren aquello a lo que están unidas.

Escalante, Discurso de la navegación, 1577, fol. 84r: El de los pies es muy terrible, porque se da con dos palos quadrados de quatro palmos, poco más o menos, de largura, que se juntan con un gonce por la una parte y con la otra con un cordel passado por ambos. // Lechuga, Discurso de la Artillería, 1611, pág. 249: Porque en ocasión servirá de que no puedan de golpe llegar los enemigos a la contraescarpa, pues para salir, se podrá hazer que, por partes, con gonzes se levante y abaxe quando se quisiere. // Ufano, Tratado de la Artillería, 1613, pág. 412: La tapa de metal que, engastada en los gonces y molinetes del mesmo metal de la pieça, tapa el fogón y lo cubre, porque, por él, en su caçoleta no entre el agua de las pluvias y moxe la pólvora de su carga, se dize comunmente diotra o braguena.

SIN.: alguaza, frontiza, gozne.

gonze, V. gonce. 
gorrón, gorrón [de guarro. Juanelo Turriano, Veinte y un libros, c.1605]. sust. $\mathrm{m}$. Mec. Púa fuerte o espiga recia de metal que, encajada en algún agujero, sirve para facilitar el movimiento giratorio alrededor de un eje vertical de alguna máquina o parte de ella (Salinero).

Juanelo Turriano, Veinte y un libros, c.1605, fol. 290v: Y, por tanto, conviene asentar el rodete primero, por causa de no aver de levantar el ruello, o de aver de acortar el exe o gorrón de yerro. // Juanelo Turriano, Veinte y un libros, c.1605, fol. 355v: Y en el exe d'esta rueda, Y, se le acomoda un gorrón, el qual está boltado, como lo dibuxaré aquí abaxo para mayor inteligencia de lo que tratamos. // Juanelo Turriano, Veinte y un libros, c. 1605, fol. 455r: Esta almenara o puerta abre muy differentemente de las otras. Tiene en el medio un exe que buelve sobre dos gorrones de hierro, y es más estrecha a la parte de abaxo que a la de arriba.

SIN.: raposo.

HOL.: máquina.

gozne, gozne [del ant. gonce 'íd.'. 1588, Fray Luis de Granada (DECH). Lobato, Notas, a. 1585]. sust. m. Herraje articulado de dos piezas, enlazadas una con otra en un mismo eje, que, al moverse, cierran o abren aquello a lo que están unidas.

Lobato, Notas, a. 1585, fol. 36: La cual ha de tener cinco pies de ancho, porque el agua suba menos, la cual ha de ser asentada con goznes por arriba, como irá figurada, y asentada en la dicha acequia, donde está la letra A, que abra hacia el río y cierre hacia la acequia.

SIN.: alguaza, frontiza, gonce.

gradilla, graílla [de grada. Villena (DECH). Juanelo Turriano, Veinte y un libros, a. 1605]. sust. f. Utensilio de hierro en forma de rejilla que se pone al fuego con distintos usos.

Juanelo Turriano, Veinte y un libros, a. 1605, fol. 381v: Es hecho este instrumento a modo de graílla o parrillas, en el qual se assienta un lienço muy gruesso a modo de un saco.

SIN.: parrilla.

grado, V. nivel de $\sim$ s. 
grafio, V. garfio.

graílla, V. gradilla.

grave, grave [del lat. grăvis 'pesado', 'grave'. Orígenes del Idioma (DECH). Falero, Tratado del espera, 1535]. adj. Fís. Dicho de una cosa: que pesa (DRAE).

Falero, Tratado del espera, 1535, fol. 5v: E los otros elementos son movibles e cada uno tiene en el esphera el sitio que, por su naturaleza, según que es puro, grave o liviano, le convenía. // Medina, Arte de navegar, 1545, fol. 3r: Pues lugar vazío no se puede poner según natura, porque la misma natura lo aborrece tanto que más consiente lo grave o pessado subir o lo liviano descender, que no permitir cossa vazía. // Juanelo Turriano, Veinte y un libros, a. 1605, fol. 9v: Porque no se ensancharía ni se derramaría si él passase esse término, mas convenía que él se levantase en alto antes que ensancharse más de lo que l'es permitido, lo qual no puede él hazer por su naturaleza grave y pessada la agua.

FAM.: gravedad, graveza.

graveça, V. graveza.

gravedad, gravedad [del lat. grăvĭtās, grăvĭtātis 'íd.'. S. XV, Juan de Mena (DRAE). Falero, Tratado del espera, 1535]. sust. f. Fís. Virtud por la cual un cuerpo grave se mueve para abajo o tiene inclinación a dicho movimiento (Autoridades). Falero, Tratado del espera, 1535, fol. 7r: Y razón ay para creer que las hezes de aquellas exalaciones que el fuego del todo no consume se ayunten, como en la fragua las escorias del hierro hazen, y por su gravedad abaxen de la esphera del fuego al centro. // Collado, Plática Artillería, 1592, fol. 51v: Por quanto, salida de aquélla la bala, inmediatamente, por su gravedad y peso camina, aunque de motu mixto, como en el capítulo de las elevaciones de los tiros diximos, hazia abaxo y procura siempre de llegar a su centro. // Juanelo Turriano, Veinte y un libros, a. 1605, fol. 3r: No puede hechar para arriba sus aguas y embiarlas para en alto hasta salidas de las fuentes, por causa que el agua no puede de suyo yr para arriba, ni menos es ella hasta hazer esso; por causa de su gravedad y peso, no va ni puede yr para arriba.

FAM.: grave, graveza.

SIN.: graveza. 
graveza, graveça, graveza [de grave. Juan Manuel (DECH). Besson, Teatro instrumentos, 1602]. sust. f. Fís. Virtud por la cual un cuerpo grave se mueve para abajo o tiene inclinación a dicho movimiento (Autoridades s. v. gravedad).

Besson, Teatro instrumentos, 1602, fol. C4v: Se buelve un palo, en cuyo medio y extremidades se embuelven ciertas cuerdas, de las quales la de en medio es tirada de una parte con la mano del maestro, y de la otra con la graveza del contrapeso, como también las otras, en cuya parte semejante hay un contrapeso, y la otra extremidad tienen asida a un palo voluble. // Besson, Teatro instrumentos, 1602, fol. K4v: La parte hazia tramontana, con el cylindro, por la graveza del peso, está fixa y firme en tierra. // Lechuga, Discurso de la Artillería, 1611, pág. 172: Y esto procede de la graveza del plomo, la qual, recogiendo en pequeño lugar grande cuerpo, recibe tanta offensa del ayre por donde passa como hará un cuerpo mayor y más ligero.

SIN.: gravedad.

FAM.: grave, gravedad.

grúa, grúa [del cat. grua 'grulla', 'grúa'. 1600, Sigüenza (DECH). Besson, Teatro instrumentos, 1602]. sust. f. Mec. Máquina compuesta de un aguilón montado sobre un eje vertical giratorio, y con una o varias poleas, que se utiliza para levantar pesos y llevarlos de un punto a otro.

Besson, Teatro instrumentos, 1602, fol. Lv: Y es la grúa un instrumento de que los architectos se sirven para subir en alto muy grandes piedras. // Juanelo Turriano, Veinte y un libros, c.1605, fol. 383r: Parésceme que no se deve dexar passar en silençio el modo con que se suben las piedras y baxen en los edifficios. El instrumento más ordinario es la grúa y la cabrilla y el ergate. // Juanelo Turriano, Veinte y un libros, a. 1605, fol. 384r: Súbense muy grandes pesos con la grúa y llévanse con ella a qualquier parte de la obra sin ningún trabaxo, por causa que el árbol o mástil juega sobre un perne de hierro, en la $\mathrm{N}$.

HIPER.: máquina.

ENCICL.: "Las grúas que se utilizaban en la construcción de puentes no eran muy diferentes de las utilizadas en otros campos de la construcción, algunas de las cuales fueron proyectadas por importantes artífices. Entre todas ellas destacan por su buena fortuna y su gran movilidad las que proyectó Juan de Herrera para acelerar las obras del Monasterio de El Escorial tras la muerte en mayo de 1567 del arquitecto Juan Bautista de Toledo" (González Tascón 1999: 123).

[IMAGEN] Pseudo-Juanelo Turriano, Los ventiún libros, c. 1605, fol. 383v, fig. 378. Besson, Diego, Teatro de los instrumentos, Horacio Cardon (trad.), 1602, pág. L2r, figura 38.

2 [Lobato, Notas, a. 1585]. sust. f. Mec. Rueda de gran tamaño que, movida por las pisadas de un hombre, proporciona movimiento al rodete de un molino.

Lobato, Notas, a. 1585, fol. 15: Esta traza es de un molino que le puede mover un hombre y moler gran cantidad de pan. Sus piezas y formas son las siguientes: una grúa como la que va arriba figurada, que es como con la que se sube piedra a un edificio, la 
cual ha de ir entablada sobre las aspas y medias aspas, para que el hombre no pueda caer ni recibir daño. // Lobato, Notas, a. 1585, fol. 15: Asentado en un eje fuerte, a la punta del cual tenga seis guijos de hierros, y en el eje injerida una entruesga que tenga la mitad menos del círculo que la grúa con sus pendazos, la cual dé en un carro de 16 palos. // Lobato, Notas, a. 1585, fol. 15: Digo que la entruesga tenga ciento sesenta pendazos y pueda estar pegada por más fuerte con la propia grúa afijada y clavada en un tímpano, y sería menos largo y embarazoso el eje y ella herirá con más fuerza yendo todo junto, y ocupará menos casa o lugar, y vendrá a dar la piedra ochenta vueltas mientras el hombre diere una vuelta a la grúa.

HOL.: molino.

[IMAGEN] Lobato, Notas, c. 1585, fol. 15.

grúa, V. molino de .

gruença, V. gruenza.

gruenza, gruença [del cat. engronçar o gronxar 'columpiar, mecer'. 1836, Peralta (DECH). Juanelo Turriano, Veinte y un libros, c.1605]. sust. f. Mec. Caja de madera en figura de pirámide inversa, que sirve en los molinos para echar el grano y que vaya cayendo poco a poco en el agujero o garganta de la piedra que lo va moliendo (Terreros s. v. tolva).

Juanelo Turriano, Veinte y un libros, c.1605, fol. 300v : El qual cubo conviene hazerle a modo de una gruença o taona donde sepone el trigo para que se muela, que cae dentro de la muela el grano. // Juanelo Turriano, Veinte y un libros, c.1605, fol. 307v: Un cubo que sea hecho a manera de taona, o de gruença o de tolva, como se acostumbra llamar, donde ponen dentro el trigo para que cayga dentro de la muela, ará moler mucho más que ningún otro género de cubo. // Juanelo Turriano, Veinte y un libros, c.1605, fol. 316v: Octavo: que ha de aver encima de las muelas una taona de madera o gruença, en la qual se acostumbra poner, dentro d'ella, el trigo o otros granos para averlos de moler, y que d'ella vaya cayendo dentro de las muelas.

SIN.: tahona 2 , tolva.

HOL.: molino.

guadaña, guadaña [del germ. waith-, probablemente como derivado (romance o germánico) del gót. *waithô 'prado, pastizal' (DECH). Lechuga, Discurso de la Artillería, 1611]. sust. f. Herramienta formada por una hoja larga y curvilínea, puntiaguda por un lado, y un mango, que se utiliza para segar. Lechuga, Discurso de la Artillería, 1611, pág. 202: Guadañas para cortar yerba... 150 
gualdera, gualdera [probablemente del * guardera, derivado de guarda. 1633, López de Arenas (DECH). Lobato, Notas, c.1585]. sust. f. Ingen. Hidrául. Cada uno de los tablones o planchas laterales que son parte principal de algunos armazones (DRAE).

Lobato, Notas, c.1585, fol. 29: Si han de ir hechas caja, han de ir de 7 en siete pies por amor de que alcanzan a gualderas, digo en el primer vertiente y el subiente, que son dos cajas, una al subiente y otra al vertiente, del largo a $7 \mathrm{y}$ del ancho a cinco pies. Y si se echan, serán menester muchas gualderas. Y, pues se han de henchir de piedra, me parece que se hinchan de argamasa [...]. // Lobato, Notas, c.1585, fol. 31: [...] y la pesquera había de ser de muchas estacas y gualderas, hechas cajas encajadas unas en otras y todas trabadas; esto donde ahora va honda la madre del río.

gubia, gubia, gurbia [del lat. tardío gu[l]b̆a, voz de or. celta; cf. irl. medio gulba, 'pico [de ave]'; gulban 'aguijón' (DRAE). Fernández de Enciso, Suma de Geographía, 1530]. sust. f. Herramienta delgada con forma de mediacaña, utilizada por carpinteros y otros artífices para labrar superficies curvas.

Fernández de Enciso, Suma de Geographía, 1530, fol. 60r: Y supongo primero que cada qual que sirbiere en este noble ministerio, demás del compás puntyagudo y cálibo que diximos arriba, a de tener en su estuche, echa a punta de diamante, para cevar la pieça, otra con garabatillo, para con ella tantear la cantidad del metal con el fogón, una gubia, para sacar algún tanto de pieça que otro ubiese cargado // García de Palacio, Instrución náuthica, 1587, fol. 117r: Quatro hachas, quatro açuelas, tres llanas, y una cóncaba para cabar ximelgas, y vergas, y calcetes y otras cosas, y hartos escoplos, gurbias, barrenas, maços, martillos, limas, trabador, cepillos y planas, almagre e hilo de lana para señalar, con otras menudencias que pertenescen a su oficio. // Anónimo, Diálogo fábrica de navios, ca. 1631, fol. 34r: Dos barrenas de costado, otras dos de medio costado, seis pequeñas de escora y barrote y tillado, una sierra grande de dos manos, otra de una mano, almagre, liñas de lana, quatro escoplos, dos gurbias.

guepejo, guepejo [probablemente del fr. guêpe 'avispa' y el sufijo -ejo (TLF). Lobato, Notas, c.1585]. sust. m. Mec. Pieza encajada en la solera, sobre la que se apoya el gorrón de un molino.

Lobato, Notas, c.1585, fol. 36: Puente de roble o encina fuerte, para tener el rodezno y piedra, con el aliviador del alto que sea necesario con el guepejo o rangua.

SIN.: palahierro, rangua.

HOL.: molino.

guija, guija [probablemente del lat. tardío [petra] aquilea, piedra aguda, der. de aquileus 'aguijón' y este del lat. aculeus (DRAE). Loçano, Alberto, Architectura, 1582]. sust. f. Piedra lisa y pequeña que se encuentra en las orillas y cauces de los ríos y arroyos (DRAE). 
Loçano, Alberto, Architectura, 1582, pág. 340: Evitarse ha esso si los lugares vazíos hinchiéredes de caña, o si tapáredes todos los escondidijos y recogimientos a las bestiecillas con greda y guijas.

FAM.: guijo.

guijo, guijo [de guija. Lobato, Notas, a. 1585]. sust. m. Mec. Punta o extremo puntiagudo de un palo o eje vertical.

Lobato, Notas, a. 1585, fol. 15: Asentado en un eje fuerte, a la punta del cual tenga seis guijos de hierros, y en el eje injerida una entruesga que tenga la mitad menos del círculo que la grúa con sus pendazos, la cual dé en un carro de 16 palos.

FAM.: guija.

[IMAGEN] Lobato, Notas, c. 1585, fol. 15.

guindal, guindal [de guinda. Entre 1493 y 1495, Nebrija (DECH). Ufano, Tratado de la Artillería, 1613]. sust. m. Cuerda de cáñamo o de cuero, del grueso de un dedo (DRAE s. v. guindaleta).

Ufano, Tratado de la Artillería, 1613, pág. 86: Cien quintales de toda clavazón, áncoras y alquitrán, cuerdas a la mano, guindales, escaletas y martinetes, faroles, turquesas o rosquillas de brea, lanternas, candelas de sebo, hachas de çera o antorchas, graso y otras menudençias. // Ufano, Tratado de la Artillería, 1613, pág. 99: A los carpinteros para los guindales y cricas, carros. // Ufano, Tratado de la Artillería, 1613, pág. 167: Con exes, ruedas y afustes, avantrains y algunos carros matos, guindales, cricas, escaletas y alçaprimes o puntales; con quatro eslisos o trineos, dos árganos o cabrestantes, con sus tornos, gúmenas, estringas, cuerdas de ligamen y de guindar las pieças.

SIN.: guindaleta $a_{1}$

FAM.: guindaleta, guindar.

guindaleta, guindaleta, guindareta [de guindal. Urrea, Vitruvio, Architectura, 1582]. sust. f. Cuerda de cáñamo o de cuero, del grueso de un dedo (DRAE).

Urrea, Vitruvio, Architectura, 1582, pág. 225: Como se aya de tirar a fuerça de braços, se an de meter, como se a dicho, tres guindaletas o cuerdas a la mano, advirtiendo que los dichos çinchos puedan servirse d'ellos por tierra llana. // Urrea, Vitruvio, Architectura, 1582, pág. 261: Y para caminar con ellos, a modo de guindaletas se engastan dos cuerdas a la mano muy adelante en dos fuertes estacas hincadas en tierra y con ellas. // Urrea, Vitruvio, Architectura, 1582, pág. 355: Asirán la mitad de cada guindaleta o cuerda y governarán la trompa y boca de la pieça de tal forma que, llegado el cuello de la pieça y desligado del aferramiento de la gumera, tengan fuertemente de las guindaletas.

SIN.: guindal 
FAM.: guindal, guindar.

2 [Celso, Reportorio universal leyes Castilla, 1553]. sust. f. Pie derecho donde los plateros tienen colgado el peso (DRAE).

Celso, Reportorio universal leyes Castilla, 1553, fol. LIIr: E el tal peso en que pesaren las monedas, sean con guindaletas. Premática de los mesmos, dada en Valencia, año CDLXXXVIII. // Celso, Reportorio universal leyes Castilla, 1553, fol. LXXXIIIr: Y tenga otro peso justo e cierto de sus balanças, y otro peso de guindaleta con sus pesas, como diximos de suso, capítulo cambiadores. // Arphe, Quilatador de la plata, 1572, fol. 7r: Y éste ha de estar en su guindaleta, y metido en una caxa guarnescida de papel, o de vidrio, para que el ayre ni el resuello no toque las balanças.

guindaleta, V. peso de $\sim$.

guindar, guindar [del fr. guinder 'íd.' y este del escand. ant. vinda 'envolver', 'devanar', 'izar por medio de un guindaste'. 1430-50, Díaz de Gámez (DECH). García de Palacio, Instrución náuthica, 1587]. v. tr. Subir en alto alguna cosa (Autoridades).

García de Palacio, Instrución náuthica, 1587, fol. 144v: Guindar: es hiçar y levantar para arriba alguna cosa. // Ufano, Tratado de la Artillería, 1613, pág. 45: Y sacar otras tan cargadas de metal en la culata que, al guindarlas en alto para montarlas o desmontarlas, es menester con un larguíssimo madero o palanca, metido en la boca de la pieça. // Ufano, Tratado de la Artillería, 1613, pág. 223: Para montar y desmontar el artillería si se ofresçiere en el camino, será menester llevar un guindal con su serviçio todo de cabeça, cabria o polea con su pie, cuerda o triça para guindar y levantar la pieça en alto;

FAM.: guindal, guindaleta.

guindareta, V. guindaleta.

gurbia, V. gubia. 


\section{$\mathrm{h}$}

hacha, acha, hacha [tomado del fr. hache 'íd.'. S. XIII, Fn. González (facha) (DECH). Collado, Plática Artillería, 1592]. sust. f. Herramienta cortante formada por una gruesa hoja de hierro con corte acerado y ojo para enastarla.

Collado, Plática Artillería, 1592, fol. 89v: Se hirán travessando árboles enteros, esquadrados con la hacha primero sobre las bancadas, pero de manera qu'el pie del un árbol venga a estar con la punta o cima del otro. // Collado, Plática Artillería, 1592, fol. 111v: Una hacheta o una açuela, un martillo de orejas, una hacha grande, limas y raspas de azero de todas suertes, una buena cantidad de clavos gruessos y pequeños // Anónimo, Diálogo fábrica de navíos, ca. 1631, fol. 28r: Y cada uno llevará una acha de cortar en la mano para que, en entrando, si el enemigo se resite, corten las jarcias y árboles y hagan agugeros en la cuvierta para bajar a la de abajo donde estuviere el enemigo.

HIPER.: herramienta.

FAM.: hacheta, hachuela.

hacheta, hacheta [de hacha (DECH). Collado, Plática Artillería, 1592]. sust. f. Hacha pequeña.

Collado, Plática Artillería, 1592, fol.

100v: Almádenas de hierro, martillos de orejas, maças, açadas y açadones de peto, hachas, hocinos y hachetas, gúmenas de cáñamo y todo otro género de cuerdas, herraduras y clavos de herrar, fuelles grandes y pequeñas, barrenas de todas maneras, yunques. // Collado, Plática Artillería, 1592, fol. 111v: Una hacheta o una açuela, un martillo de orejas, una hacha grande, limas y raspas de azero de todas suertes, una 
buena cantidad de clavos gruessos y pequeños; un par de fuelles chicas de herreros con sus tenazas de punta y dos martillos, uno grande y otro pequeño.

SIN.: hachuela.

HIPER.: herramienta.

FAM.: hacha, hachuela.

hachuela, hachuela [de hacha (DECH). Ufano, Tratado de la Artillería, 1613]. sust. f. Hacha pequeña.

Ufano, Tratado de la Artillería, 1613, pág. 422: A de tener, demás de lo dicho, una hachuela de mano, una sierra de mano, unos escoplos, cepillos y una vigornia para labrar y cortar madera de su arte y acomodar y endereçar planchas, brocas y clavillos y qüentos de los botafuegos y sus serpentinas. // Alonso Barba, Arte de los metales, 1640, fol. 61r: Vaciado el tejo de que ha de hazerse, se quite con la hachuela todo lo que estuviere esponjado, y de lo macizo solo se bata. // Alonso Barba, Arte de los metales, 1640, fol. 92v: Ábrese con la hachuela la sangradera, como queda dicho, y por ella va saliendo poco a poco toda la escoria que, por estar en la superficie y participar más de la violencia del fuego, está más cocida, y, en llegando a la que no lo está tanto, se tapa con barro y se da lugar a que la demás se cueça.

SIN.: hacheta.

HIPER.: herramienta.

FAM.: hacha, hacheta.

handar, V. andar.

harar, V. arar.

harina, arina, farina, harina [del lat. fărīna 'íd.'. H. 1220-1250, Berceo (DECH). Ortega, Conpusición Arismética y Geometría, 1512]. sust. f. Polvo que resulta de la molienda del trigo o de otras semillas (DRAE).

Ortega, Conpusición Arismética y Geometría, 1512, fol. 108v: Enprestó a un mercader un archa de farina, la qual tenía seis palmos de cada quadradura y era quadrada como un dado. // García de Palacio, Diálogos militares, 1583, fol. 33v: Tortas con miel y otros manjares delicados, varios, olorosos y preciosos vinos, rescibió solamente la harina y mandó tornar todo lo demás a los que lo avían traýdo. // Juanelo Turriano, Veinte y un libros, a. 1605, fol. 302v: Y éstos se ponen a fin de levantar o abaxar la muela, para que aga muy delgada la arina, o muy gruesa. 
FAM.: farinal, harnero.

harinero, V. molino .

harnero, arnero, harnero [del lat. (crỉbrum) fărīnārĭum 'íd.'. Entre 1493 y 1495, Nebrija (DRAE). Pérez Vargas, De re metallica, 1568]. sust. m. Utensilio de cuero o metálico agujereado para cerner o seleccionar materiales (Salinero s. v. criba). Pérez Vargas, De re metallica, 1568, fol. 6r: Como es, el passo de la ceniza patente al agua, a manera de cedaço, harnero o criva. // Juanelo Turriano, Veinte y un libros, a. 1605, fol. 409r: Ruello para moler yesso. Bacieta. Ruello para moler yesso. Algiño. Raedera. Poçal. Capaço de yesso. Cernedor de yesso. Arnero. Bacía de amasar yesso. Pala de madera. // Ufano, Tratado de la Artillería, 1613, pág. 399: El ynstrumento de la giralda y lanternas será del grandor de una rueda de molino de mano, o del que a propósito viniere, a modo de un harnero agujerado hecho de planchas subtiles.

SIN.: criba, cribo.

HIPER.: instrumento.

FAM.: farinal, harina.

[IMAGEN] Pseudo-Juanelo Turriano, Los ventiún libros, c. 1605, fol. 265v, fig. 322, en la parte inferior de la imagen.

haspa, V. aspa.

hasta, V. asta.

hastil, V. astil.

hazada, V. azada. 
hazadón, V. azadón.

hazero, V. acero.

hedificar, V. edificar.

hedificio, V. hedificio.

hedifiçio, V. edificio.

hembra, embra, enbra, hembra, henbra [del lat. fēmĭna 'íd.'. Orígenes del Idioma (DECH). Besson, Teatro instrumentos, 1602]. sust. f. Mec. Pieza que, en algunos instrumentos y artificios, tiene un hueco o agujero donde se introduce o encaja otra.

Besson, Teatro instrumentos, 1602, fol. A4v: Los dos próximos son las dos partes del tornillo, la una de las quales, que es el machio, llamaremos parte interior; la otra, que es la hembra, y es buelta hazia el mediodía, llamaremos parte exterior. // Juanelo Turriano, Veinte y un libros, a. 1605, fol. 141v: Se podían embetunar a la redonda de la embra y del macho, y el betún que sobrase se podrá quitar con una argolla de hierro, la qual esté encajada o afixada en una hasta que sea más larga que el caño, aunque la argolla no ha de ser de tanto redondo como el caño. // Juanelo Turriano, Veinte y un libros, a. 1605, fol. 325v: Y las hembras, por donde pasan los caracoles, serán muy buenas de enzina, y de roble o de serval, por ser madera muy sólida y tiene muy pocos poros en sí.

HOL.: máquina.

henbra, $V$. hembra. 
henchidero, henchidero [de henchir. Lobato, Notas, a. 1585]. sust. m. Ingen. Hidrául. Lugar en el que las cantimploras se llenan de agua.

Lobato, Notas, a. 1585, fol. 26: En la figura: El licenciado Perea la hizo, año 1558 años. Henchidero. Cantimplora. Canal de agua que vuelva. Estanque de agua. Rueda. Pilar.

HOL.: obra hidráulica.

[IMAGEN] Lobato, Notas, c. 1585, fol. 26.

henchir, enchir, henchir, hinchir, inchir, ynchir [del lat. implēre 'llenar'. H. 1140, Cid (DECH). Aurel, Arithmética algebrática, 1552]. v. tr. u. t. c. prnl. Llenar, ocupar totalmente un espacio con un líquido.

Aurel, Arithmética algebrática, 1552, fol. 91r: Y, tornada a enchir la dicha vasija de agua, puso la plata dentro y guardó assimesmo con diligencia el agua que sobresalió. // Besson, Teatro instrumentos, 1602, fol. F2v: Assí que, siendo el vaso agujerado por debaxo, para que pueda por allí hinchirse, hase primero de levantar y situar de manera que venga a estar assentado en la parte que es equidistante a la línea de poniente. // Juanelo Turriano, Veinte y un libros, a. 1605, fol. 181v: Otro modo de cisterna he pensado para que se puede hinchir con el agua que viene de algún barranco, quando llueve, o de otra parte.

FAM.: rehenchir.

hergate, V. ergata.

herir, erir, herir [del lat. ferìre 'golpear', 'dar (con algo)'. Docs. de 1090 y 1129 (DECH). Sagredo, Medidas Romano, 1526]. v. tr. u. t. c. intr. Dicho del agua: dar contra algo o caer con fuerza en ello.

Sagredo, Medidas Romano, 1526, pág. 289r: En aquel medio de las dos letras que ay, erirá con más rigor o fuerça que en ninguna otra parte, aunque ay differencia en hazer herir la agua a una mano o a la otra. // Juanelo Turriano, Veinte y un libros, a. 1605, fol. 291r: De modo que conviene que le vaya a herir la agua muy obliquamente en la rueda, como se puede comprehender por reglas de Geometría y aun de Filosophía. // Juanelo Turriano, Veinte y un libros, a. 1605, fol. 291v: Éstas son canales por donde ha de decender la agua a herir en las ruedas y rodetes.

herrada, errada, herrada [del lat. ferrrātus, ferrrāta 'dotado de hierro'. Entre 1493 y 1495, Nebrija (DRAE). Sagredo, Medidas Romano, 1526]. sust. f. Cubo de madera, con grandes aros de hierro o de latón, y más ancho por la base que por la boca (DRAE).

Sagredo, Medidas Romano, 1526, pág. 50: El vaso de los otros es como taçón o balança, el del corinthio es como cuvo o errada con que sacan agua. // Besson, Teatro instrumentos, 1602, fol. K2v: En los mesmos panderos hay cuerdas, al cabo de las quales está atado 
un palo en igual distancia al exe de la rueda mayor, en el qual hay tres herradas y otras tantas cestas. // Juanelo Turriano, Veinte y un libros, a. 1605, fol. 451r: Y que, estando colgada esta herrada, con la boca abaxo y el suelo para arriba, y después conviene que se cuelgue un peso en la assa de la herrada, el qual peso sea bastante a hazer descender la herrada dentro de la agua, que no se buelque.

FAM.: ferramenta, herramienta, herrador, herrar, herrería, herrero, herrezuelo.

herrador, herrador [de herrar. Entre 1493 y 1495, Nebrija (DECH). Montes, Instrucción y regimiento, 1537]. sust. $\mathrm{m}$. Persona que tiene como oficio el herrar las caballerías (DRAE).

Montes, Instrucción y regimiento, 1537, fol. VIIr: Otros officiales conviene llevar en el exército, que son muy necessarios, assí como clavazón para la artillería y otros aparejos; maestros para hazer curueñas, herradores para herrar los cavallos, y otros officiales. // Lechuga, Discurso de la Artillería, 1611, pág. 234: Item, avrá de toda suerte de trabaxadores en la artillería, como carpinteros, herreros, herradores, aserradores, toneleros, canastreros, cañameros, que hagan cuerda y colleras, según el trein las pidiere. // Ufano, Tratado de la Artillería, 1613, pág. 100: Y las demás personas necessarias las nombra el general del artillería a su voluntad, y son las siguientes: [...] dos maestros herreros, dos maestros mariscales o herradores de caballos; quatro carpinteros ordinarios.

FAM.: ferramenta, herrada, herramienta, herrar, herrería, herrero, herrezuelo.

herrage, V. herraje.

herraje, herrage, herraje [de hierro (DRAE). Martínez de Burgos, Reportorio premáticas y Cortes, 1551]. sust. $\mathrm{m}$. Conjunto de herraduras, aseguradas con clavos, que se ponen a las bestias (DRAE).

Martínez de Burgos, Reportorio premáticas y Cortes, 1551, fol. XXXv: Hemos sido informados que las premáticas de nuestros reynos, hechas por los Reyes Cathólicos, nuestros Señores padres y abuelos, que hablan sobre el herraje y clavazón de los herradores, se guardan mal y algunos van contra lo en ellas contenido. // Celso, Reportorio universal leyes Castilla, 1553, fol. LXXv: Clavazón y clavos de herraje de los cavallos y mulas y asnos, cómo se ha de labrar, dízese de yuso, capítulo herradores. // Celso, Reportorio universal leyes Castilla, 1553, fol. CLXIXv: La dozena de herrage cavallar valadí deve ser de XIII libras, y la dozena del herrage cavallar o mular hechizo sea de XV libras y media, y la dozena del herrage mular valadí sea de XII libras, y la dozena del herrage asnar valadí de XIV libras, y no más. 
2 [Álaba, Perfeto capitán, 1590]. sust. m. Conjunto de piezas de hierro o acero con que se guarnece un artefacto, como una puerta, un cofre, etc. (DRAE).

Álaba, Perfeto capitán, 1590, fol. 75r: Y herreros, silleros, armeros y rodeleros que reparen assí lo que conviene al herraje de carros y cavallos como por el adereço de algunas armas y instrumentos de hierro de que se suele ofrecer necessidad. // García de Céspedes, Instrumentos nuevos, 1606, fol. 44r: También se tiene de aparejar madera para los carros, herrage, poleas, roldanas, trócleas y cuerdas, tornos y leña y otras cosas.

herramienta, erramienta, ferramienta, herramienta [del lat. fërrāmenta, plural de fërrāmentum 'íd.' (DRAE). Sagredo, Medidas Romano, 1526]. sust. f. Instrumento, por lo común de hierro o acero, con que trabajan los artesanos (DRAE).

Sagredo, Medidas Romano, 1526, pág. 14: Ca de otra manera no pueden ser perfetos architetos, cuyas ferramientas son las manos de los oficiales mecánicos. // Loçano, Alberto, Architectura, 1582, pág. 148: Los instrumentos, unos son animados, como son las bestias de quatro pies; otros son mudos, como son los carros, erramientas y otros semejantes. // Juanelo Turriano, Veinte y un libros, a. 1605, fol. 265v: Todas estas herramientas y otras cosas que son necessarias para arrancar la piedra en el monte, y hazer el horno, y cocerle, y majarle la piedra hasta traerla en polvo, como conviene, para que se puedan servir d'él en las obras.

FAM.: ferramenta, herrada, herrador, herrería, herrar, herrero, herrezuelo.

[IMAGEN] Pseudo-Juanelo Turriano, Los ventiún libros, c. 1605, fol. 248r, fig. 316.

Pseudo-Juanelo Turriano, Los ventiún libros, c. 1605, fol. 252r, fig. 318.

herrar, ferrar, herrar [de hierro. H. 1300 (DRAE). Collado, Plática Artillería, 1592]. v. tr. Guarnecer de hierro una cosa.

Collado, Plática Artillería, 1592, fol. 99v: De 6 maestros herreros que sirven de herrar las caxas y ruedas, adobar las herramientas gastadas, hazer clavazón y otras cosas infinitas, cada uno 10 scudos de paga. // Juanelo Turriano, Veinte y un libros, a. 1605, fol. 230v: Y la orden que lleva a la parte de adentro: conviene herrar cada tabla en la parte que ha de yr hincada dentro de tierra. $\mathrm{Y}$ el herrarla ha de ser en el modo que va aquí abajo señalado E. // Lechuga, Discurso de la Artillería, 1611, pág. 83: Las ruedas hechas sin herrar han de ser altas, en diámetro, dos braços y quatro onças, repartidos como se sigue.

FAM.: ferramenta, herrada, herrador, herramienta, herrería, herrero, herrezuelo.

herrería, herrería [de herrero (DRAE). Aurel, Arithmética algebrática, 1552]. sust. f. Casa o molino donde se fabrica el hierro en bruto (Autoridades). Aurel, Arithmética algebrática, 1552, fol. 15v: Passando un día por una herrería (no sin inspiración buena), adonde se fabricava cierta obra con artificio de 4 martillos. // Juanelo Turriano, Veinte y un libros, c.1605, fol. 177r: Porque, levantada el agua encima del açute, puede después servir para qualquier exercicio que será neçessario, como para batán, como para herrería, de hazer andar machos y mallo, como en tales 
hedificios se acostumbran servir, y para amolar y para alimpiar armas. // Lechuga, Discurso de la Artillería, 1611, pág. 201: Muelas para herrería... 1

FAM.: ferramenta, herrada, herrador, herramienta, herrar, herrero, herrezuelo.

herrero, ferrero, herrero [del lat. ferrrārĭus 'íd'. Apol. (DECH). Fernández de Enciso, Suma de Geographía, 1530]. sust. m. Persona que tiene por oficio el labrar el hierro (DRAE).

Fernández de Enciso, Suma de Geographía, 1530, fol. LXIIv: Los quartos son los oficiales y mesoneros, y ferreros e carpinteros e maestros de hazer navíos e todos oficios mecánicos. // Besson, Teatro instrumentos, 1602, fol. G4v: La qual harmonía guardan también los segadores en las eras, ahunque sean rústicos, y también los herreros en sus hornazas, para que el sonido, igual y concorde, sea agradable. // Juanelo Turriano, Veinte y un libros, a. 1605, fol. 374v: Entiéndese esto fáçilmente sacando exemplo del herir de los herreros, que si la yunque es grande y pesada, suffre muy bien los golpes de los martillos, aunque grandes y pesados;

FAM.: ferramenta, herrada, herrador, herramienta, herrar, herrería, herrezuelo.

herrezuelo, herrezuelo [de hierro (DECH). Juanelo Turriano, Veinte y un libros, a. 1605]. sust. m. Pieza pequeña de hierro (DRAE).

Juanelo Turriano, Veinte y un libros, a. 1605, fol. 57r: Y con este nivel se puede nivelar a la redonda sin moverle de un lugar, que no decline ni de una parte ni de la otra, por raçón del cordel que va assido en aquellos dos herrezuelos I, que son agujereados para assir en ellos un cordel para templar el nivel, para le poner en la línea de la rectitud.

HIPER.: pieza.

FAM.: ferramenta, herrada, herrador, herramienta, herrar, herrería, herrero.

hexe, V. eje.

hidraula, idraula, ydraula [tomado del lat. hydraula, -ae 'íd' y este del gr.

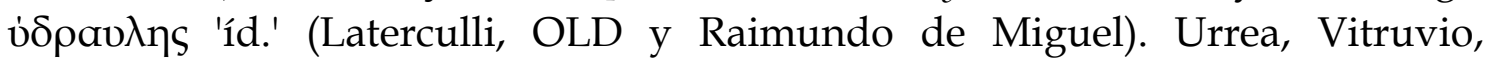
Architectura, 1582]. sust. f. Mec. Rueda hidráulica de un molino.

Urrea, Vitruvio, Architectura, 1582, fol. 131r: D'esta misma manera andan las idraulas, que son los rodeznos de los molinos, a donde ay las mismas cosas, salvo que en una cabeça del exe tienen un tímpano con dientes encerrado. // Urrea, Vitruvio, Architectura, 1582, 143v: Ydraulas: rodeznos de molino.

HOL.: molino. 
hidráulico, hidráulico, hydráulico, ydráulico [tomado del lat. hydraulĭcus

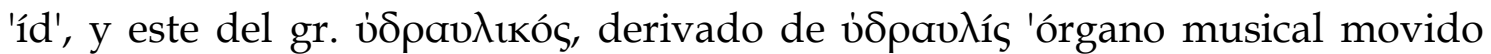
por el agua'. 1726-1739, Autoridades (DECH). Urrea, Vitruvio, Architectura, 1582]. adj. Dicho de un instrumento o máquina: que se mueve por la acción del agua. Urrea, Vitruvio, Architectura, 1582, fol. 7v: Fuera d'esto, ay también otros géneros de música que dizen hydráulicas, semejantes a órganos, la qual ninguno podrá hazer, si no es por las razones de música. // Urrea, Vitruvio, Architectura, 1582, fol. 143v: Pues quando Cthesibio consideró que el espíritu y voz nacía del tocar el ayre y exprimirlo, aprovechándose d'estos principios, inventó las máchinas hidráulicas, que son instrumentos músicos de agua, y el exprimir de las aguas, y los autómatos del porrecto, y las máchinas pintadas, y otros muchos géneros de passatiempos. // Urrea, Vitruvio, Architectura, 1582, fol. 132v: Que sea la cuenta y razón de las máchinas ydráulicas tocaré quan brevíssimamente pudiere.

FAM.: hidraula.

hinchir, V. henchir.

hobra, V. obra.

holivela, holivela [del it. olivella 'cierto ingenio de llave' (Luzio Ambruzzi). Juanelo Turriano, Veinte y un libros, a. 1605]. sust. f. Agarrador de tres piezas para sujetar sillares y otros pesos en su elevación por una grúa o aparato similar (García Tapia).

Juanelo Turriano, Veinte y un libros, a. 1605, fol. 383r: En lugar de la tenaza se pone un instrumento a modo de una escarçella, el qual llaman la holivela. // Juanelo Turriano, Veinte y un libros, a. 1605, fol. 383v: Y estos tres hierros se ponen dentro de la piedra, que se le haze un agujero en la misma forma que es hecha la holivela, mas pónese primero dentro D y F, y después se pone E. // Juanelo Turriano, Veinte y un libros, a. 1605, fol. 383v: Abaxo de la holivela hay aquellos números, los quales denotan que las dos pieças de los cabos, que es D F, que han de ser más anchos, la metad de lo que es E.

HIPER.: instrumento.

ENCICL.: "Finalmente también se utilizaba un dispositivo -sólo válido para elevar sillares- que se empleaba cuando no se quería dejar ninguna muesca o marca en la piedra. Era la holivela, formada por tres piezas de hierro que se colocaban acuñadas en 
el hueco previamente tallado de un sillar, impidiendo su escape, dispositivo que figura en Los Ventiún Libros de los Ingenios y las Máquinas" (González Tascón 1999: 124).

[IMAGEN] Pseudo-Juanelo Turriano, Los ventiún libros, c. 1605, fol. 383r, fig. 377.

hollar, hollar [del lat. vg. fullāre 'pisotear'. H. 1220-1250, Berceo (DRAE). Sagredo, Medidas Romano, 1526]. v. tr. Pisar o apretar alguna cosa caminando o poniendo sobre ella algo (DRAE).

Sagredo, Medidas Romano, 1526, pág. 39: Regla es general de los antiguos que toda pieça que sobre otra se assienta, siempre huelle sobre lleno y maciço hasta llegar a la primera piedra del cimiento. // Pérez Vargas, De re metallica, 1568, fol. 132v: Luego, esta tal ceniza o cernada se apriete con las manos y apareje, y se forme en el suelo de la fruslina un catino, a manera de crisol, hondo en el medio y corriente hazia su mitad, a manera de plato redondo o porcelana. Y, formado con un pisón, se huelle y apriete fuertemente. // Urrea, Vitruvio, Architectura, 1582, fol. 41r: Las salidas de las basas no huellen fuera de lo sólido del gruesso de la pared.

FAM.: follura, huella, huello.

huella, huella [de hollar 'pisar'. S. XVII, Autoridades (DECH). Montes, Instrucción y regimiento, 1537]. sust. f. Señal que deja el pie del hombre o del animal en la tierra por donde pasa (DRAE).

Montes, Instrucción y regimiento, 1537, fol. XVIIv: Y los guardas y cintinellas, quando hizieren su guarda, no estén dando vozes ni tañendo bozinas, porque, si estuviessen haziendo ruydo, no sentirían la huella de los enemigos quando viniessen. // Rojas, Teórica fortificación, 1598, fol. 69v: Y assimesmo se hará allí un escalón de dos pies de huella y un pie, de forma que el escalón y parapeto tengan 6 pies y medio de alto sobre el terrapleno y el dicho parapeto no tenga más de 5 pies de gruesso, según lo atrás alegado.

FAM.: follura, hollar, huello.

huello, huello [de huella. 1490, Alonso de Palencia (DECH). Martínez de Aranda, Zerramientos montea, ca. 1599]. sust. m. Sitio o terreno que se pisa (DRAE).

Martínez de Aranda, Zerramientos montea, ca. 1599, pág. 225: Tomarás en la planta por cara el huello del dicho paso, que es la distançia que ubiere desd'el punto 5 al punto 6 , y este tamaño echarás en la figura +, desd'el punto 7 al punto 8 y desd'el punto 9 al punto 10. // Martínez de Aranda, Zerramientos montea, ca. 1599, pág. 229: Y los dichos pasos se an de robar con los robos que tubieren las dichas plantas, que queden los huellos y lechos, altos y baxos, de quadrado, conforme se hiço en el dicho caracol de husillo.

FAM.: follura, hollar, huella. 
husillo, fusillo, husillo, usillo [de huso 'cilindro de un torno'. 1490, Alonso de Palencia, Nebrija (DECH). Urrea, Vitruvio, Architectura, 1582]. sust. m. Mec. Tornillo de gran tamaño, generalmente de madera, que se usa para el movimiento de las prensas y otras máquinas.

Urrea, Vitruvio, Architectura, 1582, fol. 86v: El lagar, si no se torciere con puercas, sino con otros ingenios de madera, la viga lagar no sea menos larga de quarenta pies, porque assí estará el patio desocupado para el que trata el palo o barra del husillo. // Juanelo Turriano, Veinte y un libros, a. 1605, fol. 325v: Y en la parte de arriva de los dos fusillos o caracoles ay asentado aquellas dos linternas, las quales son para que por ellas se puedan poner unas barras, para que se puedan yr bolviendo los caracoles, ya subiendo o baxando la rueda A. // Juanelo Turriano, Veinte y un libros, a. 1605, fol. 326r: Y los yerros que an de yr a la parte baxa de los usillos han de ser de esta hechura, como van aquí señalados.

SIN.: caracol, huso.

HOL.: máquina.

FAM.: huso.

huso, fuso, huso [del lat. füsus 'íd.'. H. 1220-1250, Berceo (DECH). Loçano, Alberto, Architectura, 1582]. sust. m. Mec. Tornillo de gran tamaño, generalmente de madera, que se usa para el movimiento de las prensas y otras máquinas.

Loçano, Alberto, Architectura, 1582, pág. 336: Pero la más cómmoda compuerta de todas será la que en su medio tiene un huso puesto a plomo y que se buelva. Al huso se le apegará la compuerta quadrángula, que esté tendida como en un navío de carga se descoge la vela quadrada. // Urrea, Vitruvio, Architectura, 1582, fol. 124r: Tampoco tuviéramos abundancia de manjar si los yugos, los arados para los bueyes y los demás jumentos no se ovieran hallado; ni tuviéramos las porquezuelas y husos, si no se oviera hallado el adereço del lagar. // Urrea, Vitruvio, Architectura, 1582, fol. 127v: No como Metágenes, pero de otro género hizo la máchina; porque hizo unas ruedas casi de quinze pies, y puso en ellas los cabos de la basa, y alrededor de la piedra unos husos gruessos, como dos dedos, de rueda a rueda, puestos a compás.

SIN.: caracol, husillo.

HOL.: máquina.

FAM.: husillo.

hydráulico, V. hidráulico. 
idraula, V. hidraula.

immóbil, V. inmóvil.

immóbile, V. inmóvil.

immobilidad, V. inmovilidad. 
immovible, V. inmovible.

immovilidad, V. inmovilidad.

ímpeto, V. ímpetu.

ímpetu, ímpeto, ímpetu, ínpetu [tomado del lat. impětŭs 'acción de dirigirse hacia algo'. Mediados del S. XV, J. Tallante (DECH). Falero, Tratado del espera, 1535]. sust. m. Fís. Fuerza o violencia (DRAE).

Falero, Tratado del espera, 1535, fol. 7r: Y que éstos sean los rayos que algunas vezes abaxan, los quales por pequeños que sean, por la gran distancia que ay de la esphera del fuego a la tierra, traen tanto ímpetu e furia consigo que pueden hazer la operación que vemos. // Loçano, Alberto, Architectura, (1582), 1582, pág. 19: Los ángulos mandan que se pongan hazia aquella parte donde carga la fuerça de el peso de la roca, o el ímpetu y fuerça de las aguas y vientos, para que hienda y derrame la injuria que carga y el peso. // Juanelo Turriano, Veinte y un libros, a. 1605, fol. 11r: De manera que estas aguas caminan por debajo de tierra con tanta furia y ímpetu, que todas las vezes que estas aguas se ençierran o se van apartando de su camino o canales por donde caminan, abren tan presto otros caminos de nuevo.

FAM.: impetuosidad, impetuoso.

2 [Chaves, Sacrobosco, Sphera, 1545]. sust. m. Fís. Movimiento acelerado y violento (DRAE).

Chaves, Sacrobosco, Sphera, 1545, fol. XIVr: Y a este movimiento segundo divide por medio el círculo del Zodíaco, assí como al primero dividía la aequinoctial. Pero el primer movedor arrebata con su ínpetu a todas las otras spheras, haziéndoles dar juntamente consigo una buelta a la redonda de la Tierra dentro de un día y una noche. // Chaves, Sacrobosco, Sphera, 1545, fol. LXXIVr: Todas las vezes que el Sol andava y de su proprio movimiento se movía por los signos australes y parte de los septentrionales, quando por el ímpetu del primer móbil (al qual el orbe del Sol cada día y momento siempre sigue) corporalmente poseýa el ángulo de la décima, o casa real, las sombras de qualesquiera cuerpos oppacos directamente se extendían hazia la parte diestra. // Cortés de Albacar, Breve compendio sphera, 1556, fol. XVv: El décimo cielo, llamado primum mobile o primer movedor, se mueve de levante en poniente y en veynte y quatro horas , qu'es un día natural, cumple una revolución y con el ímpetu y ligereza 
de su movimiento arrebata todos los otros cielos inferiores y les haze dar la misma buelta en veynte y quatro horas sin que ellos dexen de andar y hazer su camino.

impetuosidad, impetuosidad [de impetuoso (DECH). Besson, Teatro instrumentos, 1602]. sust. f. Fís. Cualidad de impetuoso (DRAE).

Besson, Teatro instrumentos, 1602, fol. O3v: Empero, el vaso está formado como una piña, para que sea el agua arrojada con mayor impetuosidad, porque los que son de forma de columna con menor vehemencia arrojan el agua que reciben.

FAM.: impetu, impetuoso.

impetuoso, impetuoso, inpetuoso [tomado del lat. impětǔōsus 'íd.'. $2^{\circ}$ cuarto del S. XV, Pz. de Guzmán (DECH). Cortés de Albacar, Breve compendio sphera, 1556]. adj. Fís. Que se mueve de modo violento y rápido (DRAE).

Cortés de Albacar, Breve compendio sphera, 1556, fol. IVv: En las cosas humanas ninguna más terrible ni más peligrosa es que aventurar la vida en un flaco madero, poner la persona en la furia de los inpetuosos vientos y entre las tormentas del mar. // Loçano, Alberto, Architectura, 1582, pág. 115: Y aun me plazerá aquél que fuere hecho en cerco despuntado y tundido, de manera que no quede obtuso, de suerte que se resista la dañosa presteza de la impetuosa agua. // Juanelo Turriano, Veinte y un libros, a. 1605, fol. 437r: Los siniestros que no son causados de los mismos vasillos son los furiosos vientos, que hazen fletar las impetuosas holas de la mar, o el hazer ir a dar en algún baxo de la mar, o el topar con las peñas duras.

FAM.: impetu, impetuosidad.

imprenta, emprenta, imprenta [del cat. empremta 'impresión o huella (de un sello, de un pie, etc.)'. 1482 (DECH). Apiano, Cosmographía, 1575]. sust. f. Arte de imprimir (DRAE).

Apiano, Cosmographía, 1575, fol. 36v: En esta ciudad se halló la arte muy útil de la emprenta por Juan Fausto, çerca el anno 1453. // Valle de la Cerda, Desempeño patrimonio, 1600, pág. XXIX: Pone exemplos de cosas que no se crehían, como la artillería, la emprenta y el descubrimiento de las Indias, y prueva que con erarios importarán más las Indias y sin ellos nos dañarán.

FAM.: emprimir, impresión, impresor, imprimia, imprimidor, imprimir.

2 [Escalante, Discurso de la navegación, 1577]. sust. f. Mec. Prensa en la que se estampa alguna cosa por medio de la tinta y de la presión en papel, tela, etc. Escalante, Discurso de la navegación, 1577, fol. 62r-62v : Hazen los renglones de alto abaxo, muy iguales y con mucho concierto, començando al contrario de nosotros. Esta mesma orden tienen en sus emprentas, de las quales usaron muchos años antes que en Europa. // García de Palacio, Diálogos militares, 1583, IIr: Dio licencia al dicho doctor para que pueda hazer imprimir los dichos Diálogos conforme al original que tiene 
hecho de mano, con facultad de que otro ninguno lo pueda imprimir ni vender dentro de diez años primeros siguientes, si no fuere él o quien tuviere su poder, so pena, al impressor que hiziere lo contrario, que pierda los moldes y adereços de la emprenta. // Valle de la Cerda, Desempeño patrimonio, 1600, fol. 156r: ¿Quién diera oýdos al que dixera que dava forma como un hombre diesse escriptos en un día más de mil y quinientos pliegos de papel de letra pequeña o grande, si no se supiera el artificio de la emprenta?

HIPER.: máquina.

3 [Falero, Tratado del espera, 1535]. sust. f. Taller o lugar donde se imprime (DRAE).

Falero, Tratado del espera, 1535, fol. 45v: Fue impresso en Sevilla en la imprenta de Juan Cromberger. // Lobato, Notas, a. 1585, fol. CCCXXXIXv: Fue impresso en la muy noble villa de Medina del Campo,en la imprenta de Francisco del Canto. // Collado, Plática Artillería, 1592, fol. 95v: De todas las quales empresas, provisiones y aparejos que se deven de hazer en ellas, en el libro que agora, dándome Dios vida, se dará a la emprenta, dirigido a la Magestad Cathólica, copiosamente se declara.

impresión, impresión, impressión [tomado del lat. impressĭo, -ōnis 'íd.'. S. XV, Juan de Mena (DECH). Anónimo, Premática ferias de León..., 1552]. sust. f. Acción de imprimir (DRAE).

Anónimo, Premática ferias de León..., 1552, fol. 1v: Me fue fecha relación que por vuestro aviso y relación se fizieron las primeras premáticas de los paños en estos reynos, y después las ordenanças de los dichos paños, y que de la impresión d'ello fue servido de fazer merced a Juan Ramírez e a Castañeda. // Mosquera, Comentario disciplina militar, 1596, IIv: Lo qual visto por los del nuestro Consejo, y como por su mandado se hizieron las diligencias que la premática por Nos nuevamente fecha sobre la impressión de los libros dispone. // Valle de la Cerda, Desempeño patrimonio, 1600, Vr: O traygáis fee en pública forma cómo por corretor por Nos nombrado se vio y corrigió la dicha impressión por el dicho original.

FAM.: emprimir, imprenta, impresor, imprimia, imprimidor, imprimir.

impresor, impresor, impressor [de impreso. Entre 1493 y 1495, Nebrija (DECH). Chaves, Sacrobosco, Sphera, 1545]. sust. m. Persona que tiene por oficio el imprimir o que tiene a su cargo una imprenta.

Chaves, Sacrobosco, Sphera, 1545, fol. IVr: Ni tampoco soy de tan sobervio parecer que crea que acerca de la translación d'este libro no se hallen algunos deffectos y imperfectiones, assí de parte de mi entendimiento, como por inadvertencia de los impressores. // Escalante, Discurso de la navegación, 1577, 2v: Por la qual, vos damos licencia y facultad a qualquier impressor d'estos nuestros reynos, que vuestro poder oviere, para que por esta vez podáis imprimir e imprimáis el dicho libro que de suso se haze minción. // García de Palacio, Diálogos militares, 1583, IIr: Si no fuere él o quien 
tuviere su poder, so pena, al impressor que hiziere lo contrario, que pierda los moldes y adereços de la emprenta.

SIN.: estampador, imprimidor.

FAM.: emprimir, imprenta, impresión, imprimia, imprimidor, imprimir.

impressión, V. impresión.

impressor, V. impresor.

imprimia, imprimia [de imprimir. Juanelo Turriano, Veinte y un libros, a. 1605]. sust. f. u. t. c. pl. Mec. Conjunto de dos maderos que, ajustados con tornillos, prensan las olivas molidas en algunos molinos de aceite.

Juanelo Turriano, Veinte y un libros, a. 1605, fol. 326r: Estos yerros conviene que sean como son los yerros que están en los libros de los molinos del azeyte, que están asidos a los caracoles de la imprimia que prensan la azeyte. // Juanelo Turriano, Veinte y un libros, a. 1605, fol. 333r: Y después se ponen d'ellas tres dozenas, una sobre otra, de aquellas olivas molidas, y dempués se presan con la imprimia, y ansí se va saliendo el azeyte que avía quedado en aquellas olivas molidas que avían quedado. // Juanelo Turriano, Veinte y un libros, a. 1605, fol. 334r: Los caracoles o árboles, con sus libras, que es 10 11, las cárceles donde están puestas, dentro de tierra, las libras. La U es un llano entre las dos imprimias.

HOL.: molino de aceite.

FAM.: emprimir, imprenta, impresión, impresor, imprimidor, imprimir.

[IMAGEN] Pseudo-Juanelo Turriano, Los ventiún libros, c. 1605, fol. 333v, fig. 244.

imprimidor, imprimidor [de imprimir. Falero, Tratado del espera, 1535]. sust. $\mathrm{m}$. Persona que tiene por oficio el imprimir o que tiene a su cargo una imprenta. Falero, Tratado del espera, 1535, fol. 1v: E assimismo vos doy licencia para que podáys vender el dicho tratado que assí imprimiéredes e hiziéredes imprimir, vos o qualquier librero o imprimidor que vuestro poder tovieren. // Celso, Reportorio universal leyes Castilla, 1553, fol. CLXXIXr: Y no se pueden vender por los libreros ni imprimidores de libros algunos libros que fuera d'estos reynos fueren imprimidos.

SIN.: estampador, impresor.

FAM.: emprimir, imprenta, impresión, impresor, imprimia, imprimir. 
imprimir, imprimir, inprimir, ynprimir [tomado del lat. imprimĕre 'hacer presión (en algo), marcar una huella' (DECH). 1352, Anónimo, Becerro de las Behetrías de Castilla (CORDE). Anónimo, Ordenanças paños, 1527]. v. tr. Confeccionar una obra impresa (DRAE).

Falero, Tratado del espera, 1535, fol. 1v: Y que el dicho dotor vio e examinó el dicho tratado y le halló bueno y tal, que se devía inprimir por ser tan provechoso para los navegantes. // Anónimo, Premática ferias de León..., 1552, fol. IIr: Y por la presente vos doy licencia y facultad para que vos, o la persona que vuestro poder oviere, podáys imprimir y vender los dichos libros. // Cano, Arte para fabricar naos, 1611, Vr: Y nos fue pedido y suplicado os mandásemos dar licencia y previlegio para imprimirle por veynte años, con prohibición que otro ninguno le pudiesse ymprimir sin vuestro consentimiento, so las penas que fuésemos servido de ymponer, o como la nuestra merced fuesse.

SIN.: emprimir.

FAM.: emprimir, imprenta, impresión, impresor, imprimia, imprimidor.

inartificiosamente, inartificiosamente [de inartificioso. Valles, Tratado aguas destiladas, 1592]. adv. Sin artificio.

Valles, Tratado aguas destiladas, 1592, fol. 37v: Se solía tomar inartificiosamente, unos usando de grano de trigo, otros de cebada, otros de lentejas.

inbençión, V. invención.

inchir, V. henchir.

incile, incile, inçile [tomado del lat. incile 'acequia, arroyo' (Segura Munguía). Loçano, Alberto, Architectura, 1582]. sust. m. Ingen. Hidrául. Captación o cabecera de una conducción de agua.

Loçano, Alberto, Architectura, 1582, pág. 320: Conviene que tenga el vado más bajo por un pie entero de lo que fue el lugar de donde se rompió la roca y fue hallada la agua, al qual los jurisconsultos llaman incile. // Loçano, Alberto, Architectura, 1582, pág. 320: Y para ver si desde el plano del incile la çanja del vado cavado de la derivación está más baja, y quánto decienda la obliqüidad, se han inventado ciertos instrumentos y arte muy útil. // Juanelo Turriano, Veinte y un libros, a. 1605, fol. 77r: Cosa cierta es que conviene que cada qual sea advertido en su nivelaçión, y dónde empieza y dónde ha de acabar, y dónde empieza a cavar el suelo. Los legistas le llaman a esse lugar inçile y Vitruvio le llama especo. 
SIN.: especo.

HOL.: obra hidráulica.

inçile, V. incile.

industria, industria [tomado del lat. industrŭa 'actividad, asiduidad'. 1440, A. Torre (DECH). Celso, Reportorio universal leyes Castilla, 1553]. sust. f. Maña y destreza o artificio para hacer algo (DRAE).

Fernández de Enciso, Suma de Geographía, 1530, fol. LXIr: Pero los hombres con industria buscaron formas para ello, en que les echan carnes en cierta manera e a ciertas partes a aquellas serpientes, las quales van a ellas, y en tanto los van a buscar. // Besson, Teatro instrumentos, 1602, fol. N3v: Esta nueva hechura de máquina muestra con qué industria, por medio de un atanor, añadiéndole bolsas, como en otros lugares, se puede una agua corriente de un lugar baxo, tirando también y compeliendo, hazer subir a altaria de una torre con artificio de barra. // Juanelo Turriano, Veinte y un libros, a. 1605, fol. 93r: Todas estas invenciones ha inventado la industria de los hombres para suplir a las necessidades de la vida humana y para acomodarse de lo necessario.

FAM.: industriarse, industriosamente, industrioso.

industriar, industriar, yndustriar [de industria. Anónimo, Ordenanças paños, 1527]. v. tr. u. t. c. prnl. Enseñar, adiestrar o instruir en algún arte u otra cosa (Autoridades).

Anónimo, Ordenanças paños, 1527, fol. IIIv: Hasta agora han tenido costumbre de hazer paños bervíes de menos cuenta, porque puedan yndustriarse las personas que los fazen para los hazer estambrados. // Álaba, Perfeto capitán, 1590, fol. 28v: Dos cabos de esquadra, diez conservadores de la diciplina militar, cuyo oficio será industriar y emponer la gente visoña en el lenguaje y trato de la guerra y en los términos d'ella. // Álaba, Perfeto capitán, 1590, fol. 29r: Sería de poco momento el exército que d'ella se juntasse si los que lo han de guiar y industriar fuessen tan ignorantes de los negocios de guerra como ellos de fuerça lo han de ser.

FAM.: industria, industriosamente, industrioso.

industriosamente, industriosamente [de industrioso. Besson, Teatro instrumentos, 1602]. adv. Con industria y maña (DRAE).

Besson, Teatro instrumentos, 1602, fol. M3v: Ha sido de verdad este movimiento, que en esta invención causa la subida del agua, pensado industriosamente, porque las dos ruedas, armadas tan solamente de una banda con garfios o uñezuelas.

FAM.: industria, industriarse, industrioso. 
industrioso, industrioso [del lat. industriōsus 'íd.'. H.1400, López de Ayala (DRAE). Castillo, Tratado de cuentas, 1551]. adj. Que obra con industria (DRAE). Castillo, Tratado de cuentas, 1551, fol. XXXVIr: An de considerar que si el official o administrador es persona que puede negociar y entender en cosas o tratos en que puede ganar y es persona industriosa. // Loçano, Alberto, Architectura, 1582, pág. 99: $\mathrm{Al}$ contrario, los de Ligia, por habitar en tierra pedregosa, en la qual continuamente conviene exercitarse y vivir con demasiada escaseza de vituallas, son muy industriosos y robustos. // Juanelo Turriano, Veinte y un libros, a. 1605, fol. 263r: Y saberlas muy bien distribuyr con artificio y con diligencia en los lugares más convinientes, como se espera de los hombres industriosos y de buen ingenio.

FAM.: industria, industriarse, industriosamente.

inestabilidad, instabilidad [de estabilidad. Micón, Diario grande cometa, 1578]. sust. f. Fís. Falta de estabilidad (DRAE).

Micón, Diario grande cometa, 1578, pág. 69: Y no falta el buen Mercurio, que luego sabe administrar el ánimo según su ser, las fuerças y el situ, valor, ligereza, actividad, instabilidad con el grandíssimo furiosíssimo ímpetu de su movimiento tan veloç y muy vario. // Micón, Diario grande cometa, 1578, pág. 78: Mas son tan communes que, para particularizarles, sería grande ozadía y no sé si diga temeridad, el uno por su instabilidad en el cielo; el segundo por la tanta variedad d'ellos, según los árabes y Plinio, que tantos ponen y avemos ya señalado algunos d'ellos, que apenas podremos dezir de quál género y especie d'ellos sea este presente. // Alonso Barba, Arte de los metales, 1640, fol. 22r: Como, al contrario, por la instabilidad y poca constancia que en él parece tienen los metales estando debaxo de varias formas, ya derretidos, ya quaxados, les señalan especial sugeción a los planetas, que, por la variedad que representan en sus movimientos, llaman estrellas erráticas.

ANT.: estabilidad.

FAM.: estabilidad, estable.

infinido, V. caracol $\sim$.

ingeniar, ingeniar [de ingenio. Entre 1493 y 1495, Nebrija (DECH). Valle de la Cerda, Desempeño patrimonio, 1600]. v. prnl. Discurrir con ingenio trazas y modos para conseguir algo o ejecutarlo (DRAE).

Valle de la Cerda, Desempeño patrimonio, 1600, fol. 16r: Mas, como el Marqués quiere que nada tenga fundamento, ansí se ingenia a divertirlo todo, y como los erarios se fundan de diversos particulares. 
FAM.: engeño, ingeniería, ingeniero, ingenio, ingeniosamente, ingenioso.

ingeniería, ingeniería [de ingenio. García de Céspedes, Instrumentos nuevos, 1606]. sust. f. Actividad profesional del ingeniero (DRAE).

García de Céspedes, Instrumentos nuevos, 1606, fol. 41r: Y será motivo para que los españoles traten con más cuydado las cosas de ingeniería que hasta aquí. // Lechuga, Discurso de la Artillería, 1611, pág. 243: Hallándose, por no entenderlo o no advertirlo, con error sin remedio y con cosa estropeada, con tan gran defecto como e visto en algunas hechas de ingeniería de gran ciencia.

FAM.: engeño, ingeniarse, ingeniero, ingenio, ingeniosamente, ingenioso.

ingeniero, ingeniero, injeniero, yngeniero [tomado del lat. ı̆ngěnĭerius 'íd.'. 1585, Fray Luis de León (DECH). Herrera, Institución Academia, 1584]. sust. m. Persona que tiene como profesión inventar ingenios o máquinas.

Herrera, Institución Academia, 1584, fol. 2r: Ingenieros y machinistas entendidos en la arte de los pesos, fundamento para hazer y entender todo género de máchinas de que la vida política y económica se sirve. // Juanelo Turriano, Veinte y un libros, a. 1605, fol. 418r: El modo como se a de hazer un puerto en otro lugar se a tratado, conforme a las más opiniones de los que tal arte professan. Y este exercicio era antiguamente de los architectos, y hoy día de los que el vulgo llama ingenieros y, por mejor dezir, de los que se hazen llamar ingenieros. // Juanelo Turriano, Veinte y un libros, a. 1605, fol. 419v: De modo que nadie se engañe, que el que no fuere buen architecto no puede en ninguna manera ser buen ingeniero.

FAM.: engeño, ingeniarse, ingeniería, ingenio, ingeniosamente, ingenioso.

ingenio, ingenio, yngenio [tomado del lat. ̌̆ngĕnŭum 'cualidades innatas de alguien'. Entre 1493 y 1495, Nebrija (DECH). Sagredo, Medidas Romano, 1526]. sust. $\mathrm{m}$. Facultad del hombre para discurrir o inventar con prontitud y facilidad (DRAE).

Sagredo, Medidas Romano, 1526, pág. 14: Aquéllos se llaman oficiales mecánicos que trabajan con el ingenio y con las manos, como son los canteros, plateros, carpenteros, cerrageros, campaneros y otros oficiales, que sus artes requieren mucho saber e ingenio. // Chaves, Sacrobosco, Sphera, 1545, fol. VIv: Y, assí, parece muy claro que la brevedad de la obra, y fácil y devida manera del proceder de la doctrina y su orden en gran manera disponen los ingenios para mejor y más fácilmente aprender la sciencia que oyen o leen. // Roiz, Reloges solares, 1575, fol. 10v: Ni dexamos de poner cómo se alcance a saber quán alta sea una torre o pared, quán ancha sea una fossa o un río, quán hondo sea un pozo y otras cosas semejantes, las quales el vulgo muchas vezes las tiene en poco, por la flaqueza de su ingenio.

FAM.: engeño, ingeniarse, ingeniería, ingeniero, ingeniosamente, ingenioso. 
2 [Pérez Vargas, De re metallica, 1568]. sust. m. Mec. Máquina o artificio mecánico (DRAE).

Pérez Vargas, De re metallica, 1568, fol. 191r: Pero, viendo que esta labor solamente se podía hazer en el estío, y no en todas regiones, sino en las calientes o templadas donde en el estío llueve pocas vezes, ynventaron yngenios para cozer las tales aguas y espessar y cuajar los liquores en calderos y cubos de hierro o de madera, puestos al fuego. // Acosta, Historia natural, 1590, pág. 227: El metal se muele muy bien, primero, con los maços de ingenios que golpean la piedra como batanes; $y$, después de bien molido el metal, lo ciernen con unos cedaços de telas de arambre que hazen la harina tan delgada como los communes de cerdas. // Juanelo Turriano, Veinte y un libros, a. 1605, fol. 1: Los veinte y un libros de los yngenios y máquinas de Juanelo, los quales le mandó escribir y demostrar el chatólico rei Don Felipe Segundo, Rey de las Hespañas y Nuebo Mundo.

SIN.: engeño.

HIPER.: máquina.

ingeniosamente, ingeniosamente [de ingenioso. Roiz, Reloges solares, 1575]. adv. Con ingenio (DRAE).

Roiz, Reloges solares, 1575, fol. 3r: Que fuesse en una increýble brevedad recogido, tan ingeniosamente por los fundadores de la excelente casa de Vuestra Señoría, lo que apenas en muy altos libros grandíssimos philósophos. // Núñez, Álgebra en Arithmética, 1567, fol. 67v: La opinión de Jacobo Pelletario, que muy doctamente y ingeniosamente trató la Geometría de los seis primeros libros de Euclides. // Collado, Plática Artillería, 1592, fol. 42r: La qual operación de las cuñas dichas no sólo te servirá para el effecto de amatar el bivo y ingeniosamente compartirlo, pero aun para enmendar y corregir qualesquiera otros tiros el artillero, tirados con otras qualesquiera pieças y por otro qualquiera punto.

FAM.: engeño, ingeniarse, ingeniería, ingeniero, ingenio, ingenioso.

ingenioso, ingenioso, yngenioso [tomado del lat. ingĕň̄osus 'íd.'. 1490, Alfonso de Palencia (DRAE). Celso, Reportorio universal leyes Castilla, 1553]. adj. Que tiene ingenio (DRAE).

Celso, Reportorio universal leyes Castilla, 1553, fol. CCLIXv: Y sean sabidos y ingeniosos para saber la verdad. // Santa Cruz, Libro de las longitúdines, 1567, pág. 26: El primer inventor (que yo aya sabido) que procurase dar la longitud por esta diferençia fue un Phelipe Guillén, boticario, vezino de Sevilla, hombre muy entendido e ingenioso, gran jugador de axedrez y cortador de tigera, // Urrea, Vitruvio, Architectura, 1582, fol. 5v: Por lo qual es visto que aquéllos que professan ser architectos han de ser exercitados en lo uno y en lo otro, de manera que conviene ser ingeniosos y fáciles para deprender la sciencia.

FAM.: engeño, ingeniarse, ingeniería, ingeniero, ingenio, ingeniosamente. 
2 [Álaba, Perfeto capitán, 1590]. adj. Hecho o dicho con ingenio (DRAE).

Álaba, Perfeto capitán, 1590, fol. XIr: Y de muchos buenos gustos que en ella se ocupan, fío que han de reduzir los murmuradores a que los ingeniosos discursos militares de Vuestra Merced imiten, y la nueva y admirable invención que a descubierto para reduzir a arte el uso de la artillería. // Álaba, Perfeto capitán, 1590, fol. 266r: Breve suma de los capitanes alegados en este libro, cuyo valor, esfuerço y ingeniosos ardides se proponen en su discurso por dignos de imitación // Collado, Plática Artillería, 1592, fol. 72v: El martinete es el más noble y ingenioso instrumento que hasta el día de hoy se ha inventado para el effecto de alçar pesos grandes dicho.

injeniero, V. ingeniero.

inmobible, V. inmovible.

inmóbil, V. inmóvil.

inmóbile, $\mathrm{V}$. inmóvil.

inmovible, immovible, inmobible, inmovible [tomado del lat. immovibilis 'íd.'. 1578, Aldana Medina, Arte de navegar, 1545]. adj. Fís. Que no puede ser movido.

Medina, Arte de navegar, 1545, fol. 8v: Todos estos elementos se mueven por el superior movimiento, excepto la tierra que es inmovible. // Loçano, Alberto, Architectura, 1582, pág. 18: $\mathrm{Y}$ este punto immovible que está assentado dentro del medio del círculo se dirá centro. // Juanelo Turriano, Veinte y un libros, a. 1605, fol. 8v: Y porque cerrado el ayre dentro de las tierras ralas, o sajos, o piedras, y dentro de sus juntas, y por lo mesmo dentro de las fibras y de las cavernas y concavidades de la tierra, hallándose de la tierra exhalada, muy a tarde se suele calentar y se levanta más; antes, más presto se enfría y queda en una çierta manera inmovible, por donde se viene a convertir en agua.

FAM.: inmóvil, inmovilidad, moto, motor, movedizo, mover, movible, movido, moviente, móvil, movimiento. 
inmóvil, immóbil, immóbile, inmóbil, inmóbile, inmóvil, inmóvile [tomado del lat. immōbülis 'íd.'. 1578-1590, Ercilla (DECH). Sagredo, Medidas Romano, 1526]. adj. Fís. Que no se mueve ni se puede mover.

Sagredo, Medidas Romano, 1526, pág. 27: Mayormente si le quieren cargar. Luego se esparranca y haze piernas como cavallo, por estar más immóbile y seguro de no se trastornar. // García de Palacio, Diálogos militares, (1583), 1598, fol. 114v: Porque todas las vezes que un cuerpo inmóbil toca al que se mueve (mayormente al principio de su movimiento) le impide tanto más, quanto mayor parte o tiempo va tocando en él. // Sanctiago, Arte separatoria, 1598, fol. 20r: Lo qual se demuestra bien en las apoplegías y perlesías, que por atapar con sus humores gruessos las vías del celebro, por do baxan los espíritus a las demás partes del cuerpo, y en faltando esta refeción d'este sulfre nature, quedan los tales miembros inmóviles y sin sentido.

ANT.: móvil 1 .

FAM.: inmovible, inmovilidad, moto, motor, movedizo, mover, movible, movido, moviente, móvil, movimiento.

inmóvile, $\mathrm{V}$. inmóvil.

inmovilidad, immobilidad, immovilidad [del lat. immobilìtās, -ātis 'íd.'. Chaves, Sacrobosco, Sphera, 1545]. sust. f. Fís. Cualidad de inmóvil (DRAE).

Chaves, Sacrobosco, Sphera, 1545, fol. XXXIr: De la immobilidad de la Tierra y de su determinada grandeza, y del movimiento de los tres elementos superiores. // Chaves, Sacrobosco, Sphera, 1545, fol. XXXIIv: Y lo mismo podemos entender del introyto en otro qualquier signo, por lo qual se dize en el texto que, por la entrada del Sol en los signos, se prueva la immobilidad de la Tierra. // Molina Cano, Descubrimientos geométricos, 1598, fol. 43v: Porque yo, para en quanto a mí, ya tengo por firme y creo no haver más de los tres cielos sobre que fue arrebatado san Paulo, como sé que es cierta la immovilidad d'ellos, por lo que se infiere de lo que dexo demostrado, sin valerme (como pudiera) de la verdadera opinión del mismo san Juan y demás sanctos y hombres doctos.

FAM.: inmovible, inmóvil, moto, motor, movedizo, mover, movible, movido, moviente, móvil, movimiento.

ínpetu, V. ímpetu. 
inpetuoso, V. impetuoso.

inprimir, V. imprimir.

instabilidad, V. inestabilidad.

instrumental, instrumental [de instrumento. Vandelvira, Traças de cortes, ca. 1591]. adj. Perteneciente o relativo al instrumento (DRAE).

Vandelvira, Traças de cortes, ca. 1591, fol. 3r: Y porque mexor fundamento y raçón se pueda dar d'esta arte, pondremos primero algunas definiçiones y figuras geométricas y instrumentales, para ynteligençia d'este libro.

FAM.: estrumento, instrumento.

instrumento, instrumento, istrumento, ynstrumento, ystrumento [tomado del lat. instrūmentum 'íd.'. H. 1220-1250, Berceo (DECH). Sagredo, Medidas Romano, 1526]. sust. m. Ingenio o artificio, generalmente de pequeñas dimensiones, que sirve para hacer algo.

Sagredo, Medidas Romano, 1526, pág. 73: Y con este tal instrumento meterás tus estacas todo lo que conviene, cuyas cabeças encarcelarás unas con otras, con vigas muy fuertes, y, entremedias, echarás carbón bien tapiado, y encima pornás tus piedras de cimientos, las mayores que pudieres haver, con su cal necessaria.

FAM.: estrumento, instrumental.

invención, inbençión, invención, invençión, inventión, invenzión, invinción, invinçión [tomado del lat. inventīō, inventǐonis 'íd.'. 1433, Villena (DECH). Sagredo, Medidas Romano, 1526]. sust. f. Acción y efecto de inventar (DRAE).

Sagredo, Medidas Romano, 1526, pág. 47: Contentoles, otrosí, la invención del vaso, el qual tomaron para armadura de su capitel. // Girava, Fineo, Geometría práctica, trads., 1553, pág. 6: Han parescido tantas y tan varias maneras de estudios y exercicios, entre los quales quánta preeminençia tengan los de las letras nadie havrá tan ciego que claramente no lo vea, pues que la invençión, juizio y orden de los demás cuelga de solos los estudios de letras. // Besson, Teatro instrumentos, 1602, fol. P4v: Toda la sutileza d'esta máquina está puesta en la invención de las ruedas, las quales se han de fabricar del todo semejantes a las de los relojes. 
FAM.: envención, inventar, inventiva, inventivo, invento, inventor.

2 [Sagredo, Medidas Romano, 1526]. sust. f. Cosa inventada (DRAE).

Sagredo, Medidas Romano, 1526, pág. 53: Sobre la qual invención, los architetos que después sucedieron, han ynovado tantas diferencias y acrecentado tantos de atavíos, que ya de la primera formación no ay memoria. // Juanelo Turriano, Veinte y un libros, a. 1605, fol. 145r: Y con esta invinçión se podrá servirse d'ella a diversas cosas, aunque el subirse, abajarse él mismo, pareçerá dificultoso, lo qual no es. // Juanelo Turriano, Veinte y un libros, a. 1605, fol. 372v: Y por esta razón la he puesto en demonstratión. Sólo se deven cerrar de una simple pared, la qual inventión vide en una puente que vi en Italia.

SIN.: envención, inventiva 2 .

invençión, V. invención.

inventar, enventar, inventar [tomado del lat. inventāre 'íd.'. 1475, Guillén de Segovia, La gaya ciencia (CORDE). Medina, Arte de navegar, 1545]. v. tr. Discurrir ingeniosamente algún artificio u otra cosa de nuevo (Autoridades).

Medina, Arte de navegar, 1545, fol. 14r: De la navegación escrive sant Ysidro en las Ethimologías que los lidos fueron los que primero inventaron hazer navíos. // Lobato, Notas, a. 1585, fol. 22: Este molino inventaron en Flandes para hacer a menor costa y sobre muralla, como irá. / / Juanelo Turriano, Veinte y un libros, a. 1605, fol. 78r: Y por esta causa se inventaron los aguaductos, para poder llevar el agua donde la tenían menester, y a esta causa hizieron unos grandíssimos arcos.

SIN.: enventar.

FAM.: envención, invención, inventiva, inventivo, invento, inventor.

inventión, V. invención.

inventiva, inventiva, ynventiva [de inventar. Pérez Vargas, De re metallica, 1568]. sust. f. Capacidad y disposición para inventar (DRAE).

Pérez Vargas, De re metallica, 1568, fol. 149v: Y assí en esto, como en el sinzel y buril, el uso y tiempo le dan diestreza y facilidad, porque el ayre y ynventiva no se puede 
hurtar al maestro, que es cosa propria y gracia particular de cada uno. // Pérez Vargas, De re metallica, 1568, fol. 153v: Y dar el garbo es inventiva, y es cosa propria natural, que no se adquiere, y ayudan no poco a conseguir esta abilidad la ventaja de buen maestro, el exercicio inportuno, y el uso, y aver visto muchas obras y labores y averlas imitado y contrahecho. // Pérez Vargas, De re metallica, 1568, fol. 160r: Mediante colores de los esmaltes, o piedras naturales, o contrahechas, lo qual todo se remite a la curiosidad y diligente ynventiva del maestro artificioso.

FAM.: envención, invención, inventar, inventivo, invento, inventor.

2 [Pérez Vargas, De re metallica, 1568]. sust. u. t. c. m. Cosa inventada (DRAE). Pérez Vargas, De re metallica, 1568, fol. 78r: No diremos otra cosa sino que el señor de la mina busque tales maestros y artífices que tengan experiencia, ynventivas de yngenios y máchinas, aunque, dándome Dios vida, en el Tractado de los artificios y máchinas que compongo, mediante Dios, se dirá y tractará d'esto largamente. // Pérez Vargas, De re metallica, 1568, fol. 161r: Pende del inventiva y hazénse por dos caminos: o hiriendo con punçón a la mano el engaste, y después soldando y tallando con el buril, y acabando la pieça.

SIN.: envención, invención $n_{2}$.

inventivo, inventivo, ynbentibo [de inventar. Finales del s. XVI, Autoridades (DECH). Escalante, Discurso de la navegación, 1577]. adj. Que tiene disposición para inventar (DRAE).

Escalante, Discurso de la navegación, 1577, fol. 49v: Y de gran biveza e ingenio natural, y tan inventivos en todas las artes que, con aver muchos coches y carros de cavallos, usan en los lugares de campiña de carros que son llevados a vela con el viento y los goviernan con la facilidad que a los barcos en el agua. // Vandelvira, Traças de cortes, ca. 1591, fol. 119r: Sabida la raçón y estensión de la capilla en buelta de orno, se pueden açer todas las ynbençiones de artesones y laços que al ynbentibo y prudente architecto le pareciere.

FAM.: envención, invención, inventar, inventiva, invento, inventor.

invento, invento [tomado del lat. invěntum 'íd.' (DRAE). 1454, Rodrigo Sánchez de Arévalo (CORDE). Núñez, Álgebra en Arithmética, 1567]. sust. m. Efecto de inventar.

Núñez, Álgebra en Arithmética, 1567, fol. 114v: ¡O, quán bueno fuera si los autores que escrivieron en las sciencias mathemáticas nos dexaran escriptos los sus inventos por la misma vía! // Núñez, Álgebra en Arithmética, 1567, fol. 268r: Porque nos basta para los casos de Geometría la proposición 47 del primero de Euclides, que es el invento pithagórico, con algunos fáciles documentos. // Núñez, Álgebra en Arithmética, 1567, fol. 332v: Nicolao Tartalla tanto celava los sus inventos y tanto pesar recebía porque otro los divulgasse, puesto que confesase averlos d'él deprendido. 
FAM.: envención, invención, inventar, inventiva, inventivo, inventor.

inventor, inventor, ynbentor, ynventor [tomado del lat. inventŏr, inventōris 'íd.'. H. 1440, A. Torre (DECH). Sagredo, Medidas Romano, 1526]. sust. La persona que inventa o halla y descubre de nuevo alguna cosa (Terreros).

Sagredo, Medidas Romano, 1526, pág. 12: Pues de buena razón arte griega se devría llamar y no romana, pues los griegos son los primeros inventores d'ella. // Urrea, Vitruvio, Architectura, 1582, fol. 136v: De todas las máchinas y torres he dicho lo que más a propósito me ha parecido, y quién fue el inventor, y de qué manera se han de hazer. // Ufano, Tratado de la Artillería, 1613, pág. 14: Como los primeros ynventores hallaron la fundiçión del hierro, según y como se a hecho en otra parte, las llamaron pieças de hierro colado que, para ser de las primeras, no le dieron mala forma ni encavalgamiento

FAM.: envención, invención, inventar, inventiva, inventivo, invento.

invenzión, $V$. invención.

invinción, $V$. invención.

invinçión, V. invención.

istrumento, $\mathrm{V}$. instrumento. 
jaraíz, xaraýz [del ár. șahrîy 'balsa, estanque' (DECH). Celso, Reportorio universal leyes Castilla, 1553]. sust. f. Mec. Artificio con el que se prensa la uva o la aceituna para obtener mosto o aceite, respectivamente.

Celso, Reportorio universal leyes Castilla, 1553, fol. CCCXXXIIv: Ansimesmo, las xaraýzes o lagares o molinos para hazer azeyte, o bodegas con tinajas que son en campo o en viña o en olivar que se vendieren, no entran en la venta si no fuere dicho expressamente.

SIN.: $\operatorname{lagar}_{1}$.

HIPER.: artificio.

FAM.: zafariche.

jardín, jardín, xardín [tomado del fr. jardín 'íd.', diminutivo romance del fr. ant. jart 'huerto', y este del franco *gard 'cercado'; cf. alto alem. ant. gart 'corro', ingl. yard 'patio'. Entre 1493 y 1495, Nebrija (DECH). Anónimo, Ordenanças paños, 1527]. sust. $\mathrm{m}$. Terreno donde se cultivan plantas con fines ornamentales (DRAE). 
Anónimo, Ordenanças paños, 1527, fol. 170r: Un moço entra en un jardín por tres toronjas, en el qual jardín hay quatro porteros, y dize al primero que le dexe entrar a cojer toronjas y que le dará la mitad de las que truxiere y media más sin partir. // Juanelo Turriano, Veinte y un libros, a. 1605, fol. 134v: Con esta misma invención se podrá hazer, dentro de algún xardín, que de una pequeña fuente hazer que parezca mucha el agua. // Juanelo Turriano, Veinte y un libros, a. 1605, fol. 136v: Pues se a empezado a tractar de los jardines, como cosas de contento y de regalo que son las pesqueras en ellos, o viveros de pescados, los quales son de mucho detenimiento para la vista de los que están un rato holgándose en ello.

FAM.: jardinero.

jardinero, jardinero, xardinero [de jardín. Entre 1493 y 1495, Nebrija (DECH). Loçano, Alberto, Architectura, 1582]. sust. m. Persona que tiene por oficio el cuidar y cultivar jardines.

Loçano, Alberto, Architectura, 1582, pág. 278: Cosa graciosa es lo que, acerca de nuestros passados, acostumbravan los jardineros adular a los señores con sus nombres escriptos por la hera con box o yervas olorosas. // Juanelo Turriano, Veinte y un libros, a. 1605, fol. 136v: Yo no estaré contando el modo como se a de hazer los surtidorzillos, pues entiendo que no ay xardinero que los ygnore el modo como se han de acomodar.

FAM.: jardin.

jeta, jeta, xeta [probablemente del fr. jeter 'echar, tirar'. Juanelo Turriano, Veinte y un libros, c.1605]. sust. f. Ingen. Hidrául. arag. Grifo o llave que en los depósitos de líquidos regula la salida de estos (DRAE).

Juanelo Turriano, Veinte y un libros, c.1605, fol. 184r: En esta manera de çisterna se podrá sacar el agua por jeta, que será muy menos trabajo y se sacará muy más limpia. // Juanelo Turriano, Veinte y un libros, c.1605, fol. 185v: Hásele de hazer una portezuela en lo alto para poder reconozer la cisterna, si se trasvina. Y a de aver en lo bajo d'ella, çerca del suelo, una jeta muy bien assentada para sacar el agua de la cisterna. // Juanelo Turriano, Veinte y un libros, c.1605, fol. 198r: En esta misma invención de algives se puede acomodar para sacar el agua por bajo con sus jetas, como se acostumbran sacar de unas fuentes que manan poco, que después se cierra de aver sacado el agua.

SIN.: enjeta.

HOL.: depósito.

FAM.: enjeta.

[IMAGEN] Pseudo-Juanelo Turriano, Los ventiún libros, c. 1605, fol. 198r, fig. 169. En la imagen observamos la parte externa de un aljibe. La letra $\mathrm{D}$ señala el lugar en el que se pondría la jeta.

judaico, V. betún . 
jugar, jugar [del lat. iŏcārī 'bromear'. H. 1140, Cid (DECH). Roiz, Reloges solares, 1575]. v. intr. Mec. Dicho de una pieza de una máquina: ponerse en movimiento para el objeto a que está destinada (DRAE).

Roiz, Reloges solares, 1575, pág. 57: Hecho esto, hazerse ha en los relogitos una rayuela que corte a la meridiana, que es la de las doze horas, en el punto de donde sale el fiel o punçoncito sobre el qual juega dicha agugita, y se aparte d'ella quanto fueren los grados del nordestear que antes hallamos. // Juanelo Turriano, Veinte y un libros, a. 1605, fol. 56v: Y la pieza D se va a encajar en F y juega en una pieza que está fixada en el corbate E, y juega en redondo, como la figura lo demuestra. // Juanelo Turriano, Veinte y un libros, a. 1605, fol. 325v: Y para levantar la rueda A, la qual va asentada sobre dos maderos, los quales van guarnecidos de unas lañas de yerro, y de esas lañas va otro yerro asido con otros yerros, el qual rodea, assí como van rodeando los caracoles, que es E F, los quales juegan en aquellas puercas, que es I $\mathrm{K}$, las quales tienen afixadas las dos armaduras, que es $\mathrm{G} \mathrm{H}$.

junta, junta, xunta [de juntar. 1055, Doc. de Oelschl. (DECH). Santa Cruz, Libro de las longitúdines, 1567]. sust. f. Mec. Unión de dos tubos u otras partes de un ingenio o máquina.

Juanelo Turriano, Veinte y un libros, a. 1605, fol. 7r: Mas, dado caso que las tierras y las piedras se mojen intrínsicamente, dentro de sí, no por esto la décima parte de los montes son aptos o aparejados a poder recibir en sí aguas, por causa de ser muy ralas las juntas de las hendiduras, o muy apartadas las unas de las otras en las peñas o piedras. // Juanelo Turriano, Veinte y un libros, a. 1605, fol. 277: Para hazer un betún para enbetunar las juntas de los alcaduces o caños de barro. // Juanelo Turriano, Veinte y un libros, a. 1605, fol. 279r: Y con esta mistura se suelda qualquier vaso que por las juntas se sale, ansí en frío tratándole.

SIN.: juntura.

HOL.: máquina.

FAM.: juntura.

juntura, juntura [del lat. iŭnctūra 'íd.'. H. 1220-1250, Berceo (DECH). Urrea, Vitruvio, Architectura, 1582]. sust. f. Mec. Unión de dos tubos u otras partes de un ingenio o máquina.

Urrea, Vitruvio, Architectura, 1582, fol. 135r: Y de las junturas de los maderos colgó el ariete y cubriolo con cuero de buey, porque estuviessen más seguros dentro los que tenían de herir el muro con la máchina. // Juanelo Turriano, Veinte y un libros, a. 1605, fol. 120r: De modo que el caño de plomo que estará en las junturas de los maderos se yrá doblando en el modo que será neçessario doblarse. // Juanelo Turriano, Veinte y un libros, a. 1605, fol. 120r: Y ansí tendrás tu intento, puniendo los maderos derechos con sus alguaças de metal, para que puedan jugar; será necessario que en las junturas de los maderos, que ellos jueguen. 
SIN.: junta.

HOL.: máquina.

FAM.: junta. 
ladrillo, ladrillo [del lat. *laterêllus, diminutivo de lătĕr, lătĕris 'íd.'. Fines del S. XIV, Ms. G. de J. Ruiz (DECH). Sagredo, Medidas Romano, 1526]. sust. m. Porción de tierra amasada y cocida que sirve para construir casas y muros.

Sagredo, Medidas Romano, 1526, pág. 49: Lo qual hizo assí, y para que mejor se conservassen, cubriolos con un quadrado ladrillo. // Loçano, Alberto, Architectura, 1582, pág. 53: Hechos los ladrillos, mandan que no los pongas luego en el horno, sino que primero estén muy secos, y que no estén secos antes de dos años. // Lobato, Notas, a. 1585, fol. 31: Al fin de esta pesquera se ha de hacer una puerta de dos arcos de ladrillo pequeños y bajos, por donde la gente pueda pasar a San Cosmes del Camino.

FAM.: enladrillado, enladrillar.

ladrón, ladrón [del lat. lătrō, lătrōnis 'guardia de corps, mercenario'. Orígenes del Idioma (DECH). Rojas, Teórica fortificación, 1598]. sust. m. Ingen. Hidrául. Portillo y canal que se hace en un río o acequia para sangrarlo (Salinero).

Rojas, Teórica fortificación, 1598, fol. 96r: Y lo hize ensanchar de 20, y d'esta anchura se abrió el cauz de los 2.000 passos de largo hasta la pressa, haziéndole en el camino 3 soltadores, que por otro nombre les llaman ladrones. // Rojas, Teórica fortificación, 1598, fol. 96v: Y, por hallar el río el cauz tan capaz, caminó por él sin hazer resistencia a la presa, y por ser mucha la cantidad del agua se dasaguava por los ladrones que quedavan hechos en el dicho cauz.

SIN.: soltador. 
lagar, lagar [del lat. lăcŭs 'balsa o depósito de líquidos'. (DECH). Celso, Reportorio universal leyes Castilla, 1553]. sust. m. Mec. Artificio con el que se prensa la uva o la aceituna para obtener mosto o aceite, respectivamente.

Celso, Reportorio universal leyes Castilla, 1553, fol. CCCXXXIIv: Ansimesmo, las xaraýzes o lagares o molinos para hazer azeyte, o bodegas con tinajas que son en campo o en viña o en olivar que se vendieren, no entran en la venta si no fuere dicho expressamente. // Urrea, Vitruvio, Architectura, 1582, fol. 86v: El lagar también esté muy cerca de la cozina, porque assí será provechosa la administración para el fructo de las olivas, y también tenga junta la bodega, la qual tenga al Septentrión luzes de ventanas. // Lobato, Notas, c.1585, fol. 33: En las paredes del dicho molino se encajarán unos lobos para que la puente no se pueda ir a una parte ni a otra, que serán como las berinas de un lagar en sano horadadas en cuadrado, y en aquel cuadrado entrarán las orejas de la dicha puente.

SIN.: jaraíz.

HIPER.: artificio.

2 [Sanctiago, Arte separatoria, 1598]. sust. m. Edificio donde hay un lagar. Sanctiago, Arte separatoria, 1598, fol. 122v: Tómense los sarmientos, en podando, y guárdense en los lagares o bodegas donde no se mojen ni les dé sol y guárdenlos hasta que quieran usar de la medicina.

lagar, V. viga .

lagosta, V. langosta.

lambor, V. alambor.

lamborado, V. alamborado.

langosta, lagosta, langosta [del lat. lŏcŭsta 'saltamontes', 'langosta de mar' (DECH). Besson, Teatro instrumentos, 1602]. sust. f. Mec. Dispositivo formado por dos tablas, unidas por un eje o cabeza, que regulan el movimiento de algunas piezas de máquinas. 
Besson, Teatro instrumentos, 1602, fol. Ev: Al cabo septentrional de las sierras está una langosta, cuyas extremidades septentrionales están fixas a las dos partes exteriores del caracol. // Besson, Teatro instrumentos, 1602, fol. Ev: Y, a más d'esto, estas partes exteriores están fixas a los pies de la langosta, cuya cabeça después está asida a la extremidad septentrional de las sierras, para que ellas muevan a éstas hazia arriba y hazia baxo, según totalmente el movimiento de la langosta. // Besson, Teatro instrumentos, 1602, fol. N4v: Lo que, haziéndolo valientemente, da la langosta abundancia de agua al atanor, la qual después la pértiga haze subir y la tira.

HOL.: máquina.

[IMAGEN] Besson, Diego, Teatro de los instrumentos, Horacio Cardon (trad.), 1602, pág. E2r, figura 14.

lanterna, V. linterna.

laña, laña [alteración de plaña (DECH). Loçano, Alberto, Architectura, 1582]. sust. f. Grapa, pieza de hierro para unir o sujetar dos cosas (DRAE).

Loçano, Alberto, Architectura, 1582, pág. 142: Tienen en más los clavos y lañas de cobre, que no de hierro. // Lobato, Notas, a. 1585, fol. 34: Y a su punta soldadas dos como lañas de hierro, como van señaladas; que se labren cada una por sí primero y se agujereen para después en ellos clavar la chapa. // Juanelo Turriano, Veinte y un libros, a. 1605, fol. 326r: La A es el clavo del caracol. La B es unas lañas anchas, de yerro, que van enclavadas.

lentamente, lentamente [de lento. Arphe, Lechuga, Discurso de la Artillería, 1611]. adv. Fís. Con lentitud (DRAE).

Lechuga, Discurso de la Artillería, 1611, pág. 170: Pero cierta cosa es que hasta el peso de la bala el tiro va creciendo, y no e visto passar más adelante, sin romperse y rebentar la máchina, quando también la pólvora estubiesse húmeda o fuesse de mala composición, de suerte que muy lentamente se encendiesse, aviéndose de mover mayor peso con menor fuerça. // Ufano, Tratado de la Artillería, 1613, pág. 366: El alcanphor en sí es cosa muy estimada para los tales fuegos, porque arde viba y lentamente, aunque esté debaxo del agua, y se mantiene en tal virtud por gran rato y espacio de tiempo.

ANT.: velozmente.

FAM.: lento.

lento, lento, llento [del lat. lentus 'íd.' (DRAE). Micón, Diario grande cometa, 1578]. adj. Fís. Tardo o pausado en el movimiento o en la acción (DRAE).

Micón, Diario grande cometa, 1578, pág. 85: Y para que no evaneciesse dicho seco, fuesse necessario otro más lento y denso, que también para atar y encogerse es menester el húmedo, a quien acompaña para condensar la frialdad. // Álaba, Perfeto capitán, 1590, fol. 97v: Y, hecha provisión d'estas misturas, antes de usar d'ellas se provarán, porque 
sucede no ser los materiales tan buenos como sería necessario; y antes que se ofrezca la ocasión del usar d'ellas, importará saber quáles son furiosas y quáles lentas. // Lechuga, Discurso de la Artillería, 1611, pág. 164: Pues ansí como los movimientos naturales son tanto más veloces quanto más se mueven con su movimiento natural, y tanto más lentos quanto más estorvo hallan que los divierta de su camino derecho, assí también los violentos son más veloces quanto más se opponen a los naturales, y más lentos y tardíos quanto más se allegan al natural y se apartan del puro violento.

ANT.: veloz.

FAM.: lentamente.

leva, leva [de levar 'levantar' (DECH). Llanos, Diccionario minas, ca. 1609-11]. sust. f. Mec. Cada uno de los dientes de la rueda, que sucesivamente levantan y luego abandonan a su propio peso los mazos de un batán u otro mecanismo análogo (DRAE s. v. álabe).

Llanos, Diccionario minas, ca. 1609-11, pág. 62: Aunque el nombre de ingenio comprende otras muchas cosas concernientes a él, propiamente es ingenio el artificio con que se muele el metal, que las partes principales de que consta son: canal, chiflón, rueda, eje, quijo, cureñas, chumaceras, castillo, triángulo, cabezales, cadenas, mazos, levas, sobarbos, almadanetas, tejos y mortero, de las cuales no hay necesidad de decir en particular.

SIN.: levador ${ }_{2}$.

HOL.: máquina.

FAM.: levadizo, levador.

2 [Alonso Barba, Arte de los metales]. sust. f. Barra que se utiliza para mover o levantar cosas de mucho peso.

Alonso Barba, Arte de los metales, 1640, fol. 96v: Ablándase el metal como massa y se junta en un grande pan; sácanse las escorias por boca que para ello tiene el horno, y, acabada la fundición y frío el hierro, se saca afuera con unas levas o alçaprimas.

SIN.: alzaprima, manuela, palanca ${ }_{1}$, palanga $a_{1}$, própalo, uña de cabra, uña de puerco.

HIPER.: herramienta.

levadizo, levadizo [de levar 'levantar' (DRAE). Loçano, Alberto, Architectura, 1582]. adj. Mec. Que se levanta o se puede levantar con algún artificio, quitándolo y volviéndolo a poner, o levantándolo y volviéndolo a bajar o dejar caer (DRAE).

Loçano, Alberto, Architectura, 1582, pág. 253: Pero por antigua costumbre aún entonces hazían de madera los theatros, y aún por essa razón reprehendieron a Pompeyo, 
porque puso el assiento del espectáculo, no como antes, con gradas levadizas, sino perpetuas, y después vinieron a tanto que dentro de la ciudad tenían tres grandíssimos theatros y amphitheatros. // García de Palacio, Diálogos militares, 1583, fol. 153v: Serviola: es madero que suele ser levadizo y que se muda a qualquier vanda y sólo sirve de arronçar y subir por él las áncoras. // Juanelo Turriano, Veinte y un libros, a. 1605 , fol. 389v: Llamo yo levadiza la cosa que se puede quitar y poner todas las vezes que sea menester, de modo que nadie cayga dentro del agua.

FAM.: leva, levador.

levadizo, V. puente /a.

levador, levador [del lat. lěvātōr, lěvātōris 'íd.'. Rom. de J. Hidalgo (DECH). Juanelo Turriano, Veinte y un libros, c.1605]. sust. m. Mec. Viga de madera que se utiliza para subir o bajar la muela voladera de los molinos harineros y permite controlar la separación entre las muelas.

Juanelo Turriano, Veinte y un libros, c.1605, fol. 300r: Y debaxo del árbol se le pone un dado de metal, alto medio palmo, y éste está asentado encima de un madero que llaman levador, el qual madero está acomodado en tal modo, que quando se quiere hazer levantar la muela, que muela más grueso o más molido el grano, con este levador se levanta y abaxa algún tanto el rodete, o lo levanta conforme a lo necessario. // Juanelo Turriano, Veinte y un libros, c.1605, fol. 305r: Y el madero donde está asentado el dado, que encima de aquél anda el rodete, el qual madero lo llaman levador, por razón que, quando quieren abaxar o subir la muela, ése le suelen abaxar o levantar algún tanto, y éste se llama templador.

SIN.: templador.

HOL.: molino.

FAM.: leva, levadizo.

2 [Juanelo Turriano, Veinte y un libros, a. 1605]. sust. m. Mec. Cada uno de los dientes de la rueda, que sucesivamente levantan y luego abandonan a su propio peso los mazos de un batán u otro mecanismo análogo (DRAE s. v. álabe).

Juanelo Turriano, Veinte y un libros, a. 1605, fol. 330r: Y en ese espacio se le asientan dos levadores, los quales son una aspa para mover los maços en alto. // Juanelo Turriano, Veinte y un libros, a. 1605, fol. 331r: Y en ello van asentados dos levadores, que es $\mathrm{E} E$. Los quales levadores levantan los maços en la parte baxa, que es F F, en los maços, debaxo del mismo maço, que es del mango del que sale afuera algún tanto, que tengan lugar los levadores de topar en ellos. // Juanelo Turriano, Veinte y un libros, a. 1605, fol. 332r: La canal es la A, que encamina la agua a la rueda B, la qual tiene cerrados los 
dos costados de las palas donde yere la agua, a causa que con más presteza pueda andar y bolver aquel árbol o exe $C$, el qual tiene encaxados unos levadores, los quales son $\mathrm{D} \mathrm{E} F$, que mueven aquellos tornicos que tienen encaxados los mangos de los maços, L M N.

SIN.: leva.

HOL.: máquina.

[IMAGEN] Pseudo-Juanelo Turriano, Los ventiún libros, c. 1605, fol. 331v, fig. 241, letras DEF.

leve, leve [tomado del lat. lěvis 'íd.' (DRAE). Sanctiago, Arte separatoria, 1598]. adj. Fís. Que pesa poco (DRAE s. v. ligero).

Sanctiago, Arte separatoria, 1598, fol. 1v: Porque, como en esta arte se apartan y distilan tanta variedad de cosas, assí conviene que los instrumentos sean conformes a ellas. Porque, de las cosas que se distilan y apartan, unas son leves y otras son graves. // Juanelo Turriano, Veinte y un libros, a. 1605, fol. 385v: Por razón que el palo largo, tanto quanto está apartado del punto donde mueve, tanto más leve haze la cosa que se mueve, el palo B, que no haze el palo C moviendo el peso A. // Juanelo Turriano, Veinte y un libros, a. 1605, fol. 450r: La demonstratión de las cosas, o más graves, o más leves que la agua, enséñalo A B. A es más ligera que la agua. B es igual con la agua. C es más pesado que la agua.

SIN.: ligero ${ }_{2}$ liviano.

ANT.: pesado.

FAM.: aliviadero, aliviado, aliviador, aliviar, alivio, soliviar.

libra, libra [del lat. lïbra 'libra de peso', 'balanza'. 1100 (DECH). Juanelo Turriano, Veinte y un libros, a. 1605]. sust. f. Mec. Base con forma de cilindro en la que se asienta el caracol o árbol de un molino de aceite.

Juanelo Turriano, Veinte y un libros, a. 1605, fol. 334r: El primer rodete es A; el segundo, B; el tercero es C. Y el asiento donde se muele la oliva es D. Donde se muelen es E F G H. Y donde se meten las olivas es E. Los ruellos o muelas es I K L. Sus árboles es M N $\mathrm{O}$. Las pilas son $\mathrm{P} Q \mathrm{R}$. Las libras, $\mathrm{S}$ T. Las pilas donde reciven l'aceyte y donde se pone limpio, apartado de la agua, $\mathrm{V} \mathrm{Y} \mathrm{Z} \mathrm{X,} \mathrm{de} \mathrm{modo} \mathrm{que} \mathrm{VX}$ son las pilas que reciven el azeyte que salle de las capaças. // Juanelo Turriano, Veinte y un libros, a. 1605, fol. 334r: Los caracoles o árboles, con sus libras, que es 10 11, las cárceles donde están puestas, dentro de tierra, las libras.

HOL.: molino de aceite.

[IMAGEN] Pseudo-Juanelo Turriano, Los ventiún libros, c. 1605, fol. 333v, fig. 244, letras S y T.

\section{ligaçón, V. ligazón.}


ligadura, ligadura [de ligar. Entre 1493 y 1495, Nebrija (DECH). Loçano, Alberto, Architectura, 1582]. sust. f. Pasta hecha con estopa, cal, aceite, escorias, vidrios molidos $\mathrm{u}$ otros materiales, que se utiliza para pegar o ligar piedra, madera, hueso, etc.

Loçano, Alberto, Architectura, 1582, pág. 68: Pero como toda la arte del artificio y la orden de edificar penda en parte de la naturaleza de las piedras, forma y disposición, y en parte de la pegadura y ligaduras de la cal y relleno, primero, pues, hemos de tratar brevíssimamente de estas cosas, que hazen a nuestro propósito. // Loçano, Alberto, Architectura, 1582, pág. 77: De suerte que en esto no se han de poner ningunas piedras, sino muy largas y muy anchas, y las más firmes de todas, y acommódense con ligadura continuada y bien compuesta // Loçano, Alberto, Architectura, 1582, pág. 108: Estas ligaduras en los muros ay quien no las aprueve mucho, porque dizen que la cal y la materia no convienen mucho tiempo, porque se quema y consume con las sales y ardor de la cal.

SIN.: pegadura.

FAM.: ligamento, ligamiento, ligar, ligarza, ligazón.

ligamento, ligamento [tomado del lat. lı̆gāmentum 'íd.' (DECH). Loçano, Alberto, Architectura, 1582]. sust. m. Acción y efecto de ligar o ligarse (DRAE). Loçano, Alberto, Architectura, 1582, pág. 76: De los recintos de las piedras, del ligamento y fortificación de las cornijas, para que muchas piedras se junten entre sí para el macizo de la pared. // Loçano, Alberto, Architectura, 1582, pág. 81: Y ay también por ligamento, de tres en tres pies, como por cascajo, echan piedras grandecillas, principalmente ordinarias, o también pedaços esquinados. // Juanelo Turriano, Veinte y un libros, a. 1605, fol. 158r: Y esto será una muy buena obra, de modo que el agua no la podrá mover, por raçón del muy grande peso y del ligamento de la madera y del peso de la piedra.

SIN.: ligamiento.

FAM.: ligadura, ligamiento, ligar, ligarza, ligazón.

ligamiento, ligamiento [del lat. lügāmentum 'íd.' (DECH). Loçano, Alberto, Architectura, 1582]. sust. m. Acción y efecto de ligar o ligarse (DRAE s. v. ligamento).

Loçano, Alberto, Architectura, 1582, pág. 77: Y hemos visto, también, quien aya esparcido en lugares de ligamiento láminas de plomo muy largas y en anchura iguales a las paredes. // Loçano, Alberto, Architectura, 1582, pág. 351: De los recintos de las piedras, del ligamiento y fortificación de las cornijas, para que muchas piedras se junten entre sí para el macizo de la pared.

SIN.: ligamento. 
FAM.: ligadura, ligamento, ligar, ligarza, ligazón.

ligar, ligar [del lat. lĭgāre 'atar'. 1251, Calila (DECH). Loçano, Alberto, Architectura, 1582]. v. tr. Unir, juntar o sujetar con ligaduras o nudos (DRAE s. v. atar).

Loçano, Alberto, Architectura, 1582, pág. 177: Pero, si el suelo fuere arenoso, estenderéys vigas largas enteras, en que se compongan los planos, y por las cabeças ligaréys las ataduras al clavo. // Loçano, Alberto, Architectura, 1582, pág. 177: A la cabeça de arriba se ligarán cuerdas, por lo menos tres: una, a la mano derecha; otra, a la yzquierda; la tercera se estenderá a la larga por lo largo de la viga. // Ufano, Tratado de la Artillería, 1613, fol. 274v: Y de tal manera con ellas se fueron arrimando a la hundida barca y la amarraron y ligaron fuertemente con las cuerdas del modo y manera que con las de agua se devía hazer.

FAM.: ligadura, ligamento, ligamiento, ligarza, ligazón.

2 [Juanelo Turriano, Veinte y un libros, a. 1605]. v. tr. Unir, juntar o sujetar con una sustancia u otro material.

Juanelo Turriano, Veinte y un libros, a. 1605, fol. 274v: Y después que serán secos, tomarás un poco de almástique con un yerro caliente y le yrás asentando el almástique por encima de la junta. Y buélvele a ligar muy fuertemente asta que sea seco, y estará muy firmísimo. // Juanelo Turriano, Veinte y un libros, a. 1605, fol. 275v: Después de aver enbetunado, conviene ligar muy bien la piedra con la madera, y muy estrechamente el uno con el otro, y déxese secar. // Juanelo Turriano, Veinte y un libros, a. 1605, fol. 253v: Las piedras de los ríos, las redondas, son de calidad contraria, que jamás se juntan bien con la calçina. Por causa del mucho humor que tiene en sí, no acaba jamás de ligar con la calçina.

ligarça, V. ligarza.

ligarza, ligarça [de ligar (DECH). Juanelo Turriano, Veinte y un libros, a. 1605]. sust. f. arag. Sujección del ancla en las almadías.

Juanelo Turriano, Veinte y un libros, a. 1605, fol. 248v: Llevan sólo barrena para agujerear las maderas, y el estral para cortar, para hacer remos y para cortar ligarças, y palos para empuxar las almadías y para travarlas con las ligarças. // Juanelo Turriano, Veinte y un libros, a. 1605, fol. 448r: Las áncoras han de ir atadas en la punta con la maroma. La áncora es A. La punta es B. La ligarça es C. Los ganchos es $\mathrm{M} \mathrm{N}$, que toman el lazo O. 
FAM.: ligadura, ligamento, ligamiento, ligar, ligazón.

ligazón, ligaçón, ligazón [del lat. l̆gātīō, lĭgātīonnis 'íd.' (DRAE). Sagredo, Medidas Romano, 1526]. sust. f. Unión, trabazón, enlace de una cosa con otra (DRAE).

Sagredo, Medidas Romano, 1526, pág. 46: Los primeros que assentaron capiteles sobre las colunas fueron los doros, y su capitel era un vaso redondo, a manera de taçón o balança, cubierto con un tablero quadrado, a semejança de plinto, que tenía tanta mesa quanta a ellos pareció bastava para recebir las junturas de los architraves e ligazones de las vigas que encima venían. // Loçano, Alberto, Architectura, 1582, pág. 76: Y pónense las semejantes piedras muy largas y anchas a nivel, y se ajuntan muy bien en hileras, casi que como con suelo sobreañadido se cubren las cosas fornecidas debajo la ligazón de las piedras. // Juanelo Turriano, Veinte y un libros, a. 1605, fol. 117v: Y hazerle una maravillosa estacada de madera de roble, y que ellos sean muy largos, y ponerlos muy espesos, hincados para este efecto, y trabar los unos con los otros, que estén muy bien trabados con sus ligazones de madera.

FAM.: ligadura, ligamento, ligamiento, ligar, ligarza.

ligeramente, ligeramente, lijeramente [de ligero. Medina, Arte de navegar, 1545]. adv. Fís. Con ligereza (DRAE).

Medina, Regimiento de navegación, 1563, fol. 80r: La tercera, por estar el peón boto, en manera que la rosa no se puede mover ligeramente. // Juanelo Turriano, Veinte y un libros, a. 1605, fol. 289v: Y es cosa importantíssima, por causa que, quando hyere la agua en el ángulo de la pala y de la rueda, buelve muy más pesada la rueda, y quando hyere en el medio de la pala, buelve, entonces, la rueda muy más ligeramente. // Juanelo Turriano, Veinte y un libros, a. 1605, fol. 479r: Y a más d'esto, entrará más agua en $\mathrm{D}$ que no en $\mathrm{B}$, por causa de ser muy más gruessa la pared $\mathrm{E}$ que no es $\mathrm{F}$, por ser muy más delgada pared que no es la E, y como la agua topa en cosa ancha, que le haze mayor detentión, y no camina tan ligeramente.

FAM.: ligereza, ligero.

ligereça, V. ligereza.

ligereza, ligereça, ligereza, lijereza [de ligero. H. 1275, $1^{a}$ Crónica General (DECH). Medina, Arte de navegar, 1545]. sust. f. Fís. Presteza, agilidad (DRAE).

Cortés de Albacar, Breve compendio sphera, 1556, fol. XVv: El décimo cielo, llamado primum mobile o primer movedor, se mueve de levante en poniente y en veynte y quatro horas, qu'es un día natural, cumple una revolución y con el ímpetu y ligereza de su movimiento arrebata todos los otros cielos inferiores y les haze dar la misma buelta en veynte y quatro horas sin que ellos dexen de andar y hazer su camino. // Loçano, Alberto, Architectura, 1582, pág. 323: También, para que evitéys aquel vicio de 
rebentar, retardaréys la ligereza de la agua con doblezes que no vayan anudados, sino suavemente flechados, de suerte que agora se doblen azia la diestra y después a la siniestra, y ahora suban y después a vezes deciendan. // Lobato, Notas, a. 1585, fol. 21: $\mathrm{Y}$ aunque las velas andaban despacio, traía gran ligereza y presteza y furia en el cortar.

FAM.: ligeramente, ligero.

2 [Juanelo Turriano, Veinte y un libros, a. 1605]. sust. Fís. Levedad o poco peso de algo (DRAE).

Juanelo Turriano, Veinte y un libros, a. 1605, fol. 11v: Y en la misma manera se engendran en los cuerpos de los animales varios humores, y ansí va pariendo o produziendo la tierra aguas y jugos de diversas calidades, aunque entre ellos sean muy differentes en el tacto, y en el sabor, y en color, y en el olor, y en la crasseza, y en el peso y ligereza. / / Juanelo Turriano, Veinte y un libros, a. 1605, fol. 17v: Que ya el jugo graso, por causa de su ligereça, que del ayre que tiene en sí, se halla, el qual nada por ençima de la agua y no se mezcla muy fácilmente con la agua. // Juanelo Turriano, Veinte y un libros, a. 1605, fol. 141r: Esta cosa podrase hazer sin alcaduzes, como se a dicho, por donde se aliviará del peso y del gasto, aunque no fuesse más de quitar el gasto de los alcaduzes y el asentarlos, y el gasto del embetunarlos, aunque no fuese más del peso en aver de moverlos y la mayor ligereza de la obra.

ligero, ligero, lijero, lixero [del fr. léger 'íd.', y este del lat. vg. *leviarius, derivado y sinónimo de lěvis 'ligero, leve'. 1605, Quijote I (DECH). Medina, Arte de navegar, 1545]. adj. Fís. Ágil, veloz, pronto (DRAE).

Medina, Arte de navegar, 1545, fol. 87r: Esto es según el medio movimiento de la Luna con que se ygualan los movimientos de todos los días, porque según el movimiento vero que ella haze unas vezes se dize tarda y otras ligera, el qual movimiento también se yguala por el movimiento medio. // Cortés de Albacar, Breve compendio sphera, 1556, fol. LXXIr: Y hase de advertir que la punta de la pirámide o chapitel y su agujero y la punta sobre que anda estén derechos y también la rosa, que no decline a una ni a otra parte; y si fuere más ligera de lo que es menester, hagan la punta sobre que anda algo más bota. // Juanelo Turriano, Veinte y un libros, a. 1605, fol. 349v: Esta máquina se puede hazer andar sin linterna, mas andará muy pesada, que con mucho travajo. Ansí que con la linterna andará con más ligereza. Y quantas más linternas se pondrán, tanto más ligera andará.

FAM.: ligeramente, ligereza.

2 [Arphe, Quilatador de la plata, 1572]. adj. Fís. Que pesa poco (DRAE).

Arphe, Quilatador de la plata, 1572, fol. 55r: Y por ser estos balaxes piedras que se aprecian por peso y hacen más plaça que las susodichas por ser ligeros, será el balax govierno para tassar por su área las demás, que se siguirán por el orden usado entre los más expertos lapidarios que aora biven. // Juanelo Turriano, Veinte y un libros, a. 1605, fol. 374v: Entiéndese esto fáçilmente sacando exemplo del herir de los herreros, que si la yunque es grande y pesada, suffre muy bien los golpes de los martillos, aunque 
grandes y pesados; pero si es pequeña y ligera, con pocos golpes salta y se mueve a una parte y otra. // Juanelo Turriano, Veinte y un libros, a. 1605, fol. 266v: La tierra çenosa es muy buena para hazer ladrillos muy excelentes y muy ligeros y muy durables.

SIN.: leve, liviano.

ANT.: pesado.

ligón, ligón [del lat. lŭgō, lugōnis 'íd.'. H. 1220-1250, Berceo (DECH). Juanelo Turriano, Veinte y un libros, a. 1605]. sust. m. Especie de azadón que por una parte tiene una pala y por otra una piqueta.

Juanelo Turriano, Veinte y un libros, a. 1605, fol. 172v: Mucha piedra, cal, arena, clavazones, qüerdas, anillas portaderas, espuertas de mimbre, bacietas o gamellas, açadas, palas, ligones, garruchas, carros, sierras, martillos, picos y otras infinitas cosas que para ello es menester. // Juanelo Turriano, Veinte y un libros, a. 1605, fol. 359v: En la figura: Cómo está la piedra en el horno. Forno de cal. Atizadores. Badil. Ligón. Pala. Açada. Capa para menear la cal.

HIPER.: herramienta.

[IMAGEN] Pseudo-Juanelo Turriano, Los ventiún libros, c. 1605, fol. 259v, fig. 319, situado en la parte inferior de la imagen.

lijeramente, $V$. ligeramente.

lijereza, V. ligereza.

lijero, V. ligero.

limatón, limatón [probablemente del cat. llimetó 'lima fina utilizada por los plateros'. Terreros (DELC). Collado, Plática Artillería, 1592]. sust. m. Lima de forma redonda, gruesa y áspera, utilizada por cerrajeros y otros artífices en sus oficios.

Collado, Plática Artillería, 1592, fol. 58r: Conviene hazer tres limatones de azero que tengan 8 cuchillos o esquinas cortantes alrededor, como el que en la presente figura se vee dibuxado. // Collado, Plática Artillería, 1592, fol. 58v: De los quales limatones, de necessidad, como arriba diximos, se han de hazer tres, a lo menos: uno que vaya 
començando a comer el metal gastado y otro un poco más gruesso para el effecto mismo, y el tercero para que acabe de arredondearlo de el todo y lo dexe muy liso. // Ufano, Tratado de la Artillería, 1613, pág. 209: Por mucho que trabaje el arco y las agujas y limatones, serán por lo menos menester seis horas, aunque Luis Collado en su Prática manual del Artillería no da más de quatro horas de tiempo.

HIPER.: herramienta.

linterna, lanterna, linterna [del lat. lāntěrna 'íd.'. 1402, Invent. arag. (DECH). Juanelo Turriano, Veinte y un libros, c.1605]. sust. f. Mec. Rueda pequeña y dentada que engrana otra mayor en un molino y otras máquinas.

Juanelo Turriano, Veinte y un libros, c.1605, fol. 290v: En este género de rueda no ay menester de linterna para hazer andar la muela, mas que en el exe de la rueda va una barra de yerro muy gruesa, la qual va fixada con unos cercillos de yerro, y encima de este barrón va la muela. // Juanelo Turriano, Veinte y un libros, c.1605, fol.

294v: Y si se acomodare que dé quatro, molerá mucho más, y si diere cinco bueltas la linterna, en tanto que diere la rueda una, molerá mucho más que no ará no dando más de dos. // Juanelo Turriano, Veinte y un libros, c.1605, fol. 310r: Y en el cubo de la una rueda van puestos unos caxales de madera, que es $C$, los quales hazen bolver la lanterna D; la qual lanterna, en el mismo exe, está una rueda grande, que es $\mathrm{E}$, la qual tiene unos caxales al costado, los quales mueven una lanterna, que es $\mathrm{F}$, la qual tiene su mástil, que se va a encaxar en la muela G.

HOL.: molino.

[IMAGEN] Pseudo-Juanelo Turriano, Los ventiún libros, c. 1605, fol. 294r, fig. 186, letra G.

livianamente, livianamente [de liviano. Loçano, Alberto, Architectura, 1582]. adv. Superficialmente, suavemente.

Loçano, Alberto, Architectura, 1582, pág. 182: Es útil la arena esquinada tomada de qualquier corriente; pero, mientras es más gruessa, tanto haze las serraduras más anchas y roe más fuertemente, y mientras más livianamente lima, tanto es más allegada al pulimiento. // García de Palacio, Diálogos militares, 1583, fol. 105v: Se porná en una tabla llana, donde le darán los golpes nescessarios con una maceta, livianamente, poniéndole encima una planchuela de plomo, requiriéndole muy a menudo, con la vista, por el dicho agujero o por su caña, hasta ponello derecho.

FAM.: aliviadero, aliviado, aliviador, alivianar, aliviar, alivio, leve, liviano, soliviar.

liviano, liviano [del lat. vg. *levianus 'íd.'. H. 1220-1250, Berceo (DECH). Falero, Tratado del espera, 1535]. adj. Fís. Que pesa poco (DRAE s. v. ligero).

Falero, Tratado del espera, 1535, fol. 5v: E los otros elementos son movibles e cada uno tiene en el esphera el sitio que, por su naturaleza, según que es puro, grave o liviano, le convenía. // Medina, Arte de navegar, 1545, fol. 3v: El cielo es ingenerable, ynaumentable, no puede recebir peregrinas impressiones, no es liviano ni pesado, caliente ni frío, seco ni húmedo, formal o realmente, sino virtual, porque su virtud e influxo escalienta. // Santa Cruz, Libro de las longitúdines, 1567, pág. 44: Y era que 
tocavan con la dicha piedra una aguja larga delgada y la metían en un palo delgado liviano, tanto que el aguja y el palo hiziesen ángulos derechos o figura de cruz.

SIN.: leve, ligero.

ANT.: pesado.

FAM.: aliviadero, aliviado, aliviador, alivianar, aliviar, alivio, leve, livianamente, soliviar.

lixero, V. ligero.

llabe, V. llave.

llave, llabe, llave [del lat. clāvis 'íd.'. Orígenes del Idioma (Berceo). (DECH). Lobato, Notas, a. 1585]. sust. f. Mec. Pieza que sirve para regular el paso de agua en un molino.

Lobato, Notas, a. 1585, fol. 16: Este molino muele con agua de una fuente pequeña, y no gasta más del agua que entra en el cubo, y siempre está moliendo. Y muele poco porque tiene pequeña llave. // Lobato, Notas, a. 1585, fol. 26: Y le pusimos dos trampas a la manera de llave de molino saetino, y la que recibía era de media vara de ancho, y la que soltaba, de una cuarta de ancho y una tercia de alto. // Sanctiago, Arte separatoria, 1598, fol. 16r: Y a de tener, demás de los caños dichos, otros dos: el uno por lo alto, por el qual se echa el agua en ella, y el otro por la parte baja, junto al suelo, con su llave de tornillo para vaciar el agua.

HOL.: molino.

llento, V. lento.

lobo, lobo [del lat. lüpus 'íd.'. 1057, Orígenes del Idioma (DECH). Lobato, Notas, c.1585]. sust. m. Mec. Garfio de hierro con los que se encajan algunas piezas en los molinos.

Lobato, Notas, c.1585, fol. 33: En las paredes del dicho molino se encajarán unos lobos para que la puente no se pueda ir a una parte ni a otra, que serán como las berinas de un lagar en sano horadadas en cuadrado, y en aquel cuadrado entrarán las orejas de la dicha puente. // Lobato, Notas, c.1585, fol. 33: Y el aliviadero estará por la parte de hacia la cuba, a la parte que quisieren, y de la otra parte otro pequeño que vaya dentro del lobo. Y el lobo de ésta tenga unos agujeros gruesos por donde le gobiernen, 
prendiendo allí un clavo de hierro redondo gordo que lo atraviese todo, como irá pintado, porque, si hay mucha agua, esté alto del agua y en aquello se gobierne.

HOL.: molino.

lúa, lúa [del gót. lôfa 'palma de la mano'. S. XIII (DECH). Lobato, Notas, a. 1585]. sust. f. Arco o cincha de sujeción (García Tapia).

Lobato, Notas, a. 1585, fol. 36: Rodezno y parahúso de madera, que es el común que se usa en los molinos. Ha de tener el alto que convenga, y si el primer trozo pudiere salir del alto de la cuba, es mejor, porque se apretarán mejor las lúas y cuñas. // Lobato, Notas, a. 1585, fol. 37: En la figura: Lúas. Anillos. Canal.

HOL.: obra hidráulica. 
maceta, maceta, maçeta [de maza. 1490, Alonso de Palencia (DRAE). Pérez Vargas, De re metallica, 1568]. sust. f. Martillo con cabeza de dos bocas iguales y mango corto, que se utiliza para golpear el cincel o puntero.

Pérez Vargas, De re metallica, 1568, fol. 150r: Y, estando en esto muy exercitado, se deve dar al exercicio del sinzel con un cercador de hierro a golpe de martillo o maceta, señalando y cortando el dibuxo, y otras vezes tallando con buril lo dibuxado. // García de Palacio, Diálogos militares, 1583, fol. 105v: Y, entendida assí su falta, se porná en una tabla llana, donde le darán los golpes nescessarios con una maceta, livianamente, poniéndole encima una planchuela de plomo. // Alonso Barba, Arte de los metales, 1640, fol. 99v: Con la qual se forma en la copella la concabidad que ha de tener; apriétase éste con golpe de maceta o martillo que se tendrá también para este efeto.

maçeta, V. maceta.

máchina, V. máquina. 
machinación, V. maquinación.

machinador, V. maquinador.

machinar, V. maquinar.

machinatoria, V. maquinatoria.

machinista, V. maquinista.

machio, V. macho.

macho, machio, macho [del lat. mascŭlus 'íd.', propiamente diminutivo de mās, măris, de igual significado. 1251, Calila (DECH). García de Palacio, Instrución náuthica, 1587]. sust. m. Mec. Pieza que entra en otra, como el tornillo en una tuerca, en algunos instrumentos y artificios.

García de Palacio, Instrución náuthica, 1587, fol. 93r: Y en este espacio se repartirán y pondrán ocho hembras muy fuertes, según el arte, para que en ellas jueguen y se metan los machos que se han de clavar en el timón. // Besson, Teatro instrumentos, 1602, fol. A4v: Los dos próximos son las dos partes del tornillo, la una de las quales, que es el machio, llamaremos parte interior; la otra, que es la hembra, y es buelta hazia el mediodía, llamaremos parte exterior. // Juanelo Turriano, Veinte y un libros, a. 1605, fol. 141v: Se podían embetunar a la redonda de la embra y del macho, y el betún que sobrase se podrá quitar con una argolla de hierro, la qual esté encajada o 
afixada en una hasta que sea más larga que el caño, aunque la argolla no ha de ser de tanto redondo como el caño.

HOL.: máquina.

a $\sim$ y hembra [Juanelo Turriano, Veinte y un libros, a. 1605]. loc. adv. Mec. Con un mecanismo semejante al del tornillo y la tuerca.

Juanelo Turriano, Veinte y un libros, a. 1605, fol. 284v: Por otro orden se ajuntan estos maderos, los quales se juntan a macho y embra, y éstos se enbetunan con vetún. // García de Céspedes, Instrumentos nuevos, 1606, fol. 41v: Mas, entre todos, los de barro son los mejores. Han de ser vedriados por dentro y que tengan dos dedos, por lo menos, de gruesso; pie y medio de largo, hechos a macho y hembra.

maça, V. maza.

maçada, V. mazada.

maço, V. mazo.

maçonería, V. mazonería.

majadero, majadero [de majar. H. 1220-h. 1250, Berceo (DECH). Besson, Teatro instrumentos, 1602]. sust. m. Mec. Mazo o pértiga para majar (DRAE).

Besson, Teatro instrumentos, 1602, fol. G4v: Nueva hechura de molino a braços para prensar y aparejar paños y papel, y moler especies, y esmenuzar piedras preñadas de metales para preparallas a hundir, y también para pulir y aguzar qualesquier instrumentos soltados a cigoñales y majaderos. // Besson, Teatro instrumentos, 1602, fol. G4v: A más de aquello, en el exe grande de las ruedas parecen cuatro clavos, por quanto hay quatro majaderos; los quales clavos están assí ordenados como que el tal exe fuesse dividido en quatro partes. // Juanelo Turriano, Veinte y un libros, a. 1605, fol. 322v: Y el exe de la linterna $\mathrm{E}$ es $\mathrm{F}$, el qual mueve unos majaderos que pican en los morteros G H I.

HOL.: molino.

FAM.: majado, majar, mallo.

[IMAGEN] Besson, Diego, Teatro de los instrumentos, Horacio Cardon (trad.), 1602, pág. Hr, figura 25. 
majado, majado [de majar (DRAE). Pérez Vargas, De re metallica, 1568]. adj. Golpeado, aplastado o reducido a trozos pequeños.

Pérez Vargas, De re metallica, 1568, fol. 168r: Ay pieças que se han de dorar un pedaço sí y otro que descubra la plata. Para esto se haze un betún de almagra, ajos majados, blanquimiento y cola. // Collado, Plática Artillería, 1592, fol. 81r: Tomaranse quatro o 6 pávilos de estopa de lino o de cáñamo y, aun a falta de estas cosas, se pueden hazer de esparto majado y, aun faltando esparto, se pueden hazer de cañas muy delgadas atadas en un manojo. // Rojas, Teórica fortificación, 1598, fol. 84v: Guardando en todo la buena prática que se ha de tener en hazer el zulaque para juntar los caños, hecho de cal biva, y azeite y estopa bien picada, y muy majada y maceada con pisones,

FAM.: majadero, majar, mallo.

majar, majar, maxar [del lat. *malleāre, de mallěus 'martillo' 'mazo de hierro'. H. 1140, Cid (DECH). Fernández de Enciso, Suma de Geographía, 1530]. v. tr. Golpear algo para deformarlo, aplastarlo o reducirlo a fragmentos pequeños (DRAE).

Fernández de Enciso, Suma de Geographía, 1530, fol. LIXv: En esta tierra ay una vena de tierra que se dize salamandria, la qual majan mucho en almirez fasta que se haze bava, y de aquella se hila un hilo muy delgado y se texe; // Loçano, Alberto, Architectura, 1582, pág. 55: Y por no dexar de dezir nada de lo que en este caso puede aprovechar, todo yesso con maços de madera se ha de majar y moler hasta que se buelva en harina, y guardarse en montones en lugar que esté muy seco. // Juanelo Turriano, Veinte y un libros, a. 1605, fol. 265v: Todas estas herramientas y otras cosas que son necessarias para arrancar la piedra en el monte, y hazer el horno, y cocerle, y majarle la piedra hasta traerla en polvo, como conviene, para que se puedan servir d'él en las obras.

FAM.: majadero, majado, mallo.

mallo, mallo [del lat. mallěus, mallī 'martillo', 'mazo de hierro' (Laterculi). Juanelo Turriano, Veinte y un libros, a. 1605]. sust. m. arag. Mazo o martillo grande de hierro, utilizado generalmente para forjar metales.

Juanelo Turriano, Veinte y un libros, a. 1605, fol. 177r: Porque, levantada el agua encima del açute, puede después servir para qualquier exercicio que será neçessario, como para batán, como para herrería, de hazer andar machos y mallo, como en tales hedificios se acostumbran servir, y para amolar y para alimpiar armas. // Anónimo, Diálogo fábrica de navíos, ca. 1631, fol. 34v: Su erramienta ordinaria es un mallo de meter, dos de recorrer, tres fierros de cortar, seis de galafetear, dos magajos, una sierra de mano, quatro martillos, dos grandes y dos pequeños.

FAM.: majadero, majado, majar.

mampostería, mampostería, manpastoría, manpostería [de mampostero (DRAE) 1600, Mariana (DECH). Urrea, Vitruvio, Architectura, 1582]. sust. f. 
Constr. Obra hecha con mampuestos colocados y ajustados unos con otros sin sujeción a determinado orden de hiladas o tamaños (DRAE).

Urrea, Vitruvio, Architectura, 1582, fol. 28r: Lo primero, porque las piedras de la mampostería están espessas y macizas, y assí no pueden chupar el humor de la materia de la cal, antes se conservan en humedad hasta la vejez.

FAM.: mampuesto.

2 sust. Constr. Conjunto de mampuestos que se utilizan en una obra de mampostería.

Loçano, Alberto, Architectura, 1582, pág. 62: Pero no todos entienden qué sea lo que tiene cada una naturalmente y por qué diffieran entre sí; porque no es menester, como piensan los no exercitados, poner una piedra sobre otra, y sobreponer unas mamposterías sobre otras mamposterías, sino que, como sean las partes diversas, tienen necessidad de diversas cosas e industria. // Rojas, Teórica fortificación, 1598, fol. 71r: Y lo que toca a la ripiación y contrafortes a la parte de adentro, se harán de piedra por labrar que llaman mampostería, que, assimesmo, yrá muy travada y ligada conforme a buena obra. // Juanelo Turriano, Veinte y un libros, a. 1605, fol. 432v: Y en el medio assentarán mampostería menuda, $\mathrm{y}$, de trecho en trecho, hazer traviessas algunas piedras que sean muy largas.

mampuesto, mampuesto [cmpt. de mano y puesto (DRAE). Covarrubias s. v. mampostería (DECH). Loçano, Alberto, Architectura, 1582]. sust. m. Constr. Piedra sin labrar que se puede colocar en obra con la mano (DRAE).

Loçano, Alberto, Architectura, 1582, pág. 116: Pero en las puentes, el suelo y la soldadura con obra de mampuesto se ha de igualar en igual grosseza de su arco. // Juanelo Turriano, Veinte y un libros, a. 1605, fol. 268v: Yo he visto ladrillos que no eran más largos que medio palmo y anchos tres dedos, y estos ladrillos servían para suelos y mampuestos de canto, a esquina de pescado, o a modo de espiga.

HIPER.: piedra.

FAM.: mampostería.

manadero, manadero [de manar (DECH). Loçano, Alberto, Architectura, 1582]. sust. $m$. Lugar en el que nacen las aguas.

Loçano, Alberto, Architectura, 1582, pág. 91: De estos alvañares, si no pudiere correr a la mar o a los ríos, cavarás poços en lugares acommodados hasta el manadero del agua y hinchirás la fossa con piedra redonda. // García de Palacio, Instrución náuthica, 1587, fol. 38r: El quarto caso es quando el nacimiento de la agua y el manadero están en tierra llana y que la diferencia de la altura del uno al otro es muy poca. // Collado, Plática Artillería, 1592, fol. 63v: Cerrará los manaderos por donde sale el agua y los hoyos dichos cubrirá de tablas, de tal manera que no impidan a los gastadores la hobra.

FAM.: manante, manantial, manar. 
manancial, V. manantial.

manante, manante [de manar. Juanelo Turriano, Veinte y un libros, a. 1605]. adj. Que brota o sale naturalmente de la tierra.

Juanelo Turriano, Veinte y un libros, a. 1605, fol. 74v: Una agua de una fuente que sea manante, conviene tener hecho experiencia para conozer la calidad del agua.

SIN.: manantial.

FAM.: manadero, manantial, manar.

manantial, manancial, manantial [de manante. Gral. Estoria (DECH). Loçano, Alberto, Architectura, 1582]. adj. u. t. c. sust. Que brota o sale naturalmente de la tierra.

Loçano, Alberto, Architectura, 1582, pág. 151: Y de aý adelante se han de meter raras, porque inficionan la agua con las ovas hediondas, y también el pez con tardanças, y hase de procurar que respire y entre agua manantial de fuente, río, laguna o mar. // García de Céspedes, Instrumentos nuevos, 1606, fol. 42v: Suele aver algunos pozos manantiales, lo qual se conoce quando en un pozo no se cessasse de sacar agua en un día y que a la noche llegasse la agua en el lugar donde estava a la mañana quando se començó a sacar; entonces se puede dezir que el tal pozo es manantial.

SIN.: manante.

FAM.: manadero, manante, manar.

manar, manar [del lat. mānāre 'íd.'. H. 1220-1250, Berceo (DECH). Pérez Vargas, De re metallica, 1568]. v. intr. Dicho de un líquido: brotar o salir (DRAE). Pérez Vargas, De re metallica, 1568, fol. 60r: Estas venas y fibras, o son densas, maçisas, o huecas; las sólidas y maçisas no tienen agua, pero pueden tener algún ayre; las huecas pocas vezes tienen agua y muchas ayre, y suele manar d'ellas agua. // Loçano, Alberto, Architectura, 1582, pág. 309: Y es cosa clara que en muchos lugares, o por terremoto, o de suyo repentinamente, manaron fuentes y corrieron mucho tiempo. // Juanelo Turriano, Veinte y un libros, a. 1605, fol. 47v: Mas no digo mucho, pues vemos manar agua de medio de las peñas, por donde se enforreze.

FAM.: manadero, manante, manantial.

mancha, mancha [del cat. manxa 'fuelle' y este del lat. mantica 'saquito, alforja, zurrón'. 1836, Peralta, Dicc. Arag.-Cast. (DECH). Juanelo Turriano, Veinte 
y un libros, a. 1605]. sust. f. Mec. arag. Especie de fuelle utilizado para subir agua o mover ruedas en algunas máquinas hidráulicas.

Juanelo Turriano, Veinte y un libros, a. 1605, fol. 232v: Puédese servir para este mismo efecto, para sacar agua, del instrumento de la mancha o barquín o fuellas, el qual es en la misma forma, sin faltar un punto de los que se sirven los herreros. // Juanelo Turriano, Veinte y un libros, a. 1605, fol. 233r: Y el instrumento se puede mover en diversas maneras, en especial que se puede hazer mover con la misma agua del río, que acomodadas dos manchas que sean de largo, a lo menos siete o ocho pies de largo, por causa que, quanto es mayor el instrumento, tanto mayor haze el effecto. // Juanelo Turriano, Veinte y un libros, a. 1605, fol. 233r: La rueda es K, la que mueve el agua. La qual anda en el exe L. Y las palas donde ha de yr el agua es I. La qual rueda mueve la mancha con aquella aspa H. Y es levantada la mancha en D.

SIN.: barquín, fuella.

HIPER.: instrumento.

[IMAGEN] Pseudo-Juanelo Turriano, Los ventiún libros, c. 1605, fol. 233r, fig. 314, letra C.

mandracho, mandracho [probablemente del ár. mádraŷ 'muelle, embarcadero' (Corriente). 1551, Romance (CORDE). Juanelo Turriano, Veinte y un libros, c.1605]. sust. m. Ingen. Hidrául. Puerto abierto con pared.

Juanelo Turriano, Veinte y un libros, c.1605, fol. 413r: Los puertos son en tres maneras: unos se llaman muelle, otros se llaman mandrachos. // Juanelo Turriano, Veinte y un libros, c.1605, fol. 413v: Aunque ellos son differentes en hechura, porque los muelles se cavan del todo dentro de tierra, junto a la mar; los mandrachos no es cosa cerrada como los muelles, mas de sola una pared larga que haze un amparo a los vasillos que aportan allí.

HIPER.: puerto.

mango, mango [del lat. vg. *mănŭcus 'íd.', 'gancho', derivado de mănĭca, que en latín designaba ya el gancho de abordaje y en it. tomó además la ac. 'mango (de cuchillo, etc.)'. H. 1335, Conde Lucanor (DECH). Apiano, Cosmographía, 1575]. sust. m. Parte alargada o estrecha con un extremo libre, por el cual se puede agarrar un instrumento o utensilio (DRAE).

Apiano, Cosmographía, 1575, fol. 54v: Harás una rueda pequeña con su mango, como en la figura siguiente, la qual partirás en 24 espacios de horas. // Besson, Teatro instrumentos, 1602, fol. D3v: El qual exe, siendo de la una y de la otra banda impelido por los obreros, muévense las ruedas para que las clavijas fixas en el exe, topando con los braços del mango del martillo, se alce el martillo, para que, passadas las clavijas, hiera en la yunque. // Juanelo Turriano, Veinte y un libros, a. 1605, fol. 155r: Y éstas se hincan con unas mazas de madera que sean grandes, o con maça de yerro que tenga el mango delgado.

HOL.: herramienta, instrumento.

FAM.: manil, mano. 
manil, manil [del lat. medieval manile, por posible analogía con aguamanil. 1565, Zúniga y Sotomayor (CORDE). Juanelo Turriano, Veinte y un libros, a. 1605]. sust. m. Empuñadura de una herramienta.

Juanelo Turriano, Veinte y un libros, a. 1605, fol. 284r: Y la señal para poner la argolla lo haze la barrena quando acaba de barrenar con un yerro que ay en el manil de la barrena.

HOL.: herramienta.

FAM.: mango, mano.

2 [Juanelo Turriano, Veinte y un libros, a. 1605]. sust. m. Mec. Codo que tienen los tornos y otros instrumentos y máquinas en la prolongación del eje, por cuyo medio se les da con la mano movimiento rotatorio (DRAE s. v. cigüeña).

Juanelo Turriano, Veinte y un libros, a. 1605, fol. 329v: Quando estos maniles o cigüeñas van ansí bueltos, buelven con mayor presteza que no hazen los derechos. Y pondrásele aquella barra E, agora sea de madera o de yerro, poco va en ello. // Juanelo Turriano, Veinte y un libros, a. 1605, fol. 353r: Estos émbulos van asidos ha dos barras que descienden de alto abaxo del poço, las quales les van azidos en un manil gancheado, el qual manil va dentro un exe que tiene una linterna, la qual linterna la mueve una rueda que lleva un animal. // Juanelo Turriano, Veinte y un libros, a. 1605, fol. 353v: Mueve el manil de yerro $\mathrm{D}$, el qual mueve las dos barras de yerro, que son E F, las quales dos barras juegan en ese manil $D$.

SIN.: cigüeña.

HOL.: máquina.

[IMAGEN] Pseudo-Juanelo Turriano, Los ventiún libros, c. 1605, fol. 364v, fig. 340, letra E.

maniobra, maniobra [del fr. manoeuvre 'íd.'. 1726-1739, Autoridades (DECH). Juanelo Turriano, Veinte y un libros, a. 1605]. sust. f. Obra material que se ejecuta con las manos.

Juanelo Turriano, Veinte y un libros, a. 1605, fol. 177r: Y convendrá dejar una bajada para descender abajo y para poder bajar. La maniobra que será necessaria para ello: yo querría que quando se hiziesen essas salidas de las canales, que ellas fuesen las más estrechas que pudiese ser, al un cabo y al otro, y que en el medio del edificio fuese ancho.

mano, mano [del lat. mănŭs 'íd.'. Orígenes del idioma (DECH). Besson, Teatro instrumentos, 1602]. sust. f. Hierro curvo y puntiagudo que sirve para aferrar algún objeto (DRAE s. v. garfio).

Besson, Teatro instrumentos, 1602, fol. I2v: Las demás cosas apegadas a la punta de la pyrámide más baxa son manos y garfios para asir la carga. // Besson, Teatro 
instrumentos, 1602, fol. O4v: En el cabo del qual caracol interior, a mediodía, están las manos o garfios para tirar las cargas arriba. // Besson, Teatro instrumentos, 1602, fol. O4v: Las manos o garfios de hierro, que cuelgan de la extremidad meridional del caracol interior, son semejantes a aquéllos comúnmente usados en los puertos de mar.

SIN.: garfio.

FAM.: mango, manil.

[IMAGEN] Besson, Diego, Teatro de los instrumentos, Horacio Cardon (trad.), 1602, pág. Pr, figura 53.

mano, V. molino de $\sim$.

mano, V. muela de .

manpastoría, V. mampostería.

manpostería, V. mampostería.

manuela, manuela, manuella [de mano. Collado, Plática Artillería, 1592]. sust. f. Barra que se utiliza para mover o levantar cosas de mucho peso.

Collado, Plática Artillería, 1592, fol. 74v: Pero, entonces, la gente que serán diputados a esta hobra con las manuellas procurarán de ayudar a passar adelante la pieça hasta haverla trastornado. // Juanelo Turriano, Veinte y un libros, a. 1605, fol. 390r: Han de ser los agujeros como los que se hazen con la manuela, para levantar las piedras en alto. // Ufano, Tratado de la Artillería, 1613, pág. 326: Porque, siendo así, se romperá fácilmente la dicha cuerda, a la qual, al primer movimiento, dará con la manuela o palanca dos o tres golpes para ygualar las bueltas y que laboren por ygual.

SIN.: alzaprima, leva $a_{2}$ palanga, palanca, própalo, uña de cabra, uña de puerco.

HIPER.: herramienta.

manuella, V. manuela.

máquina, máchina, máquina [tomado del lat. māchĭna 'íd.', 'andamio',

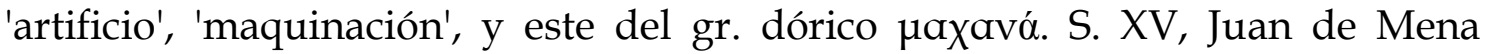


(DECH). Núñez, Álgebra en Arithmética, 1567]. sust. f. Mec. Artificio para aprovechar, dirigir o regular la acción de una fuerza (DRAE).

Núñez, Álgebra en Arithmética, 1567, fol. 114v: Y no, como Aristóteles dize en la Mechánica, de los artífices, que nos muestran de la máchina que tienen hecha lo de fuera y esconden el artificio, por parescer admirables. // Lobato, Notas, a. 1585, fol. 33: Yo, Francisco Lobato del Canto, imaginé una máquina de molino de agua estancada y de regolfo, y no le puse en efecto hasta el año 1576 años. // Besson, Teatro instrumentos, 1602 , fol. Dv: Esta máquina, propriamente, no es torno, porque lo proprio del torno es bolver en derredor algún instrumento de hierro cerca un cylindro para tornear.

FAM.: maquinación, maquinado, maquinador, maquinar, maquinatoria, maquinista.

maquinación, machinación, maquinación [tomado del lat. māchĭnātǐō, māchĭnātīōnis 'íd.' (Gaffiot). 1562, Zurita (CORDE). Urrea, Vitruvio, Architectura, 1582]. sust. f. Arte de inventar y fabricar máquinas.

Urrea, Vitruvio, Architectura, 1582, fol. 11v: Las partes del Architectura son tres: edificación, gnomónica, machinación.

SIN.: maquinatoria.

FAM.: máquina, maquinado, maquinador, maquinar, maquinatoria, maquinista.

2 [Urrea, Vitruvio, Architectura, 1582]. sust. f. Mec. Conjunto de máquinas para un fin determinado (DRAE s. v. maquinaria).

Urrea, Vitruvio, Architectura, 1582, fol. 92r: También de machinaciones escrivieron otros, como fueron Phades, Architas, Archímedes, Cthesibio, Nymphodoro, Philo, Bizancio. // Ufano, Tratado de la Artillería, 1613, pág. 421: Asimesmo, maço y martillo para clavar las dichas y otras cosas que se ofrecieren en las machinaciones del arte; tixerones, para con razón cortar las lamas o planchas de cobre y hazer d'ellas cucharas para el servicio del cargar las pieças.

3 [Besson, Teatro instrumentos, 1602]. sust. m. Mec. Mecanismo que da movimiento a un artefacto (DRAE s. v. maquinaria).

Besson, Teatro instrumentos, 1602, fol. H2v: Y toda esta maquinación de ruedas está compuesta de tres partes, en la mínima de las quales se veen unas clavijas, que con aquellos braçuelos son impelidas, que representan una cruz y se veen en el exe de las ruedas.

maquinado, machinado [de maquinar. Urrea, Vitruvio, Architectura, 1582]. adj. Mec. Regulado por la acción de alguna fuerza. 
Urrea, Vitruvio, Architectura, 1582, fol. 124r: Consideremos, pues, primeramente, y veamos del sol y de la luna y de los otros cinco planetas la constante naturaleza; los quales, si no estuviessen machinados, no se rebolverían, ni tendríamos luz en la tierra, ni madurarían los fructos.

FAM.: máquina, maquinación, maquinador, maquinar, maquinatoria, maquinista.

maquinador, machinador [de maquinar. Ufano, Tratado de la Artillería, 1613]. adj. Que maquina, piensa y discurre alguna cosa (Autoridades).

Ufano, Tratado de la Artillería, 1613, pág. 344: Salvando qualquiera grandíssima altura, dende el pie de adentro o de afuera de una fuerte y altíssima muralla o montaña, cayga sobre la machinadora gente enemiga que al opósito y pie contrario estuviere con apercevimiento de çapar, picar y minar la dicha muralla o montaña.

FAM.: máquina, maquinación, maquinado, maquinar, maquinatoria, maquinista.

maquinar, machinar [tomado del lat. māchünārī 'pensar, idear', 'tramar, urdir'. 1605, Quijote (DECH). Ufano, Tratado de la Artillería, 1613]. v. tr. Pensar, discurrir e idear medios para algún fin (Autoridades).

Ufano, Tratado de la Artillería, 1613, pág. 198: Y también, Señor, se haze por mostrar su furiosa fuerça los sitiadores y poner pavor y espanto a los sitiados, aunque ellos, por otra parte, no mondan níspolas, que lo mismo machinan, traffican, urden y traman por de dentro que los de afuera y aun con mucha más ansia, soliçitud, cuidado y diligençia. // Ufano, Tratado de la Artillería, 1613, pág. 278: Entre la estacada y el tenaçante y torre se muestra sobre quatro ruedas con algunos hombreçillos ençima y la escala y cordería que la sustiene elevada en alto, el qual sirve para, ygualándola con los ganchos o garfios de hierro con el parapeto de una baxa muralla, por medio d'ella reconosçer lo que dentro uviere, y cómo se porta, y de qué forma, la gente de su deffensa, en caso que se le machine secretamente la entrada.

FAM.: máquina, maquinación, maquinado, maquinador, maquinatoria, maquinista.

2 [Ufano, Tratado de la Artillería, 1613]. v. tr. Metal. Trabajar una pieza de metal por medio de una máquina (DRAE).

Ufano, Tratado de la Artillería, 1613, pág. 17: Y, al fin, digo que no le sería de poca estima que el tal supiese trabajar y machinar artiffiçios de fuego, tanto de guerra que de juego, porque si acaso del enemigo se hallase sitiado, poder gallarda y aventajadamente con ellos offenderle.

maquinatoria, machinatoria [tomado del lat. māchĭnātoria 'íd.'. Loçano, Alberto, Architectura, 1582]. sust. f. u. t. c. adj. Arte de inventar y fabricar máquinas. 
Loçano, Alberto, Architectura, 1582, fol. V: Y, assí, el que quisiere ser perfecto architecto, como dixo Vitrubio, conviene que tenga prática theórica, sepa Arithmética, Geometría, conozca las tres partes en que la dicha sciencia se divide, qu'es machinatoria, gnomónica y edificatoria. // Herrera, Institución Academia, 1584, fol. 15v: Y el que se hallare medianamente instructo en las dichas sciencias, y principalmente en las tres que el mismo Vitruvio pone, que son: Gnomónica, Machinatoria y Edificatoria, con justa causa se le podrá dar título de Architecto. / / Ufano, Tratado de la Artillería, 1613, pág. 279: Por la qual poca prática y la presente figura entenderá el curioso el arte machinatoria de la guerra, y de qué útil y provecho el uso d'ella sea para, a menos costa, menos peligro y más façilmente conseguir el fruto de tal arte.

SIN.: maquinación 1 .

FAM.: máquina, maquinación, maquinado, maquinador, maquinar, maquinista.

maquinista, machinista [de máquina. 1600, Sigüenza (DECH). Herrera, Institución Academia, 1584]. sust. m. Inventor o fabricante de máquinas (DRAE). Herrera, Institución Academia, 1584, fol. 2v: Ingenieros y machinistas entendidos en la arte de los pesos, fundamento para hazer y entender todo género de máchinas de que la vida política y económica se sirve; // Herrera, Institución Academia, 1584, fol. 11r: Y podrá por sí, haziendo hábito en ella el machinista, inventar muchas cosas nuevas para quando se le offrezca necessidad d'ellas.

FAM.: máquina, maquinación, maquinado, maquinador, maquinar, maquinatoria.

marea, V. molino de .

maripuente, maripuente [cmpt. de mar y puente. Juanelo Turriano, Veinte y un libros, c.1605]. sust. m. Ingen. Hidrául. arag. Acueducto o puente, generalmente elevado, colocado para hacer pasar una conducción de agua por encima de un río o arroyo.

Juanelo Turriano, Veinte y un libros, c.1605, fol. 88v: Llámanse maripuente o gallipuente quando estos arcos tan solamente, o uno o muchos, allegan de un monte a otro, o de una parte a otra de algún barranco, de adonde la toma hasta donde la deja, aunque estos arcos sean dos o tres órdenes, unos encima de otros, y aunque sean çiento ni dozientos passos. // Juanelo Turriano, Veinte y un libros, c.1605, fol. 88v: Este maripuente puede servir para dos effectos: el uno es para traher agua por él; y el otro, que sirve de puente para passar peones y de a cavallo, por evitar rodeo de camino, por causa de los barrancos. // Juanelo Turriano, Veinte y un libros, c.1605, fol. 130v: Los agujeros que ay en las dos paredes de los antepechos de esse maripuente, que es D D D, los quales agujeros son para quando viene el río muy crecido, para que se alivie de agua y augmente la baja. 
SIN.: gallipuente.

HIPER.: puente.

FAM.: carripuente, gallipuente, puente.

[IMAGEN] Pseudo-Juanelo Turriano, Los ventiún libros, c. 1605, fol. 190v, fig. 99.

maroma, maroma [del hispano-ár. mabrúm[a], y este del ár. clás. mabrūma, 'retorcida'. 1256-1263, Las Partidas (DECH). Loçano, Alberto, Architectura, 1582]. sust. f. Cuerda gruesa de esparto o cáñamo que sirve para levantar grandes pesos (Autoridades).

Loçano, Alberto, Architectura, 1582, pág. 171: Y que en el empinalle trabajaron muchos millares de hombres, teniendo todo el cerco lleno de máchinas muy altas de vigas y gruessas maromas. // Urrea, Vitruvio, Architectura, 1582, fol. 7v: Ay unos agujeros redondos por donde las maromas retorcidas se estienden con los tornos y garruchas y cerrojos, las quales maromas no se assen ni las atan sin que hagan ciertos sonidos yguales y conformes al oýdo del artífice. // Juanelo Turriano, Veinte y un libros, a. 1605, fol. 318v]: Estos molinos se hazen con unas maromas, de modo que el río no las puede mover. Y d'estas maromas ponen dos, una que va de la barca a tierra y la otra va muy adelante, asida en cosa que la detenga.

marraço, V. marrazo.

marrano, marrano [probablemente del ár. máhram 'cosa prohibida'. 965 (DECH). Lobato, Notas, c.1585]. sust. m. Ingen. Hidrául. Cada uno de los maderos fuertemente ensamblados o trabados que se sientan en el suelo del pozo o de la zanja que brota agua, para firmar los cimientos (Salinero).

Lobato, Notas, c.1585, fol. 35: Si se hubiere de poner puente o aliviadero, o marranos o rangua, o rodezno o cuba, estando hecha como pozo de 12 pies de hondo, no se podrá hacer si no es sacando el agua del dicho pozo.

HOL.: obra hidráulica.

marrazo, marraço [de marra 'mazo para romper piedras'. 1607, Oudin (DECH). Ufano, Tratado de la Artillería, 1613]. sust. m. Hacha de dos bocas utilizada por los soldados para hacer leña.

Ufano, Tratado de la Artillería, 1613, pág. 106: Tablones, puntales y otras qualesquier máquinas, como de pólvora, balas y cuerda, çapas, palas, picos, uñas de cabra, almádenas, cuñas de hierro, marraços, hachas de mano y de golpe, sierras, herrerías y carpinterías, cumplidas de maestros y herramientas. // Ufano, Tratado de la Artillería, 
1613, pág. 168: Los quales pellejos, geringas, çechas, escalas y garfios, con más quantidad de toneles, lanternas, antorchas, hachas y marraços toca proveer a la villa. // Ufano, Tratado de la Artillería, 1613, pág. 233: Los aparatos, Señor, fueron los que de ordinario se suelen llevar en el manejo del artillería: un guindal, cuerdas, hachas y marraços, con una crica o martinete.

HIPER.: herramienta.

martillada, martillada [de martillo (DECH). Arphe, Quilatador de la plata, 1572]. sust. f. Golpe que se da con el martillo (DRAE).

Arphe, Quilatador de la plata, 1572, fol. 11r: Y como esté frío, se saca el grano con unas tenazuelas delgadas y se pone sobre un tas limpio, y dánsele en un lado dos martilladas, para que despida la tierra de la copella. // Collado, Plática Artillería, 1592, fol. 56r: Haviendo, pues, dado 3 ó 4 fuertes y pesadas martilladas por derecho al clavo le dará una sola de través para romperlo. // Juanelo Turriano, Veinte y un libros, a. 1605, fol. 336v: Y esta muela sirve para allanar y quitar las señales de las martilladas en las armas.

FAM.: amartillado, amartillar, martillado, martillar, martillejo, martillo.

martillado, martillado [de martillar (DECH). Ferrofino, Descrizión Artillería, 1599]. adj. Golpeado con el martillo.

Ferrofino, Descrizión Artillería, 1599, fol. 75v: Para esto, en llegando el artillero a la pieça y mirándola en qualquier su parte, considere primero si la dicha pieça está limada por de fuera, o golpeada o martillada. // Urrea, Vitruvio, Architectura, 1582, fol. 93v: Hecha la solidación, hecharse han dentro las tejas y piedra bien martillada.

SIN.: amartillado.

FAM.: amartillado, amartillar, martillada, martillar, martillejo, martillo.

martillar, martillar [de martillo. Entre 1493 y 1495, Nebrija (DECH). Collado, Plática Artillería, 1592]. v. tr. Batir y dar golpes con el martillo (DRAE).

Collado, Plática Artillería, 1592, fol. 22v: Y aquella hoja la martillarás con un martillejo, como haze el calderero a las calderas. // Llanos, Diccionario minas, ca. 1609-11, pág. 80: Muchas veces, en más cantidad que la misma piedra en que se crio, de donde le viene el llamarse así, porque se puede martillar la plata así como está. // Lechuga, Discurso de la Artillería, 1611, pág. 59: No he consentido que se limassen por de fuera ni martillar, sino las relevaciones que sacan de metal, que son las que se hazen de entrarse por el molde, porque quedan más fuertes.

SIN.: amartillar.

FAM.: amartillado, amartillar, martillada, martillado, martillejo, martillo. 
martillejo, martillejo [de martillo. Collado, Plática Artillería, 1592]. sust. m. Martillo pequeño.

Collado, Plática Artillería, 1592, fol. 22v: Y aquella hoja la martillarás con un martillejo, como haze el calderero a las calderas.

HIPER.: herramienta.

FAM.: amartillado, amartillar, martillada, martillado, martillar, martillo.

martillo, martillo [del lat. vg. martĕllus 'íd.'. H. 1220-1250, Berceo (DECH). Montes, Instrucción y regimiento, 1537]. sust. m. Herramienta formada por una cabeza de hierro y un mango que se utiliza para dar golpes a algo.

Montes, Instrucción y regimiento, 1537, fol. Xv: Hazen la guerra como buenos cavalleros, pláticos en la guerra, y llevan assimesmo sus maças y martillos y estoques, y espadas y dagas. / / Pérez Vargas, De re metallica, 1568, fol. 78r: Este moler de los metales se haze differentemente mediante algunos ynstrumentos y máchinas de martillos, y maços de hierro, y palos clavados y ruedas que se traen a braço y otras con agua. // Juanelo Turriano, Veinte y un libros, a. 1605, fol. 374v: Entiéndese esto fáçilmente sacando exemplo del herir de los herreros, que si la yunque es grande y pesada, suffre muy bien los golpes de los martillos, aunque grandes y pesados.

HIPER.: herramienta.

FAM.: amartillado, amartillar, martillada, martillado, martillar, martillejo.

martinete, martinete [del fr. martinet 'fouet' 'marteau-pilon', oc. ant. martinet 'íd.'. 1315 (DECH). Collado, Plática Artillería, 1592]. sust. m. Mec. Mazo de hierro movido por distintos mecanismos, utilizado para alzar las piezas de artillería pesada (Varela Merino s. v. martinete).

Collado, Plática Artillería, 1592, fol. 72v: La cabria y el martinete son, assimismo, instrumentos comodíssimos y apropriados a alçar qualquiera gran peso $\mathrm{y}$, señaladamente, para encavalgar y desencavalgar el artillería. // Mendoça, Theórica y práctica, 1596, pág. 77: La he visto passar desencavalgándola con las cabrillas, martinetes o otros instrumentos, que se traen para el efecto a la misma orilla del agua, donde está puesta una maroma gruessa, que atraviessa el río. // Ufano, Tratado de la Artillería, 1613, pág. 323: La crica o martinete differente ynstrumento es muy apropiado y cómodo para alçar en alto pieça y afuste, y todo lo que se ofreciere, como con la escaleta, con solo un hombre que la acomode y ande su torno y muelle.

HOL.: máquina.

ENCICL.: El martinete es el más noble y ingenioso instrumento que hasta el día de hoy se ha inventado para el effecto de alçar pesos grandes dicho, porque es cosa maravillosa de ver que con un martinete, que no pesa 100 libras de hierro, se pueda alçar una culebrina de 13 o catorze mill libras un hombre solo. Compónese este instrumento de el movimiento de la vide perpetua, que assí la llaman los hombres de ingenio, que, por ser diffícil de hazerse y occulto el modo de labrarse y fuera de la 
plática del artillero, dexaremos por agora de specificarlo (Collado, Plática Artillería, fol. $73 r)$.

maso, V. mazo.

mástel, V. mástil.

mástil, mástel, mástil [del fr. ant. mast 'íd', hoy mât y este del fráncico mast 'íd.'. Anteriormente fue mástel. 1587, G. de Palacio (DECH). Anónimo, Ordenanças paños, 1527]. sust. m. Mec. Barra fija o giratoria que en una máquina sirve para soportar piezas rotativas o para transmitir fuerza motriz de unos órganos a otros (DRAE s. v. árbol).

Lobato, Notas, a. 1585, fol. 20: Y las velas no tienen que tocarlas, que, cualquiera que quedare al portillón del viento, prenderá y moverá un mástil de olmo grueso y redondo donde ha de estar trabada la rueda que vuelve las velas. // Juanelo Turriano, Veinte y un libros, a. 1605, fol. 291r: La barra que se pone dentro d'este árbol o mástil, conviene que ella sea quadrada, y que sea de seys palmos, y entra en el mástil de madera dos palmos, poco más o menos, según la necessidad del lugar y según la altaria del lugar. // Juanelo Turriano, Veinte y un libros, a. 1605, fol. 349v: El árbol o mástil que tiene la rueda $\mathrm{E}$, el cubo ha de ser quadrado y ha de tener afixado una palanca, la qual tiene dos anillas de yerro para asir en ellas dos cuerdas, para asir al collar del animal, para que, tirando, pueda mover esta rueda de sangre.

SIN.: árbol.

HOL.: máquina.

[IMAGEN] Pseudo-Juanelo Turriano, Los ventiún libros, c. 1605, fol. 308r, fig. 211, letra A.

maxar, V. majar.

maza, maça, maza [del lat. vg. *măttea (DRAE). Pérez Vargas, De re metallica, 1568]. sust. f. Martillo grande de madera o de hierro que sirve para golpear las cabezas de los pilotes.

Collado, Plática Artillería, 1592, fol. 57r: Hincadas, pues, las estacas dichas y a golpes de maça muy bien golpeadas y que queden derechas y bien tiessas, tendrás aparejadas las ramas de árboles de que han de ser texidos los cestones, que las mejores de todas son las de avellanero, o de roble o de castaño, pero, a falta d'éstos, el sauze será bueno. // Juanelo Turriano, Veinte y un libros, a. 1605, fol. 155r: Y conviene aguzarlos un poco para que puedan muy mejor penetrar por la tierra, mayormente si se chamuscan un poco aquellas puntas, que se endurezen mucho, para poderlas muy mejor hincar. $Y$ 
éstas se hincan con unas mazas de madera que sean grandes, o con maça de yerro que tenga el mango delgado. // Juanelo Turriano, Veinte y un libros, a. 1605, fol. 225v: Acostumbran ordinariamente todos los que hazen puentes de madera, de servirse del instrumento que llaman maça, la qual es muy grande, para hincar los maderos en el suelo del río. La qual maça se sube en alto con el torno y, con el artificio que ella tiene, ella misma se suelta y da muy grande golpe.

HIPER.: herramienta.

FAM.: mazada, mazo, mazuelo.

mazada, maçada [de mazo. Santa Cruz, Libro de las longitúdines, 1567]. sust. f. Golpe dado con una maza o un mazo (DRAE).

Santa Cruz, Libro de las longitúdines, 1567, pág. 113: Y para saber muy preçisamente la hora y parte de hora dixo que tenía consideraçión a un batán que se movía igualmente con agua de una fuente que no creçía ni menguava, por manera que le hazía dar muy a compás las maçadas, de las quales él avía esperimentado quántas dava en cada una hora, y por ellas venía a saber a qué hora y parte de hora venía la Luna con las dichas estrellas al tal punto. // Collado, Plática Artillería, 1592, fol. 54v: Y porque he visto algunas vezes romper pieças con increýble trabajo y pérdida de tiempo, procurando unos de aserrarlas con la sierra y otros a fuerça de maçadas de hierro pretender de romperla, me ha parescido poner aquí un breve y facilíssimo modo de romper el artillería con el fuego. / / Collado, Plática Artillería, 1592, fol. 56v: Y si con todo esso no querrá salir la bala, dele con una maça de hierro fuertes maçadas en la boca, que con esto vendrá luego a tierra.

FAM.: maza, mazo, mazuelo.

mazo, maço, maso, mazo [del lat. vg. *matteus, que parece ser derivado retrógrado del lat. matěŏla 'íd.'. H. 1330, Juan Manuel, Juan Ruiz (DECH). Pérez Vargas, De re metallica, 1568]. sust. m. Martillo grande de madera (DRAE).

Pérez Vargas, De re metallica, 1568, fol. 124r: Las cosas y minerales de la composición en que quedó embuelta la plata y cobre, derramando el agua, se enxuguen; y, secas, se muelan con un maço de palo. / / Juanelo Turriano, Veinte y un libros, a. 1605, fol. 279r: Y este betún no se haze muy duro, antes está casi siempre de un modo. Y también sirve sólo la raýz del olmo picándola con vino, mojando el maso con que se pica las raýzes y en vino tinto picándola, de por sí haze el mismo effecto. // Juanelo Turriano, Veinte y un libros, a. 1605, fol. 284r: Y tiénese hecho en los dos caños un señal redondo, y pónese la argolla en los dos señales, y con un maço se le va dando, en tal modo que la argolla se viene a encaxar en los dos caños.

HIPER.: herramienta.

FAM.: maza, mazada, mazuelo.

[IMAGEN] Pseudo-Juanelo Turriano, Los ventiún libros, c. 1605, fol. 331v, fig. 241, letras O y P, mazos para golpear los paños en un molino batán. 
mazonería, maçonería [del fr. maçonnerie 'íd.'. Entre 1493 y 1495, Nebrija (Clairac). Arphe, Varia Commensuración, 1585-87]. sust. f. Constr. Obra de albañilería (Elucidario).

Escalante, Discurso de la navegación, 1577, fol. 49v: Son todos muy ingeniosos y sutiles de manos, principalmente los que usan de dibuxo y maçonería, y grandíssimos pintores de follajes, páxaros y montería. / / Juanelo Turriano, Veinte y un libros, a. 1605, fol. 239v: Y unos son muy más excelentes para hazer tablas delgadas y otras maderas para hazer maçonería, y otros para sólo servir de maderas para suelos y para cubiertas.

mazuelo, mazuelo [de mazo. Loçano, Alberto, Architectura, 1582]. sust. m. Mazo pequeño.

Loçano, Alberto, Architectura, 1582, pág. 180: A mí agrádanme mucho los que, en lugar de clavillos, entre las junturas de las hileras hechas por la pared en pequeños agujeros, hincaron pedacillos de pedrenal salidos afuera, conviene a saber: con mazuelo de madera.

HIPER.: herramienta.

FAM.: maza, mazada, mazo.

mecánica, mecánica, mechánica [tomado del lat. mēchănŭca 'íd.' (DECH). 1427-1428, Villena (CORDE). Herrera, Institución Academia, 1584]. sust. f. Arte o ciencia de los mecanismos, ingenios o máquinas (Salinero).

Herrera, Institución Academia, 1584, fol. 5r: Y si consideramos los subjectos como intelligibles y sensibles, son ocho: Arithmética y Geometría de los intelligibles; Mechánica, Astrología, Perspectiva, Mensuradora, Música y Numeradora de los sensibles. // Herrera, Institución Academia, 1584, fol. 5r: Porque de la Mechánica depende la hazedora de instrumentos [fol. $5 \mathrm{v}$ ] béllicos para opugnar y deffender las ciudades y fortalezas; la hazedora de milagros con proporciones de pesos, cuya desigualdad es causa de movimiento y la igualdad de la quiete; la fabricadora de spheras, a la qual se reduze todo lo que toca a la fábrica de instrumentos, que por movimiento de ruedas muestran los movimientos celestes. // Herrera, Institución Academia, 1584, fol. 10v: El que se oviere de exercitar en la Mechánica, madre y maestra de la vida por los muchos provechos que d'ella resultan, deve de saber los seys primeros libros de Euclides, el séptimo, el undécimo y duodécimo del mismo auctor, los Equiponderantes de Archímedes, el libro de Conmandino Del centro de la gravedad, las obras de Jordano De ponderibus, las Mechánicas de Aristóteles, las de Guidobaldo.

FAM.: mecanicamente, mecánico.

mecánicamente, mecánicamente, mechánicamente [de mecánico. Núñez, Álgebra en Arithmética, 1567]. adv. De un modo mecánico (DRAE). 
Núñez, Álgebra en Arithmética, 1567, fol. 314v: Y si pretendía Oroncio que el diámetro se mediese mechánicamente, ya esto no sería conoscer por cuenta y Geometría. Y para mechánicamente medir, mejor sería medir la perpendicular, porque esto es más propinquo para saber quánta sea la área del trapezio. // Ferrofino, Descrizión Artillería, 1599, fol. 65v: Y así señalará más metal de lo que en realidad de berdad tendría la pieça en aquel lugar, como mecánicamente se puede tocar con las manos y con gusto más sabroso especular centíficamente por la 47 del $1 .^{\circ}$ de Euclides. // Lechuga, Discurso de la Artillería, 1611, pág. 238: Siendo mi principal intento, como se avrá visto, mostrar la orden que se a de guardar para formar las pieças perfectas y el uso de ellas para ganar las tierras, castillos, fuerças y batallas, que es todo lo que con ella se puede pretender, en lo dicho hasta aora, lo más mecánicamente que e podido, por ser todo lo que a esto toca, después de formadas, dadas sus caxas y lo necessario a ellas, más obra de las manos que del ingenio, no tendré necesidad de cansar a los lectores en ciencias escusadas y especulaciones de que no pueden sacar fructo.

\section{FAM.: mecánica, mecánico.}

mecánico, mecánico, mechánico [tomado del lat. mēchănŭcus 'íd.'. $2^{\circ}$ cuarto del S. XV, A. Torre (DECH). Sagredo, Medidas Romano, 1526]. adj. Dicho de un arte $\mathrm{u}$ oficio: que ante todo requiere el ejercicio manual.

Sagredo, Medidas Romano, 1526, pág. 9: De la qual opinión es maestre Phelipe de Borgoña, singularíssimo artífice en el arte de esculptura y estatuaria, varón, assimesmo, de mucha experiencia e muy general en todas las artes mecánicas e liberales, y no menos muy resoluto en todas las sciencias de Architetura. // Celso, Reportorio universal leyes Castilla, 1553, fol. CXLIVr: Y aunque sean señaladas solamente las dichas fiestas, empero dévense guardar en los juyzios ordinarios las otras fiestas que generalmente se guardan, en que los hombres no hazen sus servicios y officios mecánicos. // Cortés de Albacar, Breve compendio sphera, 1556, fol. IIv: En vuestros felicíssimos tiempos paresce que España se ha renovado y en todas las artes mecánichas se ha pulido y mejorado, ha florecido en letras y hase encumbrado en armas, y aquélla que d'ellas carecía, de las sobras puede prestar a sus vezinos.

FAM.: mecánica, mecánicamente.

2 [Sagredo, Medidas Romano, 1526]. adj. Dicho de una persona: que se dedica a un oficio manual.

Sagredo, Medidas Romano, 1526, pág. 14: Aquéllos se llaman oficiales mecánicos que trabajan con el ingenio y con las manos, como son los canteros, plateros, carpenteros, cerrageros, campaneros y otros oficiales, que sus artes requieren mucho saber e ingenio. // Sagredo, Medidas Romano, 1526, pág. 14: Los quales, según parece por nuestro Vitruvio, son obligados a ser exercitados en las sciencias de Philosophía y artes liberales, ca de otra manera no pueden ser perfetos architetos, cuyas ferramientas son las manos de los oficiales mecánicos. / / García de Palacio, Diálogos militares, 1583, fol. 51r: Como se dize en el Primero de los Machabeos, es requisito nescessario que los hombres de guerra sean de buena casta y no, como también se lee en el mismo libro, 
oficiales mecánicos, labradores y otros hombres tímidos, de poco pundonor y baxo tracto.

3 [Apiano, Cosmographía, 1575]. adj. Ejecutado por un mecanismo o máquina (DRAE).

Apiano, Cosmographía, 1575, fol. 45v: Phylopono, Pappo, Nicomedes y otros, trabajaron mucho por hallar dos líneas medias proporcionales entre qualesquiera dos, pero no pudieron alcançar esto sin ayuda de algún mechánico artificio, que no es cierto. // Apiano, Cosmographía, 1575, fol. 36r: Bolduque, Buscumducis, que quiere dezir 'selva del duque'. Muy fuerte, en la qual se hazen muchas cosas mecánicas; abundante de armas muy buenas y de hombres esforçados. // Roiz, Reloges solares, 1575, pág. 64: Echaréys primeramente la raya $\mathrm{AB}$ parallela al horizonte y muy a nivel, para lo qual ay muchos instrumentos mecánicos, y adelante porné yo uno que podrá servir también para esto.

mechánica, V. mecánica.

mechánicamente, V. mecánicamente.

mechánico, V. mecánico.

mina, mina [probablemente del fr. mine 'íd.' y este procedente de un galo *mina, celta primitivo *mein-. Vidal Mayor (DECH). Juanelo Turriano, Veinte y un libros, a. 1605]. sust. f. Ingen. Hidrául. Paso artificial subterráneo que se utiliza para conducir aguas.

Juanelo Turriano, Veinte y un libros, a. 1605, fol. 93r: Porque los aguaductos llevan el agua muy en alto para alcanzar de un monte al otro, y las minas hazen en contrario, que ellas sirven de llegar el agua de un llaño a otro. // Juanelo Turriano, Veinte y un libros, a. 1605, fol. 93v: Mas las minas que se hazen para passar agua, siempre se passa de una parte a otra del monte, caso que no sea por el medio. // Juanelo Turriano, Veinte y un libros, a. 1605, fol. $98 \mathrm{v}$ : Y porque lo he visto ocularmente, que passavan más de seys muelas de agua, no ver punto salir, ni por la mina ni por la otra parte por bajo, y pareciéndome que era cosa muy importante dar el orden que para ello es necessario.

HIPER.: obra hidráulica. 
móbil, V. móvil.

mobimiento, V. movimiento.

modiolo, modiolo [tomado del lat. modiŏlus 'vasija para beber' (Gaffiot). Urrea, Vitruvio, Architectura, 1582]. sust. m. Mec. Especie de vaso que forma parte de algunas máquinas hidráulicas.

Urrea, Vitruvio, Architectura, 1582, fol. 132r: Agora se sigue la demonstración de la máchina cthesíbica, que echa el agua en alto. Ésta se haze de metal, en cuya raýz se ponen modiolos o basos, de dos en dos, algún tanto apartados. // Juanelo Turriano, Veinte y un libros, a. 1605, fol. 349v: Ésta es la rueda de sangre, la qual llaman anoria, con sus modiolos, los quales son de varias formas. Ellos se hazen de alambre, de madera, de barro, aunque los mejores modiolos son los de alambre, y después de madera. // Juanelo Turriano, Veinte y un libros, a. 1605, fol. 353v: Y los dos caños que van de los modiolos $\mathrm{H}$ L al caño $\mathrm{N}$, no importa que ellos sean redondos más que quadrados, los quales son P Q.

HOL.: máquina.

[IMAGEN] Pseudo-Juanelo Turriano, Los ventiún libros, c. 1605, fol. 349r, fig. 266, letra B.

molar, V. piedra .

moleña, V. piedra .

moler, moler [del lat. mŏlĕre 'íd.' Orígenes del Idioma (DECH). Ortega, Conpusición Arismética y Geometría, 1512]. v. tr. Quebrantar algún cuerpo, reduciéndole a menudísimas partes, o hasta hacerle polvo (Autoridades).

Ortega, Conpusición Arismética y Geometría, 1512, fol. 128r: Este molino tiene dos ruedas, en que la mayor muele entre día y noche 50 fanegas o minas de trigo y la menor muele 40. // Acosta, Historia natural, 1590, pág. 227: El metal se muele muy bien, primero, con los maços de ingenios que golpean la piedra como batanes; $\mathrm{y}$, después de bien molido el metal, lo ciernen con unos cedaços de telas de arambre que hazen la harina tan delgada como los communes de cerdas. // Juanelo Turriano, Veinte y un libros, c.1605, fol. 333r: Aunque no es mi intención de enseñar cómo se haga el azeyte, mas de sólo demostrar el modo como se muelen las olivas, y esto es por causa que se anda con agua, aunque en muchas partes se muelen las olivas con animales, mas, por ser cosa de molino, se demostrará de una manera y de la otra. 
FAM.: amoladera, amoladura, amolar, moleta, molido, molienda, molinero, molinete, molino, muela, remoler, remolimiento, remolinar, remolino.

moleta, moleta [de muela (DECH). Sanctiago, Arte separatoria, 1598]. sust. f. Piedra pequeña que se emplea para moler esmaltes o colores.

Sanctiago, Arte separatoria, 1598, fol.49v: Y sáquese la malgama y lávese con la dicha agua tibia, trayéndole con una mano de vidro en su moleta de vidro, como los vidrieros muelen los esmaltes; o sobre la losa de mármol, como muelen los pintores las colores.

FAM.: amoladera, amoladura, amolar, moler, molido, molienda, molinero, molinete, molino, muela, remoler, remolimiento, remolinar, remolino.

molido, molido [de moler (DRAE). Anónimo, Ordenanças paños, 1527]. adj. Quebrantado, reducido a pequeñas partes o hecho polvo.

Anónimo, Ordenanças paños, 1527, fol. VIv: Otrosí, mando que ningún batanero ni pilatero no sea osado de echar ni eche a los paños que adobare la greda que oviere de echar, si no fuere molida e cernida, so pena que, si por no echar la dicha greda molida e cernida algún paño se dañare. / / Fernández de Enciso, Suma de Geographía, 1530, fol. LXVIIr: En esta tierra, e de aquí hazia al Poniente, comen los indios pan de grano de maýz molido, e hazen d'ello buen pan, que es de mucho mantenimiento. // Juanelo Turriano, Veinte y un libros, a. 1605, fol. 274r: El qual betún se haze en esta manera: tómase calcina viva, ladrillo molido, pedaços de platos y de escudillas de barro, y molerlas.

FAM.: amoladera, amoladura, amolar, moler, moleta, molienda, molinero, molinete, molino, muela, remoler, remolimiento, remolinar, remolino.

molienda, molienda [del lat. molĕnda 'cosas que se han de moler' (DRAE). Lobato, Notas, c.1585]. sust. f. Acción y efecto de moler el grano u otra cosa.

Lobato, Notas, c.1585, [fol. 20: Un molino de viento, sin velas y sin entruesga, hecho sobre una torre redonda, alta de treinta pies. Es un ingenio poco costoso y muy vistoso y provechoso para la molienda. // Llanos, Diccionario minas, c.1609-11, pág. 67: El orden que se tiene en proveerlos de agua para su molienda en la ribera de Potosí, donde se da por cuenta y la que tasadamente es menester para los ingenios [...]. // Alonso Barba, Arte de los metales, 1640, fol. 40r: El menor daño ha sido, en los beneficios de açogue, aver perdido las baxas, molienda y otros gastos con el tiempo en lo que no era metal.

FAM.: amoladera, amoladura, amolar, moler, moleta, molido, molinero, molinete, molino, muela, remoler, remolimiento, remolinar, remolino. 
2 [Lobato, Notas, c.1585]. sust. f. Mec. Máquina para moler, compuesta generalmente por una muela, una solera y los mecanismos necesarios para transmitir y regularizar el movimiento producido por una fuerza motriz, como el agua, el viento o la fuerza humana o animal.

Lobato, Notas, c.1585, fol. 26: Y, considerado que de aquella manera no se podía navegar, por aquélla y otras muchas inconvenientes y causas, se propuso que era menester quitar las pesqueras de todo el río, para lo cual se ponía todo el reino en gran falta de moliendas, porque en el tiempo seco suelen acudir [...] de veinte y catorce leguas de sus vertientes de la una ribera y la otra a moler en él. // Acosta, Historia natural, 1590, pág. 218: Todo este metal que sacan de las minas se trae en carneros del Pirú, que sirven de jumentos, y se lleva a las moliendas.

SIN.: molino 1 .

HIPER.: máquina.

3 [Acosta, Historia natural, 1590]. sust. f. Temporada que dura la operación de moler en los molinos.

Acosta, Historia natural, 1590, pág. 230: Quando se hinchen las lagunas y el año es copioso de aguas dura la molienda seys o siete meses, de modo que, también para la plata, piden los hombres ya buen año de aguas en Potosí, como en otras partes para el pan.

molinero, molinero [de molino. Celso, Reportorio universal leyes Castilla, 1553]. sust. $m$. Persona que tiene a su cargo algún molino y trabaja en él.

Celso, Reportorio universal leyes Castilla, 1553, fol. CXLIIIr: El fijo, o siervo o ahorrado, mayordomo, quintero o ortelano, molinero y otro que sea apaniaguado, no puede ser testigo en causa de su padre o señor, porque son sus familiares. // Lobato, Notas, c.1585, fol. 16: Y huelga la mitad del tiempo y muele mucho más ferozmente que no el de arriba, mientras le dura el agua, y no ocupa tanto tiempo al molinero, que, entretanto que se hinche la balsa, puede cavar una viña o huerta. // Juanelo Turriano, Veinte y un libros, c.1605, fol. 316v: Y, a más d'esto, los molineros que esto hazen, en picar la muela en la manera que se a dicho, lo hazen por aprovecharse de lo que muelen, que ordinariamente les quedan más de un almute de trigo de cada uno que muelen, de manera que es un robo manifiesto lo que hazen algunos molineros.

FAM.: amoladera, amoladura, amolar, moler, moleta, molido, molienda, molinete, molino, muela, remoler, remolimiento, remolinar, remolino.

molinete, molinete [de molino (DECH). Acosta, Historia natural, 1590]. sust. $\mathrm{m}$. Instrumento con forma de rueda con el que se remueve el agua para lavar el metal.

Acosta, Historia natural, 1590, pág. 228: [...] echan el metal en unas tinas de agua, donde, con unos molinetes o ruedas de agua, trayendo al derredor el metal, como quien deslíe 
o haze mostaza, va saliendo el barro o lama del metal en el agua que corre [...]. // Llanos, Diccionario minas, c.1609-11, pág. 9: El principal instrumento que en ellas sirve para lavar el metal es el molinete, que, a manera casi de rodezno, se trae a la redonda dentro de ellas; y los anexos a él son: cigüeñuela, peón y dedal, que sirven para el mismo movimiento, que se hace a fuerza de brazos en las tinas de mano. // Alonso Barba, Arte de los metales, 1640, fol. 42v: El metal, molido y cernido, se echa en una tina de mano, como si estuviera ya con açogue, dada la ley; y, para lavarse, échasele agua bastante. Menéase con el molinete muy bien: todo lo sutil sube arriba; lo más gruesso, o mal molido, se aparta abaxo.

HIPER.: instrumento.

FAM.: amoladera, amoladura, amolar, moler, moleta, molido, molienda, molinero, molino, muela, remoler, remolimiento, remolinar, remolino.

molino, molino [del lat. tardío molinum 'íd.', abreviación de saxum molinum 'muela' (DECH). Ortega, Conpusición Arismética y Geometría, 1512]. sust. m. Mec. Máquina para moler, compuesta generalmente por una muela, una solera y los mecanismos necesarios para transmitir y regularizar el movimiento producido por una fuerza motriz, como el agua, el viento o la fuerza humana o animal.

Ortega, Conpusición Arismética y Geometría, 1512, fol. 128r: Este molino tiene dos ruedas, en que la mayor muele entre día y noche 50 fanegas o minas de trigo y la menor muele 40. // Cortés de Albacar, Breve compendio sphera, 1556, fol. XVv: Así como si una hormiga fuese rodeando una muela de molino al contrario del movimiento de la muela, antes que la hormiga tornase al punto donde partió, que sería dar una buelta, le daría la muela muchas bueltas. // Collado, Plática Artillería, 1592, fol. 63r: Assí lo son aquéllas que el real castillo de Milán tiene alrededor de sí, en el qual abunda tanta agua manantial en aquellos fossos que podrían moler molinos con el agua que se sale de ellos, por lo que industria humana no es bastante a minarlos.

SIN.: molienda .

HIPER.: máquina.

FAM.: amoladera, amoladura, amolar, moler, moleta, molido, molienda, molinero, molinete, muela, remoler, remolimiento, remolinar, remolino.

2 [Ortega, Conpusición Arismética y Geometría, 1512]. sust. m. Casa o edificio en que hay un molino (DRAE).

Ortega, Conpusición Arismética y Geometría, 1512, fol. 128r: Un hombre va a un molino para que le muelan 80 minas o fanegas de trigo. // Castillo, Tratado de cuentas, 1551, fol. XXVIIIv: Item, puede hazer y renovar el instrumento o contracto del señor que está ya roto $(\mathrm{y})$, o entendiendo instrumento por qualquier edificio de casa, o fortaleza o molino que está roto o desbaratado o para caer, y a menester reparo. // Valle de la Cerda, Desempeño patrimonio, 1600, fol. 72v: Y, ansí, la contratación ha de ser en las demás haziendas, que tienen estas pérdidas y otra mayor, que es la diminución de la misma hipoteca, que, quedando en pie, se suele consumir y extinguirse, como son molinos, casas, olivares, viñas, huertas, tierras de regadío y otras cosas semejantes. 
batán [Juanelo Turriano, Veinte y un libros, c.1605]. loc. Mec. Máquina generalmente hidráulica, compuesta de gruesos mazos de madera, movidos por un eje, para golpear, desengrasar y enfurtir los paños (DRAE s. v. batán).

Juanelo Turriano, Veinte y un libros, c.1605, fol. 304v: Esta arzilla es la que se sirven en los molinos batanes a limpiar los paños, y esto se a de hazer ygualmente. // Juanelo Turriano, Veinte y un libros, c.1605, fol. 330r: De manera que para hazer un molino batán, conviene tener madera para ello, y conviene buscar cómodo para que tenga caýda la agua; porque, no teniendo caýda, no se puede hazer nada. // Juanelo Turriano, Veinte y un libros, c.1605, fol. 330r: De modo que los molinos batanes se hazen en lugares donde aya cantidad de agua, que sea bastante a mover una rueda, con lo demás que en ello entreviene en ello.

SIN.: batán 1 .

HIPER.: molino.

[IMAGEN] Pseudo-Juanelo Turriano, Los ventiún libros, c. 1605, fol. 331v, fig. 241.

$\sim$ de aceña [Lobato, Notas, c.1585]. comp. sintag. Mec. El que está situado dentro de un cauce de agua, cuya corriente mueve la rueda.

Lobato, Notas, c.1585, fol. 17: Molino de aceña general de ríos grandes 3. // Juanelo Turriano, Veinte y un libros, c.1605, fol. 290r: Y este género de molino muele mucho más que no muele el molino de ceña o de canal, por razón que la agua va muy más recoxida. // Juanelo Turriano, Veinte y un libros, c.1605, fol. 310v: El molino de ceña, aunque se a puesto en otra parte en particular, ame parecido ponerle en general, de modo que he puesto aquí la invención d'él.

SIN.: aceña, anoria $a_{1}$ molino de agua.

HIPER.: molino.

ENCICL.: "Los molinos hidráulicos (o aceñas) constituyeron durante siglos un elemento esencial en el paisaje de los ríos castellanos. [...] La Edad Media supuso el desarrollo y la generalización del molino hidráulico, en parte por tradición árabe y en parte también como producto del ingenio de los constructores españoles. Su técnica avanzada hace que tengamos que diferenciar vaios tipos de molinos de agua en función del modo de aprovechamiento de la energía hidráulica" (García Tapia 1997: 22). "Aunque a lo largo de la Edad Media aceña tuvo significados muy distintos, ya a mediados del siglo XVI equivale a molino (hidráulico) harinero de rueda vertical" (Catálogo Felipe II: 251).

$\sim$ de agua [Lobato, Notas, c.1585]. comp. sintag. Mec. El que está situado dentro de un cauce de agua, cuya corriente mueve la rueda. 
Lobato, Notas, c.1585, fol. 17: Hasta este año de 1577 años, se han inventado en España las suertes de molinos de agua que irán puestas en las tres planas de este libro, que van puestos de mi mano. // Besson, Teatro instrumentos, 1602, fol. H3v: Nueva manera de hazer un molino de agua, que puedan d'él muchos bastantemente servirse, ahunque haya menos agua de aquélla que es necessaria en los molinos comunes, con tal que l'agua venga a caher de algún lugar algo más alto. // Juanelo Turriano, Veinte y un libros, c.1605, fol. 322r: Sólo, estos molinos, conviene que las muelas sean muy más pequeñas que no son las de los molinos de agua.

SIN.: aceña, anoria $a_{1}$, molino de aceña.

HIPER.: molino.

ENCICL.: "Los molinos hidráulicos (o aceñas) constituyeron durante siglos un elemento esencial en el paisaje de los ríos castellanos. [...] La Edad Media supuso el desarrollo y la generalización del molino hidráulico, en parte por tradición árabe y en parte también como producto del ingenio de los constructores españoles. Su técnica avanzada hace que tengamos que diferenciar vaios tipos de molinos de agua en función del modo de aprovechamiento de la energía hidráulica" (García Tapia 1997: 22).

$\sim$ de balsa [Lobato, Notas, c.1585]. comp. sintag. Mec. El que recibe de una balsa el agua que mueve la rueda.

Lobato, Notas, c.1585, fol. 16: Molino de balsa y cubo y saetino. // Juanelo Turriano, Veinte y un libros, c.1605, fol. 312r: Este modo de molino de balsa, ella es invención de los antigos, no de aquellos antigos romanos. Es, para en comparación de los antigos, ella es moderna, y en comparación de los modernos, ella es antiga.

HIPER.: molino.

[IMAGEN] Lobato, Notas, c. 1585, fol. 16.

$\sim$ de barcas [Juanelo Turriano, Veinte y un libros, c.1605]. comp. sintag. Mec. El que se sustenta sobre una o varias barcas.

Juanelo Turriano, Veinte y un libros, c.1605, fol. 318v: De modo que los molinos de barcas se hazen en tres maneras: la primera, que con sola una barca se hazen molinos en los ríos; el segundo modo es que con dos barcas se arma un molino dentro de un río; el tercer modo es que con tres barcas se arma, encima d'ellas, un molino. // Juanelo Turriano, Veinte y un libros, c.1605, fol. 319r: Ésta es la segunda manera de los molinos de barcas, el qual molino tiene dos barcas que sustentan. / / Juanelo Turriano, Veinte y un libros, c.1605, fol. 321r: Las ruedas de los molinos de barcas son muy differentes de las otras ruedas de todos los demás molinos, porque éstas son muy largas y altas [...].

HIPER.: molino.

ENCICL.: Es un tipo de molino flotante, situado en una o varias barcas ancladas en la orilla de un río, cuya corriente hace girar la maquinaria para moler, que se sitúa en una caseta en la embarcación. Parece ser que ya el general bizantino Belisario, en el año 517, 
usó un molino de barcas para sobrevivir al asedio de Roma. Durante el Renacimiento, se utilizó mucho este tipo de molino en los ríos italianos, pero también fue usado en España. Por ejemplo, Francisco Lobato cita y dibuja molinos de barcas en sus Notas (García Tapia 1997: 28). Generalmente, este molino se encontraba situado en ríos caudalosos, puesto que no impedía la navegación (Glosario Los Veinte y un Libros). [IMAGEN] Pseudo-Juanelo Turriano, Los ventiún libros, c. 1605, fol. 319r, fig. 229.

$\sim$ de bestia(s) [Lobato, Notas, c.1585]. comp. sintag. Mec. Molino harinero cuya rueda se mueve por fuerza humana o animal.

Lobato, Notas, c.1585, fol. 17: Molino de bestia de Lobato. // Lobato, Notas, c.1585, fol. 17: Molino de bestias de Antonio Martínez y Écija. // Lobato, Notas, c.1585, fol. 25: En el año de mil y quinientos cincuenta y siete años, yo, Francisco Lobato del Canto, vecino de esta villa de Medina del Campo, hice un molino de bestias, en que gasté harto dinero, en el corral de las casas de Francisco Lobato, mi tío.

SIN.: atahona, molino de sangre, molino de tahona, tahona.

HIPER.: molino.

ENCICL.: En las Antiguas Grecia y Roma, era a los esclavos a quien se encargaba la dura tarea de mover el molino, y aunque durante la Edad Media y el Renacimiento se recurrió a animales de tiro para realizar este propósito, continuaron proliferando molinos, como los de rueda de pisar o grúa, que precisaban de la fuerza humana para su funcionamiento. En cualquier caso, los molinos movidos por animales se vieron favorecidos por el invento de la collera y el atalaje, que facilitaron el empleo de la fuerza animal en maquinaria diversa (García Tapia 1997: 12-14).

$\sim$ de bomba [Juanelo Turriano, Veinte y un libros, c.1605]. comp. sintag. Mec. Aquel en el que el agua llega hasta el rodezno a través de una bomba o saetín. Juanelo Turriano, Veinte y un libros, c.1605, fol. 290r: Esta canal de molino de bomba va muy differente, por razón que, quanto más se va acercando a la rueda, tanto más se va estrechando, de modo que donde despide la agua no es más de medio palmo de ancho, en quadro, la salida de la agua. // Juanelo Turriano, Veinte y un libros, c.1605, fol. 291r: De modo que este género de molino de bomba conviene que tenga muy más llana su canal, como se a dicho muchas vezes, por causa que, si fuesse esta canal asentada muy enhiesta por la diagonal de su quadro, aría andar muy pesada la rueda, por causa de herirle de alto abaxo. // Juanelo Turriano, Veinte y un libros, c.1605, fol.

294v: Y la agua ha de yr a erir dende la C a la D, que es dende abaxo de la diagonal del quadro, de modo que coge la agua aquel ochavo de la rueda que es desde la E hasta la $\mathrm{C}$, que va tocando aquellas palas, en qual más y en qual menos, según la agua le alcança a cada una de las palas. $Y$ esto abaste quanto al molino de bomba.

HIPER.: molino. 
$\sim$ de canal [Lobato, Notas, c.1585]. comp. sintag. Mec. Aquel en el que el agua accede al rodezno sin entrar en conductos.

Lobato, Notas, c.1585, fol. 14: Molino de canal levantada de un madero cavado, el cual, para dar agua o quitarla, solamente desde dentro del molino alarga o acorta una vara que está en una ventana de él, y trabada en una tabla cuadrada, que, si alarga, cierra, y si encoge, abre. // Juanelo Turriano, Veinte y un libros, c.1605, fol. 288r: El primer modo de molino, y el más común y universal, es el molino de canal abierta, aunque no muele mucho. // Juanelo Turriano, Veinte y un libros, c.1605, fol.

$294 \mathrm{v}$ : Esta manera de molino es con rueda grande, como el primer molino de canal que he puesto.

HIPER.: molino.

[IMAGEN] Lobato, Notas, c. 1585, fol. 14.

de cárcavo [Juanelo Turriano, Veinte y un libros, c.1605]. comp. sintag. Mec. Aquel en el que el rodete está situado en un cárcavo.

Juanelo Turriano, Veinte y un libros, c.1605, fol. 302v: Quando se abrá de poner el rodete para el molino de cárcavo, conviene ponerle de arriva para abaxo. Y en esto ay esta differencia entre estas dos maneras de rodetes. / / Juanelo Turriano, Veinte y un libros, c.1605, fol. 305v: En el asentar de las saetías, ansí de los molinos de cárcavo como de regolfo, es necessario tener en ello mucha advertencia, para que venga la agua a herir ordinariamente en el rodete. // Juanelo Turriano, Veinte y un libros, c.1605, fol. 329v: De modo que en el molino de cárcavo se le acomodará la rueda $\mathrm{A}$, que tiene su exe $\mathrm{B}$.

HIPER.: molino.

$\sim$ de contrapesos [Juanelo Turriano, Veinte y un libros, a. 1605]. comp. sintag. Mec. Aquel cuyas ruedas se mueven gracias a un sistema de contrapesos.

Juanelo Turriano, Veinte y un libros, a. 1605, fol. 310r: De modo que estas quatro ruedas, todas están asentadas en un exe. Y esto abaste quanto a esto del molino de contrapesos.

HIPER.: molino.

ENCICL.: "El molino que anda con contrapesos como relox. En él conviene que sean muy mayores las ruedas, por causa del exercisio que hazen en andar con tanto furor y con tanta presteza para aver de moler. Conviene que se le pongan muy grandes contrapesos. Y porque este molino es cosa más de reloxeros que no de Architectura, abastará avisar. Aunque en éste no están señaladas las muelas, las quales han de yr asentadas encima de $\mathrm{O}$, que la linterna $\mathrm{M}$ mueve la muela. Y la rueda $\mathrm{L}$ mueve esa linterna M. Y esa rueda L tiene sus caxales al costado de la circunferencia" (Juanelo Turriano, Veinte y un libros, a. 1605: fol. 309v).

[IMAGEN] Pseudo-Juanelo Turriano, Los ventiún libros, c. 1605, fol. 309v, fig. 214. 
$\sim$ de cubo [Lobato, Notas, a. 1585]. comp. sintag. Mec. El que dispone de un cubo que garantiza la fuerza hidráulica necesaria para mover el rodete.

Lobato, Notas, c.1585, fol. 17: Molino de cubo redondo saetino. // Juanelo Turriano, Veinte y un libros, c.1605, fol. 293v: Con teja y media de agua viva ará andar un molino de cubo que molerá, cada hora, un caýz mientras durare la agua en el cubo. // Juanelo Turriano, Veinte y un libros, c.1605, fol. 312v: En todo lo demás, ansí de botana como cárcavo y rodete, no enferece punto de los otros molinos de cubo.

HIPER.: molino.

de grúa [Lobato, Notas, c.1585]. comp. sintag. Mec. El que se mueve gracias a la acción del hombre en una grúa o rueda de pisar.

Lobato, Notas, c.1585, fol. 15: Molino de grúa que muele con un hombre.

HIPER.: molino.

ENCICL.: La rueda de pisar era "una especie de jaula cilíndrica que giraba al andar dentro una persona. Como a finales de la Edad Media y en el Renacimiento, estas ruedas de pisar se empleaban, sobre todo, para las grúas, se le denominó a veces molino de grúa" (García Tapia 1997: 12).

[IMAGEN] Lobato, Notas, c. 1585, fol. 15.

de mano [Juanelo Turriano, Veinte y un libros, a. 1605]. comp. sintag. Mec. El que se mueve gracias a la fuerza humana.

Juanelo Turriano, Veinte y un libros, a. 1605, fol. 308v: El molino de mano, el qual lo andan hombres, a lo menos dos, y a vezes uno, este género de molino muele muy poco.

HIPER.: molino.

ENCICL.: Los molinos de mano pertenecían al tipo de molinos portátiles. Los molinos portátiles, hechos con pequeñas piedras de moler, eran útiles para su empleo durante los desplazamientos, por ejemplo, de los ejércitos (García Tapia 1997: 12).

[IMAGEN] Pseudo-Juanelo Turriano, Los ventiún libros, c. 1605, fol. 349r, fig. 266.

$\sim$ de marea [Lobato, Notas, c.1585]. comp. sintag. Mec. El que está situado en la costa marítima y se mueve aprovechando la fuerza de las mareas.

Lobato, Notas, c.1585, fol. 10: Molino de marea que muele con el subiente de marea la una rueda, y cuando mengua, muele otra, como se ve en la traza siguiente.

HIPER.: molino.

[IMAGEN] Lobato, Notas, c. 1585, fol. 10. 
$\sim$ de medio regolfo [Juanelo Turriano, Veinte y un libros, c.1605]. comp. sintag. $\mathrm{Mec}$. El que utiliza la mitad de agua que el molino de regolfo.

Juanelo Turriano, Veinte y un libros, c.1605, fol. 302r: Vengamos a tratar de otro género de molino, el qual llaman (molino) de medio regolfo, al qual molino se le quita la mitad de la agua de lo que es necessario para que ande un molino de regolfo. // Juanelo Turriano, Veinte y un libros, c.1605, fol. 302v: De modo que al molino de medio regolfo no ha de tener saetía de tres quartos de palmo donde despide la agua, que en el molino de regolfo es palmo y medio de alto la saetía, que son veynte quatro minutos, que la metad de veynte quatro es doze, que es lo que ha de tener de alto la saetía del molino de medio regolfo.

HIPER.: molino.

ENCICL.: El molino de medio regolfo tiene la misma hechura que el molino de regolfo, más no se le da tanta agua como al de regolfo entero (Catálogo Felipe II).

$\sim$ de pasaje [Lobato, Notas, c.1585]. comp. sintag. Mec. Aquel en el que el agua pasa por debajo de un edificio.

Lobato, Notas, c.1585, fol. 18: El de arriba es molino de pasaje de agua. Hemos puesto cubierta la casa con crecida de agua para mostrar por qué razón muele y no se agua aunque esté debajo del agua. // Lobato, Notas, c.1585, fol. 37: En la figura: Planta de molino de pasaje.

HIPER.: molino.

[IMAGEN] Lobato, Notas, c. 1585, fol. 18.

$\sim$ de regolfo [Juanelo Turriano, Veinte y un libros, c.1605]. comp. sintag. Mec. Aquel en el que el rodete está a presión en el interior de un cubete.

Juanelo Turriano, Veinte y un libros, c.1605, fol. 293v: Y si la balsa que subiere ocho o nueve palmos de agua encima de la saetía, en molino de regolfo molerá un caýz cada ora, y aun más. // Juanelo Turriano, Veinte y un libros, c.1605, fol. 305r: Quanto más serán altos los cubetes de los molinos de regolfo, de costados, tanto mejores son, porque, siendo altos, la agua no puede tocar arriba, en el tajador, y no tocando, no causa interrompimiento ni detención al agua, ni al rodete, ni menos sale la agua por encima del tajador. // Juanelo Turriano, Veinte y un libros, c.1605, fol. 312v: La planta que se sigue es del molino de regolfo, el qual molino tiene muchas más particularidades que no tienen los otros molinos.

HIPER.: molino.

ENCICL.: Al "situar el rodezno de un molino de eje vertical en el interior de un cilindro muy ajustado, [...] el agua que impulsa al rodezno se ve obligada a girar en el interior de las paredes del cilindro, [...] (giro con el que el agua) desarrolla una gran energía, por efecto de la fuerza centrífuga, y esta energía es suficiente para impulsar con una gran potencia el rodezno que hace mover las piedras del molino directamente a través 
del eje vertical. Además, la fuerza centrífuga del agua es aprovechada aún mejor si se da a los álabes del rodezno una determinada curvatura, pues entonces, al salir el agua impulsada hacia atrás, el rodezno recibe un impulso suplementario hacia adelante, gracias al principio de acción y reacción. Estos dos principios (efecto centrífugo y reacción) son el fundamento de las actuales turbinas hidráulicas de reacción, que fueron desarrolladas en Francia a partir del siglo XIX por Fourneyron. [...] (Sin embargo) no se han encontrado noticias de que tal tipo de molino (molino de regolfo) se diese en ningún lugar del mundo antes (del siglo XVI, como ocurrió en España) y, tanto la palabra rodezno como regolfo se encuentran únicamente en documentos españoles, por lo que [...] podemos afirmar que este molino, inventado y perfeccionado en España [...] fue el directo antecesor de una máquina importante en el desarrollo del aprovechamiento hidroeléctrico: la actual turbina hidráulica de reacción" (García Tapia 1997: 28-32). "Se trata, por tanto de un rodete que aprovecha la energía del agua en parte como energía cinética y en parte como molino a presión" (Catálogo Felipe II).

[IMAGEN] Pseudo-Juanelo Turriano, Los ventiún libros, c. 1605, fol. 312v, fig. 220, planta de un molino de regolfo.

$\sim$ de sangre [Juanelo Turriano, Veinte y un libros, a. 1605]. comp. sintag. Mec. Molino harinero cuya rueda se mueve por fuerza humana o animal.

Juanelo Turriano, Veinte y un libros, c.1605, fol. 307r: Ay otro género de molino de sangre, que es que un hombre lo lleva, y éste aún tiene muy menos artificio. // Juanelo Turriano, Veinte y un libros, c.1605, fol. 318r: Bien sé que alguno me podría responder a esto que, en tal caso, se pueden hazer molinos de sangre, como tengo dada la orden d'ellos en este libro de los molinos, que se hazen andar con animales. // Juanelo Turriano, Veinte y un libros, c.1605, fol. 321v: Los molinos de sangre, hordinariamente, se llevan con animales, y por esta causa se llaman de sangre, aunque en muchas partes los llaman de taona.

SIN.: atahona ${ }_{1}$, molino de bestia(s), molino de tahona, tahona ${ }_{1}$.

HIPER.: molino.

ENCICL.: En las Antiguas Grecia y Roma, era a los esclavos a quien se encargaba la dura tarea de mover el molino, y aunque durante la Edad Media y el Renacimiento se recurrió a animales de tiro para realizar este propósito, continuaron proliferando molinos, como los de rueda de pisar o grúa, que precisaban de la fuerza humana para su funcionamiento. En cualquier caso, los molinos movidos por animales se vieron favorecidos por el invento de la collera y el atalaje, que facilitaron el empleo de la fuerza animal en maquinaria diversa (García Tapia 1997: 12-14).

[IMAGEN] Pseudo-Juanelo Turriano, Los ventiún libros, c. 1605, fol. 308r, fig. 211.

$\sim$ de tahona [Lobato, Notas, c.1585]. comp. sintag. Mec. Molino harinero cuya rueda se mueve por fuerza humana o animal.

Lobato, Notas, c.1585, fol. 17: Molino de tahona de Andalucía. // Juanelo Turriano, Veinte y un libros, c.1605, fol. 306r: El primer género de molino es el molino de taona, el qual lo anda un animal que muchos suelen llamar de sangre. // Juanelo Turriano, Veinte y un libros, c.1605, fol. 307r: Ay otro género de molino de sangre, que es que un 
hombre lo lleva, y éste aún tiene muy menos artificio. Y muélese muy poco, aún menos que el molino de taona.

SIN.: atahona ${ }_{1}$, molino de bestia(s), molino de sangre, tahona 1.

HIPER.: molino.

ENCICL.: En las Antiguas Grecia y Roma, era a los esclavos a quien se encargaba la dura tarea de mover el molino, y aunque durante la Edad Media y el Renacimiento se recurrió a animales de tiro para realizar este propósito, continuaron proliferando molinos, como los de rueda de pisar o grúa, que precisaban de la fuerza humana para su funcionamiento. En cualquier caso, los molinos movidos por animales se vieron favorecidos por el invento de la collera y el atalaje, que facilitaron el empleo de la fuerza animal en maquinaria diversa (García Tapia 1997: 12-14). La definición de atahona recogida en el Diccionario de Autoridades, "molino seco, que se usa donde no hay agua..." nos permite entrever el uso generalizado de molinos hidráulicos, allí donde las condiciones geográficas lo permitían, en la época de ese repertorio lexicográfico, así como reforzar la idea de la abundante presencia de estos molinos hidráulicos ya en época renacentista.

[IMAGEN] Pseudo-Juanelo Turriano, Los ventiún libros, c. 1605, fol. 308r, fig. 211.

$\sim$ de viento [Lobato, Notas, c.1585]. comp. sintag. Mec. El que se mueve gracias al impulso del viento en las aspas.

Lobato, Notas, c.1585, fol. 21: Año de 1556 años. Hizo hacer Gaspar Rotrilo, alemán, vecino de Almagro, un molino de viento, el más costoso que en España se había visto, el cual se hizo en tierra de Almagro, sobre una montañeta pequeña de pizarra parda. // Poça, Hydrografía, 1585, fol. 32r: La isla de Ujas es llana y baxa, en medio es lo más alto y tiene un clochel de común altor, o de ver Oest del clochel tiene dos o tres molinos de viento, y en el cabo del Noroest de la isla tiene dos farillones. // Besson, Teatro instrumentos, 1602, fol. K3v: Toda la compostura restriba en el quicio, como un molino de viento, para que la viga, voltada a poniente y apartada de la raya de mediodía doze partes, pueda ser movida.

HIPER.: molino.

ENCICL.: Los molinos de viento proceden, hasta donde se conoce, del sur de Asia, siendo el más antiguo el de eje vertical, seguramente inspirado en los molinetes de oración que marcaban los mantras o letanías en los antiguos templos budistas asiáticos. En cualquier caso, sabemos que su uso era ya corriente en el siglo VII en Persia, mientras que se piensa que en Europa no se utilizaron hasta el siglo XI y que, en este caso, podían haber sido introducidos por los árabes. En nuestro viejo continente, el tipo de molino de viento más generalizado fue el de eje horizontal, cuyas aspas son verticales y se colocan de forma perpendicular al viento dominante, bien gracias al movimiento de todo el eje del molino, bien gracias al de la caperuza del molino a la que, especialmente en España, se solían unir las aspas y su eje (García Tapia 1997: 16).

[IMAGEN] Lobato, Notas, c. 1585, fol. 22. 
$\sim$ del aceite [Juanelo Turriano, Veinte y un libros, a. 1605]. comp. sintag. Mec. Aquel en el que se prensa la aceituna para obtener aceite.

Juanelo Turriano, Veinte y un libros, a. 1605, fol. 326r: Estos yerros conviene que sean como son los yerros que están en los libros de los molinos del azeyte, que están asidos a los caracoles de la imprimia que prensan la azeyte.

HIPER.: molino.

[IMAGEN] Pseudo-Juanelo Turriano, Los ventiún libros, c. 1605, fol. 333v, fig. 244.

$\sim$ harinero [Juanelo Turriano, Veinte y un libros, a. 1605]. comp. sintag. Mec. Aquel en el que se muele el grano para obtener harina.

Juanelo Turriano, Veinte y un libros, a. 1605, fol. 323r: Y porque el molino farinero no enbaraçe donde se limpian las armas y que cada cosa tenga su lugar particular. // Juanelo Turriano, Veinte y un libros, a. 1605, fol. 373r: Que son hechos para accomodar edifficios, o molinos harineros, o batanes, o para limpiar armas, o para picar pólvora.

HIPER.: molino.

ENCICL.: "En los molinos tradicionales, la cantidad de harina dependía de la finura de su trituración; para ello se acercaban todo lo posible las dos piedras del molino: la volandera y la solera. El propio molinero, en función de la velocidad de giro de las muelas o piedras de moler y de la calidad de la harina que iba obteniendo, procedía a accionar un mecanismo llamado aliviador (según la terminología de Lobato), alivio, levador o elevador (según las expresiones más actuales), que consistía en una serie de palancas que levantaban o bajaban más o menos el eje, llamado parahuso o parahierro que hace girar la muela volandera y a la que se acopla por medio de un enganche llamado anadija. La habilidad del molinero conseguía de esta forma una harina más o menos fina. En el caso del molino hidráulico, la velocidad de giro de la muela dependía del caudal de agua que pasaba bajo el molino y hacía girar las ruedas; este caudal dependía a su vez de las variaciones estacionales que en nuestra región son muy apreciables. El molinero, o su ayudante, debía manejar las compuertas de entrada del caz, subiéndolas o bajándolas para permitir la entrada de un caudal de agua constante e independiente del que llevase el río. La operación podía hacerse a veces con una larga pértiga que se accionaba desde el propio molino, con lo cual la misma persona podía vigilar al tiempo la molienda. Incluso se podía para desde esta posición la propia rueda hidráulica" (García Tapia 1997: 32-33).

montea, montea [del fr. montée, derivado de monter 'subir'. 1600, Sigüenza (DECH). Arphe, Varia Commensuración, 1585-87]. sust. f. Arq. Dibujo de tamaño natural que en el suelo o en una pared se hace del todo o parte de una obra para hacer el despiezo, sacar las plantillas y señalar los cortes (DRAE).

Arphe, Varia Commensuración, 1585-87, fol. 3v: Joán Baptista, natural de Toledo, que fue el primero maestro de aquella famosa traça, y començó a levantar su montea con tan maravilloso efecto, que no sólo yguala con toda la Antigüedad, pero en este solo templo podría ser excedida. // Vandelvira, Traças de cortes, ca. 1591, fol. 127v: En la figura: Estas dos figuras alta y baxa demuestran la planta y montea en perfil de la 
capilla pasada qu'e declarado. / / Juanelo Turriano, Veinte y un libros, a. 1605, fol. 166r: El modo del açute es en esta manera, como lo señalaré aquí abajo, la planta y montea y el perfil d'ello.

FAM.: montear.

montear, montear [de montea (DECH). Rojas, Teórica fortificación, 1598]. v. tr. Arq. Trazar la montea de una obra (DRAE).

Rojas, Teórica fortificación, 1598, fol. 94v: Y esto se sabrá por esperiencia, mirando en el sitio donde se levantará la tal puente la mayor creciente que allí ha avido, y respeto d'ella, y algo más de ventaja, se monteará y levantará el hueco de los arcos.

FAM.: montea.

mortero, mortero [del lat. mortārĭum 'íd.'. H. 1220-1250, Berceo (DECH). Urrea, Vitruvio, Architectura, 1582]. sust. m. Instrumento de madera, piedra o metal, a manera de vaso de gran tamaño, que se utiliza para moler metales y picar piedras y otros materiales.

Urrea, Vitruvio, Architectura, 1582, fol. 95r: Mas los encaladores griegos, usando d'estas razones, no sólo hazen obras firmes, sino que, echada en el mortero la arena y la cal con grande cuydado, macean la materia con palos o vergas, y, bien amassada, usan d'ella en sus xaharros. // Juanelo Turriano, Veinte y un libros, a. 1605, fol. 276v: Para hazer otro betún, el qual se haze de piedra, la qual ha de ser molida y ase de picar dentro de un mortero que sea de metal o de piedra. // Juanelo Turriano, Veinte y un libros, a. 1605, fol. 322v: La rueda más alta, que es A, la qual es para picar pólvora. Sus caxales es $\mathrm{B}$. El exe es $\mathrm{C}$. La qual rueda mueve la linterna $\mathrm{E}$, que está afirmada encima de la armadura D. Y el exe de la linterna E es F, el qual mueve unos majaderos que pican en los morteros G H I.

HIPER.: instrumento.

[IMAGEN] Pseudo-Juanelo Turriano, Los ventiún libros, c. 1605, fol. 332r, fig. 242, letras O, P y Q.

mortimiento, mortimiento [de morter 'desembocar, acabar algo'. Juanelo Turriano, Veinte y un libros, a. 1605]. sust. m. Mec. arag. Lugar o zona en el que una pieza $\mathrm{u}$ otro objeto termina.

Juanelo Turriano, Veinte y un libros, a. 1605, fol. 295r: Ay otro modo de cubo que es quadrado, el qual se va estrechando hazia el suelo, en tal manera que viene a morir en un punto. Y conviene que sea muy liso el cubo en el mortimiento.

mota, mota [de origen incierto quizá prerromano. Doc. de 1218 (DECH). Juanelo Turriano, Veinte y un libros, a. 1605]. sust. f. arag. Pella de tierra con que se cierra o ataja el paso del agua en una acequia (DRAE). 
Juanelo Turriano, Veinte y un libros, a. 1605, fol. 79r: El camino del agua es A. Y el valle es B. La mota de tierra es C, la qual ha ygualado el camino, como se vee. // Juanelo Turriano, Veinte y un libros, a. 1605, fol. 110r: Y si fueran bajas las rías o motas, con las crecidas del río les passará por encima la mota, que la agua no la deshará ni se la llevará. // Juanelo Turriano, Veinte y un libros, a. 1605, fol. 117v: Mas donde se haze alguna mota para hazer que algún río se buelva a otra parte, conviene poner al encuentro del río una muy grande fortaleza con maderas y tablas.

HOL.: obra hidráulica.

moto, moto [tomado del lat. mōtūs, -us 'íd.' (OLD). S. XIII, Judizios de las estrellas (Laterculi). Pérez de Moya, Arithmética práctica, 1562]. sust. m. Fís. Acción y efecto de mover (DRAE s. v. movimiento).

Juanelo Turriano, Veinte y un libros, a. 1605, fol. 12r: O si es alguna otra cosa la que calienta las aguas, es menester que veamos si es el sol, o si es el viento, o si es el moto o movimiento, o si es el calor intrínseco de la misma tierra. // Juanelo Turriano, Veinte y un libros, a. 1605, fol. 293r: Causa su moto menos resistencia en la cosa que yere, y quando viene de más alto haze mayor golpe, de modo que su fuerça es mayor, la de la $\mathrm{D}$, que no es la de la $\mathrm{C}$, en el descender y hazer sus motos. // Juanelo Turriano, Veinte y un libros, a. 1605, fol. 293r: Que no haze el cuerpo C en el descender dende la E hasta la $G$, que pone más tiempo este cuerpo $C$ que no haze $D$, pues es cosa muy clara $y$ manifiesta que es más ligero en su moto o movimiento y que ello es más pesado al herir.

SIN.: movimiento.

ANT.: quiete, quietud.

FAM.: inmovible, inmóvil, inmovilidad, motor, movedizo, mover, movible, movido, moviente, móvil, movimiento.

motón, motón [del oc. cap de moton 'vigota, especie de motón', propiamente 'cabeza de carnero'. H. 1573, Eug. de Salazar (DECH). García de Palacio, Instrución náuthica, 1587]. sust. m. Náut. Especie de polea corta y gruesa por donde pasan los cabos.

García de Palacio, Instrución náuthica, 1587, fol. 100v: Debaxo del bauprés, en derecho del estay del trinquete, ha de estar fixo y colgado un motón de dos roldanas; y passarse ha por ambas un cabo de quarenta hilos. / / García de Palacio, Instrución náuthica, 1587, fol. 148r: Motones: son poleas más cortas y gruessas en su cantidad. // Anónimo, Diálogo fábrica de navios, ca. 1631, fol. 31v: Azerse aforrar y limpiar todas las poleas y motones que no laboraren bien, ensebándolas.

HIPER.: polea. 
motor, motor [tomado del lat. mōtŏr, mōtōris 'que mueve, movedor'. S. XVII (DECH). Álaba, Perfeto capitán, 1590]. sust. m. u. t. c. sust. Mec. Parte de una máquina o instrumento destinada a producir un movimiento.

Álaba, Perfeto capitán, 1590, fol. 238r: Pero en el violento contrasta y la fuerça del motor se va remitiendo proporcionalmente, y no en un instante. // Álaba, Perfeto capitán, 1590, fol. 238r: Y entonces vendrá a ser más combado y tener más perfeta forma de arco quando començare a tener el peso de la pelota sensible proporción con el ímpetu del motor. // Álaba, Perfeto capitán, 1590, fol. 238v: Y el punto Q represente el lugar de donde començó a tener sensible proporción el peso de la pelota con el ímpetu del motor.

HOL.: máquina.

FAM.: inmovible, inmóvil, inmovilidad, moto, movedizo, mover, movible, movido, moviente, movido, móvil, movimiento.

moveble, V. movible.

movediso, V. movedizo.

movedizo, movediso, movedizo [de mover. Princ. S. XIV, Zifar (DECH). Roiz, Reloges solares, 1575]. adj. Fís. Fácil de moverse o ser movido (DRAE).

Roiz, Reloges solares, 1575, pág. 46: Si este relox fuere traçado en cosa fixa, levantada a plomo sobre la raya del verdadero Levante y Poniente en la parte que va hazia Mediodía, no ay más que dezir; pero si fuere en cosa movediza, assentarse ha directamente y a plomo sobre una raya que cortare a la meridiana a ángulos rectos. // Poça, Hydrografía, 1585, fol. 18r: Esto hecho, se señalen en la misma rueda movediza los treynta y dos vientos, repartiendo un viento a cada tres quartos de hora, de suerte que en derecha de la flor de lis ya dicha esté colocado el viento norte, y en sus lados se coloquen los demás vientos según están en la aguja de marear. // Besson, Teatro instrumentos, 1602, fol. N2v: Mas estas balanças, a las extremidades, tienen una abertura luenga quasi cinco partes, y ancha, tanto que pueda coger los quicios de los atanores movedizos, que se entran por los atanores más cortos, que nuestro intérprete ha declarado no escuramente.

FAM.: inmovible, inmóvil, inmovilidad, moto, motor, mover, movible, movido, moviente, movido, móvil, movimiento. 
2 [Loçano, Alberto, Architectura, 1582]. adj. Dicho de un terreno: que no está firme o sólido.

Loçano, Alberto, Architectura, 1582, pág. 150: Al conejo, en el lugar donde ha de estar encerrado, harasle una pared de piedra quadrada hasta lo hondo de la agua, y en el espacio harás un suelo de tierra arenisca macho, dexando en muchos lugares muchos montoncillos de tierra movediza. // Urrea, Vitruvio, Architectura, 1582, fol. 41v: Y si no se hallare macizo y el lugar es de tierra movediza hasta lo hondo o estremedales o lagunas, este lugar se cabe y vazíe, y con estacas de álamo negrillo, o de oliva, o de saz, o de roble, tostadas, se estaque todo aquel lugar. // Álaba, Perfeto capitán, 1590, fol. 257r: Y si la tierra fuere movediza, con tablones y puntales se hará firme la baxada, y lo mesmo se hará en todas las otras partes que se fueren minando, si el alto d'ellas no fuere tierra firme.

mover, mover [del lat. mŏvēre 'íd.'. Orígenes del idioma (DECH). Sagredo, Medidas Romano, 1526]. v. tr. Fís. Hacer que un cuerpo deje el lugar o espacio que ocupa y pase a ocupar otro (DRAE).

Sagredo, Medidas Romano, 1526, pág. 31: Y no es de maravillar, pues se lee de dos maestros, que havían nombre Tolo y Theodolo, que tenían artificio para tornear las colunas, assí de piedra como de metal, por grandes que fuessen, y que un solo mochacho era suficiente para las rodear y mover. // Juanelo Turriano, Veinte y un libros, a. 1605, fol. 140r: Convendrá que los alcaduzes sean anchos, por causa que pueda passar el agua libremente por ellos. Y será neçessario que ellos estén muy bien encaxados, los alcaduzes dentro de estas canales, que no se puedan mover. // Juanelo Turriano, Veinte y un libros, a. 1605, fol. 318v: Estos molinos se hazen con unas maromas, de modo que el río no las puede mover.

ANT.: quietar.

FAM.: inmovible, inmóvil, inmovilidad, moto, motor, movedizo, movible, movido, moviente, movido, móvil, movimiento.

2 [Celso, Reportorio universal leyes Castilla, 1553]. v. tr. Mec. Hacer que un instrumento o máquina produzca el movimiento determinado que lo pone en funcionamiento.

Celso, Reportorio universal leyes Castilla, 1553, pág. 51: Y dize el mismo don Joán que hizo cortar piedras de los dichos peñascos para ver si heran de espeçie de magnetes o piedra ymán y que ninguna hazía mover la rosa del aguja poniéndola por todas las partes de la çircunferençia d'ella ni hazía llamamiento al hierro. // Lobato, Notas, a. 1585, fol. 15: Esta traza es de un molino que le puede mover un hombre y moler gran cantidad de pan. // Juanelo Turriano, Veinte y un libros, a. 1605, fol. 322v: Aunque en esta invención parece ser una cosa muy pesada y que no es possible que un solo animal pueda mover tanta máquina, y si la mueve, que será con muy grande trabajo, antes es todo al contrario, que con muy menos travajo mueve las tres ruedas que no aría una sola, por razón que todo este movimiento es sólo un exe. 
movible, moveble, movible [tomado del lat. movibülis 'íd'. Corbacho (DRAE). Loçano, Alberto, Architectura, 1582]. adj. Fís. Que puede moverse o se mueve por sí mismo (DRAE s. v. móvil).

Loçano, Alberto, Architectura, 1582, pág. 154: De manera que podéys entender que usaron de hogares movibles de hierro y cobre, según requería la dignidad de cada cosa, y aun aquel género de hombres de soldadesca, con la guerra, assí como todos estavan juntos. // Besson, Teatro instrumentos, 1602, fol. F3v: La cabeça de las trespuntas de hierro, de que antes se ha hablado, por esso no ha de estar fixa en la viga, como ya se ha declarado, sino movible, y que se buelva en derredor d'ella, a fin que, haviéndose ella de boltar en derredor, se haga libremente y más presto. // Juanelo Turriano, Veinte y un libros, a. 1605, fol. 340v: Y aquella bomba para las calderas conviene que esté movible, que se pueda mudar a cada caldera quando será menester.

SIN.: móvil 1 .

FAM.: inmovible, inmóvil, inmovilidad, moto, motor, movedizo, mover, movido, moviente, móvil, movimiento.

movido, movido [de mover. Medina, Arte de navegar, 1545]. adj. Fís. Agitado, meneado o transladado de un lugar a otro.

Medina, Arte de navegar, 1545, fol. 2r: Entre las cosas de gran calidad que el ingenio humano inventó para sustento de los hombres, una muy principal fue fabricar navíos en tantas diferencias, y hallar arte para los governar y traer navegando por la mar: unos movidos con velas, con la fuerça de los vientos, y otros movidos con remos, con la fuerça de los hombres. // Loçano, Alberto, Architectura, 1582, pág. 329: Empero, si la avenida sobrepujare el vallado y nadare por cima, entonces, con la allegada de las impetuosas olas, sacudiendo el suelo, se conmoverá, y las cosas movidas serán llevadas con la corriente hasta que, hecha cavadura por bajo, la obra sin cimientos se caya. // Ufano, Tratado de la Artillería, 1613, pág. 171: La virtud moviente tampoco a de ser tan fuerte que la máchina no la pueda llevar, y que la cosa movida, por demasiada ligereza, dexe de hazer la resistencia necessaria.

FAM.: inmovible, inmóvil, inmovilidad, moto, motor, movedizo, mover, movible, moviente, móvil, movimiento.

moviente, moviente [de mover (DECH). García de Palacio, Diálogos militares, 1583]. adj. Fís. Que mueve o se mueve (DRAE).

García de Palacio, Diálogos militares, 1583, fol. 114v: Hazia una y otra parte, por causa de algún poderío moviente, porque todas las vezes que un cuerpo inmóbil toca al que se mueve (mayormente al principio de su movimiento) le impide tanto más, quanto mayor parte o tiempo va tocando en él. // Molina Cano, Descubrimientos geométricos, 1598, fol. 43r: Por lo qual, se me ha de conceder ser tan firmes los cielos como lo es la tierra, y que los planetas y estrellas son por sí movientes, guardando en su curso la orden que Dios les dio. // Lechuga, Discurso de la Artillería, 1611, pág. 171: La máchina a de ser sufficiente a sufrir la fuerza moviente y la cosa movida, y ésta, que no sea tan pesada que la fuerza moviente no sea mayor y la máchina pueda regir la virtud. 
FAM.: inmovible, inmóvil, inmovilidad, moto, motor, movedizo, mover, movible, movido, móvil, movimiento.

móvil, móvil, móvil [tomado del lat. mōbùlis 'movible'. 1499, Hernán Núñez (DECH). Álaba, Perfeto capitán, 1590]. adj. Fís. Que puede moverse o se mueve por sí mismo (DRAE).

Álaba, Perfeto capitán, 1590, fol. 184r: Y porque la muralla, siendo cosa firme y maciza, resiste con más fuerça el movimiento de la bala que no la galera, que está móbil en la mar y consiente algo con el movimiento de la bala, obra ella con más fuerça en la muralla que no en la nao o galera.

ANT.: inmóvil, inmóvile.

FAM.: inmovible, inmóvil, inmovilidad, moto, motor, movedizo, mover, movible, movido, moviente, movimiento.

2 [Lobato, Notas, a. 1585]. sust. m. Mec. Mecanismo que hace que un ingenio o máquina se mueva.

Lobato, Notas, a. 1585, fol. 22: Este molino inventaron en Flandes para hacer a menor costa y sobre muralla, como irá. Aquí le veremos todo de madera. Y los ingenios y el móvil es el mismo que el de la torre.

HOL.: máquina.

movimento, V. movimiento.

movimiento, mobimiento, movimento, movimiento [de mover. H. 1250, Setenario (DECH). Nebrija, Tabla días y horas, 1517]. sust. m. Fís. Acción y efecto de mover (DRAE).

Nebrija, Tabla días y horas, 1517, IVr: Y a esta división los astrólogos llaman phýsica, de la qual usan, assí en el movimiento de los planetas y estrellas fixas, como en los tiempos por donde se miden aquellos movimientos. // Urrea, Vitruvio, Architectura, 1582, fol. 126r: Este género de máchina se llama polispaton, porque con movimiento de muchas rodezuelas se haze la obra sin difficultad y con gran ligereza. // Juanelo Turriano, Veinte y un libros, a. 1605, fol. 329r: Si se hiziere andar esta máquina con el mismo movimiento de las ruedas, acomodarse en un manil, como va señalado, al costado de la caxa, que tenga una bara que vaya de un manil ha otro de la aspa.

SIN.: moto. 
ANT.: quiete, quietud.

FAM.: inmovible, inmóvil, inmovilidad, moto, motor, movedizo, mover, movible, movido, moviente, móvil.

muela, muela [del lat. mŏla 'rueda de molino' (DECH). Ortega, Conpusición Arismética y Geometría, 1512]. sust. f. Mec. Cada uno de los discos de piedra que en los molinos permite moler lo que entre ellos se interpone.

Ortega, Conpusición Arismética y Geometría, 1512, fol. 128v: Multiplica y parte amas a dos reglas, como te he enseñado por reglas de tres, y allarás que la muela mayor a molido 44 minas o fanegas de trigo y quatro novabos de fanega, que es casi media fanega; $\mathrm{y}$, ansimesmo, hallarás que la menor a molido 35 fanegas de trigo y cinco novabos de fanega, que es poco más de media, como lo veis figurado. // Aurel, Arithmética algebrática, 1552, fol. 99v: En un molino ay tres muelas. La primera muele en tres horas 4 barcellas; la segunda, en cinco horas, 8 barcellas; y la tercera, en seys horas, 9 barcellas. // Juanelo Turriano, Veinte y un libros, a. 1605, fol. 290v: Conviene que este rodete esté asentado muy a peso, porque, no lo estando, se gastan las muelas y no muele tanto.

SIN.: piedra ${ }_{2}$, rueda 2 .

HOL.: molino.

FAM.: amoladera, amoladura, amolar, moler, moleta, molido, molienda, molinero, molinete, molino, remoler, remolimiento, remolinar, remolino.

[IMAGEN] Pseudo-Juanelo Turriano, Los ventiún libros, c. 1605, fol. 308v, fig. 212, letra A (arriba a la derecha).

2 [Urrea, Vitruvio, Architectura, 1582]. sust. f. Mec. Piedra de asperón en forma de disco, que, haciéndola girar, se usa para afilar herramientas (DRAE).

Urrea, Vitruvio, Architectura, 1582, fol. 25v: La causa es porque allí la potencia de la materia es más blanda que el topho, que es piedra arenisca como de las muelas de amolar herramientas o como toba, que es más maciza que tierra // Lechuga, Discurso de la Artillería, 1611, pág. 188: Una dozena de muelas para amolar todas las cosas que fueren menester. Hasta aquí son cosas necessarias al exército. // Lechuga, Discurso de la Artillería, 1611, pág. 201: Muelas para herrería... 1

baja [Juanelo Turriano, Veinte y un libros, a. 1605]. comp. sintag. Mec. Disco de piedra que en los molinos está debajo de la muela voladera, sobre el que se muele el grano y otras cosas.

Juanelo Turriano, Veinte y un libros, a. 1605, fol. 290v: Conviene tener advertencia en asentar primero el rodete, antes de asentar el ruello o la muela baxa, por causa de ver primero cómo yere la agua en el rodete; // Juanelo Turriano, Veinte y un libros, a. 1605, fol. 300r: El cárcavo es D, donde está asentado el rodete. La bóveda del cárcavo es E. El 
banco donde están asentadas las muelas es F. El ruello o muela baxa es G. // Juanelo Turriano, Veinte y un libros, a. 1605, fol. 308v: El vaso es A, que sirve de la muela baxa, que es $\mathrm{B}$, y el agujero es donde sale lo que se muele.

SIN.: ruello solera $_{1}$.

HOL.: molino.

$\sim$ de mano [Celso, Reportorio universal leyes Castilla, 1553]. comp. sintag. Mec. Piedra redonda y cilíndrica que, movida con las manos, se utiliza para moler y amasar alimentos.

Celso, Reportorio universal leyes Castilla, 1553, fol. CCLXXIIIr: Preseas se llaman los molinos o muelas de mano que tienen en los castillos, y carbón y leña y las otras cosas todas, sin las quales no se pueden bien ayudar de la vianda, maguer la ayan.

muelle, muelle [del cat. moll 'íd.' y este del bajo gr. $\mu \omega \lambda$ os 'íd.', que a su vez se tomó del lat. mōles 'masa' 'dique, muelle'. 1591, Percivale (DECH). Loçano, Alberto, Architectura, 1582]. sust. u. t. c. f. Ingen. Hidrául. Obra de piedra, hierro o madera, construida en dirección conveniente en la orilla del mar o de un río navegable, y que sirve para facilitar el embarque y desembarque de cosas y personas e incluso, a veces, para abrigo de las embarcaciones (DRAE).

Loçano, Alberto, Architectura, 1582, pág. 119: Estas obras hizieron los antiguos, pero otros de otra manera, de las quales no ay aquí lugar de disputar, porque la razón de ellas pertenece al enmendar el puerto y hazer la muelle, las quales cosas se dirán en su lugar. // Besson, Teatro instrumentos, 1602, fol. F3v: Nuevo género de máquina para bolver y apartar piedras grandezuelas hundidas en el agua, para que después en su lugar puedan meterse palos para rehazer un muelle viejo o hazer un nuevo, o un puerto nuevo o puente. // Juanelo Turriano, Veinte y un libros, a. 1605, fol. 413v: Los puertos son en tres maneras: unos se llaman muelle, otros se llaman mandrachos. Aunque ellos son differentes en hechura, porque los muelles se cavan del todo dentro de tierra, junto a la mar.

HIPER.: obra hidráulica.

ENCICL.: En algunos lugares se ampliaron los muelles artificiales de los puertos creando bahías artificiales para servir de complemento a las naturales y proporcionar protección frente a las tormentas y, en el Atlántico, también frente a las pleamares: el puerto de Gijón es un ejemplo notable (Keller 1999: 31).

[IMAGEN] Pseudo-Juanelo Turriano, Los ventiún libros, c. 1605, fol. 414r, fig. 413. 
nanilla, nanilla [de origen incierto Juanelo Turriano, Veinte y un libros, c.1605]. sust. f. Mec. Pieza horizontal sobre la que se asienta la muela de un molino.

Juanelo Turriano, Veinte y un libros, c.1605, fol. 300r: Y la muela que anda es H, la qual va asentada encima de la nanilla, la qual va asentada encima de aquella barra de yerro, la qual llaman badil, el qual es I. // Juanelo Turriano, Veinte y un libros, c.1605, fol. 300r: Al costado va señalado la nanilla y el badil y el árbol del rodete. // Juanelo Turriano, Veinte y un libros, c.1605, fol. 316r: Y en la parte de arriba se le haze, dentro d'este árbol, una canal para poner dentro una barra de yerro que va a entrar en la nanilla, que es un yerro que buelve la muela.

SIN.: anadija, ananilla.

HOL.: molino.

FAM.: ananilla.

[IMAGEN] Pseudo-Juanelo Turriano, Los ventiún libros, c. 1605, fol. 299v, fig. 200. 
nariz, nariz [del lat. vg. nārīcae 'íd.', resultante de un cruce de nārēs 'íd.' y 'nariz' con nāsīca 'de nariz afilada y puntiaguda'. 1171, Doc. leonés (DECH). Urrea, Vitruvio, Architectura, 1582]. sust. f. Ingen. Hidrául. Extremidad de un conducto o canal.

Urrea, Vitruvio, Architectura, 1582, fol. 95v: Mas, si el lugar no consintiere hazerse el edificio, háganse canales, y las narizes salgan a lugar abierto. // Urrea, Vitruvio, Architectura, 1582, fol. 133r: Y en cada canal está un pistomio, que es una llave con aguamaniles de hierro, los quales, quando se tuercen, abren las narizes de las canales. // Loçano, Alberto, Architectura, 1582, pág. 92: Dexarás narizes abiertas por donde se destille el humor por sus canales.

HOL.: conducto, canal.

nibel, V. nivel.

nivel, nibel, nivel [del cat. nivell (o quizás de la lengua de Oc o del francés) y este del lat. vg. lībēllum, en latín clásico lībēlla, diminutivo de libra 'balanza'. Med. S. XV, Suero de Ribera, Can. de Stúñiga. (DECH). Sánchez de las Broças, Helt Frisio, Relox español, 1549]. sust. m. Instrumento para examinar si un plano está verdaderamente horizontal (Autoridades).

Sánchez de las Broças, Helt Frisio, Relox español, 1549, fol. 24r: Para lo qual, lo primero es que el lugar donde se ha de hazer esta línea ha de ser muy llano y assentado por nivel, de manera que no esté más alto de una parte que de otra. // Juanelo Turriano, Veinte y un libros, a. 1605, fol. 49v: Mas, dejado esto aparte, el hazer de los niveles es cosa muy necessaria a muchos exercicios, como es para el labrador, como para los que empiedran calles y para canteros y maessos de casas. // Juanelo Turriano, Veinte y un libros, a. 1605, fol. 51r: Y la tabla donde van asentando el nivel, es menester que esté algún tanto alta, [a] causa qu'el que ha de señalar las líneas las pueda más cómodamente señalar en el nivel, los palmos y minutos.

FAM.: nivelador.

de agua [Juanelo Turriano, Veinte y un libros, a. 1605]. comp. sintag. El que se utiliza para hallar la diferencia de altura entre dos puntos (Javier Sánchez).

Juanelo Turriano, Veinte y un libros, a. 1605, fol. 56r: El corbate, que ansí es llamado de Vitruvio, y el vulgo le llama nivel de agua o pesso, el qual se haze en la forma que se sigue: que donde es la A es el pie, el qual es de madera, con aquellos tres pies, y de una madera muy seca y sólida.

SIN.: corbate, nivel de peso.

HIPER.: instrumento. 
$\sim$ de borneo [Juanelo Turriano, Veinte y un libros, a. 1605]. comp. sintag. El que puede girar una vuelta completa sobre un eje vertical en una alidada.

Juanelo Turriano, Veinte y un libros, a. 1605, fol. 150v: Quiero advertir que para nivelar en semejantes lugares, si no fuere con nivel de borneo, porque con el tranco no puede servir. // Juanelo Turriano, Veinte y un libros, a. 1605, fol. 150v: Y digo que el nivel de borneo es muy más verdadero que no el de tranco; hácense cien faltas en ello. // Juanelo Turriano, Veinte y un libros, a. 1605, fol.

151r: Ansí que, con muy grande brevedad, se haze con el nivel de borneo.

HIPER.: instrumento.

[IMAGEN] Pseudo-Juanelo Turriano, Los ventiún libros, c. 1605, fol. 60v, fig. 21.

$\sim$ de grados [Juanelo Turriano, Veinte y un libros, a. 1605]. comp. sintag. El que incorpora una polea graduada para poder medir el desnivel entre dos puntos bastante próximos con exactitud (Juanelo Turriano Glos., s. v. nivel de grados).

Juanelo Turriano, Veinte y un libros, a. 1605, fol. 53r: Ay otro instrumento para nivelar que se llama nivel de grados, el qual es muy diferente en su forma y hechura de los demás niveles. // Juanelo Turriano, Veinte y un libros, a. 1605, fol. 95r: Si acaso dentro de la mina fuesse necessario aver de hazer algún ángulo, por causa de abreviar camino o por hallar dentro algún impedimento, entonces convendrá servirse con otro instrumento que con el nivel de grados o con un planisferio. // Juanelo Turriano, Veinte y un libros, a. 1605, fol. 151r: Y caso que se ubiese de servir con el de tranco, antes yo me querría servir con el nivel de grados, el qual es muy más cierto que ninguno otro de los que se pueden servir.

HIPER.: instrumento.

$\sim$ de peso [Juanelo Turriano, Veinte y un libros, a. 1605]. comp. sintag. El que se utiliza para hallar la diferencia de altura entre dos puntos (Javier Sánchez).

Juanelo Turriano, Veinte y un libros, a. 1605, fol. 56r: El corbate, que ansí es llamado de Vitruvio, y el vulgo le llama nivel de agua o pesso, el qual se haze en la forma que se sigue: que donde es la A es el pie, el qual es de madera, con aquellos tres pies, y de una madera muy seca y sólida.

SIN.: corbate, nivel de agua.

HIPER.: instrumento.

$\sim$ de tranco [Juanelo Turriano, Veinte y un libros, a. 1605]. comp. sintag. Nivel rústico y poco preciso que consta de dos largas patas de madera iguales, de grandes dimensiones y un travesaño horizontal graduado. (Glosario Los Ventiún Libros, s. v. nivel de tranco). 
Juanelo Turriano, Veinte y un libros, a. 1605, fol. 50r: El primero y más ordinario instrumento es el nivel de tranco. // Juanelo Turriano, Veinte y un libros, a. 1605, fol. 54r: Y, más, que también se puede medir muy justíssimamente la longitud, y esto es por razón que el instrumento nunca se tuerze a ninguna parte, como haze el nivel de tranco. // Juanelo Turriano, Veinte y un libros, a. 1605, fol. 58v: Puédese nivelar con diversos instrumentos, y para esto pondré aquí abajo, ultra de los puestos, señalaré un nivel de tranco, aunque en la hechura es muy differente: en que éste no lleva pesso colgado, mas lleva un braço como llevan las balanzas, con dos pessos.

SIN.: tranco.

HIPER.: instrumento.

nivelador, nivelador [de nivelar (DECH). Álaba, Perfeto capitán, 1590]. sust. $\mathrm{m}$. Persona que tiene por oficio el igualar un terreno o superficie en las obras de construcción.

Álaba, Perfeto capitán, 1590, fol. 225r: Continuando este arco, hasta que viniesse a estar otra vez a nivel, por la parte de la crueña, con el llano del orizonte, que llaman los niveladores; los otros dos arcos se han de imaginar debaxo d'éstos. // Juanelo Turriano, Veinte y un libros, a. 1605, fol. 57v: De modo que el nivel o corbate a de hallarse apartado cinqüenta passos dende el de la vanderilla al mismo nivel, y otros tantos del de la regla, de modo que dende el que tiene la regla al de la vanderilla a de aver cien passos, y el nivelador está en medio de los dos. // Juanelo Turriano, Veinte y un libros, a. 1605, fol. 60v: Si por caso el nivelador no supiese llevar essa cuenta del quadro geométrico, sírvase d'esta cuenta que suelen llevar los ballesteros, la qual es muy fácil de llevar.

FAM.: nivel.

[IMAGEN] Pseudo-Juanelo Turriano, Los ventiún libros, c. 1605, fol. 60v, fig. 21.

2 [Herrera, Institución Academia, 1584]. sust. Ingen. Hidrául. Persona que tiene por oficio el conducir el agua de un lugar a otro.

Herrera, Institución Academia, 1584, fol. 3r: y, ansimismo, fontaneros y niveladores de las aguas, para los aguaductos y regadíos que en estos reynos tan importantes y convenientes serían, y para desaguar y beneficiar las minas de ricos metales. // Herrera, Institución Academia, 1584, fol. 18r: Ha de tener el nivelador práctica de hazer las composiciones de betumes para sus encañados, $\mathrm{y}$, finalmente, todo lo a este ministerio perteneciente. // Rojas, Teórica fortificación, 1598, fol. 61v: Esta regla de multiplicar círculos es muy importante para el geómetra o nivelador que encamina aguas.

noria, noria [alteración del antiguo (a)nora por influjo de acenia y acequia; (a) nora viene del ár. nā،ûra 'íd.', derivado de ná،ra 'gruñir'. S. XII (DECH). García de Céspedes, Instrumentos nuevos, 1606]. sust. f. Mec. Máquina compuesta de 
dos o más ruedas, que se utiliza para subir y sacar agua de los pozos, acequias, etc.

García de Céspedes, Instrumentos nuevos, 1606, fol. 40r: Los antiguos para este efeto imaginaron algunas máchinas, como son norias de diferentes suertes, bombas, azudas, cócleas y la tesibica que pone Vitruvio, la qual dize que sube la agua muy alto, pero es poca y con mucha violencia. // Valle de la Cerda, Desempeño patrimonio, 1600, fol. 137r: Con facilidad para comprar y relevar sus mercancías y tratos lícitos, llevándose todo por sus alcaduzes a la noria general de los erarios, quedando unos vacíos y otros llenos.

SIN.: anoria $_{2,}$ ceña.

HIPER.: máquina.

FAM.: anoria.

[IMAGEN] Pseudo-Juanelo Turriano, Los ventiún libros, c. 1605, fol. 349r, fig. 266. 
obra, hobra, obra [del lat. ŏpus, ŏpĕris 'obra, trabajo'. H. 1140, Cid (DECH). Ortega, Conpusición Arismética y Geometría, 1512]. sust. f. Construcción de arquitectura, albañilería o carpintería (Herráez).

Ortega, Conpusición Arismética y Geometría, 1512, fol. 178r: Estos tres compañeros repartieron en tal manera los días, que en fin de la obra cada uno d'ellos tuviese tantos sueldos como el otro. // Loçano, Alberto, Architectura, 1582, pág. 98: Y de allí vendremos a estas obras, que vemos amplíssimas, con theatros, estatuas y templos, porque es claro que las gentes del mundo habitaron mucho tiempo sin tener ceñidos con ningún tipo de cercas sus ciudades. // Juanelo Turriano, Veinte y un libros, a. 1605, fol. 123v: Ansí que en lo más bajo del valle se deve poner muchíssima diligencia, más que en ninguna otra parte d'esta obra.

obrero, obrero [del lat. ŏpĕrārŭus 'íd.'. H. 1220-1250, Berceo (DECH). Anónimo, Ordenanças paños, 1527]. sust. m. Persona que trabaja por jornal en las obras de las casas y en las labores del campo (Autoridades).

Anónimo, Ordenanças paños, 1527, fol. IXv: E mando a los dichos maestres que no resciban obrero alguno que gane dineros como obrero en los dichos officios, sin que el tal obrero sea examinado e tenga carta de examen. // Celso, Reportorio universal leyes Castilla, 1553, fol. CCXXXVv: Los obreros y officiales que se alquilan, quier sean hombres, quier sean mugeres, salgan a la plaça, donde se acostumbran de alquilar, con sus herramientas y mantenimiento, en quebrando el alva. // Besson, Teatro 
instrumentos, 1602, fol. D2v: De do nace que, moviendo los obreros a fuerça grande de braços la balança y tirándola, alcen el un fuelle y el otro abaxen; a aquél alçando con el palo que alça y a éste abaxando con el que baxa.

ojo, ojo, oxo [del lat. ŏcŭlus 'íd'. Orígenes del Idioma (DECH). Lobato, Notas, a. 1585]. sust. m. Ingen. Hidrául. Espacio entre dos pilares de un puente.

Lobato, Notas, c.1585, fol. 13: El agua que viene a topar cuando llueve de [las] cuestas a topar en el cauce que va por la ladera o balsa del molino, ponerla en el hondo que hubiere de llevar su corriente, y luego labrar enfrente de dicho aguacero o caño un puente de uno o dos ojos, los que sean necesarios. // Lobato, Notas, c.1585, fol. 31: En los dos ojos de la dicha puente, asentadas dos trampas, como se ponen en los molinos, anchas y no muy altas, para que no entre más agua por la dicha puente de la que los molinos hubieren menester, y lo demás vierta por la dicha pesquera, que su fin será en el costado derecho de la dicha puente al corriente del agua.

SIN.: tramada, trampo.

HOL.: puente.

2 [Juanelo Turriano, Veinte y un libros, a. 1605]. sust. m. Ingen. Hidrául. Entrada o salida, generalmente con forma redonda, de una obra de ingeniería hidráulica. Juanelo Turriano, Veinte y un libros, a. 1605, fol. 185v: El monte es la A. Y la acequia es B. La conserva del agua es C. Donde sale el agua del ojo quadrado y va a entrar en los alcaduzes, D. Y donde entran en la cisterna es E.

SIN.: boca.

3 [Juanelo Turriano, Veinte y un libros, a. 1605]. sust. m. Manantial que surge en un llano (DRAE).

Juanelo Turriano, Veinte y un libros, a. 1605, fol. 75r: Lo que se a de hazer: que, algún tanto apartado del ojo de la fuente, se vaya cavando alrededor, por ver si hallarías algún otro ojo de agua. // Juanelo Turriano, Veinte y un libros, a. 1605, fol. 75r: Mas quando ella fuesse poca agua, se deve hazer lo dicho, porque muchas vezes vemos manar muchos ojos juntos, en especial quando naçe de bajo para riba. // Juanelo Turriano, Veinte y un libros, a. 1605, fol. 75r: Mas, si el agua desciende de alto para abajo, pocas vezes verás manar ojos, mas verás que a la redonda de donde mana yrrezumando agua.

ollero, ollero [del lat. ollarŭus 'íd.' (DRAE). Pérez Vargas, De re metallica, 1568]. sust. $\mathrm{m}$. Persona que tiene por oficio el fabricar ollas y otros utensilios de barro. 
Pérez Vargas, De re metallica, 1568, fol. 35r: Que es un barro con que los olleros tiñen de color dorado y plateado los vasos que hazen subtiles. // Urrea, Vitruvio, Architectura, 1582, fol. 115v: Como si en la rueda de que usan los olleros ponemos siete hormigas y en lo baxo del centro hazemos siete caños. // Loçano, Alberto, Architectura, 1582, pág. 52: Los olleros a sus vasos los sobreuntan con greda blanca, con la qual hazen que el vidrio, muy igualmente, se derrita por encima.

oreja, oreja [del lat. aurŭcŭla 'íd.' (DRAE). Lobato, Notas, a. 1585]. sust. f. Mec. Parte lateral del puente de un molino.

Lobato, Notas, a. 1585, fol. 33: En las paredes del dicho molino se encajarán unos lobos para que la puente no se pueda ir a una parte ni a otra, que serán como las berinas de un lagar en sano horadadas en cuadrado, y en aquel cuadrado entrarán las orejas de la dicha puente. Y el aliviadero estará por la parte de hacia la cuba, a la parte que quisieren, y de la otra parte otro pequeño que vaya dentro del lobo.

HOL.: puente 3.

oxo, V. ojo. 
palahierro, palahierro [cmpt. de palo y hierro (DRAE). Lobato, Notas, c.1585]. sust. m. Mec. Pieza encajada en la solera, sobre la que se apoya el gorrón de la muela de un molino.

Lobato, Notas, c.1585, fol. 34: Luego irá quebrado las esquinas, porque no embarace al agua, que así quede en ochavo, hasta donde se ha de forjar la caja, que será de esta manera: la punta de arriba puesta al justo del cuadrado que tuviere el palo más alto, y luego forjar tres barras de hierro cuadradas para que hagan la casa, y quede el un cuadro de la tabla por donde entre el palahierro. // Lobato, Notas, c.1585, fol. 35: Palahierro... 3

SIN.: guepejo, rangua.

HOL.: molino.

[IMAGEN] Lobato, Notas, c. 1585, fol. 36. Está señalado con el número 3.

palanca, palanca, palança [del lat. vg. *palanca 'íd.', variante del clásico

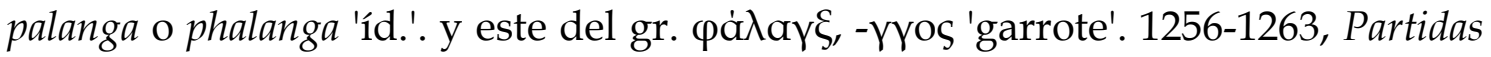


(DECH). Loçano, Alberto, Architectura, 1582]. sust. f. Barra que se utiliza para mover o levantar cosas de mucho peso.

Loçano, Alberto, Architectura, 1582, pág. 346: Alçarémoslas después con meter debajo una viga, a modo de barra, la qual misma hemos llamado palanca; quitarle heys algo por abajo con estender una cavadura poco a poco. // Collado, Plática Artillería, 1592, fol. 100v: Avellano para pólvora como de herrería, clavazón gruessa y menuda, hierro, picos, sierras, palanças, uñas de cabra, almádenas de hierro, martillos. // Juanelo Turriano, Veinte y un libros, a. 1605, fol. 392r: De modo que caminarán estos maderos por una recata hecha a una y otra parte de la puente, que los maderos no pueden sallir de un assiento, ni passar más adelante de lo necessario y empuxarla adelante con una palanca.

SIN.: alzaprima, leva $a_{2}$ manuela, palanga $a_{1}$ própalo, uña de cabra, uña de puerco.

HIPER.: herramienta.

FAM.: palanga, palanqueta.

[IMAGEN] Pseudo-Juanelo Turriano, Los ventiún libros, c. 1605, fol. 248r, fig. 316. La palanca está situada en el centro de la imagen.

2 [Lobato, Notas, a. 1585]. sust. f. Mec. Barra inflexible, recta, angular o curva, que se apoya y puede girar sobre un punto, y sirve para transmitir una fuerza (DRAE s. v. palanca).

Lobato, Notas, a. 1585, fol. 37: En la figura: Viga larga que llegaba a la otra parte porque la palanca pasase. // Besson, Teatro instrumentos, 1602, fol. Dv: Mas estos maderos más luengos se travan assí firmemente, que ni ahun en la obra se mueven de su lugar, y assí viene la palanca a carescer de su movimiento, la qual sostienen en sus extremidades, que están hazia el ángulo de poniente y de mediodía, y la qual, restribando en dos quicios, se mueve en derredor. // Juanelo Turriano, Veinte y un libros, a. 1605, fol. 348r: Con el animal se buelve el árbol A, el qual tiene encaxada la palanca B, la qual tiene unas cuerdas asidas al cavo B.

SIN.: palanga $a_{2}$

HOL.: máquina.

palança, V. palanca.

palanga, palanga [tomado del lat. phalanga 'íd', y este tomado del gr.

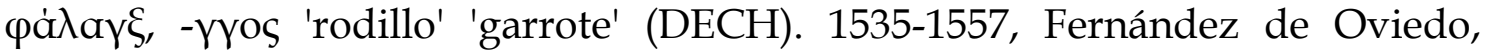
Gonzalo, Historia natural de las Indias (CORDE). Besson, Teatro instrumentos, 1602]. sust. f. Barra que se utiliza para mover o levantar cosas de mucho peso. 
Besson, Teatro instrumentos, 1602, fol. Pv: Solamente, el lector ha de ser advertido ser cosa digna de consideración que la nave que se ha de sacar esté puesta sobre unas palangas y unos maderos gruessos y redondos, para que tanto mejor y más fácilmente corra.

SIN.: alzaprima, leva 2, manuela, palanca ${ }_{1}$, própalo, uña de cabra, uña de puerco.

HIPER.: herramienta.

FAM.: palanca, palanqueta.

2 [Besson, Teatro instrumentos, 1602]. sust. f. Mec. Barra inflexible, recta, angular o curva, que se apoya y puede girar sobre un punto, y sirve para transmitir una fuerza (DRAE s. v. palanca).

Besson, Teatro instrumentos, 1602, fol. Iv: Las quales palangas son tres, y todas, con sus quicios metidos en ciertos anillos de hierro que vienen del tablado, van restribando en ellos, voltándose.

SIN.: palanca $_{2}$.

HIPER.: herramienta.

palanqueta, palanqueta [de palanca (DECH). Anónimo, Diálogo fábrica de navíos, ca. 1631]. sust. f. Palanca pequeña, regularmente formada por una barra de hierro con dos cabezas, que suele usarse en la carga de artillería.

Anónimo, Diálogo fábrica de navíos, ca. 1631, fol. 19v: Desseo saver qué artillería será menester para galeón del dicho porte de 500 toneladas, y de qué calibo, y quánta pólvora, valas, cuerda, palanquetas y demás cosas a menester cada una para un viaje o jornada de lasYndias. // Anónimo, Diálogo fábrica de navíos, ca. 1631, fol. 35v: Seis palanquetas y enramadas y de cadena; tres linternas de dados; medio quintal de cuerda, ynclusa la necessaria para la ynfantería // Anónimo, Diálogo fábrica de navios, ca. 1631, fol. 36r: Y, quando no se pudiera rendir al enemigo, estando bordo a bordo, procurar hecharle a fondo con palanquetas o pies de cabra.

FAM.: palanca, palanga.

pandero, pandero [probablemente del lat. tardío pandořus 'íd.', variante de

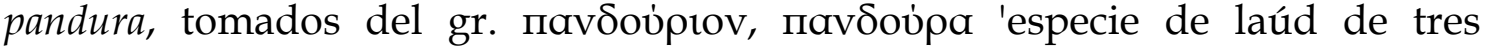
cuerdas'. J. Ruiz. (DECH). Besson, Teatro instrumentos, 1602]. sust. m. Mec. Especie de barril que forma parte del mecanismo de algunas máquinas.

Besson, Teatro instrumentos, 1602, fol. C4v: Tirándola a sí por debaxo de la parte que tiene con la mano, haga dar bueltas al palo voluble juntamente con los panderos $o$ barriletes, y, por consiguiente, también al caracol y al cylindro. // Besson, Teatro instrumentos, 1602, fol. Kv: A mediodía está la rueda mayor dentada, como es fácil de 
ver en los molinos, y ésta mete sus dientes en las aberturas de los panderos o barrilejos, que están en el mesmo exe. // Besson, Teatro instrumentos, 1602, fol. Kv: Y las mesmas cuerdas son embueltas en los panderos de más abaxo, y vienen después a rematarse en la parte de la viga que está a tramontana.

HOL.: máquina.

paradera, paradera [de parada (DRAE). Pérez Vargas, De re metallica, 1568]. sust. f. Mec. Compuerta con que se regula el agua del cauce de un molino.

Pérez Vargas, De re metallica, 1568, fol. 101v: Los fuelles se muevan con un artificio de agua, de manera que, quando quiera echar carbón, o metal, o limpiar las escorias, se pueda tener la rueda como paradera de molino.

HOL.: molino.

parafuso, V. parahúso.

parahúso, parafuso, parahúso [de par a huso, referido a cada uno de los dos husos grandes que se emplean para torcer el hilo (DRAE). Lobato, Notas, c.1585]. sust. m. Mec. Barra o eje que sustenta la muela en un molino harinero, sujeta al eje de la rueda hidráulica por un extremo y a la anadija por el otro (García Tapia 19971).

Lobato, Notas, c.1585, fol. 26: Y como yo tenía el palo y parahúso y piedra, rogome que yo y él probásemos un modelo de ello y que no gastase más de la cuarta parte, y yo otorguelo, entendiendo que no gastaríamos en el modelo de cuarenta escudos arriba. // Lobato, Notas, c.1585, fol. 36: Las piedras que este molino ha menester, además de piedras y tolva y demás aparejos de moler, son las vigas sobre las que se asienta la cuba y la dicha cuba y puente aliviada, canal y rangua, rodeznos y parahúsos, y todas estas piezas irán aquí pintadas, como se ve, cada cosa por sí, y arcos de hierro. // Lobato, Notas, c.1585, fol. 36: Rodezno y parahúso de madera, que es el común que se usa en los molinos.

HOL.: molino.

[IMAGEN] Lobato, Notas, c. 1585, fol. 36, señalado con el número 1.

parejo, parejo, perejo [del lat. *paricŭlus, dim. de par, paris, 'igual'. Girava, Fineo, Geometría práctica, trads., 1553 ]. adj. Igual o semejante (DRAE).

Girava, Fineo, Geometría práctica, trads., 1553, pág. 25: Entre las figuras, quando se hallaren algunas de un mesmo género, que no solamente tengan en igualdad parejos 
todos los lados, pero ahun los ángulos, éstas se llamarán iguales , y quando todo esto no huvieren, por el contrario, se dirán desiguales. // Besson, Teatro instrumentos, 1602, fol. G4v: Los quales clavos están assí ordenados como que el tal exe fuesse dividido en quatro partes, lo que se haze a fin que, juntamente con la utilidad, el moler sea a los oýdos apazible, no siendo desigual y no parejo. // Besson, Teatro instrumentos, 1602, fol. Nv: Tiene pues, primeramente, esta máquina al uno y al otro lado dos pies, por dezir assí, que son dos maderos parejos que cogen la balança y dentro de los quales se baxa y se alça, como por la misma figura claramente parece.

FAM.: aparejador, aparejar, aparejo, emparejar.

2 [Falero, Tratado del espera, 1535]. adj. Liso, llano.

Falero, Tratado del espera, 1535, fol. 41v: E haréys un medio círculo de hierro o de azero o de otra qualquiera cosa, que sea muy redondo e plano y parejo, y que no tenga más grossor que quanto haga sombra. / / Sanctiago, Arte separatoria, 1598, fol. 3r: Y, desque le ayan marmoleado, calen la pieça y buélbanle a marmolear como emos dicho; y así se pone el vidro uniforme y parejo en toda la pieça que se haze. // Alonso Barba, Arte de los metales, 1640, fol. 75r: Y de uno a otro ay la distancia que baste para que, con otros hechos del mismo barro fuerte, de una tercia o algo más de largo en quadro y de tres dedos de alto, se ajuste y llene lo que huviere de arco a arco, de suerte que por encima quede el suelo muy parejo y llano.

parrilla, parrilla [de parra (DECH). Pérez Vargas, De re metallica, 1568]. sust. $\mathrm{f}$. Utensilio de hierro en forma de rejilla que generalmente se pone al fuego con distintos usos.

Pérez Vargas, De re metallica, 1568, fol. 76v: Y, dentro, se van poniendo lechos de leña gruessa a la larga, unos sobre otros cruzados a manera de una reja de hierro, o de dos parrillas atravessadas unas sobre otra. // Besson, Teatro instrumentos, 1602, fol. O3v: La qual basa, a la banda de tramontana, tiene unas parrillas para firmar la máquina. // Juanelo Turriano, Veinte y un libros, a. 1605, fol. 381r: Es hecho este instrumento a modo de graílla o parrillas, en el qual se assienta un lienço muy gruesso a modo de un saco.

SIN.: gradilla.

HIPER.: insrumento.

partidero, partidero [de partir. Juanelo Turriano, Veinte y un libros, a. 1605]. sust. m. Ingen. Hidrául. arag. Parte de una obra hidráulica destinada a dividir una conducción de agua en varios cauces.

Juanelo Turriano, Veinte y un libros, a. 1605, fol. 479r: Mas al entrar en H I o en K, digo que entrará mucha más agua en $\mathrm{H}$ que en ninguna de las otras dos, por razón que la agua camina en cantidad, más junta, en $\mathrm{K}$, por estar muy más atrás su partidero que ninguno de los otros dos. // Juanelo Turriano, Veinte y un libros, a. 1605, fol. 481r: 
Pues he empeçado a demostrar las differentias que hay en los partideros de las aguas, y porque en diversas partes acaescen diversos casos a los hombres, máxime en materia de aguas hay grandes divisiones. // Juanelo Turriano, Veinte y un libros, a. 1605, fol. 481v: Y esso lo declaran las dos líneas, que son $\mathrm{E}$ y $\mathrm{F}$, de los mismos partideros, quanto más que la agua le viene con gran despedida, que no se detiene en los ángulos de los partideros para haverse de entrar en su çequia.

SIN.: partidor.

HOL.: obra hidráulica.

FAM.: partidor, partir, repartir.

[IMAGEN] Pseudo-Juanelo Turriano, Los ventiún libros, c. 1605, fol. 470r, fig. 498, letra F.

partidor, partidor [de partir. Juan Ruiz (DECH). Juanelo Turriano, Veinte y un libros, a. 1605]. sust. m. Ingen. Hidrául. Parte de una obra hidráulica destinada a dividir una conducción de agua en varios cauces.

Juanelo Turriano, Veinte y un libros, a. 1605, fol. 466v: Para haver de dividir una çequia de agua en dos partes iguales, háganse primero dos paredes a los dos costados de la çequia, que sean, a lo menos, doze palmos de largo, en la parte donde se quiere dividir, del partidor adelante. // Juanelo Turriano, Veinte y un libros, a. 1605, fol. 467r: Yo querría que las losas que se ponen en el partidor, que se pusiessen de canto, a causa que no se puede cavar por debaxo, por estar enlosado en el suelo, y essas dos losas están muy hondas. // Juanelo Turriano, Veinte y un libros, a. 1605, fol. 467r: Las paredes de la çequia es A. El enlosado es B. El partidor es C. Y donde se a de dividir el agua es D, que es donde están hincadas las losas D D.

SIN.: partidero.

HOL.: obra hidráulica.

FAM.: partidero, partir, repartir.

[IMAGEN] Pseudo-Juanelo Turriano, Los ventiún libros, c. 1605, fol. 470r, fig. 498, letra F.

partir, partir [del lat. partìi 'dividir, partir' repartir'. H. 1140, Cid (DECH). Juanelo Turriano, Veinte y un libros, a. 1605]. v. tr. Ingen. Hidrául. Dicho del agua: distribuirla por diferentes lugares mediante conducciones.

Juanelo Turriano, Veinte y un libros, a. 1605, fol. 464r: En el partir de las aguas conviene tener gran cuydado, porque hay muchos engaños en el ensanchar o ahondar las çequias.

SIN.: repartir.

FAM.: partidero, partidor, repartir.

pasaje, V. molino de $\sim$. 
pegadura, pegadura [de pegar. Entre 1493 y 1495, Nebrija (DECH). Loçano, Alberto, Architectura, 1582]. sust. f. Pasta hecha con estopa, cal, aceite, escorias, vidrios molidos $\mathrm{u}$ otros materiales, que se utiliza para pegar o ligar piedra, madera, hueso, etc.

Loçano, Alberto, Architectura, 1582, pág. 45: A éstos es contrario el roble, por ser entre sí $\mathrm{y}$ con las otras todas materias d'esta manera dessacompañada del todo y menospreciador de toda pegadura. // Loçano, Alberto, Architectura, 1582, pág. 45: El mismo vicio dizen que tienen todos los lagrimosos y crespos, y que dessechan todo género de pegadura, y también el madero que se rae y es denso, difficultosamente se pega con pegadura. // Loçano, Alberto, Architectura, 1582, pág. 46: El olmo, fresno, moral, cerezo, porque son secos, con el plátano y el álamo negro, que son de natura mojados, no convienen, y guardávanse los antiguos de no juntar con pegadura las maderas que por natura no convenían entre sí, y eran contrarias, de manera que vedaron el juntar los árboles que no eran de una misma naturaleza y el pegarlos.

SIN.: ligadura.

FAM.: apegadura, apegar, desapegadizo, desapegar, despegar, empegar, empeguntar, pegar, pez.

2 [Loçano, Alberto, Architectura, 1582]. sust. f. Acción de pegar (DRAE). Loçano, Alberto, Architectura, 1582, pág. 83: Pero si fueren los árboles menores, que no puedas de un solo tronco poner la viga entera, ajuntarás muchas en una pegadura, de suerte que en sí tengan más estrechamente la fuerça.

3 [Loçano, Alberto, Architectura, 1582]. sust. f. Unión física que resulta de haberse pegado algo con otra cosa (DRAE).

Loçano, Alberto, Architectura, 1582, pág. 76: Allí es que se sobreponga cada piedra postrera, y de suerte se engruda y se adova sobre las ya puestas, que venga a caer en medio de la pegadura de los dos de abajo, con estendimiento igualado y nivelado. // Loçano, Alberto, Architectura, 1582, pág. 311: Y en los montes advirtieron que avía cortezas unas sobrepuestas a otras y amontonadas, de suerte que por de fuera las rengles de los amontonamientos y las líneas de las pegaduras están tiradas de la mano derecha a la izquierda a nivel. // Sanctiago, Arte separatoria, 1598, fol. 3v: Y de las pieças que se an de ussar sobre el fuego descubierto, no sean tomadas con el puntel, porque se pierde el continuo del dicho vidro, y por las tales pegaduras suelen quebrarse.

SIN.: apegadura. 
pegar, pegar [del lat. picāre 'embadurnar o pegar con pez'. H. 1220-1250, Berceo (DECH). Medina, Arte de navegar, 1545]. v. tr. Juntar o unir una cosa con otra utilizando pez, betún u otro material adherente.

Medina, Arte de navegar, 1545, fol. 81r: A lo quarto, si la rosa anduviere algo acostada y no anduviere muy ygual, póngale alguna cera o pez, o cosa que pegue, por debaxo. // Juanelo Turriano, Veinte y un libros, a. 1605, fol. 274r: Este betún es muy excellente para pegar madera y hueso juntos. // Juanelo Turriano, Veinte y un libros, a. 1605, fol. 275r: Betún, el qual sirve para pegar toda cosa de barro, en especial alcaduces de varro, y también sirve a pegar cosas de barro rompidas.

SIN.: apegar.

ANT.: desapegar, despegar.

FAM.: apegadura, apegar, desapegadizo, desapegar, despegar, empegar, empeguntar, pegadura, pez.

peltrechos, V. pertrechos.

pendazo, pendazo [probablemente del lat. pittačum 'pedazo, parte'. Lobato, Notas, c.1585]. sust. m. Mec. Cada uno de los dientes de una rueda de una máquina.

Lobato, Notas, c.1585, fol. 15: Asentado en un eje fuerte, a la punta del cual tenga seis guijos de hierros, y en el eje injerida una entruesga que tenga la mitad menos del círculo que la grúa con sus pendazos, la cual dé en un carro de 16 palos. // Lobato, Notas, c.1585, fol. 15: Y encima del carro esté una rueda que tenga sesenta y cuatro pendazos, hiriendo de punta en un carro de ocho palos o nueve. // Lobato, Notas, c.1585, fol. 25: Se mostrará en la traza que en bajo irá pintada: que la rueda que la bestia trae tenía cuarenta y ocho pendazos, que de uno a otro había con su grueso una cuarta, que eran de encina y cuadrados.

[IMAGEN] Lobato, Notas, c. 1585, fol. 15.

pénula, pénula [tomado del lat. paenŭla 'cubierta de una máquina' (Agustín Blánquez Fraile). Urrea, Vitruvio, Architectura, 1582]. sust. f. Mec. Cubierta de una máquina, con forma de aguamanil.

Urrea, Vitruvio, Architectura, 1582, fol. 132r: Encima del catino, que es un vaso de metal, está la pénula, que es a modo de aguamanil buelta y bien assentada, la qual se detiene passando un cuño por una hevillera y el catino, porque la fuerça del agua no la levante. // Urrea, Vitruvio, Architectura, 1582, fol. 132r: Hinchando con apretar, echan fuera por las oberturas de los cañones el agua en el catino, del qual reciben la pénula. // Urrea, Vitruvio, Architectura, 1582, fol. 142r: Pénula: baso a manera de aguamanil. 
peón, peón [del lat. pĕdō, pĕdōnis 'íd.', conservado en todos los romances de Occidente. Doc. de 1100 (DECH). Llanos, Diccionario minas, ca. 1609-11]. sust. m. Mec. Barra giratoria de un molinete.

Llanos, Diccionario minas, ca. 1609-11, pág. 9: El principal instrumento que en ellas sirve para lavar el metal es el molinete, que, a manera casi de rodezno, se trae a la redonda dentro de ellas; y los anexos a él son: cigüeñuela, peón y dedal, que sirven para el mismo movimiento, que se hace a fuerza de brazos en las tinas de mano.

HOL.: molinete.

perito, perito [tomado del lat. pěrĭtus 'experimentado', 'entendido' (DECH). $1^{a}$ mitad del s. XVI, Bartolomé de Las Casas, Apologética historia sumaria (CORDE). Pérez Vargas, De re metallica, 1568]. adj. u. t. c. sust. Entendido, experimentado, hábil, práctico en una ciencia o arte (DRAE).

Sagredo, Medidas Romano, 1526, pág. 73: En muchos fundamentos romanos se hallan pozos abiertos, los quales mandavan abrir los peritos maestros por librar sus edificios del poder e dominio de los terremotos, los quales, hallando por do respirar, quedarían sus edificios salvos y seguros. // Urrea, Vitruvio, Architectura, 1582, fol. 8r: ¿Cómo lo podrá alcançar el architecto, el qual ha de ser perito y sabio en muchas sciencias? // Valles, Tratado aguas destiladas, 1592, fol. 43r: Matemáticas, de que él es muy perito, tomándolo por la capacidad del cubo hecho por una antigüedad que se halló en Roma, aunque éste dize que discrepa en una nonagésimanona.

perne, V. perno.

perno, perne, perno [tomado del cat. pern 'íd.' y este del latín perna 'pierna'. S. XV, Crón. de Juan II (DECH). Arphe, Varia Commensuración, 1585-87]. sust. m. Mec. Pieza de hierro u otro metal, larga, cilíndrica, con cabeza redonda por un extremo y asegurada con una chaveta, una tuerca o un remache por el otro, que se usa para afirmar piezas de gran volumen (DRAE).

Loçano, Alberto, Architectura, 1582, pág. 178: Por los agujeros de las orejuelas se passa un perno de hierro, y se le pone una assa fuerte, y a ésta una soga enlazada para tirar. // Juanelo Turriano, Veinte y un libros, a. 1605, fol. 145v: El madero K ase de enterrar dentro de tierra, delante la viga $\mathrm{I}$, la qual tiene la armadura assida con la cuerda $\mathrm{M}$, al principio de la sirga F. Y al fin es L, donde juega, sobre el perne G, el ergate. // Juanelo Turriano, Veinte y un libros, a. 1605, fol. 308v: Y este molino o molinos se hazen en tal modo, que se pueden bolver a la redonda para tomar los vientos, y, así, está asentado sobre un perne de madera donde buelve a la redonda.

HIPER.: pieza. 
pértiga, pértiga [del lat. pĕrtǐca 'íd.'. H. 1220-1250, Berceo (DECH). Ortega, Conpusición Arismética y Geometría, 1512]. sust. f. Vara larga (DRAE).

Pérez Vargas, De re metallica, 1568, fol. 192v: Hágase una cuba grande y hínchase los dos tercios de agua dulce, y luego se eche dentro la tierra salada y se rebuelva y menee con unas pértigas o varas largas rezias. // Loçano, Alberto, Architectura, 1582, pág. 331: Algunos ay que en el vallado entretexen pértigas de mimbreras, la qual obra es firme, pero de su natura dura poco tiempo. // Besson, Teatro instrumentos, 1602, fol. N4v: Hay más: que del anillo d'esta postrera parte de la balança cuelgan tres pértigas, de las quales la dos hazia fuera van a encontrarse a la barra.

pertrechos, peltrechos, pertrechos, petrechos [del lat. prōtractum 'sacado', 'producido', part. pas. de prōtrăhĕre 'hacer salir, revelar, producir'. 1490, Alfonso de Palencia (DECH). Sagredo, Medidas Romano, 1526]. sust. m. pl. Instrumentos necesarios para cualquier operación (DRAE).

Sagredo, Medidas Romano, 1526, pág. 75: Provee de todos los pertrechos que por él te fueron dichos ser necessarios, y trabaja por meter muchos y buenos oficiales que en breve tiempo acaben tu obra. // Juanelo Turriano, Veinte y un libros, a. 1605, fol. 401v: Razón será que piense el que haze la fábrica cómo la emprende, el lugar y sitio que toma, los pertrechos y materia que pone, y cómo lleva su obra hasta'l cabo. // Juanelo Turriano, Veinte y un libros, a. 1605, fol. 454v: Pudiera hazerse la máquina de piedra, y fuera menos corruptible que la madera, pero es de más gasto de pertrechos y offiçiales, aunque no se puede remediar con tanta facilidad como la madera.

pesa, pesa [de pesar. Celso, Reportorio universal leyes Castilla, 1553]. sust. f. Pieza metálica que se utiliza como término de comparación para determinar el peso de un cuerpo (DRAE).

Celso, Reportorio universal leyes Castilla, 1553, fol. CCLIXr: Y por cada pesa de las de oro no reciba más de cinco maravedís, o de las quatro pesas de los granos lleve otros cinco maravedís. // Anónimo, Repertorio tiempos, 1554, fol. XXVr: Llámase aún la natura del Sol, quando entra en su setena casa, Libra, figurada por un peso con pesa de una libra de dentro, la qual tiene en sí doze onças, como doze meses el año. // Belveder, Reduciones plata y oro, 1597, fol. VIv: Y en la otra balança ponen la pesa de los doze dineros con que fue pesada la dicha copella de plata antes de ponerla en el plomo y hornillo.

SIN.: equipondio, pondos.

HOL.: balanza.

FAM.: contrapesar, contrapeso, pesado, pesadumbre, pesar, peso.

pesado, pesado, pessado [de pesar. H. 1140, Cid (DECH). Falero, Tratado del espera, 1535]. adj. Fís. Que pesa mucho (DRAE).

Falero, Tratado del espera, 1535, fol. 6v: Apartó la parte más grave o pesada y púsola en el centro del esphera, que es el lugar más baxo que ay en ella, porque para qualquiera 
parte que desde el centro se moviesse sería subir. // Besson, Teatro instrumentos, 1602, fol. E2v: De la qual cosa se vee exemplo evidente en las cargas que trahen a cuestas, porque no poco, entonces, se alivia el que las trahe, quando la parte más pesada se pone delantera. // Juanelo Turriano, Veinte y un libros, a. 1605, fol. 289v: Y es cosa importantíssima, por causa que, quando hyere la agua en el ángulo de la pala y de la rueda, buelve muy más pesada la rueda, y quando hyere en el medio de la pala, buelve, entonces, la rueda muy más ligeramente.

ANT.: leve, liviano.

FAM.: contrapesar, contrapeso, pesa, pesadumbre, pesar, peso.

pesadumbre, pesadumbre [de pesar. H. 1220-1250, Berceo (DECH). Medina, Arte de navegar, 1545]. sust. f. Fís. Pesadez, gravedad o cualidad que se halla en todos los cuerpos y los obliga o inclina a bajar hacia el centro (Terreros s. v. peso).

Pérez Vargas, De re metallica, 1568, fol. 205r: Para esto se deven hazer algunos artesones y lagares de madera donde se recoja el agua y repose algunos días, hasta que con su pesadumbre se assiente el xugo y liquor. // Loçano, Alberto, Architectura, 1582, pág. 36: ¿Qué pensáys que ha de ser quando ayáys procurado de todo punto arredrar y empujar lexos la fuerça de las aguas acometedoras, o la pesadumbre de las rocas que caen? // Juanelo Turriano, Veinte y un libros, a. 1605, fol. 290v: Y si la agua no saliese de encima de la rueda $\mathrm{D}$, daría muy grande pesadumbre al andar, mas inmediatamente que ha dado el golpe en la álaba, luego cae.

SIN.: peso $\boldsymbol{1}_{1}$

FAM.: contrapesar, contrapeso, pesa, pesado, pesar, peso.

pesar, pesar, pessar [del lat. pēnsāre 'íd.'. Orígenes del Idioma (DECH). Anónimo, Ordenanças paños, 1527]. v. tr. Mec. Determinar el peso, o más propiamente, la masa de algo por medio de la balanza o de otro instrumento equivalente (DRAE).

Anónimo, Ordenanças paños, 1527, fol. 105v: Si quisieres saber, si un diamante que pesa 3 granos vale 20 ducados, otro que pesare 6 granos, quánto valdrá. // Juanelo Turriano, Veinte y un libros, a. 1605, fol. 26r: y donde as cavado, entonces tomarás un vasso de barro que sea recién cozido, y entonces le pesarás, y, visto lo que pessa, pondrás esse vaso dentro del hoyo que cavaste en la tierra. // Juanelo Turriano, Veinte y un libros, a. 1605, fol. 147v: Mas quiero bolver a repetir que el peso que yrá colgado debajo de la gata, que él sea de plomo, porque él haze menos bulto. Y lo que ha de pesar: a lo menos, un quintal.

FAM.: contrapesar, contrapeso, pesa, pesado, pesadumbre, peso.

peso, peso, pesso [del lat. pènsum 'peso de lana que debe hilarse'. Cid (DECH). Sagredo, Medidas Romano, 1526]. sust. m. Fís. Pesadez, gravedad o cualidad que 
se halla en todos los cuerpos y los obliga o inclina a bajar hacia el centro (Terreros).

Sagredo, Medidas Romano, 1526, pág. 24: La dórica es suficiente para sostener todo el peso y carga que a cuestas le echaren, por grande que sea. // Juanelo Turriano, Veinte y un libros, a. 1605, fol. 283v: Yo e visto que les han hecho a los costados dos paredes, a causa de conservarles, que no se quebren por causa del peso de la tierra que tienen encima. // Juanelo Turriano, Veinte y un libros, a. 1605, fol. 126r: Convendrá hazerla caminar para arriba lo más llaño que se pueda, por causa que no haga rebentar los caños el grande pesso de la agua.

SIN.: pesadumbre.

FAM.: contrapesar, contrapeso, pesa, pesado, pesadumbre, pesar.

2 [Fernández de Enciso, Suma de Geographía, 1530]. sust. m. Balanza u otro utensilio para pesar (DRAE).

Fernández de Enciso, Suma de Geographía, 1530, fol. XXXVr: Y que hizo hacer un peso muy grande, y que le hizo a Alexandre que pusiese en la una balanza cuantas joyas ricas y tesoro tenía. // Medina, Arte de navegar, 1545, fol. 7r: El séptimo signo es Libra señalado en un peso con yguales balanças para entender que, entrado el Sol en este signo a los treze de setiembre, el día es ygual a la noche. // Anónimo, Repertorio tiempos, 1554, fol. XXVr: Llámase aún la natura del Sol, quando entra en su setena casa, Libra, figurada por un peso con pesa de una libra de dentro, la qual tiene en sí doze onças, como doze meses el año.

HIPER.: instrumento.

3 [Girava, Fineo, Geometría práctica, trads., 1553 ]. sust. m. Objeto pesado que sirve para equilibrar alguna carga (DRAE).

Girava, Fineo, Geometría práctica, trads., 1553, pág. 66: Dexando, pues, desde A caer un hilo, con algún peso o perpendículo hasta que llegue hasta el pie E, quan largo fuere el hilo, tan luenga diremos qu'es la línea propuesta EF. // Juanelo Turriano, Veinte y un libros, a. 1605, fol. 53v: Y quando se querrá nivelar, convendrá que el peso cuelgue tanto, que toque en la línea de la planiçie. // Juanelo Turriano, Veinte y un libros, a. 1605, fol. 142v: Se le a de afixar unas anillas de hierro muy bien puestas, por causa que en las bajas se le puede colgar un peso que tenga quieta essa gata, que no ande bambaneando,

de balanzas [Collado, Plática Artillería, 1592]. comp. sintag. Instrumento para pesar formado por dos platillos que penden con cadenillas de los extremos de un brazo, en uno de los cuales se coloca lo que se ha de pesar y en otro las pesas. Collado, Plática Artillería, 1592, fol. 111v: Unas tiseras de sastre y otras de cortar hierro y cobre; una romana y otro peso de balanças con sus pesas; vides y tornillos de azero para si será menester adobar algún fogón gastado. / / Alonso Barba, Arte de los metales, 
1640, fol. 82v: Aya también peso de balanças para pesar la plata y, en todo caso, no falte uno pequeño, muy puntual, para los ensayes menores, como son con los que se ensayan las barras.

SIN.: peso de cruz.

HIPER.: instrumento.

$\sim$ de cruz [García de Palacio, Diálogos militares, 1583]. comp. sintag. Instrumento para pesar formado por dos platillos que penden con cadenillas de los extremos de un brazo, en uno de los cuales se coloca lo que se ha de pesar y en otro las pesas.

García de Palacio, Diálogos militares, 1583, fol. 126r: Manifiesto es, pues, que, en un peso de cruz, las dos balanças, ygualmente puestas en la línea de la directión que es en su fiel, tienen su movimiento más pesado que quando están más altas o baxas // Pérez de Moya, Manual de contadores, 1589, fol. 179r: Y de lo que se pesa con peso de cruz dan de cada 100 libras o de 4 arrobas, dos libras de a 16 onças cada una, que es la mitad de lo que se da de lo que se pesa con romana.

SIN.: peso de balanzas.

HIPER.: instrumento.

$\sim$ de guindaleta [Celso, Reportorio universal leyes Castilla, 1553]. comp. sintag. El que tiene una cuerda gruesa de cáñamo.

Celso, Reportorio universal leyes Castilla, 1553, fol. LXXXIIIr: Y tenga otro peso justo e cierto de sus balanças, y otro peso de guindaleta con sus pesas, como diximos de suso, capítulo cambiadores.

HIPER.: instrumento.

peso, V. nivel de $\sim$.

pesquera, pesquera [del lat. p̌scāărus, pŭscārŭa 'de pescado' (Blánquez). Loçano, Alberto, Architectura, 1582]. sust. f. Ingen. Hidrául. Estanque artificial donde se alimentan los peces para deleite o consumo (Glosario Los ventiún libros).

Loçano, Alberto, Architectura, 1582, 375: Pesqueras o estanques de peces. // Juanelo Turriano, Veinte y un libros, c.1605, fol. 137r: Para hazer un vivero o pesquera, cavarase 
dentro de la tierra, en tal modo que el agua no se trasvine o trasmine, ni tanpoco calentar, en tal modo que dañe a los pescados, que por causa del demasiado calor. // Juanelo Turriano, Veinte y un libros, c.1605, fol. 137v: De modo que es necessario que ello sea muy hondo, porque, quanto más honda fuere la pesquera, tanto menos se yela, y es muy mejor a los pescados, agora sea el agua de fuente o de río o de mar o de lago.

SIN.: pesquería, vivero.

HIPER.: obra hidráulica.

FAM.: pesquería.

2 [Lobato, Notas, c.1585]. sust. f. Ingen. Hidrául. Muro grueso de piedra u otro material que se construye a través de un río, arroyo o canal, para almacenar el agua a fin de derivarla o regular su curso fuera del cauce (DRAE s. v. presa).

Lobato, Notas, c.1585, fol. 11: El Rey Maximiliano de Austria mandó hacer en Valladolid, en la pesquera de los frailes de San Benito de Valladolid, un ingenio para que cerrase y abriese a la pesquera para que se pudiesen navegar el río Duero y los demás ríos de España por aquel diseño y modelo, el cual tenía la forma que diré. // Lobato, Notas, c.1585, fol. 13: Hay muchos molinos que, por no saber sus amos dar remedio a daños que se les ofrecen, los dejan perder, unos por ruines pesqueras, otros por en anegársele la balsa con lluvias, y otros porque bajan las piedras y arena de cuestas. // Lobato, Notas, c.1585, fol. 26: Y para probar el designio, hizo hacer en Valladolid una galera e hizo romper una pesquera de las aceñas de los frailes de San Benito con unas trampas que se cerraban y abrían cuando llegaba la galera.

SIN.: presa.

HIPER.: obra hidráulica.

[IMAGEN] Lobato, Notas, c. 1585, fol. 11.

pesquería, pesquería [de pesquera (DRAE). Fernández de Enciso, Suma de Geographía, 1530]. sust. f. Ingen. Hidrául. Estanque artificial donde se alimentan los peces para deleite o consumo (Glosario Los ventiún libros s. v. pesquera).

Fernández de Enciso, Suma de Geographía, 1530, fol. LXr: Porque ay muchas vallenas; e ay grandes pesquerías, do se toma mucho pescado e lo secan y llevan a vender a otras partes. // Celso, Reportorio universal leyes Castilla, 1553, fol. CIVv: Páguese diezmo de las tierras, viñas y huertas, prados, dehesas, montes donde sacan madera e leña para quemar, y de las pesquerías, y de los molinos, hornos e baños, lagares de las casas, y de todos los otros fructos y rentas que los hombres sacaren d'estas cosas. // Llanos, Diccionario minas, ca. 1609-11, pág. 158: Assí que la granja d'éstos no mucho menos mirará por el buey y ganado que por la muger: querrá el palomar, la pesquería y las otras cosas semejantes para fruto y no para regalo.

SIN.: pesquera, vivero. 
HIPER.: obra hidráulica.

FAM.: pesquera.

pessado, V. pesado.

pessar, V. pesar.

pesso, V. peso.

petrechos, V. pertrechos.

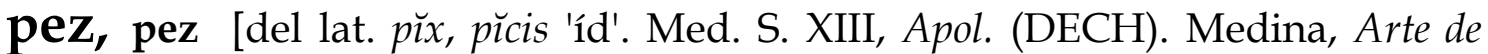
navegar, 1545]. sust. f. Sustancia resinosa obtenida de los pinos.

Medina, Arte de navegar, 1545, fol. 81r: Y si alguna parte estuviera abierta, con la dicha cera o pez lo deve cerrar. // Juanelo Turriano, Veinte y un libros, a. 1605, fol. 278v: El qual betún se haze de pez y con polvo de ladrillo molido y una poquita de cera. // Juanelo Turriano, Veinte y un libros, a. 1605, fol. 141r: Convendrá embetunar todas las canales con pez y zufre mezclado, que a veynte libras de pez, cinco de azufre.

FAM.: apegadura, apegar, desapegadizo, desapegar, despegar, empegar, empeguntar, pegadura, pegar.

phelos, V. felos.

picado, picado [de picar. H. 1140, Cid (DECH). Escalante, Discurso de la navegación, 1577]. adj. Troceado, cortado en pedazos pequeños.

Escalante, Discurso de la navegación, 1577, fol. 57v: Y de un betumen que aprendieron d'ellos a que llaman la pez, que se haze de cal y azeyte de pescado y del uname viejo muy picado que le ponen entre el costado de las naos y otro aforro nuevo de tabla que se les echa encima. // Collado, Plática Artillería, 1592, fol. 57v: el segundo modo de hazer las plataformas dichas se haze solando toda aquella plaça de losas de piedra muy 
bien picadas la largueza d'éstas ha de ser tanta como dos vezes y media es larga la misma pieça. // Juanelo Turriano, Veinte y un libros, a. 1605, fol. 279r: El qual betún se haze de sevo que sea muy bien picado, y después mesclar con el sevo carbón que sea muy molido, en polvo.

FAM.: picadura, picar, pico, piqueta.

2 [Juanelo Turriano, Veinte y un libros, a. 1605]. adj. Dicho de la muela de un molino: labrada.

Juanelo Turriano, Veinte y un libros, a. 1605, fol. 303v: Acaescerá que una muela abrá sido mal picada, de modo que, moliendo, saldrá el grano entero, por moler, a buelta de la arina. // Juanelo Turriano, Veinte y un libros, a. 1605, fol. 303v: La muela que no estava bien picada era dende la A asta en $C$ y de $C$ hasta en $B$, de modo que para averle de remediar convendrá hazer otra picadura, como ay dende la A asta en D y de la D asta en B.

picadura, picadura [de picar. S. XVI (DECH). Juanelo Turriano, Veinte y un libros, a. 1605]. sust. f. Mec. Conjunto de hendiduras de la muela de un molino. Juanelo Turriano, Veinte y un libros, a. 1605, fol. 303v: Que estas muelas, sus picaduras, es echa a canales arto hondas, que son cavados por ellas unas canales de un dedo de ondo y de dos dedos, o más espacio, de una canal a la otra. // Juanelo Turriano, Veinte y un libros, a. 1605, fol. 303v: Que si esta picadura fuese como se hazen en las muelas de los molinos de canal ho de cárcavo, que no es más honda que un caço de cuchillo, con facilidad se remediaría. // Juanelo Turriano, Veinte y un libros, a. 1605, fol. 316v: Las picaduras, conviene que vayan como van las álabas del rodete, que vayan en bueltas redondas, y an de estar en la parte de la orilla de la muela.

SIN.: canaladura 1 .

HOL.: muela.

FAM.: picado, picar, pico, piqueta.

picar, picar [voz común a todos los romances de Occidente, de creación expresiva. H. 1140, Cid (DECH). Anónimo, Ordenanças paños, 1527]. v. tr. Golpear con pico, piqueta $u$ otro instrumento adecuado, la superficie de las piedras para labrarlas, o la de las paredes para revocarlas (DRAE).

Anónimo, Ordenanças paños, 1527, fol. 128v: Un maestro de picar piedra a fecho una fuente de piedra para tener agua, y la a fecho con cinco caños, en tal manera que si abren el un caño, que en el mayor, que toda el agua que estuviere dentro saldrá en un día. // García de Palacio, Instrución náuthica, 1587, fol. 36r: Y será del modo que son las piquetas con que pican las piedras de los molinos, como todo por la demonstración que se sigue se entenderá más claro. / / Juanelo Turriano, Veinte y un libros, a. 1605, fol. 316v: También consiste el mucho moler en picar las muelas, y en eso va mucho en 
saver el modo como se an de picar para que muela toda la muela, sin que quede ninguna parte valdía.

FAM.: picado, picadura, pico, piqueta.

2 [. (DECH). Lobato, Notas, a. 1585]. v. tr. Cortar o dividir en trozos muy menudos (DRAE).

Lobato, Notas, a. 1585, fol. 14: Y es que, como es poca el agua, cuando este molino pica la piedra, no deje de correr el agua para que los de delante muelan con la garganta. // Juanelo Turriano, Veinte y un libros, a. 1605 , fol. $274 \mathrm{v}$ : Y, asados, tomarás sevo o saín de puerco, y pica todo junto en un mortero; y conviene picar muy bien todo. // Juanelo Turriano, Veinte y un libros, a. 1605, fol. 331r: En este artificio ame parecido que se podría hazer un artificio para picar pólvora de escopeta, con sólo quitar los maços y bolverlos ha asentar en otra postura.

pico, pico [del celtolatino beccus 'íd'. 3er cuarto S. XVI, Palmireno (DRAE). Pérez Vargas, De re metallica, 1568]. sust. m. Herramienta puntiaguda y acerada utilizada por canteros y empedradores para labrar y pulir las piedras.

Pérez Vargas, De re metallica, 1568, fol. 197r: Sácase d'esta manera: primeramente, se abran las canteras y, con almádavas y picos, se quiebre la peña. // Álaba, Perfeto capitán, 1590, fol. 75r: Yendo prevenidos de açadas, picos, hachas de hierro, palas, hozinos, sierras, machos de hierro y vinagre para que con celeridad gasten las piedras. // Juanelo Turriano, Veinte y un libros, a. 1605, fol. 285r: Y con el pico o con el cinzel agujéranse lo más bajo que pueda la piedra. Y después tomar la barra de yerro.

FAM.: picado, picadura, picar, piqueta.

[IMAGEN] Pseudo-Juanelo Turriano, Los ventiún libros, c. 1605, fol. 252r, fig. 318. En la imagen aparecen distintos tipos de picos.

pie, pie [del lat. pēs, pĕdis 'íd.'. Orígenes del Idioma (DECH). Juanelo Turriano, Veinte y un libros, a. 1605]. sust. m. Ingen. Hidrául. Cada uno de los pilares de un puente.

Juanelo Turriano, Veinte y un libros, a. 1605, fol. 222r: Los pies de la puente, que es A E $\mathrm{G}$, requieren ser gruesos y muy largos $\mathrm{y}$, a la parte baja, la que se a de hincar dentro de tierra, conviene ponerles sus açuches de yerro muy bien asentados. // Juanelo Turriano, Veinte y un libros, a. 1605, fol. 214r: Conviene tomar lo ancho del río para saber quán largo le viene a salir su puente, para saber yr repartiendo los trampos de la puente o tramadas, y quánto ha de aver de un pie al otro. // Juanelo Turriano, Veinte y un libros, a. 1605, fol. 225r: Esta invención de puente, ansí, sin tener ningún pie dentro de la agua. Y esta manera de puente sirve para donde los ríos son muy rápidos y son tan furiosos que ningún pie puede estar firme.

HOL.: puente. 
pieça, V. pieza.

piedra, piedra [del lat. pĕtra 'roca' y este del griego пв́трa 'íd.'. Doc. de 1042 (DECH). Anónimo, Ordenanças paños, 1527]. sust. f. Sustancia mineral, más o menos dura y compacta, que no es terrosa ni de aspecto metálico (DRAE).

Sagredo, Medidas Romano, 1526, pág. 72: Demás d'esto, nos encomendaron los viejos architetos que la piedra que se saca para los dichos edificios se detenga, antes que se labre, por espacio de dos años. // Lobato, Notas, a. 1585, fol. 31: Y después de hechas cajas todas en vertiente, llenarlas de piedra menuda y no ha de subir más la pesquera por hacia San Cosme de lo que sube el dicho llano, y un pie menos. // Juanelo Turriano, Veinte y un libros, a. 1605, fol. 360r: Quando se havrán de hazer las puentes de piedra, converná dar el orden como se han de hazer, y con quántas arcadas se han de repartir.

FAM.: empedrado, empedrador, empedrar, empedrecer.

2 [Lobato, Notas, a. 1585]. sust. f. Mec. Cada uno de los discos de piedra que en los molinos permite moler lo que entre ellos se interpone.

Lobato, Notas, a. 1585, fol. 34: Todo el gobierno principal de este molino para su bajar o subir ha de ser cuando se echare piedra nueva o fuere ya gastada la cama de abajo. // Lobato, Notas, a. 1585, fol. 36: La piedra que podrá traer este molino será de cinco pies y medio a seis de ancho y si menos fuere andará más ligero. // Juanelo Turriano, Veinte y un libros, a. 1605, fol. 302v: Y este cubo se asienta encima de quatro pieças quadradas. El vazío del cubete es A. Su grueso es B. Las piedras es C. Y el rodete anda, en el medio, con cinco, hasta seys álabas, el qual es D.

SIN.: muela 1 , rueda 2.

[IMAGEN] Lobato, Notas, c. 1585, fol. 36, señalada con el número 13.

caracolina [Juanelo Turriano, Veinte y un libros, a. 1605]. comp. sintag. arag. Aquella que es caliza o tiene cal.

Juanelo Turriano, Veinte y un libros, a. 1605, fol. 285r: Escójese una piedra que sea buena y que no sea muy fuerte, como es piedra caracolina o piedra franca, y házese del grueso que conviene. // Juanelo Turriano, Veinte y un libros, a. 1605, fol. 286r: Y estos caños de piedra conviene que sean de piedra franca, o de piedra caracolina, o de piedra calar, o de piedra arenisca que sea fuerte, o de piedra arenisca que participa de piedra de hieso. // Juanelo Turriano, Veinte y un libros, a. 1605, fol. 188v: Suélese destilar agua por algunas piedras, como es la piedra caracolina, la qual piedra es lleña 
de agujeros, a modo de esponja, y por lo mesmo de la piedra tosca, que en estas dos especies de piedra se haze passar el agua como en la esponja.

de amolar [García de Palacio, Instrución náuthica, 1587]. comp. sintag. Arenisca de cemento silíceo o arcilloso que, cuando es de grano fino y uniforme, se utiliza para afilar o aguzar los instrumentos de acero.

García de Palacio, Instrución náuthica, 1587, fol. 110v: Siempre el señor de la nao, bien advertido, ha de llevar de respeto muchas cosas sobradas, que en alguna coyuntura son de mucho fruto y dan contento. Pero, quando esto no se haga, señalaré algunas sin las quales no se puede passar buenamente, que son: dos quartos de brea que pesen doze quintales, [...] quatro candiles de linternas, dos libras de algodón para mechas, dos claveras, una piedra de amolar. // Llanos, Diccionario minas, c.1609-11, pág. 39: Es una invención de una piedra de amolar grande, que la trae una rueda de agua, y pónese el hierro con su artificio arrimado a ella de la manera que lo traen de Castilla. // Llanos, Diccionario minas, c.1609-11, pág. 83: Amoladera: Es un metal que parece piedra de amolar, y así se le dio el nombre.

SIN.: amoladera.

HIPER.: piedra.

$\sim$ molar [Alonso Barba, Arte de los metales, 1640]. comp. sintag. Arenisca de cemento silíceo, muy tenaz y resistente, de la cual se fabrican las muelas de molino (DRAE).

Alonso Barba, Arte de los metales, 1640, fol. 37r: Deshazen algunas los ñudos, y lobanillos y gomas condensadas en los cuerpos, como lo haze la piedra molar y la margagita.

SIN.: piedra moleña.

HIPER.: piedra.

moleña [Rojas, Teórica fortificación, 1598]. comp. sintag. Arenisca de cemento silíceo, muy tenaz y resistente, de la cual se fabrican las muelas de molino (DRAE s. v. piedra molar).

Rojas, Teórica fortificación, 1598, fol. 90r: Y assí, diré de los nombres de piedra de que yo tengo noticia en España, como es jaspe colorado y otros jaspeados de diversas colores; ay mármol de Filabres, y entre ello uno más duro que otro; piedra negra, que llaman piçarra; piedra berroqueña; piedra sipia; piedra de la palomera, que es blanca con muchos caliches; ay piedra de panalexo; piedra franca; piedra moleña. 
SIN.: piedra molar.

HIPER.: piedra.

pierna, pierna, pierne [del lat. pĕrna 'muslo y pierna juntos, en un animal'. H. 1220-1250, Berceo (DECH). Juanelo Turriano, Veinte y un libros, a. 1605]. sust. f. Mec. Pieza alargada y móvil de algunas máquinas.

Juanelo Turriano, Veinte y un libros, a. 1605, fol. 226r: Y las dos piernas C C tienen encima una traviesa, E, que las tiene asidas, aunque ellas se pueden estrechar y ensanchar en la parte baja, como fuere menester. // Juanelo Turriano, Veinte y un libros, a. 1605, fol. 227r: Las aristas I I K están asidas a las piernas C C con unas clavijas de yerro, que juegan en las dichas piernas de la máchina. // Juanelo Turriano, Veinte y un libros, a. 1605, fol. 227r: Las quales llañas no passan más de quanto son de grueso los braços $D$, por causa que en el subir y bajar no fuese estregando en las piernas C C.

HOL.: máquina.

[IMAGEN] Pseudo-Juanelo Turriano, Los ventiún libros, c. 1605, fol. 364v, fig. 340, letras F y G. Son las piernas en una rueda timpanada utilizada para subir agua.

pierne, V. pierna.

piesa, V. pieza.

piessa, V. pieza.

pieza, pieça, piesa, piessa, pieza [del celt. * pěttı̌a 'pedazo'. 973, Doc. riojano (DECH). Lobato, Notas, a. 1585]. sust. f. Mec. Cada una de las partes que componen un instrumento o máquina.

Lobato, Notas, a. 1585, fol. 15: Esta traza es de un molino que le puede mover un hombre y moler gran cantidad de pan. Sus piezas y formas son las siguientes: una grúa como la que va arriba figurada, // Lobato, Notas, a. 1585, fol. 36: Son las vigas sobre las que se asienta la cuba y la dicha cuba y puente aliviada, canal y rangua, rodeznos y parahúsos, y todas estas piezas irán aquí pintadas, como se ve, cada cosa por sí, y arcos de hierro. // Juanelo Turriano, Veinte y un libros, a. 1605, fol. 303r: El modo como se han de ajuntar estas pieças: la muela es A, que es la pieça del medio. Las otras pieças que llevan a la redonda son B C D E, las quales pieças [han] de bolver a la mano yzquierda para aver de moler. 
pila1, pila [del lat. pila 'columna, rimero' (DRAE). Juanelo Turriano, Veinte y un libros, a. 1605]. sust. f. Ingen. Hidrául. Cada uno de los machones que sostienen dos arcos contiguos o los tramos metálicos de un puente (DRAE).

Juanelo Turriano, Veinte y un libros, a. 1605, fol. 111r: En la parte baja de la puente, ordinariamente, les vemos las pilas socavadas en aquella parte, mucho más que no son en la parte de delante de las pilas, y ansí el suelo del río se ve muy más cavado que en ninguna otra parte. // Juanelo Turriano, Veinte y un libros, a. 1605, fol. 120r: Y la experiencia nos lo demuestra en diversas cosas, en especial en las pilas de las puentes, que nunca se gastan a raýz del suelo del río, mas gástanse más donde toca la superficie del agua. // Juanelo Turriano, Veinte y un libros, a. 1605, fol. 323v: Supropongamos que quixéssemos hazer un molino arrimado a una pila de una puente de piedra, y que después que ello fuesse hecho, el molino, creciesse el río y el molino careciesse d'este remedio.

HOL.: puente.

pila2 , pila [del lat. pìla 'mortero', 'tina de batán', derivado de pinsěre 'majar'. Doc. de la $1^{\text {a }}$ mitad del s. XIII (DECH). Celso, Reportorio universal leyes Castilla, 1553]. sust. f. Ingen. Hidrául. Pieza grande de piedra o de otra materia, cóncava y profunda, donde cae o se echa el agua para varios usos (DRAE).

Celso, Reportorio universal leyes Castilla, 1553, fol. CCXCIr: Todos los veneros de oro, plata y plomo, y de qualquier otro metal que sean en estos reynos, son del Rey, como dezimos de suso, capítulo mineros, versículo I. Ansimesmo, las fuentes y pilas y pozos salados que son para hazer sal. // Santa Cruz, Libro de las longitúdines, 1567, pág. 59: Otras personas han inventado otros reloxes de agua de más primor, y es metiendo en una pila o barreñón grande lleno de agua un vaso como cangilón huradado por abaxo y asido por lo alto con un cordel. // Pérez Vargas, De re metallica, 1568, fol. 80v: Hazen unos hoyos como casas de axedrez, donde el oro y arena menuda se detiene, y luego se sacude en una pila de agua, bolviendo la canal boca abaxo, y se apura en las bateas.

HIPER.: obra hidráulica.

FAM.: pilón.

pilatero, pilatero [del cat. pilater 'íd.' (DRAE). Anónimo, Ordenanças paños, 1527]. sust. m. Persona que tiene por oficio el asistir las pilas del batán para deslavazar y enfurtir los paños.

Anónimo, Ordenanças paños, 1527, fol. VIr: Otrosí, mando que el officio de los perayles sea dividido en dos officios, de manera qu'el pilatero tenga cargo solamente de lavar el paño para despinzar e desbruar e enfortirle del cuerpo e codena que oviere menester. // Anónimo, Ordenanças paños, 1527, fol. VIv: Y, esto hecho, qu'el tal pilatero sea obligado a le entregar al perayle limpio de xuarda y enfortido y en perfeción, para que le carde de haz y envés. // Anónimo, Ordenanças paños, 1527, fol. VIv: Otrosí, mando que ningún batanero ni pilatero no sea osado de echar ni eche a los paños que adobare la greda que oviere de echar. 
pillón, V. pilón.

pilón, pillón, pilón [de pila. 1490, Alonso de Palencia (DRAE). Pérez Vargas, De re metallica, 1568]. sust. m. Ingen. Hidrául. Receptáculo de piedra que se construye en las fuentes para que, cayendo el agua en él, sirva de abrevadero, de lavadero o para otros usos (DRAE).

Pérez Vargas, De re metallica, 1568, fol. 106v: Otros hazen unas canales de madera de piceastro y allí echan el metal y encima leña y, dándole fuego, el plomo se derrite, y por el caño o canal que está cuesta abaxo corre hundido en el pilón y los leños quedan teñidos de colorado. // Llanos, Diccionario minas, c.1609-11, pág. 40: Las libras que faltan se hace cuenta están en el pilón deshechas, y porque lo que está en él es hierro deshecho y arena de la piedra, y en realidad de verdad amoladuras, y no se puede apartar lo que es hierro para pesarse solo. // Llanos, Diccionario minas, c.1609-11, pág. 40: Conforme las que se llenan y hierro que se sabe está en el pilón, se saca la cantidad del que cabe a cada botija, y se ha de estar por lo que dijere el dueño.

HOL.: fuente.

FAM.: $p i l a^{2}$.

pilote, pilote [del fr. antic. pilot 'gros pieu pointu ferré à un bout' (DECH, TLF). S. XIX, Acad. (DECH). Ufano, Tratado de la Artillería, 1613]. sust. m. Madero rollizo armado frecuentemente de una punta de hierro, que se hinca en tierra para consolidar los cimientos (DRAE).

Ufano, Tratado de la Artillería, 1613, pág. 167: Con gran cantidad de fuertes y gruesas planchas o tablones de roble para formar las explanadas sobre las quales deve jugar el artillería y para, presto, con ellas y pilotes reparar los portillos y la royna de las baterías. // Ufano, Tratado de la Artillería, 1613, pág. 191: Si con la pala y çapa se puede hazer un pequeño asiento, puestas, como dicho tengo, de 3 en 3 y clavadas y affirmadas con sus estacones y pilotes, con sola una de la blinda (FIGURA 23) por cima.

piqueta, piqueta [de pica (DECH). Cortés de Albacar, Breve compendio sphera, 1556]. sust. f. Mec. Especie de pico con que pican la piedra en las tahonas y molinos (Terreros).

Cortés de Albacar, Breve compendio sphera, 1556, fol. LXXXIr: Y del quadrado a los extremos se ha de yr adelgazando, que quasi tenga la forma de las piquetas con que pican las piedras de los molinos, y en el medio, según longitud y latitud, ha de tener un agujero quadrado por el qual entre la vara justa. // García de Palacio, Instrución náuthica, 1587, fol. 36r: Y será del modo que son las piquetas con que pican las piedras de los molinos, como todo por la demonstración que se sigue se entenderá más claro. 
HOL.: herramienta.

FAM.: picado, picadura, picar, pico.

pistomio, V. epistomio.

Pitágoras, V. cóclea de $\sim$.

plancha, plancha [del fr. planche 'íd.' (DRAE). Fernández de Enciso, Suma de Geographía, 1530]. sust. f. Lámina de metal ancha y delgada (Covarrubias).

Fernández de Enciso, Suma de Geographía, 1530, fol.

XLVIv: Ay muchas casas de mercaderes de los que tratan en Etiopía que tienen los tejados de las casas cubiertos de planchas de oro, como acá se cubren algunas de estaño y de plomo. // Juanelo Turriano, Veinte y un libros, a. 1605, fol. 286v: Y da la razón y dize que la lámina o plancha de plomo se tuerce y se va bolviendo en redondo, y como la parte de dentro de la plancha se va estrechando. / / Juanelo Turriano, Veinte y un libros, a. 1605, fol. 437v: Y después estava cubierta de planchas de plomo vaziadas, como los caños de los órganos; toda ella era cubierta con estas planchas de plomo bien enclavadas y en las juntas de las planchas muy bien soldadas.

poça, V. poza.

poçal, V. pozal.

poço, V. pozo.

polea, polea [del lat. vg. polidŭa 'íd.', plural de *polidı̆um, tomado del gr.

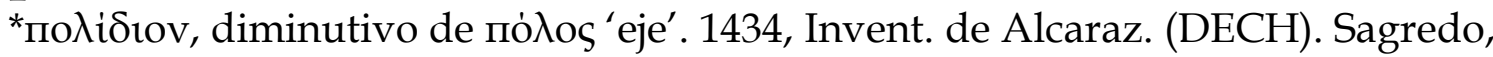
Medidas Romano, 1526]. sust. f. Mec. Rueda acanalada y móvil alrededor de un eje que se utiliza para subir pesos por medio de una cuerda o maroma.

Sagredo, Medidas Romano, 1526, pág. 37: Trochilo es otro miembro principal en la basa que, por semejar al carrillo o polea, le llamaron los griegos trochilo, que quiere dezir 'rodaja'. // García de Palacio, Instrución náuthica, 1587, fol. 151v: Poleas: son las rodajas algo largas por do entran y corren las cuerdas del navío y estas rodajas se llaman roldanas. // Juanelo Turriano, Veinte y un libros, a. 1605, fol. 143r: La argolla 
[que] tiene la polea es P. La polea es Q. Las otras dos poleas es R S. Las cuerdas que passan por las poleas es T V G X. Las que van en el tornico, Z.

SIN.: carretillo, carrillo, carrucha, carrucho, garrucha 2 , polija, recamo, tróclea.

HIPER.: máquina.

FAM.: poleame.

poleame, poleame [del port. poleame 'íd.' (DECH). Anónimo, Diálogo fábrica de navios, c.1631]. sust. m. Mec. Conjunto o acopio de poleas para una o más embarcaciones (DRAE).

Anónimo, Diálogo fábrica de navíos, c.1631, fol. 29r: En casos forzosos, como desaparejarse un galeón de los de la compañía, o rendirse un árbol, puede el capitán, si lleva alguna posaverga, jarcia, belas, poleame u otras cosas de consideración.

poleja, V. polija.

poleola, poleola [de polea. Juanelo Turriano, Veinte y un libros, a. 1605]. sust. f. Mec. Polea de pequeño tamaño.

Juanelo Turriano, Veinte y un libros, a. 1605, fol. 383r: Como se les sepa accomodar las poleolas y saber ir doblando las cuerdas por ellas, llevará en alto peso, por grande que sea. // Juanelo Turriano, Veinte y un libros, a. 1605, fol. 384v: Los ganchos entran en las anillas A B C. La poleola es D, y la de baxo es E. El tornillo es H. Los palos, I. La cuerda, G. // Juanelo Turriano, Veinte y un libros, a. 1605, fol. 450v: Assí que, para hinchirlas, es menester poner muchas poleolas con sus sogas, y en ellas assentar sus hergates, para que assí se vayan embolviendo y levantando la nave.

FAM.: polea.

polija, poleja, polija [del cat. politja 'íd.', cat. ant. y dial. polija (DECH). Collado, Plática Artillería, 1592]. sust. f. Mec. Rueda acanalada y móvil alrededor de un eje que se utiliza para subir pesos por medio de una cuerda o maroma.

Collado, Plática Artillería, 1592, fol. 11r: Dale, más, un árgano con sus cuerdas gruessas, y polijas, una cabria, un martinete, una o dos escaletas, una estruja, y cavalletes, y corlones, todas cosas necessarias para manejar y trasportar artillería de una parte a la otra. // Collado, Plática Artillería, 1592, fol. 75v: He querido representar a los lectores esta operación dicha con tantas bueltas como se veen en la figura de aquella montaña para dar a entender la virtud de el árgano, de las polijas y su potencia y en qué manera se pueden y deven de atar las polijas para servirse d'ellas. // Lechuga, Discurso de la Artillería, 1611, pág. 353: Y así, buelta la pieça y totalmente desembaraçada la cuerda de todas las poleas o polijas, con el dicho torno solamente se acabará de tirar la pieça en llegando al punto A y sitio del árgano o cabrestante. 
SIN.: carretillo, carrillo, carrucha, carrucho, garrucha 2 , polea, recamo, tróclea.

HIPER.: máquina.

polipasto, V. polispasto.

polispasto, polipasto, polispaton, polypasto [tomado del lat. pŏlyspāston 'íd.', y este del gr. по入úonaotov 'máquina formada por varias poleas para levantar pesos tirando de ellos' (DRAE). Urrea, Vitruvio, Architectura, 1582]. sust. $\mathrm{m}$. Mec. Sistema de varias poleas o garrucha con muchas roldanas por donde pasa sucesivamente una cuerda (Salinero s. v. polipasto).

Urrea, Vitruvio, Architectura, 1582, fol. 126r: Este género de máchina se llama polispaton, porque con movimiento de muchas rodezuelas se haze la obra sin difficultad y con gran ligereza. // Urrea, Vitruvio, Architectura, 1582, fol. 142v: Polipastos: instrumento para armar ballestas. // Besson, Teatro instrumentos, 1602, fol. P2v: Conviene, a más d'esto, notar que el polypasto está hecho de seys ruedezuelas, y que la cuerda que entra en él se estiende del torno del trispasto, y que su postrer cabo viene a embolverse y a atarse con el cabo de cuerda, de do pende el polypasto.

HIPER.: máquina.

polypasto, V. polispasto.

pondos, pondos [tomado del lat. pondus, -eris 'peso' (OLD). Juanelo Turriano, Veinte y un libros, a. 1605]. sust. m. Pieza metálica que se utiliza como término de comparación para determinar el peso de un cuerpo (DRAE s. v. pesa).

Juanelo Turriano, Veinte y un libros, a. 1605, fol. 289v: Y esto se puede comprehender en la romana, que quando está un mismo peso apenso o colgado en ella, que quando está el pondos más cerca del peso, que no declina, antes buelve para arriba, y quando lo apartan del punto de donde está apenso el peso, que el pondos declina con grandíssima facilidad.

SIN.: equipondio, pesa.

HOL.: balanza.

porquezuela, porquezuela [de puerca (DRAE). Urrea, Vitruvio, Architectura, 1582]. sust. f. Mec. Pieza grande con forma de tuerca utilizada en algunas máquinas. 
Urrea, Vitruvio, Architectura, 1582, fol. 124r: Ni tuviéramos las porquezuelas y husos, si no se oviera hallado el adereço del lagar. // Urrea, Vitruvio, Architectura, 1582, fol. $124 \mathrm{v}$ : Las porquezuelas junto a las cabeças tienen dos agujeros templados, de manera que puedan juntarse allí las barras. // Urrea, Vitruvio, Architectura, 1582, fol. 143r: Súcula: porquezuela de máchinas; su gruesso se dize camilo o bolsa. Pónese asida en los chelonios, que son las sortijas como ombligos en que se rebuelve con su exe.

SIN.: puerca 2 , súcula.

HOL.: máquina.

FAM.: puerca.

portadera, portadera [de portar (DECH). Juanelo Turriano, Veinte y un libros, a. 1605]. sust. f. arag. Caja grande rectangular que, colocada generalmente sobre las caballerías, se utiliza para transportar cosas.

Juanelo Turriano, Veinte y un libros, a. 1605, fol. 165v: Y donde no se podrá acomodar instrumentos, convendrá vaziar con una portadera de madera dos hombres, y con ella se vazía mucha agua. // Juanelo Turriano, Veinte y un libros, a. 1605, fol. 231v: Y con ésta se saca mucha cantidad de agua, con tal que no sea muy alta la catarata. Y también se saca mucha agua con la portadera $Q$, entre dos hombres.

FAM.: portadora.

portadora, portadora [de portar (DRAE). Juanelo Turriano, Veinte y un libros, a. 1605]. sust. f. Caja grande rectangular que, colocada generalmente sobre las caballerías, se utiliza para transportar cosas.

Juanelo Turriano, Veinte y un libros, a. 1605, fol. 430r: Assí que, para este effecto, conviene tener mucha madera serrada y por serrar, y mucha piedra y calcina en muy gran cantidad, y arena y otras infinitas cosas, como es clavazón, cuerdas, capaços, espuertas de mimbres, palas de madera, de hierro, [...] çevillas, poçales, portadoras.

SIN.: portador.

FAM.: portadera.

poste, poste [tomado del lat. pŏstis 'jamba o montante de una puerta'. H. 1400, Glosarios (DECH). Urrea, Vitruvio, Architectura, 1582]. sust. m. Madero, piedra o columna colocada verticalmente para servir de apoyo o señal (DRAE).

Urrea, Vitruvio, Architectura, 1582, fol. 136r: Sobre esta juntura se levanten los postes de juntar fuera de los quiciales, de nueve pies en gruesso. / / Urrea, Vitruvio, Architectura, 1582, fol. 141v: Mutilos: aspas que se ponen en los postes y pilares. // Lobato, Notas, a. 1585, fol. 8: Y sobre esta columna o postes de madera ha de cargar el ingenio de husillo que ha de subir el agua. 
potencia, potencia, potençia, potentia [tomado del lat. pŏtěntǐa 'íd.'. H. 12201250, Berceo (DECH). Pérez Vargas, De re metallica, 1568]. sust. f. Fís. Capacidad para ejecutar algo o producir un efecto (DRAE).

Pérez Vargas, De re metallica, 1568, fol. 38r : Y quando en la fuzión los poros del azero están bien ensanchados y tendidos, y con la potencia del fuego blandos, con la frialdad del agua, apagando el calor en él, queda una materia dura y frangible que fácilmente se quiebra y salta. // Urrea, Vitruvio, Architectura, 1582, fol. 106v: Y como nosotros tratássemos de la potencia de las aguas y de sus virtudes, me dixo que avía en aquellas sus tierras tal manera de fuentes, que los que allí se criavan tenían notables vozes para cantar. // Collado, Plática Artillería, 1592, fol. 11r: Primeramente, Su Magestad o sus ministros, generales, governadores, mandan hazer el horno, el qual conviene que sea de muy buen ladrillo fabricado, y el suelo de él, y aun las paredes muy bien encadenadas con barras de hierro, y esto porqu'el gran peso de el metal y la potencia de el fuego no puedan romper las paredes ni quebrantar el suelo y hundirlo.

FAM.: potente.

potençia, V. potencia.

potente, potente [tomado del lat. pŏtèns, pŏtèntis 'el que puede'. H. 1220-1250, Berceo (DECH). Collado, Plática Artillería, 1592]. adj. Fís. Que tiene poder, eficacia o virtud para algo (DRAE).

Collado, Plática Artillería, 1592, fol. 39v: Pero que, en tal caso, aquella potente virtud expulsiva de el elemento se emplea en hazer subir la bala más en alto. // Collado, Plática Artillería, 1592, fol. 82v: Y si en aquel tiempo esta manera de fuego era tan potente y tan temido, ajuntándole ahora, como se le ajunta, la pólvora, sin dubda alguna que él será muy más potente y vigoroso que no era aquél.

FAM.: potencia.

potentia, V. potencia.

poza, poça, poza [de pozo (DECH). Pérez Vargas, De re metallica, 1568]. sust. f. Ingen. Hidrául. Charca o concavidad en que hay agua detenida (Autoridades).

Pérez Vargas, De re metallica, 1568, fol. 83v: El suelo d'esta hornilla ha de estar un poco pendiente y cuesta abaxo, y al cabo ha de tener un agujero por donde el metal del todo derretido salga y corra a una poza o hoyo, donde se yele y haga plancha. // Pérez Vargas, De re metallica, 1568, fol. 103v: El azogue se halla en dos maneras: o en lagunas y pozas, o recogido, donde estila de las venas de la tierra, o embuelto con tierra y 
mineral. // Acosta, Historia natural, 1590, pág. 228: El metal que queda está como arena, y de aquí lo sacan y llevan a lavar otra buelta con bateas en unas balsas o pozas de agua.

HIPER.: obra hidráulica.

FAM.: pozal, pozo.

pozal, poçal [de pozo (DECH). Juanelo Turriano, Veinte y un libros, c.1605]. sust. m. arag. Cubo con el que se saca el agua de un pozo.

Juanelo Turriano, Veinte y un libros, c.1605, fol. 451r: Tomarán, pues, un poçal de madera o una herrada, la qual tenga la assa de hierro. // Juanelo Turriano, Veinte y un libros, c.1605, folio 359r: En la figura: Poçal. Bacioncillo. Bacieta o gamella. Baciete. Mortero de cal y arena. Fosa para matar la calcina. // Juanelo Turriano, Veinte y un libros, c.1605, folio 359r: En la figura: Ruello para moler yesso. Bacieta. Ruello para moler yesso. Algiño. Raedera. Poçal. Capaço de yesso. Cernedor de yesso. Arnero. Bacía de amasar yesso. Pala de madera.

FAM.: poza, pozo.

[IMAGEN] Pseudo-Juanelo Turriano, Los ventiún libros, c. 1605, fol. 265v, fig. 322, situado en el centro de la imagen, a la derecha.

pozo, poço, pozo [del lat. pŭtĕus 'hoyo' 'pozo'. Orígenes del Idioma (DECH). Fernández de Enciso, Suma de Geographía, 1530]. sust. m. Ingen. Hidrául. Hoyo o perforación artificial para encontrar una vena de agua (Salinero).

Fernández de Enciso, Suma de Geographía, 1530, fol. XLVIIIv: En esta ciudad está un pozo fecho en una peña adonde cada año se vee señalado el altura de lo que el Nilo ha de crescer aquel año, y de allí toman aviso para se remediar de las crecientes del Nilo. // Urrea, Vitruvio, Architectura, 1582, fol. 110r: Si no oviere fuentes de donde trayamos agua, es necessario cavar pozos. // Juanelo Turriano, Veinte y un libros, c.1605, fol. $349 \mathrm{v}$ : Conviene acomodar dentro del poço un caño redondo de madera, el qual llegue asta tocar la agua, el qual esté muy bien afirmado entre dos pedaços de maderos, arriva y abaxo.

HIPER.: obra hidráulica.

FAM.: poza, pozal.

premodo, premodo [probablemente tomado del lat. praemŏdum 'otra medida' (Gaffiot). Juanelo Turriano, Veinte y un libros, a. 1605]. sust. m. Ingen. Hidrául. Obra o aparato dispuesto para regular la cantidad de agua que se introduce en una acequia o canal, o que pasa por un caño u orificio (DRAE s. v. módulo).

Juanelo Turriano, Veinte y un libros, a. 1605, fol. 139v: El monte por donde se trahe el agua es A. Las peñas, B. Las canales, C. Los premodos D. Y donde buelve a salir de las 
peñas es E. // Juanelo Turriano, Veinte y un libros, a. 1605, fol. 140r: Y los alcaduzes de barro o de plomo se avrán de embetunar antes de asentarlos ençima de los premodos.

SIN.: promódulo.

HOL.: obra hidráulica.

prensa, prensa [tomado del cat. premsa 'íd.', propiamente participio femenino del verbo prémer 'apretar' (DECH). Celso, Reportorio universal leyes Castilla, 1553]. sust. f. Mec. Máquina que sirve para comprimir, cuya forma varía según los usos a que se aplica (DRAE).

Celso, Reportorio universal leyes Castilla, 1553, fol. CCLVr: No es tenudo de pechar la tal pena, si el acreedor no vendió las prensas, salvo si no las vendió porque no pudo, o si él requiriesse al deudor que se vendiessen las prendas y el deudor no lo hoviesse querido hazer. // Pérez Vargas, De re metallica, 1568, fol. 187v: Los azeytes de semillas se sacan enterneciendo primero las semillas o granos con vapor de callente y húmido, assí como es agua callente y luego exprimiéndolas en una prensa. // Besson, Teatro instrumentos, 1602, fol. Q2v: Aquí, finalmente, damos una nueva manera de prensa y angosta compuesta de tres caracoles, la qual podrá servir a la vendimia, y a prensar paños, y para stampar cartas geográphicas y tapicerías encima de cuero o tela.

HIPER.: máquina.

FAM.: aprensar, prensar.

prensar, prensar [de prensa (DECH). Besson, Teatro instrumentos, 1602]. v. tr. Apretar algo en la prensa, o mediante otro procedimiento, para compactarlo (DRAE).

Besson, Teatro instrumentos, 1602, fol. G4v: Nueva hechura de molino a braços para prensar y aparejar paños y papel, y moler especies, y esmenuzar piedras preñadas de metales para preparallas a hundir, y también para pulir y aguzar qualesquier instrumentos soltados a cigoñales y majaderos. / / Juanelo Turriano, Veinte y un libros, c.1605, fol. 333v: De modo que se muelen las olivas y, después de molidas, las sacan, con prensarlas, el azeyte. // Juanelo Turriano, Veinte y un libros, a. 1605, fol. 354v: Y en la parte baxa se le haze un agujero, en el suelo de este madero, por donde ha de salir la cera quando la van prensando, que es $C$.

SIN.: aprensar.

FAM.: aprensar, prensa.

presa, presa, pressa [del lat. prensa 'cogido, agarrado', part. de prendĕre 'coger, agarrar'. Orígenes (DECH). Loçano, Alberto, Architectura, 1582]. sust. f. Ingen. Hidrául. Muro grueso de piedra u otro material que se construye a través de un río, arroyo o canal, para almacenar el agua a fin de derivarla o regular su curso fuera del cauce (DRAE). 
Loçano, Alberto, Architectura, 1582, 369: Fortalezas, presas y defensas de los albañares. 129. 30. // Rojas, Teórica fortificación, 1598, fol. 96r: Y a la primera creciente que vino, por estar la presa más baxa de lo que solía, passó por cima d'ella, y con la horrura, lima, cieno y suziedad que trahía el agua, fraguó y mazizó toda la piedra seca. // Rojas, Teórica fortificación, 1598, fol. 96r: Y por ser el fundamento donde se avía de hazer la pressa (para atajar el río y encaminallo al molino) de arena y cascajo, huvo siempre dificultad en ello, porque siempre que hazían la pressa con cal y arena, por ser materia muy fuerte, socavava el agua por debaxo de la fábrica y se salía por allí.

SIN.: pesquera 2 .

HIPER.: obra hidráulica.

FAM.: represa, represado.

ENCICL.: En general, en la época, ni la Corona ni los ayuntamientos estaban muy "dispuestos a invertir sumas considerables en la construcción de caminos, ya que, a diferencia de otras obras públicas, su financiación no resultaba nada fácil $\left[{ }_{, \prime \prime}\right]$. En la práctica. preferían hacer obras de regadío (presas, azudes, canales) que se financiaban con los nuevos impuestos sobre el aumento de la producción agrícola una vez que entraban en servicio, construir abastecimientos de agua que se podían financiar cobrando tasas a los nuevos consumidores o haciendo una derrama sobre los vecinos (Catálogo Felipe II: 86).

pressa, V. presa.

pretil, pretil [del lat. *pěctŏrīle, de pěctŭs, pěctŏris 'pecho'. H. 1625, Céspedes (DRAE). Escalante, Discurso de la navegación, 1577]. sust. m. Ingen. Hidrául. Murete o baranda que se coloca en los puentes y otros lugares para prevenir caídas.

Escalante, Discurso de la navegación, 1577, fol. 36v: Entrando barcos cargados de todo género de mantenimientos y mercaderías, con calles del un lado y otro de los canales por do se navega, espaciosas con sus pretiles y puentes de hermoso edificio y, particularmente, a las salidas de las ciudades para passar los fossos y ríos.

SIN.: antepecho.

HOL.: puente.

promódulo, promódulo [probablemente del lat. pro mŏdŭlo (ingěnīi) 'según su capacidad' (Blánquez Fraile). Juanelo Turriano, Veinte y un libros, a. 1605]. sust. m. Ingen. Hidrául. Obra o aparato dispuesto para regular la cantidad de 
agua que se introduce en una acequia o canal, o que pasa por un caño $u$ orificio (DRAE s. v. módulo).

Juanelo Turriano, Veinte y un libros, a. 1605, fol. 140v: Y el madero que está cubierto es $\mathrm{K}$. El tablón que tiene encima y el pedazo que cubre las dos juntas [de] las canales, que están puestas encima de los promódulos, es M M.

SIN.: premodo.

HOL.: obra hidráulica.

própalo, própalo [probablemente del cat. perpal 'palanca de madera o de hierro' (DECH). Juanelo Turriano, Veinte y un libros, a. 1605]. sust. m. arag. Barra que se utiliza para mover o levantar cosas de mucho peso.

Juanelo Turriano, Veinte y un libros, a. 1605, fol. 386r: Y la piedra donde cobra fuerça el própalo y el hombre es $\mathrm{C}$, que sin ella no podría mover sino con muy grande trabajo. // Juanelo Turriano, Veinte y un libros, a. 1605, fol. 386r: Y tanto quanto es más largo el própalo $B$, tanto más fácil es el movimiento de la cosa que se mueve. // Juanelo Turriano, Veinte y un libros, a. 1605, fol. 430r: Cuerdas, capaços, espuertas de mimbres, palas de madera, de hierro, açadas, picas, própalos de hierro, maças de hierro, bacietas o gamellas de madera grandes y pequeñas, de toda suerte muchas tablas.

SIN.: alzaprima, leva $a_{2}$, manuela, palanca ${ }_{1}$, palanga $a_{1}$, uña de cabra, uña de puerco.

HIPER.: herramienta.

[IMAGEN] Pseudo-Juanelo Turriano, Los ventiún libros, c. 1605, fol. 252r, fig. 318.

puente, puente [del lat. pōns, pŏntis 'íd.'. Orígenes del Idioma (DECH). Fernández de Enciso, Suma de Geographía, 1530]. sust. u. t. c. f. Ingen. Hidrául. Fábrica de piedra o madera que se construye sobre los ríos y otros sitios para poder pasarlos.

Fernández de Enciso, Suma de Geographía, 1530, fol. XLIIr: Entre esta Comagena y Capadocia está una puente que atraviessa al río Éufrates con un castillo muy fuerte. // Collado, Plática Artillería, 1592, fol. 89r: Pero quando el río será tan ancho que no se puede hazer puente en poco tiempo, mas puede ser vadeado de la gente de a pie, acostumbraron muchos valientes conductores de exércitos travessar el río con esquadras de cavallos. // Juanelo Turriano, Veinte y un libros, c.1605, fol. 212r: Podrase hazer puentes en diversas maneras. Puédese hazer una puente sobre unos barquillos pequeños, con sólo tablas que traviesen del uno a lo otro, como ellas sean gruessas, para passar qualquier exército.

HIPER.: obra hidráulica.

FAM.: carripuente, gallipuente, maripuente. 
ENCICL.: Además este tipo de puente de madera se utilizaba habitualmente para reparar total o parcialmente otros puentes (González Tascón 1999: 109). También puede estar construido con barcas.

[IMAGEN] Puente 1: Pseudo-Juanelo Turriano, Los ventiún libros, c. 1605, Figura 287, fol. 214v. B: tirante; EH: rebotantes; F. antepecho.

Puente hecho con barcas: Pseudo-Juanelo Turriano, Los ventiún libros, c. 1605, fol. 205v, fig. 277.

2 [Lobato, Notas, a. 1585]. sust. f. Mec. Fábrica de piedra o madera que en los molinos regula el paso del agua.

Lobato, Notas, a. 1585, fol. 31: En los dos ojos de la dicha puente, asentadas dos trampas, como se ponen en los molinos, anchas y no muy altas, para que no entre más agua por la dicha puente de la que los molinos hubieren menester, y lo demás vierta por la dicha pesquera, que su fin será en el costado derecho de la dicha puente al corriente del agua. // Lobato, Notas, a. 1585, fol. 34: El aliviadero ha de ir con la puente, puesto como parece en la plana de enfrente, en el cuadro alto. // Lobato, Notas, a. 1585, fol. 36: Puente de roble o encina fuerte, para tener el rodezno y piedra, con el aliviador del alto que sea necesario con el guepejo o rangua.

HOL.: molino.

levadizo/a [Montes, Instrucción y regimiento, 1537]. comp. sintag. Ingen. Hidrául. El que puede levantarse por medio de poleas y cuerdas o cadenas.

Montes, Instrucción y regimiento, 1537, fol. XVIIr: La segunda, que tenga su fuessa de agua en torno del muro por la parte de fuera, de hondura de una gineta y de ancho de pica y media, o de dos picas, con sus puentes levadizas por donde entre y salga la gente de la ciudad; y la tercera, que tenga muchas vituallas para el mantenimiento de la gente de guerra. // Loçano, Alberto, Architectura, 1582, pág. 214: Assimismo, se puede hazer caer rompiendo los bulsones, que son los maderos que levantan y abaxan el puente levadizo con las cadenas que asen en ellos y en él. // Juanelo Turriano, Veinte y un libros, c.1605, fol. 390v: El modo como se ha de hazer esta puente levadiza, para haver de çerrar lo que queda abierto de la puente, y aunque es un poco difficultoso de hazer, quitar y poner, el qual yo enseñaré aquí.

HIPER.: obra hidráulica.

puerca, puerca [del lat. pŏrca 'íd.' (DECH). Lobato, Notas, a. 1585]. sust. f. Pieza con un hueco labrado en espiral que se utiliza para ajustar clavos y tornillos.

Lobato, Notas, a. 1585, fol. 34: Estas chavetas pueden ser muelles, como van señalados, o de tornillo; los clavos, gruesos, con sus puercas que los aprieten. :

FAM.: porquezuela.

2 [Urrea, Vitruvio, Architectura, 1582]. sust. f. Mec. Pieza grande con forma de tuerca utilizada en algunas máquinas. 
Urrea, Vitruvio, Architectura, 1582, fol. 86v: El lagar, si no se torciere con puercas, sino con otros ingenios de madera, la viga lagar no sea menos larga de quarenta pies, porque assí estará el patio desocupado para el que trata el palo o barra del husillo. // Juanelo Turriano, Veinte y un libros, a. 1605, fol. 326r: Y ésas van dentro de aquellos maderos que tiene el caracol en el medio, y en lo alto anda por dentro de la puerca o embra del caracol.

SIN.: caracola, porquezuela, súcula.

HOL.: máquina.

puerco, V. uña de .

puerta, puerta [del lat. pŏrta 'portón, puerta grande'. Orígenes del idioma (DECH). Fernández de Enciso, Suma de Geographía, 1530]. sust. f. Armazón de madera $u$ otra materia que se engozna y pone en un quicio y se asegura con una llave o cerrojo que regula su abertura y cierre.

Lobato, Notas, a. 1585, fol. 18: Se ha de entender así: que por detrás de la muralla de la ciudad tiene la puerta el dicho molino y no puede entrar más agua del que sale por las puertas cuadradas que se muestran. // Juanelo Turriano, Veinte y un libros, a. 1605, fol. $328 \mathrm{v}$ : La qual máquina conviene que tenga unas puertas, para abrir y cerrar esta arca, en tres partes, para tomar la arina en cada parte como la querrán tomar. // Juanelo Turriano, Veinte y un libros, a. 1605, fol. 455r: La puerta D se abre de otra manera. Buélvese sobre un perne, como las demás, pero ábrese teniendo el gorrón en medio.

FAM.: compuerta.

puerto, puerto [del lat. pŏrtŭs 'entrada de un puerto', 'puerto' (DECH). Fernández de Enciso, Suma de Geographía, 1530]. sust. m. Ingen. Hidrául. Lugar en la costa o en las orillas de un río que por sus características, naturales o artificiales, sirve para que las embarcaciones realicen operaciones de carga y descarga, embarque y desembarco, etc. (DRAE).

Fernández de Enciso, Suma de Geographía, 1530, fol. XXVr: Es una de las mayores escalas de tierras de christianos; dentro de esta baýa está El Puerto de Sancta María, que es buen puerto. En este puerto entra el río de Guadalete, e aquí fue la batalla do se perdió el Rey don Rodrigo que perdió a España. // Besson, Teatro instrumentos, 1602, fol. Lv: Manera de nueva máquina para descargar qualesquier navíos llegados al puerto, cargados de columnas y cargas de otras cosas semejantes. // Juanelo Turriano, Veinte y un libros, a. 1605, fol. 402r: Llamémosle, pues, al puerto, un receptáculo de naves o diversas species de baxeles, para que allí estén seguras de las muchas borrascas y grandes tempestades que podrían padescer.

HIPER.: obra hidráulica. 
ENCICL.: En la época, las obras portuarias tenían una financiación más fácil que otras (caminos, por ejemplo), imponiendo sisas sobre la pesca o tasas por el derecho de anclaje (Catálogo Felipe II: 86).

2 [Juanelo Turriano, Veinte y un libros, a. 1605]. sust. m. Ingen. Hidrául. Parte de un azud por donde pasan barcas y almadías.

Juanelo Turriano, Veinte y un libros, a. 1605, fol. 171r: En todos los açutes que son en los ríos grandes, suelen tener por donde pueden passar barcas y almadías de maderos, el qual llaman puerto a esse lugar. / / Juanelo Turriano, Veinte y un libros, a. 1605, fol. 171r: Y estos puertos se deven hazer conforme a la corriente del río, y deve ser muy largo, por raçón que, quanto más es largo el puerto, ay menos peligro de recibir daño las cosas que passan por ello, que es K. // Juanelo Turriano, Veinte y un libros, a. 1605, fol. 171v: El açute es A B: la A es un alambor y la B es lo llano del açute por la parte de arriba. Donde es C D es el puerto, con sus mesas a los costados.

HOL.: obra hidráulica. 


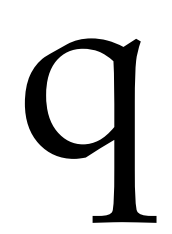

qubete, V. cubete.

quelonio, chelonio [tomado del lat. chĕlōnŭum 'grapa o garfio de diversos

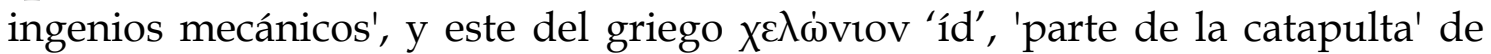

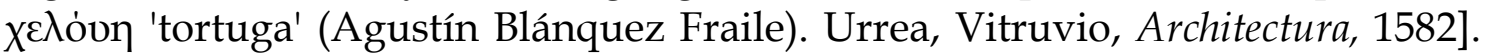
sust. m. Mec. Máquina para levantar pesos formada por tres vigas de madera ensambladas por la parte superior, de donde cuelga una garrucha con su maroma.

Urrea, Vitruvio, Architectura, 1582, fol. 139v: Chelonio: máchina que llaman cabra; tiene dos sortijas o assas como ombligos en que se rebuelven las rodezuelas o carrillos.

SIN.: cabra, cabria, cabrilla.

HIPER.: máquina. 
2 [Urrea, Vitruvio, Architectura, 1582]. sust. m. Mec. Aro o argolla que forma parte de algunas máquinas.

Urrea, Vitruvio, Architectura, 1582, 140r: Chelonio: miembro de máchina en que la súcula se ase, y se pone un exe que tenga en medio un tímpano ancho, que algunos llaman rueda y otros peritrochium. // Urrea, Vitruvio, Architectura, 1582, 143r: Súcula: porquezuela de máchinas; su gruesso se dize camilo o bolsa. Pónese asida en los chelonios, que son las sortijas como ombligos en que se rebuelve con su exe. Tiene un tímpano o rueda ancha que dizen peritrochion.

HOL.: máquina.

quiciado, quiciado [de quicio (DECH). Urrea, Vitruvio, Architectura, 1582]. adj. Movido o girado en un quicial.

Urrea, Vitruvio, Architectura, 1582, fol. 136r: Éstos estén encima de las maderas quiciadas.

FAM.: desquiciar, quicial, quicialera, quicio, resquicia, resquicio.

quicial, quicial [de quicio (DECH). Urrea, Vitruvio, Architectura, 1582]. sust. $\mathrm{m}$. Madero que asegura y afirma las puertas y ventanas.

Urrea, Vitruvio, Architectura, 1582, fol. 56v: De tal manera se han de traçar las designadas puertas, que las salidas de los quiciales cardinales tengan de la altura de toda la luz la duodécima parte. // Urrea, Vitruvio, Architectura, 1582, fol. 136r: Sobre esta juntura se levanten los postes de juntar fuera de los quiciales, de nueve pies en gruesso, por todas partes de un palmo y un pie, que disten entre sí por pie y medio. // Urrea, Vitruvio, Architectura, 1582, fol. 136r: Encima d'ellas se pongan los cabrios, metido uno en otro en los quiciales, que estén levantados nueve pies.

SIN.: quicialera.

FAM.: desquiciar, quiciado, quicialera, quicio, resquicia, resquicio.

[IMAGEN] Urrea, Vitruvio, Architectura (1582), figura 66.

quicialera, quiçialera [de quicial (DECH). Vandelvira, Traças de cortes, ca. 1591]. sust. f. Madero que asegura y afirma las puertas y ventanas.

Vandelvira, Traças de cortes, ca. 1591, fol. 43v: Luego traçarás la faja donde an de estar las quiçialeras, señalada con la $\mathrm{H}$, la qual faja a de quedar a nibel, y, así, comiença a capialçar desde la línea I.

SIN.: quicial.

FAM.: desquiciar, quiciado, quicial, quicio, resquicia, resquicio. 
quicio, quicio [de origen incierto parece haberse sacado secundariamente de resquicio 'abertura que hay entre el quicio y la puerta', que antiguamente era rescrieço, significaba 'grieta', 'rendija' y deriva de *excrepitiare 'resquebrajarse'. Lucano de Alfonso X (DECH). Medina, Arte de navegar, 1545]. sust. m. Parte de las puertas o máquinas en que entra el espigón del quicial, y en que se mueve y gira.

Loçano, Alberto, Architectura, 1582, pág. 219: Las puertas tienen sus proporciones de miembros. Entre los miembros, el principal es el quicio. // Besson, Teatro instrumentos, 1602, fol. Cv: Allende d'esto, el caracol ha d'estar en la metad de l'arca, y allí tener su movimiento libre, restribando en su quicio; el qual quicio se mete en aquel agujero redondo que hazia poniente se vee en la figura entera de todo el instrumento. // Besson, Teatro instrumentos, 1602, fol. H2v: Empero, del caracol que parece notarás esto: que él sirve a alçar y baxar la muela de piedra, y que está fixo y se pone en lugar del quicio para que, puesto el tal caracol en el centro de la maça, pueda la rueda libremente voltarse.

FAM.: desquiciar, quiciado, quicial, quicialera, resquicia, resquicio.

quiçialera, V. quicialera.

quiçio, V. quicio.

quietar, quietar [del lat. quietāre 'íd.' (DRAE). Juanelo Turriano, Veinte y un libros, a. 1605]. v. trans. u. t. c. prnl. Fís. Sosegar, apaciguar, aquietar (DRAE). Juanelo Turriano, Veinte y un libros, a. 1605, fol. 397r: Tiene de su naturaleza el mar que hecha a la orilla todas aquellas cosas que los ríos llevan a la mar, porque aquellas cosas que de sí se suelen mover mediante el movimiento, después que han hallado assiento, quietarse o pararse, y en hallando tal lugar para afirmarse, pues vemos que ordinariamente la mar trahe a tierra mucha quantidad de arena, y algunas vezes dexa las piedras, que no las hecha a tierra. // Juanelo Turriano, Veinte y un libros, a. 1605, fol. 437r: Y podemos dezir que los puertos son las moradas d'estos vasillos, y que sirven como a los animales las cavallerizas, para quietarse, como en una morada de mar.

ANT.: mover.

FAM.: quiete, quieto, quietud.

quiete, quiete [del lat. quiēs, quiētis 'descanso' (DRAE). Herrera, Institución Academia, 1584]. sust. f. Fís. Carencia de movimientos (DRAE s. v. quietud).

Herrera, Institución Academia, 1584, fol. 5v: Porque de la Mechánica depende la hazedora de instrumentos béllicos para opugnar y deffender las ciudades y fortalezas; la hazedora de milagros con proporciones de pesos, cuya desigualdad es causa de movimiento y la igualdad de la quiete; la fabricadora de spheras, a la qual se reduze 
todo lo que toca a la fábrica de instrumentos, que por movimiento de ruedas muestran los movimientos celestes.

SIN.: quietud.

ANT.: moto, movimiento.

FAM.: quietar, quieto, quietud.

quieto, quieto [tomado del lat. quiètus, - $a$, -um 'quieto, apacible, tranquilo', propiamente participio de quiescěre 'descansar', 'estarse quieto'. 1570, C. de las Casas (DECH). Medina, Arte de navegar, 1545]. adj. Fís. Que no tiene o no hace movimiento (DRAE).

Medina, Arte de navegar, 1545, fol. IVv: Capítulo XV. Cómo la tierra está quieta y no se mueve. // Juanelo Turriano, Veinte y un libros, a. 1605, fol. 137r: Las aguas, por estar quietas, suelen mudar color y hazerse muy verdosas. // Juanelo Turriano, Veinte y un libros, a. 1605, fol. 147v: Podrase bajar dentro d'este instrumento un gancho con su vara, que sea muy larga, para poderse assir a alguna mata o alguna resquizia o agujero de la peña, para poder estar muy más quieto y aun para alguna cosa que le hiziese molestia en no dejar allegar la gata a la peña.

ANT.: movido.

FAM.: quietar, quiete, quietud.

quietud, quietud [tomado del lat. quietūdo 'íd.'. 1515, Fernández de Villegas (DECH). ]. sust. Fís. Carencia de movimientos (DRAE).

Cortés de Albacar, Breve compendio sphera, 1556, fol. Xr: Los philósophos le llamaron mundo porqu'es en sempiterno movimiento, al qual ninguna quietud es concedida. // Juanelo Turriano, Veinte y un libros, a. 1605, fol. 41r: Por causa de la quietud del agua, o las unas se asubtilarían y otras se harían pessadas y otras viscosas, de modo que harían siempre variación, por causa del movimiento que hará la una más que la otra, por causa de participar de ruynes exhalaciones y otras de más humor. // Juanelo Turriano, Veinte y un libros, a. 1605, fol. 315r: Porque, empeçando a penetrar, no sosiega jamás la agua de yr buscando por dónde penetrar, porque es la agua de tal naturaleza, que procura siempre de penetrar y de querer hinchir todo lugar vazío, por allar quietud.

SIN.: quiete.

ANT.: moto, movimiento.

FAM.: quietar, quiete, quieto.

quinaria, quinaria [tomado del lat. quīnārĭus, quīnārăa 'relativo a cinco' (Gaffiot). Juanelo Turriano, Veinte y un libros, a. 1605]. sust. f. Ingen. Hidrául. Caño o fístula de cinco dedos de diámetro. 
Juanelo Turriano, Veinte y un libros, a. 1605, fol. 286r: Agora fuesen lo caños o fístulas o trompas de plomo como de alambre, como de bronze, o alcaduces de barro, o de qualquier otra materia que ellos fuesen, los llamavan quinaria, por razón del diámetro, el qual era compuesto de cinco partes de un dedo.

SIN.: quinario.

HIPER.: caño.

FAM.: quinario.

quinario, quinario [tomado del lat. quīnārĭus 'relativo a cinco' (Gaffiot). 1490, Alfonso de Palencia (CORDE). Juanelo Turriano, Veinte y un libros, a. 1605]. sust. $\mathrm{m}$. Ingen. Hidrául. Caño o fístula de cinco dedos de diámetro.

Juanelo Turriano, Veinte y un libros, a. 1605, fol. 286v: De modo que el quinario de Vitruvio a sido de mayor capacidad o de mayor cabida que no a sido el senario de Frontino, porque las planchas o láminas eran en ancharia de cinco dedos, que es, a saver, beynte quadrantes con quatro onzenos. // Juanelo Turriano, Veinte y un libros, a. 1605, fol. 286v: Y que la encavadura, que ella no se enbeve nada, como dize Frontino, principalmente en los quinarios que están fundidos encima de cuero muy delgado. // Juanelo Turriano, Veinte y un libros, a. 1605, fol. 286v: La forma del quinario era la más común, y la más alabada de todas.

SIN.: quinaria.

HIPER.: caño.

FAM.: quinaria.

quubete, V. cubete. 
rallado, rallado [de rallar. Pérez Vargas, De re metallica, 1568]. adj. Desmenuzado con un rallo.

Pérez Vargas, De re metallica, 1568, fol. 185v: Si el que se pega es barro o madera, es buen çulaque queso anejo rallado, mezclado con agua callente, y massado y molido con cal viva.

FAM.: rallo.

rallo, rallo [del lat. rāllum 'instrumento para raer', derivado de rādĕre 'raer'. H. 1400, Glos. del Escorial (DECH). Juanelo Turriano, Veinte y un libros, a. 1605]. sust. $\mathrm{m}$. arag. Chapa con agujeros menudos que se utiliza generalmente para rallar.

Juanelo Turriano, Veinte y un libros, a. 1605, fol. 74r: Y estas planchas es menester que sean agujereadas de unos agujeros menudos, a modo de rallo.

HIPER.: herramienta.

FAM.: rallar. 
rambla, rambla [del hispano-ár. rámla 'arenal' y este del ár. clás. ramla 'arenal'. 1286, Doc. murciano (DECH). Juanelo Turriano, Veinte y un libros, a. 1605]. sust. f. Lecho o suelo de de arena depositado como consecuencia de las avenidas de una corriente de agua.

Juanelo Turriano, Veinte y un libros, a. 1605, fol. 114r: Y todos los ríos que tienen muy grandes corrientes y grandes caýdas no se pueden navegar, por causa de su grandíssima velocidad y también de los grandes mudamientos que hazen ordinariamente, y por causa de las grandes ramblas que hazen. // Juanelo Turriano, Veinte y un libros, a. 1605, fol. 474v: A más d'esto, conviene tener gran cuydado en el medir estas cosas, porque acaesçe que en algunos ríos, que hazen muy grandíssimas ramblas, ansí de la una parte como de la otra. // Juanelo Turriano, Veinte y un libros, a. 1605, fol. 474v: Aunque muchas vezes no haze estas ramblas igualmente, porque, si a una parte dexa el río, a otra toma, porque yo he visto muy pocas vezes que dexen los ríos a las dos partes, si no es en el verano, que entonces vienen a faltar las aguas.

rangua, rangua [probablemente del lat. rānula 'rana pequeña', por el gruñido de esta pieza al girar el molino. 1680, Autoridades (DECH). Lobato, Notas, c.1585]. sust. f. Mec. Pieza encajada en la solera, sobre la que se apoya el gorrón de un molino.

Lobato, Notas, c.1585, fol. 25: Esta rueda andaba la mitad de ella metida en un pozo de agua, para que conservase la madera y diese agua a la rangua, porque no ardiese ella y el hierro del palo. // Lobato, Notas, c.1585, fol. 34: Toda esta herramienta puede ser de hierro, como aquí va señalado, excepto la rangua, que ha de ser de metal campanil, como la de las aceñas, cuadrada como dado, para que por seis partes aproveche. // Lobato, Notas, c.1585, fol. 35: Si se hubiere de poner puente o aliviadero, o marranos o rangua, o rodezno o cuba, estando hecha como pozo de 12 pies de hondo, no se podrá hacer si no es sacando el agua del dicho pozo.

SIN.: guepejo, palahierro.

HOL.: molino.

[IMAGEN] Lobato, Notas, c. 1585, fol. 36, señalada con el número 5.

raparar, V. reparar.

raposo, raposo [de rabo (DRAE). Lobato, Notas, a. 1585]. sust. m. Mec. Púa fuerte o espiga recia de metal que, encajada en algún agujero, sirve para facilitar el movimiento giratorio alrededor de un eje vertical de alguna máquina o parte de ella (Salinero s. v. gorrón).

Lobato, Notas, a. 1585, fol. 34: Ha de tener, por lo menos, el primer trozo tanto alto como la cuba, antes más que menos, y la caja en que entra la pieza de arriba ha de ser muy fuerte y cuadrada al justo con el palo, y una cuarta más larga para en que ande el raposo. // Lobato, Notas, a. 1585, fol. 34: Y luego se harán dos arcos de hierro justos para que aprieten con sus cuñas de madera el uno con el otro, y el raposo, y una regla 
de encina u olmo que apriete el palo en la caja. // Lobato, Notas, a. 1585, fol. 34: Todo el gobierno principal de este molino para su bajar o subir ha de ser cuando se echare piedra nueva o fuere ya gastada la cama de abajo, y, por tanto, no hay que hacer sino hacer el raposo alto cuando se echare la cama nueva e irle cortando como se fuere gastando, que para el hacer harina muy poco movimiento ha menester hacer.

SIN.: gorrón.

HOL.: máquina.

rayo, rayo [del lat. rădŭus 'varita', 'rayo de carro', 'rayo de luz'. H. 1220-1250, Berceo (DECH). Besson, Teatro instrumentos, 1602]. sust. m. Mec. Cada una de las piezas que a modo de radios del círculo unen el cubo a las pinas de una rueda (DRAE).

Besson, Teatro instrumentos, 1602, fol. D4v: Mas se nos offrece la rueda, de cuya maça salen doze rayos que son impelidos con esta clavija, que parece en aquella rueda movediza. // Besson, Teatro instrumentos, 1602, fol. O4v: La qual muela, a braços la bueltan dos obreros que empuxan los rayos, de do nace que las fuerças d'esta máquina son totalmente grandíssimas, como sea que un mesmo caracol interior esté metido en tres exteriores y voltado. // Juanelo Turriano, Veinte y un libros, a. 1605, fol. 344v: El exe de la rueda de la anoria es A, donde han de yr asentados los rayos, B, los quales no han de ser más de dos, que passen por el exe A y hagan una cruz perfecta.

HOL.: rueda.

[IMAGEN] Pseudo-Juanelo Turriano, Los ventiún libros, c. 1605, fol. 347r, fig. 261, letra B.

rebentar, V. reventar.

rebolber, V. revolver.

rebolcar, V. revolcar.

rebolver, V. revolver. 
rebotante, rebotante [de rebotar. Juanelo Turriano, Veinte y un libros, a. 1605]. sust. m. Mec. Calza, contrapunta, zoquete o muesca que sirve de freno o contraempuje (Salinero).

Juanelo Turriano, Veinte y un libros, a. 1605, fol. 160v: Es la otra armadura para açute, la qual es muy bien conçertada en las piezas: los tirantes $L M$, porque éstos son el principio de la máchina; y los rebotantes, qu'es $\mathrm{S} T$, que van a herir en V. // Juanelo Turriano, Veinte y un libros, a. 1605, fol. 215r: Los rebotantes E van a cada pie dos, el uno al contrario del otro, de modo que se vienen a topar en el medio del madero D. // Juanelo Turriano, Veinte y un libros, a. 1605, fol. 216r: Los dos rebotantes, que están hazia el corriente del agua, a la parte de detrás, ayudan mucho.

HOL.: obra hidráulica.

[IMAGEN] Pseudo-Juanelo Turriano, Los ventiún libros, c. 1605, fol. 214v, fig. 287, letras E y H. Son los rebotantes en un puente de madera.

recamo, recamo [probablemente del it. recamo 'bordado', del it. ricamare 'bordar' y este del ár. ráqam, 'tejer rayas en un paño', 'bordar'. Probablemente sirvió el catalán de intermediario. 1612, Sz. de Figueroa, Autoridades (DECH). Urrea, Vitruvio, Architectura, 1582]. sust. m. Mec. Rueda acanalada y móvil alrededor de un eje que se utiliza para subir pesos por medio de una cuerda o maroma.

Urrea, Vitruvio, Architectura, 1582, fol. 124r: En lo alto se ata una tróclea, que es como exe, que algunos llaman recamo, y pónense en ellas dos rodezuelas que dan su buelta por sus exes. // Urrea, Vitruvio, Architectura, 1582, fol. 143v: Tróclea: máchina que la dizen recamo, tiene su exe y rodezuelas. // Besson, Teatro instrumentos, 1602, fol. M2v: Los que entienden el uso del polypasto o recamo de los architectos, éstos, sin declaración, pueden, con sola la figura, entender la proposición.

SIN.: carretillo, carrillo, carrucha, carrucho, garrucha ${ }_{2}$, polea, polija, recamo, tróclea.

HIPER.: máquina.

[IMAGEN] Urrea, Vitruvio, Architectura (1582), fol. 124v, figura 120 (polea en lo alto).

recata, recata [del cat. regata 'íd.'. Covarrubias (DECH). Juanelo Turriano, Veinte y un libros, a. 1605]. sust. f. arag. Reguera pequeña o surco por donde se conduce el agua a las eras (DRAE).

Juanelo Turriano, Veinte y un libros, a. 1605, fol. 175v: Y en la parte de delante se a de retraher y hazer dos recatas de alto abajo, que es $Z$ y $R$, después aquel lugar donde passa el agua, que es en V. // Juanelo Turriano, Veinte y un libros, a. 1605, fol. 175v: Y como se avrán puesto esos maderos por essas dos recatas, y luego tener aparejado muchos hombres para que vayan hechando tierra. // Juanelo Turriano, Veinte y un libros, a. 1605, fol. 393r: Donde es la S T son las canales por donde han de caminar las bolas de la puente. La $\mathrm{V}$ es donde va encaxada la puente por aquella recata.

HIPER.: obra hidráulica. 
receptáculo, receptáculo, recetáculo, recetáquulo [tomado del lat. rěceptäcŭlum 'íd.'. H. 1440, A. Torre (DECH). Cortés de Albacar, Breve compendio sphera, 1556]. sust. $\mathrm{m}$. Cavidad en que se contiene o puede contenerse cualquier sustancia (DRAE).

Juanelo Turriano, Veinte y un libros, a. 1605, fol. 46r: Y si se viere algún lugar que parezca que está cavado a modo de un receptáculo de aguas, y si se demuestran más verdes las yervas en un lugar que en otro, // Juanelo Turriano, Veinte y un libros, a. 1605, fol. 342r: El recetáquulo o tino que recive las lexías de las canales es E. Y el otro recetáculo por donde viene del cubo E es F. // Juanelo Turriano, Veinte y un libros, a. 1605, fol. 350r: Donde él es puesto y juegan los dos cavos y pasan las bolas, debaxo de aquellos dos maderos que tienen el caño D, que es $\mathrm{E}$. El recetáculo es $\mathrm{F}$, el qual recoje la agua que sacan las bolas.

recetáculo, V. receptáculo.

recetáquulo, V. receptáculo.

reçumar, V. rezumar.

redificación, $V$. reedificación.

redificaçión, $V$. reedificación.

reedificación, redificación, redificaçión [probablemente del lat. *rĕaedíficātĭo 'íd.'. 1521-1543, Epístolas familiares de Fray Antonio de Guevara (CORDE). Juanelo Turriano, Veinte y un libros, a. 1605]. sust. f. Acción y efecto de reedificar (DRAE).

Juanelo Turriano, Veinte y un libros, a. 1605, fol. 253r: Escrive Tacio, que quando Nerón rehedificó la ciudad de Roma, por causa del grandíssimo quemamiento que avía hecho, y para esta redificación se servió de la piedra de Albano y de Gabino para maderos. // Roxas, Sumario milicia, 1607, fol. 45v: Faltando nierbos para su redificaçión, las matronas dieron de buena gana sus cabellos a los maridos para socorro de la defensa.

FAM.: edificación, edificado, edificador, edificante, edificar, edificatorio, edificio, reedificar. 
reedificar, reedificar, rehedificar [tomado del lat. rěaedǐficāre 'íd.' (Segura Munguía). Fernández de Enciso, Suma de Geographía, 1530]. v. tr. Volver a edificar o construir de nuevo lo arruinado o lo que se derriba con tal intento (DRAE).

Fernández de Enciso, Suma de Geographía, 1530, fol. XXXIXv: En esta provincia de Margiana edificó Antiocho una gentil cibdad por ver la tierra tanto fértil y buena, a la qual llamó Antiochía ; y después fue destruyda, pero tornose a reedificar y está próspera. // Celso, Reportorio universal leyes Castilla, 1553, fol. CCXXXVv: Si se derribare o cayere la yglesia de cimiento, no se puede reedificar sin licencia del obispo. // Juanelo Turriano, Veinte y un libros, a. 1605, fol. 253r: Escrive Tacio, que quando Nerón rehedificó la ciudad de Roma, por causa del grandíssimo quemamiento que avía hecho, y para esta redificación se servió de la piedra de Albano y de Gabino para maderos.

FAM.: edificación, edificado, edificador, edificante, edificar, edificatorio, edificio, reedificación.

regadera, regadera [de regar. 1680, Autoridades (DECH). Llanos, Diccionario minas, c.1609-11]. sust. f. Ingen. Hidrául. Zanja o canal por donde se conduce el agua, generalmente para regar tierras o para acercarla a alguna localidad.

Llanos, Diccionario minas, c.1609-11, pág. 43: Como regaderas de muchachos cavadas en el mismo suelo y acabadas de levantar y formar con barro y pedrezuelas (porque no es menester más), negocio todo ello que lo hace un indio en poco espacio de tiempo y que, en acabando de servir, se deja así y se deshace.

SIN.: acequia $_{1}$, cequia ${ }_{1}$.

HIPER.: obra hidráulica.

FAM.: regadio, regar.

regadío, regadío [de regado. Entre 1493 y 1495, Nebrija (DECH). Fernández de Enciso, Suma de Geographía, 1530]. sust. m. Terreno dedicado a cultivos que se fertilizan con riego (DRAE).

Fernández de Enciso, Suma de Geographía, 1530, fol. XXXIr: Todas las tierras de las riberas d'este río son fértiles, son tierras de regadío. // Loçano, Alberto, Architectura, 1582, pág. 239: A esta casilla la rodeava un bosque entretexido de todo género de frutas, y estava el lugar verde en prado de regadío, y no faltavan a cada paso la rosa y copia de las flores, todo ello oloroso, alegre y de recreación. // Valle de la Cerda, Desempeño patrimonio, 1600, fol. 72v: La contratación ha de ser en las demás haziendas, que tienen estas pérdidas y otra mayor, que es la diminución de la misma hipoteca, que, quedando en pie, se suele consumir y extinguirse, como son molinos, casas, olivares, viñas, huertas, tierras de regadío y otras cosas semejantes.

FAM.: regadera, regar. 
2 [Herrera, Institución Academia, 1584]. sust. m. Ingen. Hidrául. Sistema de canales o conductos para regar tierras de cultivo.

Loçano, Alberto, Architectura, 1582, pág. 327: En el campo de Verona, lleno de piedras redondas, y por otra parte desnudo, y del todo no fértil, en algunos lugares, con muy ordinario regadío, hizieron que se cubriesse por encima una costra de césped y se levantasse encima un prado muy alegre. // Loçano, Alberto, Architectura, 1582, pág. 327: Cyro cortó el Ganges con muchos regadíos. // Herrera, Institución Academia, 1584, fol. 3r: Y, ansimismo, fontaneros y niveladores de las aguas, para los aguaductos y regadíos que en estos reynos tan importantes y convenientes serían, y para desaguar y beneficiar las minas de ricos metales.

HIPER.: obra hidráulica.

regar, regar [del lat. rügäre 'regar', 'mojar'. 1161, Oelschl. (DECH). Celso, Reportorio universal leyes Castilla, 1553]. v. tr. Esparcir agua sobre una superficie, como la de la tierra, para beneficiarla, o la de una calle, una sala, etc., para limpiarla o refrescarla (DRAE).

Celso, Reportorio universal leyes Castilla, 1553, fol. XIIv: Agua de fuente agena, si alguno por derecho de servidumbre puede tomar para regar su heredamiento, el dueño de la fuente o pozo no puede dar a otro poder de aprovecharse de la dicha agua, sin consentimiento de aquél que tiene el derecho de la tal servidumbre, salvo si el agua fuesse tanta que notoriamente bastasse para todos. // Besson, Teatro instrumentos, 1602, fol. Nv: Nuevo instrumento de balança con que el agua corriente es levantada a cierta altaria y inunda la tierra que se ha de regar, y entretanto está la rueda escondida dentro de l'agua para que el sobrado calor no la henda. // Juanelo Turriano, Veinte y un libros, a. 1605, fol. 78r: De modo que me pareze que se a declarado harto esta materia del llevar de las aguas, assí en caños como en azequias para regar, mas quédanos de las açequias o fosas para navegar.

FAM.: regadera, regadío.

2 [Fernández de Enciso, Suma de Geographía, 1530]. v. tr. Dicho de un río o de un canal: Atravesar una comarca o territorio (DRAE).

Fernández de Enciso, Suma de Geographía, 1530, fol. XLVIIIv: E quando aquél pecó cessaron los ríos de regar la tierra, e vino la lluvia e nuestro trabajo, e Dios en memoria de aquello dexó a este Nilo que regasse esta tierra y que no lloviesse en ella.

regolfar, regolfar [de golfo (DRAE). Juanelo Turriano, Veinte y un libros, a. 1605]. v. intr. Dicho del agua: retroceder contra su corriente, haciendo un remanso (DRAE).

Juanelo Turriano, Veinte y un libros, a. 1605, fol. 164v: Donde es la A es la boca del acequia. Y donde es la B es una pared del açute que haze regolfar la agua para que entre en la acequia. 
regolfo, regolfo, regolpho [de golfo. 1555, Greg. Hernández (DECH). Juanelo Turriano, Veinte y un libros, a. 1605]. sust. m. Vuelta o retroceso del agua o del viento contra su curso (DRAE).

Juanelo Turriano, Veinte y un libros, a. 1605, fol. 123r: O pensar que con esso la levantará, porque es grandíssimo herror pensar esso, que con dezir que haziéndola hazer restaño o tesón o entivo o regolpho, que por esso se levantará en grande cantidad en alto el agua.

FAM.: regolfar.

regolfo, V. molino de medio $\sim$.

regolfo, V. molino de $\sim$.

regolpho, V. regolfo.

rehedificar, $\mathrm{V}$. reedificar.

rehenchir, rehenchir, rehinchir [de henchir (DECH). Loçano, Alberto, Architectura, 1582]. v. tr. Volver a henchir algo reponiendo lo que se había menguado (DRAE).

Loçano, Alberto, Architectura, 1582, pág. 76: Y pienso que aquello no es de menospreciar, que conviene rehinchir todas las concavidades y en ninguna parte dexar vacío. // Lobato, Notas, a. 1585, fol. 32: Todo el más gasto para remediar este molino, esta pesquera, la cual, como va figurada honda de madera, encarcelados los pinos y clavados con sus tarugos unos con otros, estarán muy fuertes, y después rehenchido entre las estacas y pinos de piedra menuda. // Juanelo Turriano, Veinte y un libros, a. 1605, fol. 100r: Y después de ser asentados, convendrá yr rehinchendo lo que queda de bazío entre los maderos y la tierra del monte, a causa que no se venga a caer la tierra encima de los maderos. 
FAM.: hinchir.

rehinchir, V. rehenchir.

remo, remo [del lat. rēmus 'íd.'. Juan Ruiz (DECH). Escalante, Discurso de la navegación, 1577]. sust. m. Mec. Instrumento de madera, en forma de pala larga y estrecha, que sirve para mover las embarcaciones haciendo fuerza en el agua (DRAE).

Urrea, Vitruvio, Architectura, 1582, fol. 79r: También, en las naos los remos están debaxo del agua derechos y parecen estar quebrados. // Loçano, Alberto, Architectura, 1582, pág. 142: Y conviene que los escudos del navío y los pechos sean fuertes, y algo más promptos para que por la fuerça e ímpetu de las velas o remos echen el navío adelante, y después azia la popa vaya adelgazando. // Juanelo Turriano, Veinte y un libros, a. 1605, fol. 248r: Mas estos remos que ponen a las almadías no es para que ellas caminen, mas sólo para yrlas guiando, que vayan en el corriente del agua.

HIPER.: instrumento.

remoler, remoler [de moler (DECH). Alonso Barba, Arte de los metales, 1640]. v. tr. Moler mucho algo (DRAE).

Alonso Barba, Arte de los metales, 1640, fol. 45r: Y porque suele hazerse pelotillas y, quando esto no suceda, se esponja y engruessa la harina con el fuego, es conveniente remolerla antes de incorporarla. // Alonso Barba, Arte de los metales, 1640, fol. 66v: No se eche a mal el relabe hasta bolverlo a ensayar por fuego, y remolerlo, si d'ello tuviere necessidad.

FAM.: amoladera, amoladura, amolar, moler, moleta, molido, molienda, molinero, molinete, molino, muela, remolimiento, remolinar, remolino.

remolimiento, remolimiento [de remoler (DECH). Loçano, Alberto, Architectura, 1582]. sust. m. Acción de remoler (DRAE).

Loçano, Alberto, Architectura, 1582, pág. 329: Porque el remolimiento de las aguas y el remolino es una cierta barrena del río. // Alonso Barba, Arte de los metales, 1640, fol. 54r: Y falta después de lo que se echó en el caxón, más o menos, conforme fue mayor o menor su remolimiento y abundancia de lis. // Alonso Barba, Arte de los metales, 1640, fol. 54v: La caparrosa causa con más violencia este remolimiento en el açogue por su naturaleza.

FAM.: amoladera, amoladura, amolar, moler, moleta, molido, molienda, molinero, molinete, molino, muela, remoler, remolinar, remolino. 
remolinar, remolinar [de remolino. Pérez Vargas, De re metallica, 1568]. v. intr. Dicho de una cosa: hacer o formar remolinos (DRAE).

Pérez Vargas, De re metallica, 1568, fol. 119v: Y, quando el oro comiença a recogerse y remolinar fundiendo, se le eche otro poco de estibio porque no salte y se salga del crisol. // Juanelo Turriano, Veinte y un libros, a. 1605, fol. 299v: La agua va derecho a herir a la otra parte del cubo, de modo que ella no tiene lugar de yr remolinando por dentro del cubo. // Juanelo Turriano, Veinte y un libros, a. 1605, fol. 299v: Y siguiendo la circunferencia del cubo no puede, en ningún modo, parar de no remolinar, y remolinando la agua en el cubo es impossible dexar de toparse un remolino.

FAM.: amoladera, amoladura, amolar, moler, moleta, molido, molienda, molinero, molinete, molino, muela, remoler, remolimiento, remolino.

remolino, remolino [de molino. Entre 1493 y 1495, Nebrija (DECH). Medina, Arte de navegar, 1545]. sust. m. Movimiento giratorio y rápido del aire, el agua, el polvo, el humo, etc. (DRAE).

Medina, Arte de navegar, 1545, fol. 18r: Esto es que vemos que el viento levanta de la tierra el polvo y las pajas y lo sube derechamente en alto en aquello que vulgarmente se llama remolino y éste también se causa o haze en la mar como en la tierra. // Loçano, Alberto, Architectura, 1582, pág. 112: Hanse de evitar los remolinos y tragaderos del agua y los semejantes, los quales males están por los ríos. // Juanelo Turriano, Veinte y un libros, a. 1605, fol. 110v: Y tanto más furor llevará y rebolvimientos que sean furiosos y más turbios, donde ay aquellos remolinos.

FAM.: amoladera, amoladura, amolar, moler, moleta, molido, molienda, molinero, molinete, molino, muela, remoler, remolimiento, remolinar.

reparar, raparar, reparar [del lat. rĕpărāre 'íd.'. Juan Ruiz (DECH). Celso, Reportorio universal leyes Castilla, 1553]. v. tr. Arreglar algo que está roto o estropeado (DRAE).

Celso, Reportorio universal leyes Castilla, 1553, fol. CCXXXIVv: No se pueden vedar las obras que se hizieren reparando las obras e lavores antiguas, o alimpiando los caños, y reparando los tejados y otras obras necessarias que fuessen para mantener las casas. // Juanelo Turriano, Veinte y un libros, a. 1605, fol. 401v: Pero haya hecho él la obra, que esté bien acabada y puesta en su punto, y digan lo que quisieren, que si algo huviere, no será por su culpa, sino por descuydo de los moradores o de los señores de la tierra, que no tienen cuydado de reconoscer y reparar las fábricas que tanto les importan, porque el artífice ya dio cuenta de su talento dexando la obra como convenía, que el hacella perpetua, esso no es del artífiçe. Vayan ellos reparando el edifficio y no perdonen a la bolsa, que la materia que los señores dieron al artífice, aquélla puso. // Anónimo, Diálogo fábrica de navios, ca. 1631, fol. 34v: El buzo es de mucha ymportancia en una nao, pues mediante su resuello va abajo y recorre por debajo del agua todo el galeón y busca por donde la haze, con que se repara la que suele hazer, y muchos navíos se salvan, que, si no se llevasen buzo, se quedarían en la mar. 
reparo, reparo [de reparar. H. 1220-1250, Berceo (DECH). Celso, Reportorio universal leyes Castilla, 1553]. sust. m. Restauración o remedio (DRAE).

Celso, Reportorio universal leyes Castilla, 1553, fol. LXIIr: Los cavalleros no son tenudos a contribuyr en los reparos de muros de las ciudades e villas do moraren con los otros vezinos. // Llanos, Diccionario minas, c.1609-11, pág. 50: La imposición de los granos que pagan los indios de la mita en Potosí tuvo origen (a lo que por tradición se alcanza) de que, habiéndose de poner ministros en el Cerro para la defensa de los indios y reparo de las minas, pareció al Señor Virrey, don Francisco de Toledo, se repartiese un tanto cada año a las personas que tuviesen indios repartidos, conforme a la cantidad de cada uno. // Lechuga, Discurso de la Artillería, 1611, pág. 182: Para hazer los reparos a las baterías y contrabaterías y cerrar alguna abertura, muy a propósito se an hallado siempre los cestones.

FAM.: reparar.

repartir, repartir [de partir. 1490, Alonso de Palencia (DECH). Juanelo Turriano, Veinte y un libros, a. 1605]. v. tr. Ingen. Hidrául. Dicho del agua: distribuirla por diferentes lugares mediante conducciones.

Juanelo Turriano, Veinte y un libros, a. 1605, fol. 106r: Y su altura no será más de tres varas y media, aunque se aya cavado mucha más cantidad, por raçón que, quanto más van metidas debajo de tierra, tanto más seguras y muy más fresca será el agua, y aver mucha cantidad de agua para poderla repartir en diversas partes, si el pueblo fuesse grande. // Juanelo Turriano, Veinte y un libros, a. 1605, fol. 129r: Convendrá ussar algún artificio para que la agua tenga poco cuerpo en alto. De modo que, para hazer edificio, convendrá repartir la agua en tres o quatro partes, o en más, según la mucha cantidad. // Juanelo Turriano, Veinte y un libros, a. 1605, fol. 467r: Para repartir la agua conviene tomar toda la cantidad de la más agua que venga en la çequia, y medir lo ancho y lo alto de la agua.

SIN.: partir.

FAM.: partidero, partidor, partir.

represa, represa [del lat. rĕpressus, rĕpressa 'contenido', de rĕprimĕre 'contener' (DRAE). Juanelo Turriano, Veinte y un libros, a. 1605]. sust. f. Ingen. Hidrául. Abrazadera, armella, especialmente para engargolar caños (Salinero).

Juanelo Turriano, Veinte y un libros, a. 1605, fol. 283v: El segundo modo de alcaduzes son éstos, B C D, los quales tienen aquella represa, que es $\mathrm{E}$, la qual no dexa entrar el alcaduz más de quanto allega a la E.

HOL.: obra hidráulica.

FAM.: presa, represado. 
represado, represado [de represar. Álaba, Perfeto capitán, 1590]. adj. Dicho de un líquido: que está detenido o estancado.

Álaba, Perfeto capitán, 1590, fol. 173r: Y dize Serapión que las minas d'él son como las de la sal, porque se halla que se haze de aguas no corrientes que, estando estantías y represadas, se congelan y, condensadas, casi se hazen piedra. // Lechuga, Discurso de la Artillería, 1611, pág. 267: O haziendo presa, passada la fuerza, para que represadas y detenidas las aguas, queden las ruedas de las pistas y las de los molinos empalagadas.

FAM.: presa, represa.

respiradero, respiradero [de respirar. Entre 1493 y 1495, Nebrija (DECH). Urrea, Vitruvio, Architectura, 1582]. sust. m. Ingen. Hidrául. Abertura por donde entra y sale el aire en las obras de ingeniería hidráulica (DRAE).

Urrea, Vitruvio, Architectura, 1582, fol. 95v: Mas, si alguna pared tuviere contina humedad, apártese d'ella un poco y edifíquese otra pared delgada apartada d'ella quanto se suffriere, y entre dos paredes se ponga una canal más baxa que el nivel del cónclave, que tenga las narizes a lugar abierto. Pero si se edificare hazia lo alto, déxense respiraderos, porque si el humor no tuviere salidas por las narizes abaxo y arriba. // Urrea, Vitruvio, Architectura, 1582, fol. 109v: Pero si la fuerça del vapor arrebatare la luz, entonces, a la mano derecha e yzquierda del pozo se hagan unos respiraderos, por los quales, como por las narizes, despedirán aquellos espíritus. // Besson, Teatro instrumentos, 1602, fol. M2v: Envención nueva, no de tener en poco, con que, sin atanores y respiraderos, se puede sacar agua de un pozo muy hondo, con solamente dos poleas, de manera que el que tira el jugo sienta tan solamente la metad del peso.

SIN.: espiradero.

HOL.: obra hidráulica.

resquicia, resquizia [de resquicio. Juanelo Turriano, Veinte y un libros, a. 1605]. sust. f. Hendidura pequeña (DRAE s. v. resquicio).

Juanelo Turriano, Veinte y un libros, a. 1605, fol. 147v: Podrase bajar dentro d'este instrumento un gancho con su vara, que sea muy larga, para poderse assir a alguna mata o alguna resquizia o agujero de la peña, para poder estar muy más quieto y aun para alguna cosa que le hiziese molestia en no dejar allegar la gata a la peña.

SIN.: resquicio.

FAM.: desquiciar, quiciado, quicial, quicialera, quicio, resquicio.

resquicio, resquicio, resquizio [del lat. ${ }^{*}$ re-excrĕp $(i)$ tiare, derivado de crĕp(i)ta, participio de crĕpāre 'crujir'. H. 1280, $1^{a}$ Crón. Gral. (DECH). Juanelo Turriano, Veinte y un libros, a. 1605]. sust. m. Hendidura pequeña (DRAE). Juanelo Turriano, Veinte y un libros, a. 1605, fol. 7r: Mas las fibras de las piedras o peñas son ellas muy unidas y sólidas, y que el agua no pueden recibir más los resquizios y 
aberturas y endeduras de las piedras. // Juanelo Turriano, Veinte y un libros, a. 1605, fol. 35r: Esta calidá de agua va goteando por los resquizios de las peñas y luego se va a convertir en piedra. // Alonso Barba, Arte de los metales, 1640, fol. 18r: Pero si el lugar fuere angosto y tan apretado que las dichas dos exalaciones humosas no tengan salida, buscándola por entre los resquicios y hendeduras de las peñas o lugar mineral, se engruessan y convierten en los que llaman medios minerales.

SIN.: resquicia.

FAM.: desquiciar, quiciado, quicial, quicialera, quicio, resquicia.

resquizia, $V$. resquicia.

resquizio, V. resquicio.

restaño, restaño [de restañar (DECH). Juanelo Turriano, Veinte y un libros, a. 1605]. sust. $m$. Remanso o estancamiento de las aguas (DRAE).

Juanelo Turriano, Veinte y un libros, a. 1605, fol. 123r: O pensar que con esso la levantará, porque es grandíssimo herror pensar esso, que con dezir que haziéndola hazer restaño o tesón o entivo o regolpho, que por esso se levantará en grande cantidad en alto el agua. // Juanelo Turriano, Veinte y un libros, a. 1605, fol. 131r: Y con esta caýda se haze que ella se levante con hazer restaño, de modo que ella viene a levantarse hasta lo necessario.

resurtir, resurtir [de surtir. Entre 1493 y 1495, Nebrija (DECH). García de Céspedes, Instrumentos nuevos, 1606]. v. intr. Dicho de un líquido: brotar, saltar, o simplemente salir, y más en particular hacia arriba.

García de Céspedes, Instrumentos nuevos, 1606, fol. 27r: Acontece esto quando de diversas partes han concurrido venas de agua y, encontrándose unas con otras, resurten a la superficie de la tierra.

SIN.: surtir.

FAM.: surtidor, surtir.

retornear, retornear [de torno (DECH). Ufano, Tratado de la Artillería, 1613]. v. tr. Volver a tornear.

Ufano, Tratado de la Artillería, 1613, pág. 420: Con su pineta o bracete de hierro, para con ella retornear la viroleta, para que la una de sus vides entre por medio de la maça del çoquete que fuere enastado. 
FAM.: destornear, entorneado, torneable, torneado, tornear, tornero, tornillo, torno.

reventar, rebentar, reventar [probablemente del lat. vg. *repentare 'aparecer, salir con ímpetu o de pronto'. ¿1251?, ¿Calila? (DECH). Pérez Vargas, De re metallica, 1568]. v. intr. Dicho de una cosa: abrirse por no poder soportar la presión interior (DRAE).

Pérez Vargas, De re metallica, 1568, fol. 111v: Lo qual conviene que se haga quando los vapores con mucha fuerça suben en la destilación, porque si entonces el clavo no se quitasse, reventarían los vasos y perderse ýa la destilación. // Juanelo Turriano, Veinte y un libros, a. 1605, fol. 76r: Quando los alcaduzes son de una misma manera, van a peligro de rebentar, por causa del mucho ayre que en ellos se encierra. // Juanelo Turriano, Veinte y un libros, a. 1605, fol. 161r: Entrando mucha agua, más de lo ordinario, haze rebentar el azequia por muchas partes, haze caer las ribas o costados de la cequia y causa muchos daños.

ENCICL.: Y esto es la causa que algunos hornos rebientan, es el darle el fuego reguroso antes que las flamas ayan açendido arriba, y como no exhala la humedad, enciérrase dentro, y de necessidad conviene que rebiente y que se exhale por alguna parte (Juanelo Turriano, Veinte y un libros, a. 1605: fol. 259v).

reverter, reverter [del lat. rĕvĕrtĕre 'íd.'. H. 1250, Libro de Alexandre (DECH). Lobato, Notas, c.1585]. v. intr. Dicho de una cosa: rebosar o salir de sus términos o límites (DRAE).

Lobato, Notas, c.1585, fol. 32: Y así no reverterá el caño por ninguna parte si no fuere si parare de moler algún molino. // Lobato, Notas, c.1585, fol. 32: Y esto reverterá en el vertedero de ladrillo que está junto al molino que está muy bueno, reforzándole.

FAM.: divertir, trasverter, vertedero, verter, vertiente.

revolber, V. revolver.

revolcar, rebolcar [de volcar. Collado, Plática Artillería, 1592]. v. tr. Echar algo sobre alguna cosa, estregándolo y refregándolo en ella.

Collado, Plática Artillería, 1592, fol. 80v: Hecho esto, se molerá del açufre y pólvora de artillería partes yguales, y de aquella pólvora se estenderá sobre una mesa y, quitados los palillos de la bala, se rebolcará muy bien sobre aquella mixtura de polvo, lo que se haze para que mejor abraçe el fuego.

FAM.: volcar.

revolver, rebolber, rebolver, revolber, revolver [del lat. rĕvŏlvĕre 'íd.'. H. 1220-1250, Berceo (DRAE). Sagredo, Medidas Romano, 1526]. v. tr. Menear algo de un lado a otro, moverlo alrededor o de arriba abajo (DRAE). 
Sagredo, Medidas Romano, 1526, pág. 74: Quiérese sobar y revolver mucho porque no quede ninguna parte por mezclar, e no se quiere gastar luego. // Juanelo Turriano, Veinte y un libros, a. 1605, fol. 276v: Y después de fundido, pondrás dentro el vidre y rebolverás muy bien el vidre con el çufre. // Juanelo Turriano, Veinte y un libros, a. 1605, fol. 278r: Y esta masa ase de revolver con un yerro o pala de yerro, y ásele de yr añadiendo de los polvos.

SIN.: arrevolver.

ANT.: desarrevolver.

FAM.: arrevolver, desarrevolver, desenvolver, envolver, envuelto, volteado, voltear, volver, vuelta.

rezumar, reçumar, rezumar [de zumo. 1475, Guillén de Segovia (DECH). Lobato, Notas, a. 1585]. v. intr. Dicho de un líquido: salir al exterior en gotas a través de los poros de un cuerpo (DRAE).

Lobato, Notas, a. 1585, fol. 32: Y si a las primeras cajas quisieren hacerlo de argamasa con cal, será más fuerte, porque no rezumará el agua. // Juanelo Turriano, Veinte y un libros, a. 1605, fol. 21r: Y que por causa de la hendidura se va por aquella parte rezumando alguna poquita de agua. // Juanelo Turriano, Veinte y un libros, a. 1605, fol. 364r: Y conviene poner en obra mucha gente para sacar la agua, que no se ha de parar día ni noche, por causa de la agua que va reçumando.

2 v. intr. u. t. c. prnl. Dicho de un sólido: dejar pasar a través de sus poros o grietas gotas de algún líquido (DRAE).

González de Medina, Examen fortificación, 1599, pág. 112: Hanse de hazer unos poços grandes y bien hondos para cisternas, enlosados y encamisados de piedra, muy bien revocados con algún betún, que se pueda tener seguridad de que no se reçumarán ni los podrán sangrar por fuera.

roba, rova [del hispano-ár. rúba 'íd.', del árabe clásico rub' 'cuarta parte' (DECH). Collado, Plática Artillería, 1592]. sust. f. arag. Instrumento que se utiliza para allanar terrenos y limpiar de fango los fondos de los puertos y ríos.

Collado, Plática Artillería, 1592, fol. 67r: Rompían la superficie de ella primeramente con los arados y después con la pala y açadón, y aun con otro instrumento llamado rova removían la tierra que estava arada a las partes inferiores de aquella alteza. / Juanelo Turriano, Veinte y un libros, a. 1605, fol. 366r: Assí se pueden accomodar otros muchos instrumentos para este mesmo effecto de sacar el lodo. Se puede accomodar una rueda que le saque; puédese accommodar una rova, que sacará mucha quantidad de lodo. // Juanelo Turriano, Veinte y un libros, a. 1605, fol. 445r: Puédese sacar el lodo de un puerto con otro instrumento, el qual llaman en algunas partes rova, el qual sirve a los labradores para allanar las heredades. Este instrumento es fácil de hazer, porque hay poco artificio en él, aunque yo he puesto este instrumento en otra parte. 
ENCICL.: Rova es instrumento que con él toman la tierra de un lugar y la llevan a otro, mayormente que este instrumento acostumbran los labradores para allanar los campos quando no están llaños. Y con este instrumento se va sacando y limpiando el lugar por donde se a de fundar. Y este instrumento ya está puesto quando tractamos del limpiar de los puertos (Juanelo Turriano, Veinte y un libros, a. 1605: fol. 230r).

rodada, rodada [de rueda (DECH). Mendoça, Theórica y práctica, 1596]. sust. f. Señal que deja impresa la rueda de un vehículo en el suelo por donde pasa (DRAE).

Mendoça, Theórica y práctica, 1596, pág. 70: Los quales caminan de ordinario en esta forma, que es llevar el primer carro cargado de çapas y açadones, a quien sigue un afuste para señalar las rodadas del camino que se ha de hazer, y luego las pieças ligeras. // Ufano, Tratado de la Artillería, 1613, pág. 252: La postrera pieça de artillería, por ser algo más grave que las primeras y aver ellas y el agua robado y abarrancado con sus rodadas el camino de passo, se ahondaron y embazaron tanto sus ruedas en el terreno que no la podían tirar ni sacar fuera los caballos.

FAM.: rodadizo, rodaja, rodar, rodete, rodezno, rueda.

rodadizo, rodadizo [de rodar (DECH). Loçano, Alberto, Architectura, 1582]. adj. Que rueda con facilidad (DRAE).

Loçano, Alberto, Architectura, 1582, pág. 329 : Y será del todo movedizo el que estuviere lastrado en la ribera de greda, y en campo llano globosso y rodadizo suelo.

FAM.: rodada, rodaja, rodar, rodete, rodezno, rueda.

rodaja, rodaja, rodaxa [de rueda (DECH). Sagredo, Medidas Romano, 1526]. sust. f. Mec. Pieza circular y plana, de madera, metal u otra materia, que forma parte de una polea.

Sagredo, Medidas Romano, 1526, pág. 37: Trochilo es otro miembro principal en la basa que, por semejar al carrillo o polea, le llamaron los griegos trochilo, que quiere dezir 'rodaja'. // García de Palacio, Instrución náuthica, 1587, fol. 151v: Poleas: son las rodajas algo largas por do entran y corren las cuerdas del navío y estas rodajas se llaman roldanas. // Urrea, Vitruvio, Architectura, 1582, fol. 125r: Esta máchina es común a los marineros, y llámanla cabra, y es, assimismo, muy común en los pozos, para sacar agua, que es el carrillo con su rodaxa de metal o de madera.

SIN.: garrucha, roldana.

HOL.: polea. 
FAM.: rodada, rodadizo, rodar, rodete, rodezno, rueda.

rodar, rodar [del lat. rŏtāre 'íd.'. Entre 1493 y 1495, Nebrija (DECH). Urrea, Vitruvio, Architectura, 1582]. v. intr. Dicho de un cuerpo: dar vueltas alrededor de un eje, sin mudar de lugar (DRAE).

Urrea, Vitruvio, Architectura, 1582, fol. 127v: Y cierto, ni sin la rotundación, el movimiento del porrecto, ni sin el porrecto, pueden levantar la carga las bueltas del instrumento para rodar. // Roxas, Sumario milicia, 1607, fol. 45v: Y unas ruedas de madera, aunque sea verde, y çilindros de palos gruesos para echar a rodar, los quales lleban por delante no sólo los soldados, mas los caballos. // Juanelo Turriano, Veinte y un libros, a. 1605, fol. 114v: Y éstos conviene hincarles unas estacas para tenerlos firmes, a causa que el agua no los hiziese rodar.

FAM.: rodada, rodadizo, rodaja, rodete, rodezno, rueda.

rodaxa, $V$. rodaja.

rodel, rodel [probablemente del prov. rodella 'escudo redondo' (DRAE). Besson, Teatro instrumentos, 1602]. sust. $\mathrm{m}$. Contorno de una superficie redonda. Besson, Teatro instrumentos, 1602, fol. M2v: Mas, para que se vea claríssimamente la buelta y rodel de la cuerda arriba notada, de la qual cuelga todo el negocio, diré cómo ella, primeramente, por el un cabo está atada al torno.

rodete, rodete [de rueda. S. XVI, Autoridades (DECH). Juanelo Turriano, Veinte y un libros, c.1605]. sust. m. Mec. Rueda hidráulica horizontal con álabes. Juanelo Turriano, Veinte y un libros, c.1605, fol. 290v: Conviene tener advertencia en asentar primero el rodete, antes de asentar el ruello o la muela baxa, por causa de ver primero cómo yere la agua en el rodete. // Juanelo Turriano, Veinte y un libros, c.1605, fol. 291r: La rueda o rodete conviene que sea, al menorete, de ocho palmos, aunque será muy mejor de diez que no de ocho, aunque no consiste tanto en la mucha ancharia de la rueda, quanto consiste en la mucha cantidad de agua. // Juanelo Turriano, Veinte y un libros, c.1605, fol.

$294 \mathrm{v}$ : Estos molinos tienen rodete, y no rueda grande, el qual rodete anda llano y no drechos.

SIN.: rodezno.

HOL.: molino.

FAM.: rodada, rodadizo, rodaja, rodar, rodezno, rueda. 
ENCICL.: En el texto suele designar una rueda horizontal, pero como se utiliza simultáneamente.

[IMAGEN] Pseudo-Juanelo Turriano, Los ventiún libros, c. 1605, fol. 297r, fig. 195, letras E y F.

rodezno, rodezno [del lat. vg. * 'rŏtĭč̆nĭus 'íd.', y este del lat. rŏta 'rueda'. 1065 (DECH). Urrea, Vitruvio, Architectura, 1582]. sust. m. Mec. Rueda hidráulica horizontal con álabes.

Urrea, Vitruvio, Architectura, 1582, fol. 131r: D'esta misma manera andan las idraulas, que son los rodeznos de los molinos, a donde ay las mismas cosas, salvo que en una cabeça del exe tienen un tímpano con dientes encerrado. // Lobato, Notas, c.1585, fol. 36: Hame parecido que para este molino será mejor el rodezno de hierro, y el primero y segundo trozo son de madera asimismo, y el rodezno de otra manera, y que será más feroz y de más fuerza, porque el de madera va echado y no muele sino con la carga. // Juanelo Turriano, Veinte y un libros, c.1605, fol. 290v: Y por esta causa esta manera de rodeznos se acostumbravan hazer de pieças, mas agora se acostumbran hazer differentemente, que se hazen de sólo dos pieças de carrasca, y vase cavando los álavas en ello, y después se le pone un cercillo de yerro para que le conserve más tiempo unidas estas dos pieças juntas.

SIN.: rodete.

HOL.: molino.

FAM.: rodada, rodadizo, rodaja, rodar, rodete, rueda.

[IMAGEN] Lobato, Notas, c. 1585, fol. 19.

roldana, roldana [del cat. ant. rotlana 'roldana', 'rodaja', 'corro'. 1573, E. de Salazar (DECH). García de Palacio, Instrución náuthica, 1587]. sust. f. Mec. Pieza circular y plana, de madera, metal $\mathrm{u}$ otra materia, que forma parte de una polea. García de Palacio, Instrución náuthica, 1587, fol. 98r: Y con un motón al cabo de cada uno, con sola una roldana y por ella han de tener passado otro cabo de quarenta hilos, que llaman amante, tan largo que llegue al plan de la nao, y éste tambien tendrá una polea de dos roldanas. // García de Palacio, Instrución náuthica, 1587, fol. 153v: Roldanas: son las rodajas que están dentro de las poleas y motones. // Ufano, Tratado de la Artillería, 1613, pág. 320: La polea o cabeça suelta del guindal será larga 2 pies y ancha $3 / 4$ de pie. Sus roldanas, ambas a 2, serán como las de la cabeça fixa del mesmo guindal.

SIN.: garrucha ${ }_{1}$, rodaja.

HOL.: polea.

romana, romana [del lat. [stătêra] rōmāna 'balanza romana'. 1397, Invent. arag. (DRAE). Santa Cruz, Libro de las longitúdines, 1567]. sust. f. Instrumento 
que sirve para pesar, compuesto de una palanca de brazos muy desiguales, con el fiel sobre el punto de apoyo (DRAE).

Santa Cruz, Libro de las longitúdines, 1567, pág. 85: Y puesto en lo baxo del meridiano un peso de hierro o de plomo con su garavato, como el que se pone en la romana para saber el peso que alguna cosa tiene. // Juanelo Turriano, Veinte y un libros, a. 1605, fol. $82 \mathrm{v}$ : Aya en cada fundición muy fiel romana para pesar el metal que se recibe y saber la cantidad del que se funde. // Alonso Barba, Arte de los metales, 1640, fol.

$289 \mathrm{v}$ : Y esto se puede comprehender en la romana, que quando está un mismo peso apenso o colgado en ella, que quando está el pondos más cerca del peso.

HIPER.: instrumento.

rosa, V. rosca.

rosca, rosca, rosa [de origen incierto quizá prerromano. H. 1300 (DECH). Lobato, Notas, a. 1585]. sust. f. Cada una de las vueltas de una espiral, o el conjunto de ellas (DRAE).

Lobato, Notas, a. 1585, fol. 30: Ha de tener una vara de alto la entrada, y una vara de ancho la rosca, y una vara de alto. Y será como aquí va pintado, de la altura que sea necesario. // Juanelo Turriano, Veinte y un libros, a. 1605, fol. 350v: El río, hásele de hazer quatro subidas, digo quatro roscas, que le vayan rodeando a la redonda del mástil o ánima.

HOL.: espiral.

FAM.: enroscado, enroscar, enroscarse.

2 [Collado, Plática Artillería, 1592]. sust. f. Resalto helicoidal de algunas piezas. Collado, Plática Artillería, 1592, fol. 58v: Para que metiéndola por fuerça, hagan presa las roscas de la vide en el metal del agujero. / / Collado, Plática Artillería, 1592, fol. 61r: Sea de lo que fueren, que todos han de ser retorcidos y hechos a manera de una rosca y empapados en betumen de brea hecha de dos partes de pez y una de sebo, derretido todo junto en una caldera. // Juanelo Turriano, Veinte y un libros, a. 1605, fol. 325v: Y estos caracoles, fueren echas las roscas al torno, yrían muy más dulces en el bolverlos.

rotundación, rotundación [tomado del lat. rŏtŭndatio, rŏtŭndationis 'íd.' (Gaffiot). Urrea, Vitruvio, Architectura, 1582]. sust. f. Fís. Movimiento que consiste en girar en redondo.

Urrea, Vitruvio, Architectura, 1582, fol. 127v: Ya he declarado lo que me ha parecido ser necessario para las máchinas tractorias, de los quales, los movimientos y virtudes, que son dos cosas diversas entre sí, como se juntan, assí produzen principios para dos effectos: uno de porrecto, que el griego llama ythian; otro del rodar, que llaman chiclotin. Y cierto, ni sin la rotundación, el movimiento del porrecto, ni sin el porrecto, pueden levantar la carga las bueltas del instrumento para rodar. 
rova, V. roba.

rueda, rueda [del lat. rŏta 'íd.'. H. 1220-1250, Berceo (DECH). Montes, Instrucción y regimiento, 1537]. sust. f. Mec. Cada una de las piezas en forma de disco que giran alrededor de un eje en los carros y otros medios de transporte, permitiendo su movimiento.

Montes, Instrucción y regimiento, 1537, fol. VIv: Y para la llevar más a plazer, haga los carretones a la francesa, las ruedas altas, porque caminará más con él. // Apiano, Cosmographía, 1575, fol. 6r: Parallelos se dizen cosas que van enparejadas y siempre igualmente apartadas entre sí, como las rayas hechas por las ruedas del carro. // Lobato, Notas, a. 1585, fol. 3: Hice yo, Francisco Lobato del Canto, a mi costa, para la fiesta de la Santa Vera, siendo mayordomo Juan Gallego, un carro de 4 ruedas en el que se iba el emperador Heraclio sentado en una silla de oro.

HOL.: carro

FAM.: rodada, rodadizo, rodaja, rodar, rodete, rodezno.

2 [Ortega, Conpusición Arismética y Geometría, 1512]. sust. f. Mec. Cada uno de los discos de piedra que en los molinos permite moler lo que entre ellos se interpone.

Ortega, Conpusición Arismética y Geometría, 1512, fol. 128r: Un hombre va a un molino para que le muelan 80 minas o fanegas de trigo. Este molino tiene dos ruedas, en que la mayor muele entre día y noche 50 fanegas o minas de trigo y la menor muele 40 . // Ortega, Conpusición Arismética y Geometría, 1512, fol. 128r: Demando que, echando el trigo en amas, si estas dos escomencian juntamente y acaban juntamente, que en quánto tiempo molerán las dichas 80 fanegas de trigo y quántas fanegas o minas en aquel tiempo abrá molido cada una rueda. // Ortega, Conpusición Arismética y Geometría, 1512, fol. 128v: Multiplica y parte, como te he enseñado por regla de tres, y allarás que en 21 ora e un tercio de ora les dos ruedas an molido o molerán las 8 fanegas de trigo.

SIN.: muela $_{1}$, piedra $a_{2}$

HOL.: molino.

3 [Pérez Vargas, De re metallica, 1568]. sust. f. Mec. Pieza en forma de disco que forma parte de algunas máquinas hidráulicas, cuyo movimiento se produce por el impulso de la corriente. 
Pérez Vargas, De re metallica, 1568, fol. 78r: Este moler de los metales se haze differentemente mediante algunos ynstrumentos y máchinas de martillos, y maços de hierro, y palos clavados y ruedas que se traen a braço y otras con agua, como açudas y anorias, que, porque son cosas diffíciles y que cada uno las ha de ver con los ojos. // Juanelo Turriano, Veinte y un libros, a. 1605, fol. 288v: De modo que, el moler poco o mucho, es la causa la rueda que recibe el golpe de la agua de la canal. Dévese asentar la canal en esta manera: supropongamos que de donde empieça a recevir el agua la canal hasta despedirla de sí, que va a herir en la rueda, conviene que la canal esté asentada. // Juanelo Turriano, Veinte y un libros, a. 1605, fol. 289r: Aquí abaxo pondré unas differencias de ruedas, cómo les yera la agua en ellas y en quál d'ellas se verá, manifiestamente, dónde ará mayor fuerça la agua en ellas y en quál menos.

HOL.: máquina.

cerrada [Juanelo Turriano, Veinte y un libros, a. 1605]. comp. sintag. Mec. Aparato de elevación del agua, formado por una rueda vertical giratoria que posee una serie de compartimentos radiales en los que voltea el agua para su elevación.

Juanelo Turriano, Veinte y un libros, a. 1605, fol. 346v: Empeçaremos por las más fáciles máquinas, la qual es la rueda timpanada; otros la llaman rueda cerrada. La qual rueda es de esta manera: que se haze a beneplácito, digo, su diámetro, grande o pequeño, como fuere necessario para que ella sirva. // Juanelo Turriano, Veinte y un libros, a. 1605, fol. 347r: Ésta es la máquina que la levanta menos la agua en alto que ninguna de las demás que se hazen para levantar agua en alto. Ésta es la rueda timpanada o la rueda cerrada.

SIN.: felos, rueda timpanada, tímpano .

HIPER.: máquina.

[IMAGEN] Pseudo-Juanelo Turriano, Los ventiún libros, c. 1605, fol. 347r, fig. 261.

timpanada [Juanelo Turriano, Veinte y un libros, a. 1605]. comp. sintag. Mec. Aparato de elevación del agua, formado por una rueda vertical giratoria que posee una serie de compartimentos radiales en los que voltea el agua para su elevación.

Juanelo Turriano, Veinte y un libros, a. 1605, fol. 346v: Empeçaremos por las más fáciles máquinas, la qual es la rueda timpanada; otros la llaman rueda cerrada. La qual rueda es de esta manera: que se haze a beneplácito, digo, su diámetro, grande o pequeño, como fuere necessario para que ella sirva. // Juanelo Turriano, Veinte y un libros, a. 1605, fol. 347r: Ésta es la máquina que la levanta menos la agua en alto que ninguna de las demás que se hazen para levantar agua en alto. Ésta es la rueda timpanada o la rueda cerrada.

SIN.: felos, rueda cerrada, tímpano 1 .

HIPER.: máquina. 
ruello, ruello [del lat. rŏtŭlus 'ruedecilla' (DECH). Juanelo Turriano, Veinte y un libros, a. 1605]. sust. m. Mec. arag. Rodillo de piedra (DRAE).

Juanelo Turriano, Veinte y un libros, a. 1605,: En la figura: Segur o estral. Açuela. Axa. Tintero de almagra. Compás. Liña. Palanca. Ruello. Barrena. Ruello.

HIPER.: herramienta.

FAM.: rodada, rodadizo, rodaja, rodar, rodete, rodezno, rueda.

[IMAGEN] Pseudo-Juanelo Turriano, Los ventiún libros, c. 1605, fol. 248r, fig. 316. Aparecen dos ruellos, situados en la parte inferior de la imagen, uno a la derecha y otro a la izquierda.

2 [Juanelo Turriano, Veinte y un libros, a. 1605]. sust. Mec. arag. Disco de piedra que se hace girar rápidamente alrededor de un eje y sobre la solera, para moler lo que entre ambas piedras se interpone (DRAE s. v. muela).

Juanelo Turriano, Veinte y un libros, a. 1605, fol. 335r: Después de cogidas, las cortan a pedaços menudos, y después la muelen con un ruello de piedra grandíssimo, que a lo menos es de alto nueve palmos y de grueso uno. $Y$ éste, que sea de una piedra muy fuerte. $\mathrm{Y}$ ansí se muele como se muelen las olivas, mas mueve el ruello con animales. // Juanelo Turriano, Veinte y un libros, a. 1605, fol. 335v: Y su árbol tiene el ruello E, el qual muele la caña cortada. $\mathrm{Y}$ en la parte baxa del árbol del ruello ay un yerro, $\mathrm{F}$, el qual es corvado para que vaya abaxando la caña debaxo del ruello, para que se muelga. // Juanelo Turriano, Veinte y un libros, a. 1605, fol. 336r: Y de aquí la toman y la ponen debaxo del ruello. Y después de molida, la van poniendo de unos vasos, y de aquí la ponen en unas capaças de esparto, casi como las que acostumbran poner las olivas molidas, y las van prensando por la misma manera que las olivas.

SIN.: voladera.

[IMAGEN] Pseudo-Juanelo Turriano, Los ventiún libros, c. 1605, fol. 265v, fig. 322.

3 [Juanelo Turriano, Veinte y un libros, c.1605]. sust. Mec. arag. Disco de piedra que en los molinos está debajo de la muela voladera, sobre el que se muele el grano y otras cosas.

Juanelo Turriano, Veinte y un libros, c.1605, fol. 290v: Conviene tener advertencia en asentar primero el rodete, antes de asentar el ruello o la muela baxa, por causa de ver primero cómo yere la agua en el rodete. // Juanelo Turriano, Veinte y un libros, c.1605, fol. 300r: El banco donde están asentadas las muelas es F. El ruello o muela baxa es G. // Juanelo Turriano, Veinte y un libros, c.1605, fol. 335r: Y éste, que sea de una piedra muy fuerte. $\mathrm{Y}$ ansí se muele como se muelen las olivas, mas mueve el ruello con animales.

SIN.: muela baja, solera 1 . 
HOL.: molino.

runa, runa [del cat. runa 'íd.', de origen incierto. 1817, Acad. (DECH). Juanelo Turriano, Veinte y un libros, a. 1605]. sust. f. Polvo de las piedras que resulta de una obra de albañilería.

Juanelo Turriano, Veinte y un libros, a. 1605, fol. 369v: Dexando todo esto aparte, conviene que, quando se assentare los sillares de los cimientos, ir colligando las unas con las otras con sus gafas de hierro, y emplomadas, y con sus pernes de hierro emplomados, o con otro metal, porque la runa no le consuma.

FAM.: enrunar. 
saetía, saetía [probablemente del ár. šaytîyya 'íd.'. 1256-1263, Partidas (DECH). Juanelo Turriano, Veinte y un libros, c.1605]. sust. f. Mec. En los molinos, canal angosto por donde se conduce el agua hasta la rueda hidráulica (Salinero).

Juanelo Turriano, Veinte y un libros, c.1605, fol. 290v: Porque, si fuese asentado una vez, no se podrá acomodar tan bien como se acomodará el rodete, por causa que conviene, o acercarle más, o apartarle algún tanto más de la saetía. // Juanelo Turriano, Veinte y un libros, c.1605, fol. 291v: Y esto se entiende, ansí de madera, como de piedra y como de qualquier otro género de saetías o de canales, cubiertas o descubiertas, las quales son, ellas, differentes, como aquí abaxo irán varias, por causa de la mucha o poca agua que abrá. // Juanelo Turriano, Veinte y un libros, c.1605, fol. 292r: La tercera canal o bomba o saetía, que su quadro es K L M N, la qual su perpendicular es doze y su basa es quinze, que es $\mathrm{MN}$, de modo que su basa es tres más que no es su altaria la diagonal del paralelogramo, y esto causa el tener mucha más agua que no tiene la segunda.

SIN.: bomba $_{2,}$ canal $_{3,}$, saetín.

HOL.: molino.

ENCICL:: "De la parte inferior del cubo arranca la saetía -llamada a veces saetín o bombaque conducía el agua a gran velocidad a los rodeznos" (Catálogo Felipe II).

[IMAGEN] Pseudo-Juanelo Turriano, Los ventiún libros, c. 1605, fol. 297r, fig. 195, letras C y D; observamos dos saetías en la parte inferior de un cubo de un molino.

saetín, saetín, saetino [de saeta. 1726-1739, Autoridades (DECH). Lobato, Notas, c.1585]. sust. m. Mec. En los molinos, canal angosto por donde se conduce el agua hasta la rueda hidráulica (Salinero). 
Lobato, Notas, c.1585, fol. 16: Y hiere el saetín en la rueda del témpano echado en unas cuchares cavadas en arco y que pasan a la parte baja los agujeros de las cuchares, como se muestran en la traza. // Lobato, Notas, c.1585, fol. 17: Rodezno común de saetino 2.

SIN.: bomba , $_{\text {canal }}$, saetía.

HOL.: molino.

ENCICL.: "De la parte inferior del cubo arranca la saetía -llamada a veces saetín o bombaque conducía el agua a gran velocidad a los rodeznos" (Catálogo Felipe II).

[IMAGEN] Lobato, Notas, c. 1585, fol. 17.

saetino, V. saetín.

saltadero, saltadero [de saltar (DECH). Lobato, Notas, a. 1585]. sust. m. Ingen. Hidrául. Surtidor de agua (DRAE).

Lobato, Notas, a. 1585, fol. 37: Marco para el saltadero con lo que dicho tengo a Luisa Mateo, clavado por arriba y suelto de los tres lados, seis dedos más ancho por cada cabo.

HOL.: obra hidráulica.

FAM.: saltar, salto.

saltar, saltar [del lat. saltāre 'bailar', 'dar saltitos, brincar, retozar'. H. 12201250, Berceo (DECH). Pérez Vargas, De re metallica, 1568]. v. intr. Fís. Dicho de un líquido: salir hacia arriba con ímpetu (DRAE).

Pérez Vargas, De re metallica, 1568, fol. 115v: Y el agua parezca azeyte, porque, si después se echa, suele, o crescer el agua tanto que se derrama, o saltar la redoma. // Loçano, Alberto, Architectura, 1582, pág. 322: Después, por causa de deleytes, para tener aguas que saltassen azia arriba en las fuentes de los jardines y en los baños, començaron a llevallas con obra de arcos de fábrica en algunos lugares, alta por más de ciento de veynte pies y larga más de sesenta mil passos. // Juanelo Turriano, Veinte y un libros, a. 1605, fol. 306v: De modo que la saetía S hiere en la álaba T, y da en el medio d'ella, por donde la agua no puede saltar para arriva.

FAM.: saltadero, salto.

salto, salto [del lat. saltŭs 'salto'. H. 1140, Cid (DECH). Lobato, Notas, a. 1585]. sust. m. Fís. Caída de un caudal de agua.

Lobato, Notas, a. 1585, fol. 8: Y las otras dos partes han de salir por otra canal, para que con ella riegue una huerta o muela un molino dándole huida a donde pueda tener salto conveniente. // Lobato, Notas, a. 1585, fol. 18: Y después sale, como se ve, debajo de la 
otra agua, siguiendo su corriente y viaje, casi sin salto ninguno, sino llano. // Lobato, Notas, a. 1585, fol. 27: Su Majestad las mandase deshacer para que se navegase por Duero hasta Valladolid, desde el gran salto que dicen que el río Duero hace abajo de Miranda, y venir a Zamora y Toro.

FAM.: saltadero, saltar.

sangradera, sangradera [de sangrar (DECH). Pérez Vargas, De re metallica, 1568]. sust. f. Ingen. Hidrául. Cauce con el que se da salida a parte de las aguas de un pozo o canal.

Pérez Vargas, De re metallica, 1568, fol. 54v: Si es monte o collado, más fácilmente se cava y beneficia, porque pueden hazer sangraderas para el agua, que suele ordinariamente estorvar la cava de las venas. // Loçano, Alberto, Architectura, 1582, pág. 320: Llamo sangradera al lugar destinado para el uso, adonde queréys que venga la agua, para que de aý, o libre, o para sus ciertos usos se derrame. // Alonso Barba, Arte de los metales, 1640, fol. 100v: Se abre con mucho tiento con la hachuela un camino o sangradera muy sutil por donde vaya saliendo.

SIN.: desangradera, sangría.

HOL.: obra hidráulica.

FAM.: desangradera, desangrar, sangradero, sangrar, sangre, sangría.

sangradero, sangradero [de sangrar (DECH). Urrea, Vitruvio, Architectura, 1582]. sust. m. Ingen. Hidrául. Canalón por el que se desagua el agua de lluvia. Urrea, Vitruvio, Architectura, 1582, fol. 80r: Y también tengan las coliquias, que son los sangraderos de la lluvia y las canales y goteras, que son corrientes por el medio, desde los ángulos o rincones de las paredes hasta los ángulos de las vigas que buelvan en el ayre. // Urrea, Vitruvio, Architectura, 1582, 140r: Coliquias: sangraderos de la lluvia. // Urrea, Vitruvio, Architectura, 1582, 143v: Toscánico: primero género de concavidades, quando, puestas las vigas en la anchura del portal, salen afuera y sostienen dentro y fuera en las maderas canales, lluvias, sangraderos y goteras que caen al patio.

HOL.: obra hidráulica.

FAM.: desangradera, desangrar, sangradera, sangrar, sangre, sangría.

sangrar, sangrar [del lat. sanguĭnāre 'íd.' (DECH). Álaba, Perfeto capitán, 1590]. v. tr. Ingen. Hidrául. Dar salida a un líquido en todo o en parte, abriendo conducto por donde corra (DRAE).

Álaba, Perfeto capitán, 1590, fol. 46v: Mas si fuere tan hondo que no dé lugar a poderse vadear, si corriere por campaña rasa, será muy buen socorro sangrarle en diversas partes para que, repartido el golpe del agua en muchos braços, se disminuya su hondura hasta que quede en términos que se dexe fácilmente apear. // Collado, 
Plática Artillería, 1592, fol. 63r: Las aguas que fácilmente se quitan con solamente sangrar el fosso, como se usa, son aguas recogidas de arroyos o de alguna acequia; las aguas de corriente rápida y, mayormente, si son de algún río caudaloso, con difficultad grande se quitan y raras vezes salen con ello los que lo tientan. // González de Medina, Examen fortificación, 1599, pág. 9: Y lo que se tiene por peor, es la falta de agua que puede tener por más cuydado que se tenga, porque, si es de fuente que venga de fuera, puédese quitar con facilidad; si nace dentro, puédese sangrar por de fuera.

FAM.: desangradera, desangrar, sangradera, sangradero, sangre, sangría.

sangre, sangre [del lat. sanguis, sanguĭnis 'íd.'. H. 1140, Cid (DECH). Fernández de Enciso, Suma de Geographía, 1530]. sust. f. Líquido de color rojo que circula por las arterias y venas de los animales.

Fernández de Enciso, Suma de Geographía, 1530, fol. XXXVIIr: Esta costa tiene de longitud setenta e cinco leguas, tiene buenos puertos; en esta costa biven los scitas, los quales resciben agradablemente los huéspedes, y después los matan y se los comen; beven sangre mezclada con leche; son mala gente; biven vida pastoril por la mayor parte. // Juanelo Turriano, Veinte y un libros, c.1605, fol. 278v: El qual betún se haze en esta manera: tomarás cal viva y sangre de buey o de qualquier otra sangre, y amasar la calcina con la sangre, ansí caliente, como sale del animal quando le degüellan. // Juanelo Turriano, Veinte y un libros, c.1605, fol. 197r: Y a qué ayan ussado dar de sangre a estos algives, yo no hallo para qué ayan podido servirse de la sangre, si no fuese para cerrar las quebrazas de la calzina, y no para otro; antes digo que la sangre de qualquier animal, que sería bastante a hazer corromper la agua dentro de muy pocos días, caso que la sangre fuese muy bien seca, que la haría heder y que conviene lavar donde ella se aya puesto con cosas que le quiten aquello de la sangre.

FAM.: desangradera, desangrar, sangradera, sangradero, sangrar, sangría.

\section{V. molino de .}

sangría, sangría [de sangrar (Lüdtke,1978: 353). García de Céspedes, Instrumentos nuevos, 1606]. sust. f. Ingen. Hidrául. Cauce con el que se da salida a parte de las aguas de un pozo o canal.

García de Céspedes, Instrumentos nuevos, 1606, fol. 42r: Que trata cómo se tiene de dar la sangría a los pozos manantiales. // García de Céspedes, Instrumentos nuevos, 1606, fol. 42v: Si este pozo estuviere en parte alta, de suerte que donde se le da la sangría pueda tener la agua corriente, se podrá hazer; de otra manera, no. // García de Céspedes, Instrumentos nuevos, 1606, fol. 43r: Algunos han dado la sangría a los pozos haziendo la çanja de manera que viniesse a dar al suelo del pozo y, [...] después de aver gastado cien mil ducados en ella, se les ha perdido la agua.

SIN.: desangradera, sangradera. 
HOL.: obra hidráulica.

FAM.: desangradera, desangrar, sangradera, sangradero, sangrar, sangre.

scala, V. escala.

scansoria, V. escansoria.

scorpión, V. escorpión.

secha, V. cequia.

sedaço, V. cedazo.

senaria, senaria [tomado del lat. sēnārŭus, sēnārĭa 'compuesto de seis'. Juanelo Turriano, Veinte y un libros, a. 1605]. sust. f. Ingen. Hidrául. Caño o fístula de seis dedos de diámetro.

Juanelo Turriano, Veinte y un libros, a. 1605, fol. 286r: Agora fuesen lo caños o fístulas o trompas de plomo como de alambre, como de bronze, o alcaduces de barro, o de qualquier otra materia que ellos fuesen, los llamavan quinaria, por razón del diámetro, el qual era compuesto de cinco partes de un dedo. [...] La senaria, la qual tiene seys partes en cada diámetro.

SIN.: senario.

HIPER.: caño.

senario, senario [tomado del lat. sēnārŭus 'compuesto de seis'. Juanelo Turriano, Veinte y un libros, a. 1605]. sust. m. Ingen. Hidrául. Caño o fístula de seis dedos de diámetro.

Juanelo Turriano, Veinte y un libros, a. 1605, fol. 286v: De modo que el quinario de Vitruvio a sido de mayor capacidad o de mayor cabida que no a sido el senario de Frontino, porque las planchas o láminas eran en ancharia de cinco dedos, que es, a saver, beynte quadrantes con quatro onzenos. 
SIN.: senaria.

HIPER.: caño.

FAM.: senaria.

serner, V. cerner.

serón, serón [de sera 'espuerta'. H. 1400, Glos. del Escorial (DECH). García de Palacio, Instrución náuthica, 1587]. sust. m. Especie de cesta de esparto grande que sirve para carga de una caballería.

García de Palacio, Instrución náuthica, 1587, fol. 110v: Quatro açadones, dos porras de hierro, doze espuertas, seys serones, seys cadenas para escotillas, doze candados, caldera de brea. // Juanelo Turriano, Veinte y un libros, a. 1605, fol. 326r: Y la pieça de madera, que es D, la qual tiene a los dos cavos los serones E E, los quales suelen llamar otros espiga.

serrado, serrado [de serrar (DECH). Loçano, Alberto, Architectura, 1582]. adj. Cortado o dividido con la sierra.

Loçano, Alberto, Architectura, 1582, pág. 83: Las tablas y toda la demás materia, porque se sacan de viga serrada, provarse han luego por la limpieza y entereza de la viga. // Juanelo Turriano, Veinte y un libros, a. 1605, fol. 430r: Assí que, para este effecto, conviene tener mucha madera serrada y por serrar, y mucha piedra y calcina en muy gran cantidad.

SIN.: aserrado.

FAM.: aserrado, aserrador, aserradura, aserrar, serradura, serrar, sierra.

serradura, serradura [de serrar (DECH). Loçano, Alberto, Architectura, 1582]. sust. f. u. t. c. pl. Partículas de madera que se desprenden al serrar (DRAE). Loçano, Alberto, Architectura, 1582, pág. 182: Pero, mientras es más gruessa, tanto haze las serraduras más anchas y roe más fuertemente.

SIN.: aserradura.

FAM.: aserrado, aserrador, aserradura, aserrar, serrado, serrar, sierra.

serrar, serrar [del lat. sěrrāre 'serrar' (DECH). Loçano, Alberto, Architectura, 1582]. v. tr. Cortar o dividir con la sierra (DRAE). 
Loçano, Alberto, Architectura, 1582, pág. 41: No trastornes ningún árbol que se aya de aplanar o serrar, antes que eche sus frutos y maduramiento de simiente. // Besson, Teatro instrumentos, 1602, fol. D4v: Al tiempo que el engeño se aplica a la obra, ellas cayan siempre derechamente y buelvan a serrar. // Juanelo Turriano, Veinte y un libros, a. 1605, fol. 253r: Se halla en diversas partes de esse reyno una especie de piedra blanca, la qual con facilidad se puede serrar, como se haze la madera y el alabastro.

SIN.: aserrar.

FAM.: aserrado, aserrador, aserradura, aserrar, serrado, serradura, sierra.

setinaria, setinaria [tomado del lat. sěptēnārŭus, sĕptēnārĭa, 'compuesto de siete'. Juanelo Turriano, Veinte y un libros, a. 1605]. sust. f. Ingen. Hidrául. arag. Caño o fístula de cinco quinarias de diámetro.

Juanelo Turriano, Veinte y un libros, a. 1605, fol. 286r: Agora fuesen lo caños o fístulas o trompas de plomo como de alambre, como de bronze, o alcaduces de barro, o de qualquier otra materia que ellos fuesen, los llamavan quinaria, por razón del diámetro, el qual era compuesto de cinco partes de un dedo. [...] La senaria, la qual tiene seys partes en cada diámetro. Y en la setinaria, la qual es de siete cincos.

HIPER.: caño.

sierra, sierra [del lat. sěrra 'sierra de aserrar'. H. 1140, Cid (DECH). Pérez Vargas, De re metallica, 1568]. sust. f. Herramienta formada por una hoja de acero dentada sujeta a una empuñadura y que se utiliza para cortar madera u otros objetos duros.

Pérez Vargas, De re metallica, 1568, fol. 9v: Assí como el artífice y official, con el martillo, con el açuela, con la sierra y con el cinzel compone y perficiona las formas de su arte. // Besson, Teatro instrumentos, 1602, fol. D4v: Porque las sierras, ni deven jamás bolver atrás ni ir adelante, siendo el árbol que se ha de serrar el que se acerca y va a ellas. // Juanelo Turriano, Veinte y un libros, a. 1605, fol. 172v: Açadas, palas, ligones, garruchas, carros, sierras, martillos, picos y otras infinitas cosas que para ello es menester.

HIPER.: herramienta.

FAM.: aserrado, aserrador, aserradura, aserrar, serrado, serradura, serrar.

sillar, sillar [de silla. Entre 1493 y 1495, Nebrija (DECH). Urrea, Vitruvio, Architectura, 1582]. sust. m. Constr. Cada una de las piedras labradas que forma parte de una construcción de sillería (DRAE).

Urrea, Vitruvio, Architectura, 1582, fol. 27v: Una de sillares o piedras quadradas y otra hilada de pedernales o piedras duras, y assí hazen el edificio tan firme que dura para siempre. // Juanelo Turriano, Veinte y un libros, a. 1605, fol. 314v: Y conviene que sea muy bien hecha y bien asentada, por razón que no se trasmine la agua por las juntas de los sillares. // Juanelo Turriano, Veinte y un libros, a. 1605, fol. 389r: Mejor modo de 
sillar es la B que la A, por razón del quadrado, que muy mejor assienta el sillar encima y carga muy bien, porque es ir assegurando las pieças ha que tengan más fuerça.

FAM.: sillería.

sillería, sillería [del ant. sillarería y este de sillar (DECH). Urrea, Vitruvio, Architectura, 1582]. sust. f. Constr. Fábrica hecha de sillares asentados unos sobre otros y en hileras (DRAE).

Urrea, Vitruvio, Architectura, 1582, fol. 76r: Después d'esto, con piedra quadrada de sillería suba el muro guiado y hecho con junturas largas, de manera que las junturas y travazones (principalmente del medio) sean tales, que las piedras queden fuertes y fixas. // Juanelo Turriano, Veinte y un libros, a. 1605, fol. 172v: Los azutes que se hazen de piedra son muy diferentes de los de madera, porque muy pocas vezes se pueden hazer en los grandes ríos de piedra y calzina, agora sean ellos de manpostería o de sillería, por causa del grandíssimo impedimento que hazen las aguas // Juanelo Turriano, Veinte y un libros, a. 1605, fol. 419r: Pues sabe labrar muy maravillosamente de mampostería y de sillería, $y$, a más d'esto, que sabe labrar una cornisa con un papo de paloma.

FAM.: sillar.

sinzel, V. cincel.

sinzelado, V. cincelado.

sinzelar, V. cincelar.

sirga, sirga [de origen incierto quizá del antiguo sirgo 'seda'. 1463 (DECH). García de Palacio, Instrución náuthica, 1587]. sust. f. Cuerda gruesa de esparto que, utilizada generalmente para llevar embarcaciones, forma parte de algunas máquinas.

García de Palacio, Instrución náuthica, 1587, fol. 154r: Sirga: es yr a la sirga llevar a orillas de tierra el navío asido a alguna cuerda, tirando personas d'ella o caballos que van andando por la dicha tierra. // Juanelo Turriano, Veinte y un libros, a. 1605, fol. $145 \mathrm{v}$ : El ergate A es el que se buelve a la redonda, andando alrededor, el qual coje y descoje a un mismo tiempo la sirga E. // Ufano, Tratado de la Artillería, 1613, pág. 226: 
O llevado de una a otra parte sin la comodidad y ayuda de los çinchos, que se tira con ellos como quien lleva una barca a la sirga.

sobarbo, sobarbo [del lat. sub arbŏre 'debajo del árbol' (DRAE). Llanos, Diccionario minas, c.1609-11]. sust. m. Mec. Espina gruesa que, movida por las levas, levanta los mazos de algunos molinos.

Llanos, Diccionario minas, c.1609-11, pág. 62: Propiamente es ingenio el artificio con que se muele el metal, que las partes principales de que consta son: canal, chiflón, rueda, eje, quijo, cureñas, chumaceras, castillo, triángulo, cabezales, cadenas, mazos, levas, sobarbos, almadanetas, tejos y mortero, de las cuales no hay necesidad de decir en particular.

HOL.: molino.

socavado, socavado [de socavar. Lucano, Alfonso X, Almazán, Juan Ruiz (DECH). Sagredo, Medidas Romano, 1526]. adj. Excavado, que se le ha quitado parte de su masa o grueso.

Sagredo, Medidas Romano, 1526, pág. 18: Corona es otra moldura principal y retilínea, cuya figura es quadrada y, por la parte baxa, socavada. // Juanelo Turriano, Veinte y un libros, a. 1605, fol. 111r: En la parte baja de la puente, ordinariamente, les vemos las pilas socavadas en aquella parte, mucho más que no son en la parte de delante de las pilas.

FAM.: cava, cavadura, cavar, encavadura, excava, excavar, socavar.

Socavar, socavar, soscavar [de cavar. 1490, Alonso de Palencia (DECH). Sagredo, Medidas Romano, 1526]. v. tr. Excavar por debajo algo, dejándolo en falso (DRAE).

Sagredo, Medidas Romano, 1526, pág. 65: Contiene en la calva su moldura, que toma la sexta parte del ancho, e por la parte baxa se socava, según que de suso, quando de su formación hablamos, tenemos mostrado. // Sánchez de las Broças, Helt Frisio, Relox español, 1549, fol. 13v: Será bien que toda aquella parte de la regla que anda sobre el círculo movible se socave o lime, de manera que ni la regla, bolviéndose en torno, impida al círculo movible, ni tampoco el movible. // Juanelo Turriano, Veinte y un libros, a. 1605, fol. 110v: Havrá hecho una cava y avrá socavado la mota, hasta tanto que del todo sea arruynada.

FAM.: cava, cavadura, cavar, encavadura, excava, excavar, socavado.

soga, çoga, soga [del lat. tardío sōca 'íd.'. 980, Docs. Oelschl. (DECH). Medina, Arte de navegar, 1545]. sust. f. Cuerda gruesa de esparto (DRAE).

Medina, Arte de navegar, 1545, fol. 62v: Predicando allí la Fe de Jesuchristo, los obispos de los templos de los ýdolos le pusieron una soga al cuello y le arrastraron. // Urrea, Vitruvio, Architectura, 1582, fol. 125r: Y la tróclea que está atada al palo, junto a su 
rodaxa, se ate una soga y torne a la tróclea que está atada junto a la cabeça de la máchina. Alrededor de la rodaxa baxe una soga de lo alto y buelva a la porquezuela que está en lo baxo de la máchina. // Besson, Teatro instrumentos, 1602, fol. Dv: Y es, finalmente, a guisa de los tornos con que la çoga de los pozos se embuelve, de do se saca agua mediante una rueda.

soldado, soldado [de soldar. Pérez Vargas, De re metallica, 1568]. adj. Pegado, unido, natural o artificialmente.

Pérez Vargas, De re metallica, 1568, fol. 184r: Suelen con lienços mojados en agua fría humedecer esta sierpe, la qual deve estar muy bien soldada. // Lobato, Notas, a. 1585, fol. 34: Y su fuerza ha de ser hasta donde clava la álabe, pero no ha de ir cuadrado por detrás, porque su tope no haga estorbo, sino que parezca que corta el agua tendido su grueso, y a su punta soldadas dos como lañas de hierro, como van señaladas; que se labren cada una por sí primero y se agujereen para después en ellos clavar la chapa. // Juanelo Turriano, Veinte y un libros, a. 1605, fol. 478v: Para ençender el fuego con agua, que paresçe cosa tan contraria al juizio de los más hombres, házese un vaso de arambre de dos pieças, muy bien soldado.

FAM.: soldadura, soldar.

soldadura, soldadura [de soldar. 1490, Alonso de Palencia (DECH). Celso, Reportorio universal leyes Castilla, 1553]. sust. f. Unión natural o artificial de dos partes quebradas o divididas (Autoridades).

Celso, Reportorio universal leyes Castilla, 1553, fol. CCCVr: El que ayuntare a su vaso o ymagen pie ageno o otro miembro de ymagen, si la soldadura fuere hecha con plomo, no gana, por ende, el señorío de la cosa ajuntada. // Loçano, Alberto, Architectura, 1582, pág. 116: Pero en las puentes, el suelo y la soldadura con obra de mampuesto se ha de igualar en igual grosseza de su arco. // Alonso Barba, Arte de los metales, 1640, fol. 67r: El durar poco las calderas o peroles ordinarios con el açogue es, o por tener algunas soldaduras, o por averse batido de cobre no macizo.

FAM.: soldado, soldar.

2 [Pérez Vargas, De re metallica, 1568]. sust. f. Material que sirve y está preparado para soldar (DRAE).

Pérez Vargas, De re metallica, 1568, fol. 154r: El principal aviso es templar la soldadura, assí de plata como de oro, de manera que sea más blanda que el metal de la pieça que se quiere soldar. // Pérez Vargas, De re metallica, 1568, fol. 154v: La común soldadura es un poco de plata fina, y su mitad de cobre y su quarta parte de latón o cobre quemado. // Pérez Vargas, De re metallica, 1568, fol. 154v: La razón de usarse soldaduras differentes es por los esmaltes en el oro y porque, soldada una vez una pieça, si se torna al fuego para soldar con ella otra. 
soldar, soldar [del lat. sŏlĭdāre 'consolidar, endurecer'. H. 500, S. Avito (DECH). Cortés de Albacar, Breve compendio sphera, 1556]. v. tr. Pegar y unir alguna cosa natural o artificialmente (Autoridades).

Cortés de Albacar, Breve compendio sphera, 1556, fol. LXXVIIr: Hechas estas tabletas o almenillas se han de soldar en el alhidada, entre el centro y extremidades d'ella. // Lobato, Notas, a. 1585, fol. 34: Podrase soldar de esta manera, después de hecho, una punta, como parece, y media vara o tres cuartas de cuadrado por partes, abajo muy igual, para que entre allí el rodezno. / / Juanelo Turriano, Veinte y un libros, a. 1605, fol. 285r: Los caños de alambre no se pueden soldar uno con otro como se haze los de plomo. Los de alambre se sueldan muy differentemente.

FAM.: soldado, soldadura.

solera, solera [del lat. sŏlarĭa, de sŏlum 'suelo'. 1633, López de Arenas (DRAE). Lobato, Notas, c.1585]. sust. f. Mec. Disco de piedra que en los molinos está debajo de la muela voladera, sobre el que se muele el grano y otras cosas.

Lobato, Notas, c.1585, fol. 20: Y más: que en el grueso de la pared donde todo cargare, ha de ser la solera ancha, y en la vuelta que llevare la dicha torre, y asentada por el medio de la pared, y acanalada. // Alonso Barba, Arte de los metales, 1640, fol. 72v: Consta qualquiera d'ellos de dos piedras grandes y duras, llana la de abaxo, que llaman solera, assentada a nivel sobre el plan de la tierra; en forma de rueda o queso entero la de arriba, en los trapiches que mueven cavalgaduras, como en las atahonas o molinos de azeitunas. // Alonso Barba, Arte de los metales, 1640, fol. 72v: Sólo digo que para el presente intento no han de ser las soleras llanas, sino cóncabas, con capacidad bastante para que las voladeras de arriba puedan andar sin estorvo.

SIN.: muela baja, ruello

HOL.: molino.

FAM.: ensolar, suelo.

2 [Sanctiago, Arte separatoria, 1598]. sust. f. Ingen. Hidrául. Superficie del fondo en canales y acequias (DRAE).

Sanctiago, Arte separatoria, 1598, fol. 14v: Y el testero que está hacia la caldera a de tener dos agujeros, el uno en medio del testero y el otro en la parte baxa, junto a la solera del canal.

HOL.: obra hidráulica.

soliviar, soliviar [del lat. *subleviāre y este de levis 'leve' (DRAE). Loçano, Alberto, Architectura, 1582]. v. tr. Ayudar a levantar algo por debajo (DRAE). Loçano, Alberto, Architectura, 1582, pág. 209: Por la altura de la frente, en los triglifos occurrentes del frisso a plomo, se señalen tres surcos derechos y igualmente distantes entre sí, cortados con ángulo de esquadría, rectos hasta que tengan de abertura un 
módulo, y de la una y otra parte se solivian los vivos de las vandas hasta que quede en ancho medio módulo. // Urrea, Vitruvio, Architectura, 1582, fol. 122r: De la otra parte, una medida de ygual peso con el peso del felos o tímpano, y tanto quanto el felos es soliviado del agua, tanto el peso del arena buelve abaxo el exe y el exe al tímpano. // Juanelo Turriano, Veinte y un libros, a. 1605, fol. 166v: Y quanto más pesso se le carga encima, tanto más se haze segura la obra, por raçón que el peso la va calando para el suelo, para soliviarle para arriba, como ay muchas formas que lo hazen.

SIN.: aliviar 2.

FAM.: aliviadero, aliviado, aliviador, alivianar, aliviar, alivio, leve, livianamente, liviano.

soltador, soltador [de soltar (DECH). Rojas, Teórica fortificación, 1598]. sust. m. Ingen. Hidrául. Portillo y canal que se hace en un río o acequia para sangrarlo (Salinero s. v. ladrón).

Rojas, Teórica fortificación, 1598, fol. 96r: Y d'esta anchura se abrió el cauz de los 2.000 passos de largo hasta la pressa, haziéndole en el camino 3 soltadores, que por otro nombre les llaman ladrones.

SIN.: ladrón.

HOL.: obra hidráulica.

soplador, soplador [de soplar (DECH). Besson, Teatro instrumentos, 1602]. sust. $m$. Persona que tiene por oficio el ejercer su fuerza sobre una cuerda que, a través de una polea, ejecuta el movimiento de unos fuelles.

Besson, Teatro instrumentos, 1602, fol. D2v: Estas cosas son fáciles. A levante están los sopladores y el peso colgado de una viga, cuya altaria es de dos mesuras tres partes. Cerca están los fuelles; después la hornaza, que es quasi como las ordinarias, quitado el peso.

FAM.: soplar, soplo.

[IMAGEN] Besson, Diego, Teatro de los instrumentos, Horacio Cardon (trad.), 1602, pág. D3r, figura 11.

soplar, soplar [del lat. sŭfflāre 'íd.'. Med. S. XIII (DECH). Medina, Arte de navegar, 1545]. v. intr. Mec. Hacer que los fuelles $\mathrm{u}$ otros artificios adecuados arrojen el aire que han recibido (DRAE).

Pérez Vargas, De re metallica, 1568, fol. 73v: Estando el carbón grande encendido, se eche dentro la massa del metal en el agujero y hoyo y se cubra con otro carbón ancho ardiendo, y soplando con los fuelles reziamente, hasta que funda la massa y por la parte baxa del agujero del carbón, que es lo más angosto, corra el estaño en el vaso o tiesto de barro. // Pérez Vargas, De re metallica, 1568, fol. 100r: Quando se funde lo menudo, es menester soplar el fuelle quedo y a espacio; quando lo mediano, más a priessa. 
soplo, soplo [de soplar. Alonso de Palencia (DECH). Medina, Arte de navegar, 1545]. sust. m. Mec. Acción y efecto de hacer soplar fuelles y otros artificios (DRAE).

Pérez Vargas, De re metallica, 1568, fol. 83r: Y conviene mucho que el que los fuelles trae, si no es yngenio, lo sepa bien hazer, trayéndolos unas vezes a priessa y otras a espacio y a compás, conforme a la orden del maestro fundidor, que deve ser tal, que entienda el soplo del ayre que el metal demanda y su fundición. // Pérez Vargas, De re metallica, 1568, fol. 83v: La orden que se ha de tener con el carbón es que, lo primero que se echare en el hondo del horno hasta cubrir la tovera de los fuelles no sea gruesso, porque no ympida el soplo del ayre, sino mediano y limpio, y luego se eche un lecho de carbón gruesso y el horno se hincha de carbón boltizo. // Alonso Barba, Arte de los metales, 1640, fol. 84v: La quema es preparación necessaria en metales que tienen açufre, o antimonio o betunes, si se han de fundir en hornos castellanos con carbón y soplo de fuelle.

FAM.: soplador, soplar.

sortiga, V. sortija.

sortija, sortiga, sortija [del lat. sortĭcŭla 'aro, anillo', derivada de sors, sortis 'suerte'. H. 1220-1250, Berceo (DECH). Urrea, Vitruvio, Architectura, 1582]. sust. f. $\mathrm{Mec}$. Aro o argolla que forma parte de algunas máquinas.

Urrea, Vitruvio, Architectura, 1582, 139v: Chelonio: máchina que llaman cabra; tiene dos sortijas o assas como ombligos en que se rebuelven las rodezuelas o carrillos. // Juanelo Turriano, Veinte y un libros, a. 1605, fol. 144r: Y en las quatro sortijas ha de estar asido quatro pedazos de cuerda que vayan [a] asirse en una sortija grande, donde se a de asir una cuerda que sea de muy buena groseza, que ella pueda sustentar el peso de la gata. // Juanelo Turriano, Veinte y un libros, a. 1605, fol. 144v: La L es la maroma en que cuelga la gata. Y donde es la primera sortija es A, la qual está assida en un ñudo de la maroma L.

HOL.: máquina.

soscavar, V. socavar.

spirital, V. espirital. 
spiritual, V. espiritual.

stabilidad, V. estabilidad.

stable, V. estable.

stampa, V. estampa.

stampador, V. estampador.

stampar, V. estampar.

súcula, súcula, súscula [tomado del lat. sŭcŭla 'cabria'. 1843, Ac. (DECH). Urrea, Vitruvio, Architectura, 1582]. sust. f. Mec. Pieza grande con forma de tuerca utilizada en algunas máquinas.

Urrea, Vitruvio, Architectura, 1582, fol. 125r: Si en las obras oviere grandes pesos, no se puede confiar en la súcula, más de la manera que está assida con los chelonios. // Urrea, Vitruvio, Architectura, 1582, fol. 128r: Y puesta en la súcula con las bueltas de los hierros, haze que se levante la carga, de la qual súcula los peçones, como centros estendidos en los chelonios, y metidos hierros en sus agujeros con las cabeças bueltas a compás, manera de torno, bolviéndose, levantan la carga. // Urrea, Vitruvio, Architectura, 1582, fol. 140r: Chelonio: miembro de máchina en que la súcula se ase, y se pone un exe que tenga en medio un tímpano ancho, que algunos llaman rueda y otros peritrochium.

SIN.: caracola, porquezuela, puerca.

HOL.: máquina.

suelo, suelo [del lat. sŏlum 'base', 'fondo', 'suelo', 'tierra en que se vive'. H. 1140, Cid (DECH). Sagredo, Medidas Romano, 1526]. sust. m. Superficie de la Tierra (DRAE).

Sagredo, Medidas Romano, 1526, pág. 11: Entre otras muchas medidas que los antiguos alcançaron cerca de la comensuración del cuerpo humano, hallaron que el ombligo era natural centro de todo el cuerpo, ca un hombre echado en el suelo, tendidos y abiertos 
los braços y las piernas, el compás que uviere del ombligo a los dedos de las manos es el mesmo que ay del ombligo a los dedos de los pies. // Juanelo Turriano, Veinte y un libros, a. 1605, fol. 22v: Es quando hallamos [que] el suelo donde pissamos es la tierra floxa y húmeda, y que, pisando, el suelo se abaja, por raçón del pesso del que pisa encima. / / Juanelo Turriano, Veinte y un libros, a. 1605, fol. 66r: Harase en este modo: que se hincará en el suelo dos palos, distantes el uno del otro seys passos.

FAM.: ensolar, solera.

2 [Urrea, Vitruvio, Architectura, 1582]. sust. m. Superficie inferior de algunas obras hidráulicas.

Urrea, Vitruvio, Architectura, 1582, fol. 108r: D'esta manera, si con canales, la muralla por do el agua fuere, sea firme, y el suelo del arroyo tenga las medidas levantadas, y no menos en cien pies de medio pie, y aquellas murallas sean como bóveda, porque el sol no toque al agua. // Lobato, Notas, a. 1585, fol. 36: Canal: la tabla derecha ha de tener 20 pies de largo y la izquierda diecinueve. El suelo ha de tener tres cuartas de entrada de agua y una de salida, antes menos que más, si el pozo fuere de diez pies. // Juanelo Turriano, Veinte y un libros, a. 1605, fol. 180v: Las cisternas se deven hazer en tal modo y manera, ansí en el suelo como en lo demás, a la redonda, que ella sea muy firme y sólida, que no se extermine por ninguna parte.

HOL.: obra hidráulica.

sumidero, sumidero [de sumir (DECH). Loçano, Alberto, Architectura, 1582]. sust. m. Conducto o canal por donde se sumen las aguas (DRAE).

Loçano, Alberto, Architectura, 1582, pág. 335: Y después disponed en los lugares convenientes y oportunos sumideros de agua, aguatochos $\mathrm{y}$ herradas, $\mathrm{y}$ todo instrumento para secar.

HOL.: obra hidráulica.

surtidor, surtidor [de surtir. Juanelo Turriano, Veinte y un libros, c.1605]. sust. m. Ingen. Hidrául. Ingenio hidráulico utilizado generalmente en los jardines que permite que de un caño brote el agua con fuerza hacia arriba.

Juanelo Turriano, Veinte y un libros, c.1605, fol. 284v: Ansí que, si no fuere donde ay algún surtidor de agua donde conviene acomodar muchos caños pequeños para hazer el effecto del surtir de la agua, o donde conviene que el caño sea doblegado para hazer algún ángulo. // Juanelo Turriano, Veinte y un libros, c.1605, fol. 136r: Y también se puede acomodar que en la misma aya un surtidor, el qual ha de ser para lavar las manos estando a la mesa. // Juanelo Turriano, Veinte y un libros, c.1605, fol. 136r-fol. 136v : Quando se querrá acomodar surtidores debajo de los ladrillos, que salgan entre las juntas o debajo de algún enlossado, que por entre las juntas o entre yervas, como mejor parezca a cada uno. 
HOL.: obra hidráulica.

FAM.: resurtir, surtir.

surtir, surtir [de origen incierto voz emparentada con el fr., oc. y cat. sortir 'brotar, saltar (agua, etc.)', 'proveer de algo', 'producir (efecto)' (DECH). Pérez Vargas, De re metallica, 1568]. v. intr. u. t. c. sust. Fís. Dicho de un líquido: brotar, saltar, o simplemente salir, y más en particular hacia arriba.

Pérez Vargas, De re metallica, 1568, fol. 162v: Porque si no va bien enxuto el esmalte, avexiga en el fuego y surte. // Juanelo Turriano, Veinte y un libros, a. 1605, fol. 284v: Ansí que, si no fuere donde ay algún surtidor de agua donde conviene acomodar muchos caños pequeños para hazer el effecto del surtir de la agua, o donde conviene que el caño sea doblegado para hazer algún ángulo.

SIN.: resurtir.

FAM.: resurtir, surtidor.

súscula, V. súcula. 


\section{tacajamar, V. tajamar.}

tahona, tahona, taona [del hispano-ár. tahúna, y este del ár. clás. țāhūn[ah], 'molino'. 1256, Doc. de Sevilla (DECH). Urrea, Vitruvio, Architectura, 1582]. sust. f. Mec. Molino harinero cuya rueda se mueve por fuerza humana o animal. Urrea, Vitruvio, Architectura, 1582, fol. 87r: Los graneros y fevilia, que son almiares do se guarda el heno, las paneras para encerrar el farro, las tahonas para moler, parece que se deven hazer fuera de la alcaería [...]. // Rojas, Teórica fortificación, 1598, fol. 78v: Y no basta que la ciudad o castillo esté bien fortificada con todos los dichos requisitos o con otros mejores, si no está muy bien proveýda de conveniente presidio para su defensa, con mucha provisión de vituallas, de carne salada [...] y harina para hazer pan fresco, teniendo hornos aparejados para ello, algunas tahonas o ingenios para moler trigo y una fragua.

SIN.: atahona ${ }_{1}$, molino de bestia(s), molino de sangre, molino de tahona.

HIPER.: molino.

FAM.: atahona. 
ENCICL.: En las Antiguas Grecia y Roma, era a los esclavos a quien se encargaba la dura tarea de mover el molino, y aunque durante la Edad Media y el Renacimiento se recurrió a animales de tiro para realizar este propósito, continuaron proliferando molinos, como los de rueda de pisar o grúa, que precisaban de la fuerza humana para su funcionamiento. En cualquier caso, los molinos movidos por animales se vieron favorecidos por el invento de la collera y el atalaje, que facilitaron el empleo de la fuerza animal en maquinaria diversa (García Tapia 1997: 12-14).

2 [Juanelo Turriano, Veinte y un libros, a. 1605]. sust. f. Mec. Caja de madera en figura de pirámide inversa, que sirve en los molinos para echar el grano y que vaya cayendo poco a poco en el agujero o garganta de la piedra que lo va moliendo (Terreros s. v. tolva).

Juanelo Turriano, Veinte y un libros, a. 1605, fol. 314v: Y donde están las tahonas, en aquella pared $\mathrm{R}$, conviene que aya dos escalas, a los dos cabos, que es $\mathrm{S} S$, para subir a poner el grano en las tahonas.

SIN.: gruenza, tolva.

HOL.: molino.

[IMAGEN] Pseudo-Juanelo Turriano, Los ventiún libros, c. 1605, fol. 308r, fig. 211, letra S.

3 [Juanelo Turriano, Veinte y un libros, a. 1605]. sust. f. Mec. Barcaza de fondo plano, provista de una trampilla abatible, sobre la que se deposita el material extraído al ahondar y limpiar puertos y canales.

Juanelo Turriano, Veinte y un libros, a. 1605, fol. 382r: La qual tahona o gruença ha de ser como aquella de los molinos donde se hecha el trigo para moler, la qual ha de tener una portezuela en el suelo, que lo occupe todo, y hase de abrir hazia baxo. // Juanelo Turriano, Veinte y un libros, a. 1605, fol. 445r: Y la tahona que está en el barco recibe el lodo que vierte la rueda C. // Juanelo Turriano, Veinte y un libros, a. 1605, fol. 446r: Y ase de vaziar en una tahona, como está fixada en aquel barco, para sacar afuera el puerto; de modo que será menester tener dos barcos con sus tahonas, para que, quando la una va a vaziar, la otra esté para henchir.

SIN.: atahona $a_{2}$.

tahona, V. molino de .

tajadera, tajadera [de tajar (DECH). Collado, Plática Artillería, 1592]. sust. f. Cuchilla, a modo de media luna, que se utiliza para tajar algo. 
Collado, Plática Artillería, 1592, fol. 11r: Sustenta allí, aun más, Su Magestad a los fundidores una fragua con sus fuelles, cepos, martillos grandes y pequeños, tenazas, escópolos, tajaderas y atizadores de hierro. // Alonso Barba, Arte de los metales, 1640, fol. 96v: Córtase con tajaderas en pedaços que, bueltos a caldear con un gran martillo que también trae el agua, los estienden y acomodan.

FAM.: tajado, tajador, tajamar, tajante, tajar.

2 [Juanelo Turriano, Veinte y un libros, a. 1605]. sust. f. Ingen. Hidrául. arag. Compuerta que se pone para detener la corriente de agua (Salinero).

Juanelo Turriano, Veinte y un libros, a. 1605, fol. 311v: Cada uno de los rodetes tiene su levador y su dado, y también tiene cada canal su tajadera para que no entre agua en ella. // Juanelo Turriano, Veinte y un libros, a. 1605, fol. 319r: En el hazer parar estos molinos, se les pone una tajadera de madera en la parte de delante, y como la superficie de la agua topa en ella, luego para, con palmo y medio que cale dentro en el agua. // Juanelo Turriano, Veinte y un libros, a. 1605, fol. 321r: Esta tajadera es en la forma que aquí abaxo yrá formada. La qual es A, que entra dentro de la agua, y B C es donde se haze con unas clavijas, para que la tenga firme en el lugar que se quiere que esté.

SIN.: cobertor, $r_{2}$ tajador.

HOL.: obra hidráulica.

tajado, tajado, taxado [de tajar. Sagredo, Medidas Romano, 1526]. adj. u. t. c. sust. Cortado.

Sagredo, Medidas Romano, 1526, pág. 51: Lo tajado es una quatorzena parte y lo retraýdo una novena.

FAM.: tajadera, tajador, tajamar, tajante, tajar.

tajador, tajador [de tajar. Gran Conquista de Ultramar (DECH). Juanelo Turriano, Veinte y un libros, a. 1605]. sust. m. Ingen. Hidrául. arag. Compuerta que se pone para detener la corriente de agua (Salinero s. v. tajadera).

Juanelo Turriano, Veinte y un libros, a. 1605, fol. 303r: El tajador que se pone encima del cubete, se pone a fin que, como trae tanta furor la agua, que se levanta para arriva y sale del cubete. // Juanelo Turriano, Veinte y un libros, a. 1605, fol. 303r: Y saliendo la agua por encima, no molerá tanto quanto molería tuviendo el tajador encima. // Juanelo Turriano, Veinte y un libros, a. 1605, fol. 305r: Y el covertor o tajador es la B, que es de dos pedaços, aunque en él no ay puntales para tenerle firme.

SIN.: cobertor ${ }_{2}$, tajadera 2 .

HOL.: obra hidráulica. 
FAM.: tajadera, tajado, tajamar, tajante, tajar.

tajamar, tajamar, taxamar [cmpt. de taja y mar. Princ. s. XVII, Inca Garcilaso (DECH). Lobato, Notas, a. 1585]. sust. u. t. c. f. Ingen. Hidrául. Obra de cantería que se construye en la corriente de las aguas en figura angular, para que corte el agua y se reparta igualmente por un río (Salinero).

Lobato, Notas, a. 1585, fol. 31: Al fin de esta pesquera se ha de hacer una puerta de dos arcos de ladrillo pequeños y bajos, por donde la gente pueda pasar a San Cosmes del Camino, que va de la pesquera de Carreño con una tajamar en medio pequeña y baja. // Rojas, Teórica fortificación, 1598, fol. 95r: Y puesta esta segunda caxa y bien entablada, se limpiará toda el arena y tierra movediza dentro d'ella, y, llegado a plan y suelo firme, se dará principio con cal viva para tomar el agua, y desde allí levantar la fábrica del pilar con la cantería muy gruessa y bien ligada y trabada con sus ligazones, poniendo las puntas de los taxamares a la parte de donde viene el río.

HOL.: obra hidráulica.

FAM.: tajadera, tajado, tajador, tajante, tajar.

ENCICL.: En general los puentes españoles de la segunda mitad del siglo XVI presentan un cierto arcaísmo, que se pone de relieve en el diseño de tajamares y espolones que con frecuencia suben hasta la calzada para formar apartaderos (González Tascçon 1999: 115).

tajante, tajante [de tajar. Ufano, Tratado de la Artillería, 1613]. adj. Que taja o corta.

Ufano, Tratado de la Artillería, 1613, pág. 176: Y, asimismo, quando se da el asalto son muy buenas, con unas buenas y tajantes espadas en las manos.

FAM.: tajadera, tajado, tajador, tajamar, tajar.

tajar, tajar, taxar [del lat. taliāre 'cortar', 'rajar', derivado del lat. talĕa 'retoño'. $2^{\mathrm{a}}$ mitad s. X, Glosas de Silos (DECH). Sagredo, Medidas Romano, 1526]. v. tr. Dividir algo en dos o más partes, generalmente con un instrumento cortante.

Sagredo, Medidas Romano, 1526, pág. 51: El tablero ha de haver en cada uno de sus lados tanto quanto fuere el alto del capitel y más tres séptimas, al qual se le tajan las puntas de los cornijales.

FAM.: tajadera, tajado, tajador, tajamar, tajante.

taladrar, taladrar [de taladro. 1490, Alonso de Palencia (DECH). Collado, Plática Artillería, 1592]. v. tr. Agujerear alguna cosa con un taladro. 
Collado, Plática Artillería, 1592, fol. 58v: Y nota que el meter dentro del fogón aquel hilo de hierro sirve a falta de trepante o taladro, que haviendo esto no hay necessidad de otra cosa, sino taladrar el agujero. // Juanelo Turriano, Veinte y un libros, a. 1605, fol. 423r: He pensado un modo de un taladro, que con él se taladrasse y se hiziessen unos agujeros en ella. // Ufano, Tratado de la Artillería, 1613, pág. 209: Y una que yo, Señor, vide barrenar, duró bien 8 horas en taladrarse.

FAM.: taladro.

taladro, taladro [del lat. tardío tarātrum 'íd.', voz de origen céltico. H. 1400, Glos. de Toledo (DECH). Anónimo, Repertorio tiempos, 1554]. sust. m. Herramienta a modo de barrena de gran tamaño que se utiliza para agujerear la madera u otra cosa.

Anónimo, Repertorio tiempos, 1554, fol. LXVIIIv: Y después, con una varrena pequeña o con un delgado taladro horada la dicha vara por los puntos que havías compassado. // Juanelo Turriano, Veinte y un libros, a. 1605, fol. 227v: Que la barrena a de ser a modo de taladro, y a de ser muy gruessa, y aun muy pessada, que a lo menos ha de pessar dozientas libras de hierro. // Anónimo, Diálogo fábrica de navíos, ca. 1631, fol. 34r: Terná su erramienta toda, como quatro achas aceradas y encabadas, dos azuelas, un martillo grande, dos pequeños, un taladro o barrena grande para pernos, un medio taladro, dos barrenas de costado, otras dos de medio costado, seis pequeñas de escora y barrote y tillado.

HIPER.: herramienta.

FAM.: taladrar.

taona, V. tahona.

tarabilla, taravilla [del hispano-ár. taráb, y este del ár. clás. țarab 'música' y el sufijo -illa. Juan Ruiz (DECH). Juanelo Turriano, Veinte y un libros, a. 1605]. sust. f. Tabla de madera, pendiente de una cuerda sobre la piedra del molino harinero, para que la tolva vaya despidiendo la cibera, y para conocer que separa el molino, cuando deja de golpear (DRAE s. v. cítola).

Juanelo Turriano, Veinte y un libros, a. 1605, fol. 308v: La taona, B. El torcedor, C. El canalete es D. La cítola o taravilla es E. La caxa que recoje la arina es F. // Juanelo Turriano, Veinte y un libros, a. 1605, fol. 317r: Y con este movimiento haze caer el grano dentro de la muela, el qual es llamado del vulgo taravilla. // Juanelo Turriano, Veinte y un libros, a. 1605, fol. 317r: La taona es A. El templador, B. El canalote, C. La taravilla, D. La armadura es $\mathrm{E}$, hecha aochavada, y otras ay redondas.

SIN.: cítola. 
HOL.: molino.

[IMAGEN] Pseudo-Juanelo Turriano, Los ventiún libros, c. 1605, fol. 308v, fig. 212, letra E (arriba a la derecha).

taravilla, V. tarabilla.

tarugo, tarugo [de origen incierto probablemente prerromano y emparentado con los galos tarinca 'perno o clavija' y taratrum. 1386, López de Ayala (DECH). Lobato, Notas, a. 1585]. sust. m. Trozo de madera con forma cilíndrica o cónica que, encajado en un agujero, se utiliza para asegurar y fijar alguna cosa.

Lobato, Notas, a. 1585, fol. 32: Todo el más gasto para remediar este molino, esta pesquera, la cual, como va figurada honda de madera, encarcelados los pinos y clavados con sus tarugos unos con otros, estarán muy fuertes, y después rehenchido entre las estacas y pinos de piedra menuda. // Rojas, Teórica fortificación, 1598, fol. 52v: Y juntamente se irán pisando assimesmo los céspedes, y a las hiladas de en medio entre cada cama de fagina se irán clavando con unos tarugos de madera, de palmo y medio de largo cada uno y un dedo de gruesso, los quales se hazen de lo que se desperdicia de la leña de la fagina. // González de Medina, Examen fortificación, 1599, pág. 141: Otros quieren que se hagan con barcas que tomen todo el circuito, pegadas, y que, cargadas de piedras, dadas barrenos en medio y tapados con sus tarugos, a una se desatapen y se vayan en fondo por igual, que unas ayudarán a otras.

tascón, tascón [del cat. tascó 'cuña en general'. G. Soriano (DECH). Juanelo Turriano, Veinte y un libros, a. 1605]. sust. m. Cuña de madera que se emplea en algunos empalmes.

Juanelo Turriano, Veinte y un libros, a. 1605, fol. 156v: La G es la segunda manera de empalmadura, la qual es hecha para poner dos tascones o cuñas, que es $\mathrm{M}$ y $\mathrm{N}$, que van dobladas las enpalmaduras. // Juanelo Turriano, Veinte y un libros, a. 1605, fol. 316r: Y quando se pone el badil, se pone unos tascones de madera de enzina, para que esté en el medio del mástil.

taxado, V. tajado.

taxamar, V. tajamar.

taxamar, V. tajamar. 
taxar, V. tajar.

témpano, témpano, ténpano [del lat. tympănum 'pandero', 'rueda', 'grúa'. Lobato, Notas, a. 1585]. sust. m. Mec. Cada uno de los dos lados o tapas de una rueda o linterna de molino.

Lobato, Notas, a. 1585, fol. 16: Y hiere el saetín en la rueda del témpano echado en unas cuchares cavadas en arco y que pasan a la parte baja los agujeros de las cuchares, como se muestran en la traza. // Lobato, Notas, a. 1585, fol. 17: Molino de aceñuela de témpano 5 .

SIN.: timpano 2 .

HOL.: rueda $a_{3 .}$

FAM.: tímpano.

templador, templador [de templar (DECH). Juanelo Turriano, Veinte y un libros, c.1605]. sust. m. Mec. Viga de madera que se utiliza para subir o bajar la muela voladera, controlando así la separación entre las muelas.

Juanelo Turriano, Veinte y un libros, c.1605, fol. 302v: En los costados del cubete de medio regolfo, como de regolfo entero, conviene hazer a los costados del cubete dos agujeros quadrados o redondos para acomodarles unos templadores. Y éstos se ponen a fin de levantar o abaxar la muela, para que aga muy delgada la arina, o muy gruesa. // Juanelo Turriano, Veinte y un libros, c.1605, fol. 305r: Y el madero donde está asentado el dado, que encima de aquél anda el rodete, el qual madero lo llaman levador, por razón que, quando quieren abaxar o subir la muela, ése le suelen abaxar o levantar algún tanto, y éste se llama templador.

SIN.: levador $r_{1}$

HOL.: molino.

2 [Juanelo Turriano, Veinte y un libros, a. 1605]. sust. m. Mec. Pieza que sujeta y dirige el canalón por el que el grano cae desde la tolva hasta la muela de un molino.

Juanelo Turriano, Veinte y un libros, a. 1605, fol. 312r: El templador es H, el qual es para hazer que cayga el grano dentro de la muela, o muy apriesa o muy a espacio. // Juanelo Turriano, Veinte y un libros, a. 1605, fol. 317r: El qual templador se tuerce, o se sube, o se baxa: subiendo, cae muy a paso, y baxando, cae el grano muy aprisa; de modo que esta canal va guiando el grano al agujero de la muela. // Juanelo Turriano, 
Veinte y un libros, a. 1605, fol. 317r: La taona es A. El templador, B. El canalote, C. La taravilla, D. La armadura es E, hecha aochavada, y otras ay redondas. El farinal es F. La pala, G. La escova es H. Y en la parte de tras de la taona, donde es la K, es donde se pone el grano dentro de la taona.

SIN.: torcedor.

HOL.: molino.

[IMAGEN] Pseudo-Juanelo Turriano, Los ventiún libros, c. 1605, fol. 312r, fig. 219, letra H.

tenaça, $V$. tenaza.

tenaçante, $V$. tenazante.

tenaçón, $V$. tenazón.

tenasante, $V$. tenazante.

tenaza, tenaça, tenaza [del bajo latín hispánico tenaces 'íd.'. H. 1220-1250, Berceo (DECH). Pérez Vargas, De re metallica, 1568]. sust. f. u. t. c. pl. Instrumento de metal, compuesto de dos brazos trabados por un clavillo o eje que permite abrirlos y volverlos a cerrar, que se usa para sujetar fuertemente una cosa, o arrancarla o cortarla (DRAE).

Pérez Vargas, De re metallica, 1568, fol. 168r: Luego se tome de la punta en su torno, con una tenaza se passe por la hilera y sus palacios y agujeros, hasta que quede del gruesso que es menester. // Loçano, Alberto, Architectura, 1582, pág.

178: Los antiguos usavan de una regla de hierro en que ponían los primeros nudos de las cuerdas y de las poleas, y, principalmente, en el assir peso de piedra usavan de tenazas de hierro. // Juanelo Turriano, Veinte y un libros, a. 1605, fol. 383r: Y pónesele una tenaza al cabo de la cuerda, para subir las cuerdas o baxarlas. La tenaza es de hierro, está hecha sobre la letra X.

HIPER.: herramienta.

FAM.: tenazante, tenazón. 
tenazante, tenaçante, tenazante [de tenaza. Ufano, Tratado de la Artillería, 1613]. sust. $m$. Tenaza de gran tamaño utilizada para romper objetos de metal. Ufano, Tratado de la Artillería, 1613, pág. 278: Que es la figura que entre la estacada y el tenaçante y torre se muestra sobre quatro ruedas con algunos hombreçillos ençima y la escala y cordería. // Ufano, Tratado de la Artillería, 1613, pág. 278: O bien servirá la dicha ynvençión para, arrimada a una ventana de una torre o casa fuerte, con el tenaçante, tenaças, maço y hachuela romper sus guardaportes y enrexamientos. // Ufano, Tratado de la Artillería, 1613, pág. 279: El tenazante o rompedora tenaça se puede, çiertamente, creer que con su poca fuerça romperá fáçilmente las barras o rexas de hierro.

SIN.: tenazón.

HIPER.: herramienta.

FAM.: tenaza, tenazón.

tenazón, tenaçón [de tenaza. Ufano, Tratado de la Artillería, 1613]. sust. m. Tenaza de gran tamaño utilizada para romper objetos de metal.

Ufano, Tratado de la Artillería, 1613, pág. 278: A cuyo ministerio aprovechará un tenaçón, marcado con la letra $\mathrm{C}$, y un maço de madera o martillo de orejas con la hachuela de mano, apuntada con el punto 2 .

SIN.: tenazante.

HIPER.: herramienta.

FAM.: tenaza, tenazante.

ténpano, V. témpano.

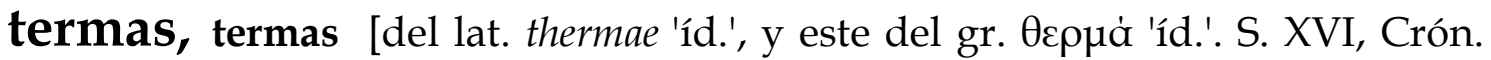
Gral. de Ocampo (DECH). Sagredo, Medidas Romano, 1526]. sust. f. pl. Ingen. Hidrául. Baños públicos de los antiguos romanos (DRAE).

Sagredo, Medidas Romano, 1526, pág. 74: Y d'este tal hormigón son edificadas las termas y otros muchos edificios antiguos en Roma. // Juanelo Turriano, Veinte y un libros, a. 1605, fol. 196r: En Roma ay infinitíssimos, de una increýble grandeza, que es cosa de admiraçión, los quales muchos d'ellos son hedificios antiguos, a los quales llamavan termas, por donde podrán [ver] los que son curiosos de las cosas antiguas, en Andrés Fulvio, // Juanelo Turriano, Veinte y un libros, a. 1605, fol. 200v: Y anlos llamado por diversos nombres: los unos los han llamado termas, y otros baños, y otros los han llamado siete zonas, y aun del nombre de los príncipes que lo han mandado hazer. 
tesíbica, cthesíbica, tesíbica [tomado del lat. ctesibǔcus, ctesibǐca 'perteneciente o relativo a Ctesibio' (Manuel Valbuena). Urrea, Vitruvio, Architectura, 1582]. sust. f. u. t. c. adj. Mec. Máquina hidráulica de metal utilizada para subir el agua por medio de modiolos o vasos.

Urrea, Vitruvio, Architectura, 1582, fol. 132r: Agora se sigue la demonstración de la máchina cthesíbica, que echa el agua en alto. Ésta se haze de metal, en cuya raýz se ponen modiolos o basos, de dos en dos, algún tanto apartados. // Urrea, Vitruvio, Architectura, 1582, 139v: Catino: baso de la máchina cthesíbica; como plato. // Juanelo Turriano, Veinte y un libros, a. 1605, fol. 231v: Y conviene tener mucha qüenta en la cantidad, por causa de saber acomodar los instrumentos que para ello son menester; que si ubiere mucha hondura de agua, convendrá servirse de unos instrumentos, como es la cóclea, como la tesíbica, con bombas.

SIN.: $\boldsymbol{b o m b a}_{1}$.

HIPER.: máquina.

ENCICL.: Se llama así por Ctesibio, sabio de Alejandría.

"Cuando había que abastecer a una población numerosa, lo primero que se hacía era busca la forma de elevar el agua desde el río hasta la ciudad por medio de algún mecanismo hidráulico. Uno de los más famosos era la torre de Augsburgo; esta torre, construida en la década de 1540, probablemente sirvió de inspiración, gracias a los relatos de otros viajeros, a otras torres en que una o dos bombas elevaban el agua hasta la cubeta, desde la cual una segunda bomba la elevaba aún más, de manera que, tras tres o cuatro etapas, el agua estaba lo bastante alta como para fluir por gravedad en dirección a las fuentes públicas y a las tinajas y aljibes de los consumidores privados" (Catálogo Felipe II: 28). Las tesíbicas o bombas se utilizaban también en el achique de terrenos fanganosos, "sobre todo en la primera fase, ya que cuando el agua arrastraba cienos y fangos, dejaban de ser eficaces, pues se obstruían con gran facilidad" (González Tascón 1999: 196).

[IMAGEN] Pseudo-Juanelo Turriano, Los ventiún libros, c. 1605, fol. 353r, fig. 272.

timpanada, V. rueda $\sim$.

tímpano, tímpano [tomado del lat. tympănum 'pandero', 'rueda', 'grúa'. S. $\mathrm{XV}$, Juan de Mena (DECH). Urrea, Vitruvio, Architectura, 1582]. sust. m. Mec. Aparato de elevación del agua, formado por una rueda vertical giratoria que posee una serie de compartimentos radiales en los que voltea el agua para su elevación.

Urrea, Vitruvio, Architectura, 1582, fol. 129r: De las máchinas para sacar agua, y, primero, de la rueda maciza que llaman tímpano. // Urrea, Vitruvio, Architectura, 1582, fol. 129r: Y, primero, diré del tímpano. Esta máchina no levanta el agua en alto, pero saca desembaraçadamente gran muchedumbre de agua. Fabrícase un exe a torno o compás, con las cabeças afferradas con planchas. 
SIN.: felos, rueda cerrada, rueda timpanada.

HIPER.: máquina.

FAM.: témpano.

2 [Lobato, Notas, a. 1585]. sust. m. Mec. Cada uno de los dos lados o tapas de una rueda o linterna de molino.

Lobato, Notas, a. 1585, fol. 15: Digo que la entruesga tenga ciento sesenta pendazos y pueda estar pegada por más fuerte con la propia grúa afijada y clavada en un tímpano, y sería menos largo y embarazoso el eje y ella herirá con más fuerza yendo todo junto, y ocupará menos casa o lugar, y vendrá a dar la piedra ochenta vueltas mientras el hombre diere una vuelta a la grúa. / / Juanelo Turriano, Veinte y un libros, a. 1605, fol. 443r: Podrás también hazer abrir en otro modo: que en el tímpano de la linterna D, poner una clavija quando quiere que se abra la bolsa, y ansí se abrirá. Que las cuerdas B C han de ir juntas y bolverse en la linterna E, si no fuere quando la querrá hazer abrir, que cavalgue ençima de la clavija G.

SIN.: témpano 1 .

HOL.: rueda

[IMAGEN] Lobato, Notas, c. 1585, fol. 15.

tina, tina [del lat. tina 'íd.'. Anónimo, Ordenanças paños, 1527]. sust. Vasija grande, de forma de caldera, que sirve para el tinte de telas y para otros usos (DRAE).

Anónimo, Leyes lanas e pañosAnónimo, Ordenanças paños, 1527, fol. VIIr: Otrosí, mando que no puedan traer juntos en las tinas más de dos paños e un pedaço, fasta medio paño quando más, so pena que el tintorero que más metiere en las dichas tinas pague dozientos maravedís por la primera vez. // Besson, Teatro instrumentos, 1602, fol. M4v: Aquí, pues, primeramente se vee una gran tina, a cuyos lados están dos assaz gruessos maderos, do el torno es voltado, que tiene en la parte oriental un trispasto que lo lleva. // Alonso Barba, Arte de los metales, 1640, fol. 42v: El metal, molido y cernido, se echa en una tina de mano, como si estuviera ya con açogue, dada la ley.

FAM.: tinaja, tinajón, tino.

tinaja, tinaja, tinaxa [del lat. *tīnăcula, diminutivo de tìna, tìnae 'vasija'. 1235, Juan Ruiz (Segura Munguía). Celso, Reportorio universal leyes Castilla, 1553]. sust. f. Vasija grande de barro cocido, y a veces vidriado, mucho más ancha por el medio que por el fondo y por la boca, y que encajada en un pie o aro, o 
empotrada en el suelo, sirve ordinariamente para guardar agua, aceite $u$ otros líquidos (DRAE).

Urrea, Vitruvio, Architectura, 1582, fol. 100r: Assientan también sobre los sarmientos barras de plomo y atapan las tinajas con cobertores, porque, atapadas, no echen fuera el vapor. // Besson, Teatro instrumentos, 1602, fol. Q3v: En la postrera parte hay un rhombo orbicular, hecho a manera quasi de tinaja, cuyo movimiento es libre. // Juanelo Turriano, Veinte y un libros, a. 1605, fol. 343r: De modo que, recojida cantidad de tierra, tómase unos vasos hechos de barro, a modo de tinajas, que tengan más anchas las bocas que no el vientre.

FAM.: tina, tinajón, tino.

tinajón, tinajón, tinaxón [de tinaja (DECH). Collado, Plática Artillería, 1592]. sust. $\mathrm{m}$. Vasija tosca de barro cocido parecida a la mitad inferior de una tinaja (DRAE).

Collado, Plática Artillería, 1592, fol. 78v: Toma un tino o un tinajón que sea grande y cúbrelo todo de tablas de pino muy bien acepilladas. // Collado, Plática Artillería, 1592, fol. 78v: Deshaz, pues, toda aquella máquina y echa aquella agua del tinajón o tina en una caldera, dale fuego hasta que hierva y ve sacando el salitre como en la segunda recepta se declara. // Sanctiago, Arte separatoria, 1598, fol. 104v: Y póngase otro tinajón debaxo en que se resciva, y échenle agua la cantidad que fuere menester para sacar la sustancia.

FAM.: tina, tinaja, tino.

tinaxa, V. tinaja.

tinaxón, V. tinajón.

tino, tino [del lat. tìnum 'íd.' (DRAE). Collado, Plática Artillería, 1592]. sust. m. Vasija grande, generalmente de madera, que se utiliza para recibir y almacenar líquidos.

Collado, Plática Artillería, 1592, fol. 79v: Echarás en cada tino 120 libras de salitre bien refinado, y échale tanta agua clara que se torne líquido. // Juanelo Turriano, Veinte y un libros, a. 1605, fol. 342r: El recetáquulo o tino que recive las lexías de las canales es E. // Juanelo Turriano, Veinte y un libros, a. 1605, fol. 343v: Y ansí va esta agua a un grandíssimo tino de madera, donde recibe de las caxas y de este tino, que está enterrado dentro de tierra.

FAM.: tinaja, tinajón, tina. 
[IMAGEN] Pseudo-Juanelo Turriano, Los ventiún libros, c. 1605, fol. 337v, fig. 249, letra H.. Es un tino para escaldar las lanas en un ingenio para lavarlas.

tirante, tirante [de tirar. S. XVI (DECH). Juanelo Turriano, Veinte y un libros, a. 1605]. sust. m. Mec. Madero que abarca el ancho del cuchillo en una armadura y soporta un esfuerzo de tensión.

Juanelo Turriano, Veinte y un libros, a. 1605, fol. 159v: Es necessario que en ello aya muchas estacas hincadas, las quales conviene que estén muy bien hincadas en el suelo, a lo menos las que tienen los tirantes A C. // Juanelo Turriano, Veinte y un libros, a. 1605, fol. 160v: Es la otra armadura para açute, la qual es muy bien conçertada en las piezas: los tirantes $\mathrm{L} \mathrm{M}$, porque éstos son el principio de la máchina; y los rebotantes, qu'es S T, que van a herir en V. // Juanelo Turriano, Veinte y un libros, a. 1605, fol. 214v: El madero D es el que recibe encima de sí el tirante B. Éstos no se an de empalmar, por causa que el trecho no ha de ser más largo de lo que es el madero o los maderos ordinarios.

[IMAGEN] Pseudo-Juanelo Turriano, Los ventiún libros, c. 1605, fol. 214v, fig. 287, letra B. Es el tirante en un puente de madera.

tolva, tolva [del lat. tŭbŭla 'trompetita' (DECH). Pérez Vargas, De re metallica, 1568]. sust. f. Mec. Caja de madera en figura de pirámide inversa, que sirve en los molinos para echar el grano y que vaya cayendo poco a poco en el agujero o garganta de la piedra que lo va moliendo (Terreros).

Pérez Vargas, De re metallica, 1568, fol. 82v: Estos hornos de fuelles unos los hazen y forman a manera de tolva de molino de pan; otros hazen una manga derecha como un cubo de molino, y otros les dan otras formas y hechuras diferentes, a su modo. // Urrea, Vitruvio, Architectura, 1582, fol. 131r: En esta máchina está colgada la tolva que da a las muelas trigo, y bolviéndose, se haze la harina. // Lobato, Notas, c.1585, fol. 36: Las piedras que este molino ha menester, además de piedras y tolva y demás aparejos de moler, son las vigas sobre las que se asienta la cuba y la dicha cuba y puente aliviada, canal y rangua, rodeznos y parahúsos, y todas estas piezas irán aquí pintadas, como se ve, cada cosa por sí, y arcos de hierro.

SIN.: gruenza, tahona $_{2}$.

HOL.: molino.

tonel, tonel [tomado del fr. ant. tonel 'íd.', diminutivo de tonne 'tonel grande' y este del lat. tardío tunna 'íd.'. Lucano de Alfonso X (DECH). Celso, Reportorio universal leyes Castilla, 1553]. sust. m. Cuba grande (DRAE).

Juanelo Turriano, Veinte y un libros, a. 1605, fol. 422v: Y si no hallare corcho, ponga barriles o toneles pequeños, y assirlos con unas sogas, con pesos que tengan firmes los barriles en el suelo. // Ufano, Tratado de la Artillería, 1613, pág. 275: El último puente de la presente figura muestra llanamente cómo sobre toneles o maderamen se puede fabricar un puente ligero para, atrabesado, con él salvamente passar un fosso. // Ufano, Tratado de la Artillería, 1613, pág. 313: Sacará fuera de cada tonel que uviere menester un puñado, aviendo muy bien metido la mano en el medio de la pólvora. 
torcedor, torcedor [de torcer (DECH). Juanelo Turriano, Veinte y un libros, a. 1605]. sust. m. Mec. Pieza que sujeta y dirige el canalón por el que el grano cae desde la tolva hasta la muela de un molino.

Juanelo Turriano, Veinte y un libros, a. 1605, fol. 308v: La caxa farinal es R. La taona es S. Su canalón es V. El torcedor, T. La cítola es X. Donde firma el exe E, es K. Y donde firma el árbol de la muela es L. / / Juanelo Turriano, Veinte y un libros, a. 1605, fol. 308v: La muela que anda es A. La taona, B. El torcedor, C. El canalete es D. La cítola o taravilla es E. La caxa que recoje la arina es F. / / Juanelo Turriano, Veinte y un libros, a. 1605, fol. 309r: Y la taona es M. Y el canalón es N. El torcedor es O. La caxa que recoje la arina es $P$. $Y$ la pala con que se coxe es $Q$.

SIN.: templador 2 .

HOL.: molino.

[IMAGEN] Pseudo-Juanelo Turriano, Los ventiún libros, c. 1605, fol. 308r, fig. 211, letra T.

torneable, torneable [de tornear. Besson, Teatro instrumentos, 1602]. adj. Que se puede tornear o labrar en un torno.

Besson, Teatro instrumentos, 1602, fol. C2v: Torno nuevo y geométrico para reduzir a figura oval qualquier cylindro y piña, con sus ornamentos, de qualquier materia torneable.

FAM.: destornear, entorneado, retornear, torneado, tornear, tornero, tornillo, torno.

torneado, torneado [de tornear. Ferrofino, Descrizión Artillería, 1599]. adj. Labrado en redondo.

Ferrofino, Descrizión Artillería, 1599, fol. 153r: Y començando por las lonchas, las quales serán de madera, torneadas, largas tres palmos y medio, o a lo más una bara, cuyo diámetro o güeco sea como el diámetro de 6 libras. // Juanelo Turriano, Veinte y un libros, a. 1605, fol. 460v: Han de ser de alto ocho palmos, y en la parte de arriba se hagan dos agujeros redondos, que sean iguales, y poner una pieça, que sea redonda, de la una pieça a la otra, la qual sea torneada y que ella pueda jugar muy libremente en los agujeros.

SIN.: entorneado.

FAM.: destornear, entorneado, retornear, torneable, torneado, tornear, tornero, tornillo, torno.

tornear, tornear [de torno. 1330-1343, Juan Ruiz (DECH). Sagredo, Medidas Romano, 1526]. v. tr. Labrar y pulir un objeto en el torno (DRAE).

Sagredo, Medidas Romano, 1526, pág. 31: Y no es de maravillar, pues se lee de dos maestros, que havían nombre Tolo y Theodolo, que tenían artificio para tornear las colunas, assí de piedra como de metal, por grandes que fuessen, y que un solo 
mochacho era suficiente para las rodear y mover. // Besson, Teatro instrumentos, 1602, fol. C2v: Esta manera de tornear que nos propone este torno, no solamente no se ha de tener en poco, pero antes se ha de recebir con ánimo alegre y agradecido. // Juanelo Turriano, Veinte y un libros, a. 1605, fol. 315r: Más digo: que si possible fuesse que se pudiese tornear por la parte de dentro, que sería muy mejor, por causa que no quedarían rayas ni de oyos.

SIN.: entornear.

FAM.: destornear, entorneado, retornear, torneable, torneado, tornero, tornillo, torno.

tornero, tornero [de torno. 1490, Alonso de Palencia (DECH). Anónimo, Leyes lanas e paños, 1538]. sust. $\mathrm{m}$. Persona que tiene por oficio el hacer obras en el torno (DRAE).

Anónimo, Leyes lanas e paños, 1538, fol. 7r: Las personas que filan en ellos tienen necessidad de yr a menudo a los dichos torneros para que les adoben los dichos tornos, e que d'ello reciben mucho daño. // García de Palacio, Instrución náuthica, 1587, fol. 108v: Solíanse usar las bombas a la inglesa, flamenca o italiana, mas la esperiencia ha mostrado que no son tan buenas ni provechosas como las que ahora se usan en nuestra España. Y pues éstas los torneros las hazen y los carpinteros de la nao las entienden, no pondré la traça y forma d'ellas. // Ufano, Tratado de la Artillería, 1613, pág. 397: Y para fabricar y formar los torreones, el artíffice se deve ayudar del tornero, para que de fuerte madera labre bien los canales y agujeros donde se deven encaxar y alojar los petares.

FAM.: destornear, entorneado, retornear, torneable, torneado, tornear, tornillo, torno.

tornillo, tornillo [de torno. 1490, Alonso de Palencia (DECH). Lobato, Notas, a. 1585]. sust. m. Pieza de hierro alargada y en espiral que sirve para unir o armar otras piezas.

Lobato, Notas, a. 1585, fol. 36: Esta cárcel me parece que clavará bien con cuatro tornillos gordos de hierro, porque se desarmen cuando quisieren, sin romper la madera por los agujeros que van señalados. // Besson, Teatro instrumentos, 1602, fol. $\mathrm{A} 4 \mathrm{v}$ : Los dos próximos son las dos partes del tornillo, la una de las quales, que es el machio, llamaremos parte interior; la otra, que es la hembra, y es buelta hazia el mediodía, llamaremos parte exterior. // Juanelo Turriano, Veinte y un libros, a. 1605, fol. 50v: Algunos los hazen unos tornillos de yerro para poderle desarmar y llevarle muy más cómodamente este instrumento.

FAM.: destornear, entorneado, retornear, torneable, torneado, tornear, tornero, torno.

torno, torno [del lat. tornus 'íd.', y este del gr. tópvos 'torno, instrumento de torneador o tornero' derivado de teipeıv 'perforar'. H. 1220-1250, Berceo (DECH). Urrea, Vitruvio, Architectura, 1582]. sust. m. Mec. Máquina consistente en un cilindro dispuesto para girar alrededor de su eje, alrededor del cual se 
enrolla una maroma o cadena, y que, movida a mano o mecánicamente, permite levantar o desplazar pesos.

Urrea, Vitruvio, Architectura, 1582, fol. 7v: En la parte derecha y en la yzquierda, ay unos agujeros redondos por donde las maromas retorcidas se estienden con los tornos y garruchas y cerrojos, las quales maromas no se assen ni las atan sin que hagan ciertos sonidos yguales y conformes al oýdo del artífice. // Lobato, Notas, a. 1585, fol. 27: Y encajada por abajo y por arriba en una canal que estuviese la de abajo honda en el agua, que pudiesen nadar las barcas sin topar abajo en la dicha canal, la cual, para abrir, se tirase de la una torre con las cadenas que fuese menester, de hierro, fuertes y delgadas, con tornos, y de la otra se tirase con otras para la cerrar. // Juanelo Turriano, Veinte y un libros, a. 1605, fol. 143r: Este torno a de estar acomodado en la gata, a las espaldas del hombre que trabaja, y porque no ay lugar más conviniente que es en este lugar.

HIPER.: máquina.

FAM.: destornear, entorneado, retornear, torneable, torneado, tornear, tornero, tornillo.

2 [Sagredo, Medidas Romano, 1526]. sust. m. Mec. Máquina consistente en un cilindro dispuesto para girar alrededor de su eje, que se utiliza para labrar en redondo piezas de madera, metal, hueso, etc.

Sagredo, Medidas Romano, 1526, fol. 31: No menos se halla muchas colunas y muy grandes de metal, con tanta diligencia acabadas, que todos los que las veen juzgan ser labradas al torno. // Loçano, Alberto, Architectura, 1582, pág. 45: Y si era menester hazer algo redondo en el torno, usavan de la haya, moral, terebinto y, principalmente, del box, que es el más macizo de todos y muy fácil de tornear, y del évano para cosas súbtiles; y no menospreciavan el olmo blanco para hazer estatuas y pinturas, ni tampoco el negro, el salce, el carpe, el serval, sahúco y higuera. // Besson, Teatro instrumentos, 1602, fol. C3v: Otro género de torno, nacido d'éste de cerca, para tornear, cavar y ornar, a guisa de huevo, taças y jarros de qualquier materia que sufra hierro.

HIPER.: máquina.

[IMAGEN] Besson, Diego, Teatro de los instrumentos, Horacio Cardon (trad.), 1602, pág. C3r, figura 7.

toro, toro [del lat. taurus 'íd.'. 1102, Oelschl. (DECH). Urrea, Vitruvio, Architectura, 1582]. sust. m. Mec. Leño grueso torneado que forma parte de algunas máquinas, como el ariete.

Urrea, Vitruvio, Architectura, 1582, 143v: Toro: un leño gruesso torneado de la máchina arietaria, en el qual, puesto el ariete, arrojándolo y recogéndolo, haze grandes effectos.

HOL.: ariete.

torre, torre [del lat. tŭrris 'íd.'. Doc. de 929, Oelschl. (DECH). Lobato, Notas, a. 1585]. sust. f. Mec. Cuerpo de un molino de viento.

Lobato, Notas, a. 1585, fol. 20: Un molino de viento, sin velas y sin entruesga, hecho sobre una torre redonda, alta de treinta pies. // Lobato, Notas, a. 1585, fol. 20: Es un 
ingenio poco costoso y muy vistoso y provechoso para la molienda. Y muele en lo bajo, que no ha necesidad de aspas grandes que circunden la torre, porque el viento le toma en la superficie de la torre. // Lobato, Notas, a. 1585, fol. 20: Y no han de ser sino poco más altas del entablamento que por de fuera fuere hecho, el cual ha de estar armado sobre una rueda que cargue sobre la pared de la torre.

HOL.: molino.

[IMAGEN] Lobato, Notas, c. 1585, fol. 20.

tractorio, tractorio [tomado del lat. tractōrŭus, tractōrŭa, tractōrŭum 'que sirve para arrastrar' (OLD). Urrea, Vitruvio, Architectura, 1582]. adj. u. t. c. sust. Dicho de una máquina: que sirve para arrastrar cargas.

Urrea, Vitruvio, Architectura, 1582, fol. 123v: La tercera, es tractoria, para traer arrastrando, y llámase en griego banacison. // Urrea, Vitruvio, Architectura, 1582, fol. 124r: De las máchinas tractorias que en los templos y obras públicas se usan. // Herrera, Institución Academia, 1584, fol. 10v: Y para se hazer versado en la práctica de muchas máchinas y saber qué es máchina, lea a Vitruvio, en el 10 libro, el qual la divide en tres: scansoria, spirital y tractoria, a las quales se ayunta la tormentaria.

HIPER.: máquina.

tramada, tramada [de tramo. Juanelo Turriano, Veinte y un libros, a. 1605]. sust. f. Ingen. Hidrául. arag. Espacio entre dos pilares de un puente.

Juanelo Turriano, Veinte y un libros, a. 1605, fol. 214r: Para saber yr repartiendo los trampos de la puente o tramadas, y quánto ha de aver de un pie al otro, para saberla hazer con orden y concierto y medida. // Juanelo Turriano, Veinte y un libros, a. 1605, fol. 216v: Y más d'esta raçón, que se haze que entran muy menos pies, por causa del hazerse muy más anchas las tramadas, que a lo menos son de cinqüenta palmos de ancho cada tramada. // Juanelo Turriano, Veinte y un libros, a. 1605, fol. 248r: En Italia he visto ríos que trahen tres órdenes de maderos, unos sobre otros, y tres tramadas de largo.

SIN.: ojo ${ }_{1}$, trampo.

HOL.: puente.

trampa, trampa [del onomatopéyico tramp, voz que imita el ruido de un cuerpo pesado en marcha. 1505, PAlc. (DECH). Lobato, Notas, c.1585]. sust. f. Ingen. Hidrául. Compuerta que en los molinos y canales permite la entrada y salida de agua.

Lobato, Notas, c.1585, fol. 26: Y para probar el designio, hizo hacer en Valladolid una galera e hizo romper una pesquera de las aceñas de los frailes de San Benito con unas trampas que se cerraban y abrían cuando llegaba la galera. // Lobato, Notas, c.1585, fol. 26: Y para esto hicimos una cantimplora de madera cuadrada de una vara de cuadrado de unos tablones muy gruesos y anchos, $\mathrm{y}$, hecha, la asentamos en el estanque, al caño de él hacia la Moraleda, y le pusimos dos trampas a la manera de 
llave de molino saetino, y la que recibía era de media vara de ancho, y la que soltaba, de una cuarta de ancho y una tercia de alto. // Lobato, Notas, c.1585, fol. 27: Y si las barcas fuesen de doce de ancho, hacer la trampa de diez y seis pies de ancho, digo la salida, y que desde las torres se pudiese levantar la dicha trampa tanto que las dichas barcas pudiesen salir por abajo.

SIN.: aguatocho.

HOL.: obra hidráulica.

[IMAGEN] Lobato, Notas, c. 1585, fol. 27.

trampo, trampo [del onomatopéyico tramp, que imita el ruido de un cuerpo pesado. 1490, Alonso de Palencia (DECH). Juanelo Turriano, Veinte y un libros, a. 1605]. sust. m. Ingen. Hidrául. Espacio entre dos pilares de un puente.

Juanelo Turriano, Veinte y un libros, a. 1605, fol. 214r: Conviene tomar lo ancho del río para saber quán largo le viene a salir su puente, para saber yr repartiendo los trampos de la puente o tramadas, y quánto ha de aver de un pie al otro. // Juanelo Turriano, Veinte y un libros, a. 1605, fol. 219r: Esta puente es muy differente de las demás que se han hecho, la qual es de un solo trampo o trecho. // Juanelo Turriano, Veinte y un libros, a. 1605, fol. 221r: Alcanzará de un trampo al otro con muy grande avanzamiento de madera, para poder hazer toda cosa y por anchos que ellos sean los trampos.

SIN.: ojo 1 , tramada.

HOL.: puente.

tranco, V. nivel de .

tranco, tranco [de tranca. 1490, Alonso de Palencia (DECH). Juanelo Turriano, Veinte y un libros, a. 1605]. sust. m. Nivel rústico y poco preciso que consta de dos largas patas de madera iguales, de grandes dimensiones y un travesaño horizontal graduado (Glosario Los Ventiún Libros).

Juanelo Turriano, Veinte y un libros, a. 1605, fol. 150v: Quiero advertir que para nivelar en semejantes lugares, si no fuere con nivel de borneo, porque con el tranco no puede servir, por causa de los lugares ásperos y breñosos.

SIN.: nivel de tranco.

HIPER.: instrumento.

trapiche, trapiche [del mozár. * ${ }^{*}$ rapič y este del latín trăpētum o trăpētus 'molino de aceite', que procede del griego tpancıv. 1535, Fernández. de Oviedo, Historia de Indias III, 11 (DECH). Alonso Barba, Arte de los metales, 1640]. sust. m. 
Mec. Potosí. Molino con una piedra grande horizontal que se utiliza para moler metales.

Alonso Barba, Arte de los metales, 1640, fol. 72v: Los que llaman ingenios para moler los metales, son muy sabidos y usados dos modos de reduzirlos a hazerlos a harina con piedras: llaman al uno trapiche y maray al otro. // Alonso Barba, Arte de los metales, 1640, fol. 72v: Consta qualquiera d'ellos de dos piedras grandes y duras, llana la de abaxo, que llaman solera, assentada a nivel sobre el plan de la tierra; en forma de rueda o queso entero la de arriba, en los trapiches que mueven cavalgaduras, como en las atahonas o molinos de azeitunas. // Alonso Barba, Arte de los metales, 1640, fol. 73r: A: tintín; B: barreta; C: agua que entra; D: la lama que sale con el agua; E: cocha o lugar en que se recogen; F: suelo del trapiche o maray quadrado; G: solera redonda; H: boladera de trapiche; I: boladera de maray; K: palo largo con que se mueve.

HIPER.: molino.

trasminar, trasminar [de minar. H. 1630, Paravicino, Autoridades (DECH). Juanelo Turriano, Veinte y un libros, a. 1605]. v. tr. u t. c. intr. u. t. c. prnl. Dicho de un olor, de un líquido, etc.: Penetrar o pasar a través de algo (DRAE).

Juanelo Turriano, Veinte y un libros, a. 1605, fol. 187v: Ésta es la manera del remediar las cisternas que se trasminan. La cisterna que se trasmina es $\mathrm{A}$. Y la greda que se pone entre la cisterna y pared, B. Lo que queda, donde es la C, es el lugar que se a de hinchir de greda. // Juanelo Turriano, Veinte y un libros, a. 1605, fol. 304r: Pues, para conocer si un cubo trasmina, para conocer esta falta conviene que el tal cubo se hincha de agua, y poner dentro un pedaço de çuro que sea grande. Y el çuro se hyrá ad aquella parte donde el cubo se trasmina, y verase el suro yr a la redonda. // Juanelo Turriano, Veinte y un libros, a. 1605, fol. 314v: Lo segundo, que la pared del molino que afronta con la balsa, conviene que sean muy recias, por razón de las saetías, que a lo menos conviene que sea de sinco varas de espasio, y a de ser de cantería. Y conviene que sea muy bien hecha y bien asentada, por razón que no se trasmine la agua por las juntas de los sillares.

SIN.: trasvinar.

FAM.: mina.

trasverter, trasverter [de verter (DECH). Sanctiago, Arte separatoria, 1598]. v. intr. Dicho de un recipiente: exceder de su capacidad hasta derramarse su contenido (DRAE s. v. rebosar).

Sanctiago, Arte separatoria, 1598, fol. 132r: Y desque ayan hecho esto y lo consideraren, verán cómo grangean muchas cosas, porque no serán molestados del humo que resciben de quando las ollas trasvierten en la lumbre por estar muy llenas.

FAM.: divertir, reverter, vertedero, verter, vertiente. 
trasvinar, trasvinar [de vino (DECH). Juanelo Turriano, Veinte y un libros, a. 1605]. prnl. Dicho de un olor, de un líquido, etc.: Penetrar o pasar a través de algo (DRAE s. v. trasminar).

Juanelo Turriano, Veinte y un libros, a. 1605, fol. 279r: Y con esta mistura se suelda qualquier vaso que por las juntas se sale, ansí en frío tratándole. $\mathrm{Y}$ éste sirve para qualquier vaso que tenga licor dentro y que se trasvine. // Juanelo Turriano, Veinte y un libros, a. 1605, fol. 137r: Para hazer un vivero o pesquera, cavarase dentro de la tierra, en tal modo que el agua no se trasvine o trasmine, ni tanpoco calentar, en tal modo que dañe a los pescados, que por causa del demasiado calor. // Juanelo Turriano, Veinte y un libros, a. 1605, fol. 185v: Hásele de hazer una portezuela en lo alto para poder reconozer la cisterna, si se trasvina. Y a de aver en lo bajo d'ella, çerca del suelo, una jeta muy bien assentada para sacar el agua de la cisterna.

SIN.: trasminar.

trespuntas, trespuntas [cmpt. de tres y punta. Besson, Teatro instrumentos, 1602]. sust. f. pl. Mec. Vara larga con cabeza movible en forma de tridente utilizada en algunas máquinas para mover pesos.

Besson, Teatro instrumentos, 1602, fol. F3v: Porque los agujeros que en ella parecen sirven para affermar las trespuntas, que están lexos de su última parte septentrional dos mesuras. // Besson, Teatro instrumentos, 1602, fol. F3v: En las quales trespuntas el pintor ha errado, porque la caveça se havía de hazer movible. // Besson, Teatro instrumentos, 1602, fol. F3v: La cabeça de las trespuntas de hierro, de que antes se ha hablado, por esso no ha de estar fixa en la viga, como ya se ha declarado, sino movible, y que se buelva en derredor d'ella.

HOL.: máquina.

[IMAGEN] Besson, Diego, Teatro de los instrumentos, Horacio Cardon (trad.), 1602, pág. F4r, figura 20.

tripasto, V. trispastos.

tripastos, V. trispastos.

trispasto, $\mathrm{V}$. trispastos.

trispastos, tripasto, tripastos, trispasto, trispastos [tomado del lat. trispāstos 'íd.' y este del griego tpionaotov 'máquina de tres ruedas o poleas' (Bailly). 1708, 
Tosca (DECH). Urrea, Vitruvio, Architectura, 1582]. sust. m. Mec. Máquina compuesta por tres poleas utilizada para elevar pesos.

Urrea, Vitruvio, Architectura, 1582, fol. 143v: Tripastos: máchina de tres rodezuelas.

HIPER.: máquina.

2 [Besson, Teatro instrumentos, 1602]. sust. m. Mec. Máquina para elevar grandes pesos, consistente en un tubo arrollado en hélice alrededor de un cilindro giratorio sobre su eje.

Besson, Teatro instrumentos, 1602, fol. Gv: Y si no bastasse para levantar los arietes, entonces se ha de añadir el mango, con que la rueda mayor se buelve en derredor el caracol infinido, que llaman trispasto. // Besson, Teatro instrumentos, 1602, fol. I2v: Mas a este torno da ayuda el trispasto, puesto al término d'él, a tramontana, y es aquel instrumento que vulgarmente llamamos caracol infinido, cuya figura está en la figura treynta y nueve, buelta hazia el ángulo de ocidente y tramontana. Este tripasto tiene tanta fuerça, que no hay palabras para poder declaralla. / / Besson, Teatro instrumentos, 1602, fol. Pv: Una suerte de máquina no dessemejante a aquélla que antiguamente sacó a luz Archímedes en Çaragoça de Cicilia, quando por obra del trispasto o caracol sin fin, y con sola una mano, metió de la tierra en el mar una nave de grandaria estraña, mirándolo el rey Hierón con una infinidad de pueblo; los quales, juntando en uno todas sus fuerças, no bastaron a hazerlo.

SIN.: caracol infinido, caracol sin fin.

HIPER.: máquina.

[IMAGEN] Besson, Diego, Teatro de los instrumentos, Horacio Cardon (trad.), 1602, pág. G2r, figura 22.

tróchea, V. tróclea.

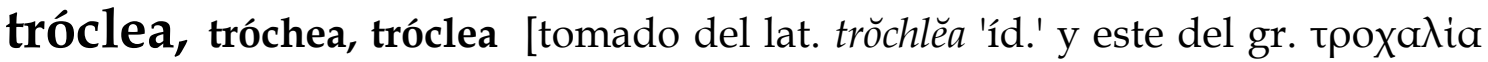
'íd.' (DECH). Urrea, Vitruvio, Architectura, 1582]. sust. f. Mec. Rueda acanalada y móvil alrededor de un eje que se utiliza para subir pesos por medio de una cuerda o maroma.

Urrea, Vitruvio, Architectura, 1582, fol. 125r: En lo alto de la máchina esté la tróclea con una maroma, y desde allí se echen sogas al palo. Y la tróclea que está atada al palo, junto a su rodaxa, se ate una soga y torne a la tróclea que está atada junto a la cabeça de la máchina. // Urrea, Vitruvio, Architectura, 1582, fol. 126r: Después buelven a la tróchea baxa y entran por la parte de dentro, por unas ruedas baxas que tiene; desde allí tornan a la tróclea superior y entran por la puerta de fuera en la de dentro por las ruedas baxas. // García de Céspedes, Instrumentos nuevos, 1606, fol. 44r: También se tiene de aparejar madera para los carros, herrage, poleas, roldanas, trócleas y cuerdas, tornos y leña y otras cosas.

SIN.: carretillo, carrillo, carrucha, carrucho, garrucha, polea, polija, recamo. 
HIPER.: máquina.

ENCICL.: Las que dizen trócleas son a semejança de la letra que los griegos llaman cita, que es la rueda sobre que anda la soga; d'esta manera se sube y se abaxa la carga fácilmente (Urrea, Vitruvio (1582), fol. 125r).

[IMAGEN] Vitruvio, Architectura. Traducción de Lázaro de Velasco, folio 124v, figura 120.

tromba, tromba [del it. tromba 'trompa' (DRAE). Juanelo Turriano, Veinte y un libros, a. 1605]. sust. f. Ingen. Hidrául. Pieza hueca de metal, generalmente cilíndrica, por donde se conducen las aguas.

Juanelo Turriano, Veinte y un libros, a. 1605, fol. 191r: Las trombas de plomo o caños, éssos son menos dañosos que no son las de alambre. // Lechuga, Discurso de la Artillería, 1611, pág. 169: Y esta misma razón es la de las trombas para sacar agua, en las quales, tirando arriba aquel palo, porque se adelgaza el aire que está entre él y el agua, atrae agua y muchas vezes tierra y piedra.

SIN.: cafia, fístula,trompa $a_{2}$ tuba.

HOL.: obra hidráulica.

trompa, trompa, tronpa [de origen onomatopéyico común a todos los romances de Occidente y a lenguas de otras familias. H. 1295, $1^{a}$ Crónica General (DECH). Juanelo Turriano, Veinte y un libros, a. 1605]. sust. f. Tubo por el que se sopla el vidrio.

Juanelo Turriano, Veinte y un libros, a. 1605, fol. . 285r: También se pueden hazer caños de vidre, aunque ellos no pueden ser muy largos ni tampoco muy gruesos. Ellos se pueden hazer arto largos, mas muy delgados, por causa del llevar en el ayre el vidre con aquella trompa con que soplan.

2 [Juanelo Turriano, Veinte y un libros, a. 1605]. sust. f. Ingen. Hidrául. Pieza hueca de metal, generalmente cilíndrica, por donde se conducen las aguas.

Juanelo Turriano, Veinte y un libros, a. 1605, fol. 286r: Libro que enseña cómo se hagan los caños de plomo o fístulas y trompas de metal. // Juanelo Turriano, Veinte y un libros, a. 1605, fol. fol. 286r: Agora fuesen lo caños o fístulas o trompas de plomo como de alambre, como de bronze, o alcaduces de barro, o de qualquier otra materia que ellos fuesen, los llamavan quinaria, por razón del diámetro, el qual era compuesto de cinco partes de un dedo. // Juanelo Turriano, Veinte y un libros, a. 1605, fol. 287v: Y caso que se aya de hazer ángulo, agora se ponga alcaduces o fístulas o trompas, convendrá encaxarlos con la misma piedra, y enbetunarla muy bien la piedra con los caños, y hazer subir la agua en alto.

SIN.: cafia, fístula, tromba 2 , tuba. 
HOL.: obra hidráulica.

tronpa, V. trompa.

tuba, tuba [tomado del lat. tŭba 'íd', 'trompeta'. 1431, Anónimo, Retablo para la iglesia de Santa María (DECH). Ortega, Conpusición Arismética y Geometría, 1512]. sust. f. Ingen. Hidrául. Pieza hueca de metal, generalmente cilíndrica, por donde se conducen las aguas (DRAE).

Ortega, Conpusición Arismética y Geometría, 1512, fol. 107v: Los quales 60 y 5 treinta y dosabos multiplica por la longura de la tuba, como por 6, y allarás que monta $360 \mathrm{y}$ quinze sezenes de un entero, los quales todos son palmos quadrados. // Urrea, Vitruvio, Architectura, 1582, fol. 132r: La fístula o tuba, que es el caño, se tiene de refirmar y levantar en alto.

SIN.: cafia, fístula, tromba, trompa $a_{2}$.

HOL.: obra hidráulica. 
uña, uña [del lat. ŭngŭla 'íd.'. 1112, Oelschl. (DECH). Ufano, Tratado de la Artillería, 1613]. sust. f. Mec. Cada uno de los garfios o puntas corvas con los que están armadas algunas ruedas de máquinas.

Besson, Teatro instrumentos, 1602, fol. M3v: Porque las dos ruedas, armadas tan solamente de una banda con garfios o uñezuelas, con differente movimiento impelen el pandero enclavijado en derredor. // Besson, Teatro instrumentos, 1602, fol. M3v: La qual también haze que la rueda de su exe, armada con uñezuelas, buelva el pandero enclavijado del exe de en medio. // Besson, Teatro instrumentos, 1602, fol. M3v: Assí, dos ruedas dentejadas, por medio del movimiento de la balança, hazen que las ruedas armadas por la metad de uñezuelas las metan y enclavijen entrecambiadamente y por vezes en el pandero enclavijado

HOL.: rueda.

de cabra [Ufano, Tratado de la Artillería, 1613]. comp. sintag. Barra que se utiliza para mover o levantar cosas de mucho peso. 
Ufano, Tratado de la Artillería, 1613, pág. 277: Y con la uña de cabra, designada con la C, encaxándola entre las caxas de la bastida o entre las estacas, a fuerça de braços, desencaxar los clavos de los trabesaños.

SIN.: alzaprima, leva 2 , manuela, palanca ${ }_{1}$, palanga, própalo, uña de puerco.

HIPER.: herramienta.

[IMAGEN] Ufano, Tratado de la Artillería, 1613, pág. 77, fig. 35.

$\sim$ de puerco [Ufano, Tratado de la Artillería, 1613]. comp. sintag. Barra que se utiliza para mover o levantar cosas de mucho peso.

Ufano, Tratado de la Artillería, 1613, pág. 322: Haze fuerça el alçaprime o la uña de puerco para, como se a dicho, levantar en alto la testa o cabeça del afuste con su pieça.

SIN.: alzaprima, leva 2 manuela, palanca, palanga $_{1}$, própalo, uña de cabra.

HIPER.: herramienta.

usillo, V. husillo. 
vacía, V. bacía.

valança, V. balanza.

valançado, V. balanzado.

valançar, V. balanzar. 
valanza, V. balanza.

valanzado, V. balanzado.

valanzar, V. balanzar.

vara, bara, vara [del lat. vara 'travesaño en forma de puente', 'horcón para sostener algo', propiamente femenino del adjetivo varus, $-a,-u m$ 'estevado' 'patizambo'. H. 1250, Libro de Alexandre (DECH). Medina, Regimiento de navegación, 1563]. sust. f. Palo largo y delgado (DRAE).

Medina, Regimiento de navegación, 1563, fol. 40r: Tome dos varas de madera limpia, tan gruessas como el dedo, y sean tan altas que puestas en el suelo derechamente lleguen a ajustar con la vista del hombre, ora sea de estatura alta o baxa. Hechas estas dos varas de un mismo tamaño, júntense por la una parte una con otra con un gonçe subtil, por manera que, aunque estén juntas, se pueda mover cada una por sí. / / Pérez Vargas, De re metallica, 1568, fol. 192v: Y este humor se haze por artificio, compuesto de una mezcla de tierra salada o salitrosa y de aguas, d'esta manera: hágase una cuba grande y hínchase los dos tercios de agua dulce, y luego se eche dentro la tierra salada y se rebuelva y menee con unas pértigas o varas largas rezias. // Juanelo Turriano, Veinte y un libros, a. 1605, fol. 329r: Si se hiziere andar esta máquina con el mismo movimiento de las ruedas, acomodarse en un manil, como va señalado, al costado de la caxa, que tenga una bara que vaya de un manil ha otro de la aspa.

FAM.: varal.

varal, varal [de vara. 1490, Alonso de Palencia (DECH). Escalante, Discurso de la navegación, 1577]. sust. m. Vara muy larga y gruesa (DRAE).

Escalante, Discurso de la navegación, 1577, fol. 60r: Échanlo en unos estanques que forman en el agua a manera de cerco sobre unos varales y red basta de arambre, a do los sustentan hasta que se acabe la pesquería, que dura algunos días. // Loçano, Alberto, Architectura, 1582, pág. 150: A las gallinas dalas en su gallinero un portalejo hazia el Mediodía, cubierto de mucho polvo de ceniza, y sobre él aplicarás los nidales y un varal en que se acojan de noche. // Besson, Teatro instrumentos, 1602, fol. Dv: Hay, empero, más: que dentro de la palanca está fixo y passado un varal derecho y maciço, que hazia mediodía tiene casi un medio cerco, en cuyo medio hay una abertura de la mesma forma.

FAM.: vara. 
varca, $V$. barca.

varniz, V. barniz.

varra, V. barra.

varrena, V. barrena.

varreno, V. barreno.

varro, V. barro.

vaso, basso, baso, vaso, vasso [del lat. vasum 'íd.' (DRAE). Sagredo, Medidas Romano, 1526] sust. $\mathrm{m}$. Recipiente de metal, vidrio $\mathrm{u}$ otra materia que sirve para contener líquidos $\mathrm{u}$ otros materiales.

Sagredo, Medidas Romano, 1526, pág. 74: La cal que se desborona quando la sacan del horno no es tan buena como la que sale entera e liviana, e retiñe quando la tocan, como vaso bien cozido; la qual, quando la mojan, respinga, dando de sí truenos e arrojando en alto las elaciones y vapores de la humidad del agua. / / Besson, Teatro instrumentos, 1602, fol. F2v: Otro género de vaso que sirve casi a lo mesmo que el primero; empero, tiene demás esta particularidad: que por el mesmo agujero por do se vazía, si quieres, puedes hinchirle de diversos liquores, y esto sin que los liquores en alguna manera se mesclen. / / Juanelo Turriano, Veinte y un libros, a. 1605, fol. 341r: La que es de tierra es de la misma calidad que la de la alumbre, que, después de aver sacado la tierra para el caparroso, se haze d'ella unos molones grandes en unas eras que sean llanas, y déxase así amontonada aquesta tierra quatro o cinco o seys meses, y cada quinze días, o cada mes, la rebuelven asta qu'ella se va quemando de sí mesma, que de negra se buelve como coniza. Y quando está bien quemada, entonces se pone dentro de unos vasos de madera, a modo de caxas, y házesele una canal que va de la una caxa a la otra, hasta llegar al cavo. 
2 [Juanelo Turriano, Veinte y un libros, a. 1605]. sust. m. Ingen. Hidrául. Tubo corto, particularmente el que forma, junto a otros, las cañerías.

Juanelo Turriano, Veinte y un libros, a. 1605, fol. 468r: De modo que el passar de la agua por un vaso que sea ancho y que no sea alto, passará más agua que no hará por otro vaso que sea quadrado; passará menos agua, porque la agua ordinariamente se suele ensanchar y no levantarse en alto, y esto es la causa que la agua, de suyo, ella se va ensanchando. Aunque cada uno de los vasos tengan tanta circumferençia el uno como lo otro, no por esso dexará de caber más agua en B que en A. // Juanelo Turriano, Veinte y un libros, a. 1605, fol. 283r: Pues he dado la orden cómo se a de nivelar la tierra para llevar fuentes y otras aguas para el servicio de los pueblos, y también para remediar las necessidades, ansí para bever como para regar, para navegar. Y porque conviene que dé el orden cómo se an de hazer las cequias, las quales sirven de vasos para tener las tales aguas. // Juanelo Turriano, Veinte y un libros, a. 1605, fol. 286v: Vitruvio pone que, estando de cinco en cinco, hazen que no ayan menos de ciento, y da de largaria a todos diez pies, y pónelos por peso su cabida o capacidad. Dize el mesmo Vitruvio que se entiende los nombres de los vasos según su cabida de sus dedos que tiene las planchas de ancho, las de metal, antes que d'ellas se formen d'ellas las fístulas o vasos.

SIN.: caño

HOL.: cañería.

vasso, $\mathrm{V}$. vaso.

veintena, veintena, veyntena, vintena [de veinte. Juanelo Turriano, Veinte y un libros, a. 1605]. sust. f. arag. Caño o fístula de dieciséis quinarias de diámetro. Juanelo Turriano, Veinte y un libros, a. 1605, fol. 286r: Agora fuesen lo caños o fístulas o trompas de plomo como de alambre, como de bronze, o alcaduces de barro, o de qualquier otra materia que ellos fuesen, los llamavan quinaria, por razón del diámetro, el qual era compuesto de cinco partes de un dedo. [...] Y con esta orden se va procediendo con el mismo augmento asta la vintena, la qual contiene en sí diez y seys quinarias.

HIPER.: caño.

vela, vela [del lat. vela, plural de velum 'íd.' (DRAE). Lobato, Notas, a. 1585]. sust. f. Mec. Conjunto o unión de paños o piezas de lona o lienzo fuerte, que se amarran a las aspas de un molino para recibir el viento que las impele.

Lobato, Notas, a. 1585, fol. 20: Un molino de viento, sin velas y sin entruesga, hecho sobre una torre redonda, alta de treinta pies. // Lobato, Notas, a. 1585, fol. 20: Y las velas no tienen que tocarlas, que, cualquiera que quedare al portillón del viento, prenderá y moverá un mástil de olmo grueso y redondo donde ha de estar trabada la 
rueda que vuelve las velas. // Lobato, Notas, a. 1585, fols. 23 y 24: Y esto sea de tablas entablado muy justamente, ya que, cuando el viento ventare, moviendo con velocidad las velas, levante y arroje aquel agua a la tierra que tuviere más cercana.

HOL.: molino de viento.

[IMAGEN] Lobato, Notas, c. 1585, fol. 21.

velocidad, velocidad, veloçidad, velozidad [del lat. vēlōcìtās, -ātis 'íd.'. 1490, Alonso de Palencia (DECH). Falero, Tratado del espera, 1535]. sust. f. Fís. Ligereza o prontitud del movimiento (Autoridades).

Falero, Tratado del espera, 1535, fol. 24v: Y en la Luna porque, por su mucha velocidad, no se siente retrogradación e solamente le dizen tardacurso. // Lobato, Notas, a. 1585, fols. 23 y 24: Ya que, cuando el viento ventare, moviendo con velocidad las velas, levante y arroje aquel agua a la tierra que tuviere más cercana. // Juanelo Turriano, Veinte y un libros, a. 1605, fol. 112v: Bolviendo a la materia empezada, digo que la velocidad de un río es causada del suelo del mismo río, por ser declinado o dependiente y no llaño. Todo río que tendrá el suelo llaño, nunca caminará su agua con mucha velozidad.

FAM.: veloz, velozmente.

veloçidad, $V$. velocidad.

velos, V. veloz.

veloz, velos, veloz [tomado del lat. vělox, vělōcis 'rápido, presto, veloz'. S. XV, Mena, Santillana (DECH). Falero, Tratado del espera, 1535]. adj. Fís. Acelerado, ligero y pronto en el movimiento (DRAE).

Falero, Tratado del espera, 1535, fol. 24r: Como la Luna se mueve en la primera esphera, que es muy menor que la quarta, que es en la que el Sol se mueve, su curso e camino es muy más breve y veloz. // Besson, Teatro instrumentos, 1602, fol. H2v: Vienen a dar en los palos cruzados de tal manera, que la mayor rueda se mueva su poco a poco y, después, más impelida, cobre movimiento más veloz. // Juanelo Turriano, Veinte y un libros, a. 1605, fol. 13r: Y que tengan muy rezíssimas sus corrientes, y que su movimiento es muy rápido y muy veloz, no por esso se hazen calientes ni se nos buelvan calientes gamas.

ANT.: lento.

FAM.: velocidad, velozmente. 
velozidad, V. velocidad.

velozmente, velozmente [de veloz. Chaves, Sacrobosco, Sphera, 1545]. adv. Fís. De manera veloz (DRAE).

Chaves, Sacrobosco, Sphera, 1545, fol. XVr: Halló que las estrellas se avían movido velozmente $\mathrm{y}$, considerando la circulación y calidad del movimiento, dixo que la octava sphera se movía en cada sesenta años. / / Acosta, Historia natural, 1590, pág. 219: El azogue, que por otro nombre se llama argén vivo, como también le nombran los latinos, porque parece plata viva según bulle y anda a unas partes y otras velozmente. // Juanelo Turriano, Veinte y un libros, a. 1605, fol. 351r: Y quanto mayor fuere la rueda, tanto más velozmente andará la rueda, y tanta más agua sacará la clóclea del río o del poço.

ANT.: lentamente.

FAM.: velocidad, veloz.

ventear, ventear [de viento. Lucano de Alfonso X (DECH). Lobato, Notas, a. 1585]. v. intr. Ingen. Hidrául. Dicho del agua: salir de un conducto a un espacio abierto.

Lobato, Notas, a. 1585, fol. 9: Y esta manera es sólo para conservar la altura de su nacimiento, para que no la pierda por la mucha distancia que ha menester la corriente. Hácese a este fin: que por aquellas partes ventea el agua y jamás se romperán los caños.

FAM.: ventícula.

ventícula, ventícula [de viento $(\mathrm{DECH})$. Juanelo Turriano, Veinte y un libros, a. 1605]. sust. f. Mec. Válvula de una bomba constituida por una plancha de cuero que, en algunas máquinas hidráulicas, permite el paso del agua en un sentido y lo impide en el opuesto (Catálogo Felipe II).

Juanelo Turriano, Veinte y un libros, a. 1605, fol. 353v: Y sus ventículas es I M, las quales ventículas han de ser dos planchas de metal, agugeradas a la redonda, por donde pueda entrar la agua. // Juanelo Turriano, Veinte y un libros, a. 1605, fol. 354r: El émbulo es $\mathrm{F}$, que entra dentro en A y llega hasta encima del cuero $\mathrm{B}$, y haze que entre la agua en el caño $H$, que passa por la ventícula I M. / / Juanelo Turriano, Veinte y un libros, a. 1605, fol. 233v: Y estas ventículas han de estar afirmadas en una sola parte, a causa que se puedan levantar quando la mancha atrahe a sí el agua.

HOL.: $\boldsymbol{b o m}_{\boldsymbol{1}} \boldsymbol{a}_{1}$.

FAM.: ventear. 
[IMAGEN] Pseudo-Juanelo Turriano, Los ventiún libros, c. 1605, fol. 353r, fig. 272, letras M e I. Ventículas en una máquina tesíbica.

vernís, V. barniz.

verniz, V. barniz.

vertedero, vertedero [de verter. 1726-1739, Autoridades (DECH). Lobato, Notas, c.1585]. sust. m. Lugar por donde se vierte algo (DRAE).

Lobato, Notas, c.1585, fol. 31: El remedio que tiene el molino de Mondragón es el siguiente: el salto, por la pesquera ser muy alta y tener poco vertedero, y agora perdido como está mientras la casa estuviere en pie, me obligaría a le tornar hacer muy bueno. // Lobato, Notas, c.1585, fol. 31: Y estas cajas y estacas han de entrar en el dicho llano hasta que casi vengan a estar enfrente de la pesquera vieja de Carreño, que vaya siempre al hilo del agua, que en todo el largo tenga doscientos y cincuenta pies de largo, y todo a nivel, porque ha de ser toda vertedero que vierta en la madre vieja.

FAM.: divertir, reverter, trasverter, verter, vertiente.

2 [Lobato, Notas, a. 1585]. sust. m. Ingen. Hidrául. Depósito de aguas sucias o llovedizas.

Lobato, Notas, a. 1585, fol. 32: Y así no reverterá el caño por ninguna parte si no fuere si parare de moler algún molino. Y esto reverterá en el vertedero de ladrillo que está junto al molino que está muy bueno, reforzándole.

SIN.: albañal .

HIPER.: obra hidráulica.

[IMAGEN] Lobato, Notas, c. 1585, fol. 31.

verter, verter, vertir [del lat. vertěre 'girar, hacer girar, dar vuelta', 'derribar', 'cambiar, convertir'. Orígenes del idioma (DECH). Loçano, Alberto, Architectura, 1582]. v. tr. Derramar o vaciar líquidos (DRAE).

Loçano, Alberto, Architectura, 1582, pág. 318: El lago es en tres maneras: uno (que por hablar assí) está firme, que, conteniéndose con tanto, con sus aguas por ninguna parte vierte; // Juanelo Turriano, Veinte y un libros, a. 1605, fol. 284r: En tanto modo, que en estos caños se vierte el agua d'ellos por no estar enbetunados los ladrillos con los caños. // Juanelo Turriano, Veinte y un libros, a. 1605, fol. 352r: Y la quarta cóclea toma la agua en $F$, que es la $G$, y la lleva a vertir en $H$.

FAM.: divertir, reverter, trasverter, vertedero, vertiente. 
vertiente, vertiente [de verter (DECH). Fernández de Enciso, Suma de Geographía, 1530]. sust. u. t. c. m. Declive o sitio por donde corre o puede correr el agua (DRAE).

Fernández de Enciso, Suma de Geographía, 1530, fol. XXIVr: El otro es Duero, en cuyas vertientes entra lo que comúnmente llaman Castilla; la otra es el río Marín, que toma a Galizia. // Girava, Fineo, Geometría práctica, trads., 1553, pág. 103: Sea l’altura dada para medir $\mathrm{EF}$, que baxe dende $\mathrm{F}$ hasta $\mathrm{E}$, pendiente como la vertiente de un tejado. // Juanelo Turriano, Veinte y un libros, a. 1605, fol. 178r: De modo que donde ay la A B es un medio redondo, $\mathrm{y}$ donde ay $\mathrm{C} D$ es otro medio redondo y al rebés, que es convexo. Y lo mismo es F E. Y los dos bocales son $\mathrm{H}$ I. El qual açute es hecho a dos vertientes.

FAM.: divertir, reverter, trasverter, vertedero, verter.

vertir, $V$. verter.

vesque, besque [del cat. vesc y este del lat. v̌sscum 'muérdago'. 1490, Alonso de Palencia (DECH). Juanelo Turriano, Veinte y un libros, a. 1605]. sust. m. arag. Masa hecha con muérdago que se utiliza para cazar pájaros.

Juanelo Turriano, Veinte y un libros, a. 1605, fol. 279r: Ay otro género de betún, el qual se haze de corteza de raýzes de olmo y de la yerba que se haze el besque. Éste se haze picando juntas estas dos cosas, y conviene picarlas mucho.

ENCICL.: El muérdago formaba parte de algunos betunes.

vetumen, $V$. betumen.

vetún, V. betún.

vetunar, $V$. betunar.

veyntena, $\mathrm{V}$. veintena. 
vidre, $\mathrm{V}$. vidrio.

vidriado, vidriado [de vidriar. Arphe, Quilatador de la plata, 1572]. adj. Que tiene un barniz transparente y esplendoroso como el vidrio.

Arphe, Quilatador de la plata, 1572, fol. 38r: Después que aya hervido lo que baste hasta que la redoma se pare amarilla, se tienen unas vasijas vidriadas grandes y llenas de agua dulce. // Álaba, Perfeto capitán, 1590, fol. 97r: Y compuesto todo con azeyte de yemas de huevos en un vaso de tierra vidriado o de vidrio. // Juanelo Turriano, Veinte y un libros, a. 1605, fol. 271r: Puédense hazer muchas lavores, como he dicho, y muchas invenciones de ladrillos vidriados para los suelos.

SIN.: alvidriado 1 .

FAM.: alvidriado, alvidriar, vidriar, vidriero, vidrio.

vidriar, vidriar [de vidrio (DECH). Loçano, Alberto, Architectura, 1582]. v. tr. Dar al barro un género de barniz que tiene la transparencia y el esplendor del vidrio (Autoridades).

Loçano, Alberto, Architectura, 1582, pág. 52: Algunos ay que quieren que los ladrillos se vidrien. / / Juanelo Turriano, Veinte y un libros, a. 1605, fol. 270v: Éstas las envernizan o las vidrian los que las quieren vidriar, y también sirven sin vidriarlas.

FAM.: alvidriado, alvidriar, vidriado, vidriero, vidrio.

vidriero, vidriero [de vidrio (DECH). Pérez Vargas, De re metallica, 1568]. sust. m. Persona que tiene por oficio el trabajar el vidrio y los esmaltes.

Pérez Vargas, De re metallica, 1568, fol. 46r: Los vidrieros y alfahareros se aprovechan y usan d'estos medios minerales. // Loçano, Alberto, Architectura, 1582, pág. 338: Y piensan que viene esso por la copia de los vidrieros, porque cierta cosa es que se limpia el ayre muy ] mucho con los fuegos. // Sanctiago, Arte separatoria, 1598, fol.49v: Y sáquese la malgama y lávese con la dicha agua tibia, trayéndole con una mano de vidro en su moleta de vidro, como los vidrieros muelen los esmaltes.

FAM.: alvidriado, alvidriar, vidriado, vidriar, vidrio.

vidrio, bidrio, vidre, vidrio, vidro [del lat. vittrěum 'objeto de vidrio', derivado de vitrum 'vidrio'. H. 1220-1250, Berceo (DECH). Anónimo, Repertorio tiempos, 1554]. sust. m. Cuerpo liso, diáfano y transparente, formado artificiosamente por la violencia del fuego de arena muy pura y blanca, bien 
lavada o de piedras limpias y relucientes y cenizas de la sosa, entre otros ingredientes (Autoridades).

Anónimo, Repertorio tiempos, 1554, fol. XVIIIv: En los metales, sobre el cobre, alcrevite e hierro, sobre el vidrio y todos los hornos. // Loçano, Alberto, Architectura, 1582, pág. 38: Las cosas que conviene hazer aparejar son éstas (conviene a saber): cal, arena, piedra, materia; item, hierro, cobre, plomo, vidrio, y las semejantes; y, principalmente, officiales que no dexen de ser exercitados, // Juanelo Turriano, Veinte y un libros, a. 1605, fol. 285r: También se pueden hazer caños de vidre, aunque ellos no pueden ser muy largos ni tampoco muy gruesos.

FAM.: alvidriado, alvidriar, vidriado, vidriar, vidriero.

vidro, V. vidrio.

viento, V. molino de .

viga, biga, viga [probablemente del lat. biga 'tronco de dos caballerías que tiran en un carro', 'carro tirado por ese tronco'. H. 1140, Cid (DECH). Urrea, Vitruvio, Architectura, 1582]. sust. f. Mec. Madero largo y grueso que forma parte de algunas máquinas y que, generalmente, se utiliza para sostenerlas.

Urrea, Vitruvio, Architectura, 1582, 140v: Ergata: viga sobre que se assienta la máchina y en que se rebuelve la maroma para subir la carga. // Besson, Teatro instrumentos, 1602, fol. M2v: Hay, más, una viga en igual distancia al exe, en cuyas extremidades están sendas poleas. // Juanelo Turriano, Veinte y un libros, a. 1605, fol. 145v: La armadura es $\mathrm{D}$, que tiene el ergate. En la parte $\mathrm{H} \mathrm{H}$ son dos maderos o vigas hincadas de delante para tener el armadura, que no (FIGURA 111) resvale para delante.

FAM.: envigamiento, envigar.

lagar [Urrea, Vitruvio, Architectura, 1582]. comp. sintag. f. Mec. Madero horizontal de gran tamaño, articulado en uno de sus extremos, que se utiliza en los lagares para exprimir la uva o la aceituna.

Urrea, Vitruvio, Architectura, 1582, fol. 86v: El lagar, si no se torciere con puercas, sino con otros ingenios de madera, la viga lagar no sea menos larga de quarenta pies, porque assí estará el patio desocupado para el que trata el palo o barra del husillo. // Urrea, Vitruvio, Architectura, 1582, fol. 86v: La anchura del lagar no sea menos que de diez y seys pies, porque assí avrá cumplidamente lugar libre y desocupado para 
rebolverse los que entienden en la obra; mas, si fuere necessario que en aquel lugar aya dos vigas lagares, darse han a la anchura veynte y quatro pies.

HOL.: lagar.

vintena, $V$. veintena.

visinfín, visinfín [del fr. vis sans fin 'íd.'. Juanelo Turriano, Veinte y un libros, a. 1605]. sust. f. Mec. Aparato para elevar agua, consistente en un tubo arrollado en hélice alrededor de un cilindro giratorio sobre su eje, oblicuo al horizonte, y cuya base se sumerge en el depósito (DRAE s. v. rosca de Arquímedes).

Juanelo Turriano, Veinte y un libros, a. 1605, fol. 145r: Y muy mejor sería acomodarle la visinfin que ningún otro instrumento, por causa que, aunque el hombre se canse en subir o bajar, puede descansar, que no socorrerá punto la cuerda más de quanto sería moviendo la visinfin.

SIN.: caracol $_{2}$, clea, cóclea, cóclea de Pitágoras.

HIPER.: máquina.

[IMAGEN] Pseudo-Juanelo Turriano, Los ventiún libros, c. 1605, fol. 350v, fig. 268.

vituminoso, V. betuminoso.

vivero, vivero [del lat. vīvārŭum 'semillero', 'criadero de animales acuáticos' (DECH). Juanelo Turriano, Veinte y un libros, c.1605]. sust. m. Ingen. Hidrául. Estanque artificial donde se alimentan los peces para deleite o consumo (Glosario Los ventiún libros s. v. pesquera).

Juanelo Turriano, Veinte y un libros, c.1605, fol. 136v: Pues se a empezado a tractar de los jardines, como cosas de contento y de regalo que son las pesqueras en ellos, o viveros de pescados, los quales son de mucho detenimiento para la vista de los que están un rato holgándose en ello. // Juanelo Turriano, Veinte y un libros, c.1605, fol. 137r: Dévese cavar en estos viveros a los costados, y hazer algunos agujeros para que los pescados tengan un amparo quando sientan algún ruydo. // Juanelo Turriano, Veinte y un libros, c.1605, fol. 137v: Los viveros que se suelen hazer en las partes marítimas y en las partes que son çenosas, se crían muy mejor un género de pescados que no otras, en especial los pescados que son anchos y delgados.

SIN.: pesquera, vivero.

HIPER.: obra hidráulica. 
voca, V. boca.

vocal, V. bocal.

voladera, boladera, voladera [de volar. 1726-1739, Autoridades (DECH). Alonso Barba, Arte de los metales, 1640]. sust. f. Mec. Disco de piedra que se hace girar rápidamente alrededor de un eje y sobre la solera, para moler lo que entre ambas piedras se interpone (DRAE s. v. muela).

Alonso Barba, Arte de los metales, 1640, fol. 72v: Sólo digo que para el presente intento no han de ser las soleras llanas, sino cóncabas, con capacidad bastante para que las voladeras de arriba puedan andar sin estorvo. // Alonso Barba, Arte de los metales, 1640, fol. 73r: F: suelo del trapiche o maray quadrado; G: solera redonda; H: boladera de trapiche; I: boladera de maray; K: palo largo con que se mueve.

SIN.: ruello 2 .

HOL.: molino.

volcar, bolcar [de revolcar. Covarrubias (DECH). Urrea, Vitruvio, Architectura, 1582]. v. tr. Torcer o trastornar algo hacia un lado o totalmente, de modo que caiga o se vierta lo contenido en ello (DRAE).

Urrea, Vitruvio, Architectura, 1582, fol. 126r: Mas tener un solo madero trae este provecho: que quando quisiere, puede bolcar la carga a la mano derecha o yzquierda, por los lados. // Juanelo Turriano, Veinte y un libros, a. 1605, fol. 431v: Y muchas vezes piensa hombre que, por ser la piedra grande y pesada, muy mejor se le puede cargar ençima qualquier peso, y, cargada, buelca luego y causa muy grande daño. // Juanelo Turriano, Veinte y un libros, a. 1605, fol. 451r: Y que, estando colgada esta herrada, con la boca abaxo y el suelo para arriba, y después conviene que se cuelgue un peso en la assa de la herrada, el qual peso sea bastante a hazer descender la herrada dentro de la agua, que no se buelque.

FAM.: revolcar.

voltado, boltado, voltado [de voltar. Besson, Teatro instrumentos, 1602]. adj. Fís. Vuelto, torcido o puesto al revés.

Besson, Teatro instrumentos, 1602, fol. O4v: Como sea que un mesmo caracol interior esté metido en tres exteriores y voltado. / / Juanelo Turriano, Veinte y un libros, a. 1605, fol. 355v: Y en el exe d'esta rueda, Y, se le acomoda un gorrón, el qual está boltado, como lo dibuxaré aquí abaxo para mayor inteligencia de lo que tratamos. 
SIN.: volteado.

FAM.: voltar.

voltar, boltar, voltar [probablemente del fr. volter 'executer une volte' (TLF). Besson, Teatro instrumentos, 1602]. v. tr. u. t. c. prnl. Fís. Dar vueltas a alguien o algo (DRAE s. v. voltear).

Besson, Teatro instrumentos, 1602, fol. F3v: No ha de estar fixa en la viga, como ya se ha declarado, sino movible, y que se buelva en derredor d'ella, a fin que, haviéndose ella de boltar en derredor, se haga libremente y más presto. // Besson, Teatro instrumentos, 1602, fol. O4v: La qual muela, a braços la bueltan dos obreros que empuxan los rayos, de do nace que las fuerças d'esta máquina son totalmente grandíssimas. // Besson, Teatro instrumentos, 1602, fol. O4v: Cuyos agujeros son fabricados a manera de un caracol exterior, para que en ellos pueda voltarse el caracol interior.

SIN.: voltear, volver.

FAM.: voltado.

volteado, bolteado, volteado [de voltear. Pérez Vargas, De re metallica, 1568]. adj. Fís. Vuelto, torcido o puesto al revés.

Pérez Vargas, De re metallica, 1568, fol. 183v: Y de la cubierta sale una sierpe de cobre hueca, o caño retorcido, bolteado, con algunas concavidades. // Urrea, Vitruvio, Architectura, 1582, fol. 13v: Y procurar que las calles de la entrada no estén derechas, sino que estén bolteadas y torcidas; // Arphe, Varia Commensuración, 1585-87, fol. 14r: Gallo es ave muy alegre y de plumas largas y bolteadas en la cola, y la cresta y barvas coloradas; su altura, una quarta.

SIN.: voltado.

FAM.: arrevolver, desarrevolver, desenvolver, envolver, envuelto, revolver, voltear, volver, vuelta.

voltear, boltear, voltear [de vuelta. H. 1580, Fray Luis de León (DECH). Lobato, Notas, a. 1585]. v. tr. Fís. Dar vueltas a alguien o algo (DRAE).

Lobato, Notas, a. 1585, fol. 20: Hasta que quede de 4 ó 5 pies de ancho, y traiga 16 pies de largo, hecho casi en media vuelta, o vaya volteando. // Ufano, Tratado de la Artillería, 1613, pág. 324: Revolbiendo poco a poco el torno del muelle con la manuela de su sigoñal, que se muestra a la parte esterior, así que rebolviendo y bolteando de una a otra parte la rueda del torno y muelle.

SIN.: voltar, volver.

FAM.: arrevolver, desarrevolver, desenvolver, envolver, envuelto, revolver, volteado, volver, vuelta. 
volver, bolver, volver [del lat. vŏlvĕre 'hacer rodar', 'hacer ir y venir', 'enrollar', 'desarrollar'. H. 1140, Cid (DECH). Sagredo, Medidas Romano, 1526]. v. tr. Fís. Dar vueltas a alguien o algo (DRAE s. v. voltear).

Sagredo, Medidas Romano, 1526, pág. 51: Como no pudiessen de allí passar, se tornavan a inclinar y bolver hazia baxo y se enroscavan. // Urrea, Vitruvio, Architectura, 1582, fol. 136r: Y han de estar también templados, que tengan los quicios y agujeros donde las barras traspassadas desembaracen el bolver; de tal manera que, si fuere menester, puedan passar por los arbolillos hazia todas partes. / Collado, Plática Artillería, 1592, fol. 58r: La qual massa ha de quedar en forma quadrada, pero que a la una parte d'ella quede formando aquel cigoñal, que es aquella cabeça que con la letra A está señalada, la qual sirve para, con una cigüeña de hierro, bolverla a una parte y a la otra, como se bolvería una barrena.

SIN.: voltar, voltear.

FAM.: arrevolver, desarrevolver, desenvolver, envolver, envuelto, revolver, volteado, voltear, vuelta.

vuelta, buelta, vuelta [del lat. *vŏlŭta 'íd.' (DRAE). Sagredo, Medidas Romano, 1526]. sust. f. Fís. Movimiento de una cosa alrededor de un punto, o girando sobre sí misma, hasta invertir su posición primera, o hasta recobrarla de nuevo (DRAE).

Urrea, Vitruvio, Architectura, 1582, fol. 127v: Y cierto, ni sin la rotundación, el movimiento del porrecto, ni sin el porrecto, pueden levantar la carga las bueltas del instrumento para rodar. // Lobato, Notas, a. 1585, fol. 26: Y después, pasando por encima de cierta parte de la barranca la vuelta de la cantimplora, y que vaciase el otro brazo en una rueda de molino que luego moviese. // Juanelo Turriano, Veinte y un libros, a. 1605, fol. 306r: La saetía L es muy mejor que no es la F, por razón que yere más derechamente en la buelta de la álaba N, y salva muy maravillosamente el canto del rodete $\mathrm{M}$ en $\mathrm{P}$.

FAM.: arrevolver, desarrevolver, desenvolver, envolver, envuelto, revolver, volteado, voltear, volver.

dar $\sim$ s [Fernández de Enciso, Suma de Geographía, 1530]. loc. v. Fís. Hacer que algo tome un movimiento circular (Terreros).

Lobato, Notas, a. 1585, fol. 15: Y ocupará menos casa o lugar, y vendrá a dar la piedra ochenta vueltas mientras el hombre diere una vuelta a la grúa. // Besson, Teatro instrumentos, 1602, fol. C4v: Y assí el caracol, que impelía antes al instrumento, buelve atrás entonces, solamente empuxándolo quando da bueltas el cylindro, y entonces, finalmente, retirándolo quando él se desembuelve. // Juanelo Turriano, Veinte y un libros, a. 1605, fol. 77v: Porque en el azequia, quándo se ensancha, quándo se estrecha, quándo da bueltas, que todas estas cosas causan detención. 
xaraýz, V. jaraíz.

xardín, V. jardín.

xardinero, V. jardinero.

xeta, V. jeta. 
xunta, V. junta. 
ydraula, V. hidraula.

ydráulico, V. hidráulico.

ynbentibo, $V$. inventivo.

ynbentor, V. inventor. 
ynchir, V. henchir.

yndustriar, V. industriar.

yngeniero, V. ingeniero.

ynprimir, V. imprimir.

ynstrumento, V. instrumento.

ynventiva, $V$. inventiva.

ynventor, $\mathrm{V}$. inventor.

ystrumento, V. instrumento. 
yunque, yunque [del ant. iuncue 'íd.', procedente, con probabilidad, de un lat. vg. incude y éste del lat. ı̌ncūs, -ūdis 'íd.' (DECH). Aurel, Arithmética algebrática, 1552]. sust. u. t. c. f. Metal. Prisma de hierro acerado, de sección cuadrada, a veces con punta en uno de los lados, encajado en un tajo de madera fuerte, que utiliza el herrero para trabajar a martillo los metales.

Aurel, Arithmética algebrática, 1552, fol. 15v: Passando un día por una herrería (no sin inspiración buena), adonde se fabricava cierta obra con artificio de 4 martillos, vio el harmonía y oyó el sonido que cada uno de los quatro martillos por causa de la yunque en el ayre sonava. // Besson, Teatro instrumentos, 1602, fol. D3v: Una máquina, la qual deve seguirse tras la precedente, no solamente por su novedad, pero ahún por su excelencia, para mover sobre una yunque un tan grande martillo con fatiga de dos hombres, que no harías más con cavallos o con agua. // Juanelo Turriano, Veinte y un libros, a. 1605, fol. 374v: Entiéndese esto fáçilmente sacando exemplo del herir de los herreros, que si la yunque es grande y pesada, suffre muy bien los golpes de los martillos, aunque grandes y pesados; pero si es pequeña y ligera, con pocos golpes salta y se mueve a una parte y otra.

SIN.: ayunque.

HIPER.: instrumento. 
zaborra, çaborra [del lat. săbŭrra 'lastre' (DECH). Juanelo Turriano, Veinte y un libros, a. 1605]. sust. f. arag. Piedra pequeña, sin labrar (DECH).

Juanelo Turriano, Veinte y un libros, a. 1605, fol. 304v: Después de aver hecho esto, conviene hazer otro suelo, hecho de çaborra con cal, y yrle maceando, como se hizo la lechada, muy ygualmente. // Juanelo Turriano, Veinte y un libros, a. 1605, fol. 304v: El primer suelo de la lechada conviene que sea de grueso un palmo y medio, y el suelo de la çaborra conviene que sea de grueso dos palmos.

zafariche, çaariche [del ár. șahrîy 'balsa, estanque'. 916, Doc. leonés (DECH). Juanelo Turriano, Veinte y un libros, c.1605]. sust. m. Ingen. Hidrául. arag. Estanque (Autoridades s. v. zafareche).

Juanelo Turriano, Veinte y un libros, c.1605, fol. 274v: Betún para enbetunar xetas de fuentes o de çaariches que sea de agua.

FAM.: jaraíz.

zahorí, çaorí [del hispano-ár. *zuharî 'geomántico', 'zahorí', y este del ár. clás. zuharī 'geomántico', der. de az-zuhara 'Venus' (DRAE). Juanelo Turriano, Veinte y 
un libros, c.1605]. sust. m. Persona que tiene por oficio el buscar aguas subterráneas.

Juanelo Turriano, Veinte y un libros, c.1605, fol. 36r: Sólo para [que] los que tractan o hazen professión d'esta materia de llevar aguas, que el vulgo llama fontaneros o çaorises, tubiesen alguna notiçia de las calidades de las aguas, y para que sepan discernir y hazer eleción de la buena a la mala.

zanja, çanja, zanja [de origen incierto igual que el port. sanja (DECH). Sagredo, Medidas Romano, 1526]. sust. f. Excavación larga y estrecha que se hace en la tierra para echar los cimientos, conducir las aguas, defender los sembrados o cosas semejantes (DRAE).

Sagredo, Medidas Romano, 1526, pág. 71: Las molduras de los embasamentos y çanjas, que se ponen alderredor de los edificios, no quieren ser muy tendidas, ni de mucha halda. // Loçano, Alberto, Architectura, 1582, pág. 319: La razón de guiar al agua, en dos maneras: porque, o se deriva por çanja de agua, o se recoge por arcaduzes. // García de Céspedes, Instrumentos nuevos, 1606, fol. 38r: Esto assí conocido, alrededor del nacimiento de la agua, se hará una çanja, y no muy honda, porque suele acontecer, si se ahondasse mucho, perderse la agua.

zaranda, çaranda [del hispano-ár. sarand y este del persa sarand 'cedazo'. Med. S. XI (DRAE). Pérez Vargas, De re metallica, 1568]. sust. f. Especie de criba grande que se utiliza para cribar la paja.

Pérez Vargas, De re metallica, 1568, fol. 79v: Pero estas lagunas donde se lava el oro, o son horadadas a manera de criva o çaranda, para que el oro salga por los agujeros y el metal grave con la arena menuda. // Pérez Vargas, De re metallica, 1568, fol. 80r: Y el arena menuda y oro cae en la canal por los agujeros de la capa y las piedras y gijas gruessas se quedan en la caxa, que es como criva o çaranda. // Collado, Plática Artillería, 1592, fol. 91v: Primeramente, harás una buena provisión de hachas, açadas, palas de hierro, çarandas o crivas grandes hechas de mimbres o de cuerdas de cáñamo o de esparto, maças grandes de madera y pisones de enzina.

HIPER.: herramienta.

zatara, çatara, zatara [probablemente del hispano-ár. hatțára, 'pontón, pasarela'. 1611 (DRAE). Collado, Plática Artillería, 1592]. sust. f. Balsa, especie de plancha formada por maderos ensamblados, que se emplea para navegar o transportar cosas por agua, especialmente por los ríos (Diccionario Histórico s. v. almadía).

Collado, Plática Artillería, 1592, fol. 89r: Acostumbraron otros de passar las aguas de corriente rápida con almadías, que assí se llaman una composición de maderos muy gruessos, encadenados los unos con los otros y sobre ellos pueden hir muchos soldados, a la qual almadía llaman zátara en Italia.

SIN.: almadía 2. 
2 [Juanelo Turriano, Veinte y un libros, a. 1605]. Conjunto de maderos ensamblados dispuestos a la orilla de los ríos, utilizado por los tintoreros para sacar allí el tinte de los paños.

Juanelo Turriano, Veinte y un libros, a. 1605, fol. 338r: El suelo d'esta çatara es D. Los que lavan el paño son E F, y el paño, G, que lavan. La $\mathrm{H}$ es otra çatara hecha de tablas enclavadas encima de dos medias tablas. // Juanelo Turriano, Veinte y un libros, a. 1605, fol. 338v: Y eso sirve para acabar de sacar del paño la tintura, porque ésa, en aviendo peso encima de la çatara $\mathrm{H}$, luego se unde dentro de la agua, aunque no del todo. // Juanelo Turriano, Veinte y un libros, a. 1605, fol. 338v: Mas que los hombres que toman el paño, cogido de manera que, dándole con unas barras muy largas al paño, ansí, alternativamente, quándo [el uno] y quándo el otro, hasta que le han sacado afuera, todo, de la çatara.

zedaço, V. cedazo.

zerner, V. cerner.

zerrajero, V. cerrajero.

zinzel, V. cincel.

zivilla, V. cibilla.

zulacado, çulacado [de zulacar (DECH). Pérez Vargas, De re metallica, 1568]. adj. Untado o cubierto con zulaque.

Pérez Vargas, De re metallica, 1568, fol. 184r: Y en lo alto de la sierpe se ponga el alambique çulacado y su recipiente, d'esta forma: Suelen con lienços mojados en agua fría humedecer esta sierpe, la qual deve estar muy bien soldada. 
zulacar, çulacar [de zulaque (DECH). Pérez Vargas, De re metallica, 1568]. v. tr. Untar o cubrir con zulaque (DRAE).

Pérez Vargas, De re metallica, 1568, fol. 183v: El agua de vida, o agua ardiente y quinta essentia, se destila del vino, el qual se echa en un vaso de cobre estañado y el vaso se cubre y çulaca. // Pérez Vargas, De re metallica, 1568, fol. 198r: Dévese por dedentro çulacar muy bien, porque el agua no se salga, con un çulaque hecho de cal reziente apagada en vino, mezclada con clara de huevos, escama de hierro molida, y azeyte y algodón.

FAM.: zulacado, zulaque.

zulaque, çulaque, zulaque [del hispano-ár. suláqa 'íd.', derivado de salaqa 'cocer, hacer hervir', y este del griego бuג入oyń 'colección'. 1505, PAlc. (DRAE). Pérez Vargas, De re metallica, 1568]. sust. m. Ingen. Hidrául. Pasta hecha con estopa, cal, aceite, escorias, vidrios molidos u otros materiales, que se utiliza para tapar las juntas de los arcaduces en las cañerías de aguas y para otras obras hidráulicas (DRAE).

Pérez Vargas, De re metallica, 1568, fol. 186r: Es también çulaque estremado cal y enxundia de puerco, o de pez, y clara de huevo y estopas. // Rojas, Teórica fortificación, 1598, fol. 84v: Y si se ofreciere algún arroyo o río, se harán alcantarillas o puentes conforme el sitio lo pidiere, guardando en todo la buena prática que se ha de tener en hazer el zulaque para juntar los caños, hecho de cal biva, y azeite y estopa bien picada, y muy majada y maceada con pisones, que, por no detenerme más, me remito en lo que falta al curioso artífice. // García de Céspedes, Instrumentos nuevos, 1606, fol. 41v: Estos caños se tienen de juntar con un çulaque, que se hace de cal y azeyte, y si el azeyte fuere de linaza será mejor, y estopas picadas.

SIN.: $\boldsymbol{b e t u ́ n}_{2}$.

HOL.: obra hidráulica.

FAM.: zulacado, zulacar. 


\section{SELECCIÓN DE IMÁGENES}

En este elenco de imágenes no vamos a hallar todas aquellas a las que hemos hecho referencia en el glosario, aunque sí que encontraremos la mayoría de estas. Esto se debe fundamentalmente a que Los Ventiún Libros de los Ingenios y Máquinas, texto del que hemos extraído la porción más significativa, es un códice que contiene una gran compilación de dibujos y, pese a que los consideramos de gran interés en lo que se refiere a nuestro trabajo lexicográfico, sería imposible aglutinar todos aquí. En cualquier caso, el lector podrá buscar la referencia correspondiente en el propio texto o en la edición de imágenes que existe en la edición del DICTER en la red.

Las imágenes que hemos recopilado son las que aparecen en el glosario como referencia a los siguientes términos que aparecen a continuación:

Acequia $1_{1}$

Acequia $_{2}$

Aguaducto

Aguatocho

Aja

Álabe

Alambor

Albardón

Aliviador

Aljibe

Almenara

Anadija 
Ananilla

Ánima

Ánima de la cóclea

Anoria

Antepecho

Árbol

Arcaduz

Arco

Arista

Armadura

Armazón

Asno

Aspa

Atanor

Azada

Azud

Azuela

Bacía

Badil

Balanza3

Balaustre

Balsa 
Baños

Barrena

Boca

Bomba2

Botana2

Burato

Caballo

Cabria

Cabrilla

Caja farinal

Cajal

Canal$_{1}$

$\mathrm{Canal}_{3}$

Canalete

Canalón

Canalote

Cantimplora

Cañal$_{2}$

Caldera

Cantimplora

Caño (cuadrado)

Capirote 
Caracol infinido

Cárcel

Carretón

Carrucha

Cequia

Cernedor

Cibilla

Cigoñal

Cigüeña

Cisterna

Cítola

Cóclea de Pitágoras

Corazón

Corbate

Cuba2

Cubete

Cubo

Cuchara

Desaguadero

Eje

Enjeta

Entruesga 
Escurridero

Espiradero

Estral

Fíbula

Gata

Gaula

Gavia

Grúa 1

Grúa2

Guijo

Harnero

Herrada

Holivela

Langosta

Levador

Libra

Linterna

Majadero

Manil

Mano

Maripuente

Mástil 
Mazo

Modiolo

Molino batán

Molino de balsa

Molino de balsa y cubo

Molino de barcas

Molino de canal

Molino de contrapesos

Molino de grúa

Molino de mano

Molino de marea

Molino de pasaje

Molino de regolfo

Molino de sangre

Molino de tahona

Molino de viento

Molino del aceite

Muela

Muelle

Nanilla

Noria

Nivel de agua 
Nivelador

Palanca

Partidero

Partidor

Pesquera2

Peso

Pico

Pie

Pierna

Pila

Pozal

Própalo

Puente

Rebotante

Rodaja

Rodete

Rodezno

Rueda

Rueda cerrada

Rueda timpanada

Ruello

Saetía 
Saetín

Suelo

Tahona

Tarabilla

Templador

Tesíbica

Tirante

Torcedor

Torno2

Torre

Trampa

Trespuntas

Uña de cabra

Vela

Ventícula

Vertedero

Para facilitar la búsqueda de las imágenes a partir de las referencias del glosario, las hemos colocado, en primer lugar, de acuerdo con el texto en el que aparecen recogidas, teniendo en cuenta el orden de estos que señalamos a continuación:

Notas (c. 1585) de Francisco Lobato

Los Ventiún Libros de los Ingenios y Máquinas de Juanelo (c. 1605) del Pseudo.Juanelo Turriano. 
Teatro de los instrumentos (1602) de Jacques Besson, traducido por Horacio Cardon.

Dentro de la selección de imágenes de cada texto, incorporamos estas por orden de figura o del folio o página. Son bastantes las imágenes que, solas, hacen referencia a varios términos del glosario; por otra parte, también hay imágenes que contienen, en el texto que se adjunta a estas, términos que no hemos incluido en nuestro glosario porque no los hemos considerado imprescindibles. Sin embargo, estos términos sí que aparecerán aquí, puesto que acompañaban a la imagen en la obra correspondiente. En los casos en los que nos ha sido posible, hemos añadido una explicación respecto a lo que representa toda la imagen en conjunto. 
Folio 9: arcaduz, atanor.

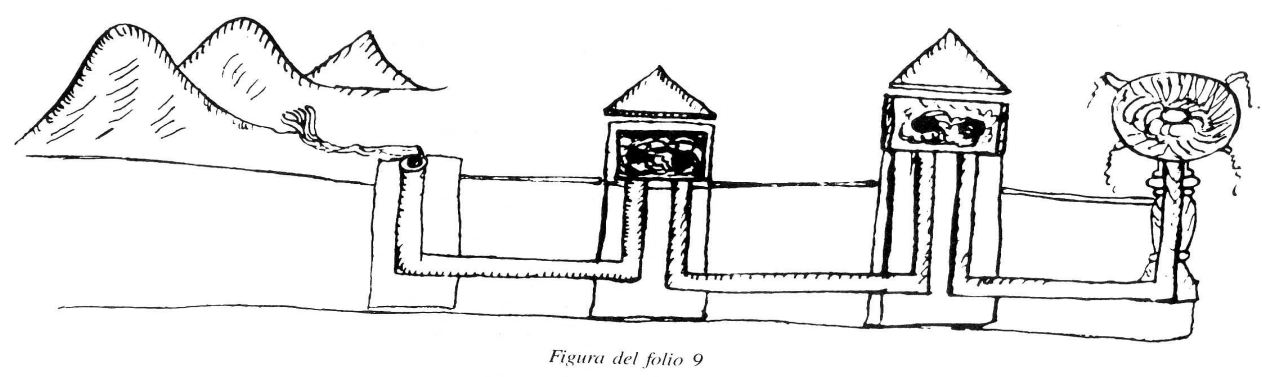

Folio 10: molino de marea

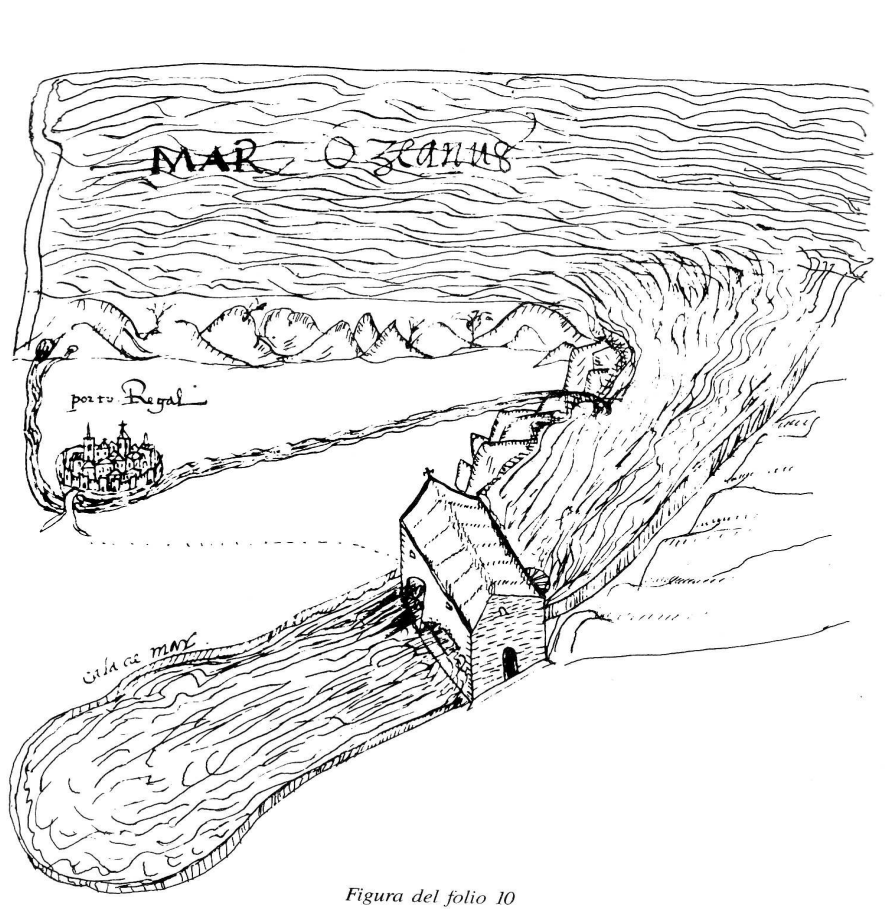


Folio 11: pesquera 2 .

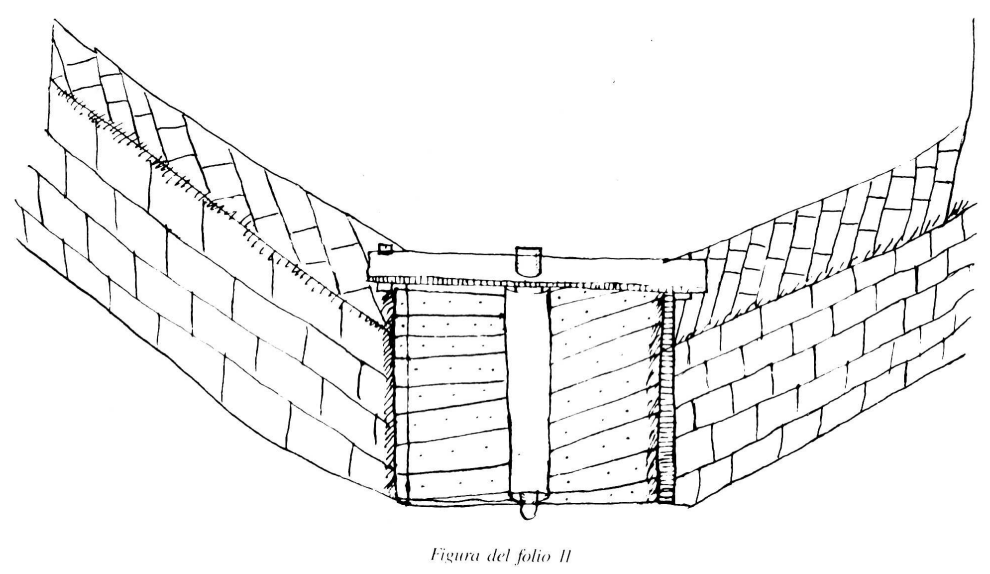

Folio 14: molino de canal.

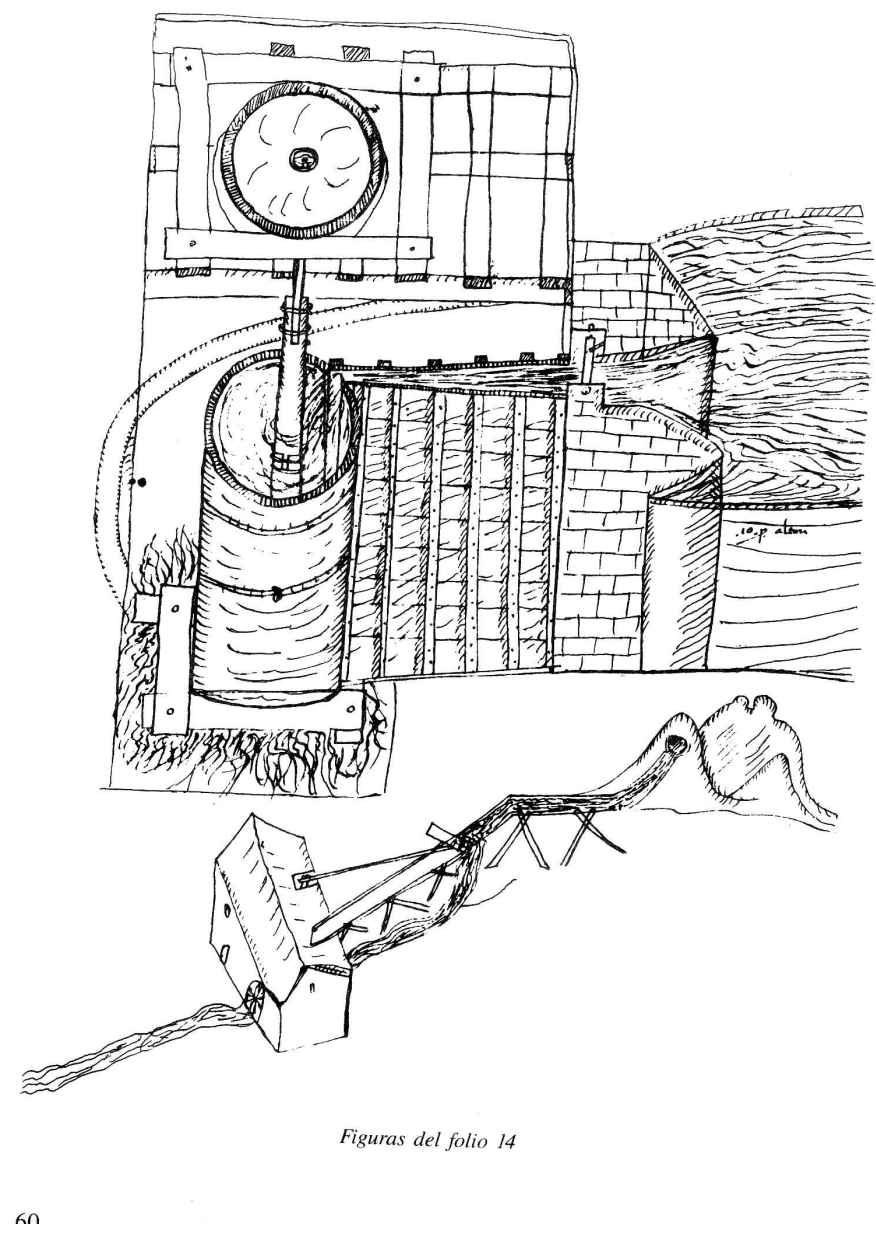


Folio 15: entruesga, grúa 2, guijo, molino de grúa.
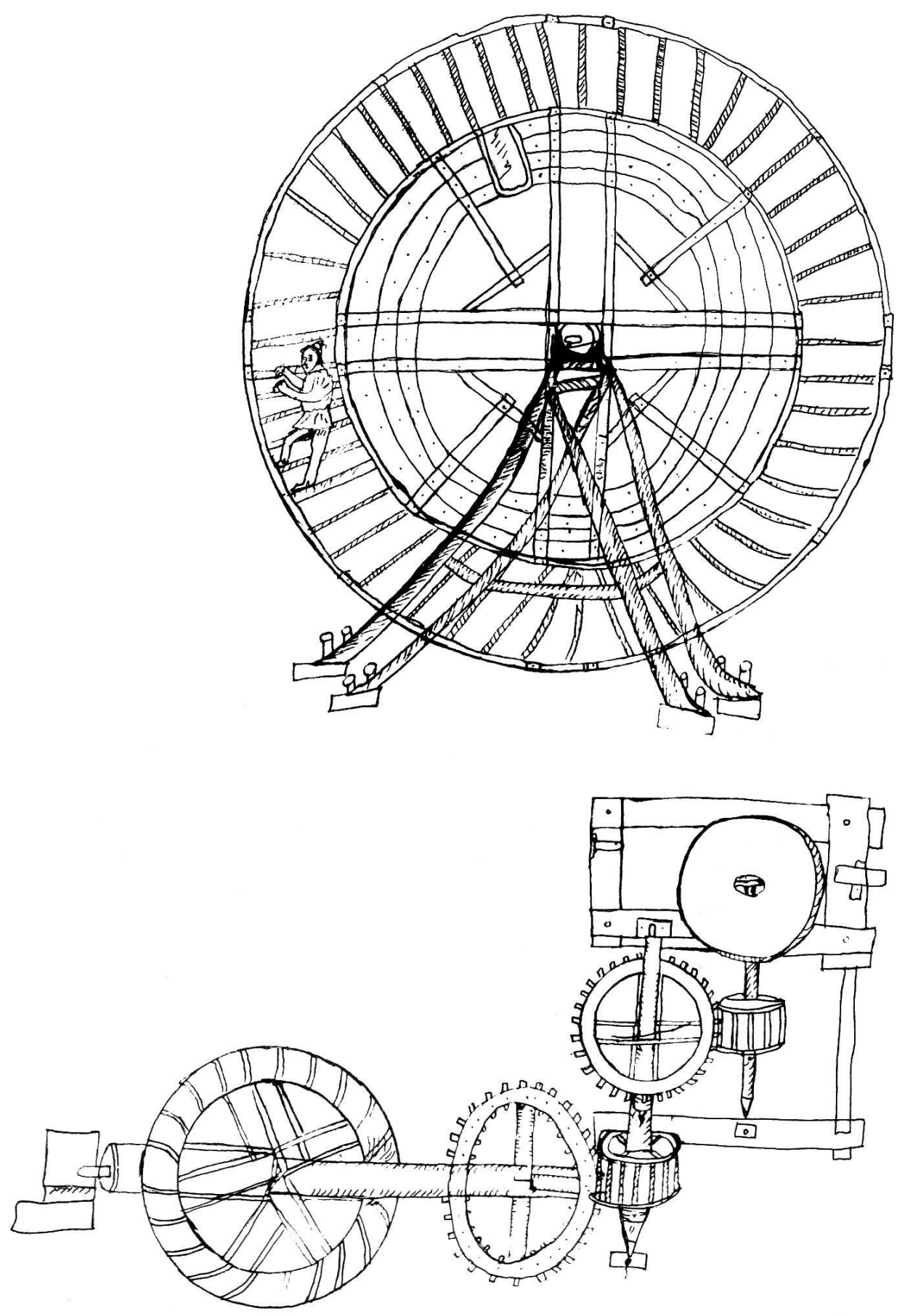

Figuras del folio 15 
Folio 16: cuchara, molino de balsa.

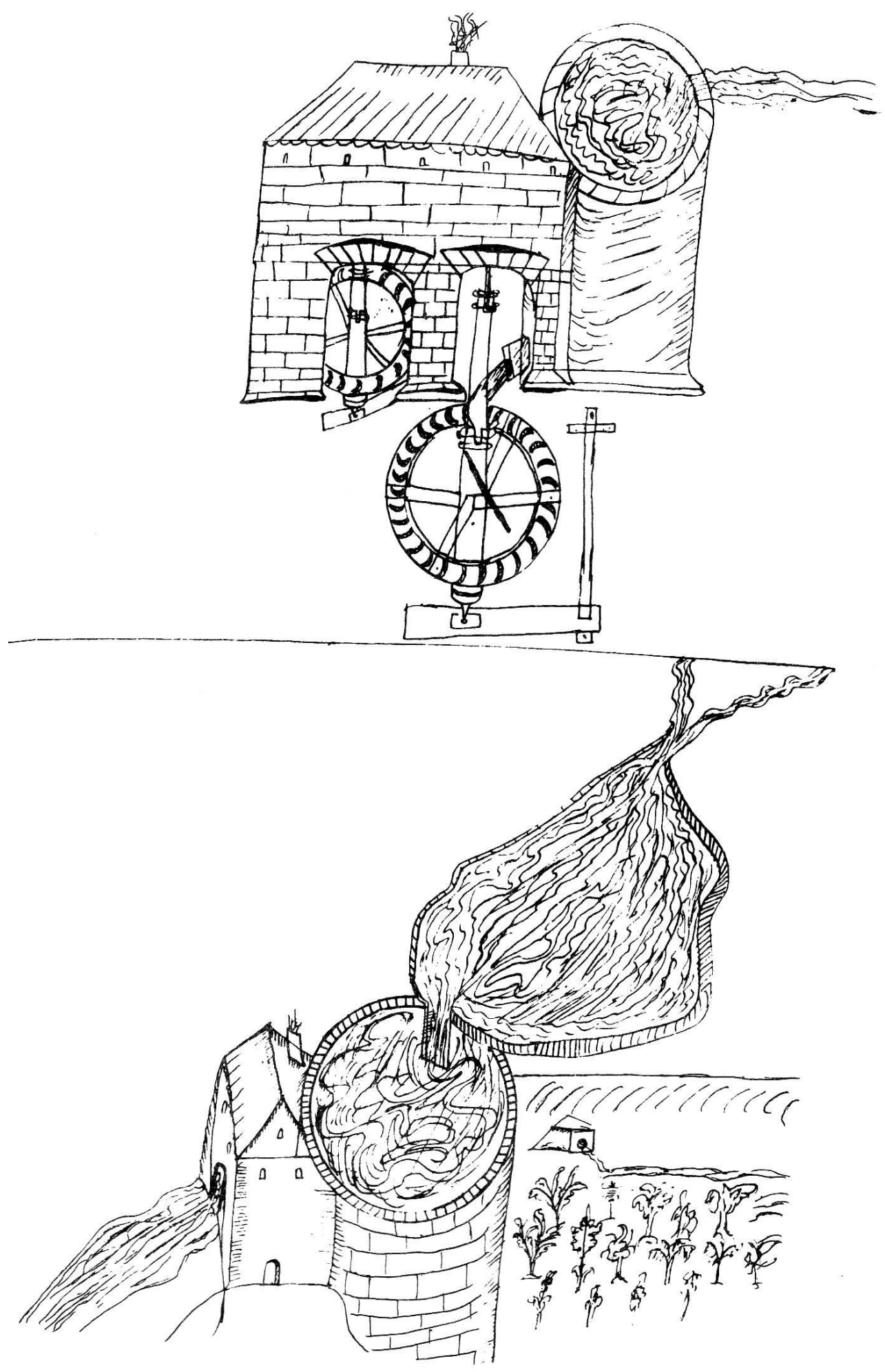

Figuras del folio 16 
Folio 17: saetín.

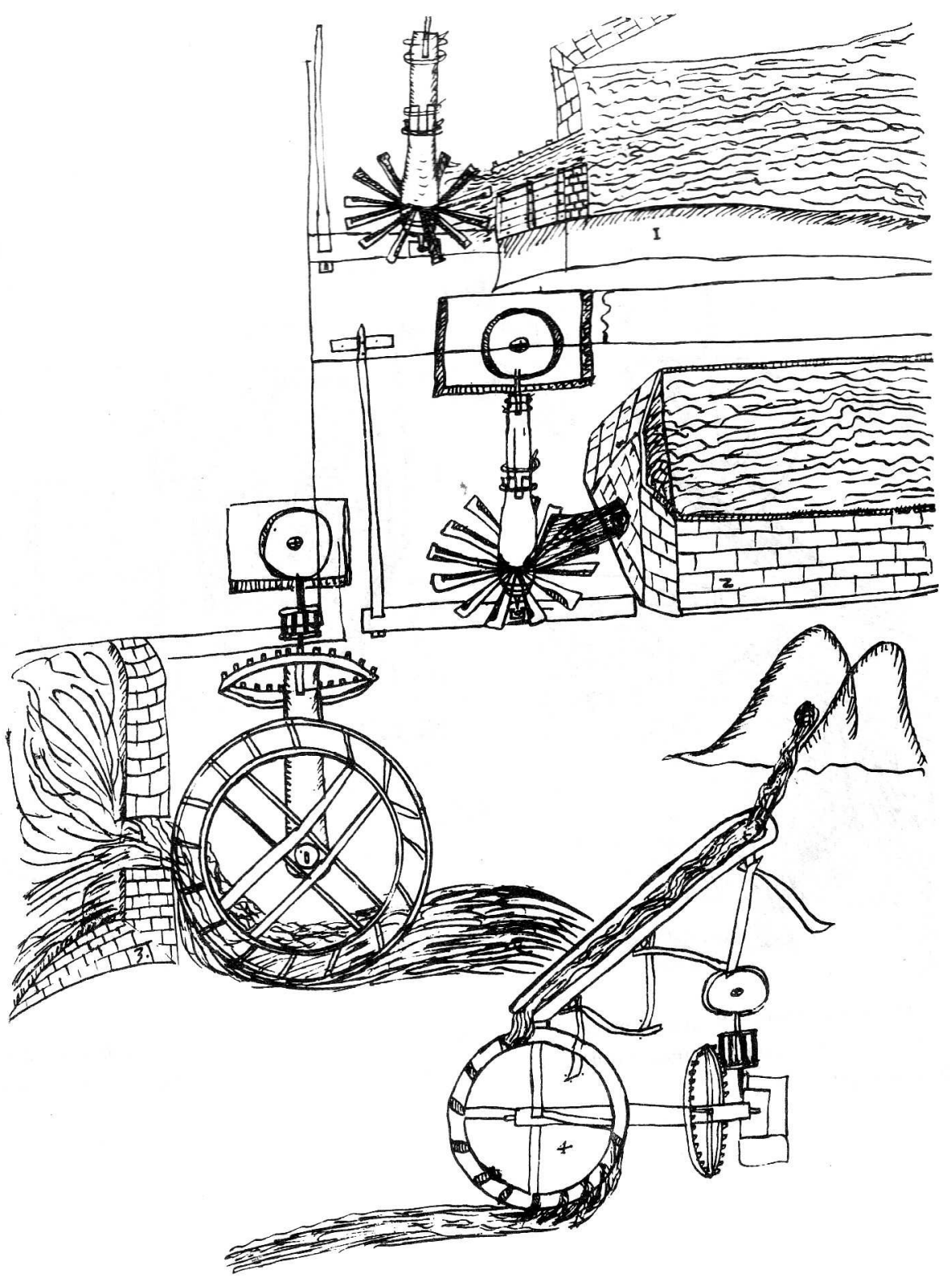

Figuras del folio 17 
Folio 18: molino de pasaje, rodezno.

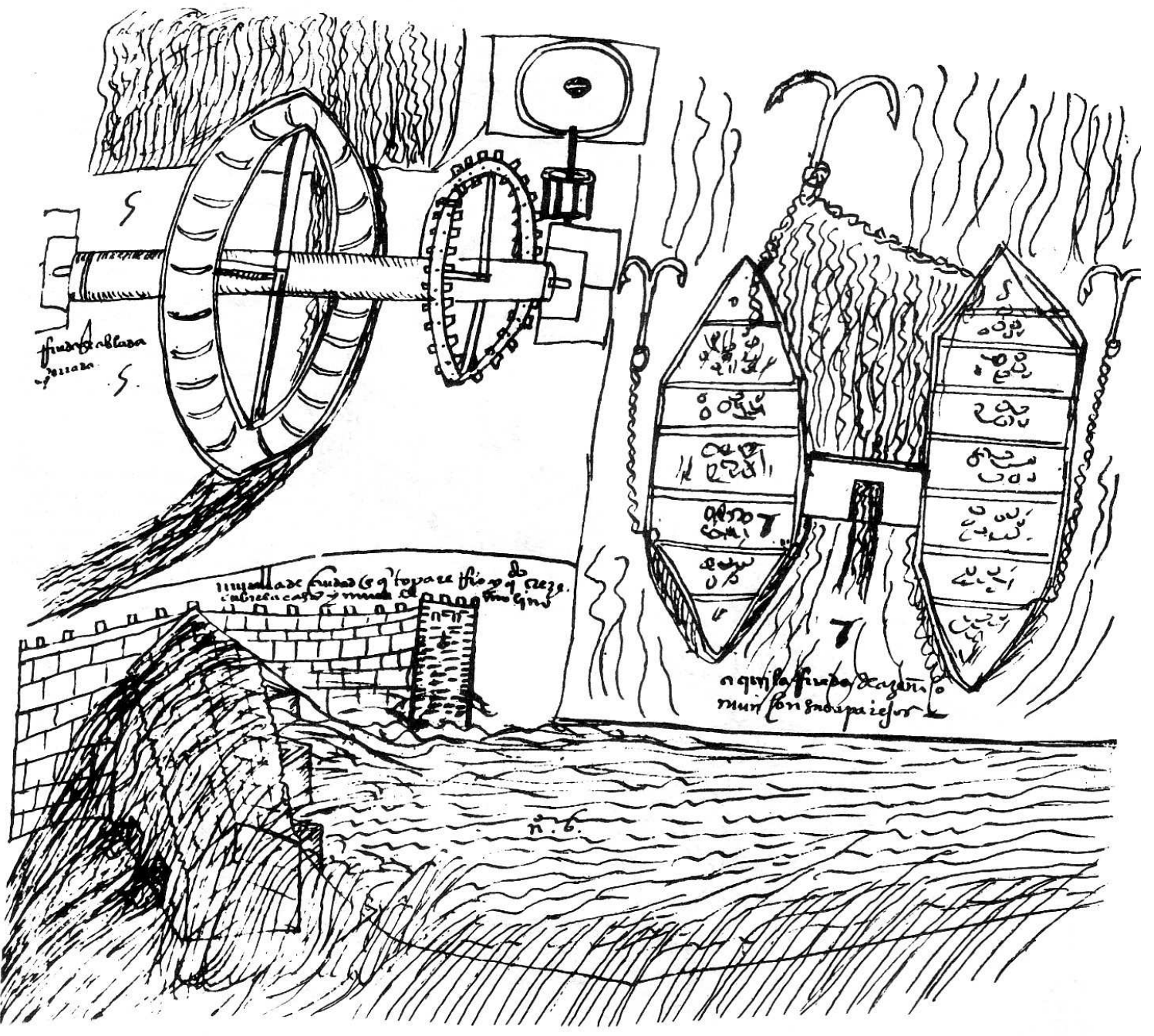


Folio 19: aspa, balaustre, cubo, torre.

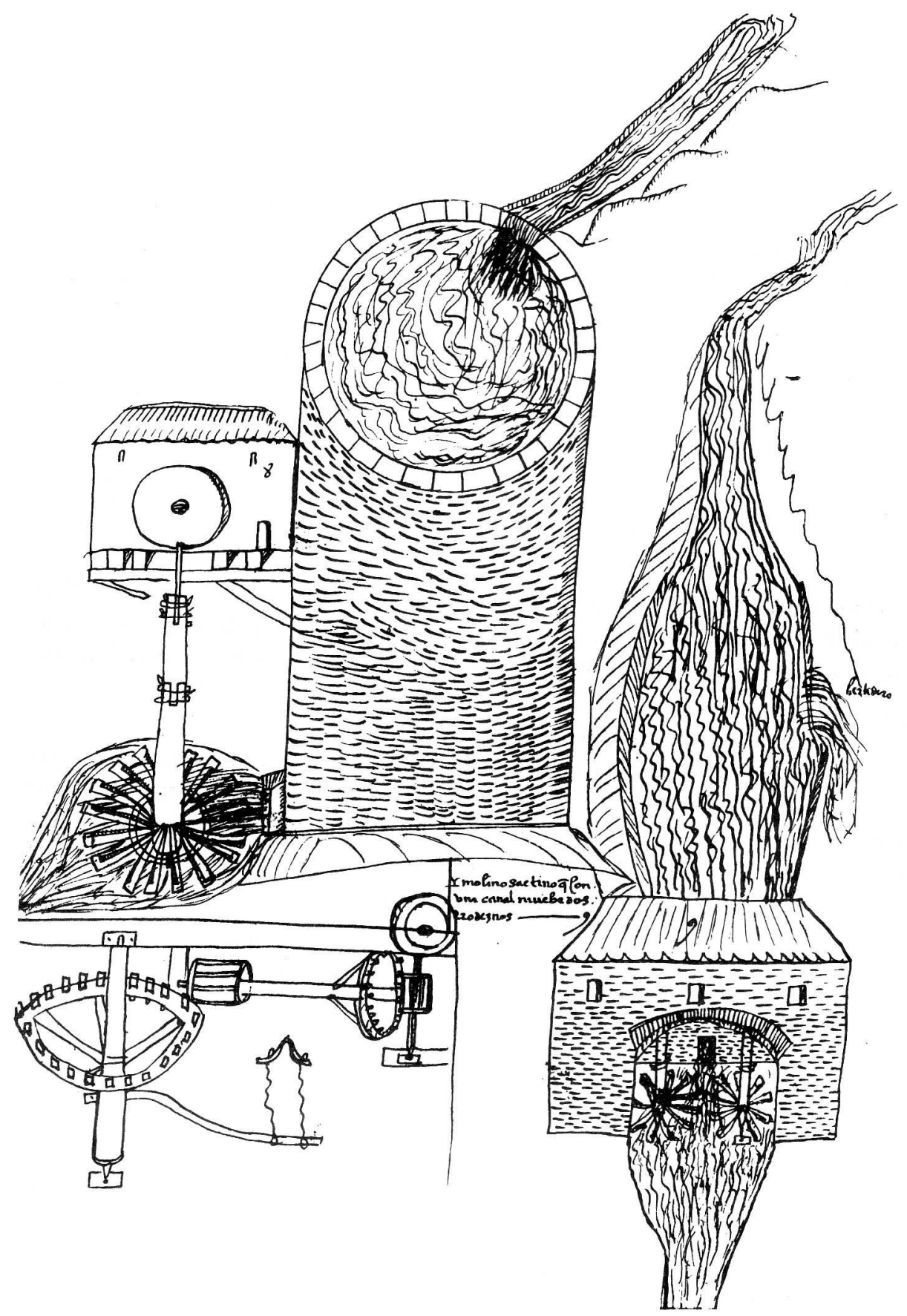


Folio 20: aspa ${ }_{2}$, capirote, vela.

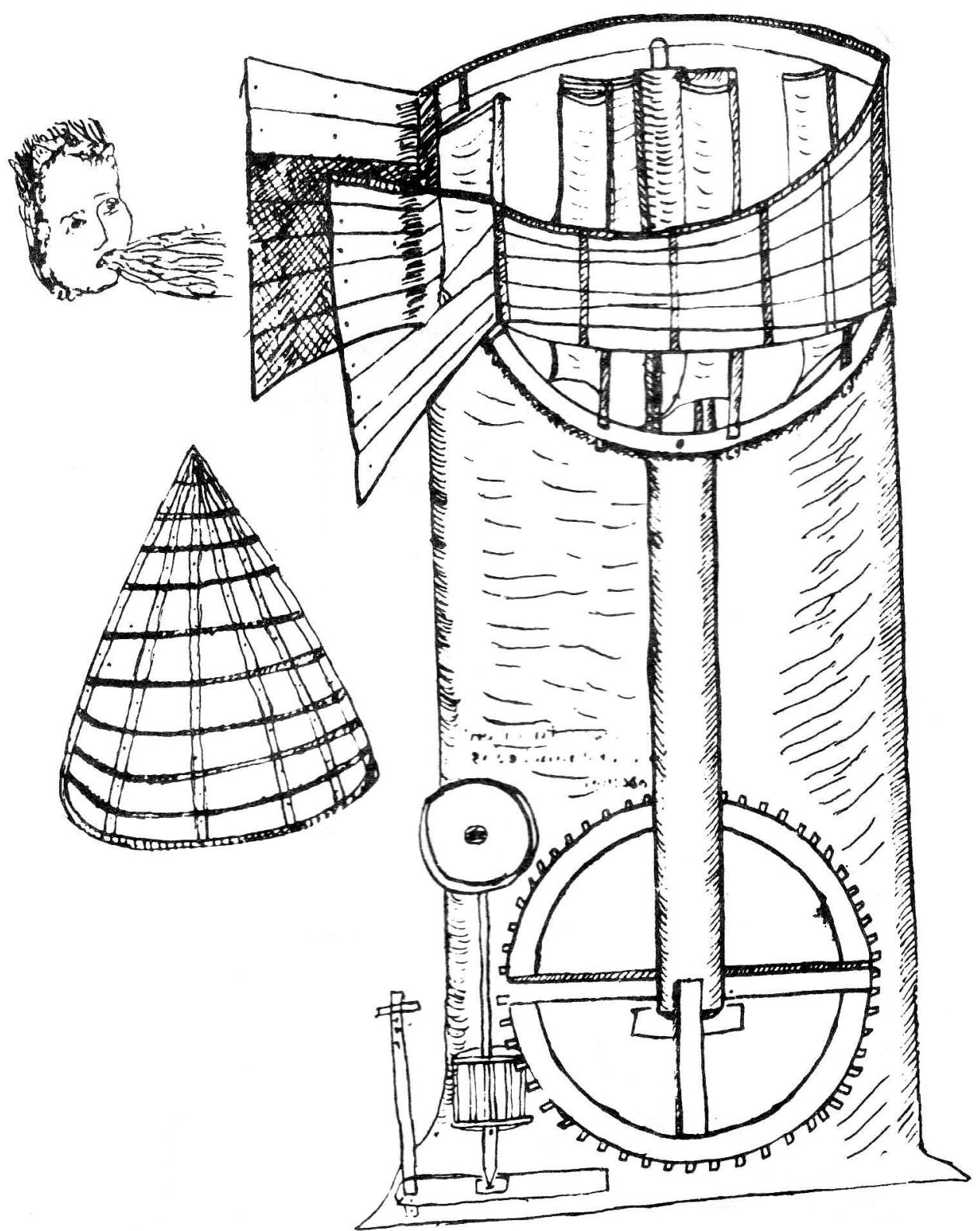


Folio 21: entruesga.

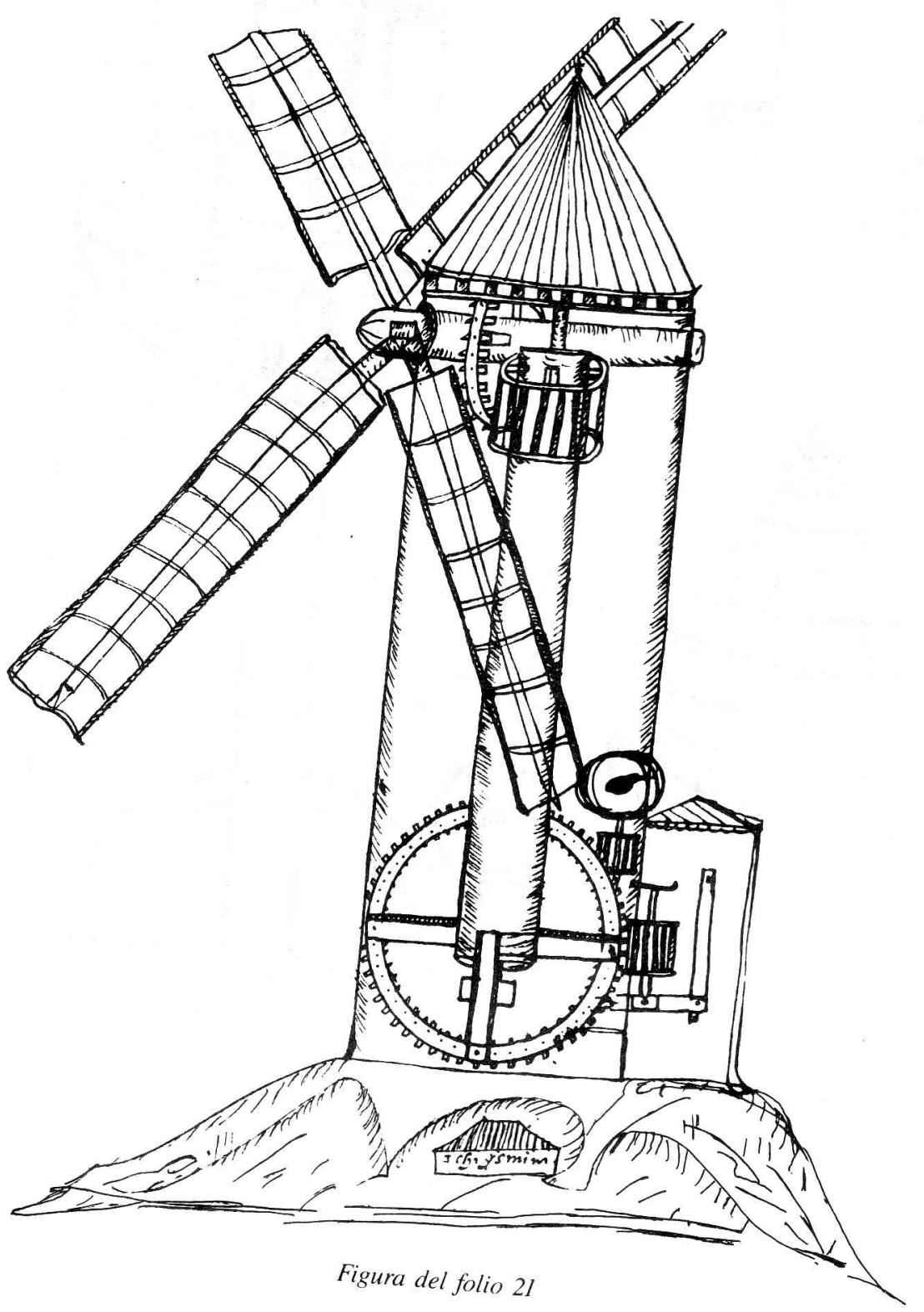


Folio 22: molino de viento.

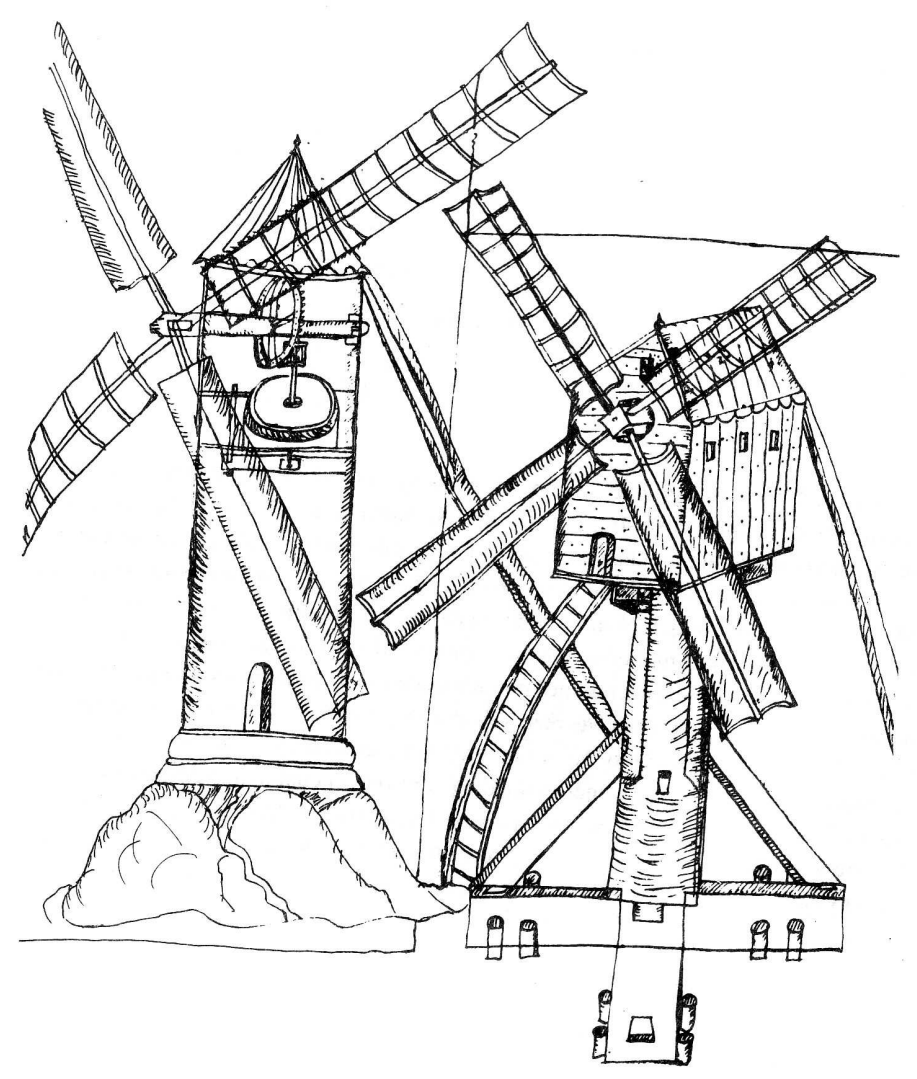

Folio 26: cantimplora.

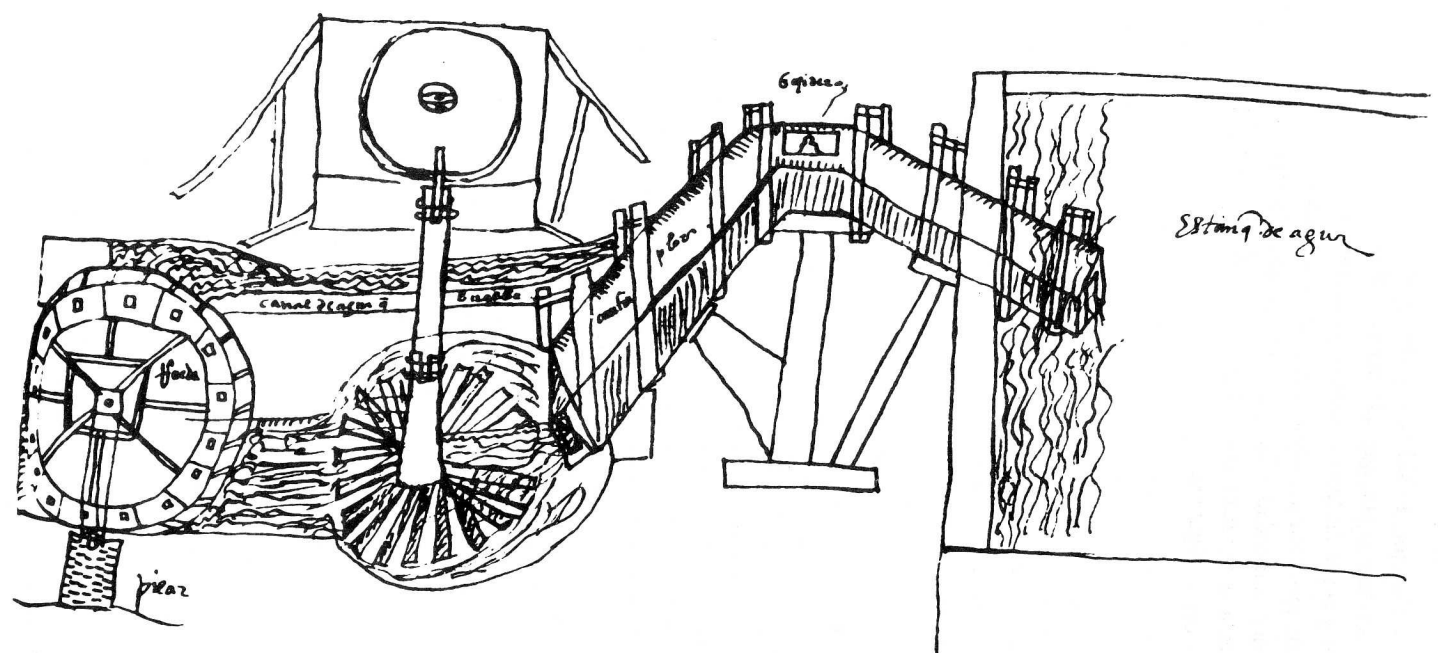


Folio 27: aguatocho, trampa.
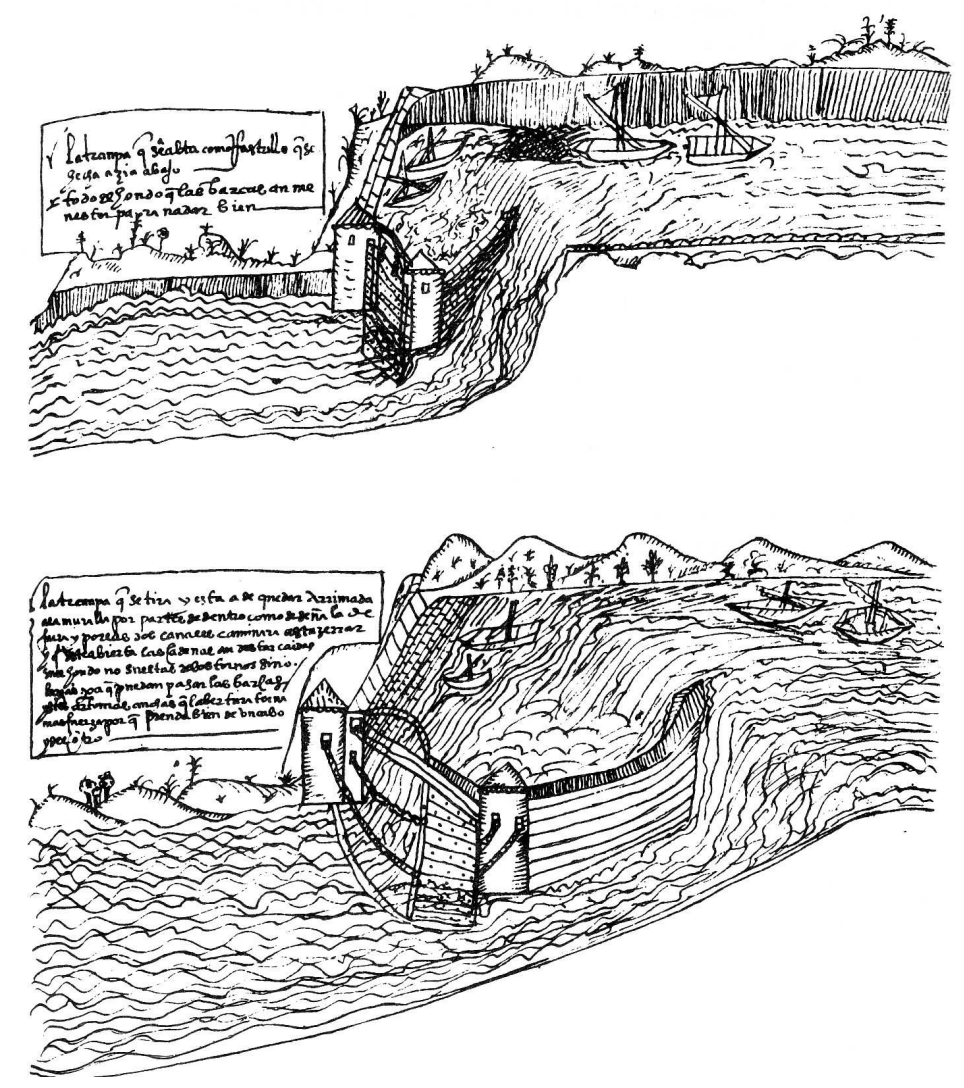
Folio 35: acequia ${ }_{2}$.

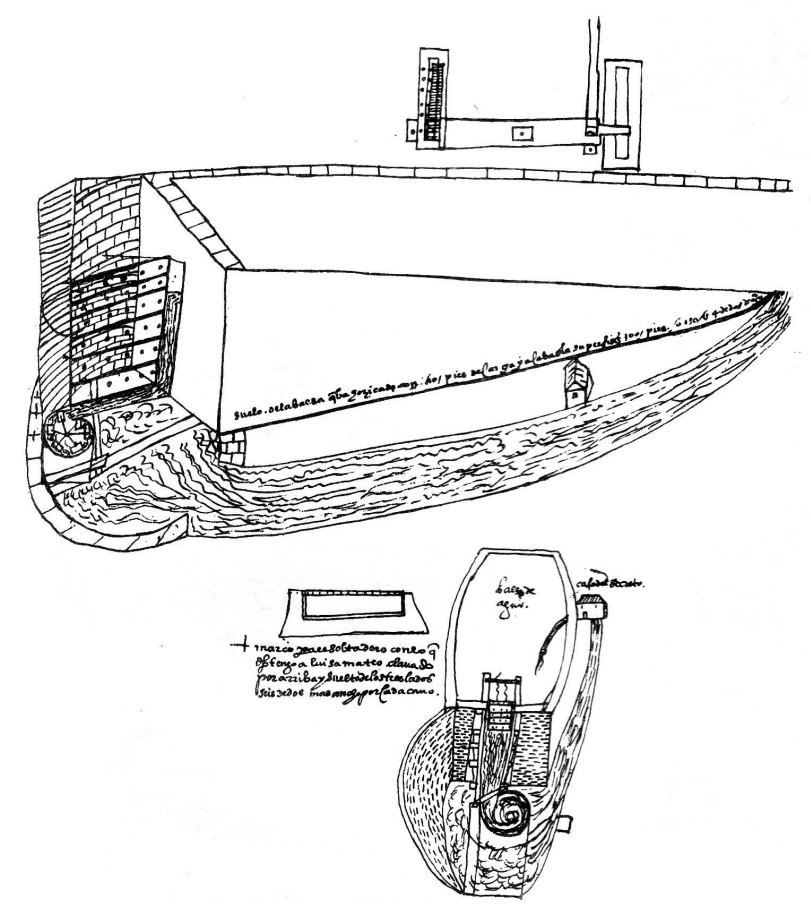


Folio 36: aliviador (núm. 6), anadija (núm. 4), cuba (núm. 9), cárcel (núm. 8).
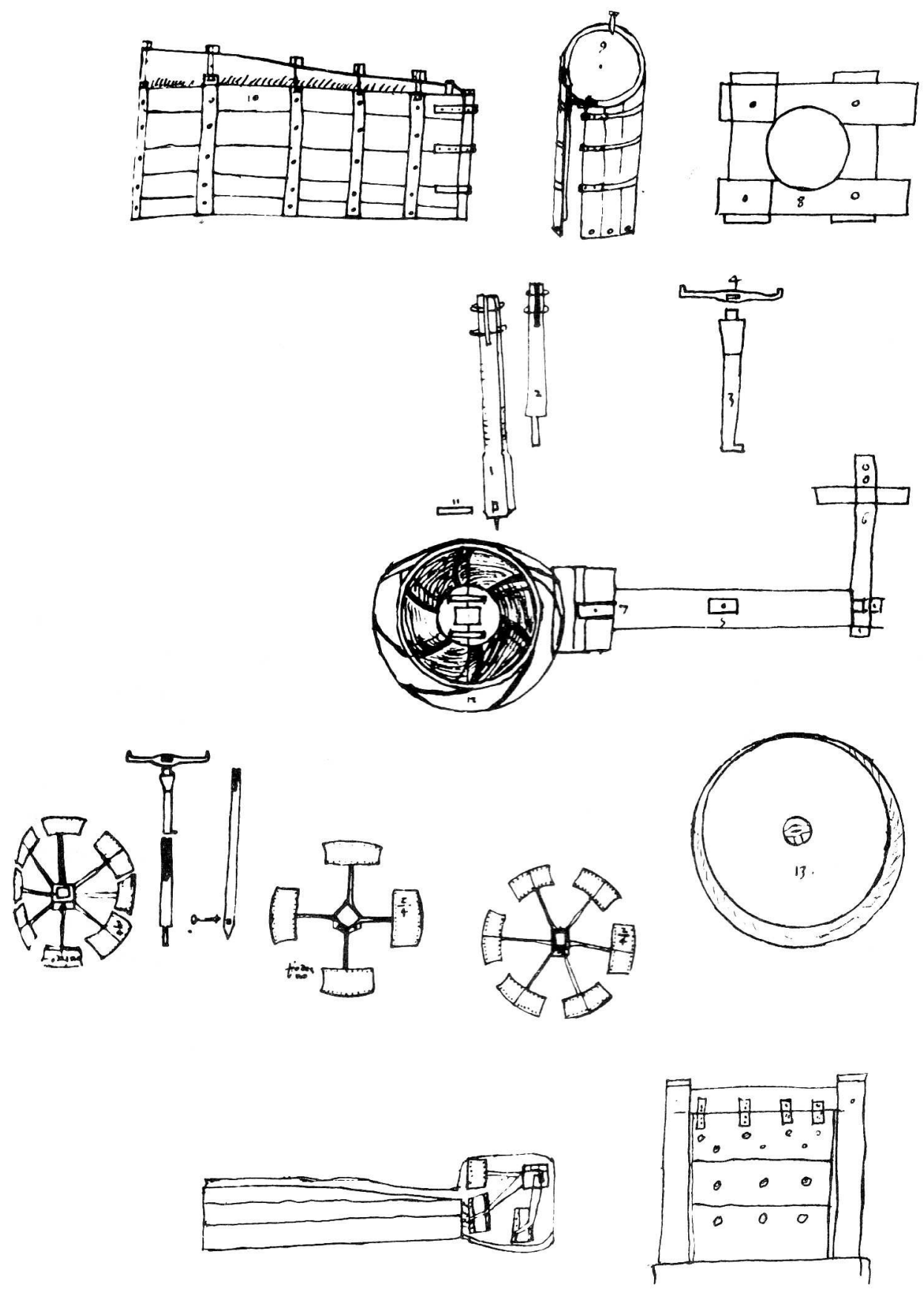
9.2. IMÁGENES DEL TEATRO DE LOS INSTRUMENTOS (1602) DE DIEGO DE BESSON (TRADUCCIÓN DE HORACIO CARDON)

Página C3r, figura 7: torno $_{2}$.

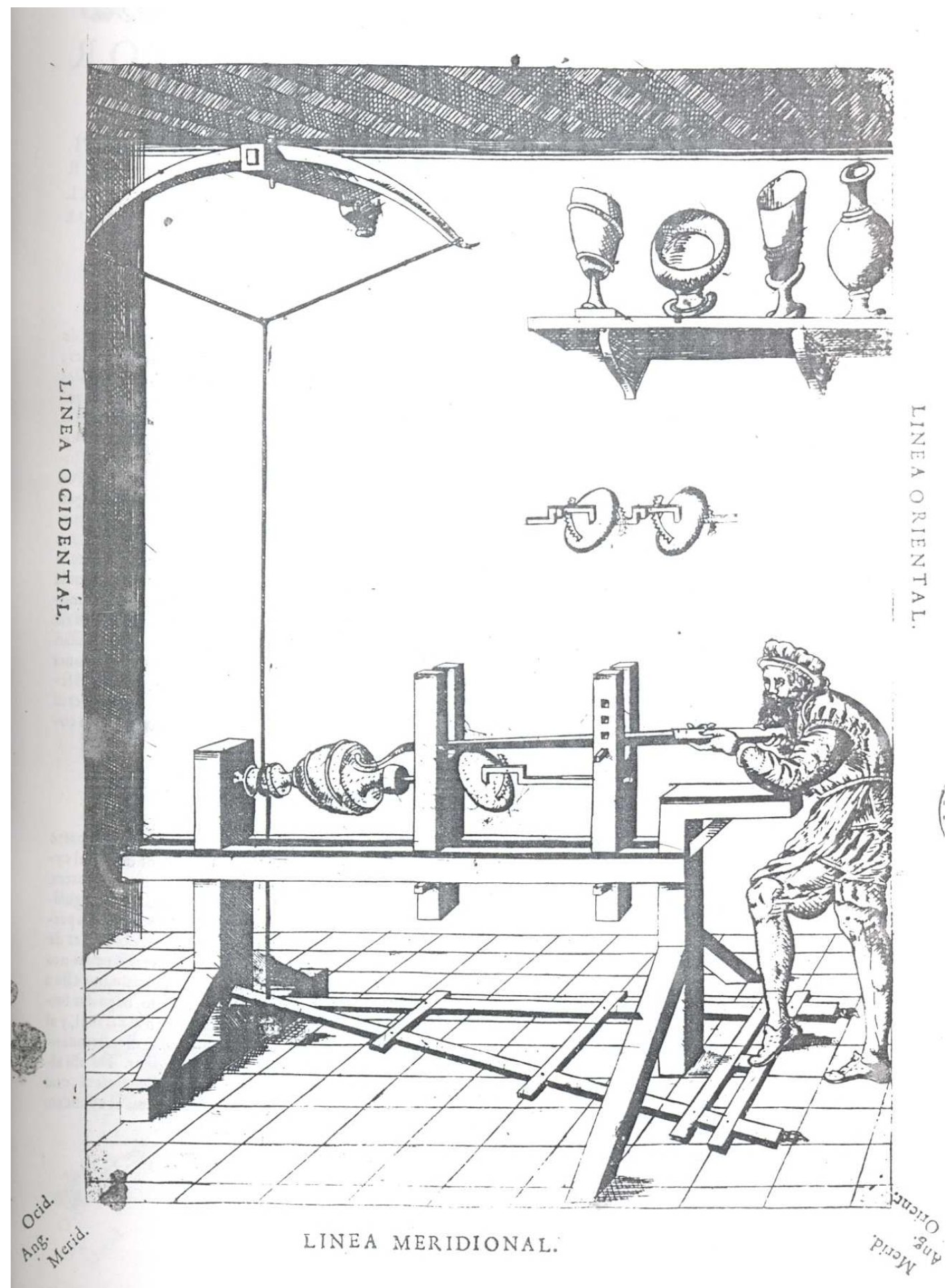


Página D3, figura 11: balanza, soplador.

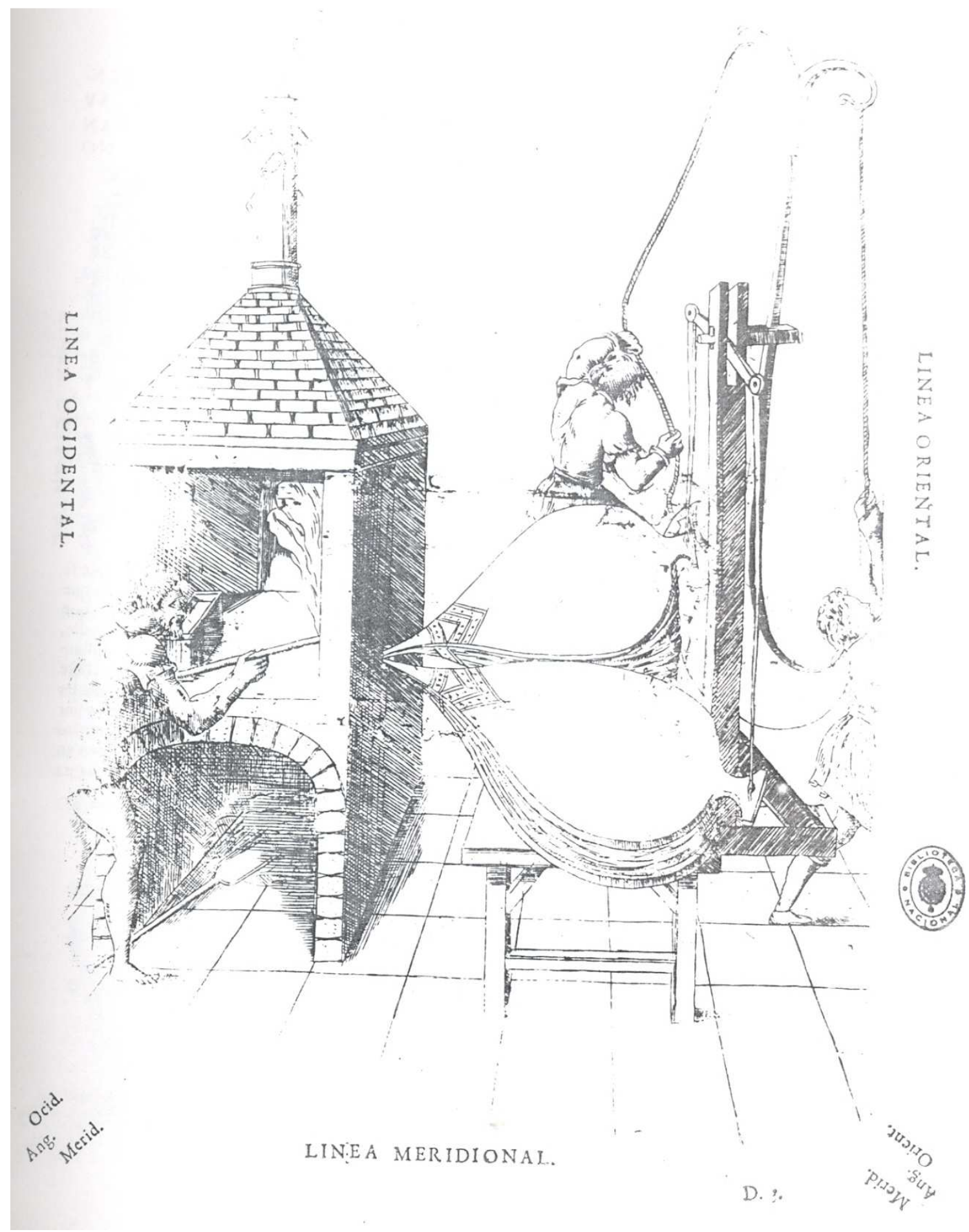


Página E2r, figura 14: langosta.

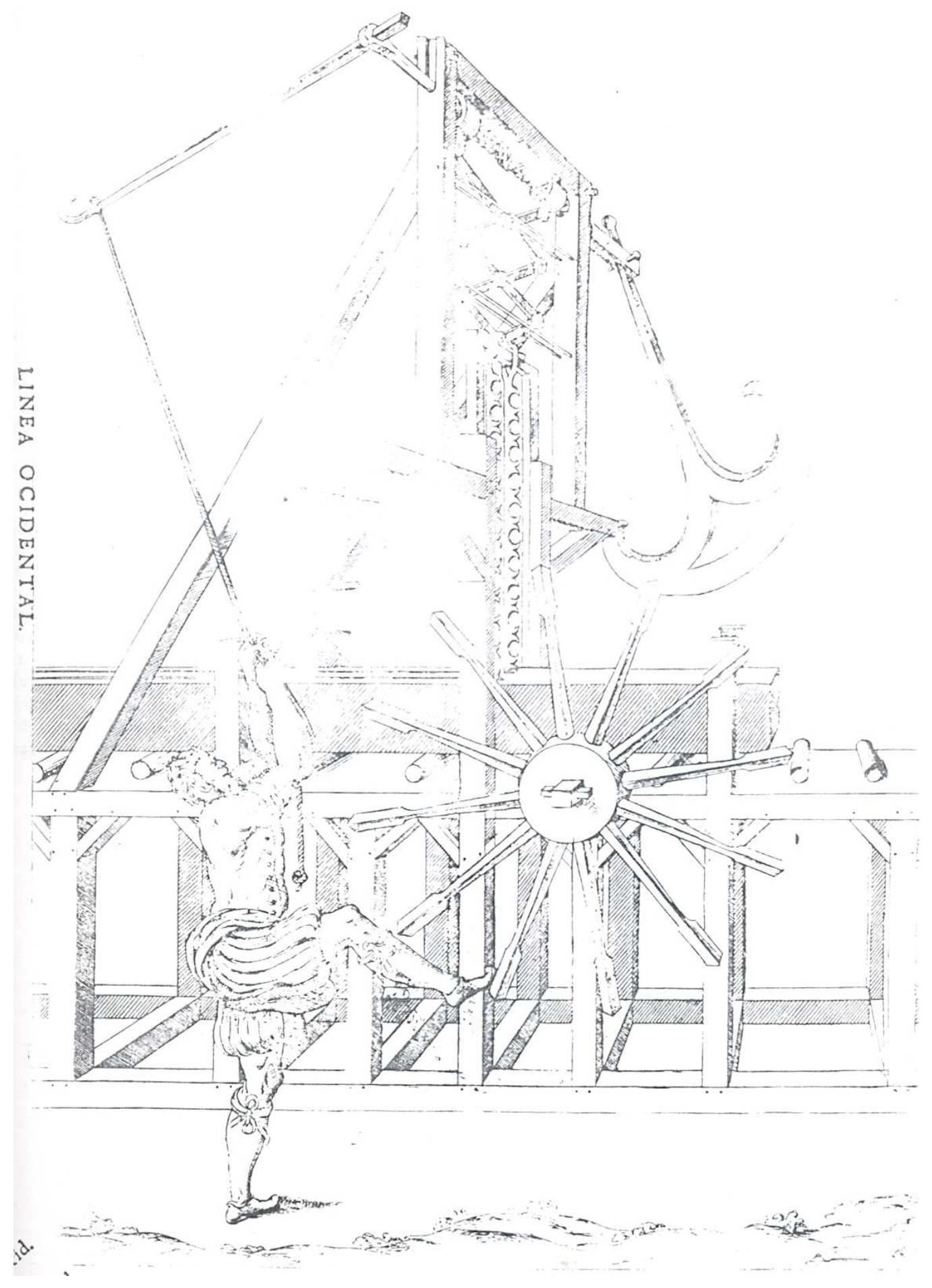


Página F4r, figura 20: trespuntas.

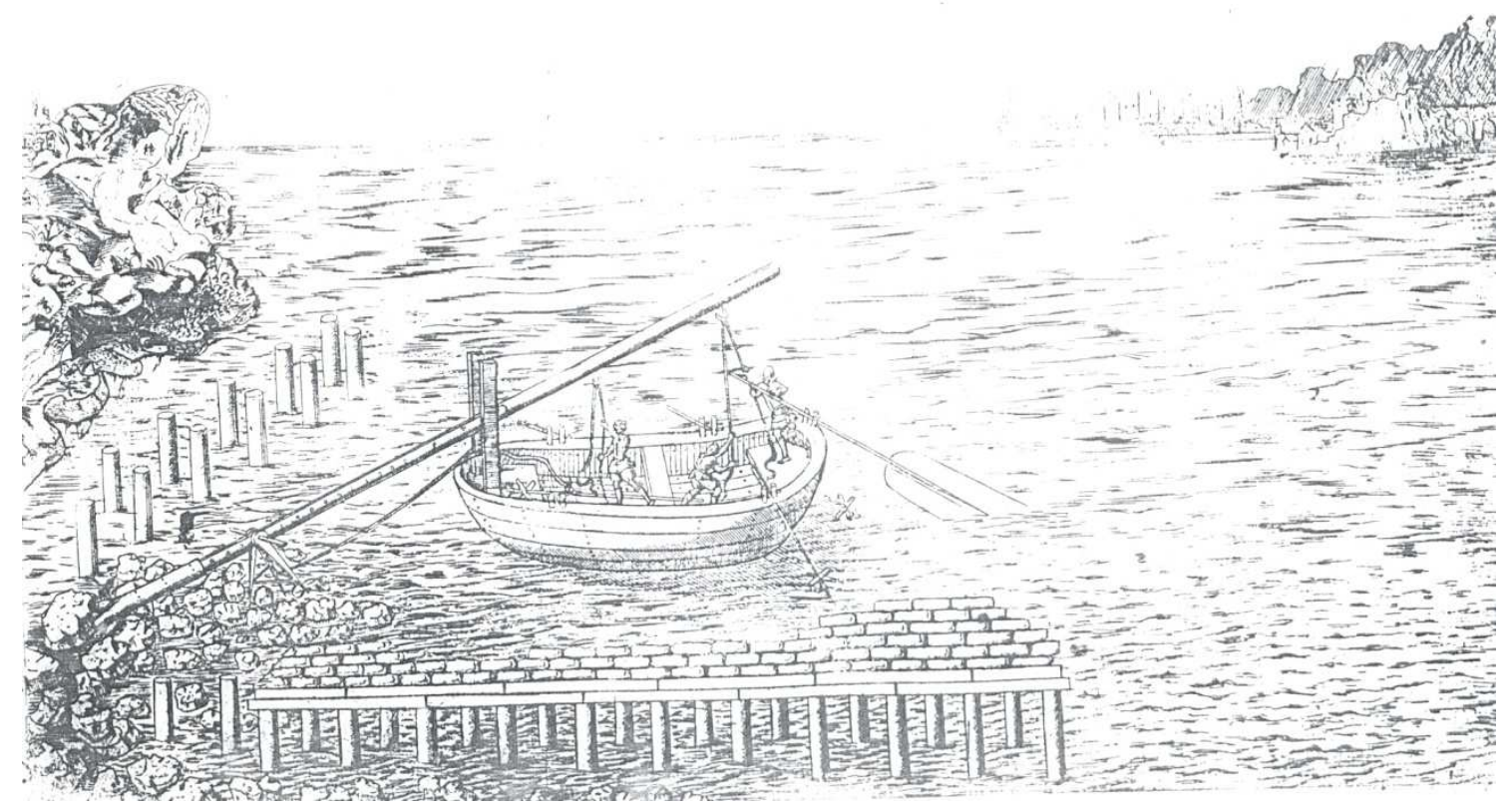

Página G2r, figura 22: caracol infinido, caracol sin fin.

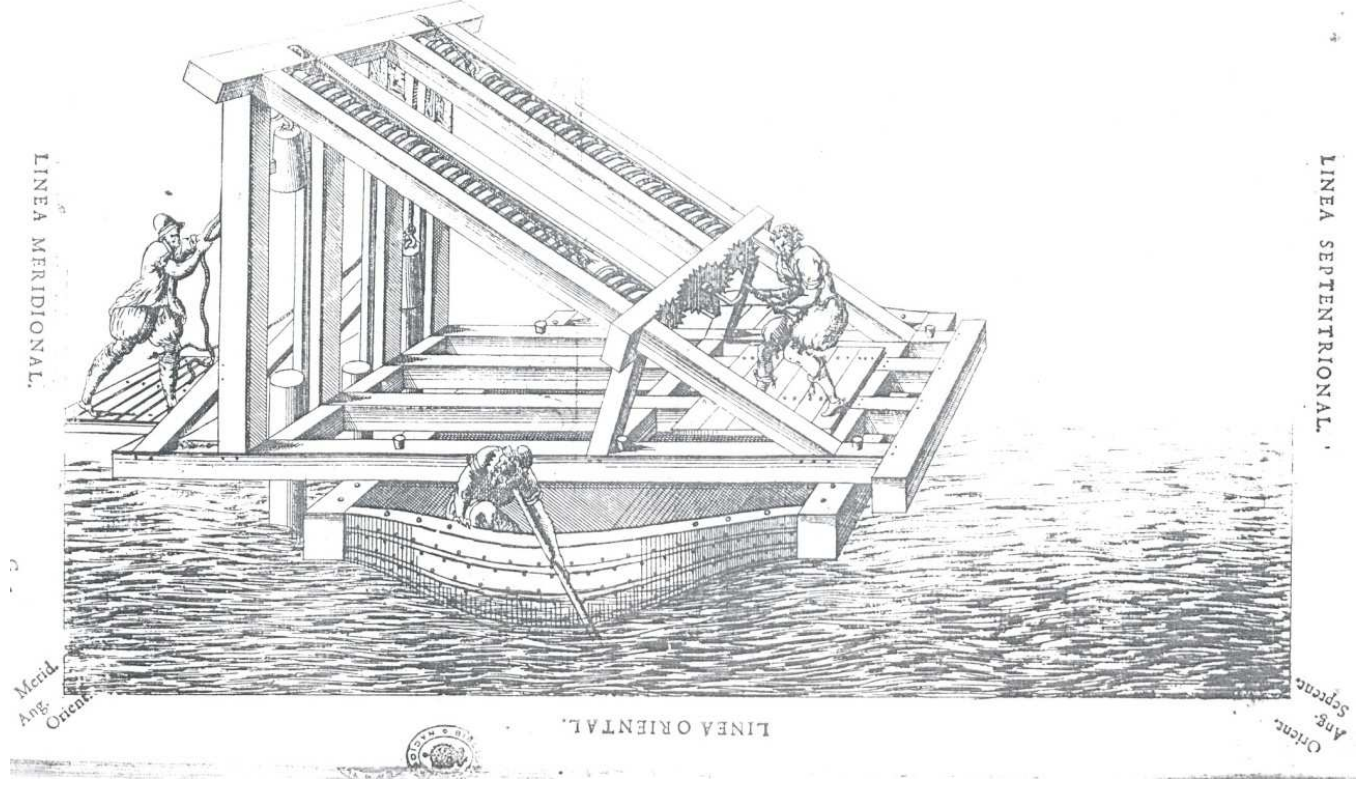


Página Hr, figura 25: majadero.

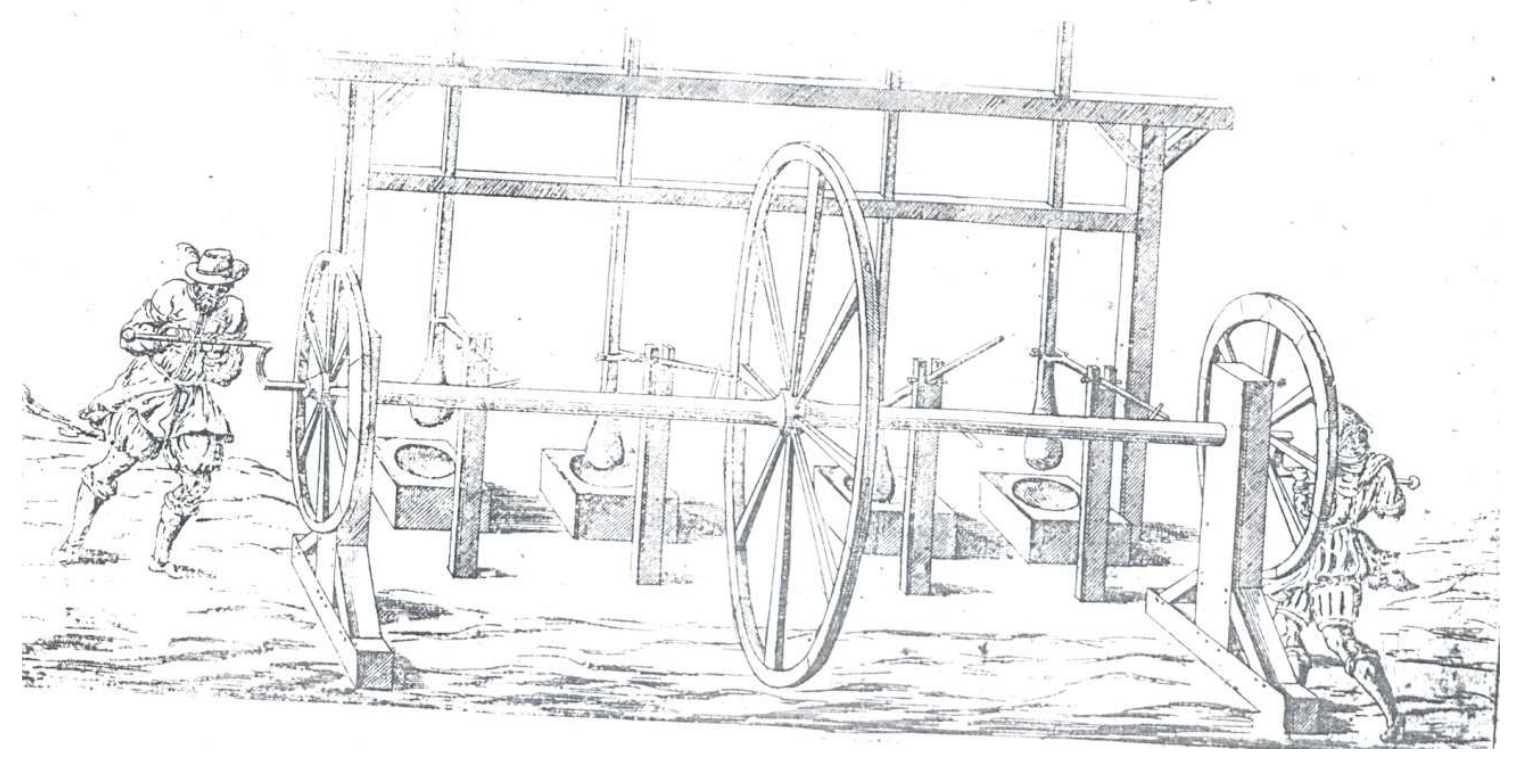


Página L2r, figura 38: grúa ${ }_{1}$

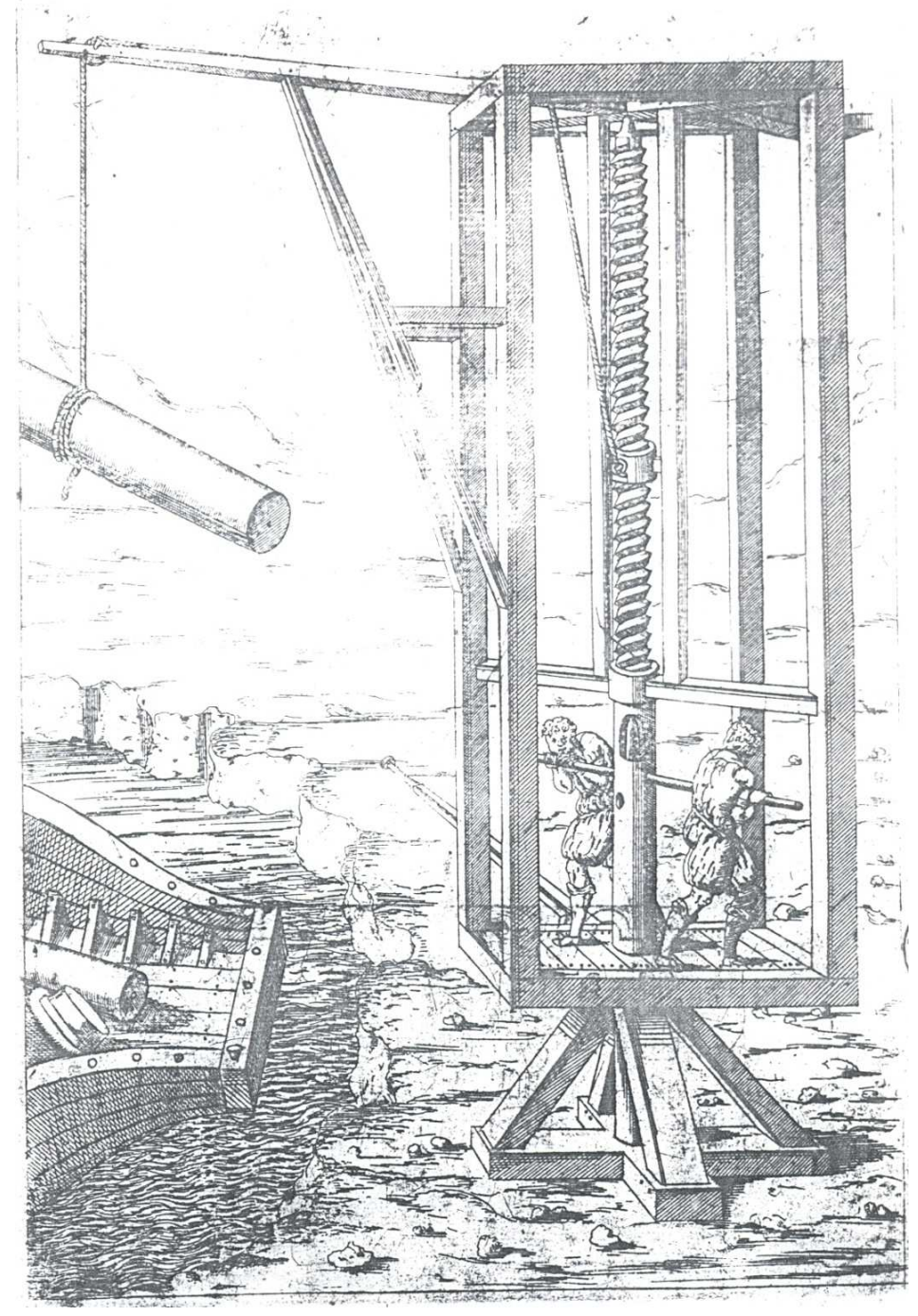


Página N4r, figura 48: cigoñal, enjeta.

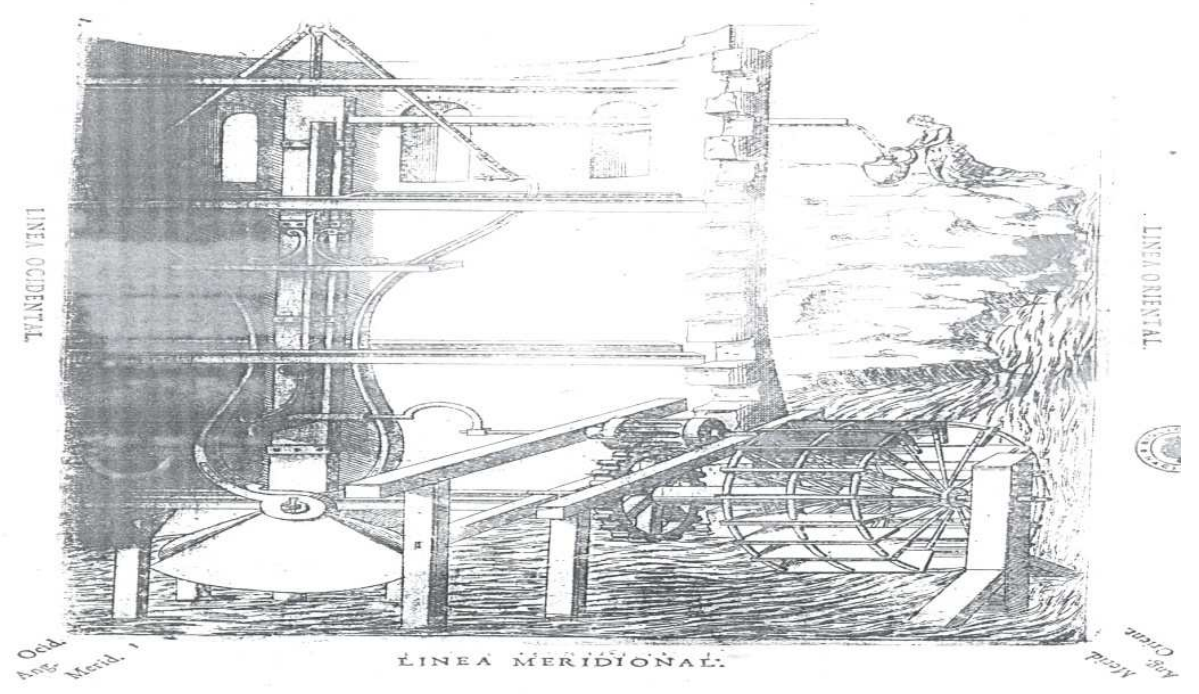

Página Pr, figura 53: mano.

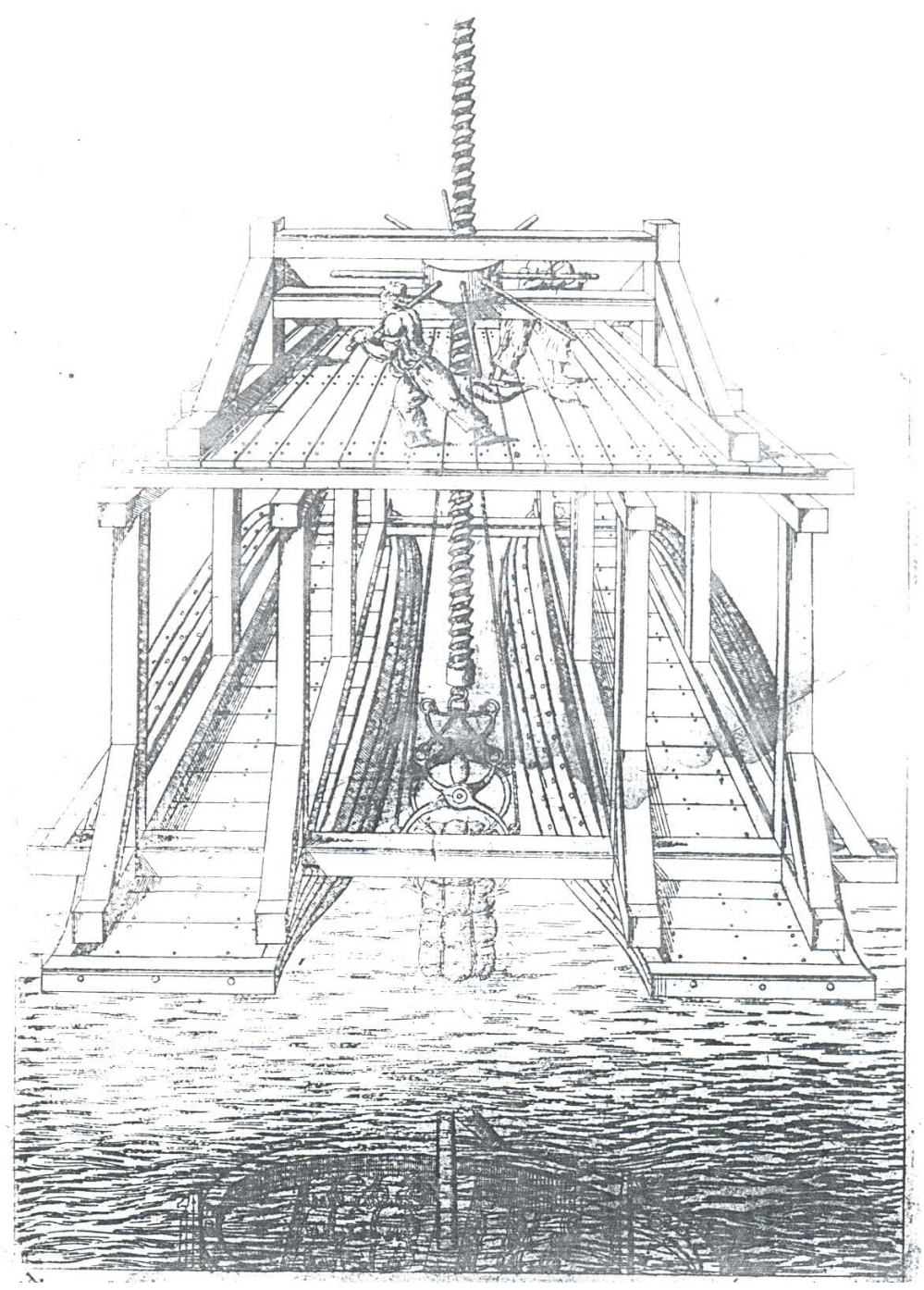




\section{Imagen 1}

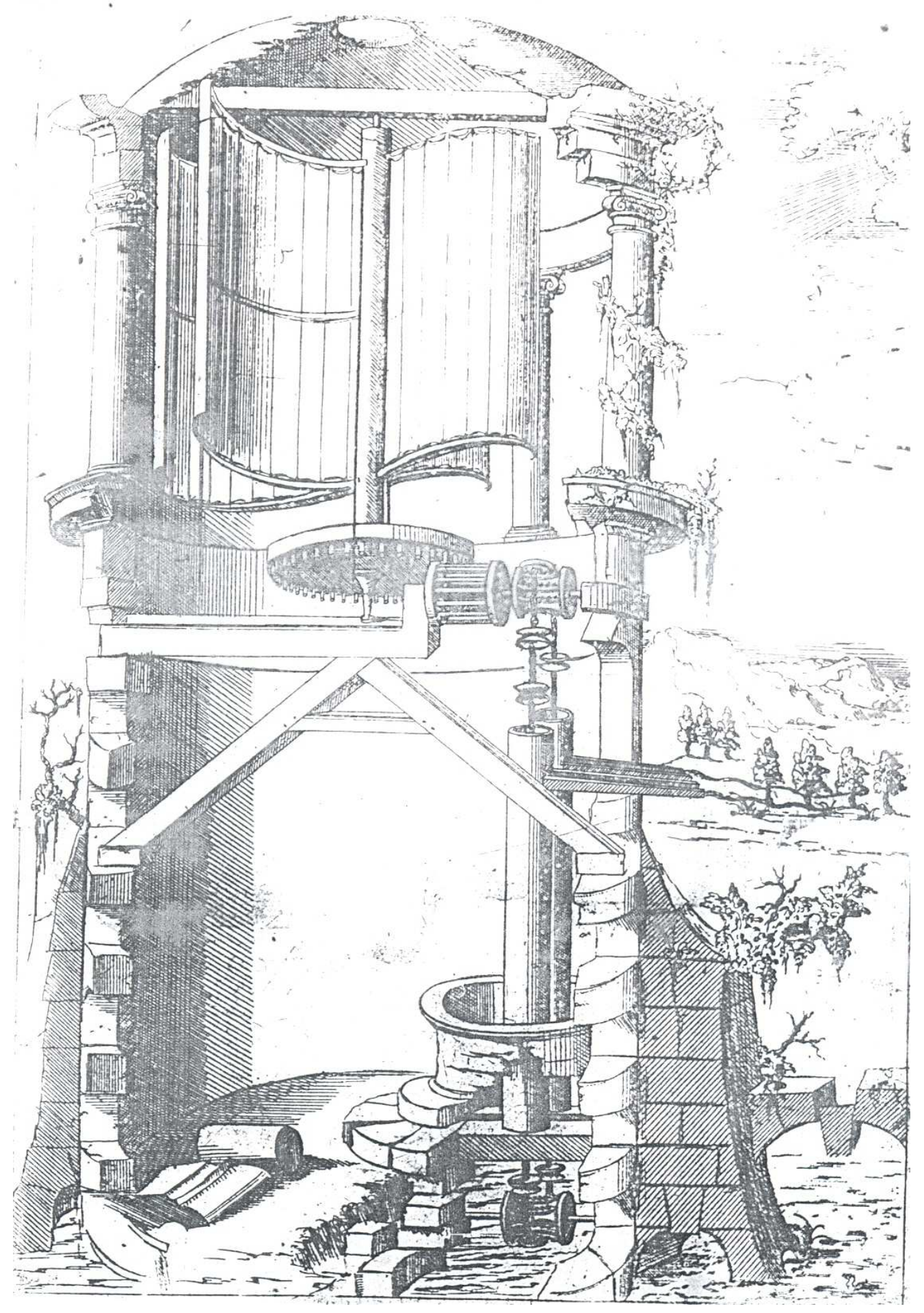

Esta imagen es curiosa porque en el texto, el autor dice que al pintor se le han olvidado pintar los aguaduches (folio O2r). 
Imagen 2

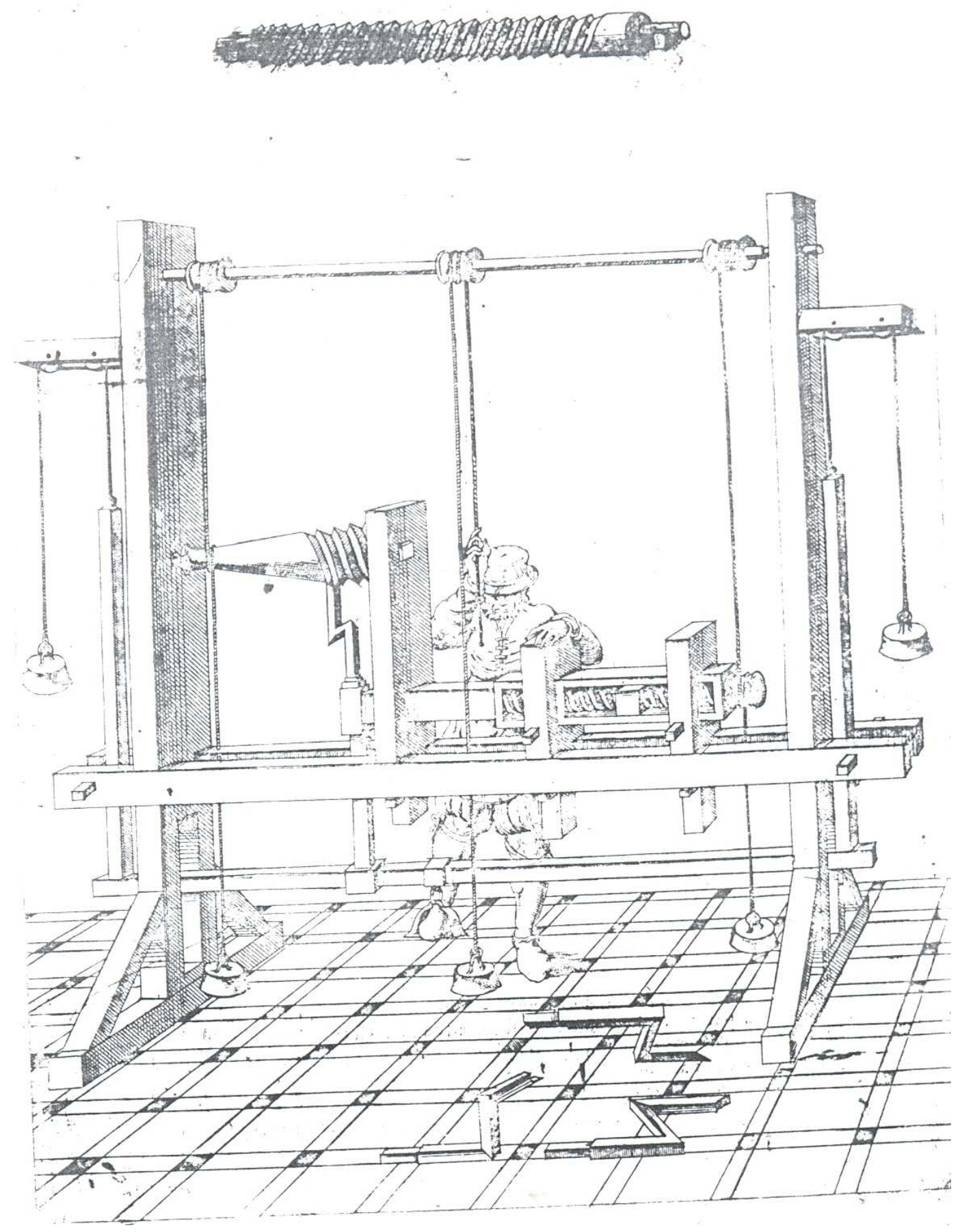

Torno para esculpir formas redondas. 
Imagen 3

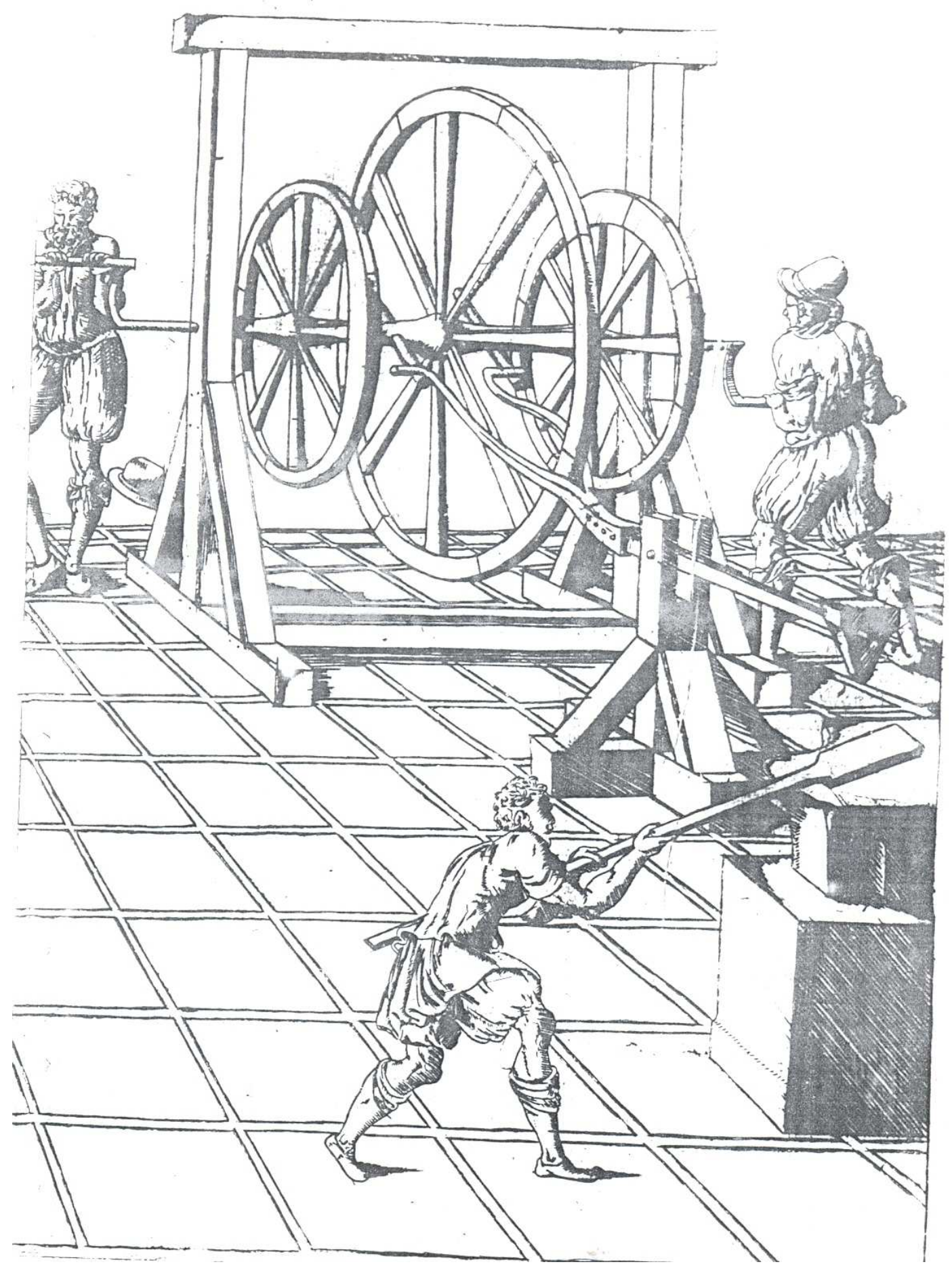

Máquina para mover un yunque. 


\section{Imagen 4}

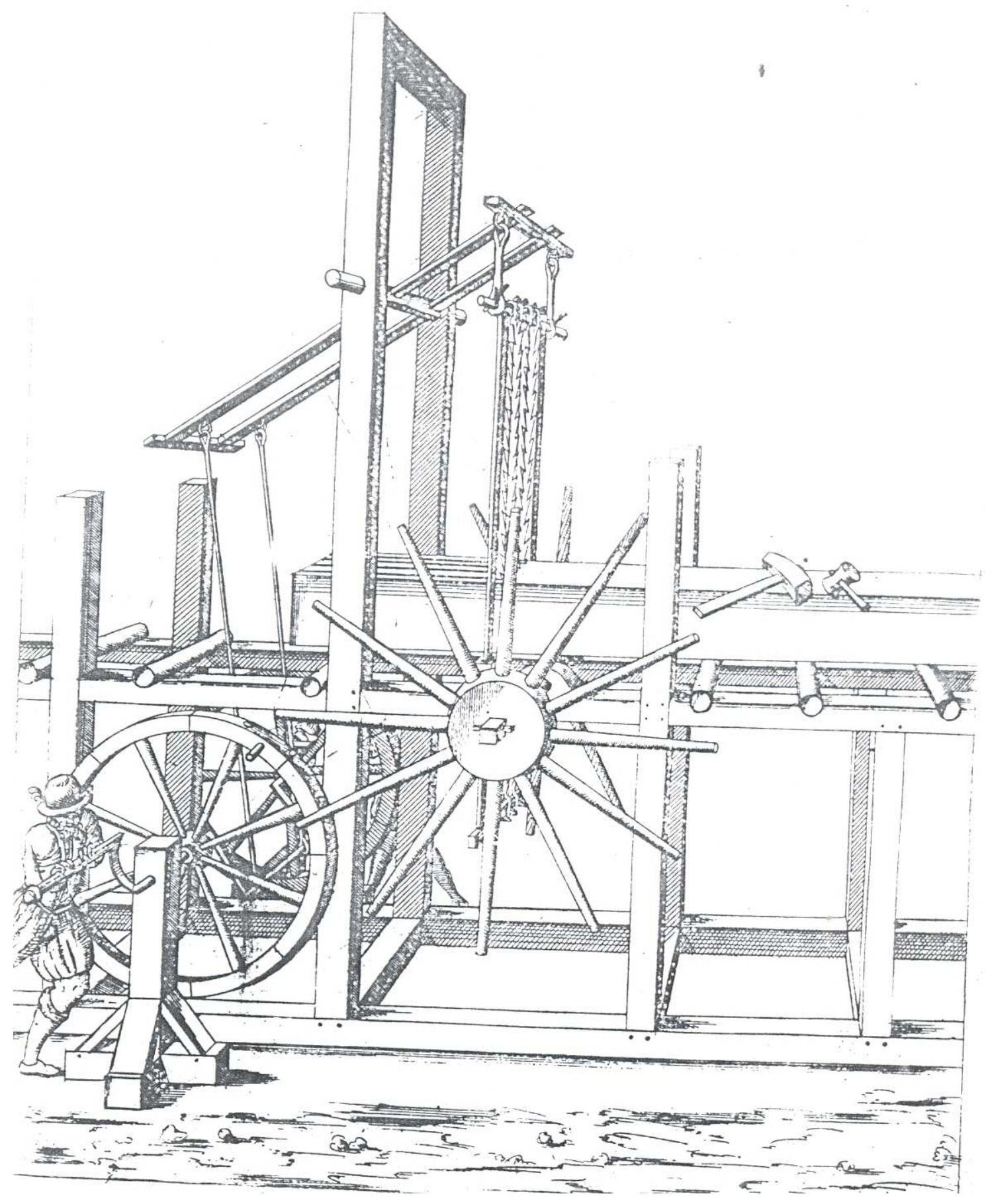

Ingenio para cortar árboles. 


\section{Imagen 5}

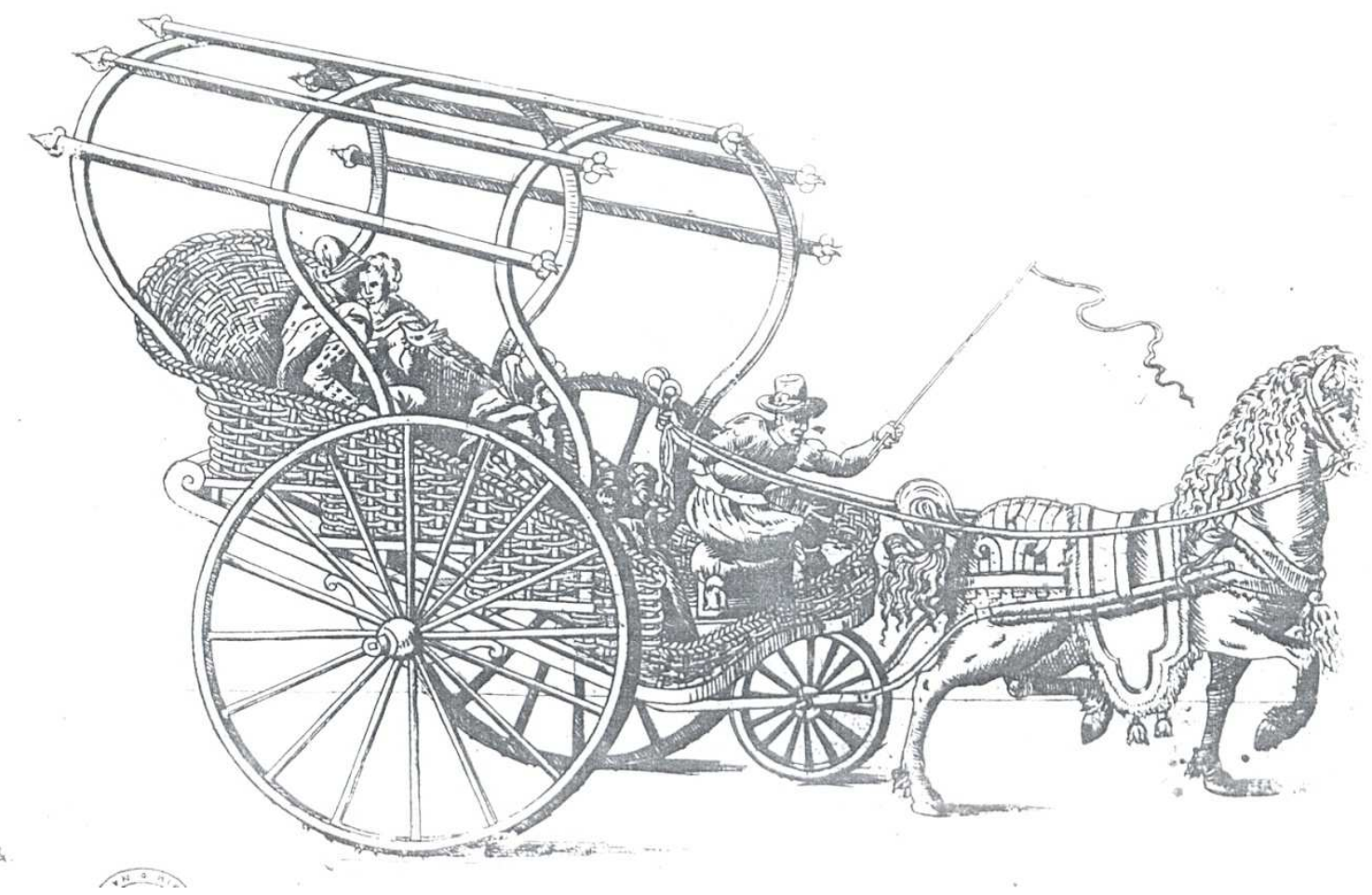

"Nuevo tipo de carro". 
9.3. IMÁGENES DE LOS VEINTE Y UN LIBROS DE LOS YNGENIOS Y MÁQUINAS DE JUANELO (C. 1605)

Folio 56r, figura 18: corbate, nivel de agua.

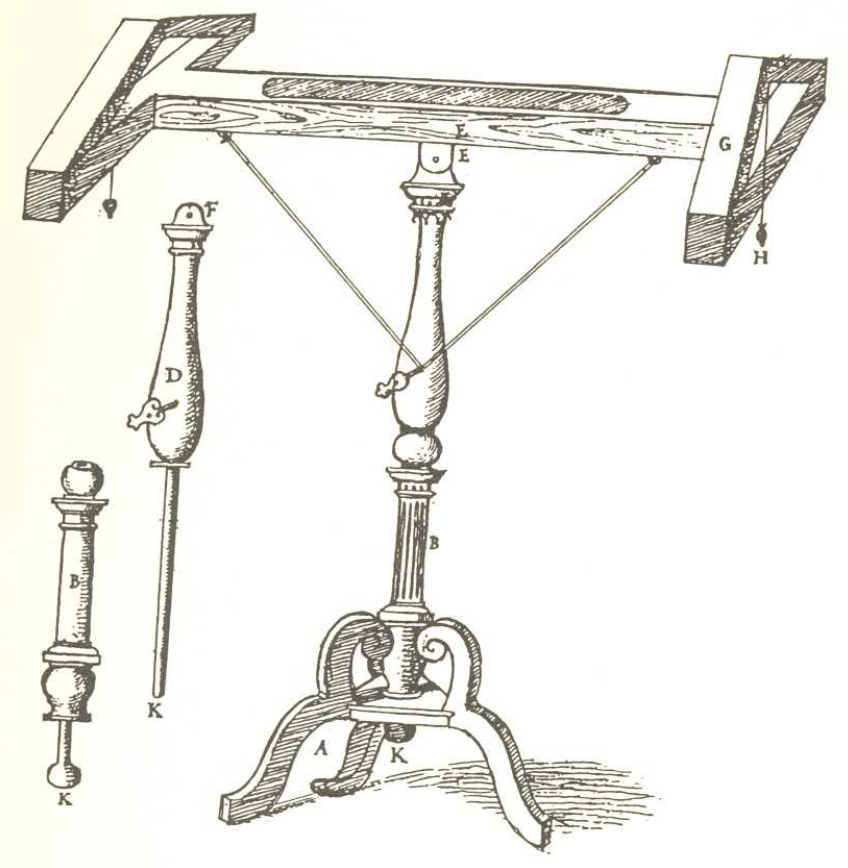

Folio 60v, figura 21: nivel de borneo, nivelador.

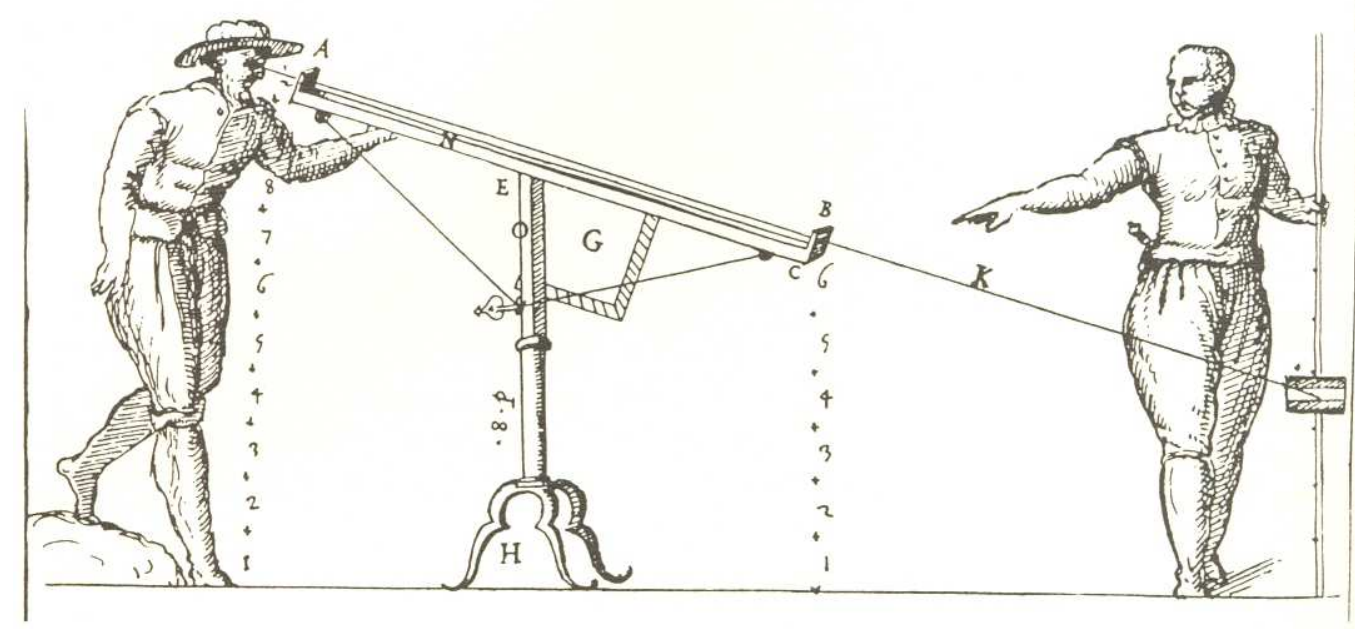


Folio 79v, figura 45, letra E: acequia ${ }_{1}$

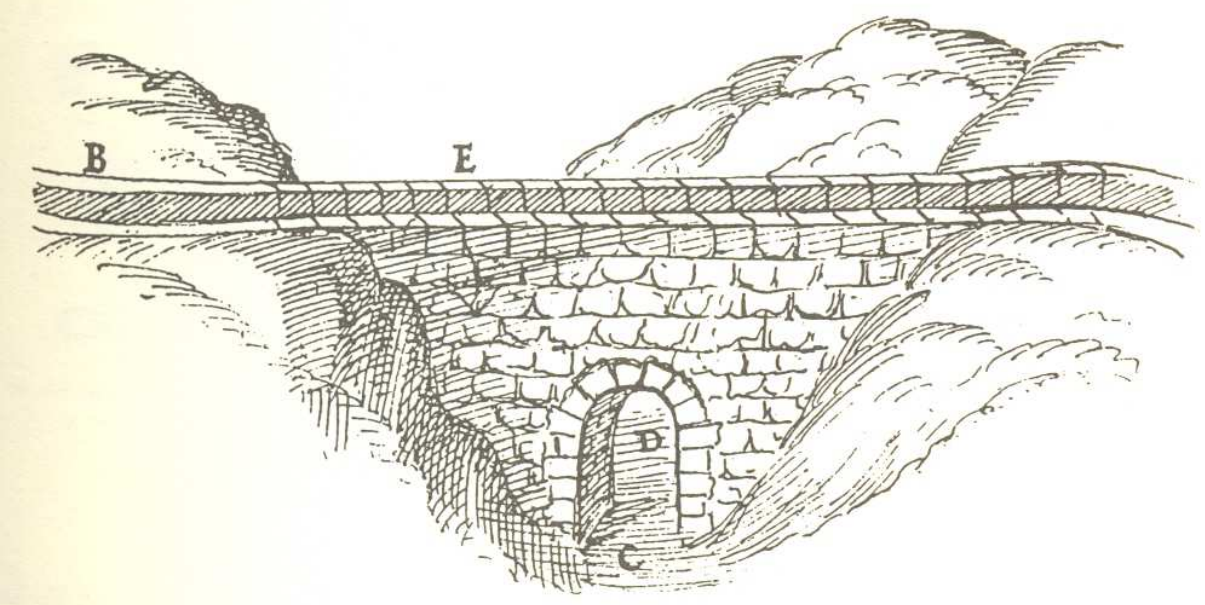

Folio 81r, figura 48: canal $_{1}$.

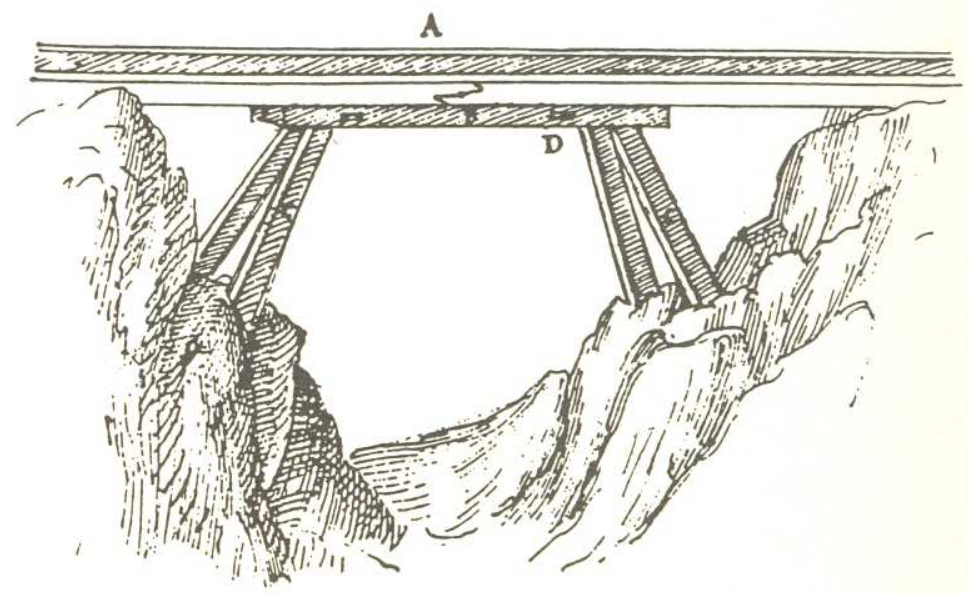


Folio 84v, figura 54: aguaducto.

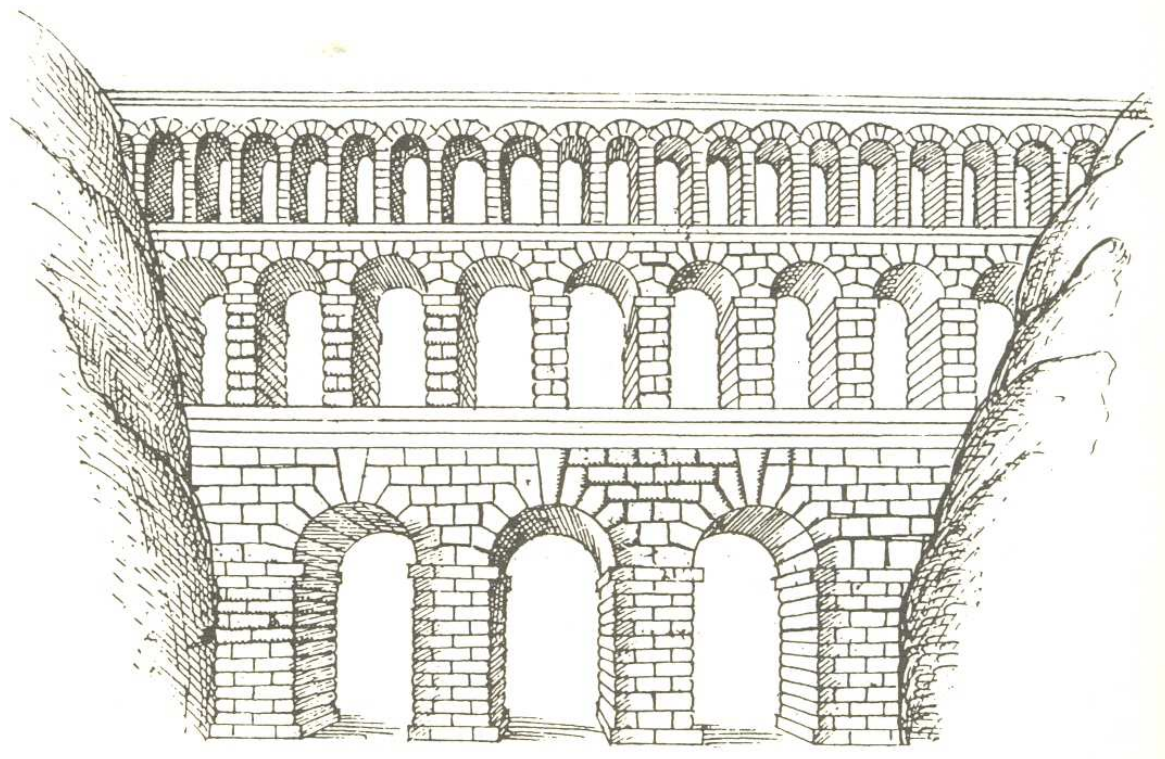

Folio 108v, figura 76: A: boca, B: almenara, C: escurridero.

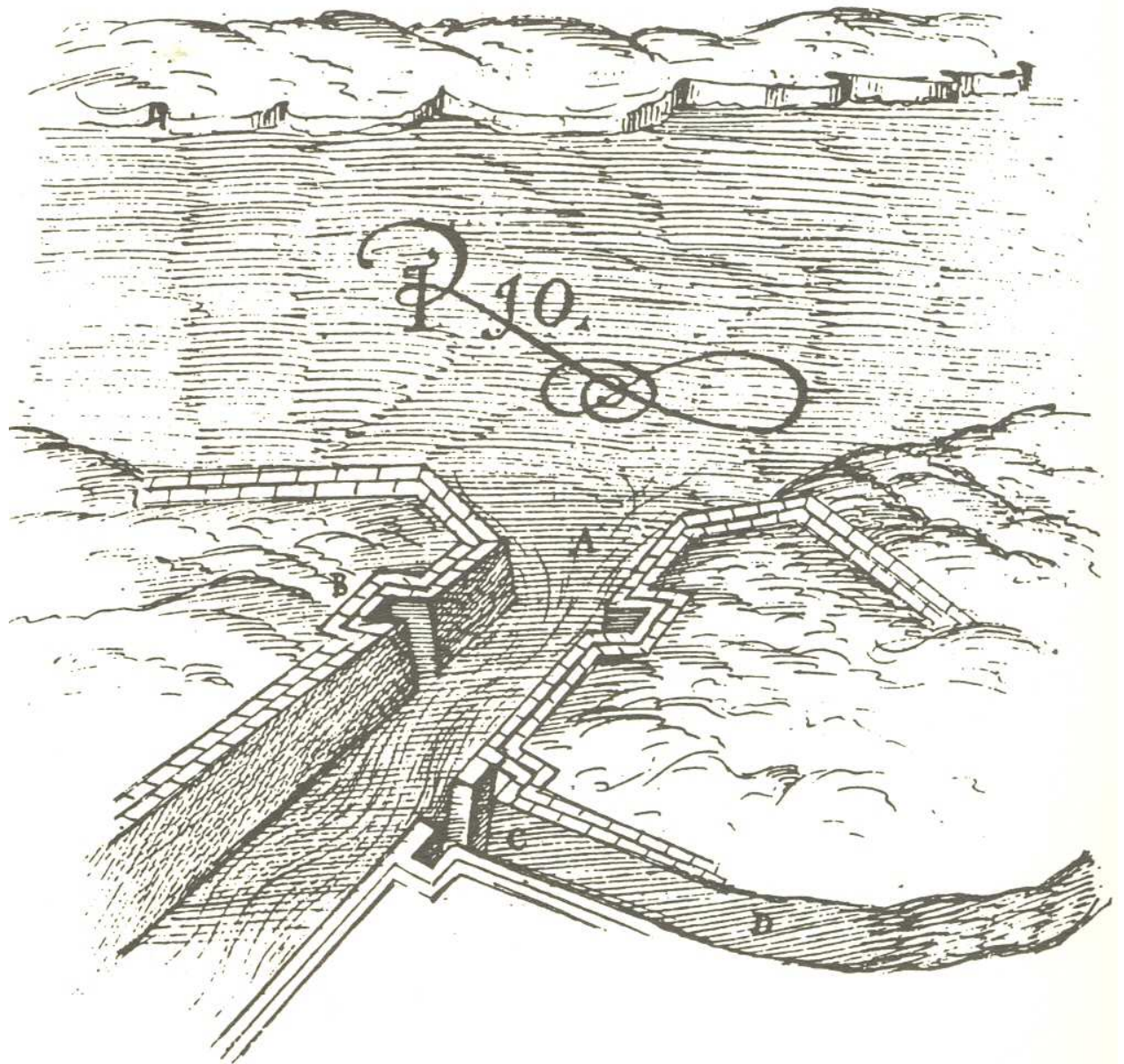


Folio 122r, fig. 91: cantimplora.

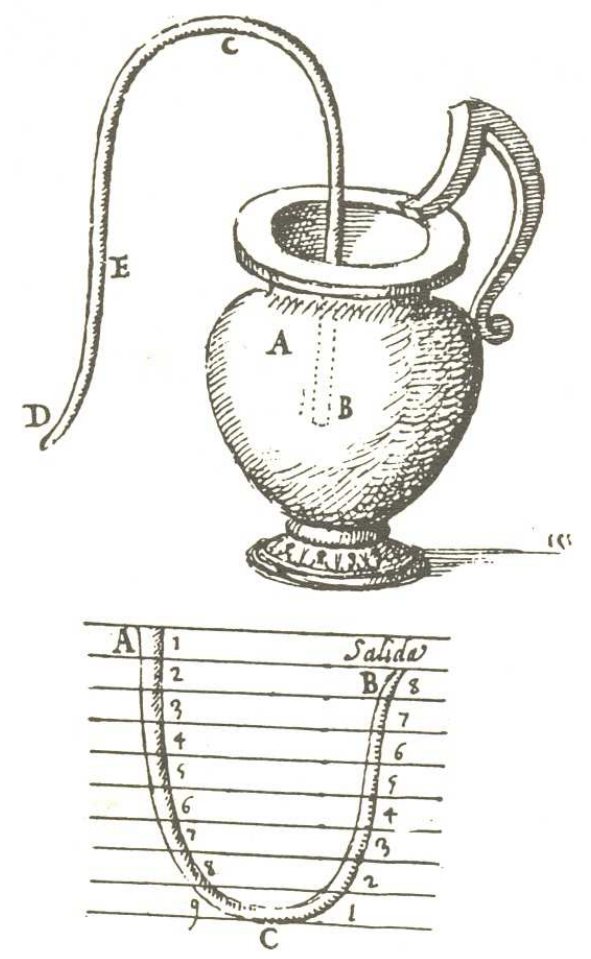


Folio 143v, figura 110: gata, gaula, gavia.

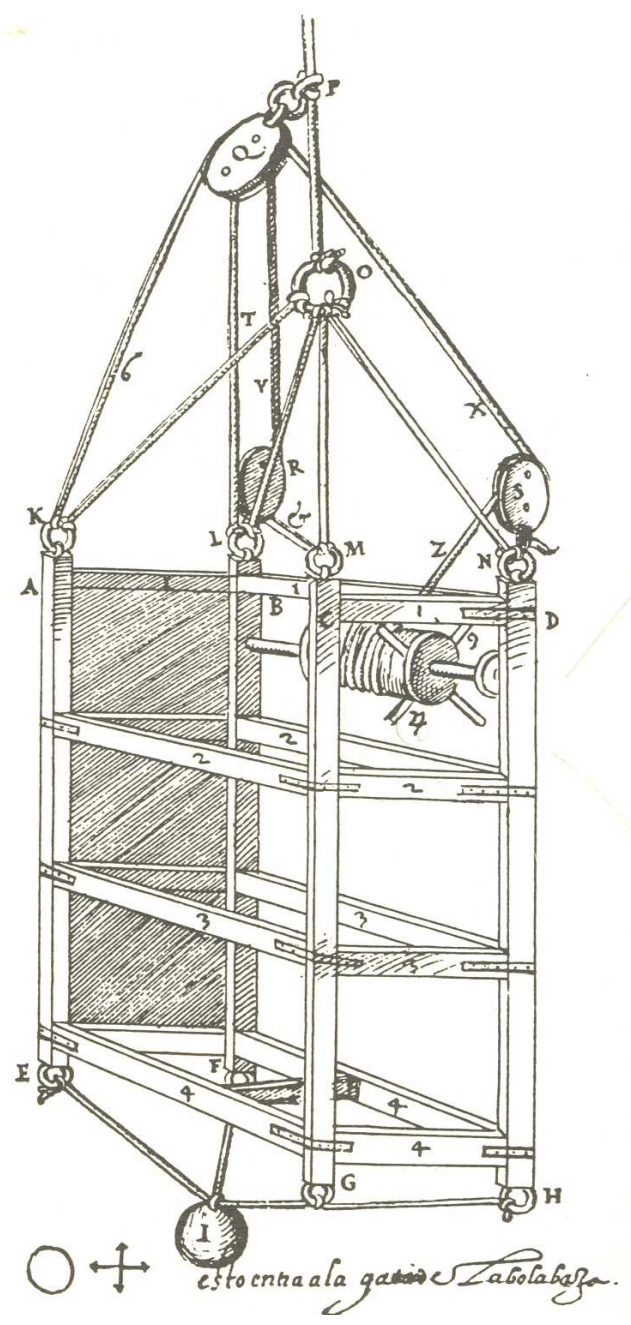

Folio 158v, figura 129: armazón de azud de madera.

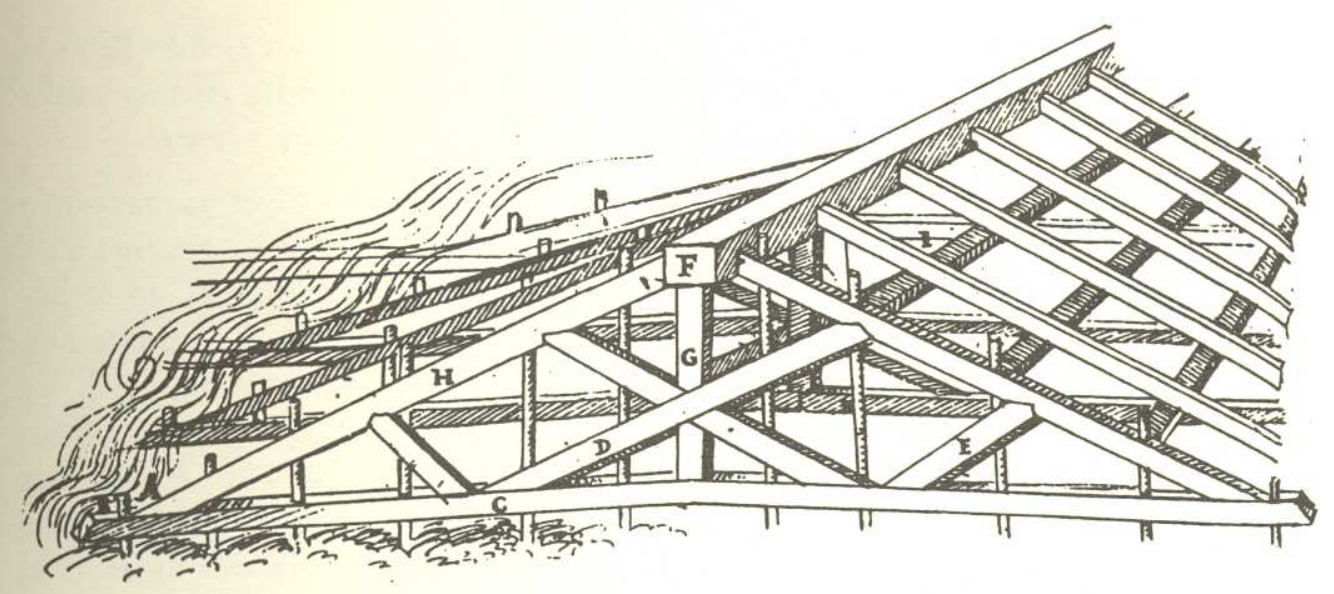


Folio 164r, figura 138: azud de piedra.

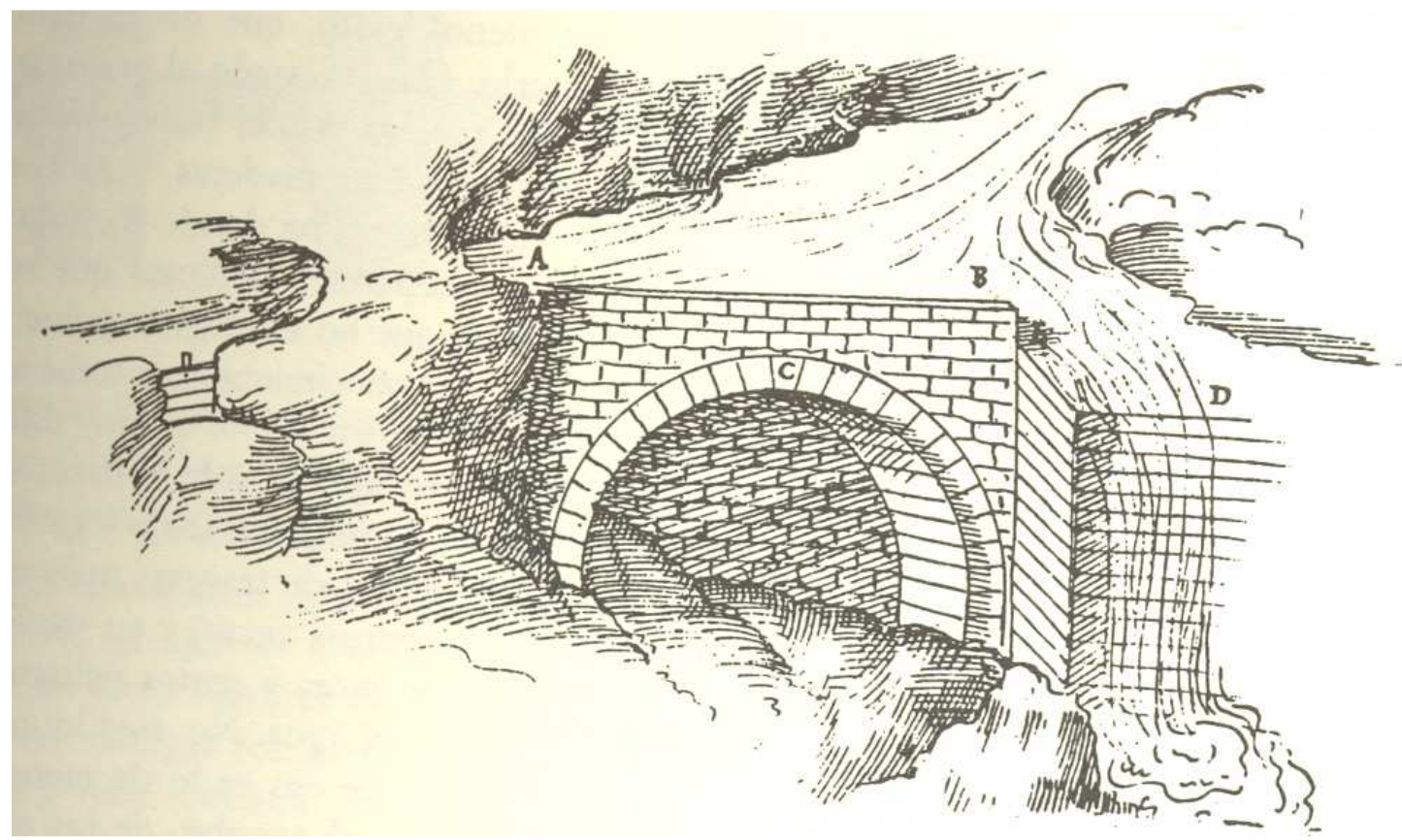

Folio 181v, figura 158: cisterna.
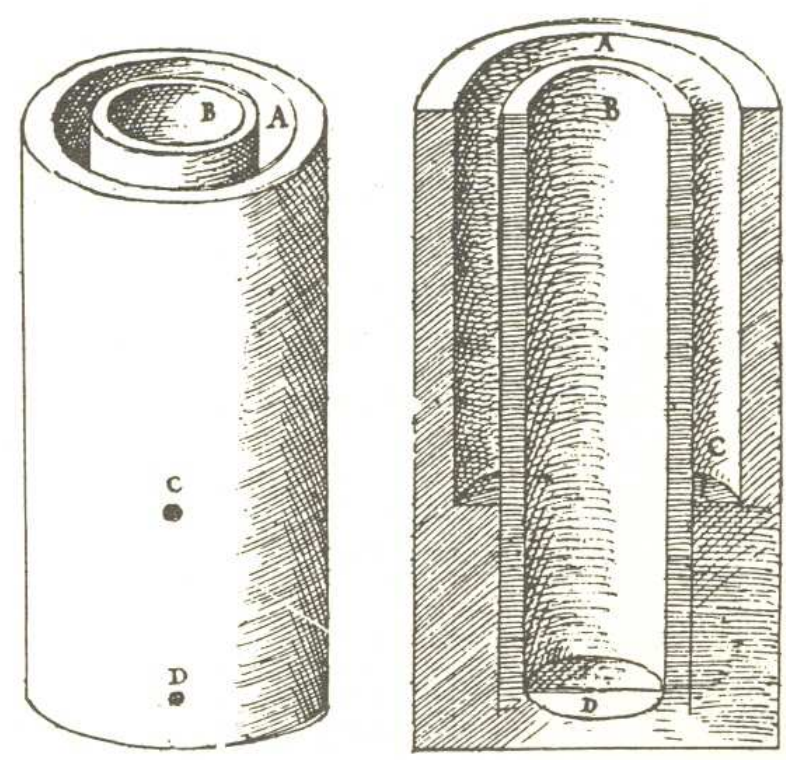
Folio 184v, figura 161: aljibe (cuadrado).

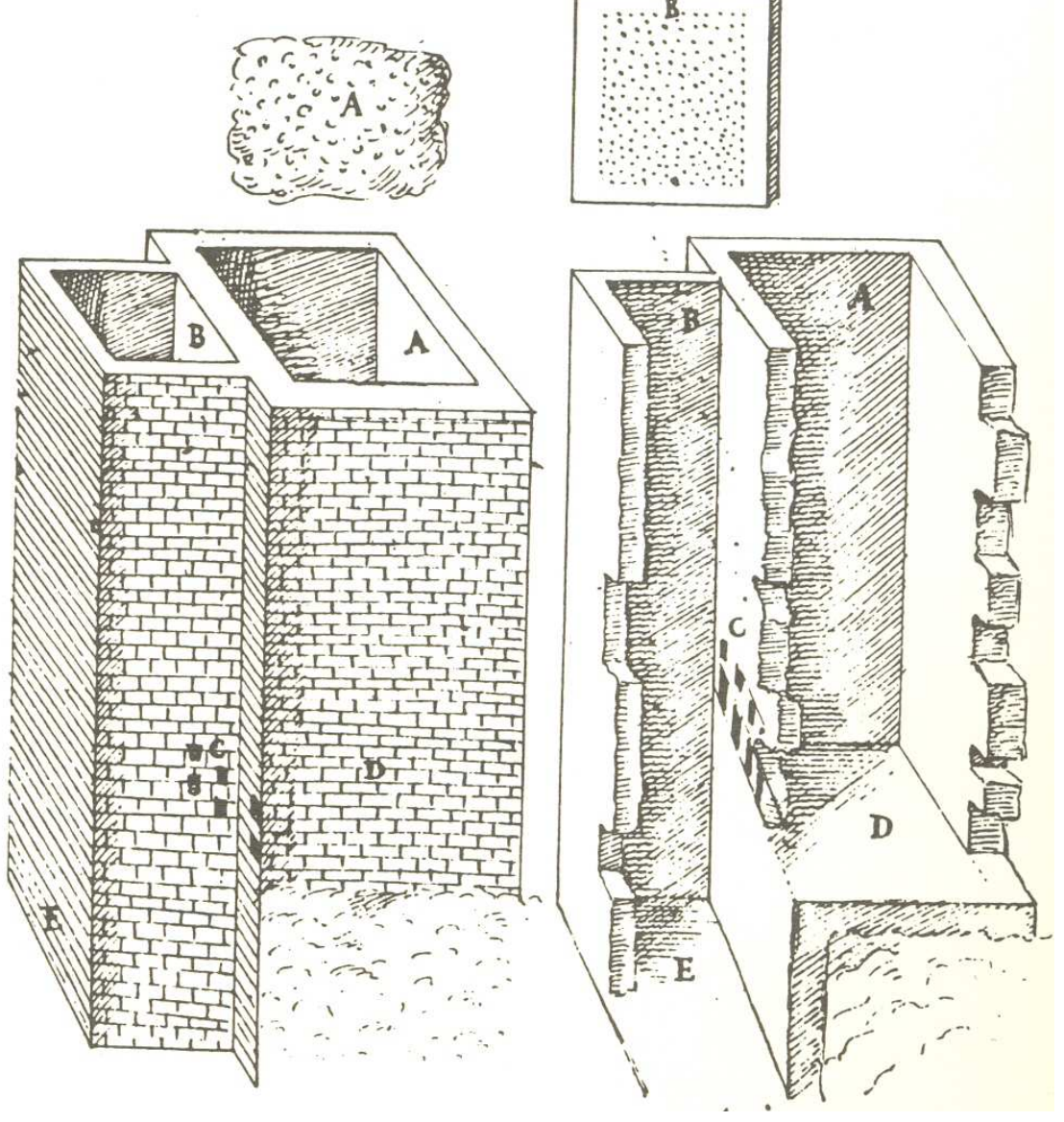


Folio 190v, figura 99: maripuente. FF: paredes; QQQ: pilas; EEE: bocas de las bóvedas.

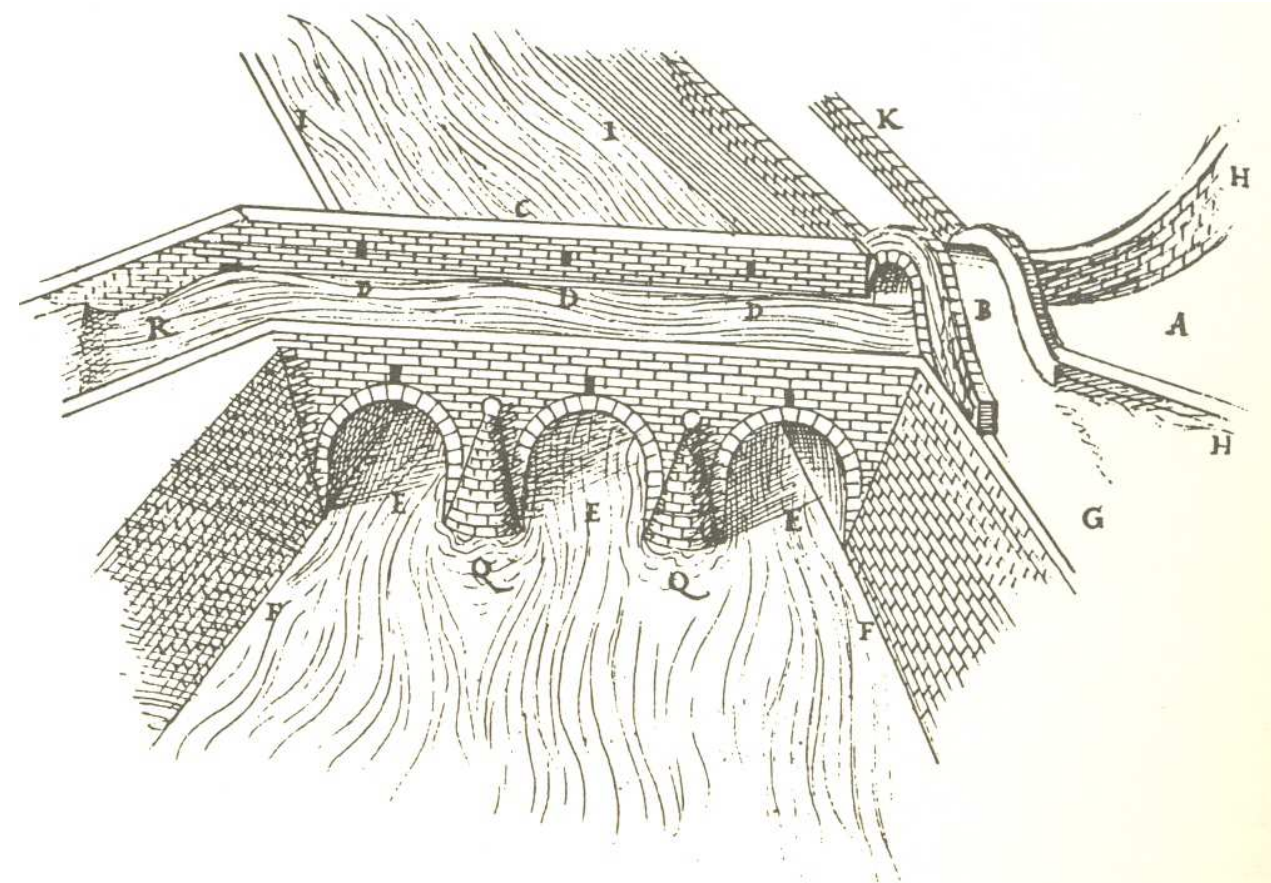

Folio 203v, figura 175: baños.

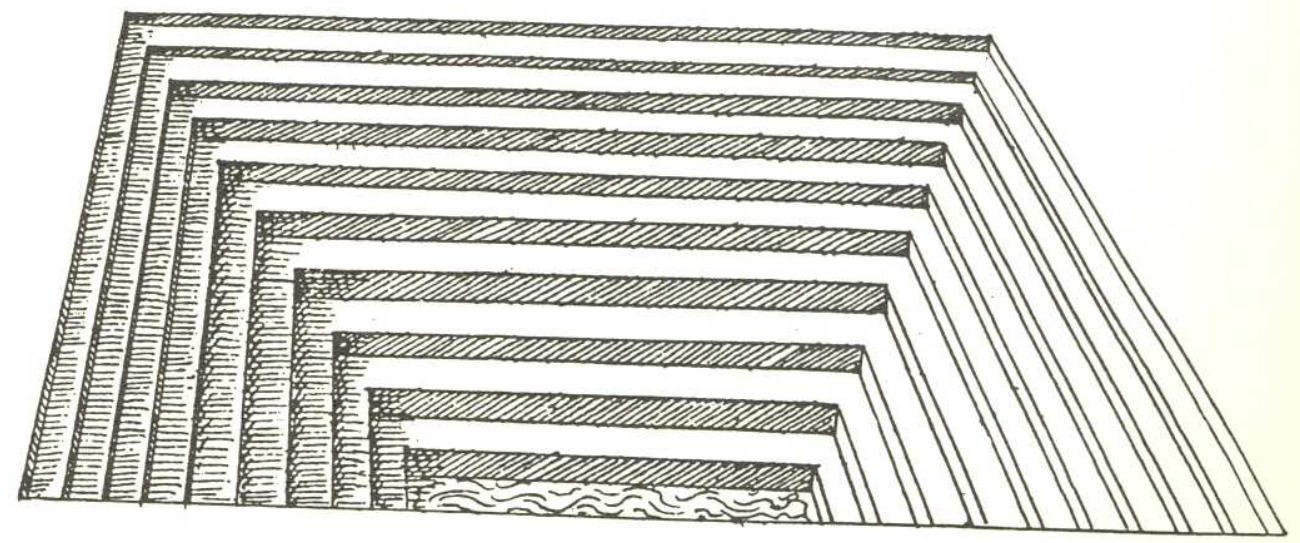


Folio 205v, figura 277: puente hecho con barcas.

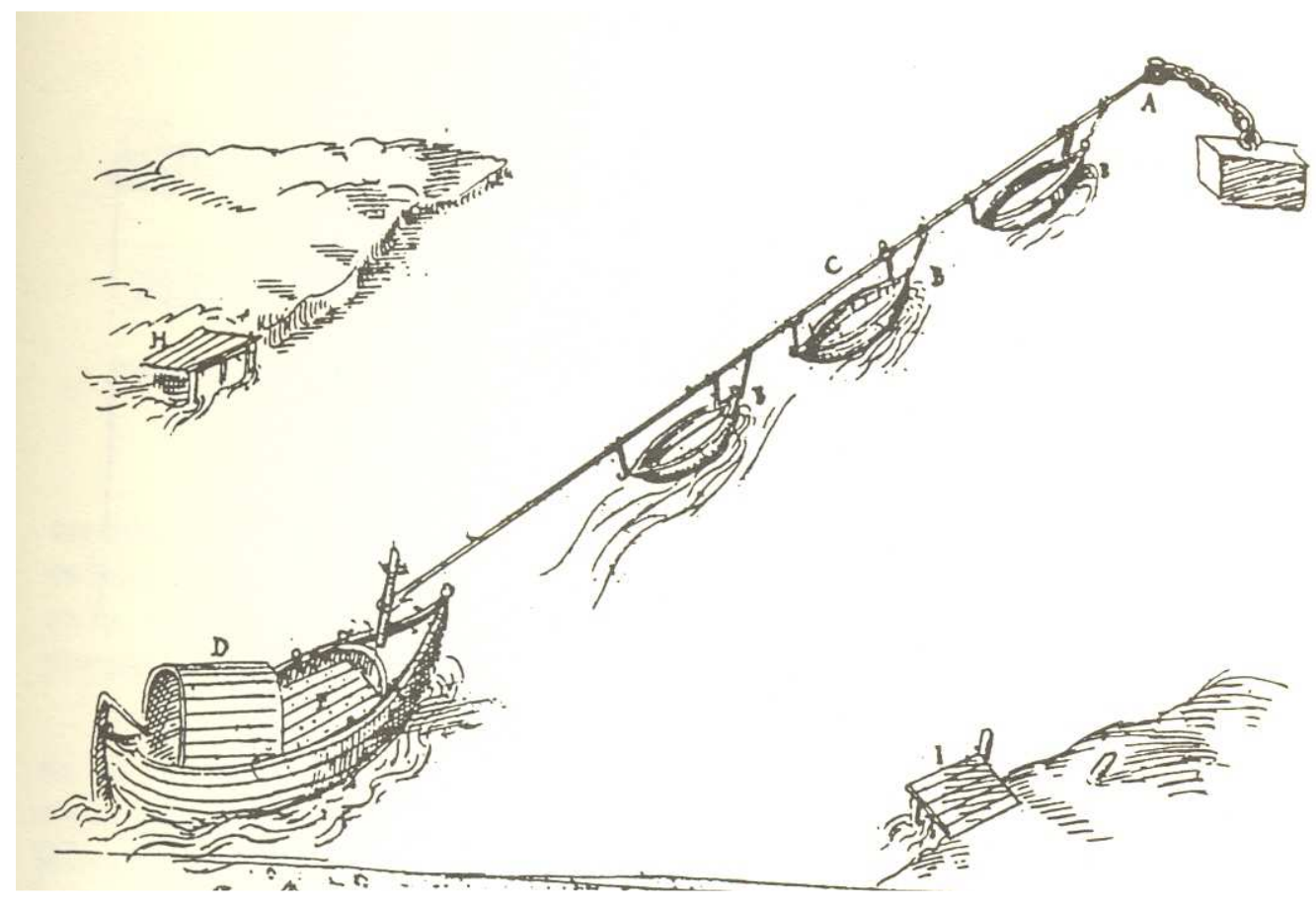

Folio 211v, figura 284: puente hecho con odres.

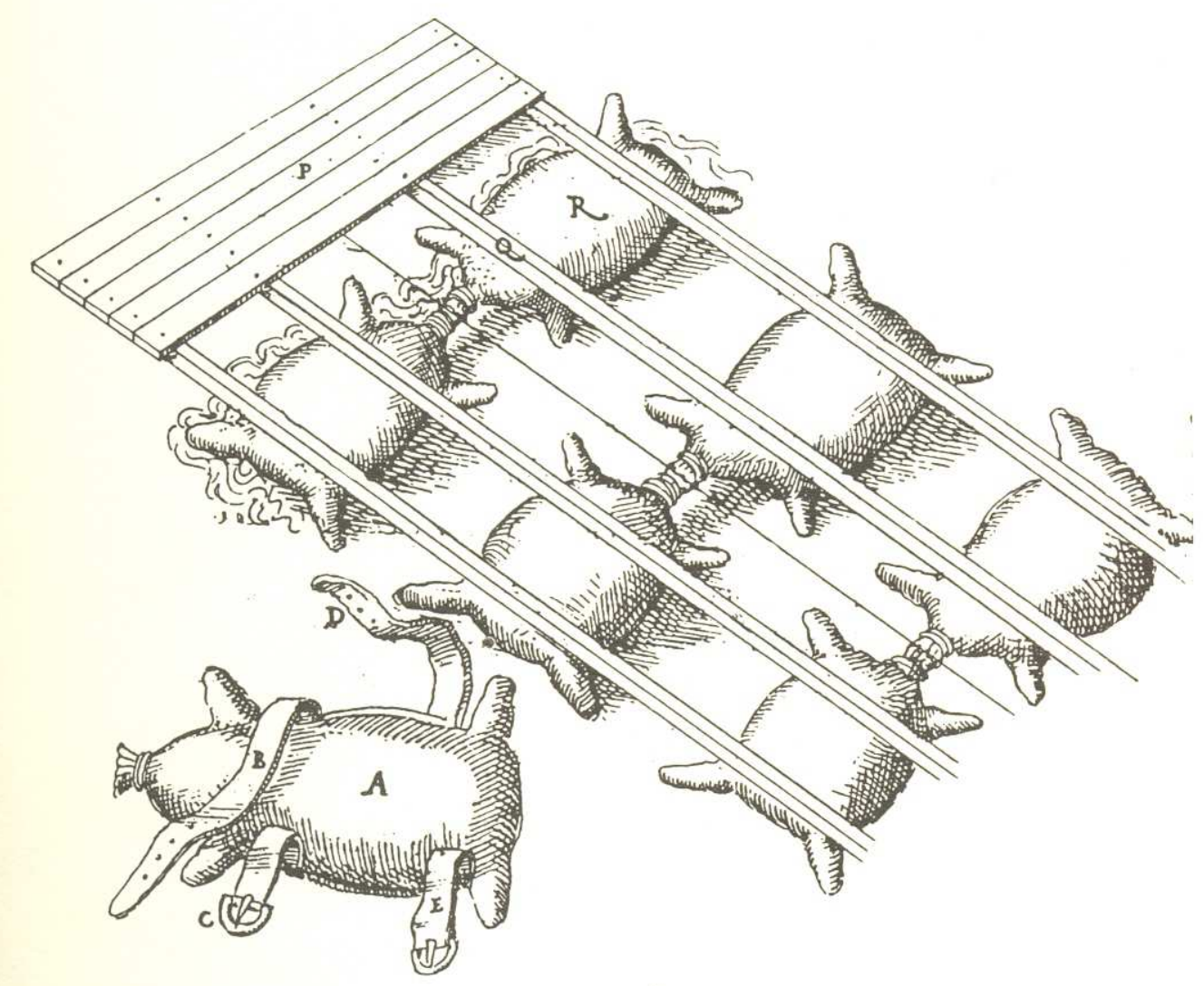


Folio 214v, figura 287: puente 1. B: tirante; EH: rebotantes; F: antepecho.

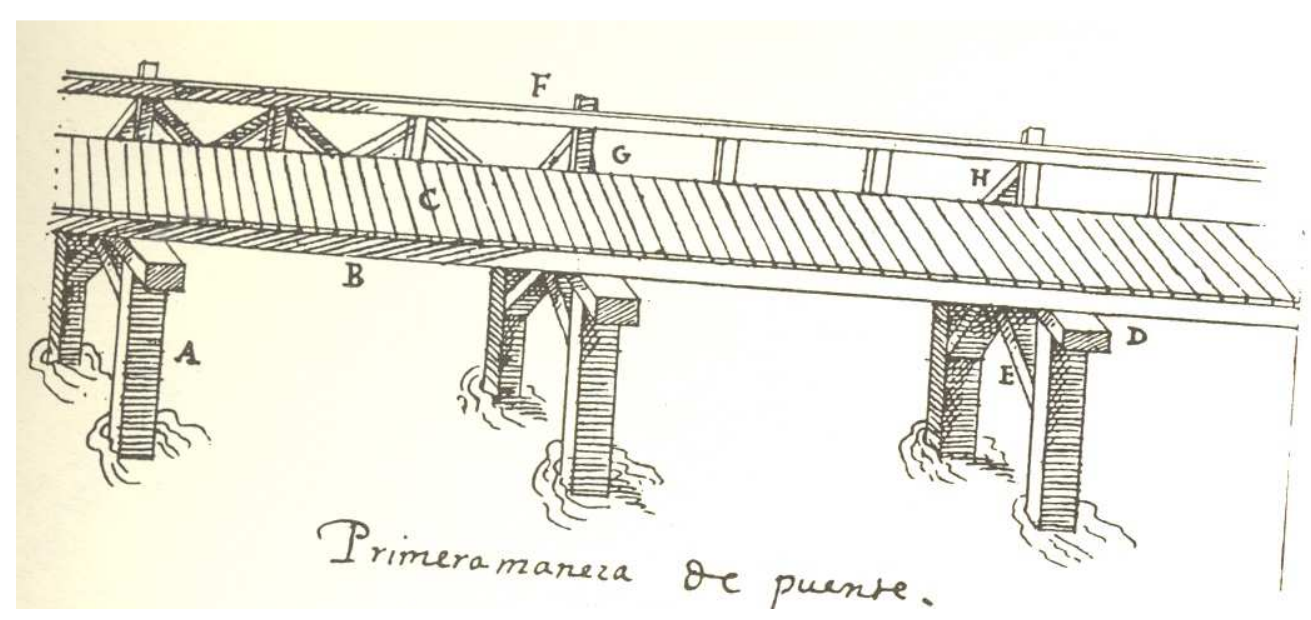

Folio 215v, figura 289: puente 2. H: Fíbula.

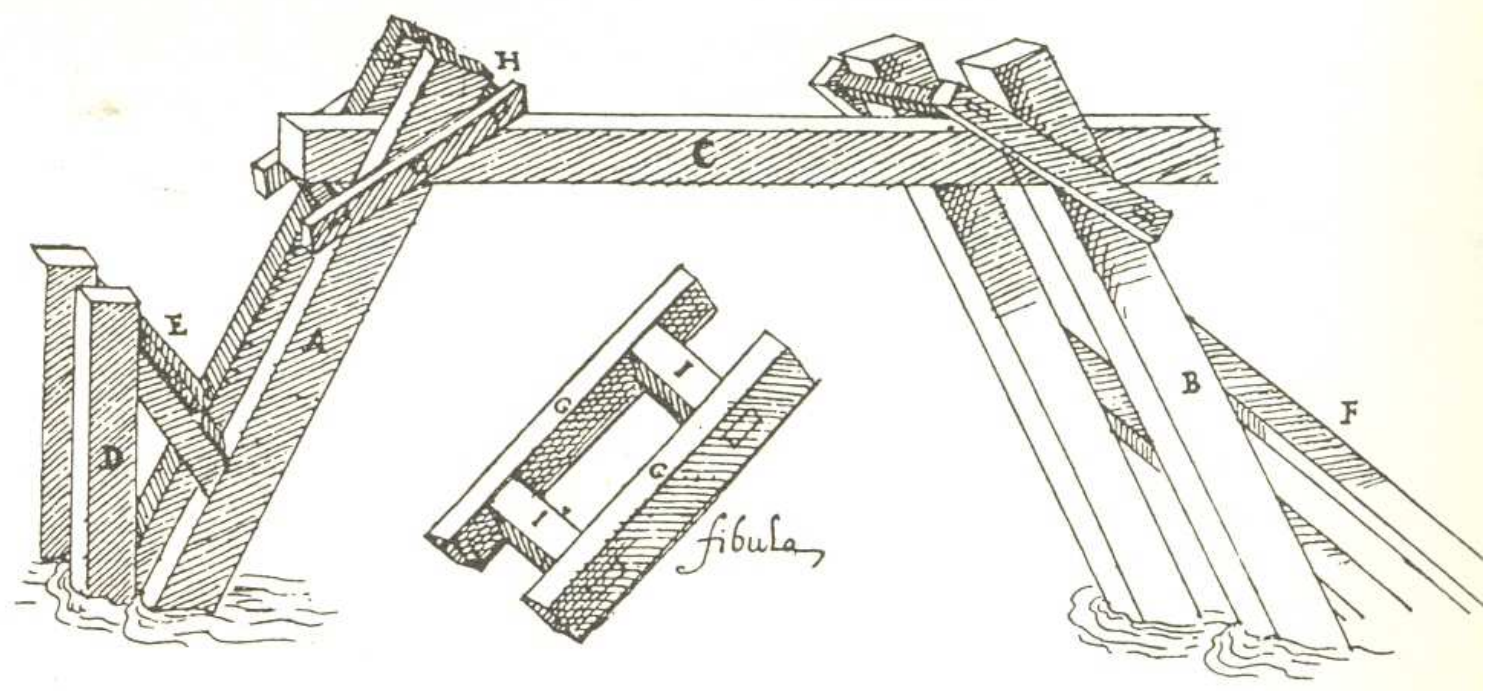


Folio 218v, figura 293: puente 3. C: rebotantes; G: maderos; A: tirantes.

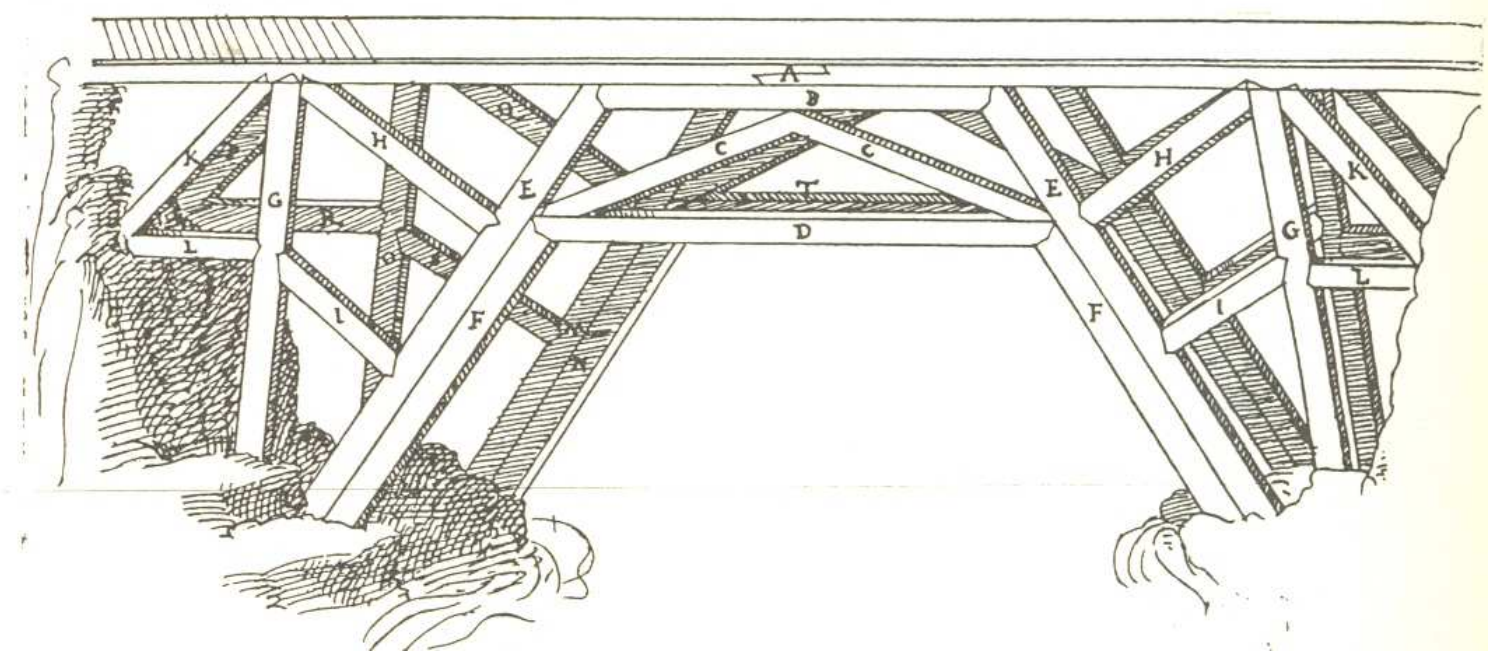

Folio 221v, figura 296: puente 4. KO: aspas1; AEGL: pies; RQP: traviesas o cadenas; DITV: rebotantes; CC: ménsulas o zoquetes.

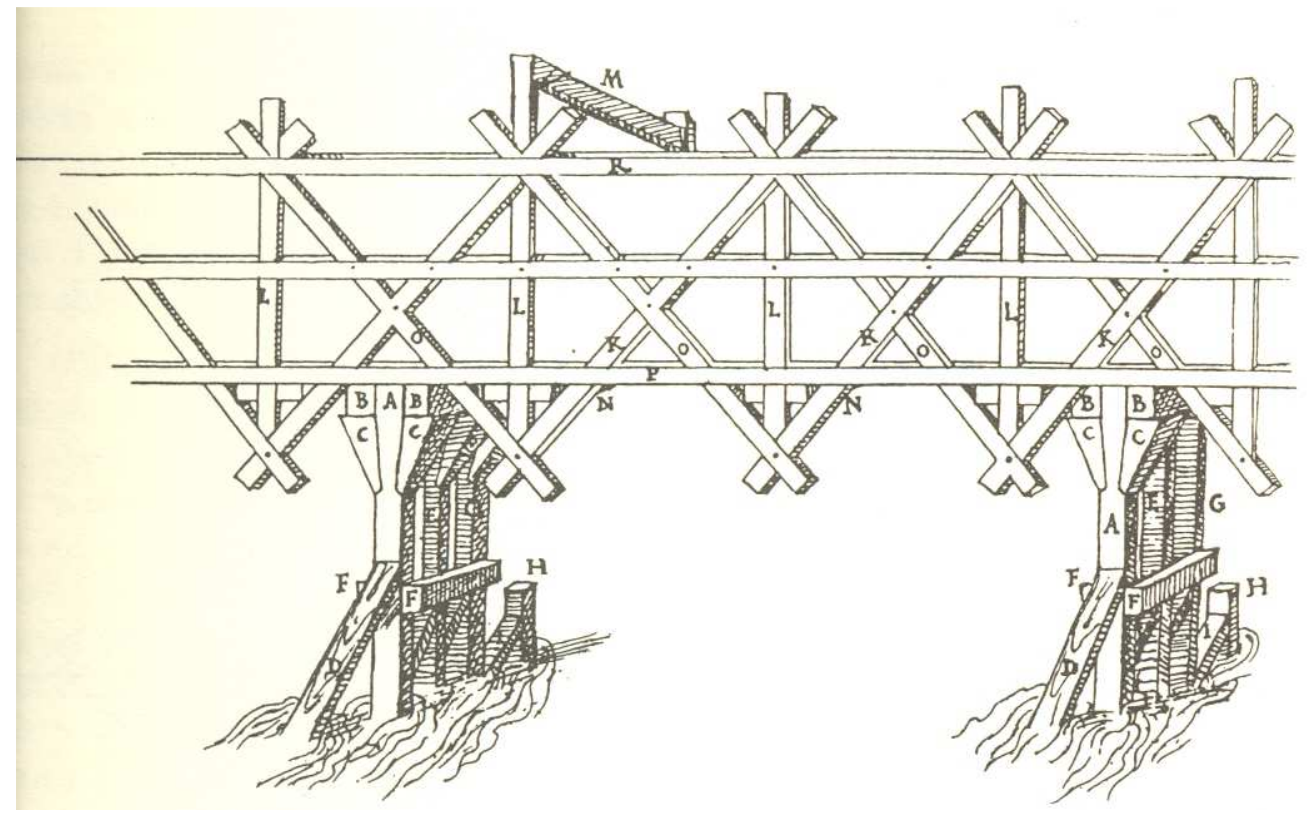


Folio 224r, figura 303 (letra I): arista.

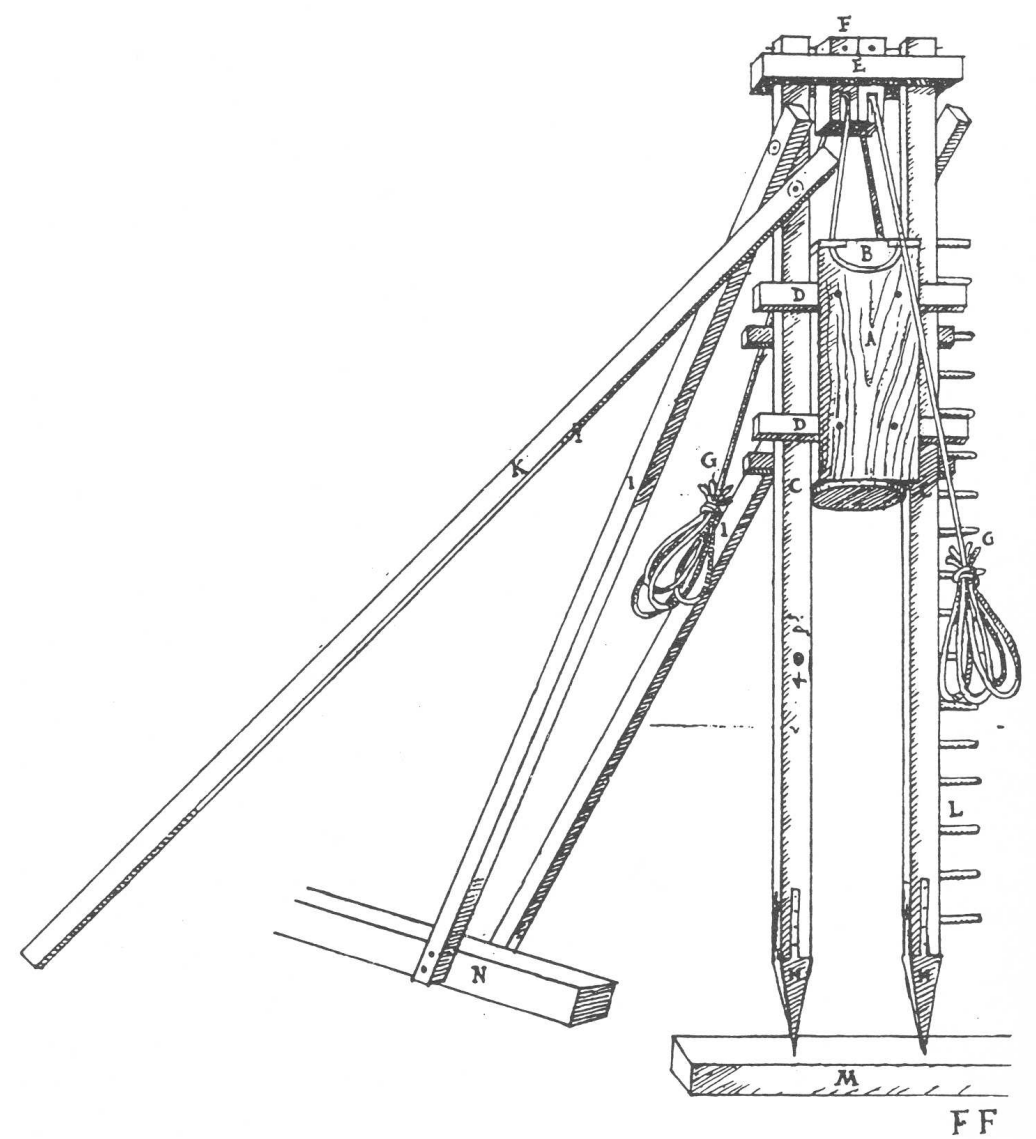


Folio 248r, figura 316: herramientas.

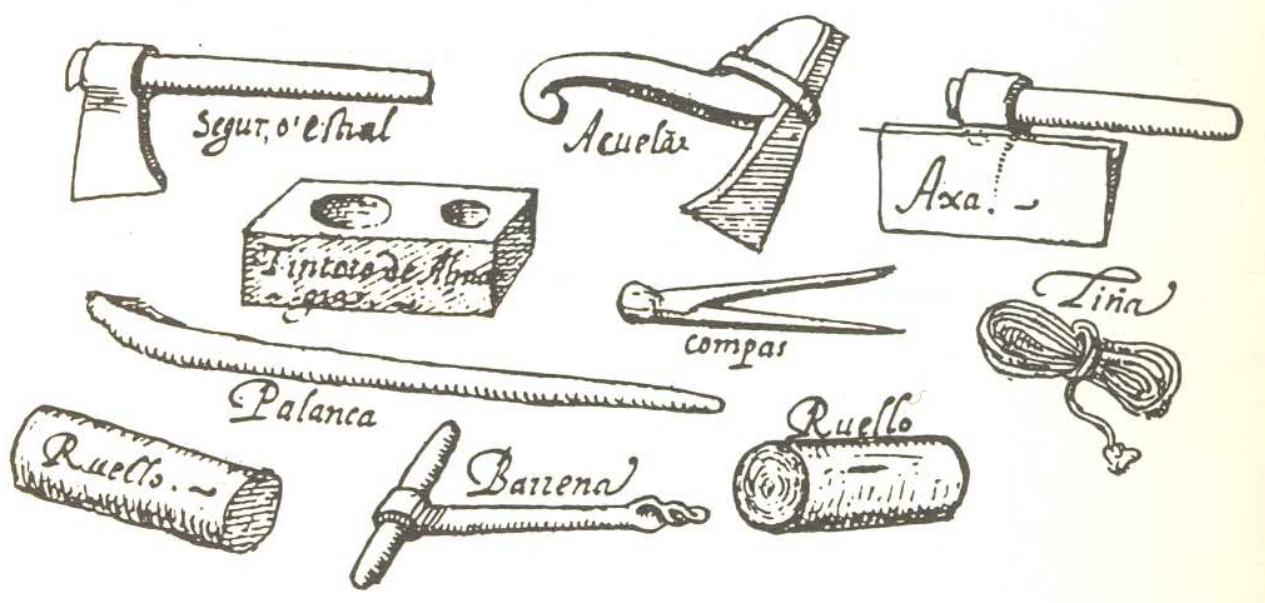

Folio 252r, figura 318: herramientas.

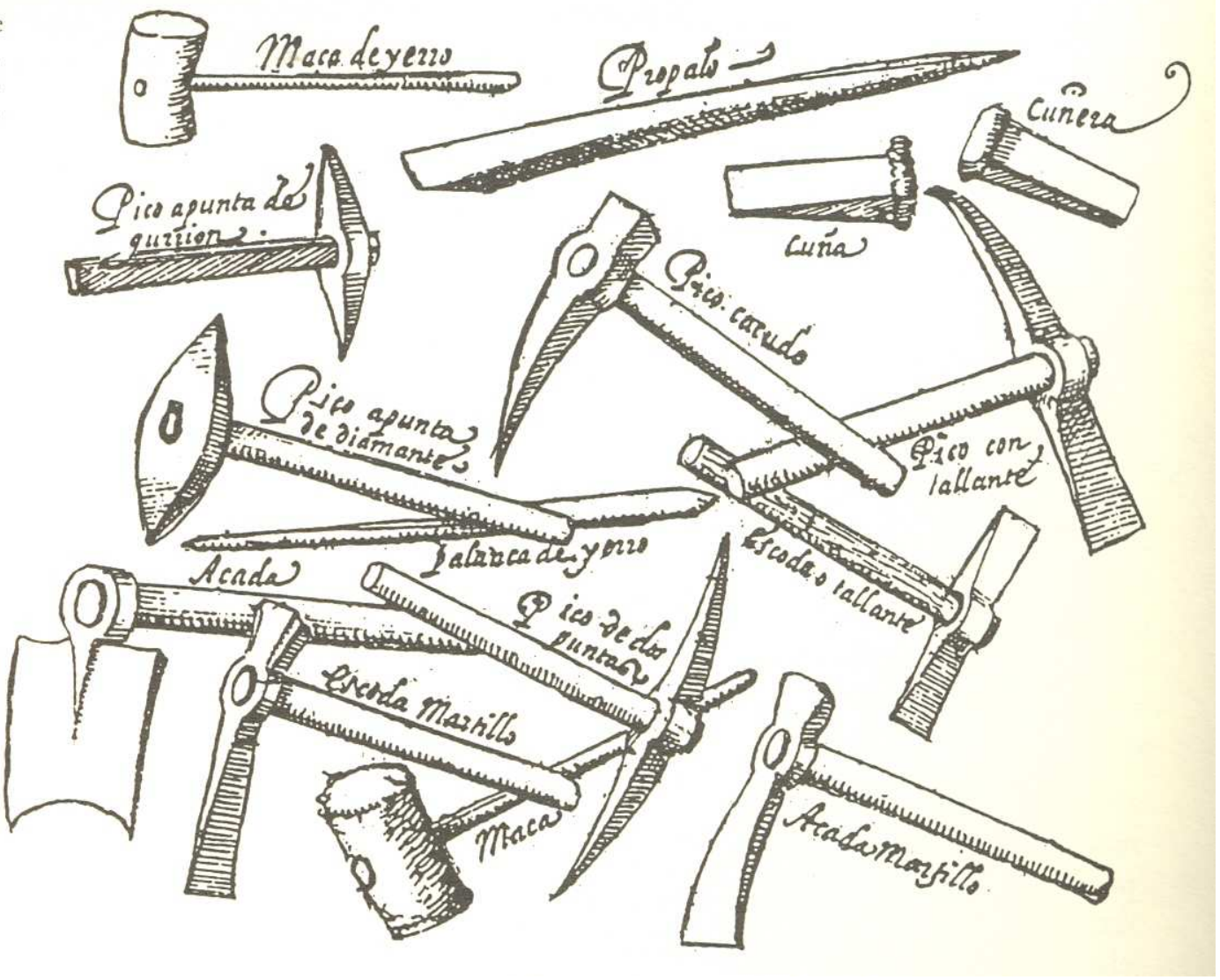


Folio 259v, figura 319: hornos de piedra y sus herramientas.

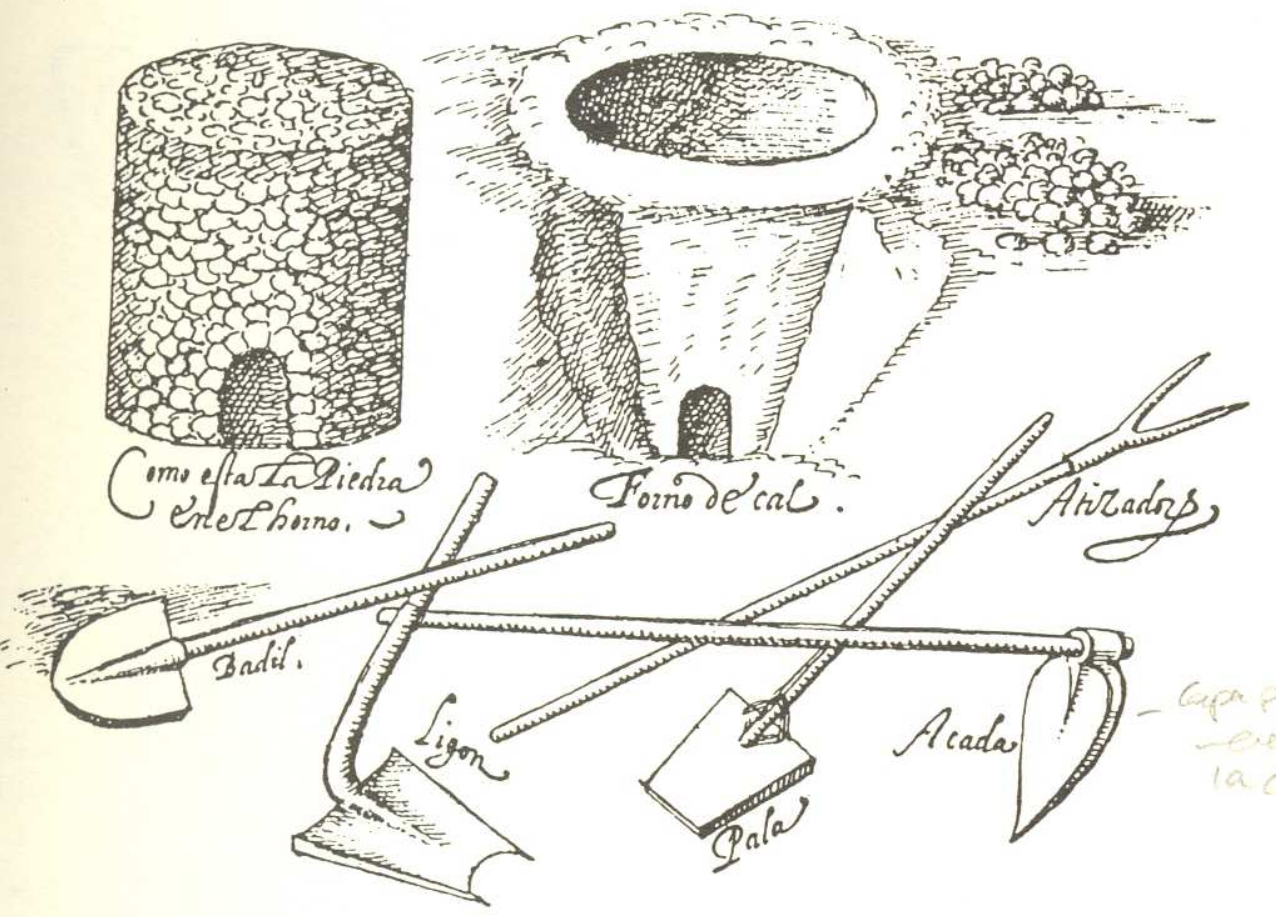


Folio 265v, figura 322: ruello ${ }_{2}$.

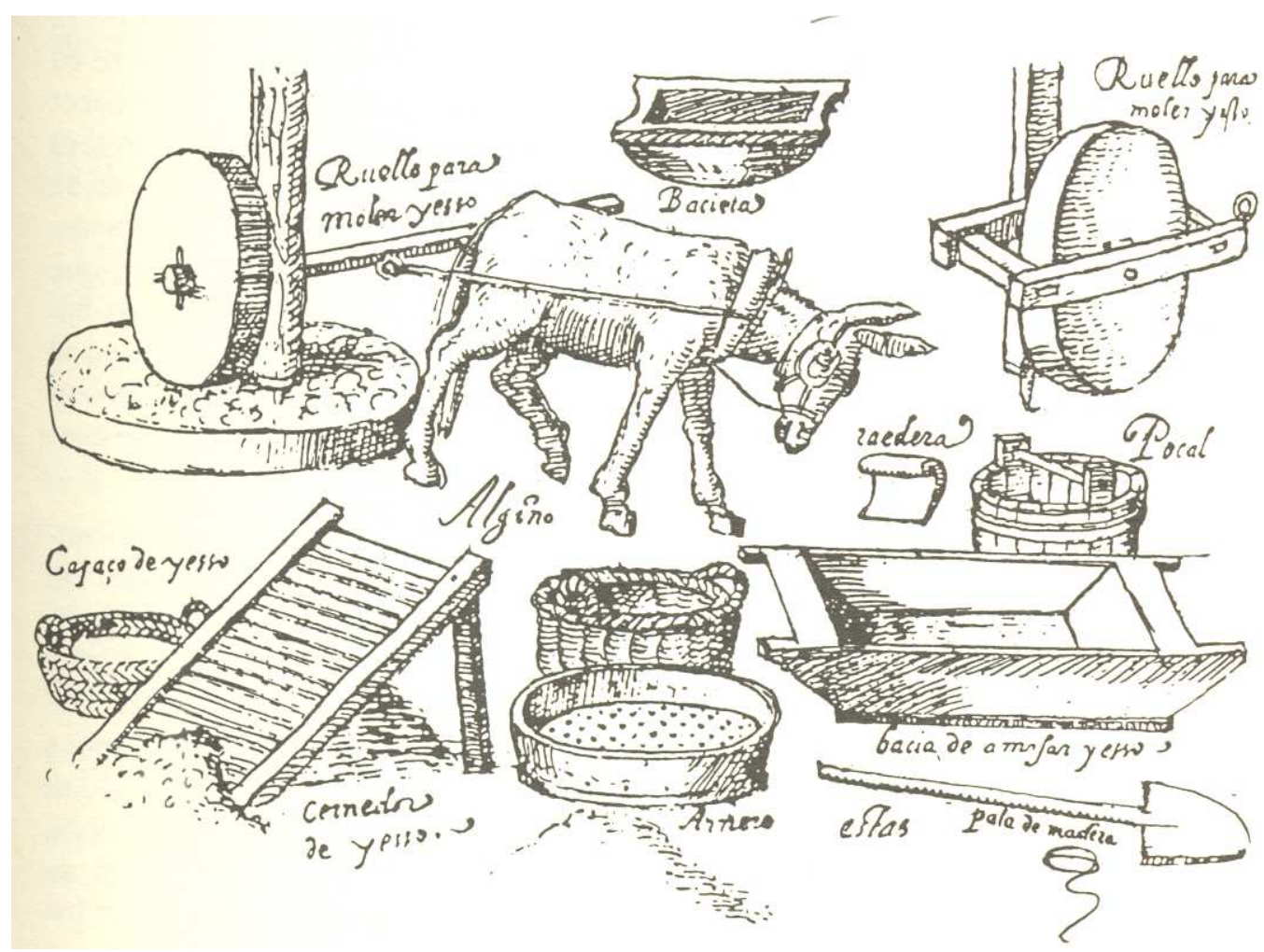

Folio 283v, figura 30: arcaduz.
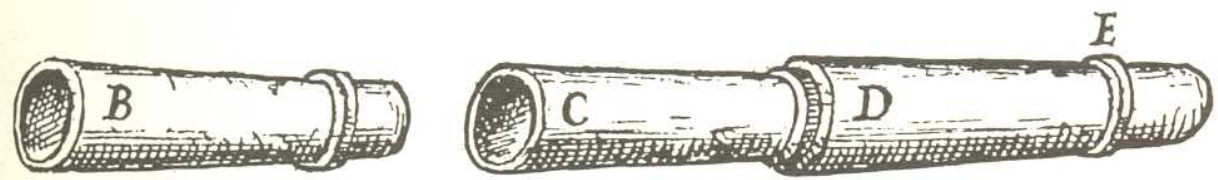
Folio 285r, figura 36: caños cuadrados.

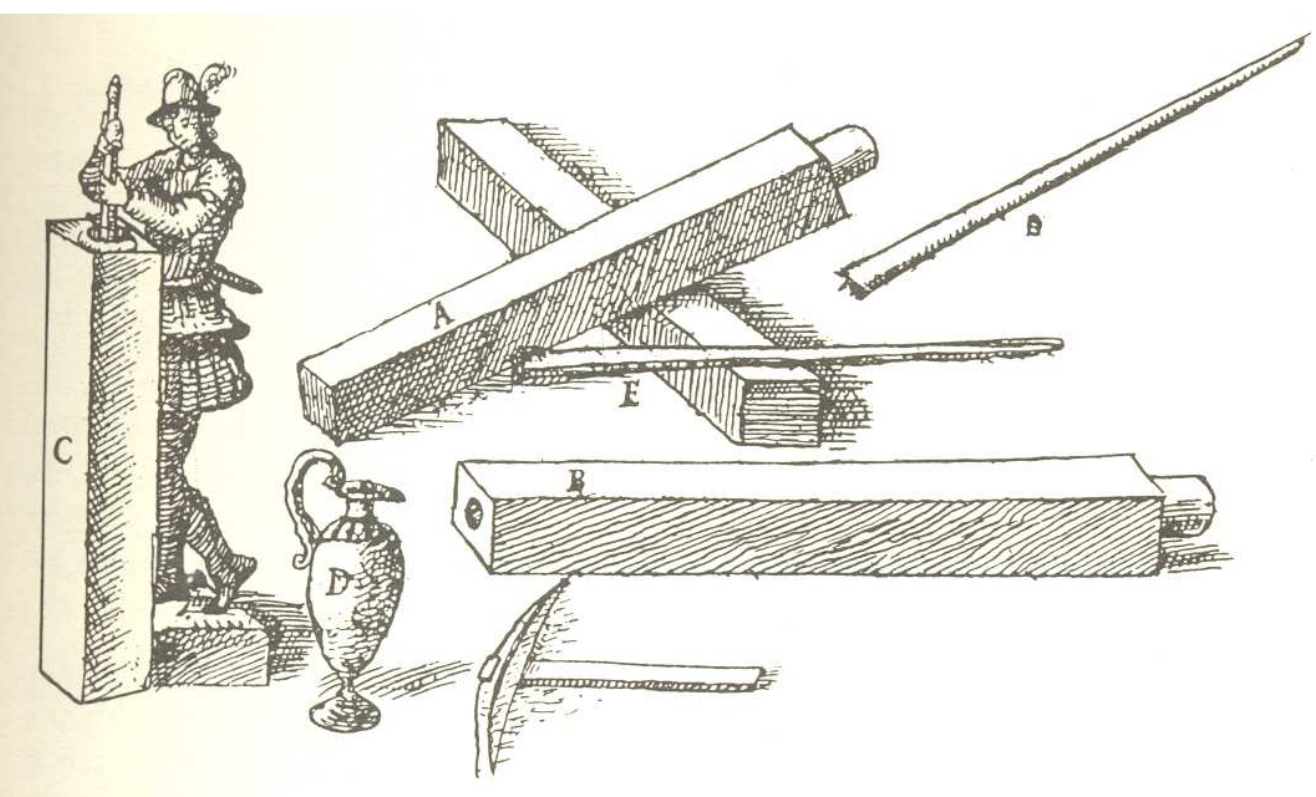

Folio 290r, figura 179: álabe.

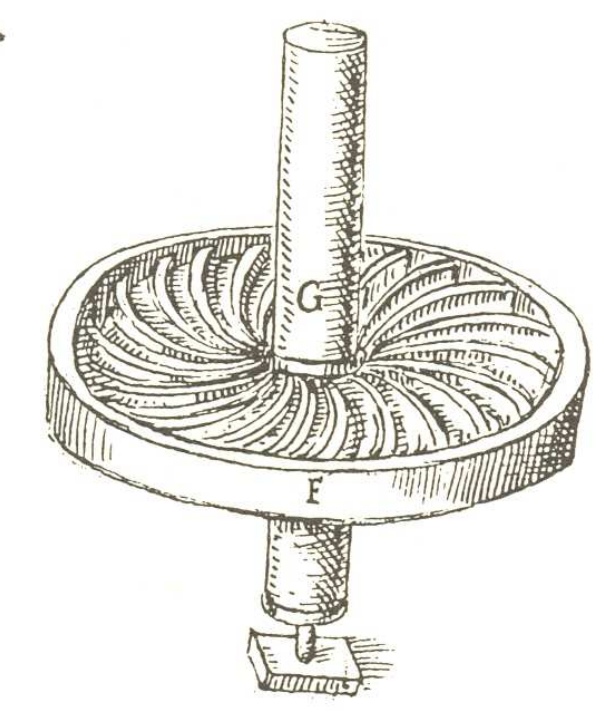


Folio 295r, figura 188: cubo. A: cubo; B: suelo; C: saetía; D: botana2.

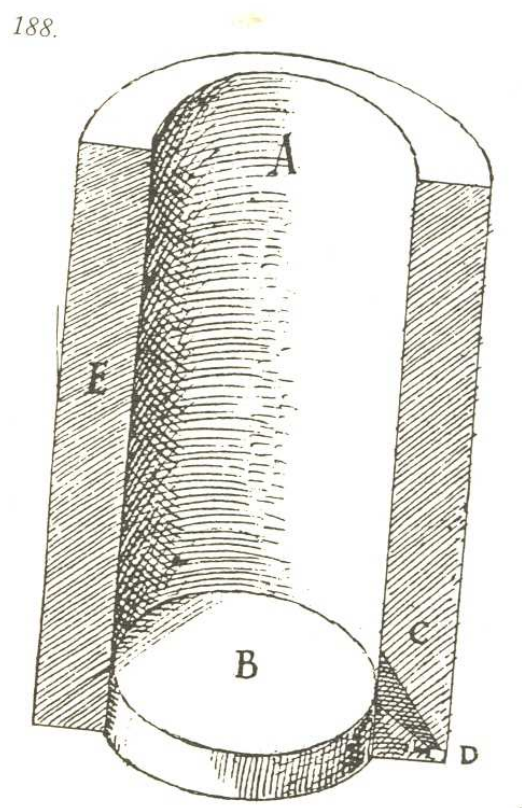

Folio 297r, figura 195: A: cubo; C,D: saetías; E, F: rodetes.
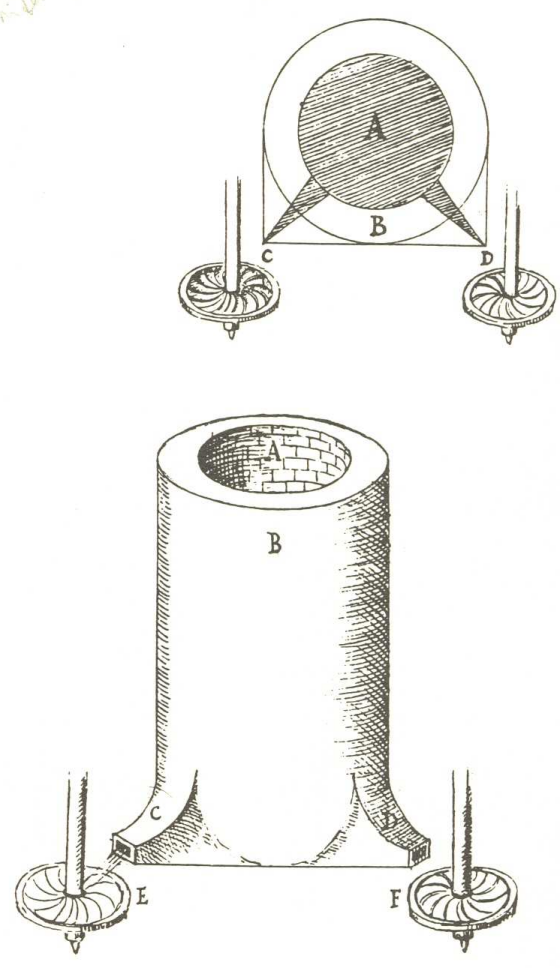
Fol. 299v, fig. 200: anadija, ananilla, nanilla.

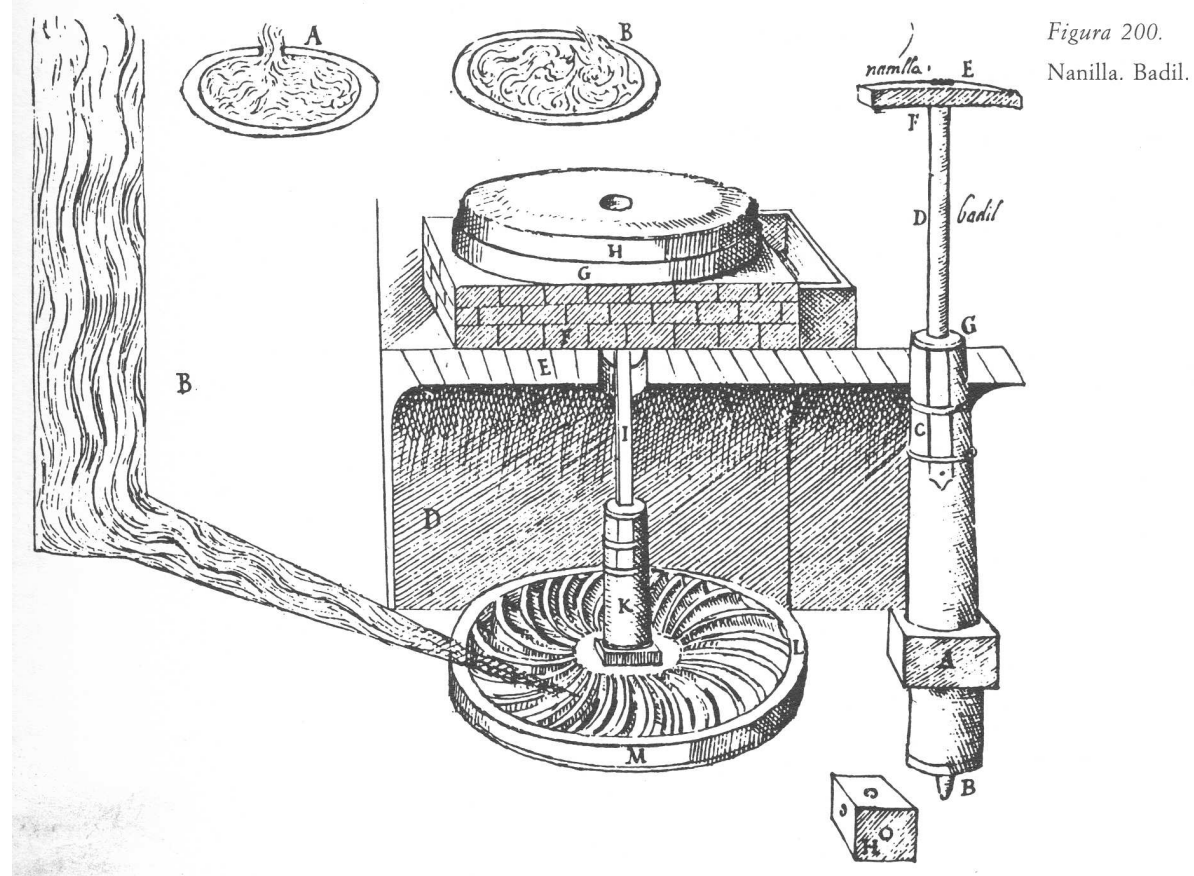


Folio 308r, figura 211: molino de tahona. A: mástil; B: rueda; C: cajales; D: linterna; E: eje; F: rueda; G: cajales; H: linterna; R: caja harinal; S: tahona2; V: canalón; T: torcedor; X: cítola.

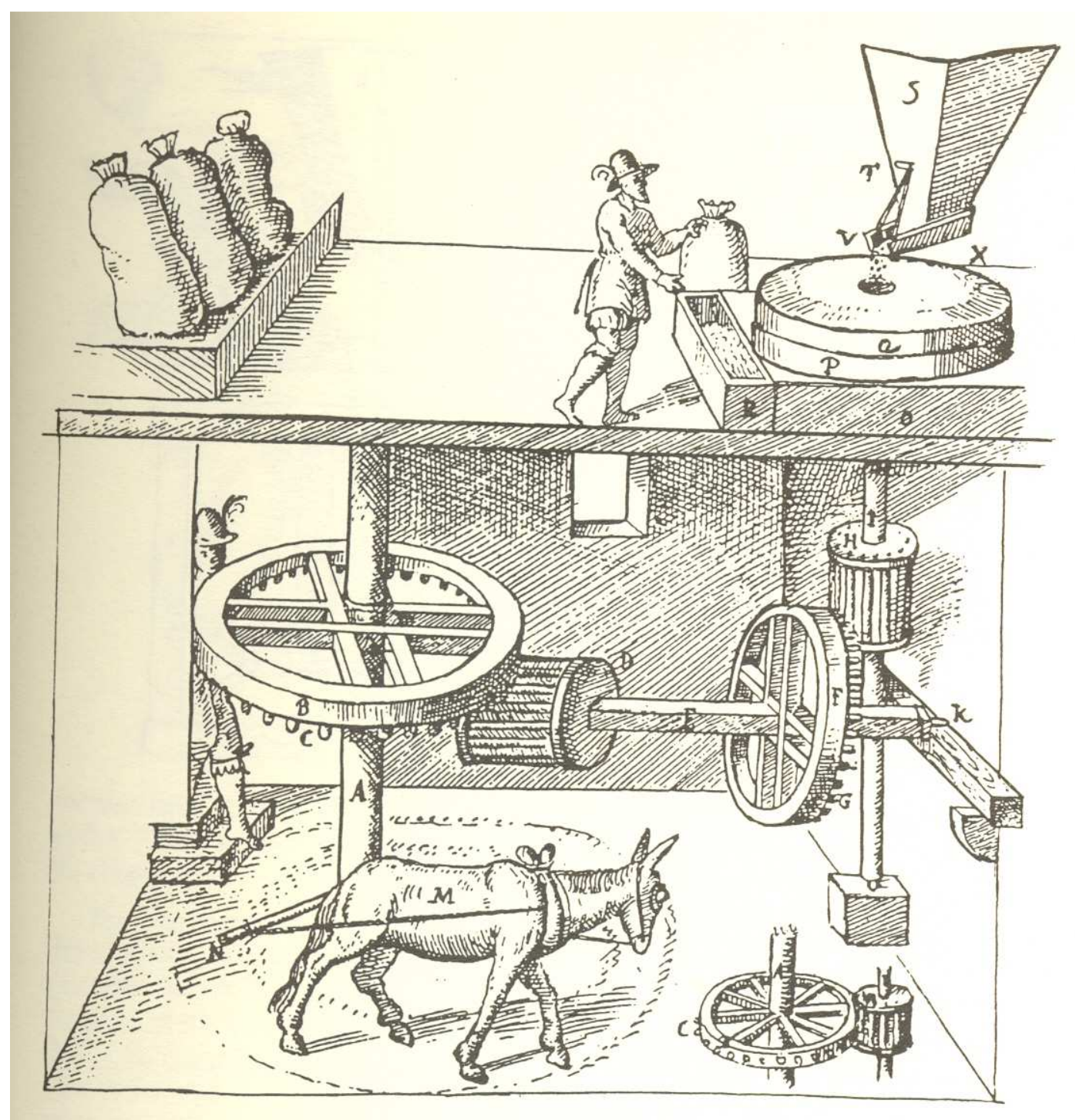


Folio 308v, figura 212: molino de mano. A: muela; B: tahona; C: torcedor; D: canalete; E: cítola o tarabilla; F: caja farinal; G: armadura. K: cigüeña; M: ananilla.

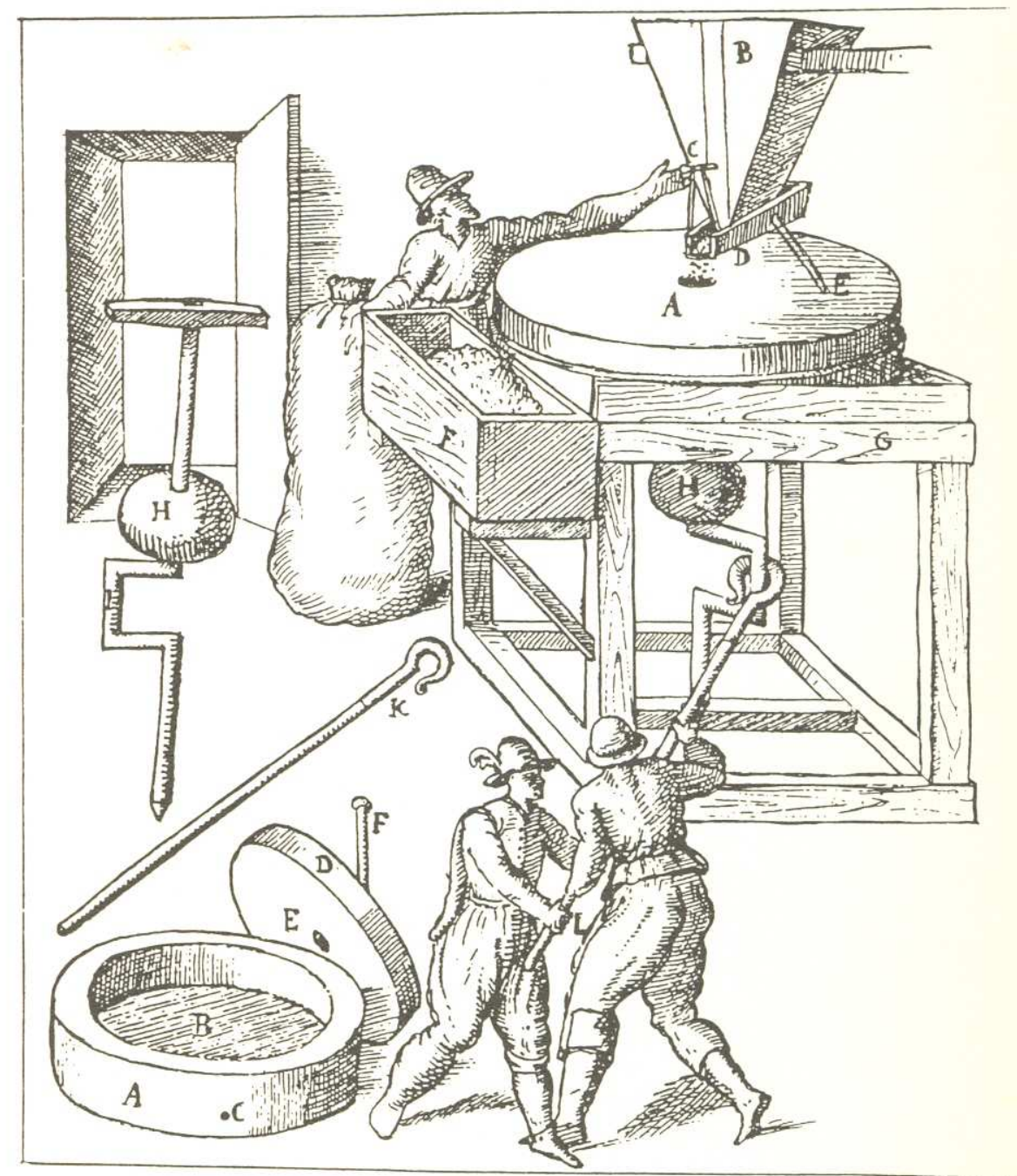


Folio 309r, figura 213: molino de viento. A: vela; C, D: cajales; E: mástil; F: linterna; G: rueda; K: mástil; L: muela; M: tahona; N: canalón; O: torcedor; P: caja farinal; Q: pala.

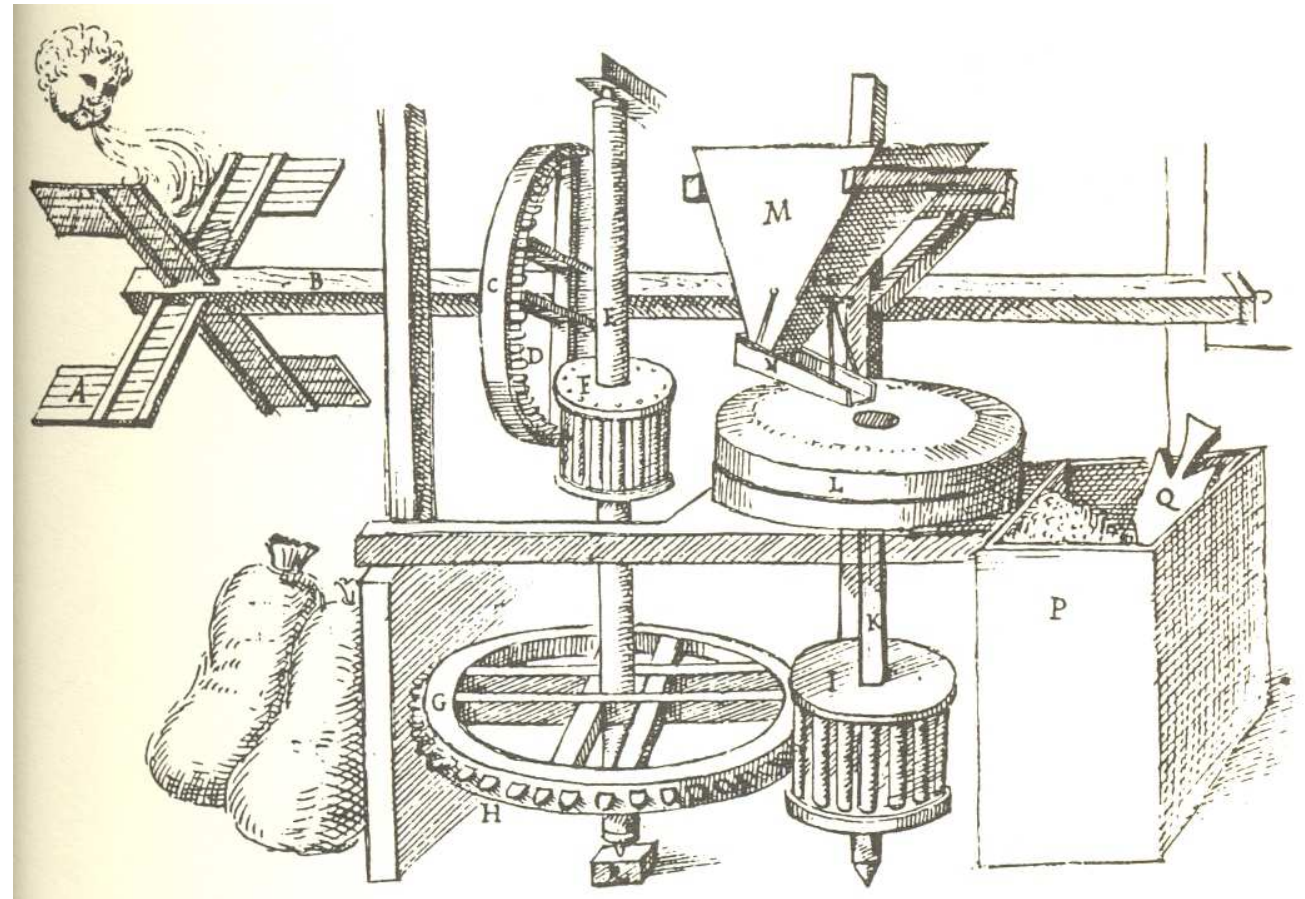

Folio 309v, figura 214: molino de contrapesos.

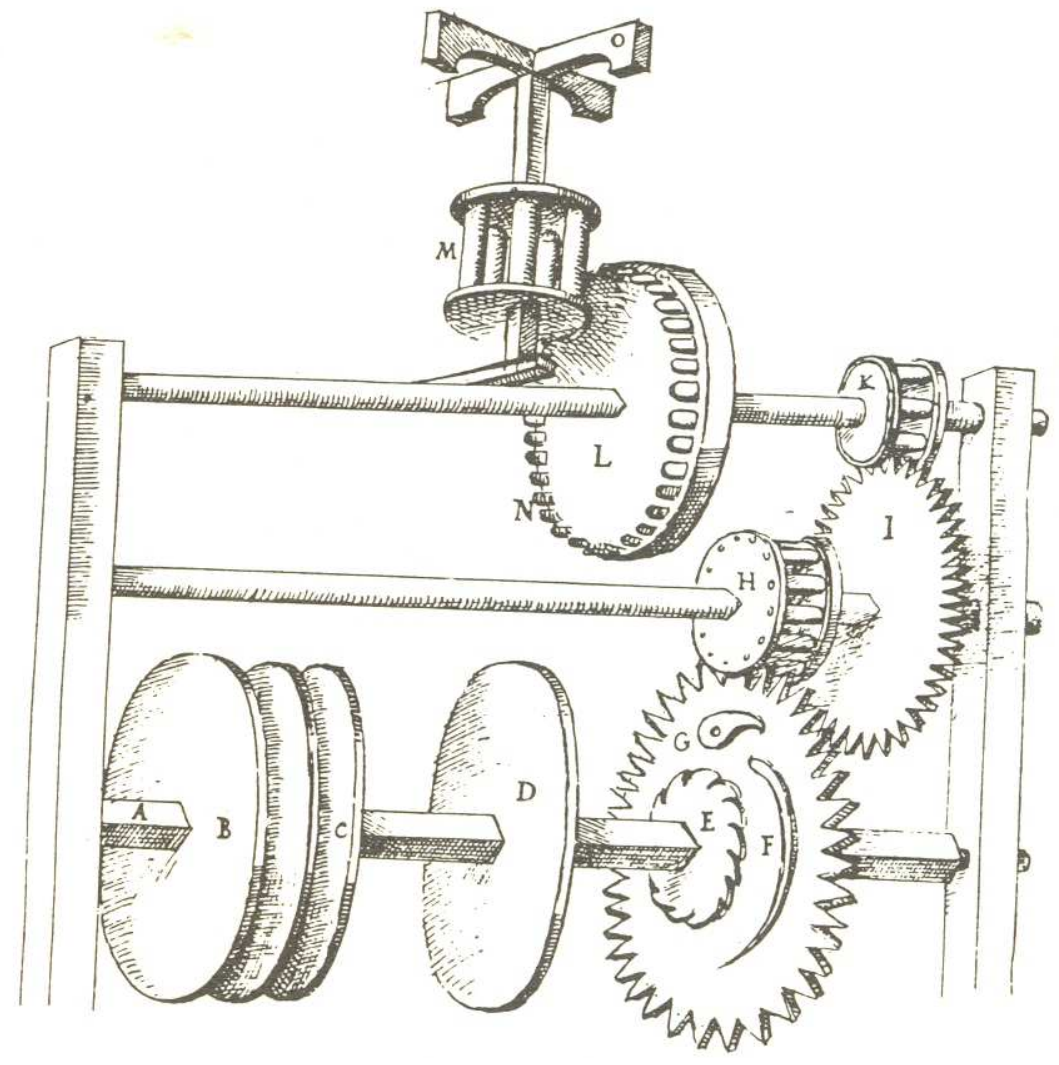


Folio 311v, figura 218: molino de balsa y cubo.

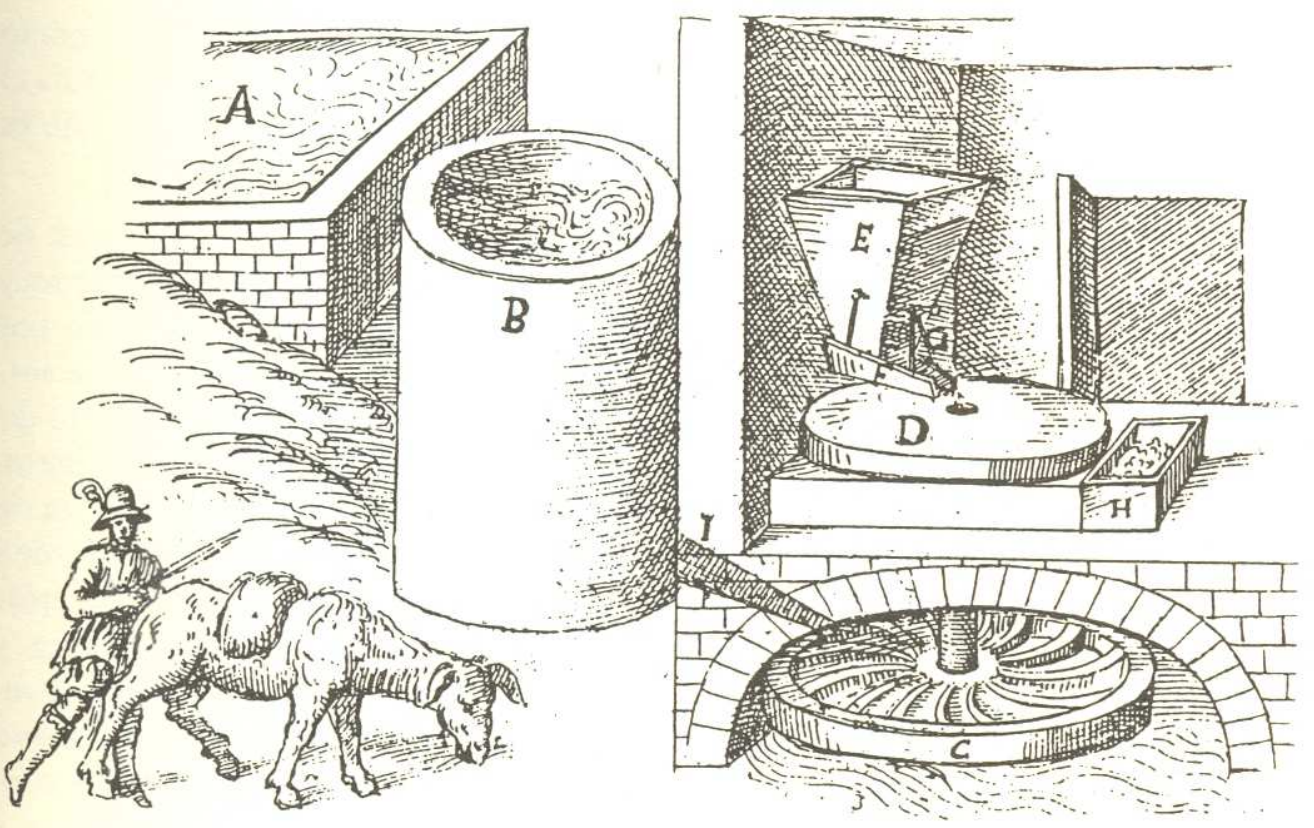

Folio 312r, figura 219: molino de balsa. A: balsa; B: almenara o desaguadero; CD: saetías; E: rodete; F: muela; G: tahona; H: templador.

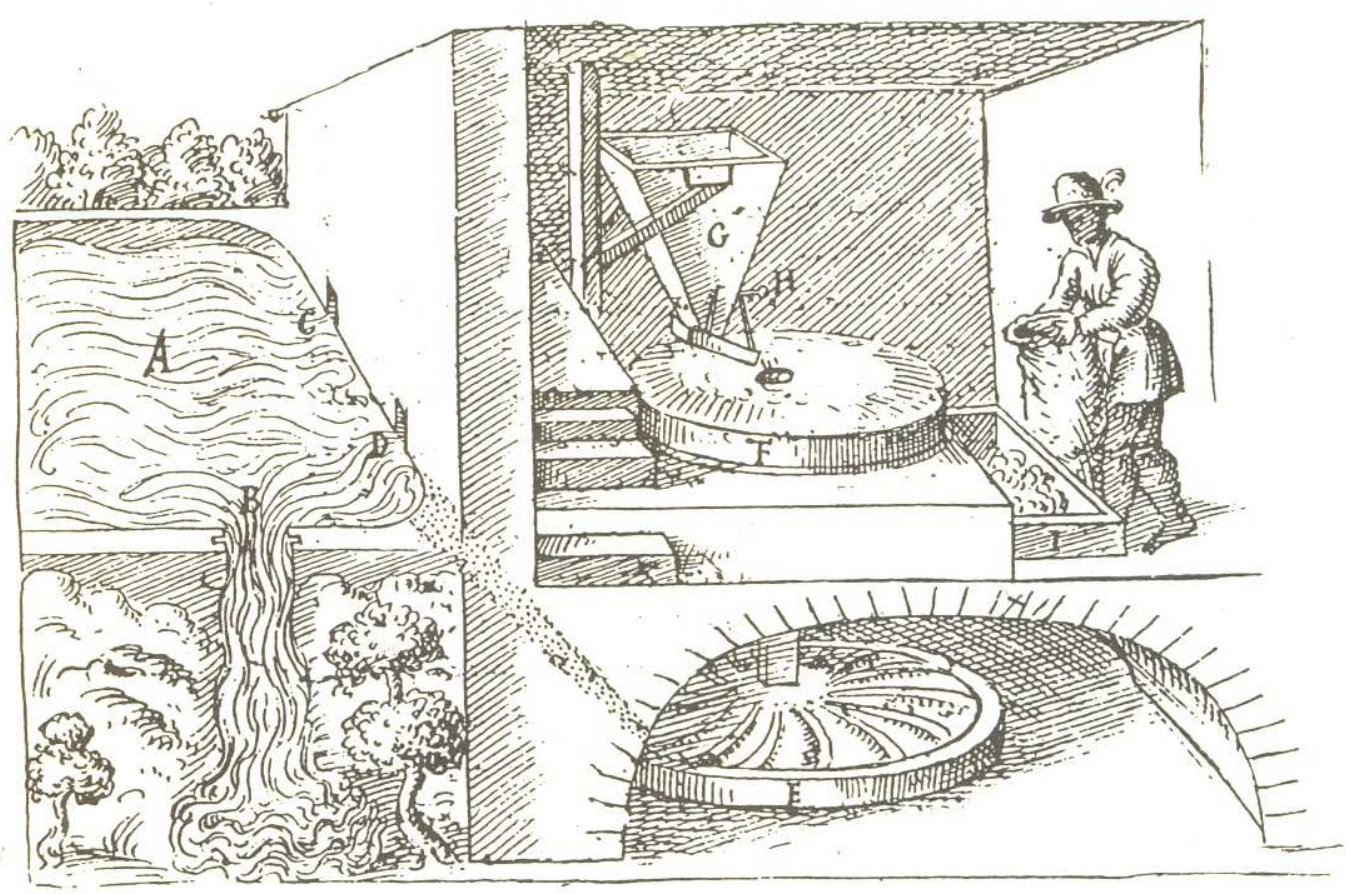


Folio 312v, figura 220: molino de regolfo. A: balsa; CCC: saetías; EEE: botanas; GGG: espiraderos; FFF: cubetes.

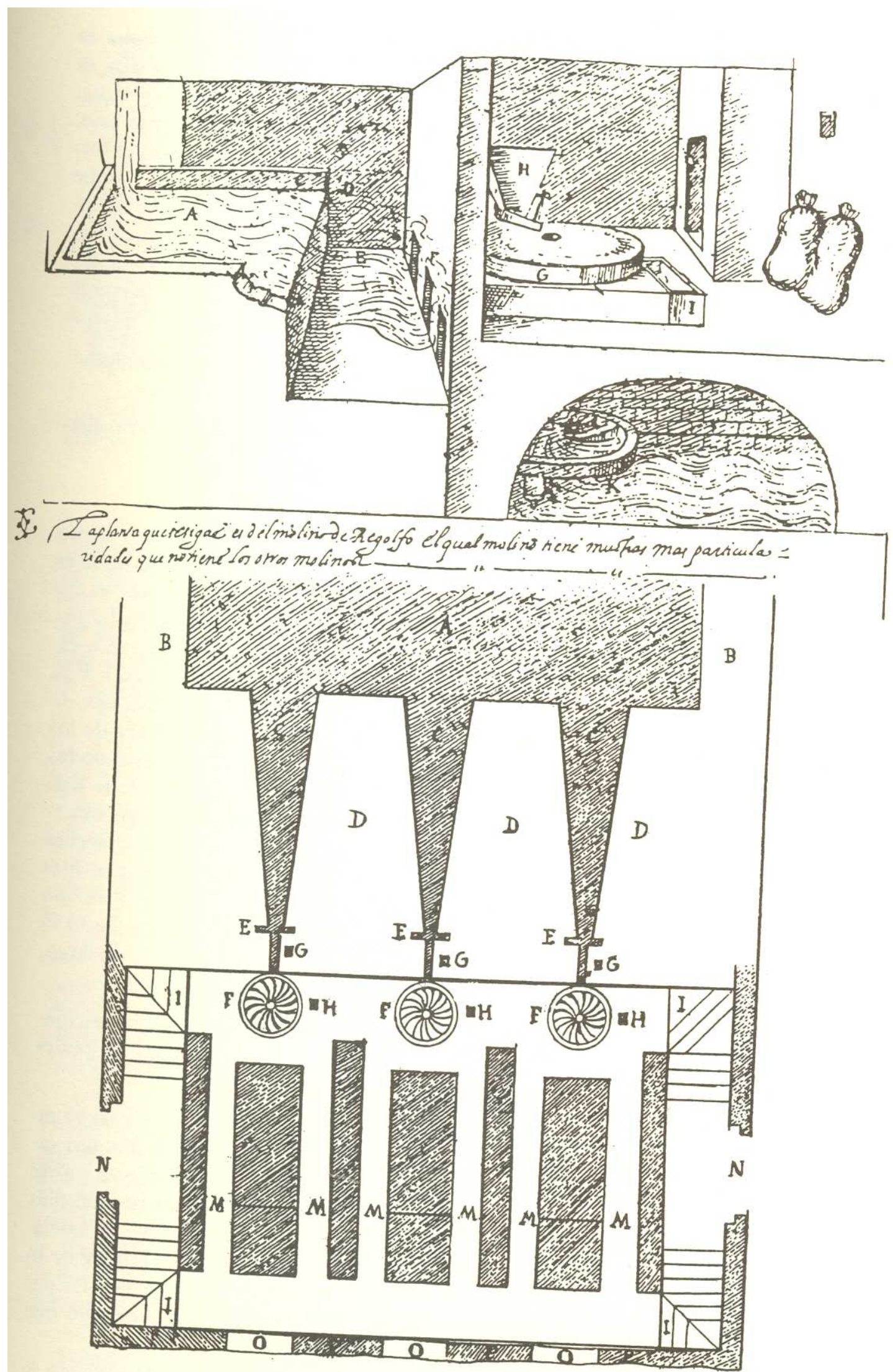


Folio 317v, figura 227: A: tahona; B: templador; C: canalote; D: tarabilla; E: armadura; F: harinal; G: pala; H: escoba.

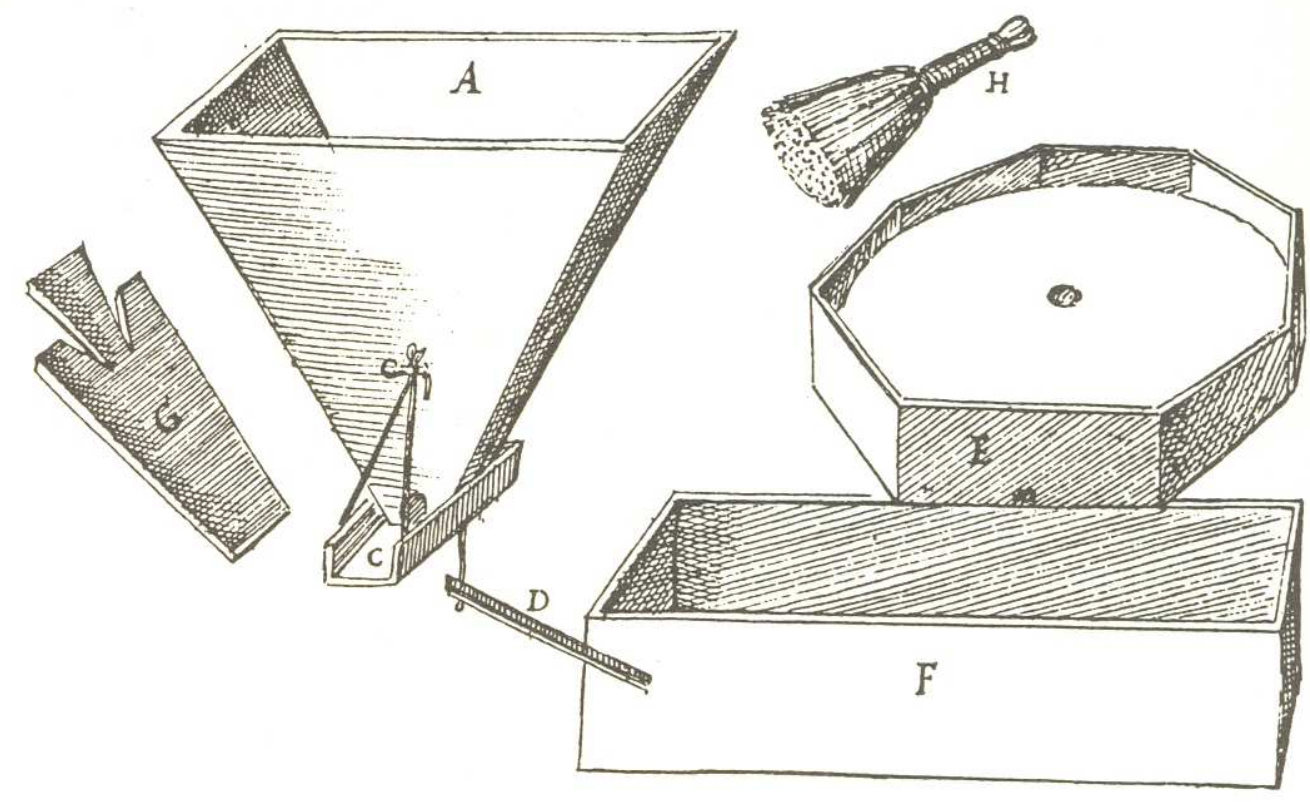

Folio 318v, figura 228: molino de barca sola.

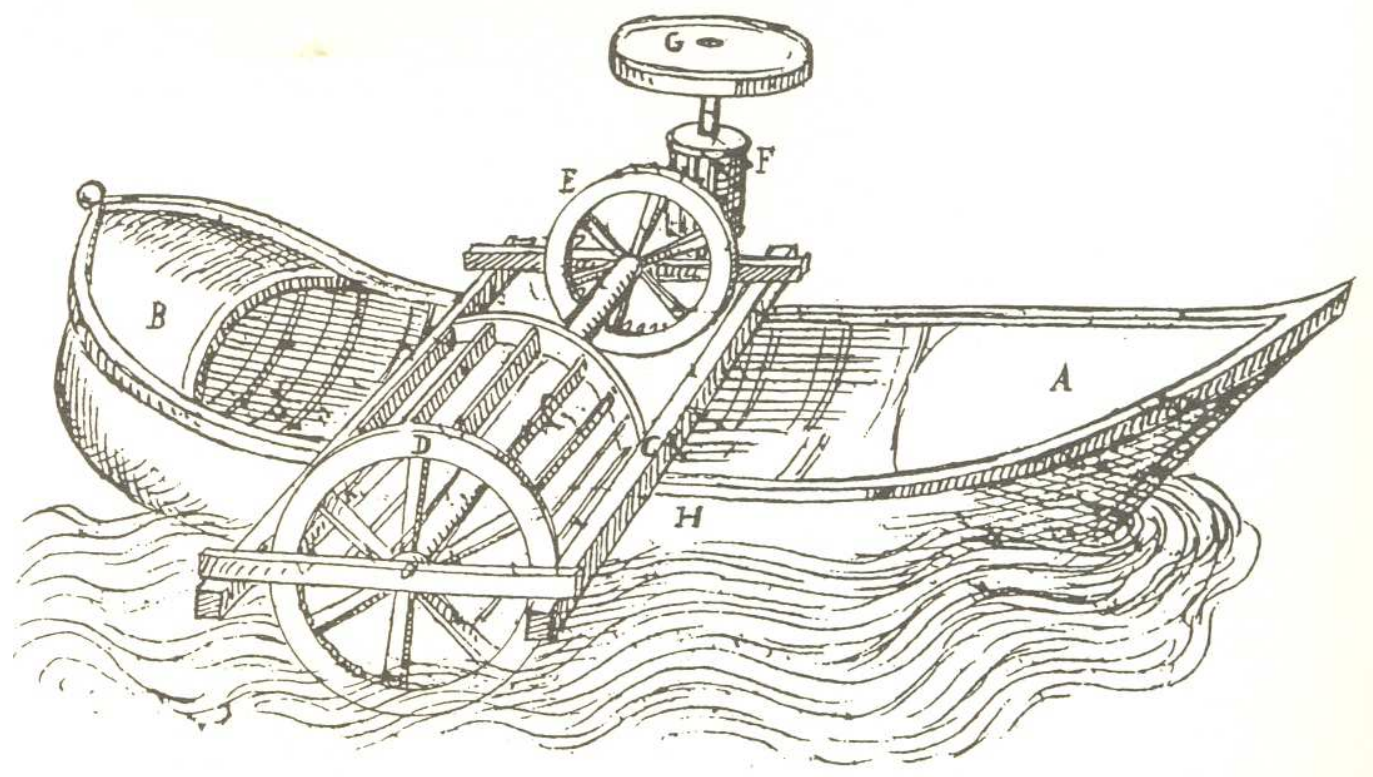


Folio 319r, figura 229: molino de barcas.

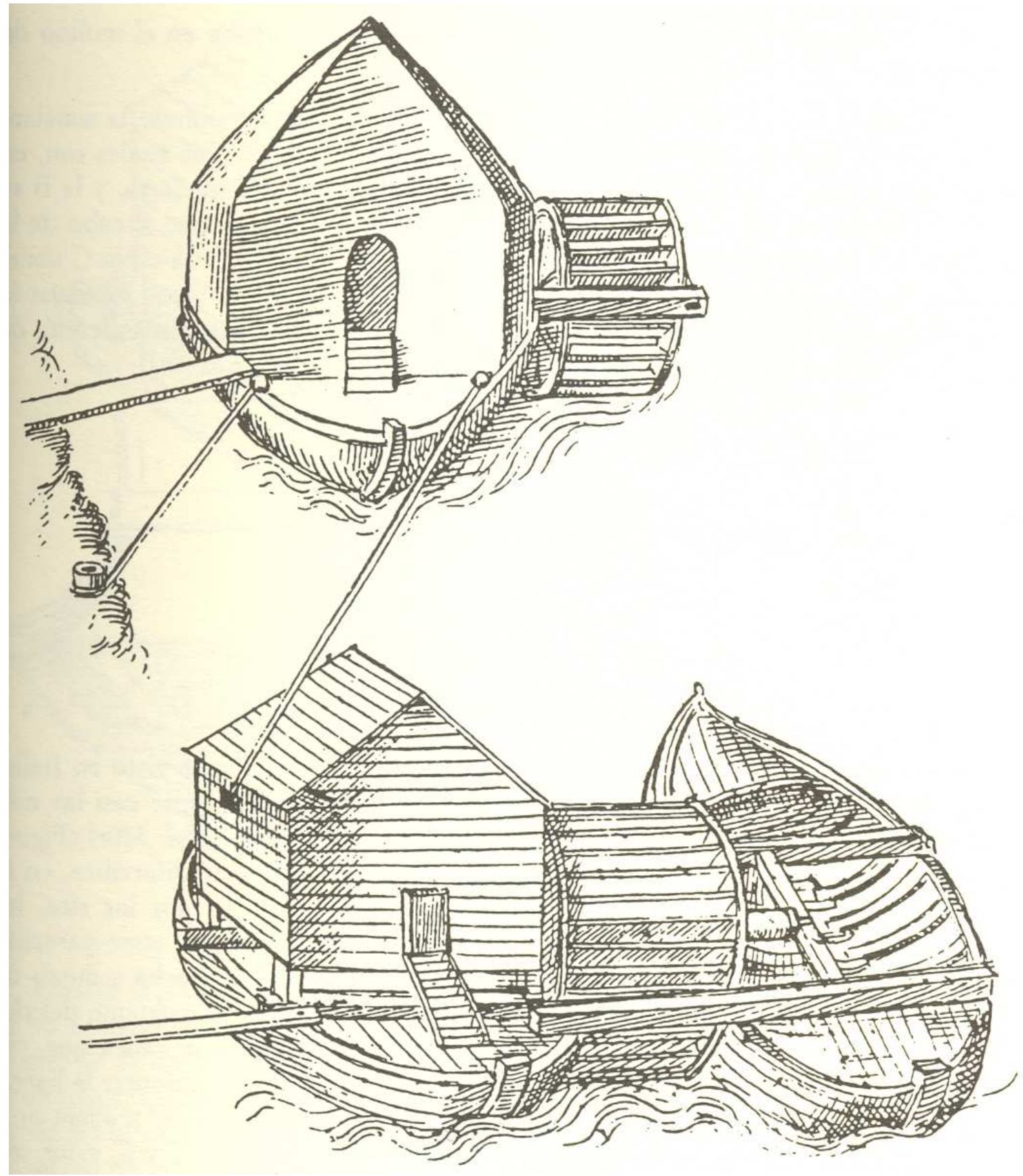


Folio 321v-322r, figura 234: invención, con un solo animal, para moler, limpiar armas y picar pólvora.

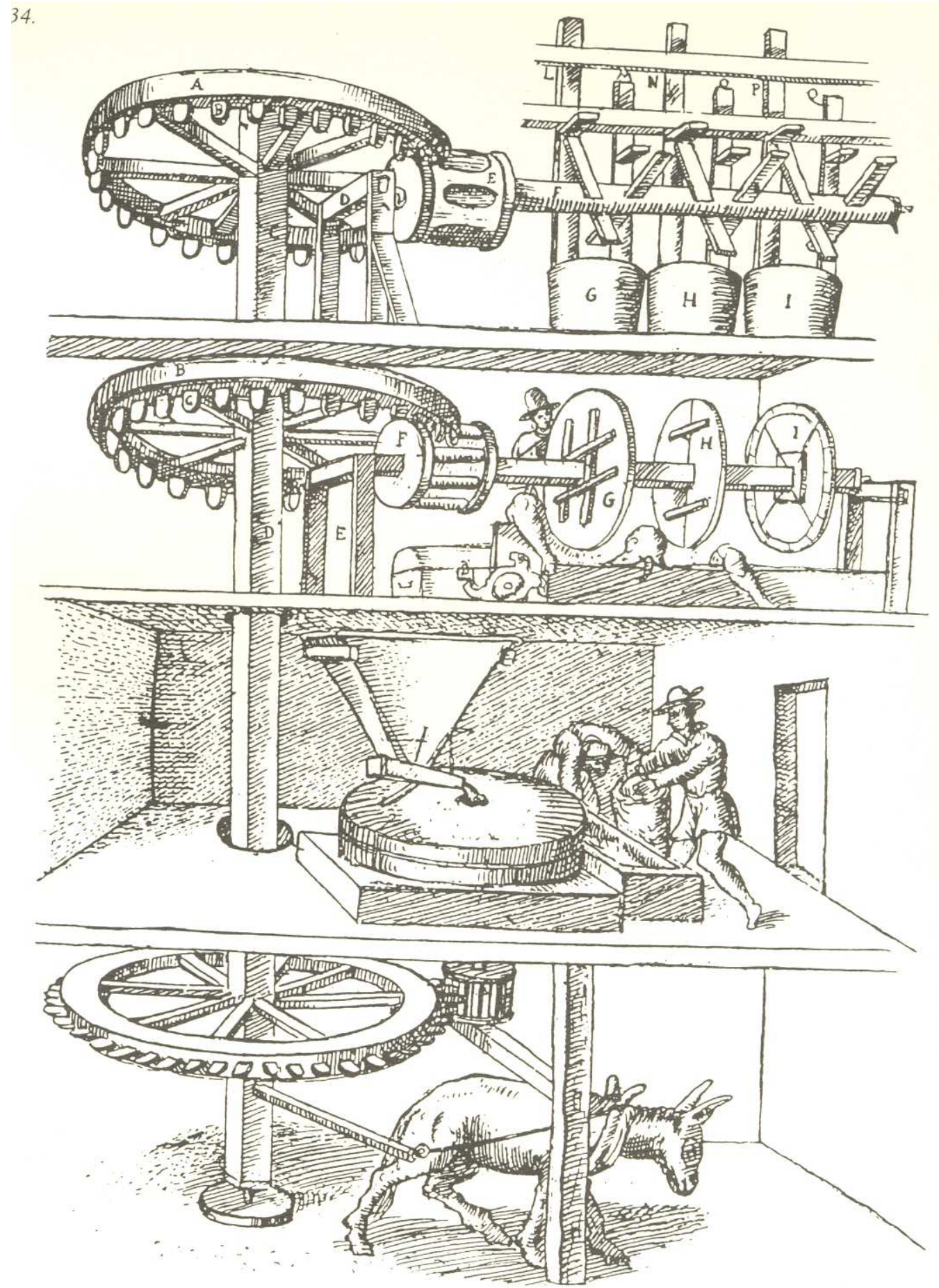


Folio 328v, figura 239: A: tahona; E: manga o burato; T: arca, donde se recogen los distintos tipos de harinas.

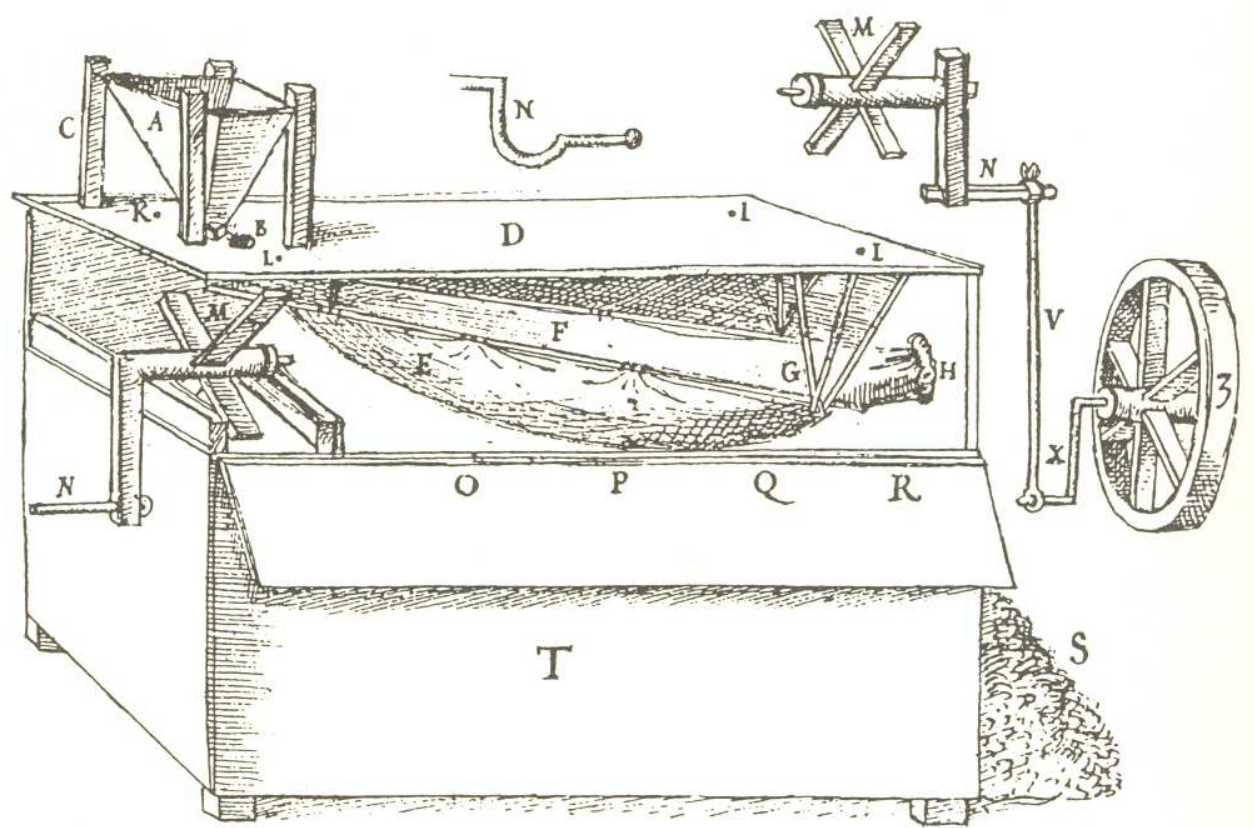

Folio 331v, figura 241: molino batán. B: rueda, C: palas; D: árbol; EE: levadores; MN, OP: mazos; G: pila.

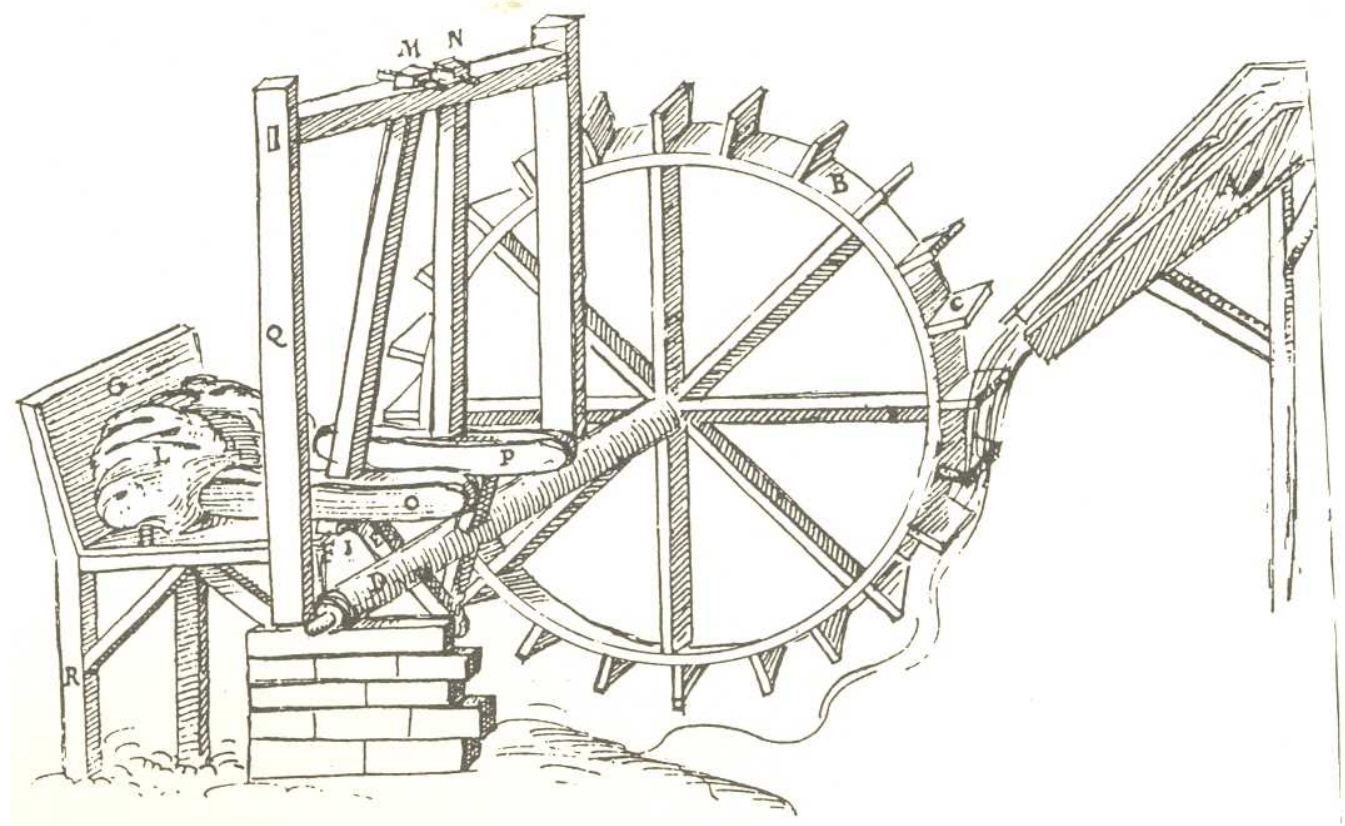


Folio 332r, figura 242: artificio para picar pólvora.

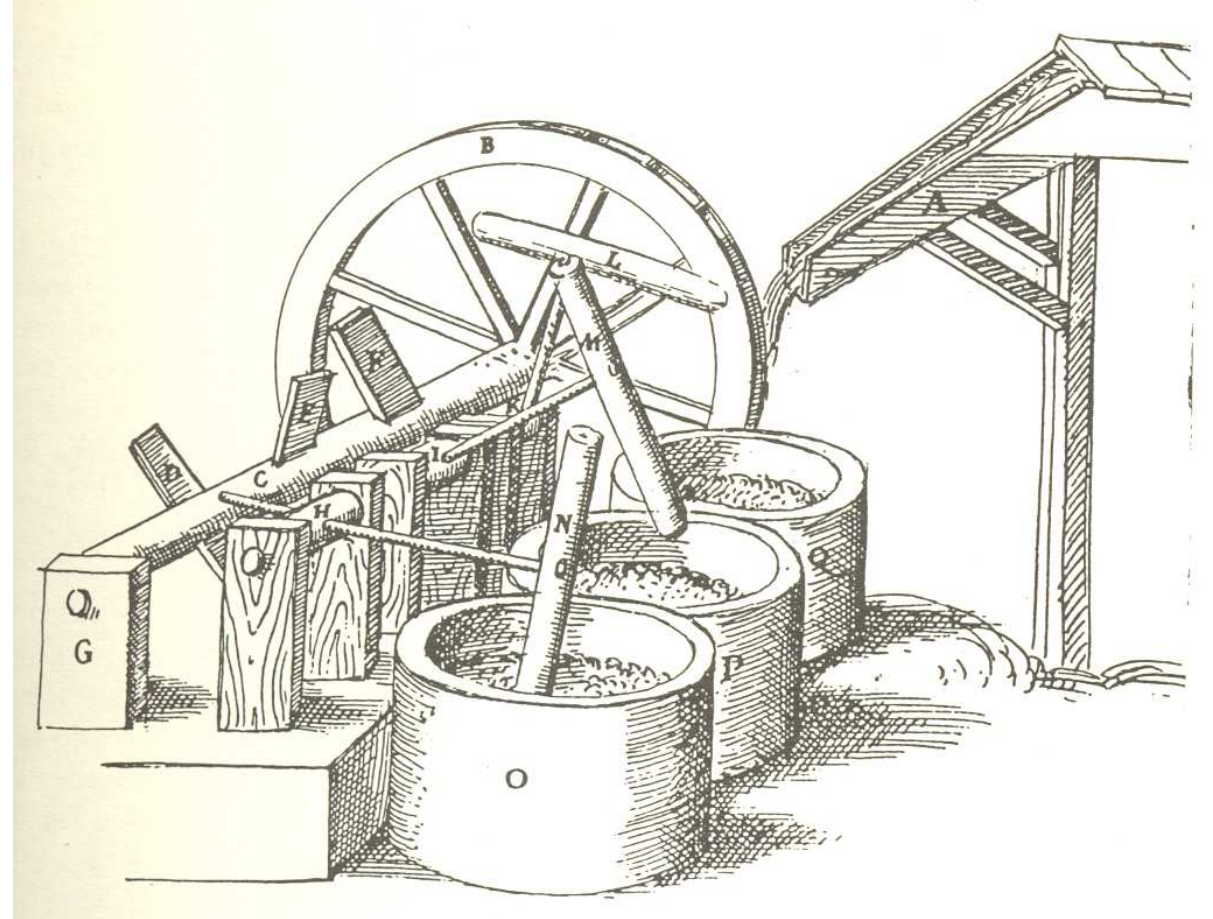

Folio 333v, figura 244: molino del aceite. IKL: ruellos o muelas; ST: libras.

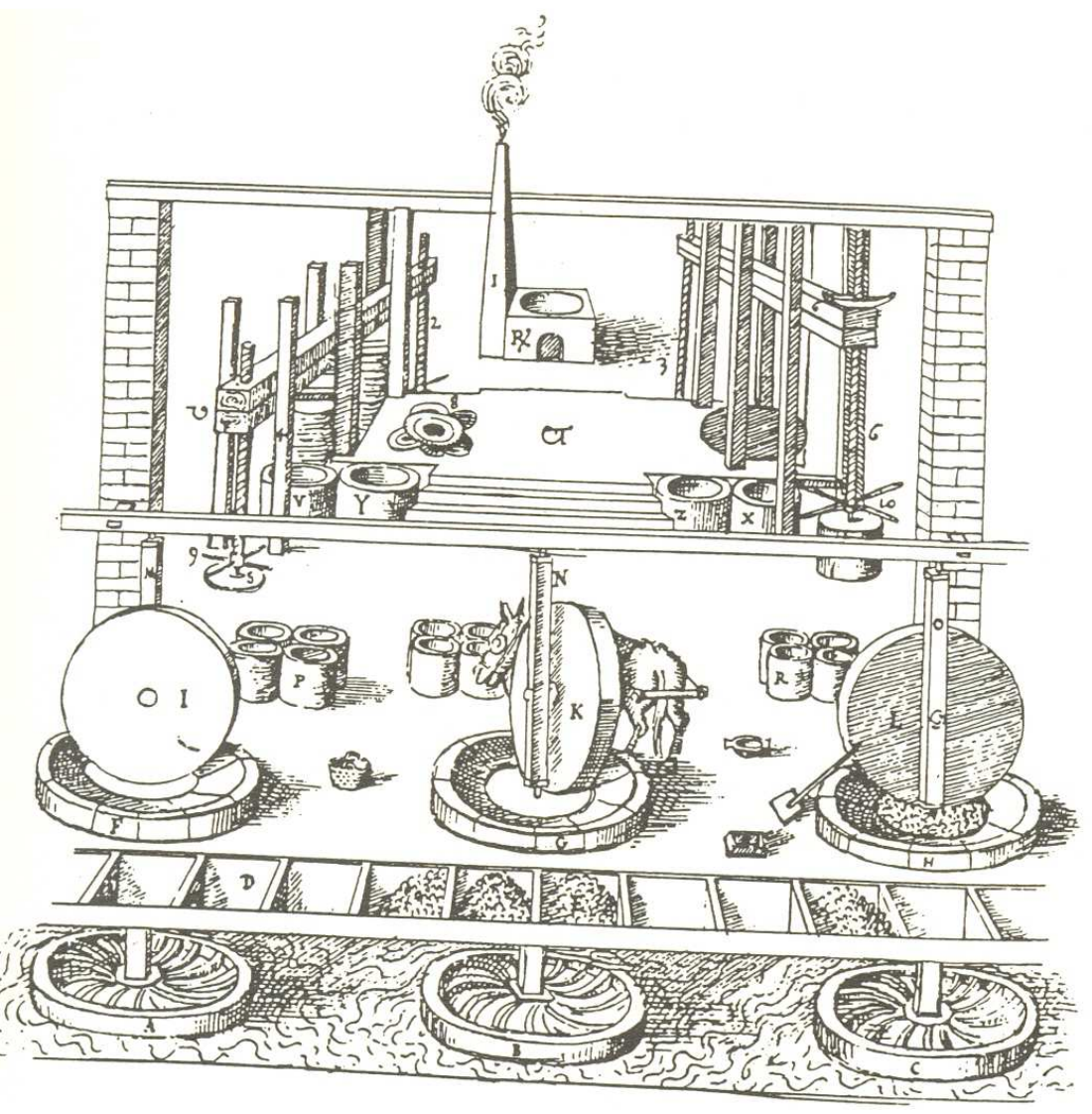


Folio 337v, figura 249: artificio para lavar lanas.

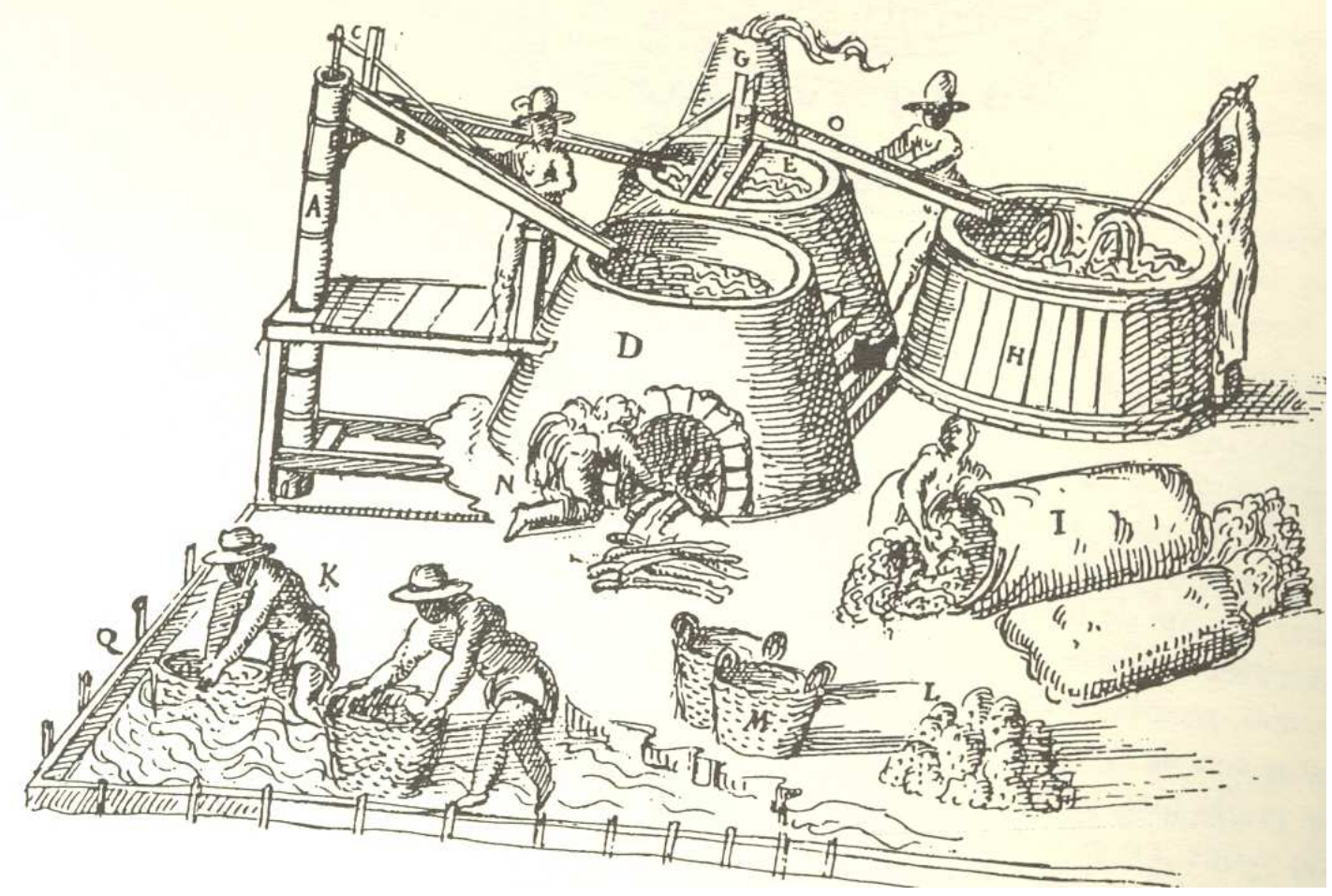

Folio 347r, figura 261: rueda timpanada o rueda cerrada. E: manil $_{2}$ o cigüeña; FG: piernas; $\mathrm{H}$ : $\mathrm{Canal}_{3}$.
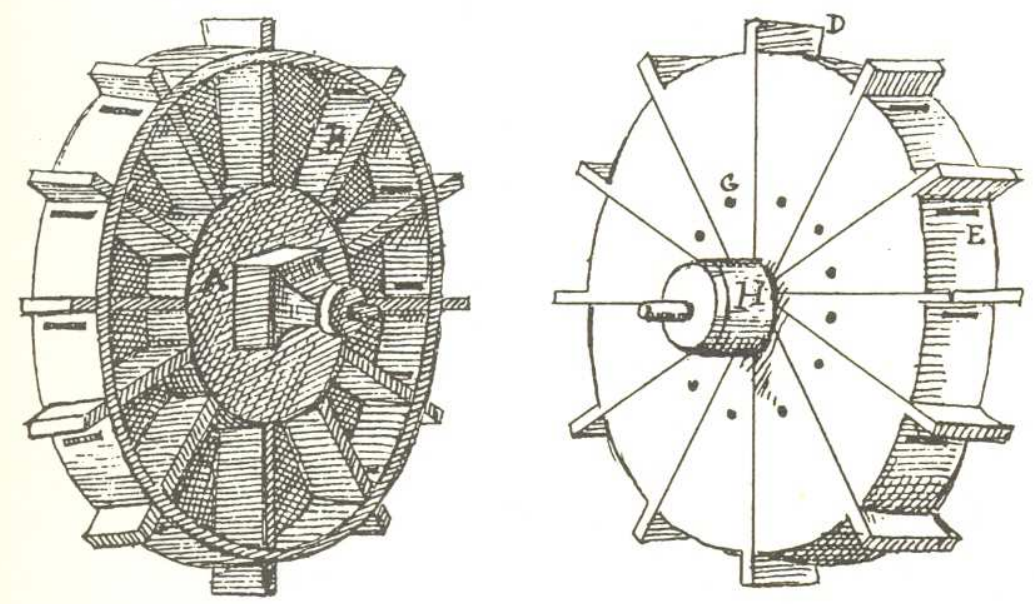
Folio 347r, figura $261_{2}$ : rueda timpanada o rueda cerrada.

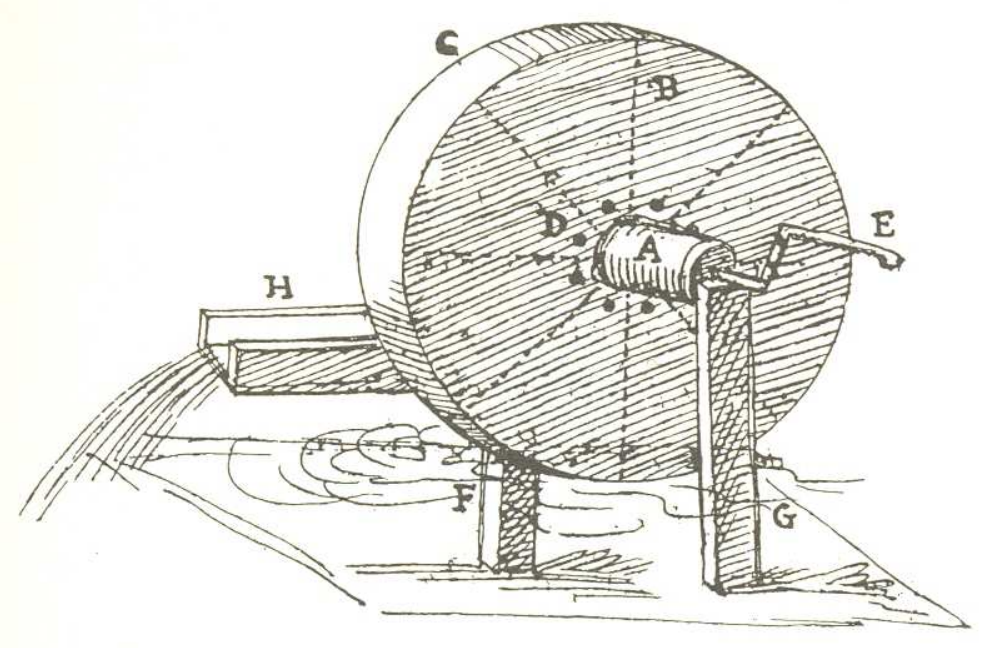

Folio 349r, figura 266: molino de sangre. A, B, C: modiolos; F: cadenas; G: ruello de madera; E: rueda.

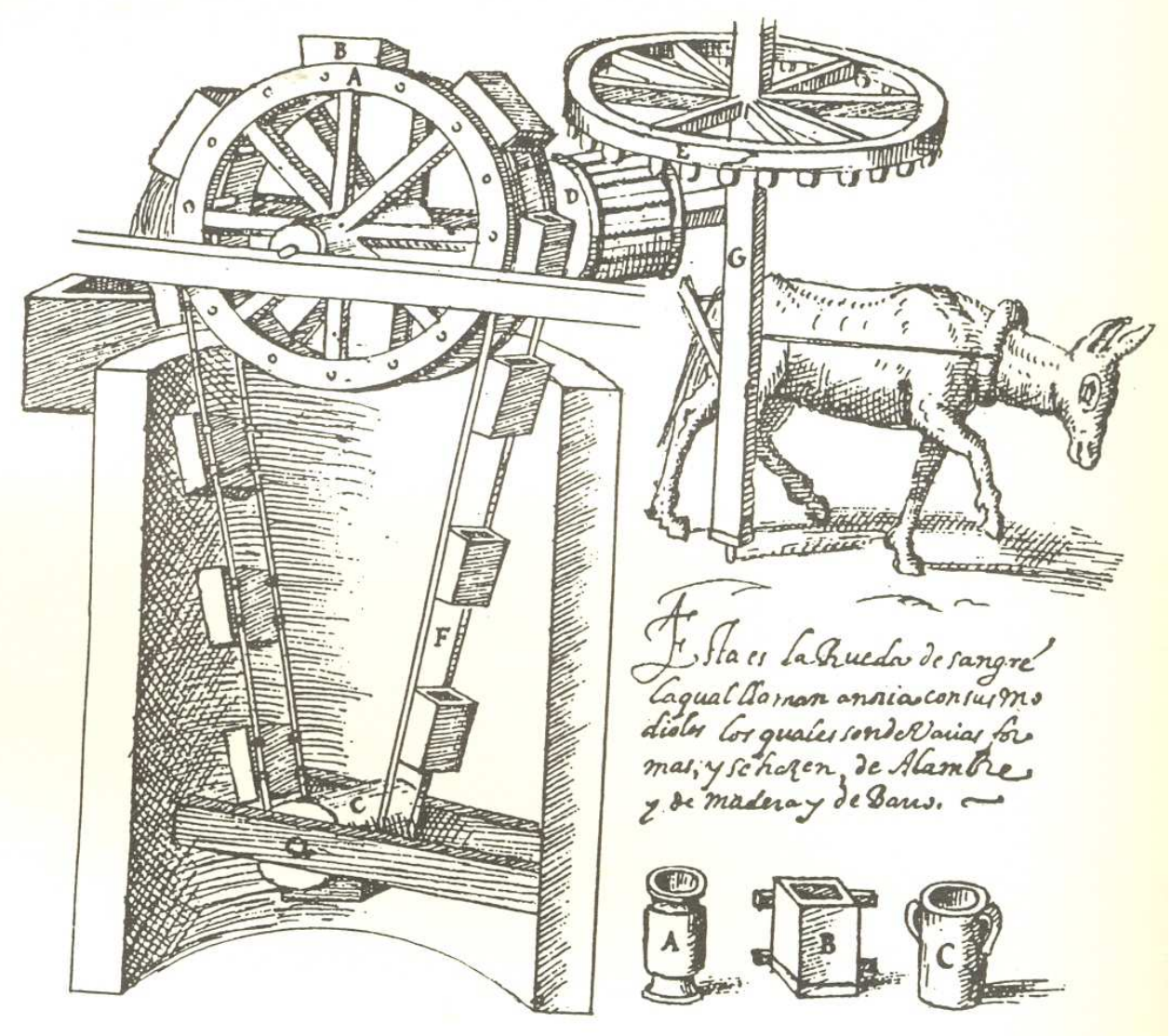


Folio 350v, figura 268: cóclea de Pitágoras.

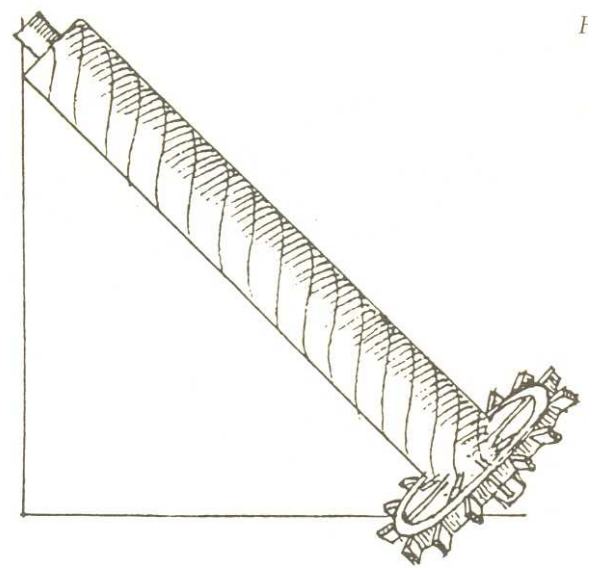

Folio 353r, figura 272: tesíbica. HL: modiolos; IM: ventículas.

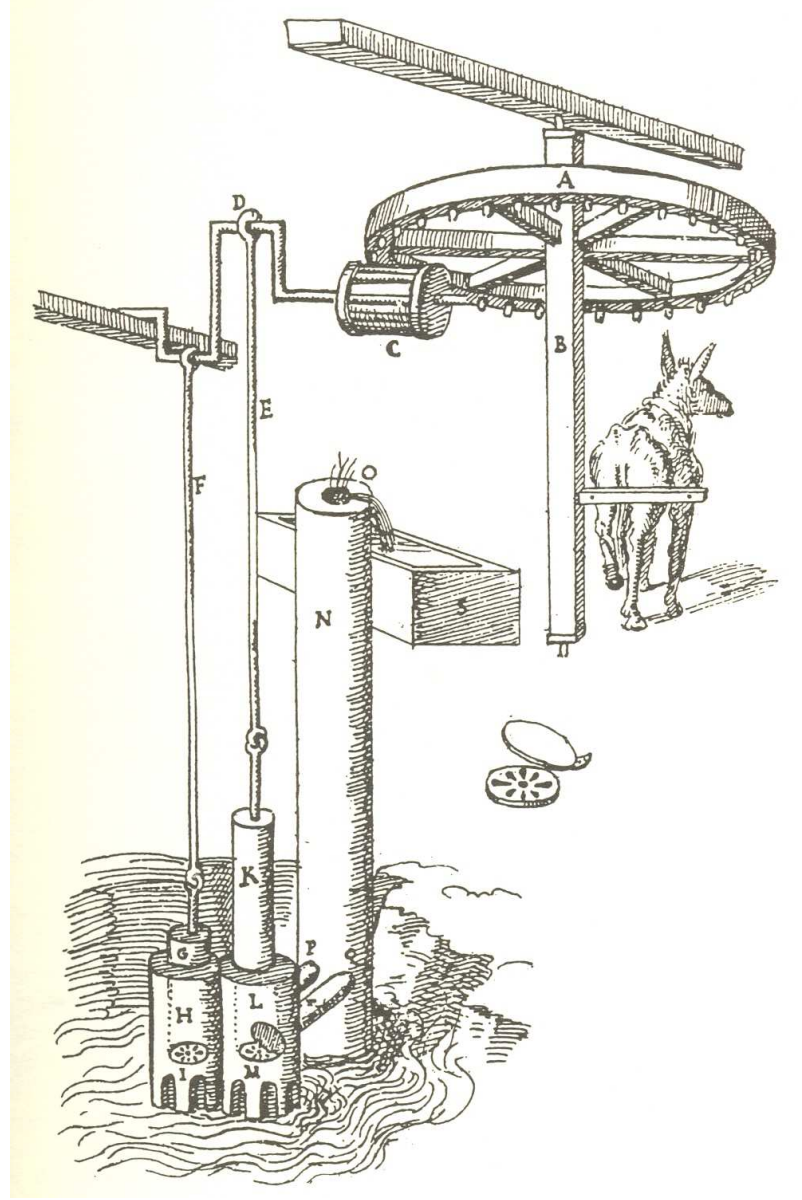


Folio 356r, figura 275: X: calderas; V: horno.

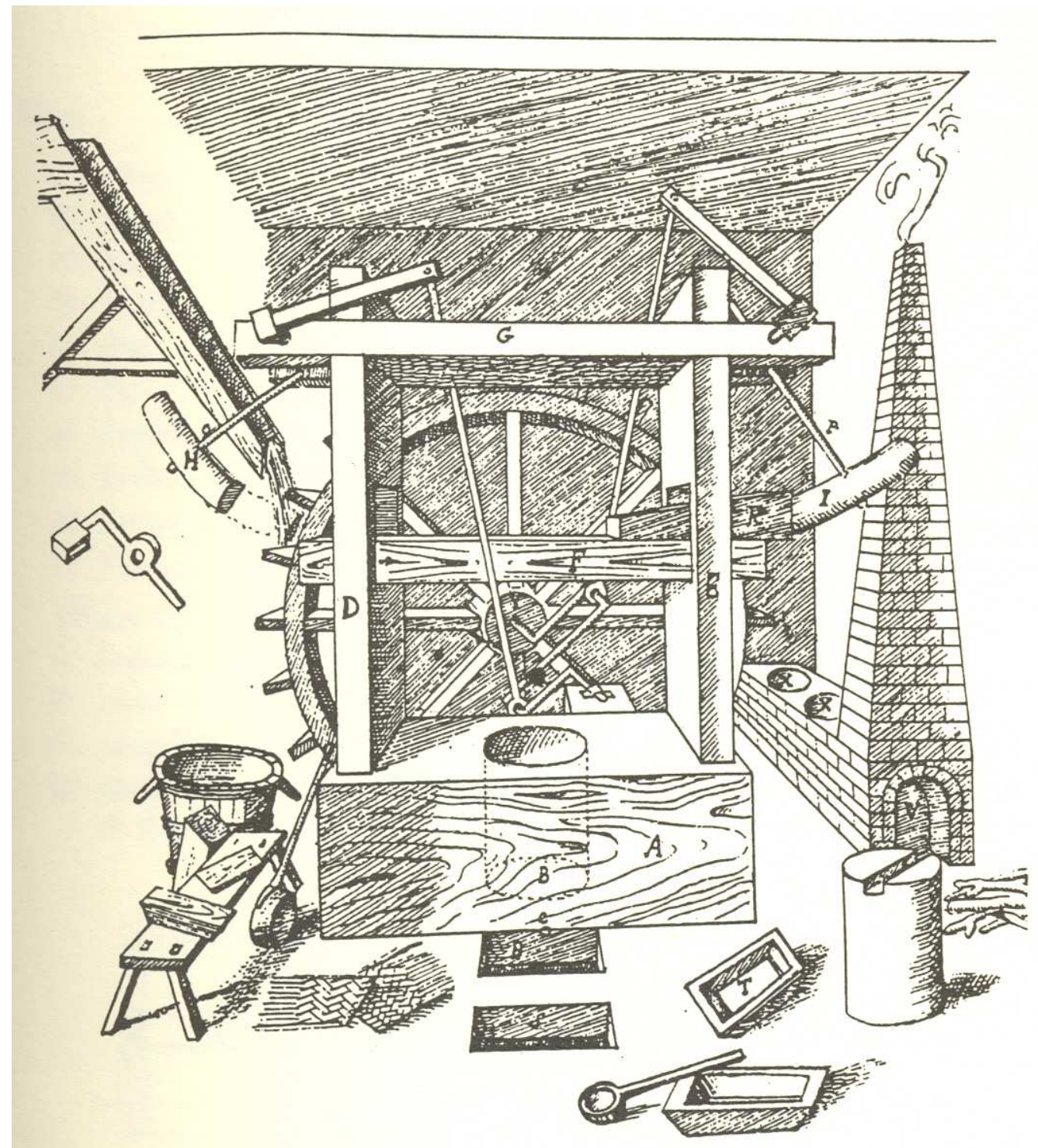


Folio 364r, figura 339: ánima de una bomba o de la cóclea.
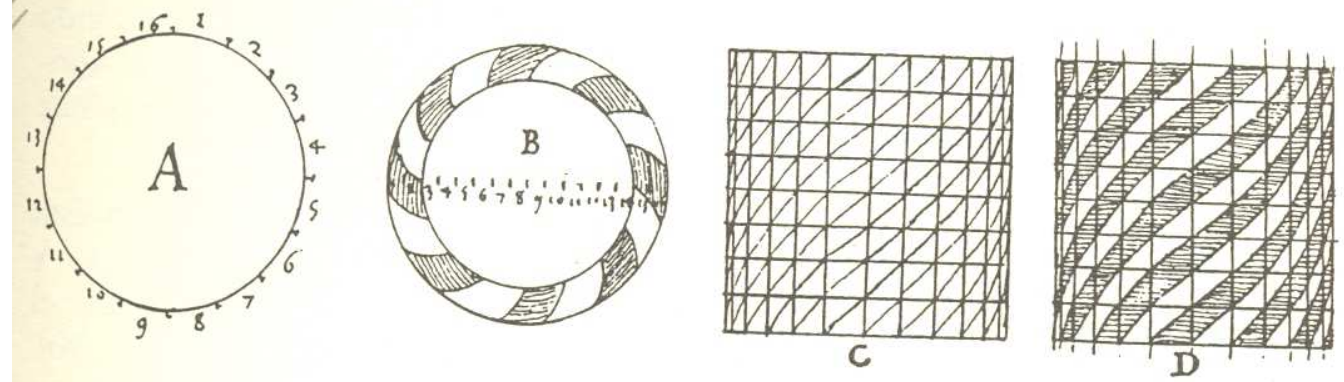

Folio 364r, figura 3392: Bomba . L: palo; F: bomba; I: ánima.

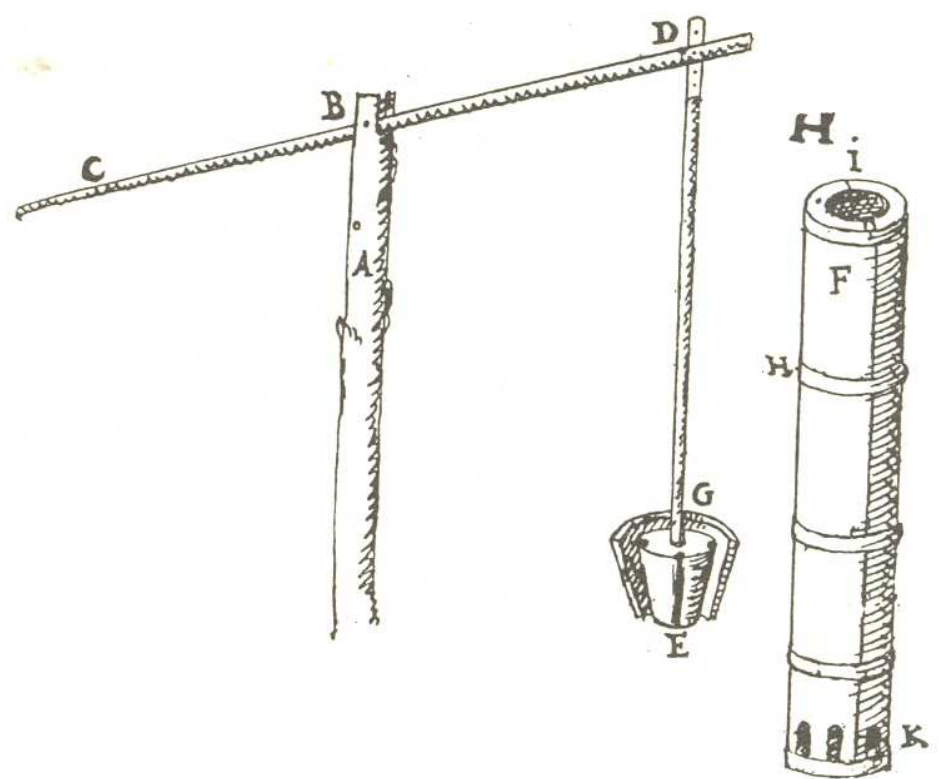

Folio 383r, fig. 377: holivela.

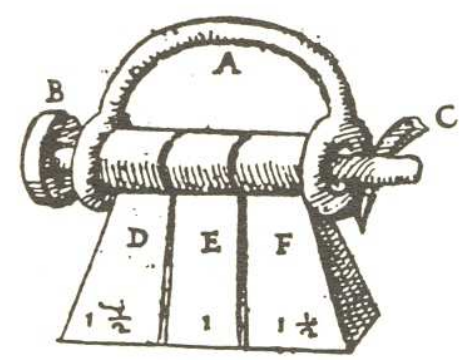


Folio 383v, figura 378: carruchas, rodajas.
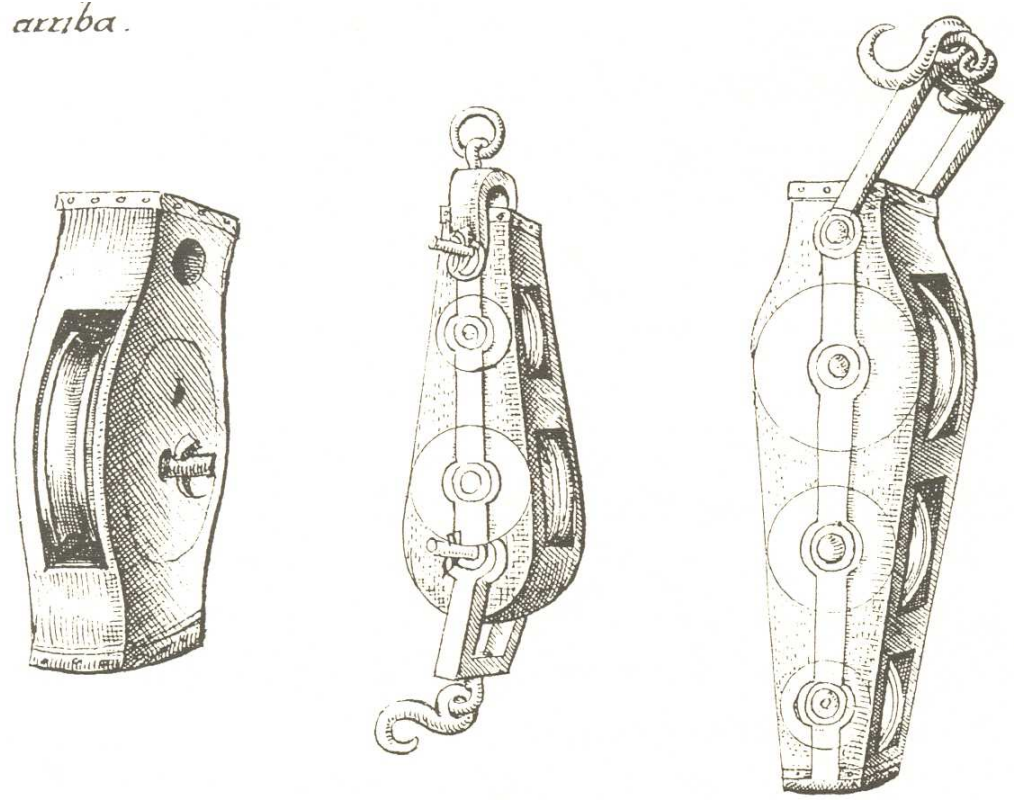

Folio 383v, figura 378: grúa. E: cuerda; F: árbol; H: carrucha. Q: caballo, asno, albardón, cibilla de la grúa, corazón; P: peso.

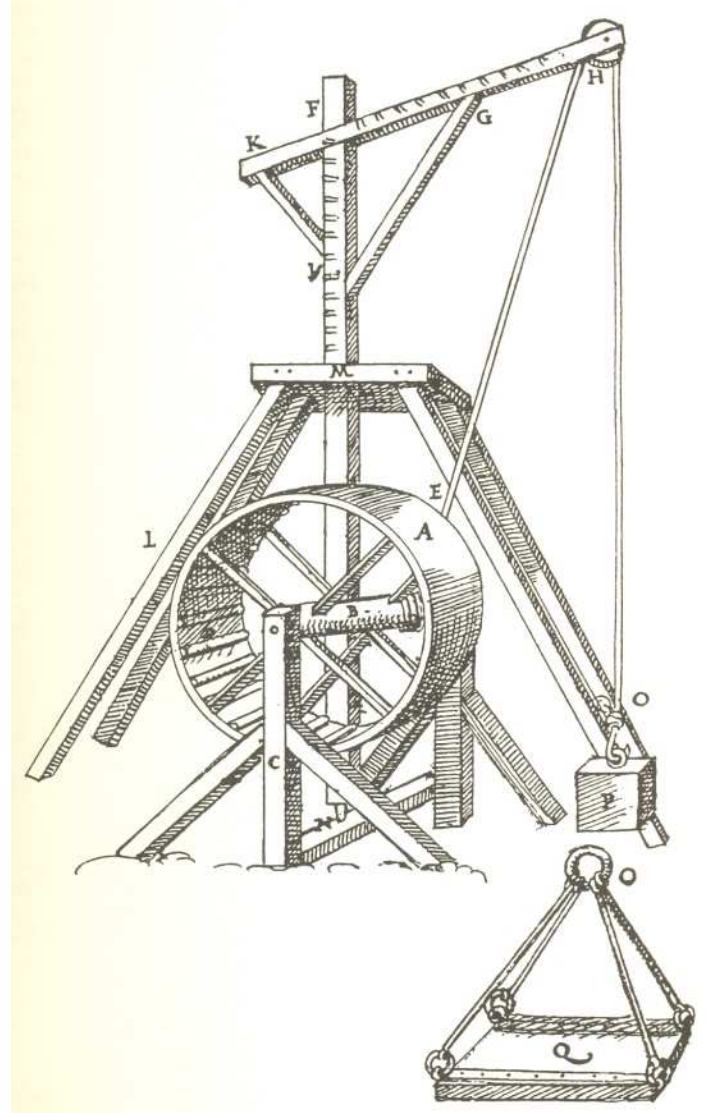


Folio 384v, figura 380: cabrilla.

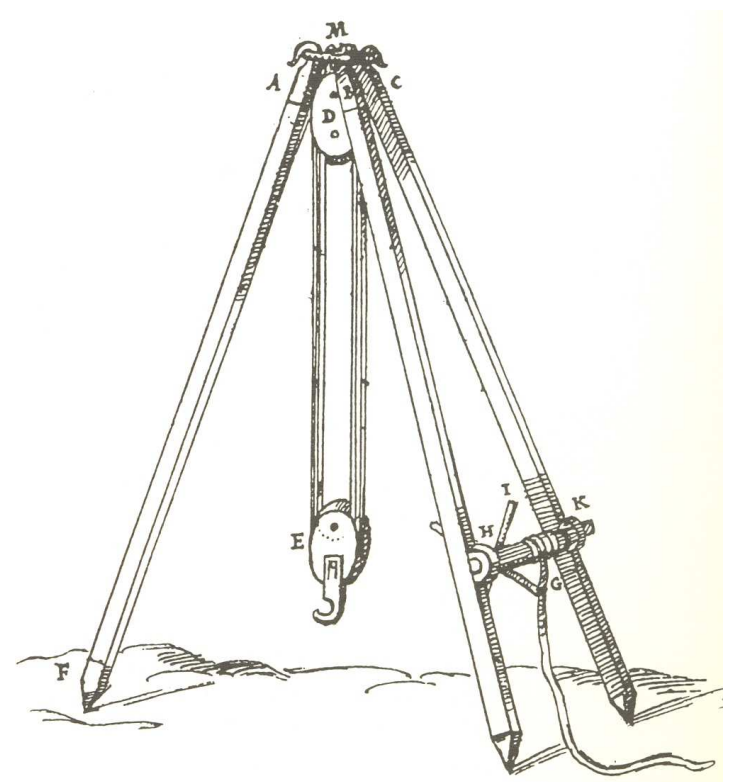

Folio 384v, figura 381: cigüeña.

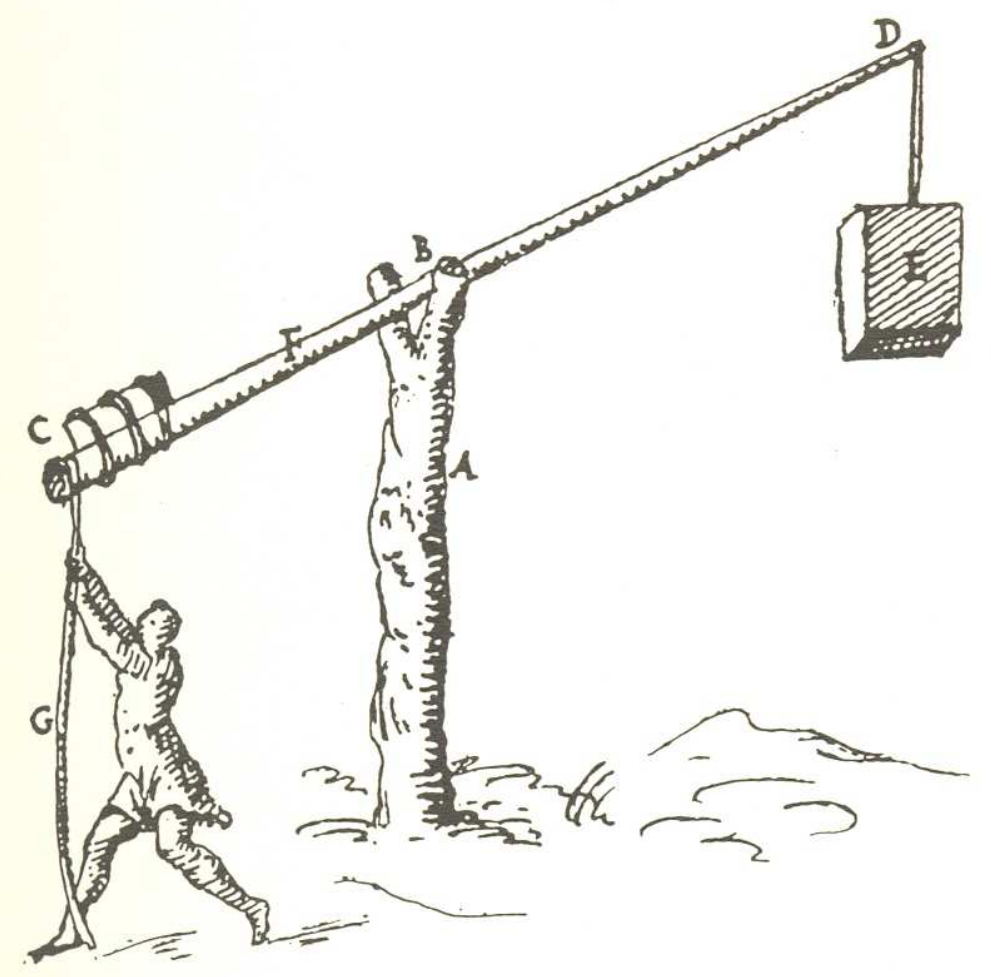


Folio 414r, figura 413: muelle. A: antepecho; B: alambor; C: donde se atan las naos; D: gradas; G: antepecho o pared; F: escalera dentro del puerto; KH: bóvedas; I: arco.

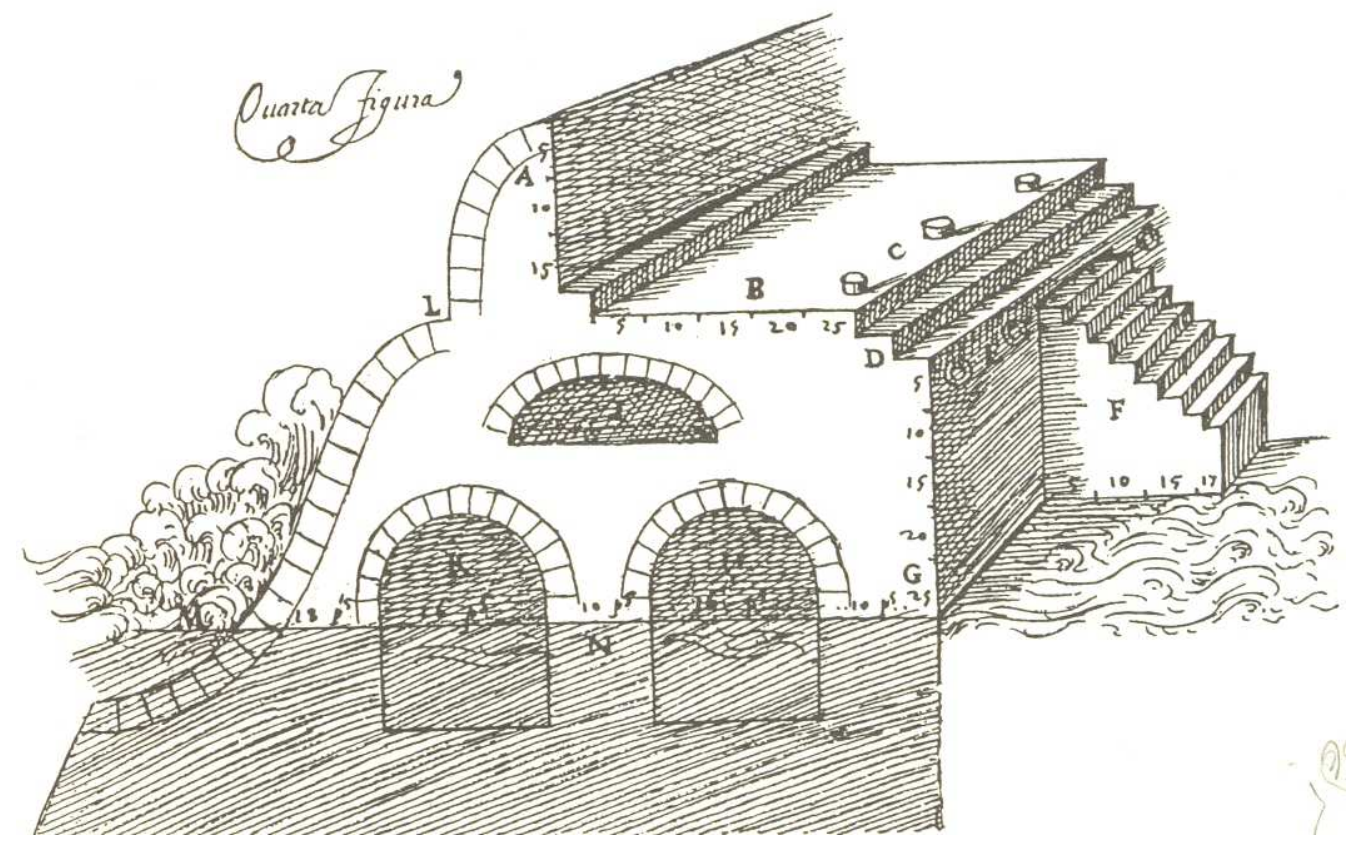

Folio 442v, figura 443: artificio para limpiar puertos.

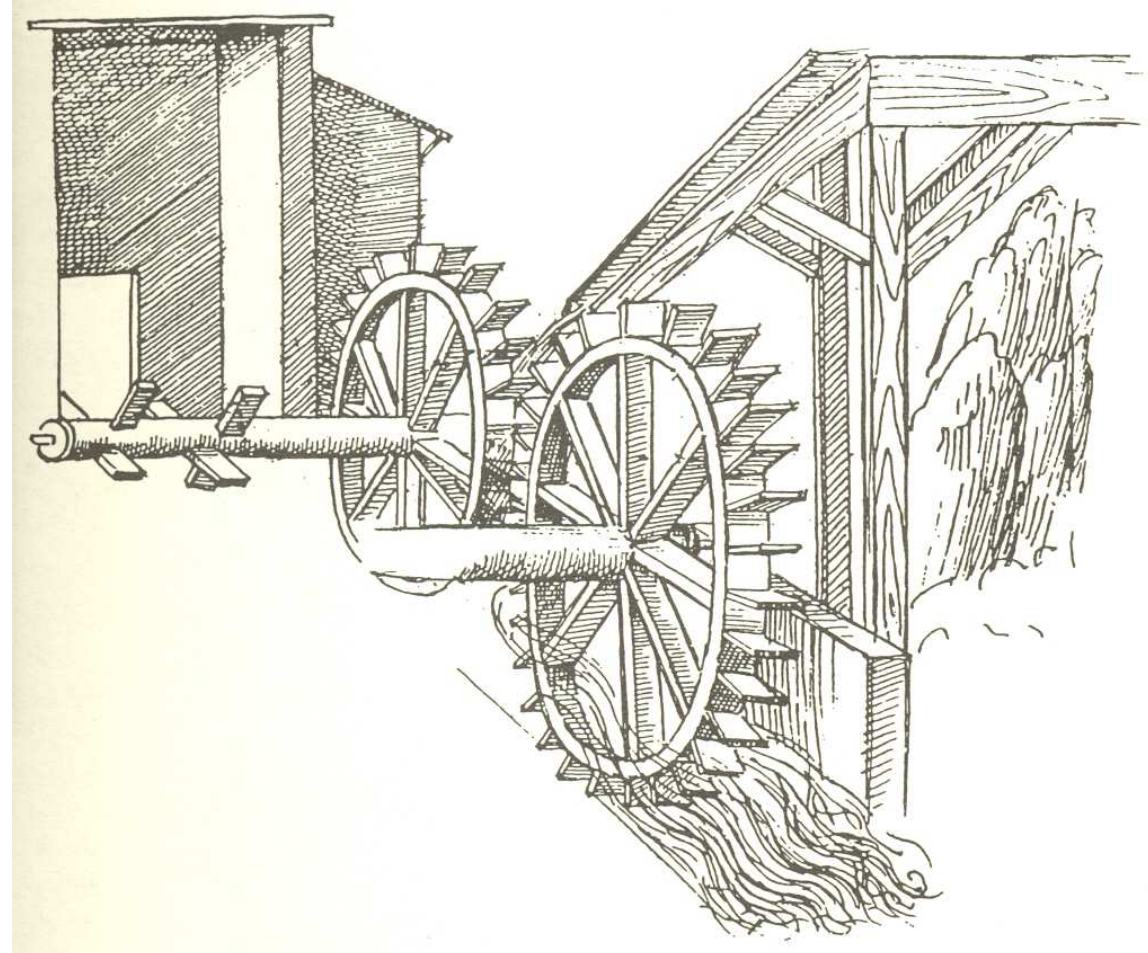


Folio 458v, figura 467: carretón.

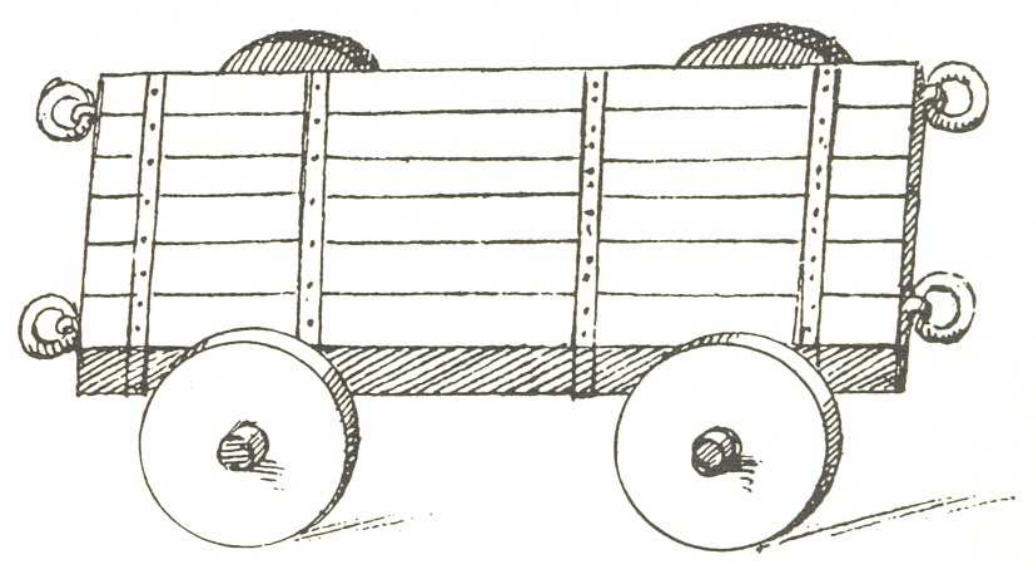

Folio 470r, figura 498, letra F: partidero, partidor.

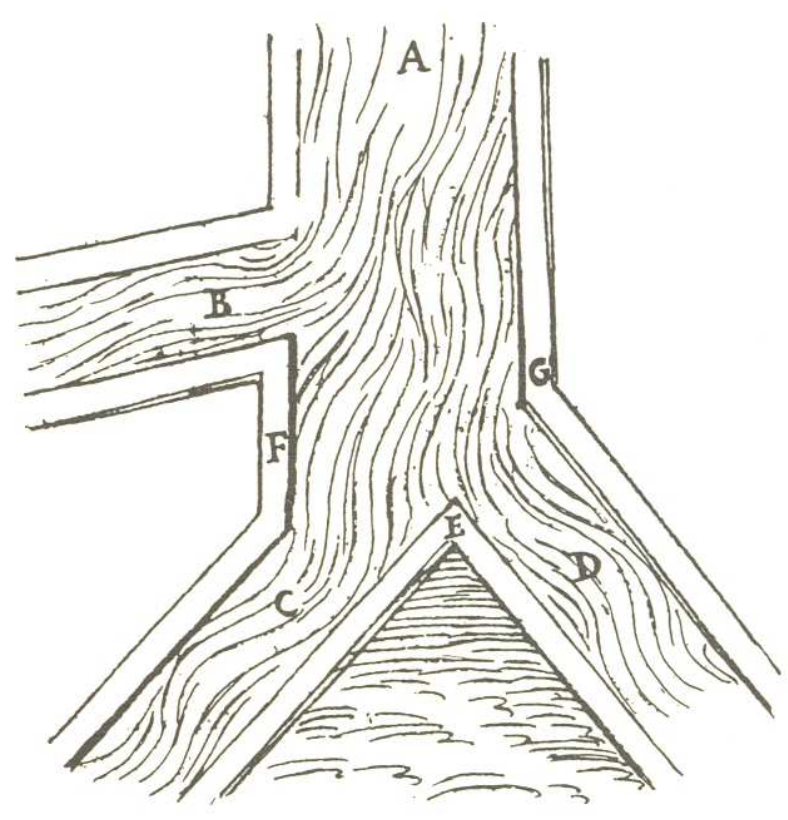


9.4. IMAGEN DE LA TRADUCCIÓN DE LÁZARO DE VELASCO (A. 1564) DE LOS X LIBROS DE ARCHITECTURA DE MARCO VITRUVIO POLIÓN

Folio 124v, figura 120: cabria con fíbula en lo alto.

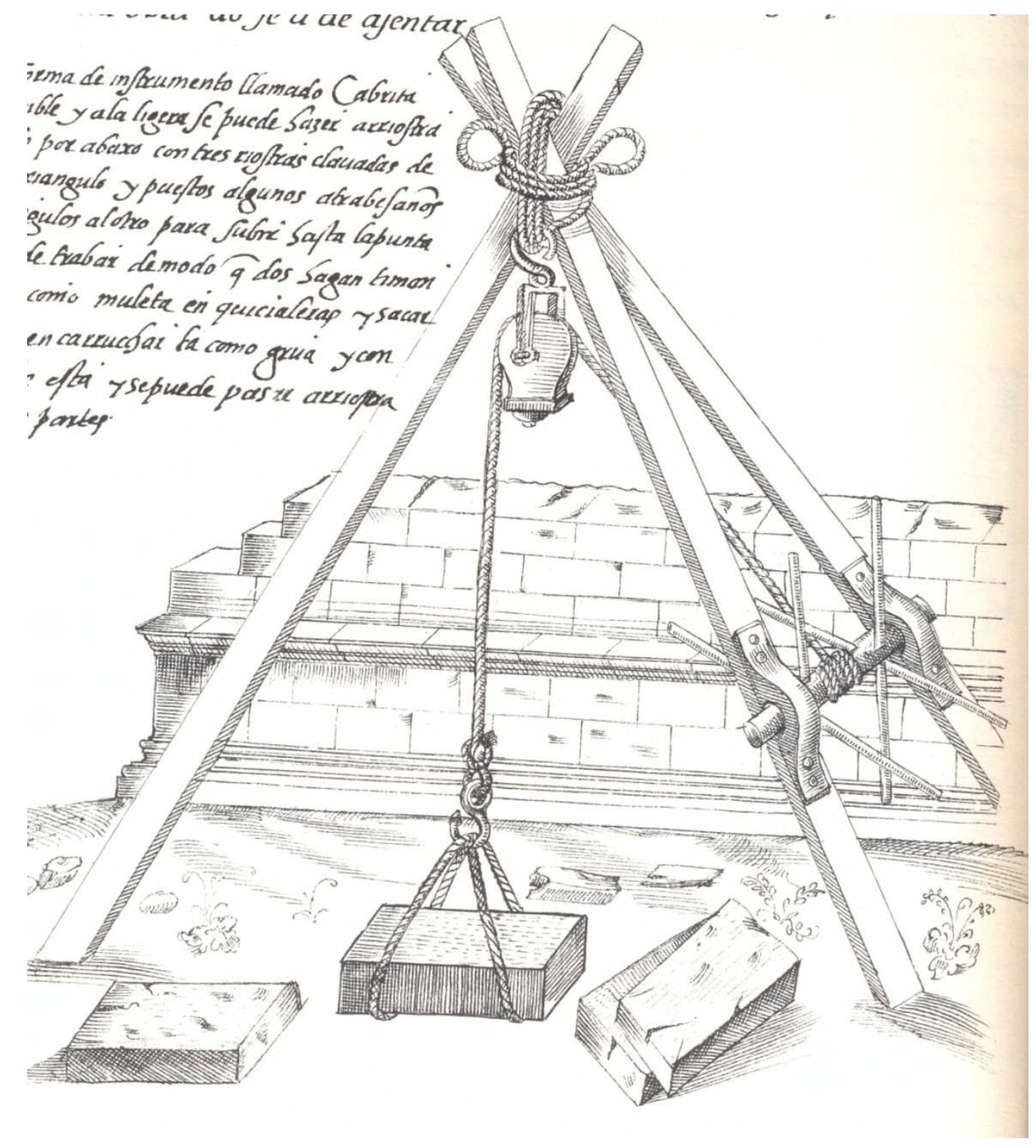


9.5. IMAGEN DEL TRATADO DE LA ARTILLERÍA (1613) DE DIEGO DE UFANO

Página 77, figura 35: uña de cabra.

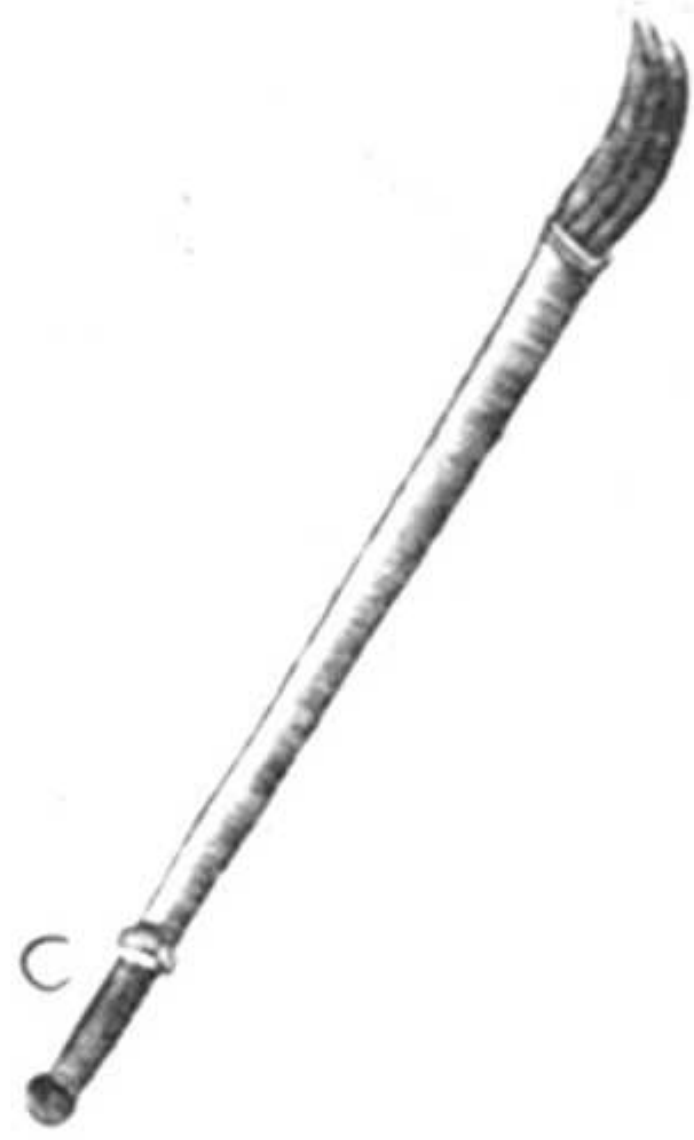




\section{REFERENCIAS BIBLIOGRÁFICAS}

\subsection{REPERTORIOS LEXICOGRÁFICOS}

Adrados, Francisco R. (1994), Diccionario griego-español. Madrid: CSIC, Instituto de Filología.

ANDOLZ, Rafael (1992), Diccionario aragonés. Zaragoza: Mira Editores.

BAILLy, Anatole (2000 [1894]), Le Grand Bailly. Dictionnaire Grec-Français. Édition revue par L. Séchan et P. Chantraine. Paris: Hachette.

Bernal, Chesús y Francho NAGore (eds.) (1999), Diccionario aragonés [ed. facsímil del mss. a. finales s. XVIII]. Zaragoza: Edizions de l'Astral.

BLÁNQUeZ Fraile, Agustín (2012 [1967]), Diccionario español-latino. Madrid: Gredos.

Blas Gabarda, Fernando y Fernando Romanos Hernando (2008), Diccionario aragonés: chistabín-castellano. Zaragoza: Gara d'Edizions.

Callebat, Louis y Philippe Fleury (eds.) (1995), Dictionnaire des termes techniques $d u$ De architectura de Vitruve. Hildesheim; New York: OlmsWeidmann.

Chantraine, Pierre (1990), Dictionnaire étymologique de la langue grecque. Paris: Éditions Klincksieck.

CHusé GIL, Antón (1999), Léxico aragonés de Sos del Rey Católico. Zaragoza: Crica d'edizions.

Clairac y SÁEnz, Pelayo (1877), Diccionario general de arquitectura $e$ ingeniería. Madrid : Zaragozano y Jayme.

[DECH] CoRominas, Joan y José Antonio Pascual (1980-1991), Diccionario Crítico Etimológico Castellano e Hispánico. Madrid: Gredos. 
COROMINAS, Joan (1986), Diccionari Etimològic i Complementari de la Llengua Catalana. Barcelona: Curial Edicions Catalanes.

CORRIENTE, Federico (2004 [1999]), Diccionario de arabismos y voces afines en iberorromance. Madrid: Gredos.

(2008), Dictionary of Arabic and Allied Loanwords. Leiden,

Boston: Brill.

COVARRUBiAS, Sebastián de (1995 [1611]), Tesoro de la Lengua Castellana o Española. Madrid: Castalia.

Cuervo, Rufino José (1994), Diccionario de construcción y régimen de la lengua castellana. Bogotá: Instituto Caro y Cuervo.

Curell Aguilà, Clara (2009), Diccionario de galicismos del español peninsular contemporáneo. Strasbourg: Eliphi.

ESEVERRI HuAlDE, Crisóstomo (1994), Diccionario etimológico de helenismos españoles. Burgos: Ediciones Aldecoa.

GAFFIOT, Félix (2000 [1934]), Le Grand Gaffiot Dictionnaire Latin-Français. Nouvelle édition revue et augmentée sous la direction de Pierre Flobert. Paris: Hachette.

[Salinero] GARCía SALINERO, Fernando (1968), Léxico de alarifes de los Siglos de Oro. Madrid: Real Academia Española.

[Laterculi] GRADENWITZ, Otto (1904 [1860]), Laterculi vocum Latinarum : voces Latinas et a fronte et a tergo ordinandas. Leipzig: S. Hirzel.

GutiéRrez CuAdrado, Juan (dir.) (1996), Diccionario Salamanca de la Lengua Española. Madrid: Santillana, Universidad de Salamanca.

ICAZA LOMELL, Leonardo ( $2^{\mathrm{a}}$ mitad s. XX, sin datación), Glosario de términos hidráulicos. México [ejemplar conservado en la Fundación Juanelo Turriano]. 
LABURU, Miguel (1992), Breve vocabulario que contiene términos empleados en Documentos Marítimos Antiguos. San Sebastián: Departamento de Cultura y Turismo, Diputación Floral de Guipúzcoa.

LEWIS, Charlton T. y Charles SHORT (1879), A Latin Dictionary: Founded on Andrews' Edition of Freund's Latin Dictionary. Oxford: Clarendon Press.

LiDDEL, Henry George and Robert SCOTT (1996 [1843]), A Greek-English Lexicon. Revised and augmented throughout by Sir Henry Stuart Jones. Oxford: Oxford University Press.

MAdOZ, Pascual (1999 [1891]), Diccionario Geográfico-Estadístico-Histórico de España y sus posesiones de Ultramar. Madrid: Agualarga.

MARTínez RuIZ, Antonio (2008), Vocabulario básico bilingüe aragonéscastellano y castellano-aragonés. Huesca: Publicazions d'o Consello d'a Fabla Aragonesa.

Miguel, Raimundo de (2003), Nuevo diccionario latino-español etimológico. Madrid: Visor Libros.

Moliner, María (2001), Diccionario de uso del español. Madrid: Gredos.

NebriJA, Antonio de (1979 [1492]): Diccionario latino español. Barcelona: Puvill.

(1951 [1495]): Vocabulario español-latino. Madrid: Real Academia Española.

-_--- (1981 [1516]): Vocabulario de romance en latín. Madrid: Castalia.

[OED] Oxford English Dictionary: http://www.oed.com/

[OLD] (1968 -), Oxford Latin Dictionary. Oxford: At the Clarendon Press.

PALENCIA, Alonso de (1967 [1490]), Universal Vocabulario en latín y en romance. Madrid: Comisión Permanente de la Asociación de Academias de la Lengua Española.

PerAltA, Mariano (1987 [1853]): Ensayo de un diccionario aragonéscastellano. Zaragoza: Ediciones Moncayo. 
PHARIES, David (2002), Diccionario etimológico de los sufijos españoles. Madrid: Gredos.

Quintana Cabanas, José María (1987), Raíces griegas del léxico castellano, científico y médico. Madrid: Dykinson.

[DHE] Real Academia Española (1951-1996), Diccionario Histórico de la Lengua Española. Madrid: Imprenta Aguirre.

(1990 [1726-1739]), Diccionario de Autoridades. Madrid:

Gredos.

(2001a), Diccionario de la Lengua Española. Madrid: Espasa

Calpe.

[DRAE] __ (2001b), Nuevo Tesoro Lexicográfico de la Lengua Española. Madrid: Espasa Calpe [DVD-ROM].

[CORDE] _ _ Corpus Diacrónico del español. http:/ / www.rae.es/

[NDHE]__ Nuevo Diccionario Histórico del español.

http://www.frl.es/ , Mapa de diccionarios. http:// www.frl.es/

Rosal, Francisco del (1992 [1786-17]), Diccionario etimológico, ed. de E. Gómez Aguado. Madrid: CSIC.

SÁNCHEZ GonzÁlez de Herrero, María Nieves (dir.) (2000), Diccionario Español de Documentos Alfonsíes. Madrid: Arco/Libros.

SEgura Munguía, Santiago (2001), Nuevo diccionario etimológico latínespañol y de las voces derivadas. Bilbao: Universidad de Deusto. (2006), Diccionario por raíces del latín y de las voces derivadas. Bilbao: Universidad de Deusto.

TERREROS Y PANDO, Esteban (1987 [1786-1788]), Diccionario castellano con las voces de las ciencias y artes. Madrid: Arco/Libros. 
[TLF] Trésor de la Langue Française. Dictionnaire de la langue du XIXe siècle et du XXe siècle (1789-1960) dirigido por P. Imbs. Paris: Éditions du Centre National de la Recherche Scientifique.

[TLIO] Tesoro della Lingua Italiana delle Origini <http:/ / tlio.ovi.cnr.it/>

Thesaurus Linguae Latinae. Editus auctoritate et consilio Academiarum quinque germanicarum Berolinensis, Gottingensis, Lipsiensis, Monacensis, Vindobensis (1990-1990). Lipsiae: In Aedibus B. G. Teubneri.

Valbuena, Manuel de (1854), Diccionario español-latino. París: Librería de Garnier Hermanos.

VAREla MERINO, Elena (2009), Los galicismos en el español de los siglos XVI y XVII. Madrid: CSIC.

[Elucidario] VERA BOTI, Alfredo (2004), Elucidario: arquitectura del Renacimiento: significado de los términos según los tratadistas y evolución histórica de los elementos utilizados en la arquitectura, sus oficios y en el urbanismo. Murcia: Real Academia Alfonso X el Sabio.

[Glosario Los Ventiún Libros] VV.AA., incluido en la edición facsímil de Los Ventiún libros de los Ingenios y Máquinas de Juanelo Turriano, Vol. I-VII. Madrid: Fundación Juanelo Turriano.

\subsection{ESTUDIOS LINGÜÍSTICOS E HISTÓRICOS}

ABAD NeBot, Francisco (2008), Historia general de la lengua española. Valencia: Tirant lo Blanch.

AliAgA JimÉNEZ, José Luis (2000), Aspectos de lexicografía española. El léxico aragonés en las ediciones del diccionario académico. Zaragoza: Institución Fernando el Católico.

Almela PÉRez, Ramón (1999), Procedimientos de formación de palabras en español. Barcelona: Ariel. 
[ALEA] Alvar, Manuel (1961), en colaboración con A. Llorente y G. Salvador, Atlas lingüístico y etnográfico de Andalucía, I. Granada: Universidad, Sevilla, Geha, láminas 239-244.

Alvar EzQUERRA, Manuel (1995), La formación de palabras en español. Madrid: Arco/Libros.

(1998), “El léxico de un molino de agua en Alhaurín el Grande (Málaga)", en Manuel Alvar EzQuerra y Gloria CORPAS PASTOR (Coords.), Diccionarios, frases, palabras. Málaga: Universidad de Málaga, pp. 127145.

Álvarez De Quindós y BAENA, Juan Antonio (1993 [1804]), Descripción histórica del Real Bosque de Aranjuez. Aranjuez: Doce Calles.

AMADOR RodRíGUEZ, Luis Alexis (2009), La derivación nominal en español: nombres de agente, instrumento, lugar y acción. Frankfurt am Main: Peter Lang.

AmBADIANG, Théophile (2000 [1999]), “La flexión nominal. Género y número", en Ignacio BOSQUe y Violeta DEMONTE (dirs.), Gramática descriptiva de la lengua española, Vol. 3. Madrid: Espasa-Calpe, pp. 4843-4913.

ARACIL, Alfredo (1998), Juego y artificio. Autómatas y otras ficciones en la cultura del Renacimiento a la Ilustración. Madrid: Cátedra.

ARIAS MONTANO, Benito (2006[1571]), Libro de José o sobre el lenguaje arcano. Huelva: Universidad de Huelva.

ARNTZ, Reiner y Heribert PICHT (1995), Introducción a la terminología. Madrid: Fundación Germán Sánchez Ruipérez / Pirámide D. L.

BAjO Pérez, Elena (1997), “La clasificación de las voces según su procedencia etimológica, con especial referencia al DCECH". Moenia, 3, pp. 411458.

Benito QuintanA, Luis (1971), “Nota preliminar. Las mecánicas ilustradas de los siglos XVI y XVII. El teatro de los instrumentos matemáticos y 
mecánicos", en Jacques BESSON, Teatro de los instrumentos y figuras matemáticas y mecánicas. Madrid: Alpuerto, pp.12-61.

Bergua Cavero, Jorge (2004), Los helenismos del español. Madrid: Gredos.

BlÁZquez Herrero, Carlos (1999), Obras hidráulicas en Aragón. Zaragoza: Caja de Ahorros de la Inmaculada de Aragón.

(2005), Zaragoza, dos milenios de agua. Zaragoza: Acualis

Taller de Estudios.

BORGNIS, Giuseppe Antonio (1818-1823), Traité complet de mécanique appliquée aux arts [...]. Paris : Bacellier [10 vols.].

Buenafuentes de la MATA, Cristina (2006), Procesos de gramaticalización y lexicalización en la formación de compuestos en español. Bellaterra: Universitat Autónoma de Barcelona [Tesis Doctoral].

BUESA, Tomás (1959), "Americanismos", en Enciclopedia Lingüística Hispánica, V. II. Madrid: Consejo Superior de Investigaciones Científicas, pp. 325-348.

Bustos GisBert, Eugenio de (1986), La composición nominal en español. Salamanca: Ediciones Universidad de Salamanca.

CABré Castellví, María Teresa (2003), “El lenguaje científico desde la terminología", en Bertha M. GuTiÉRREz Rodilla (ed.). Burgos: Fundación Instituto Castellano y Leonés de la Lengua, pp. 19-52.

CÁmara Muñoz, Alicia (1993), “El ingeniero Sabatini”, en Catálogo de la exposición Francisco Sabatini, 1721-1797. Madrid: Real Academia de Bellas Artes de San Fernando, pp. 437-460.

CÁMARA MuÑoz, Alicia (2008), “La profesión de ingeniero: los ingenieros del rey", en Manuel SILVA SuÁREz (ed.), Técnica e ingeniería en España I. El Renacimiento. De la técnica imperial y la popular. Zaragoza: Real Academia de 
Ingeniería, Institución "Fernando el Católico", Prensas Universitarias de Zaragoza, pp. 129-168.

Castelli, Patricia (2011), La estética del Renacimiento. Móstoles (Madrid): Antonio Machado Libros.

ClAIR, Colin (1998), Historia de la imprenta en Europa. Madrid: Ollero \& Ramos.

Clavería NADAL, Gloria (1999-2000), «Latinismo y ¿cultismo? en la documentación jurídica medieval». Anuario de Lingüística Hispánica, XV-XVI: 1130.

Clavería Nadal, Gloria y Joan Torruella (1993), “Formación de términos en los léxicos especializados de la lengua española", en SAGER, Curso práctico sobre el procesamiento de la terminología. Madrid: Fundación Germán Sánchez Ruipérez, Pirámide, pp. 315-344.

COLÓN DOMÉNECH, Germán (1959)1', “Occitanismos”, en Enciclopedia Lingüística Hispánica, V. II. Madrid: Consejo Superior de Investigaciones Científicas, pp. 153-192.

(1959)2, "Catalanismos", en Enciclopedia Lingüística Hispánica, V. II. Madrid: Consejo Superior de Investigaciones Científicas, pp. 193-238.

(2002)1, "Elementos constitutivos del léxico español", en Albert Soler y Núria Mañé (eds.), Para la historia del léxico español. Madrid: Arco/Libros, pp. 19-44.

$(2002)^{2}$, "De arabismos interhispanos", en Albert Soler y Núria Mañé (eds.), Para la historia del léxico español. Madrid: Arco/Libros, pp. 4554. 
(2002)33, "Lexicografía contaminada: a propósito de martín pescador y martinete", en Albert Soler y Núria Mañé (eds.), Para la historia del léxico español. Madrid: Arco/Libros, pp. 213-230.

CORBIN, Danielle (1987), Morphologie derivationnelle et estructuration du lexique, 2 vols. Tubinga: Max Niemeyer Verlag, pp. 208-282.

CóRDOBA DE LA LlaVe, Ricardo (2002), "Las técnicas preindustriales", en José María LóPEz PiÑERo (dir.), Historia de la ciencia y de la técnica en la Corona de Castilla. Siglos XVI y XVII, Vol. III. Salamanca: Junta de Castilla y León, pp. 223431.

CORPAS PASTOR, Gloria (1996), Manual de fraseología española. Madrid: Editorial Gredos.

Correa Rodríguez, José Antonio (2008 [2004]), “Elementos no indoeuropeos e indoeuropeos en la historia lingüística hispánica", en Rafael CANO (coord.) Historia de la lengua española. Barcelona: Ariel, p. 35-57.

CORRIENTE, Federico (1992), Árabe andalusí y lenguas romances. Madrid: Editorial MAPFRE.

COSERIU, Eugenio (1977), Principios de semántica estructural. Madrid: Gredos.

D'AlEMBERT et DiDEROT (1981 [1713-1784]), Discurso preliminar de la Enciclopedia / Investigaciones filosóficas sobre el origen y naturaleza de lo bello. Barcelona: Orbis.

Esteban Piñeiro, Mariano y María Isabel Vicente Maroto (2002), “La Casa de la Contratación y la Academia Real Matemática", en José María LóPEZ PIÑERO (dir.), Historia de la ciencia y de la técnica en la Corona de Castilla. Siglos XVI y XVII, Vol. III. Salamanca: Junta de Castilla y León, pp. 35-51. 
FERNÁNDEZ GAliAnO, Manuel (1967), «Helenismos», en Manuel Alvar, Antonio BAdíA, R. de BALBÍN, L. F. Lindley CintRA (dirs.), Enciclopedia Lingüística Hispánica. Madrid: CSIC, II: 51-77.

FERNÁNDEZ VALLÍN, Acisclo (1989[1893]), Cultura científica en España en el siglo XVI. Sevilla: Padilla Libros.

FERRANDO ARAMO, Verónica (2002), “Colocaciones y compuestos sintagmáticos: dos fenómenos léxicos colindantes", en Alexandre VEIGA, Miguel GonzÁlez Pereira y Montserrat SOUTO Gómez (eds.), Léxico y gramática, colección Linguas e Lingüística, 3. Lugo: Tris Tram, pp. 99-107.

Flórez Miguel, Cirilo (2005), “Las artes mecánicas en la época de Cervantes", en VV. AA. La Ciencia y la Técnica en época de Cervantes. Salamanca: Ediciones Universidad de Salamanca, pp. 51-62.

FrAGO GraCiA, Juan A. (1985), “Las fuentes documentales aragonesas y el diccionario etimológico español de J. Corominas", en Archivo de Filología Aragonesa XXXIV-XXXV. Zaragoza, pp. 601-682. (1999), "La cultura del Renacimiento (1480-1580): la lengua", en José María Jover ZAMORA (dir.) Historia de España. Menéndez Pidal. Madrid: Espasa Calpe, t. XXI, pp. 579-629.

Frago Gracia, Juan A. y José A. GARCÍA-DiEGO (1988), Un autor aragonés para Los ventiún libros de los ingenios y de las máquinas. Zaragoza: Diputación General de Aragón.

García Gallarín, Consuelo (2007), “Derivación, lexicalización y analogía: el caso Delgado CoBos de los diminutivos", en Delgado Cobo, Inmaculada y Alicia PUIGVERT OCAL (coords.), Ex admiratione et amicitia. Homenaje a Ramón Santiago, Tomo I. Madrid: Eds. del Orto, pp. 501-522.

GARCíA GARCíA, Isabel e Ignacio GOnZÁleZ TASCÓN (2004), Guía bibliográfica de la Historia de la Ingeniería Civil. Madrid: Ediciones del Umbral. 
GARCía TAPIA, Nicolás (1990), Ingeniería y arquitectura en el Renacimiento español. Valladolid: Universidad de Valladolid.

(1997)1 ${ }^{1}$ Los Ventiún Libros de los ingenios y máquinas de Juanelo, atribuidos a Pedro Juan de Lastanosa. Zaragoza: Departamento de Educación y Cultura.

$(1997)^{2}$, Molinos tradicionales. Valladolid: Castilla.

(2001), Un inventor navarro. Jerónimo de Ayanz y Beaumont (1553-1613). Pamplona: Universidad Pública de Navarra.

(2002), “La ingeniería”, en José María LóPEZ PIÑERO (dir.), Historia de la ciencia y de la técnica en la Corona de Castilla. Siglos XVI y XVII, Vol. III. Salamanca: Junta de Castilla y León, pp. 437-465.

(20081), Patentes de invención españolas en el Siglo de Oro. Madrid: Ministerio de Industria, Turismo y Comercio. (20082), "Privilegios de invención", en Manuel SILVA SuÁREZ (ed.), Técnica e ingeniería en España I. El Renacimiento. De la técnica imperial y la popular. Zaragoza: Real Academia de Ingeniería. Institución Fernando el Católico, pp. 669-698.

GarcíA-Diego, José A. (1983), Pseudo-Juanelo Turriano: Los Ventiún libros de los ingenios y de las máquinas. Madrid: Colegio de Ingenieros de Caminos, Canales y Puertos. (1996), “Reflexiones sobre Los Ventiún libros de los Ingenios y Máquinas", en VV.AA., Los Ventiún libros de los Ingenios y Máquinas de Juanelo Turriano, Vol. I-VII. Madrid: Fundación Juanelo Turriano, pp. 21-74.

García-Diego, José Antonio y Nicolás García TAPIA (1987), Vida y técnica en el Renacimiento. Manuscrito de Francisco Lobato, vecino de Medina del Campo. Valladolid: Universidad de Valladolid. 
GÓMEZ CAPUZ, Juan (1998), El préstamo lingüístico. Concepto, problemas y métodos. Valencia: Universidad de Valencia.

Gómez Martínez, Marta y José Ramón CARriazo Ruiz (2010), La marcación en lexicografía histórica. San Millán de la Cogolla: Cilengua.

Gómez Martínez, Marta y Maa Nieves SÁnchez GonzÁlez de Herrero (2010), “La marcación diatópica”, en Marta GómEZ MARTínEZ y José Ramón CARRIAZO RUIZ, La marcación en lexicografía histórica. San Millán de la Cogolla: Cilengua, pp. 109-169.

GonZÁlez Ollé, Fernando y Manuel CASAdO Velarde (1992), “Spanisch: Wortbildungslehre (La formación de palabras)", en Lexicon der romanistischen Linguistik, T. 6, 1, Aragonesisch / Navarresisch, Spanisch, Asturianisch / Leonesisch. Tubinga: Niemeyer, pp. 91-109.

GONZÁlez TASCóN, Ignacio (1987), Fábricas hidráulicas españolas. Madrid: Turner. (1999)1, "Presentación", en VV.AA, Felipe II: los ingenios y las máquinas. Ingeniería y obras públicas en la época de Felipe II. Madrid: Sociedad Estatal para la Conmemoración de los Centenarios de Felipe II y Carlos V, pp. 19-23.

(1999)2, "Los caminos y los puentes", en VV.AA, Felipe II: los ingenios y las máquinas. Ingeniería y obras públicas en la época de Felipe II. Madrid: Sociedad Estatal para la Conmemoración de los Centenarios de Felipe II y Carlos V, pp. 85-136.

(1999)33, “Ingeniería portuaria”, en VV.AA, Felipe II: los ingenios y las máquinas. Ingeniería y obras públicas en la época de Felipe II. Madrid: Sociedad Estatal para la Conmemoración de los Centenarios de Felipe II y Carlos V, pp. 137-208.

(1999) 4 , “Obras de regadío", en VV.AA, Felipe II: los ingenios y las máquinas. Ingeniería y obras públicas en la época de Felipe II. Madrid: Sociedad 
Estatal para la Conmemoración de los Centenarios de Felipe II y Carlos V, pp. 209-240.

(1999)5, “Ingenios y máquinas para la industria", en VV.AA, Felipe II: los ingenios y las máquinas. Ingeniería y obras públicas en la época de Felipe II. Madrid: Sociedad Estatal para la Conmemoración de los Centenarios de Felipe II y Carlos V, pp. 241-309.

(2008), "La difusión medieval del molino hidráulico", en VV.AA., Ars mechanicae. Ingeniería medieval en España. Madrid: Fundación Juanelo Turriano / Ministerio de Fomento / Cedex, pp. 99-118.

GranAdA MARTínEZ, Miguel Ángel (2008), “Valoración filosófica de la técnica", en Manuel SILVA SuÁREZ (ed.), Técnica e ingeniería en España I. El Renacimiento. De la técnica imperial y la popular. Zaragoza: Real Academia de Ingeniería. Institución Fernando el Católico, pp. 67-94.

GUILBERT, Louis (1975), La creativité lexicale. París: Larousse.

GUTIÉRREZ CUADRADO, Juan (2006), “La etimología en los diccionarios generales: reflexiones sobre catálisis y sus derivados", en Elisenda BERNAL y Janet DeCESARIS (eds.), Palabra por palabra. Estudios ofrecidos a Paz Battaner. Barcelona: Universitat Pompeu Fabra.

GuTIÉRREZ RodiLlA, Bertha (1993), “Los términos relacionados con la medicina en el Diccionario de Autoridades". Boletín de la Real Academia Española, tomo 73 , cuaderno 260, pp. 463-512.

(2005), El lenguaje de las ciencias. Madrid: Gredos.

Herráez Cubino, Guillermo (2007), El léxico de los tratados de cortes de cantería españoles del siglo XVI. Salamanca: Ediciones Universidad de Salamanca [CD-ROM].

HERRERO INGELMO, José Luis (1994-1995), Cultismos renacentistas. (Cultismos léxicos y semánticos en la poesía del siglo XVI). Separata del Boletín de la 
Real Academia Española, LXXIV-LXXV, en Estudios de lexicología y metalexicología actual. Tübingen: Max Niemeyer, pp. 159-167.

JiMÉNEZ Ríos, Enrique (2010), “¿Traducción o creación léxica? Sobre primeras documentaciones a finales del XV", en Robert VERDONK y María Jesús MANChO DuQUe, Aspectos de la neología en el Siglo de Oro. Lengua general y lenguajes especializados. Amsterdam: Editions Rodopi.

Keller, Alexander G. (1999), “Introducción”, en VV.AA, Felipe II: los ingenios y las máquinas. Ingeniería y obras públicas en la época de Felipe II. Madrid: Sociedad Estatal para la Conmemoración de los Centenarios de Felipe II y Carlos V, pp. 24-40.

KIAULEHN, Walther (1959-1964), Los ángeles de hierro. Origen, historia y poder de las máquinas. Barcelona: Labor.

LACA, Brenda (1986), Die Wortbildung als Grammatik des Wortschazes. Untersuchungen zur spanischen Subjektnominalisierung. Tubinga: Narr.

LANG, Mervin F. (1992), Formación de palabras en español. Morfología derivativa productiva en el léxico moderno. Madrid: Castalia.

LAPESA, Rafael (1999 [1981]), Historia de la lengua española. Madrid: Gredos.

LÁZARO MORA, Fernando A. (2000[1999]), “La derivación apreciativa”, en Ignacio BOSQUE y Violeta DEMONTE (dirs.), Gramática descriptiva de la lengua española, Vol. 3. Madrid: Espasa Calpe, pp. 4645-4682.

Llaguno de Amírola, Eugenio (1977), Noticias de los arquitectos y arquitectura de España desde la restauración (reedición). Madrid: Turner.

LÓPEZ GARCíA, Rafael (2006), Molinos hidráulicos: apuntes de historia y tecnología. Alcalá Grupo Editor: Alcalá la Real (Jaén). 
López Piñero, José Ma (1979), Ciencia y Técnica en la Sociedad Española de los siglos XVI y XVII. Labor: Barcelona.

(2002)1, “Introducción”, en José María LÓPEZ PIÑERO (dir.), Historia de la ciencia y de la técnica en la Corona de Castilla. Siglos XVI y XVII, Vol. III. Salamanca: Junta de Castilla y León, pp. 11-18. (2002)², “Las áreas de la actividad científica y su integración en las corrientes ideológicas e intelectuales", en José María LóPEZ PIÑERO (dir.), Historia de la ciencia y de la técnica en la Corona de Castilla. Siglos XVI y XVII, Vol. III. Salamanca: Junta de Castilla y León, pp. 221-229.

LÓPEZ-OCÓN CABRERA, Leoncio (2003), Breve historia de la ciencia española. Madrid: Alianza Editorial.

LORENZO, Javier de (2009), Ciencia y artificio. El hombre, artefacto entre artefactos. La Coruña: Netbiblo.

LÜDTKE, Jens (1978), Prädikative Nominalisierungen mit Suffixen im Französischen, Katalanischen und Spanischen. Tubinga: Niemeyer.

MALDONADO, José Luis y Armando GARCía GonZÁLEZ (2002), La España de la técnica y la ciencia. Madrid: Acento.

MALKIEL, Yakov (1988), “Apocope: Straight; Through Contact of Languages; Via Suffixal Polarization: The Spanish Derivational Morphemes and Word-Final segments -ín and -ino", HR 55, pp. 409-434.

(1992), "Las múltiples fuentes del sufijo español -io", Voces 3, pp. 133-148.

Mancho Duque, Ma Jesús, Guillermo Herráez, María Teresa Cantillo Nieves y José Ramón Carriazo Ruiz (2004), “Léxico especializado y lexicografía del Renacimiento", en $\mathrm{M}^{\mathrm{a}}$ Paz Battaner y Janet Ann DeCesaris, De lexicografía: Actes del I Symposium Internacional de Lexicografia. 15-18 de maig de 2002. 
Barcelona: Institut Universitari de Lingüistica Aplicada, Universitat Pompeu Fabra, pp. 503-546.

Mancho Duque, Ma Jesús (dir.) y Mariano Quirós García (coord.) (2005), La ciencia y la técnica en la época de Cervantes: textos e imágenes. Salamanca: Ediciones Universidad de Salamanca [DVD].

MANChO DuQue, Ma Jesús (2005), “La divulgación científica y técnica en castellano en la época de Cervantes", en VV. AA., La Ciencia y la Técnica en época de Cervantes. Salamanca: Ediciones Universidad de Salamanca, pp. 17-50.

(2008), "Sobre balanza y su red léxica en los textos de la Ciencia y la Técnica del Renacimiento, Revista de Investigación Lingüística (Revista de la Universidad de Murcia), no 11, Lexicografía y léxico históricos, pp. 189-207.

(2012)1 , “Aproximación terminológica a una parcela de la Física renacentista", en Quaderns de Filologia. Estudis lingüistics, 17. Valencia: Lengua y Ciencia: Recepción del Discurso Lingüístico. Pp. 211-233.

(2012)², “El Diccionario de la Ciencia y la Técnica del Renacimiento (DICTER): un puente filológico entre dos orillas del conocimiento", en D. Corbella, J. Dorta, A. FAJARdo, L. IZQUiERdo, J. MedinA y A. Nelsi (coords.), Lexicografía hispánica del siglo XXI: Nuevos proyectos y perspectivas. Homenaje al profesor Cristóbal Corrales Zumbado. Madrid: Arco/ Libros. Pp. 401-420.

Maravall, José Antonio (1972), Estado moderno y mentalidad social. Siglos XV a XVII, 2 Vols. Madrid: Revista de Occidente.

MARCHIS, Vittorio (1994), Storia delle machine: tre milleni di cultura tecnologica. Roma : Laterza.

MARÍN, Rafael (2009), “Del participio al adjetivo”, en Elena de MiguEL et alii. (eds.) Fronteras de un diccionario. Las palabras en movimiento. San Millán de la Cogolla: Cilengua. 
MARTín García, Josefa (2007), "Las palabras prefijadas con des-", en Boletín de la Real Academia Española, Tomo LXXXVII, Cuaderno CCXCV, enerojunio 2007, pp. 5-27.

Martín HerRero, Cristina (2006), El léxico de la cronometría y de los instrumentos de medición del tiempo en textos científico-técnicos del Renacimiento español. Trabajo de Grado dirigido por la Dra. MANCHO DUQUE, presentado el 20/12/2006 en la Universidad de Salamanca. Calificación: Sobresaliente Cum Laude.

(2010), "Acerca de Juanelo Turriano y su artificio", en $\mathrm{M}^{\mathrm{a}}$ Teresa Encinas Manterola et alii (eds.), Ars longa. Diez años de AJIHLE. Vol. I. Buenos Aires: Voces del Sur, pp. 323-333.

MENÉNDEZ PIDAL, Ramón (2005 [1869-1968]): Historia de la lengua española. Vol. I. Madrid: Fundación Menéndez Pidal.

MegaheY, Leslie (prod.) (2003), Leonardo da Vinci. El gran genio del Renacimiento. Barcelona: BBC [DVD].

Miranda POZA, José Alberto (1994), La formación de palabras en español. Salamanca: Ediciones Colegio de España.

Moreno De AlbA, José Carlos (1986), Morfología derivativa nominal en el español de México. México D. F.: Universidad Autónoma de México.

Moreno NiETO, Luis y Ángel Moreno Santiago (2006), Juanelo y su Artificio. Antología. Toledo: D. B. Ediciones.

NAvascués Palacio, Pedro (2008), "Sobre las artes mecánicas", en VV.AA, Ars mechanicae. Ingeniería medieval en España. Madrid: Fundación Juanelo Turriano / Ministerio de Fomento / Cedex, pp. 21-31.

Otaola Olano, Concepción (2003), Introducción a la lexicología de la lengua española. Madrid: UNED. 
PACEY, Arnold (1980), El laberinto del ingenio. Ideas e idealismo en el desarrollo de la tecnología. Barcelona: Gustavo Gili.

PAscual Rodríguez, José Antonio (1985), “El léxico relacionado con el lagar en castellano medieval", en José L. MelenA (ed.), Symbolae Ludovico Mitxelena Septuagenario Oblatae. Vitoria: Instituto de Ciencias de la Antigüedad / Universidad del País Vasco.

PENA, Jesús (1980), La derivación en español. Verbos derivados y sustantivos verbales, Anexo 16 de Verba. Santiago de Compostela: Universidade de Santiago. (2000 [1999]), “Partes de la morfología. Las unidades del análisis morfológico", en Ignacio BOSQUE y Violeta DEMONTE (dirs.) Gramática descriptiva de la lengua española, Vol. 3. Madrid: Espasa Calpe, pp. 4305-4366.

(2003), "La relación derivativa", en ELUA. Estudios de Lingüística de la Universidad de Alicante, 17. Alicante: Universidad de Alicante, pp. 505-517.

PENNY, Ralph (1998 [1993]), Gramática histórica del español. Barcelona: Ariel.

PHARIES, David (2002), Diccionario etimológico de los sufijos españoles. Madrid: Gredos.

PORTO DAPENA, José Álvaro (2002), Manual de técnica lexicográfica. Madrid: Arco/Libros.

POTTIER, Bernard (1968 [1967]), Presentación de la lingüística. Madrid: Alcalá.

RAINER, Franz (1993), Spanische Wortbildungsslehre. Tubinga: Niemeyer. (2000 [1999]), “La derivación adjetival”, en Ignacio BOSQUE y Violeta DEMONTE (dirs.), Gramática descriptiva de la lengua española, Vol. 3. Madrid: Espasa Calpe, pp. 4595-4643. 
(2002), “Convergencia y divergencia en la formación de palabras en las lenguas románicas", en Joaquín A. GARCía-MedALL VILLANUEVA, Aspectos de morfología derivativa en español. Lugo: Tris Tram, pp. 97-133.

ReguANT, Salvador (2003), "Perspectivas sobre la terminología, el discurso y la cultura científicos", en Bertha M. GutiérRez RodilLA (ed.). Burgos: Fundación Instituto Castellano y Leonés de la Lengua, pp. 69-109.

[NGLE] Real Academia Española de la Lengua (2010), Nueva gramática de la lengua española. Madrid: Espasa.

RIFÓN, Antonio (1997), Pautas semánticas para la formación de verbos en español mediante sufijación. Santiago de Compostela: Universidade de Santiago de Compostela.

SÁENZ RIDRUejo, Fernando (2008), Ingeniería y obra pública civil. Zaragoza: Real Academia de Ingeniería, Institución "Fernando el Católico", Prensas Universitarias de Zaragoza, pp. 345-384.

SÁNCHEZ MARTíN, Fco. Javier (2009), El léxico de la geometría aplicada a la técnica en el Renacimiento hispano. [Tesis defendida el 27/01/2009 en la Facultad de Filología de la Universidad de Salamanca, dirigida por la Dra. MANCHO DUQUE. Calificación: Sobresaliente Cum Laude].

SÁNCHEZ ORENSE, Marta (2007), Estudio del léxico de la industria textil y de la sastrería en la época renacentista. [Trabajo de Grado defendido el 12/07/2007 en la Facultad de Filología de la Universidad de Salamanca, dirigido por la Dra. MANCHO DuQue. Calificación: Sobresaliente Cum Laude].

SÁnCHEZ Ron, José Manuel (1999), Cincel, martillo y piedra. Historia de la ciencia en España (siglos XIX y XX). Madrid: Taurus.

SÁNCHEZ-Prieto BorJa, Pedro (1992), “Alternancia entre el lexema con y sin prefijo en castellano medieval (el verbo)", en Manuel ARIZA, Rafael CANO ET ALII (eds.), Actas del II Congreso Internacional de Historia de la Lengua Española. Madrid: Espasa-Calpe, pp. 4505-4594. 
SANTIAGo Lacuesta, Ramón y Eugenio Bustos Gisbert (2000[1999]), “La derivación nominal", en Ignacio BOSQUE y Violeta DEMONTE (dirs.), Gramática descriptiva de la lengua española, Vol. 3. Madrid: Espasa Calpe, pp. 4505-4594.

SANTOS Río, Luis (2002), “Aspectos de la sufijación adjetival -ivo, con especial atención a su vertiente relacional", en Joaquín A. GARCÍA-MEDALL VillanueVa, Aspectos de morfología derivativa en español. Lugo: Tris Tram, pp. $151-166$.

SERRANO-DOLADER, David (1995), Las formaciones parasintéticas en español. Madrid: Arco/Libros.

(2000 [1999]), “La derivación verbal y la parasíntesis”, en Ignacio BOSQUE y Violeta DEMONTE (dirs.), Gramática descriptiva de la lengua española, Vol. 3. Madrid: Espasa Calpe, pp. 4683-4755.

SILVA SuÁREZ, Manuel (2008)1" , "Presentación. Modernidad y técnica en el Imperio", en Manuel SILVA SuÁREZ (ed.), Técnica e ingeniería en España I. El Renacimiento. De la técnica imperial y la popular. Zaragoza: Real Academia de Ingeniería, Institución "Fernando el Católico", Prensas Universitarias de Zaragoza, pp. 13-26.

$(2008)^{2}$, “Sobre Técnica e Ingeniería: en torno a un excursus lexicográfico", en Manuel SILVA SuÁREZ (ed.), Técnica e ingeniería en España I. El Renacimiento. De la técnica imperial y la popular. Zaragoza: Real Academia de Ingeniería, Institución "Fernando el Católico", Prensas Universitarias de Zaragoza, pp. 27-66.

$(2008)^{3}$, “El lenguaje gráfico: inflexión y pervivencias", en Manuel SIlva SuÁREz (ed.), Técnica e ingeniería en España I. El Renacimiento. De la técnica imperial y la popular. Zaragoza: Real Academia de Ingeniería, Institución “Fernando el Católico”, Prensas Universitarias de Zaragoza, pp. 243-310. $(2008)^{4}$, “Apuntes biográficos”, en Manuel SILVA SUÁREZ (ed.), Técnica e ingeniería en España I. El Renacimiento. De la técnica imperial y la popular. 
Zaragoza: Real Academia de Ingeniería, Institución "Fernando el Católico", Prensas Universitarias de Zaragoza, pp. 701-738.

Tagliavini, Carlo (1973), Orígenes de las lenguas neolatinas. México: Fondo de Cultura Económica.

Thibault, André (2009), "Prólogo", en Clara Curell Aguilà, Diccionario de galicismos del español peninsular contemporáneo. Strasbourg: Eliphi, pp. VII-VIII.

TORRENS Álvarez, María Jesús (2007), Evolución e historia de la lengua española. Madrid: Arco/Libros.

TruesDell, Clifford (1975), Ensayos de historia de la mecánica. Madrid: Tecnos.

VAL Álvaro, José Francisco (2000 [1999]), “La composición”, en Ignacio BOSQUE y Violeta DEMONTE (dirs.), Gramática descriptiva de la lengua española, Vol. 3. Madrid: Espasa Calpe, pp. 4757-4841.

VAREla OrtegA, Soledad (1996), Fundamentos de morfología. Madrid: Síntesis.

(2005), Morfología léxica: la formación de palabras. Madrid:

Gredos.

VAREla OrtegA, Soledad y Josefa MARTín García (2000 [1999]), “La prefijación", en Ignacio BosQUE y Violeta DEMONTE (dirs.), Gramática descriptiva de la lengua española, Vol. 3. Madrid: Espasa Calpe, pp. 4993-5040.

VELASCO, Lázaro de (trad.) (1999 [ca. 1564]), Los X Libros de arquitectura de Marco Vitruvio Polión. Cáceres: Cicón Ediciones.

VERGER, Jacques (1999 [1997]), Gentes del saber en la Europa de finales de la Edad Media. Madrid: Editorial Complutense.

Vicente Maroto, María Isabel (1997), "Juan de Herrera, científico", en Juan de Herrera, arquitecto real. Barcelona / Madrid: Lunwerg, pp. 157-207. 
VILlAR DíAZ, María Belén (2008), “Modelos estructurales”, en Elena de Miguel (ed.), Panorama de la lexicología. Barcelona: Ariel.

VV.AA. (1996), Los Ventiún libros de los Ingenios y Máquinas de Juanelo Turriano, Vols. I-VII. Madrid: Fundación Juanelo Turriano.

[Catálogo Felipe II] VV.AA. (1999 [1998]), Felipe II: Los ingenios y las máquinas. Ingeniería y obras públicas en la época de Felipe II. Madrid: Sociedad Estatal para la Conmemoración de los Centenarios de Felipe II y Carlos V.

WÜSTER, E. (1998 [1979]), Introducción a la teoría general de la terminología y a la lexicografía terminológica (trad.). Barcelona: IULA. 